250. 206

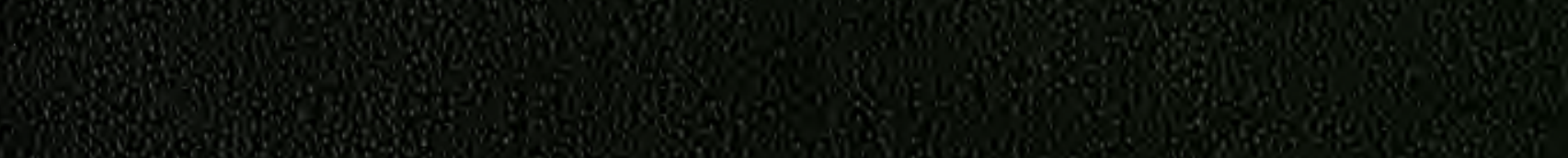

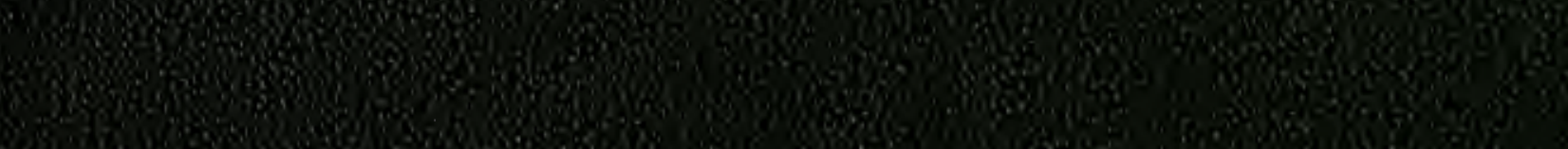

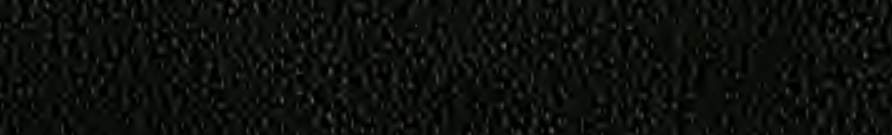




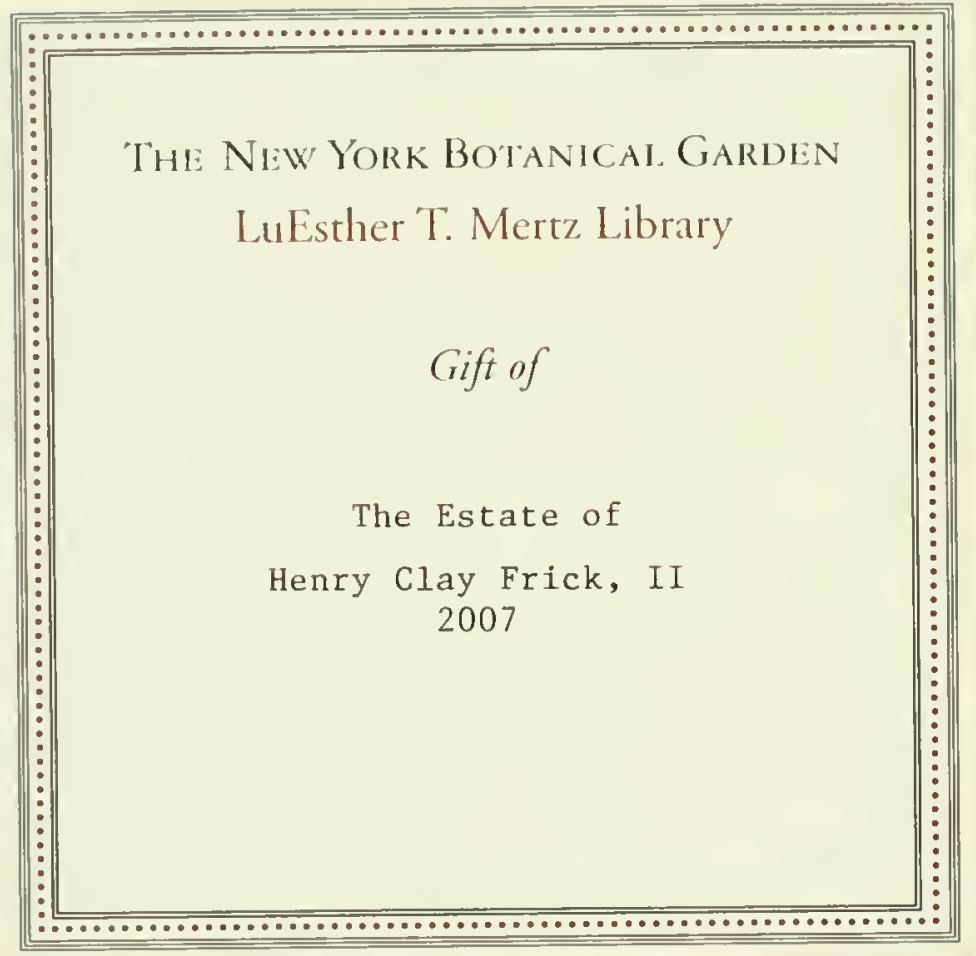






\section{.}




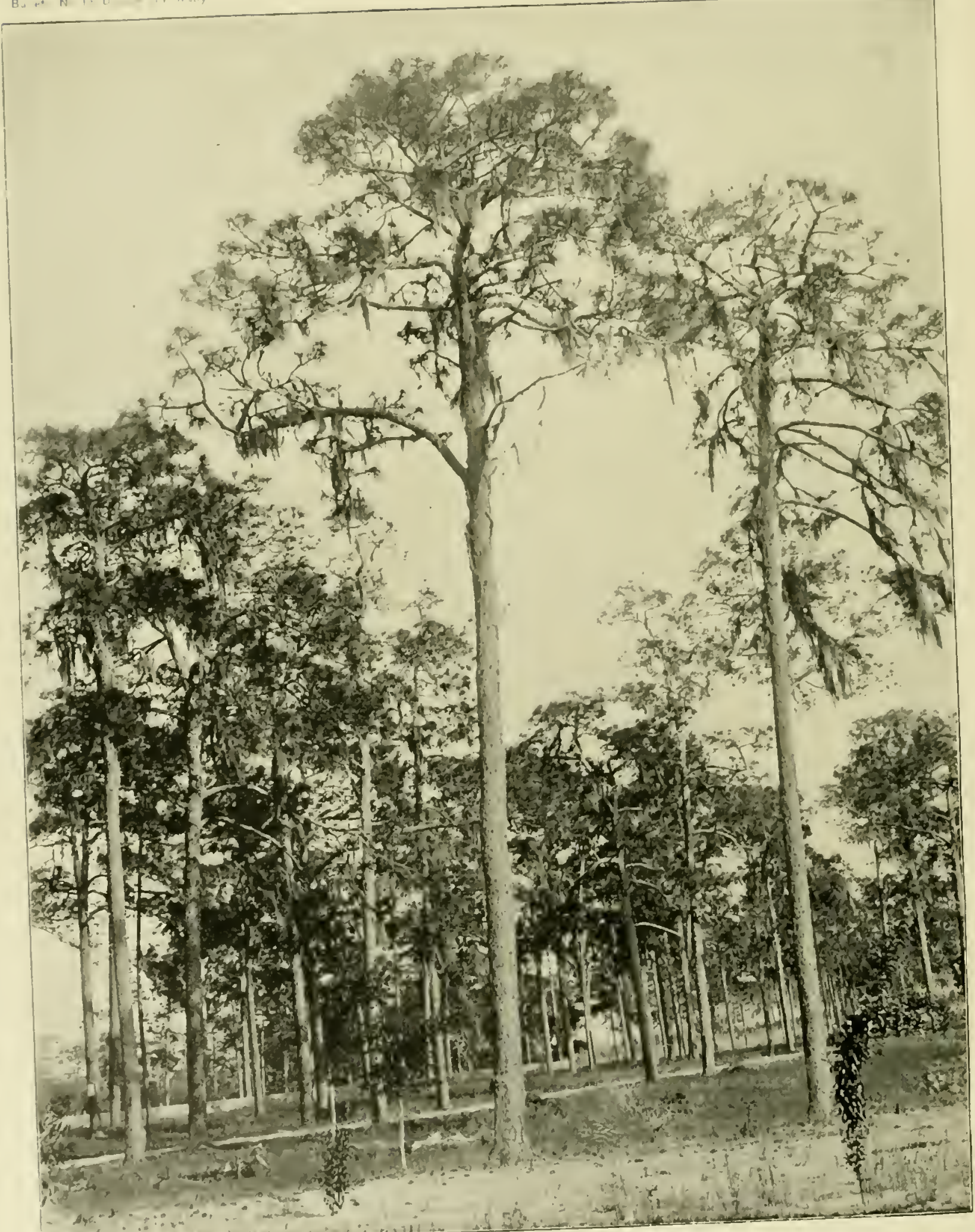


BULLETIN No. 13.

\section{U. S. DEPARTMENT OF AGRICULTURE.}

DIVISION OF FORESTRY.

T I I E

\section{TIIIBER PINES 0I: THIE SUUTHERN INITED STITES.}

By CHARLES MOHR, Ph. D.

TOGETHER WITH

A DISCUSSION OF THE STRLCTLRE OF THEIR WOOD.

By FILIBERT ROTH.

PRF,PARED UNDER "THE DIRECTIGN OF B. F. FERNOW, CHIHF OF THE, DIVISION OF FORESTRY.

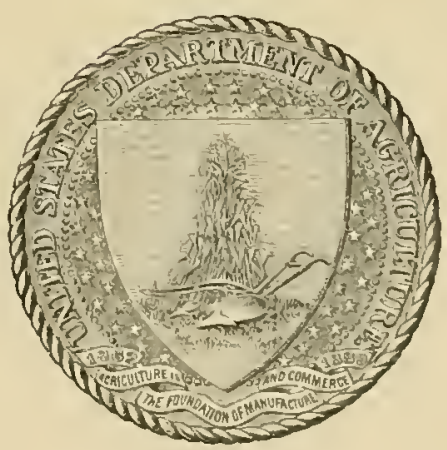

WASHINGTON:

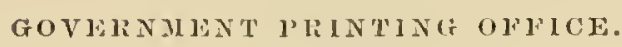

1 si! 6 . 
The Timber Pines of The Southern United Stotes $\ldots \ldots \ldots \ldots \ldots \ldots \ldots$. Cherles Viokr

A Diecussion Cf The Structure of Their hood Filibert Roth

The White Pine................. S S Iding Insect Enenies of The White Pine........ ............... H. Chittenden The llood of The White Pine...Filihert Roth 



\title{
LETTER OF 'TRANSIITTAL.
}

\author{
Uniteid STATES IDEPARMext of Agriculture, \\ DIVISION OF JORESTRY, \\ W'ushingtom, H. C., Huy 26, 1896.
}

Sir: I have the honor to submit herewith for publication a series of monegraphs on the five pines of economic importance in the Sonthern Enited States, a result of many gears' study by 1). Charles Mohr, the well-known anthority on the botany of the Sonthern States and agent of the Jirision of Forestry.

The first draft of these monographs was prepared several years ago, but it was then found that in orler to matie them fully satisfactory and useful to the practitioner much adclitional information was neerled, especially reganding the rate of growth and other sylvicultural as well as technological questions. This information ins been gradually acemulated as our facilities liave permitted. The extended investigations carried on in this division may be cousidered quite exhanstive, esperially in regard to the mechanical properties of the wool of these pines. An interesting chapter on the wool stlucture by Mr. Filibert lioth has been alded, and a comparative study of the economie, sytvicultural, and technical characteristies and value of the pines under consideration-a résumé, as it were, of the contents of the monographs-is to be found in the introduction by the writer.

The pineries of the South furnish now, or will in the near future, the most important staples of our humber industry. According as they are treated, carefully or wastefully, they will continue for a longer or shorter time to be a wealth-pnoducing resouree of the Sonth. To aid in securing a true conception of the extent, conclition, and value of this resource, and of the nature, revelopment. characteristics (botanical, sylvienltural, and technological) of these pines, these monograplis have been written, with the hope of inducing rational forestry nethols in their nse and repronluction. Resprectfilly;

Hon. .J. StenLing Morton, I3. L. FERNOW, Chief of Dirision. Secretury of Agriculture. 



\section{CONTENTS.}

Page.

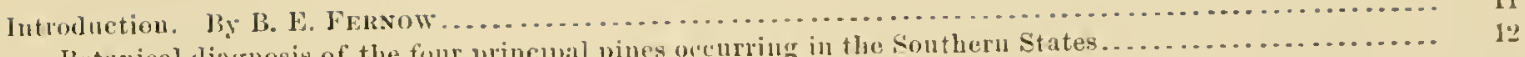

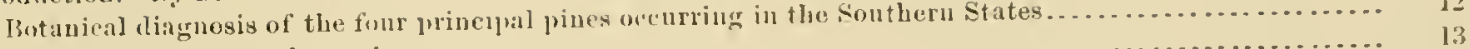

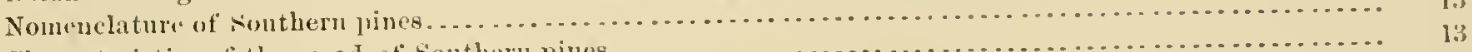

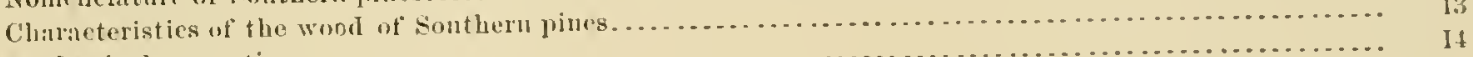

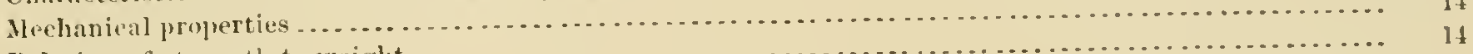

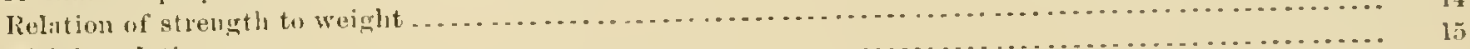

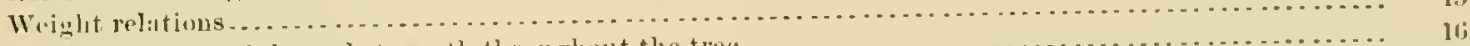

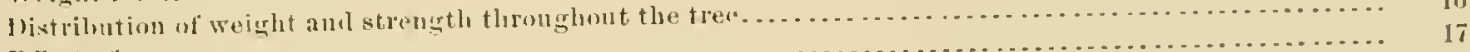

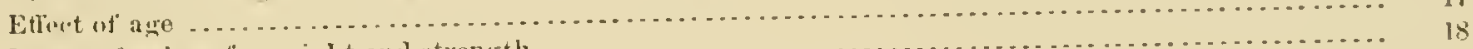

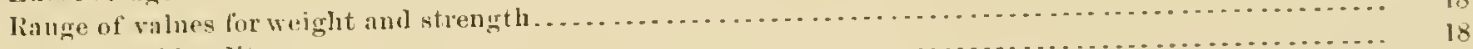

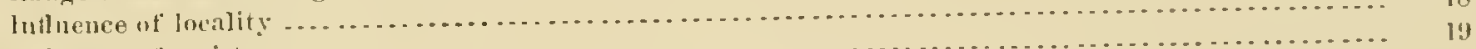

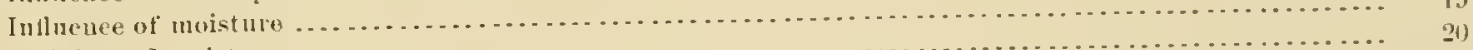

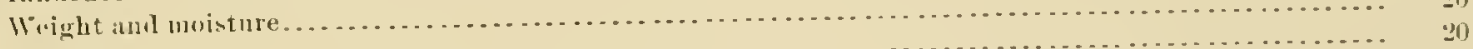

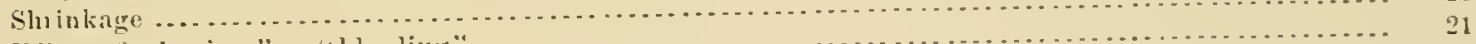

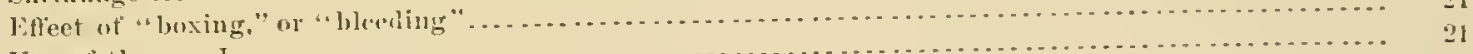

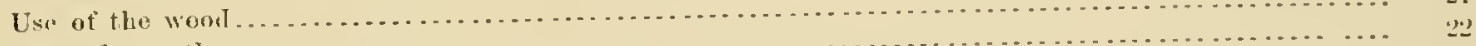

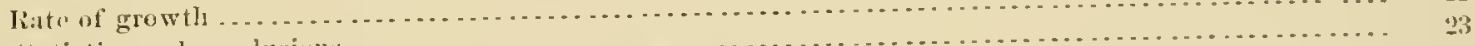

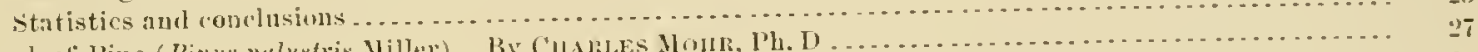

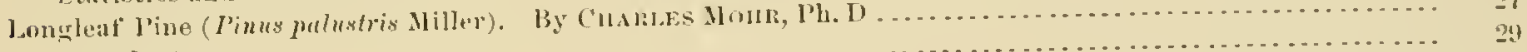

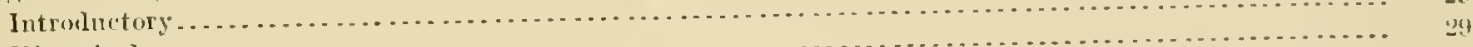

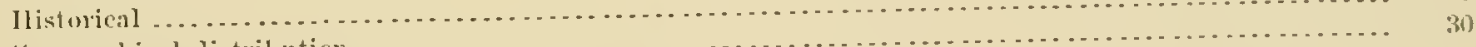

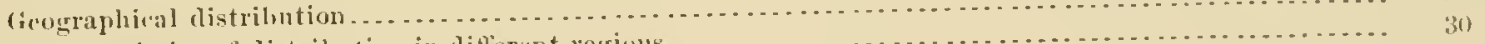

Characteristics of distribntion in ditlerent regions . . . . . . . .

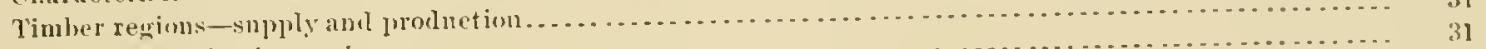

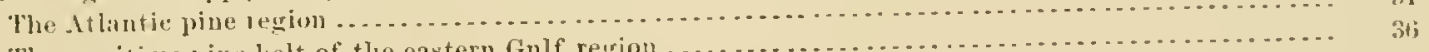

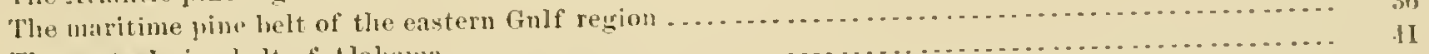

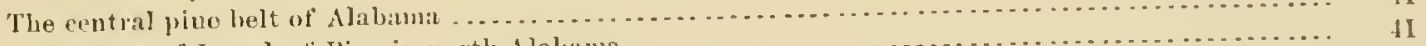

The forests of l.mol

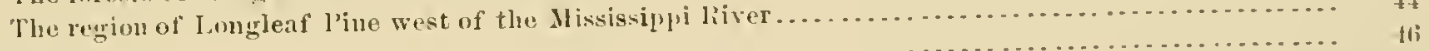

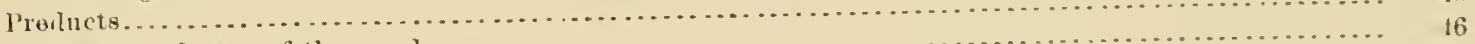

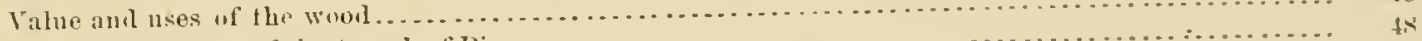

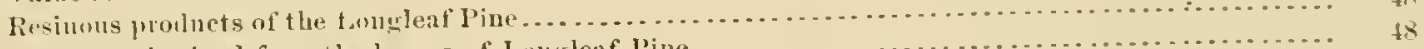

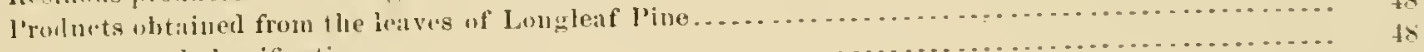

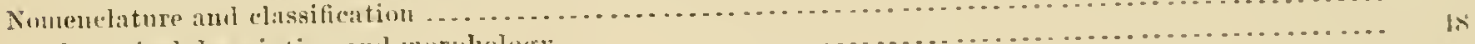

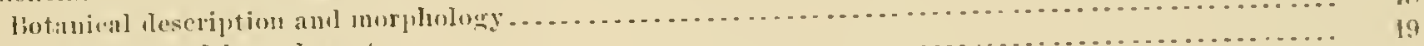

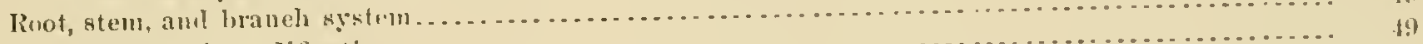

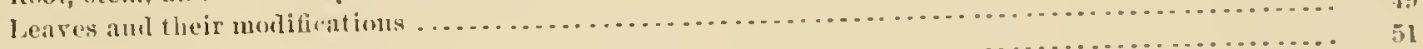

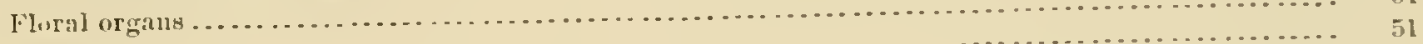

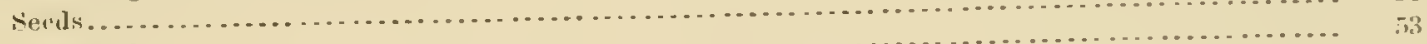

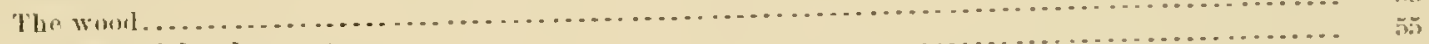

firowtl am derelopment. . . . . . . .

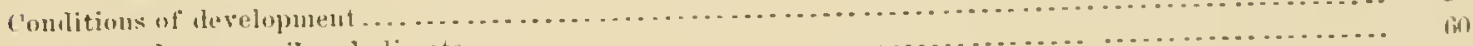

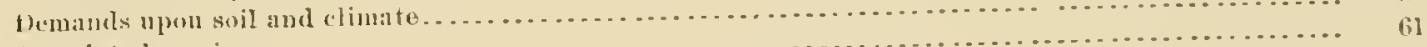

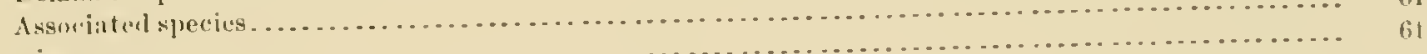

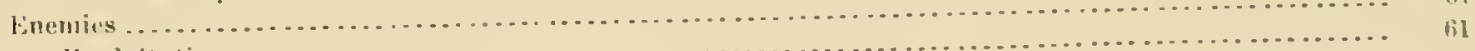

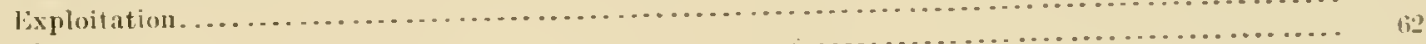

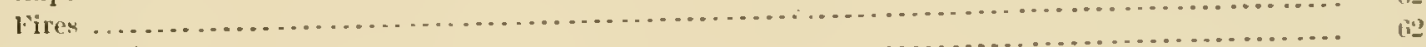

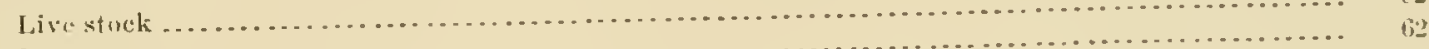

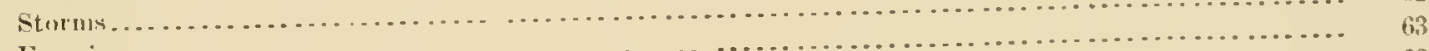

Fun

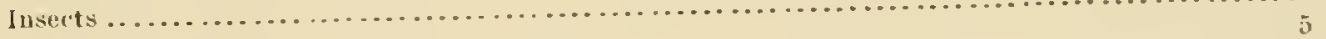




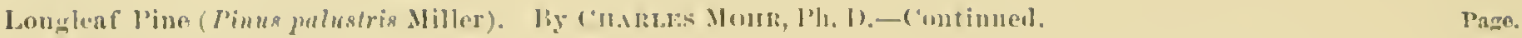

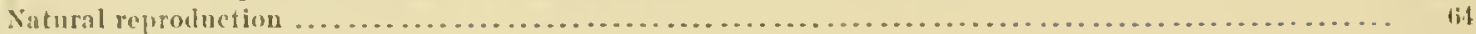

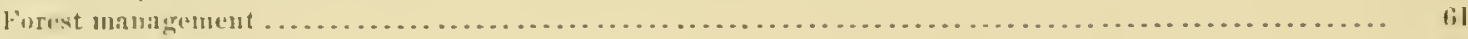

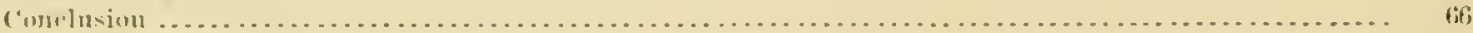

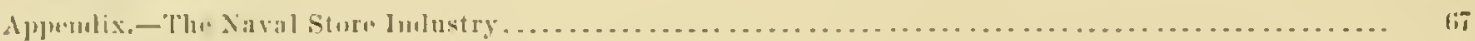

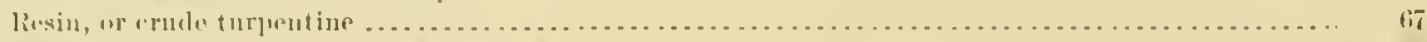

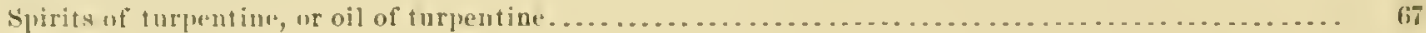

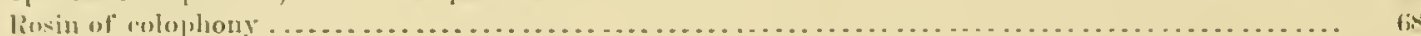

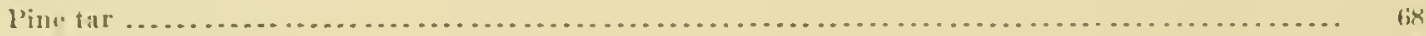

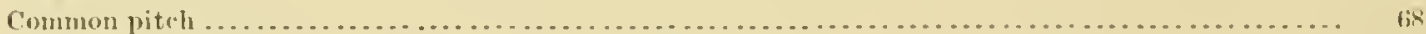

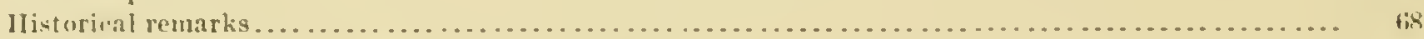

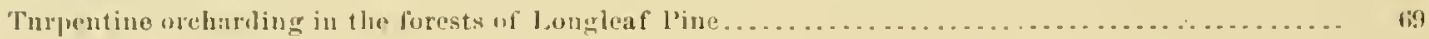

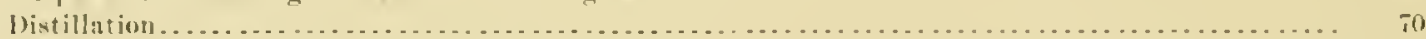

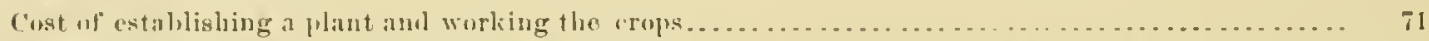

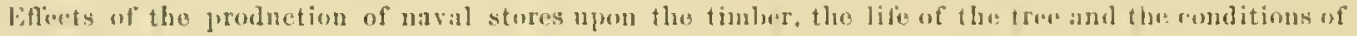

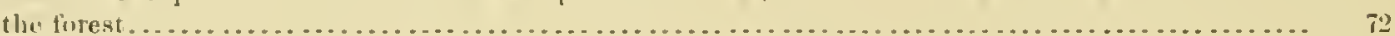

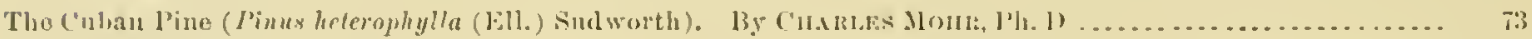

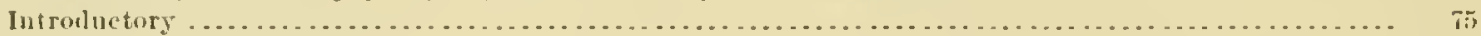

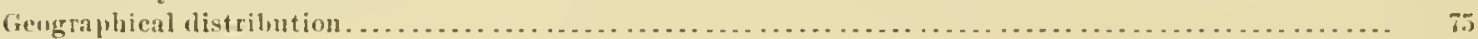

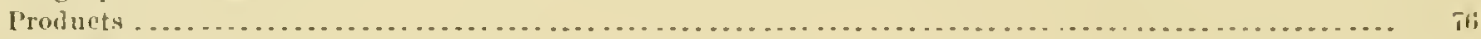

liminons proluets . . . . . . . . . .

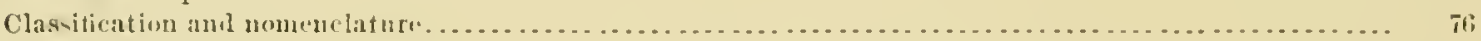

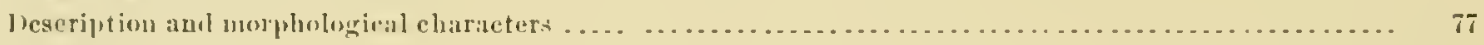

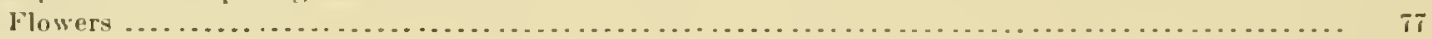

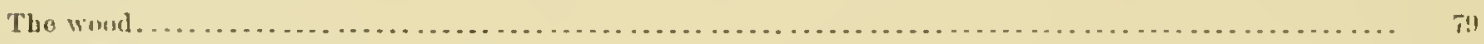

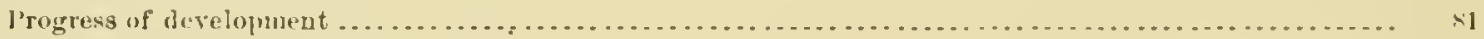

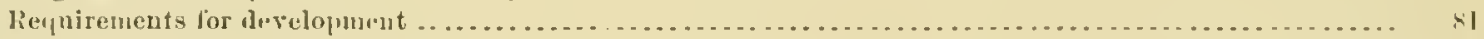

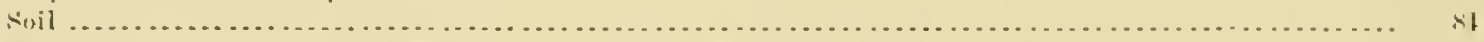

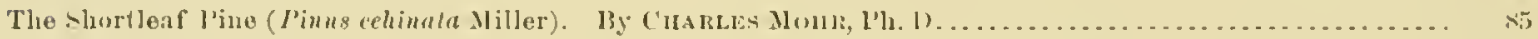

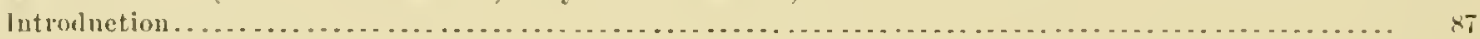

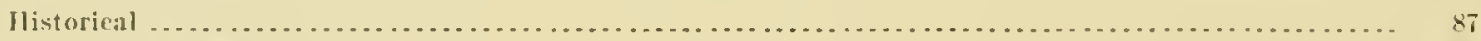

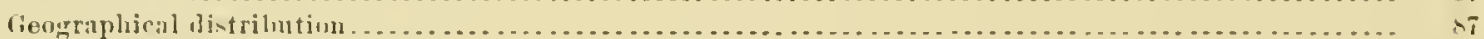

Characteristi's of distribution in ditlerent regions. . . . .

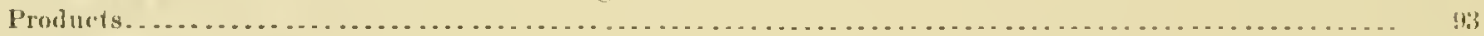

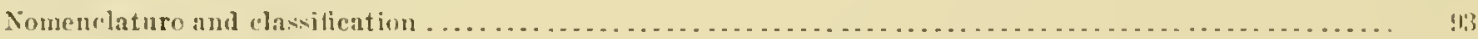

Botanical deseription . . . . . . . . . . . . . . . . . . . . . . . . . . . . . . . . . . . . . . . . . .

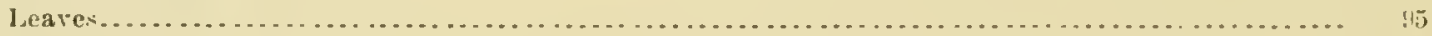

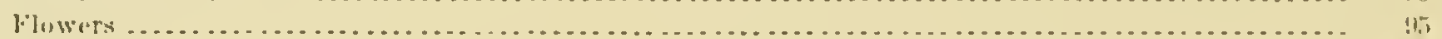

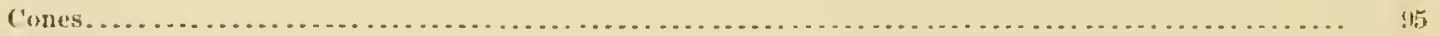

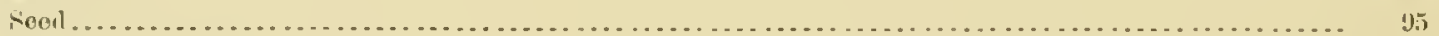

Tho woml. . . . . . . . . . . . . . .

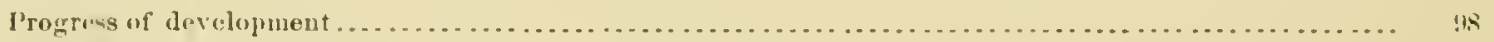

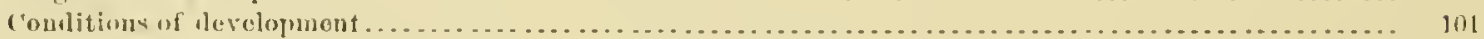

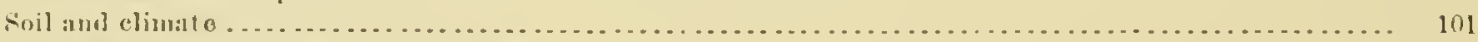

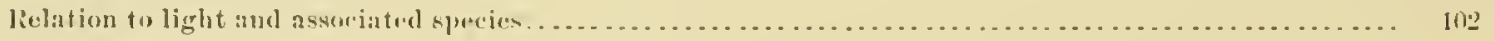

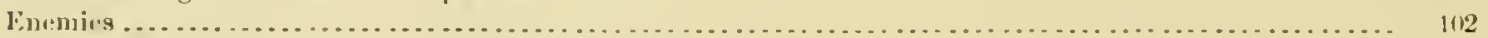

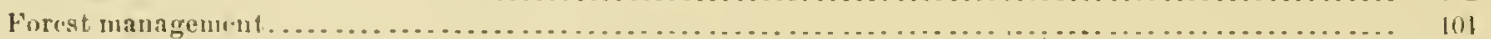

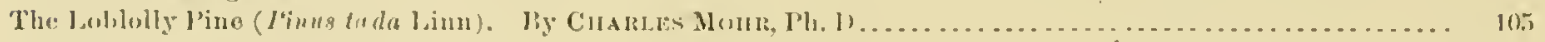

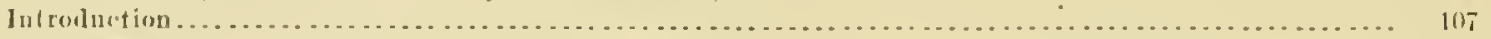

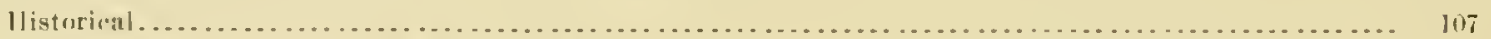

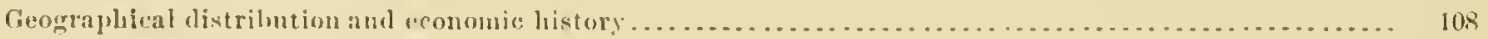

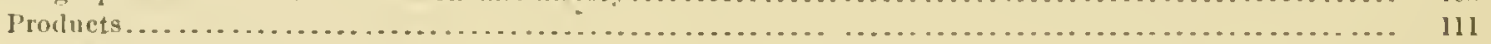

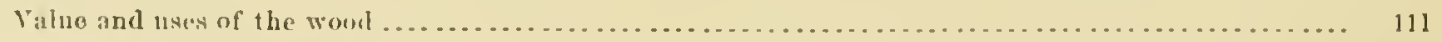

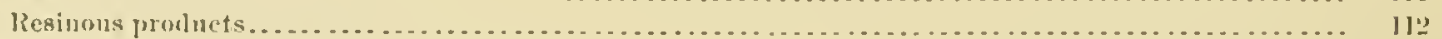

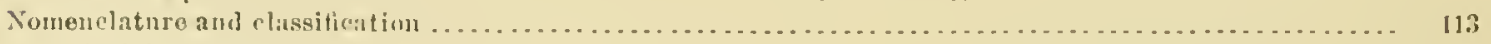

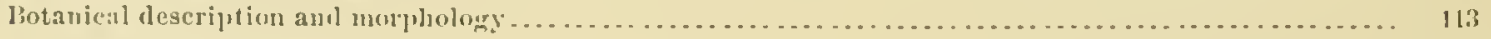

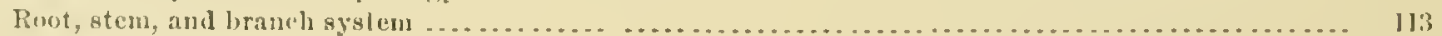

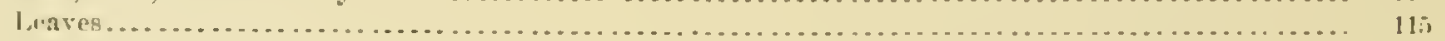

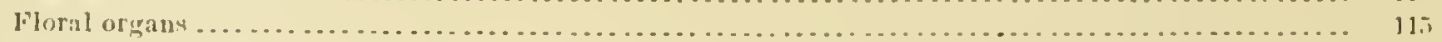

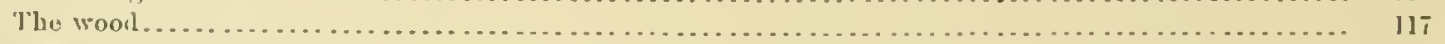

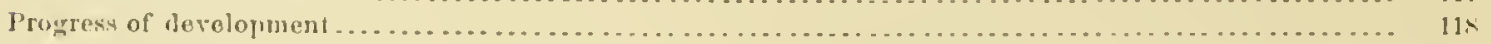

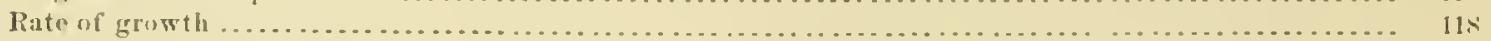

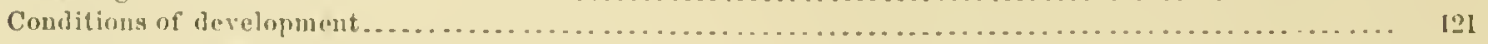

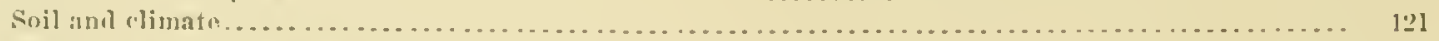

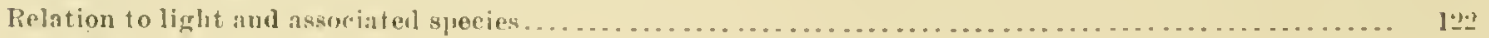

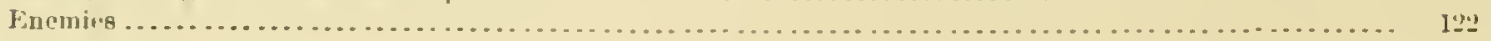


The Loblolly l'ine (Pinus tada Linn), By ('Inarliss Monr, I’h. D.-Continuel. I’age.

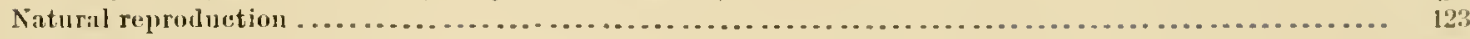

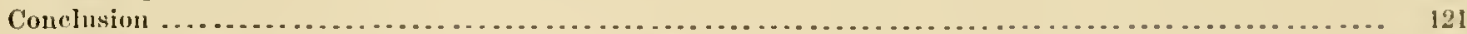

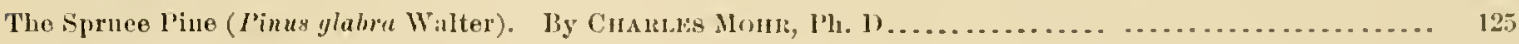

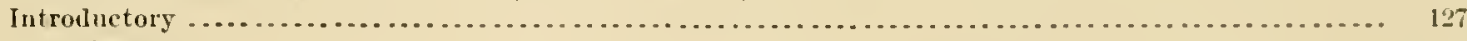

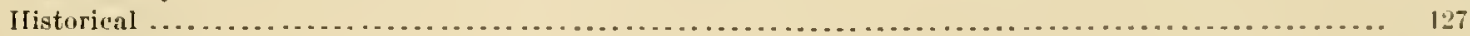

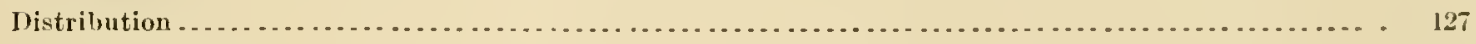

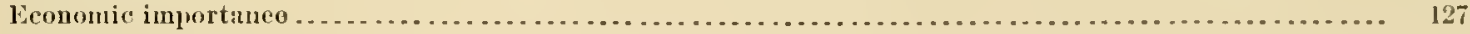

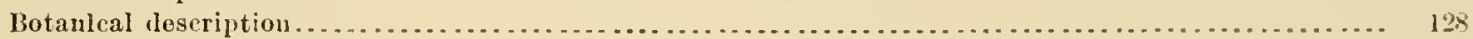

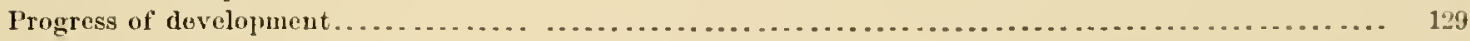

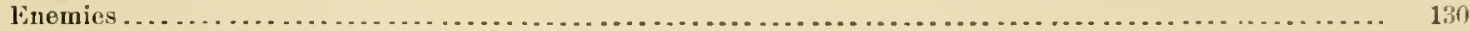

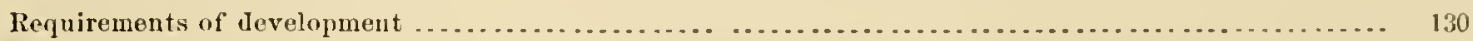

Notes on the structure of the wood of the fire pines, I'inus palustrix, heterophyllu, chinalu, twda, and glabra. liy Filizert Rotil ..........

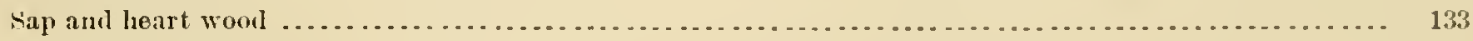

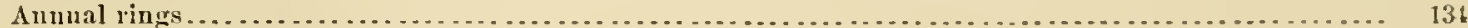

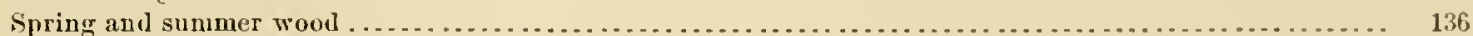

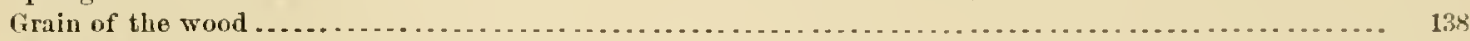

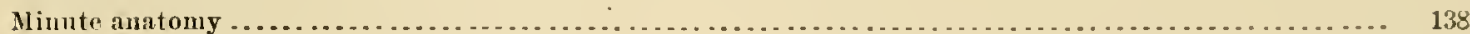




\title{
ILLUSTRATIONS.
}

\author{
PLATES.
}

Page Frontispier'e.

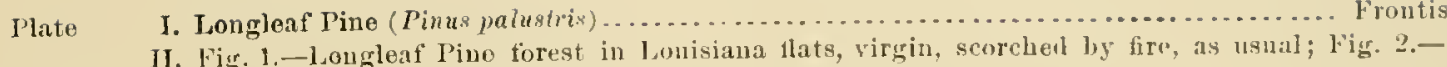

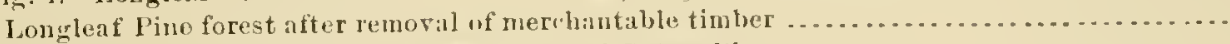

III. Map showing ristribution of Longleaf Pine aud Culsan l'ine............................

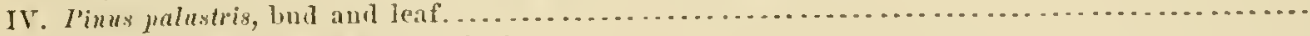

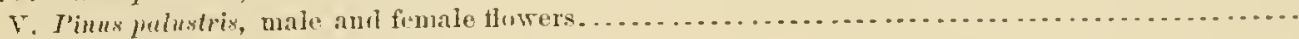

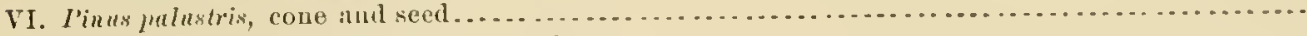

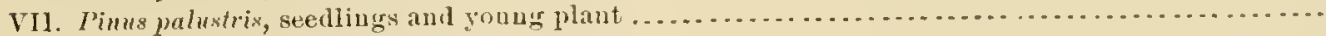

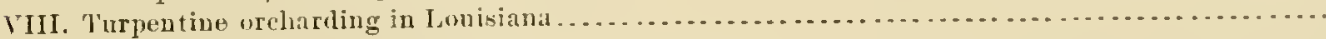

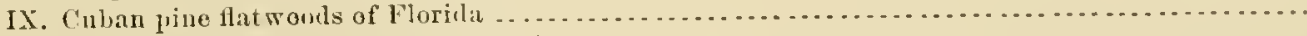

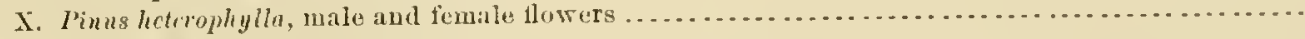

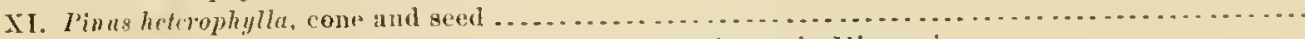

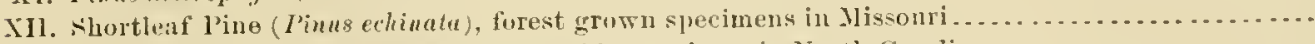

XII. Shurtleaf l'ino (I'inus echinata), a roalside specineu in Yorth Carolina....................

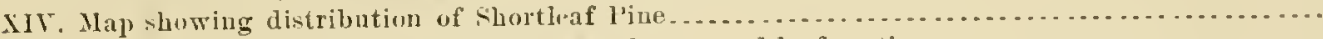

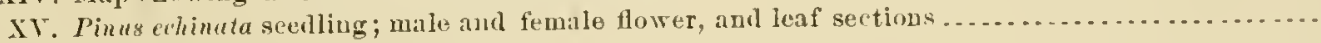

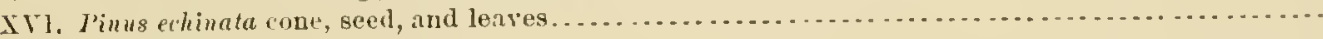

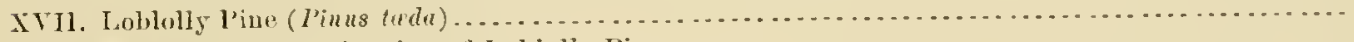

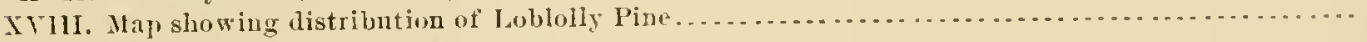

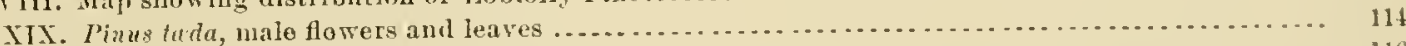

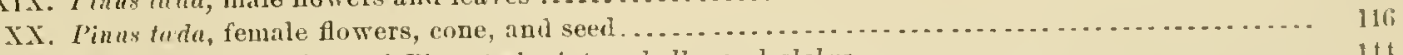

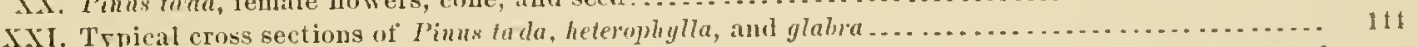

XXII. Typical cross sections of I'inus palustris and exhinata, and radial sections of $J^{\prime}$ inus palustris and

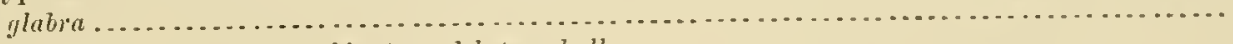

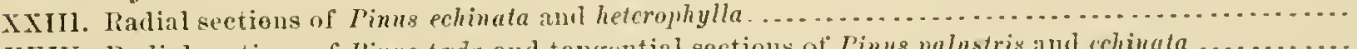

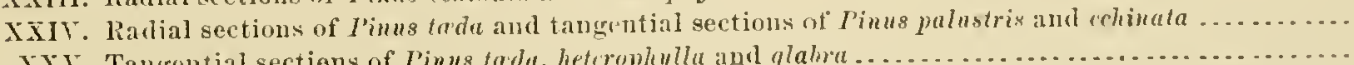

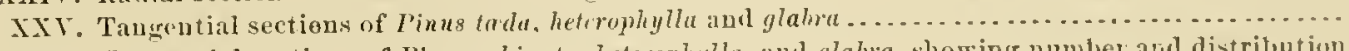

XXVI. Tangential sections of Pinus chinate, heterophylla, and glabra, showing number and distribution

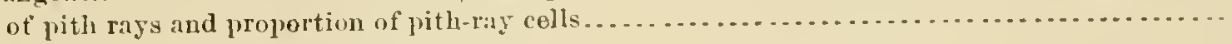

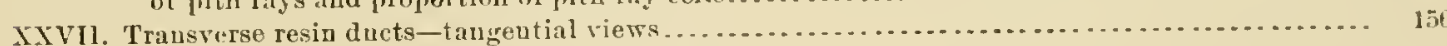

\section{FIGUREN.}

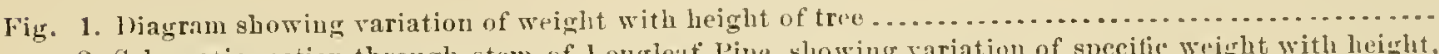
2. Schematic section through stem of Longleat Pinc, slowing variation of specific weight with height,

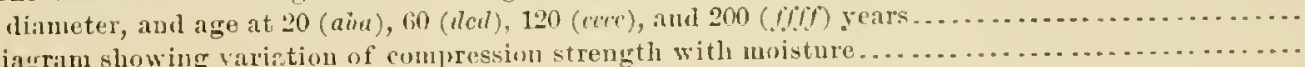

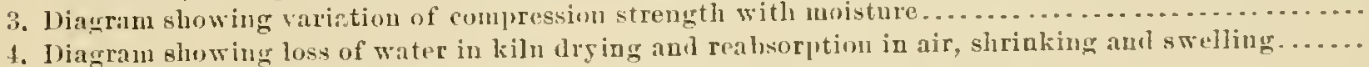

4. Diagram shewing loss of water in kiln diging and realsorption in air, shrinkmg aun swe

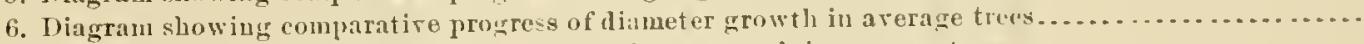

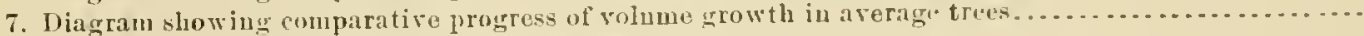

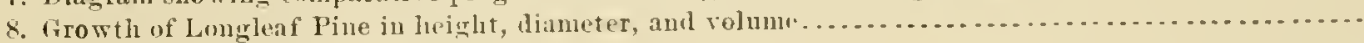

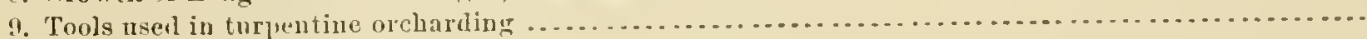

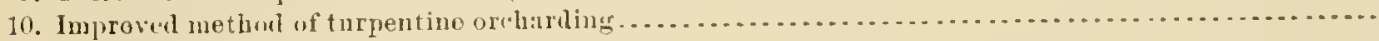

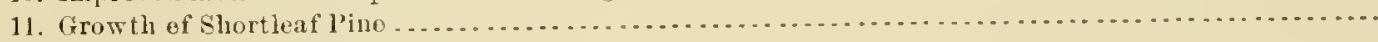

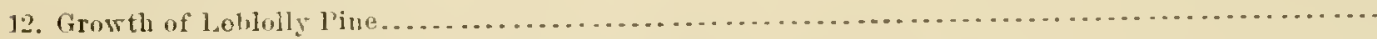

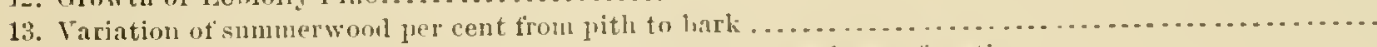

1. Tariation of specific gravity with sumuerwond jor cont and age ot section. ....................

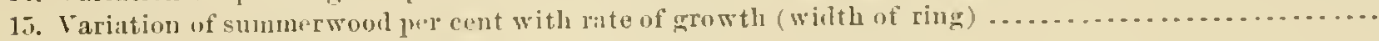

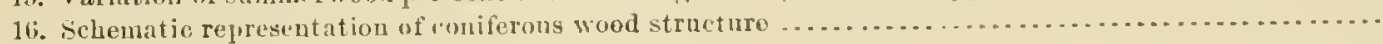

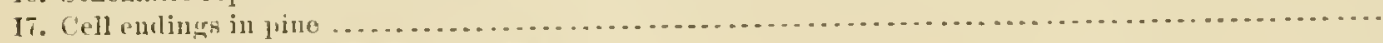

18. Cross section of normal and stunted growth. 


\section{INTRODUCTION.}

In ignorance of the natmre and withont appreeiation of the economic ralne of their resources, pioneers scluanler and destroy withont regard to the futnre the richus thes find. We lave done so in the United States and are contimning to du so althongh the pioneering stage should have been passed, especially with our forest resourees. We have exploited them as if they were mives, instead of crops which can be harvested and reproduced contiunously, and we have lone so in a most wastefin manuer; nay, we have by irrational methods of exploitation, no doulit dne in part to the necessities of a rapilly developiug conntry, in many cases destroged the conditions for natural reprorluetion of the nore valuable timber species. Fire and indiscrininate pasturing have also assisted in the process of deterioration.

We are just beginning to realize that our timber supplies are not unlimited: that our magnifieent timest resonrces have been despoiled and need at least more consideration; that sooner or later forestry will become, nay, is now, a neeessity.

Forestry is the art of prodncing, wanaging, and haresting wood erops. To be snecessful in this art it is of conrse neessary to understand the nature of the crop-tu be acquainted with the life history, the conditions of development reruired by each species of tree composing the crop. Such knowledge can be in part, at least, lerived from observations male in the natural forests, and from these observations the manner in which the difterent speeies shonld be treated and rnles of managenent may be deternined.

The time tor the application of forestry-that is, rational methous of treating the rood erophas not, as many seem to smpose, come only when the matmal forest growths have been despoiled and deteriorated. On the contrar, when the ax is for the first time applied, then is the time for the application of forestry, for it is possible so to cut the original natural forest erep that it can reproduce itselt in a sujerior manner. The judieious and systematic nse of the ax alone, iu the hands of the forester, will seenre this result.

Hence these monographs on the life history of the Sonthern pines have been written primarily to enable the owners of Souther'n pineries, who are now engaged in exploiting them, to so modify their treatment of the same as to insure continued reproduction instead of complete exlanstion, which is threatened miler present methols.

The pines are the most important timber trees of the worlu. They attain this importance from il combination of properties. In the first place, they possess such qualities of strength and elasticity, combined with comparatively light weight and ease of working, as to fit them specially for use in construetion which requires the largest amonnt of wood ; next, they wenr as forests in the temperate zones, often to the exehsion of every other species, so that their exploitation is made easy and profitable; thirdly, they are readily reproduced and tolerably ynick growers: and, lastly, they oceupe the joorest soils, producing valuable crops from the dry sauds, and henee are of the greatest ralue from the staudpoint of national eronomy.

The Sonthern States abound in those sandy soils which are the home of the pine tribes and were once covered with seeningly bomuless forestis of the same. There are still large areas mintouched, yet the greater portion of the primeval forest has not only been eulled of its best timber, but the repeated conflagrations which follow the lumbering, and, still more disastronsly, the turpentine gatheres' operations have destroyed notonly the remainder of the original growth, but the vegetable mold and the young aftergrowth, leaving thonsands of square miles as blacliened wastes, devoid of usefulness, aud redneing by so much the potential wealth of the Sonth.

There are, in general, four belts of pine forest of dillirent types recoguizable, their bonndaries runing in general direction somewhat parallel to the eoast line: (1) The eoast plain, or pine-barren flats, within the tidewater region, 10 to 30 miles wirle, onee ocenpied manly by the wost raluable 


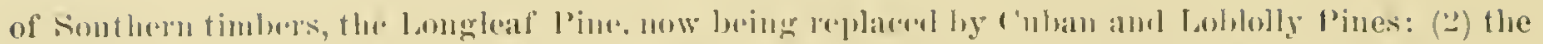

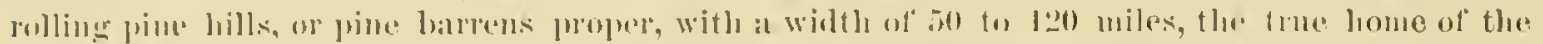

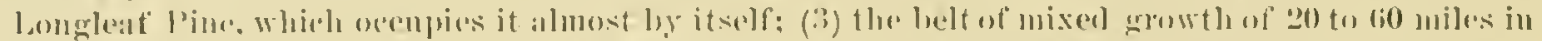

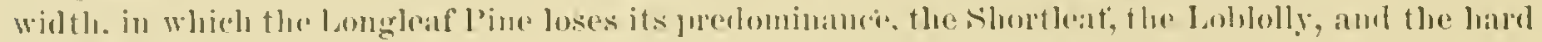

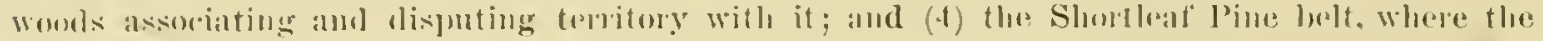

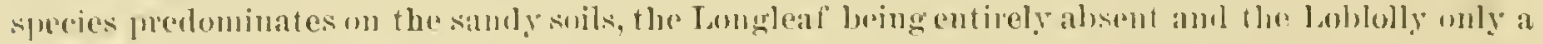

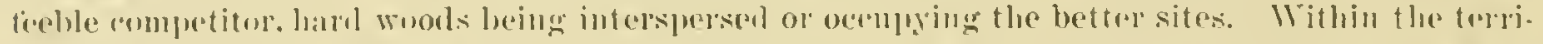

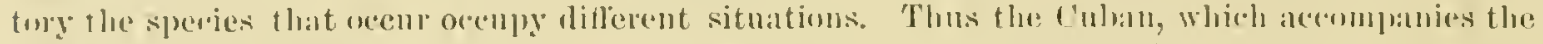
langleaf, "lsmally orenpes the less well duined sitnations, together with the loblolly, which,

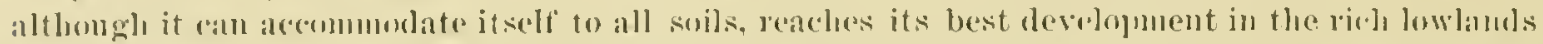

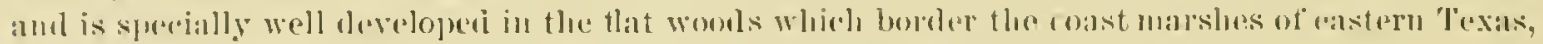
where it assuldates with the Shortleat l'ine it also seeks the moister sitnation.

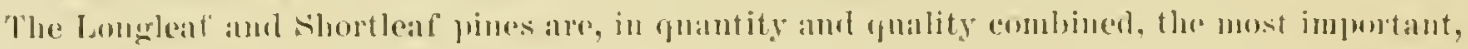

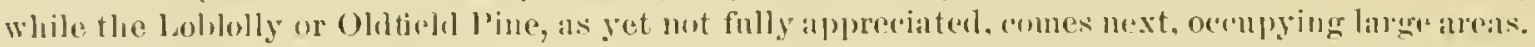

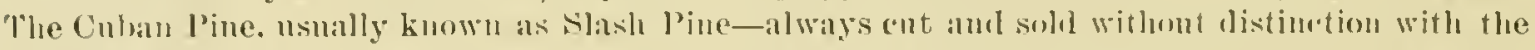

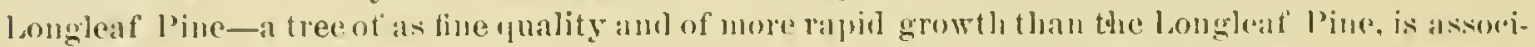

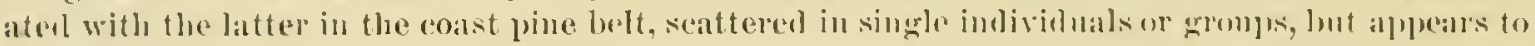
increase in weater proportion in the goung growth, heing ly its mamer of development in ardy

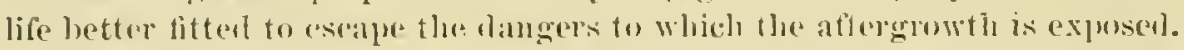

liesides these four most important pines. there are al number of others of less signifirance.

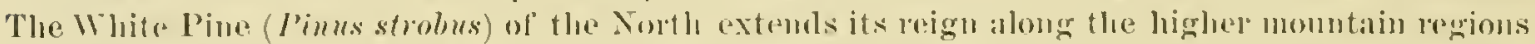
of North Carolina into (isengia, furming a valutble timber tree, Jut of small extent. 'The Sprume I'ine, to which a short chapter is devoted in this bullatin, deselops into timber size, lut is foums

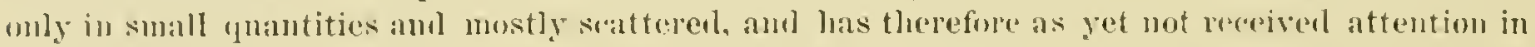
lumber markets; but its qualitios, and especially its forestal value, leine a pine which andures

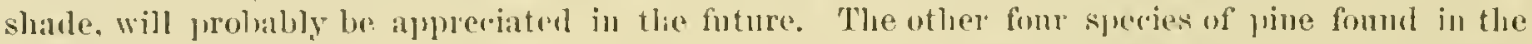
Sonth, which apjear in the talsle below, whing gives thoir lontanimal distinctions, do not develop

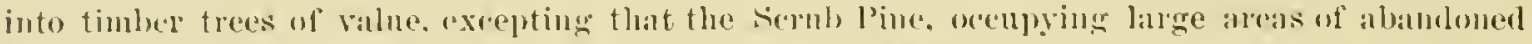
fields in Virginia, furnishes a considerable amount of firewool.

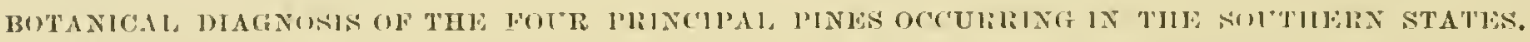

\begin{tabular}{|c|c|c|}
\hline Speries. & I'inus palustris MIIll.r. & I'inus le terophyllu (lill.) sulw. \\
\hline Leraver. & 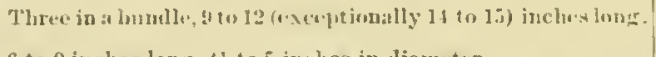 & 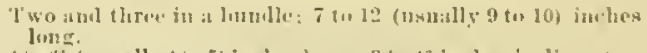 \\
\hline $\begin{array}{l}\text { fones (opin) } \\
\text { Siciles } . . . . . . .\end{array}$ & 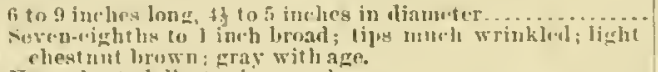 & 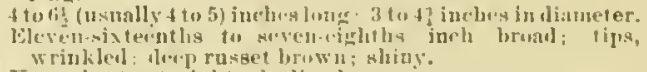 \\
\hline Prirkles & Very slint, ilelisute in & 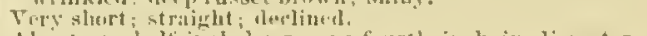 \\
\hline 3inds & 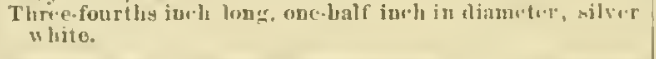 & 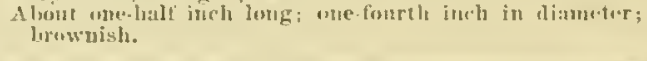 \\
\hline Siperies. & Jinus whinata Miller. & Jinueserder loints. \\
\hline Leaven & 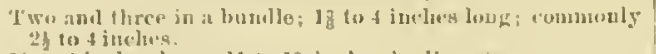 & Three in a lunedle: 5 to 8 inclese lobug. \\
\hline 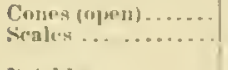 & 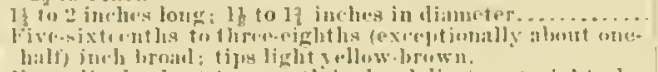 & 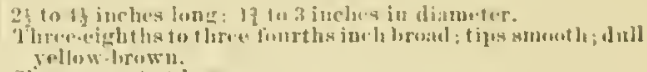 \\
\hline l'rickle & 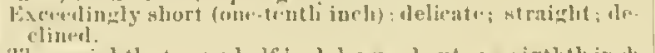 & Sliort: alont at bant. \\
\hline Burdm & 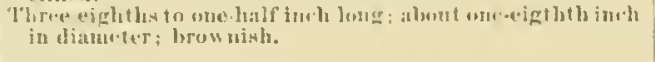 & 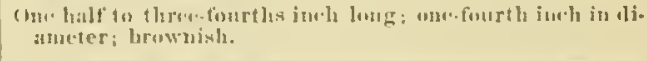 \\
\hline
\end{tabular}

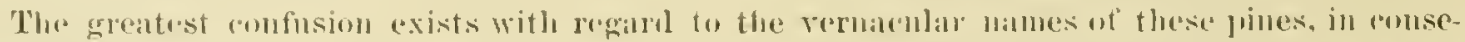
quence of which information regarding them, given by the native pojulation, must always he

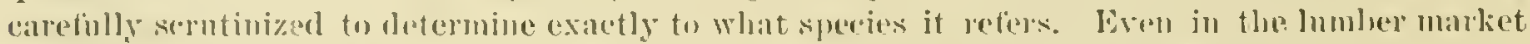

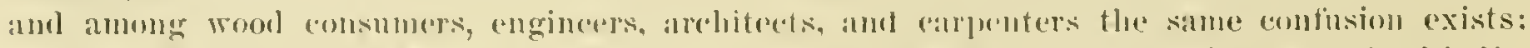

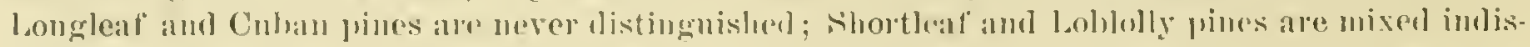

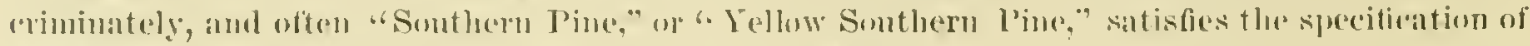
the arehitect and may come from any of the fom sjecies. 
To assist in charing this ronfusion the following symopsis of botanical and vernacular names is here inserted:

NOMLXCLATTLE OF NOTTHELN P'XES.

\begin{tabular}{|c|c|c|c|c|}
\hline liotanical nanes..... & 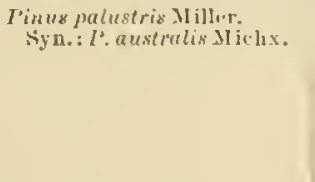 & 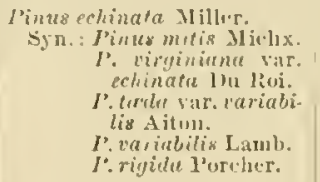 & $\begin{array}{c}\text { linus trria I,inu. } \\
\text { syn.: Itinue twia var. te } \\
\text { nuifolia Aiton. }\end{array}$ & 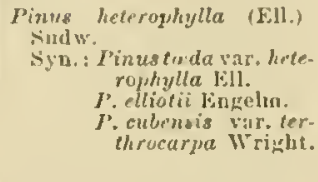 \\
\hline liest connmon names. & IONGLEAF IPNE. & SHORTLEAF PINE. & LONLULLY PINE. & CINAN INE. \\
\hline $\begin{array}{l}\text { Jocal, narket, aud } \\
\text { lumbermen's }\end{array}$ & 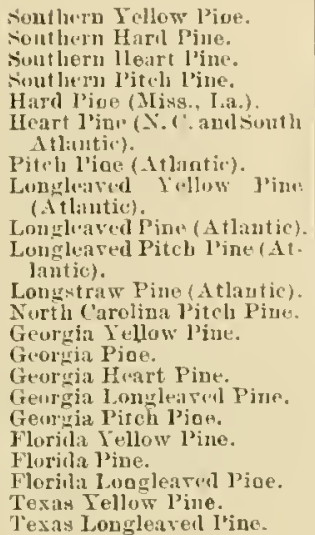 & 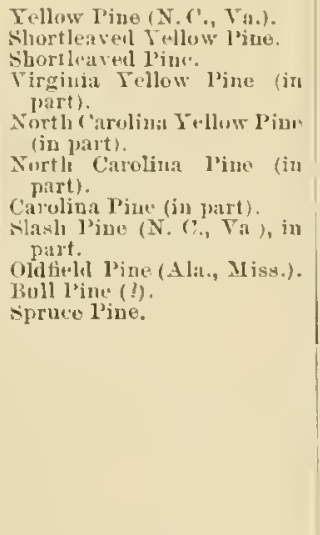 & 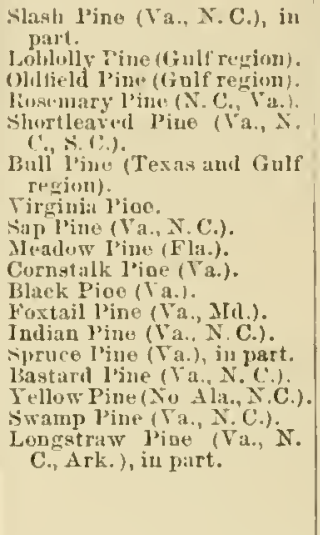 & 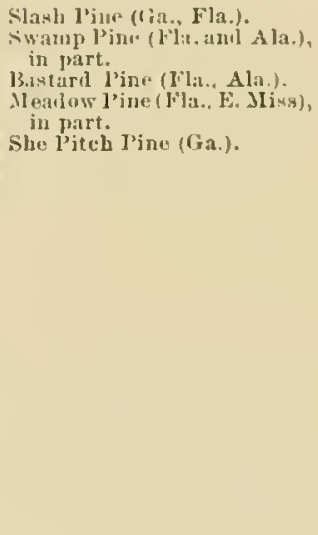 \\
\hline
\end{tabular}

While it is easy enough to reeognize the species in the field by their botanical ehanacters, it is difticult and often impossible to distinguish then in the wood by mele macroscopic inspection or examination with the magnifier and withont the aid of the microseope, nor are the miscroseopie features so fur recognized sufficient for sprecifie distinction.

A long-continned study of these woods by Mr. Filibert Roth, of the Jivision of Forestry, has not developed any characteristies which would be always relialole in distinguishing the speeies. The best that can be done is to give a synopsis of eharacters, by which they differ generally when larger yumities, as in the log or lumber pile, are nuder inspection.

CIIARACTERISTICS OF THE WOOD OF NOUTHERN PINES.

Dingnostic features of the wood.

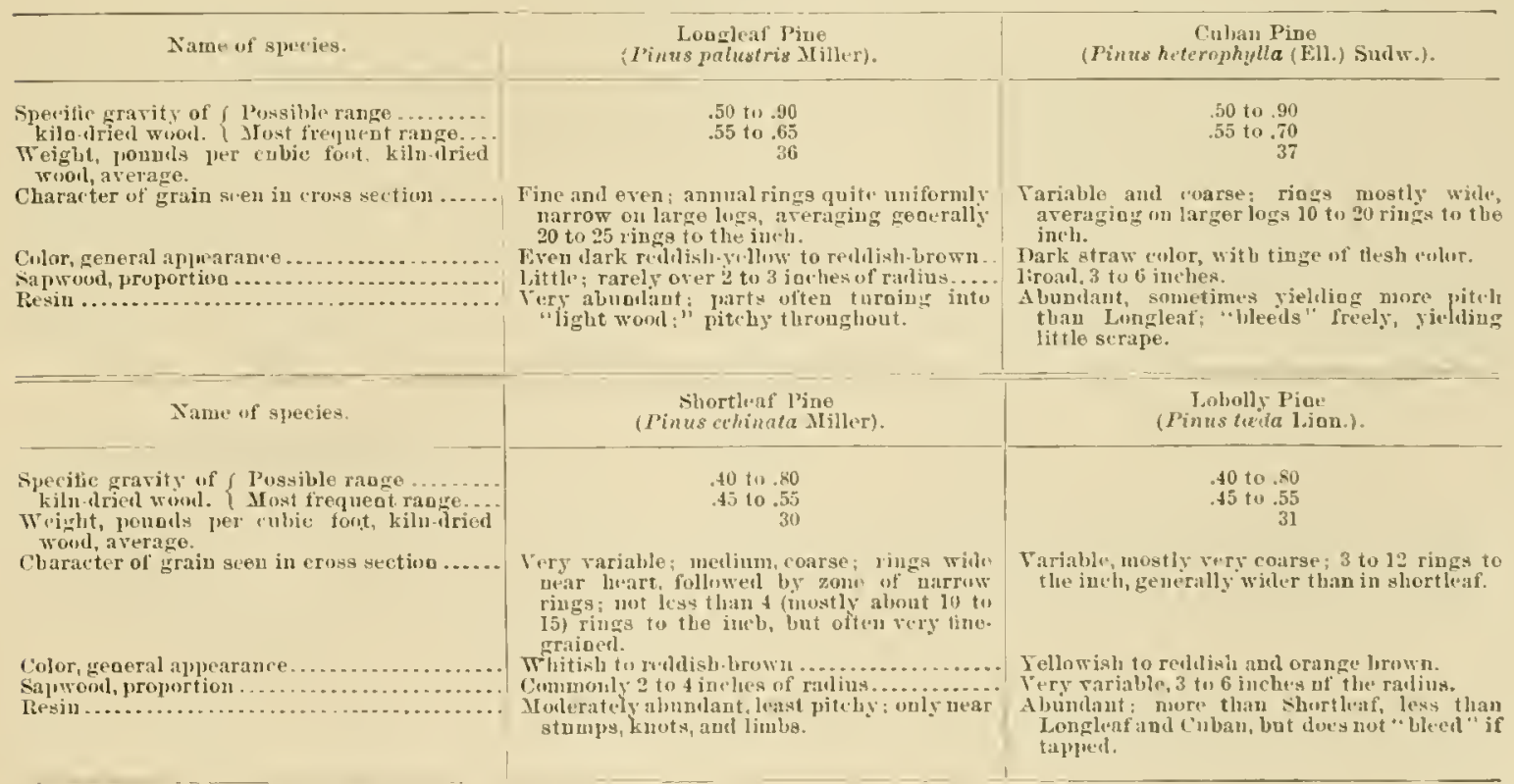




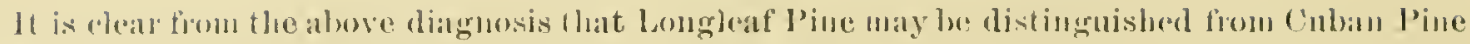

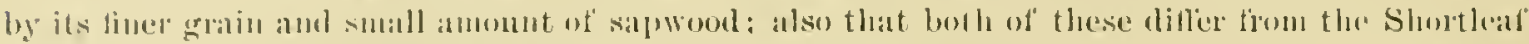

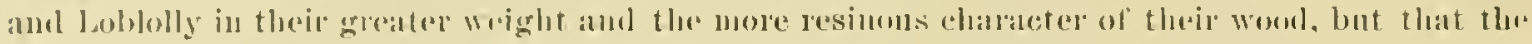
noor of the two last natmed speceies is rarely distinguishable boyond dombt.

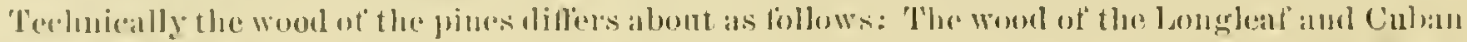

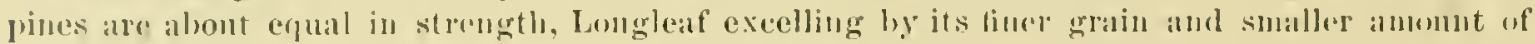

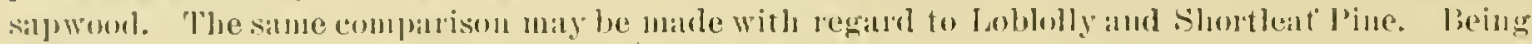

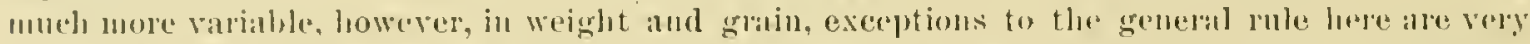
mmerous. Of the last-maned species it may be said that the word derived from more sonthern focalities is enenerally heavier and stronger than northern grown-a fart especially apparent in the calse of the Shortheal l'ime.

The extensive investigations carried on by the bivision of lorestry during the last three to four years manly on these pines permit us to give the bollowing resume of their mechanimal properties derived form not less 01 1.1n 20,000 tests and as many mensurements and weighings. We enote this intormation from Cireular 12 of the division:

\section{MISTANICAL, PIOPRRTES.}

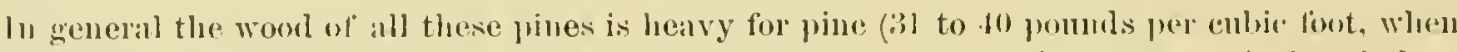

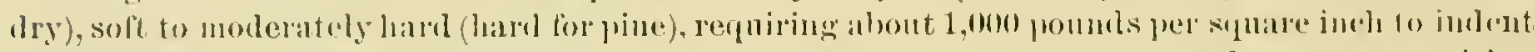

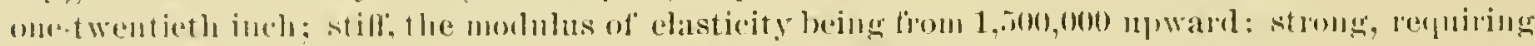

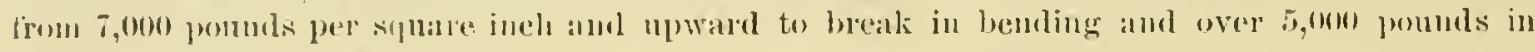
compression when yardedry.

The values grivo in this arentar are averages based on a large mumber of tests from which ouly delective pieres alre excluked.

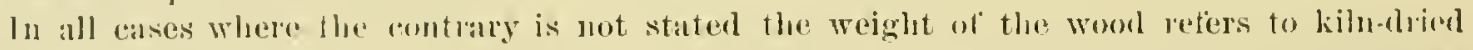

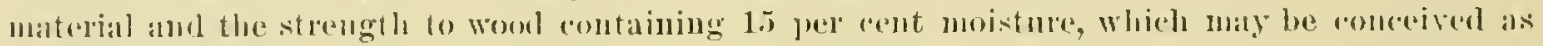
just on the border of air-alried condition. The tirst table gives fairly well the range of strenglh of ('ommercial timber.

Sverage strength of southe't l'ine.

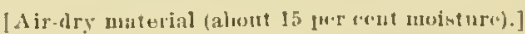

\begin{tabular}{|c|c|c|c|c|c|c|c|c|c|c|c|c|c|c|}
\hline \multirow{4}{*}{ Sintur. } & \multicolumn{5}{|c|}{ Compression strrogth. } & \multicolumn{7}{|c|}{ Beuding strength. } & \multirow{4}{*}{ 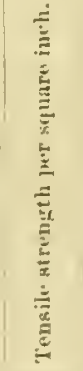 } & \multirow{4}{*}{ 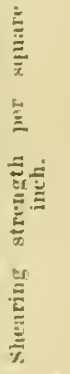 } \\
\hline & \multirow{2}{*}{\multicolumn{2}{|c|}{$\begin{array}{l}\text { Arrage of all } \\
\text { valicl tests. }\end{array}$}} & \multicolumn{2}{|l|}{ grain. } & \multirow{3}{*}{ 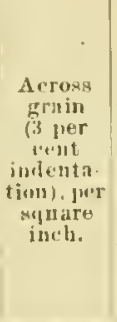 } & \multicolumn{4}{|c|}{ 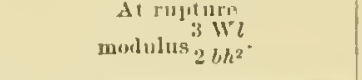 } & \multirow{3}{*}{ 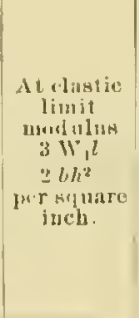 } & \multirow{3}{*}{ 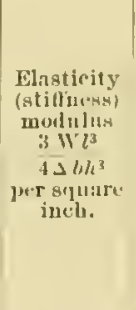 } & \multirow{3}{*}{ 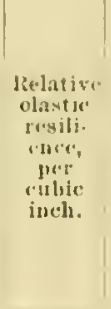 } & & \\
\hline & & & $\begin{array}{l}\text { Averns } \\
\text { fortle we: } \\
\text { ons ofen } \\
\text { of all thes }\end{array}$ & 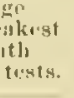 & & \multirow{2}{*}{\multicolumn{2}{|c|}{$\begin{array}{l}\text { Averago of all } \\
\text { valis tests. } \\
\text { Absolute, } \\
\text { jurt Joln } \\
\text { siluare tive. } \\
\text { inch. }\end{array}$}} & \multirow{2}{*}{\multicolumn{2}{|c|}{ 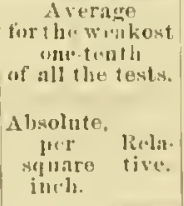 }} & & & & & \\
\hline & 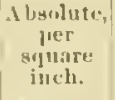 & $\begin{array}{l}\text { Rela- } \\
\text { live. }\end{array}$ & 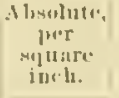 & $\begin{array}{l}\text { lisla. } \\
\text { tive. }\end{array}$ & & & & & & & & & & \\
\hline 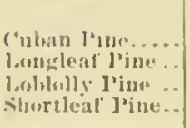 & 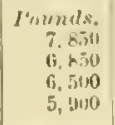 & $\begin{array}{r}100 \\
47 \\
83 \\
75\end{array}$ & $\begin{array}{r}\text { I'ounda. } \\
6.500 \\
5.650 \\
5,350 \\
4,800\end{array}$ & $\begin{array}{r}801 \\
87 \\
82 \\
74\end{array}$ & $\begin{array}{r}\text { Pounds. } \\
1,0 \text { ino } \\
3,16613 \\
490 \\
940\end{array}$ & $\begin{array}{r}\text { I'umnls. } \\
11,950 \\
10,900 \\
10,100 \\
3,230\end{array}$ & $\begin{array}{r}100 \\
311 \\
84 \\
77\end{array}$ & $\begin{array}{r}\text { I"unnds. } \\
\times, 750 \\
8,8100 \\
8,100 \\
7,000\end{array}$ & $\begin{array}{r}100 \\
101 \\
92 \\
80\end{array}$ & $\begin{array}{r}\text { Itounds. } \\
\text { 1., } 4: 0 \\
8.500 \\
8,150 \\
\quad 7,200\end{array}$ & $\begin{array}{l}\text { Pounds. } \\
2,301,010 \\
1, \quad, 90,000 \\
1,451,0100 \\
1,600,000\end{array}$ & $\begin{array}{c}\text { Joumels. } \\
2.5 \\
2.3 \\
2.25 \\
2.05\end{array}$ & $\begin{array}{l}1,68 \\
11,300 \\
15,200 \\
11,400 \\
13,400\end{array}$ & $\begin{array}{l}L \Delta, 0 \times \\
680 \\
706 \\
600 \\
6,48\end{array}$ \\
\hline
\end{tabular}

RELATION OF STREXCTU TO WTIGHT.

The intimate relation of strength and specife werght has heen well established by the expreriments. The average results obtained in connection with the tests themselves were as follows:

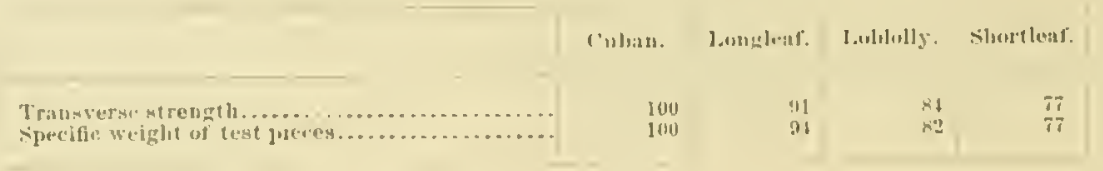


Sinee, in the determination ot the speeitic gravity above given, wood of the same per eent of moisture (as is the case of the values of strength) was not alway's involved, and alsu since the test pieces, owing to size and shape, can not perfectly represent the weod of the entire stem, the following resnlts of a special incpuiry into the weight of the wood represents probably more alecurately the weight and with it tho strength relations of the fonl species.

\section{WEIGHT RELATIONS.}

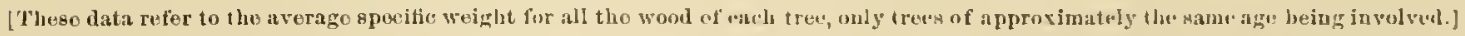

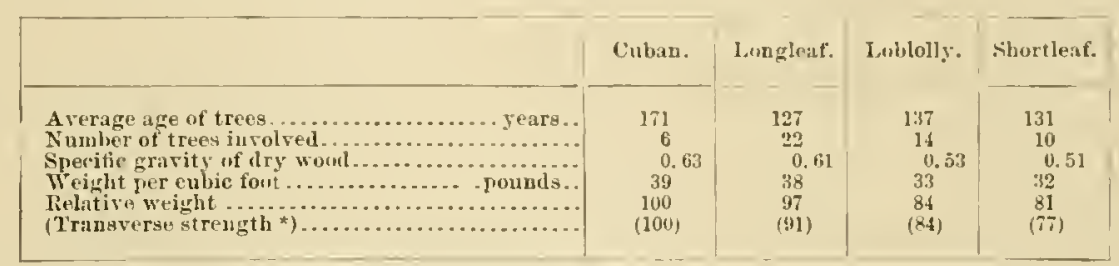

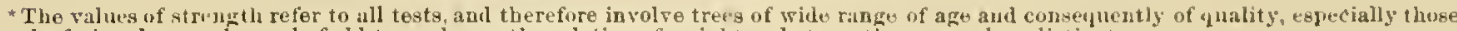
of Longleaf; involve much woul of old trees, hence the relation of weight and strength appears less distinct.

From these results, although slightly at variance, we are justitied in eoncluding that Cnban and Longleat l'ine are nearly alike in strength and weight and excel Loblolly and Shortleaf by abont 20 per eent. Of these latter, eontrary to common belief, the Loblohly is the heavier ancl stronger.

The weakest material wonld differ from the average material in transverse strength by about 20 per cent, and in compression strength by abont 30 to 35 per cent, excent Cuban Pine, for which the difference appears greater in transverse and smaller in compression itrength. It must, of conrse, not be overlooked that these figmes are obtained from full-grown trees of the virgin forest, that strength varies with physical conclitions of the material, and that therefore an intelligent inspection of the stick is always necessary betore applying the values in practice. They ean only represent the average conditions for a large amount of material.

DISTRIBUTION OF WEIGHT AND STRENGTI THROUGHOUT THE TREE.

Weight rend strength of wood at different heights in the tree.

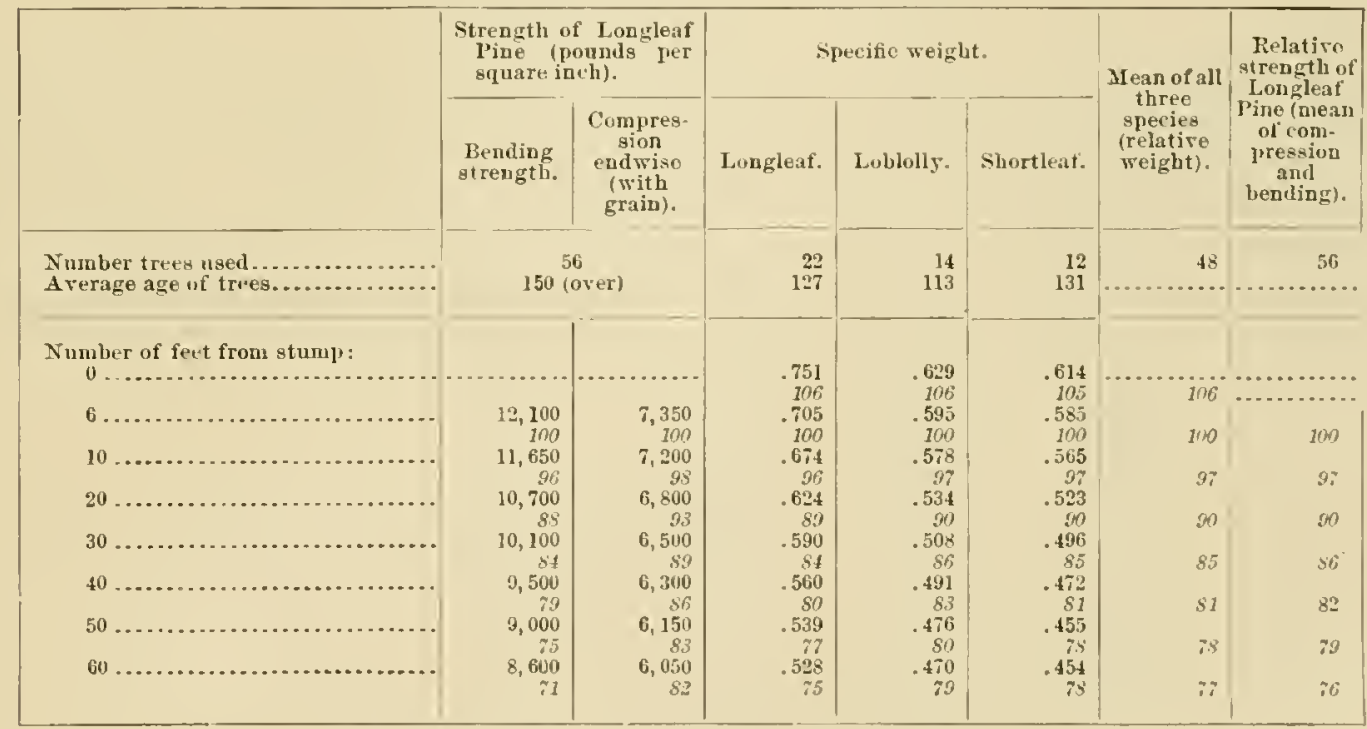

Note.-Relative values are indicated by italic tigarex. 
In any we tree the woen is lighter and weaker ats we pass from the base an the tof. This is true of every tree and of all four spereses. The deerase in reight and strength is most pronomed in the first 20 teet from the stmup and grows smaller mpwarl. (Soce lig. I.)

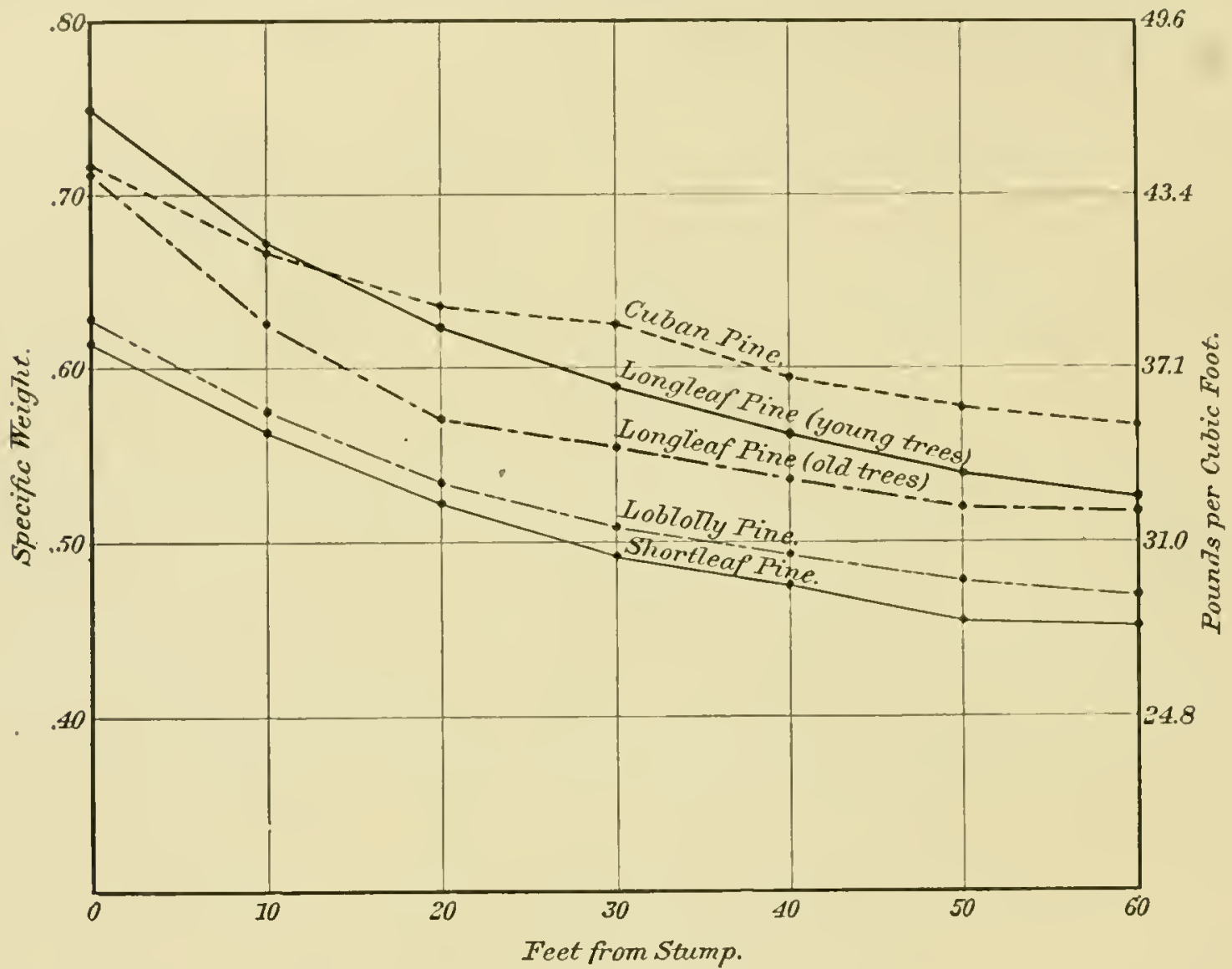

Wug. 1,-I)iagram aluwing variation of" weight with lusglat of tru.

This great diflerence in weight and strength between lutt and top finds explanation in the relative willth of the summerwoon. Since the specific waight of the dark summerwood band in each ring is in thrifty growth from 0.90 to 1 , while that of the springworl is anly ahout 0.40, tho: relative amount of summerwool finrushes altogether the most delieate and alewrate measure of these differences of weight as well as strength, and hence is the surest rritcrion for oenlar inspection of gnality, especially since this relation is free fom the disturbing influence of loth resin and moisture contents of the wool, so conspienus in weight determinations.

'Tle following figmes slow the distribution of tha summerwool in a single tree of Longleat" Pine, als an exanple of this relation:

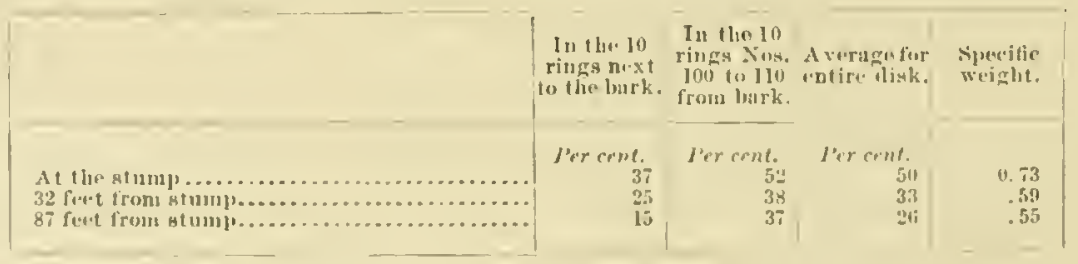


Logs from the top "an uslatly be rengnized by the latger pereentage of sapwoml and the subller proportion and more regulal untlines of the bands of summerwood, which are more or less wary in the butt logs.

looth weight and strength valy in the different parts of the same cross seetion from cernter to frerifil. ery, and though the variations alpear fiernently irregular in single individuals, a detinite law of rela. tion is nevertheloss discernible in large averages, and oure determined is readily observalole in every tree.

A separate incuiry, avoiding the many rariables which enter into the meelsanieal tests, permits the following dednetions lin the worl of these pines, and esperially for longleaf; the data leferring to weight, but by inference also to strength:

1. The variation is greatest in the butt logn (the heaviest part) and least in the top logs.

$\because$. The variation in weight, hence also in strength, from center to periphery dejests on the rate of growth, the heavier, stronger wool being torned during the perior of most rapuid growth, lighter and weaker woos in ols age.

3. Aberations from the normal growth, due to unusual seasous and other disturbing causes, clond the uniformity of the law of variation, thus oceasion. ally leading to the formation of heavier, broad ringed wood in old, and lighter narrow-ringed wood in young trees.

4. Slow-growing trees (with nar'uew rings) lo not make less heavy, nor heavier wool thall thriftily glown trees (with wide rings) of the same age. (See tig. 2.)

\section{BFEECT OF AGE.}

The interior of the butt log, representing the young sapling of less than fifteen or twenty years of age, and the central portion of all logs containing the pith and two to five rings arljoming, is always light and weak.

The hea viest wool in Iongleat and Cuban Pine is formed between the ages of fifteen and one hundred and twenty years, with a specilic weight of over 0.60 and a maximum of 0.66 to 0.68 , between the ages of forty and sixty yars. The wood tormed at the age of about one hundred years will lave a speeific weight of 0.62 to 0.63 , whieh is also the average weiglt for the entire wood of old trees; the woorl formed after this age is lighter but does not fall below 11.no up to the two humberlth year; the strength varies in the same ratio.

lis the shorter-lived Loblolly and Shortleaf the perion tor the formation of the haviest wood is

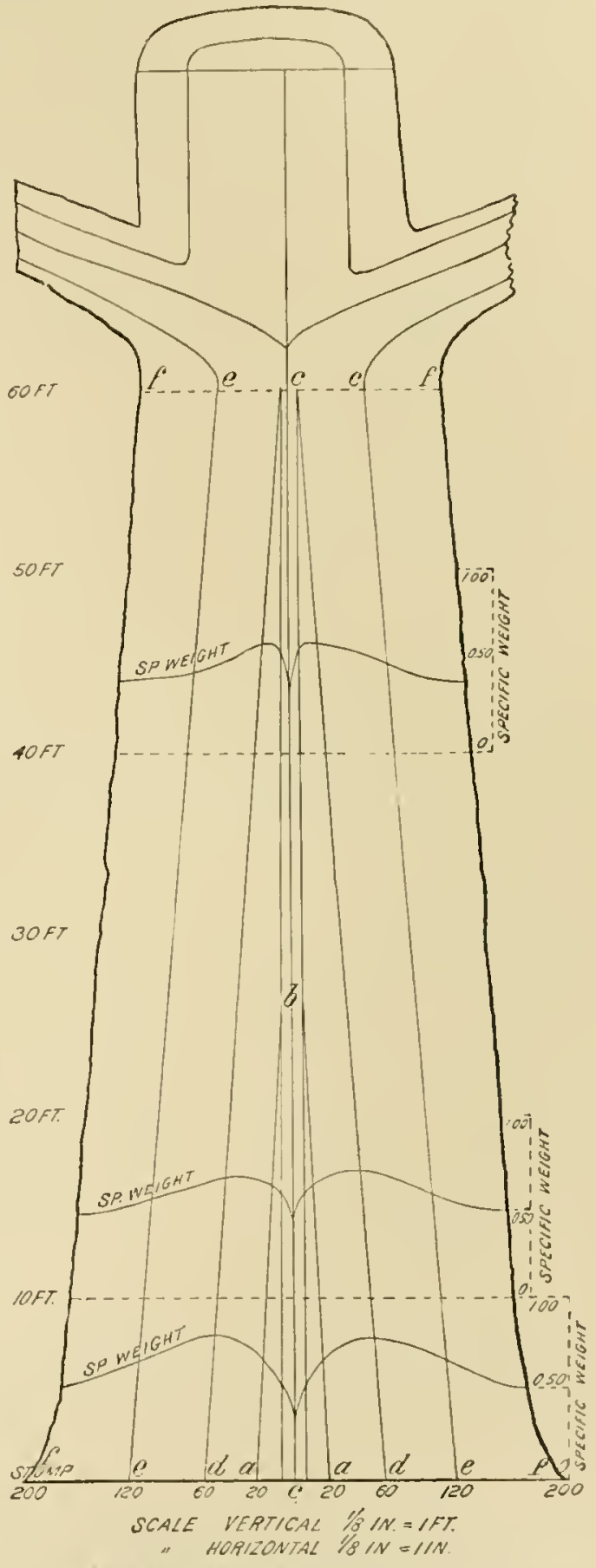

Fra. 2.- Schematic sectinn through stem of Loumleaf Pine, showing variation of sprecite reight with height, diametir, anci agh at twenty $(a b a)$, sixty $(d a l)$, one hudred and twenty (eere), aul two huvdred (fff) years. between the ages of fifteen and cighty, the a verage weight being then over 0.50 , with a maximum of 0.57 at the age of thirty to forty. The arerage weight for old trees $(0.51$ to 0.52$)$ lies about the seventy-fifth year, the weight the+l falling ofl to ahont 0.45 at the age of one hundreal and forty, and eontinning to decrease to behow 0.38 , as the trees grow older. 
That these statemonts refer only to the rear portions of each log, and are variably allected at rack whorl of knots ("rery 10 to 30 inches) aceornling to their size, and also by the variable

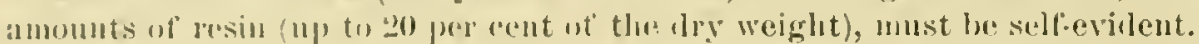

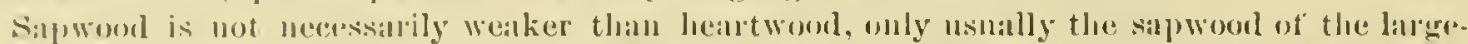
signd trees wo are now using is rejnesented by the narow ringed onter part, which was fonmed during the old-ate perion of growth, when naturally lighter and weaker woul is male; but the wood formen dinring the more thrity dianeter growth of the first eighty to one hundred yearssapwoml at the tine, ehanged into heartwod later-was even as sapwool the heaviest and strougest.

\section{RATGE OF VAITES FOR WEIGIIT AND S'THENGTII.}

Athonghi the range of values for the individual tree of any given species varies from lontt to toj, and from center to periphery by 15 to 2.5 per enent, and oecasionally more, the deviation from average valums from one individual to another is not usually as great as has heen believed; thus, of 56 tres of Longleaf Pine, fre trees valied in their averige strength ly less than 10 per cent lrom the average of all 56.

The following table of weight (which is a direct and fair indieation of strength), representing all the wood of the stem and excluding knots and wther defects, gives a more perfect idea of the rauge of these values:

Liange of speeific weight with age (kiln-hicd rood).

[T'u avoid fractions the valuca are multiplied by 100. ]

\begin{tabular}{|c|c|c|c|c|}
\hline & f'uban. & Lonjlear. & lablully. & Shortleaf. \\
\hline Xumber of trees inrolved..... & 24 & 16 & 60 & 56 \\
\hline 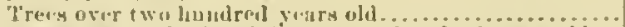 & 61 & 5i & & \\
\hline 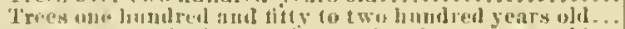 & 63 & 59 & 50 & \\
\hline 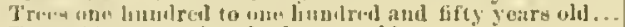 & ... & 60. 5 & 5.3 & 51 \\
\hline 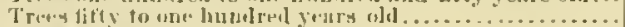 & 01 & 62 & 53.4 & 55 \\
\hline 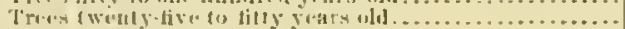 & 55 & 61 & $5 i$ & 57 \\
\hline Treem under twenty live jears old. & 51 & 55 & 45 & 53 \\
\hline
\end{tabular}

Though occa: onally some very exceptional trees ocenr, especially in Loblolly and shortleaf, the range on the whole is generally within remarkably narow huits, as appears lrom the following table:

Range of nperific ueight in trees of the same age approximutcly; aterages for whole trees.

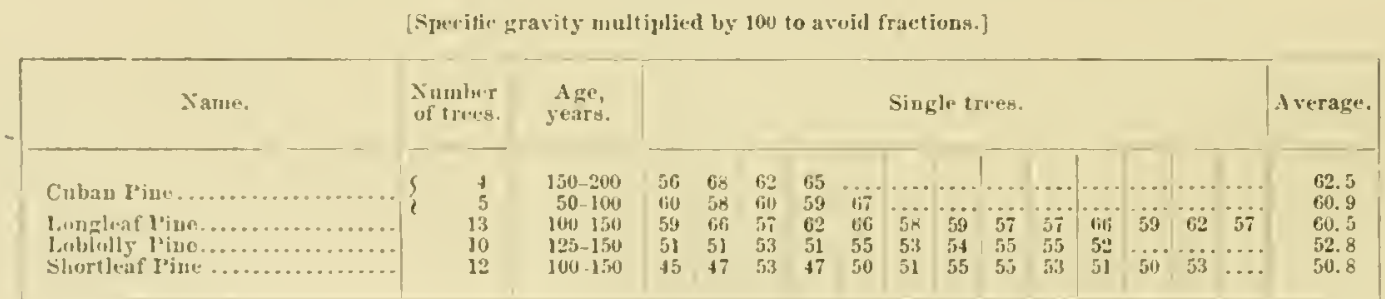

From this table it would appear that single individuals of one species would approximate single individuals of another species so closely that the weight distinction seens to fail, but in large nunbers, for instauce earloals of material, the averages above given will preval.

JYFLUISTE OH: LOCALITY.

In both the Cuban and Longleaf Pine the locality where grown aplears to have but little infunce on weight or strength, and there is no reason to believe that the longlear line from one Stats is better than that from any other, since suel variations as are claimed eall be found on any 41)-acre lot of timher in any Statr. Lint with Loblolly, and still more with Shortleaf, this serus not to be the case. being widely distribnted over many loealities diflerent in soil and elimate, the growth of the: Shortheaf Pine serms matcrially intluenced by location. The wood from the Sonflurn Coast and Gulf region and even Arkansas is generally leavier flan the woul from loealities farther north. Very light and fine grined woor is seldom met near the sonthern limit or the range, while it is almost the rule in Misimli, where forms resembling the Sorway Pine are ly no meatus rare. The Lublolly, oecupying both wet and dry soils, varies accordingly. 


\section{INFLUEYCE OF MOISTULE.}

This influence is among the most important, henee all tests have been made with due regard to moisture contents. Seasoned wood is stronger that green and noist wool; the diffirence between green and seasoned wood may amomt to 50 and even 100 per cent. The inlluence of seasoning consists in (1) briuging by means of shriukage about 10 per cent more tilers into the same sonlue incls of cross seetion than are contained in the wet wool; (ㄹ) shrinking the cell wall itself by about 50 per cent of its cross section and thus hardening it, just as a cowskiu becomes thimer and harler by dryiug.

In the following tables and diagram this is fully illustrated; the values presented in these tables and diagrams are bised on large numbers of tests and are finly safe for orlinary use. They still require further revision, sinee the relations to density, ete, have hall to be neglected in this study.

Influence of moisture on strength.

\begin{tabular}{|c|c|c|c|c|c|c|c|c|c|c|}
\hline & \multirow{2}{*}{$\begin{array}{l}\text { Jer } \\
\text { cent of } \\
\text { nojs- } \\
\text { ture. }\end{array}$} & \multicolumn{4}{|c|}{ A verage of all valid teats. } & \multicolumn{5}{|c|}{ liolative values. } \\
\hline & & Cubau. & $\begin{array}{l}\text { Long- } \\
\text { leaf. }\end{array}$ & $\begin{array}{l}\text { Lob. } \\
\text { lolly. }\end{array}$ & $\begin{array}{l}\text { Short- } \\
\text { levat. }\end{array}$ & Cuban. & $\begin{array}{l}\text { Long } \\
\text { lenf. }\end{array}$ & $\begin{array}{l}\text { Lob. } \\
\text { lolly: }\end{array}$ & $\begin{array}{l}\text { Short } \\
\text { leaf. }\end{array}$ & $\begin{array}{l}\text { Aver. } \\
\text { ityo. }\end{array}$ \\
\hline \multicolumn{11}{|l|}{ Bending strength : } \\
\hline & $3+$ & 8,450 & 7,660 & 7,370 & 6,900 & 100 & 100 & 100 & 100 & 100 \\
\hline 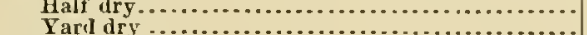 & 30 & 10,050 & 8,900 & $8,6.50$ & 8,170 & 118 & 116 & 117 & 118 & 117 \\
\hline & $\begin{array}{l}15 \\
10\end{array}$ & 11,950 & 10,900 & 10,100 & 9,230 & 142 & 142 & 138 & 134 & 139 \\
\hline \multicolumn{7}{|l|}{ Crushing end wise: } & 182 & 168 & 160 & 173 \\
\hline 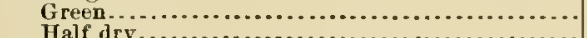 & $33+$ & 5,000 & 4,450 & 4,170 &, \pm 160 & 100 & 100 & 100 & 100 & 100 \\
\hline 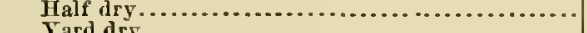 & 20 & 6,600 & 5,450 & 5,350 & 5,100 & 132 & 122 & 128 & 122 & 126 \\
\hline 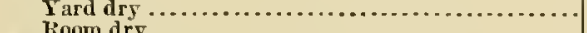 & 15 & 7,850 & 6,850 & 6,500 & 5,900 & 157 & 154 & 156 & 142 & 152 \\
\hline 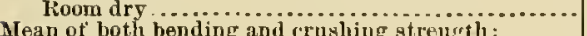 & 10 & 9,200 & 9,200 & 8,650 & 7,000 & 184 & 206 & 206 & 168 & 191 \\
\hline \multicolumn{11}{|l|}{ Mean of both bending and (rushing strength : } \\
\hline 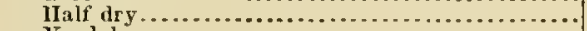 & 20 & & & - & ...... & 125 & 119 & 122 & 120 & 122 \\
\hline Yard dry $\ldots \ldots \ldots \ldots \ldots \ldots \ldots \ldots \ldots \ldots \ldots \ldots \ldots \ldots \ldots \ldots$ & 15 & .......... & .......... & ......... & .......... & 149 & 118 & 147 & 138 & 146 \\
\hline 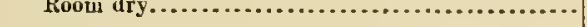 & 10 & . . . & & & …….. & 182 & 194 & 187 & 164 & 18: \\
\hline
\end{tabular}

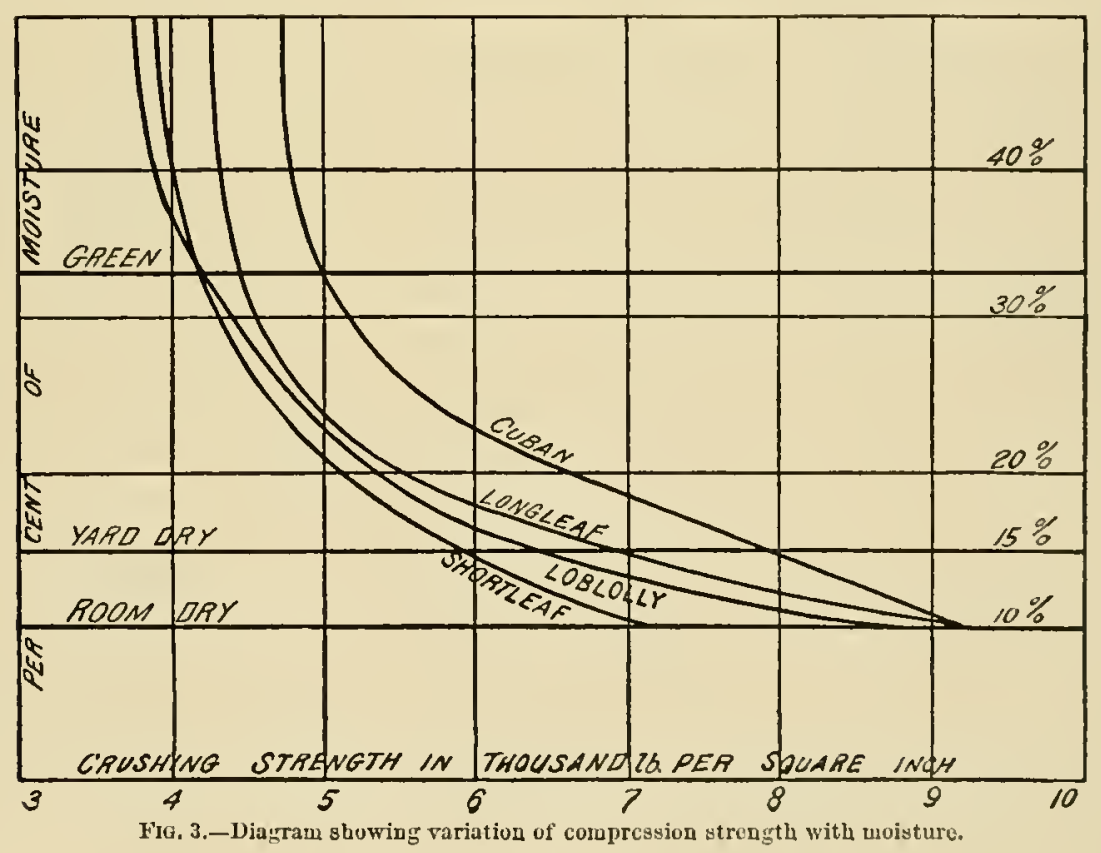

It will be observed that the strength increases by about 50 per cent in ordinary goorl yard seasoning, and that it ean be inereased about 30 per cent more by complete seasoning in liln or house.

Large timbers require several years before even the yard-seasoned condition is attained, but 2-ineh and lighter material is generally not used with more than 15 per cent of moisture. 
WHIGIT AND MOISTERF.

So fin the wriglit of only the lihlu-dry wool has hern considered. Ln fresh as well as all yart

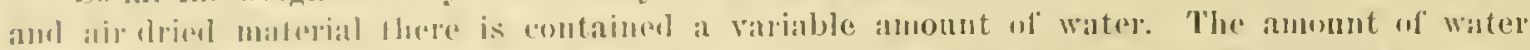

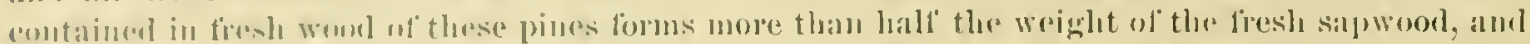

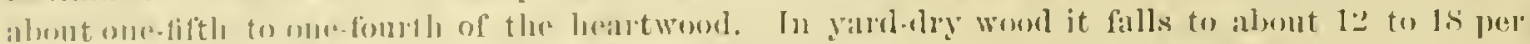

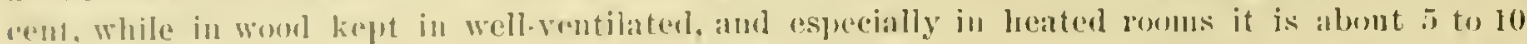
prerent. varying with sime of piere, part of trees species, temperature, and humidity of air.

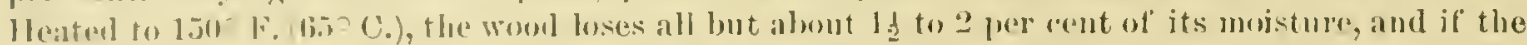

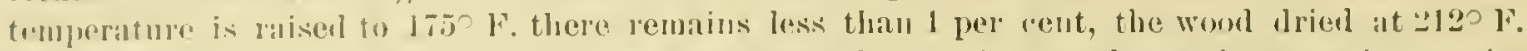

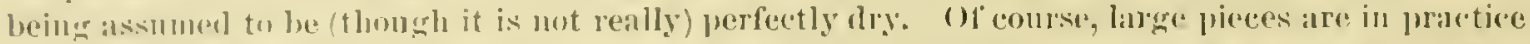

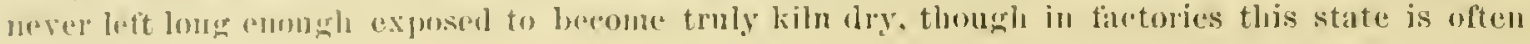
alproanlied.

As bong as the water in the wool amounts to abont 30 per eent or more of the dry wejoht of

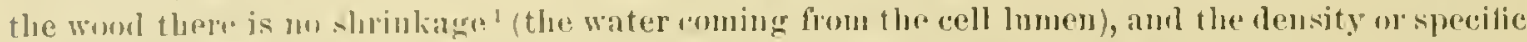
gravity changes simply in direct propurtion to the loss of water. When the moisture per cent fills below albut 30 . the water eomes form the cell wall, and the loss of water and weingt is aceom.

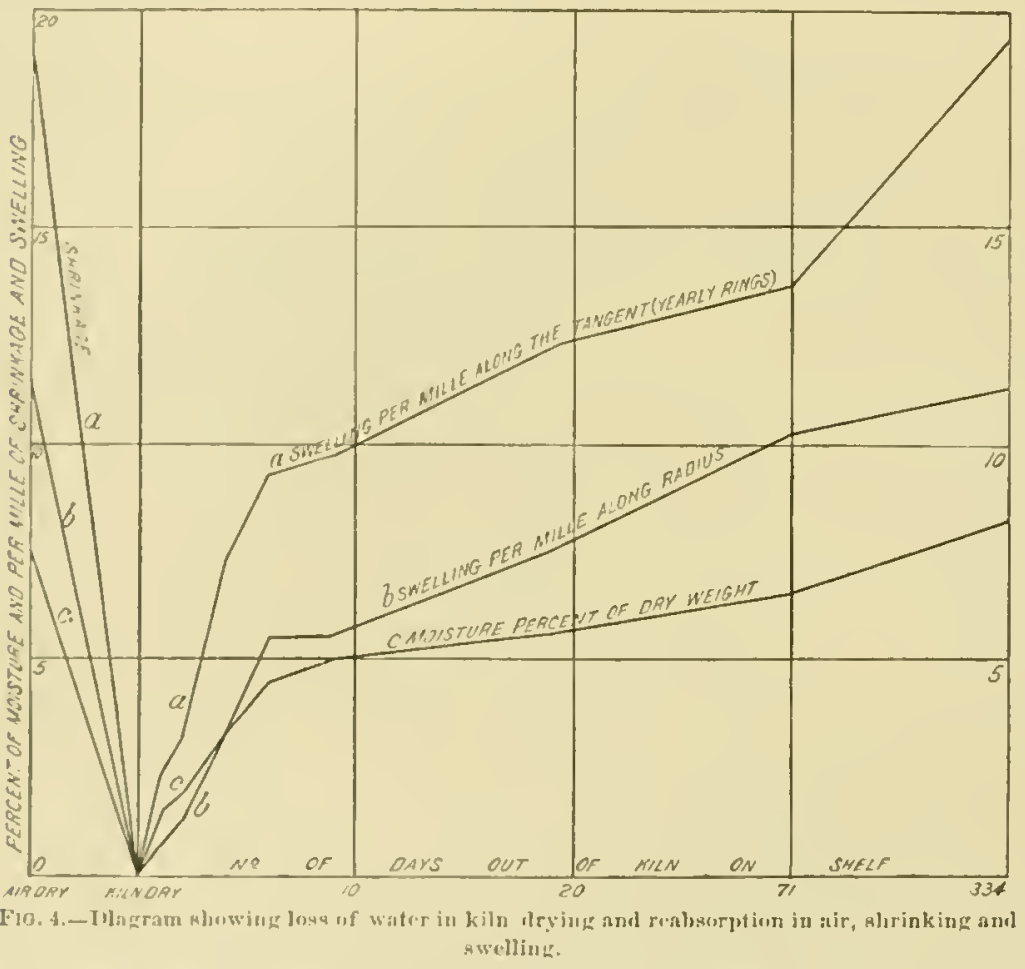
panied by a loss of volumr, so that both factors of the fine tion

$$
\text { Specific gravity }=\begin{aligned}
& \text { weight } \\
& \text { volume }
\end{aligned}
$$

are aflerted, and the change $i_{11}$ the specilie gravity no longer is simply foroportional to the loss of water or wroight. The loss of wigglit and rol. unc, lowever, boing unerjual and disproportionate, a marked redurtion of the sperifie rravity takes plater, ammomuting in these pines to about $S$ to 10 jer eent of the speceilic weight of the dry woot.

\section{SIRINKAGF. .}

The hehavion of the wood of the Sonthern pines in shrinkage does not difler materially. Grnelally the heavier woul shrinks the most, and sapwowd sluninks about one-fouth more

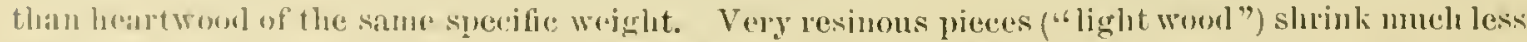

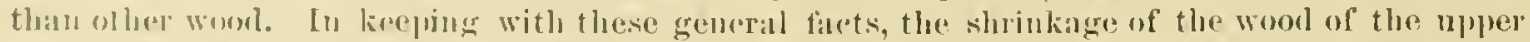
logs is usually 151020 per cent less than that of the but preces and the sludinkage of the heary

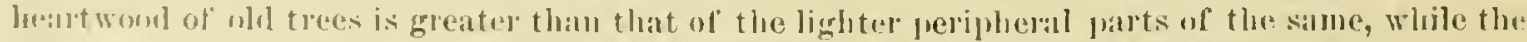
slurinkiege of the heary woul uf saplings is greatest of all. On the whole, the wool of these pines.

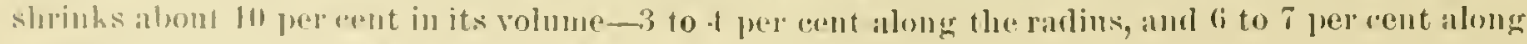
the tangent ol : llong tlor yarly rings.

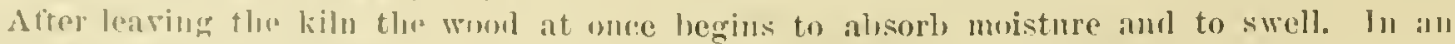
experiment with shme pienes of loblolly and shortlenf, representing ordinary flowring or siding

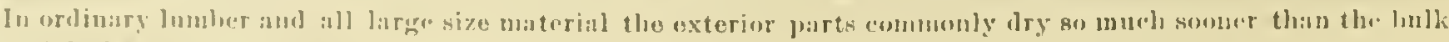

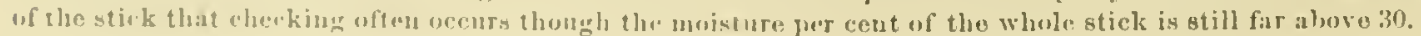


sizes, these regained more than half the water aud underwent over half the total swelling during the first ten diys after leaving the kihn (see fig. 1). Liven in this less than air-dry word the changes in weight far excel the changes in volume (sum of ralial and tangential swelling), anul, therelore, the specilie gravity even at this low per cent of moisture was deereased by drying and increased by subsequent absorption of moistnre. Immersion and, stil] morr readily, boiliug cause the wool to return to its original si\%e, but temperatnes even alove the hoiling point do not prevent the wood from "working," or shrinking and swelliug.

In lig. $t$ are represented the results of experiments on the rate of loss of water in the dry kilu and the reabsorption of water in the air. The wood used was of lobblly and shortleaf Pine kept on a shelf in an ordinary room before and after kiln drying. The measurements were male with caliper.

$$
\text { EFFEC'T OF "BOXING," OR "BIAEHDING." }
$$

"Blecding" pine trees for their resin, to which only the Longleal" and Conban Pine are subjected, has grenerally been regarded as injurious to the timber. Both durability and strength, it was claimed, were impaired by this process, and in the specitications of many architects and lange consumers, such as raitway eonpanies, "bled" timber was exchuded. Since the utilization of resin is one of the leading imbstries of the Sonth, and since the process affects several millions of dollars" worth of timber every year, a special investigation involving mechanical tests, physical and ehem. ical analyses of the wood of bled and nublerl trees foum the same Iocality were enrred ont by this division. The results prove eonelusively (1) that bled timber is as strong as unbled it of the same weight; (2) that the weight and shrinkage of the wool is not affertal by bleeding; (3) that bled trees contain practically neither more nor less resin than unbled trees, the loss of resin referring onty to the sajwood, and therefore the durability is not affeeted by the bleeding process.

'l'he following table shows the remarkable numerieal similarity between the average results for three gronps of trees, the higher values of the bled material being readily explained by the difference in weight:

\begin{tabular}{|c|c|c|c|c|}
\hline Longleaf Pine. & $\begin{array}{l}\text { Numbier uf } \\
\text { tests. }\end{array}$ & $\begin{array}{l}\text { Specific } \\
\text { weightit of } \\
\text { test pieces. }\end{array}$ & $\begin{array}{l}\text { Pending } \\
\text { strength } \\
\text { wr square } \\
\text { inch. }\end{array}$ & $\begin{array}{l}\text { Compression } \\
\text { st rength } \\
\text { per sipunre } \\
\text { inch. }\end{array}$ \\
\hline 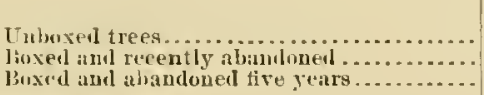 & $\begin{array}{l}400 \\
390 \\
5: 35\end{array}$ & $\begin{array}{r}1 \text { erecut. } \\
0.74 \\
.79 \\
.76\end{array}$ & $\begin{array}{r}\text { I'vunds. } \\
12,358 \\
12,961 \\
12,586\end{array}$ & $\begin{array}{r}\text { I'ounds. } \\
7,1613 \\
7,813 \\
7,575\end{array}$ \\
\hline
\end{tabular}

The anome of resin in the wood varies greatly, and trees growing sille ly side differ within very wide limits. Sapwool contains but little resin ( 1 to 4 per cent), even in those trees in which the heartwool contains abundance. In the heartwood the resin forms from in to 24 per cent of the dry weight (of which abont one-sixth is turpentine), and ean not be renoved by bleeding, so that its yuantity remains unatrected by the process.

Ibled timber, then, is as useful tor all purposes as unbled.

UNE OF 'IIIE WOOD.

In its nse the woot of all fou species is much alike. The coarse grained, heavy, resinons forms are especially suited for timbers and dimension stull; while the fine grained wood, whaterer species it may belong to, is used for a great variety of purposes.

At present distinction is but rarely male in the speeies and in their use; all fonr species are used much alike, although clifferentiation is very desirable on acconnt of the dillerence in quality. Formerly these pines, except for local nse, were mostly ent or hewn into timbers, but especially since the use of dry kilus has become general and the simple oil finish has displaced the minghtly painting and "graining" of wool, Sontheru pine is ent into every form and grade of lumber. Nevertheless, a large proportion of the total eut is still being sawed to order in sizes above (; by 6 inches and lengths above 20 feet for timbers, for which the Longleaf and Cuban Pine finrnish ideal material. The resinous eondition of these two pines make then also desirable for railway ties of lasting quality. 


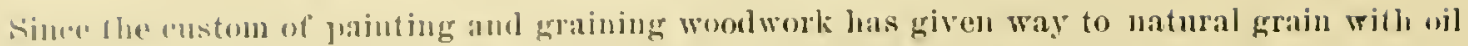
finish, the woml of these harl jines is becoming very popular for juside finish.

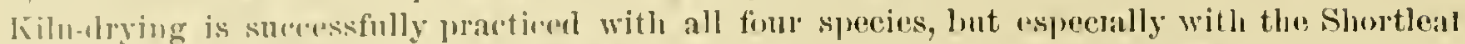
and lablully gines which, if not aldifially seasoned, aro liable to "blue." The wood ean be died w ithout meat injury at high temperatures.

RATF OF GROWTH.

'The speries naturaly drvelop somewhat diflerently, aceording to the soil eomlitions in which thry orenr. Without guing into a hetailed disemssion, which will le found in the body of this

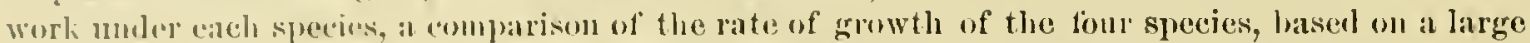

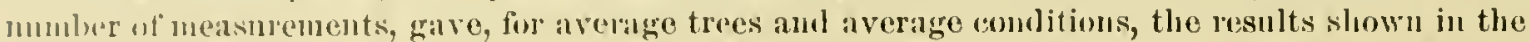
acomplanying diagrams (figs. 5 to 7 ), which permit the determination of the rate of irrowth at diflerent perions ot" their life.

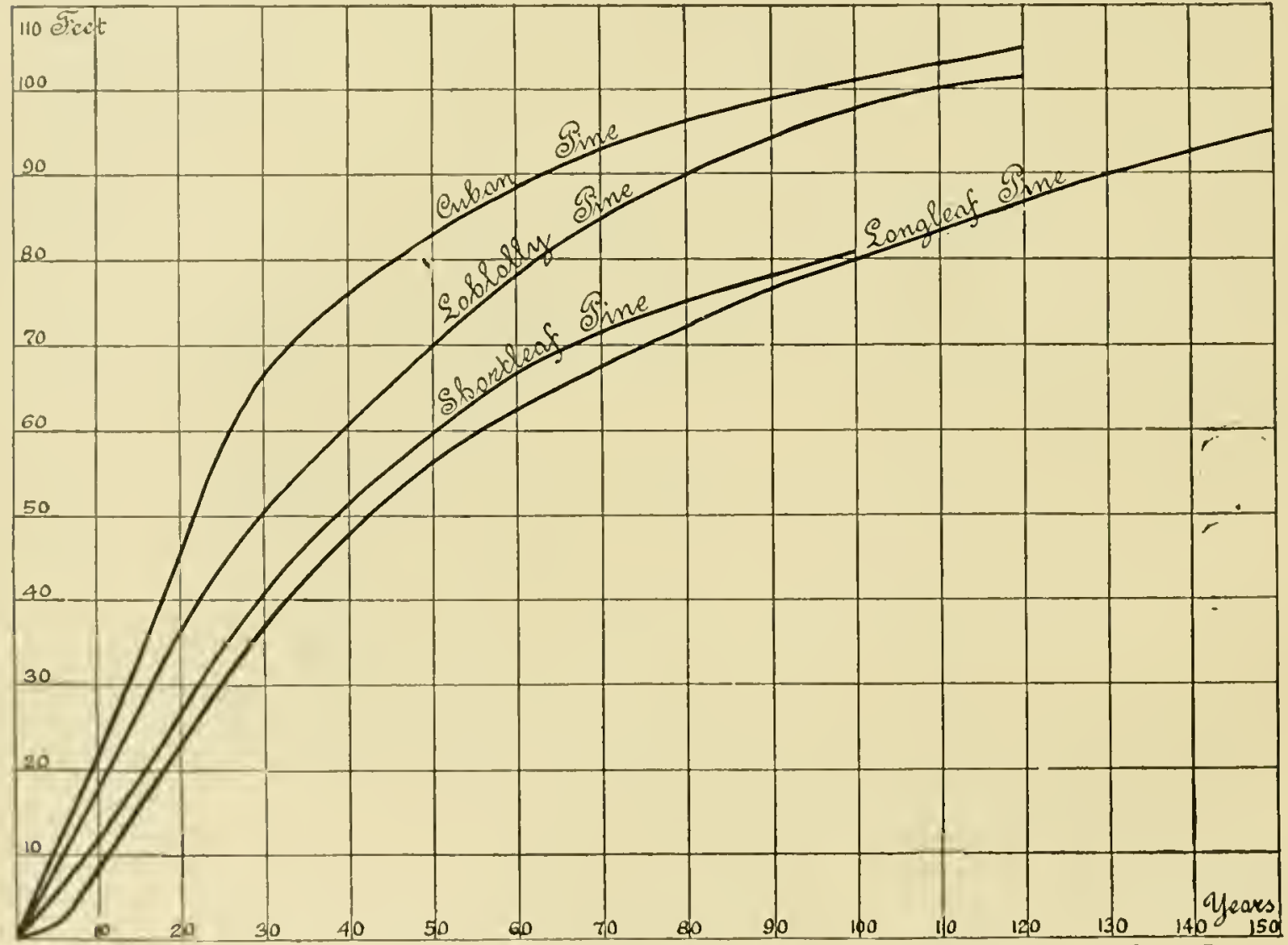

Fia. 5.-Diagram showing emparative progrega of height growth In average trens.

From these it alpears that the Culnan Pine is by far the most rapic grower, while the Longleaf Pine, which usually grows associated with the former, is the slowest, Joblolly and Shortleaf occulpying a poxilion lutwern the two.

Tho lungleaf shows for the tirst five to seven yoars hardly any development in leeight and

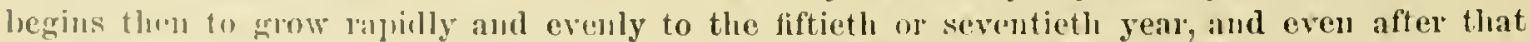
jeriol, thumgh the rate is somowhat diminished, progresses evenly and steadily, giving to the jeirlit rulve a smooth aml persistent vhajacter.

The liamotel glowth slows the same even and persistent progress from the start, and the volnue growth also poneresses cren]y alter the rapid lejert-growth rato is passeul at seventy years.

The Cuban line ceases in its maximum rule of liejuht glowtl at thirty yoars, staris with its diameter growth at about the rate of the Loblolly, but after the twenty-fifth year leaves the latter 
behind for the next twenty-five to thirty years, then proceds at about the same rate, but persisting

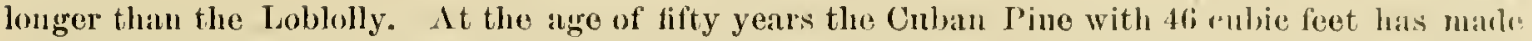
nearly twice the amount of the Loblolly and more than four times that of the Longleaf, but at one lundred years the difference is reduced, being then 115,901 , and in cubic feet, respectively, lor the three speeies.

Both Loblolly and Shortleaf l'ine reach their maximun growth sooner than the other two speeies. While these still show a persistently ascending line at one hundred and twenty to one hundrel and forty years, the rate of growth in the Loblolly shows a decline after the one hundredth year, and the Shortleaf has lone its best by the eightieth year. These facts give indications as to the rotation under which these various speeies may be managed.

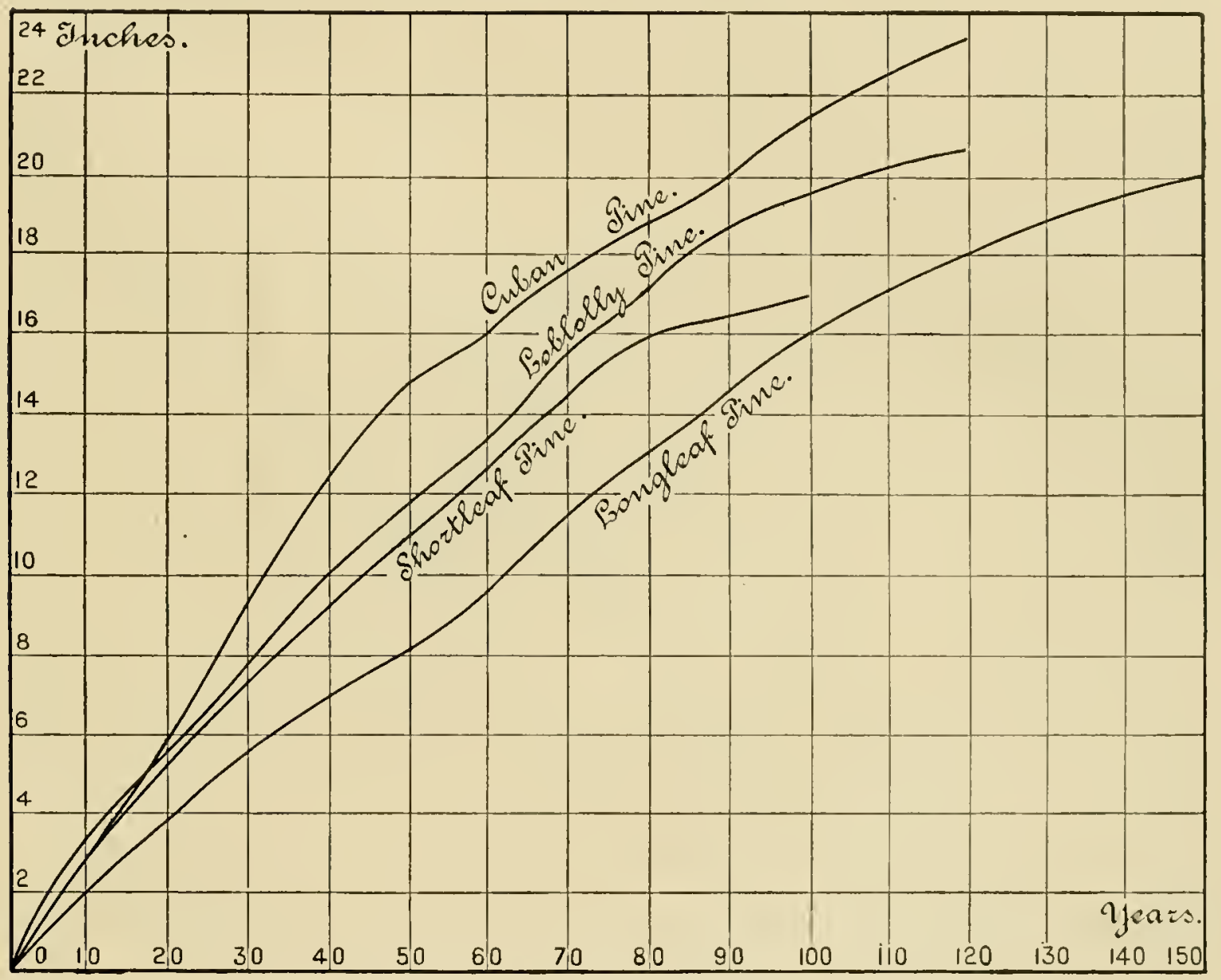

Fra. 6.-Diagram showing comparative progress of diameter growth in a verage trees.

As stated before, the growth of trees, especially in the virgin forest, is quite rariable eren for the same speeies and same soil eonditions; an average, therefore, like the one presented in the diagrans, however perfect, eould apply only when large mumbers are considered. Thus there are fast-growing trees of Longleaf and slow-growing of Cuban or Loblolly I'ine. Yet the diagrams will fairly well represent the average growth, with the possible exception of the Cuban Pine, for which the number of measurements was too small to furnish reliable data.

\section{STATISTICS AND CONCLUSIONS.}

The greatest diffenlty 1)r. Mohr has found is in the statistical portions of his work. 'To deter: mine the amounts of remaining timber supplies of the various speeies is almost in impossibility without a rery elaborate and laborions eanvass, which, to be sure, it would appeal onr duty to 


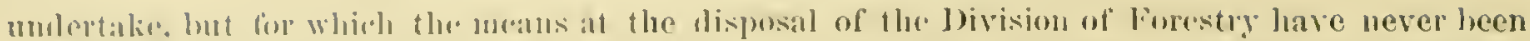

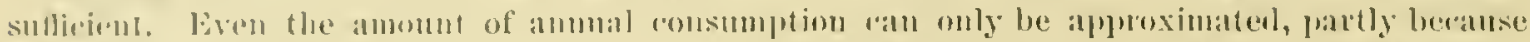

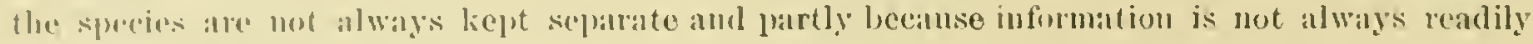

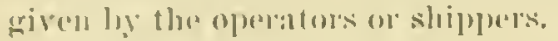

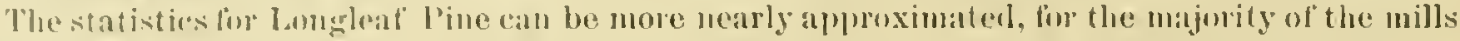
engaged in its exploitation cut lasmly any other timber; mornover, its geographical limits are more elearly defined, so that event the area of remaining smplies is not entirely legond onr ken.

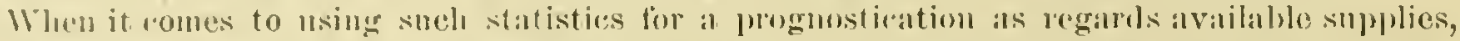
ano1hor diflienly arises in the change of stambands of matcrial recugnized as manketable and the

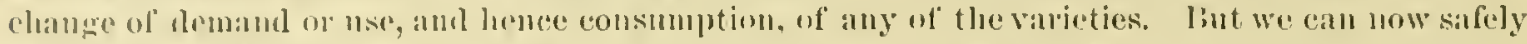
assme that the standard ol size and quality, which was high when the census fignes of 1580 were

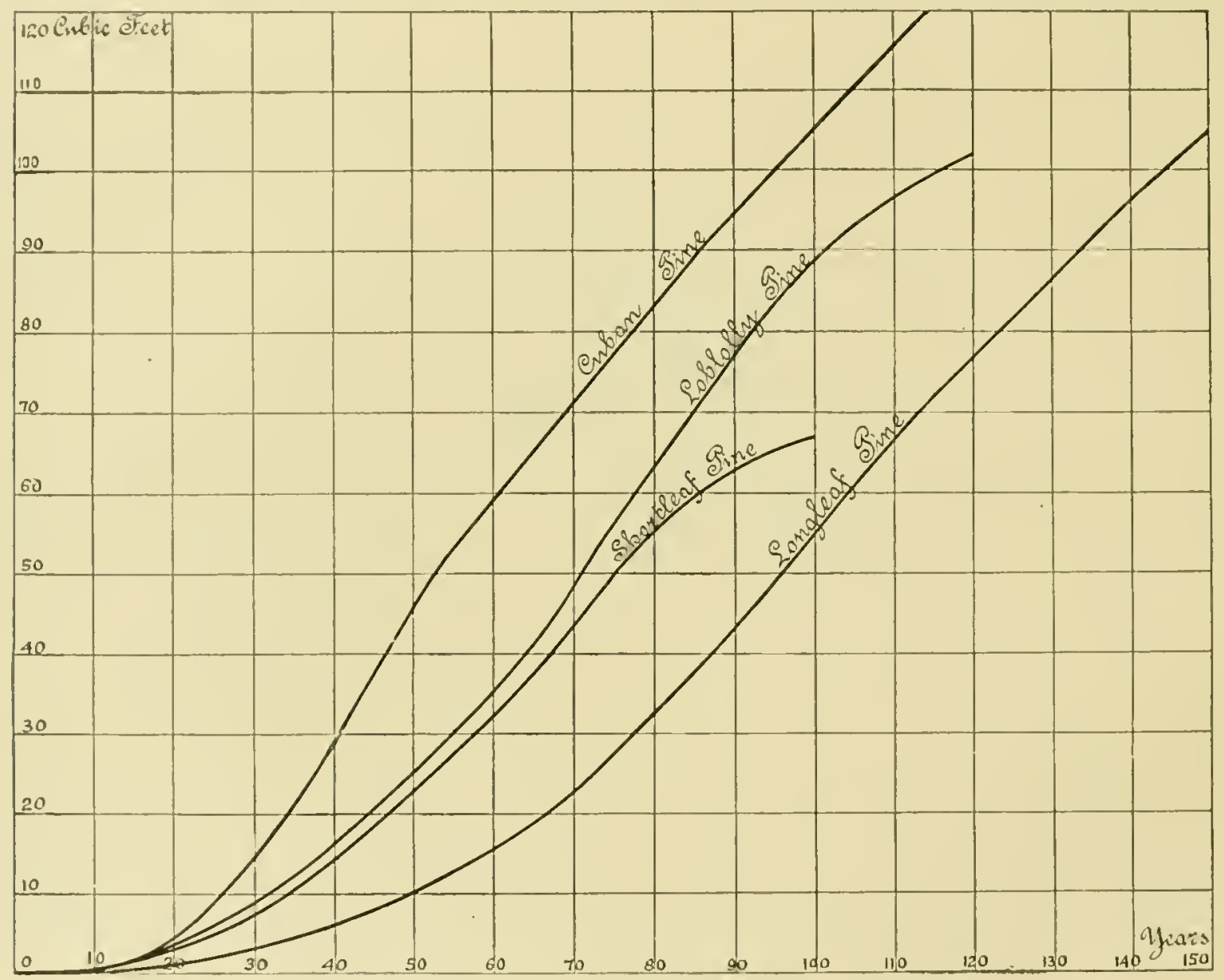

F10. 7.- Diagram showing comparative progregs of volume growth in arerage trees.

estimated amb lience marle them appear bolow the truth, has now smok nearly to the lowest level, any stiek that can be plared on the mill down to 10 -inch and s.inch heing fit material. There is also no danger of any reduction in the cut for any reason exeept a temporay one due to such guneral business depression as that experienced thronghont the last two years. Inchease of consumption of Sonthern timber is bumnl to follow the imminent exhanstion of the pine supplies

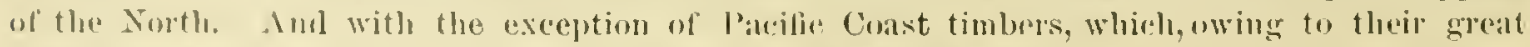
listance, have so lin male but litle rompetition in listern markets, mo new undiseoverenl timber resonre will intuence tlue cut of Sonthern pine.

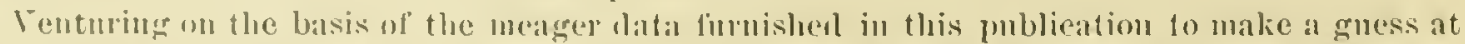
thr probalhe supply and lamand, we may with due reserve state that the anomut of pine timbrer ready for lumber mannficture standing in the Sonth ean not be above $2.50,000,000,000$ feet, and 
more likely will fall fur below $200,000,000,000$ leet, while the figure for present and lowest future ammal consumption may le approximated at near 7,000,000,000 teet, boarl measure.

There is nobody who knows or man know the arotual condition of supplies, and whoever has an opinion on the subject will have to bring at least as good a basis or a better one for such opinion than the data furnished in the following monogralus.

There is nu attempt to predict from the foregoing figmes the absolute exhanstion of the pine supplies of the South within forty or tifty years, althongh sneh a result would appear not unlikely. Competition of other timber's, and substitutes for the nse of wool (which, to be sure, never in the history of the world have rednced wool consumption), and especially changes in present methors of exploitation, may lengthen out supplies for a short time; or, if we begin rational forestry now, these forests may be kept a sonrce of contimous sulplies, even thongh rednced.

Those who rely upon the spontancous natural reproduction ol these pines to fill the gaps unade in the virgin timber will do well to read the chapters on natural reprodnction and the incidental renarks regarding the conditions for renewal and the aplearance of the aftergrowtl; or, lettri, tramp though the vast region of "ulled pine woods and ubserve what the basis of their reliance is, as the writen of these monographs has done throngh forty years of his life. If, in addition, they stmly the chapters on conditions of development, they will realize that the Longleaf I'ino is bound to disappear largely even in the regions where it reigned snprene; that the Cuban Pine, no despicable substitute, will talie its place in the lower pine belt, if allowed to propagate at all; lut on large burnt areas the grow th of serubby oalis and brush will forever exclude this sprecies which iminently needs light. Loblolly and Shortleaf, better fitted for warfare witl other species, will do much in their respertive halitats to recuperate, except in the mixed forest. where they are culled aud the hard woods are left to shade out the aftergrowth; or where the continnous conflagrations have destroyed the mokl and aftergrowth and given over the suil to scrubby brushgrowth, which for ages will either prevent the gradual retmu of the pines or inpede their renewal and growtl. Considering that the timber on which we now rely and on which we base our standards comes from trees usmally from one hmulred and fifty to two humbed years or more old, and that none of these pines makes respeetable timber in less than from sixty to one lumired and twenty-fire years, the necessity of timely attention to their renewal is further empinasizen.

The owners of timber land and the operators of mills are the only people who ean improve these conditions, and this by a more rational treatment of their property. If they can be made to realize now that what they own and hold as a temporary speculation will, in a short time, when supplies lave visibly decreased, hecome a firstelass investment, and, hy its revennes, beeonr. a greater sonre of wealth under competent management with a view to reprowhetion than that which they have deriver from it hy the mere robbing of the old timber, they night talie steps at least against the umecessary damage done to it by fire and cattle. Permanency and contimity of owuership appear to he the first condition to insure such results, and therefore corporations which are not of an ephemeral character and men of large wealth are most desirable forest owners.

The monographs here presinted will, it is hoped, aid in this realization, and the information regarding the conditions of development of the different speeies will furnish suggestions as to the forest management which, modified according to local conditions and economic considerations, may be employed to secure the perpetnity of the Sonthern pineries.

\section{Washington, D. C., June 5, 1596.}

\section{B. E. FERTOW.}

1 The entire regien within which these pines neenr in merchantable condition comprises abont 230,000 sinuare miles or, iu round numbers, 117,000,000 acres; for land in firms, etc., 10,000,000 acres must ho deducted, and allowing as much as two-thirds of the remainder as representing pine lands (the other to hardwods), wo would have about $90,000,000$ acres on which pine miy oucur. An averige growth of 3,000 feet per arre, an extravigant figure when referrerl to such an area, would unke the possible stund, $270,000,000,000$ feet, provided it was in virgin coudition and uot mostly culled or ent. 
Plate II.

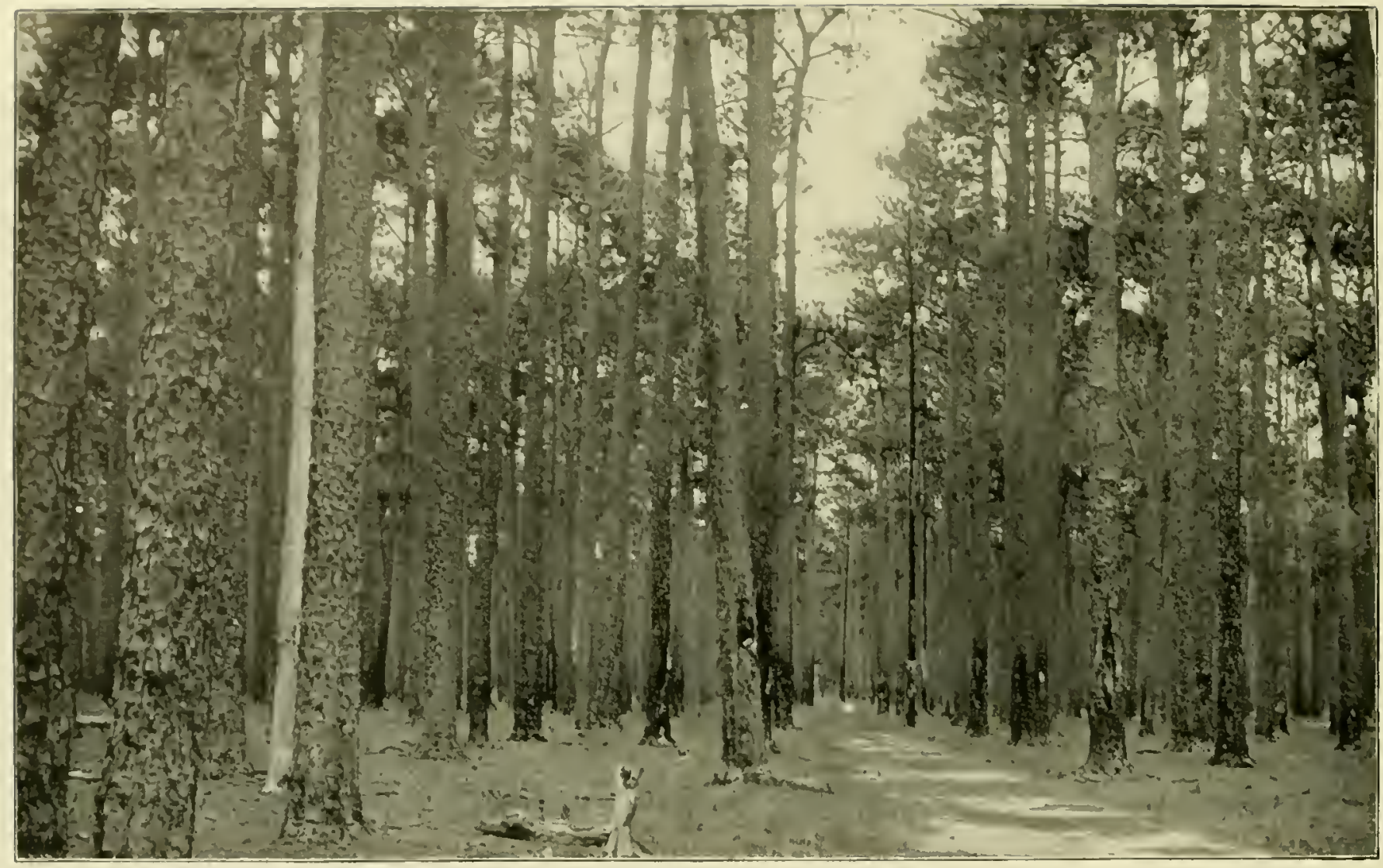

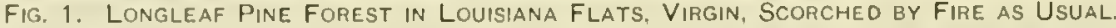

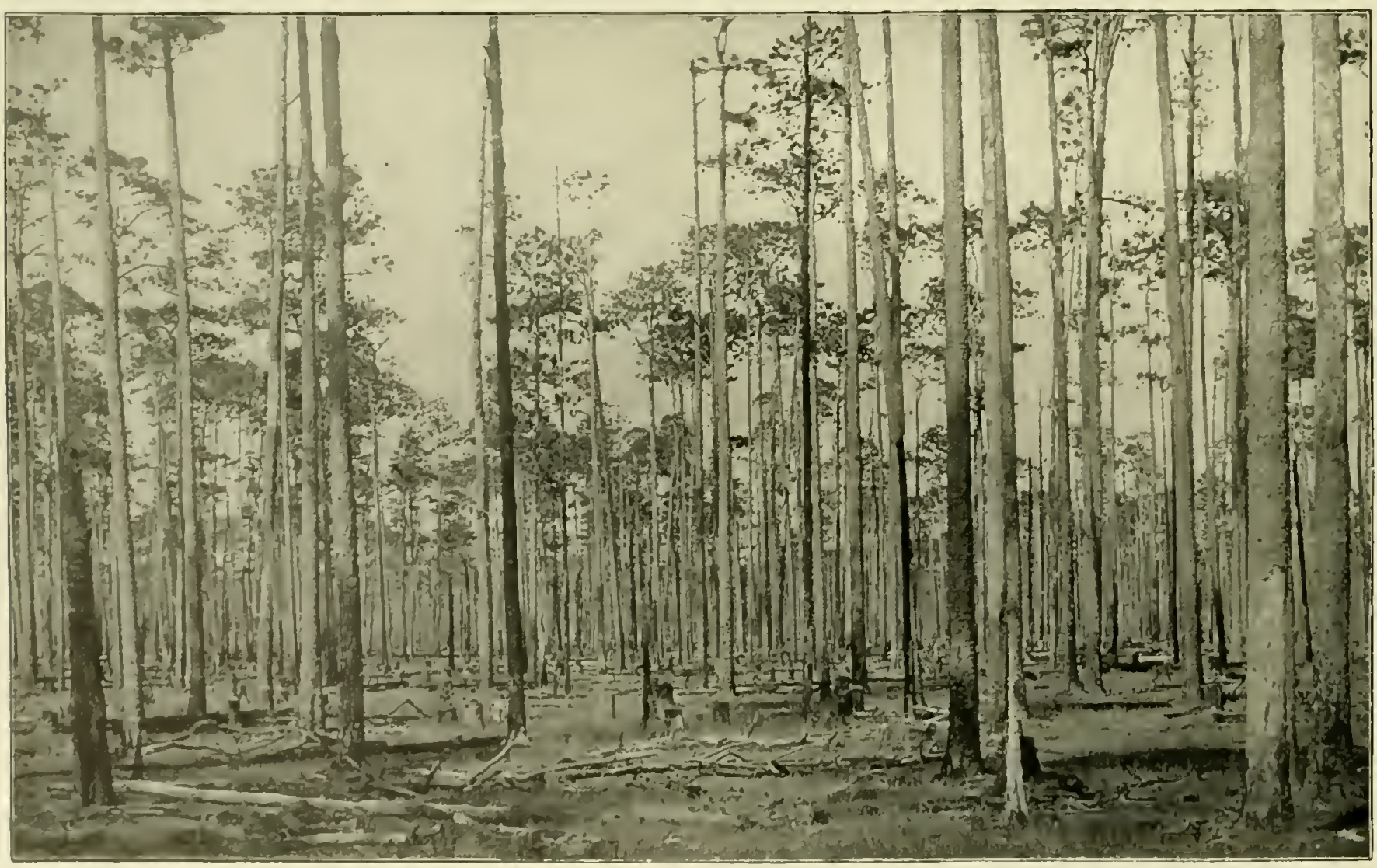




\section{THE LONGLEAF PINE.}

(PINUS PALUSTRIS Miller.)

Geographicht DISTRIBUtion.

Produets AND USES.

BOTANICAL DESCRIPTION.

DESCRIPTION OF WOOD.

Progress of DEVELOPMENT.

CONDITIONS OF DEVELOPMENT.

Forest manageuent.

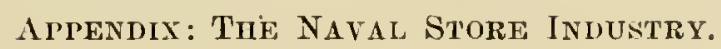




\section{THES I,ONGI,FAH ININE.}

('rinus palustris Miller.)

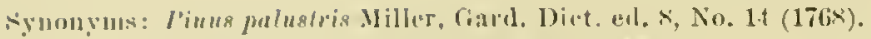

l'inus luleq Walter, l'l. Cal. 23:3 (1788).

Jiuns ustrulis Miehaux f., Hivt. Arl. Am. i. lit, t. 6 (180)3).

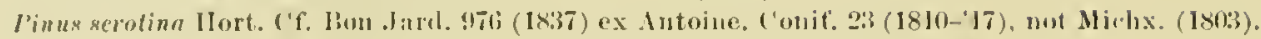

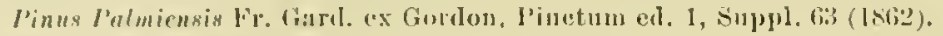

l'inns l'almikri Manetti ex rorsl., l. c. (186i-).

\section{LOCAL, OR C'OMMON NAMES.}

Jongleaved l’ine (Del., X. C., S. C., (Ba., Mla., Fla., Miss., I.is., T'ox.).

Southern l'inn (N. C., Ala.. Miss, L.a.).

Vellow l'in: (Dul., N. C., S. C., Ala., Vla., J,a., Tex.).

Turpentias l'ine (X. C..).

linaminary line (N. C.).

Bruma l'ine ("lenn.).

H:ırı I'im" (Ala., Iliss., 1.a.).

(ievrriat l'ino (J)el.).

Fit I'ine (southern states).

Suntluern Yellow l'ine (reurral).

Soutlurn Ilaral l’ine (general).

Southurn Jla:irt l'ine (gentril).

surhurn l'itcli l'inn (creneral).

lleart l'ine (N. C. and Sontlu'n Atlantie region).
Pitch P'ino (Atlantic region).

Inngleaverl Yellow Pinc (Atlantie mgion.)

Longleavel l'itch l'inc: (Atlantic reninn).

Jung-straw Pine (Atlantic regron).

North Carolinal Jituh l'ine (Yil., N. C.).

(ieoriria follow Pine (Atlantic region).

Genrupia Pine (general).

(uorgia Heart l'ine (general).

fienria longlenverl l'ine (Atlantio region).

Genrua l'itch l'ine (Atluntic recriou).

Florida lellow l'ine (Atlantic region).

Floricla l'ine (Atlantie region).

Florida longleaved Pino (Atlantic regrion).

Texas vellow Pinc (. thantio merinn).

f'exas Longleaved l'ine (Atlintir region). 


\title{
THE LONGLEAF PINE.
}

\author{
By Cimarles Momr, l'h, 1).
}

\section{INTRODUCTORY.}

The Longleaf Pine is the tree of widest ilistribution and of greatest eonmereial importance in the Sonthern Atlantic forest region of eastern North Anerica, covering, with scarcely any interruption, areas to be measured by tens of thonsands of square miles and finmishing useful material.

The timber wealth of the forests of Longleaf Pine, muclu of which is still untonched, has given rise to industries which involve the outlay of vast capital and an extensive employment of labor, thins closely affecting the prosperity of a large part of the Sonthern States as well as the inclus. trial aud commereial interests of the whole comintry.

With the impending exhanstion of the pine forests of the North, the lumber interests of the conntry are steadily tending to center in the Sonth, attracted chiefly ly the forests of Longleaf I'ine.

The Old World, which has heretofore depended almost entirely upon the pine forests of Canada and of the Northern United States for timber for heavy constrution, is already importing a large amomit of hewn and sawn square timber and of lumber from the Sonthern pine forests. Most of the lumber nsed for ordinary bnilding purposes in the West Indies, on the coast of Mexico, and in many of the States of Sonth America is furnished by the mills situaten in the Longleat I'ine region. The unprecedented increase, during the last quarter of a century, of the population in the timberless regions of the far West, as well as in the conntry at large, enormously angment the drafts made upon these forests, threatening their eventual exhanstion and ultimate destruction muless measures are taken by which these supplies nay be perpetnated. The solution of the diffienit problem of devising such measures can come only as a result of a study of the life listory of the Lougleaf Pine, of the conditions required for its growth and best development, of the laws regulating its distribution, and of the possibilities for its natural or artificial restoration.

\section{HISTORICAL.}

The economie importance of the Longleaf Pine was well reeognizerl in carly times. Bartram, ${ }^{\text {? }}$ in tive year 1777, in lis wanderings along the western shore of Mobile Bay, had his attention attracted by three very large iron pots, or kettles, each with a eapacity of several hundred gallons, near the remains of an oll fort or settlement, which he was informed were userl for the purpose of boiling down the tar to pitch, there being vast forests of pine in the vicinity of this place. "In Carolina," this writer proceels, "the inhabitants pursue a diflerent method. When they are going to make pitch they dig large holes in the ground, which they line with a thick coat of good clay, into which they conduet a sufticient quantity of tar and set it on fire, suflering it to burn and eraporate for some time, in order to convert it into piteh, and when cool, put it into barrels until they have consumerl all the tar and made a sufficient quantity of pitel for their purposes."

Humphrey Marshall, one of the earliest writers on North American forest trees, ${ }^{2}$ mentions the Longleaf Pine nuller the name of the "largest three-leaved marsh pine, as acconnted equal to any for its resinous products." In North Carolina crude resin, tar, and pitch figmed as important and valuable exports during the later colonial times, During the period from 1766 to $1769,8130,000$

' liartram's 'Travols througl Noth and sonth Carolina. I'hilatelphia, I7.90.

2IIumpley Marshall: Arbustum Americanum, or the Ineriean Grove. P'hilidelphia, 1785. 
Worth of these stores were exported yearly; among then were 88,111 barels of crude resin, valued

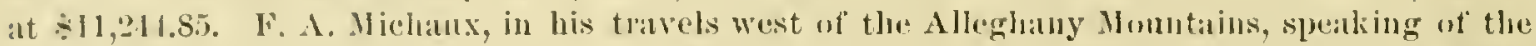
low country of the Carolinas, salys:" "Seven-fenths is covered with pine of one species, l'inus palustris, whith, as the sull is drier and lighter, grows lottier; these pines, enumbered with very few branches and which split even, are prefered to other trees for building fonces on plantations." In his subsequent work llichan gives for the first time an aceurate and defailed accomt of the products of this tree and their industrial and commercial importanee, as well as of its distribution :und il deseription of its specitic characters.

Norls,-In sketching the topographieal features of those regions of the Longleaf line foresta, which did not come unler the personal obsurvalion of the writer, the plyysiographical deseriptions of the Cutten States on lhe Athantic

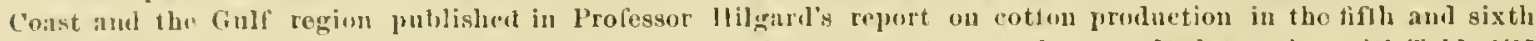
bolumes of the Census of Inso wre freely drawn upon, and these reports woro also consulted, fogether with Tablo l'll in the statisties publislued in the census roport on prodnetions of agriendturo in the compulation of forest areas.

In the stalements of the amount of longleaf l'ine standing in the several states in $I \times 80$ and of the cut during the same year, the figures given in l'rof. Charles S. Sirgent's report, Vol. $1 X$ of the Tentl Censue, were introduced, and for those which rolato to Alabama and Mississippi the writer is mostly responsible. No otlorts have been spared to arrive at a correct estimate of the total amount and value of senure timber, lumber, and naval stores produeed during the deeale ending with the year 1890 and during the husiness year 1893 , in ord.r to place in a propur light the econonie importanee of the tree and its bearings upon the industrial and commereial interests of the contry, and also to show the ripid inerease of the industries depending direetly upon tho resources of this tree. Tho statements griven are, however, of neecssity ouly approximations filling below the limits of truth. as it was impossible to ascretin with any degree of neeuraey the quantities entering into home consumption. Thus a faetor of uo little inportanee had to bu negleeted.

The thanks of the writer are lue to the gentlomen who kindly ansisted hin by their prompt replies to bis inquiries in his search for information, and who in other ways havo aflorded him aid.

\section{GEOGRAPIIICAL DISTRIBUTION.}

'The Longleat Pine is principally confined to a belt about 12:5 miles in width in the lower parts of the Sunthern States which border upon the Atlantic and the Gulf shores. The northern linit of the tree is found on the const near the southern boundary of Virginia below Nurfolk, north latitude $36^{\circ} 30^{\prime}$. From here the forests of the Longleaf l'ine extend sonthward along the coast region to Cape Canaveral, areross the peninsula of Florila a short distance soutl of Tampa Bay, westward along the Gulf Coast to the uplands which border upon the alluvial deposits of the Mississippi. West of that river forests of this species eontinue to the Trinity liver in Texas; in that State its northeru limit is found to reach hardly 320 north latitude, while in Louisiana and Mississippi it extends harlly more than half a degree farther north, and in Alabama under $34^{\circ} 30^{\prime}$ the tree is foumd to ascend the extreme southern spurs of the $\Lambda$ pralachian chain to au altitude of between 901 and $1,(100$ feet. Thus the area of the distribution of the Longleat Pine extends from $76^{\circ}$ to $96^{\circ}$ west longitude and from $283^{\circ} 30^{\prime}$ to $36^{\circ} 30^{\prime}$ north latitude. (Sec il. III.)

With reference to the elistribution of this species as depending upon geolngieal formation, it may he sald that its forests are ehietly contined to the sandy and gravelly deposits designated by Professor llilgan's as the orange sind, or hatilyette strata of Pust-Tertiary formation, which of late isregarded as the most recent member of the Tertiary formation. Thesesiliceous sands and pebbles, which to such rast extent cover the lower part of the Southern States and form also more or less the covering of the surlice throughont the older Tertiary region, ofler the physical eonditions most suitable to the growth of this tree.

\section{CIIARACTERISTICS OI DISTRIBUTION IN DIFFERENT REGIONS.}

This great maritine pine belt east of the Mississippi liver prescnts such differences in topmglaphical teatures and such diversity of jhysical and medhanioal conditions of the suil as to permit a distiultion of thee divisions going from the coast to the interion:

1. The coastal pluin, or low pine barens within the tide-water region, extends from the seashore inland tor a distance of trom 10 to 30 miles and over. The forests of the Longleaf Pine which

'Travels West of the Alleghanies, by F'. A. Jichanx. I'aris, 1s03.

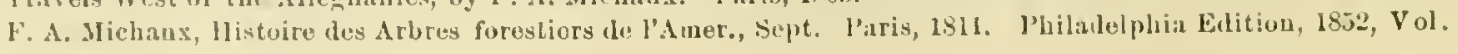
III, l. Lot et sery. 


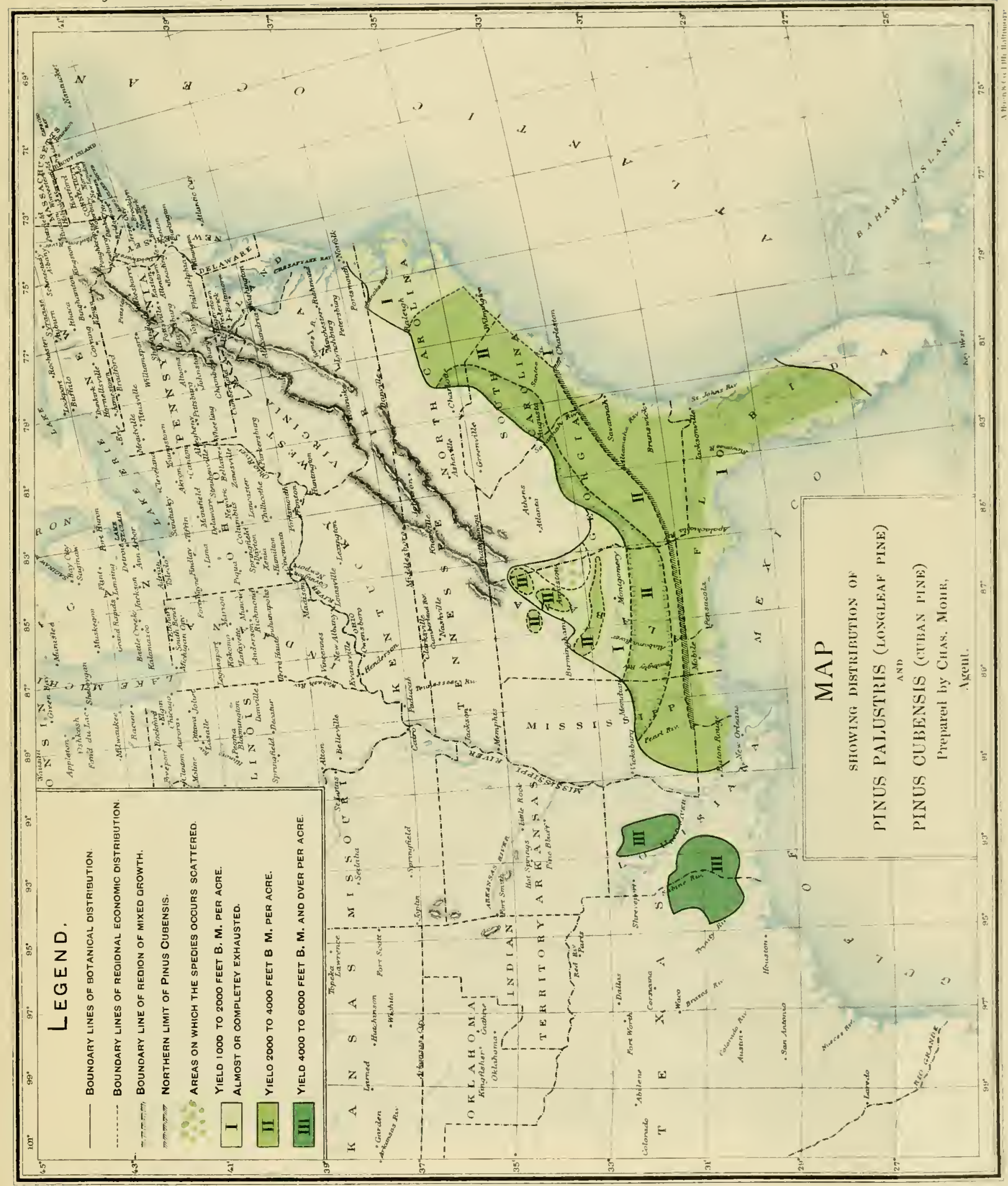


oceupy the poorly drained grassy flats of the plain are very open, intersected by numerons inlets of the sea and by brackish marshes. They are also interupted by swamps densely covered with Cypress White Cedar, White and Red bay, Water Oak, live Oak, Magnolia, Tupelo (imn, and liack Gum and again by grassy sivanuas of greater or less extent. On the higher level, or what might be called the first terrace, with its hetter doined and more loamy soil, the Longleaf l'ine once prevaled, but almost everywhere in the coastal plain the original timber has been removed by man and replaced ly the Loblolly l'ine and the Cuball P'ine.

2. The rolling pine lands, pine hills, or pine barrens proper are the true loone of the LongLeaf Pine. On the Atlantic Coast these uplands rise to hills over 600 feet in height, while in the Gulf region they form broal, gentle undulations rarely exceeling all elevation of :300 feet. Thus sprealing out in extensive table-lands, these hills are covered exclusively with the forests of this tree for many hundreds of sifune miles without intermption. Here it reigns suprene. The monotony of the pine torests on these table-lands is mubroken.

3. The npluer division, or region of mixed growth. With the appearanee of the strata of the 'Tertiary formation in the mpler part of the pine belt, the pure forests of the Longleaf l'ine are confined to the ridges eapped ly the drifted sands and pebbles and to the rocky lieights of siliceons ehert, alternating with open woods of oak (prineipally Post Oak), which orenpy the richer lands of the ealeareous loams and marls. llowever, where these loans and marls, rich in plant food, mingle with the drifted soils, we find again the Longleaf Pine, bnt assoeiated with brual-leaved trees and with the Loblolly and Shortleat Pine. Here the Longleaf Pine attains a larger size and the number of trees of maximum growth per acre is found almost lonble that on the lower division.

TIMBEL REGIONS-SUIPIS AND IPLODUUTYON.

The forests of Lougleaf P'ine ean be conveniently disenssed by referring to the following geographical and limited areas:

The Atlantic pine region;

The maritime pine belt of the eastern Gulf States;

The central pine belt of Alabama;

The forests of Longleaf l'ine of north Alabama (Coosa basin, ete.);

The regions of Longleaf Pine west of the Mississippi River.

TIE ATLANTIC PINE REIION.

The Atlantic pine region in its exteut from the sonthern firontier of easteru Virginia to the peninsula of Florida embraces the oldest and most populous States of the Longleat Pine listrict, and here the forests have sufferen most severely by lumbering, the production of naval stores, and elearing for purposes of a griculture.

Firginin.-Whe forests of the Longleaf Pine on the southeastern border of Virginia have almost entirely disappeared, and are, to a great extent, replaced by a second growth of Loblolly l'ine.

North Carolina.-In Nortlı Uaroliun the area over which this tree once prevailed nua be estimated at from 14,000 to 15,000 square miles, leaving ont of anleulation the coastal plain with its extensive swamps, wide estnaries, and numerous inlets. Fron the northern frontier of the State sonthward, some distance beyond the Nense River, in the agrienltural district, the forest growtl on the level or but slightly undulating pine land is of a mixed chameter, the Longleat species being largely superseded by the Loblolly l'iue, together with widely scattered Shortleaf l'ine and ilecidnons trees-White Oak, Red Oak, Post Oak, Black Oak, and more rarely Mockernut and Pignut IIickory, and Dogwool. In this section the lumbering interests are ehiefly dependent npon the Loblolly I'ine (Pinus teilu), better known to the inhabitants as the Shortstraw, or Shortleaf Pine (not to be confonuled with the true Shortleaf Pine). The forests of Longleaf Pine begin at Bogne Inlet, extend along the coast to the sonthem homdary of the State, and inlund for a distanee varying between 50 and 135 miles.

The highly silieeous soil of these pine barrens oflers but little indncenent for its cultivation; the inhabitants, therefore, from the earliest time of the settlenent of the State lave ehietly been engaged in pursuits based on the products of the pine forests. Here the production of navial 
steres was first carried on; rosin, tar, and pitch tigured in early colonial times anong the most inportant anticles of expont. In conseguence, the forests of the longlable Pine have heen, with but slight exceptions, invaled lyy turpentine orehadding. and at the presut time hy far the greater

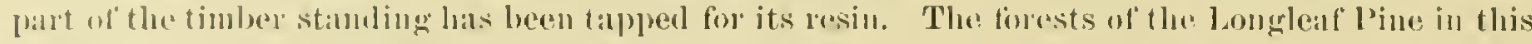
State covere the largest area in the basin of cape Far. Rivel, wilh Wilmington the matu port of

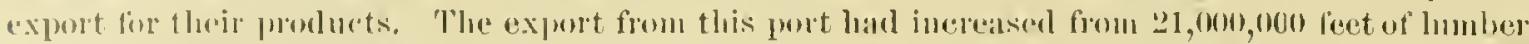

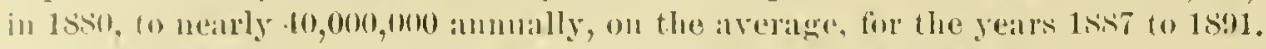

The torests of the Longleal l'ine on the banks of the Nense liver, in elohston Connty and in Wayne Connty, are almost exhansted; about fo to in per cent of the timber saln at (ioldsboro and Dorem is Lomgloaf Pine timber from that section, and is invariably blem. A considerable ummber of the troes from the old turpentine orrolads, with the excoriated surlise of the trunk

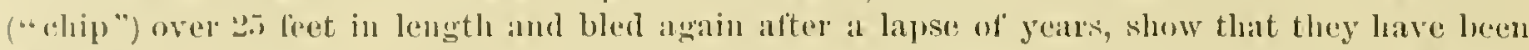
worlied for their resin for twenty to twenty-fine years in sncession, and al fer a longer or slurter

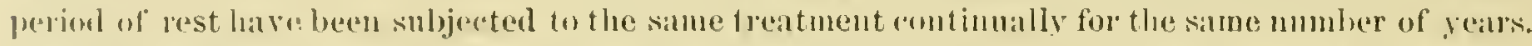

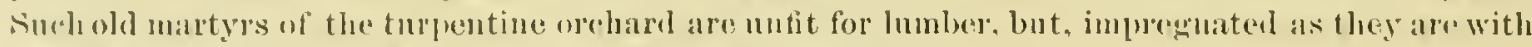
resin, ane used for piling and fin posts of great durability.

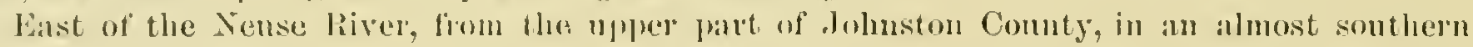

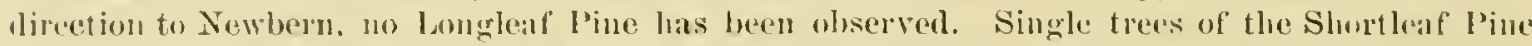

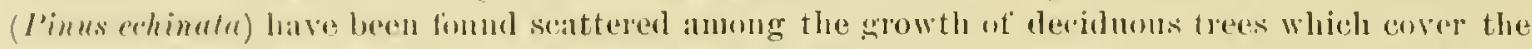
ridges lutween the Trent and Nense rivers, and isolated tracts of a fow acres of the longleaf speries are met with in the low hats of the sime section, which were in 1 s9 alunost exclusively occuphed by the Lohlolly l'ine.

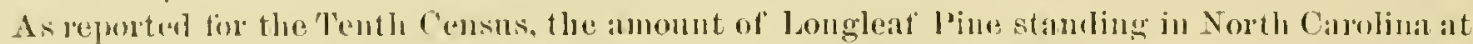
the heginning of the rensus year was estimaled to be 5,2 ,

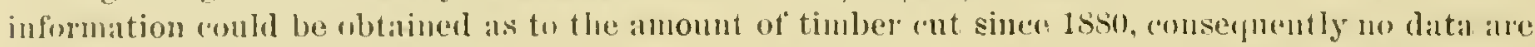
at hand from which to compute the anomit now standing. The "ut for the year 1850 is given in

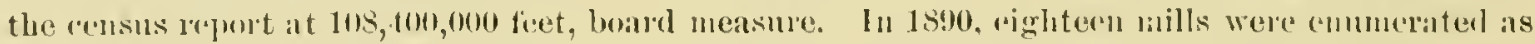
engaged in sawing cxolusively longleaf P'ine timber, ahmost all situated in the hasin ol' Cape leall

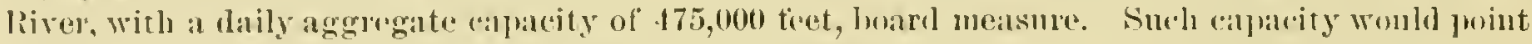

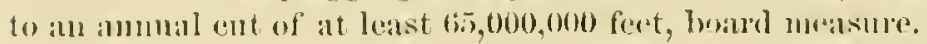

Slatement of the shipments of waval stores from llilminglon, I. 1 :

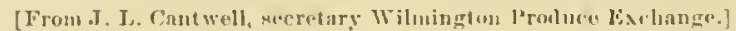

\begin{tabular}{|c|c|c|c|c|c|}
\hline & Sear. & $\begin{array}{l}\text { Surits of tur- } \\
\text { putine. }\end{array}$ & Iiosin. & $\begin{array}{l}\text { Comdre resin } \\
\text { or turpentinlo. }\end{array}$ & J':ur. \\
\hline \multicolumn{2}{|c|}{ 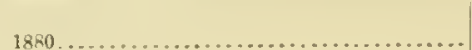 } & $\begin{array}{l}\text { rask:s. } \\
\text { ly5, }: 85\end{array}$ & harrels. & liarrels. & Iarrels. \\
\hline $1 \times 81$. & 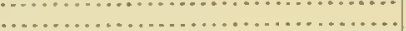 & 10,100 & 450,000 & $\ddot{2} \ddot{3} \ddot{z}$ & \\
\hline $18 \times 2$ & $\because$ & 84,376 & $435,9 y 5$ & 3,188 & 60,133 \\
\hline $18 \times 3$. & $\begin{array}{l}\cdots \\
\ldots\end{array}$ & $87,(151)$ & 483,432 & $31,9 \mathrm{Gt} ;$ & 75,544 \\
\hline 1844 & ............. & $78,47 x$ & 434,376 & $45,9+6$ & $85,2: 10$ \\
\hline $1 \times 8.7$. & ................ & 71,145 & 310,808 & 35, 294 & 70,530 \\
\hline $1 \times B 6$ & (n....... & 63.5811 & 321,942 & 27,600 & 61,145 \\
\hline $1 \times=\pi$. & $\cdots$ & 71,112 & $3+1,335$ & 21,572 & lis, 143 \\
\hline 18.48. & & 63,437 & $210,5\} 0$ & $1 \times, 171$ & (1i3, 1603 \\
\hline 1×89. & & 60,168 & $351,8 \div 7$ & 19.082 & $08,8: 4 ;$ \\
\hline $8: 10$ & ............. & $70, \geq 89$ & 385,523 & & $71,14+4$ \\
\hline $18: 4$ & & 67,480 & 34: 500 & 16,900 & (is, $71: 0$ \\
\hline $\mathrm{j} \times 1 y_{2}^{2}$ & $\ldots \ldots \ldots$ & $59,-83$ & $2 \times 7,200$ & 15,5013 & 07,900 \\
\hline 1693. & & $5,8,3,36$ & 271,8191 & 15,500 & 711, 5010 \\
\hline $18: 1$ & & $46,0: 36$ & $189,9(11)$ & 4, guo & $45,5(x)$ \\
\hline & Totial ....... & $1,111,155$ & $5,5611,051$ & $\because(i 1.021:$ & 869,323 \\
\hline & Baluo & $\$ 19,000,0100$ & $\$ 10,000,000$ & $\$ 331.500$ & $\$ 1,100,0011$ \\
\hline
\end{tabular}

Total vuluo, x:30,500,000.

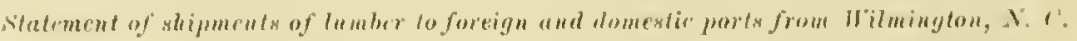

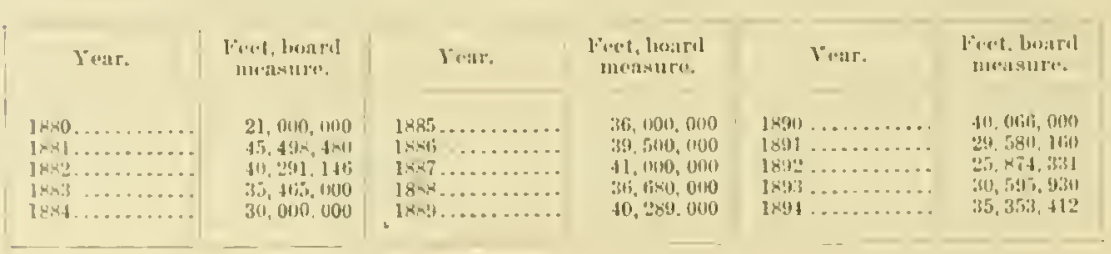


South Carolina.-The forests of Iomgleal" l'ine in this State follow more clusely the eorast lines.

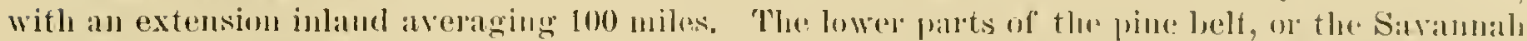
region, is low and hat, rising but slowly above the batekish manses and alluvial lamds bordering the sea. Thaversed by eight large rivers with wide csturies and borderol by extorsive swamps

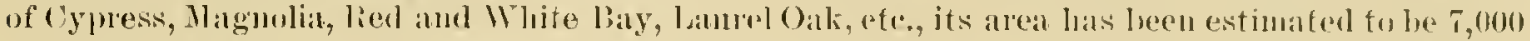
square miles, f, 000 square miles of which an ocempien by swamp lands, imeluibug the grassy marshes on the const. In the low, jerfectly level pine banchs, with a soil of tine, ampated,

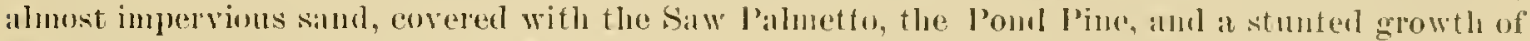
the Cnban and Lohlolly- Pine, fhe longleaf' l'jne is rarely seen, and always ol dwarfed growtl. In the flat woods bordering the alluvial swanps, heavily timberes with loblolly and cuban I'ine, the Longleaf l'ine makes its appearance more frequently, and finally prevails almost exelnsively on

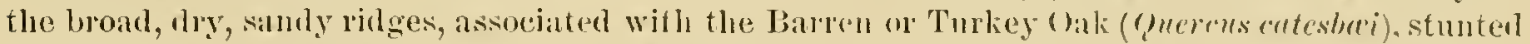

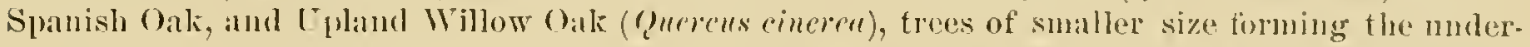
growth. The timber growth on these ridges is rather open and of goor quality. As has been observed near lidgeland, in the comnties of lieantint and Hampton, the forests lave to a large extent given way to the plow, and along the railuads they lave been destroged ly turpentine orcharding. Upon 1 acre, representing finily the original timber growth of the furests on these ridges, 48 trees of a diameter of from 12 to $2 /$ inches at breast high, with a height of from so to 110 feet, were fomnd. Of these, 4 yiehled sticks of ("lear timber averaging l.s feet in length with mean dianeter of 18 inches, equal to 2,000 feef, lowd measure, of first-rlass lumber. These trees varied in age from 136 to 145 years; 8 trees yielded sticks of timber free from limbs to feet in length with mean dianeter of 17 inches, equal to 3,-00) feet, houd measure, age on the average 140 years; 12 trees yielded 35 feet length of clear timber with mean dianeter of 16 inches, enfual to 3,600 feat of merchantable lumber, age from 130 to 136 years; s trees averaged 12 inches mean diameter, length of timber 30 feet, equal to 950 feet, boarl measme, age from 110 to 1 tis gears; 4 trees averiged 10 inches mean diameter, length of clear timber 24 feet, wood saply thronghonf, yieldiug 200 feet of lumber, age from so to 8.5 years,

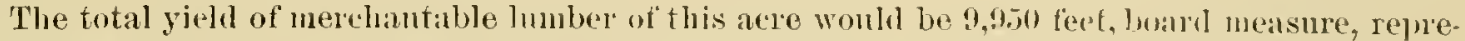
senting the average of the betfer puality of these timber lands. As in the adjuining states. the forests along fle railroal lines for a wide distance have been subjectod to turpentine orelarding, and but a small pereentage of the timber standing has escaped the ax of the "box" cutter. The recejpts of uaval sfores at Charleston during the ten years from 1880 to 1830 averaged ammally $5 \pi, 50$ ) casks (50 gallons to a cask) of spirits of tupentine and 205,920 barrels of rosin, with the largest receipts in 1880 of 60,0011 casks of spivits of turpentine and 2209,940 barrels of rosin, and the smallest of 40,253 aksks of spinits in 1s8s, and 170,066 larrels of rosin in 18st.

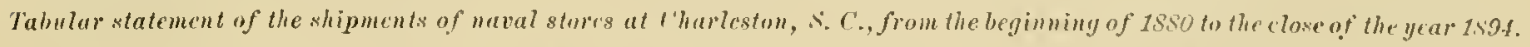

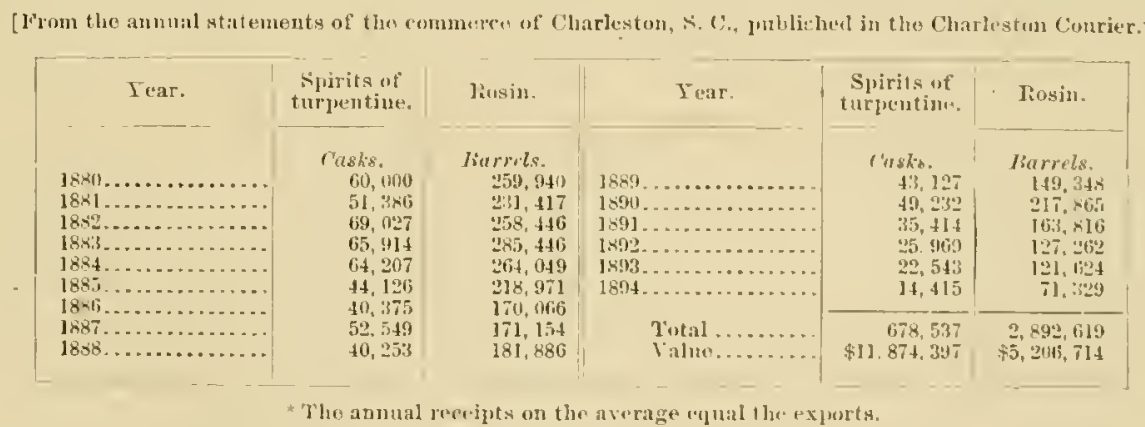

The rolling pine hills borlering upon the that wools, or swamp, reach eievations of 130 to 250 teet alsove the sea, with a width of tion so to 40 miles, and, ats on the pine ridges of the low pine barrens mentioned before, the upland oaks form the spanse undergrowth in the forests of

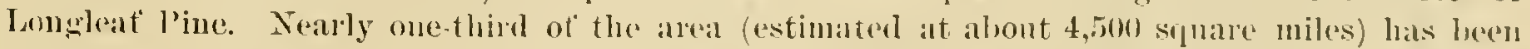
opened to eultivation. These rolling pine lands rive on their morthern borders aluruptly to a range of steep hills over 600 feet above sua level, covered with a rather seanty growtl of Longleat $17433-N_{0} .13-3$ 


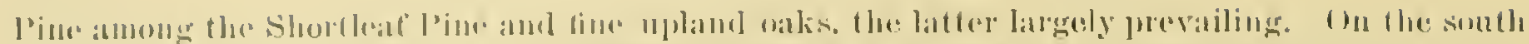

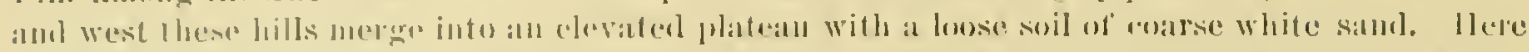

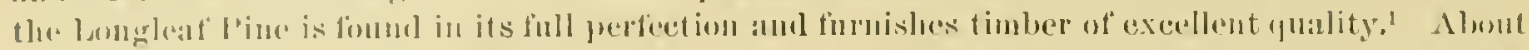

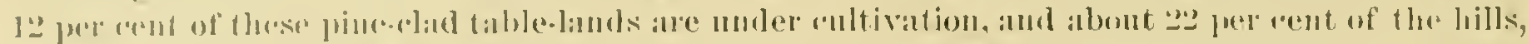

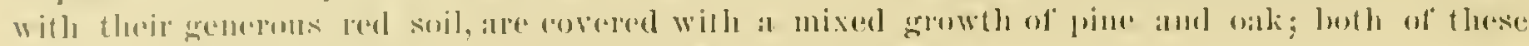

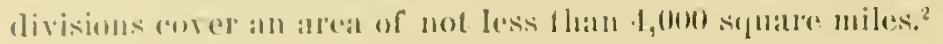

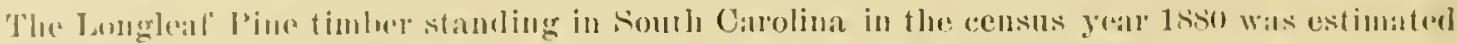

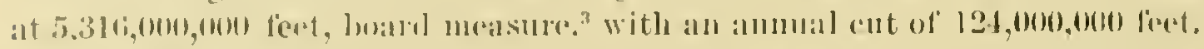

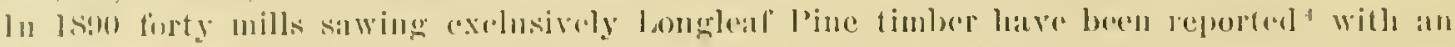

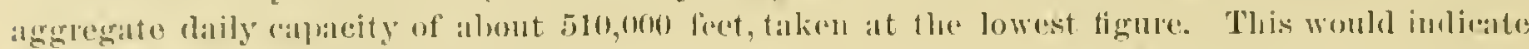

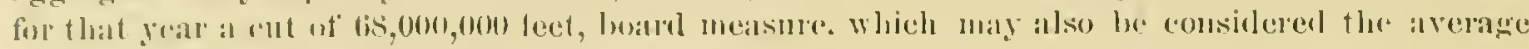
annual ent for the last filteen years.

The exports of lumber from Charleston, the ehief port, have since the year $15 s$ st steadily

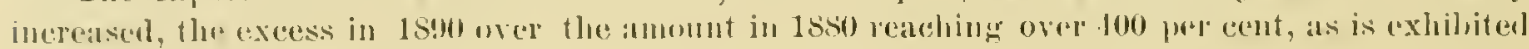
in the following statencint:

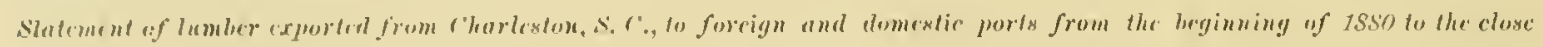
of 18 is.

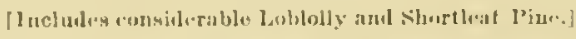

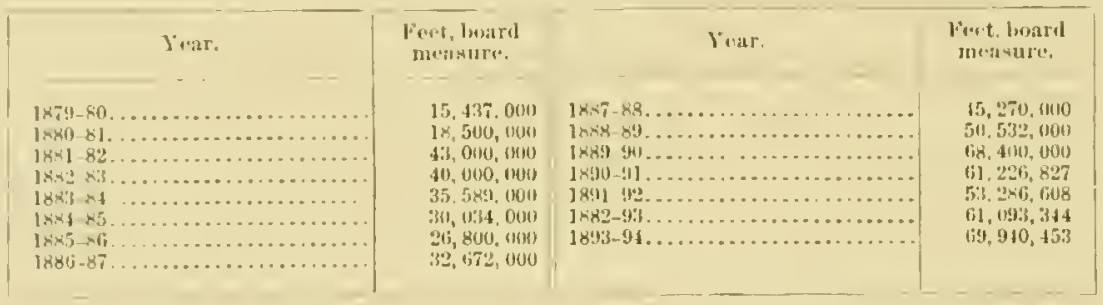

Cicorgia - The great pine state of the South, which has given to the lomgleaf l'ine the name of

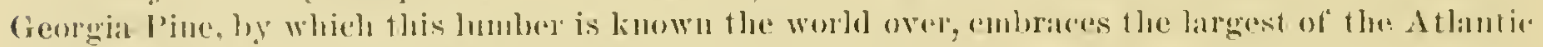

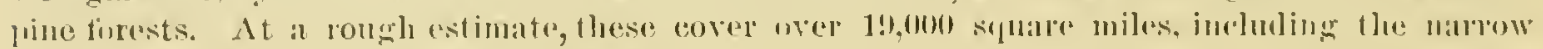

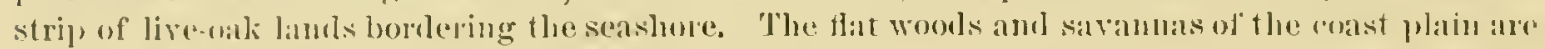
liom 10 to 1.5 miles wide. They are almost chtirely striplent of their growth of lomgleal' l'ime.

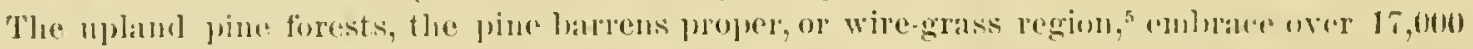

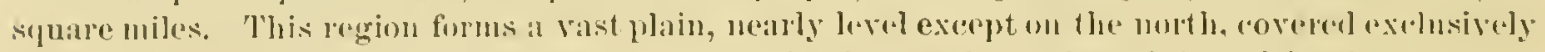

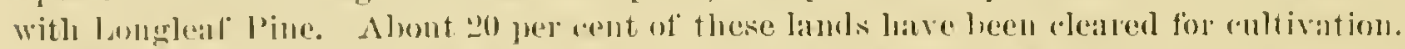

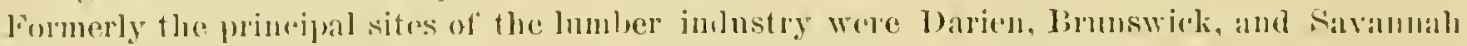

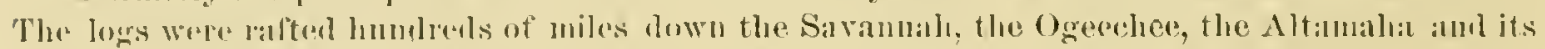

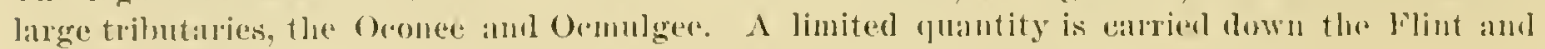
Chattahoodine rivers to A palimelicolit. The raiboads, however, smply the mills now to the largast extent.

The forests of these pine uplands ale in quality, and originally in quantity, of theil timbel

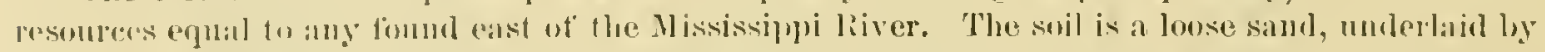

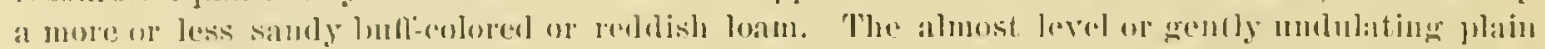

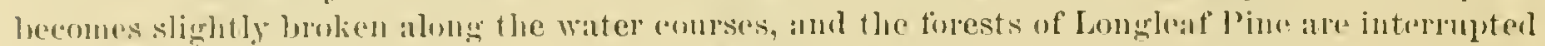

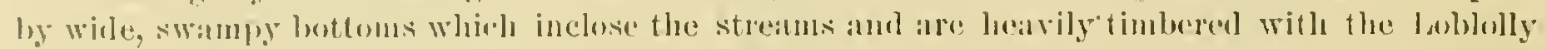
P'ine, Guban l'ine, Lantel llak. Witur Oak, Magnolia, White and lind bay, and Gypexs. On

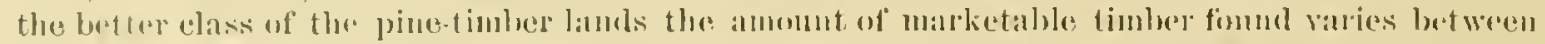

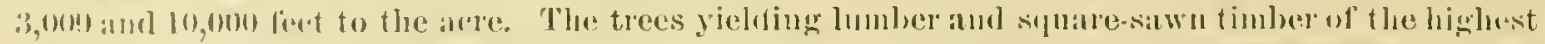

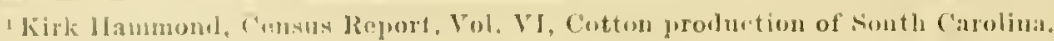

Jammond, 18

liepurt of Tentli census, Vil. 1.J.

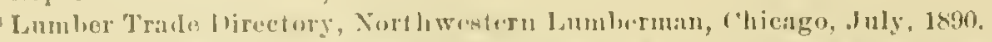

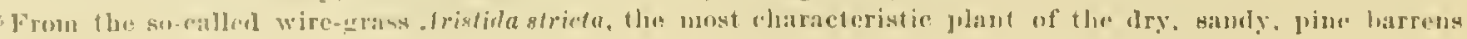

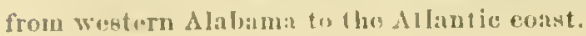


grade were fonnd to make stieks of from 40 to 15 feet long, perferetly cleall of limb knots, and is to 23 inches moan diameter, giving from tion to 750 fiet of Immber, with the sapwoor fiom le to 2 inclies wide.

The following measmements of trees fom an suall tract of forest mutomehed ly the ax serve as a tatir average sample of its timber' growth:

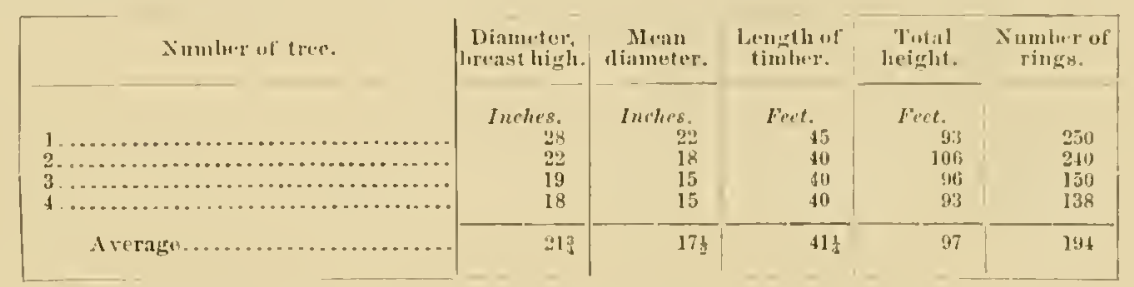

Along the mumerous railoud lines and the navigable streams amd their tributaries andmitting of the driving of logs, the forests have been completely striphed of their merchantable timber, and the demuded areas to a considerable extent are at present muler cultivation. The magnificent forests on the Altahana River and between its tributaries, the Oemulgee and Oconee rivers, and als on the Ogeedhee River, have been puctically exhansted and are utterly devastated by the tapping of the trees for tmpentine. In fact, more than two-thirds of all the timber sawn at present has been blerl. The timber from the turpentine orchards, abandonerl for years past, is being rapidly removed to the mills, and the vast areas ocenpied by them will, within a short time, be almost completely denuled of the Longleaf Pine, its place being taken ly scrubby oaks, dwarf hickories, and Persimnon. The timber is transferred to the mills mostly by steam-eruippal tramroads, and the products of the tmpentine distilleries in the remoter districts are lamled to the highways of eumnere by ox teams for distanees of l' miles and over.

Considering the removal for their timber of trees far helow medium size and during the best period of their growth, the destruction of still younger trees by turpentine oreharding; and ot the young seedlings by tire, the prospeet for the future of the lumber industry and the renewal of the forests of Longleaf I'ine in this region are gloomy. Mang of the intelligent men praetically interested in the timber lands of this State aver that the exhanstion of the forests of the Longleaf Pine is a question of but a short space of time, to be aceomplished before another generation has passed.

The amount of timber standing at the end of the rensus year 1880 had been com[nter at $16,778,000,000$ feet, hoard measure, and the cut at $272,743,000$ feet.

From the publication rnoted, it appears that in the year 1890 there were 88 sawmills in operation in the great pine belt of Georgia, sawing exchsively Longleat" Pine timber. On the basis of lowest figures eited, the daily eut at these establishments during that year would not fall short of $1,667,000$ feet.

No statistical returns of the lumber trade previous to 1854 could be obtained at Sarmuah, Darien, or Brnuswick. The export from the first of these ports averagerl about $73,000,000$ feet, board measnre, a year, showing but slight fluctuation during the period heginning with 1854 to the elose of 1889 , when in the subsecfnent two years the annmal averago inereased to $115,000,0,0$ feet, board measure. The exports from Darien and Prunswick, averaging \$2,000,000 and Si, 1000,000 feet, respectively, for a similar period of timc, show also but small ditlerences from one year to another. About $30,000,000$ to $33,000,000$ feet are rafted down the Flint and Chat tahoochee rivers, to be sawn at $\Lambda$ palachicola. With the spread of the sawmils aleng the railroad lines in the upper part of the pine region, the shipments of humber by rail to distant Northern malliets increased steadily, mutil in 189 ' it was foumd that the production of longleat Pine Iunber shiplued by rail to Northern markets exceeded $60,000,000$ feet. 


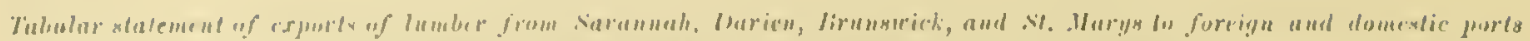

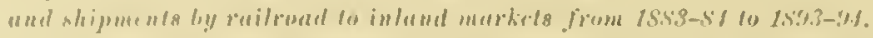

\begin{tabular}{|c|c|c|c|c|c|c|c|c|}
\hline Vieatr. & Mas annals. & larie:u & lirıנинwick. & Sit. Mary*. & $\begin{array}{l}\text { Savannah } \\
\text { liailrual. }\end{array}$ & $\begin{array}{l}\text { rylerwinn } \\
\text { ly rail. }\end{array}$ & Jlint lisur. & 'J'utal. \\
\hline $82.2-\cdots+.$. & lict. N. .If. & Fint, N. Jfo & IVAt, IS, W & Fior, fi, yf & $F+n, N, M$ & 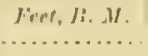 & 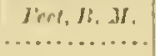 & 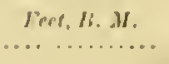 \\
\hline$j x=1+k i \ldots$ & 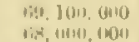 & 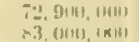 & 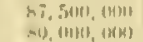 & 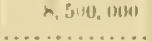 & & & & . \\
\hline Istiti-n $7 \ldots$ & 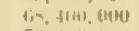 & (H)1, (11H), H(1) & MM, (B)II, (HII) & & & & & \\
\hline $1 \times-1-8<\ldots$ & E(1, 4111), (1011) & (16). (6) & th. (K)U, (t)11) & ... & ..... & .. & .. & . \\
\hline $1=0$ & 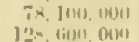 & s.i. $(11111 .(11+1)$ & $52.10100 .61 k$ & & & & & \\
\hline $\begin{array}{l}12,2,-\{k\} . \\
18 !(1-0) .\end{array}$ & 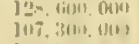 & 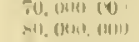 & $\begin{array}{l}81010,01118 \\
=11,1000,11111\end{array}$ & & $\cdots \cdots$ & & & \\
\hline 139192 & lilx, 3111, 100 & sit & $\times 0.1 m$ & & $511,0000,000$ & if, suco, on & $33,6100,000$ & to3, zini onim \\
\hline $1 \times 90-93 .$. & $11 \mathrm{ti}, 161,0 \mathrm{kt}$ & 8.5. (1111). (1)tis) & 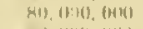 & & $50,0101,4100$ & 16. 0011.0000 & ........ & $3+7$, 11100 , , \\
\hline$\ldots \ldots \ldots \ldots$ & $7 i, f(t), 0011$ & $\therefore \therefore, 0019,1008$ & 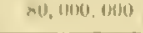 & 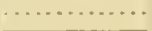 & $511,0140,000$ & & $\cdots \cdots$ & 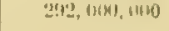 \\
\hline Tutal! & 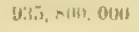 & $233,(4 \times 1),(0) 11$ & 831.2001, & 17. 000,000 & 1511.000 .000 & $32.9(1), 000$ & 0,010 & \\
\hline
\end{tabular}

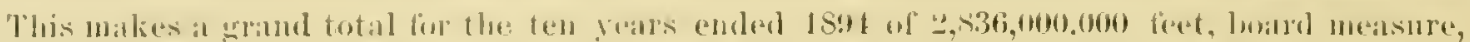

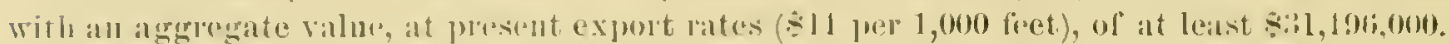

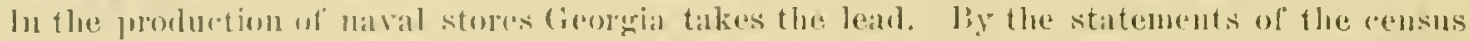

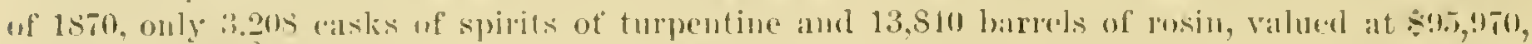
were produerd iluring that yalr in the state. In the course of the following ten years this industry progressed stoudily and rapidly. In 1885 exports fom savamah, at presut the

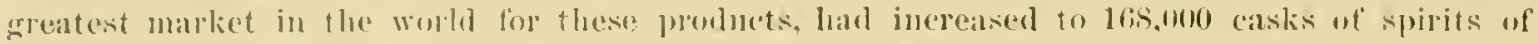

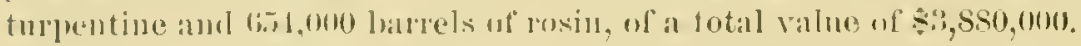

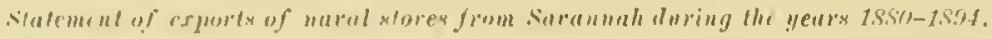

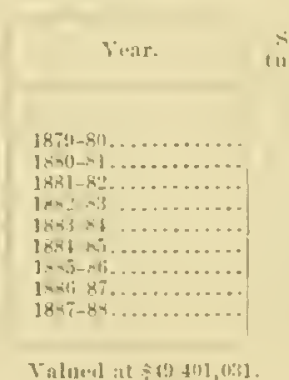

\begin{tabular}{|c|c|}
\hline $\begin{array}{c}\text { Spirita uf } \\
\text { turph-ution. }\end{array}$ & lictsin \\
\hline 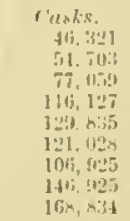 & 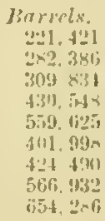 \\
\hline
\end{tabular}

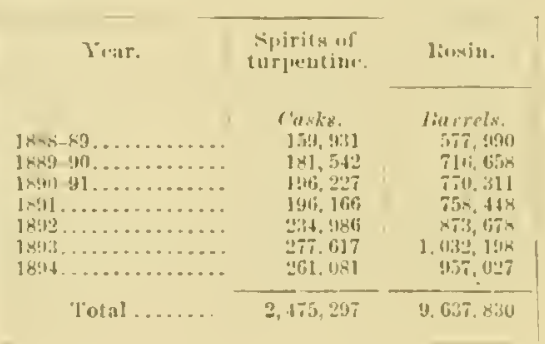

The highest priers for these stores in Sa Finnah were obtained in 18511 , with s. 19.50 per eask of

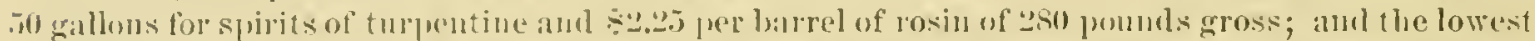

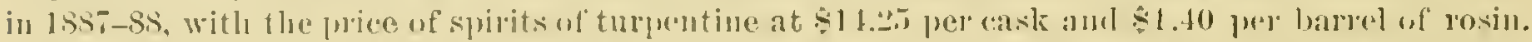

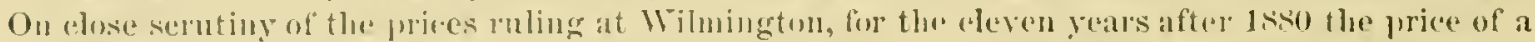

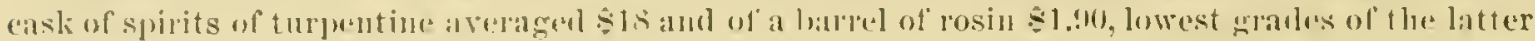
exclucled.

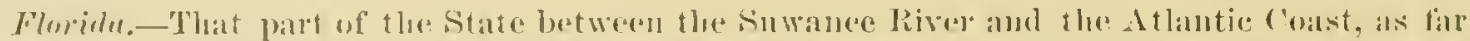

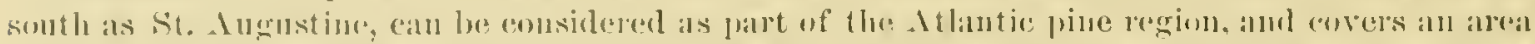

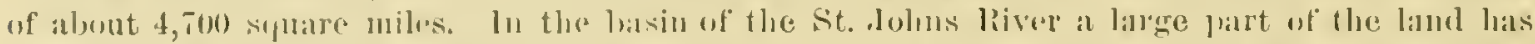
been devoted to the "ultivation of the eitrus fruits. The prineipal sites of the mannacture of

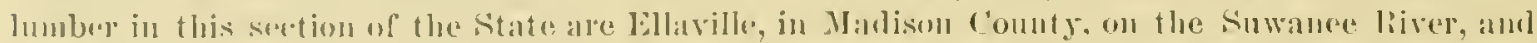

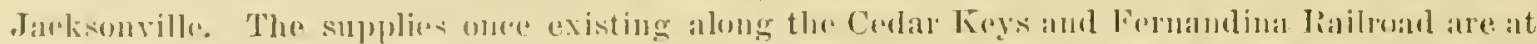

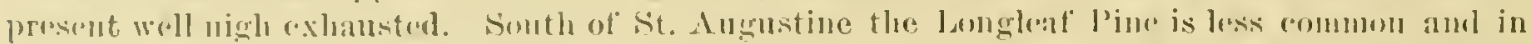

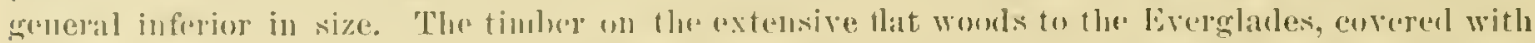

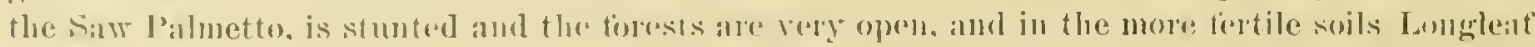

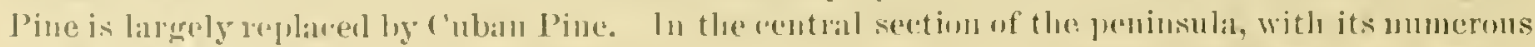

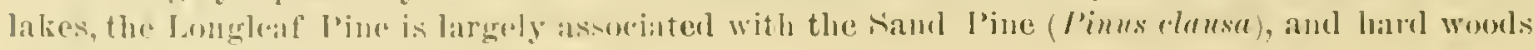
prevail on the mplaud lımmunek laurls.

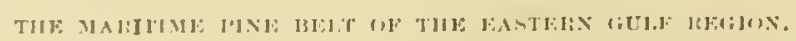

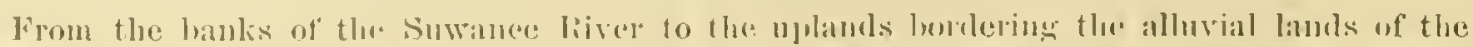

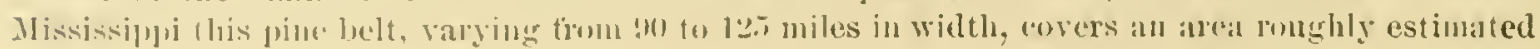




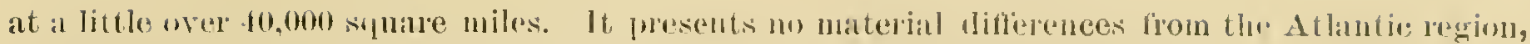
of which it is a direct antimation, being similan to it in loth soil and climate.

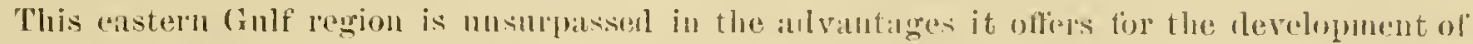

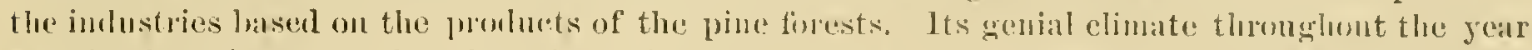
permits the nuntermptem exploitation of its almulant resonres of resinums poulnets and of timber of the best quality. The fine larbors and safe madsteads on the Gulf Coast are rear hed loy navi. gable rivers, which, with their tribntalies, cross the lower division in every diretion, ind give realy and oheap transportation to its ports, while great railway lines allord easy communication with inland matkets. This region thus presents indurements seareely foum elsowhere for the investment of eapital and labor in the development of thresumes of its forests.

It is impossible to arrive at anything like an acculate estimate of the anmunt of timber standing at present, or of the rate of its eonsmmplion. since in the returns of the annual lumber froduct that needed for home consumption has not heren inchulerl.

Westem Fluridn.-Placing the eastern limit of that part of Florida to be consinlered as belonging to the (inlf pine region at the lower ande of the Suwance liver, the area included comprises abont 7.200 synare miles, exchsive of the stamps and marshes of the coist. 'The forests of longleat P'ine form a nartow strip along the course of the Suwanee diver and along

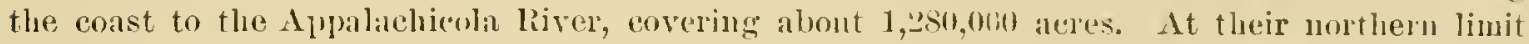
they merge into the oak and liekory mulands of middle Flonila. Alomg the roast they are surronmled by matshes and swamps, rendering them lithicult of acess, conseruently they have remained untonched. The sime may be sivil of the pine forests between the Appalachicola and the Choctawhitchee ribers. 'These have been invaled to sone extent along the banks of the latter river to supply the small mills situated on the bay of the simse name.

The pine lands of western Florida rise slowly above the coastal plain am form a vast explan:c, of slightly minlating surface. Those smromuling Perdinlo, Jensurola, Jiackwater, and Mary St. Galves Bay, the ollest sites of active lumber indnstry in the Gult region, were stripued of their valuable timber more than thirty year's ago, and since that time lave been "nt over again.

The largest traets of tinely timbered virgin forests of Longleaf l'ine are found in the undulating nplands from the Perdido and Eseambia river's along the Alibana State line to the banks of the Choctawhatchee River. East of this river, in the same direction, where the gunger Tertiary strata make their aplearance, fongleat Pine becomes associated with had mooks, with southrin Spruce Pine adted in the valleys. Since the opening of the Pensacola and Atlantic Ianlual considerable tuantities of sawn square timber find their way to Pensacula from these remoter forests.

A linge portion of the timber supplied to the mills along the roast having becn deriver from Alabama, it is impossible to arrive at an exant estimatro of the probluots of thro forest of western Florida.

Statement of export of hew'n stuare timber, sarn square limber, and lumbry lo foreign and domestir ports from lensacolu, Fla., from $15 \% 2-i 0$ to $159 ?-93$.

[From Ilyer A liro.'s anmull circulars.]

\begin{tabular}{|c|c|c|c|}
\hline - Yerar. & $\begin{array}{l}\text { spuro hewn } \\
\text { timber. }\end{array}$ & 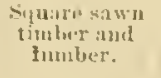 & Total. \\
\hline 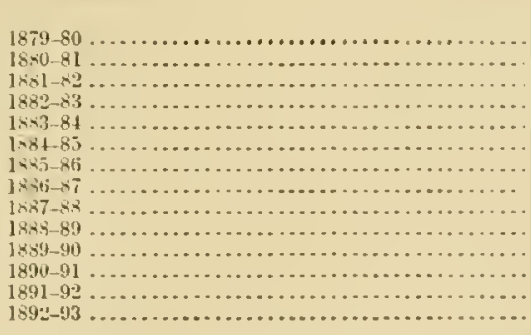 & 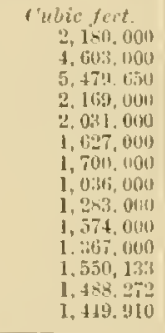 & 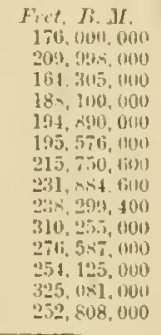 & 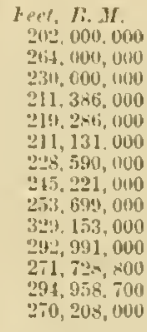 \\
\hline Total...... & & & $3,534,352,300$ \\
\hline
\end{tabular}

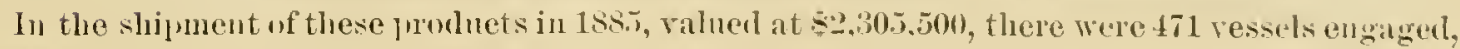
of 294,595 tous, of which 370 of 95,922 tons dencerl for foreign ports. 


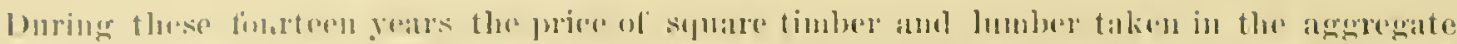

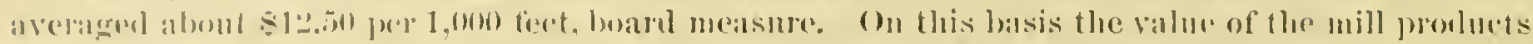

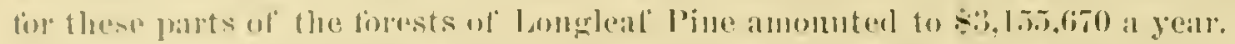

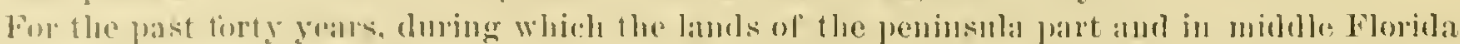
hatre pasised mostly into possession of small proprietors, no natral stores have hern produced in this section. In western liloribla, howaver, in poximity to the lonisville and Nashrille and

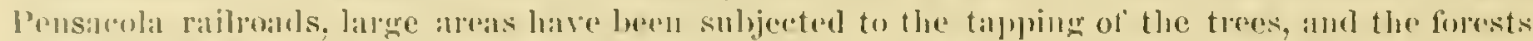

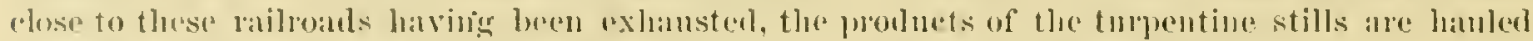
for a distance offen cxoreding 10 miles and find their maket mostly at Mobile.

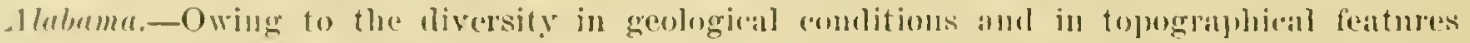
prevailing in this state, the distribution of the Janglut line presents within its loorlers peruliarities mot fomml elsewhere. It appears in ther separate regions-the maritime pine belt, the aentral pine belt, and the pine forests of the Consa basin and other ontlying forests in north Alabina.

The coast pine belt extends from the (inlf shore inland for" a distance of from 90 to 100 miles,

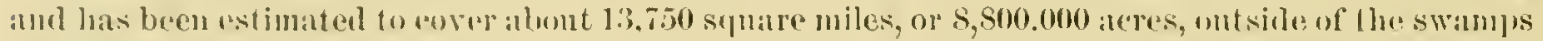
and that woods of the coast plain. The latter, perfertly level or rising in genthe swells above the tidewater marshes, is almost completely stripperl of its original timber growth. After its removal the Longleat ['ine has largely been replaced by Cuban l'ine.

The rolling pine mplamds rise to a lieight of trom 2001 to 350 feet above the lowlands of the coast. In the lower grat of this pine belt, where the samb and wracly deposits ol the latest tertiary strata jrevalil, the Longleat l'ine forms pme forests, with the exception of the narrow

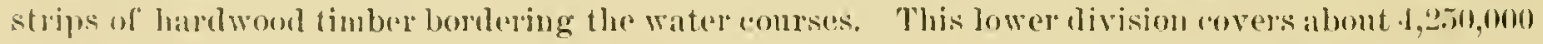
acres. In the extent and puality of their timber resonres these longleaf pine furests an be

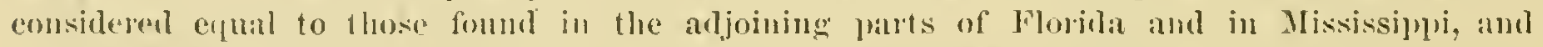
unsurpasserl by those of the most fiomed sections of the Athantic pine forrest.

The following measurements of trexs felled near Wallawe, Excambia County, in collecting the matrial for the Lnited states timbrer tests, will serve to represent filirly the "prility of the merehantalle timber in enformity with the standand in vogne at the mills in 1580, and the rolation of age to growth:

Measurements of five tres.

\begin{tabular}{|c|c|c|c|c|c|c|}
\hline Niumlwr of trre. & $\begin{array}{l}\text { Diameter, } \\
\text { liresut } \\
\text { hiell. }\end{array}$ & $\begin{array}{c}\text { Tolial } \\
\text { leiglut. }\end{array}$ & $\begin{array}{l}\text { Jimge un } \\
\text { stum! }\end{array}$ & $\begin{array}{l}\text { Ifiumeter } \\
\text { below } \\
\text { rrown. }\end{array}$ & $\begin{array}{l}\text { Mean dian } \\
\text { et"r of } \\
\text { timber. }\end{array}$ & $\begin{array}{l}\text { Longth of } \\
\text { timber frice } \\
\text { of limb. } \\
\text { knots. }\end{array}$ \\
\hline 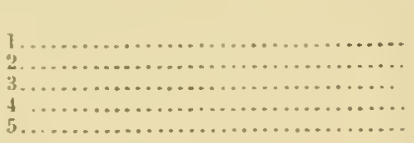 & $\begin{array}{r}\text { Iuches. } \\
26 \\
19 \\
16 \\
18 \\
19\end{array}$ & $\begin{array}{l}\text { Pert. } \\
106 \\
111 \\
111 \\
113 \\
113\end{array}$ & $\begin{array}{l}216 \\
189 \\
1 \times 3 \\
1: 6 \\
1: 2\end{array}$ & $\begin{array}{r}\text { Jucluss. } \\
\text { is } \\
14 \\
12 \\
15 \\
13\end{array}$ & $\begin{array}{r}\text { Inclues. } \\
22 \\
16 \\
11 \\
17 \\
110\end{array}$ & $\begin{array}{r}\text { Prapt } \\
50 \\
50 \\
43 \\
50 \\
50\end{array}$ \\
\hline Avrage..... & 1!1, 0 & 111 & 1913 & 14.5 & 17 & 51 \\
\hline
\end{tabular}

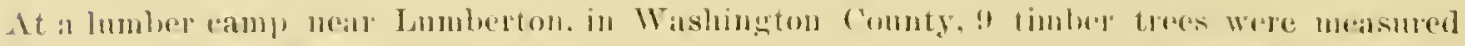
showing on the arorage a mean dianeter of 17 inches, the rear sticks areraging to fant in length.

Lpon I acre, selected at ramlom in the momehed forests north of Springhill, Mobile Conty,

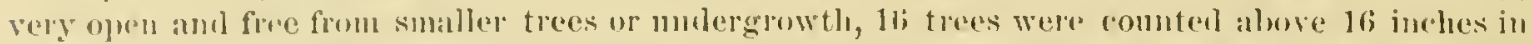

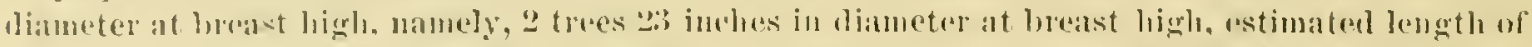

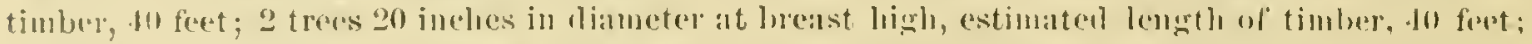

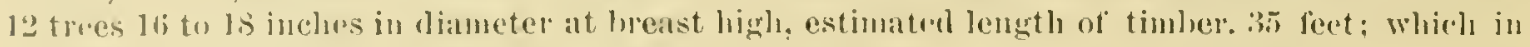

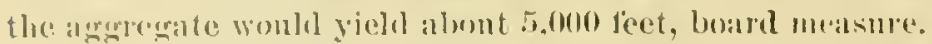

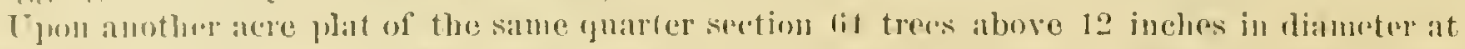

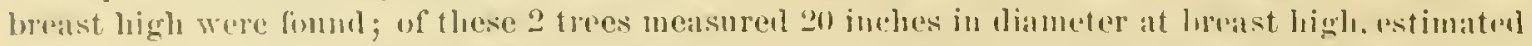

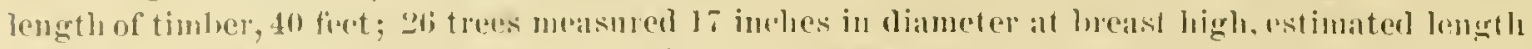
of timbar, 3fi fret; :26 trees measured 13 inches in diameter at breast highl, estimated length of timber, 24 feet. 
Upon a thirl plat exepptionally heavily timbered, 4i trees were connted, ol which is trees were 25 inches in diancter at hreast high, the clear timber a veraging ino leet in length; 12 trees 22 inches in dianeter at breast high, length of timber 50 leet, and as trees 11 to 18 inches in diameter, average length of timber estimated at 30 feet. Such a stand wonli indicate a yield of merchantable timber of at least 15,000 feet, board measure, to the acre. All over this lower division bogge trascts are frequently met with, in which the sour, black soil is covererl witl, sphagnum, or bog moss; these support mly a few scattered pines. On many of the steeper riclges the soil is pure sand and the pine growth is smill and inferior, leing largely replaced ly barren Oak, Sparkleberry, and the evergreen heather-Jike shrub r'routioln fricoides.

In this lower division of the maritime pine belt the manutacture of humber and the produetion of naval stores is carried on most actively. These produets lind their ontlet chietly at Molile, while more than one-third of the humber "xporter from Pensacola (to the amomit of at least rou, 000,000 teet ammally for the past few years) is also derived liom this divisiom. In the mper half of the maritime pine belt, with the apprarance of the onterops of limestones and limy marls of the Lower Tertiary (Eocene) formation, the country becomes more lroken, with sterper lills and wider valleys, and a cliange in the eharacter of the flora takes place, particularly manifest in the nature and distribution of the tree growtl. In the fertile valleys and on the lower flanks of the lills broad-leaved trees, mostly Post Oak, Black Oak, Mockernut, Bitterunt, Pigunt, and Magnolia prevali, interspersed with Shortleaf P'ine, Loblolly Pine, and lied Cedar-the Longleaf Pine oceupying sporalic patrles of drifted sands and pebbles. On the sterp and fregnently wide ridges capped by these deposits, and on the rugged hills of the buhstome and flinty (herts this tree forms the principal growth, and is in the openings more or less associated with broad-leaved trees. From this commingling of cone-bearing and decidnons trees and the alternations of pine forest and oak woots, this upher division las lieen designated as the region of nixed growth, which at a rongl estimate can be sail to cover about 5,000 square miles.

In the deep soil of light loam and strong loamy sands the Lungleat l'ine attains a splendid growtlu and the number of large trees on a given area is greater than found in the luwer division. The following measurements of 5 trees felled for test logs liarly represent the average dimensions of the timber trom these liills in the vicinity of Thomasville, Clarke Connty:

Measurements of fire trees.

\begin{tabular}{|c|c|c|c|c|c|c|}
\hline Numler of tree. & $\begin{array}{l}\text { Rings in } \\
\text { stuiup. }\end{array}$ & $\begin{array}{l}\text { Plameter } \\
\text { breast } \\
\text { bigh. }\end{array}$ & $\begin{array}{l}\text { Diametur } \\
\text { leloww } \\
\text { crown, or } \\
\text { tol! encl } \\
\text { of timber. }\end{array}$ & $\begin{array}{l}\text { Mran } \\
\text { liameter } \\
\text { of timber. }\end{array}$ & $\begin{array}{c}\text { T.' ogth } \\
\text { of timber. }\end{array}$ & $\begin{array}{l}\text { Total } \\
\text { lovirlit of } \\
\text { iriece. }\end{array}$ \\
\hline 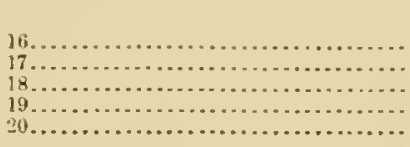 & $\begin{array}{l}202 \\
163 \\
210 \\
160 \\
110\end{array}$ & $\begin{array}{c}\text { Inclies. } \\
20 \\
21 \\
23 \\
20 \\
20 \\
17\end{array}$ & $\begin{array}{c}\text { Inches. } \\
15 \\
14 \\
16 \\
19 \\
13\end{array}$ & $\begin{array}{c}\text { Inches. } \\
18 \\
17 \\
19 \\
22 \\
15\end{array}$ & $\begin{array}{r}F o t \\
45 \\
40 \\
40 \\
40 \\
30\end{array}$ & $\begin{array}{l}\text { Feet. } \\
108 \\
115 \\
110 \\
111 \\
92\end{array}$ \\
\hline Averagr ............... & 171 & 21.2 & 15.4 & 18.2 & 39 & 106.3 \\
\hline
\end{tabular}

Many of the trees of larger size were found atfected by wind-shake in the dirertion of the rings of growtl (ring-shalie), in many instances impairing wreatly the puality of the timber. The forests on these lills are open, with a comparatively small number of young trees. Cpon 1 acre selected at ratudom 46 trees were combed; of this number were fonud 4 trees of a diameter of 25 inclies breast high, and the length of timber about 40 feet; 10 trees of a diancter of 22 inclies breast high, and the length of timber abont 31 ; feet; 26 trees of a dianeter of 18 inches breast ligh, and the length of timber about 30 leet; 6 trees of a diameter of 15 inelies breast ligh, aud the length ol timlier about 25 feet.

On the average each oue of these trees wonld yield about $4(1)$ to 450 feet, board measure. On another acre 44 trees were found dillering in their average dimensiou but slightly from the above, and inclieating a yield between $I S, 000$ and 19,000 feet of lumber" to the ace. In this mpere part of the coast pine hett lumbering and turpentine oreharding have not developed to any great extent, owing to its inaccessibility. However, where railroads traverse the section, the manufucture of 


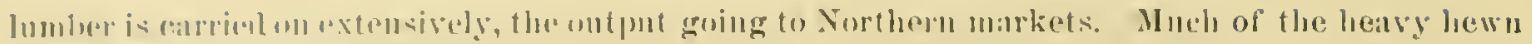

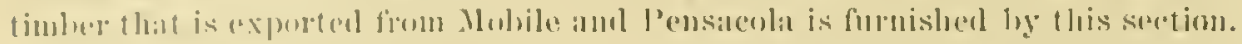

In ablloctine the statisties an the lumbering interests in the maritime pine belt of dlahama

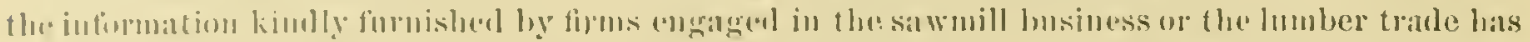

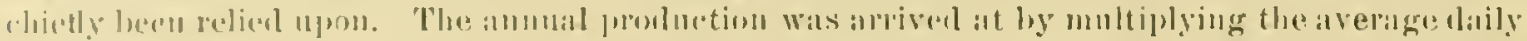

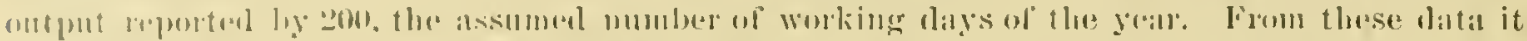

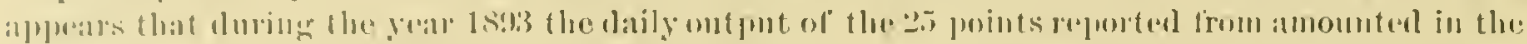

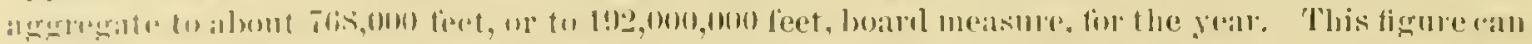

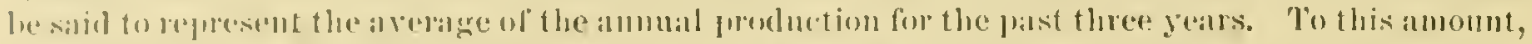

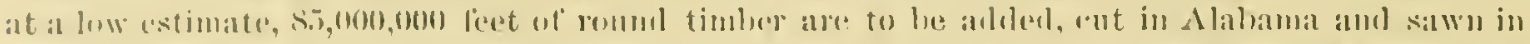

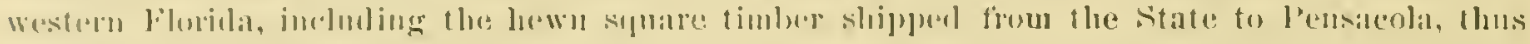

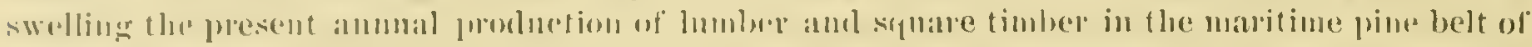

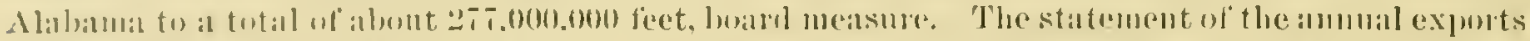

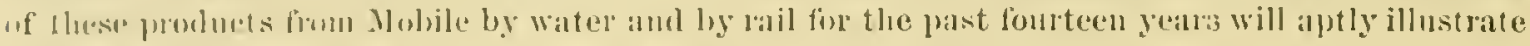

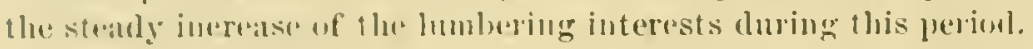

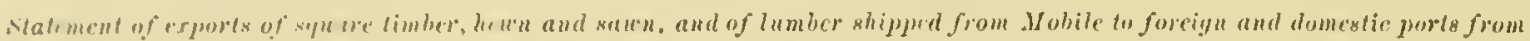

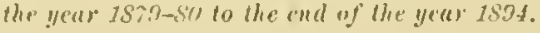

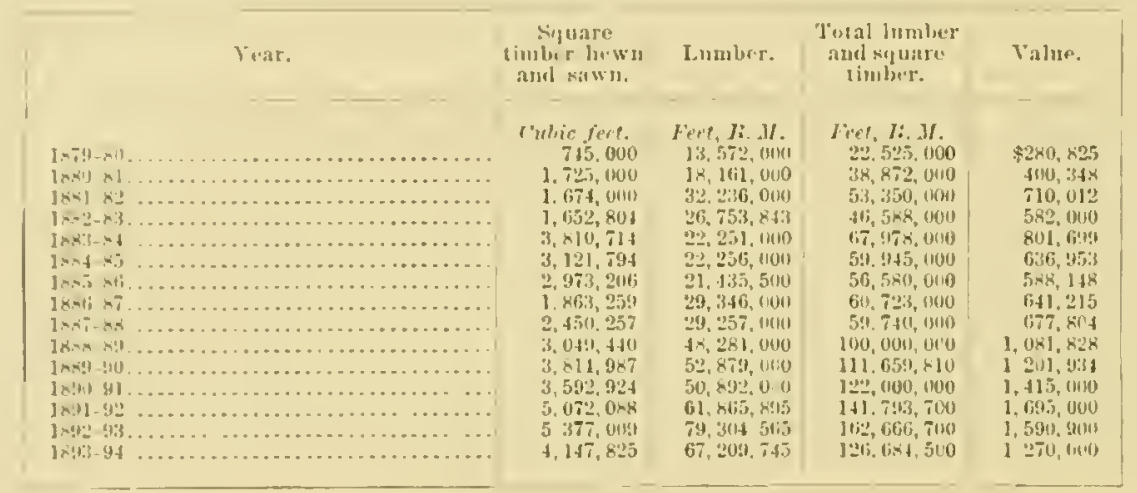

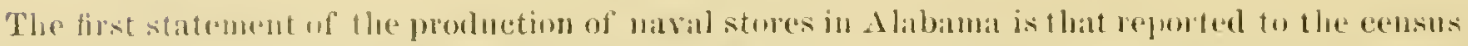

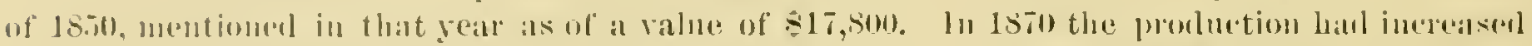

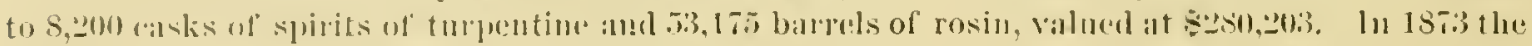

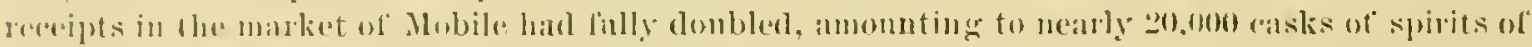

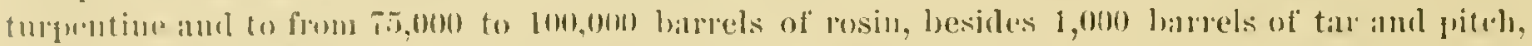

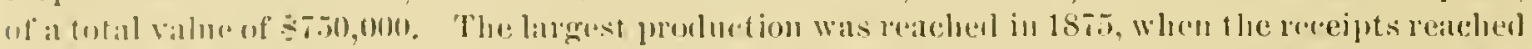

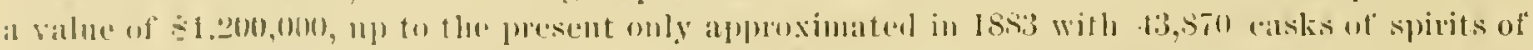

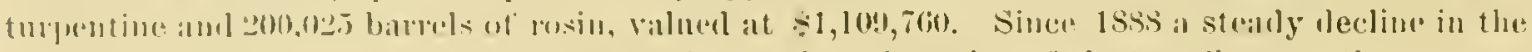

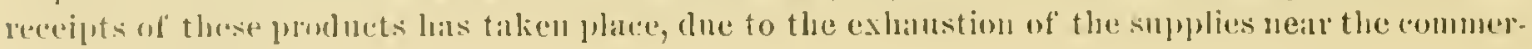
cial hijwlitys.

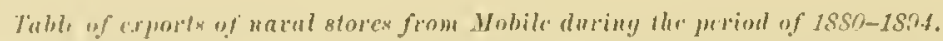

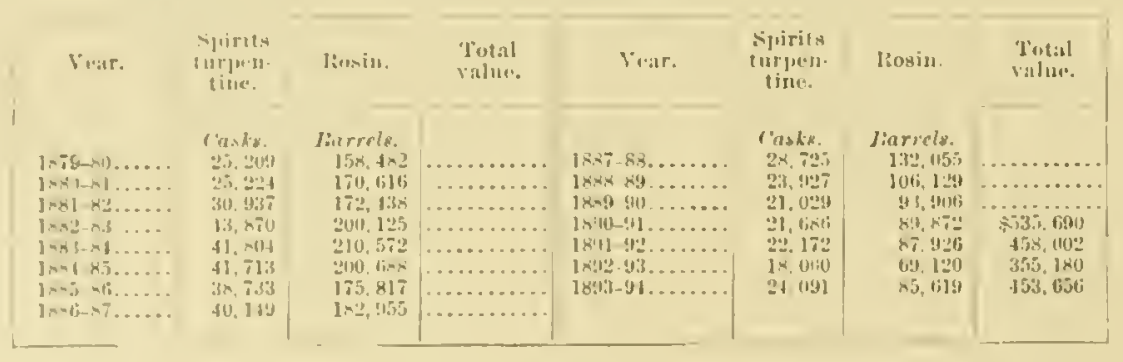


TIE C"F.TIAL, PISE IBFIT OF ALABMA.

The middle portion of the state is crossed from its eastrom lommary nearly to its western, with aldecided northern trend along the westron londer, by a belt of drifted loamy sands, pebbles, and light boams corered in the matern and central parts with an almost continums forest of Longlati l'ine, interrupted only by strips of hard wool which ocouply the bottom lands. In its eastern ratent the Lomgleaf l'ine beromes assoniated with uphand oaks, hickories, ant Shortleaf Jine, the

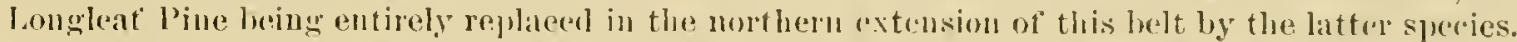

This region of glatrelly hills, as it is designated in the agrientural reports, ${ }^{1}$ is 200 miles in length, 5 to 35 miles in widh, and extends orer abont 22,000 square miles. In the sections where the forest consists almost exchusively of lomgleaf l'ine the stand of timber is heary and of fine quality. Operators claim tor these timber lamds a yielol of from 5,000 to 6 , 000 feet of merchantable timber to the acre, excluding all trees under 12 inclues climeter.

Ever sinee the opening of the great raiload lines leading fo Northern markets the manfarture of lumber in this central pine belt has been earried on with mabated aetivity. In 1850 mot less than $80,000,000$ feet, board measme, were transported by the Lonisville and Yashiville liatilroal alone, mostly to the great Northwestern center's of commerce. In $18 \mathrm{~s}$ (i the production declined to $50,(10,000)$ feet. At present most of the older mill sifes liave been alnandoned and a few new ones established in other localities. Colonel Warlsworth reports 12 mills in operation located along the Lonisville and Nashrille Lailural, with an output of a little over $40,000,000$ feet al year on the arerage of the prast few years. Th this is to be added the produetion of the few mills on the Alobile and Birminglan Railroad, which will increase the present production in the central pine belt to about $5(0,000,000)$ feet a year.

TIIE FORESTS OF IONTILEAF ININI IN NOITHI MLABAMA.

Forests of Longleaf l'ine prevail with mole or lessinternption in the basin of the Coosa liver, principally on the beds of fluty pebbles and light, sambly lom which follow the npper conrse of the river from the base of the Looknt Momatin lange near Gadsclen to a short distance beyond the State line in Floygl County, Ga., where the longleal Pine thuls its northern limit in abont 34 o north latitude, at an elevation above the sea of alsont bon feet. With the reaplearance of the above deposits south of Callom Comty the pine forests extend on the eastem sidle of the valley south to Childersburg. On the isolated ridges of old Silurim sandstone (Potsdan), and the metamorphic region adjoining, the Longleat line is seattered and stmited and is not found at a greater height than 1,000 feet above the sea. In proximity to the mineral region the rugged hills and mountain sides have been completely demuled, the pine having heen "ut for chareoal to supply the blast furnares. In the ralleys the forests of Jongleaf Pine are of average density and the timlur. is considered of excellent quality, partinularly in the northern part of the valley in Etowah and Cherolee comties. On the lower hith the timber is less abundant and somenhat inferior in size. The measurements of five trees fielled in the hilts near lienfrue, Talladega Connty, can be said to fairly represent the average quality of this pine timber. The undergrowth in the open forest covering the low ridges and thr narrow valley's is dense, consisting of Blackjack, Spanish Oal, Pigmut, and Bitternut llickory.

Mecsurments of fire tres.

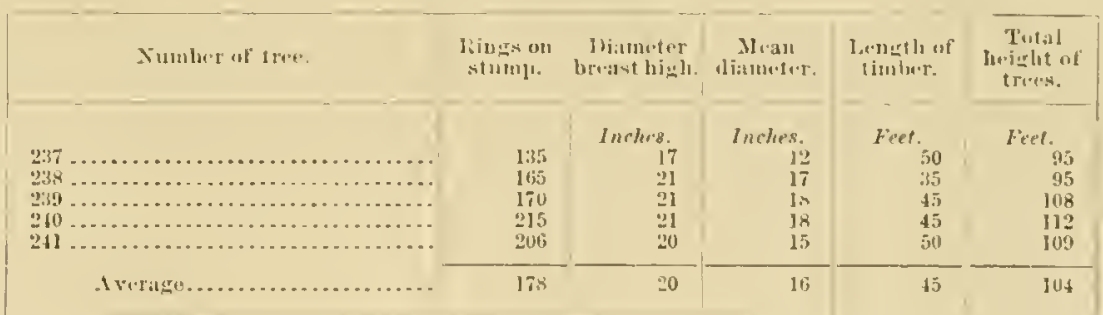

'E. A. Smith: Agricultural lescurees of Alabama, Vol. V. Reports of Ceological Survey of Alabama. 


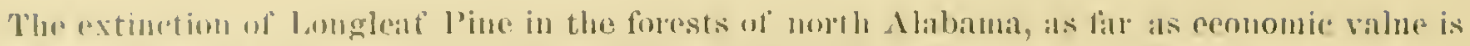

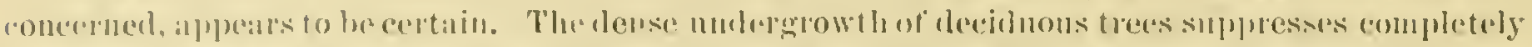

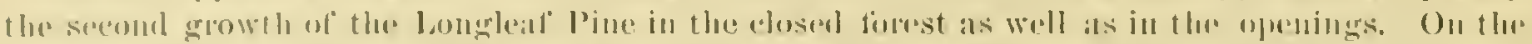

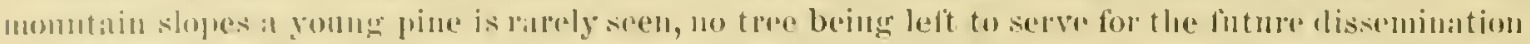
wit the speries, and the few sondlings sporadieally springing up are invariably destroyed by the tiring ol the herbage ane yeall after another.

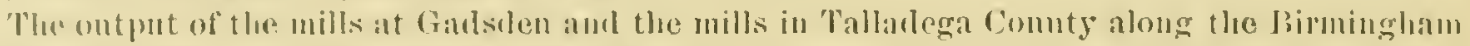

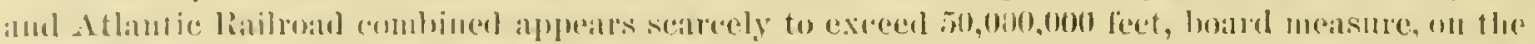

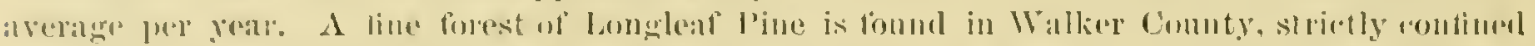

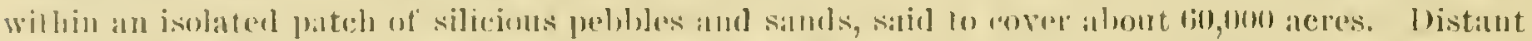
almot 10 miles fion the nearest railonal this forest has beon but slightly invaded, and that to serve al sulall local demamil.

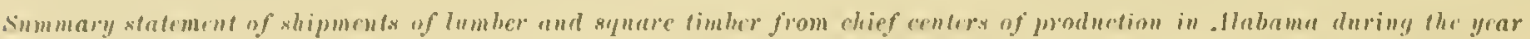
$189 ?$

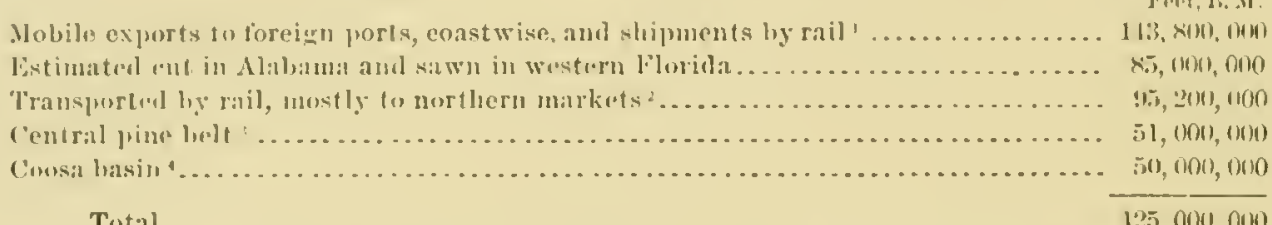

Mississippi.-What has beren said of the forests of the matritime pime helt in Alabama applies in general to the sume redgion in Mississippi. The coastal plan ahove the exteusive grassy marshes

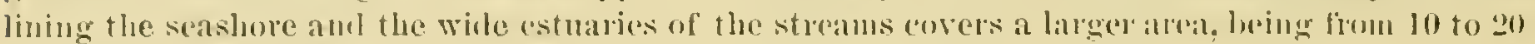

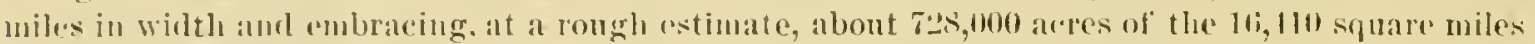
within the limits of the pine belt. 'The broal, seateely fereeptibleswells, with a soil of sandy

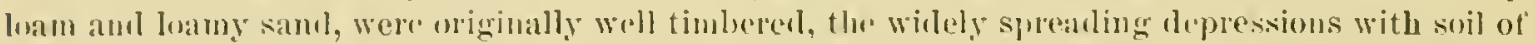
finc, compandes sand, ponty dhained, bearing a sparse and inferior timber srowth. The timber

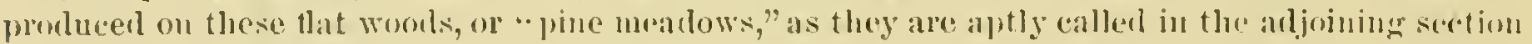
of Alabana, heing of slow growth, is hard and of line grain, frergnenty with the libers of the youngur woul antorted and of varied tints of color. 'This so-alled curled pine is susceptible of high finish and is much appreciated for fine calhinet work. There is comparatively little valuable timber left in this cuastal plain. The remainder serves bargety for the making of eharconal and rord wood for the New Urleans market.

The rolling pine lands, rising sndlenly above the plain, al most exelnsively covered by the Lung-

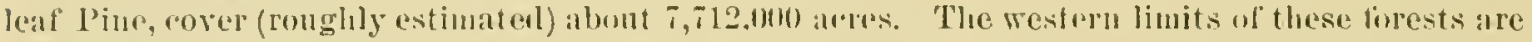

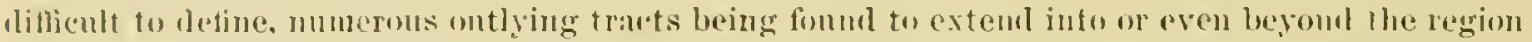
of the loamy lrills. 'The region of mixed growth, characterizing the mper division of the maritime pine leet in Alabanna, enters the State in the shape of a triangle, with the base along the Alabama

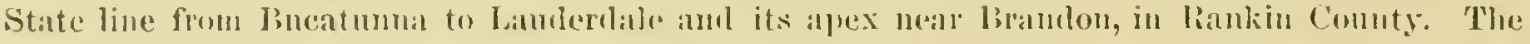

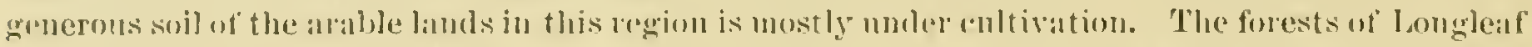

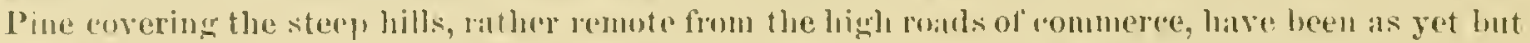

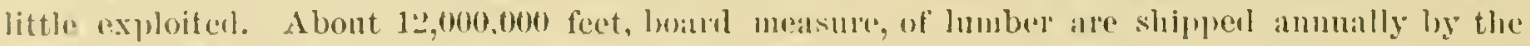
way of the Mobile and Ohio liailroat, mostly to Mohibe, from this region of mixed erowth.

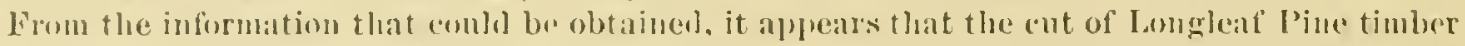

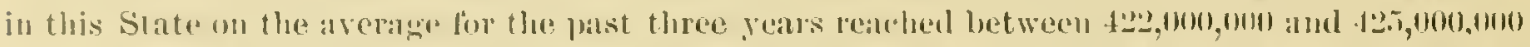

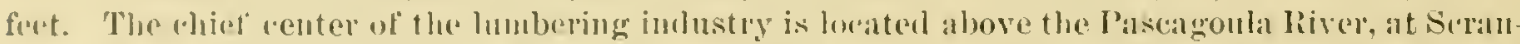

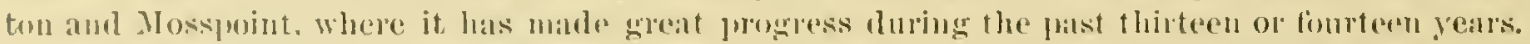

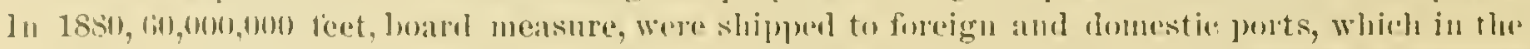

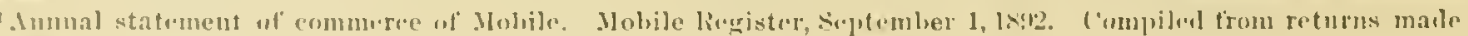
lo the Molile lsoand of "Trate.

Pronluction of mills sonth of Montemery, etr.

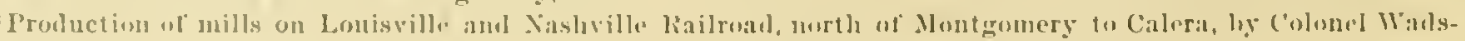
wo:tl.

Productiou of milly ou Śouthern liailway, norıh ot selma to stantou, by M. Ilausou. 
year 1892 had increased to $127,100,000$. Comparatively much larger increase is noticeable in the shipments ly rail to inlant markets. By the reports comteously furnished by the auditor of

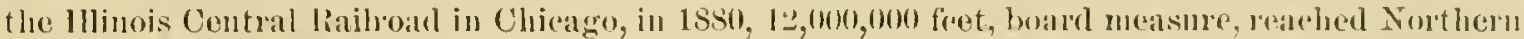

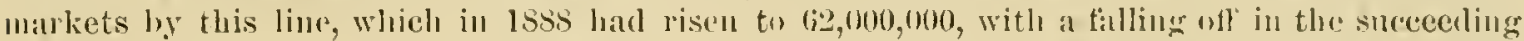
year to $5:, 000,000$. In 1592 the shipments increaserl again to $85,240,000$, and reached in 185,3 1 s1,424,0101 feet, board measme.

With the oprening of the New Orleans and Northenstem liailmal, in 1s5:3, the lumbering

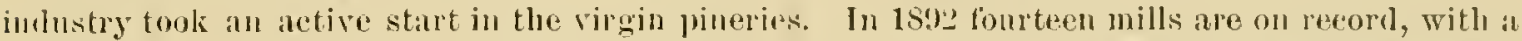
daily capacity of not less than 400,000 feet; this amomit corresponding fully to the actual ontput for 1891 as well as 1892. Arcorling to Ar. Rich, of Richburg, in conseguence of the depression luring the year 1893 , the output was reduced about one-lialt.

The following table of partial data regarding anmal shipments, made during the thirteen years ending with 1803 , from the "hief centers of production show's elearly the constant increase ul the lumbering industry since the close of the year 18si):

Tabular statement of lumber shipped annually by water and by rail from the centers of production in Mississippi, 18r?-s0, $1883-33$.

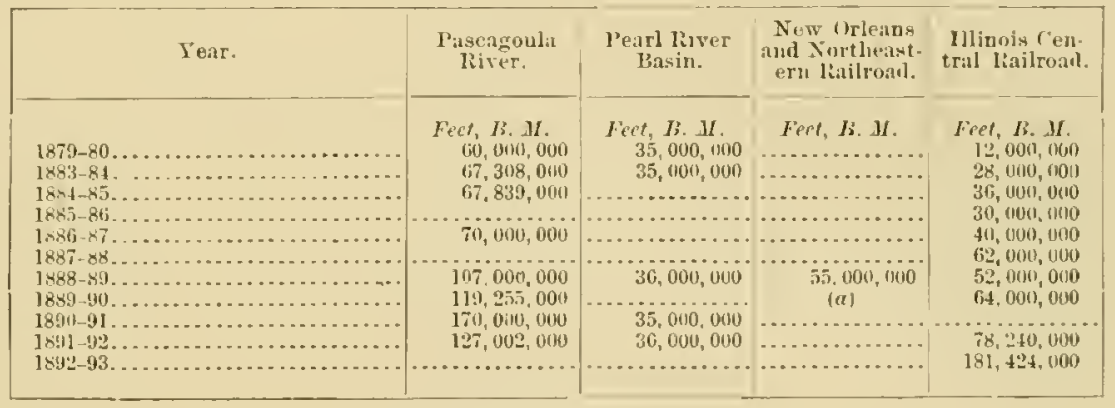

a From $60,000,000$ to $90,000,000$.

RECAPITELATION FOR 1891-92.

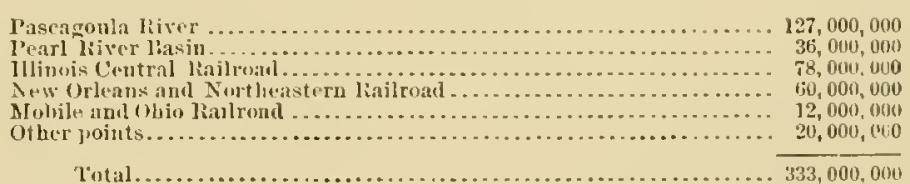

From this amount are to be cledncted abont $19,000,000$ feet of lumber received from Mobile to complete cargoes, and 12,000,000 feet of timber ent on the westem frontier of Alabama ant findinir an ontlet at Paseagoula by the Eseatawpa River, leaving a round 300,000,000 feet. board measure. for the cut in Mississippri in 15!2, against 108,000,000, the cut reported to the census in 1850 .

With the exhaustion of the forests along the P'ascagonla and Lscatampa rivers and a fow points between these strenms and the Peall liver, which had been accomplished before the begimming of 18s0, the naval-store industry lemained almust dormant in the State until it began to receire a new start by the opening of the New Orleans and Northeastern Railroad. The prodnetion of the distilleries along this roal can be said to average about 15,000 casks of spirits of turpentine and 75,100 barrels of rosin annually since 1890 , which are mostly disposen of in the New Orleans market.

Letstern Lomisiana.-Forests of Longleat l'ine cover the upper part of astern Lomisiana to the extent of abont 3,850 sunare miles. Their western limit might be said to follow the Amite liver, Int can not be clearly detined, since these forests toward the west pass gralually into the mixul growth of Shortleaf Pine, waks, and hickories on the uplands whild border the loottom linds of the Mississippi liver. Slightly muluating that weods cover finly one-fifth of the area, and, with a somewhat loamy, porous soil, support a hetfes timber growth than is gencrally found in the flat fine barrens of the plain. Owing to their proximity to the coast, these forests have been exten. sively invaled. The pine hills embrace abont 1,619,200 acres. Their forests have remained al most

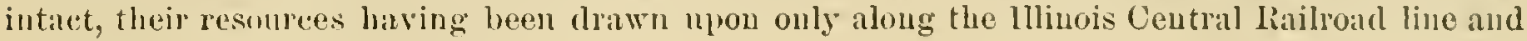
the tributaries of the Pearl liver. 


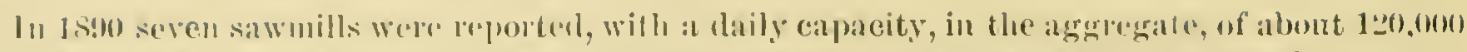

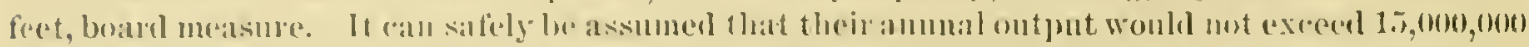

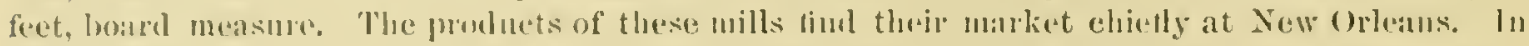

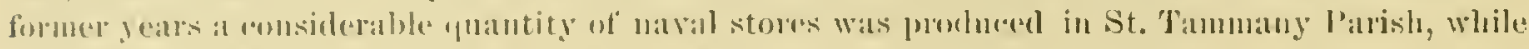

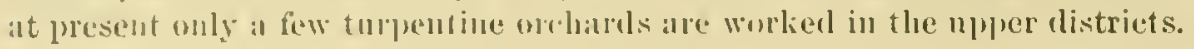

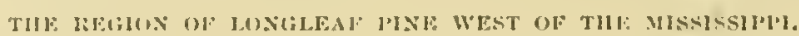

The importanee of the pine forests in the western ciulf resiom can not be overestiuatent.

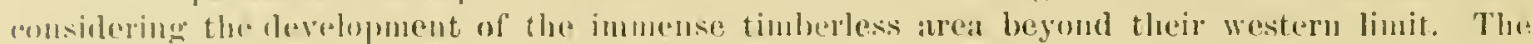

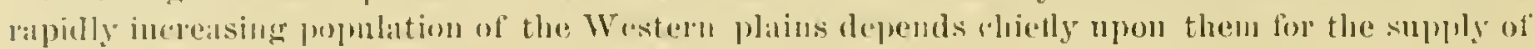

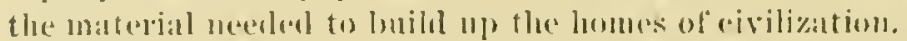

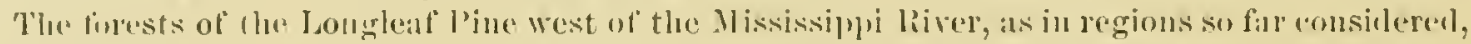

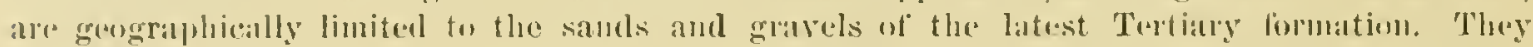

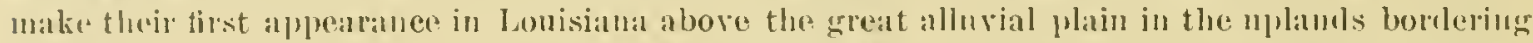
lhe valley of the Oualhita am follow its comse for fol miles, then extem west. skirling latie

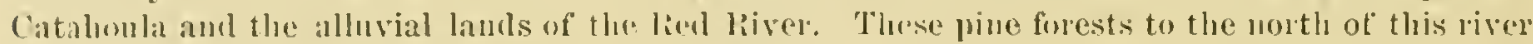

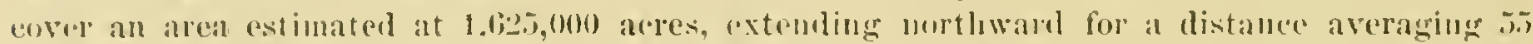
miles. Jowad their northeru limit the forests pass grablually into a mixed growth of deedruons fres and shortleat l'ine. In the center of this region the pine ridgas alternate with tracts of

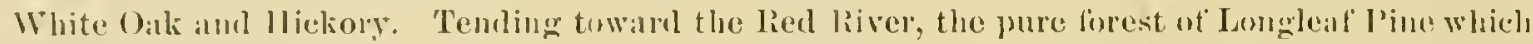
covers the muhlating uplands is mubroken and las up to the present leen but slighty invangel ly the ax. (O) the low hills of this northern division of the pine belt of northwestern lonisiana

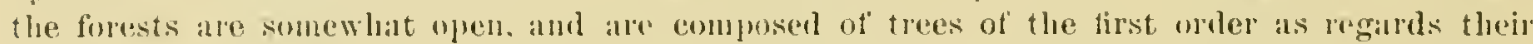

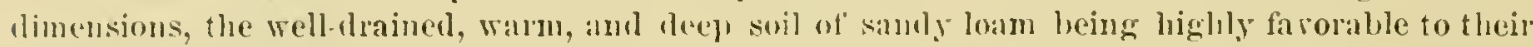
levelopment. This fact is clearly shown in the following statement of the ages and dimensions of six trees fielled for test logs:

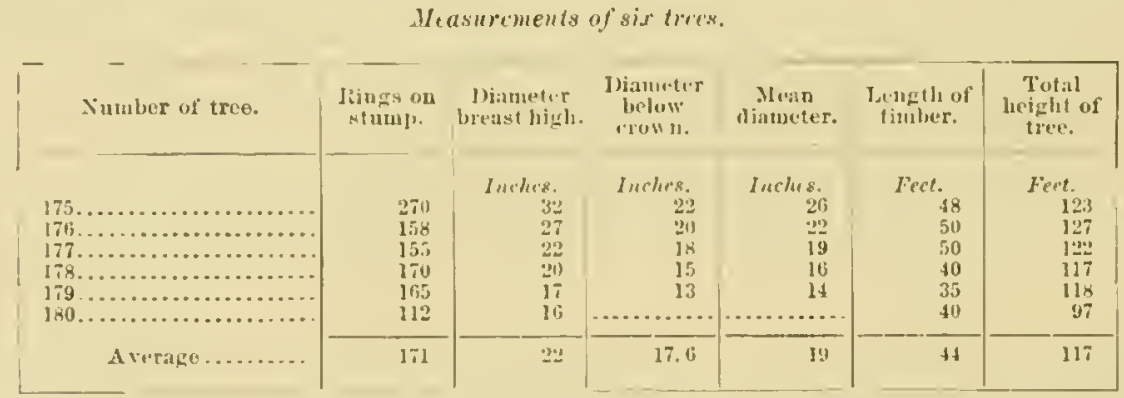

Upon 1 ace of the same plat, with the timber standing matler above the average, 35 trees were foumd. Of these there were 14 of 24 inches biametef at breast high, estimated length of timber, ti) feet; li of 1!) inches dianoter at hreast high, estimated length of timber, fl fect; !) of 17 inchus diameter at breast high, estimated length of timber, aj feret; 9 of 13 incles dianeter at breast high, estimated length of timber, 30 leet.

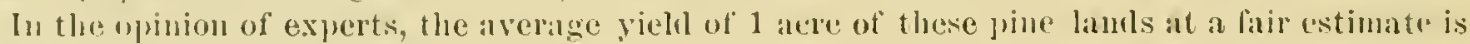
unt less than di,000 feet, boiml measure.

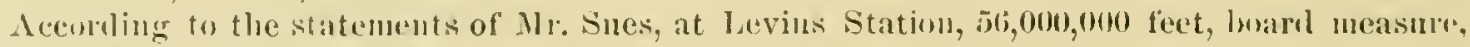
were shipped, in $18 \% ! 2$, from the mills of this section.

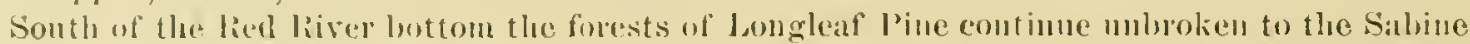
liver" and sonth to the trecless salvanas of the coast in Calcasien Parish, their easteru bumulary parallel with the eastern bommlary of that parish. liomghly estinlaterl, these forests cover an areal of abont "2,665.000 acres. linom the matshy lowlands of the const to the ujper tributaries of the Cilleasion lavere, "p to Ilicliory and beckwith ereeks, the conntry is poorly drained, almost pertectly level, with a lighly retentive and somewhat impervions ray subsoil. In eonsequene. these pine flats are, for the grealle fiat of the year, more or less covered with water. These low, wet pine forests wre stripperl soma yours ago of all their merelantable timber, and only at comparatively small mubel of trees of less than 12 inches in dianeter were left standing. On 
these abamboned timber lands a young pine is rarely seen, the seerls shoul in the fall heing apt to rot in the water-soaked soil, or, if they happent to germinate, the scellings ano drowned duriug the winter rains. On the lands rising gently alove the flat wooks, with tlac rirges still low and wide and nften more or less imperlectly drained, longlent pins is lomml of an exceedingly fine growth. 'lhe tress in the dense forest are tall aml slemler, and their timber is equaled wnly by the timber of the sume elass growing in the valley of the Noehes livor, in 'lexis.

The following measmrements of five trees felled for test logs in the forests in tha mper part of Calcasien P'alish, between llickory and Beckwith creeks, will serve as a lair representation of the timber growth on these low, broal rilges:

Measurements of fire trees.

\begin{tabular}{|c|c|c|c|c|c|c|}
\hline Number of tree. & $\begin{array}{c}\text { lings on } \\
\text { stump. }\end{array}$ & $\begin{array}{l}\text { Diameter } \\
\text { breast ligh. }\end{array}$ & $\begin{array}{l}\text { lianeter } \\
\text { bulow } \\
\text { crowus. }\end{array}$ & $\begin{array}{c}\text { Mrean } \\
\text { diameter. }\end{array}$ & $\begin{array}{l}\text { Lemgth of } \\
\text { timber. }\end{array}$ & $\begin{array}{l}\text { Tolal } \\
\text { tretelit of } \\
\text { trete. }\end{array}$ \\
\hline 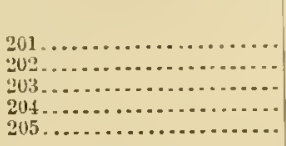 & $\begin{array}{l}196 \\
195 \\
190 \\
180 \\
167\end{array}$ & $\begin{array}{r}\text { Inches. } \\
28 \\
23 \\
21 \\
19 \\
16\end{array}$ & $\begin{array}{r}\text { Inches. } \\
93 \\
16 \\
14 \\
15 \\
13\end{array}$ & $\begin{array}{r}\text { Inches. } \\
\text { y4 } \\
1 ! \\
17 \\
17 \\
14\end{array}$ & $\begin{array}{l}\text { Fert. } \\
50 \\
50 \\
40 \\
41 \\
37\end{array}$ & $\begin{array}{l}\text { Feet. } \\
119 \\
127 \\
117 \\
102 \\
127\end{array}$ \\
\hline Average. & 1.4 .3 & 21 & 16 & $1 \%$ & 43 & 118 \\
\hline
\end{tabular}

Upon 1 aere, selected on the back of a low swell which miglit be said to represent the average of the timber standing, $4 . t$ trees in all were comber. Of thase, 3 trees measured 2.5 inches diameter at breast high, with a length of clear timler estimated at sol fet; 6 trees measured $2: 3$ inches diameter at breast high, with a length of clear timher estimated at io liet: 19 trees measured 18 inches diameter at breast high, with a lemgth of clear timber astinatul at 40 lret; 14 trees measmed $1 \pm$ inehes diameter at breast high, with a length of clea timber estimated at 3 fi feet, corresponling in the ageregate to somewhat orer 1.j,000 feet, bourd measure.

On another acre consilered firit rass, rather level land, the soil fresh to wet throughomt the yar, 72 trees were connted. Of this mmber, $1+$ were tomm 2 inches dianeter at brast. ligh, with an estimated length of timber of an feet; 5 were lomml 24 inches dianeter at breast ligh, with an ustimated length of timber of 50 fert; 13 Were found 23 inches diameter at breast high, with an estimated lengtl of timber of so feet; 8 were fonnd 21 inehes diameter at breast high, witl an estimated length of timber of 40 feet; 10 were foum an inchus diameter at breast ligh, with an estimated length of timber of 40 feet: 11 were fomm 18 inches diameter at breast high. with an extimated length of timber of 10 fect; 11 were tomul 18 inches liameter at breast hicrl, with an estimated lengrth of timber af 36 teet.

According to these fignres the timber standing on this acre wond anomit to not less than 3.5,000 feet, board measure.

The chief site of the lmmber industry of western lumisiana is at Lalie Charles. Aecorling to the information furnished by irr. George Loek, of Lockport, La.. the annual ontput of the

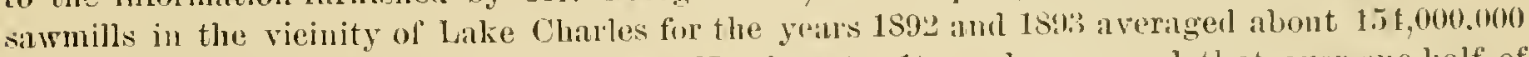
feet, board measmre, all shipped West and Northwest. It can be assumel that over me-lialf of the lumber sawn at Orange, in Texas, is ent on the eastern banks of the sabine River, which anomint has to be credited to the ent of Lomisian:ı.

Summary of the production of Longleaf l'ine lumber in the State of Lowisiana in 150 ?.

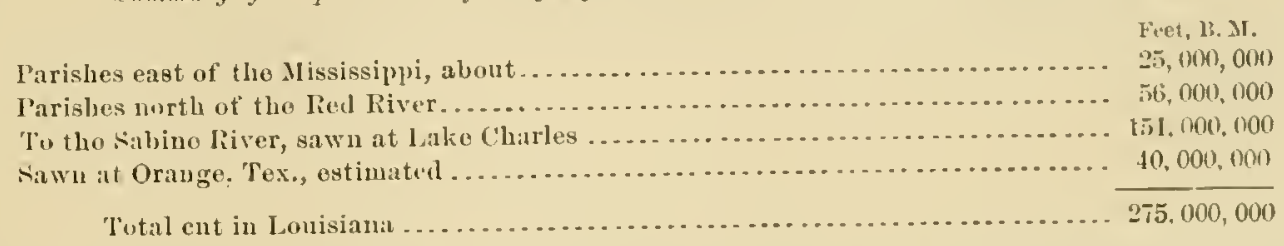

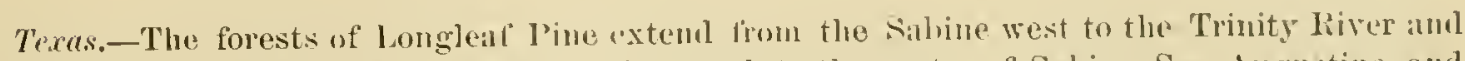
from the grassy savannas of the coast region north to the center of Sabine, Sin Augustine, and 


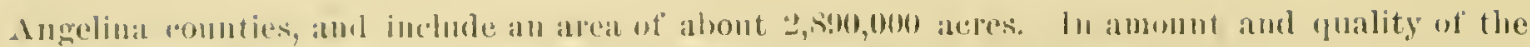

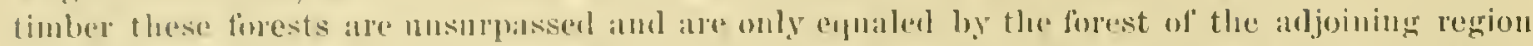

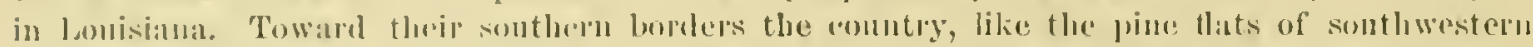

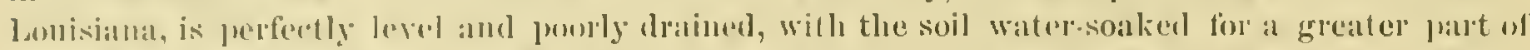

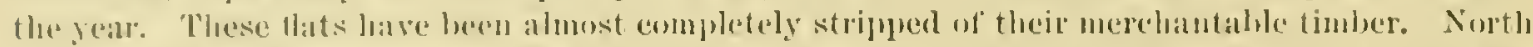

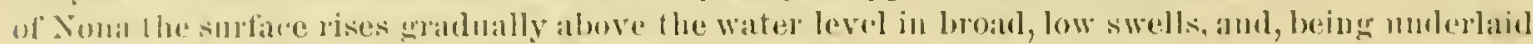
by strata of stitl loams, is more or less defiejent in drainage. Tlue intervening wile thats alre frequently averes] with a donse growth of large shrubs and small-sized trees, consisting of

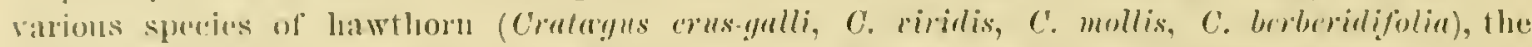

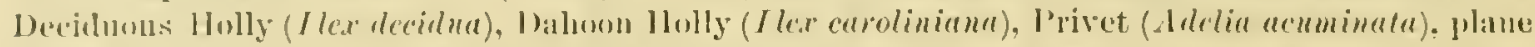
trees, and maternolias. These impenetrahle thickets are common, and often corer many seflare

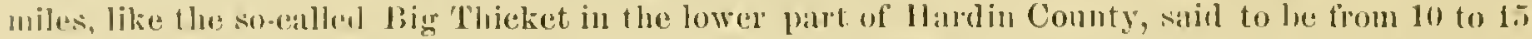
miles wide, either way. The growth of longleaf l'ino which eovers the gentle, widle swolls, is drose, uf line proportions, and of remarkably rapid development. The average age of tive trees felled northwest of Nona, I. fo 25 inches in diameter, is but little over one lumdred and tifty years, as the following measmements show:

Measurements of fice trees.

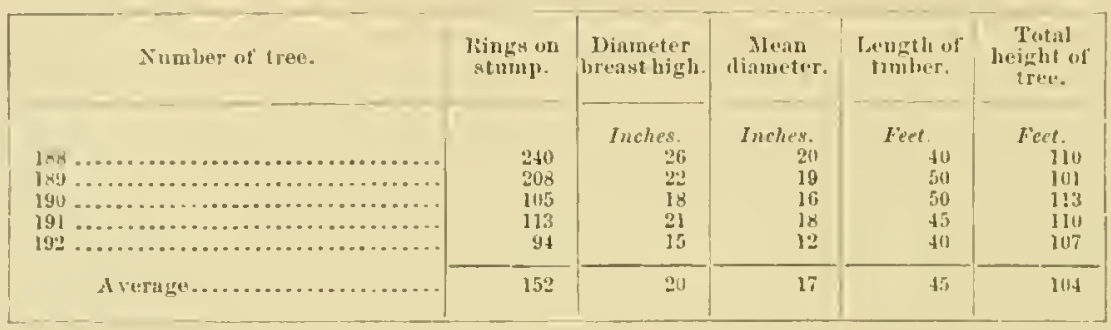

In this region, owing to the direct commmication of several railman lines with the grent

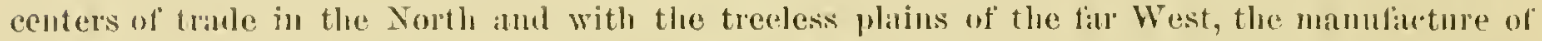
lumber has made a wonderfin progress during the past twelve years. In lsso the cut of langleat" l'ine in this State has been estimated at $66,450,000$ feet. From information reneived fiom praties

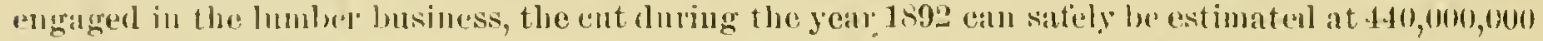
feet. The renters of lmulor probluetion are Grange and Beamont, luat a great anomint is cut at the mills along the several lines of railway passing through this region.

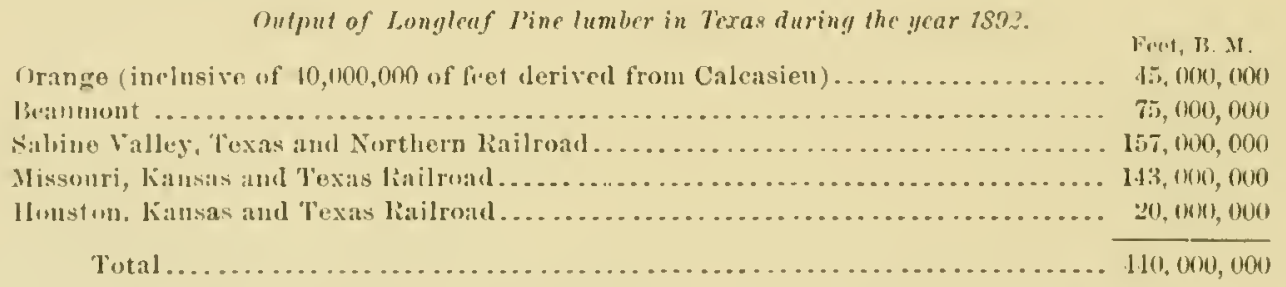

For the reneral of the forests of lomerleal Pinc in this regrion there is as lit the hope muler their

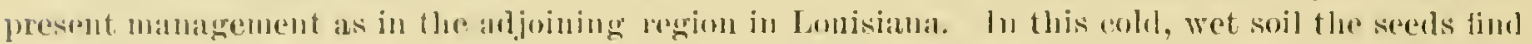

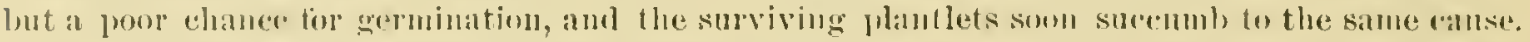
In the pine llats seedlings are rarely obselved amoug the tall brom sedge grasses (A ulropmym)

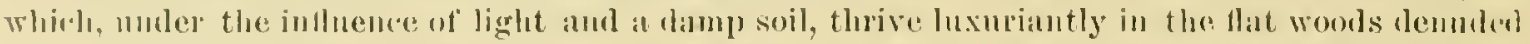
of thein timber growth, imparting to them the aspeet of waving mealows or salvanlas.

lRODI'C'I'S.

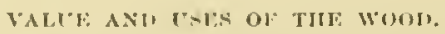

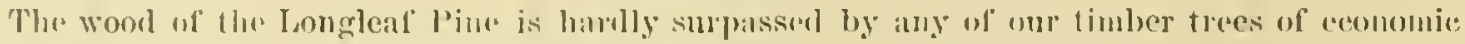

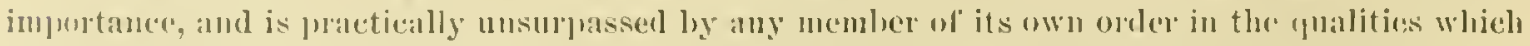
are reyuired for purposes of construction, thus taking the fiest plate anomer its congeners. 
The timber from the damp llat woods of the coastal plain east of the Mississiploi Rivele, with

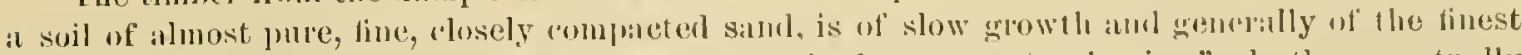

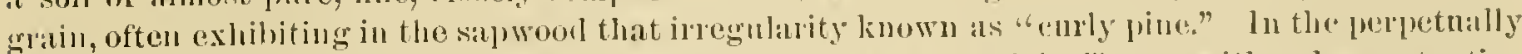
famp to wet soil of the pine flats in sonthwestern Lomisiana and in l'exis, with a deap retentive snbsoil richer in nutritive elenents, ansing a better and puicker development of the tree, the woul is of a mole open main. Owing to the exeellent qualities ol the wool ol lungleat" l'ine, its use in the varions meshancal arts and industries is as extensive as it is manifold. lts greatest value rests in its adaptability for heavy constructions-in naval arohiterture, for masts and spars; in civil engineering, for the building of hrilges, vialucts, trostlework, and lor supprests in the constrnetion of bnildings. Lajge yuantities of long and heavy slicks of square timber sawn ol hewn dor surh purposes are shipperl to the British ports and to the dockyols of the lingopean continent, witl a constantly increasing demand.

In the building of railroal cars, where great strength aml elasticity is needed, the timler of Longleaf l'ine is preferred to any otler. For this purpose sticks from :36 to t"2 feet, 10 by 12 inches, are required, free from blemish.

luormms yuantities of the younger timber of this tree are cut every year to serve tor crossties, user by the railroads not only in the pine regions, but in other parts ot the ewuntry. The lenand for these ties forms a constant and increasing dralt upon the forest. The ties leliveren are, on the average, $8 \frac{1}{2}$ feet long, 9 inches wirle, and 7 inches thick, and must be all heartwood and free from blemish. The trees selected for this purpose are from 15 to 16 inches in diameter, anl preferably ouly the butt ents are accepter. On an avelage 10 cross-ties are cut from 1 alere, each tie representing a $l o g$ which would make at least 75 superficial feet of lmmber. Since snel a tie, realy for the roadbed, contains not more than so feet, board measme, it will be readily secen what an enormous waste results fiom this practice.

On the danp, sandy tracts of the lower Sonth, such ties will last five or six years, and 3,000 ties are needed for 1 mile of roal. Hence, for the construction of the 3,210 miles of railroar

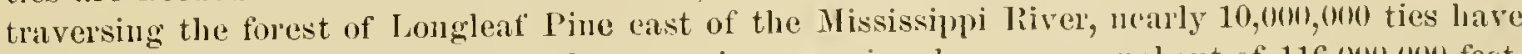
ben required, which being renewed every sis years involves an annmal cul of $116,0010,00 n$ feet, board measure, to which must he added the amount exported to other regions.

In the Sonthern States, the West Inclies, many places on the coast of Mlexico, and Central and South America the lumber of the Longleaf Pinc forms the rhief, if not the only, material in the eonstruction of houses. For similar purposes considerable quantities are of late years shippel to PTorthern markets, East and West, replacing in many cases, at least in parts of the buildiugs, the lumber of the White Pine, on accomnt of its incleasing scareity. The tine grained and "eurly" varieties of longleaf Pine lumber, by their beanty and the high polish of which they are susceptible, begin, of late years, to take a place among the higher-priect kinds of wood for ornamental insicle work.

The importance and value of Lomgleaf Pine lumber as a material for constructions can not he better evidencerl than by the fact that little less than 1,500,000,000 feet, boand measure, or ahont one-third of all the lumber mannfactured in the Sonth, is being exported from Sontheru ports anumally to domestic and foreign ports, besiles furnishing almost the only material used at home in the construetion of llwellings and all kinds of buillings. It also supplies material for furniture, als well as fuel, both in the form of firewom and chareoal, and its exploitation aftorks the means of subsistence to thomsands.

Lighturorl. Whenever the sapword of the tree is laid hare copions exudation of resin talies place and the surounding woot becomes charged with it. Thus the wood of the trunks of the trees tapped for the extraction of their resin som becomes charyed with this along the stallifed surfice, and, as with the evajoration of water liom the dead woorl, the resinifieation proceeds and the wood inereases in weight and dumbility. In low, danp places particularly this process takes nate more extensively. This resin-charged wool is termed lightwoul. 'The lightwoml timber, considered very durable when exposed to alternating conditions of moisture and dryness, is murl preterred for posts, etc. Leing highly inflammalole, it serves for torrhes and lindling, and lience its name. Of late yearis a protitable industry las been started to ntilize the resinous stumps of abaudoned orehin!els as kindling material by cutting the same colose to the giouml and then, veneer 


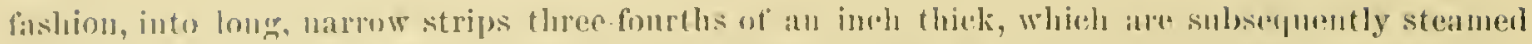

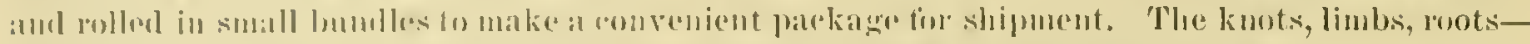

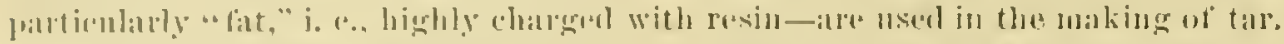

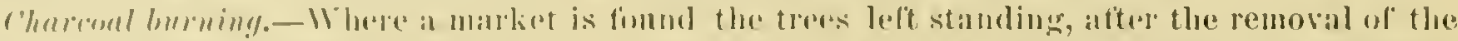

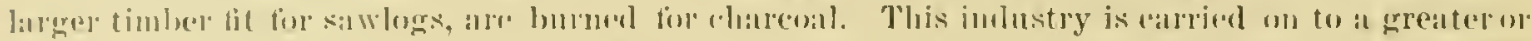

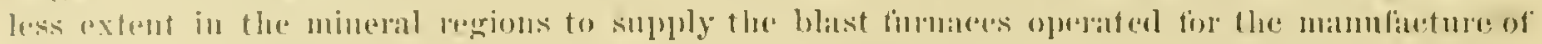

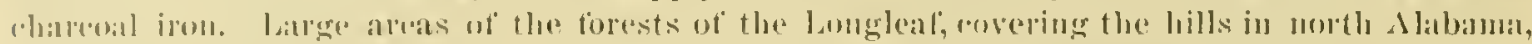

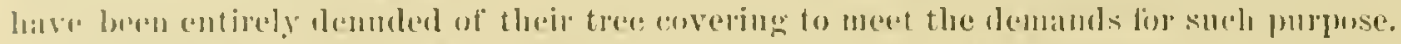

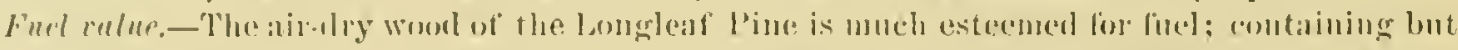

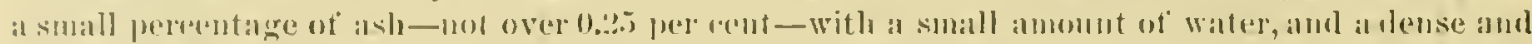

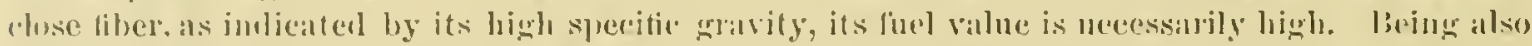
astily jutlammablr, jt js pretermel where quick and jutenso hout is renuirerl, as, for inslance, in

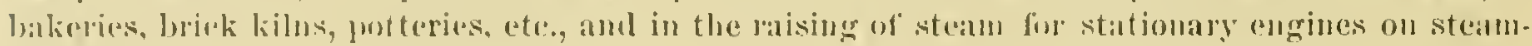

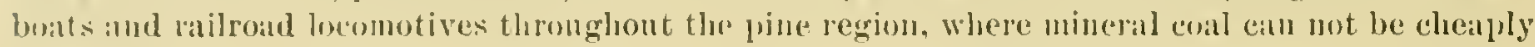
ubtaincel.

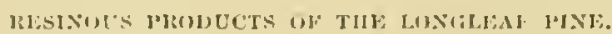

It call sifely be asserterl that amoug the trees of the sane order there is foumd no other

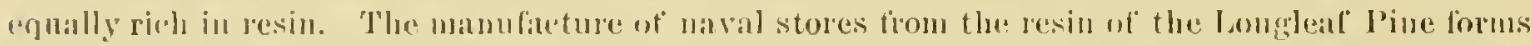

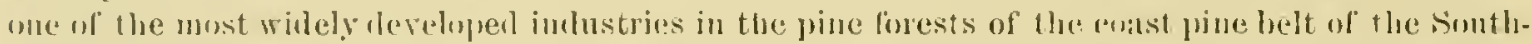

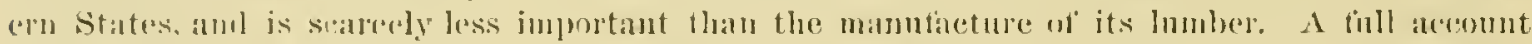

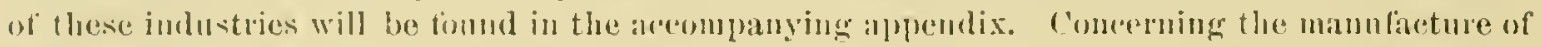
lal: piteh, tal oils, and utler pumbets o[ destructive distillation of the woul an of rosin oil, see the liejurt of the Chiet of Forestry, 1s!!', page :35i, etc.

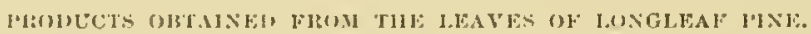

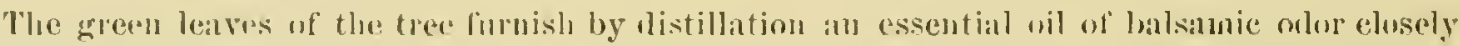

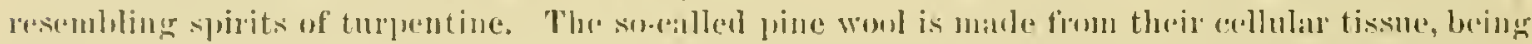

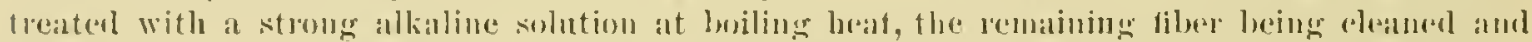

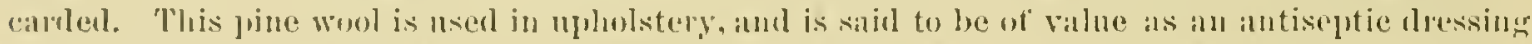

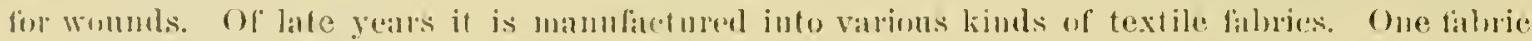

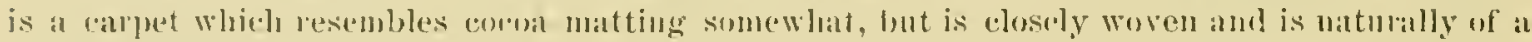

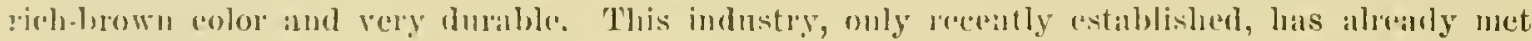

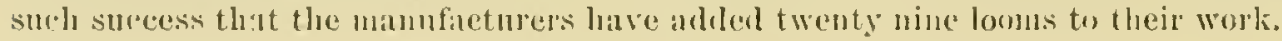

\section{NOMEYTIATLEE AND CLASSIFICATION.}

'This tree was first lescribed by Miller in the year 176s under the name of Jinus pulustris.

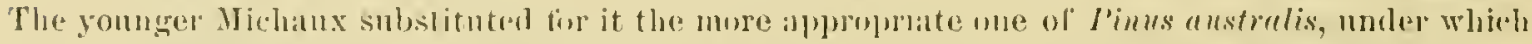

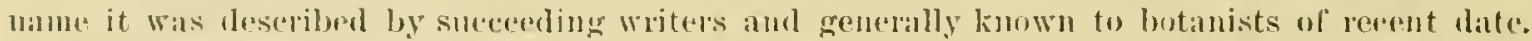

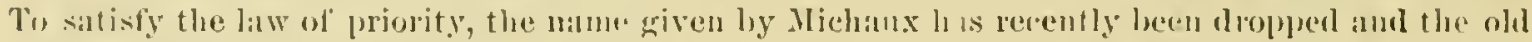

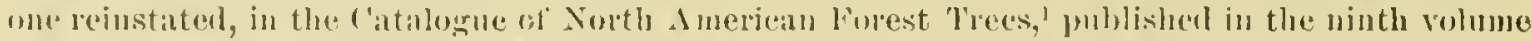

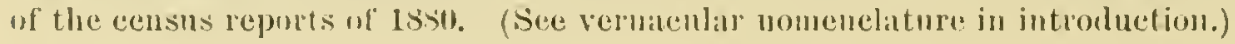

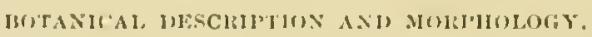

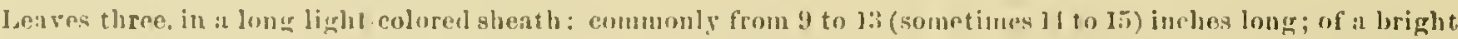

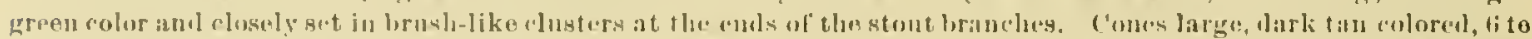

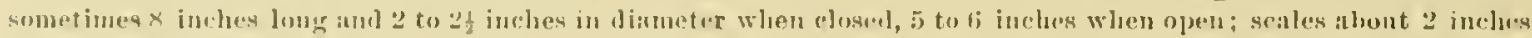

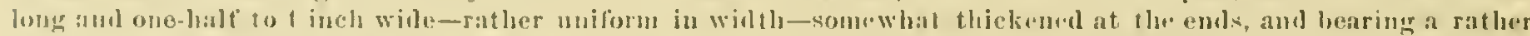

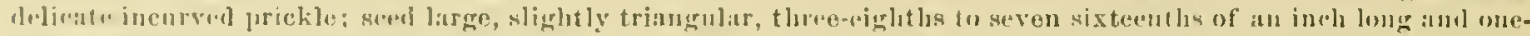

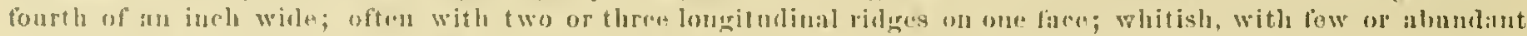

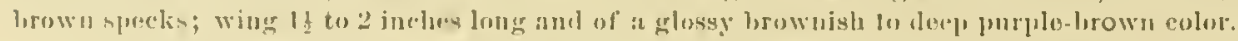

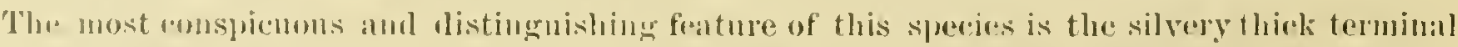

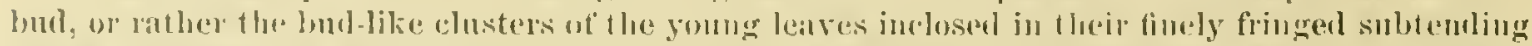

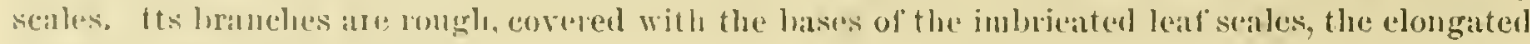
silvery fringes having lallon oull.

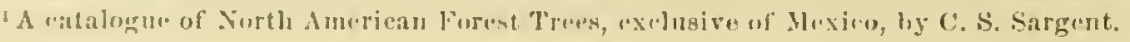


JOOT, STEM, A.И HRANCH SYSTE.M.

The Longleaf Pine attains a height averagiug 100 feet, rarely exceeling 110 feet, with a diameter breast high, when tully glown, varying between 20 : unt :36 inches, ranely mole. The tall, straight, very gradually laperiug truuk arises from a massive tapmot which, in litrolable sitnatious, penetrites the soil to a depth of from 12 to 15 deet, and sometimes much more. It lass several stont, comparatively short lateral mots, which assist the tree in its loblu by slant. ing deeply into the gromul, and some of greater length are placed mure or less near the surfarer. Its erown is open and elougated, of irregnlan shape, abont one hall to one thind of its leeight. The stout limbs are larely over 20 feet in length, twisterl and gnaled amb sparingly blancherl. The trunk is covered with a redlish-brown bark, one-fimrth to three-lourths of an inch thick, furrowed throngldont its finl length, crossed horizontally by deep fissmes, and sealing oft" in thin, bluish, almost transparent rhombie hakes.

L.HVIES AND THEIR MOHFICATIONS.

Like all the pines, this speries produces during varions stages of its growth seven different modifications of leaves as recognized by botanists, all more or less slectic in character:

(1) Cotyledonary, or seed leaves (hirst leaves of the embryo), which soou wither aurl disappear (Pl. VII, $a, b)$. (2) Primary leaves sueceeding the former immediately on the main axis (Pl. VII, c), which either wither or later on are transformed into, or succeeded by, more or less permanent bracts or seales eovering the branches (Pl. V, a). (3) The secombary or toliage leaves rising from the buds prodneed in the axils of the primary leaves or of the bud stales by which they are represented (Pl. VIl, d), permanent foliage of the tree, with three leaves in one sheath. (t) The bud seales forming the sheaths of the folinge leaves (Pl. IV, $b, c, d$ ) at base. (5) Involueral bracts of

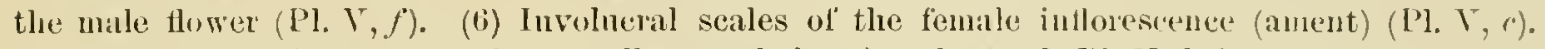
(7) The bracts which support the earpellary scale bearing the seed (Pl. V, h). ${ }^{\text {t }}$

The prinary leaves, which suceed the cotyledons on the primary axis, are in form and structure true leaves. They are solter than the final foliage leaves, have a broan base, alle rounded on the dorsal side and not chanueled, the whitish transparent margins being tinely but distinetly denticulate. It is rare that secondary leaves proceed from the axils of these chlorophyll-bearing primary leaves. With the wore frequent alpearanee of the ordinaly leaves, these primary leares wither and henceforth appear as triangular seale-like eoriaceous persistent bracts, with broad, hyaline, long-fringed edges, in the axils of which the undeveloped branchlets are produced bearing the secondary or foliage leaves.

The chloropliyll-bearing pimary leaves exhibit a simple structure. The fibro-vasenlar bunle is single, embedded in a wider ring of large cells free from chlorophyll, and the resinous dncts fewer in number, one, or racly more than two, being iregularly situated in the elulorophyll bearing parenchymatous tissmes, and mostly external, i. e., close to the thick epielermis. But fert of these leaves are formed atter the appenranee of the foliage leaves, and a ten of them persist thronghont the lirst season. ${ }^{2}$ The eataphyllary leaves forming the sheath of the foliage leaves are in this species composel of eight successive pairs of bud scales; those of the first pair are blunt, flat, deeply concave and coriaceons, with sharp edges; the other's are more membranaceons and with tringed edges, the closely interworen elges entwining the base of thi' faseicle. In the secondary leaves the very numerons stomata form, on both sides, regular longitudinal rows. Parallel with these, at regular distances between them and embedled in the parenchymatoms tissue, are fonml bundles of numerons, elongated, thick-walled cells, the so-called hy prilemal or strengthening cells. The resin duets, not over tive in number, desenibed by Eugeluans as internal, have been fond in the specinen examined rather parenchymatous, invariably so on the dorsal sirle.

Three of the secoudary or trine foliage leaves are united into one bundle, inclosed at the base by a persistent sheath from one-half ineh to au inch in lengthe formed by the but seales or cataphyllary leaves. On the older trees the leaves are rarely over s inches in length, but during the periods of most artive growth they ane found 12 to 18 incles long. They are finely sermlate, ronuded on the back, channeled, and obtusely trimgular in eross section.

1 George Engelmann: Revision of the Genns l'inns. Transictions of the St. Lonis Acaclemy of Scjence, 188.2.

"Eugelmann: Revision of tienas l'inus. 'Trans. St. Louis Acakemy of science, I85'2, p. 5. $17+33-N o .13-1$ 


\section{FXPLANATION OF PtAFF"}

Fig. a, branly showing the termina! spring shoot of the season with rharateristic, large silvery white winter bul; the bumlles of leaves arise from the axils of the leat-lurats af the last two neasous, the first leatres of the second

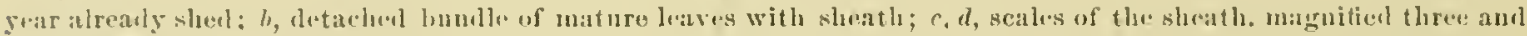

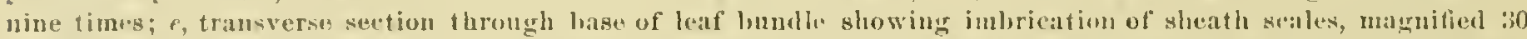

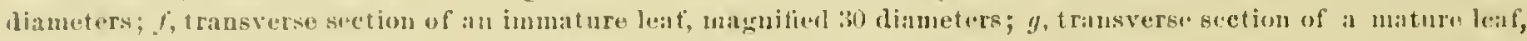

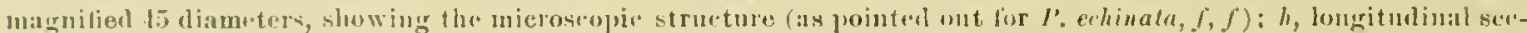

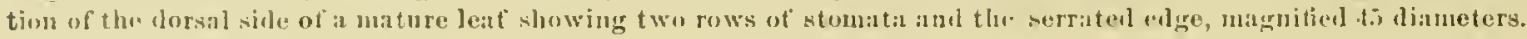



Owing to the shedding of the older leaves at the end of the second year and to the short anmal growth of the axis, the leaves on the older trees ale conspicuonsly crowded into dense tufts or tassels on the tips of the bramehlets.

The high development of the organs of transpiration, as slown by the inmense mumber of breathing eells, clearly indieates that forests of the Longleat' I'ine, and in finct of most evergreens, are not less important than forests of deciduous trees in inthencing atmospherie conditions, particulinly when ii is consillered that in the former, clothed with perpetnal foliage, this function suffers but little intermution of its activity.

FIORAT, ORGANS.

The male and female flowers are sometimes found on the same branch; they are, homever, more frequenitly situated on dillerent buanches, the male fluwer's mostly on the lower (Pl. V, b). The male flowers eonsist of a slender axis, the staminodial colnmu, aronnd which the numerons naked anthers are rensely erowder, forming a cylindrical eatkin-like flower from 2 to 2 inches and over in length, surromuled at the base by a ealyx-like involnere eonsisting of trelve orate somewhat leathery bracts, of which the lowest pair or exterior ones are laterally compressed, strongly keeled, and much smaller. The connective of the dark-rose purple anthers spreads ont in a semiorbicular dentienlate crest; a number of these male fowers are crowded aronnd the base of this year's shoot, forming a dense whorl. After the discharge of the pollen the withererl flowers remain for several months on the tree. The pollen remaining for a long time suspender in the air is often walted to widely distant localities. In the latiturle of Mobile its discharge takes place during or shortly after the second week of March.

The female thowers (see Pl. V, ") are united in a subterminal oval, ereet, short-stalked eatkin, whieh is also surrounded hy an involnce, the bracts being more numerous, longer, more acuninate, and membranaceous than those of the male flower.

The earpellary scales bearing ovules ane oblong oval, tipped with a strong reflexed point, and are almost hidden by the thin llat seales by which they are subtended, which, however, they soon surpass in size. Dning the first year the young cones make but slow progress in their growtl. On the openiug of the secoul season they are searcely over an inclo long; during the summer they inerease rapidly and reach their full size during the latter part of the fall. The cones are placed horizontally on the branches below the terminal bud (subterminal), sessile, slender, conical with al slight curve and from 6 to 8 inches long; of a dull tan color; the thick seales are light to dark chestnut brown on the inside, 2 inches or slightly over in length, and hear on their exposed end, or apophysis, a small but prominent tubercle armed with a short reeurved prickle (see Pl. VT). Plate VI exhibits truly and fully the open cone and especially the fine markings on the apophysis of the seale. The cones are shed in the latter part of the winter of the seeond year, rarely remaining to the following spring. On breaking from the branches they leave the lorrest rows of the seales behind.

SEEDS.

The seeds are strongly convex, oblong, oval, less than a half inch long, aud surrounded by the long oblique wing (see Pl. VI). The shell is whitisl, at the front faee marked by three promi. nent ridges, flat, smooth, ancl darkly spotted on the posterior side. It ineloses an oily liemel, eovered by a white seed cont; rieh in mutritious matter and palatable, the seeds furnish in fruitful years an abundance of mast. They are shed before the fall of the cone during the dry weather, most abundantly during the iatter part of the fall (end of October or November the best time for their collection) and in a lesser degree during the winter. They germinate easily after reacling matnrity, and it often happens, in wet, sultry weather, that they begin to spurout before leaving the cone, in whieh ovent the whole erop is destroyed. This, togetler' with the killing of the flower's by late frosts, seems to be one of the main eanses of failure of the seed crop so frectuently observed. From the behavios of the seed just mentioned and from its olealginous eharacter it is to be inferced that the period of time during which the seeds retain the power of germination under ordinary circumstances is but a short one, but as a matter of fict seeds a little orer a year old have been known to germinate. 


\section{FXILAXATIUS OF PLATLS V ANII VI.}

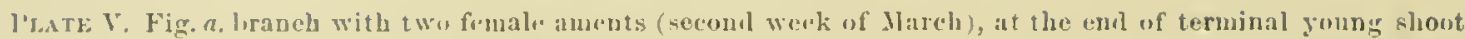

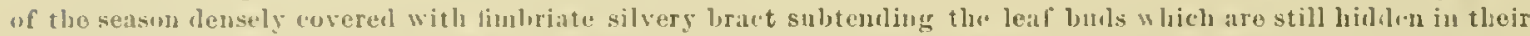

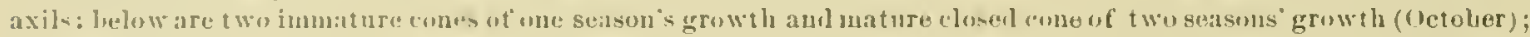

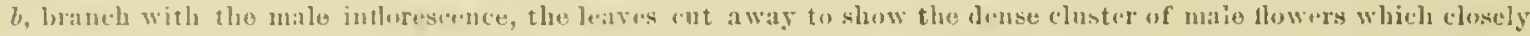

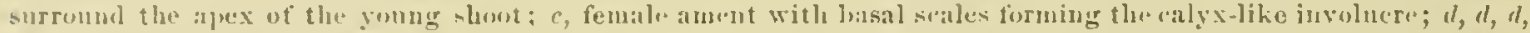

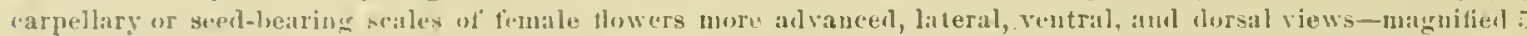

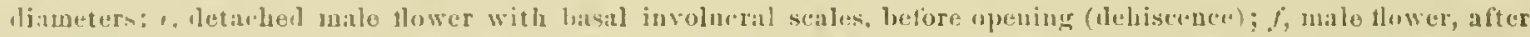
disebarne of the pollen; $g$. threr detacherl anthers, lower silles showing longitudinal slits of ihe pollen saces just

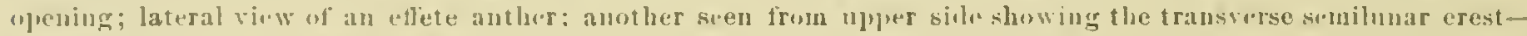

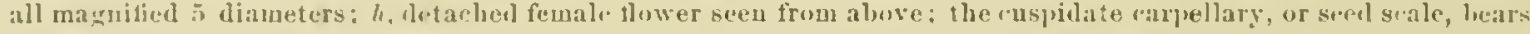

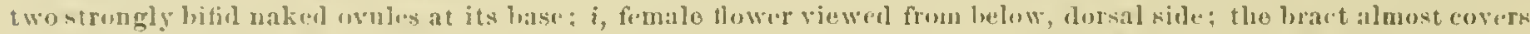
the carpellary scale, leiving only the tip of the latter and the ensps of the oruies visible: inagnified is diameters.

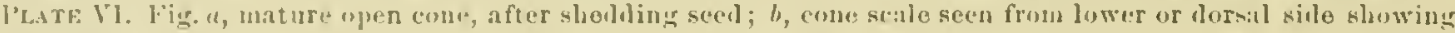

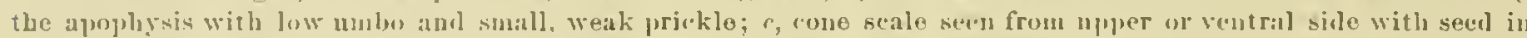

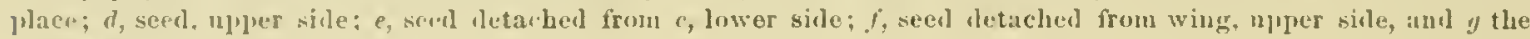
silme seen fron lower side. 


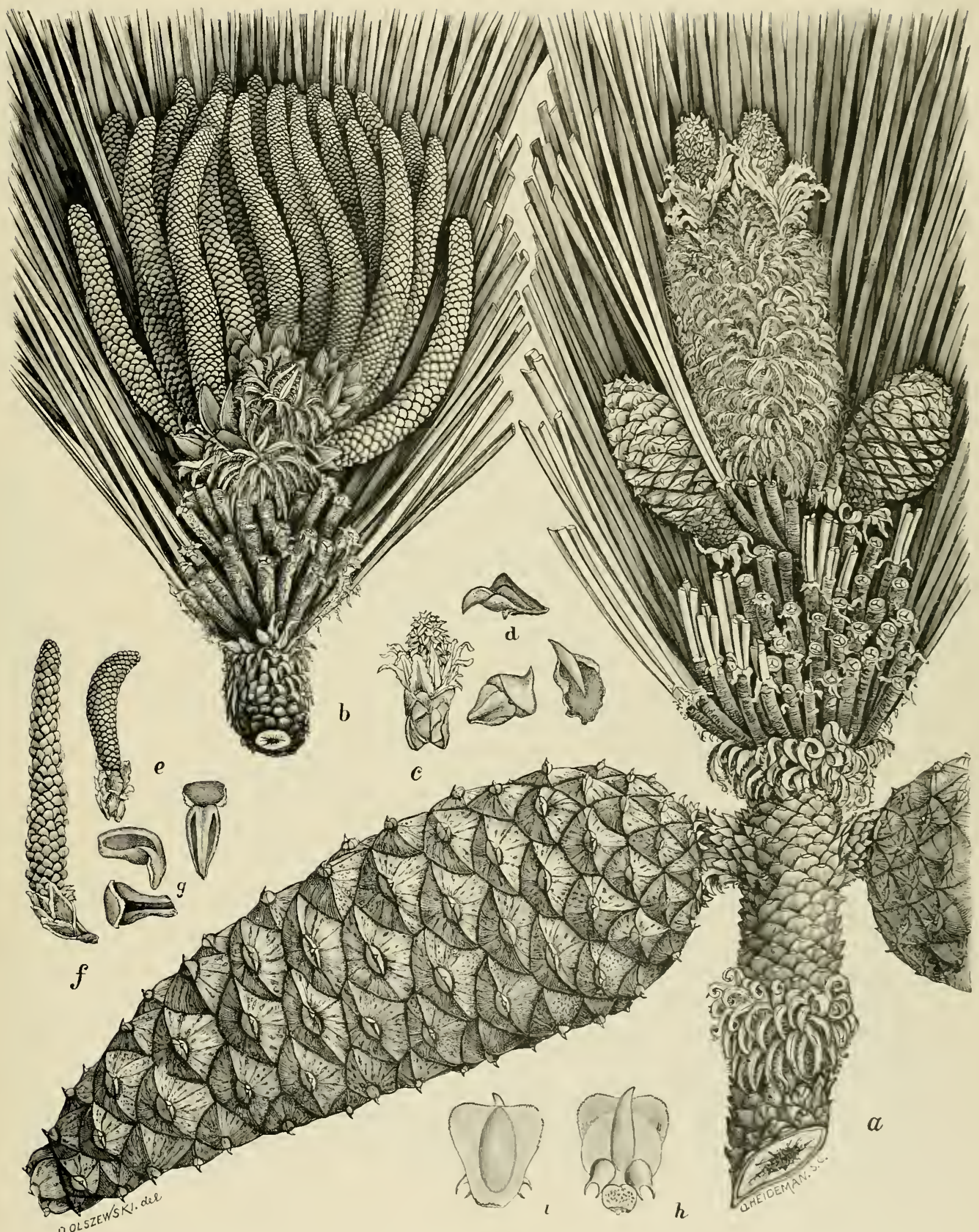





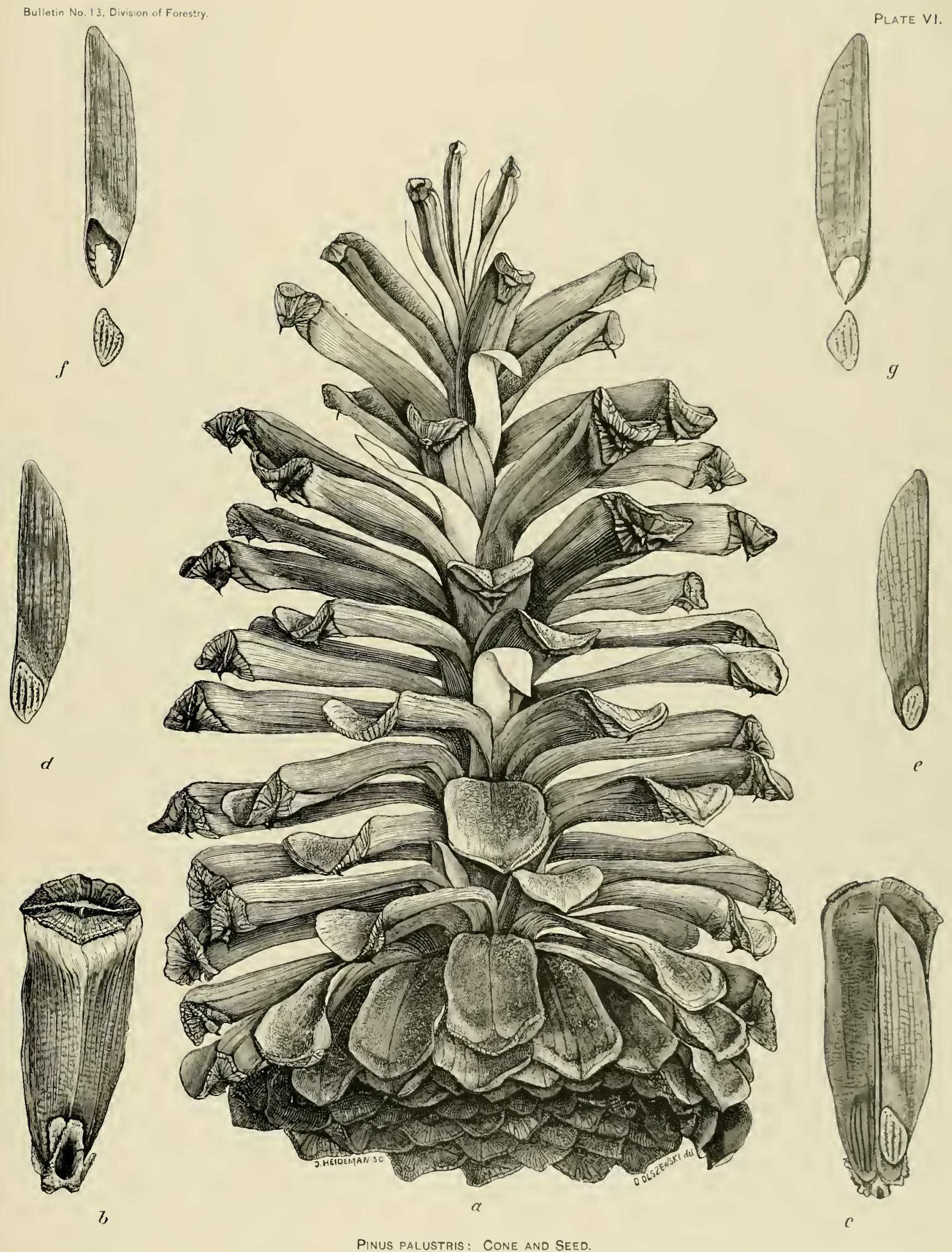



THI: WOON, 1

The woml of the Isngleal line is heavier and stromger than that of any other pime offeren in

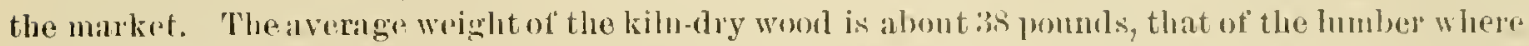

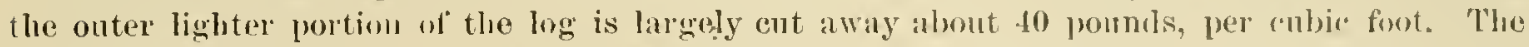

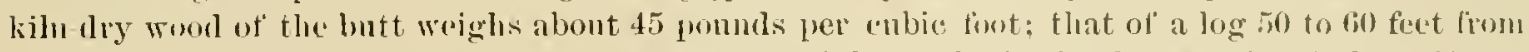

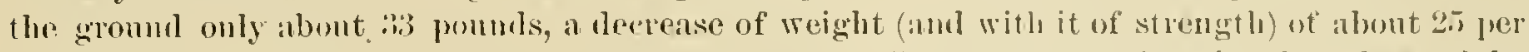
rent. Similarly the word of inner portions of a log are 15 to so per rent lieavier than these of the onter portions; or, in other works, the wood laid on when the tree is young is lueavier than that laid on when it is old, quito contrary to the common helief which secus to assoriate the light sapwool color of the young sapling with inferior material. The wood shrinks about 10 per erout of its volume in lrying, about 6 to 7 per cent along the rings (tangentially) and 3 to 4 per cont along the ladius; seasons easily and withont great injury. As in othor pines, the greatest amount of water is contained in the sipwood, varying from 30 to 50 per cent of the weight of the fresh wood, while tho heartwool contains hut abont 20 per eent.

In its stifiness and strength the woor is remarkable. The average of a gieat number of tests intieates for the dry wood of Longleaf Pine an elasticity of $1,5+0,000$ pounds prer square inch; strength in eross breaking, 10,900 pounds per square inch; strengtl in compression, 6, S.) ponnds jer square inch; strength in tensiou, 15,200 ponnds per sipuare inch; strength in sheariug, 706; jonnds per squari inch.

In its structure the wood of the Longleat Pine resemliles that of the other Sonthern pines. Silpwod and heartworl are well defined; on the fresh cross section tho former is light yellowish white, the latter a yellowish brown; drops of himpid resin ooze from every resin duet in the salp woud, the surface of the heartwood remains lry (exceptions only in "lightwool"). The sapwond contains much more water, hnt is far less resinous than tho heartwool. This latter contains 5 to 10 per cent of resin (1 part tupentine to 15 to 20 parts resin), while in the former the resin

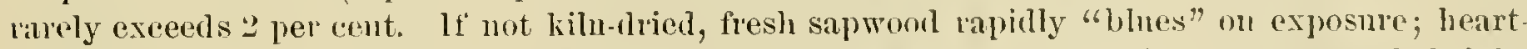
wood does not, and in general excels the sapwood iu durability. On dyying, thw sapwood shrinks mole than the heartwood of the same reight. Contrary to common belief, the rood substauce. ot cell wall, is not increased in the change from saprool to heartwool, the walls do not givow thicker, the cavities of the cells do not dill nu with foreign matter, nor loes the strength wi the woor seem to be increased by the clange. In general the width of the saproul is greatest in young and thrifty trees, grows smaller in ohl and stunted trees, is greatest in the lower parts of the stem and smaller in the top amd branches. In old logs the sapwood is manle up of from 70 to 100 rings, showing that the wood of any one ring remains in older trees seventy to one bumbed years in the saproorl emolition before it changes to heartwood. In young trees this period is much shorter. twenty-tive tu forty years commonly snllicing fir thrifty treos at the age ol sixty to seventy years, lout in stunted individuals it is materially polonged. The share of the sapwool in the total volume of the sten is always considerable; even in typical old trees ot this speries it forms 40 per cent and nowe, while thrifty stems nuder one humbed years are practically all sapmool.

The annual, or yearly, rings are clearly detimed; they are wirlest near the pith and grow lather miformly narrowes towam the hark. In the inner part a width of one-twelfth of an inch is quite common; the rings near the bark of old logs usually measure less than one twenty-tiftl of an imell, often seatcely one fiftieth of an inch. Fol old trees the average width for the entire stem may be set at abont one-twentieth to one-twenty filth of an incli. Each ring consists of two well-marlied parts, an inner, softer, whiter part, the springwood, and an onter, harler. and darker portion, the smmmerwool, so called becanse formed duriug the latter part of the growing suasur.

The amount of the smmmerwool in each ring differs in diflerent parts of the tree. It forms abont ti per cent of the volume of all the woul of the stump, and ouly about "s.t prep cent of the woud bo teet from the butt. It is geater in the heavy innel part of an uld log than in the lighter outer portions, and being of a darker rolor furnishes a convenient means of distinguishing leatry wood. In its fuer anatumy (listology) the woor resembles that of the other pines ot the treda group. (For the details ol structure see the comparative stuly ly Mr. lioth "lppenterl to these monograplis.)

'This statemont is furnished by Mr. Filimert Ruth, in chargu of timber investigntions in tho Division of Forestry. 
EAILANATION OF PLATF VII.

[Figures natural siza, "xuept where ol herwisu noted.]

Fig. ", germinatiug sced; b, young swedling (early spring) with the 8 cotyledons just unfolmil; r, seedling a few weeks oldor, showing reutral eluster of prinary leaves just unfolding; $d$, seedling at the end of thes first or beximing of the serond sison, showing humbles of true foliage (secondiry) leaves sueceding the primary leaves which have disappeared; ", poung trec, 3 to f gears old, with characteristic large root system: one-thircl matural size. 


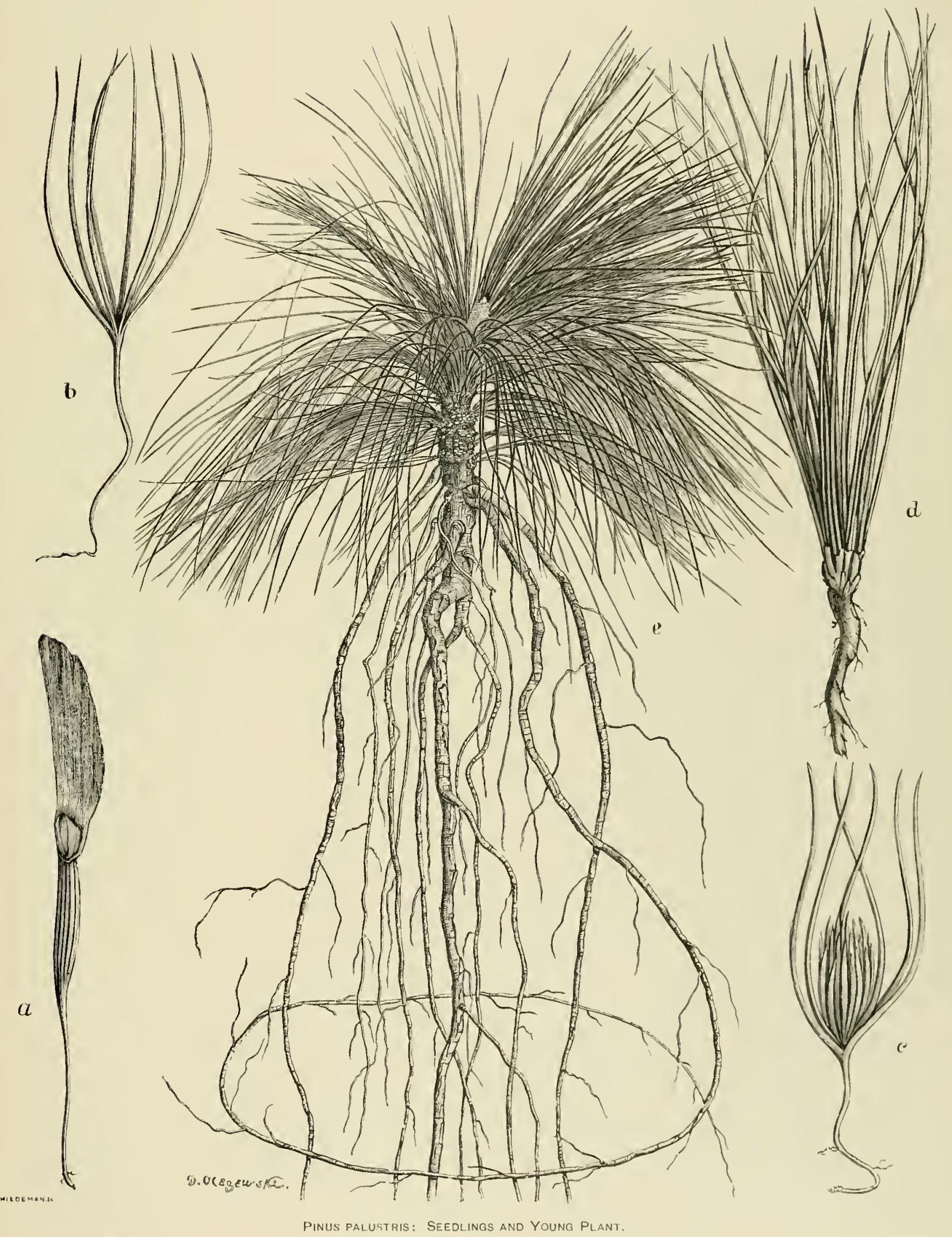



(IBOWIL ANI, DEVEIAPMINT

In a finitful year, before the elose of the season, with the advent of spring, a dry and sumy state of the atmosphere favoring the fall of the seed, the seedlings are fomm to come up almudantly in "very opening of the torest where the rays of the sun strike the dry ground. The lower (hypocotyledonary) part of the axis of the plantlet is elose to the ground, with aight to ten ereet colyledons from 1 to $1 \frac{1}{2}$ inches in length, their tips inclosed in the shell of the seed, with the lonm wing persistent and borne banner-like at the top of the flantlet (Pl. V1l, "1). The chumation of the ascending axis proceds slowly, growth in length being letarded until a relain thiekues. has been attained, resembling in this respect the growth of the strm of endogenons trens.

I'pon examination of a seedling in the hatter pirt of $A_{\text {luril }}$ the cotyledous had disappeared and the canlicle was lound to be from one eighth to one-lourth of an inch long, its length not exceding its diameter, hidden by a dense tuft of the needle-shaped prinary leaves, which chsely invest the terninal hut. At this stage a few fascicles of secondary leaves are already showing themsclves, still inclosed in their sheaths.

Dnring the tirst three or fom years its energy of growth is mainly expenderl upon the development of its powerful root system (see PI. VII, e). Before the first suriun season has pasied, the stout spindle-shaped taproot of the seedling is found to be wer 3 inehes in length and provider with several fine lateral rontlets, sometimes nearly as long as the main root.

With the opening of June the primary leaves covering the axis are nearly all withered, only a few remaining to the end of the season. With the development of the snupressed secondary axes from which the foliage leaves proceed. the primary leares are redured to chatly fimbriate bracts. Only few of these primary leaves retain the needle shaped form and green rolor, nanely, those from which mo leaf-bearing branchlets were developed. During the first season nany of the finsticles of the foliage leaves contain only two leaves, and sheaths inclosing only one leat are frequently observed.

By the end of the first year the stem of the plantlet is rarely over three-fourths of an inch in length, the main root having attained a length of from $S$ to 10 inches.

IInving reached the end of the second year the taproot is lound from 's to 3 freet in length. the stem scarcely $1 \frac{1}{2}$ inches long, with an inerease of diameter harlly perreptible. The enical turmination of the spring shoot is now densely covered with the delicately fringed loracts inchsing the buds of the foliage leaves, which inlurt to it the appearance of a silvery white tuft, by which this species is recognized at first sight.

During the following two years the growth proceeds but slowly, the lenerth by the end of the fourth year averaging not more than 5 inches with a thickness of three fourths to seven-eighths of an inch. During the same time the taproot is tound to gain constantly buth in thickues. and length (se l'l. VIl,e). A few single branches now make their appearnce on the main axis. The increase of growth from one season to another mp to the serenth or eighth rear is difficult to follow, sinee the difference in the appearance of the spring and summer wood cells in the spongr wood of young trees is hardly perceptible, and the rings of annal growth, even as suen in cross sections prepared for micro:copical examinatıon, are mostly too indistinct to atlond a safe criterion of their age. As far as could be observed the growth proceeds equally slowly during the fifth and sixth years, the plant at the ent of that period being from 5 to 7 or $7 \frac{1}{2}$ inches in length.

stage of rupirl growth.-With its seventh year the tree nay be sald to enter on its most vigorons growth. Ienceforth the stem (primary axis) inereases rapidly in length, and the development of branches (lateral axes) proceeds at an erpual rute in regular whorls, to which the symmetry of the tree in that stage of its development is due. During the seventh year, gencrally, the tree dombles its length, and during a number of successive years the rate of gronth in that direction varies between 10 and 20 inches annully, as is clearly shown hy the length of the internodes separating the whorls. As the branches inerease in length they pronnce, in the sane order mostly, two opposite secombary branches. With the rapid expansion of the leat sulface, the formation of wood keeps pace. The rate of growth in diameter, as well as in height. chring this period, is of eonrse variable according to differences in the physical condition of the soil as well as in the available amount of plant food and moisture it contains, and no less upon clitherees in temperature and of exposure to light and air. These variations are clearly shown 


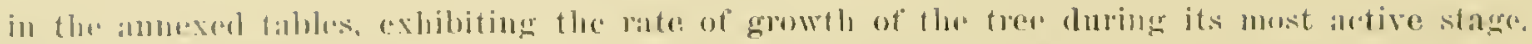

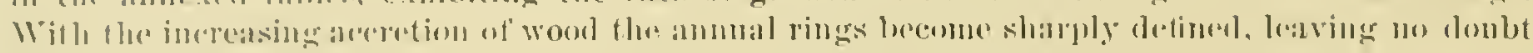

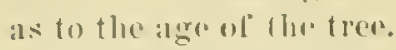

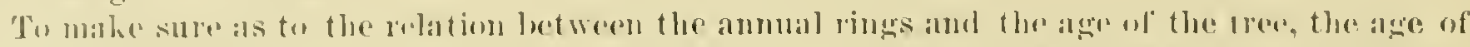

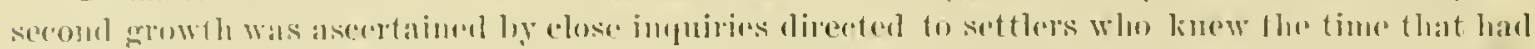

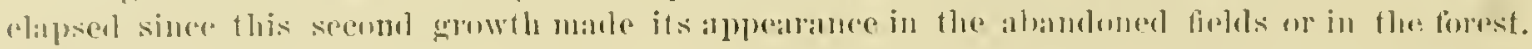

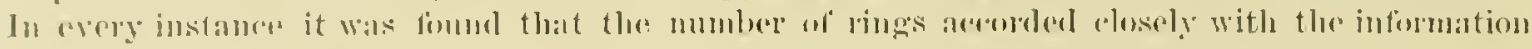
eliciterl.

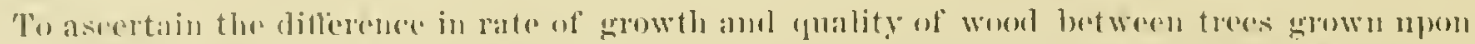

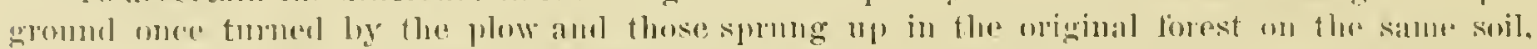

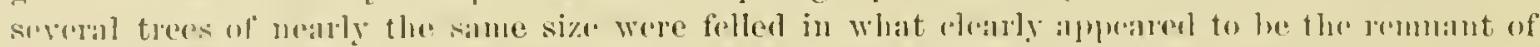

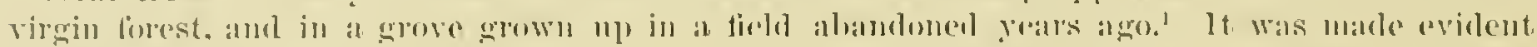

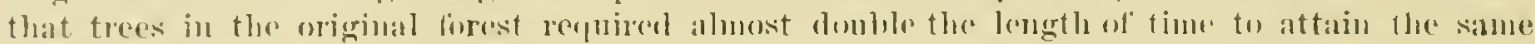
dimension.

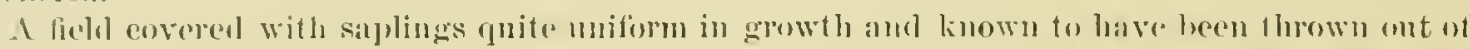

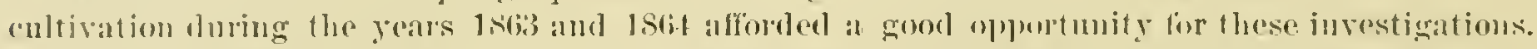

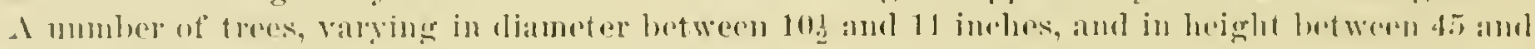
.0) fiet, showed from 30 to 35 rings of growth. The length of the spring shoots on the main stem of these trees was fomme (.lune si) to be from 21 to 24 inclues.

In another fine grove, rovering a lield whieh was known wh have bern cultivated fon the last

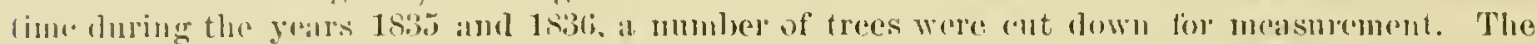

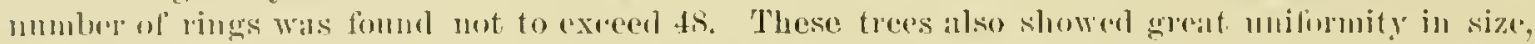

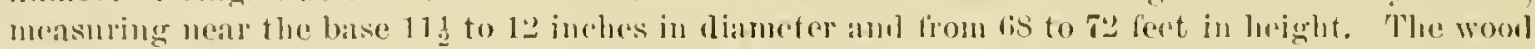

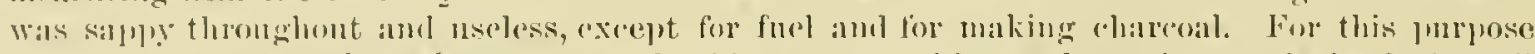

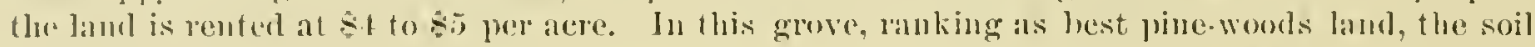

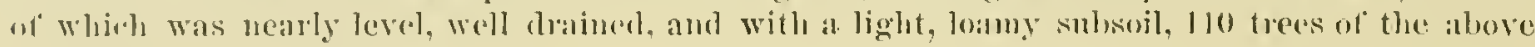
dimensions were combted on 1 acre.

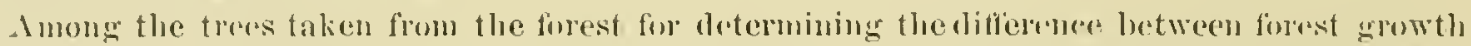
and liekl trees, one meisuring 12 inches in dianeter and 60 feet in height showed si rings of

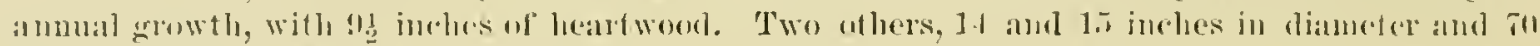

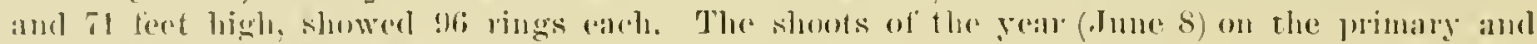
lateral axes of these frees were found to be hut liftle orer 1 inch in lingth.

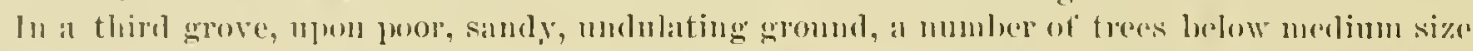

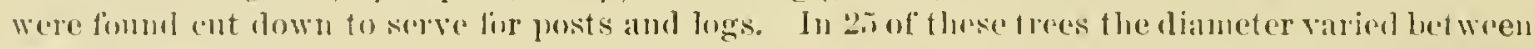

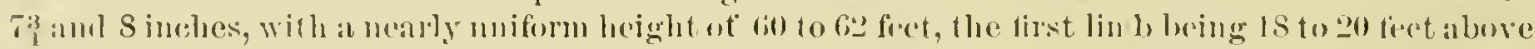

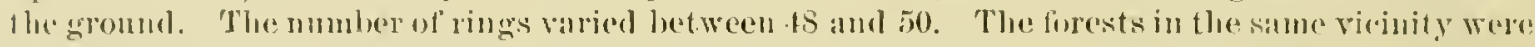

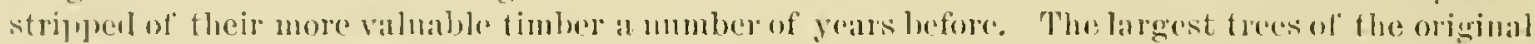
forest growth remaining were from 12 to 15 inches in diancter. Several ware lomeght donn for

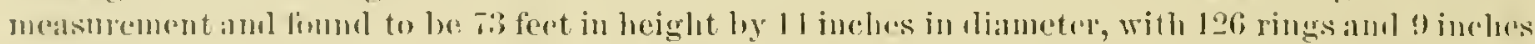

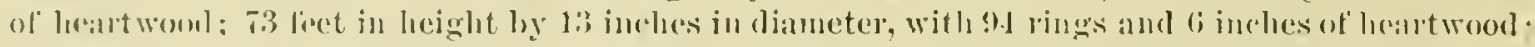

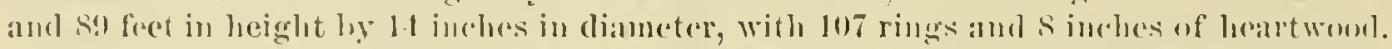

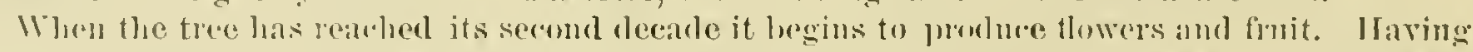

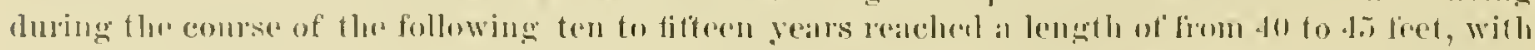

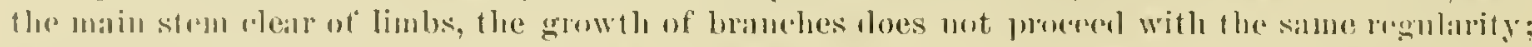

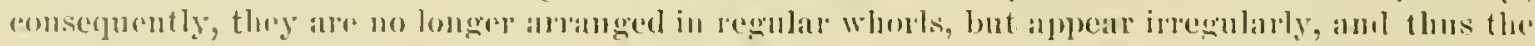
symulety of the tron is inst.

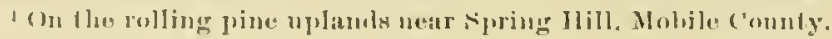


PERIOD OF RATID GRIOWTII.

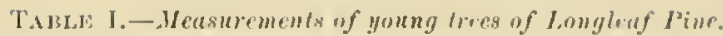

\begin{tabular}{|c|c|c|c|c|c|c|}
\hline \multirow{2}{*}{$\begin{array}{l}\text { Ninulier } \\
\text { wi trees. }\end{array}$} & \multirow{2}{*}{ 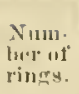 } & \multirow{2}{*}{$\begin{array}{c}\text { Diums. } \\
\text { ter } \\
\text { hrostst } \\
\text { ligh. }\end{array}$} & \multicolumn{2}{|c|}{ [Iriglt. } & \multirow[b]{2}{*}{ l,us:ality. } & \multirow[b]{2}{*}{ lewalarhs. } \\
\hline & & & Ton & 'linlil. & & \\
\hline 1.... & 8 & $\begin{array}{c}\text { Inchirs. } \\
13\end{array}$ & Fref. & Fent. & Springhill Ala..... & 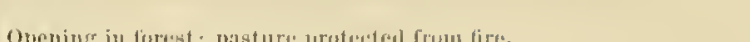 \\
\hline (..... & 9 & 13 & $\cdots \cdots$ & $5 z^{12}$ & .... & lom. \\
\hline $3 \ldots$ & 11) & 11 & ... & $22^{2}$ & ......lilı ... & (Mil lit.lil; last limo plenwoul in lavis. \\
\hline $4 . . .$. & 10) & $2^{-}$ & & $x_{12}^{n}$ & .... do & Inthinilst uf forest. \\
\hline $\begin{array}{ll}18 . \ldots \\
5\end{array}$ & 10 & 2 & 5 & $10^{12}$ & Errins statimn, Jat. & "1un nizg in tortint. \\
\hline 6....... & II & $\begin{array}{l}23 \\
5\end{array}$ & $\cdots$ & 11 & Suriuglall, dlit...... & 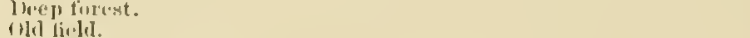 \\
\hline $319 \ldots$ & 11 & 2 & 6 & 17 & 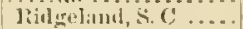 & "upan torast. \\
\hline & 12 & 23 & . & 16 & 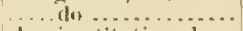 & 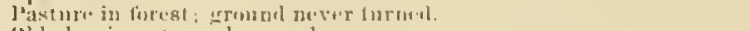 \\
\hline $\begin{array}{l}19 . . \\
8 \ldots\end{array}$ & 13 & $\begin{array}{ll}4 \\
2 \\
2\end{array}$ & 9 & $\frac{22}{15}$ & Lavins Statius, lat. . & 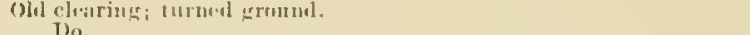 \\
\hline & 12 & $2^{-1}$ & 9 & 14 & liulgelanil, $九$ C ....... & Oquening in tureat ; sitnoly uplamuls. \\
\hline $318 .$. & 13 & 4 & 8 & 21 & ....tut ............ & 11,3. \\
\hline $9 . .$. & 13 & 27 & $x^{2}$ & 15 & Springhill. A la. & Wowd past are. \\
\hline $10 .--$ & 13 & $3 \frac{i}{4}$ & & 19 & 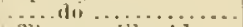 & O) hl tielil. \\
\hline $248 \ldots$ & 13 & 4 & 8 & 21) & "Thumasille, Ala & (1)reninger in furest: lills. \\
\hline $317 \ldots$ & 14 & 4 & 7 & 21 & Iikdgelanel, S C ..... & 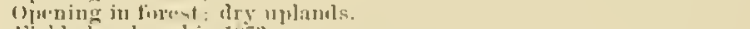 \\
\hline $11 \ldots \ldots \ldots \ldots$ & 15 & $5 \frac{1}{2}$ & 8 & 35 & Springhill, Ala ..... & 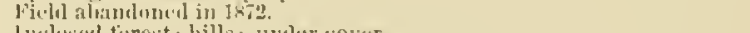 \\
\hline $\begin{array}{ll}260 \\
199\end{array}$ & $\begin{array}{l}16 \\
18\end{array}$ & $\frac{4}{3}$ & $\stackrel{x}{11}$ & $\begin{array}{l}16 \\
23\end{array}$ & Thomasville, Ala ... & 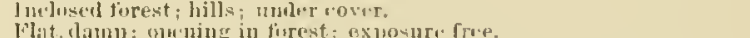 \\
\hline $198 \ldots$ & 19 & $\tilde{2}$ & $1:$ & 211 & (lin & 1). \\
\hline 194. & $\because 11$ & 6 & 18 & 47 & $\ldots$ (lo & 1,ight swoll iu "pen forest : "xprosura firen: \\
\hline $12 \ldots$ & 20 & 10 & -. & $4 ! !$ & Springlill, Ala & 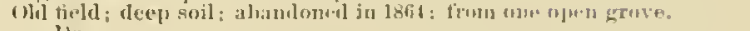 \\
\hline $13 .$. & 21 & 1010 & ... & 55 & .... dio .......... & In. \\
\hline $14 \ldots \ldots \ldots . . . . . .6$ & 21 & 10 & $\cdots$ & 511 & $\ldots \ldots$ ilo $\ldots . . . . .$. & lnoton \\
\hline $15 \ldots \ldots \ldots \ldots$ & $\begin{array}{l}25 \\
22\end{array}$ & $\prod_{3}^{11}$ & ii & $\begin{array}{l}50 \\
21\end{array}$ & Thomisville, Ala... & 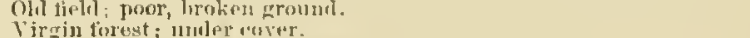 \\
\hline $246 \ldots$ & 211 & $\overline{4}$ & 14 & 39 & - . $110, \ldots . . .6$. & 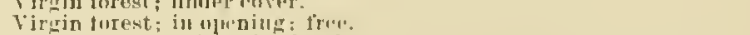 \\
\hline $316 \ldots$ & 21 & 6 & 10 & 28 & liilgeland, si C.... & Gpen forest: samly "lulanils: free. \\
\hline $195 \ldots . .$. & 25 & 7 & 24 & 47 & Nona, Iix .......... & 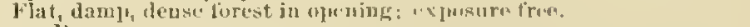 \\
\hline 194. & 23 & 4 & 2) & 44 & ..... do ....... & [31.. \\
\hline $196 \ldots \ldots \ldots \ldots$ & 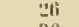 & 6i & 17 & 44 & 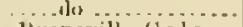 & It/k. \\
\hline $209 \ldots \ldots \ldots \ldots$ & 36 & 4 & 15 & 35 & $\begin{array}{l}\text { liyansville, Calr:z- } \\
\text { sieu l'arjsh, Lal. }\end{array}$ & Flat, damp; op"n fornst. \\
\hline 210. & $3 ! !$ & 4 & 17 & 37 & $\ldots \ldots$ lo $\ldots . . . . . . . .$. & $1 \%$. \\
\hline 315. & 40 & 6 & 21 & 5.1 & - & Do. \\
\hline $\begin{array}{ll}315 . \\
307 .-\end{array}$ & 40 & $\begin{array}{l}8 \\
6\end{array}$ & $\begin{array}{l}17 \\
33\end{array}$ & $\begin{array}{l}6: 1 \\
5 .\end{array}$ & lijilgeland, s. C . & \\
\hline 3.36 & 43 & 6 & 28 & 47 & $\begin{array}{l}\text { Tivansvill, La ..... } \\
\text { Thumasvilio, Alal ... }\end{array}$ & 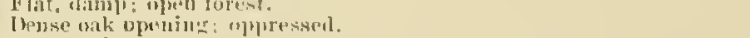 \\
\hline 258. & 43 & 4 & 34 & 56 & 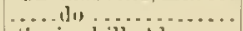 & J11 opwn forest. \\
\hline 16. & 4R & $x^{2}$ & $\ldots \ldots$. & (i0 & Springhill, Al:t . . . . & old pasture, "In poor horoken gromud. \\
\hline $17-21$ & 52 & 8 & & 61 & ....di......... & 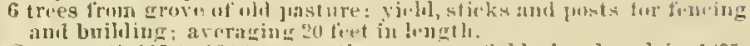 \\
\hline $22-2$ & $4^{4}$ & 11 & & 73 & .10 & 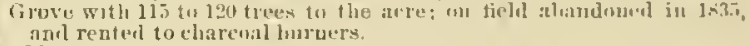 \\
\hline $22 a$ & isi & $\alpha$ & & 58 & $\ldots . . .111$. & ()!l pistura: \\
\hline 723. & 71 & 5 & & 46 & Clnine hala, A la... & 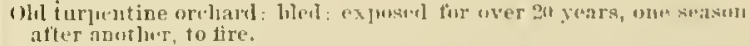 \\
\hline $25 . \ldots . . . . . .$. & 78 & 6 & 47 & 62 & Thmasville, ila. & linter correg of firrest. \\
\hline $23 a \ldots$ & 80 & bi & & 52 & Clunchulis. Ala .. & 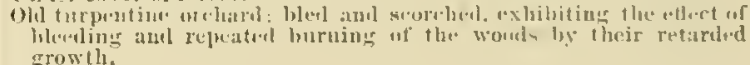 \\
\hline $24 a$. & $8 \mathrm{i}$ & 8 & 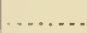 & $5 !)$ & ..... dlo & 1). \\
\hline $25 a-$ & 93 & 7 & & 58 & .....do. & 1 1). \\
\hline $26 \ldots$ & 105 & R & ........ & 56 & .... do ....... & Do. \\
\hline 27. & 105 & 8 & . . . . . & $5 !$ & ....tila. & Do. \\
\hline
\end{tabular}

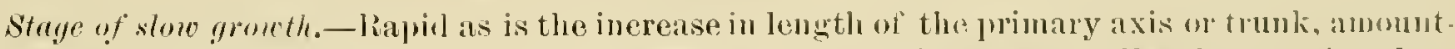
ing during the first late century, in the average, to 11 or 15 inclus ammally, the rate is suluse-

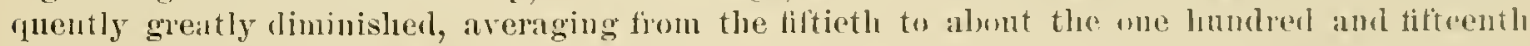
year lut from t to 5 inches, and from this time to the age of two lundred and fifty reas anly $1 \frac{1}{3}$ inches-that is, at a relative rate of 10,3 , and 1 in the three snecessive periods. The decrobse in the aceretion of wond corresponds with the rednetion in the growth of the hranches and consteguent reduetion of toliage. From what has been salid, it is seen that the Lomgleaf l'ine attains matmrity of growth, with the best qualities of its timber', at an age of fiom one hundreal and eighty

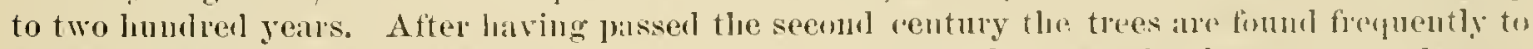
be wind shaken and otherwise hefective. The deterioration of the weather heaten crown lesens the vitality of the tree, and the soil, muler prevailing conditions, beomes less and lexs farorable. In consequence, the trees become liable to disease and mostly fall prey to the attackis of parasitir fungi (red heart). Instances of trees which have reached the maximum age of two humberl and seventy-five or thee hundred years are exceptional.

In order to asecrtain the age required to firmish merehantable timber of dirst quality, meas. urements were made of a mumber of logs in a log anup in the renlling pine mplands of the lower division of the coastal pine helt near Lumbertun, Waslington ('ounty, Ala, firom flie proults obtained $i_{j}$ appears that in this section of the eastem (inll region, at the lowest fignure, two humbed years are regnisite to pronhe logs of the dimensions at preseut ent at the sawnills. 


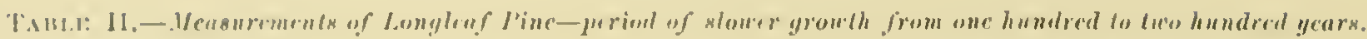

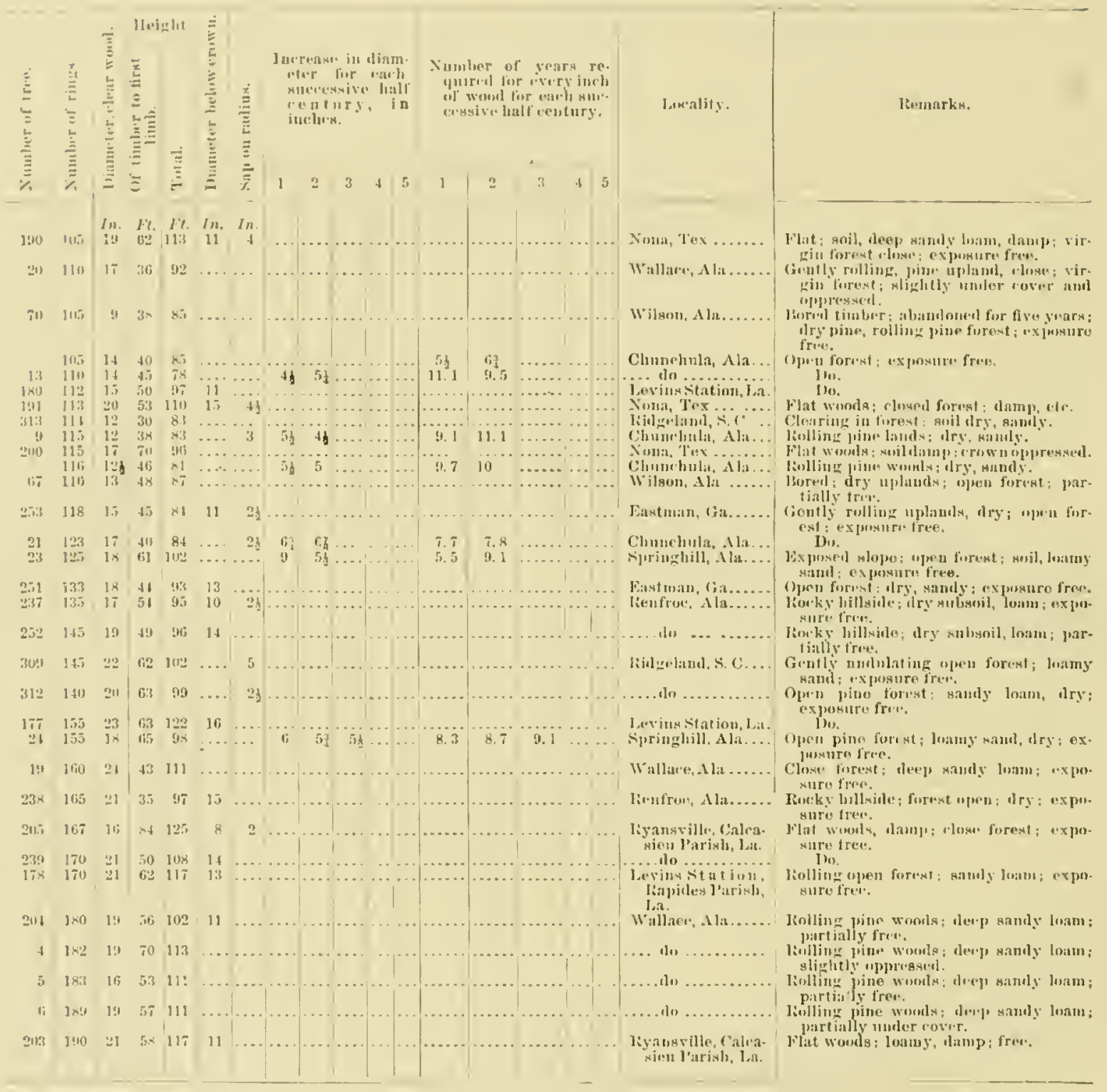




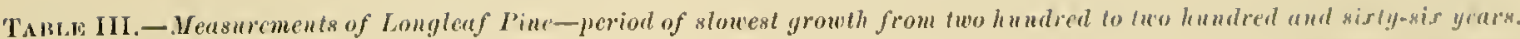

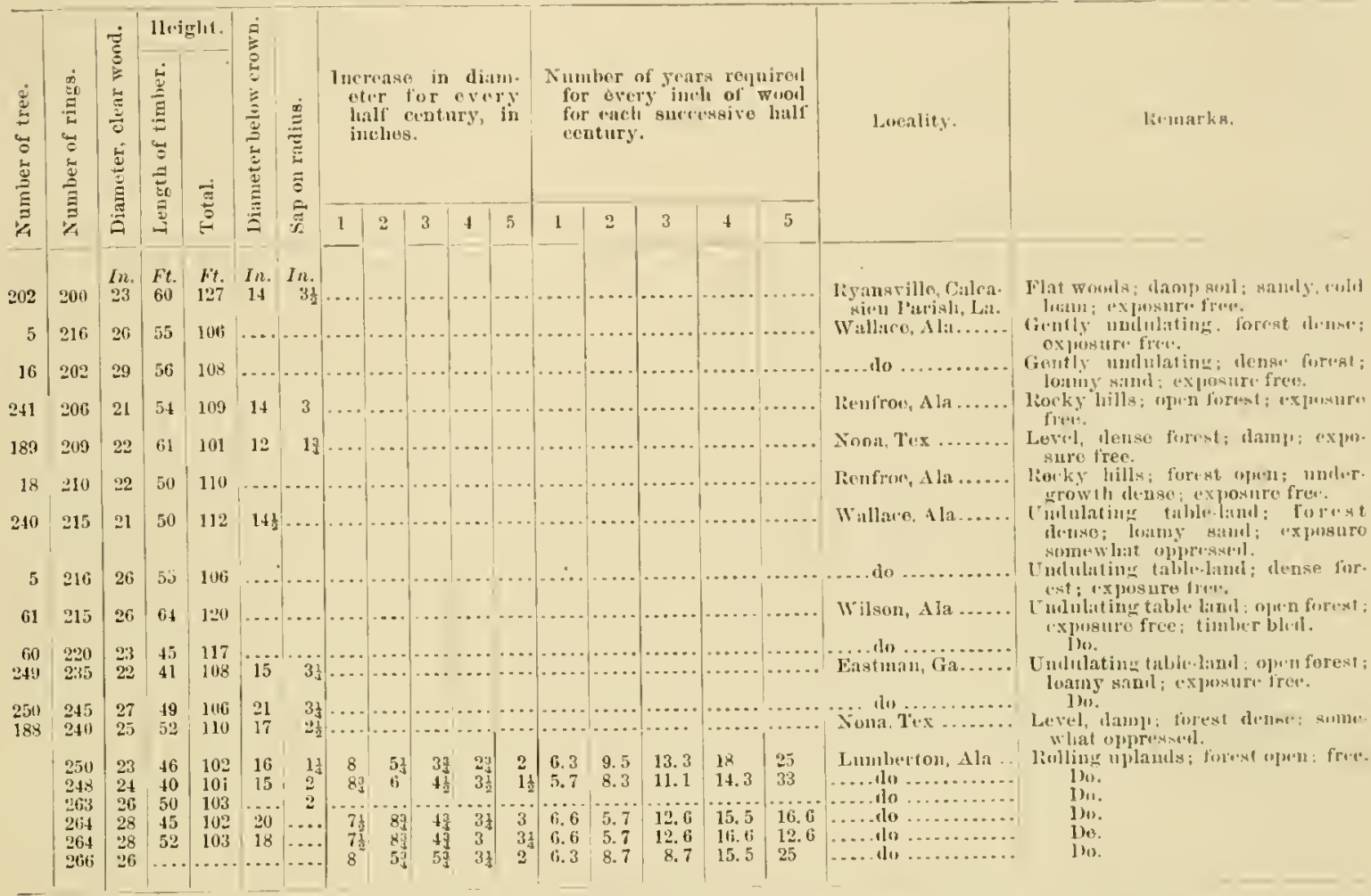

'The following table and diagran (tig. s) present the average results ot a dratuilud sturly of over sixty trees eolleeted in diflerent localities. Since only the pant of the slem trom stump upwarl is represented, the seedling period of slow growth fimls no expressim. It will be observent that the growth in height is a maximum between the age of ten and thioty years, amonnting to 1.1 fort for

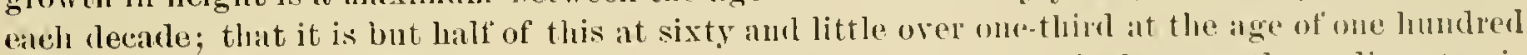
years. As planly indicated in the tine, miform grain of the wour, the wowth m diameter is remarkably uniform until the tree reaches the age of about one humlred yous. From this on it deereises rapidly aur is scureely more than onc-fourth as great at one lunklred and eighty as it is at one lumbred. The rate of growth in volume increases steadily up to the one hmulredth jear. reaching a maximum of over 1.2 cubie feet per year, but decleases, thongli very slowly, tirom that tiue forwarl, being only about one-half enbic foot per year when the tree leuclies the age of one hundreel and eighty years.

Liate of growth of Longleaf l'ine.

\begin{tabular}{|c|c|c|c|c|c|c|c|c|c|c|c|c|}
\hline \multirow[b]{2}{*}{ Age. } & \multirow{2}{*}{$\begin{array}{c}\text { Diam- } \\
\text { efer } \\
\text { with } \\
\text { bark } \\
\text { (broast } \\
\text { higli). }\end{array}$} & \multirow{2}{*}{ 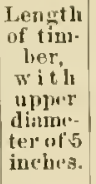 } & \multirow{2}{*}{$\begin{array}{l}\text { Heiglit } \\
\text { of trie. }\end{array}$} & \multicolumn{2}{|c|}{ Volume. } & \multicolumn{5}{|c|}{ Periodical accretion. } & \multirow[b]{2}{*}{$\begin{array}{l}\text { Arernga } \\
\text { annual } \\
\text { areretion. }\end{array}$} & \multirow[b]{2}{*}{$\begin{array}{l}\text { Corrent } \\
\text { aevrotion. }\end{array}$} \\
\hline & & & & Irve. & Leg. & Docade. & $\begin{array}{c}\text { Dhiamo- } \\
\text { ter. }\end{array}$ & Ileigrtht. & $\begin{array}{c}\text { A rea of } \\
\text { cross suc. } \\
\text { tions. }\end{array}$ & Volıme. & & \\
\hline $\begin{array}{r}10 \\
20 \\
30 \\
40 \\
50 \\
60 \\
70 \\
80 \\
90 \\
100 \\
120 \\
140 \\
100 \\
180\end{array}$ & $\begin{array}{r}\text { Inches. } \\
2.0 \\
3.8 \\
5.5 \\
7.0 \\
8.1 \\
9.6 \\
11.5 \\
13.0 \\
14.5 \\
16.0 \\
18.0 \\
19.5 \\
20.5 \\
21.3\end{array}$ & $\begin{array}{c}\text { Fet. } \\
\ldots \ldots . \\
\cdots \ldots . \\
16 \\
24 \\
34 \\
44 \\
52 \\
56 \\
60 \\
65 \\
73 \\
40 \\
85\end{array}$ & \begin{tabular}{r|} 
Feet. \\
9 \\
23 \\
37 \\
48 \\
56 \\
62 \\
67 \\
72 \\
70 \\
80 \\
87 \\
93 \\
98 \\
103
\end{tabular} & $\begin{array}{r}\text { ru. fiet. } \\
0.12 \\
1.20 \\
3.35 \\
7.06 \\
10.75 \\
15.26 \\
24.16 \\
33.18 \\
43.57 \\
55.85 \\
76.87 \\
96.44 \\
112.30 \\
12.206\end{array}$ & $\begin{array}{r}\text { Cu.feet. } \\
\ldots \ldots . . . . . \\
\ldots \ldots . . . . . \\
5.61 \\
0.30 \\
13.99 \\
23.11 \\
32.27 \\
42.66 \\
54.94 \\
75.87 \\
95.49 \\
111.50 \\
121.20\end{array}$ & 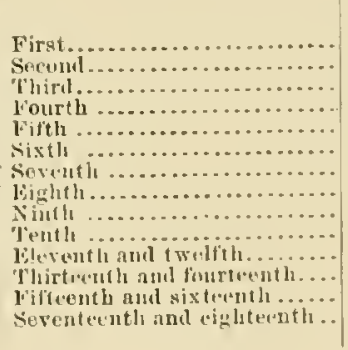 & \begin{tabular}{|c|} 
Inches \\
1.4 \\
1.8 \\
1.6 \\
1.2 \\
1.2 \\
1.4 \\
1.6 \\
1.0 \\
1.2 \\
1.1 \\
1.8 \\
1.6 \\
.8 \\
.75
\end{tabular} & $\begin{array}{r}\text { Fiet. } \\
9 \\
14 \\
14 \\
11 \\
8 \\
6 \\
5 \\
5 \\
4 \\
4 \\
7 \\
6 \\
5 \\
5\end{array}$ & $\begin{array}{r}\text { Niffout. } \\
(1,1) \\
.04 \\
.07 \\
.04 \\
.04 \\
.12 \\
.17 \\
.19 \\
.16 \\
.17 \\
.311 \\
.29 \\
.16 \\
.12\end{array}$ & $\begin{array}{l}\text { ('u. fict. } \\
0.12 \\
1.118 \\
2.15 \\
3.71 \\
3.69 \\
4.51 \\
8.90 \\
9.112 \\
10.39 \\
12.28 \\
21.02 \\
12.62 \\
15.8 t \\
10.70\end{array}$ & $\begin{array}{l}\text { Cu. Seet. } \\
\text { 0.01 } \\
.116 \\
.11 \\
.18 \\
.21 \\
.25 \\
.35 \\
.41 \\
.14 \\
.511 \\
.64 \\
.69 \\
.70 \\
.67\end{array}$ & $\begin{array}{r}\text { ru. firt. } \\
0.01 \\
.11 \\
.21 \\
.37 \\
.37 \\
.45 \\
.89 \\
.911 \\
1.01 \\
1.23 \\
1.0 . \\
.94 \\
.79 \\
.53\end{array}$ \\
\hline
\end{tabular}




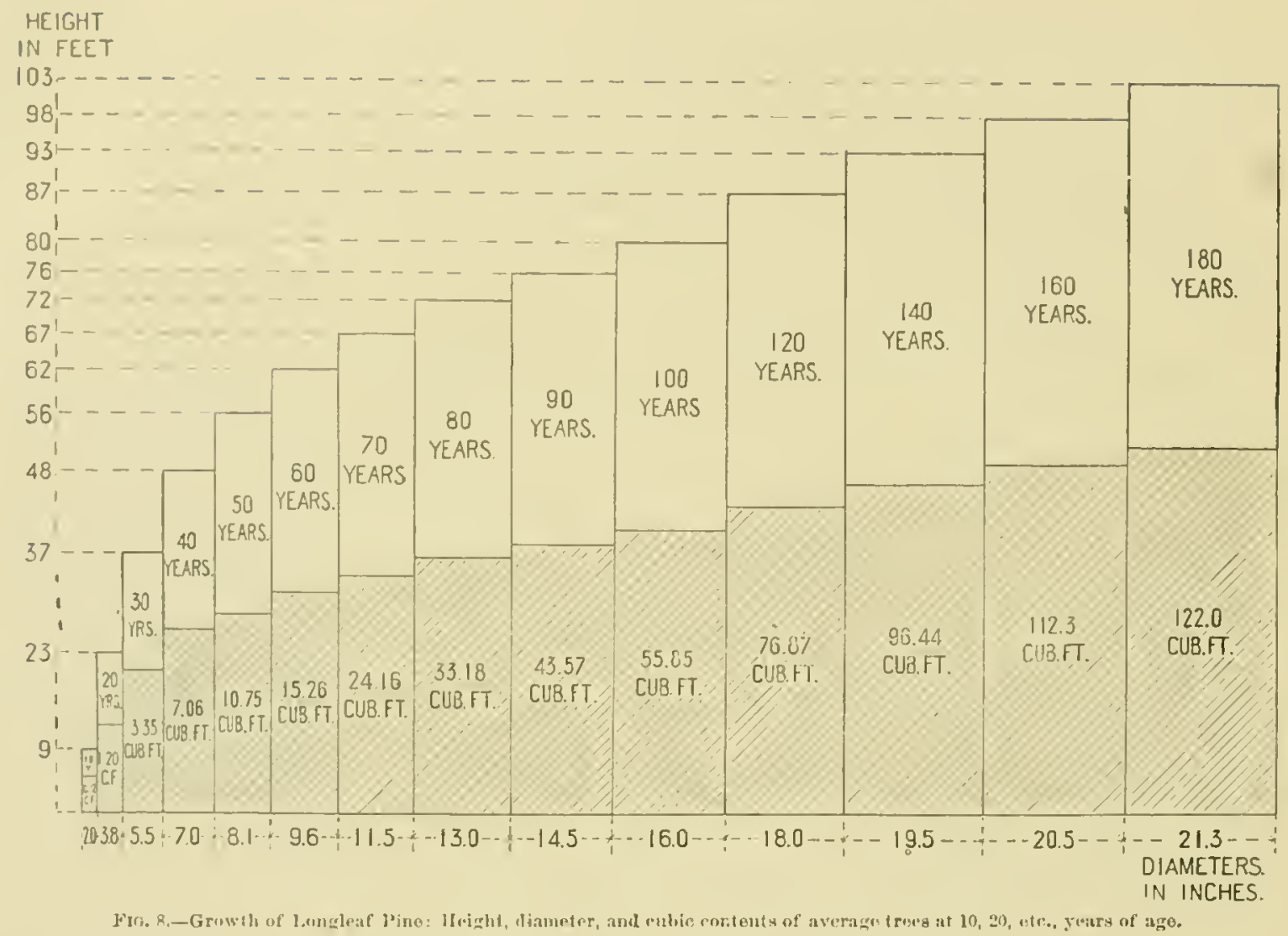

(ONHTHNG OF DETELUPUENT.

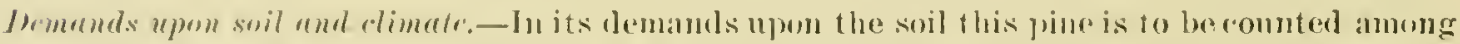

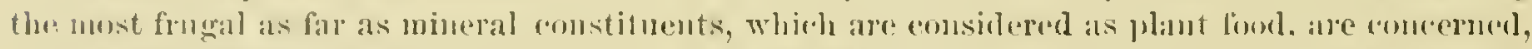
il only the merbanical consitions which influenere favorable soll moisture are not wanting. It thrives lwest on a light silic(ons soil, loamy sand or pebbles or light sandy batm, with a slightly

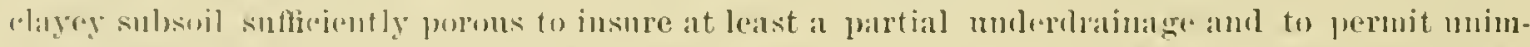

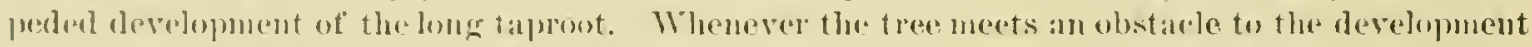
of this rowt it remains morr. or less stunterl.

The luxurance of the growtl and increase in sime of the timber, howeser, is greatly influ-

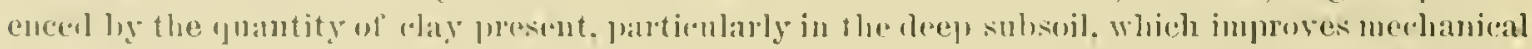
and moisture comblitions. This is strikingly exlibited in the timber of the level pine flats west of

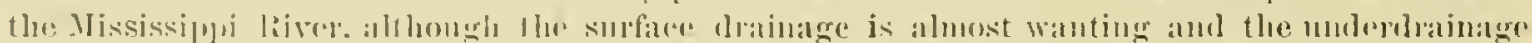
throment the Joany strata slow, so that the surfare of the soil remins damp or water-soalied for

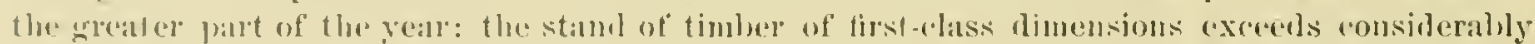

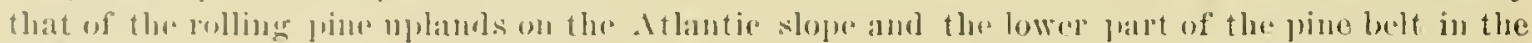

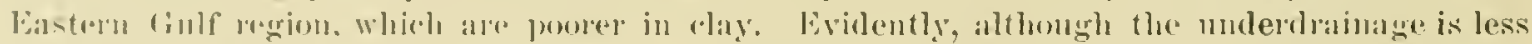

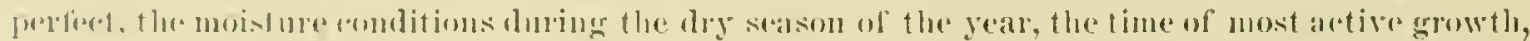

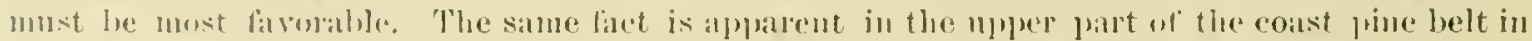

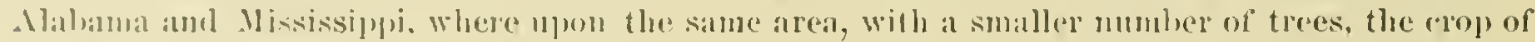

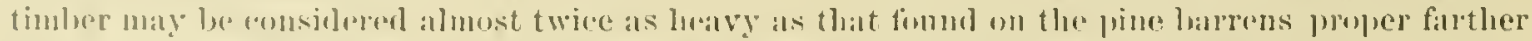

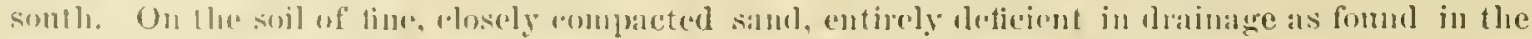

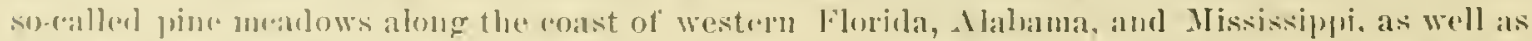

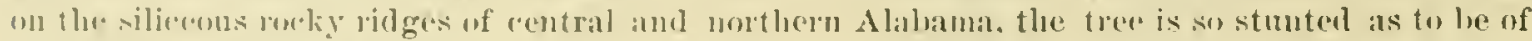
little or no valul for it: timber.

"It is mither temperature alone. nor minfall and moisture comblitions of the atmospliere alone, that inthence tree growth, bat the relition of these two cliuatic factors, which determines the 
amount of transpiration to be performed by the foliage, and agatin with must species we must place this transpiration movement into mation with arablabe soll moisture, in order to determine what

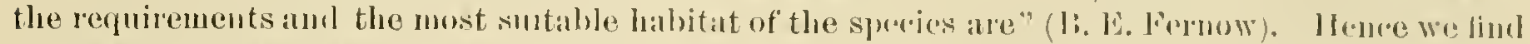

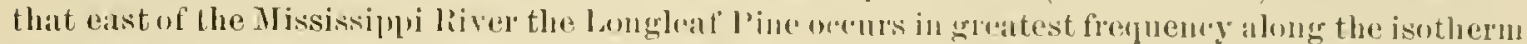

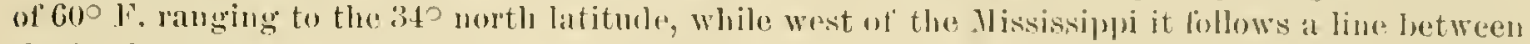

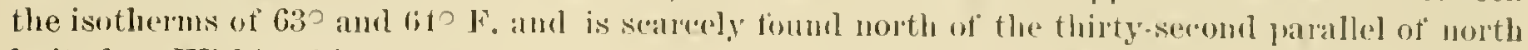
latitude. Within this area of its clistribution it is exposed to wide variation of temperature aud moisture comblitions.

Under the intluned of the vapor-laden breeges from the Mexican Gulf and an cyenly distributed raintall ranging from ty to bis inches dning the yatr, the Longleaf I'inc alplears of the same thrift and vigne of growth in the interior of Alabama nuder 340 to :35 noth latitule, with the ther-

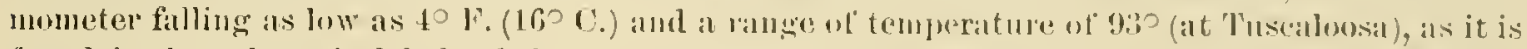

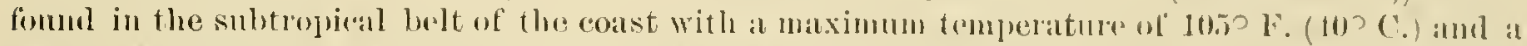
range of temperature of "IP west of the Mississippi River, although the tempelatume reaches rarely a minimum of 150 and 12 , respectively, at the northern limit of the tree in these States, the diminished humidity of the atmosphere and lesser lanfall, particularly during the waner season, account for its absence. There can be no loubt that the greater exposure to the violence of the sudden gusts of dry and cold wind known in Texas ats "dry northers" exercises also no small influence in liniting the Longleaf I'ine.

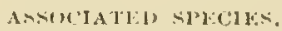

The Longlear I'ine is eminently a gregarious tree, covering areas ol wille extent, to the almost

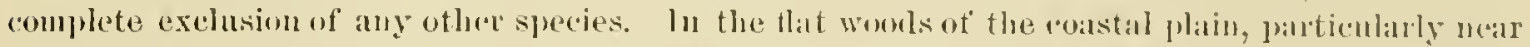
its northern linit on the Athantio Slope, it is not infrepnently assoriated with the loblolly l'ine; farther sonth and along the Gulf Const to the Mississippi liver, more an less frequenty with this

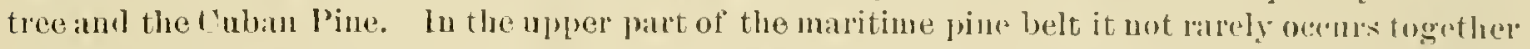
with the Shortleat' l'je and the Loblolly Pine intermixed with the deciduons trees of th. Inplands, viz, the Black Oak, Spanish Oak, Blackjiack, Bittrinut, Mockermut Ilickories, and Blark (ium.

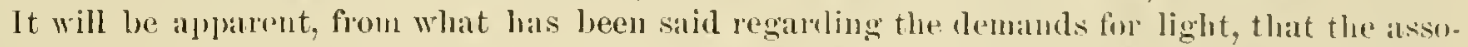
ciated sprecies must be either slower growers or later concrs, il the Longleaf line is to survive in the mixtme. As has been pointed ont olsewhere, with the culling of the longleaf l'ine fron the mixed growths it must soon cease to play a part in thrm, since its renewal umber the shatle of the remaining associates is impossible.

\section{HNEMES.}

The greatest danger threatening the existence of the lorests of Longleaf l'ine must be ascribed to the agency of man, since their destruction is caused chictly by the revlidess manner in which they are depleted withont lieed to recuperation. The right of ownership has been generally acquined on sueh low terus that since no value las been attached to the lamb without the. timber, despoliation has been carred on with no other object than the quickest return at momentary profits.

KXIPLOTTATIN.

Such management could not but entail tremendous waste, a large perentage of the body of the trees felled being left on the gromm to rot or to serve als finel for the contlaglations whin sconn these woods almest every year. Intinitelg greater than the injuries indlicted upon the finest by the logger and by getting ont "ross-ties and hewn sifulde timber, which ronsist whictly in the accumulation of combustible waste, are those mased ly the prodnction of naval stores. When the fact is eonsidered that the procluction of the 40,000 harrels of spirits of turpentine, which on an average during the latter hall of this decale amually reached the marliet of Mohife alone, implies the devastation of almut 70,000 acres of virgin forest. the destmetion ander by this industry appears in its full enormity. Under the managenent of the turpentinc orchards prevaling at present, trees of" such small size are tapperl that they are mable to rexist the fonce of the winds, and in a few years ane juevitably prostrated, while the larger trees, wealiened by the severe gashes on almost every side, hecome largely wind-shalien and the timber after a tew years almost wortliless. 
While a juldoions tapping is mot only justitied, lut demanded, ly an ecomomie system of

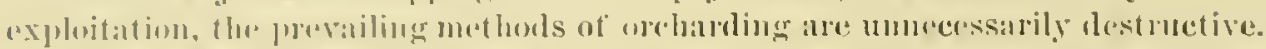

The tapping of sappling timber not yet ripe ther the silw, and the destructive fires starter in monnertion with this imlustry, anmihilating all young growth, prevent any renewal of the forest,

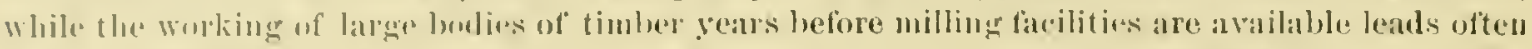

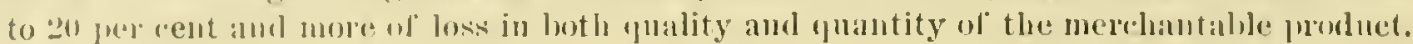

HIRE.

The ereatest injury to which the pine forests are subject in eonsequernee of turpentins ordanding arises firm the fires which are started every spring lor the purpose of getting rid of

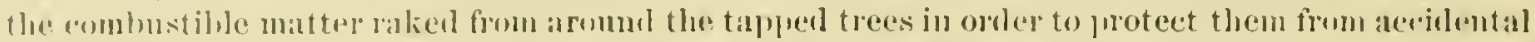
"ontlagrations while they are worked. Thuse forest fires, spreading fin begoud thejr intended limits, distroy motirely the gomgent progeng of the pines, stunt the growth of the more advanced trees, alul anse the min of" a large number of older ones in the abandonol turpentine oredards.

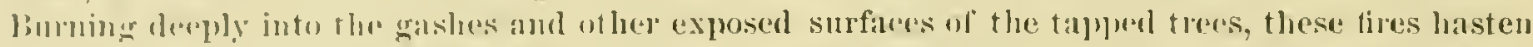

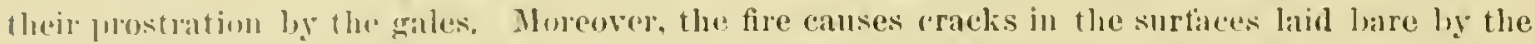
ax and the puller areasions greatro aposure to atmospherie action, thus inducing more or less

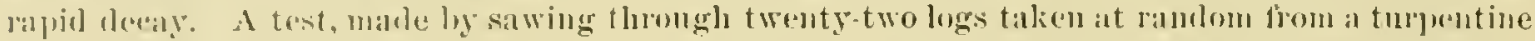

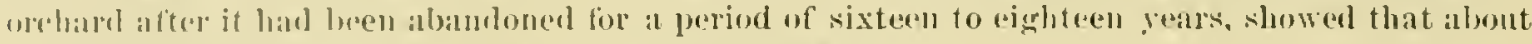
one-halt of the timbel was fartially decayed and shaky.

licsibles the production of maval stores as a cause of forest tires, there is another searcely less

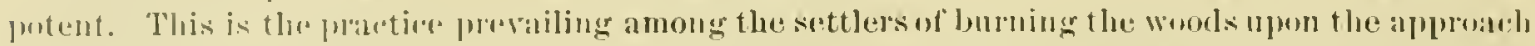
uf every spring in molel to hasten the growth of urass for their famished stordi. Fires are also troplently started through the carelessness of loggers and hunters, in the preparation of the gromul

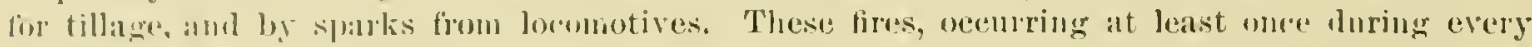

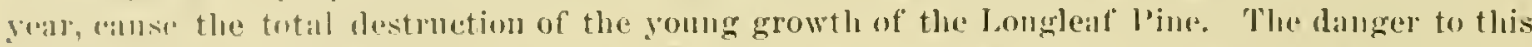

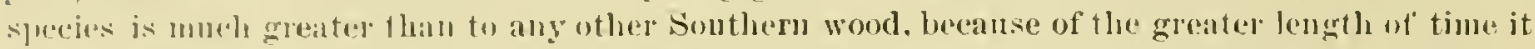

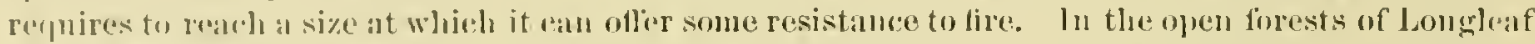

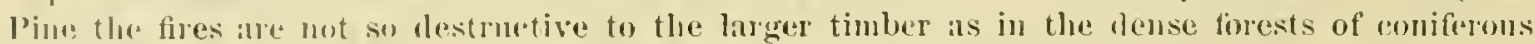
trees further noth, Irees of larger size being, with some exeptions, but slightly, if at all, directly damale (a)l.

Anther serions damage, Jowever, resulting from the liequent recurrence of fires is the destruction of all rougetable matter in the soil. Deprived of the mulching needed fon the retention (1) moisture. the maturally porous and dry soil, now rendered absolutely arid and lauren, is no longer eapable of supporting any larger tree growth or other useful vegetation.

J.IVE SHOR

Of mo less danger to the existence of the forests of longleaf l'ine is the injury eansed by live stork. This ancory, slow in its action, is sure to lead to their destruction muless restricton to some

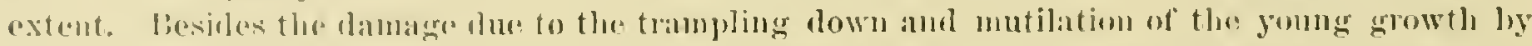

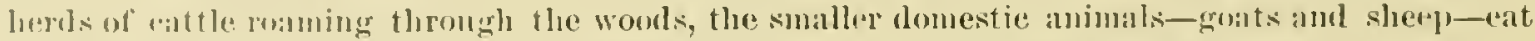
the tufts of the temder folinge of the sodlings, while hogs are seen digging up and chewing the spengy and temler routs of the young plants. As a further agency in the way of the renewal of this speries, the destruetion of the matme cones might he mentioned. ansed principally by the

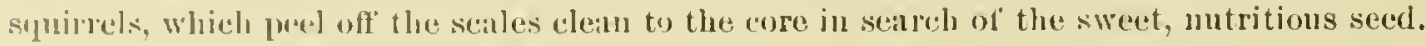

STORM:

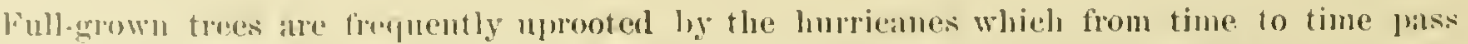

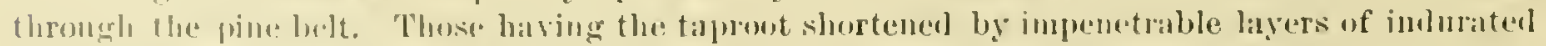

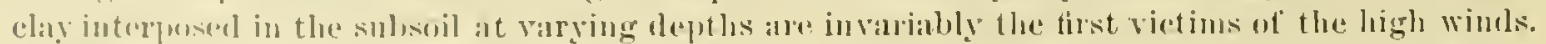

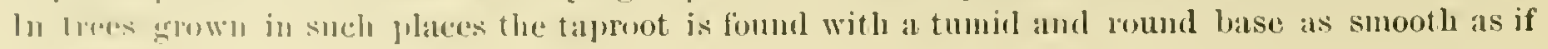
jolisherl. 
iriscx.

Firequently full-grown trees are fomul to show signs of rapid decay. These are reergnizerl by the gratnally dying of the smaller limbs and their lalling on; in consequence of the rutting of the woor surrounding their base; and after having been cast oft a hole or diseatsed spot remains in the trunk, which is infested by a large fingus of the gemus Polyporus (junk lowes, junk stools). The lieartwood of such trees is of" a reddish color, solt, wallyy, and full of small chinnels, cansedl by the brealing down of the walls of the wool cells, filled with the anyectium, the so-called spawn of the fungus, the threads of which also penetrate the medullary rays. Such punts or reel-hart timber is fomnd mostly on the ridges in the poorest soil. Apparently superanmated trees irre most frequently fomd aftlicterl with this rot.

IXSECTS.

The Longleaf l'iue, thronghout its existence, is exposed to the llanger of destmetinn ly the ravages of insects, hosts of which, belonging to varions orclers, are fonnd to infest it firom the earliest stages of its development. Cpon the tufts of the tender primary leares of the seedling are often fomul feeling large mumbers of a yellow, black-striped caterpilar, the larvin ot a species of sawtly (Lophyrus).

The cambinm of trees felled in the latter part of the summer is soon fouml swarming witl the larval brond of bark beetles, which after a short time infest the trees growiug uear by, causing, as las been again aud again observed, the death particularly of the trees of younger growth over exteusive areas. Hence the necessity of stopping the practice of felling trees during the sumner season. Aceorling to information kinlly furnished by Mr. Schwarz, of the Entomolocical Inivision of the United States Dejartment ot Agriculture, most if not all the species of the barli beetles, the fimily Tomicide have more than one annual generatiou, and iu the Southern states they have, in all probability, thee. The summer generation develops in a very short tine, pussibly within four or five weeks, and the perfect beetles issuing from the trees felled in Angust will in Sejtem. ber attack the healtlyy trees near by for want of more suitable fool. The raviges spoken of by Miclanx refer, no donbt, to these species of Tomicinte beetles which enter the solich wonl of trees, e. g., Gnathotrirlus muteriarius and Iyleborus pulescens. The galleries of these timber beetles or allied species are found to pentrate the roor to the beart. The grating noise mate by the larve of the large ceramboil beetle, the Monohammus, while engagerl in its work of destruetion frequently strikes the ear in the forest. That there is a large number of species belunging to different orders preying on the Longleaf Pine and more or less destrustive to the life of this tree is apparent from the following communieation from Mr. Schwar\%:

The number of insects to be found on the Lougleaf Pine is vers larere and comprises species of most oriers, but a complete list of them has never been published and the habits of nost of them have never been carefully studiel. Ouly those which are really injurions to the tree need to he cousidererl.

Order Iymenoptera: Several species of sawtlies (Tenthedinidte), occasionally very injurions to the younger tress, the larvis defoliating the brimches. The speries thus far ohserved are Lophyrus abbotii, Leach: Lophyrns Leconlci, Fitch, and three or four less conmon species.

Order Colcoptera, slip B : Round-headed lorers (larwa of Cerambycider) aflect the trees similarly to the Imuprestidu, but their burrows are always eyliudricul. and some species bore only under the lourk. The most abuntant and destructive is Monohamma titillator, Fabr., lut there are nany other speries, of which the following is a partial lint: Scuphinus soharicollis, Lee.; Asmum moestum, llahd.; Criocephalus nubilus, Lec.; Eupogonius fomentosis, 1lald.; ferntho. cimes nodesus, Fabr. In the finily Curenlionide, the worst enemy of the pine trpe in the more Northern states. Pis*odes strobi is rare in the region of the Longleaf Pine, but another species, I'achylobins piritms, Germ., the larvin of which bore moler the bark, is quite common aml greatly injurious to the Longleaf l'int. Of its more dangerous enemies the Scolytid beetles, which inostly bore their galleries under the bark, only al l'ew speries cinturing the sulid wood, the following are known to infest Pinus palustrix: Pityohhthorns pulcarinx, \%im.; 1'. annectens, Lee.; Tomicus culligraphus, Ger.; T. arulsus, Eich.; T. cacographus. Lec.; Crypturgus utomns, Lec.; Dindroctonus tercbrans, Oliv.; D. frontalis, Zim.; Hyluste's porculus, Er.; IT. erilis, ('hap.

The fow species entering the solid wood are Platymus quadridentatus, Olis,; Gnathotrichus materiurius, Fitel, anut

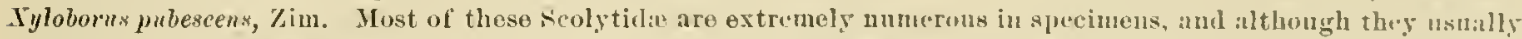
infest injurenl or diseased trees, yet in cases of excessivo multiplication or fir waut of proper food they often attuck healthy trees, which within one or two years succumb to their attacks. 


\section{NATULAL, REPROHUV'THOX.}

Cortain proliaritius inherent lo this species form a series of ubstacles in the way of its

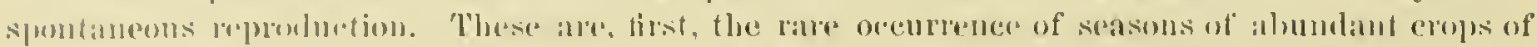

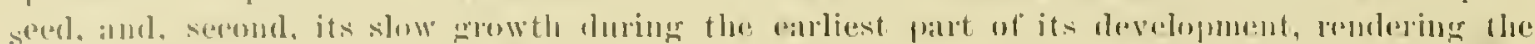

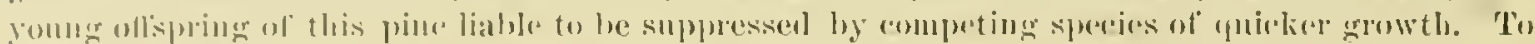

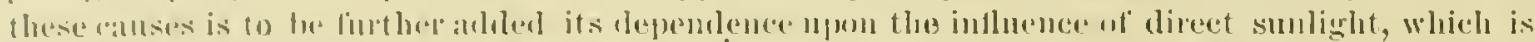

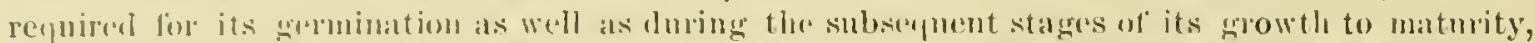

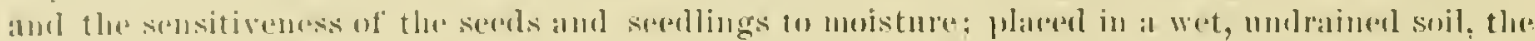

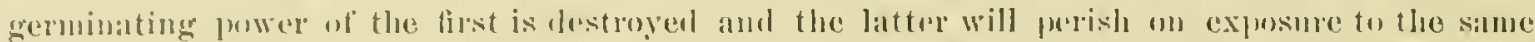

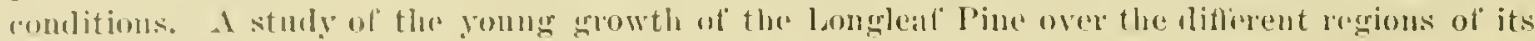
habitat leads mavoilabile to the condusion that the chandes for the renumbetion of its forests,

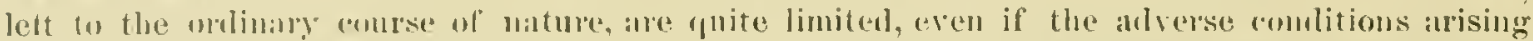

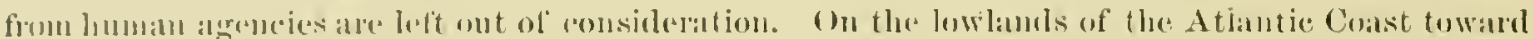

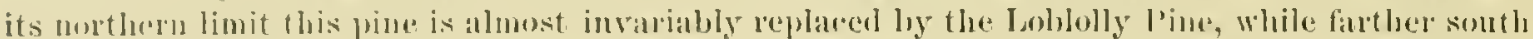
and in the coistal platu of the Gult states ast of the Mississippi liver, alter its removal, it is replaced partly by the lablolly l'ine and largely ly the Cuban l'ine, ()n the wide expanse of uplands rising above the coastal plain with their broad rielges of a soil of sandy loam, the young troes of the lomgleat l'ine are mer with in every stage of gow th. Attaining however, during the

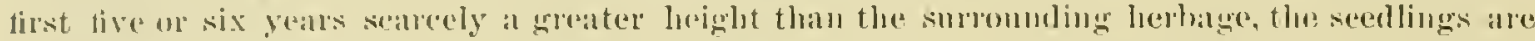

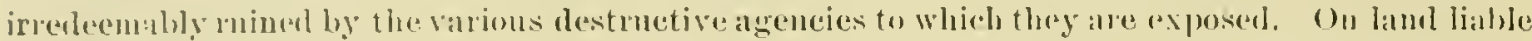

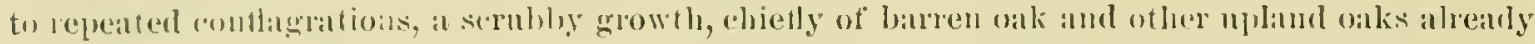
mentioned, takes pussession and eveludes by its shate the pine. If mon the dolling pine lands or

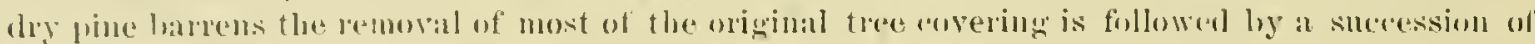

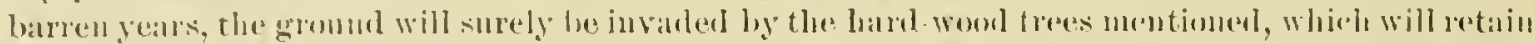

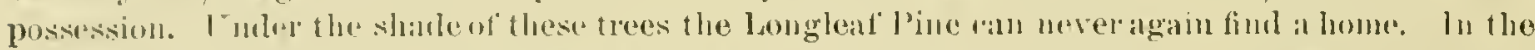
stronger soil of the upper division of the matime pine belt, the region of mixel growth, where the

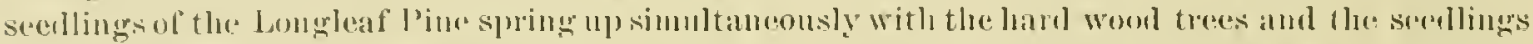

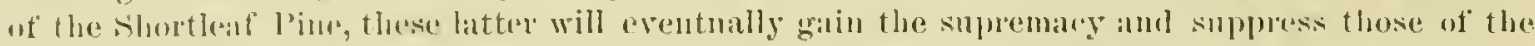

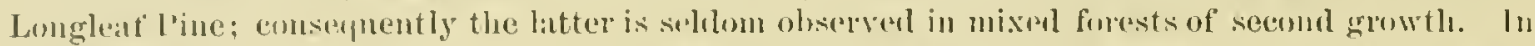
the Hat wouds, patrtirularly in the pine bats of southwestorm Lomisiana and Texas, with a soil

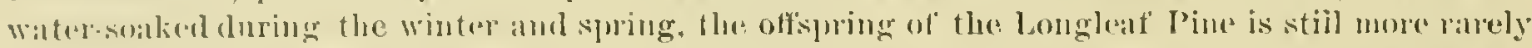
met with for the reasons statrol. From these fauts it is evilent that, owing to natural causes, combind with the mrestrieted sway of the intluenes leading to its destruetion ly human agency,

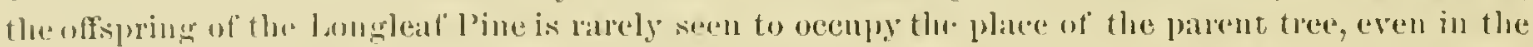

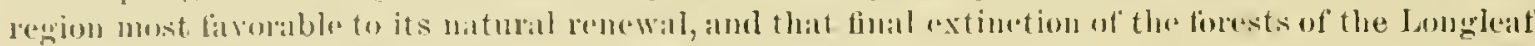
l'ine is inevitible muless foroper' lorest mantagement is applied.

\section{FURES'T MANAIIEMEN'T.}

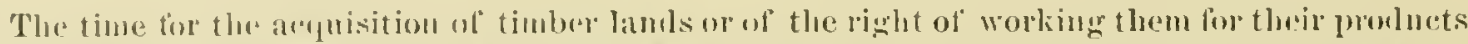

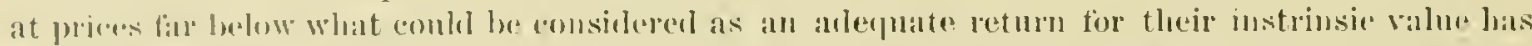

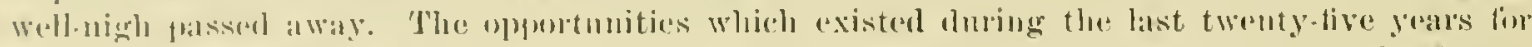

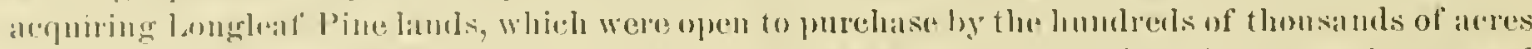

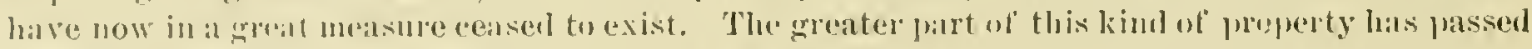

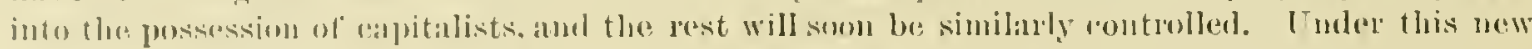

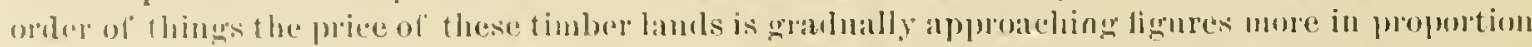

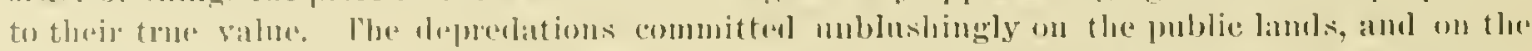

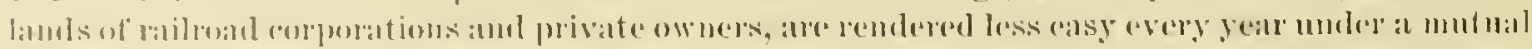

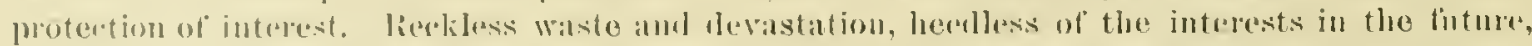

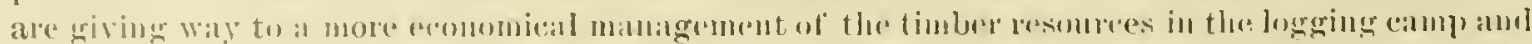

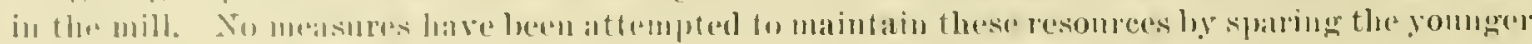
timber in its best stage of growth from the as, on to provide in any other way for the protection ambl presereation of the younger growth. 
What has leen said of the geographical distribution of this tree and its demands mpon elimate, soil, and exposure, demonstrates that east of the Mississippi liver it can be suceessfully growill all over the maritime plain of the Sonthern Stutes (Anstro- liparian zone) and in the interior of Ala. bana, through a lange region of the Cumolinian and the extreme sonthern extension of the Apualachian zone to an elevation ahove the sea filling little short of 1,000 feet. And the sandy soils of this region, largely too poor for agricultural use, are far cxeellence Lomgleat pinelauds. In the renewal of the forests of Longleaf P'ine, npon areas denuled, the fact must be borne in mind that to produce timber which is unler present conditions considered of linir merchantable quality at period of not less thin one humber and fity years is required, and that to produce timber of the strength, clearness, and durability for which it is heht in such high esteem the slow growth under the severe and hardening comlitions involved in the struggle for light in the crowder forests is necessary. Hence, economie reasons would point to the maintenance and conservative manige. ment of the existing torests of Longleaf Pine and their renewal by natmil reprortuction, and perhaps best the methou of seleetion which under the present conditions aprears the most practieable, iuvolving chictly methods of protection.

By this metlod all or most of the mature trees, correspouding in their proportions to the most desirable quality of timber, are cut and the rest left to grow till they reach similar dimensions, to be in their tnru replacel by the seeond growth, which in the openings fiom time to time springs "1). In fact, this method was followel in the earlier days of the timber industry in the several regions of the longlear l'ine, where the forests were being enlled for the best sizes at intervals of from fifteen to thirty years. But owing to the exhanstion of the mature pine from forests within distance of railroad lines and water courses, which necessitates great outlays of calpital for constructing tramroads or waterways, the original practice of selection bas been abandoned, no tree being spared at present that will make a stick of timber, however small, as long als it fiuds a sale in the market. Care shonld of course be taken to leave always enongl seed trees evenly distributed, and the chiet care is to be directed to the protection of the seedlings and other young growth from the destrutive agencies mentioned-tire, cattle, and the cucroacli. ment of invading species. A forest moler such management would nereswarily present a great diversity in the growth of the trees, and the length of time between one entting and the next would be equally variable. It must be remarked that the demand of this speeies for the mulin. dered access of direct sunlight during the time of germination and successive stages of glowth might prove a serions obstacle to the continued suceess of this metiod of solection; and the "group method," as deseriber in the report of the chief of the Division of Forestry for 1s94, might be sub. stitnted with advantage. Where it is desired to reestablish the growth of Jongleaf l'ine upon dennded areas, the gromd nust be cleared of every olstadele in the way of free access of the rays of the sun before the sowing. Owing to the ease with which the seeds gemmate and the seed. lings take root in the ground, but slight preparation of the same would he required, and there wonld be no difficulty in proenring a goul stand. If transplanting is to be resorted to, the seedlings should be taken up during the fall or winter succecding the first seasun of their grutrtl, before the further development of the rapidly growing taproot, the precantion always being taken to prevent auy injury to the rootlets and their drying out before their transter to the gromd. Since the trees clear themselves easily of branches, the stand in the plantation in the earlier stages does not need to be as dense as with other speeies. In order to secure improvement and permaneney of fivorable soil conditions, the litter from the shedding of the leaves and grathal decay of herbage shonld be leit undisturbed on the ground.

There can be hardly any cloubt that the introduction of other shaty species would greatly assist in improving soil conditions and producing more lapid development of the pine. Care would have to lie taken to bring in these species later, say between tifteen and twenty years, when the pine has begun to make its rapid height growth and ean eseape the slade of its neighbors.

For the present, however, the economie conditions are hardly got ripe for any artiticial reforestation, hut the great importance of this valuable forest resouce to the industrial and commercial development and prosperity of the people living within its limits shonld be apparent enongh to keep them at least from preventiug its natmral reproduction. The growth of the young timber after the first few yoars is rapid onougl, as may be seen firom the table on page 57 , ant 17433-No, $13-5$ 


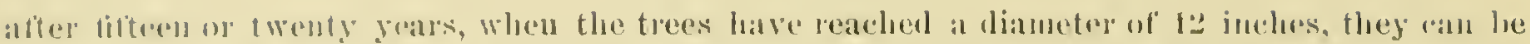

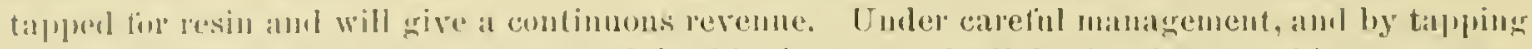

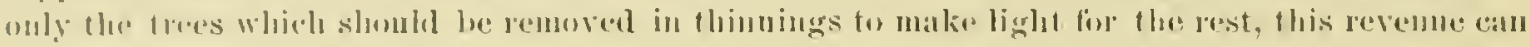
be whtalued withont in any way ingating the final harvest value.

\section{rONCLISION.}

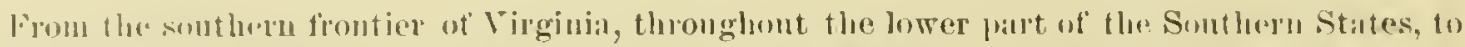

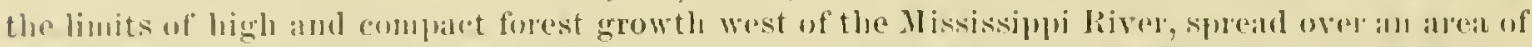

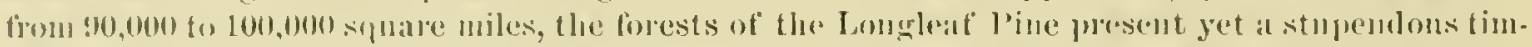

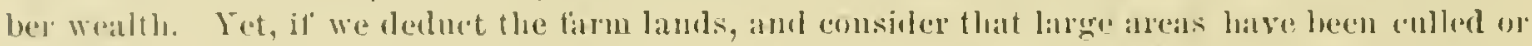
"atirely dommlod of the original growth, we may estimate that the anoun of timber standing can at best not receed $1001,000,000,000$ feet, and is jurobably mull less, while the ant, which at present

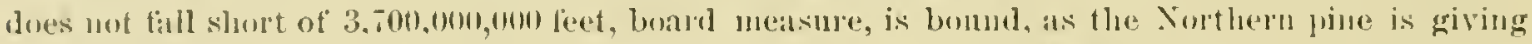

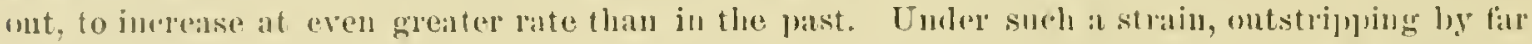
the josibilities of therir reprornetion, the exhanstion of the resonres of these forests within the

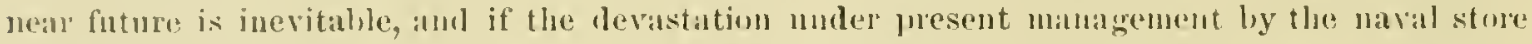
industry and the destruction camsed by fire and domestic animals is combinned their extermination as lin as practical purposes are concerned must be regarded as equally certain. 


\title{
APPENDIX.
}

\author{
THE NAVAL STORE INDUSTRY.
}

The resinous product of the Longleaf pine furnishes the raw material for the production of naval stores, one of the most infortant industries in connection with the resonrees of the American forests. At present the buik of these stores used in the world is derived from the forests of Longleaf Pine, and hence this industry is almost entirely eonfined to the const pine leelt of the Southern States, the proportion eontributerl by France, Austria, and other conutries beiug insignifieant.

For the year 1892 the foreign export of spirits of turpentine alone anounted to orer 260,000 casks and the total production exceeded 350,000 easks. To prodnce this amount of spirits at least 2,500,000 acres must have been in orehard, aud since over one-third of the total production is furnished by orehards being worked for the first year, over 800,000 acres of virgin forest must be attacked aumilly to supply present denumuls.

Under the name of naval stores are counprised the products derived directly or indirectly from the resinous exudation of coue-bearing trees, mostly pines, incInding tar, the product of the destructive distillation of the wool of pines highly eharged with resinons matter. The name is undoubtedly derived from their extensive consmuption in the shipyards and on board of vessels. These prodnets are:

IEESIN, OR CRIDE TLRIPETINE.

The resin of the Longleaf 1 'ine recently exuderl is almost colorless, or of a pale straw eolor, of the consistency of honey, having a terebinthinons odor and taste, and like all substances of the same elass is insolnble in water, but soluble in alcohol, ether, and spirits of turpentine. It con. sists of a volatile oil and a solid resin held in solution partially suspenled in the former. The best quality is obtained duriug the first year the tree is worked, known as "virgin dip" or "soft white gum," which is almost colorless and contains the largest quautity of volatile wil. In the following year it is of a deeper yellowish color, the "yellow dip," which with each sureeeding year becomes darker in color, more riseid, and poorer in volatile oil."

The resin towarl the close of the season produced on the tree under the influeuce of a cooler temperature is 'alled hard gum, or scrape. This solidified resin of whitish to yellowish color contaius only half of the quantity of the spirits of turpentine obtained from the dip or suft gum. By the distillation of the crude turpentine the naval stores of most importance to trade are obtained.

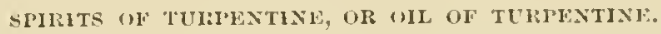

Spirits of turpentine, or oil of turpentine, is the rolatile constituent of the resin. This licuir when freshly prejared is eolorless, of a peeuliar oulor and taste, of a clensity varying betweeu 0.85 and 0.87 , volatile at ordinary temperatures, boiling betreen $304^{\circ}$ and $3: 00 \mathrm{~F}$. It turns polallizel light to the right, a charanteristic feature of the Ameriean spirits of turpentine, anost of the spirits from other sources polirizing the light to the left. In its pure state this volatile oil is free from oxygen, being a hydrocarbon of the composition of $\mathrm{C}_{10} \mathrm{H}_{10^{\circ}}$. It is highly inflammable aud

1 It is still an open question whether this deteriorntion is necessary or only owing to faulty manipulatiou. Experiments to suttle this yuestion are now in prorress in the lorestry Division. 
burns with at sooty thamr. It is a soml solvent for many resins, wax, fats, calontehouc, sulphur, and phosplonus, and is used in the ants and industries for the preparation of varnishes, in paints,

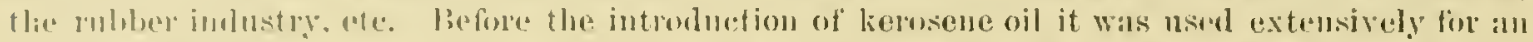
ilimminator; it is also nsed in medieine internally and exfermally and when as an allulterant of valums trantial wils.

manix, on tom.olmoxy.

The solin anstitnent of the "rude turpuntine which forms the residne remaining after its dis.

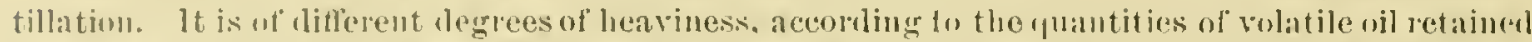
atter distillation, is buttle. easily powlecel, of a glassy luster, and of the specitio gravily of 1.07,

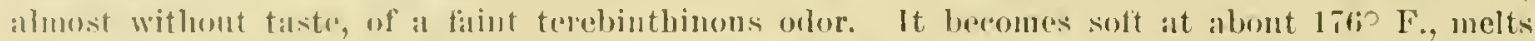

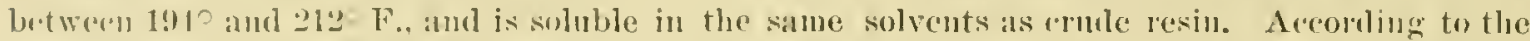

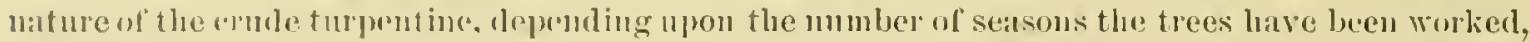
it shows diflorent ponerties in regard to the transmission of light, and in color. It is either perfectly transparent, thanslucent, or almost oparme and almost colorless, or a pale straw color to

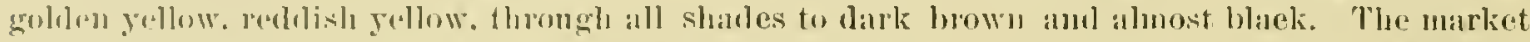
value of this artiole is astirely regulated by these poperties. In the Ameriean market the follow. inge grades arr distingnished: WW (Water Whitor and W(: (Window (ilass), the lightest and

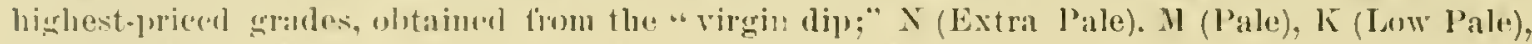
I (liond No. 1), ll (No. I), F (Good No. 2), L (No. 2), I) (Gool Striun), C (Strain), B (Common Strain). ant A (likak).

INE TAL:

This is not rantly a by-pronluct of the turpentme orehard, but is produced by the alestructive distillation of the wood itsell. It is chiefly produced in Sorth Carolina, where this iudustry has been carried on sine the carliest eolonial times. Suall quantities ane produced in other" sections of the Suntleru pine belt, mostly for lome consumption. l'erfectly ary woon of the Longleaf Pine, dear limbs and trunks seasoned on the stump, from which the sapwood has rotfed, are cut in suitable billets, piled into a conieal stack, in a rirenlar pit, lined with elas, the renter communi. cating ly a depressed channel will, a receptacle-a hole in th" grouml-at a distance of : to $^{4}$ feet trom the prile. The pile is covered with sod and earth, and otherwise treated and managed

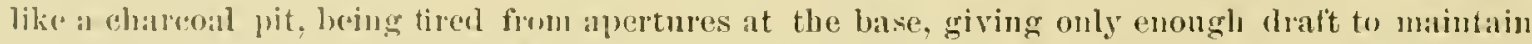
slow smolibring combustion. After the ninth day the tar begins to llow and eontinnes for several

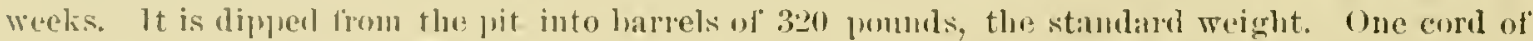
dry" "fat" or "light wood" finmishes from fo to in gallons of tar. The price of pine tar is quoted

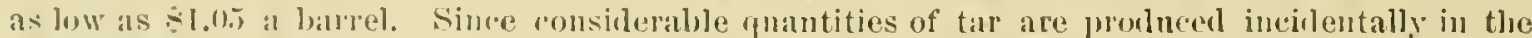
destmetive distillation of wood in imon reforts for ehareoal and other products, the price has been wreatly depressorl.

consum hitril.

The best pualify is obtained by boiling down tar until it has lost alout one-third or more of its weight. The navial pitch of commere has more or less rosin of the lowest grade added to it. Pitch is also whtained as the resilue monaning from the dry distillation of rosin for rosin oil.

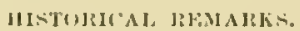

The tappling of the trees for the crucle turpentine and the mamfincture of lar and pitel was

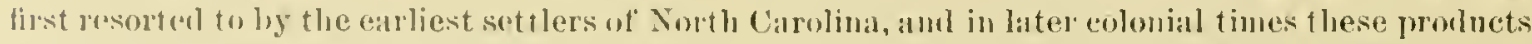

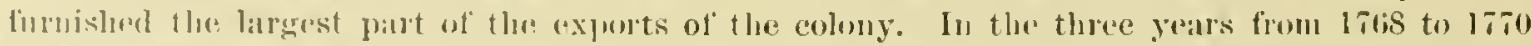

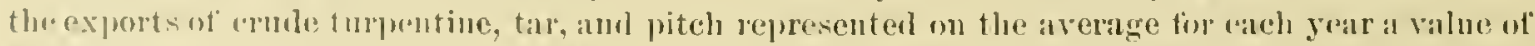

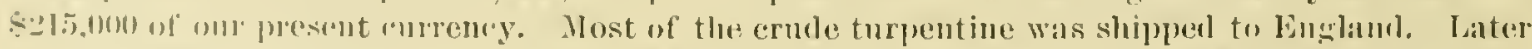
the distillation of spirits ol monentine was carriced on in elumsy iron retorts in North Canolina and in Porthern cities. The introduction of the eoppere still in 1 s.3. resulted in a largely

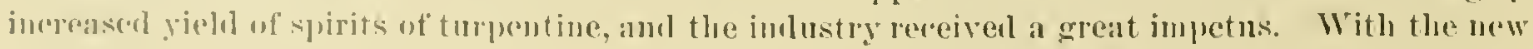

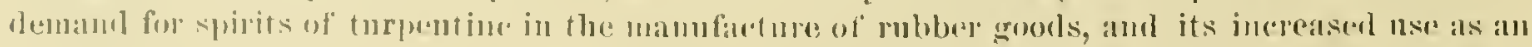

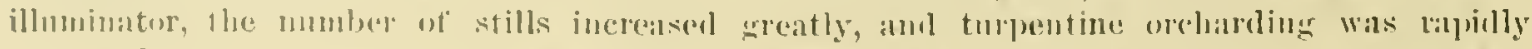
catended sonth and west beyond its original linit. The large consmnption of sporits of turpentine 

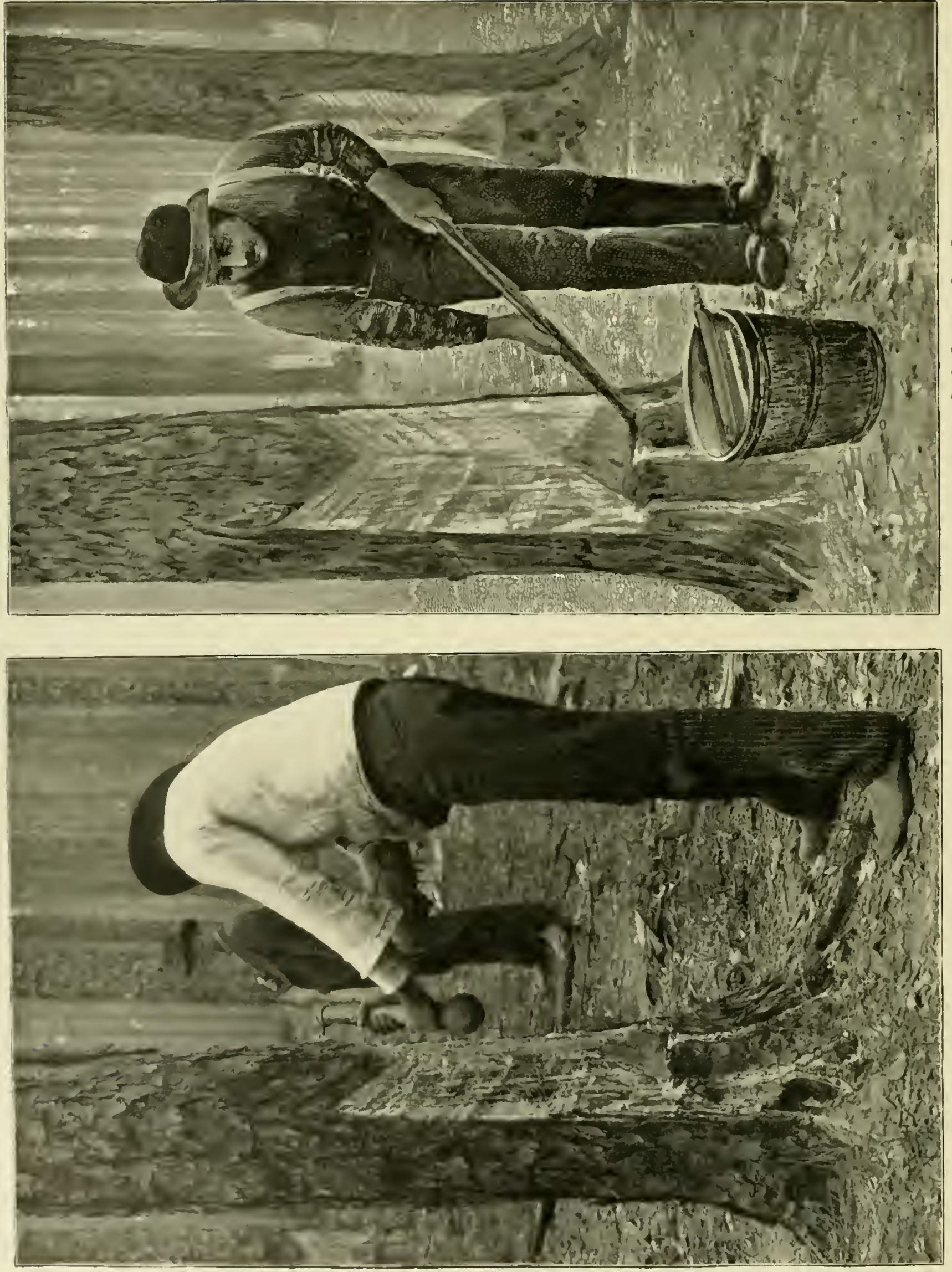
cansed such an increase in its production that the residnary product, rosin, hecanne largely in excess of the demand, and, in conserpuence, much depresiatent. This lenturtion of punfits in the husiness eansed the transfer of the stills from fle leading markets to the somere of the law material, the torest. From that time, 1St1, dates the great progresis marle in the extension of this industry. Up to that time more than half of the crude tmpentine was distilled in North Canolina, but thenceforth the industry spreal into the States of south Carolina. Georgial. Floridia, and the Gulf States to the Mississippi River.

It the close of the war the clemand for splirits of turpentine was not so great as before, petroleum products of several kinds having leeen fonnd to take its place not only for illuminating, lut also for other purposes. With the general extension of arts and manufartures all over the world, there has since been an increasing demand for spirits of turpentine and rosin. The exports of these artieles in the year IS90 anrounted to $\$ 8,135,339$ in value.

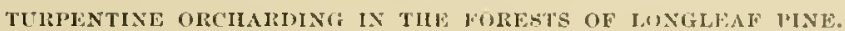

In the establishment of a turpentine orehard and a still, two points must be eonsidererl, namely, proper facilities of transportation to shipping points aml a suflicient supply of water for the condensel conneeted with the still. The copner stills generally in use have a calpacity of albout 800 gallons, or a charge of 20 to 25 barrels of crulle turpentine. For' such a still to be (olurgerl twice in twenty-four hours during the working season, 4,000 acres of pine hum of a good average stand of timber are required. This area is divided into twenty pareels each of 111,000 boxes, as the receptacles are called, which are cut into the tree to receive the exuding resin. Such a parcel is termed a erop, constituting the allotment to one lahorer for the task of chipping. The work in a turpentine orchard is started in the eallier part of the wiuter witl the cutting of the boses. Untit some years past no trees were boxed of a diameter less than 14 inches; of late, however, saplings under 10 inches in dianeter are boxed. Trees of full growth, according to their circunference, receive from two to four boxes, so that the 10,000 boxes are distributerl anoug 4,000 to 5,000 trees on an area of 200 acres.

The boxes are eut (see Pl. VIII) from $S$ to 12 inches above the base of the tree, 7 inches deep) and slanting from the outside to the interior, with an angle of abut 35 . In the alnit trees they are 14 inches in greatest diameter and 4 inehes in greatest width, of a rapacity" of abunt : pint:. The cut above this reservoir forms a gash of the same rlepth and about 7 inches of' greatest height. In the meantime the ground is laid bare around the tree for a distance of $2 \frac{1}{2}$ to 3 feret, and all combustihle material loose on the gromul is raked in heaps to be hmed, in oriler to protect the trees against danger of eatehing fire during the contlagrations which are freifuently statch in the pine forests by design or carelessness. The employment of fire for the protection of the turpentine orehard against the same destructive agency necessarily involves the total destruction of the sualler tree growth, and it left to spread withont control beyoul the proper limit, often carries ruin to the adjoining forests.

During the first days of spring the turpentine begins to tlow and chipling is begun, as the work of scalritieation is termed, by which the surface of the tree ahove the box is hail bare beyond the youngest layers of the wood to a depth of about an incli from the ontside of the bark. The removal of the bark and of the onternost layers of the woort-the ".hiplning" ol "hatcing"-is done with a peculiar tool, the "hacker" (tig. 9,,$f)$ ), a strong knife with al rurved edlge, fastencd to the end of a landle bearing on its lower end an inon ball abont + pommls in weight, to give increased force to the stroke inflicted on the tree, and thus to lighten the labor of chipling. As soon as the scaritied surface ceases to discharge turpentine theely, fresh incisions are marlo with the hacker. The chipping is repeaterl every week from Ilareh to October on Yovenber, extending generilly over thirty-two weeks, and the height of the elnip is increased abont $1 !$ month. The resin acemulated in the boxes is apped into a fail by a that trowel-shaped dipper (fig. 9, a) and then transferred to a barrel for transportation to the still. lu the first seasun fim

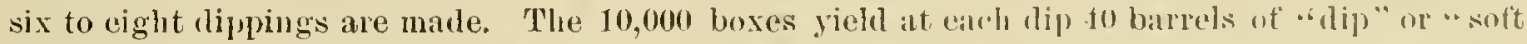
gum," as it is reckoned in Alabama, to be of "240 poumls net weight. The flow is most copinus during the height of the summer (July and Angust), diminishes with the andent of the conder season, and ceases in October or November. As soon as the exmdation of the resin is arrested and 
the resiu begius to harden under the inllurnee of a lower temperature it is arefully seraped from

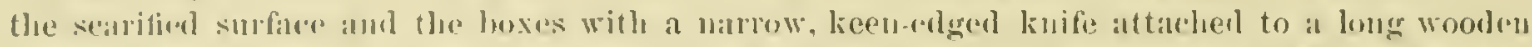

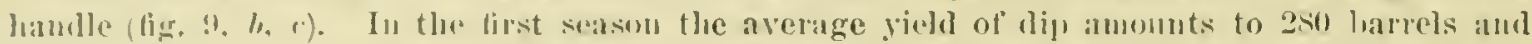

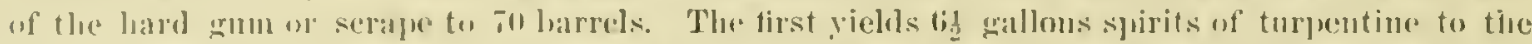
Inarel of 241 poumds met, ind the latter $: 31$ pounds to the barel, resulting in the production of

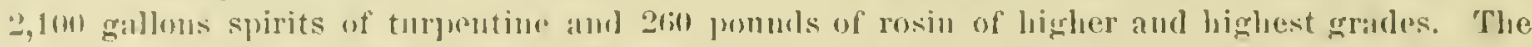

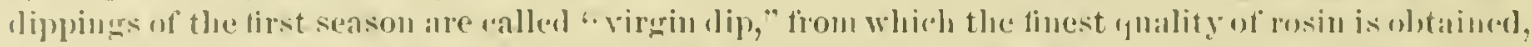
srated in the market as Water White (WW) and Wudnw Glass (WG). In the smond year fim

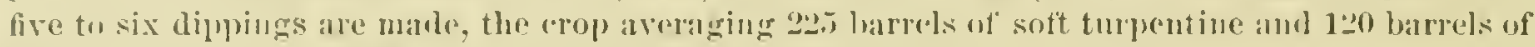
scrape. malking altugetler almut 1.900 gallons spirits of turpentine.

The rosin, of which abont "20u barrels are prodncel, is of a lighter or deeper amber color, and perfecty transparent, of medium ynality graded as I, II, and ti. In the third am fourth years the number of dippings is rednced to three. With the flow oser a more extended surface, the turpentine thiekens moler prolonged exposure to the air and loses some of its volatile oil, partly brevaporation and partly by oxidation. In the third season the dip amounts to alwout 100
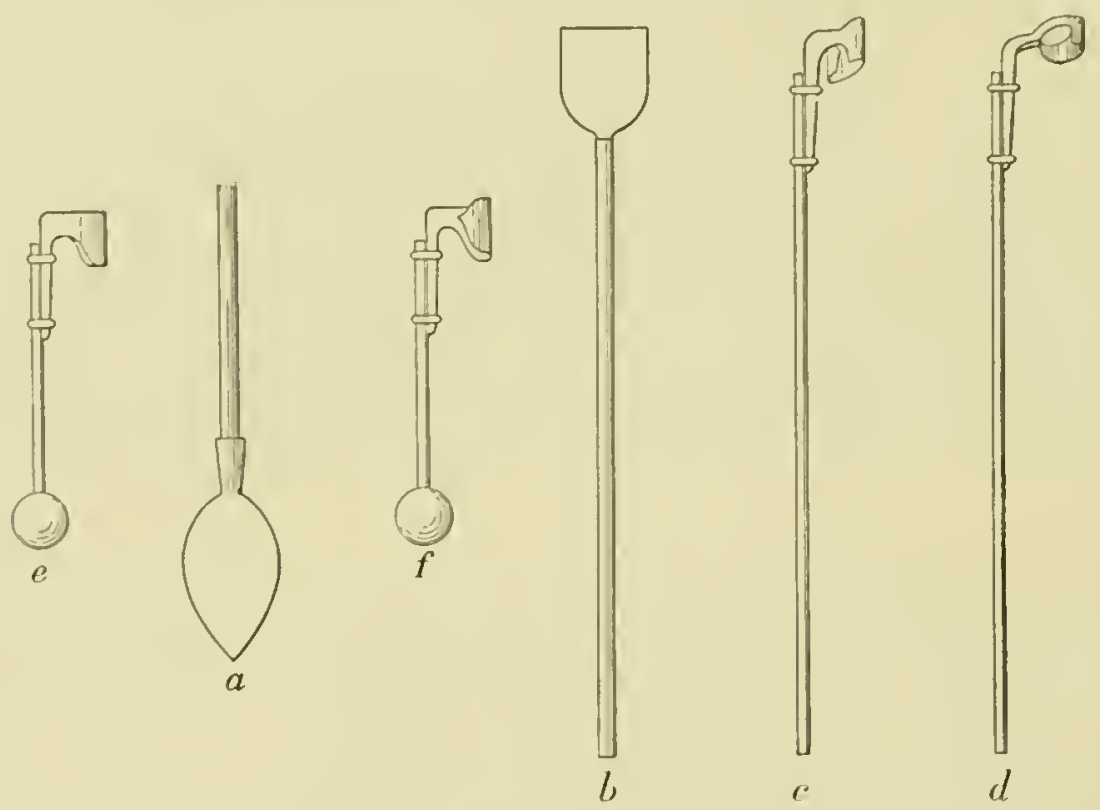

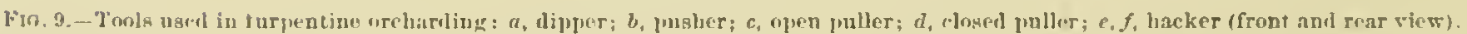

barrels and the serape to about 100 barrels, yielding about 1.100 gallons spirits of turpurine and 100 barrels of rosin of a more or less dark color. less transpurent, and cranded as li. li, and 1 ). In the fourth and last year three dipuings of a somewhat smaller quantity of soft tmperntine than that obtained the season before and 100 barrels of scrape are ohtained, with a yeld searcely" realizing 300 gallous of spirits of turporutine and 100 harrels of rusin of lowest punlity, chassed as $\mathrm{C}, \mathrm{B}$, and $\mathrm{A}$. After the fourth year the turpentine orehard is generally abandoned. Owing to the

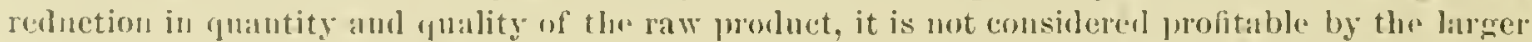
operatmes to work the trees for a longer time. It is only in Nortl, Caroliua that the smallev landowners work their trees for ten or more snecessive seasons, protert the tres against fire, and after giving them rest for a series of years, ajply new box's on spleces left between the old chips"reluxing."

WSTIILATH:S.

The juroress of distillation is earried on in the ordinary way, and refunires fare and rexperience to ubtain largest fuantities of rosin of highest grate and to guard agaiust overhwatug. Afler

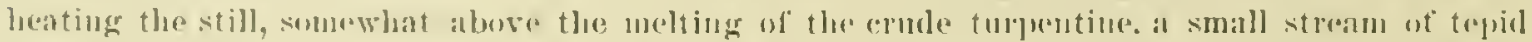
water from the toju of the enmlenser is condureted into the still and allowed to run until the and of the process. A latrge quantity of water runs over with the spirits of turpentiuc, which is 
collered in a harel, where it sejsuates from the water and is then immediately transferied into barrels. After the wil has ceased to run freely the heating of the still and the inthro of water las to be carefully regulated. After all the spirits of turputine has been distilled over, the fire is: removed and the contents of the still are drawn off ly a tap connected with the botton. This residumm, molten rosin, is at first allowed to run through a wire cloth and is immediately strained again througl comse cotton cloth or cotton batting, made for the purpose, into a large trough, from which it is ladlen into barrels. The legal standand weight of the commercial prekage is

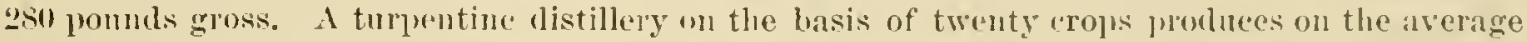
during the four gears that the boxes are worked 2,400 (askis or 120,000 gallons of spirits of turpentine and abont 12,000 barrels of rosin or $2,800,000$ pounds, the lowest grades, I3 and $\mathrm{A}$, excluded, a total ralne of abont $1,0,000$ at average prices. The prices of spirits rary at present from "s to 40 cents a gallon, eren throngh the same season, acconding to supply and demanl in the market. The arerage quotations on December 30, 1392, at Wilmington were "s cents for spirits and $\$ 1.91$ for a barrel of rosin down to grade C.

COST OF FSTABLISHANG A PLANT AND WORINNG TIE CROPS.

Timber lands with the privilege of boxing the timber for a term of four gears are renterl at the rate of $\$ 50$ per erop of 10,000 bnxes, or 200 acres. The establishment of a plant for the working of trenty crops, or 4,000 aeres of timber land, requires an investment of abont $\$ 5,00 n$, inclnding the buildings, stills, machinery for pnmping water, tools, and teams. According to the statements of an experienced operator, the cost of working the trees of one crop during the four years, which is mostly done by the fol,-that is, the making and cornering of the boxes. inspecting the same, laking around the trees, chipling, dipping, seraping, hanling the crude turpentine to the still, iucluding enst of barrels for spirits of turpentine, and for the rosin and superintending the crop-amounts to abont $\$ 2,300$ per erop, or $\$ 46.000 \mathrm{for}$ the twenty arops. If to this amount the interest, 6 per cent prer amum, on the eapital invested and the depreciation in the value of the plant during the four years is alderl, with s me other incidental expenses (taxes, etc.), the cost of the production of the 120,000 gallons of spirits of turpentine and 12.000 barrels of merchantable rosin' foots np to not less than $\$ 50,000$.

A method of improving on the present prictice by employing an earthen pot instead of the injurions "box" las been pateuted and practically introdnced by J. C. Schuler, of West Lake, La. The arrangement is repre- Ftg.10.-Improred method of turputine orcharding. sented in tig. 10, its main feature being an earthen pot

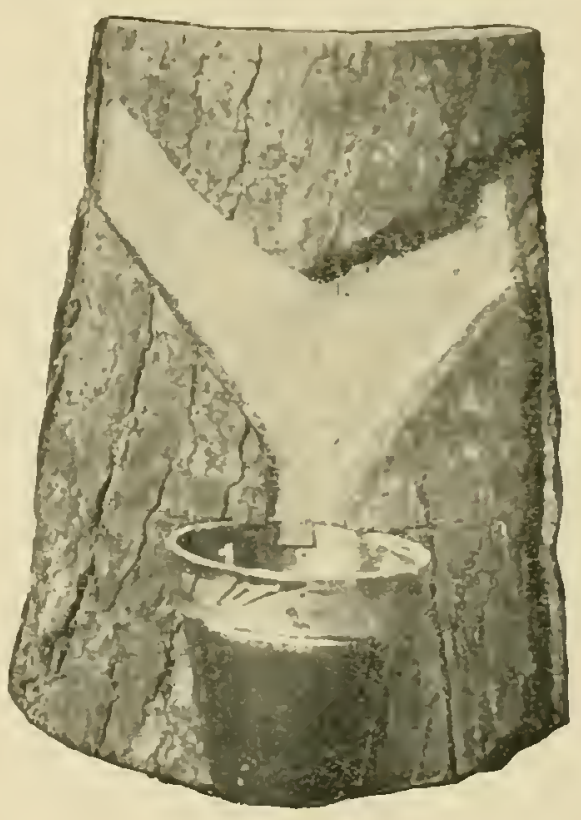
which can be moved as the sear is lengthenel. thus rentucing the distance over which the resin las to flow, and with this tho amonnt of volatilization and loss of spirits of turpentine. The methor resembles that employed in France (see Report of Chief of Forestry. Uniter States Department of Agrienture, 18!2, page 347), and, thongh its general application in this ('onutry is not yet secured, it is certainly a step in the right direction.

Mr. Solunler admits that the first cust for providing the enps, putting them up. and remoring them the secoml season raises the expense of wotking a crop of 10.000 eups for two seisons to stlil, against $\$ 190$ for cutting 10,000 boxes expended moler the old system in morking one "rop for two seasons, all other expenses eonnected with the work being considered emmal. On the nther haul, Schuler clains that the difference is vastly overbalaneel by the increased yeld of erule [mpentine obtained by his enj methods, amounting for one erop worked two years to 190.5 harrels. al 53.50 per barrel; after dedneting the extra expense involved by his method, this would leare a met balanee of stlo per erop in favol of the enj system. lle also chams that this ammut is still further augmented if the larger quantity of spirits of turpentine and the higher quality of resiu obtained 


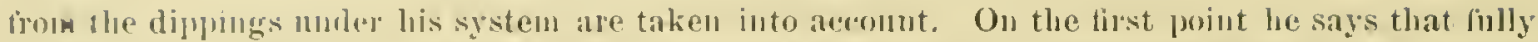
one-eightle of the amde turpentine bought to the still from the hexes consists of ehipe, sand, and

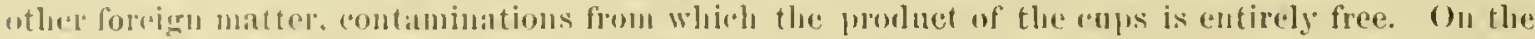
sirend point he refers to the high grades of rosin resulting frotn the distillation of the crude turlentine form the enjes, which almost entirely "lasses with the highest and higher grades.

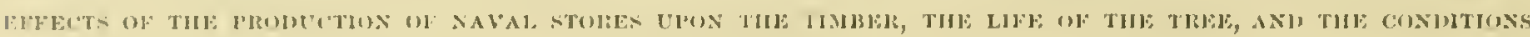

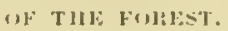

fin the present managenent of the tmpentine orchards in the Sonthem pine forests a great deal of crude turpuntue is wasted. mueh of the valuable spouts of turpentine is lost by rolatilization in passing over the long chip face on its way to the bos, and much of the resin is lowered in its gradc and value by oxidation conseguent to exposure and by admixture of foreigu substancesbatk, cosal. dist. "ote.

Concerning the eflect of the taplfing of the trees mpon the timber, there exists no reason on plupsiologieal or antomical gromuls for considering it injurious, and the opinion held by many, that the qualities of timber are imprined by bleeding, finds no support when it is considered that the leartwood remains matlected. The resinons enntents of the heartwod heing solidified and the formation of the resin taking place mily in the newly formed woorl, the leartwood ean mot participate in the flow of the resin, the dischnre being necessarily antined to the supwom. This fact has heen fully substantiated by the work of the bivision of forestry. by which it has not only been shown that the strength of the hentwowd, the most important it not the only part of the tree nsel for lumber, has in no wise been diminished, hut also that the durability of the timber, as fur as it depends 11pon its resinons contents, can not be imjaired by hleeding. It is only in that part of the butt log around the ahip that the prality of the timber becomes somewhat impaired-the wood becoming highly chargen with resin is remdered more brittle and hatrel to work, with a tendency 10 gum "1] the tools. Indinectly, however, a considerable propertion of the boxed tinbur hecones damaged if not utilizd shortly after having been blerl. It is often lelt standing tor a

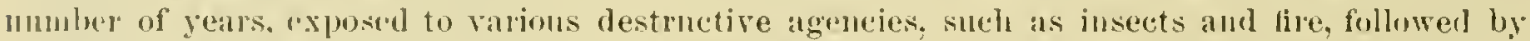
parasitie fungoid growtl. Lange capricorn heetles bore their way through flo callus suromuling the rhip and through and beyond the sapwoot. Thongh the inmmerable tissures which arr caused by fires, air and water charged with the spores of palasitic fungi fiud outrance to the bouly

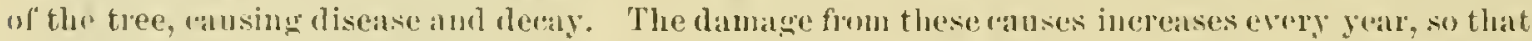
from then alone the timbre from a turpentine orehand ababloned for a dozen years was found

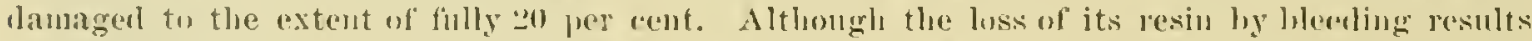
physiologically in no disect injury to the tree, the womd indicted by tapping, like any other wound, intertores with its healthy growth and, particularly in the ease of trees of smaller size, canses their

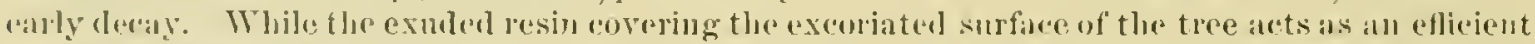
antis'jetic, allording a firm protertion against the access of the spores of fungi, it endangers the life of the tree, if exposerl to fire, by its greater intlammability, the heat purduced by its flane

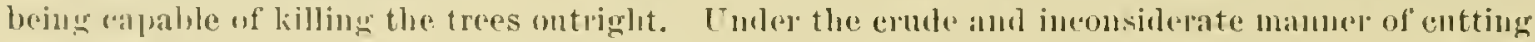
the box's, all of the trees of smaller size and many of the largel trees are blown rown, and al

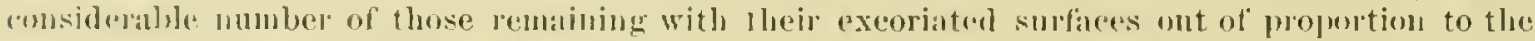
reeuperative power of flie trees alre domed to perish smmen or later in "onserfunce of such treaturist.

These injuries intlicted upon the individual tres, in connection with the fires starter with the opening of the season one year alter another, canse suld damage to the foress as to rilcet finally their fotal destruction. Fire heing allowed to swep over lange arens, its force increased in the tmpentine orrhards by the exposed resinons surfices of the trees, and by trees blown down and the dibris eosering the gremul, an immense anount of timber is destroyed. 'Trees which have mot

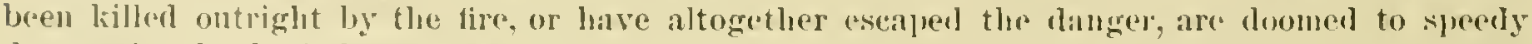
destrnction ly lank buttes and pine loorers, which find a breeding place in the living tress prostratal be the wimls during the smmmer, the bromls of" whiph rapidy infest the standing trees. which invariably suremul, to the pest the same season. In ronserfurence, the forrsts invaded by

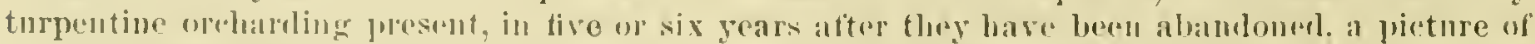
min aml desolation painful to helubl, and in view of the restruetion of the sectlings and the yomuger growth all hope of the restoration of these magnilicent forests is exeluded. 

Plate IX.

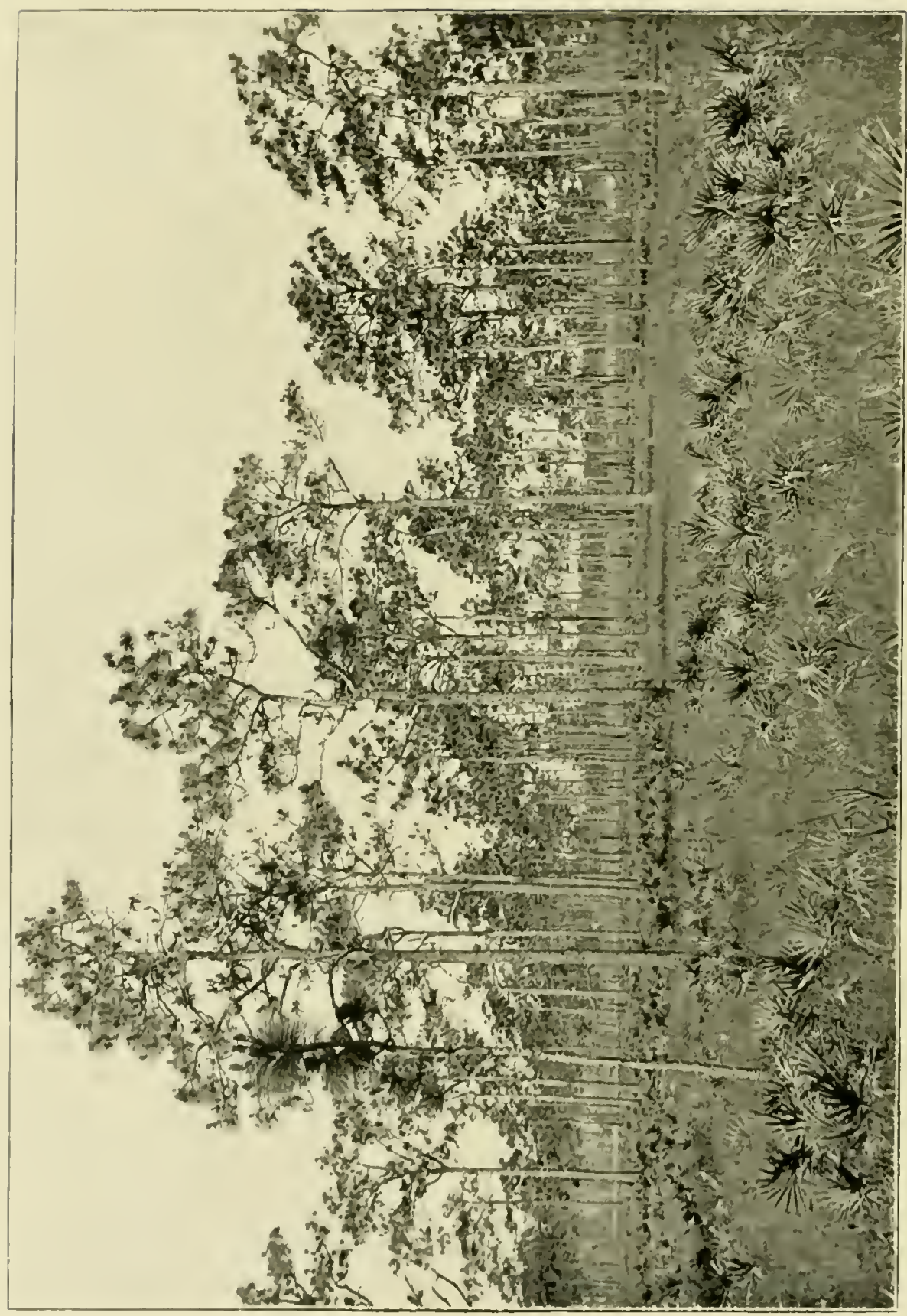




\section{THE CUBAN PINE.}

(PINUS HETEROPHYLLA (ELL.) SUdW.)

Geograpingal, Distribution.

Products.

Classification ani Nomenclature.

DESGRTPTION AND MORPHOLOGiCal Characters.

P'ROGRTSS OF DEVELOPNEN'?

Requirements for Develorient. 


\title{
TIIE CIIIBAN I'INE.
}

\author{
(linus helerophylla (1:11.) sudw.)
}

Syuonyms: P'mus lerla var, helermplylla lillott, sk. ii, bait (1821).

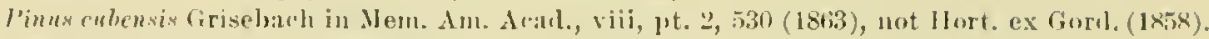

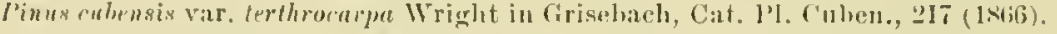

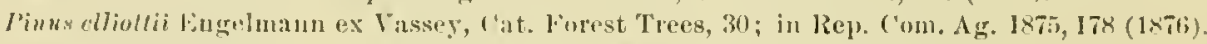

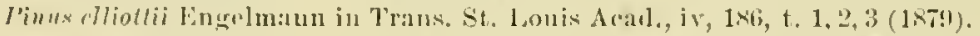
linus heterophylla (Ell.) Sulworth in 3ull. Torr. liot. (!. XX, 15 (18:3).

\section{COMNON OHE JOCAL NAMLS.}

Slaslı I'int) (Ala., dliss, (ial., Fla.).

swamp J'm. (Flat., Miss., dla.), in part.

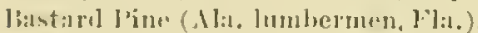

Mealow l'ine ((Gil., Fla., K. Miss.), in part. l'itcil line (ria.).

She J'iteh l'ine (6:is.).

Shro Piun (fiı. and Fla.). Spruce l'ine (So. Ala.). 


\section{THE CUBAN PINE.}

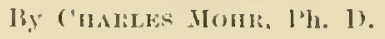

\section{INTRODUCTOLY.}

Confined within narrow limits along the coast of the extreme Sonthem States rast of the llississippi liver, little known and mostly contommled with its allied species, the value of the Cuban l'ine has heen scarcely reengnized. A "loser investigation of the properties ol its wood, of its life lisstory, and of the part it plays among the forest growtl som diseloses its economic importance. Convincer that to met proper appresiation the merits possessed by this pine need only to be manle more generally known, their ronsideration in this place among the biological investigations of the more important timber trees of the conterous order will explain itself.

'This tree was not known to the earlier American botanists. Elliott first' took notice of it as a distinet form, and he regarded it as a variety of the Loblolly l'ins. It remaned still pratically nuknown as a seprarate species for another lalt eentury, until nur the beginning of the past decade, when it was again brought to notice of botanists by Dr. Millishann, of Blutlton, S. ('.: 1)r. Engelmann exhibited clearly its specific characters, and for the tirst time directed attention to the economic value of this pine by discussing the development of the tree and the cpulitien of its timber." (1) areonut of the coarser grain of its wood and the large amonnt of sipwoorl, this timber was leet to be of little value. and the tree received little or no altention ly the lumberman. It is only very lately, especially since kiln-llying has beeme more gineral, that its value is being recognized and appreciated, and under the name of "slash l'ine" it is cut and sold withont discrimination with the Longleaf' Pine, with which it is usually associated.

\section{GEOGRAPIICAL IHSTIIBUTION.}

The Cuban Pine is a tree of the coast region in the subtrop!cal region of North Aneriea mast of the Mlississippi River, and also of the neighboring tropies, being found in llonduras and cuba (see Pl. III). In the Uniter States the tree is contined to the eastern belt of the Anstro-ripariali or Lonisianian life zone of American biologists, from $33^{\circ}$ north latitude in Sonth Carolina along the coast to the extrenity of the penimsula of Florida. Towarl the west the tree extends along the coast of the full to the P'earl River Valley. It is principally restricted to the coast plain, but on the (inlf Coast and along the water courses it extends inlanel to a distance of fully 60 miles from the sea. On the Atlantio Coast it penetrates the interior nearly to the limit of the roist pine belt, as has been observerl in dieorgia in the valley of the ocmulger River, wrer 100 miles distant from tide water. Groves of the Cuban pine slirt the low shores of the mumeroms inlets and estnaries of these consts, and cover the ontlying islands. Hore or less associated with the Lobloly and the Longleat Pine, it torms a part of the timber arowth of the open pine forests whieh in unbokn monotony cover the tlats for long alistanees. It is only in the lower part of Florida, where the tree extends from the Atlantie alosis to the (inli of Mexion, south of 'ape Canaveral and biscayne Bay, that, as the only pine there, the cuban pine forms forests by itself. Towarl the interior it ocenrs seattered among the varied growth of broul-leaferl evergreens and eone-bearing trees which cover the swamps along the streams. Since it is invariably ent and sold

\footnotetext{
' liliott, sketrh '2, pagre $2(63$.
}

"Eugelman: Revision of the genus Pims and description of l'inus elliolli, Transactions st. Louis Arill. Sui., vol, 4,1880 . 
withont distinction, no figures "an lo griven of its anmal consumption, nor is it possible to form event an approxinate extimate of the standing supplies. "The old timber goes, of conlse, as liast is that of the Longleaf l'ine, but in is reprometion it autstrips the latter. Wherever in the roas plan the original growth of the Longleal l'ine has been removerl, the Cuban l'ine takes, in a great unasture, possession of the ground, in some localities associated with the lablolly l'ine. Fonug forests in avery stage of growtl are soen rovering tracts of greater or lesser extent, promising important supplies ol resinous jurolucts, timler, and furl.

\section{Plioneg':}

As a timber tree the l'nban l'ine is little interiol to the longleal' Pine. It furnisles sticks of

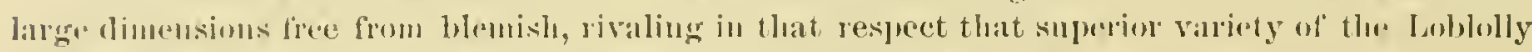

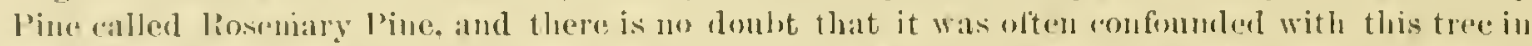

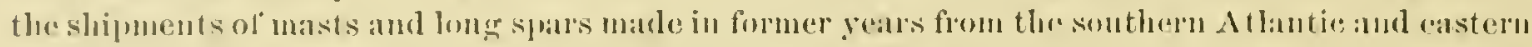
Gulf ports. In the lmuber mills on the Atlantic Coist the timber of this tree is indiscriminately sawn alum shipeded with that of the longleat Pirce.

It remains get to be proved whether the coarser structure of the woul of the culan l'ine would render it less durable. It is certinu, howeror, that this rom cause, which might interfere with its ressatance to atmospheric intluences or to contact with the soil, will he fondel an arl vantage if the preservation of the timber is to be secured by its impregnation with antiseptic solutions, mere open structure permitting readier infiltation.

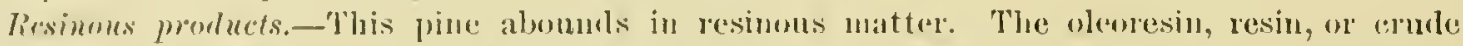

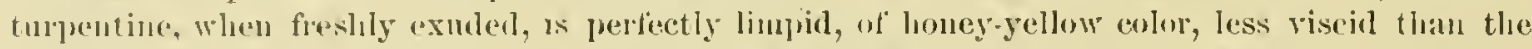
resinns proluct of the Lomgleat pine, and to all appearances richer in volatile oil or spirits of

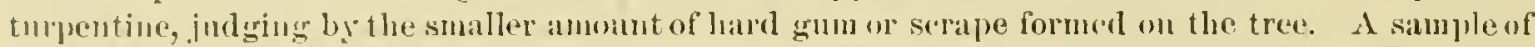
the dip of the first year lrom south Canolina was to all appearance exposerl for a short time in the box to atmosplherie intluences. Fxamined by Prof. W. Kremers, Vniversity of Wisconsin, the resin showerl an cunnlsion-like apjearance and separated upon standiner into leavier gramules and into a lighter, transparent, yellowish liquid. Its specilie gravity at $200(?$. Was fomd 1.0253. 1)=32.4230

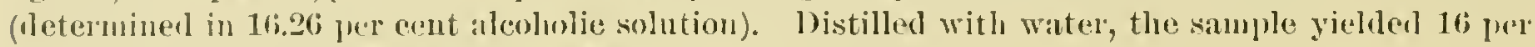
cent of ail of the sperifie glas rity $0.865(200 \mathrm{C}$.$) . I =9.620$.

In view of the rajul destrution of the forests of Longleall l'ine, the principal source of resin, the futuro inportance of the Cuban l'ine in the prodnetion of naval stores becomes all once apjarent, "specially when it is considered that it reproduces itself so mull more rearily. Liven now, on the roast of Sonth Carolina and Georeria, a lange proportion of resiuns products is rlerived

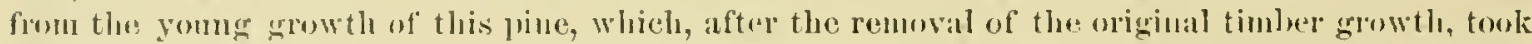
jussession of the grommd. It is climed by the turpentine gatleerers in these Stales that at an age of from thirty to forty years the trees are sufticiently large for tapping with advantage, and that jotected against fir a spontaneons renewal takes julace, and after a period of forty years the new crop is rearly for profitable "xploitation.

In Washington Connty, Ala., "m the more or less extensive flats that intervene between the

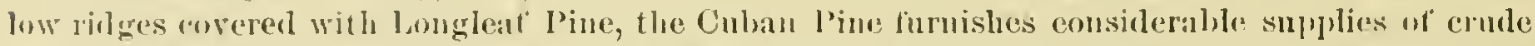

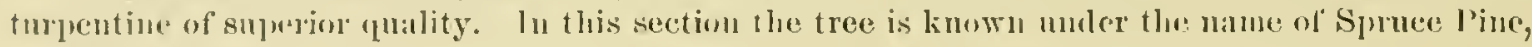
in misnomer, leathe to its confusion with an entirely different tree, the true Sonthern Spruce Pine (l'inus ylabrie).

\section{CLASTHLATIUN A.TH NOMLACLATULL.}

Irimus hetorophyllu is closely allied to the Longleaf Pine, forming with this and two other species

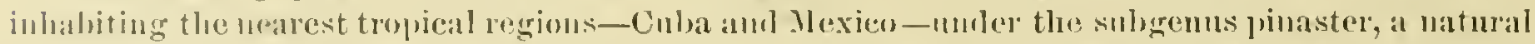

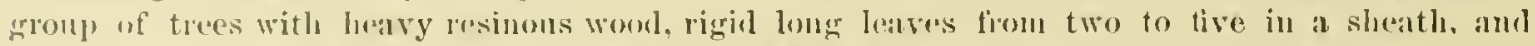
subterminal or lateral, horizontal or retlexed cones, lesignated by linglentmu as the gromp of the Euanstrales, ur longleaf pines. Jirst distingushed by liliott as l'inus tede valr. heterophylla and remaining subsenflently unkown for more than fitty years, the specific characters of this pine were

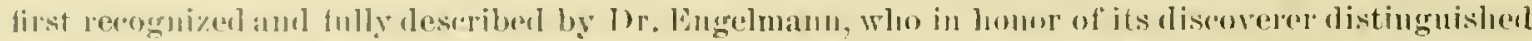
the tree under the name of I'inus elliollii, tiuding himself' soon afterwards "onvinced of the filentity 
of his species with l'inus cubensis of (irisebuch. liecently these various forms wero found to he the same as Elliott's, to which they have heen referred with his varietal ramu heterophylla raisurl to specific lank. The tree is little known amoln the imhabitants of the region of its growth; it is generally regarder as a mere variety or hastarl torm of the Longlent or the lublolly l'ine. In

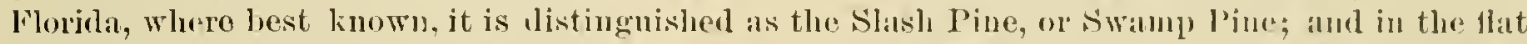
wouls along the sashore in Alabama am Mississippi as Mealow Pine. In il fow localitics in Alabana it is generally called Spruce l'ine.

\section{DESCRIPTION ANI) MOTPHOLOGICAL ('HARACTFLS.}

The leaves, two or three in a bundle, are surromnded hy a smooth sheath from one-half to nearly an inch in length, which, shose and smooth dnling the first season, locone louse and sluriveled in the secomd year (Pl. X, l). The leaves are from 5 to 12 , mostly 9 inches in length and thre-fourths of a line wide, glossy, of a deep-green rolor and closely serrulate with a short. rigid point. lounded on the back, the hinary leaves deeply conuve and the termate bluntly kealed. They arise from the axils of fringed deciluoms bracts, are lemsely cruwled towarl the end of the branches, and are sheal by the elose of the second season. Bundles with two leares are most frequently observed in younger trees and almost invariably on the fertile luanehlets.

The resin ducts are intermal, variable in size, and in muber from four to six and over, close to the thin-iwalled lumlle sheaths, which inclose two closely approximate tibrovascular lumbles, often coalescing. The finuvasenlar region, like the ducts. shows no hypodermal wr strengthening cells. The hypodermal cells mulerlying the epidernis are as large as the epidemal rells, in the angles of one or several hayers.

Flowers. - The catkin-like male flowers (1) $X, a, b)$, from $1 \frac{1}{2}$ to 2 inches long, are of lark purple (royal purple) rolor, supporterl on a short stalk and smrommled ly about a dozen involuchal coriaceous bracts, of which the lowest pair is strongly keeled (1'. X, l, slightly magnified), the others being oblong with fringed alges. From ten to twenty of these cylindrical flowers are crowiled in dense clusters below the ajex of the youngest sloots, and are shed alunstimmediately atter the discharge of their abumdant pollen. The anthers are erowned with a purplislr crescent-slaped dentienlate crest. The femile flowers form an oval, pink-colored anent borne on atalk, from one. lualf to 1 inch in length, which singly, more frequently several in number, are foduced close to the terminal bud of the shoot of the season (Pl. X, d). First ereet, they are, at the lapse of a month, horizontally lefleeted, the shoot bearing then increasing rapidly in length duriug the same time, long before the unfoldiug of its leaf buds. The involucral seales or bratets wheh surround the female catkin are more numerons, narrower, longer, and more menbranacens than those form. jug the involucra of the male flowers. The carpellary seales are round with a slemler, eresot tip, their lowel half covered by the broad retuse bract.

A tree discovered by Dr. Mellichamps near Bluffton, S. C., showed the remarlable anomaly of proulucing androgyuous Howers regularly every season. In most of the specimens eximined every one of the male towers clustering around the base of the lerminal lund of the very younger shoot had the mper part of the thoral axis covered with female flowers, appeaning like a distinct inflorescence smperinposed npon the staminodial column, occupying genemlly one-third of its height. In one of the flowers they were scen to extend near to its base. In a single instance it wis observed that the female thowers extenter on one side ot the staninolial colmmn in a numow streak among the stamens.

In a specimen from the same locality the terminal shoot of the season, excecling in length the male flowers by which its base was suroumled, was bearing a nornal subterminal female anuent. The short-stalked cones are ovate or coniul, lather olstuse, lonizontally retlexed, thom \pm to in inclues long, abont $2 \frac{1}{2}$ inches greatest wilth, of glossy leather-brown or hazel rolor (l'l. XI, $\ell$ and b): seales abont "2 inelies long averaging tive-eighths of an inch in wirlth, somewhat flexible, the prominent riclge of the pyramial striated umbo with a short, mostly straight, strong prielilo (1'I. XI, r aml d). By the end of the first season the conelets are scarcely an inch long (l’l. I. 1 ). Before the close of the summer of the suceeding year, the cones have reached their tull size, maturing during the month of Oetober. In the ripe cones, allealy described, the apophyses of the scales in the lowel rows ale almost pointless, becoming on the mpler strongly murronate. The rones remain on the tree nutil the apploach of the noxt summer, leaving on thriu sepration the lowest rows of the scalcs behind. 


\section{EXI'L.LATILN OF PLATEX.}

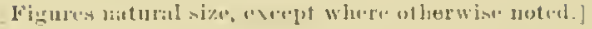

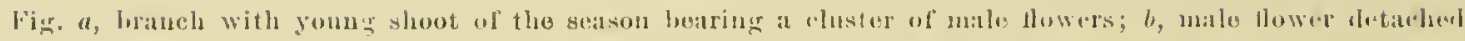

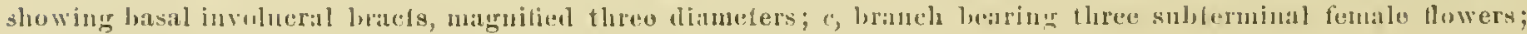
d, d, characteristically reflexed immature cones of one season's growtl. 


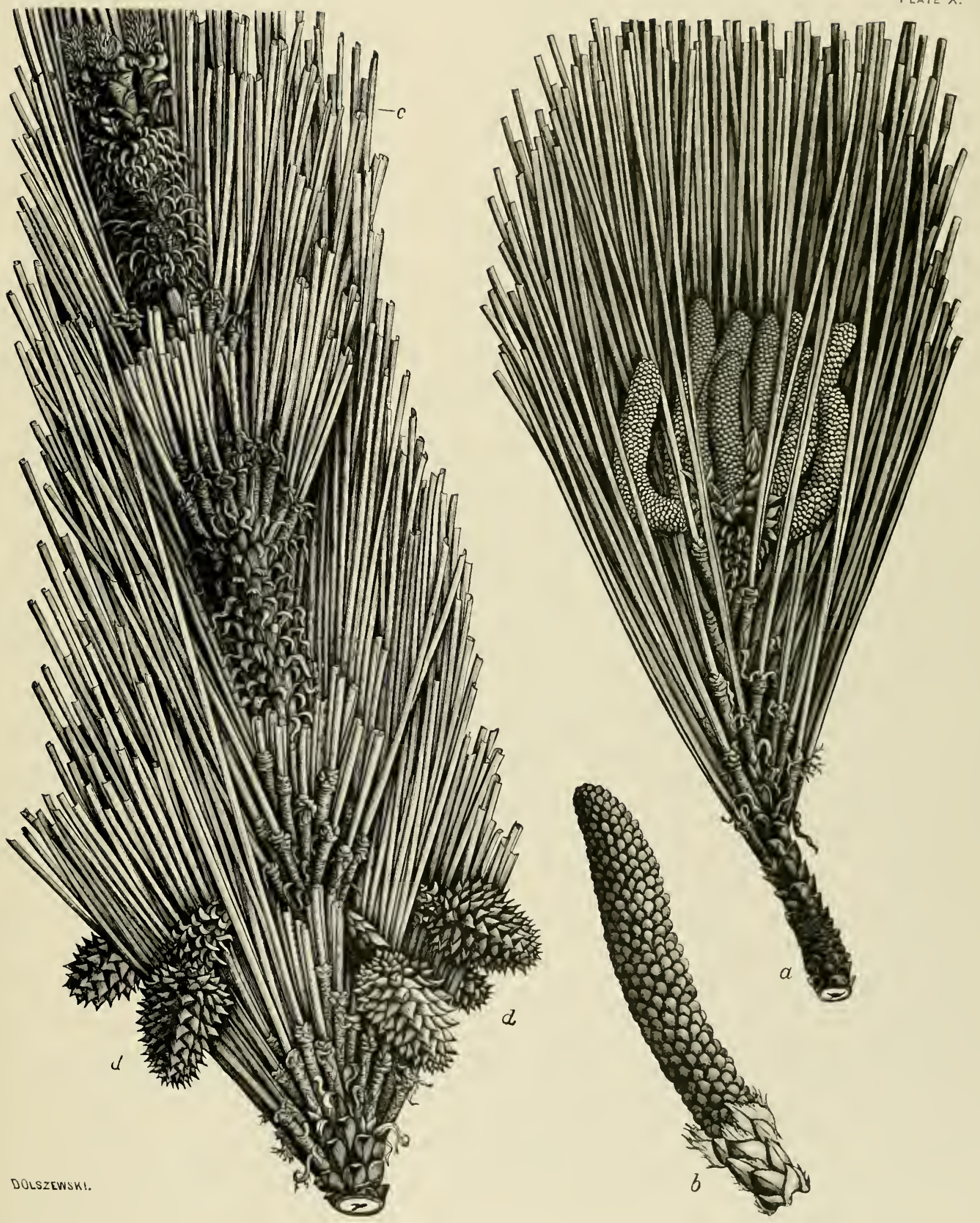



The triangular blatk roughish seeds 201 to at little over 3 lines loner with a few faint ridges; the brown, obtuse, and somewhat oblique wing ( $\mathrm{l} l \mathrm{XI}, e, f, g$ ) about 1 inch in length is deciduous in germination. This ypecies at all stages of grow th can le distingnished from the Loblolly l'ine by the deep-green foliage, the glaneous liue of the young, temer shoots, and rarying number of leaves in a bundle-from the Longleat' l'ine by the thinner, almost smootl, terminal buds, and in the adult state, from both of these species, with which it is found fiecuently associated, by its eones.

\section{THE WOOD.}

As in the Loblolly, the sapwoor is wile in the young trees, neasuring usually about $t$ inches and furming in thrity trees fifty to seventy years old abont 80 per cent of the total rolume. $A \mathrm{~s}$ the trees grow older, however, this preponderance of sapwood ceasis's, and in trees one lumblrenl and tifty to two hundred years old only 35 to 50 per cent of the total volume of the trunk was fomul to be composed of sipwool. As in the ease of the pines alreary mentionel, the rhange from say. wood to heartwood begins when the tree (or disk) is abont twenty-five to thirty rains old, and the process is retarded as the tree (or disk) grows older, so that when any une disk is sixty years old the saptrool eontains abont forty rings, and reaches eighty rings or more by the time the tree (or disk) is two hundred years of age. As a consecuence the sapwood of the dislis of the main part of the trunk in old trees is formed of nearly the same number of rings, and wnly near the top it marked diminution appears, while in a tree sixty years old the sapwood of the stmuly ma have forty rings and that of a disk 40 feet from the ground only twenty-tive riugs. As in other pines, the width of the sapwood is quite variable and is always greatest in young and thrifty trees.

When green the wool of this speries is too heary to float well; its weight raries chictly with the amount of sapwood, and is therefore greatest in sapling timber. The saprood itself is frectuently heavier than water, and where the water in the sapwool aud a large amount of resin in the heartwood combine, the weight of the entire disk frerucutly approaches 60 poumls to the enbie foot.

Filn-dried, the wood of trees one hundred to one hundred and fitty years old was tomd on an average to weigh about 39 pounds per enbic foot, thus excelling in weight even the valuable longleaf Pine. The woor of very young trees is deciledly lighter, as is also that of rery old trees, the heaviest wood being formed during the age of thriftiest growth or between the twentieth and eightieth year. The presence of resin in the heartwood, as couspienous in this species as in Long. leaf Pine, materially adds to the weight of the rood, so that the lienrtwool of old trees is invariably heavier than the same wood had been while in a saprood eomlition. As in other pines, the butt is heariest and the toplog lightest; thus in trees over one hundred and fifty years of age the wool at the butt weighs 44 pounds per eubie toot, 37 pounds at 38 feet, and only 32 pounds at 60 feet from the stmpl, a difference anomting to over 25 per cent. This difference is greatest in the young sapling and is remarkably nniform for all adult trees examined.

In strength, as in weight, the wood of Cuhan P'ine excels. The following tigures represent the generil average of a loug series of experiments on woul especially collected:

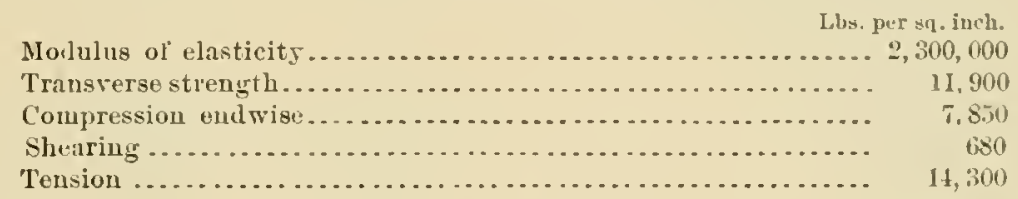

The average weight of the pieces tested was 49 pounds per enbic foot, the onter lightrr part of the old trees having largely been eut away in shaping the pieces, so that muly heary woorl had been testerl. The above figures require, therefore, a reduction of abont 20 per cent to represent the true average strength of all the wood of entire trees.

The amonnt of water contained in the fresh woul depends on the proportion of sapwool. In this latter it forms about 60 ler cent of the weight of fresh wool; in the heartwood only itbout 20 per cent. Aceordingly, fresh logs of sapling timber seventy years old have abont tin per cent. logs of trees over one hundred and fity years old only abont 30 per "ent of water. The moorl dries easily and without great injury, even if seasoned in the dry kiln. 


\section{EXPLANATION OF PLATI XI}

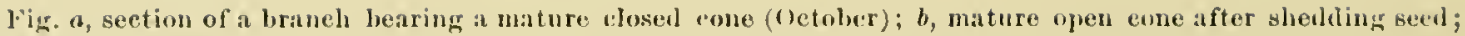

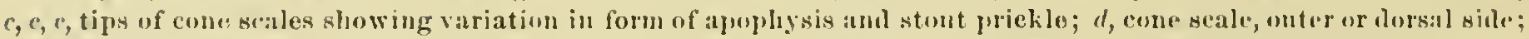
e, inner or ventral side of cone seale with seed in place; $f$, sced with wing detached; $g$, need and wing intact. 


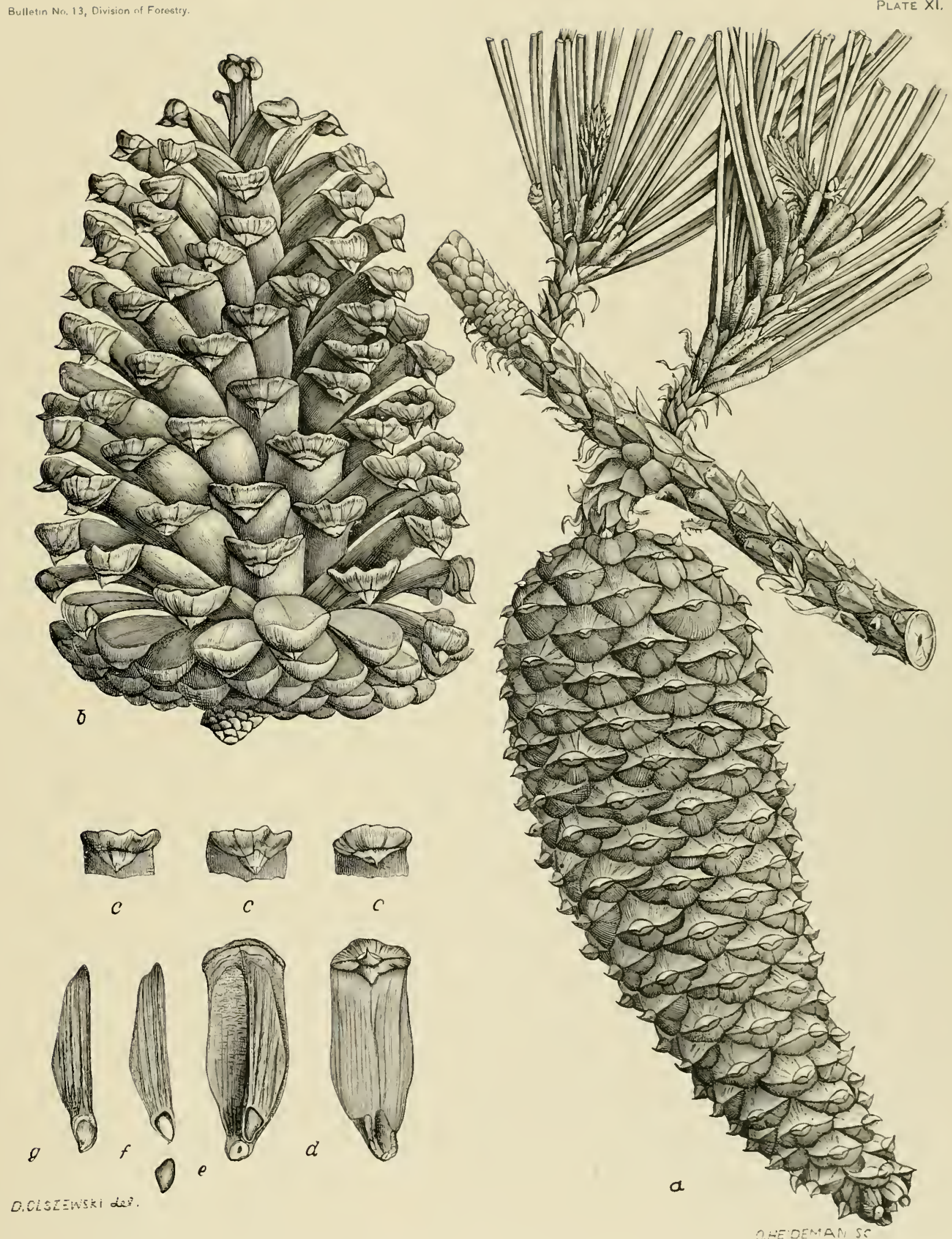



The shrinkage during drying is very rousiderable for sapwool, and therefore all young timber,

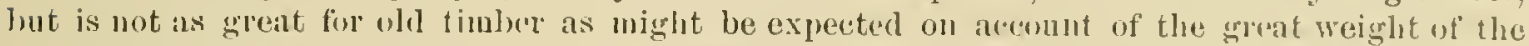
wook. Yonng timber shrinks trom 12 to 13 jer cent of its volume, the wood ol old trees (over one lrundreal and fitty years) only abont 11 per cent, and in all trees the anount of slirinkage is grealest in the heaviest disk of the lutt and decreases npward very much in proportion of the decrease in weight.

In its structure the wood resembles that of the Loblolly in every respeet. Summerwood

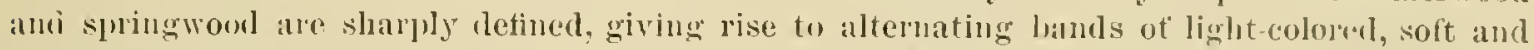
dintecolored hard bands of wood conspirnous in every sertion. For details of structure see the comparative study by $11 x$. lioth appended to these monographs.

\section{PROGILSS OF DEVELOPMENT.}

This is the earliest flowering of the Sonthern pines. The buds of the male floters make their appearance in the early purt of December, aud the flowers open during the last day's of Jaunury and during the first week of February. This species produces abunlant erops of cones "very year, alnost withont failure; they ripen in the fall of the second year; the seeds are disehargend through the winter of the serond year until siring. Germinating easily, their seedlings are tound to conne

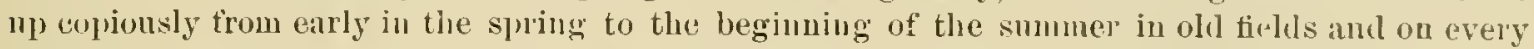
opening in the vicinity of the parent trees, wherever the rays of the sun reach the ground. The plautlets bear six to seven seed-leaves (cotylechons). As soon as these have finly expanded the terminal bud derelops rapilly, and the first interno 'e ot the stem, increasing quickly in length, is densely covered with the soft, narrow, linear, pointed, primary leaves, which are fully an inch long. Before the end of the secont month, in the axils of some of the leaves, the undevelopred branchlets, beiluing the fiscicle of the foliage leares, make their appearanee. With the further derelopment of the foliage leaves, increasing in number during the growing season, the primary leaves witlen' away. By the close of the first season the plantlets are from $S$ to 9 inches high, with a very slender taproot and many lateral rootlets near its nprer end. After the beginning of the second season but few of the prinary leaves are found to support the buds of the ioliage leares. The tendeney to the production of secondary axes beromes wanifest by the apprarance of a single branchlet; on having reached the end of their second year the plants are from 12 to 15 inches high, with a taproot not more than 4 im hes long; at the end of their third year they average little less than 2 feet in height, with the taprenot 6 inches long-the laterals being mueh longer. The crown irom this period develojs in regular whorls for a long succession of years.

The Cuban Pine, in its rate of growth and when fully grown, exceeds in its dimensions the Longleaf Pinc. The tapront, less powerful than in its allies, is assisted by mighty lateral ronts ruming near the surfice of the gromul to supmort the tall, sturdy trunk, rising to a height of 110) or 115 feet, with a diameter of $2 \frac{1}{2}$, not unfrequently exceeding 3 , feet, clear of limbs for a height of from 60 to 70 feet above the ground. The heavy limbs are horizontally sprealing, from 222 to 24 feet at their greatest length, somewhat irregularly disposed; they form in the trees of full growth a rather dense erown of ronuled ontline. Trees of the dimensions mentionet. having passed the fulhess of their growth, are found to be from one lumdred to one hundred and forty year's old, accorling to the surrounding conditions. 'The thiek balk is of a elear, reddish color, lanninated, and exfoliating in thin, brual, purplish tlakes.

Seedlings of the Longleaf Pine, which those of the Cuban Pine somewhat resemble, can be readly distinguished at this period by the disproportion of height and diameter and absence of branch growth in the former. The rate of growth differs, of course, aceording to the conditions of soil and exposure.

Saplings showing five rings of ammal growth were found from th to nearly 6 feet in height, with a diameter of fiom three-fourths to seven-eighths of an inch; between the age of from ten to twelve years the trces measure from 10 to 18 fect in height, with the stem elear for over half its length-even when grown in the open-and trom "up to $t$ inches in diameter. From this stace on the rate of wrowth proceeds most raphidly. At eighteen and twenty years heights of 10 to 50 feet aud over, and dianeter's from 9 to 10 inches across the stump, cut elose to the ground, are ittained:

$17433-$ No. $13-6$ 


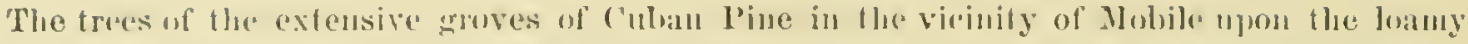

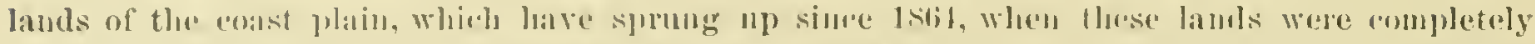

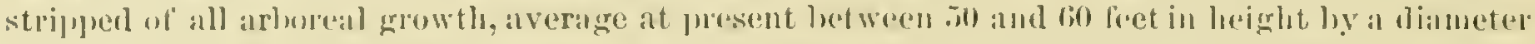

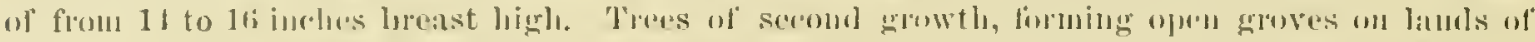
similar elaracter, and also more or less duficient in drailage, forty-five to sixty-live years old,

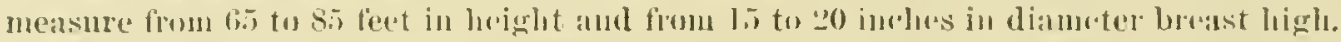

At the enge of a heavily wooled swamp, in a jerpetually wel, sandy, and muelig soil atmi slirted by lange longleat l'ines oremping the steep slope rising from the hot tom, a trer measur

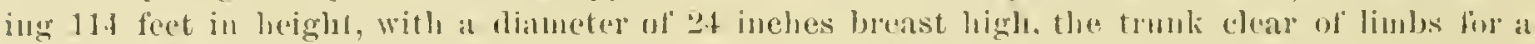

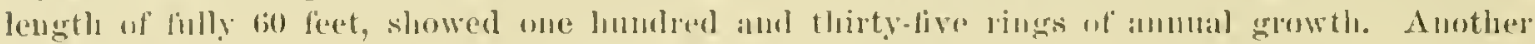
tree felled deeper in the salme swamp, of lank growth, with a poorly develoged comb, rising to

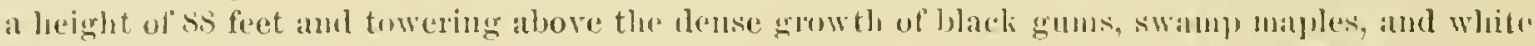

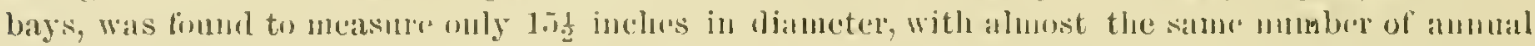

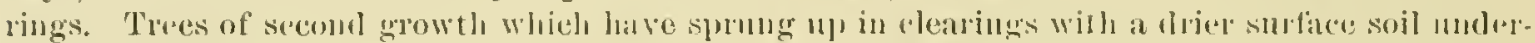

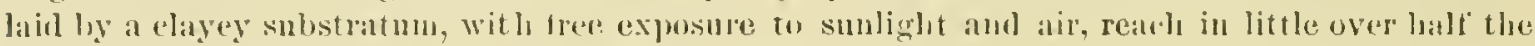
time the full size of those produced in the foresterovered swanps.

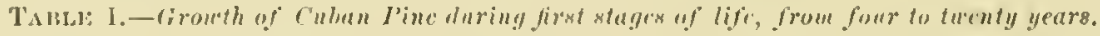

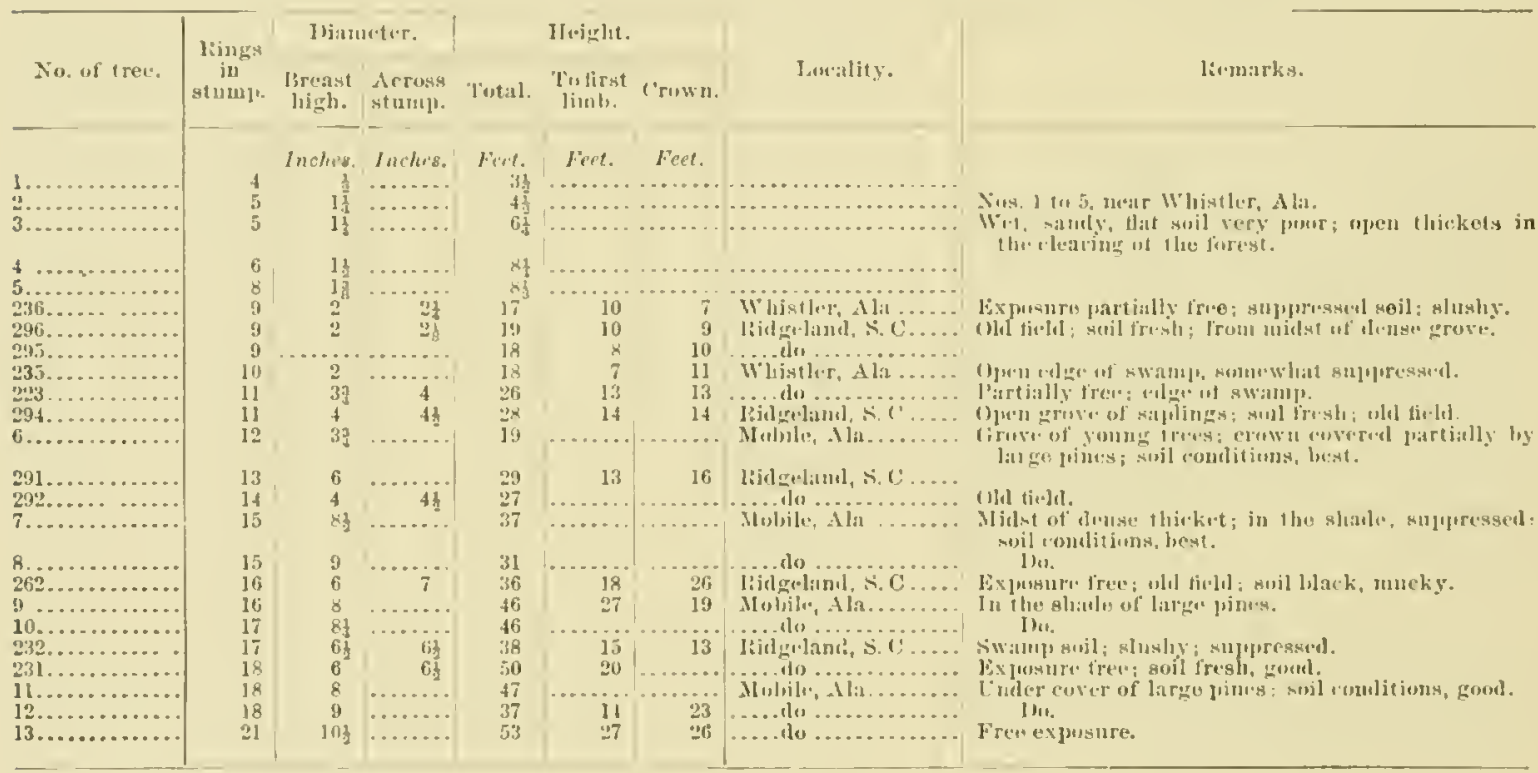


TABLE I1.-Growth of Cuban I'ine during middle and last stages of life, from forty to one hundred and forty-fire yeurs.

\begin{tabular}{|c|c|c|c|c|c|c|c|c|c|c|}
\hline \multirow[b]{2}{*}{ No. of tree. } & \multirow[b]{2}{*}{$\begin{array}{l}\text { liingrs } \\
\text { in } \\
\text { stutuly. }\end{array}$} & \multicolumn{4}{|c|}{ lliameter. } & \multicolumn{3}{|c|}{ Huight. } & \multirow[b]{2}{*}{ Lorality. } & \multirow[b]{2}{*}{ lirmarks. } \\
\hline & & $\begin{array}{l}\text { lireast } \\
\text { high. }\end{array}$ & $\begin{array}{l}\text { Across } \\
\text { xturup. }\end{array}$ & $\begin{array}{l}\text { Below } \\
\text { cruwb. }\end{array}$ & Me:ı. & $\begin{array}{r}\text { Total } \\
\text { levght. }\end{array}$ & $\begin{array}{c}\text { Length } \\
\text { to } \\
\text { roown. } \\
\text { olear. }\end{array}$ & $\begin{array}{l}\text { Lengtb } \\
\text { of } \\
\text { cruwn. }\end{array}$ & & \\
\hline $1 \ldots$ & 40 & $\begin{array}{r}\text { Inchess. } \\
1 \pm \frac{1}{2}\end{array}$ & Inches. & $\begin{array}{l}\text { Inches. } \\
\ldots \ldots \text {..... }\end{array}$ & $\begin{array}{l}\text { Tuches, } \\
\text {......... }\end{array}$ & $\begin{array}{l}\text { Feet. } \\
\text { G0 }\end{array}$ & $\begin{array}{r}\text { Feet. } \\
39\end{array}$ & $\begin{array}{l}\text { Fect. } \\
24\end{array}$ & Alobile, Ala. & Midst of grove, crowifol: thomp, sandy \\
\hline 290. & 43 & 12 & & & & Git) & 34 & 32 & liidgel:tnd, ㄴ. C & 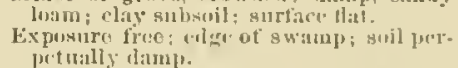 \\
\hline 230 . & 51 & $12 \frac{1}{2}$ & & & & 87 & 51 & .. & Whistler, Ala... & $\begin{array}{l}\text { Edwe swamp: woil tresh to danp: trrow th } \\
\text { lank; sap. } 5 \text { inches. }\end{array}$ \\
\hline & 52 & 17 & $17 \frac{1}{2}$ & & & 83 & 50 & 36 & Mobile, Alit. & Eilge of grow. \\
\hline 3. & 55 & 19 & & & & $\pi 4$ & 40 & & $\begin{array}{l}\text { Stucktou, lakald win } \\
\text { County, Ala. }\end{array}$ & $\begin{array}{l}\text { Expowure trea: springy hillside; soil } \\
\text { roarse, Bandy, and gravelly. }\end{array}$ \\
\hline $4 \ldots$. & $\begin{array}{l}55 \\
56\end{array}$ & $\begin{array}{ll}20 \\
2 !\end{array}$ & 25 & $\begin{array}{l}13 \frac{1}{2} \\
19\end{array}$ & & 72 & $\begin{array}{l}50 \\
47\end{array}$ & $\begin{array}{l}32 \\
32\end{array}$ & 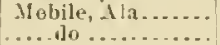 & $\begin{array}{l}\text { Expmenre free; opmn grove: } \\
1 \text { to. }\end{array}$ \\
\hline 289. & 60 & 16 & 4 & & & 90 & 59 & 31 & liorlgelaud, S.C... & $\begin{array}{l}\text { Low yine 1lat, oplen; ; soil unsint and black, } \\
\text { sour. }\end{array}$ \\
\hline 288. & $\begin{array}{l}70 \\
87\end{array}$ & $\begin{array}{l}21 \\
20\end{array}$ & & & & 83 & $\$ 1$ & 42 & .....do & $\begin{array}{l}\text { Exprusure fres: soil noist and black, sonr. } \\
\text { Springhill 'dqe of \& wanp: danp, sandy". }\end{array}$ \\
\hline 286. & 101 & 34 & & & & 98 & 18 & 50 & Rikgeland, S.C.... & 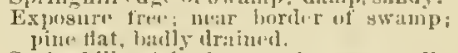 \\
\hline $7 \ldots$ & 110 & 22 & & & & 90 & 613 & 30 & & $\begin{array}{l}\text { Springhill ricli bummerk, perpetually } \\
\text { dany; mannolia, rod bay, spruce gum; } \\
\text { Census } 18 \times 0 \text {. }\end{array}$ \\
\hline 227. & 110 & 20 & & & & 113 & 71 & 42 & Whistler, Ala.. & 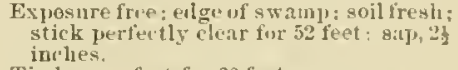 \\
\hline 225 . & 126 & 26 & & & & 13 & 78 & 52 & $\ldots . . c$ & Timber jerfect for 60 feet. \\
\hline & 133 & 24 & 25 & $14 \frac{1}{2}$ & $21 \frac{1}{3}$ & 11 & $6 !$ & 58 & & 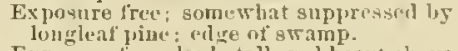 \\
\hline 226. & 127 & 20 & & & & 104 & 80 & 24 & ..... du & $\begin{array}{l}\text { Exposure fire; lank, tall; red hent abovo } \\
5 \text { if fet. }\end{array}$ \\
\hline 228. & 132 & 22 & & & & 119 & 73 & & .....tho & $\begin{array}{l}\text { Base of hili: a fint-luoking tree; timber } \\
\text { clear for } 50 \text { teet. }\end{array}$ \\
\hline 229. & 145 & 26 & & & & 116 & i3 & & do & $\begin{array}{l}\text { Swimp aimays slushy; free from knots } \\
\text { fur over } 63 \text { teet. }\end{array}$ \\
\hline $9 . .$. & 145 & $12 \frac{1}{2}$ & & $7 \frac{1}{2}$ & & 67 & 21 & .. & .....lo & $\begin{array}{l}\text { of suppresifel growth: in millule ul } \\
\text { swarup: soil pure sand, mostly covered } \\
\text { with water. }\end{array}$ \\
\hline
\end{tabular}

From Table Ill the rapid growth of this species is quite apprarent. It will be observed that good trees are abont 20 feet high at ten, 45 feet at twenty, and wer 80 feet high at filty years of age, when the rapin rate of npward growth comes to a stop. It apjuens, also, that the greatest mass of wood for any decade is found at the early age of tifty, the grow th in rolume being nearly 15 cubic feet for these ten years, aud that at ninety the growth in volume is only about two-thirds of the maximun; that at oue humbed years the average aumal growth nearly equals the current growtl, thus indicating that the age of proper exploitation has been reacher, $i, e_{\text {. }}$ that now the tree is ripe for the $a x$, as tar as profitable growth, represented in volume aceretion, is eoncerned.

TABLE 1II.-Growth of Cuban Pine.

\begin{tabular}{|c|c|c|c|c|c|c|c|c|c|c|c|c|}
\hline \multirow[b]{2}{*}{ Age. } & \multirow[b]{2}{*}{$\begin{array}{c}\text { Diametor } \\
\text { with bark } \\
\text { (hreast } \\
\text { higli). }\end{array}$} & \multirow{2}{*}{$\begin{array}{c}\text { Length } \\
\text { of log } \\
\text { with } \\
\text { upper } \\
\text { diancter } \\
\text { of } 5 \\
\text { inches. }\end{array}$} & \multirow[b]{2}{*}{$\begin{array}{l}\text { Height } \\
\text { of tree. }\end{array}$} & \multicolumn{2}{|c|}{ Volume. } & \multicolumn{5}{|c|}{ Periodical growth fur each decale. } & \multirow[b]{2}{*}{$\begin{array}{l}\text { Arerage } \\
\text { anumal } \\
\text { accretion. }\end{array}$} & \multirow[b]{2}{*}{$\begin{array}{l}\text { Current } \\
\text { accrition. }\end{array}$} \\
\hline & & & & Tree. & $\begin{array}{l}\text { Log up to } \\
5 \text { inches } \\
\text { diancter. }\end{array}$ & Deoade. & $\begin{array}{l}\text { Diam- } \\
\text { eter. }\end{array}$ & 11 teight. & $\begin{array}{l}\text { Area uf } \\
\text { cross } \\
\text { acetions. }\end{array}$ & Tolume. & & \\
\hline & Inches. & Feet. & Feet. & Eubic fert. & Cubie feet. & & Inched. & Feet. & siy. feet. & rubicfetet. & Cub. feet. & Cub. fetet. \\
\hline $10 \ldots$ & 2.9 & 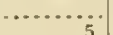 & 20 & 0.50 & $\ldots \ldots \ldots$ & First $\ldots \ldots \ldots \ldots \ldots$ & 2. 1 & $\begin{array}{l}20 \\
25\end{array}$ & 0.02 & 0.50 & 0.05 & 0.05 \\
\hline & $\begin{array}{l}5.9 \\
9.3\end{array}$ & 24 & $\begin{array}{l}40 \\
66\end{array}$ & 14.95 & 13.41 & Secend........ & 2.6 & 25 & .10 & 3.74 & 21 & .37 \\
\hline 10. & & & & 14.95 & $\begin{array}{l}13.06 \\
29.23\end{array}$ & Third ............... & 3. 0 & 21 & .20 & 10.71 & .50 & 1.07 \\
\hline & 13 & & 83 & 29.70 & 23.23 & Fonrth $\ldots \ldots \ldots \ldots$ & 2.6 & 7 & .2 & & & 1. \\
\hline & 14.8 & 60 & 83 & 17.01 & 45.53 & 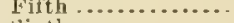 & 2.5 & 8 & .31 & 17.31 & .94 & 1.73 \\
\hline & 7.0 & 60 & 89 & 59.65 & 58.35 & Sixth $\ldots . . . . . . . .$. & 1.2 & 6 & .1 & 12. & & 1. \\
\hline 10 & 17. & 69 & 93 & 72.25 & 71.17 & Seventh ............ & 1.: & 4 & .19 & $12 . t i 0$ & 1.03 & 1.26 \\
\hline & 18.8 & 76 & 96 & 84.05 & 83.1 & (.......... & 1.2 & 3 & .2 & 11. & & 1.1 1 \\
\hline & $20 . \theta$ & 83 & 99 & 95.03 & 94.31 & Nintle -............ & 1.2 & 3 & 22 & 10.98 & 1. 05 & 1.10 \\
\hline & 21.4 & 90 & 101 & 105. & 105.48 & Tenth . .............. & 1.0 & 2 & .20 & 10.94 & 1.06 & 1.09 \\
\hline 110. & 22.4 & 96 & 103 & 115.58 & 115.27 & Eleventh ............ & 1.0 & 2 & .20 & 9.61 & 1.05 & .96 \\
\hline 120. & 23.4 & 100 & 105 & 125.18 & 124.96 & Twelft! ........... & 1.0 & 2 & .25 & 9.70 & 1.04 & .96 \\
\hline
\end{tabular}




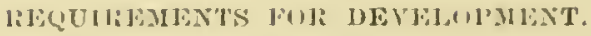

soil.-For its best development the Cuban l'ine requires a light, sably, but constantly damp

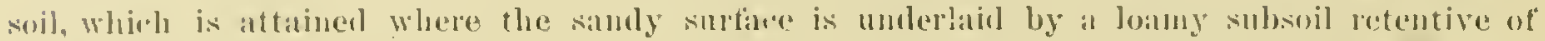

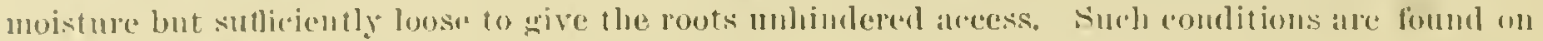

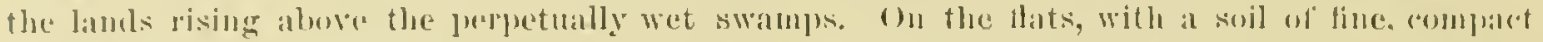

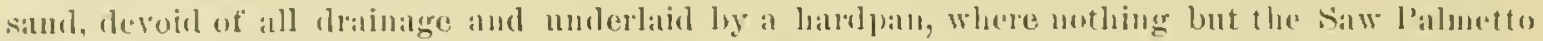

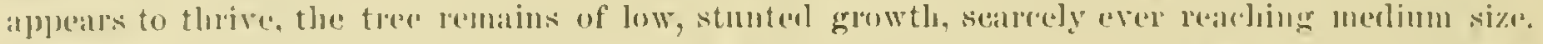

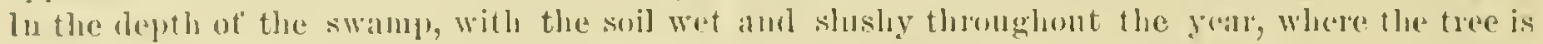

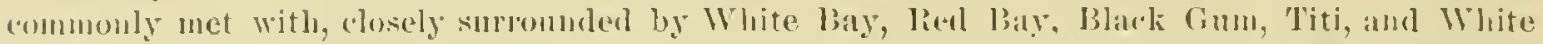

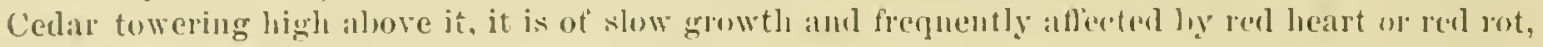
particularly near its northern limit. It is never fomm in alluvial bottoms, and eschews the dey, pine-baren hills, requiring a moderate but sure and even supply of suil moistne.

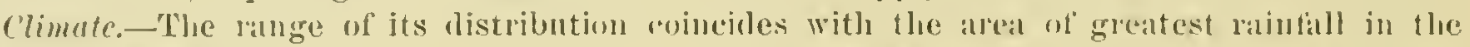
Southern States, which, evenly distributed throngla all seasons, anomnts for the year, in the mean, to 60 and $6 \pm$ inches.

The Cuban l'ine demands a warm climate, free from excessess in the range of tempreature, as is aflorded by the vieinity ot the sea. It is fomm in greatest abmuland and most ferfert within

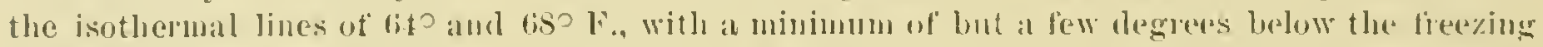
print. The trer, as observed at Hobile, has escaped minjured the serres and mprecedented long spell of ice and suow during the latter part of damury and lirst week of Febundu, 1 sqy. when the themometer fell as low as $110 \mathrm{~F}$., the flowers muloling nuimbared by trost duriug the suceeding tirst days of miller weather.

In its dependence on light it is less exacting than either the Longleal line or the Joblolly

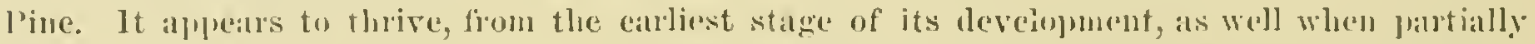
slated as in the open, in this respect resembling the sonthern spruce l'ine. It is clue to thesic facts, combined with the lajuid progress of its growth from the earliest stage, that the Cubau

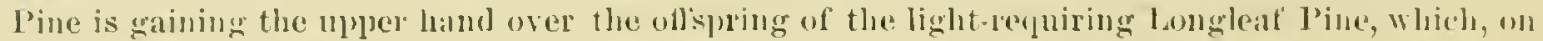

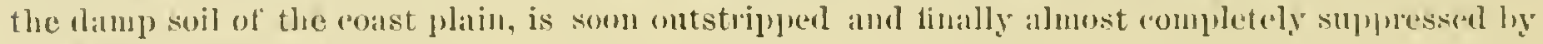
the secellings of this tree.

In the inlerent eapacity for matural reproduction, or in the advantages for the remewal of its forests ly man, the Culan l'ine is not surjassed by any other of the speedes with which it is found associaten. This trea commands. itsalf strongly to the tree planter in the coast plan of the lower

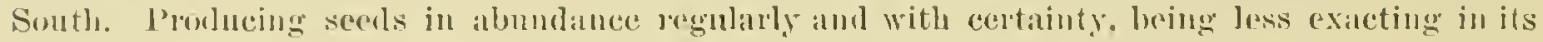
demands tor direet sunlight, and lience suecesstinly resisting the eneroalenent of competing species, heing less lialsle to sucenmb to the destructive ageneies of tire on aceount of its more laphid development in arly life, it has greater pronise of stleress than the others. If to this is added the dajurl rate of growth, the great value of its timber, being equal to the Longleaf, if mot siljerion, and the abmulant yeld of its valuable resinms probluet, it leceomes covdent that in the reforestation of the how pine lands of the Sontheru coast region the Cuban pine is to be prefered to any other, not ouly within its origrinal houndaries, but as far beyoud its range of natural distribntion as the climatic refunirements of the tree will permit. 



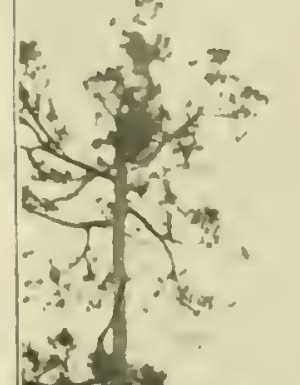

in

se

sit?

潾 6

SW

Mrow

H.

1) 2 (4)

3

3.

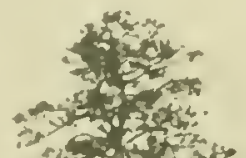

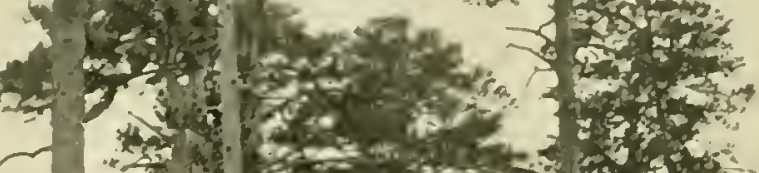

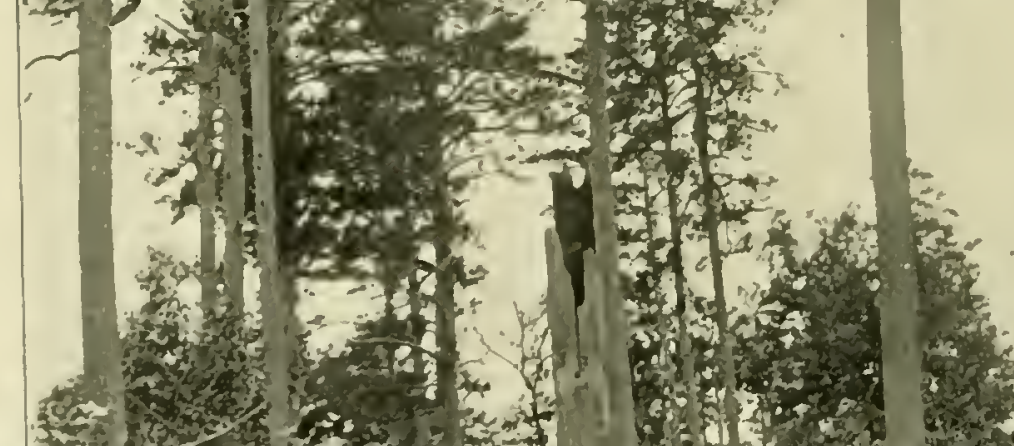

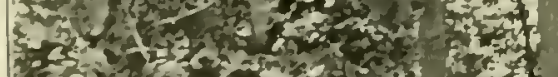

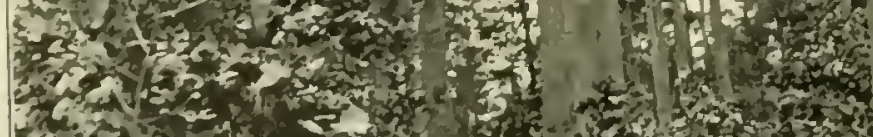

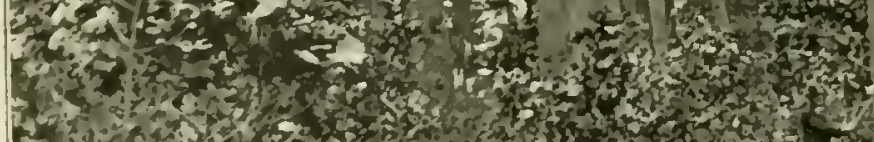

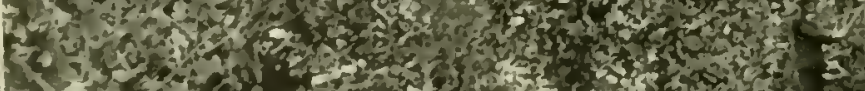

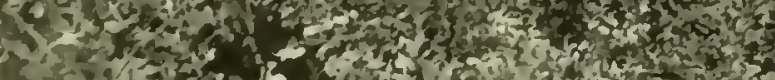




\section{THE SHORTLEAF PINE.}

(PINUS ECHINATA Miller.)

BCONOMIO IISTORY AND IMATRIBUTION.

DOTAXICAL IMACERTION.

DESCLIPTION OF W(NOH.

Progress of DeVleopyent.

CONDITIONS OF DETELOPMLNT.

Folest Managlenext. 


\title{
THIE SIIORTLHAH TTNE.
}

\author{
(I'inus echinata Miller.)
}

Spunyms: Jinus eshinala Miller, Gard. Dict., ed. \&, Lio. 12 (1768).

J'inus riryiniuna var. rchiuata l)u Roi, Harbk., ii, 38 (1772).

I'inus fuda frariabilis Aiton, Ilort. lew., ed, 1, iii, 368 (1759).

Pinus mitis Michaux, Fl. Bor. Am., ii, 204 (1803).

I'inus rarubilis l.anhert, I'iuns, ed. 1, i, 22, t. 15 (1803).

finus royleana . I:mieson ex Lindley, in Jonru. Hort. Soc., ix, 52 (1855).

l'inus intomedia Fischer ex Gordon, l'inetum, ed. 1, 170 (185*), not I) Roi (1772'.

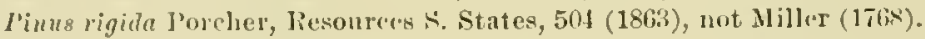

Pinus lutea l.odliges ex Gordon, l'inetum, edl, 1, 170 (1858), not Walter (175R).

I'inus roylei Lindlley ex Gord., 1. c.

\section{COMMON OR LOCAL NAMFS}

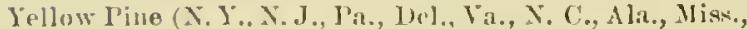
Liı., Ark., Mo, lll., Ind., kans. (mearce), (thio).

Slortleareol l'inu (N. ('., S.. ('., Ga., Ala., Miss., l'l:1., La., Ti.x., Ark.).

Spruten l'iue (1)el., 11 iss., Ark.).

Jull l'in. (V'a.).

Short Sicliat Pine (Del.).

J'itili l'ino (Mo.).

Ioor Pin. (J"]a.).

86
Sluptleavid Tellow Pine.

lellow l'ine (X. (', Van.; ling. lit.)

Virginia Yellow Pin. (Va.) in part.

North Carolina Yellow l'ine (N. C., Va.) in part North ('arolina l'ine (N. C., Va.) in pirt.

Carolina Pine (N. C., Va.) in pist.

Slash J'ine (N. C., Va.) in part.

Oldfield Piue (Ala., Miss.). 


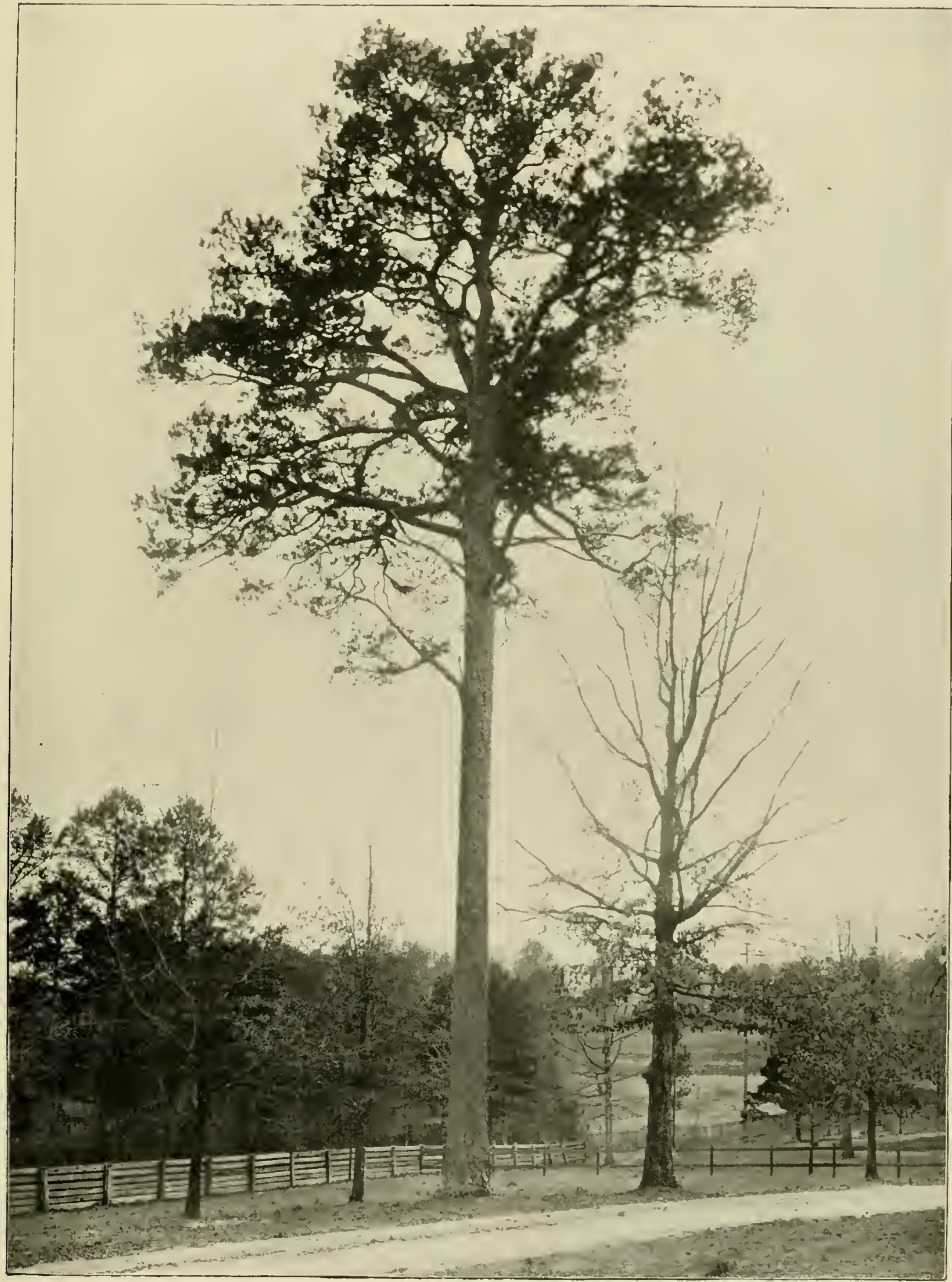






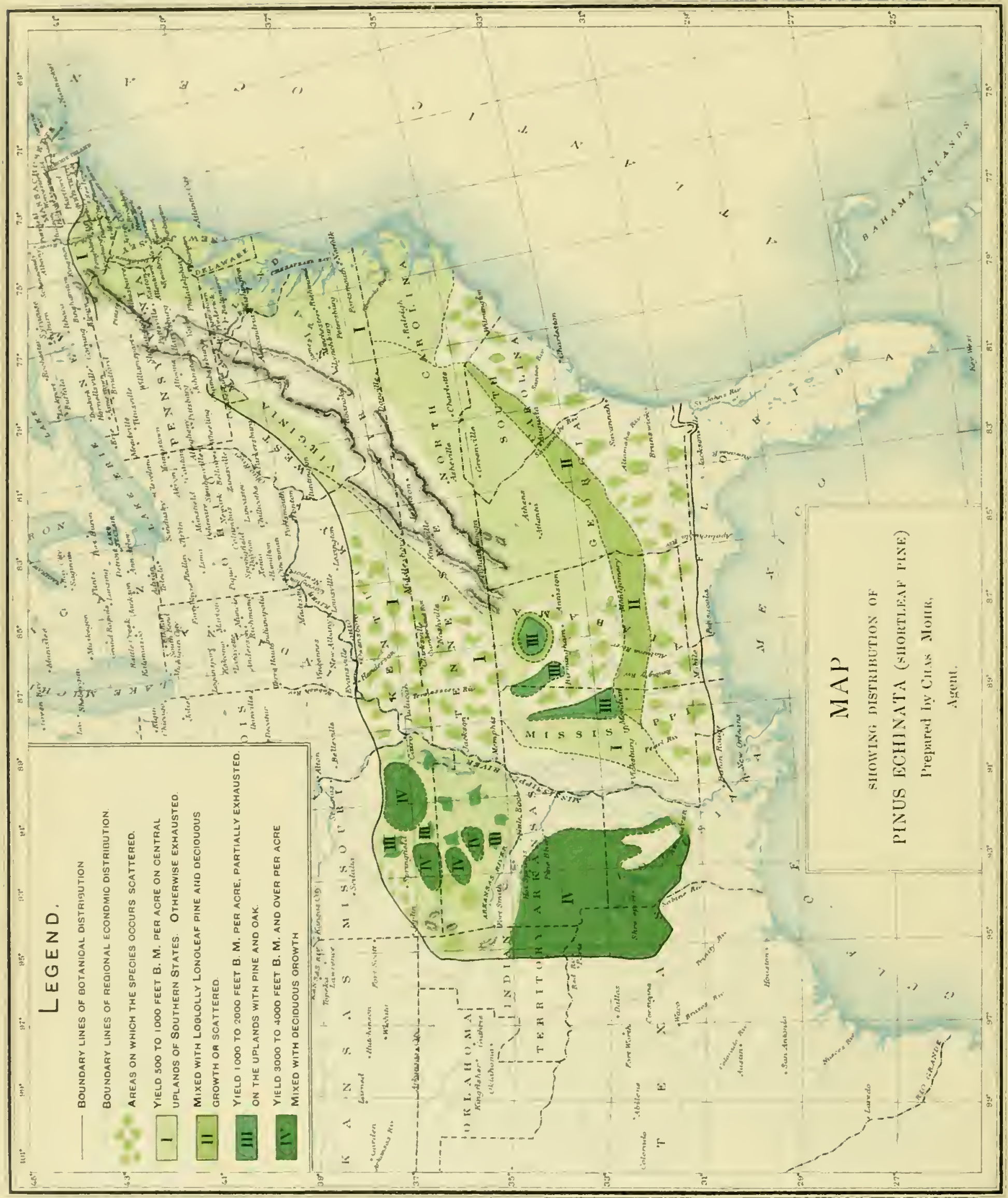




\title{
THE SHORTLEAF PINE.
}

\author{
liy Gindulat Monli, Pli, T.
}

IXTRONICTORY.

Among the timber troes of the Atlantic forest regin the Shortleaf Pine ranks with the first of those noted for their ecomomic inportance. Eqnally abundant, distribnter over a wider area, and in the quality of its word but little inferior, it takes its place next to the Longleaf Pine. When maintenance of forest and prodnction of timber muder a rational system of forestry is to become the rule, this species above all others of sontherly distribntion will claim attention, for it can he safely asserted that of the coniferons trees adapted to the elimatic conditions of the sonthern Atlantic forest, no other an be fomn of better promise for the production ot. valuable timber in the shortest time.

\section{IISTORICAL.}

The Shortleaf Pine, hesides furnishing to the colonists the supplies of pine timber required for the construction of their dwellings, formed in early colonial times an article of export to the mother conntry and the West lurles. Michanx, the younger, writing in the first years of this century, speaks of this timber tree as becoming scaree near the ports. It seems that the specifie characters of this tree were but imperfectly muderstood by the urfier investigators of onr sylva. 'They were first accurately detined by Michanx, the fithel, who desuribed this thec in his Flora Americaua Borealis II, 204 (1803), muler the name of l'inus mitis. A still more detailen descrip. tion was soon afterwards given by Michanx, the son, in his work m Amerionn forest trees (Hist. Arb. Amer., 1, 52, t. 3, 1s10), with a full account of its ralne as a timber tree, the qualities amul uses of its wool, and all that was known in those chys of its place in the forest. Besides the account given of the tree ly the Rev. M. A. Curtis, of North Carolina, in lis .. Trees of North Carolina," little has been adled to on linowledge of this pine until the julliution in Professol" Sargent's report on the Furests of North Aneriea.' of the results of the investigation which the writer had carried on in the Ginlf States, and Professor Harvey in Arkansas. ${ }^{3}$

For valuable information on the occurence of this pine on the Atlantic Coast and rest of the Alleghany Monntuins, the writer is inclutel to the kinchess of correspondents active in the field of botany. In regand to the area over wheh this species is found distribnted in the Sonthern States, the information contained in the physiographic descriptions of the severa] connties of the cotton States, in Professor Hilgarl's report on eutton prohnction, ${ }^{4}$ were chiefly relied upon.

\section{(FEOGRAPHICAL DISTRIBITTON.}

The Shortleaf Pine is widely chistributed from the Atlantic Seaboarl to the treeless plains of the Indian Territory muder 950 west longitule over $23 \frac{10}{2}$ from east to west and 100 from sonth to nortli, namely, from $31^{\circ}$ north latitude to Long Islant, New York, or $41^{\circ}$ north latitnde along the Attantic Coast, while in the in ferior it only reaches to 390 in western Virginia. According to F. A. Michanx, the Shortleaf Pine extender originally as far nortl as Albany, $\mathrm{S}$. $\mathrm{I}$. The tree is at present not known in New Tork outside of Long Island, and its existence even in Pennsylvania is considered

${ }^{1}$ Forest of North Ameriea, Volume IX of Tenth Census. (C. A. Sargent, 1880.)

${ }^{2}$ C. Mohr: "Forest 'Trees of the ftulf Region" (Im. Jour. Forestry, Vol, I, 1883).

" "Forest Trens of Arkausas." (Harvey: Am. .Jonr. of For., Vol. I.)

1lilgard: 'Tenth Consns Report. Fols, V and VI. 


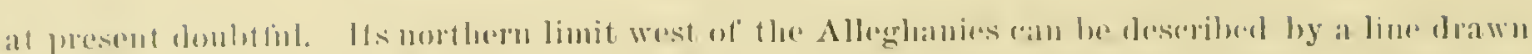

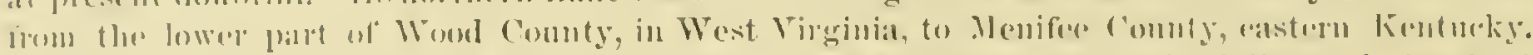

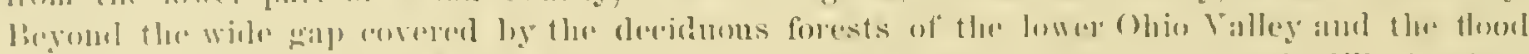

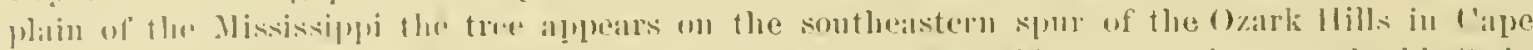

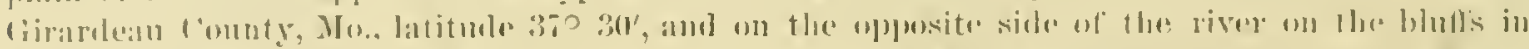

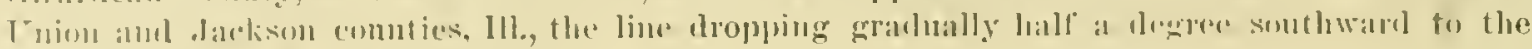

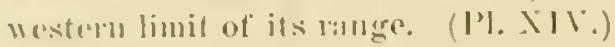

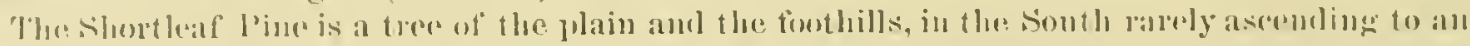

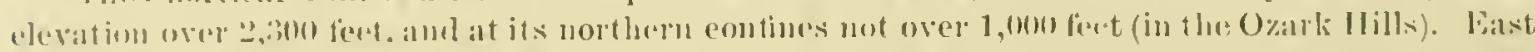

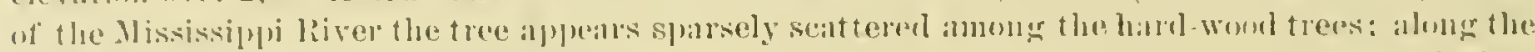

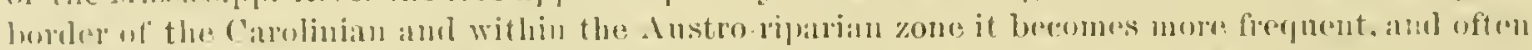

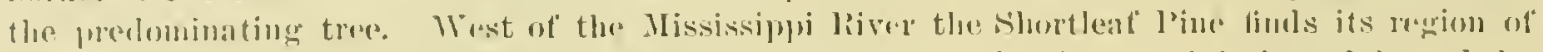

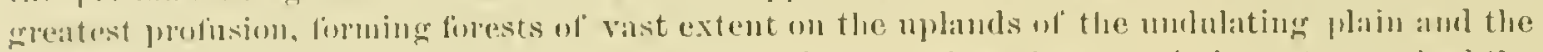

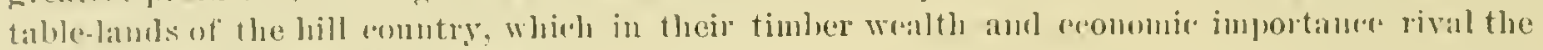
great lumbering regions liatluer soutl.

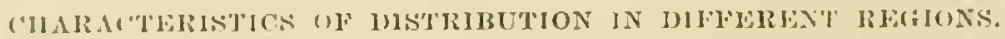

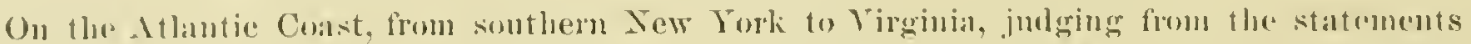

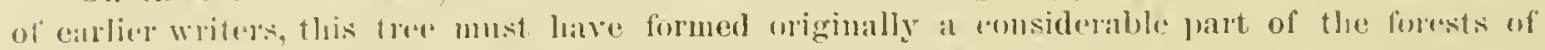

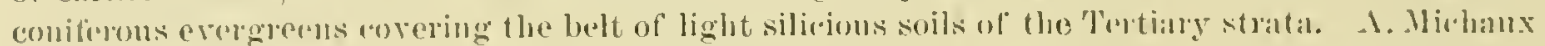

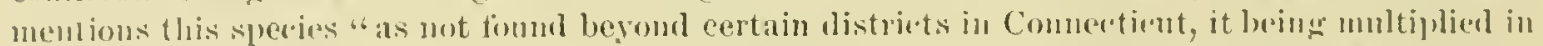

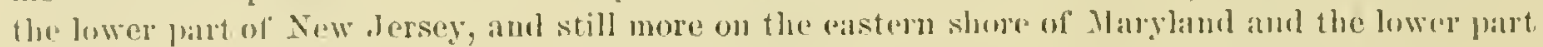

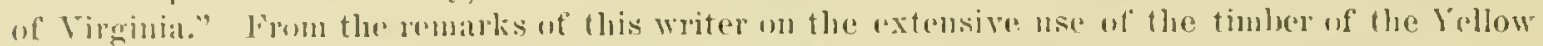

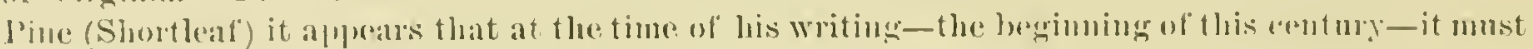

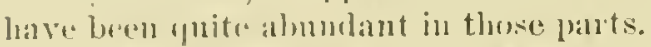

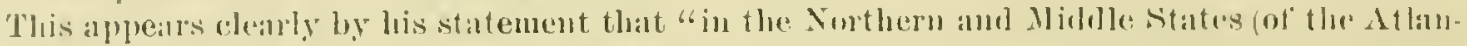
tic: Sealuart) and in Virginia, where, fo a distanee of 1., miles from the sea, all houses are built

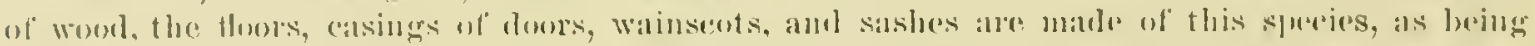

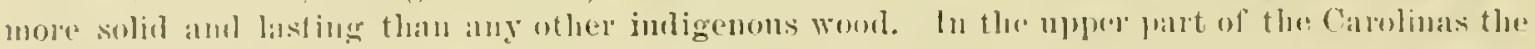

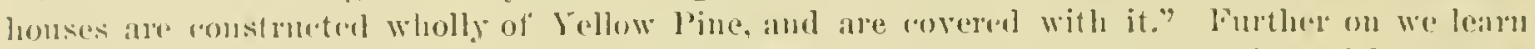

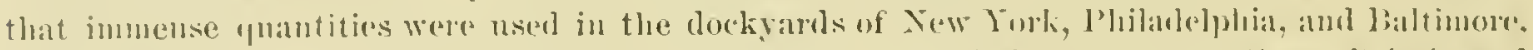

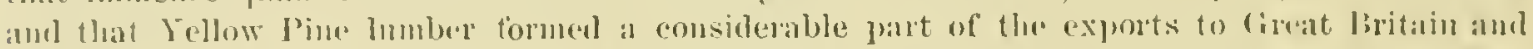
the West Indies. Since that time this tree has in the regin mentioned not moly bun reaserl to

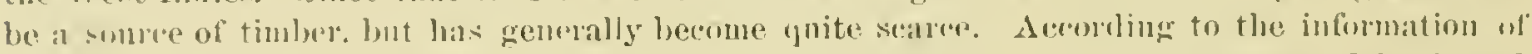

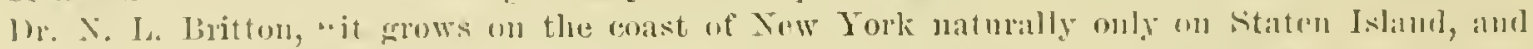

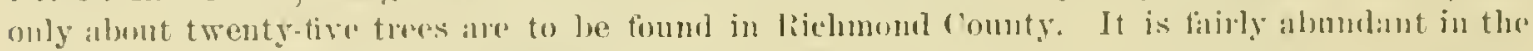

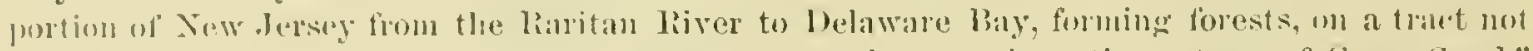
more tlan sulles, and it is also toumd in Delaware on the same formatim ont(rop of (ijeen Sand."

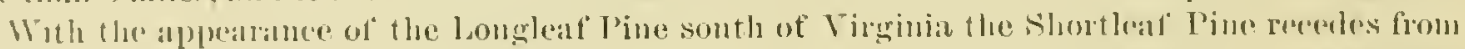

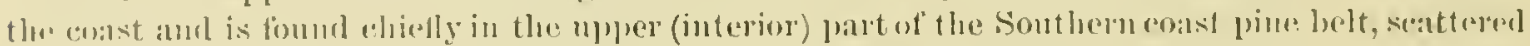

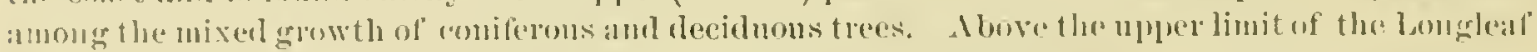

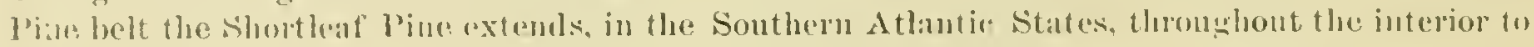

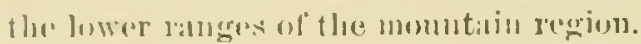

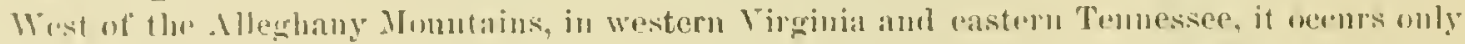

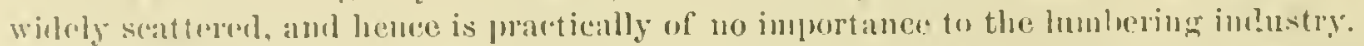

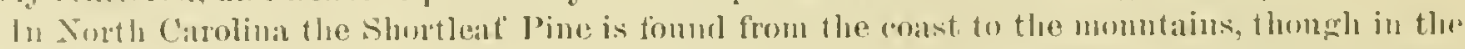

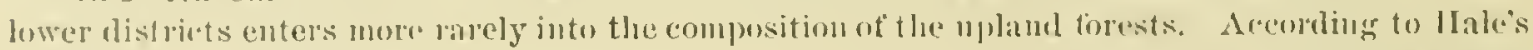
report on the wouls of North camolina the tree is fouml in the majority of ennties of the sitate,

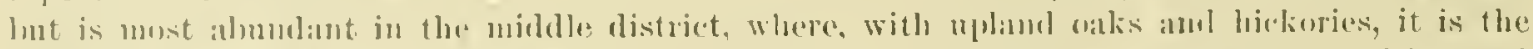

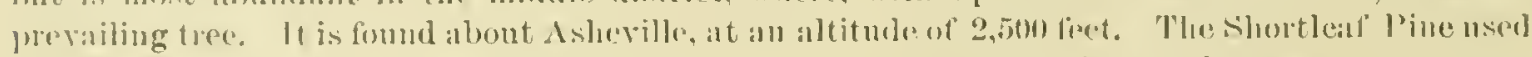

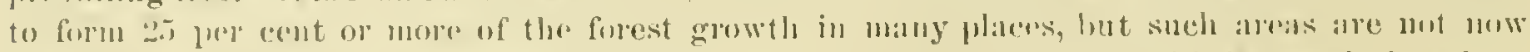

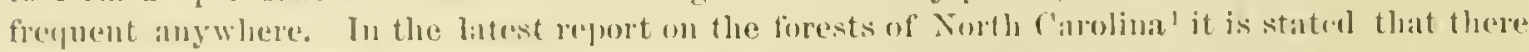

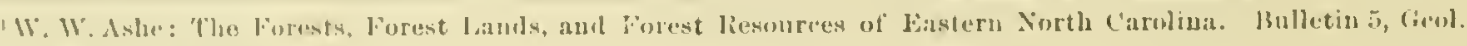
survoy, X. C., 1891, page 11. 


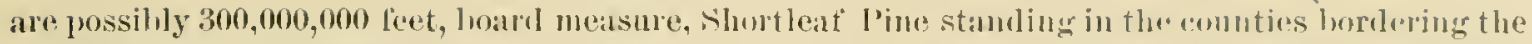
oak uplands in the mastorn part of the state.

In Sonth Carolina this pine is similarly distribnted sparingly in the anst region and more frequent in the midland eountry to the lower monntain ranges.

In Georgia, in the lower part of the coast pine belt, the Shord leal" l'ine is rarcly met with. (In the sandlinls in the eenter of the state. forming the northern border of the pine helt, it ocenrs mixed with the longlent l'ine among the inferior liard wool timber. In the roginn of crystalline rocks, which embraces the more or less monntainons njper halt' of the state, covering over 1?, (mon square miles, at an average elavation of abont 2,500 leet, this tree is most frequent, in many parts predoninating.

In the three States last named the Shortleaf Pine was uriginally most abmulant in the regions now most derusely populated, and hence their supplies of timber are more or loss cxhansted, numbly of the so-called North Carolina l'ine sent to market being Loblolly Pine. Tomng forests, howrur. of this tree are seen everywhere on the hills and monntain slopes, where the origmal timber growth has been removed, and on the worn-ont lands abandoned ly the cultivator.

In Florida the Shortleat l'ine is confined to the mplands alomg the northern border of the State, seattered anoug the Longleaf l'ine and hard wood trees. In the uorthwestern part, it approaches the seashore within a distance of from 2.5 to 30 miles on the isolated patches of red loam lands, where, together with the Longleaf l'ine, it is associatrd with the sonthern Spruce Pine (Tinus glatira).

In Alabama and Mississippi the Shortleaf Pine is rarely seen in the lower part ot the coast pine belt, but forms a more or less eonspicnous part of the forest rovering of thr uplands in the central and uper sections. and sometimes preclominates to such an extent over the lard woods as to impart to the worllands the somber aspeet of a pme pine forest. In the region of erystalline rocks, with its arid ranges in Alabama, covering an area a little over 3,000 square miles, between the Coosa liver and the southern tributaries of the Tallapoosa, the tree is less frefuent than in the region of the same fomation in Cieorgia, the Longleat here taking its place. In the northern part of Alabama, on the talule-land of the Warrior coal tiekd wer an area of fully 5.900) styare miles, mostly in forest, the Shorthat Pine forms a more prominent feature of the growth. This is the case particularly in tho eastern part of this area, where the tree ocenpies mostly the summits and steep declines with a thin, dry suil, while in the deeper and moister soils the Loblully line takes its place. In Cullman Comnty, altitude 800 feet, where mmerons ace measurements lave been made, rarely over "2, 000 feet, boarl measure, of this timber have been foum upon one arere, and it can safely be sald that in the localities where it is more frequently met with the averagis stand does not exreed 1 ,inn feet to the acre on this table-land. The supplies of shortleaf line timber are rapilly diminishing before the demands of a rapidly inereasing population and of the adjacent centers of the mining industry, and their total exhanstion is sure to be effected within a short time.

Wherever the original timber growth has been removed on these mplinds the young growth of the Shortleaf l'ine is rapilly spreading and iredominates over the deciluons trees. The timber trees of full growth averige on these table lands abont 22 inches in dianeter lireast high and 1.5 feet in height, furnisluing elear sticks of from 35 to 15 feet in length. Such trees have been found with from 90 to 13.5 rings of annual gerowth on the stump.

Four trees felled in the vieinity of 'ullman showet the following dimensions:

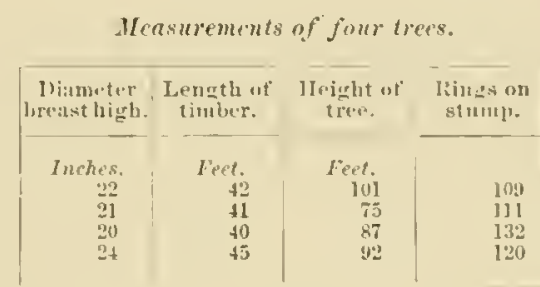

On the gravelly hills of the northern extension of the central pins belt in clalman the Shortlear Pine hecomes frefurntly the predominating tree in the forest of oak and lickong. In Lamar Connty, Ala., and in northeastern Mississippi it forms forests which in the latter State give 


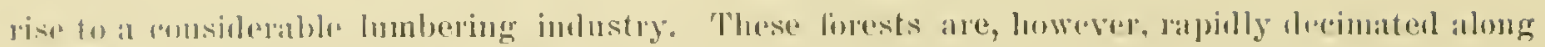

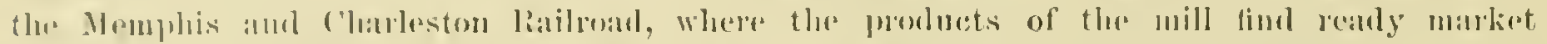

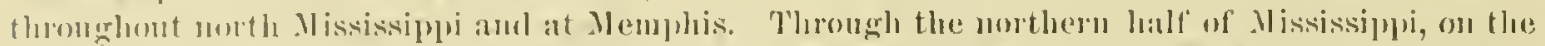
divide which separates the watros flowing into the Mississippi River from those of the Tombiengee,

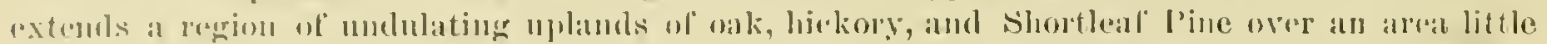

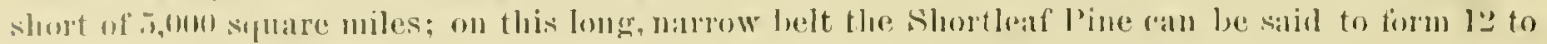

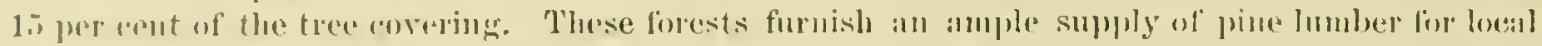

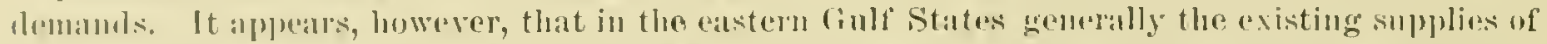

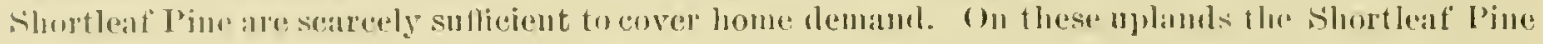

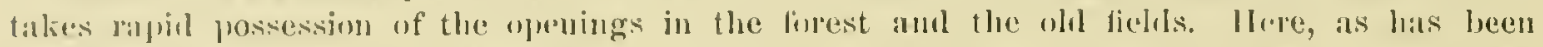

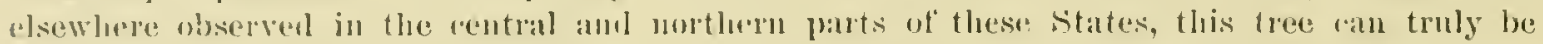

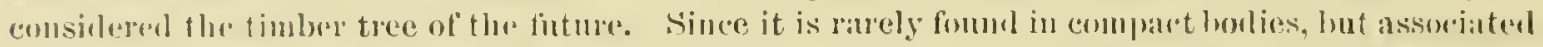

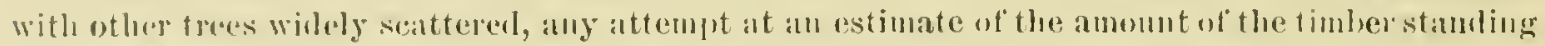

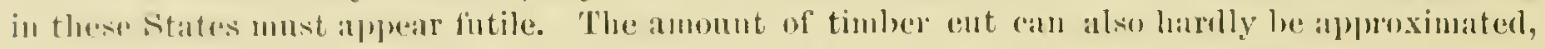
sime it forms ouly a part of the cut of the mills in these states.

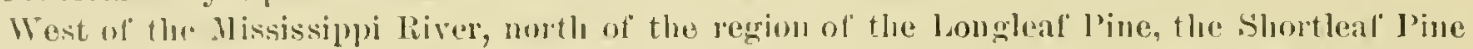
is fouml most abmudiunt aul in fullest perfection. It is in these Westrin forests that the slortloaf Pine dinds its hest development, and forms fure forests, extemling over many lundreds of

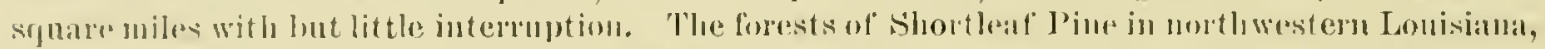

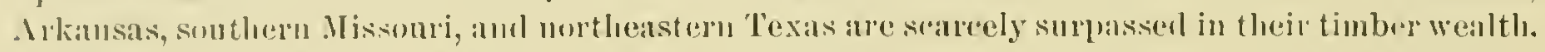

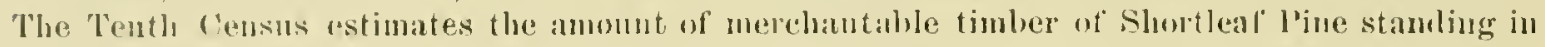
$15 s 0$ in these Western forests at $57,000,(100,000$ feet, hourd measure, exdlusive of the forests in sonthern Vissomi and the Inlian Territury.

In Lonisinua the Shortleaf l'ine is merpally distributerl over the mulands north of the Longleaf l'ine segim hetween the (Hachita River and the eastern boumbry of Trxas, embracing an area of al little over $8, m u$ sifuare miles. Along the mortlernextent of the Lomisiana and Texas State line this pine forms pure forests, and also prevaibs in many localities on the moland along the borrler of Arkansas. The resonres of pine timber in these mixed forests of maks, hickories, and shortleat Pine, renovid as they are trom the highways of tratlic, have been but slightly drawn "lpon.

In Arkansas, in the hilly and momtainous regron on both sides of the Arlansas liver, orer 19.000 styure miles in extent, the shortleaf l'ine forms a latge part of the tree covering of the siliceous rorky soil and forpuently extensive forestion the wide table-lands. On the mblamb of Follow loam sontlo of the hills the tree predominates, especially on the low ridges of gravel and,

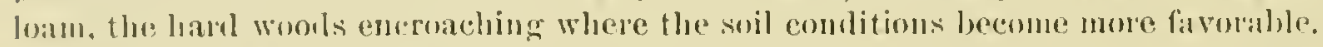

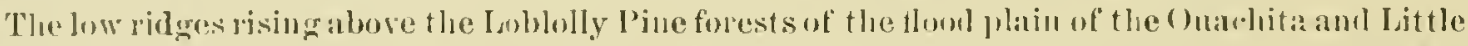

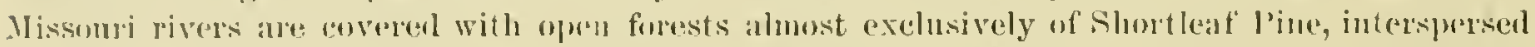
with a few White Oalks, lost and Spanish Oaks, rarely alsove medium size. In the vicinity of

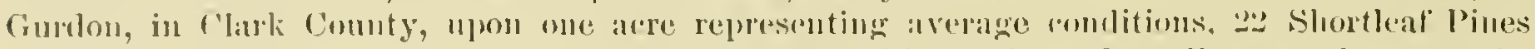

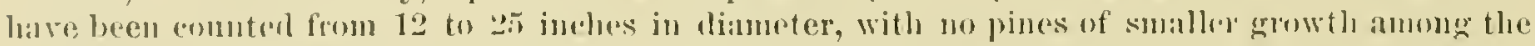

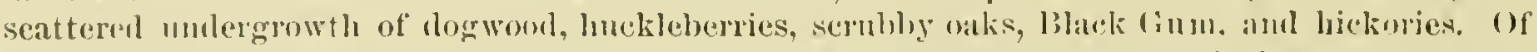
this number, 8 tres measured from 21 to 25 inches; 1 trees from 18 to 20 inehes; 6 trees from 1.7 to 17 inches and '2 trees 12 to 1.1 juches in dianeter breist high, judicating a stand perrere of about 6,000 feet, loard measure.

Five trees, rejesentiug the average timber inow th of the forest selecterl for timber tests, were found of the following dimensions:

Morsurements of fire trees.

\begin{tabular}{|c|c|c|c|c|}
\hline $\begin{array}{l}\text { binmeter } \\
\text { brenth ligh. }\end{array}$ & $\begin{array}{l}\text { tongth wis } \\
\text { timblur. }\end{array}$ & $\begin{array}{l}\text { Irright of } \\
\text { tree. }\end{array}$ & $\begin{array}{l}\text { ISingu un } \\
\text { stump. }\end{array}$ & Sinpwotrl. \\
\hline Inches. & wot. & Feet. & & Inclifs, \\
\hline 20 & $\begin{array}{l}60 \\
47\end{array}$ & $\prod_{106}^{110}$ & $\begin{array}{l}120 \\
132\end{array}$ & $3 \frac{13}{36}$ \\
\hline 19 & 10 & $10 ! 0$ & 3112 & $3^{-2}$ \\
\hline ik & 36 & (1) & 1211 & 3 \\
\hline 25 & 43 & ד17 & 143 & 3 \\
\hline
\end{tabular}

On the arid hills of flinty sandstone the trees are of inferior growth, as olserved in Ifot Springs County, in the vicinity of Malvern. (On their steep slopes the pines are rarely found to exceed 18 
inches in diameter breast high and 75 feet in height, clear of limb for the length of abont 3.5 feet. In a number of trees from 120) to 125 rings were connted on the stmmp. The woor produred on these hills is of a lighter color, less resinous, and of a fino grain. Specimens of finisherl lumber from such timber resemble somewhat that of the White l'ine. The hatri-wood trees, mostly Spanish Oak and Post Oak, seattered beneath the pines, are scrulby and of no value for their timber.

Along the railroad lines the forests have become exhansted for a distame of trom 5 to 10 miles on either side, and the timber from the virgin forests is conveyerl to the mills on stean tramroarls. It appears that of late year's about $550,000,000$ to $560,000,000$ fet, board measure, of pine timber are sawn annully in Arkimsas sonth of the Arkansas liver. In this amomt the loblolly line lumber is ineluded, which is indiscriminately sawn and put with the Shortleaf l'me on the market as Arliansas Yellow Pine. The bulk of the produet of the sawmills in this section is whipped by rail to the markets of the Northwest.

In the northern part of 'Texas, east of the prairie region, liom the lied liver Valley to the northern bordes of the Longleaf Pine region (under latitnde :920 N.), extends an area of onk, hickory, and Shortleaf Pine mulands, stated in the agrienltural report as covering 35,000 square miles. In the southern extent of this area the distriets where the Shortleaf Pine prevails are popularly known as the "Pineries." Yorth of the Sabine River, from Longview throngh Cass and Bowie comnties, the shortleaf Pine forms compact forests over many lundreds of square miles. Near Bevins, in Cass Connty, whero the pine forests were more elosely investigated, the morlerately dense timber growth eovers the undulating country down to the lowlands of the lierl River in Lonisiana. The sandy gray loam forming the rather compact soil of the surface is muderlaid by laminated stiff elayey marls, which at the depth of aljont 4 feet lecome quite impervious to water. liackjack, Spanish Oak, and Post Oak of stmnted growtl are seattered beneath the pine. The pine appears to be of slower growth; trees of full size-that is, from 20 to 24 inches in diameter-were found to have reached an age of from 195 to 210 years. The upper part of the timber of snch old trees is frequently affected by rot, a defect nudonbtedly to be ascribed to the cold, impervions subsoil.

From 6,000 to 7,000 feet of mereliantable timber are elaimed as an atvelage stand for these timber lands. Every tree abure 10 inehes in dianeter at breast leiglit is ent tor the mills. After the removal of the pine the hard woods gain rapidly in the rate of their growth, soon shading the gronnd completely. Yonng pines are rarely seen in the natural openings, the seedings being ton frequently destroyed by fire. In the clearings, where the original tree growth has been completely removed and the pine takes quick possession of the gromud, the second growth, it not lished outright by the tires which again and again devour the suromoling tall weeds and broom grasses, becomes too severely injured to be of any promise.

Four trees, selected as representing fairly the average merchantable timber of the Shortleaf Pine forests of northeastern Texas, showed the following record:

Mcasuroments of four irees.

\begin{tabular}{|c|c|c|c|c|}
\hline $\begin{array}{l}\text { Diameter } \\
\text { breasthigh. }\end{array}$ & $\begin{array}{l}\text { Lenirth of } \\
\text { timber. }\end{array}$ & $\begin{array}{l}\text { Height of } \\
\text { tree. }\end{array}$ & $\begin{array}{l}\text { liings in } \\
\text { stum]r. }\end{array}$ & $\begin{array}{l}\text { Sipwood } \\
\text { on stump. }\end{array}$ \\
\hline $\begin{array}{r}\text { Inches. } \\
24 \\
23 \\
18 \\
17\end{array}$ & $\begin{array}{r}\text { Feet. } \\
36 \\
40 \\
45 \\
42\end{array}$ & $\begin{array}{r}\text { Feet. } \\
120 \\
109 \\
95 \\
94\end{array}$ & $\begin{array}{l}195 \\
205 \\
102 \\
102\end{array}$ & $\begin{array}{r}\text { Inches. } \\
3 \\
3 \\
5 \\
5.1 \\
5.1\end{array}$ \\
\hline
\end{tabular}

The forests of Shortleaf l'ine near Longview, which was in 1880 the site of a most aetive lunber indnstry, have been nearly exhansted, aud with diminished supplies along the New Orleans and Pacifie Railway the business lus greatly declined. The anmal output of the 30 mills sitmated along this roar, and its braneh from Cartlage to Panolit, does not at present in the aggregate exceed $70,000,000$ feet, board measure. From the information obtained in 1892 it appears that in 1S91-92, 200,000,000 feet, board measure, were handled in Texarkana, the product of the mills at that place and immeriate vicinity, and also that the shipments of the mills south of the Red River in the same year reached about $105,000,000$ feet, hoard measure. 


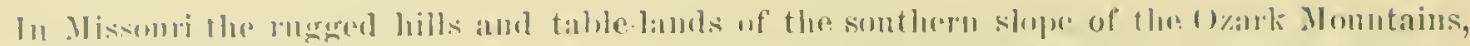

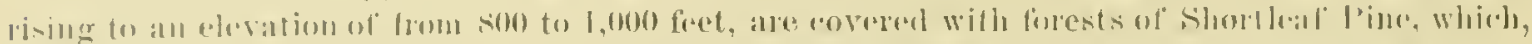

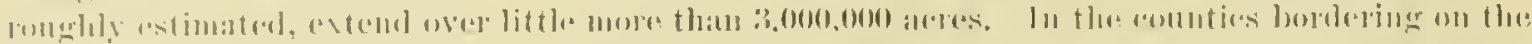

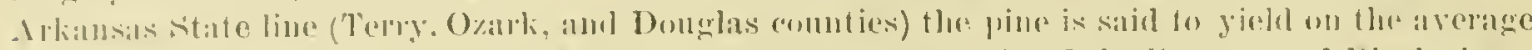

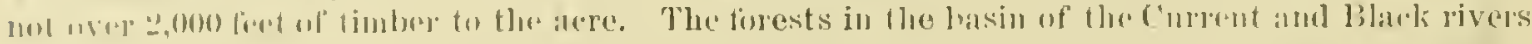

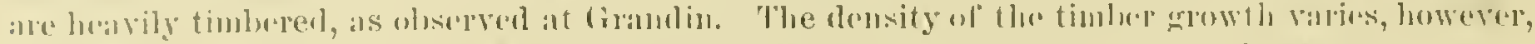

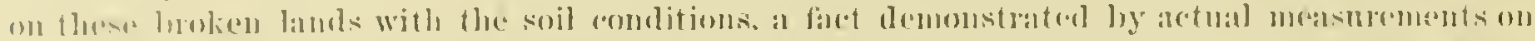

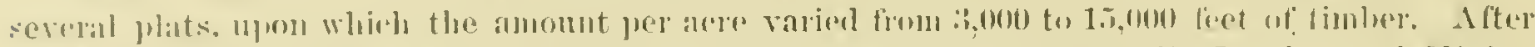

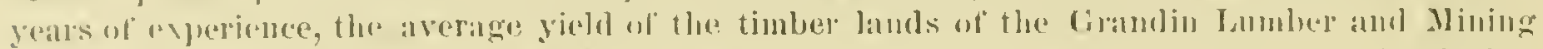

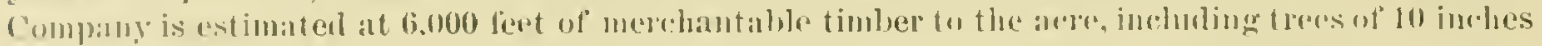
in diatureter.

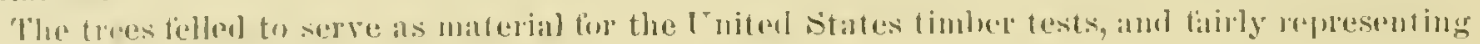

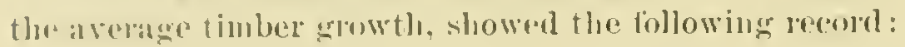

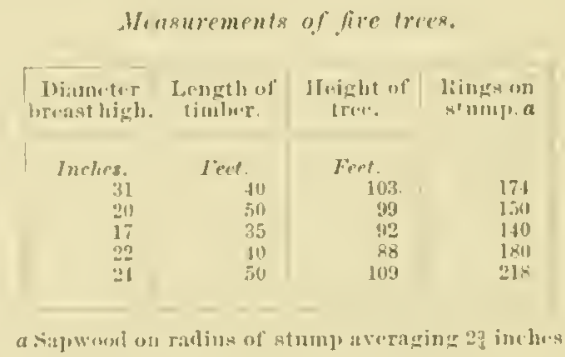

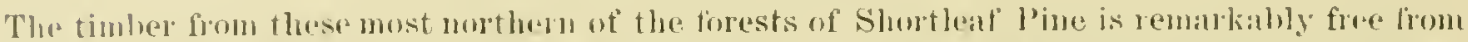

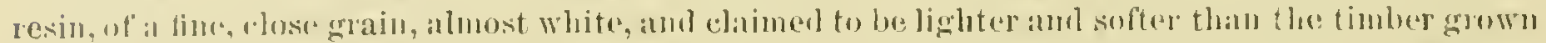

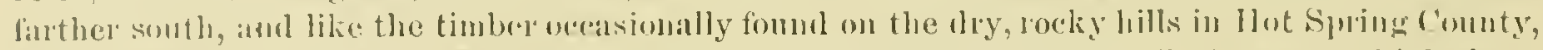

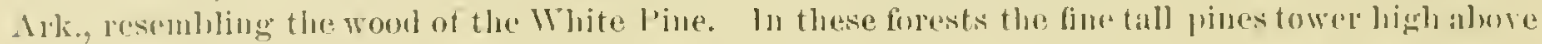
the stunted searlet, Basck, and White (1alis and hickories, but the growth of these hard woods almost rompletely oberporrars the second growth of pine.

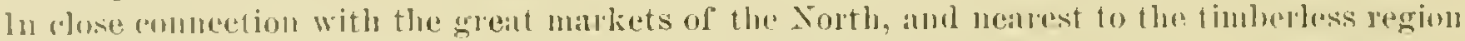
of the Sorthwest, the manufarture of lunber in this region is fully dereloperl. Areording to infermation receivel at Gandin, the ont put of the mills lowaten along the Current livere Valley

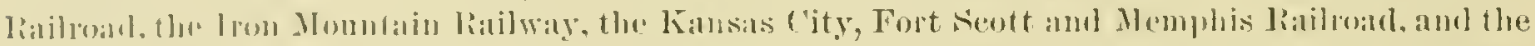

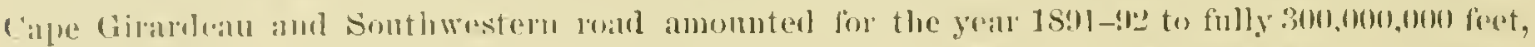

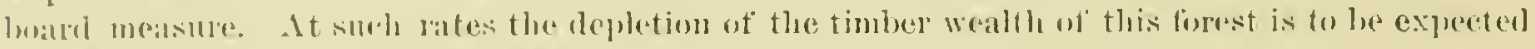
betore another generation bas patsed away.

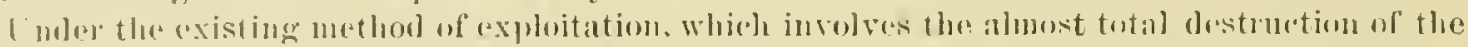

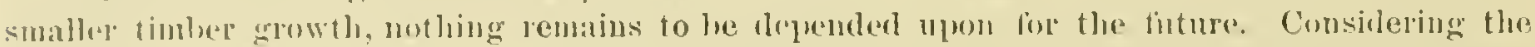
dillinolties in the way of their natural renewal, there is no hope left for their restoration on these

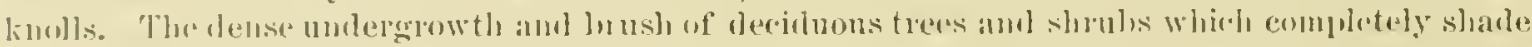

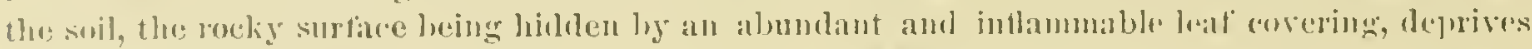

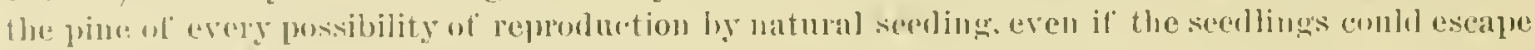
llestrutution by tire.

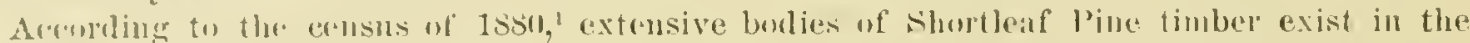

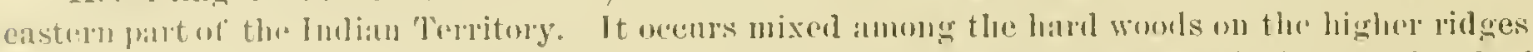
of the timlwe lalt in the Chowtaw Xation, 60 miles in length, and considerable bouldes of shortleaf

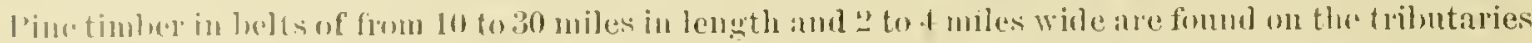

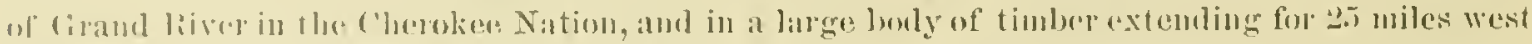

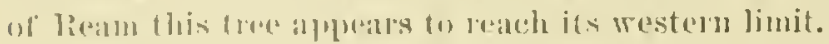

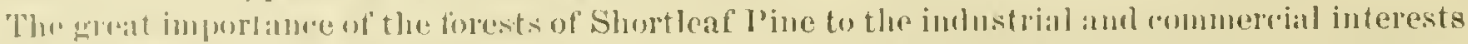

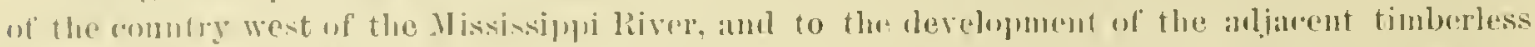

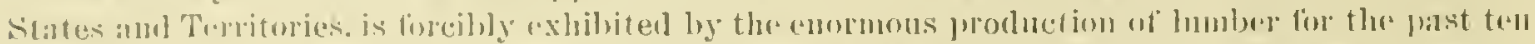

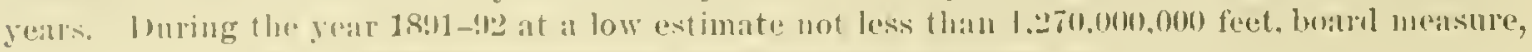


have been shipped from points in Texas, Arkansas, and sonthern Miswori to Northern markets. This amont may be swelled by the proluetion east of the Mississipuri to romin numbers of $1,500,000,000$ feet, boird measure.

As stated before, an estimate of the timber of this species standing is impossible on arecount

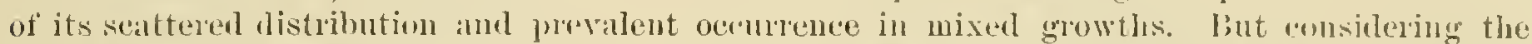

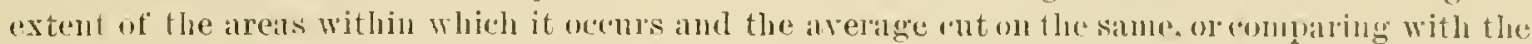
amonnts of Longleal P'ine, which on accomst of the complact bodies in which it occur's, an he mone realily approximated, it is sate to assume that very moch less than $100,000,000,000$ feet remain a vailable, while the ant can be roughly estimated at $1,500,000,000$ feet, board measure.

\section{PROUUCTS.}

Anong the coniferons trees of eastern North America the Shortleat Pine stmurls next to the Longleat' l'ine in imprortance to the lumber industry and in the value of its timber. Freer from resinons matter, softer, more easily worked, not less susceptible of a good linish, the

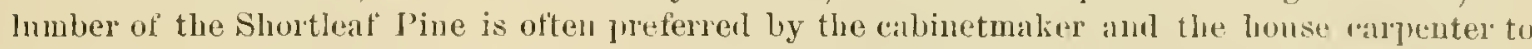
that of the Longleat' l'ine. Less tenacious, and of less power of resistance under strain, it is principally user for the lighter tranework in buildings, for weatherboarding, flooring, ceiling, Wainscoting, eases ion windows and door's, for frames and silles of all kinds, and for shingles. Most of the dwellings located within the distriets where this tree prevails are built alnost entirely of Shortleaf Pine humber, which bears ample testimony to its widle usefulness. It is also extensively employed in car building. for cross-ties, and in the mannfincture of furniture.

\section{NOMENCLATURE AND YLASNIFICATIOX.}

This species, like all of the same genus of a decidedly Sonthern distribution in the Atlantic forest, lrelongs to the seetion Pinester as defined by bingelnam, with cones of tongh, woody seales their exposet embs thickened by an mbonate swelling (apophysis), which is armed with a weaker or stronger deciduons or persistent prickle or mucro. It was first described by Miller in the year $176 s$ as Pinns echimutu. ${ }^{1}$ and under that name recognized by the carliest writers on North American forest trees; ${ }^{2}$ it was subsernently named by an obscure writer l'imns rirginiun, var. cechinatu, In Roi. Michanx described this tree in his North American Flora ${ }^{3}$ under the mame of Pinns, mitis, which receiver general recognition and by which it is known to botanists to the present lay. Pinus curubilis, the name under which it was described at about the same time ly Lambert, ${ }^{5}$ was alopted by Wildenow, and following that author by P'ursh, Nuttall, linliott, and a few others of the writers on the botany of this country, In following strictly the rule of priority, ant present most strongly alvorated as the ouly measure to avoid further the confusion anising from an endless number of synonyms, l'inus mitis, the name under which it is generally known, will lave to be abandoned, and the more obseme one, Pinus echinath, moder which this species was first published, restored.

Great confusion is causer by the vinious alpellatious this tree his received in the English rernacular, being indiscriminately called Shortlenf P'ine, Yellow P'ine, and Spruce Pine. althongh most widely known under the first of these names, and in the narkets it is now sumewhit donbtfully established under the name of North Carolina Pine. In the States of the lower sonth it is fie"puently confoumded with the Loblolly Pine, as the timber of the two is often, if not mostly, mixed. I. A. Curtis, in his "Trees of North Carolina," selerterl for this tree the nane of Yellow Pine, strongly recommending its general arloption in orler to introduce greater uniformity in the designations of our forest trees. Cnfortmately the same n:me is in many of the Sonthern lumbering districts bestowed npon the Longleaf I'ine, particularly when the timber is spoken of. It is often anite impossible to determine to which of the two speeies the timber is to be referred when under that name it is quoterl in the rejorts of the lumber markets.

'Miller's Jictionary, stlu ed., 1768: Lomlon.

Darshall's Arborotum Americanum: l'hiladelphia, 17.5.

${ }^{3}$ Du lioi flb.

'A. Michaux's Flora Amer, horeal., Paris, 1803.

${ }^{5}$ Description of the Genns I'imus: A. B. Lambert, 1803 and 1824. 


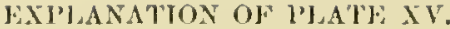

[Fizures natural size, oxcept where otherwisn notul.]

Fig. a, brancl, from a lower limb learing malo infloreseenee with fluwers in a dense chster (first week of April,

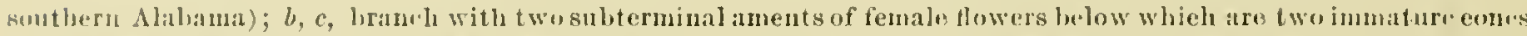
of on season's growth; d, hetached malo tlower shuwing basal involueral seales, mignitied 3 dianeters; e, germi-

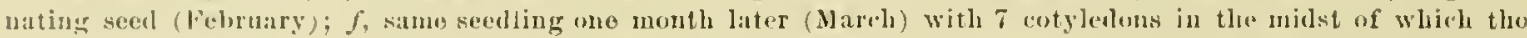
terminal but shows the jrimary leaves apleariug; $g$, secdling abont the close of the first seasm with ferminal -Inster of trus (secondary) leaves, lelow which are seen the withered primary lavos; h, i, ransverso aection through

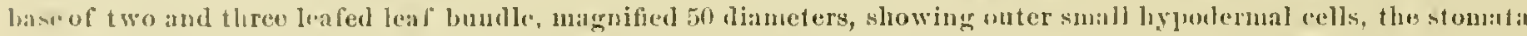

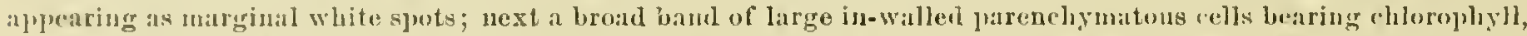
witlsin whill, at the angles of the leaf, mesin ducts appoar as large openings; the dark areas in the center are tibro. vasentir buulles surrounded ly a singlo row of thin-walled cells (bundle sheath). 


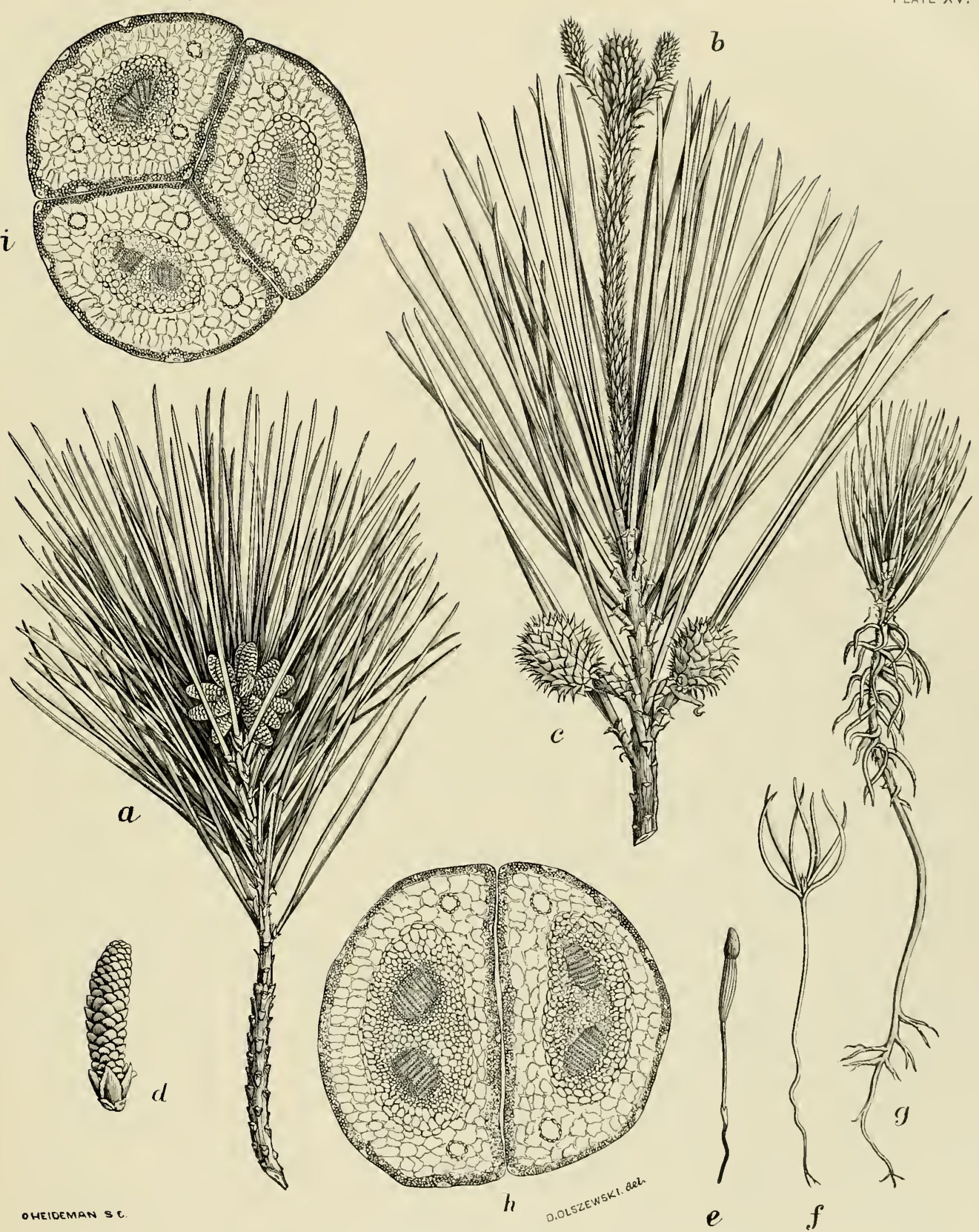

Pinus echinata: Seedling, male and female flower, and Leaf Sections. 

Under the name of Spunce l'ine, in the extreme Sonthern districts, it is inviliably confoumled with the true sonthern Sprnce Pine (l'imus glubro), lle species which in several points it closely resembles and to whieh it is most closely related.

\section{BOTANICAL DESClBIPTION.}

Leaves mostly 2 (sometimes 3 ) in a short sheath, 3 to 5 inches long; cones $1 \frac{1}{2}$ to 2 inches lond, oval or somewhat conical; scales with a short, tender, straight, and tinally incurved furckle, light brown. Seeds rather small, two-fifths of an ineh long, ly one-tenth to one-righth of an imcli wide, with dark, scittered or eontluent specks; the wings are reddish brown amb about me-hall of an ind h long. The young sloots are of a glancons violet enlor. The hark of mature trees is rather thick and broken up in sunturish plates. The difterent general appearance of the tree will almost al ways serve to anickly distinguish it from the closely related Serub Pine (I'inus rimginiuna) which is distinguished by its slorter and more rigid leaves. Any doubt can be removed ly trying the twigs; those of the Scrub Pine are tongl while those of the Shortleaf Pine suap oft reanlily. The bark is of a light redclish brown color, and on the lower part of the tmuk in full-grown trees three-fourths to tully one inch thick crossed by leep furrows, and thaky.

The limus are arranged in more or less regular wholls, nuder full exposture, torning a crown with the ontline of a truncated pyramid, by whioh the tree ean be recognized from a distance and distingnished from kindred species with which it happens to be associated. The oldest and stontest limbs are rarely over 20 to 25 feet in length, and are somewhat drooping.

It is indeenl a beantiful tree, with its stately, gently tilpering trmuk and its finely shilped full crown clotled in an abundance of foliage, bearing the stamp of thrifty and vigorous growth.

Lences. -The secondary or folinge leaves are fonnd mostly $2 \mathrm{in}$ it sheath, and m shoots of rigorons growth often 3 are fomm in a bundle; oceasionally whole trecs alre seen with 3 leaves in a

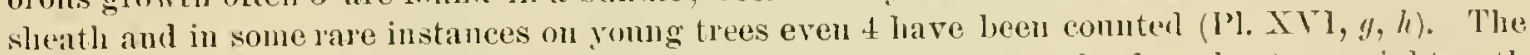
leaves rary from 3 to 4 inches aud a little over in length; they are slender, abont one-eighteenth of an inch wide, strongly coneare, slightly tristed, fintly semulate, and abruptly sharp pointed, while young of a yellowish and later on of a deeper green color. In the cruss section (1'l, $\mathrm{X} Y, h, i)$ they present a senicirenlar ontline; examined muler the microscope they show on both sides ahmt ten rows of minte stomata (breathing pores) the small epidermal cells muderlad by a single layel of rather thin-walled hypulermal or strengthening cells; in the specimens examined from 3 to 4 peripheral resin dncts were fond, the bundle sheath consisting of a single row of eells. 'The sheath invests the leaves closely and rarely exceeds at any stages of growth three-sixteenths of an inch; the leares are shed during the latter part of their serond year.

The bract-lilie scales ( $P$ l. XV, b. (.), modified prinary leaves, which densely cover the rom shoots and in the axils of which the foliage leaves are produced, are while young of a grayish color, closely appressed, lanceolate, acmminate, and fringed; with the subsernent development of the foliage leaves and the increase of the shoot in length, their tips become dried and are cast ott. As the tender shoots becoule hardened they assmme a glancons purplish rolor.

Flowers.-The flower bnds make their appearance during the latter part of the winter and begin, in stations of southern latitudes, to open near the end of Marels (Baldwin Connty, Ala., March 26), and farther north from three to four weeks later (Cullman, Alit, April 2S). The staninate flowers are closely sessile, to the number of fifteen to trenty surrounding the terminal but (Pl. XV, a), which at the time has seancely grown to the length of an eighth of an incls. The staminal column, of a pale purplish color, does not exceed three-fourths of an inch in lengtli, is less than me-eighth of an inch in thickness, and is suromiled by eight or nine decnssate seales, those of the first pair being strongly keeled and scincely half the size of the other's (1'l. $\mathrm{XV}, \mathrm{d})$. The "rest of the anthers is nearly cireular and slightly denticulate. The male fluwers are shed immediately after the diseharge of the pollen. The female flowers are miterl in an oblong, obtuse, short-stalked catkin of a delicate rose-pink color, abont one-fourth of an inch in length. They are rarely single, but mostly from two to fonr, produced closely below the apex of the youngest shoot (l'l. $\mathrm{XV}, b$ ). The stije of the catkin, not over three-eighths ot an inch in length, is invested by twenty to twenty-finc byaline lanceolate, pointed, involucral seales, those immeriately surrounding the flowers being widely spreading. 'The bracts subtending the carpellary scales cover the latter to the base of their long, subulate, erect tips. 



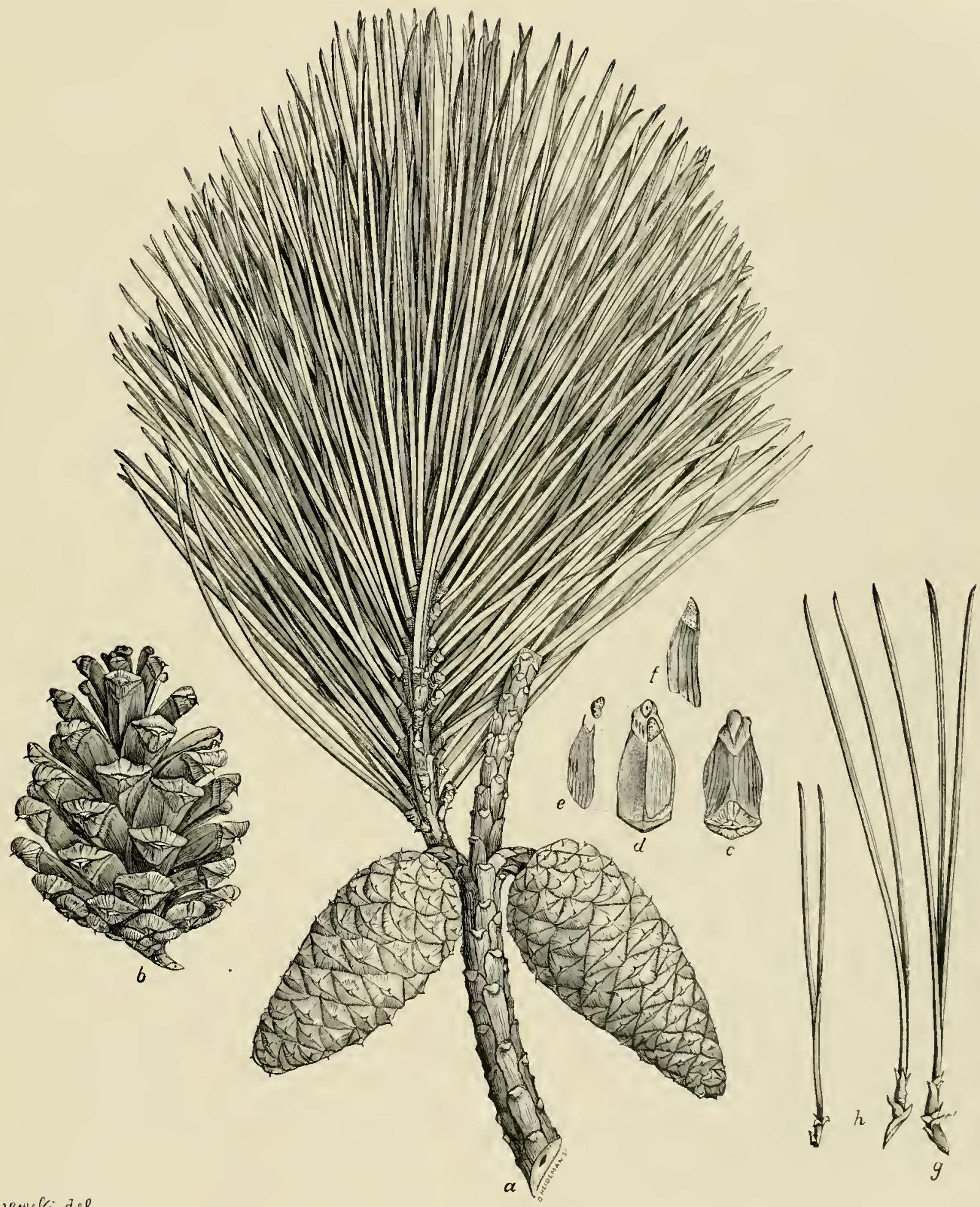



After fertilization has taken place the shoots bearing the fortile llowers increase lapilly in length. Fertile catlius ane frequenty found on the older branches, produced on branchlets thom advatitions buds. The tree begins to produce flowers when fion ten to twelve years old, according to expostre; male flowers have been observed me or two seasons earlier.

Cones.-Every :eason cones are prodnced in wreat abundance. The conclets of the first year, borne on a short, horizontal stalk, are wal in sloape, searcely one-half an iuch in length, the stpurrose tips of the scales giving them the echinate appearance from which the botanical name tirst given to this species wats untonbtedly derived (Pl. XV, c).

Fully matured by the end of the second yeall, the cones are uparly sessile, ovil, of alll wh leather brown color, $1 \frac{1}{2}$ to rarely 2 inches long, and when open, nealy as wille; they are trepumtly smooth (Pl. XVI, a, b). The seales are hard, with a slightly swelled alpoplysis, devoil of or armed with the weak, more or less deciduons prickle (Il. XVI a,d). The cones open early in the tall, and remain, after the dischange of their seeds, tor several years on the branches. In cunsequence, the older trees are covered with them thromgh all seasons.

seed.-The Shortleat Pine prodnces seeds in greatest abnudance; its crops seem never to fail. The seeds are small, triangular, three sixteent hs of an inch long by one-eighth of an inch wide, the laarl, ronghisl testa markel with three indistinct ridges and more or less with confluent specks; the wing is of a light, redhish brown, half an inch in length and deciduons during germination $(\mathrm{Pl} . \mathrm{XV}, e, f)$. The seeds retain their vitality tor several years; fresh, they will gernnuate in from ten to fiftetn days. The mumber of seeds to the onnce is about 5,000; wafted by the wind over wide distances and germinating early during the hist days of spring, their offispring are fonnd to talie possession of every opening in the forest and of the old fields in localities tavorable to their glowth.

THF WOOD.

The wood of Shortleat Pine resembles that of the Loblolly in almost every respect. The sapwood is clearly defined, being quite broad, and oven in very old trees forms fully one late of the total rolnme of the trunk. In thirteen trees one humbed to one bumdred and fitty gears uld, the average width of sapwod was found to be about 4 inches, while even in trees over one hundred and fitty yean's old its average wilth was 3 inches. In the former ease. the sapwroul formed for to To per cent of the volume of the logs; in the latter, 50 to 55 per cent, while in a set of tres fitty to one huntred year's old it formed tully 80 per cent of all the wood. The change from saprood to hardwood proceeds much as in Loblolly Pine. It begins when the tree (or any disk) is about tweuty-five to thirty Jears oh, aud is retarded more and more with age, so that in old trees as many as eighty or even one hundred rings wre counted in the sapwood, while in yonug and thrifty trees not more than thirty to forty may aceru.

In keeping with the large amount of sapwoon, the weight of green shortleaf l'ine is rather great, varying, for entire logs, from 45 to 55 pounds per cubic foot, comnonly a pproatehing 60 prounds in the largely water-fillen outer portions of the salpwool.

When kilndried, the woon of trees one humderl to one humben and tifty years old weighs: on the average abont 32 pounds per unbe foot. As in other pines, the butt is 15 to 20 per cent heavier than the top, and the wood of the inner forty to tifty rings excels in weight and strength the woml of the onter parts of old logs. As was staterl for Loblolly. the sapwood may be light, leary, wak, or strong, accorling to the age of the tree from which it is ohtaned. As might be expected from the great range of distribution of this tree, its wood, like that of Loblolly, raries withn very wide limits. Specimens from Missonri (near its northern limits) are generally lighter and less resinous thau those fron farther south, and frequently resemble the wood of the Forway Pine, while many select specimens firm the Gulf and South Atlantic States rival in weight and strength the hest grades of Longleaf l'ine. In its streugth, as in its weight, the Shortleaf follows Loblolly l'ine.

The average of a large series of tests furnishes the following average ralues for dry piees of this species:

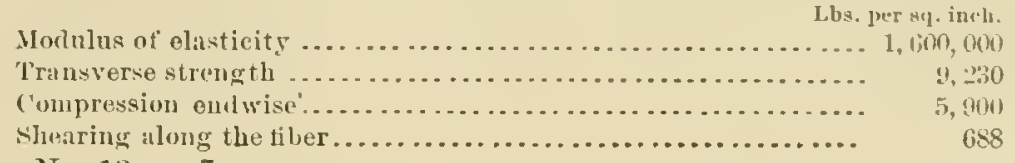




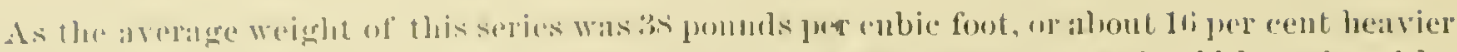

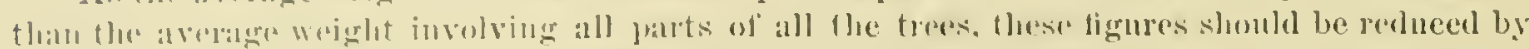

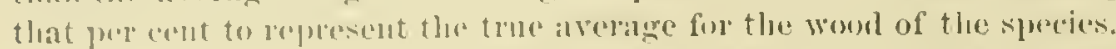

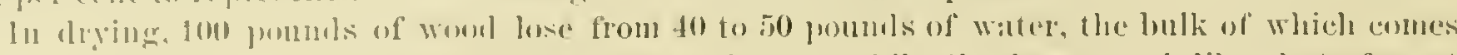

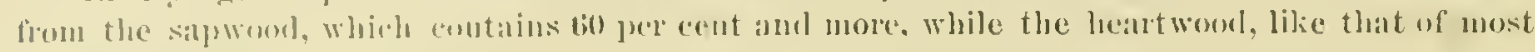
jines. continins alwout 25 per rent.

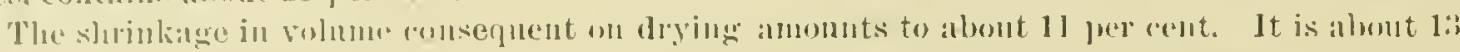

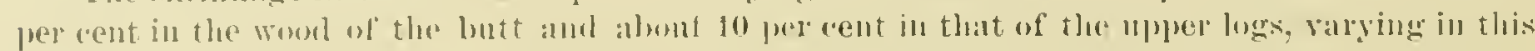

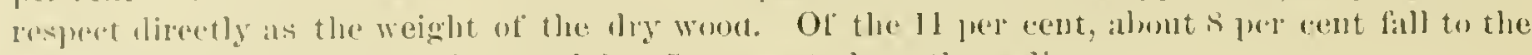

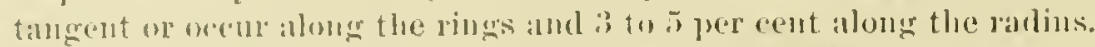

"The strueture of the woul of" Shortleat leine is esiscutially the sime as that of Loblolly. Sum.

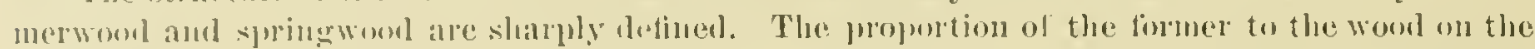
whole varies, as in boblolly, in the silne manner as the weight of the wool, being greater in the butt than tople, greater in the wood of the inner rings than in the wood lanther ont, and greatly reduced in all cises where the growth of the tree is sublenly retarlen by unforouble seasoms, but is otherwise quite ind ('pendent of the wislth of the rings.

lor details of structure, emsult the eomprative study of Mr. Roth, appeuled to these monograpls.

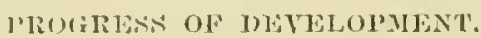

The sueds begrin to strell and to germinate in the early days of spring. In Mobile Comnty, on the end of the first walk of 1 areh, the plantlets had their rotyledons fully unfolded, which were found to valy lim six to seven in number, with the lower (hypoentyledomaly) pant of the axis from $1 \frac{1}{2}$ to 2 inches long, the rontlets being somewlat less in length (Pl. X V, e.g). The development of the upper part of the axis ("anlinde) from the terminal budlet and of the primary acerose leaves

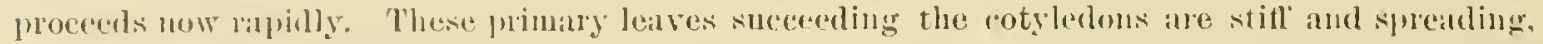

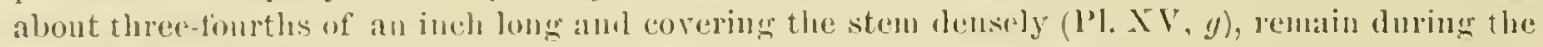
lirst season, withering from below during the warmer part of the season. By" the close of the first season the caulicle or first sherst. has attained a length of fiom : to t inches. On the shoot of the second seatsm (ratrely betine) the secondary leaves, which constitute the foliage, malie theip

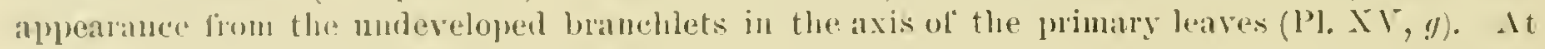

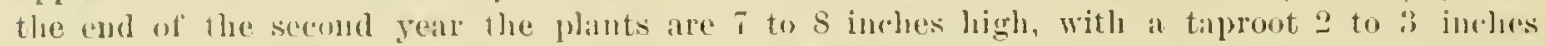

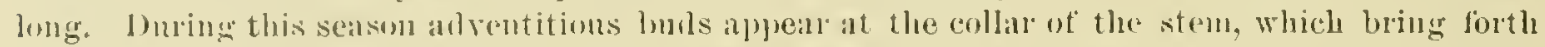
vigorous sprout, particulaly if the stem has sustained the slightest injury. These shoots ane covered with primary leares, which ane retaines lon one seasun. They ane alt to form strongr

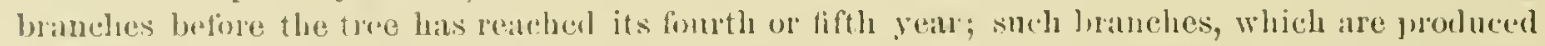
prolisely from the stmmps of larger trees, scarrely survire another seasom. It is ranely that branches are prodneed in the second year, the tirst branches appearing generally in the third season in whorls of three to four. In the third year toliage leaves alone are prolnced in the axils

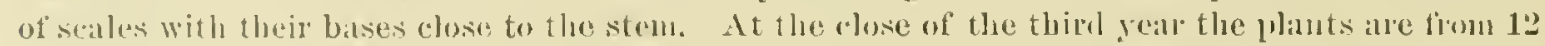
to 15 in hes high. Sow the development of the rout system advances raphilly, the tapmot being ly this time almut 8 or 10 iurhes long, with strong lateral roots often double that length. Both

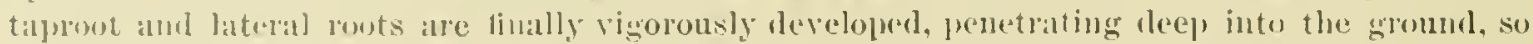
that trees of this speries are ranely buwn lown by winds. At the end of the fourth year the

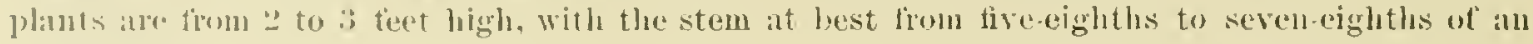
inch thick.

The branchess of the whorls hegin now in their turn to develop brandulets in whorls of secondary order. The deredopment of the primary axis and its branch system proceds leneetorth in the

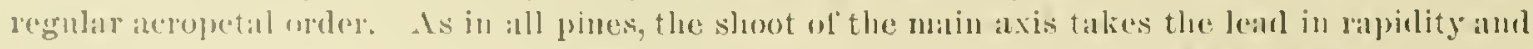

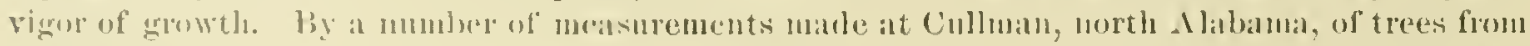

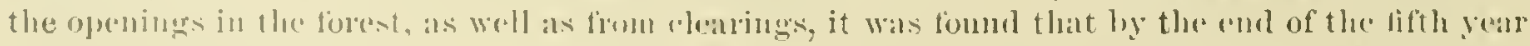

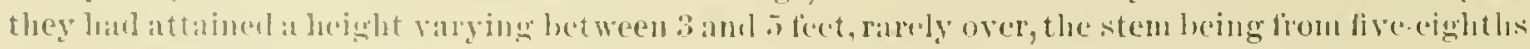

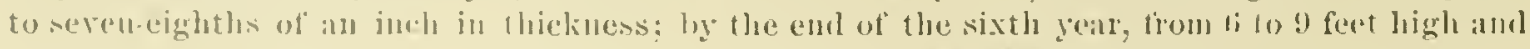

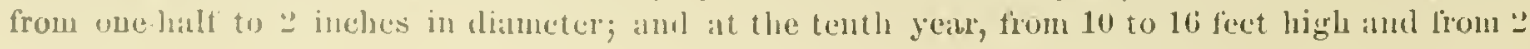


to $2 \frac{1}{2}$ inches in diameter. At the age of fifteen to twenty years, with a total height of from 20 to: $; 0$ fect and a diameter breast high of $t$ to 5 inches, the erown of the tree uneupies from onn. half to tive-eighths of its height. Henceforth thronglrout the period of puickest growth its ritr is greatly inthenced by conditions of light and soil. At the age of fifty yats the height of the troes varies between fll and bo fect and the diameter loreast high between 10 and 14 inches. About this age, or perhaps a slort time before, the height growth begins to derline and the branches become somewhat reclining below and spreading toward the top, and conserpuently the liead of the tree becomes more romded in ontline. Between the ages of sixty and seventy years the trees are, from 50 to 70 feet high and from 12 to 1.5 inches in dianeter, with the tronk clear of limbs for 30 to rarely over 40 feet. From this perion on the growth procereds at a slower rate. On reaching its one hundredth year the tree has attained a leight between 90 and 95 feet and a diancere ot from 16 to 19 inches at most. IIaving now passed its period of vigorous life, the growth is lienceforth insignificant. Between the ages of one hundred and tirenty and one hundred and thirty year's trees were found 90 to 110 feet high and from 18 to 24 inches in dianeter. The oldest tree encountered in the measurements, with two hundred and eight lings of annual growth in the stump, searcely exceeded 109 feet in height and measured 24 inches in diameter. The largest. tree felled was 117 feet high and 25 inches in dianeter, with one hundred and forty-thwe rings in the stump. Oceasionally trees are found of a diameter exceeding 3 feet, but such are exceptional.

TABLE I.-Crrouth of shortleuf l'ine (P'inus crhinata), from eight to figty years.

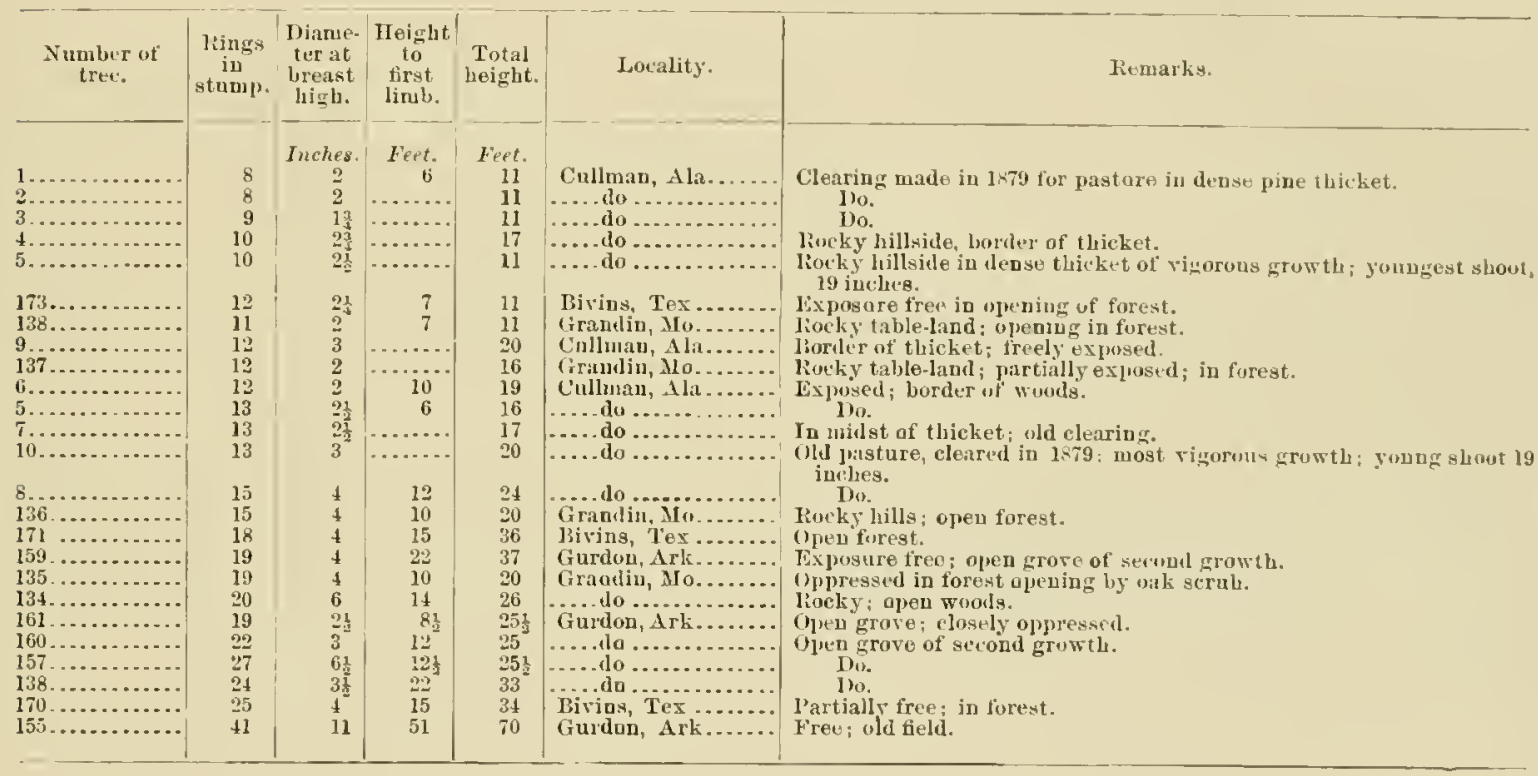




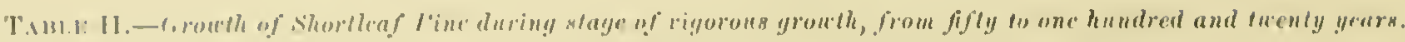

\begin{tabular}{|c|c|c|c|c|c|c|c|c|}
\hline 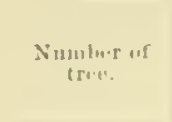 & $\begin{array}{l}\lim _{\text {ing }} \\
\text { stump. }\end{array}$ & 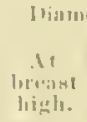 & $\begin{array}{l}\text { lirlusw } \\
\text { crowsul. }\end{array}$ & 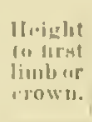 & $\begin{array}{l}\text { Tiotial } \\
\text { lioightit. }\end{array}$ & $\begin{array}{l}\text { l.englt } \\
\text { inither. } \\
\text { timinr. }\end{array}$ & larculity. & linmarkis. \\
\hline $10 \%$. & 5: & Inrlies. & Inches. & lime & Fet & Fret. & Ruvins, Tex. & In forest: soil cold, wnderdrainago dedicjent: "x. \\
\hline $10 \mathrm{k} . . .$. & initi & 15 & & (2): & $\begin{array}{lll}511 \\
81\end{array}$ & & 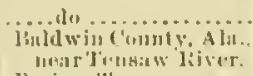 & 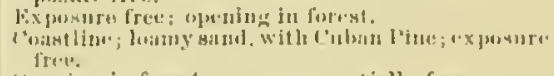 \\
\hline $10 \mathrm{ii}$. & $\begin{array}{c}i: \\
102\end{array}$ & $l_{12}^{12}$ & & $i_{i=2}$ & ail & 32 & 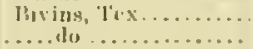 & 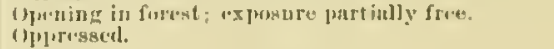 \\
\hline & $10:$ & $1 k^{2}$ & & i. & 19 & & 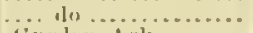 & \\
\hline $15 \div$ & 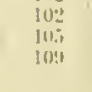 & \begin{tabular}{l}
$1: 1$ \\
$1: 5$ \\
\hdashline$: 2$
\end{tabular} & 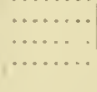 & $\begin{array}{l}3 n \\
32 \\
42\end{array}$ & $\begin{array}{c}109 \\
\text { ifi.1. } \\
101\end{array}$ & $\begin{array}{l}34 \\
311 \\
40\end{array}$ & 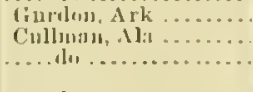 & 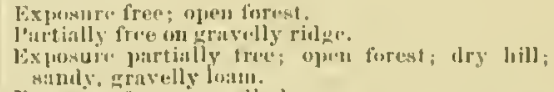 \\
\hline $\begin{array}{l}n 1 \ldots \ldots \ldots \ldots \ldots \\
1,1, \ldots \ldots \ldots \ldots \ldots\end{array}$ & $\begin{array}{l}111 \\
111 \\
110\end{array}$ & $\begin{array}{l}21 \\
17 \\
\cdots 2\end{array}$ & wan. & $\begin{array}{l}41 \\
415 \\
45\end{array}$ & $\begin{array}{l}i 4 \\
93 \\
9: 3\end{array}$ & $\begin{array}{ll}41 i \\
i:\end{array}$ & 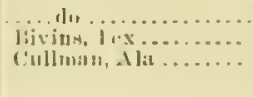 & 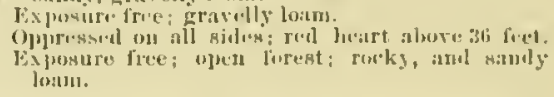 \\
\hline
\end{tabular}

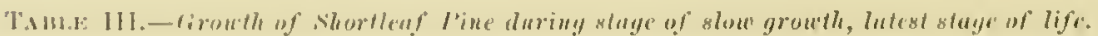

\begin{tabular}{|c|c|c|c|c|c|c|c|c|}
\hline $\begin{array}{l}\text { Numblar of } \\
\text { of trace. }\end{array}$ & 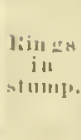 & $\begin{array}{c}\text { M1 } \\
\text { broaq1 } \\
\text { loighl. }\end{array}$ & $\begin{array}{l}\text { lindow } \\
\text { cruwn. }\end{array}$ & 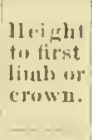 & $\begin{array}{l}\text { Total } \\
\text { heirtst.t. }\end{array}$ & 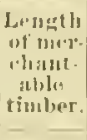 & Lowality. & lietnarks. \\
\hline & 120 & $\begin{array}{c}\text { Ineles. } \\
\text { ty }\end{array}$ & $\begin{array}{l}\text { Inclies. } \\
\text { ….... }\end{array}$ & $\begin{array}{l}\text { Fieet. } \\
45\end{array}$ & ring. & Feet. & Collman, $A$ la .... & 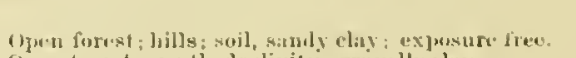 \\
\hline $\begin{array}{ll}150 . . \\
153 .\end{array}$ & 100 & $\begin{array}{ll}20 \\
211\end{array}$ & 13 & $\begin{array}{l}7.3 \\
47\end{array}$ & $\sqrt[110]{4.5}$ & 60 & Gurdlus, Ark..... & (1) nn torest; gentle desilivity : grivelly clay. \\
\hline $150 a$ & 132 & 24 & 19 & 47 & 100 & $\begin{array}{r}45 \\
43\end{array}$ & 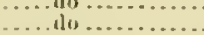 & $\begin{array}{l}\text { lli.: } \\
\text { llin. }\end{array}$ \\
\hline $1: 9$ & $1: 32$ & 21 & 12 & $\frac{12}{32}$ & $\begin{array}{ll}87 \\
92\end{array}$ & $\begin{array}{l}40 \\
38\end{array}$ & Cinllmin, Alit. & 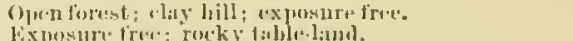 \\
\hline 31. & $14: 3$ & $\ddot{2}$ & 2013 & 46 & 117 & 45 & (iurvoni, Ark & 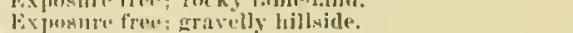 \\
\hline & 150 & 200 & ..... & 50) & 11111 & 50 & Grumelin. Mo. & 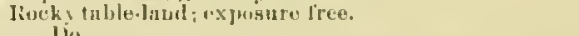 \\
\hline !30. & $\lim _{x \rightarrow 0}$ & 22 & & 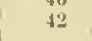 & !1] & 40 & .....do do............. & 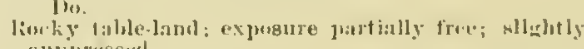 \\
\hline $\begin{array}{l}162 \\
163 .\end{array}$ & $\begin{array}{l}195 \\
: 214\end{array}$ & 24 & $\ldots$. & 37 & 119 & 37 & Bivin & 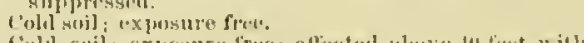 \\
\hline & & & & & & & & 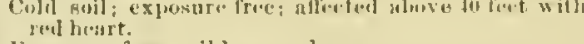 \\
\hline & 218 & 25 & 22 & 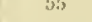 & 110 & 50 & & 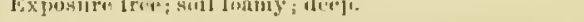 \\
\hline
\end{tabular}

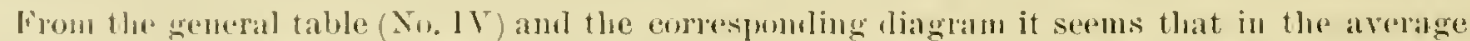
the tree at twanty is about 30 feret ligh, reaches an) fiet at the age of forty, and that its growth in leeight is in the main linished at the eary age of 60 . ln keeping with this, the growth in dianeter is guite rapid duming the first fifty years, continues at a noterafe pace lip to so, when the age of extrome slow growth is entered. 
RATE OF GROWTH OF SHORTLEAF PINE.

TABLe IV.- Liate of growth of Shortlcaf I'ine.

\begin{tabular}{|c|c|c|c|c|c|c|c|c|c|c|c|c|}
\hline \multirow[b]{2}{*}{ Age. } & \multirow[b]{2}{*}{$\begin{array}{l}\text { Diameter } \\
\text { with bark } \\
\text { (breast p } \\
\text { higli). }\end{array}$} & \multirow{2}{*}{$\begin{array}{l}\text { Longth } \\
\text { of log } \\
\text { with njt- } \\
\text { per dian. } \\
\text { eter of } 5 \\
\text { ins:lios. }\end{array}$} & \multirow[b]{2}{*}{$\begin{array}{l}\text { Total } \\
\text { loight of } \\
\text { tree. }\end{array}$} & \multicolumn{2}{|c|}{ Volums. } & \multicolumn{4}{|c|}{ P'eriodical growth liy decades. } & \multirow[b]{2}{*}{ Volume. } & \multirow[b]{2}{*}{$\begin{array}{l}\text { Avrage } \\
\text { annual } \\
\text { accrotion. }\end{array}$} & \multirow[b]{2}{*}{$\begin{array}{l}\text { Current } \\
\text { accretion. }\end{array}$} \\
\hline & & & & Trues. & $\begin{array}{l}\text { Log up to } \\
5 \text { iuclies } \\
\text { dian- } \\
\text { uter. }\end{array}$ & lecestes. & $\begin{array}{l}\text { Di:Im- } \\
\text { etcr. }\end{array}$ & II.jiglit. & $\begin{array}{l}\text { Area of } \\
\text { eruss } \\
\text { sertion. }\end{array}$ & & & \\
\hline 10 & $\begin{array}{c}\text { Inches. } \\
3,0\end{array}$ & Fiet. & Feet. & Gu.jt. & $C w, f t$. & & Inclies. & I'tet & $\therefore y, j t$. & lin.jt. & cheft. & ru. $f$. \\
\hline 20 & 5.2 & (n... & $\begin{array}{l}11 \\
27\end{array}$ & $\begin{array}{l}0.32 \\
2.21\end{array}$ & …..... & Firat $\ldots .$. & 2.2 & $\begin{array}{l}11 \\
16\end{array}$ & 0.03 & 1). 32 & 0.03 & 1. 03 \\
\hline 30 & 7.4 & 15 & 41 & 7.55 & 6.37 & l'bivl... & $\begin{array}{l}2.3 \\
-.2\end{array}$ & 1.4 & $\begin{array}{l}.07 \\
.1 .1\end{array}$ & 1. 89 & .11 & .19 \\
\hline 4i) & 9.3 & 26 & 51 & 14.00 & 12.98 & Fourth,...... & $\ddot{1.6}$ & 10 & $\begin{array}{l}.11 \\
.113\end{array}$ & 5. 34 & .25 & .53 \\
\hline 50 & 11.0 & 38 & 60 & 22.18 & 21.18 & Fifth ........ & I. i & 9 & .17 & 8.12 & .40 & 81 \\
\hline fill & 12.7 & $4 x$ & 67 & 31.97 & 31.10 & Fixth .......... & 1. 6 & 7 & .21 & 9. 7!! & .53 & .98 \\
\hline 70 & $\begin{array}{l}14.5 \\
16.0\end{array}$ & 56 & & 43.96 & 43. 32 & Serventh ............ & 1.6 & 1 & .21 & 11.19 & 62 & 1. 20 \\
\hline $\begin{array}{l}80 \\
90\end{array}$ & $\begin{array}{l}16.0 \\
16.5\end{array}$ & 61 & 75 & $\begin{array}{l}5 t i .54 \\
60.53\end{array}$ & $5.9 .9 \mathrm{I}$ & Eixhth $\ldots . . . . . .$. & 1.5 & 4 & .23 & 12.58 & .711 & $1.21 \%$ \\
\hline 100 & 17.0 & 67 & 81 & 67.68 & $\begin{array}{l}61.89 \\
67.05\end{array}$ & 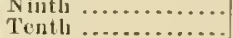 & .6 & 3 & .10 & 5. .143 & .69 & .60 \\
\hline & & & & & & & & 3 & .07 & 5.15 & & \\
\hline
\end{tabular}

\section{HEIGHT}

\section{IN FEET.}

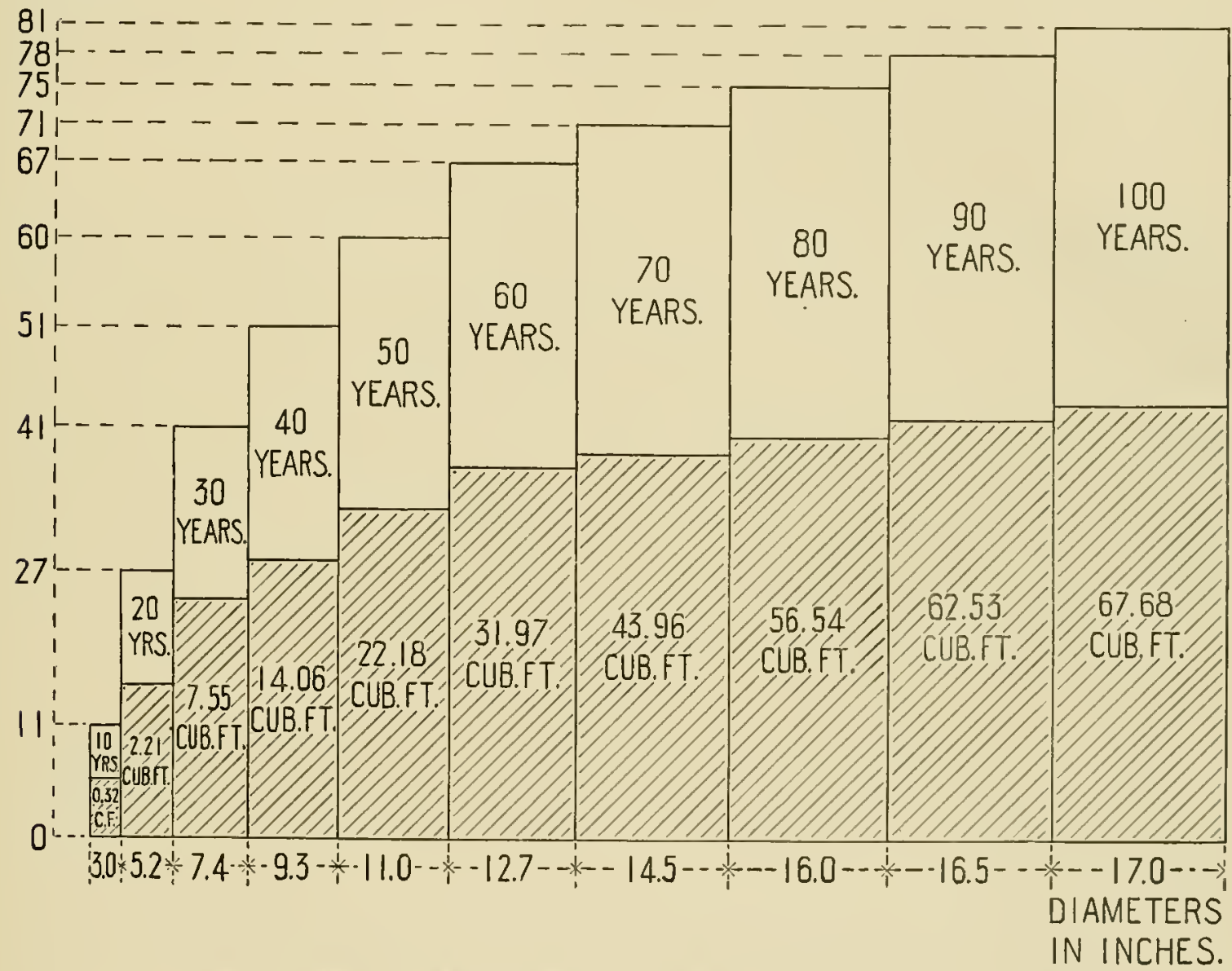

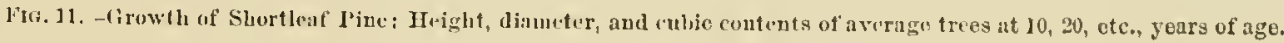

\section{CONDITIONS OF DEVELOPMENT.}

Soil and climate.--The Sholtleaf l'ine prefer's a well-dhained, light sandy or gravelly elay soil or warm loam, even if deticient in the elements of plant food. Soils of this character which are fond widely prevailing over the mululating or broken uplands, if only of sullicient depth, will produce this tree in greatest perfection. It avoids the strongly calcareons and the rich alluvial soik, as well as purely silicins, being dependent ou the presence of a certain amomut of clay by which the mechanical condition of the soil is inproved, rendering it more compact and unore 
retrutive of moisture. 'That a purely sindy and highly porous soil is mot fovomble to this tree is slown by the stunter errowth of the watils sometimes fomml in the openings of the forests of longhenf line an the sandy, arial uplands in the lower part of the const pine bedt.

Distributerd in is rangr over 10 dewees of latitude and expmsed to wide differences of tamperature, it shows almost the same thritt of growth near its northeru linits under the isotherm uf 50 l. . and in regions where the thermometer lalls to near 20 P below zero, as in lower latitules wirl a mean anmal tempcrature of $6 . \mathrm{L}^{\circ} \mathrm{F}$. It can, therefore, endme a considerable range of temjeriatime.

The anmlitions of atmospharic moisture evidently exercise a much more decided influenee orer its distribution. and, withont donbt, npon its individual develojment. The tree is found in greatest abundance and of best growth where, within the limits of its distribution, the annual raintal] vares betwern 4 s to 52 inches, it is less liechent in the districts where the precipitation

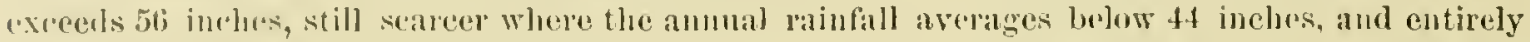
wantingr where this is less than d0 inches. Hence it is lound best developed in the mper part of the Gulf States and west of the Mississippi liver in aljacent mortlern distriets linm the interior

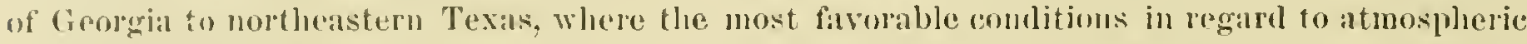
preripitation prevail. The tree seems to aroid the hunid air of the coast along the Gulf, as well as along the seaslove of the Southern Atlantic States, nor does it aseend the momntains in these States above an altitude of :50) leet.

\section{IELATIUN TO IAGHT ANI ASNOCIATED SPECIES.}

The Shortlenf l'inr. like most pines, is a light needing speries, being, lowerer, less sensitive to a deficiency in this direstion than the Longleat and Cuban pines, wheh later succumb in competition with the Shortleat Pine. Origrinally the Shortleal' l'ine is fomm more or less asso-

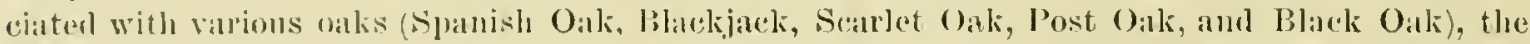
Mockermut and the l'ignut 1lickory, and more rarely with the Chestunt, the Mountan Oilk, and the Sernl, l'ine. All of these species prefer the warm, lighter soils of the mplands. These companions of the shortleaf line ale joined in the lower sontlern states by the lablolly and

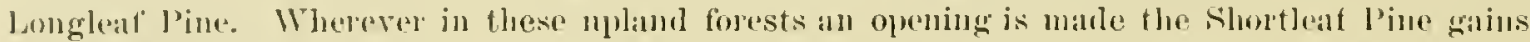
ore its : issociates, finding its only successfin rival in the Loblobly l'ine. It is in the Sontheru States proverbial that in the njuand forests "the pine is erowling ont the lourl-woor timber," a fict rarly olserved. The displatement is effected either gradnally in the course of time, or instantly when the lemoval of the original timber growth has been sudien. In the upper part of the maritime pine belt, where it is associated with the longleaf l'ine, the latter is sure to be replaced by the Shortleat species, often joined in the conrse of such invasion by the Loblolly Pine.

\section{ENEMHES.}

Tittle is known of the fungoid parasites and of the inseets endangering the life of the Shontlanf line. Fom my own olservation, it seems that this thee is less andected by the former than the other pines of the sime region. In the lumbering listrifts of Alabanal a disease called

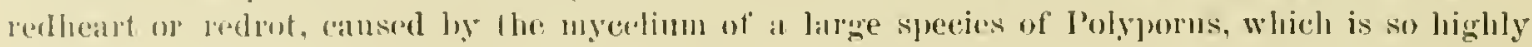
destructive to the langleaf Pine, is in this species almost mnknown. In northeastern Texals this disuase was found to allect the superinmuted timber trees, which were over two humber years

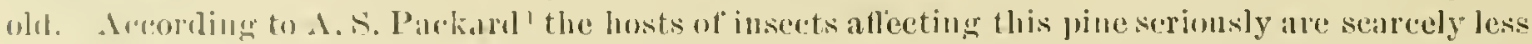
in number than those infestingr the longleat Pine; Sts enemies belong to the samo or very nearly

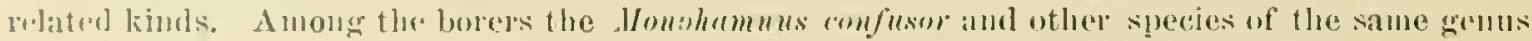

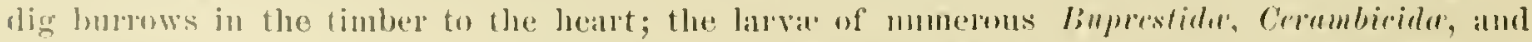

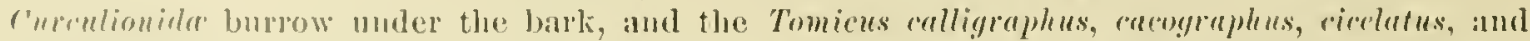
uther species of Scolylide, at certain seasons are in immense numbers carrying on their work of dextmotion in the cambinm layer, leaving in wonderful alelineation on the inside uf the bark the malks of their permicions arotivity and eansing the speedy death of the tree.

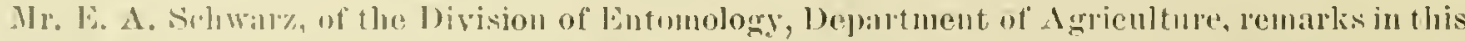

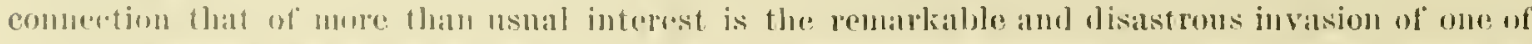


these bark-boring Seolytid beetles (Dendroctonus frontulis), which in former years was universally considered a rare speries. This invasion starter in 1858 from the monntainoms megins of West Virginia and within four years spreal throughont the Alleghung Hountains and anjarent lowlands from l'ennsylvania to the Carolinas. The amonnt of damage ablused by this bertle within that time to the Shorteaf Fine and other pine trees has ben enormons. A contagions disease, puobably of a fungoid chameter, terminated in 1892 this invasion just as smdelenly as it had commencerl, and in 1S93 not a single living beetle could be fonnd thronghout the infisted region. The white froth

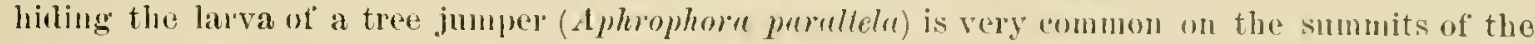
twigs, the larva of the sawflies are seen at the sane season to beed on the tender, youmg foliage, which is also infesterl by a small white Gelechial depositing its oggs on the leaves, the larvie boring

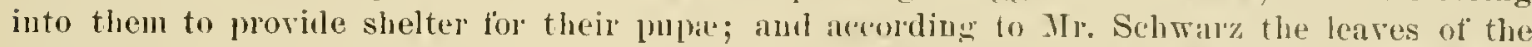
Shortleat Pine are tiequently fouml completely covered by a sale insert (Mytiluspis pinifolin'), causing what is termed in New England the "white malady" of the pine. Of the llat-headed borers, larve of the buprestide, the most injurious speries ane Chrysobuthris rlentipes (Germ.), Calcophorn virginiensis (Drury); less common, Calmphora yeorgiun (Lec.) and Buprestis lineata Fab. (Silhwarz).

Exposed to the same dangers of destruction by forest fires and by live stock of every kind, which threaten the Longleaf species with extermination, the chances of this pine to resist then and to escape sneh eventually are more favorable in eonsergneme of the greater facilities for its reprodnetion and of its rapidity of growth luping the earliest stages of its existence.

The pernicions influences of the first of these agencies is, however, paintinlly risible near the settlements where the forest is exposed to its effects one season after another. In snch localities the pines are of stunted growth; in the middle stage-thein rery mine of life-they exhibit signs of heeay and early heath. But few of the younger trees exposed to fine were found un close examination to be fiee from defects and marks of impending disease.

Confined to the gentle slopes of the low hill conntry, to rolling nulands, and to broad table-lands, this tree is searcely exposed to llestruction by torrents and floorts. Cusonght for its resinous jnices, it is not subjected to the wholesale destruction cansed by the prevalent methols enployed in the manufacture of naval stores. No other timber tree found in the sontheru portion of the Atlantic forest region is more easy of natural reproduction than this speries throughout the widle range of its distribution. This is readily accounted for by its areat fecumbity, the seerls produred in great abundance almost withont finhre every year being pofusely spreal lor and wide, and germinating ensily wherever the proper soil and a chance is offered for their rereption. By their thrifty growth the seenlings soon gain the mper hand over the contemporar growth of other species.

Thronghout the interior of the A thantie and the (nulf States traets of npland, originally eorered with fime oak forests, which laal been cleared tor cultivation and but little over half a century ago abandoned, are fonmul at present ocenpied by the Shortleat Pine, forming dense groses of trees 65 feet anc orer in loeight, with a diancter of 10 to 12 inches, stamling 1 is to 20 feet aprart, with no nutergrowth whatever.? Such young forests, met with in erery stage of yrowth. afford highly instructive lessons of the ways taken by nature in the spontaneous restoration of the torest. In such spontaneons growths of the Shortleaf P'ine the saplings form from the first mostly deuse thickets. Before having arrived at their tenth year the work of thinning has atetively begnu by the death and speely decay of the wrikest. Thus favored by the acess of light and air, the surviving trees shoot rapilly upward, the most aspiring indiviluals spreading ont their crown, overshadowing those lagging behind, which being thus ent off fom the influenes alwore all others required for their existence, one after another die. Before the trees have reached the midrle stage of their growth the stand of timber in the yomg forest appears to be dimly established, and during the following period, embracing less than half a century, they have attained the fullness of their growth, fimishing timber thlly matures and of the dimensions and puality renuired by the present standard. Uncheeked by destructive induences the rotation of a crop of timber of the Shortleaf Pine prodnced withont the interference or assistance of man, can be suid to be ancomplished within a perior of trom eighty-five to ninety-fire years.

'Charles Mohr: I'roceedings of the Fourth Anuma lleeting of tho American Forestry Congress, Bostou, sertember, 1885. 


\section{FORFST MAYAGEMENT.}

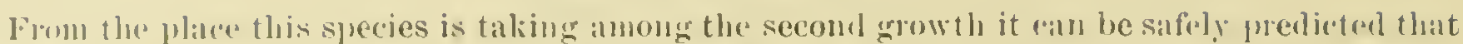

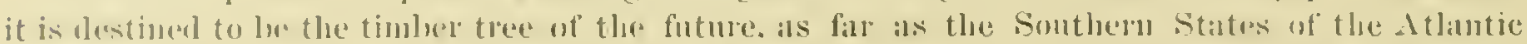

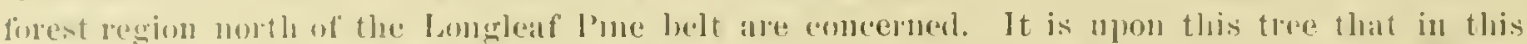

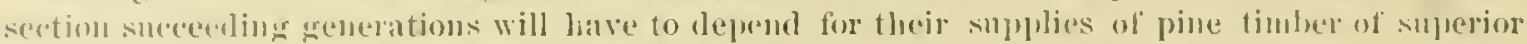

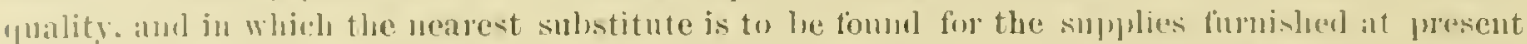

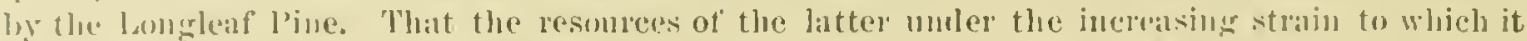

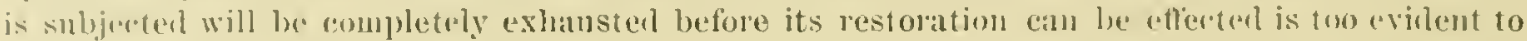
alluit of any doubt.

Anong the timber trees of the roniferons order foum in the Athantio forests, there is, then, searcely a species presenting strunger chams to the attention of the forestop than the Shortleaf

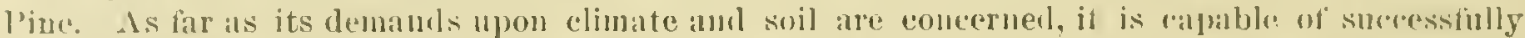

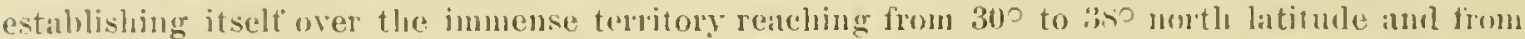
the Atlantie Slope to the reeless plains of the West, embracing within these limits areas of wirle extent, with all the conlitions required for the hest development of this species, and in wreat measme ad:upted to nothing better than the growth of timber. Of not less importance than its vilue as a timber tree are its facilities for natmal renewal, resulting from the abundant ropps of

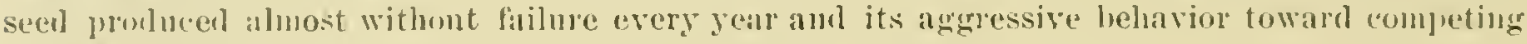
specirs in the successful struggle for the possession of the soil.

from a closer observation of the young forests of spontanems growth at dillerent stages, it is applarent that in the cestablishment and rearing of a forest of shortleaf l'ine. where mother trees exist, nature repuries compratively little assistance from the hands of the forestor, and that the efforts of the litter will be chicfly conlined to moasurs of juotection against rlestruction by tire and against the injuries cansed by inronds of live stock duriug the earlier stages of growth.

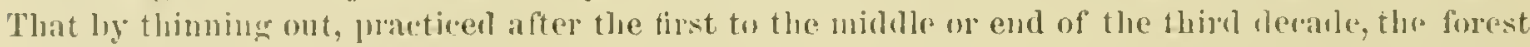
growth wenlal be benetitel, there can be but little donbt. To what extent, ly surle interference,

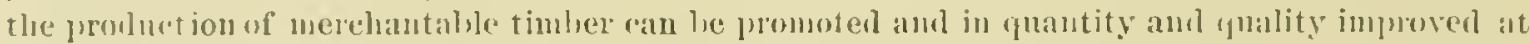

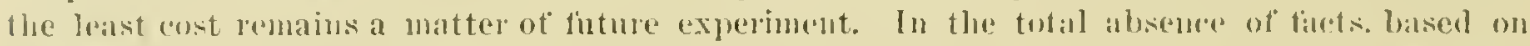

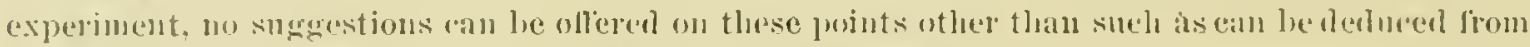

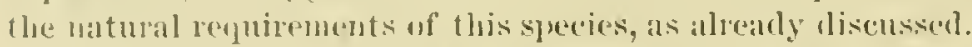

In ronclusion, it ean le silfoly assertrel that the shortleaf pine is destined to talse al jominent place in the forest mangement of the tintmo thoughont the regions fivorable to its growtl, not

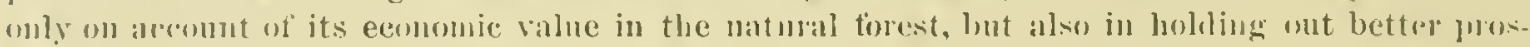
jects fo the forest planter for the proluction of timber of higher yuality in the shortest time than any tree of the same orren in the Sonthern Atlantic forest reerion. That the uethouls of it

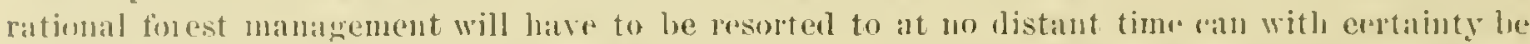
predicterl, althongh the timber wealth "xisting at present in the vast territory of its gruwth may alpeas enormons.

(of ereat importance in the reforestation of lange areas, this tree is of no less signitienure to

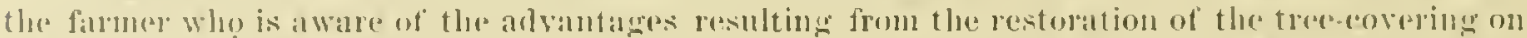

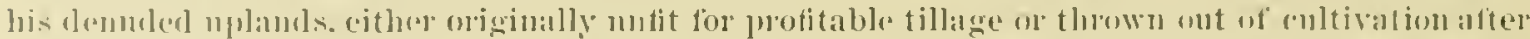

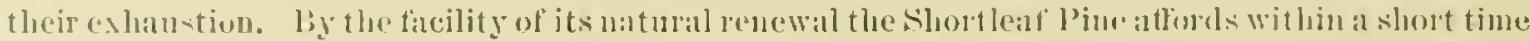

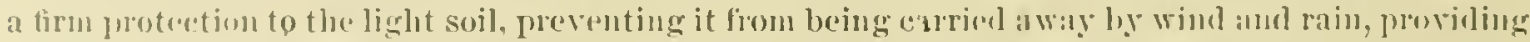
a slecter for the crops and for insectivorons birds, a lasting income of increasing supplies of timber and luel ou lands that yield no other protit whaterer, and to the lands abandoned after their exhanstim a "hance for their reenperation while resting under the cover of its slathle. 


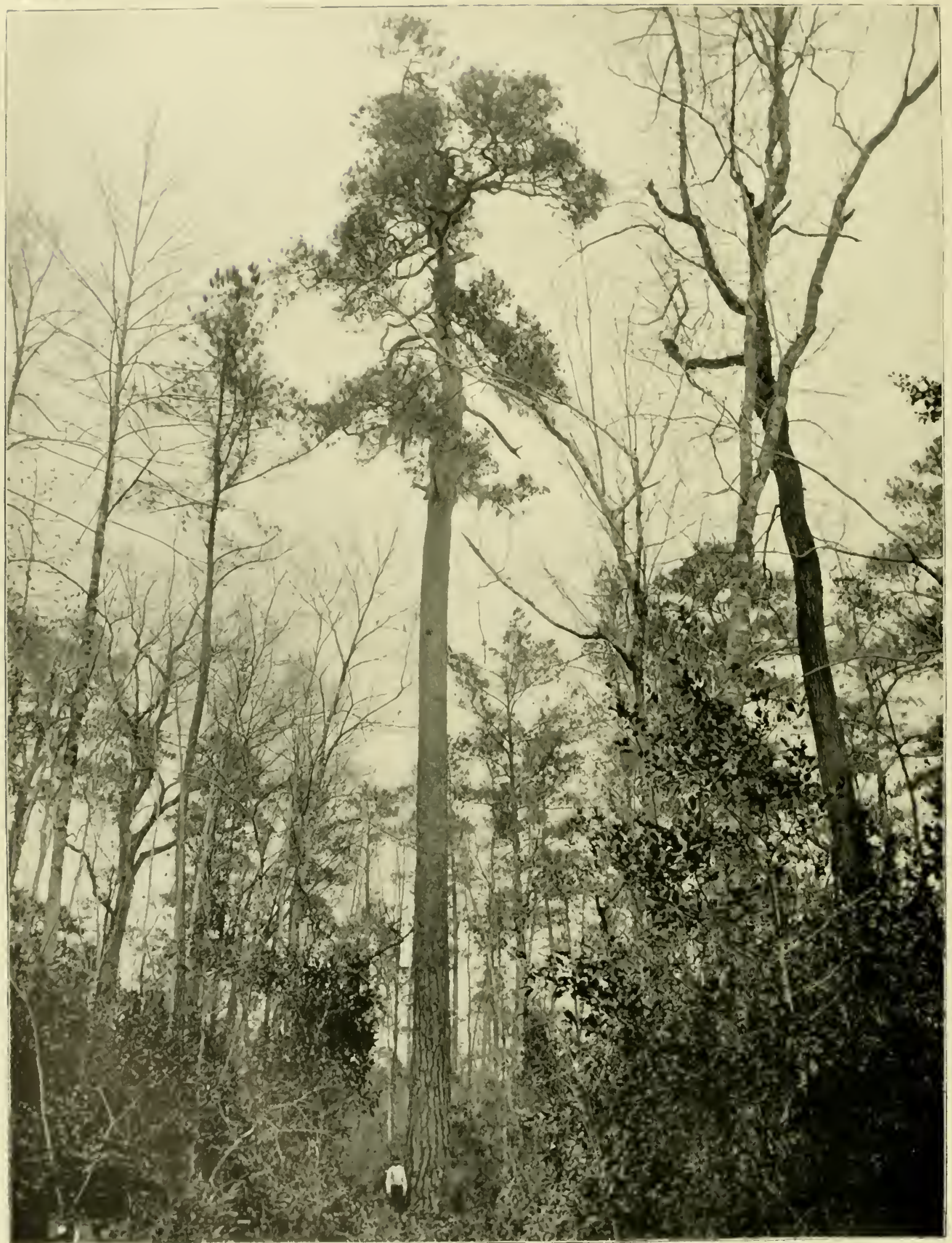




\section{THE LOBLOLLY PINE.}

(PINUS TADA Linn.)

HISTORY AND DISTRIBUTION.

Products.

DEACRITITN, BOTANICAL.

DENCTIPTION OF WOOD.

PROGRESS OF DEYELOPJENT.

CONDITIONS OF JEVELOPMENT.

REPRODECTION. 


\section{THE L,OBI,OLL. ININ.}

(linus feda linn.)

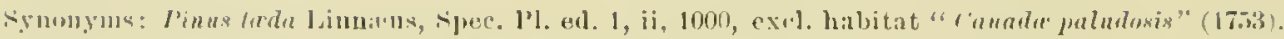

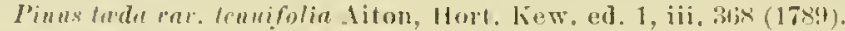

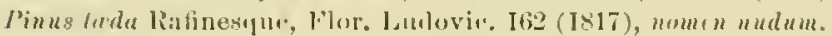

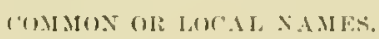

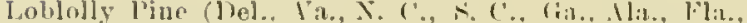
Miss., Tua., Tox., Mrk.).

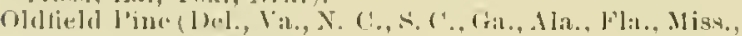
Lal. 'Pex., Ark.).

Toreh l'ine (Eng Jit.).

Slortleat line (1,a.).

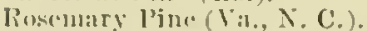

-lash l'ine (lo., X. C.), in pitt.

long sichat l'ine (llw) .

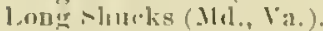

llarok slasle l'ine (s., (')

Frankincense l'inte (lit.).

Slurtleat l'ine (Va, ., C., A. ('.).

$10 f$ lull l'inc (Tix. and (iulf rogiont).

Vir rintal'im:

Sil] l'me (Vil, X. ('.)

de:ilow lime (Flit.).

('orustillk l'ine: (Yit.).

likarle l'ine (Vis.).

loxtial l'imu (Vil., Mal).

Indian Pine (Va.. X. C.

spruese l'ine ( $\mathrm{Ya}$.) in jart.

liastarde l'ino (Via., X. (C.).

lellow l'ino (.Y. Ala., N. ('.).

swampl'ine (V:a, N. C)

Longstlaw l'ine ( $\mathrm{C}^{2}, \mathrm{X} . \mathrm{C}^{\circ}$ ), in part. 


\title{
THE LOBLOLLY PINE.
}

\author{
liy Charles Monir, I'h. D.
}

INTRODUCTION.

Among the trees remakahle tor the part they take in the spontaneous renewal of the forests in the Sonthern Atlantic region after the destructire interference by nan, the loblolly l'ine is most prominent. This readiness to ocupy the gronme lends to it a special economic significance in forest growth, aside from its value as a sonree of timber and as an abundant source of fincl. There can be no donbt that in the future management of the forests of the lower Sonthern States the Loblolly l'ine will be assigned a highly important place. This view is confirnerl by the fact that in the older of the states within the limits of its alistrihntion, where the original timber growth has suffered greatest reduction, as in North Carolina, the second growth of this tree is largely lepended upon to furnish the timber supply for the existing lumbering industry.

Although known to have contributed to the necessities of the earliest settler's of these roasts, and forming at present a large part of the lumber supplies reaching the marlets cast and west of the Mississippi liver, the merits of the Loblolly Pine and its economic bearings are generally but little understood, wide differences of opinion abont its value as a timber tree prevailing. Snel diversity of opinion is in itself a sufficient reason for a fuller investigation of its life history.

In the preparation of this monoglaph the writings of F. A. Michans and Rev. M. A. ('urtis ${ }^{2}$ and the report of the Tenth Census ${ }^{3}$ have been consulted. To I'rof. Lester Ward and Mr. Canby thanks are due for valuable information on the distribution of the Loblolly Pine toward its northern limits. Inch information of practical vahe was elicited by the Division of Forestry from numerons manufacturers of and dealers in lnmber in the lower part of Virginia and in North Carolina, which has been largely quoted.

\section{HISTORICAL.}

The Loblolly P'ine was recognized as a timber tree of valne by the ealliest settlers of lower Virginia and North Carolina. Its timber was langely used in the "onstrnction of theil dwellings. Michanx states that three fourths of the honses in lower Virginia were built of Loblolly l'ine, and that its mighty trunks, fumishing shafts of clear timber of largest size, were in early days held in high esteem for masts by the navies of the world. The distinctive charmeters of the tree were clearly miderstood by the ealliest writers on North Amerien botany. l: A. Minam defined the northern limits of the tree and its distribution in the sonthem Atlantic states, and first pointer to its economic valne. The liev. M. A. Curtis gives an aconnt of its distribution in North Carolina and recogniond the form distinguished in that State as Shash l'ine or Rosemary Pine. Investigations of the torest glowth by the writer, under the direstion of l'rot: Charles S. Sargent, tor the Tenth Census, and later investigations made in the transmississippi region, muder the direction of the Division of lorestry, have led to a more accurate knowledge of the

${ }^{1}$ Michaux, F. A. The Nolth Ameriean Silva. Philadelphia, 1856.

2 Curtis, If. A. The Timber Trees of North Carolina, Geol. and Natural History Survey of North Curolina. Part III, Botany. Laleigh, 1860.

${ }^{3}$ Volume 9 of the Tenth Census. Charles s. sargent. 
lintribution of this tre in the bouthwestarn states, to the establishment of its western and mollem bundary lines, and to a more general appreciation of its ecomonic inportance in its (aistrom and western lainge.

(EMOGIRAIIICAL DISTRIBUTION ANI) ERONOMU IIISTORY.

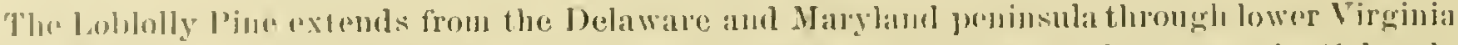

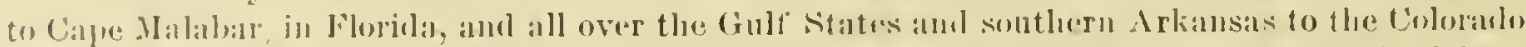

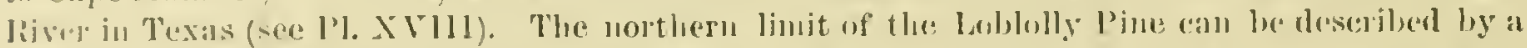

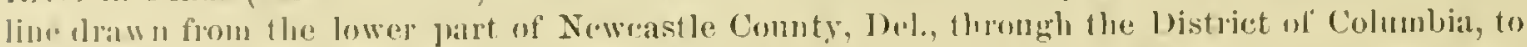

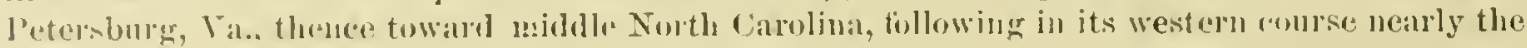

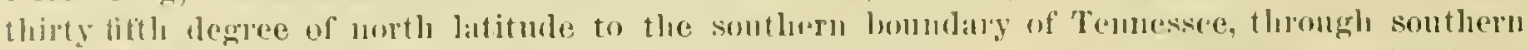

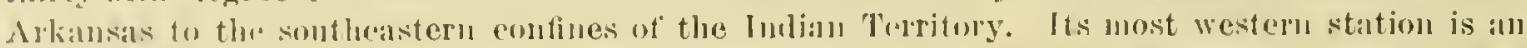
isolateal tract of small extent near hastrop, Tex., the sole and last representative of the $\Lambda$ thantic pines in the sonthwist.

Michanx the yomger established the northem limit of the Loblolly line near Frederieks-

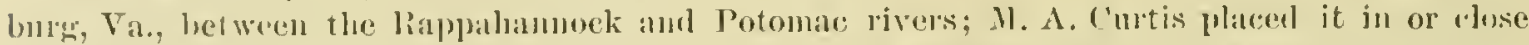

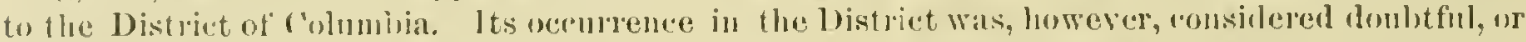
merely acridental, until in 1885 it wats contirmed by 1)r. (ieorge Vasey, who discovereal a group of fullgrown trees in the wods near the lieform Siluol. Ml. Willian C'anby states that he "foumd in the lower part of Neweastle comuty, Del, a good many Loblolly P'ines, and from the point mentioned it beenes more aml more plentiful and widespread in the Delandure-Maryland leninsmlis."

(1) the Atlantic slope, near its northern linit, the Loblolly l'ine oecurs most frepuently in the Hat lanks of the tidewater districts, forming rarely continuous foresto, more frequently less compart bodies of timber, associated with the Shortleaf l'ine, oaks, amb other hard-wool trees.

In Virginia this tree is not foumd beyond the northern limit of the Tertiany strata of the coast reerion, and is nut net witl west of l'etersburg and lichunoni.

In the lower part of this State, as in North rarolina, the lobblolly Pine was formerly fomm in

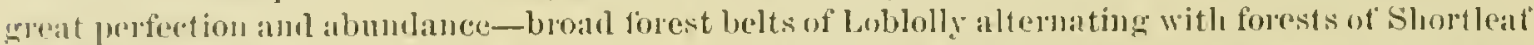

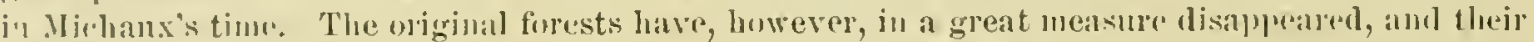
poresesy, of second or third growth, is now depended upon as the prineipal sonre of lumber. On the lands exhansted by the earlier planters, and which hate been abandoned for several Enerations, the timber of this sal l'ine, or Oldfield P'ine, lats in many localitins at tained dimensions and a degree of matmrity fitting it for all purposes for which timber of the original grewth is cmployel. This important liat is eonfirmed ly praties engaged in the lumber business in soutleastcrul Virginia and in rastern Nortlı Carolina.

from infurmation recepved it is evident that in these parts the second growth of hoblolly l'ine

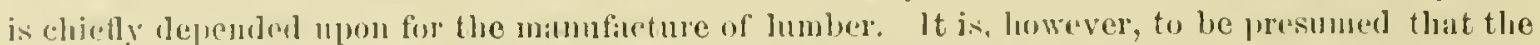
Shortleat l'ine contritutes not a small part of the timber supply. lioth of these trees are known by the inhabitants as shortleal l, or Shortstraw, l'ine, and their timber is sawn indiscrimintely; the

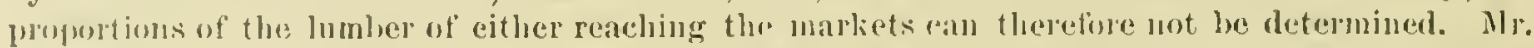

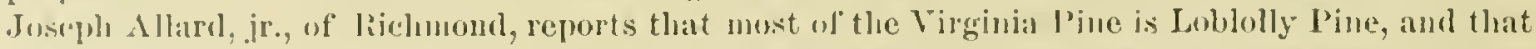

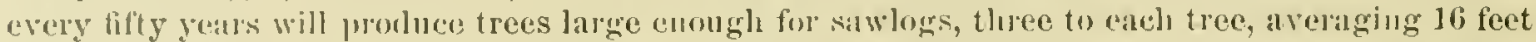
in length. Ir. Sparrow, of Brooke, Stafford Connty, states that the pine ol this connty, and in Carolinr County, is aluost entirely of the Oldfeld l'ine (Loblolly l'ine), and that in the latter from

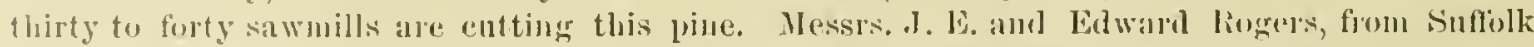

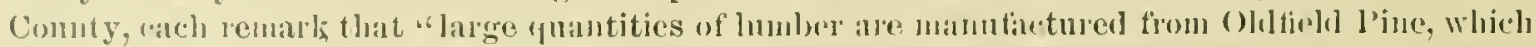

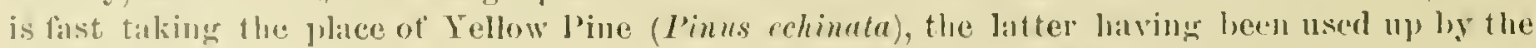
salwinlls in this sectinn." plow, young timber is, according to the sane accounts, ent into joists,

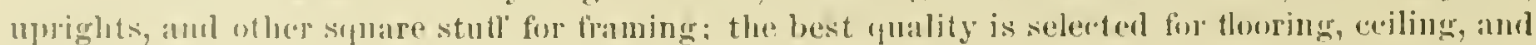

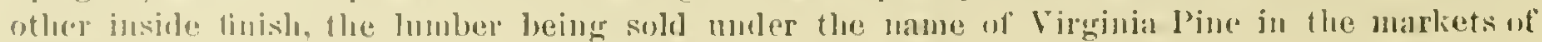
Waslinegtom, baltimore, alud Philatelphia.

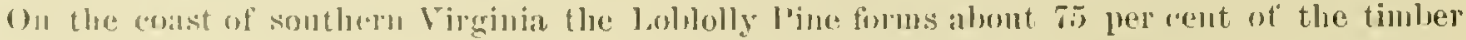
standing. Accorling to all ancounts the original growth is rapidly disappearing, but the exceed- 


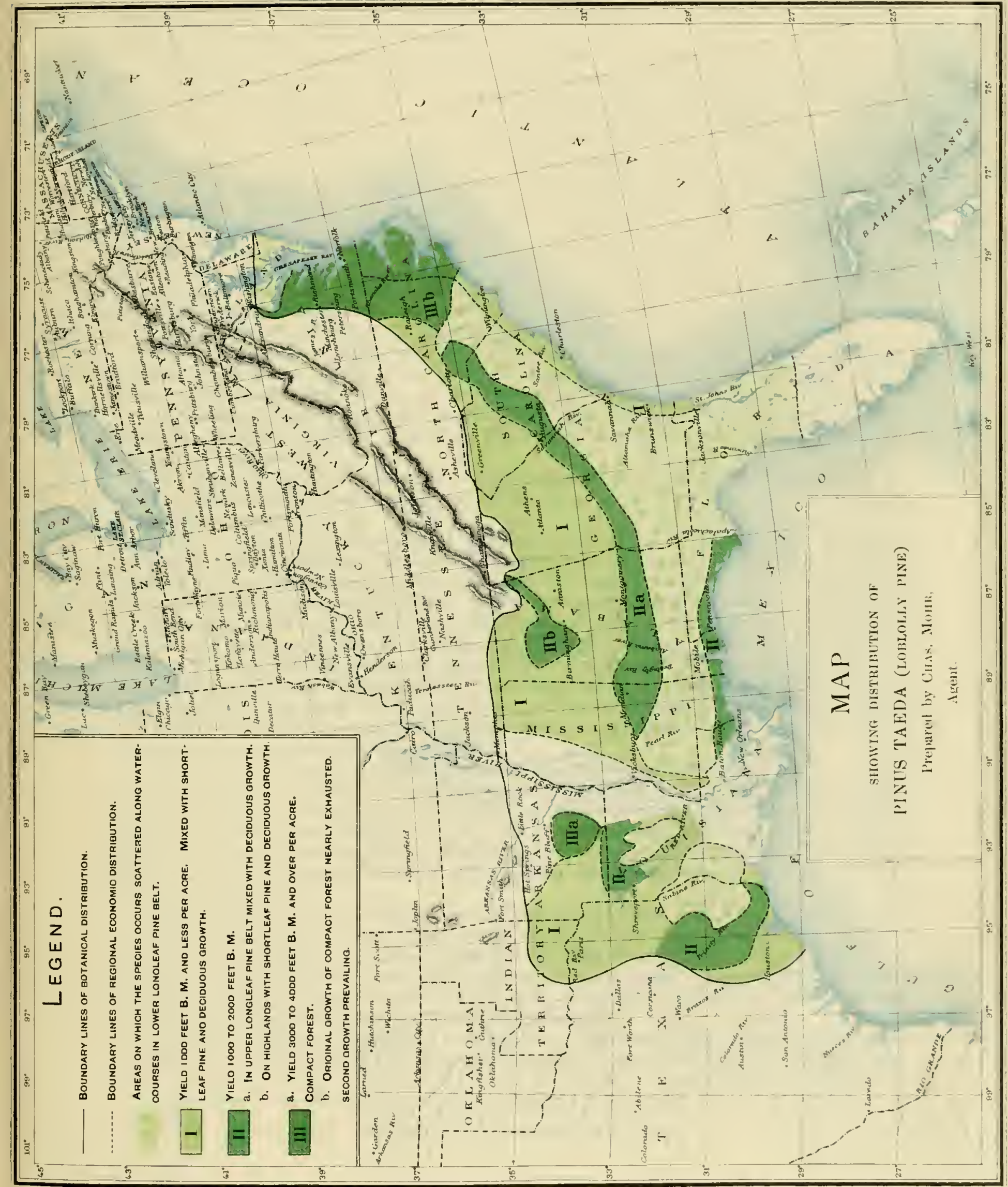


ingly lange area of" exhansted lands abandmed in that section hy the "ultivators during al longr period of time has been taken entire possession of hy this tree.

In North Carolina the Loblolly is the prechominating tree throughout the eastern roast plain and in the lower part of the State. where it forms extensive forests, more or liss freruently intersueried with longlaf l'ine. Sonth of Caje Fear liver, however, the latter jrevails almost exclusively. In the extensive region watered by numerons streams tlowing into llbenarle and Famlien somuls, in the rich, moist soil of the wide swamps above tite water, the Loblolly rearlhes its luest development, attaining dimensions which place this tree among the timber trees of first order. The primeval forests ot this jine have, however, almost completely disappeared in this regirn, and with them the gigantic trees of this speeies known by the people as liosenary Pinc, once so lighly prized and eagerly songht in shipbuilding. Farther sonth, in the low pine barrens, this tree is largely superserled lyy the Jongleaf Pine, and is principally confined to the borders of the swamps and to the bottoms along the water conrses. Thromghont the lower part of the coast pine belt, after the removal of the original timber growth, the progeny of the Loblolly line imuediately. takes possession of every opening, and particularly of the fielus thrown out of cultivation.

"The principal kinds of Loblolly renguized by the lumbernen under distinet names are:

"1. Rosemary P'ine, the best kind from the trees of best development, of a fine grain but heary, hard, dumble, with but a small proportion of sapwond. At present scarcely known by name at the mills in the section where lialf a century ago it abonndexl.

"2. Swamp or Slash Pine, of a "oarser grain. with about one-half of the diameter of the tree in sapwood. This lind comprises most of the timber of original growth, and the oldest and best matured second growth.

"3. Oldfield Pine, by the rapidity of its growth, is very coarse-grained aud for the greater part sap, seareely one-tourth of the dimmeter leing heart. At present the mincipal sunce of the timber supplies in the coast region." 1

At the sarmills at Golisboro, close to the borler of the Longleat P'ine region, over 5o per cent of the lumber sawn is Loblolly Pine. On a trip through the forests letween the Feuse and Trent rivers it was observed that the Lollolly Pine forms over two-thirds of the tree covering, almost entirely of second growth, of dimensions to turnish sawlogs of from 10 to 15 incles mean cliameter by a length of fiom 15 to 30 feet. The sandy swells and kuolls rising above the flats originally covered with the Longleaf' Pine are not infergnently oucupied by a young growth of Loblolly. The mills it Newbern and ricinity are almost solely depending for their Inmber supplies upon these forests of second growth. The same conditions are prevailing in Inplin and in Pender Conuty, by the reports of operators. Mr. C. C. Williams, at Teacheys, in Duplin Conuty, states that 66 per cent of the timber sawn is Loblolly Pine. mostly of seroml growth, furnishing timber for ereosoting and lumber for luilding purposes.

Mr. Banman, at Burgaw, reports that the Oddfield Pine (Loblolly of second growth) is coning more and more into use every year, and the lemand for this kind of lumber is greatly increasing. In a number of the Nerbern jonrmals of 18 !l it is stated that over $60,000,000$ feet of lumber, boarl measure. Tere produced in $1891 \mathrm{ly}$ the mills of that place and the vicinity. In the bulletin quoted the ontput of the nine mills in operation during 1893 is given at $38,000,000$ feet, board mens. ure. The timber delivered at the mills sells for about $\$ 5$ per 1,000 feet, and the price of rough lumber averages $\$ 12$.

In the latest report on the forests of North Carolina the acreage of the Loblolly Pine, including the land covered with the second growth, and where the loblolly Pine is taling the place of the Longleaf Pine, is stated as exceeding $4,000,000$ acres. The stamling merehantable timber ean be said to cover 1,150,000 acres. Allowing 4,000 feet, board measure, to the alcre, this will make $4,600,000,000$ feet of standing Loblolly l'ine in 1893. The total 'nt of Loblolly Pine for the same year has leen reported at $290,000,000$ feet, board measure. ${ }^{2}$

In South Carolina and Georgia the Loblolly Pine is confined all over the coast pine belt to the more or less swimpy borders of the pine barrens scattered anong the brouldeat" evergreens and

${ }^{1}$ The Forests, Forest Lauds, and l'orest Products of Eastern North Carolina. W. W. Ashe, p. $41,13 u l l, 5, x$. C. Geol. Survey.

? W. W. Ashe, linlletin No.5, North Carolina Geul. Nurrey, hilleigh, 1894. p. 41. 


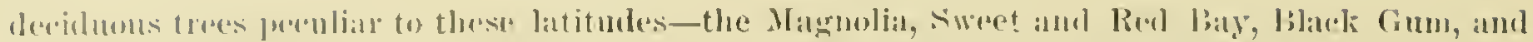

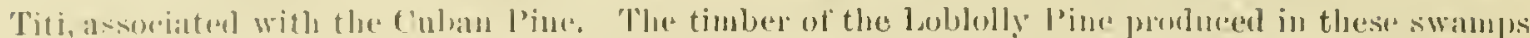

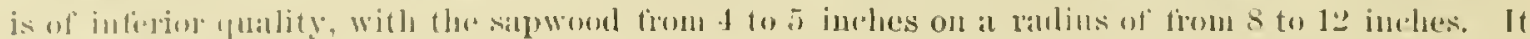

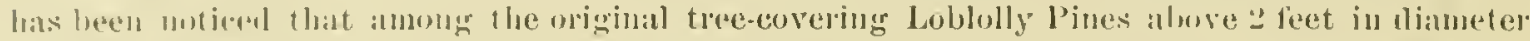

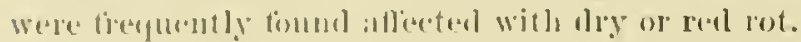

(Ho the dry rolling pine "lplands of these states to the foot of the montain langes, lising to an

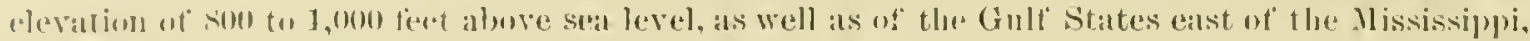

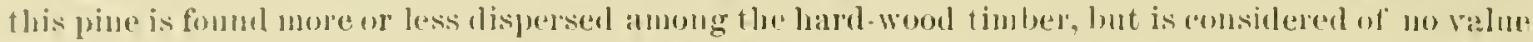

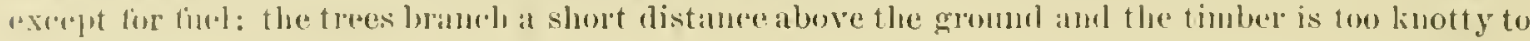
ber lit tine lumber.

Five trees from the damp, flat pine barrens bordering npon the swamps, fellew for test logs in Jlauprou County. S. C.. showed the following dimensious:

\begin{tabular}{|c|c|c|c|c|c|}
\hline $\begin{array}{l}\text { Somble.r of } \\
\text { rings on } \\
\text { stmanp. }\end{array}$ & $\begin{array}{l}\text { 1) jamelares } \\
\text { at breist } \\
\text { higls. }\end{array}$ & $\begin{array}{l}\text { Hoight } \\
\text { "if tive. }\end{array}$ & $\begin{array}{l}\text { Lengll of } \\
\text { timber. }\end{array}$ & $\begin{array}{l}\text { Thameler } \\
\text { herlow } \\
\text { crown. }\end{array}$ & $\begin{array}{l}\text { sapwowed } \\
\text { on radiny } \\
\text { of houtt. }\end{array}$ \\
\hline 103 & Inclies. & Finlis & Feet. & Inclice. & $\begin{array}{r}\text { Jucles. } \\
51\end{array}$ \\
\hline 103 & 22 & 118 & 70 & 14 & 41 \\
\hline (i) & 17 & 103 & 66 & 13 & 3 \\
\hline 35 & 19 & 112 & 53 & 14 & \\
\hline 63 & 14 & 90 & 54 & ? & 3 \\
\hline
\end{tabular}

In peninsula Florida the lablolly line is more ravely found, its plates in the old tields being

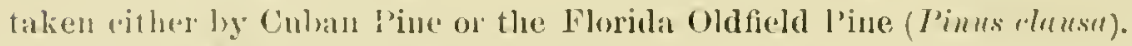

In the astern Gult States throughont the coast pine belt the loblolly Pine is seattered along the swimps bortering the water conrses. Until of late years it has been cut only on sperial onders

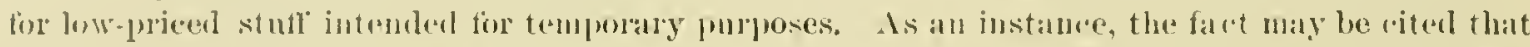
the millions of feet of spunre sawn timber and of lumber reguired tor the buildings of the New Orlans Wurll's Exposition we mostly Loblolly P'ine, sawn al Pendington, Mliss. Since the

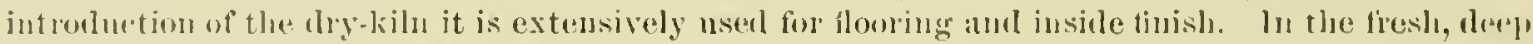
soil of light loam of the const phaln and the valleys in the mplen part of the pine belt-the region of mixed ghowth-this tree is fomm in great pertietion. In thesedistricts it linuishesclear sticks of from soll to (in feet and over in length. A consillerable propontion of the long and heary stieks of lewn timber reaching the lobile market for uxport as "piteh pine" eoming from the upluer division of the eorst pine belt in Alabama are loblolly Pine. The timber of the Loblolly l'ine from

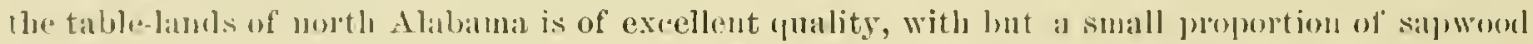
from 2 to 3 inches on a ralius of from 10 to 12 inelies, heasy, of a tine eluse grain and hence of greater durability and strength. The lumbre from that region finds a ready matret, being uset for all the purgosess of the honse carpenter, and is imliseriminately sold with the probuet of the Slurtleaf I'ine.

On the table-lands of the Warrior coal tield the loblolly L'ine is lecter teveloped than in any other part of this or the aljoining State of llississippi. If mot limul in rompart finests of any

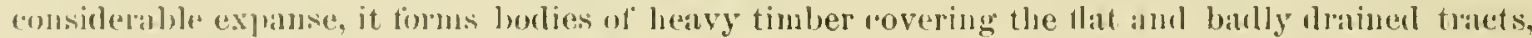
from a few to many aces in extent, associated with the hard woml growth peculian to a moist soil. It might be said that about one-hall" of the jome timber growth of these highlands ansists of the Lobloll!y I'ine.

The following measurements have been talien of trees felled in Cullman Comnty, Ala., from heavily timbered laul sereral arros in extent:

\begin{tabular}{|c|c|c|c|}
\hline $\begin{array}{l}\text { lingzen on } \\
\text { stump. }\end{array}$ & $\begin{array}{c}\text { ginuotor } \\
\text { breamt lighl. }\end{array}$ & $\begin{array}{l}\text { Height of } \\
\text { tree. }\end{array}$ & $\begin{array}{l}\text { Jeninth of } \\
\text { tim!er. }\end{array}$ \\
\hline $\begin{array}{l}7 x \\
156 \\
104 \\
137\end{array}$ & $\begin{array}{r}\text { Ineliey. } \\
21 \\
01 \\
213 \\
114\end{array}$ & $\begin{array}{r}\text { line } \\
101 \\
103 \\
101 \\
106\end{array}$ & $\begin{array}{r}\text { Fine. } \\
41 \\
40 \\
45 \\
57\end{array}$ \\
\hline
\end{tabular}


In Lonisiana, west of the Mississiplu lottom, the Loblenly l'ine is foumd frepmently seattered in the level weods bordering upon the grassy marshes of the coast. North of the resion of the Longleat l'ine on the pine thats with a poor, samly, und ained soil, between lake lieandean and Bayon Danchitt, extending to the Arkinsas State line, this speeies forms the frincipal tree covering. The tree is cut only for local cousmmption in the absence of means of trinsprortation.

ln Arkansis heavily timberel forests of Loblolly l'ine cover the that wouls in the sunthenstern part of the State and the region of the 'Tertiary and Post-Tertiary formation. The lower levels in the rolling "plands are covered with heavily timbered forests of the loblolly line. It forms in this State an inportant lactor in the mann factme of lnmber. From observations male in the logring eamps in connection with the principal points of production along the St. Lonis and lron Mountain Railroad south of Gurdon and on the St. Lomis and Sonthwestern Ritilnat it ean be safely assmmen that abont one-hall" of the lumber cut and shipped as "Yellow P'ine" to Northern unarkets from southwestem Alkansas is Loblolly l'ine, the other half being shortleaf. The flool plain of the little Missonri River and the Onachita liver is covered with extensive fon ests of this tree. The deep soil, a stitf sandy loam, flooded after every rainfall, prodnees a heary and tinely developed timber growth. Upon one acre, representing fairly the average of the merchintable timber standing, 30 trees were comnted of from 12 to 45 inches in liameter at breast high; of this number were found: One tree $4 \mathrm{~s}$ inelies in diameter at breast high, length of timber estimated at 40 feet; one tree 36 inches in diameter at breast high, length of timber estimated at 35 feet; three trees 30 inches in diameter at breast high, length of timber estimated at 35 foet; seven trees 23 inches in clianeter at breast ligh, length of timber estimated at 35 feet; three trees 1.5 inches in diameter at breast high, lengtl of timber estimated at 3.5 feet; fifteen trees 12 to 15 inches in diameter at breast high, length of timber estimated at $2+$ feet.

Measurements oj four trees.

\begin{tabular}{|c|c|c|c|c|}
\hline $\begin{array}{l}\text { lings oi } \\
\text { stump. }\end{array}$ & $\begin{array}{l}\text { lhiameter } \\
\text { at breast } \\
\text { ligh. }\end{array}$ & $\begin{array}{l}\text { Heigut of } \\
\text { tree. }\end{array}$ & $\begin{array}{l}\text { Irianteder } \\
\text { below } \\
\text { erowu. }\end{array}$ & $\begin{array}{l}\text { Length of } \\
\text { timber. }\end{array}$ \\
\hline $\begin{array}{r}85 \\
150 \\
83 \\
110\end{array}$ & $\begin{array}{r}\text { Inches. } \\
17 \\
21 \\
20 \\
22\end{array}$ & $\begin{array}{r}\text { Feet. } \\
85 \\
105 \\
96 \\
109\end{array}$ & $\begin{array}{r}\text { Inches. } \\
12 \\
14 \\
12 \\
12\end{array}$ & $\begin{array}{l}\text { Feet. } \\
47 \\
58 \\
37 \\
68\end{array}$ \\
\hline
\end{tabular}

The timber of these trees was almost liree of any defeets; say from 3 to 4 inches on radius.

In Texas this species is distributed in greater or less abundance to the south and southwest of the Shortleat I'ine region over an area exceeling 6,500 square miles. There is even less basis for statistical statenents legarding timber standing at present and consmuption than for the Shortleaf Pine, since it is not even recognized as a partienlar species, and always ent together with the latter, especially between the T'rinity and the Brazos rivers. No data lave lately been obtained of the anmal production of lumber derived from the loblolly Pine forests in this State, but in the light of the statements of the Tenth Census' it must contribnte largely to the timber smplies of this State. According to this authority, the merehantalule timber of loblolly standing in 1850 was estimated at $20,907,000,000$ feet, board measure, and the cut for the same year at $61,500,000$ feet, board measure.

\section{P’RODL'T'ハ.}

VALUE ANI CSES OF THE WOUD.

Considered solely as the source of furnishing an abnudant and cheap material for purposes where strength and inmbility are not the first considerations, the Loblonly l'ine would be entitled to take its place amwng the timber trees of greater importance. The average tree of full growtl, as it is generally lound in the original torest on a poorer soil, furnishes timber with a fair proportion of heartwood, with sticks of firom 30 to 50 feet and over in length, fiee from blemish ame in some points searcely inferior to the timber of the Shortleaf and sometimes cren of the Longleaf I'ine. In fact, the seiected lunber of Loblolly classes with the latter in many of the markets for the same 


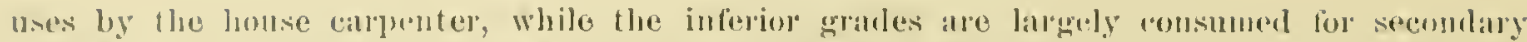

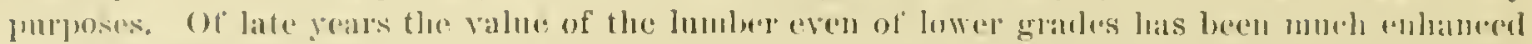

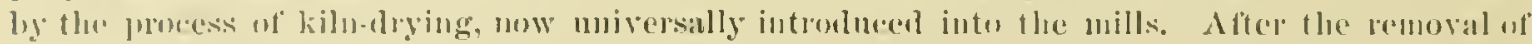

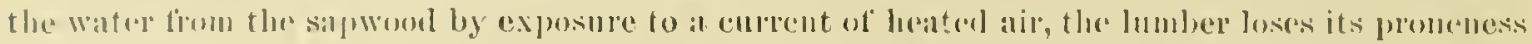

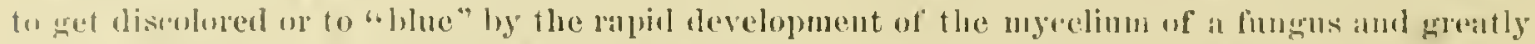

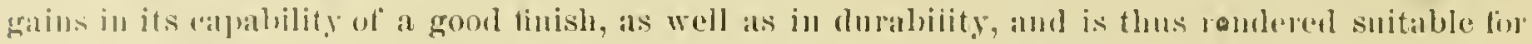
maly gurjuses for which, without such treatment, it would he rejerefod.

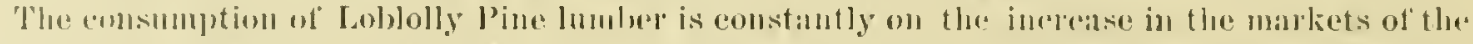

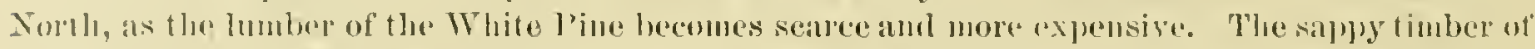
serond growth is every gear coming more in demand, especially in forcign marliets, where this

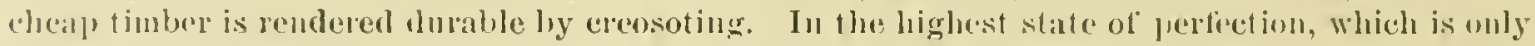
attained in the regions most favorable to its development, mo other pine was docomed of highlere value or was more earerly solght after for masts and other lieave sjalls of ships. lielore the

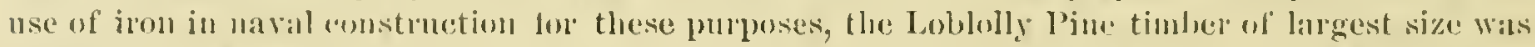

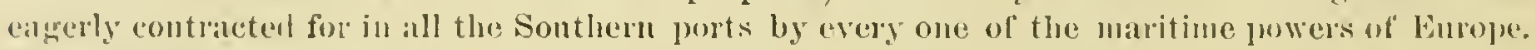

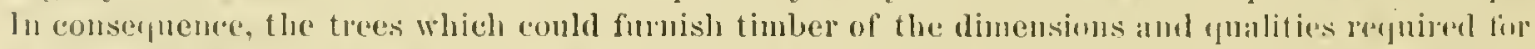

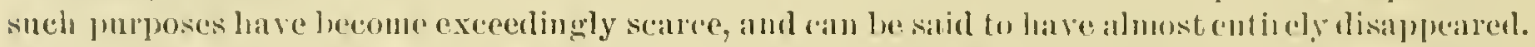

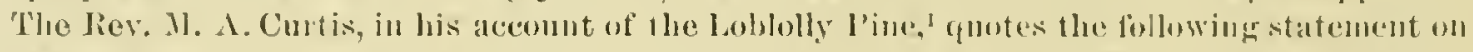

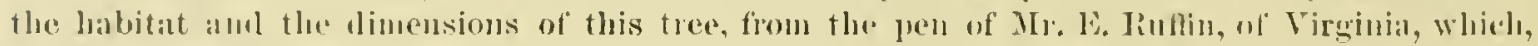
illustrating a feature of lhe life of the Sontlern forest forever past, I can met reflain finm intro. duciug liere:

This (Elaslı l'ine) tree crows only on low, moist la nils, and is the heter for timlier and wrows larger in proportion

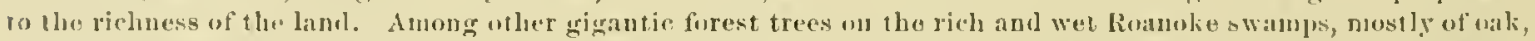

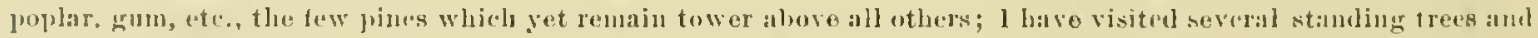
stumps of others which have hern cut down and which measured 5 feet in dianeter, and were supposed to havo low

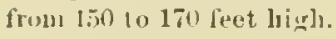

In evirlence of the dimensions of the trees, the writer gives the sizes af ilue spuated stiols ent in Bertic Comnly, male into a laft, amd shipped in 18 iti by way of the B) ismal Swamp ('anal to New

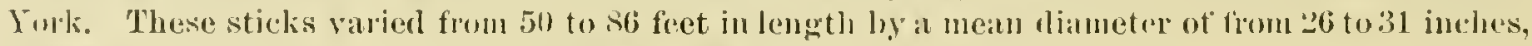

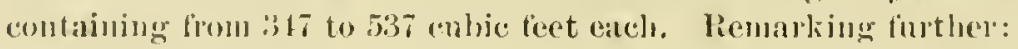

All of these sticks are nearly all hoartwoul; thence it follows that lhe proporlion of heartwonl must have

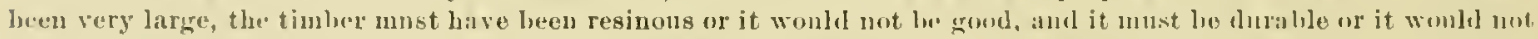
servo for masts and other long spiars for ships exposed to the alternations of wetling and elrying, and lor which only the bist naterials are permitted to he need.

The inlerior arowth of the loblolly l'me furnishes vast supplies of cordworl. Immensio "funtities ale shipned from the const of Virginia and Vorth Carolina to the linere cities on the Atantic seabuabl. It is chielly used whore a brisk thane with a quick leat is required, vi\%, in balkeries, luicklilus, and the kilus of potteries. In its fun value, the wool of this tree ranks with the better vlass of resinons trees. Iange quantities of the wood are also used for the burning of chalecoal.

\section{IERLNOUS PJUDV'CTR.}

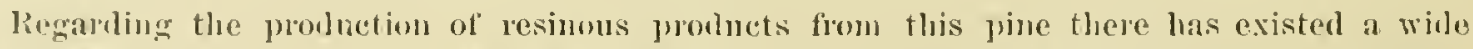

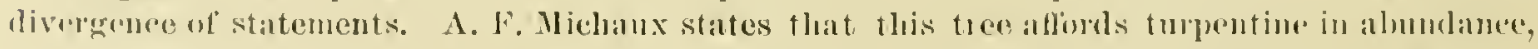

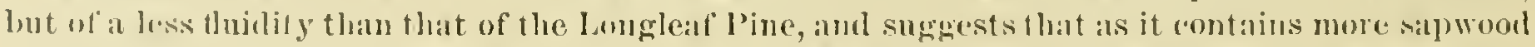

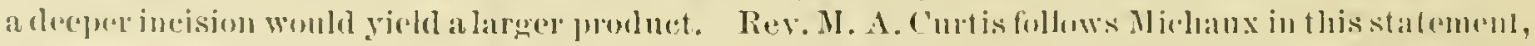

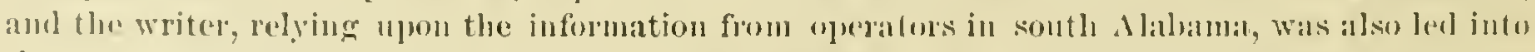

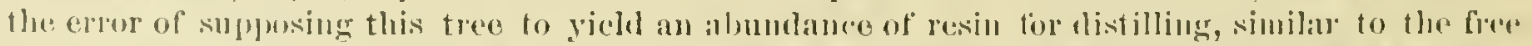

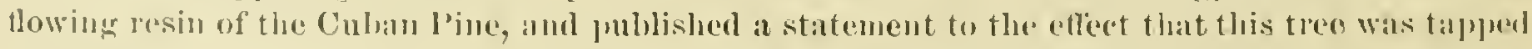

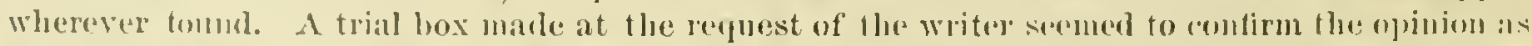

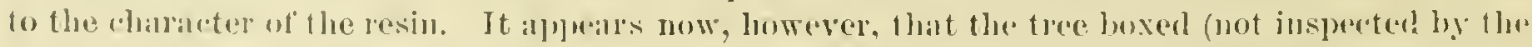

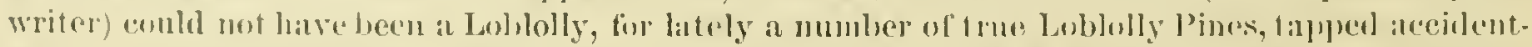
aly ju a torpentinc orehard, were fonnd in Washington Commy, Ala., and showed that the resin 
of this pine does not flow freely and ladrens so rapidly on exposure that it can not be profitably worked. An experienced operator at the place contimed this to be the experience errywlice with this kind of pine. The statements reganding the use of this tree for its resinons proluct rau therefore only bo explained by a confusion of names applied to the diflerent pines, and it was most likely the Cuban l'ine to which the openator's reterred.

In a report lately jublished by the State geologist of North Carolina the remark is made: "It is said that the crude turpentine of the Loblolly l'ine has so much water in it that it yields only a poor sjuits of turpentine." This, to be sure, is a misconception; but the statement ronfirms the finct that this species is not tapped for its resin, which had also been obselved by the writer at short time previonsly in the Lublolly I'ine forests of North Carolina as well as Sonth Carolina anul Georgia.

From an extensire series of analyses of the resin of fresh specimens of both Longleaf and Ioblolly Pine eollected in Georgia and South Carolina, it appears that the wood of Loblolly contains but little less resin than that of Longleaf; that the distribution of resin in the log is puntinally the same, and, what seems most remarkable, that the composition of the resin, as far as the relation of spirits of turpentine and rosin is concerued, is nearly the same (being ynite vintiable in lroth), so that the absence of free "bleculing" or abundant resin exndation ean not be due to a lack of liguid oil, but must be eanserl by other physiologieal peculiarities.

\section{NOMENCLATULI: AND CLASSIFICATION.}

The Loblolly and half a dozen other species, wostly Pacilic aud Mexican, ${ }^{2}$ form a natural group of timber trees ineluded in Englemann's Eutada, which might fitly be designated as the gronp' "toreh pines," and can be chaneterized as embraeing trees, mostly of larger size, with more or less resinous, coarse grained wool, long leaves by threes in a faseiele, and with lateral cones provirled with thiek, woorly scales bearing a stont, sharp prickle. The distinctive elharacters of this species have been early reeognized by Plnckenet, one of the earliest writers on $\Lambda$ merican plants ${ }^{3}$ and Limbus descrihed the tree under the name of Pimus tede which was adopted subsequently by all botanists. The name given to this pine by Linnams in 1753 has never been changed. In 17 s9 Aitan established a variety, $I^{\prime}$. Tedu val. tenuifolia (Hort. Kew., II, 368), whieh, however, has not received recognition.

\section{JOTANICAL DESCRIPTION AND MORPHOLOGY.}

Leares three in the close, elougated sheath, 6 to 9 inches long, slender, stiff, rigilly pointerl, channelen, and strongly kceled on the mpper side, of a pale green color; cones nearly sessile, single, in twos or threes, ronndish-orate or ovate-obloug, aliont 3 inches long, with the scales hard and woody, the pyramidal apophysis with a strong, recurved prickle; seeds small, their wing an inch or over long.

This species is easily distinguished from its most frequent assoriates-the Longleaf and Slort. leaf Pine-by its slightly glancous foliage at all seasons, and by its more slenter and alnost smooth terminal buds; from the former and from the latter by the more robust shoots and buds; and from both the species named, and also from the Cuban Pine, ly its charaeteristie cones.

RUOT, STEM, AND HRANCH SYSTEM.

The stont tapront of this pine is assisted by puwerful latelals which divile into numerous branehes and deseend into the soil, usually at a short distance from the trunk; hut where a hard. confuact subsoil is encountered they are often seen to run for a greater or less distance near the surface. In the localities most favolable to its growth, the massive trunk of the Loblolly Pine is in its dimensions not surpassed by any other pine of the Atlantic forest region. In such eases the tree attains a height of 120 to 150 feet and over, with a diameter of from 4 to 5 fect lireast high, and with the trunk clear of limbs for a length of from 60 to 80 reet.

The Forests, Forest Lands, and Forest Products of Easteru North Carolina, by W. W. Ashe. Bulletin af of the Geological Survey of North Carolina, 1895.

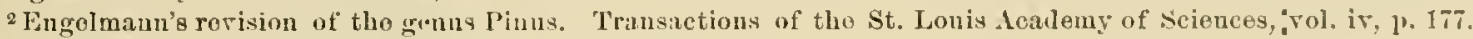

3Pluckenet: Amalges tum botanicum. London, 1696.

'Linnitus: Apecies plantarum, $1000,1753$. $17433-$ Yo. $13-\mathrm{S}$ 
HATIANATION OH PLATE XIX.

[Figures natural size, except when ot herwise noted.]

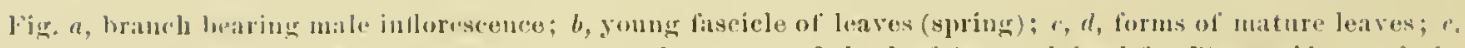
transverse section of leaf handle showing structural characters of the leal (as explain ul for linus echinate, $f, f)$ : magnified 20 diameters.

11.1 


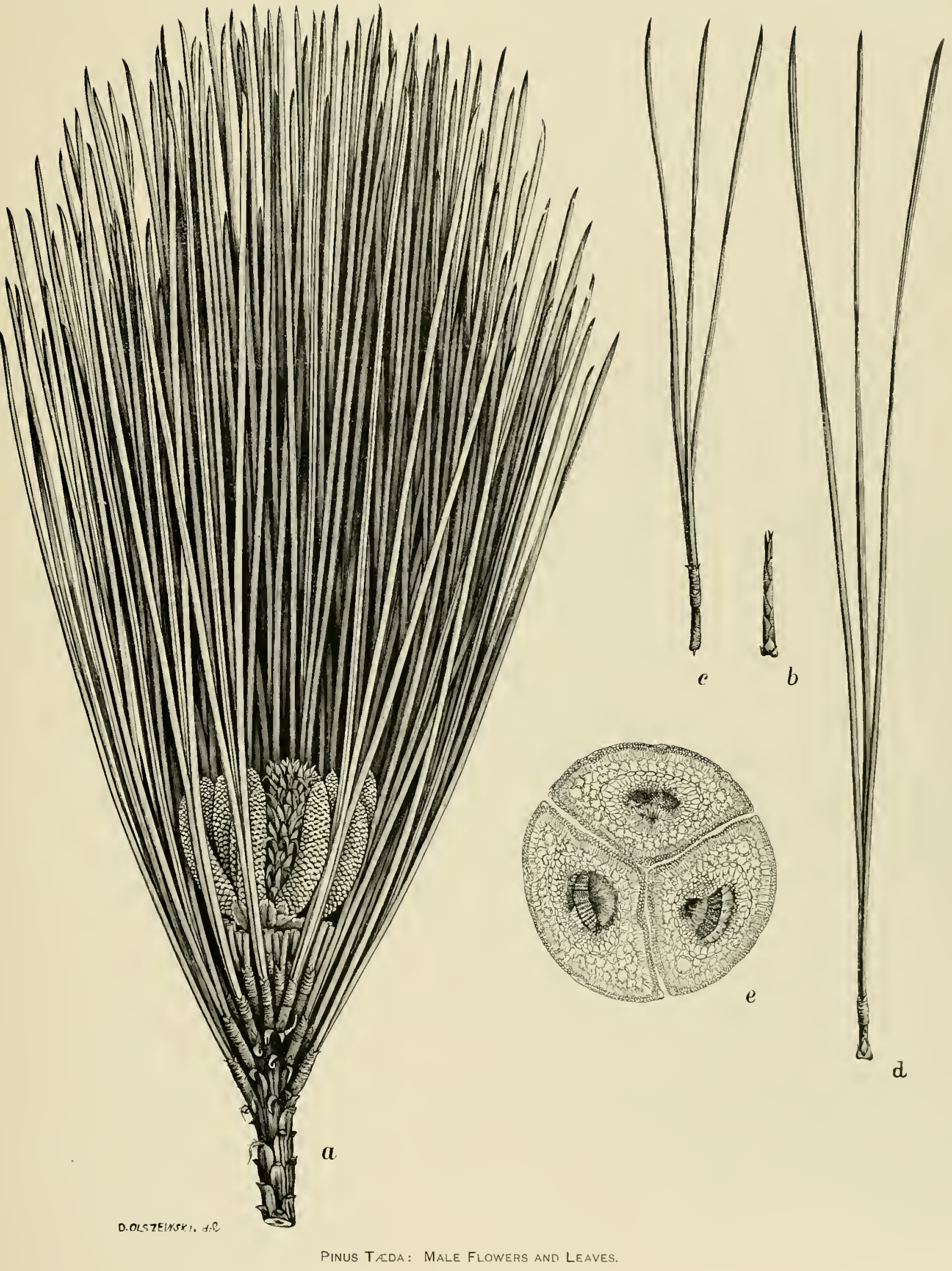



Snch trees, however, have at no time been plentiful and at present are rarely met. In its average growth the diameter of the trunk, breast high, measures from 20 to 24 inches, and the height from 95 to 110 leet. In wet places, somewlat distender alt its base, the trunk tapers very gradually to the crown, which covers from one-thirl to one half of its height. The lowest limbs are horizontally spreading, and towarl the uper part of the tree they beene grahually more creet. The largest limbs are rarely found over zo feot in lengtlı. The mimary branches diviling in a renular order of ramification into mumerous branclies and branchlets, the erown becones full and complat towarl the top. The bark of the full-grown tree is, in the lower part of trunk, fiom 1 to $1 \frac{1}{2}$ inches thiek, generally rough, of a grayish color, becoming smoother, flaky, ancl reddish brown as the tree grows older.

LEAVES.

The leaves are muited, to the number of three, in a smooth, elose sheath, which in the young foliage is about 1 inch long and in the next season searcely laalf that length. (I'l. XIX, ", h, $l$.)

In the bushy growth of less than ten years the leaves are scarcely 5 inches in length, resembling elosely the foliage of the Shortleaf Pine of equal age. Prof. I. Ward notes this resemblance as a singnlar fact, which, as he very pointedly remarks, has the effect of obscuring the gradual aplearance of this species among the young growth of the Shortleat l'ine. In the following years the leaves are from 7 to 9 inches long, less densely crowded on the slender branches than in the Longleat and Cuban Pine, and persisting to the third year; the foliage is of a more open spray. The leaves are stiff, slightly twisted, roughish on the finely serrulated edges am the prominent midrib, channeled on the upper side, abruptly tipped by a rigid, sharp point (Pl. XIX, ‘', d), and "ft a pale green color. They are scarcely one-sixteenth of an inch wide, about half as thick, ancl present in the cross section on the dorsal side a convex and on the ventral side a strongly triangular ontline. Examined uuter the mieroseope they show on both surfuces from 10 to 12 rows of rather large breathing pores (stomata), alternating with rows of numerons hypodermal or strengthening cells, in several layers. The cells of the bundle sheath are thin walled; the fibrovasenlar bundles are, on their ventral sille, surrounded by a single row of small strengthening cells. The rather large resinous ducts, trom 3 to 5 in number, are peripheral, and placed irregularly mostly abont the angles (Pl. XIX,e); sometimes smaller ducts are observed elose to the bundle sheath.

FLORAL ORGANS.

The staminate flowers are crowded, from 18 to 20 in number, below the apex of the youngest shoot. (Pl. XIX, u.) 'They are from three-fourths to one inch long, of sulphur-yellow color, and surrounded at the base by from 8 to 10 ovate to lanceolate, leathery, involucral seales: the lowest pair is much shorter than the others and strongly keeled; those of the uppermost row are longest, narrow, lanceolate, and reflexed. The anthers are crowned with an erect orbicular erest. After the liseharge ol the pollen the flowers are gradnally shed. The pistillate flowers form an oblong, erect catkin, borne on a short stalk, singly, in pairs, sometimes 3 to t, below the apex of the shoot (PI. XX, a) of the season, which by the time of blooming has already reached a length of several inehes and is covered with the well-adranced leaf buds. Inchuling their stipe, the fenale anents are about one-half to thee-fourths of an inch long, surroumled by from 15 to 20 involneral seales similar to those of the staminate flower. The carpellary scales are ovate, lancerlate, tapering to a sharp, erect, and somewhat reflexed and twisted point. The small bracts subtending the scales are orbieular, searcely covering their base.

The flowers open, in the coast region of the lower Sunthern States, abont the second week of March (Mobile, Ala., Nimeh 15 to 20), and in the interior from four to five weeks later (Cullman, Ala., April 2⿰氵).

Immediately after pollination the female 'atkins increase rapilly in size; before ten dars have lassed the carpellary scales have donbled in size, and their tips becone stiflly ereet, the bracts having remained stationary in their growth, and the fertile shouts having grown to the length of S inches and over. This period passed, the growth of the conelets during the rest of the seasou proceeds very slowly. 


\section{EXPLANATION OF PLATE XX.}

Fig. "b, banch hearing $t w 0$ suhterminal aments of fomble tlowers at end of shoot of the seasun: b, inmature

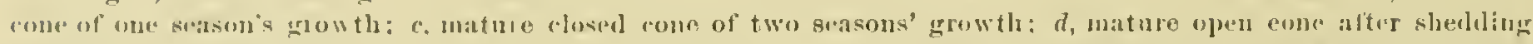

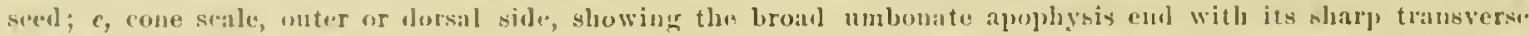
rilges and the s!ont retlexed prickle; $f$, inner or ventral viow of the same with the sired in plare; $g$, need and wing dietachedl. 


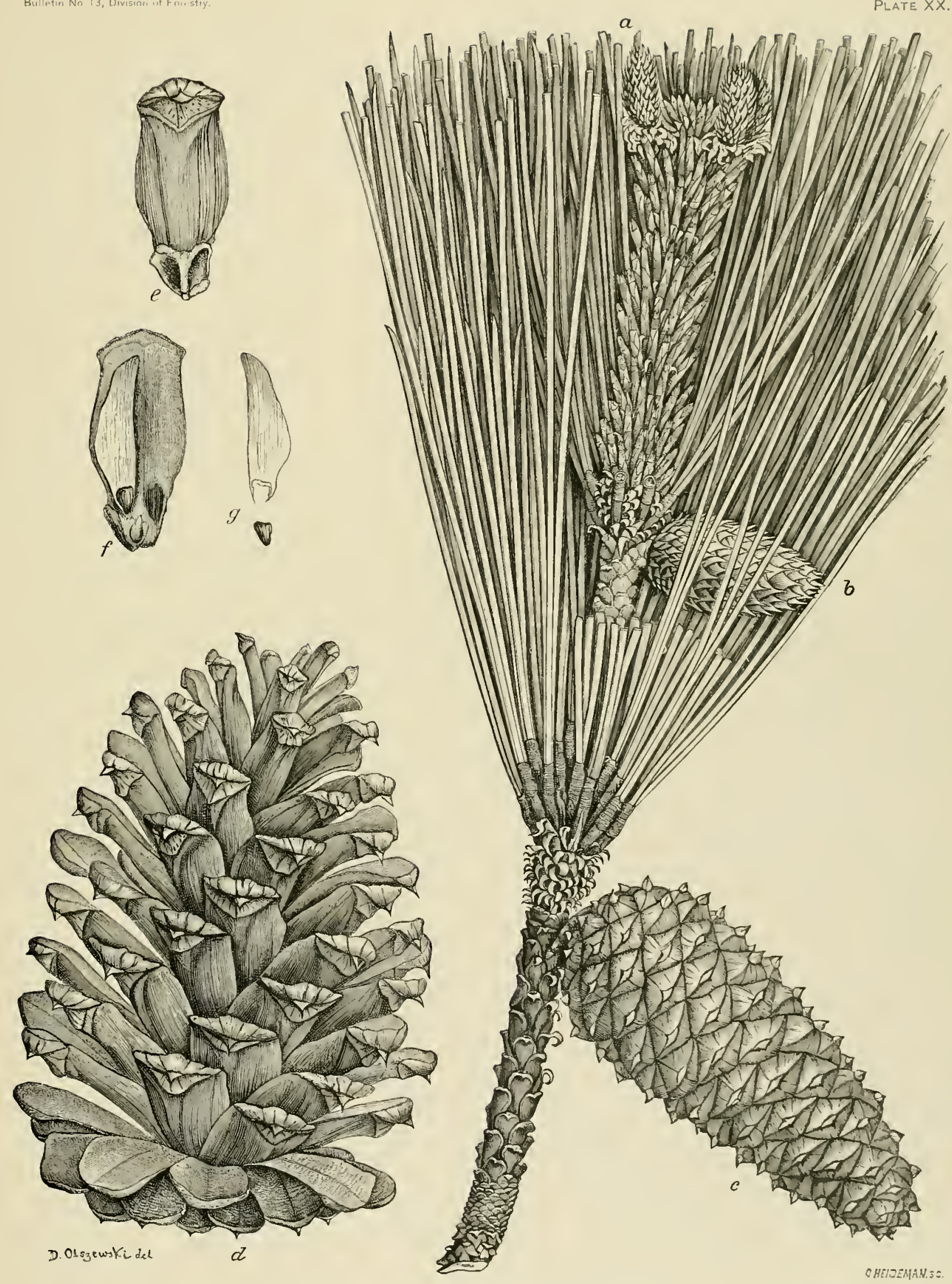



At the beginning of the second season the immature cones are scarcely une-half inch wille and less than an inch long ( $\mathrm{Pl}$. $\mathrm{XX}, \mathrm{b}$ ), and from that time on increase in size and by the following October have reached their maturity. The ripe cones are lateral, almost sessile, broadly conical or ovate in shape, rarely over 3 inches in length (PI. XX, $c$, d), when fully opened $1 \frac{1}{2}$ to 2 inches wide, and of a light wood-brown color. The pyramidal, swelled, expused ends (apophyses) of the hard, woody seales with a sharp transversal ridge are armed with a stout, straight, or slightly reflexed prickle. (Pl. XX, e.) Having reaclied their matnrity, the cones open slowly, the serds buing gradnally discharged during the finl and winter seasons. The cones alle aft to remain on the tres till the end of anothel year, and wh'n they finally separate from the batuch by the breaking loose of their very short stalk, leave none of their basal seales hehinl. The seeds are irregularly trmnate or rhomboid in ontline, intlaterl, sharpedged, with two to thee more or less distinct rid ges, rough. ish, dark brown to almost black, and surrounder to the hase by the narrow border of their delicate wing (Pl. XX, g, $\left.f^{\prime}\right)$, which is over an inch long and from one-fonth to one-eighth of an inch wide.

TIIE WOOD.

Among the pines of the sonthern Atlantic forests noted for their economic importance the Loblolly is helu least in value as a timber tree. This opinion is chiefly foumded on the lesser durability of its wood, heing more speedily given to decay miler the combined influences of dampness and air, and also on the supposition of its being of less strength than the other pine timbers. There is searcely a timber tree existing that shows wider differences in the quality and value of the timber. This is strikingly demonstrated when the timber of a tree of full average growth, grown on land broken by the plow, is compared with the timber of a tree in its highest perfection taken from the primeval forest. In the fomer case the wood is crossgrained, salpy, aud quick to decaly. In the latter it is funer grained, resinons, has less sapwoon, and approaches the timber of the Lougleaf Pine.

In general, the well-marked, lighter-colored sapwool is quite broat, and usnally about 4 inches, frequently 6 inches aud more. It is wider in young, thrifty trees, narrower in old and stunterl or slow-grown timber; forms about 60 to 70 per cent of the total volune of stems over one hundred years of age, and 80 to 90 per cent of trees sixty to one lumulred years old. The formation of heartwood does not hegin belore the age of twenty-five, the process being retarled as the tree, or better the particular part of the stem, grows olfer, so that while the imermost sapwood in a log or disk with twenty-six rings is twenty-tive years oll, the innermost say ring is thirty-five years old when the $\log$ attains the age of forty-tive; it is forty-five years old when the log is sixty-five, and abont seventy or even more years old when the log reaches the age of one huvdred and fifty or two hmulred. It follows that the sapwood is formed of fewer rings in young trees and in the npper part of older stems, but owing to the greater rapinity of growth in these parts the willth of the sapwood does not always follow this same law. Since neither wilth of the ring, nom that of the denser snmmerwood, the thickness of the cell walls, nor any other important strnetmal fatmre is changed when the wool of any ring changes from sap to lieart wool, the prevatent notions of sapwood being necessarily either coanse or fine grained, light, and weak, are erroneons. The sapwood of a young, well-grown tree is course-grained, heavy, and strong; that of an old tree is fine-grained, light, and weak. Since durability on exposure is not to be expected of the saproou of any pine, the prejudices against the sapwood, ant therefore all young timber of this particular kind, are un warranted. With proper treatment, it will serve all purposes for which any pine wood of its grain and weight can be employed.

Owing to the great amount of water soaked sapwood the weight of green Loblolly timber is very great, varying elietly between 50 and 55 ponuds to the enbie foot, with the sapwood commonly approaching 60 ponnds to the cubie foot. Kiln-dried, the wood of the entire trunk of trees one lumbred to one hundred and fifty years old weighs abont 3.3 pounds per eubie toot. In sneh trees the wood of the logr 50 feet from the ground is about 20 per cent lighter (and weaker) than that of the bntt $\log$, and the woorl next to the bark in the bntt $\log$ is 15 to 20 per cent lighter than the wood of the imer fifty to sixty rings.

In strength the wood of the Loblolly varies chiefly with weight (the same degree of seasoning always presumed), and keeping this in mind, compares favorably with that of any other conifer. 


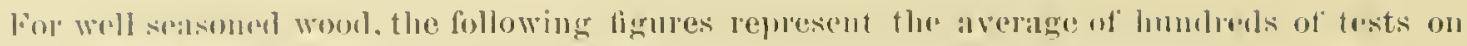

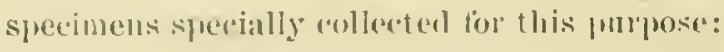

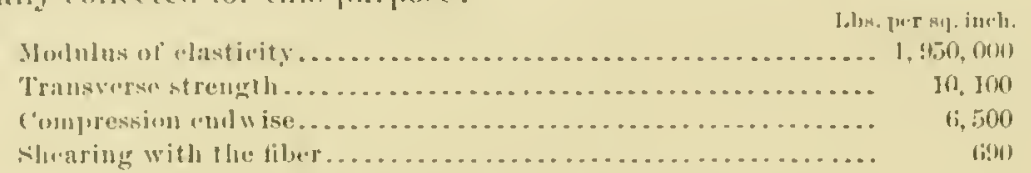

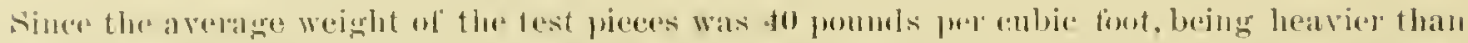

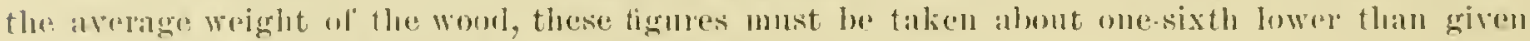

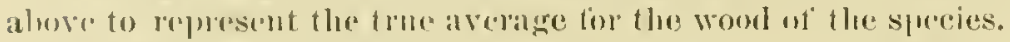

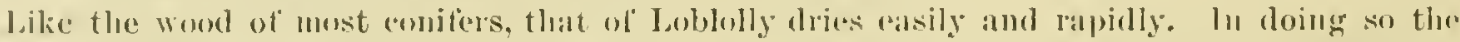

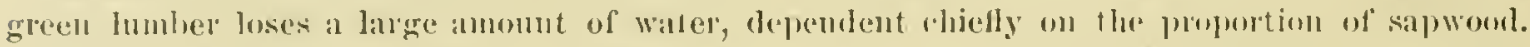

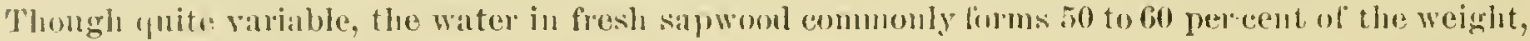

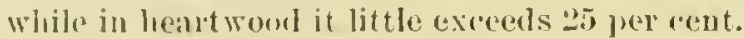

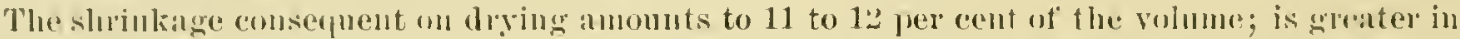
the lmuber af the hut than in that from the top logs, varying in this respert fom la per wemt at

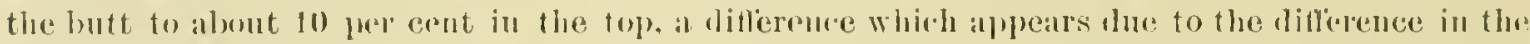
weight of the woul of the different sertions. As in other pine, about two-thirls or sorelleights per rent of this shrinkago falls to the tangent (i.e., is alomg the riugs) and abont 1 to 5 pere cent to the ramills.

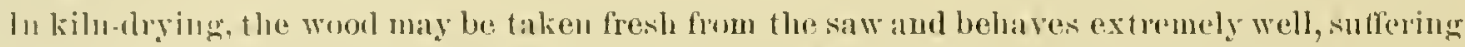
no grout injury, at fact which has greatly enhanced its value hy facilitating its oxploitation.

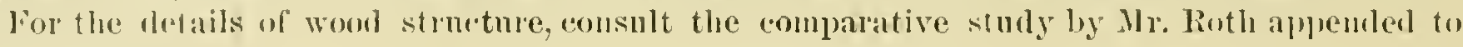
these monographs.

\section{IROMRESS OF HEVELOIMIENT.}

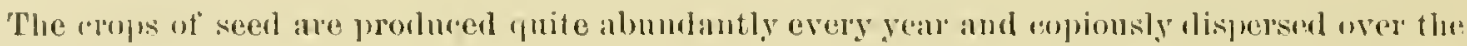

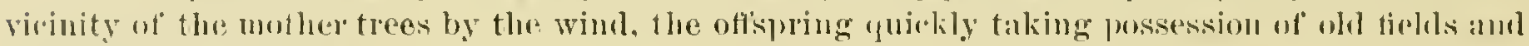
cleariugs in the forest.

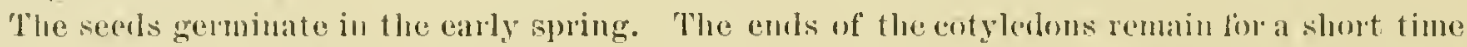
atter germination inclosed in the endosperm. The number of the germinal learos (cotyledons) is mostly six, maly seven. At the time of the nufohling of the cotylobus the lower (hyponotyle-

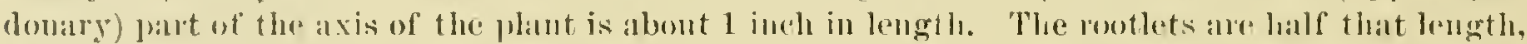
and are provided with several acropetal serondary rootlets. The ranlich groms lipiolly, and is sum covered with the still, nedleshaperl, and strongly serrulated primary leaves. Jiefore the

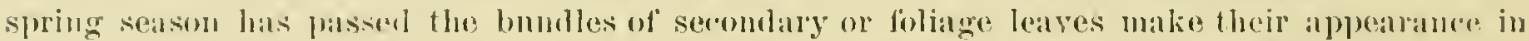
the axils of the formel. At the close of the summer seasun the plantlet las attained a height of

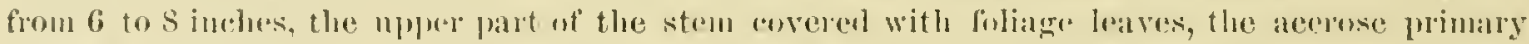
leaves of the hwel pant having completely withered. In rexamining a lange mumber of yomug

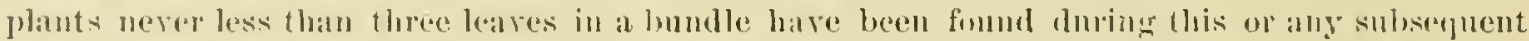

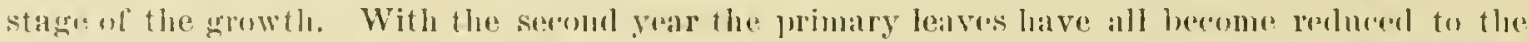

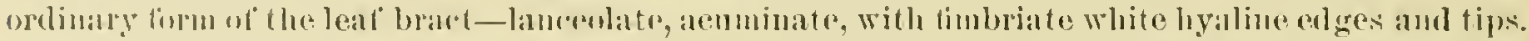

In all the specinons examincel it was fomm that the growtlo ot the main axis proverled less

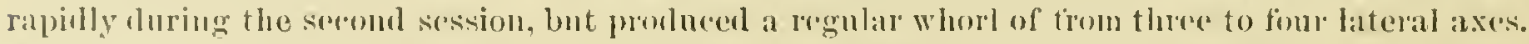
At the chese of the second year the main stem rarely exrents lo inelus in heinht.

$\Delta t$ the end af thein thind year the plants are fom ls to 20 inches high, the stem being fom

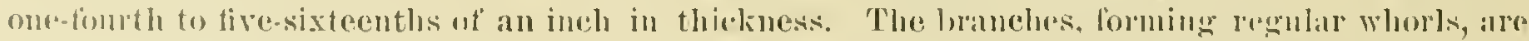

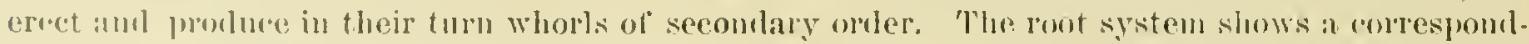
ing inrerase, the taproot being from 6 to 8 inches loms, wilh mumerons stout lateral roots.

\section{RATE OF GROWTH.}

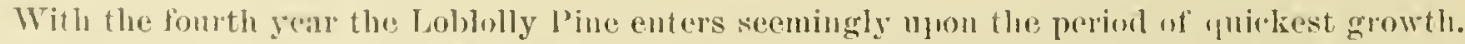

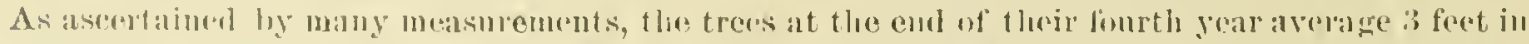

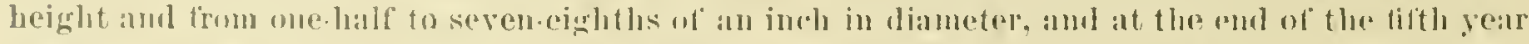

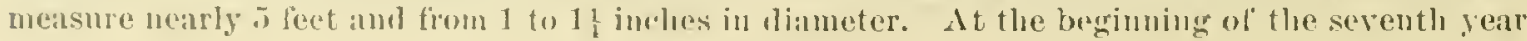


the tree attains a height of 10 feet, and with the close of the first decalle trees are found 12 to 16 feet high and firm 23 to 3 inches in liancter. Some trees begin to mature their first cones by the tentli year.

The above measmements were made in 1890 in the vicinity of Culluna, $\Lambda$ la., on trees taken indiscriminately from the midst and near the borler of a dense pine thicket covering a fich plower for the last time in 1SS2, and from an aljoining wioning in the forest protected lrom fire and but rarely used for pasture.

Aceording to a muber of measmements made of trees in the sontheru Atantie States, the Gulf region, and southern Arkansas, the Loblolly l'ine leaches at the tenth year, on the average, a height of 20 feet, donbling this height during the succeeding decade. Iuring this period of quickest growth the increase in height proeeds at the rate of a feut per anum, anc trees twenty years old average 4 inches in diancter breast high. At the age of fifty years the trees are fyom 65 to 75 feet in lieight (average about $70 \mathrm{fect}$ ) and 1.5 imehes in dianeter breast high. The annul increase for tnis period of thirty years is about 1 foot in height and 0.3.5 inch in dianeter. From mumerons observations it appeals that the Loblolly Pine attains the fulhess of jts growth at the age of one hundred years, with a height, on the average, of 110 lect and a dianeter breast bigh of 2 feet, the length of merohantable timber varying between io and 60 feet. The annual rate of lieight growth during the second half cuntury is abont aight-tenths of a foot, and the diameter growth eighteen one-humlerlths of an inch. Henceforth the growth in height remains almost stationary. A dozen trees from one linudred to one hundred and fifty years old were fonmu to vary from 99 to 125 feet in height, with a length of tiumk free from limbs of from 60 to 65 feet and from 19 to 27 inches in liameter at breast height.

From the annexed tabulated records of grow th it lecomes evident that nnder similar conditions of soil and exposmm the rate of increase for the various stages of gow th show but slight differences in localities widely distant from each other.

TABLE 1.-Growth from fire to firty yenrs.

\begin{tabular}{|c|c|c|c|c|c|c|}
\hline No. of tree. & $\begin{array}{l}\text { No. of } \\
\text { rings. }\end{array}$ & $\begin{array}{l}\text { Di:muetur } \\
\text { (breast lighl). }\end{array}$ & $\begin{array}{l}\text { Ileight to } \\
\text { firat Jimblo }\end{array}$ & $\begin{array}{l}\text { Total } \\
\text { lueight. }\end{array}$ & Loeality. & Remarks. \\
\hline & & Inches. & Feet. & Feet. & & \\
\hline & $\begin{array}{l}5 \\
5\end{array}$ & $\frac{1}{1}$ & (n............ & $5^{6}$ & Collman, Ala... & $\begin{array}{l}\text { ('learing male firr jasture in } 1879 \text { : dense pine thichet. } \\
\text { Do. }\end{array}$ \\
\hline 3... & 6 & 2 & 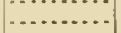 & 10 & .....do ........... & $1 \%$. \\
\hline $4 \ldots$ & 6 & $1 \frac{1}{2}$ & ............ & 7 & ....do $0 . . . \ldots . .$. & 1hir. \\
\hline $5 \ldots$ & 6 & $1 \frac{2}{2}$ & $\cdots \cdots \cdots$ & $8 \frac{3}{12}$ & Whistler. A !a ... & Ealge of swampy linmmus. \\
\hline $6 \ldots$ & 7 & $2_{3}^{3}$ & 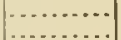 & $10^{\circ-1}$ & Cullman, dja... & Clonring, dense pine thicket. \\
\hline $\begin{array}{l}7 . \ldots \\
8 . . .\end{array}$ & $\begin{array}{l}7 \\
9\end{array}$ & $\begin{array}{l}3 \downarrow \\
2 \xi\end{array}$ & $\begin{array}{c}\cdots \cdot \\
\cdots \cdots\end{array}$ & 12 & 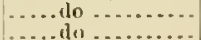 & $\begin{array}{l}1 \% 0 . \\
1 \% \text {. }\end{array}$ \\
\hline 9 & 9 & 2 & $\cdots$ & $\begin{array}{l}133_{18}^{8} \\
12^{6} \\
18\end{array}$ & ....d do & Do. \\
\hline $10 \ldots \ldots \ldots$ & 10 & 27 & & $18^{18}$ & $\ldots . .10 \ldots$ & Do. \\
\hline $22+\ldots$ & 11 & 2 & 8 & 23 & $\ldots \ldots-\ldots 11, \ldots .$. & 10. \\
\hline $12 \ldots \ldots \ldots \ldots \ldots$ & 12 & $\begin{array}{l}37 \\
32\end{array}$ & & $\frac{20}{24}$ & & $\begin{array}{l}16.0 . \\
100 .\end{array}$ \\
\hline - $\ldots \ldots \ldots$ & $\begin{array}{l}12 \\
12\end{array}$ & $\begin{array}{l}3 \frac{1}{4} \\
2 \frac{1}{3}\end{array}$ & $10^{7 \frac{2}{2}}$ & $\begin{array}{l}24 \\
21\end{array}$ & Whistler, Ala... & \\
\hline $189 .$. & 13 & $2^{3}$ & 13 & 19 & Gurtin, Ark... & (1) \\
\hline $271 \ldots$ & 13 & $2 \frac{2}{2}$ & 13 & 20 & Eastman, fia.... & Lo. \\
\hline 222. & 14 & 3 & 10 & 25 & Whistler, Ala... & Filge of' lummonck sliglitly oppressed; partially covered. \\
\hline 148. & 14 & $2 \frac{1}{3}$ & 8 & 21 & Eastman, (ial... & Opening in forest; umler aver; frestl soil. \\
\hline $272 \ldots$ & 14 & 2 & 7 & 21 & Gurtom, Alth... & "Jpening in furest; expesmre free; lamp soil. \\
\hline 221. & 15 & 4 & 12 & 35 & Whistlex, Ala... & Wu pentle slecline; opening in formst : suil fresh. \\
\hline 232. & 16 & 6 & 13 & 30 & ..... do & Dn. \\
\hline $\begin{array}{l}219 \ldots \\
220 \ldots\end{array}$ & $\begin{array}{l}17 \\
18\end{array}$ & $\begin{array}{l}6 \\
6\end{array}$ & $\begin{array}{l}16 \\
17\end{array}$ & $\begin{array}{l}39 \\
43\end{array}$ & .... do $\ldots$ & $\begin{array}{l}\text { Natural opening near swamp; soil damp. } \\
\text { Do. }\end{array}$ \\
\hline $220 \ldots \ldots \ldots$. & $\begin{array}{l}18 \\
20\end{array}$ & 4 & $\begin{array}{l}17 \\
28\end{array}$ & $\begin{array}{l}43 \\
33\end{array}$ & ....dd & Oppriessuil. \\
\hline $270 \ldots \ldots . . .6$. & 21 & 4 & 22 & 45 & Eastman, Ga. & Nafural opening in forest: under cover. \\
\hline 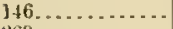 & 26 & $4 \frac{1}{3}$ & 38 & 33 & Fimrdon, Ark... & Natural opening in linest; exposure free. \\
\hline $269 .$. & & $4 \frac{1}{2}$ & 32 & 43 & Eastman, (jal.... & Fatuml oprening in forcst; suppressed. \\
\hline$\ldots \ldots \ldots$ & 22 & 8 & 25 & 55 & .....10 & ()ill tirld : fresh deep loatur free. \\
\hline ......... & 2.1 & 6 & 17 & 39 & G.de de.......... & Oll ficld : opluressid. \\
\hline $187 \ldots \ldots \ldots \ldots \ldots$ & 32 & $\frac{4 \frac{1}{4}}{6}$ & $\begin{array}{l}30 \\
38\end{array}$ & $\begin{array}{l}47 \\
5.3\end{array}$ & Gurdun, Ark.... & $\begin{array}{l}\text { In open forest : expositro froe. } \\
\text { Opeu lorest ; exposurw tree. }\end{array}$ \\
\hline $145 \ldots \ldots \ldots \ldots$ & 32 & 6 & 36 & 56 & .... do .... & 1)u. \\
\hline $266 \ldots$ & 35 & 12 & 51 & 77 & Eastman, Ga.... & 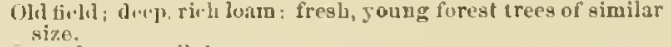 \\
\hline $143 \ldots \ldots \ldots . .$. & 48 & 16 & 30 & 66 & Gurilou, Ark.... & Olen forcut ; snil damp. \\
\hline $14 \ldots \ldots \ldots \ldots$ & $4 t$ & 15 & 33 & 68 & Stocktun, A & 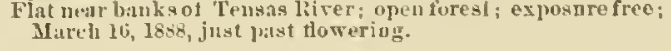 \\
\hline
\end{tabular}




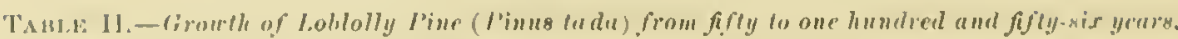

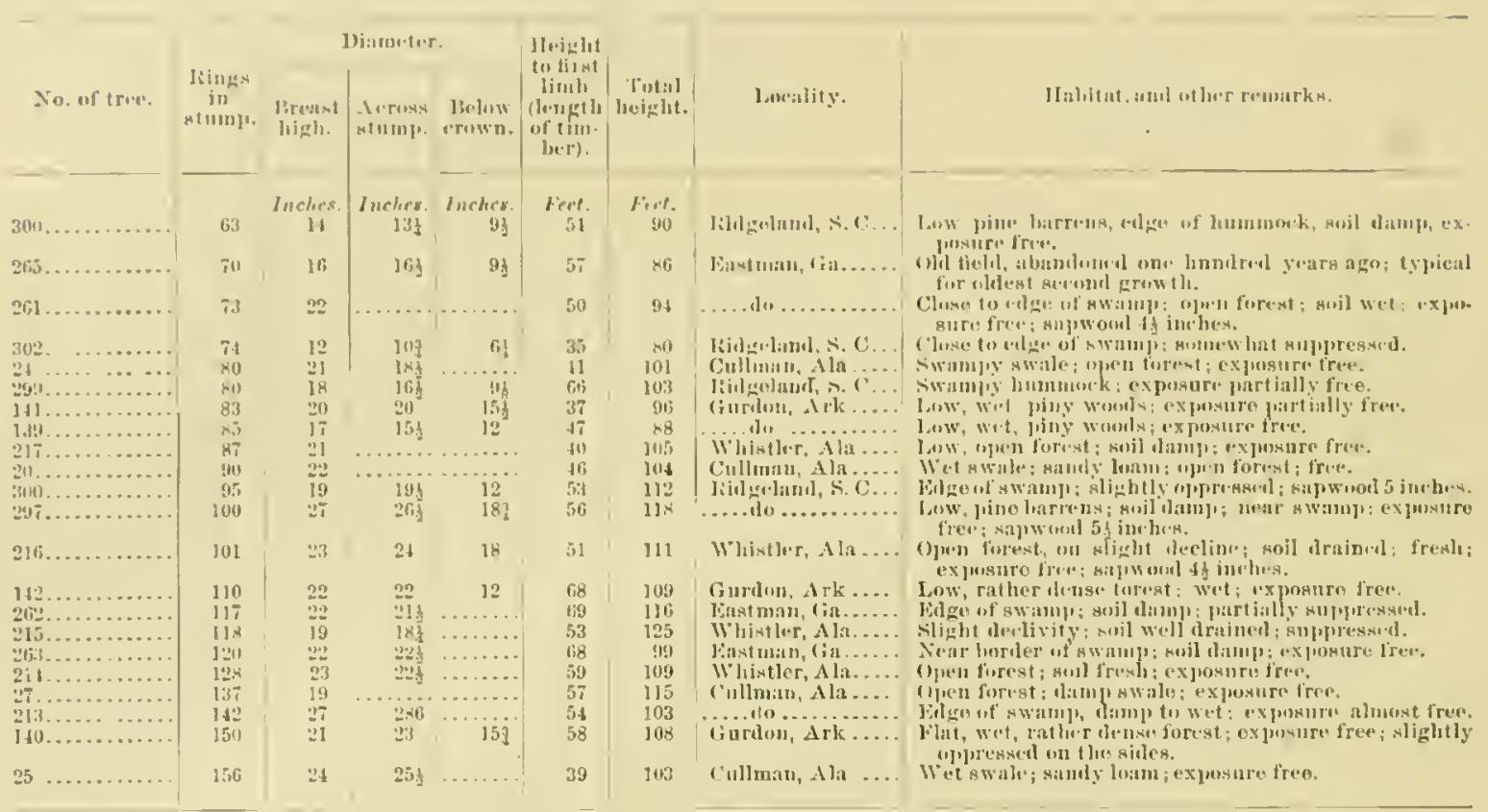

From Table 111 and the eorresponding diagram, based upon a considerahle number of trees, it apperars that the Loblolly l'ine is nearly 40 feet high when twenty years old; that the length of the murumialile timber ( $(10$ feet) is attained at the age of forty ; that this shaft has a basal diameter of 20 inclas at the age of one humbed years, and that the age of thrifty growth is uractically at an end when thr tree is one hundred and ten years old. Compang this table with those for Longleaf and shortleat pines, the excellenee of the Loblolly becomes appurent. 
T.xise III.- liate of growth of Loblolly I'in'.

\begin{tabular}{|c|c|c|c|c|c|c|c|c|c|c|c|c|}
\hline \multirow[b]{2}{*}{ Age. } & \multirow{2}{*}{$\begin{array}{l}\text { Diameter } \\
\text { witl liark } \\
\text { (breast } \\
\text { high). }\end{array}$} & \multirow{2}{*}{ 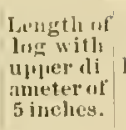 } & \multirow{2}{*}{$\begin{array}{l}\text { Tutal } \\
\text { hodight of } \\
\text { true. }\end{array}$} & \multicolumn{2}{|c|}{ Volnme. } & \multicolumn{5}{|c|}{ Poriudieal atecretion ur growth pwr decade. } & \multirow{2}{*}{$\begin{array}{l}\text { Averages } \\
\text { annuitl } \\
\text { arcretius. }\end{array}$} & \multirow[b]{2}{*}{$\begin{array}{l}\text { Currunt } \\
\text { merstion. }\end{array}$} \\
\hline & & & & Tree. & $\begin{array}{l}\text { Log up to } \\
5 \text { fuelu's } \\
\text { diaueter. }\end{array}$ & Duseade. & Dianeter. & lla.iglit. & $\begin{array}{l}\text { Ariat of } \\
\text { erins sece } \\
\text { tiril. }\end{array}$ & Vैแlımm. & & \\
\hline Tirs. & & & & r'u. $f_{0,60}$ & ru. ft. & & Inches. & lect. & Aiq. fret. & f'u. fi. & ru. fle. & r'u. ft. \\
\hline $\begin{array}{l}10 \\
20\end{array}$ & $\begin{array}{l}3.4 \\
5.6\end{array}$ & ........ & $\begin{array}{l}18 \\
37\end{array}$ & $\begin{array}{l}0.60 \\
3.05\end{array}$ & (n....... & First ...... & $\begin{array}{l}2.4 \\
2.3\end{array}$ & 10 & $\begin{array}{l}0.03 \\
.18\end{array}$ & 0.60 & 0. 06 & 0.06 \\
\hline 31 & 7 & 23 & 5 & $\ddot{8}$. & 7. $4 i$ & $1 .$. & & ] & .11 & 5.67 & .14 & .24 \\
\hline 411 & 10. & 3 & Gi & 16. & 15. & $\mathrm{th}_{\mathrm{i}}$ & 2 & 11 & 1 & 7.91 & 41 & .57 \\
\hline 50 & & 4 & 7 & 25. & & 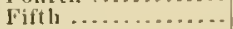 & & y & .1 & 8. & .57 & .87 \\
\hline 60 & 13 & 5 & & & & & & 8 & . 1 & & .59 & 1. 03 \\
\hline 70 & & c & 8 & 49 & 47 & nth & & 7 & .2 & & .70 & 1. 3.3 \\
\hline 80 & 17 & i. & 9 & & & . & & 5 & .2 & & .38 & 1.31 \\
\hline 90 & & 7 & i) & 78. & 77. & $\mathrm{Ni}$ & & 5 & .1 & &.$\times 7$ & $1.5 \%$ \\
\hline 100 & 19. & 8 & 0 & & & &. & 3 & .1 & 11. & .89 & 1.14 \\
\hline 110 & & 8 & ji) & $n$ & & onth. & .8 & 2 & .1 & & ..$K T$ & .66 \\
\hline 120 & 20.7 & 85 & 102 & 100.00 & 101.23 & 'I'welitls ... & .5 & 2 & .10 & 6. 00 & .85 & .60 \\
\hline
\end{tabular}

HEIGHT

IN FEET.

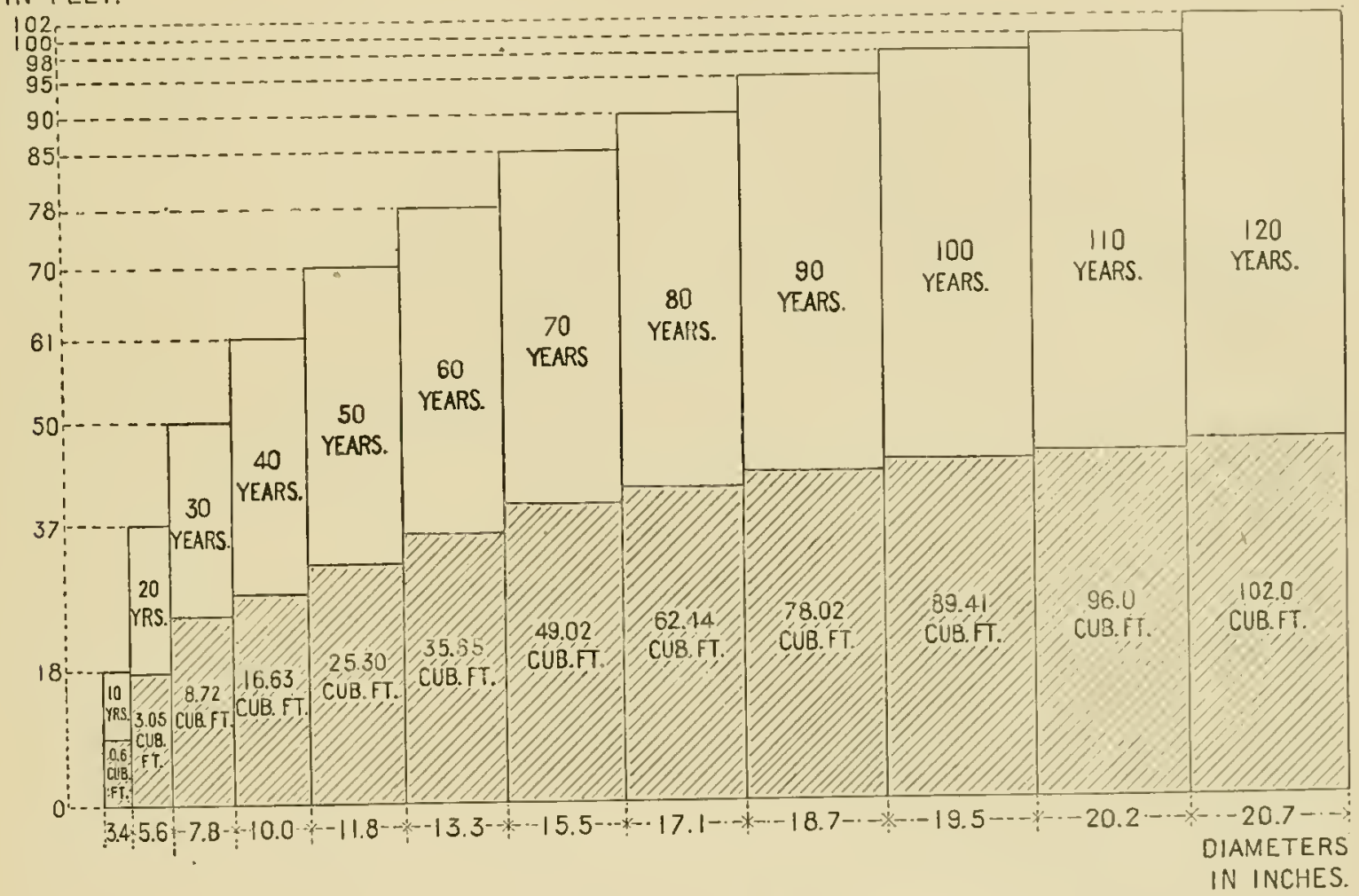

Fin. 12.-Growth of Tolulolly l'ine: Height, diameter, and cubic contents of arerago trues at 10, 20, cte., years of age.

CONDITIONS OF DHVELOPMENT.

SOIL ANI CLIMATE.

The Loblolly Pine prefers a moist, cool, sandy or light loamy soil, which, if not alwats moist, should lave a greater retentiveness for moisture than is required by nost of the otluer mpland pines. It reaches its greatest perfection in the perpetually moist or tieslo forest lamets, with a suil of a sandy loam, lich in vegetable mokl-the accummlation of ages-which border the swamps of the coast region. The tree is mot found on the porous, lighly silicems soils of the more elevated mlands, where the Iongleaf l'ine almost exelusively prevails: it also aroids heavy elay and caleareons soils of tho mplauds and the alluvial lauds.

The Joblolly l'ine is a tree of austral regions confined to the humid belt of the Austro-ripalian or Louisiana zone aud the lower border of the Garolinian life zone, which, on the Atlantic Coast, 


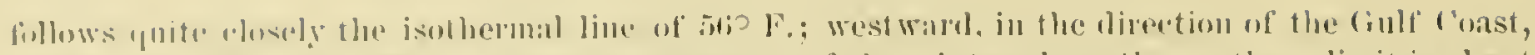

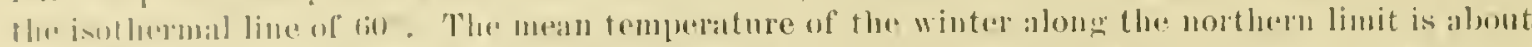

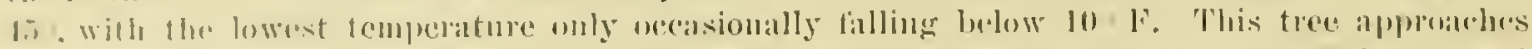

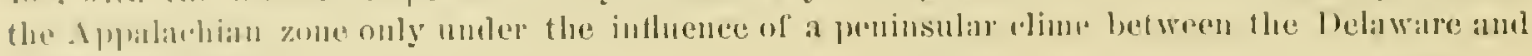
l'hesalpralie bilys.

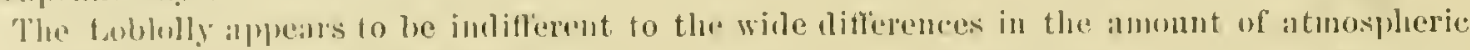

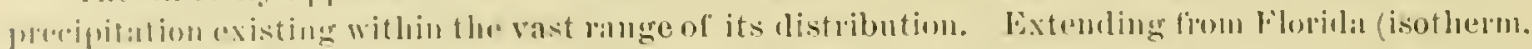

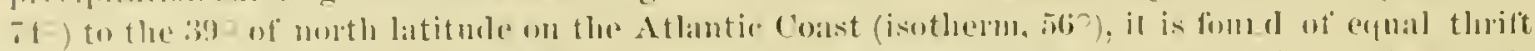

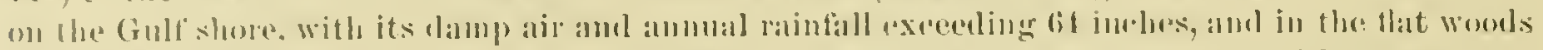

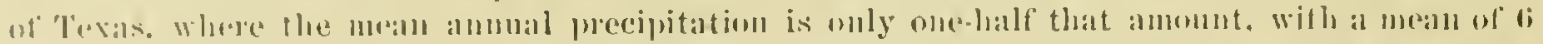

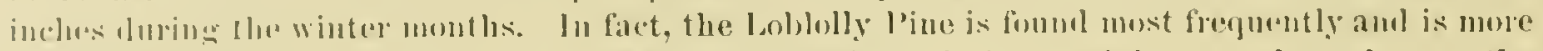

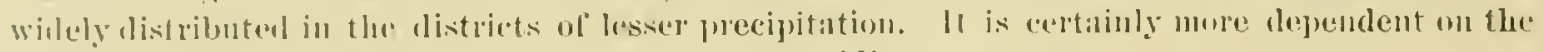
supplies of sul mosisture than upon atmospheric lumidity.

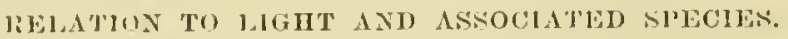

This species is less exacting in its lemands for direct sunlight than the kindred speries within

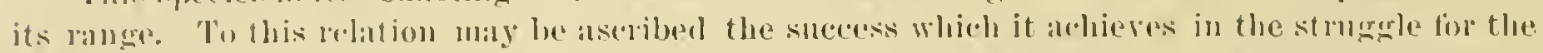
pussessinn of the soil with the shortleaf Pine. Observing this antest as it is going on betwen

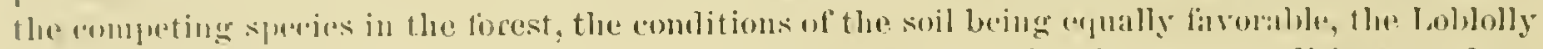

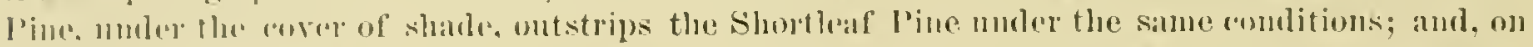

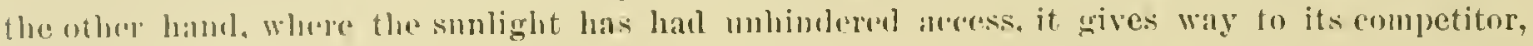

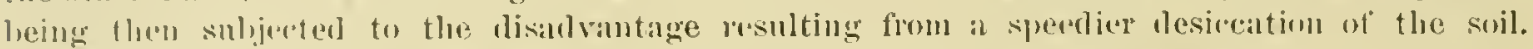

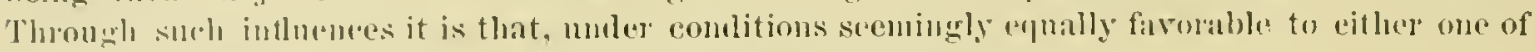
these pines, now the one and now the other is fomml to preslominate.

In the lecp forests wovering the rich swampy lands of the enast regious, the lobloty l'ine forms companatively a small part of the ribh and varied growth consisting chiclly of decislums

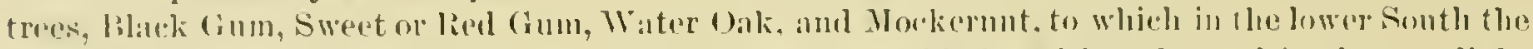

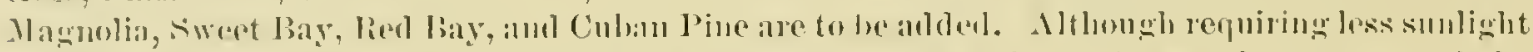
than most pines, in the glomuy impenetralue sharle of these lense forests the progery of the

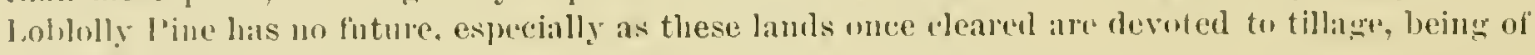
great aterioultural valure.

On the lands of a poores, more exposed soil in the marinime plain of the somthern Atlantic Statex. in Virginia and Yortl Cambina, and in sonthwestern Thxas, this pine forms more or less compriat forests. In fluese forests the tree is always suceeded by its own progenge either in the ennise of nature or after the artificial removal of the original forest growth. On the coist of

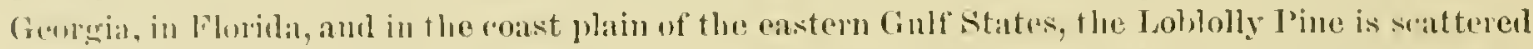

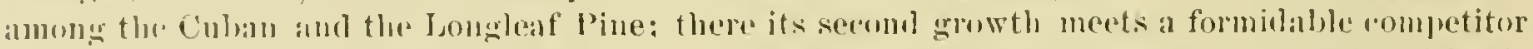

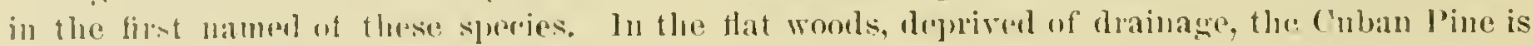
always fomm to vastly out mumber the Loblolly among the young forest growth. In the upper part of the great maritime pine belt the boblolly l'ine is frequently fomd among the mixerl growth of

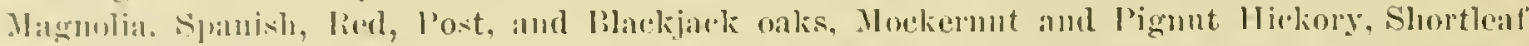
l'ine, and somtrem sunnce Pine. Thronghont this region the tree takes alnost undisputed pussessien of the old tirelds.

In the interior, on the mplands of oaks and Shortle:af l'ime, the I,oblolly is sure to gath the mpere hand and to retain its lobl among the young forest growth, giving way fo its most ageressive

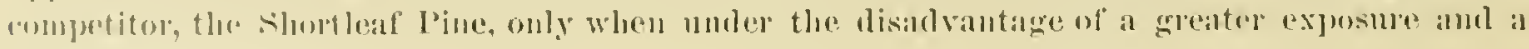
erreatter latek of moist ure in the soil.

\section{FNEMIIS.}

l'rincipally (ondined to low, damp localities, not easily lable to invasion by the frepunent

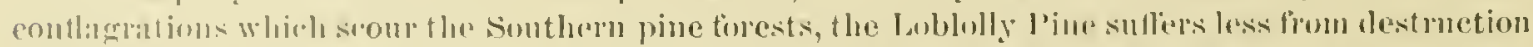

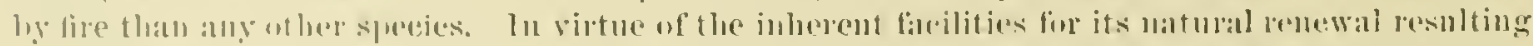

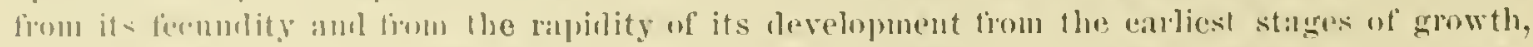
any damages inflictud by that agency are more easily repaired. The same camses atloul it also 
greater protection against incmrsions of live stock. As also olswerver in the Shortleaf P'ine, the rapirly growing seedlings form, after a few years, thickets of such density as to bu avoider by the larger qualrupreds, and by the time such thickets, in the comss" of natural thinning nut have become nore open, the trees have reached abmensions which place them beyond the danger of being tramped down or otherwise injured by live stock. The rapiel spoud and thrift of the second growth, muprotected and nucared for, olserved everywhere within the range of the distribution of this pine, are witnesses to its greater immunity firm such dangers.

Owing to the large amonnt of sapwood, the timber of the Loblolly is more liable to the attareks of tungi and to the ravages of insects. The myrohium (spawn) of large polyporous fimgi is found trequently infesting the wooly tissne of the living tree, the hypha (tilanents) of the spawn destroying the walls of the wool cells, cansing the wood to assmme a redilish color and rendering it brittle in the same way as is observed in the liring Longleaf Pine timber affected with the tiscase called "red heart." It sems that the destruction "aused by this discase in the lublolly l'ine is from the start more rapid in conseqnence of the buger proportions of sapwoorl, and perluaps ulso

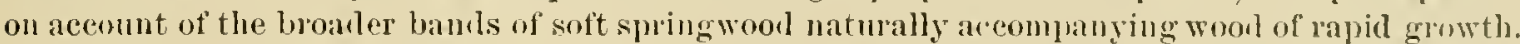

In a piece of wood examined in north Alabama, the filaments of the spawn of one of these thugi crosing each other in every direction were fonnd to forn a dense film interposed between the spring and summer wood, eansing its easy sepuntion in the direction of the roncentric lings. and, as the destruction of the wood proceds, forming finaly a complact layer of the uature of amalon, or timder. In the longitudinal section the rays were foum full of carities, cansed by the breaking down of the cell walls, and these eavities were filled with the white filu of these filaments, which similarly affected the adjoining tracheids of the resinons summerwoorl.

The felled timber lett on the ground is soon infestud by a hust of fungi of the genera Agrricus, Trumits, Lentimus, l'olyporus, and others, the nearer identitication of which has not been molertaken.

From the very limited ohservations that have heen made it clemry appears that this pine suffers equally as much, if not more than the other pines of Sonthern growth from insect enemics of varions kinds. The larve of the same capricom beetles (Cerambicille) burrow in the body of the timber. Those of the momd-headed borers (Caleophora) dig their channels in thr sapwood. as is indieated by the ocenrence of several species of jumping beotles (Jiumestide) which are fomnd clinging to the leaves and banches of this tree. The unst fatal injury it sustains is cansed by the hark borers (Tomicider); this pest particularly afferting the trees during the tormation of the last cambinm layer in the later smmmer months. Trees felled in Angust are immediately infested by multitules of these destroyers. Favoled by a high temperature and an abundance of nomrishment, several generations of them sncced each other before the elose of the season, the countless broods soon infesting every tree in the vicinity and carrying their work of llestruction over the full cxpanse of the young forest growth. Under this aftiction the forests often present, by theil drooping rusty-colored foliage, a sarl jicture of disase and decay. Weevils

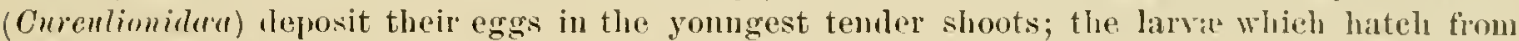
them at their way into these shonts, cansing their decay, and thus destroy the symmetry of the tree and juprair the usefulness of the resulting timber. Other speries of the same family puneture the ohler braches, lay their eges in the exuled resin, their larva injuring the tree in a simila way. The larve of spittle inseds injure the terminal buds, which are also foum infested by the larvir of Pitch-moths (lietinia), eansing them to wither. The foliage seems to be less frepuently attacked by sawtlies (Lophyrux) than the tender young leaves of the longleaf Pine, as by tho rapidity of their growth the young leaves snoner harden, and are therefore less relished by these depredators. The evirlences of the work of the pine-leaf miners (caterpilia of Gelediu) hatre been freconently observed in Alabama, and everywhere are seen the deformitios caused by anll thes and scale insects.

\section{NATLIAA, REPLODECTION.}

If the Shortleat Pine has been spoken of emphatically as the future timber tree of the lisht rolling uplands of the interior, the Joblolly I'ine might be fitly desiguated as the timber thee ot greatest promise in a large part of the coast plain fou the middle Atlantic states to the limits of compact forest growth beyour the Mississippi liver. 'The promptness with which it colunizes the 
old lirhels and wher alearings, and the tenacity with which it retains from one generation to another the rromm ond takel pussession of, clearly point to the important part this tree is to take when the

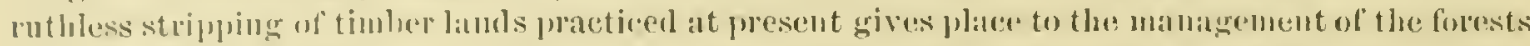

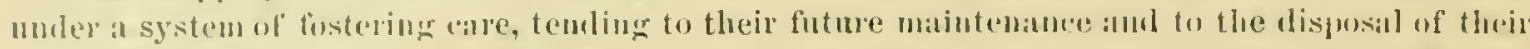
resonces on the principle of true economy with an eye to the future welfore of the conntry. Co timber tree will be fomm better adapted for forest planting in the sumbern part of the Atlantic: forest division. It is only in the narrow belt of that wouls along the shomes of filorida,

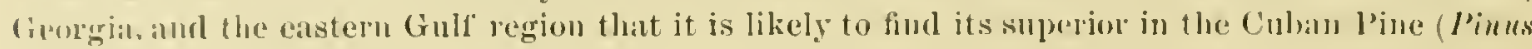
heteroplingllet).

Piesiles the advantages of aldptability to varied soil and climate, it excels in rapility of growth during the eirliest stages, and the coprons prodnction at seels, which, almost without lail, are plentifully distriluted every year over the vieinity of the piarent trees. $A$ s an evilende of the. facility with which the reproduction of a compact forest by this pine is eflected, it is only necessary to point ont the spontanems groves near the settlements, representing, as they do, every stage of development.

In the coast regin the second glowth, if not interfored with under poper soil ronditions, yiells in fifty to sixty yenrs timler of dimensions rembering it fit to be silwn into lubluer well adapted for various nses, as alrealy mentioned.

\section{CONCLTSIUN.}

In this attempt at a sketch of the life history of this tree, the object was constantly kejet in view of placing its value anong the proluets of the Sonthern forests in the proper light. From the consideration of the structure of the wool and its physical properties it elearly appurs that althongh inferior to the wool of the Longleaf and Cuban pines, the timber of this species fully equals that of Shortleaf Pine, and that the present practice of trating them as ecpuivalent seems therefore justifiel.

As an abunlant and cheap source of timber of iuferion grades, and especially when the

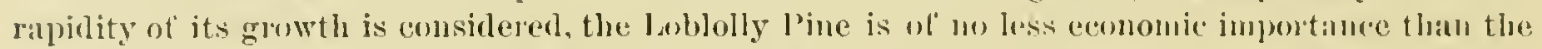
other timber trees of the same section. At present helal in low esterm in the great lumbering astricts of the lower Sontls, where the supplies of the superior timber of the Longleaf l'ine still abound and receive the preference, the value of the timber of the hoblolly line is fuickly recognized in other districts which, but a short while ago boasting of similar resumres, are num stripped

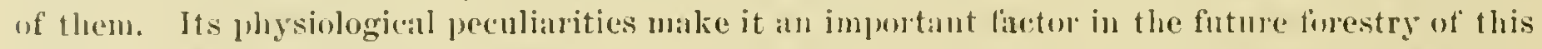
section. Its jupagation is suetessful over a vast expanse in the sontheru sertion of the $\Delta$ tlantic forest region, and by its jroductive eapacities, mole of devolopment, and lehlavior towarl conpeting sprecies in the strugrule for existence, the Loblolly l'ine jossesses great aulvantages hor its natural and artiticial renewal, adapting it particularly for the restoration of the forests on the lowlands of the maritime region. 


\section{THE SPRUCE PINE.}

(PINUS GLABRA WaIt.)

HISTORICAL.

Distrimetion.

ECONOMIC Importance.

Botanical Description.

Progress and Developient.

ENEMIES.

liequirements of Develophent. 


\section{TIIE SIPITCE PINE.}

\section{('iuns glabra Walt.)}

Synonyns: Pimrs glalira Walter, Fi. Caroliuiana, 237 (1788).

I'iais mitis 3 (?) paupera Wool, C'l. Book, cul. 41, bitio (18:5is).

('OMMON OR LOCAL NAMES.

Spruce l'ine (S. C., Ala., Fla.).

Colar l'jue (Jiss.).

White l'ine (rla.).
Wralter's Pine (S. ( $\circ)$.

Lowland spruce Pine (Pla.). Poor l'ine (l'lar.). 


\section{THE SPRUCE PINE.}

By Cinares Mohr, Ph. D.

INTRODUCTORY.

The Spruce Pine is the least common of the pines found in the lower Sonthern States. The tree is frequently confonnded by the inhabitants with the Shortleaf l'ine. to which it is elosely related. Its vernacular names are, in different sections of its range, applied to several other pines; in Florida to the Sand l'ine (I'inus eleuse), in north Alabama to the sernb l'ine (l'imus ringinimne), and in the sonthern part of this State even to the Cnban Pine. Althongh never forming extensive bodies of timber, being for the most part widely scattered among the broadleaf evergreens and decidnous trees with which it is assochated, and in the quality of its wood of low rank, this little known tree has been given a place here among the monographs of the timber pines of the sonth Atlantie forest region in order to dispel for the future its confusion with some of these trees, and at the same time to attract the attention of the tree planter to it as the only one of its kind which thrives and propagates in the sharle, keeping its gromud elosely surounded by the luxuriant and varied tree growth with which it is associated, and soon outstripping the same by the rapidity of its growth. Considering that among all others of its kind in the sane region it attains the fullness of its growth in the shortest time, with dimensions which render it valuable for many of the purposes for which the softer and lighter linds of timber are used, its economic importance can not be ignored.

\section{HISTORICAL.}

The Spruce Pine was first recognized as a distinct speeies and deseribed as Pinus glabra by Walter, in his Flora Carolinensis in 17SS, having since that time been linown under this name by the botanists. Hidlen in the remote semiswampy dense forests, it eseaped the at tention of later botanists. Neither the Mlichauxs, father and son, nor Nuttall were aware of its existence. It was nnknown for fnlly three-fourths of a century until rediscovered by L'rofessor Ravenel in the swamps of Berkeley County, S. C. Ten years later the tree was described in Chapman's Flora, 1860. It was recognized by I'rofessor IIilgard in the Pearl River' Valley, Mississippi. In 1880 its distribution was tracel by the writer through the Gnif region to its western limit in the eastern parishes of Lonisiana.

\section{DISTRIBUTION.}

The Sprnce Pine is a tree of the sontheastern Atlantic forest, eonfined to the sulntropical region or the Louisianian zone of Anerican botanists, within that part of the coastal plain of the sonthern Atzantic and the Gulf States embraced between the thirty-first and thirty-third degrees of north latitude; from Sonth Carolina through middle aud northwestern Florida to Louisiana, with its westem limit between the Pearl and Mississippi rivers. This tree is mostly fomm single or in groups on the low termees with a fresh or damp soil pich in humns, rising above the swamps subject to frequent overflow. It is seldom seen to form eompact borlies of timber; snch have only been observed betreen the Chattahoochee and Choctawhatchee rivers, in northwestern Florila, where, to all appearances, this tree finds its best development on isolated tracts of fertile red loan lands.

\section{ECONOMIC IMPORTANCE.}

Nowhere forming pure forests of any extent, this pine is of little importance to the lumbering interests of the present, and its timber has never become an article of commerce. Althongh the timber is of inferior quality, it furnishes lumber of dimensions equaling the best of onr timber 
gines. It is light, soft. easily worked, and eajable of enoul linish, and is without doubt fit for

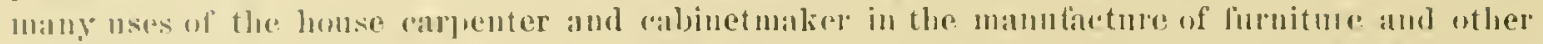
purpuses. Owing to the larea fereentage of ash and sualle quantity of resinnus matter, the actial fure value of the worl of the sjurne Pine is lower than that of the other sonthern pines: for its resinons prolnet the tree is considered of no value, since the resin roes not run when it is talpperl.'

In its wood the Spunes l'ine resembles Loblolly. The sajwoon is wille, and even in trees

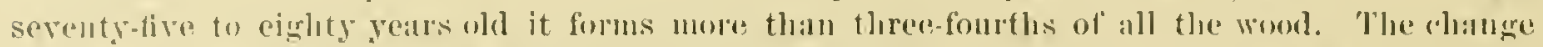
from silp to heart woul hegins as early as in the pines mentioned, and as in these is retarded with age and also with any suppression of growth, suthat in stunferl young trees the elange begrins later, and the sipuroml of these, as well as old trees, is always composed of a greater mumber of

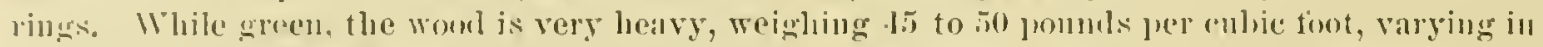

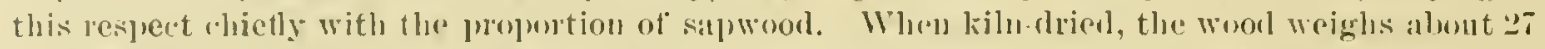

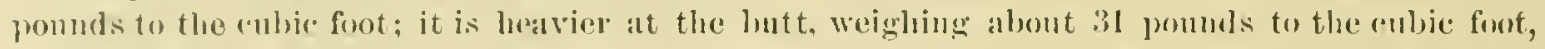
and lightest near the top, where its weight falls as low as 2.5 ponduds fo the enbic foot. As in other pines, the heaviest woot is produced by goung trees. The amount of water contained in the

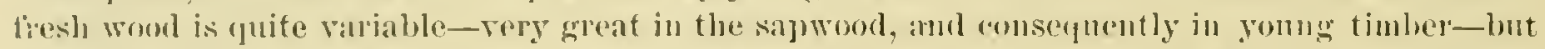
falls little below so per cent of the weiglit of green timber on the whole. Its belavion in alrying is the sane as in light wrades of Loblolly; it dries rapidly and without murlo injury, shriuling, during this process, ly about 10 per cent of its volume.

The strength of this wool is, as in other conifers, closely related to its weight. Accordingly, the sipruec l'ine is inferior to both shortleal' and Loblolly.

lrom careful experiment it appears that its-

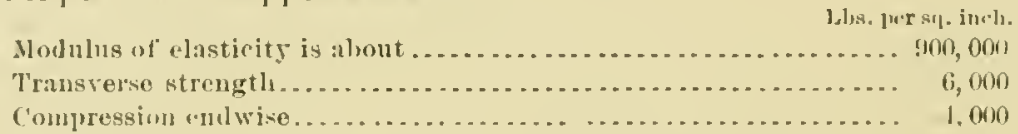

In its struefure the word resembles too closely that of flue Loblolly to mable as yof any identification on this teature, and the deseription for the wom of the Lohlolly answers frerfetly for the prodnet of this species. As in Loblolly and other hatrd pines, summerword and springwom are almays well detined, the summerwood forming from 15 ip to do per rent of the fotal volume, dillering in this respert from the White J'ine which it has been claimed to resemble. Thuns while decidedly sofor on the whole than Lohlolly it is by no means fo he expected that the Spruce I'ine eall hope to serve as a general sulstitute for the true White Pint.

\section{BOTANICAL DESCRIP'LIOX.}

Leaves invariahly in pairs, with short and elose sheath; soft, slender, $1 \frac{1}{2}$ to 3 inclues long, twisted; cones short-stalked, lurizontal or reflexed, tho come seales with a that apophysis, the depressed umb unalmed or witls a minnte weak erect pricklis.

The Spruce l'ine is readily distingushed by the close lank of its trutk which in the erown and the limbs is jerfectly smooth and of a light gray color; in lobliage and in eones it resembles most

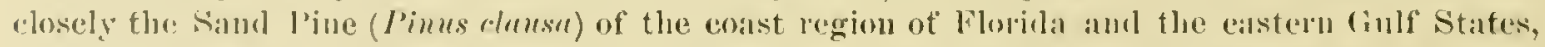
which however is distinguisherl by the more prominent apophysis of the rone soales, almed with a slunt, stont, reflexed prickile. The Shorleat' Pine, to which it is next related, is ristinguished by

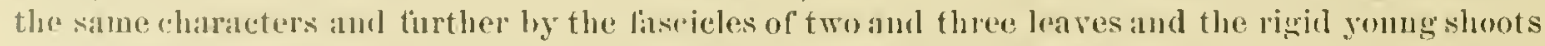

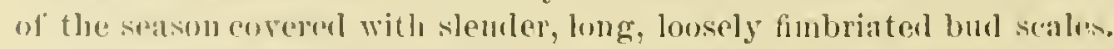

The laswes are ancave, faintly serrulate, short pointed, and are shed during the latter part of the second satson or the beginuing of the third.

In the detaik of their structure they ditler little from the leares of the Shontleaf Pine: the rows of heatluing pores (stomatal) are numerons on both surfures; the strengtheningr cells of the

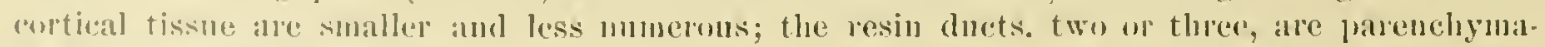
tous, the eells of the bundle sheath thin walled. The two tibro-rasenlar humbles distant and withent strengthruing rells.

' liavenel: l'rocurl, of lillintt Societ., Charleston, I, 52. 
The male flowers are lateral, sessile, and about one-half to three-fourtlıs of an inch long, slender, surrounded by five to six pairs of slort ovate, rather obtuse stifl suales, with a narrow, membinaceons lacerated border. The erest of the anther is elliptieal, with fine denticulations. The small female aments are mostly single, short stalked, the earpellary scales lauce-shaped with slender tips and snbtended hy the short infertile bract.

The cones are mostly single with a short stalk and of various shapes on the sane tree, from ronnd to oblong ovate or more or less cone-shitped, from 1t to 2 inclies long, and, on the opening of the scalcs trom three-fourths to one inch wide, of a light tawny eolor. The suales are softer and more flexible than in the Shortleaf I'ine, the apophysis broaler, with tho mubo depressed, unamed, or with a minute, weak, ereet, and deciduous prickle, the ridge faint, hazel-brown on the inside. The somewhat triangular ronghish seeds, black with brown specks, about three. sixteenths of an inch long and one-eighth inch wide, separating easily from the wing which is little over one-half inch long and surroumds the seed to the base.

\section{PROGRESS OF DEVTLOPIENT.}

The Spruce Pine begins to flower and to produce perfect seeds at an age of twelve to fifteen years, in greatest abundance between twenty and forty years; the Howers appear during the earliest part of Hareh; slortly after pollination the female aments assume a horizontal position, and finally become more or less reflerted. At the end of the first season the conclets are of the size of a large pea. The cones mature in the second year in the month of September; the seeds are freely shed enly in the fill. 'They germinate during the full and early in the coning spring; the plantlets, with eight to ten slender, soft cotyledons, are over an inch long. The terminal buil develops rapidy, densely covered with the slender, soft primary leaves which are sharp pointed and frequently over an inch in length. Larly in April seedlings are found over one-half toot long, later in the season fiscicles of the foliage leaves appear in the axils of the upper prinary leaves, when the lower wither and disappear near the end of the season. At this stage the seedlings are generally a foot high with the root system less developed than in its lindred species at the same age; the taproot scarcely 2 inches in length with a few short lateral roots.

With the twentieth year the trees are generally from 30 to 35 feet high and 4 to $4 \frac{1}{2}$ inches in diameter, the stem clear of limbs for the length of about 1' feet. 'They attain their' full growth at an age of from sixty to seventy-live years.

The trees for the United States timber tests from the border of the swamps on the banks of the Tensaw River in Baldwin County, Ala, showed the following dimensions and age:

Yeasurements of five trees.

\begin{tabular}{|c|c|c|c|c|c|}
\hline No. of tree. & $\begin{array}{l}\text { Rings on } \\
\text { stump. }\end{array}$ & $\begin{array}{c}\text { Diameter } \\
\text { breast high. }\end{array}$ & $\begin{array}{l}\text { Length of } \\
\text { timber. }\end{array}$ & $\begin{array}{c}\text { Ileight of } \\
\text { tree. }\end{array}$ & $\begin{array}{l}\text { Sian ou } \\
\text { radins. }\end{array}$ \\
\hline $45 \%$ & 78 & $\begin{array}{r}\text { Inclies. } \\
22\end{array}$ & Feet. & Feet. & $5+$ \\
\hline 459 & 53 & 17 & 56 & 96 & $5 \frac{1}{2}$ \\
\hline $460^{\circ}$ & $\begin{array}{l}46 \\
75\end{array}$ & $\begin{array}{l}15 \\
22\end{array}$ & $\begin{array}{l}40 \\
57\end{array}$ & $\begin{array}{l}85 \\
99\end{array}$ & AII $\mathrm{Ra}$ ! \\
\hline 461 & 83 & 23 & 60 & 116 & 5 \\
\hline
\end{tabular}

From these figures it appears that the two trees forty-six and fifty-three (average forty-nine) years old have an average volume of 63 cubie feet and grew at the rate of about 1.3 cubie feet, while the three trees seventy-five to eighty-three (average seventy-eight) gears old have an average volume of about 152 cubic feet and an average yearly growth of about 2 cubic feet. The following represents a typical case:

Growth of spruce rine.

\begin{tabular}{|c|c|c|c|c|c|c|}
\hline \multirow{2}{*}{$\begin{array}{l}\text { Rings on } \\
\text { stump. } a\end{array}$} & \multirow{2}{*}{$\begin{array}{l}\text { Height of } \\
\text { tree. }\end{array}$} & \multirow{2}{*}{$\begin{array}{l}\text { Diameter } \\
\text { without } \\
\text { bark. }\end{array}$} & \multirow{2}{*}{$\begin{array}{l}\text { Tolume of } \\
\text { wood. }\end{array}$} & \multicolumn{3}{|c|}{ A rerage yearly growtl in- } \\
\hline & & & & Il oight. & I) iametrr. & Volume. \\
\hline $\begin{array}{l}10 \\
20 \\
30 \\
45\end{array}$ & $\begin{array}{r}\text { Fet?. } \\
37 \\
51 \\
67 \\
84\end{array}$ & $\begin{array}{c}\text { Inches. } \\
5 \\
k .5 \\
12 \\
15\end{array}$ & $\begin{array}{r}\text { ('ubic fl. } \\
2.5 \\
9.5 \\
26 \\
51\end{array}$ & $\begin{array}{r}\text { Feet. } \\
3.7 \\
1.4 \\
1.6 \\
1.1\end{array}$ & $\begin{array}{r}\text { Inches. } \\
0.5 \\
.3 \\
.3 \\
.2\end{array}$ & $\begin{array}{r}\text { Cubicft. } \\
0.2 \\
1.7 \\
1.6\end{array}$ \\
\hline
\end{tabular}




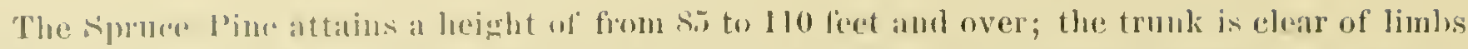

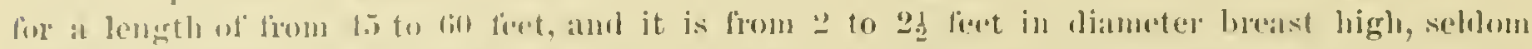
"xoreding 3 tert. T'he burgest trees observed were abont 120 fect in height by a girth of fuily 10 leet breast high.

The taprout appears to be less strongly develoged than in the shortleaf. the lower lateral roots

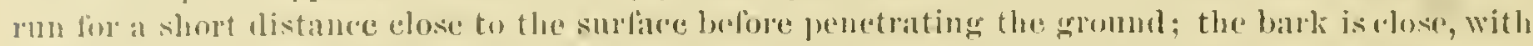

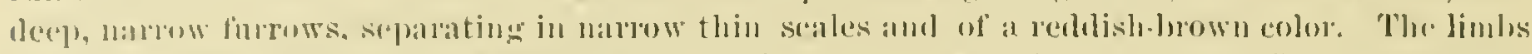
are borizntal, dividing in retangular sprealing branches and branehlets. The leaves also

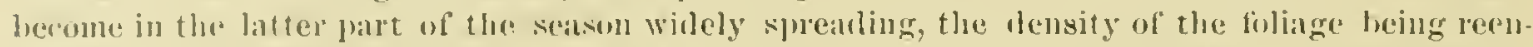
forced by the leaves of the short branchlets produced on the older branehes from andrentitions burls. To this sprearling hahit of thr ultimate division of the branches and of the leaves is due the peraliar spray of the foliage, similar to that of the true ceedars.

\section{F.YEMIFS.}

No ohservations have heen made of the injuries intlieter mon this tree by insects. Trees, after having passed the perion of full growth, at the age of about log years are very trefucntly allected with dray in tho stump and with redheart in the top. In the damp hummods lands the

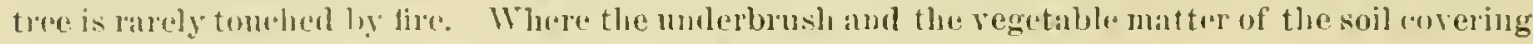
lias been dustroyed by repeated contlagrations, however, the troes begin to sicken and som die.

\section{REQUIIEMFNTS OF DEVELOJMEXT.}

'The Spruce Pine retuires the wirm elimate of the subtropieal zone, with a mean annnal temperature of ahme tio Fand a mean temperature of $495 \mathrm{~F}$. in the winter months (in rentral Alabana the thermometre lalls sometimes to an extreme of 50 l.), and the humid atmosphem of the coastal plain, with a mean amual ruinfall al 51 inches, evenly distributed throm ghont the yoar. 'l'his tron will endure, during the early stages of' its growth, more shate than any other of' the

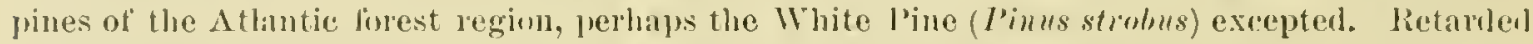

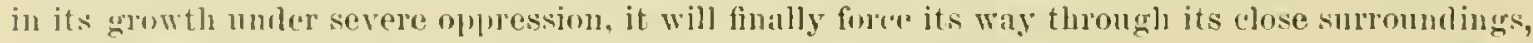
anl having gainel a freer aress to light, it jusles its crown rapinly above the bruad leaverl evergrens and deciluons trees which huxuate on the same gromd. It demands at loose soil, riel in lumns, fresh to moist but uot wet, with a lleej porous subsoil, which in these lands is frepuently a light, sandy loam.

The Spruce l'ine is never fonnd in the forest of the alluvial bottoms with their heary soil, sul. ject to frequent overtlow, nor in the dry, sandy pine forests. Where it tinds the soil ronditions most fivorable to its growth, Mignolias, Curomber trees, sweet Gum, Mockerunt Hirkory, an\} lbuech are foun of greatest thrilt, not infrequently assoeiated with the Shortleaf and the Lublolly junes. The mudergrowth on such lands is luxuriant, consisting of Dogwood, Holly, Summer lanw,

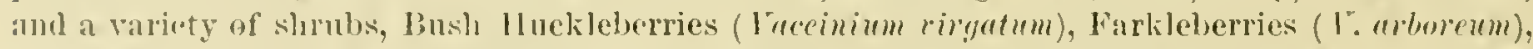
Storax linshes (styrur grombifolium), Cornals (Cormus sericea), and lihe Palmetto, forming dense

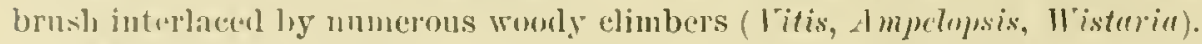

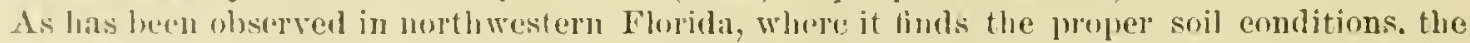
second growth of this pine som ocenpies the clearings mate in the original forest. Tracts of young

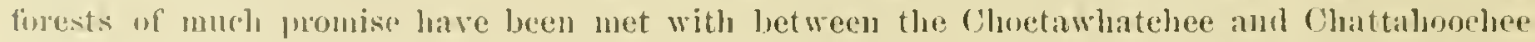
rivers. The hmmnock land, forming the home of the Spuree Pine, being with the increase of the population rapinly claimed for cultivation, this beantiful pine will soon be sulely contined to the must remote and inacessible lowalies. lieing the only really soft pine of the Southern States, and having loy its shale endurance a peenliar forest value, this tree will probably form an important part in the future, when forestry has become an established business. 
NOTES ON TIIE STRUCTURE OF THE WOOI) OF TIIE FIVE SOUTHERA PISES.

(I'inus palustris, tada, echinata, helerophylla, glabra.)

SAI AND HEALTWOOD.

Axnual litings.

SPRTYi AND SUMMER WOOD.

Graty of THE WOOD.

Mivete ANATOMY. 



\section{NOTES ON THE STRUCTURE OF THE WOOD OF THE FIVE SOLTHERY PINES.}

(I'inus palustris, heterophylla, echinata, tadı, glabra.)

liy FiLIHELT himti,

In charge of Timber Physicy, Jivision of Forestry.

The wood of these pines is so much alike in aprearance and even in minute strueture that it ean be discussed langely withont distinction of species. The distinctions, as far as there are any, have been pointed ont in the introdnetion. Here it is proposed to give in more detail the elar acteristies of the woor strueture.

SAP AND HEART WOOD.

All five speeies have a distinct sap and heartwood, the sap being light yellow to whitish, the heart yellowish to reddish or orange brown. The line of demareation between the two is well defined, without any visible transition stage. The location of this line does not as a rule eoineide with the line of any anmal ring, so that the woud of the same year's growth may be sap on one side of the tree and heart on the other. The difterence in this condition may amonnt to ten $0^{\circ}$ twenty rings, which on one sille of the same section will be heart, on the other side sap.

There is considerable variation in the relative width of the two zones as well as the number of rings involved in either and also in the age at which the transition from silp to heartwoor begins. This age was rarely found to be below trenty years; as a rule the transfomation begius in young trees when the particnlar section of the tree is between twenty and twenty-fire years old, bnt the progress of heart formation does not keep pace with the anmul growth, being more and more retarded as the tree grows older, so that while in a section twenty-five years old twenty-two rings may be sapwood, at thirty-five years the sapwood will comprise only thirty rings; at forty-tive years, forty rings; at eighty years, fifty rings; and in seetions two hundred years old the onter eighty" to one lundred rings will still be sap. A young tree of Lougleaf Pine (No. 22) was, for instance, fonnd to show the following relations:

\begin{tabular}{|c|c|c|c|}
\hline Section. & $\begin{array}{l}\text { Jleight } \\
\text { frum } \\
\text { sfump. }\end{array}$ & $\begin{array}{l}\text { Age of } \\
\text { serition. }\end{array}$ & $\begin{array}{c}\text { linge of } \\
\text { sap. }\end{array}$ \\
\hline $\begin{array}{c}\text { III } \ldots . . . \\
\text { IV } \ldots . . . \\
\text { VII } \\
\text { III........ }\end{array}$ & $\begin{array}{r}\text { Fet. } \\
0 \\
14 \\
22 \\
30 \\
42\end{array}$ & $\begin{array}{r}\text { Fears. } \\
40 \\
38 \\
30 \\
24 \\
18\end{array}$ & $\begin{array}{r}\text { Dumber. } \\
40 \\
33 \\
27 \\
23 \\
17\end{array}$ \\
\hline
\end{tabular}

The ehange from sap to heart wood begins earier in young trees than in the younger portions of older trees; in these latter, seetions thirty-six and forty years old are quite commonly found still entirely made ul of sapwood, while in young trees, as stated above, the ehange begins before the age of thirty years.

The progress of the transformation is somewhat influenced by the rate of growth; it is slower in slow-growing trees and usually also on the slower-growing radius, i. e., there are more rings of 
sapwool. The willt of the saprood. on the other haml, stands in relation to the rate of growth in an epposite manner: it is willer in young and thrifty than in old and stmuted trees, and widest along the greatest rallins of any section: similarly, it is willer in the faster-growing Loblolly, Cuban, and siprne pines than in the slow growing longlual.

liesiles lowing of a lightel colol the salpwond ditlers from the heartwonl in several respeets. Its resill is limprid ant onzes out of the poreson resilu ducts of any fresh cut; that of the heart wod loces not flow. exeept in rare mises, from saturaterl pieces or "light wood." The sapwool contains much less rusin-lotl rosiu and turpentine-than the heart wool. Tluns in a sertion of Lougleitf the salwood contained only 0.2 pre rent of turpentine and 1 per eent of rosin, while the heart containes from 2 to 4 jere cent of turpentine and 12 to 21 grer cent of rosin, and thongle this is an extreme case the heart generally las three to five times as much resinous matter as the salp. The fiesh sapwook contains three to live times as much free water as the heatwood and is, even when seasunel. mole lygeroseopic and subject to relatively greater shrinkage than the heart. This (apacity for taking mp water realily is probably one of the reasons why sipwoml deays more realily. In addition, the parenchyma rells of the medullary rays and resin ducts (see further on) rontain, at least in the outer parts of the sapwond. living jutoplasm and reserve foul materials which are readily seized mon ly fungi which cause "blung" and decay. Such living tissue does mot exist in the heartwood. The heartwon in old logs genelally is heavier than the sapwood. This is not due to any later thickening or growth of its cell walls. after their original formation, but is due chictly to fwo canses:

1. The heartwool of old logs was fimned when the tree was yomnger, and made, naturally, heavier wool.

2. The aceumulation of resin in the heat alrealy referred to increases of ten very consideralily the weight of the heartwool.

In the salne way the sapwool of old lngs, such as supply the sawmils, is weaker than the heartwod of the same logs, but this is nut becanse the wood is in the salpwood ennlition, but becase it is lighter aud its smumerwood per cent smallex, being, as stated before, the product of old ane when heavy and strong wood is uo longer formed. Chemieally the wood sulstance of sapwood is practically like that of heartwood; the coloring substanws which permeate the cell walls in heartwool appear to be infiltrations, i. e., deposited in the walls from solutions; they are insignificant in amonnt, and their true nature, especially the processes learing to their formation, are wut yot filly understond. The most morlern views which cousider these coloring bodies or leartwood snlystances as prodnets of oxidation of tambin still reguire confirmation.

\section{AYNUAL RIXGS.}

The layers of growth, known and appearing on any cross section as anmual rings, show rery distinctly in the wood of these pines. In a section $s$ or 10 fect from the wround the rings are widlest at the ecuter, of considerable wilth for the first thirty to tifty rings, the period of most rajicl growth in heiglit: then they grow more and more narrow toward the periphery. In the last sixty to om lumbled rings of very old logs the decrease is rery small, the rings remaning practically of the sane wiltlı. 'Tle same your's growth is nsually willer in the upper part of the stem, both in gonug and old trees. but the arerage width of the rings is naturally greater ii the mper part only of young trees; in old and also in stunted trees it is smaller, since in these the upper portions do not shate in the more rapild growth of the early years.

lings over lalf an inch wide are therthently seen in Loblolly and orenr in Sprnee L'in'; rings one-fonth of an inch in width ocrur in very thrifty saplings of all tive speries, funt the average wilt hof the rilgs for sapling timber is usually less l han one fourth of an inch, onmmonly one-eighth. In trees over one hundred years old it drops to one-twelfth of an inclind even below. The average wilth of the rings is nomally suallest in Longleaf l'ine, being one-twenty-filt of an ineli and less. (See also tables and diagrans of rate of growth in the introduction, as well as in the several monographs.)

The influence of orientation on the wilth of the rings is completely ohsenred hy other, more potent inthences, so that sometimes the radius on the nortlis sirle, other times thit of some other 
side, is the greatest; alid it is a common observation to see this relation rary within wille limits. cren in the trunk of tha same tree.

Stuntel trees of longleaf l'ine over one lundred yeals old with an arerage wilth of ring of one-fitietl of an inch are frepurenty met with in old timber: of lhe uther species no such trees

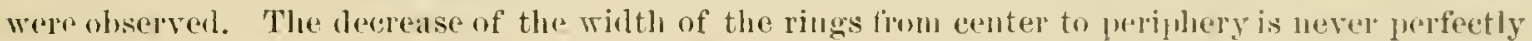
uniform. Not only do consucutive rings litfer within considerable limits, lunt furpuently zones of narower rings, inchuling thirty ol more years' growth, listurb the gencral regularity. Where these zones ronsist of very narrow rings, one-fittieth of an inch or less, the wool is of distinrtly lighter color and weight. Since the value of this elass of woor depends not only on its strength and stiffness lut also on the fineness of its rings (grain), in so tar as the grain intluences both the

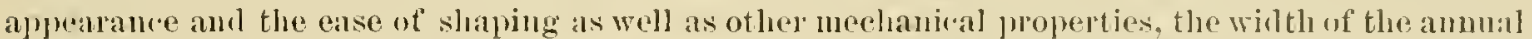
ring is of gleat importance, fon a technical point of view, the lineprelinged (grained) wond of the sime weight always deserving and mostly reeiving preference.

The rings of the limbs are namower than the corresponding rings of the stem. Moreorer. they are usually of ditlerent widths on the ujper and lower sicte of the sane branch. those of the lat ter excelling in wirlth thase of the tormer. Frefuently the wider lower part of a ring of a branel appears like a "lune" "m the cross section, quite wide (one-rghth of an inch aud urore) in its lowrr median part, and searcely visible, often entilely fading out, on the upjer side. This difference is conmonly accentuated by the appearance of the woml itself. In the upper jast the wool of the ring is normal and light colored, wwing to a very small summerwoml per cent; on the lower wids part, the "lune," the wood is emmmonly of redaish eolor, either aven thromghont the entire width of the ring, or else in several varicolored bauds, which give the appearance of two or more sejarate i]-rlefined rings. Sometines the earliest former springroor is included in this unusual coloration, at other times only the median portion of the ring. This " red wood," as it has heen termed by the French and German writers, is eomposed of very thich wallod cells amel increases markedly the weight of the wood, so that the wool of the side containing it is msially much the heaviest. It is of interest that the several "lunes" in any cross section ocen ralely, if arer, exactly one above the other, but commonly the radius passing throngh the midlle of ome *. lune " makes an

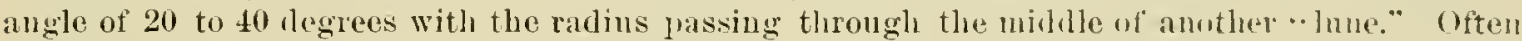
successive "lunes" show considerable deviation in position anul commonly diffir iu width or legree of development. Accepting the most recent explanation of this phenomenom as expessed by Ilartig and Cieslar, it wonld appear that the formation of these broad ". lunes" of especially strong cells is due to pressulestimulus on the growing cambium, cansel by the wejuld of the limb and its peculiar position, increased at all times by movements ut the limb lue to the winc. Moreover it seems that the formation of one well-developed "lune" prelieves for a time the pressure. and with it the necessity for a repetition of this formation. 'fluese " lunes" are most conspicuons.

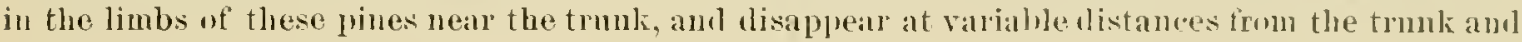
with them disappears the eccentricity and the difference in appealance and woight of the wood of the limbs. Immerliately at the junction of limb and sten the pressure is constant. anul the result is the formation of almost muiformly thick-walled tissue in all parts of the ring, giving to the ". knot" its great weight and hariuess.

Lmues similar to those of the limb are frofuently observed in the stems of small treas; wherever this las been noted it was found on the mulerside of a leaning or "urved portion.? Oceasionally sucl a "lune" extends for 12 and more fect uj and down.

Quite distinet foun this modifiention of the anmal ring is another monitication fiequently seen. especially in young trees, giving rise to so-r"alled "false" rings. It consists in the aplearance of one or more, rately two, lark-nolored lines, which precede the true sumunerwood band of the ring. 'These lines. resembling the summerwoor in colol and composed like it ot thick-walled rells, follow the true springwond of the yatr and are separated fiom the summerwoud and fiom each otluel (if them are more than one), by ar light-colored line resembling springwonl. While ocrasionally this is somewlat mislealing in comting the rings, a moderate magnitioution nsually suttices to

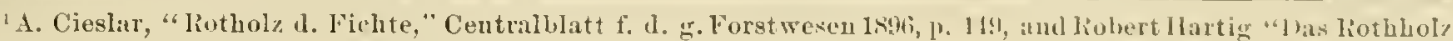
ler Fichte" in Forstlich-naturwissenschaftich" Zoitschrift, 1866, p. 165.

2Cieslar producel them at will hy hembing young spluce saplings. 
distinguish the real charantor of the tissues, as deseribed later on. A more serims diflieulty aldises in rury wh, slowly growing trees, where the ring sometimes is representerl by only oue to

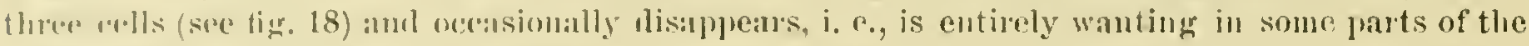
moss sertion. Cincrally these cases, due to various eauses, are too rare to serionsly interfere in the patalulishment of the age of a tree.

\section{SPRITG AND STMMFR WOOD.}

The dimprence between spring and summer wood is strongly marlied in these pines, the transition from the former to the latter being normaly abrupt aurl giving to the ammal ring the

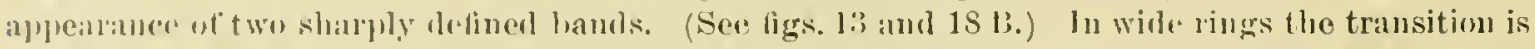
somedines gratulal. The sumingworl is light colored, has a sperifie gravity of about $10 . \$ 0$, and thus weighs somewhat less than half as much as the darler summerwool, with a specitie gravity of about 0.901 to 1.05, so that the weight and with it the strength of the wool is greater, the larger the amomnt of sommerword. (See diagram, tig. 14.)

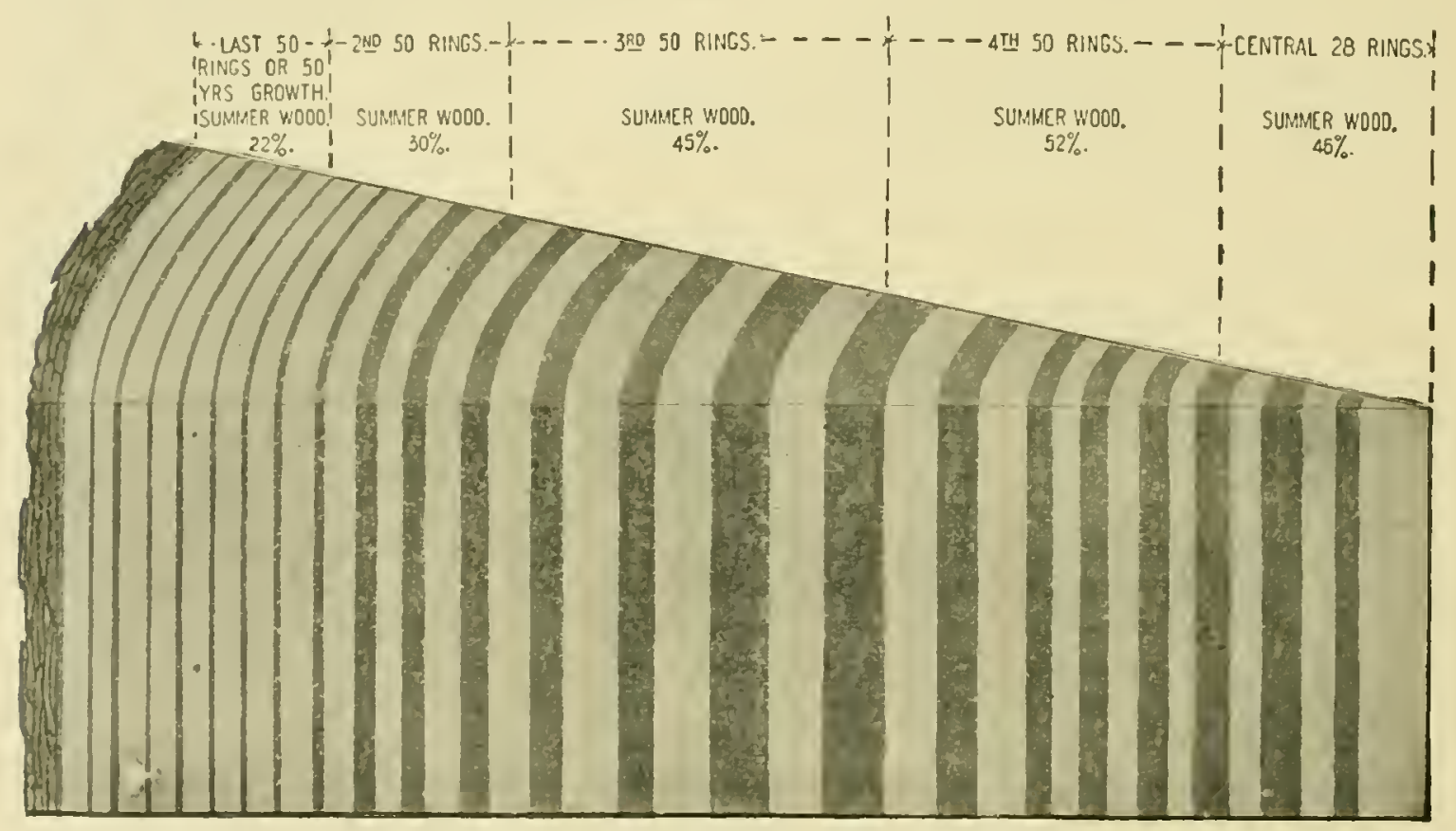

Fig. 13.- Trariation of Bummerwool per cent from pith to bark.

The alsolute willth of the sumnerwoul varies generally with the wilth of the ring (see diagram, tig. 15), i. e., the wider the ring the willer the summerwoenl band. It decreases in an cross serotion of an old log from near the pith to the jeriphery, ant in the same haver, from the stmmp to the top of the tree. Whore the growth of the stem is very encentrin, the wood along the greater lardins las the greatest projurtion of summerwood; thus, in a disk of longleaf, for instance, there

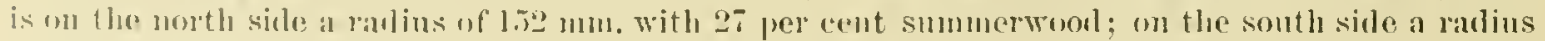

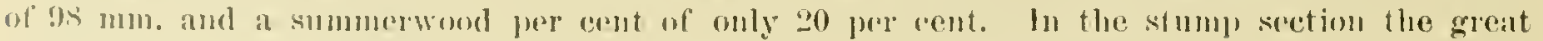

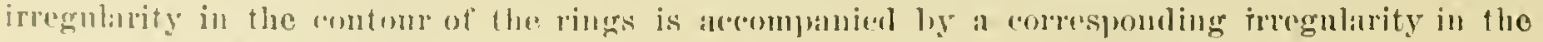
ontline of the summerword.

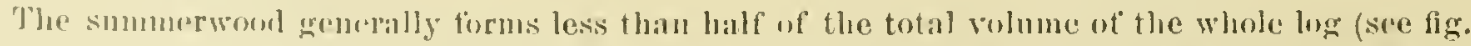
1.3); it forms a greatog jart of the coatse grained worl which was goww while the tree was young than in the fine ringed onter parts of the log, grown in the old age perion. It also forms a grrater part in the volume of the but than of the togu loge and thus fnlly explains the well-known difference in the woight, struggtla, aud value of the various parts of the tree. The following talsle serves to ilhastrate this joint. The mumbers in mall line rofer to the arorage values for the same ten ammal

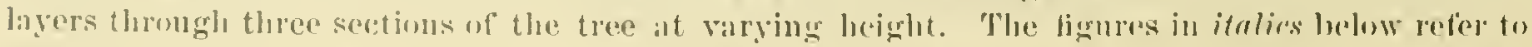

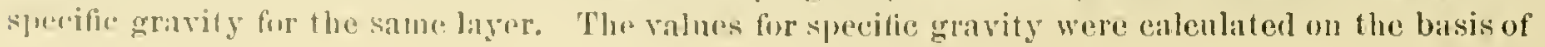


allowing a specific gravity of 0.40 for springwool and 0.90 for summerwool, the values for the eutire disks as actually observed being given below:

Summerwood per cent and specific gravily in variows parts of a tree of Longleaf I'ine.

\begin{tabular}{|c|c|c|c|c|c|c|c|c|c|c|c|c|c|c|c|c|c|c|c|c|c|c|c|c|c|}
\hline Rings from periphery. & $\begin{array}{l}1 \\
\text { te } \\
10\end{array}$ & $\begin{array}{l}11 \\
10 \\
20\end{array}$ & $\begin{array}{l}21 \\
10 \\
30\end{array}$ & $\begin{array}{l}31 \\
t, 0 \\
40\end{array}$ & $\begin{array}{l}41 \\
20 \\
50\end{array}$ & $\begin{array}{l}51 \\
t .0 \\
60\end{array}$ & $\begin{array}{l}61 \\
+0 \\
70\end{array}$ & $\begin{array}{l}71 \\
\text { to } \\
80\end{array}$ & $\begin{array}{l}81 \\
t \theta \\
90\end{array}$ & $\begin{array}{c}91 \\
10 \\
100\end{array}$ & $\begin{array}{c}101 \\
\text { to } \\
110\end{array}$ & $\begin{array}{c}111 \\
\text { to } \\
120\end{array}$ & $\begin{array}{c}121 \\
\text { to } \\
1330\end{array}$ & $\begin{array}{l}131 \\
t 0 \\
140\end{array}$ & $\begin{array}{c}141 \\
10 \\
150\end{array}$ & $\begin{array}{c}151 \\
\text { to } \\
160\end{array}$ & $\begin{array}{c}161 \\
10 \\
170\end{array}$ & $\begin{array}{c}171 \\
(1) \\
180\end{array}$ & $\begin{array}{c}181 \\
\text { to } \\
190\end{array}$ & $\begin{array}{c}191 \\
10 \\
200\end{array}$ & $\begin{array}{c}201 \\
\text { to } \\
210\end{array}$ & $\begin{array}{c}211 \\
\text { to } \\
220\end{array}$ & $\begin{array}{c}221 \\
\text { to } \\
2: 0\end{array}$ & $\left|\begin{array}{c}231 \\
10 \\
236\end{array}\right|$ & $\begin{array}{l}\text { Aver } \\
\text { age } \\
\text { fur } \\
\text { total. }\end{array}$ \\
\hline Seetion I, 3 feet from ground. & $\begin{array}{r}39 \\
.59\end{array}$ & $\begin{array}{r}41 \\
102\end{array}$ & $\begin{array}{r}40 \\
.60\end{array}$ & $\begin{array}{r}12 \\
.61\end{array}$ & $\begin{array}{r}38 \\
.59\end{array}$ & $\begin{array}{r}35 \\
.67\end{array}$ & $\begin{array}{r}45 \\
.62\end{array}$ & $\begin{array}{r}32 \\
.56\end{array}$ & $\begin{array}{r}44 \\
699\end{array}$ & $\begin{array}{c}66 \\
.78\end{array}$ & $\begin{array}{r}43 \\
61\end{array}$ & $\begin{array}{r}43 \\
.61\end{array}$ & $\begin{array}{c}52 \\
.66\end{array}$ & $\begin{array}{r}56 \\
63\end{array}$ & $\begin{array}{r}48 \\
61\end{array}$ & $\begin{array}{r}46 \\
.63\end{array}$ & $\begin{array}{r}48 \\
.144\end{array}$ & $\begin{array}{r}43 \\
. / j 1\end{array}$ & $\begin{array}{l}47 \\
.03\end{array}$ & $\begin{array}{l}47 \\
.63\end{array}$ & $\begin{array}{r}52 \\
. t i\end{array}$ & $\begin{array}{l}45 \\
.62\end{array}$ & $\frac{42}{61}$ & $\begin{array}{r}a 15 \\
.47\end{array} \mid$ & $\begin{array}{r}45 \\
6255\end{array}$ \\
\hline 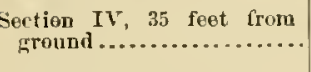 & 26 & 24 & 25 & 34 & 28 & 24 & 20 & 24 & 35 & 49 & 31 & $\begin{array}{r}33 \\
56 i\end{array}$ & $\begin{array}{ll}43 \\
61\end{array}$ & 34 & $\begin{array}{r}40 \\
60\end{array}$ & $\begin{array}{r}31 \\
55\end{array}$ & $\begin{array}{c}34 \\
57\end{array}$ & $\begin{array}{c}33 \\
.56\end{array}$ & $\begin{array}{r}33 \\
36\end{array}$ & $\begin{array}{l}31 \\
55\end{array}$ & $\begin{array}{r}22 \\
51\end{array}$ & $\begin{array}{l}1,6 \\
43\end{array}$ & & . & 29 \\
\hline $\begin{array}{l}\text { Section VII, } 70 \text { feet from } \\
\text { ground..................... }\end{array}$ & $\begin{array}{r}23 \\
.51\end{array}$ & $\begin{array}{l}16 \\
.45\end{array}$ & $\begin{array}{r}17 \\
.48\end{array}$ & $\begin{array}{r}18 \\
.49\end{array}$ & $\begin{array}{r}18 \\
.49\end{array}$ & $\begin{array}{r}20 \\
.50\end{array}$ & $\begin{array}{r}16 \\
.48\end{array}$ & $\begin{array}{r}20 \\
.50\end{array}$ & $\begin{array}{r}18 \\
.4 ?\end{array}$ & $\begin{array}{r}26 \\
.53\end{array}$ & $\begin{array}{r}21 \\
.50\end{array}$ & $\begin{array}{l}24 \\
.32\end{array}$ & $\begin{array}{r}19 \\
.49\end{array}$ & $\begin{array}{r}19 \\
.49\end{array}$ & $\begin{array}{r}22 \\
.51\end{array}$ & $\begin{array}{c}16 \\
45^{\circ}\end{array}$ & $\begin{array}{r}18 \\
.49\end{array}$ & $\begin{array}{c}c 2 \\
.11\end{array}$ & & & & & & . & $\begin{array}{r}18 \\
.490\end{array}$ \\
\hline
\end{tabular}

$a$ Six rings next to pith.

b Two rings.

cone ring.

The ebsersed values of specific gravity for tho thren sections are $0.700,0.560$, and 0.490, rospectively.

It will be noticed that the greatest difference between the ealenlated and the actnal valne of specific gravity oceurs in the section at the stmmp. This is fully accounter for lyy the fact that large amounts of resin, not considered in the valnes of smmerwool per cent, always neenr in this portion, adling from 5 to 20 per eeut to the weight of the wood.

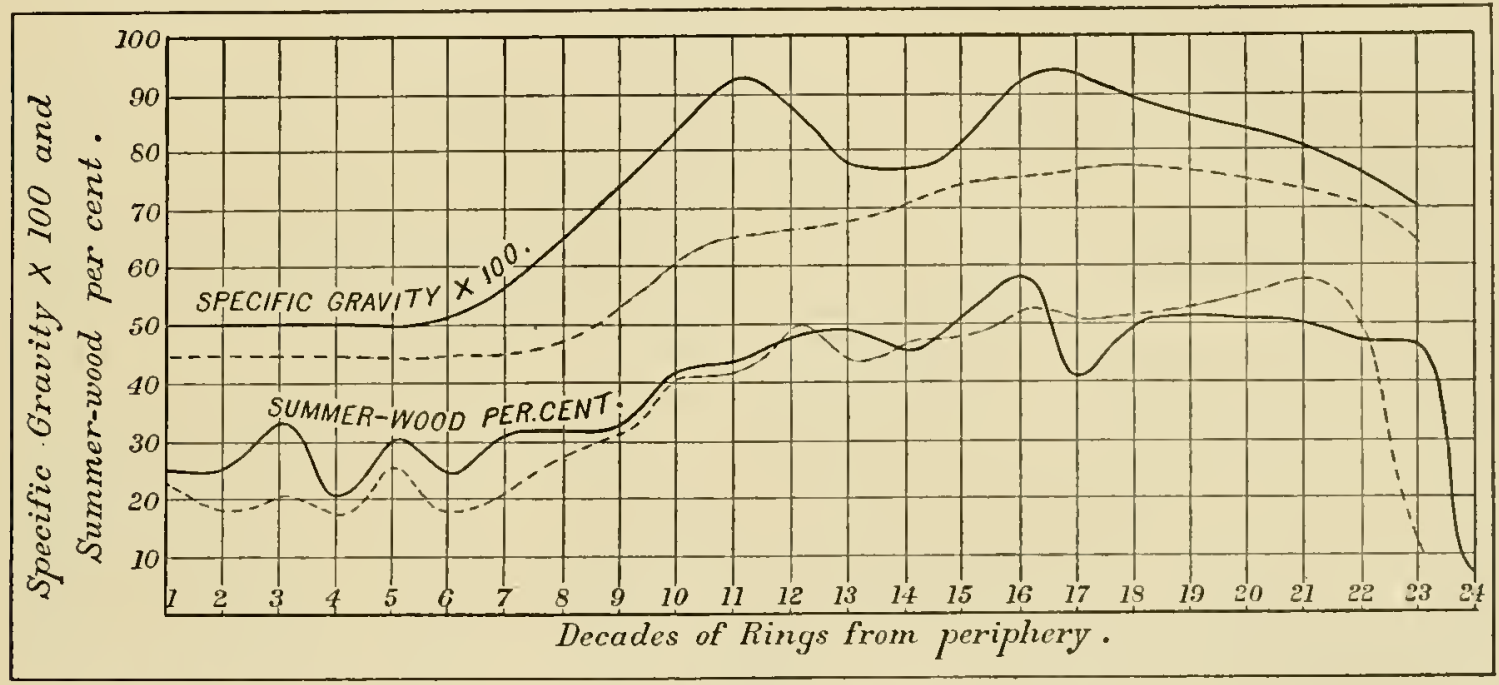

Fia. 14.-Variation of specific gravity with snmmerweod per cent and age of section in Lengleaf Pine, the solicl lines reforring to a section 3 feet from tho gronnd, the dutted lines to ono 14 feet from the ground. (Specific gravity as actually obscrved on pieces of 1 inch radial extent.)

In struted trees the summerwood forms nearly as great a per cent of the total volume for the whole tree as in thrifty trees of the same age, but in the stunted growth, or extrmely narrow ringer portion of otherwise normal trees, the per cent of summerwool is markedly decreased, a feature which beconic conspienons in the lighter color of the woor of such portions. (See diagrani, fig. 15.) Where, out the other hand, the rate of growth in an old tree is sudilenly increased by the accessibility of more light, for instance, the summerwood per cent also is disproportionately increased, but this disproportion appears to he more transient, i. e., a decrease in the summerwood per cent sets in sooner than for the rate of giowth or the wilth of the rings. (See fig. 15.) In some of the rapidly grown Loblolly and suruce Pine the summertrool forms but a small part of the first ten to twenty years' growth, and in all cases the first few rings about the pith have but little summerwood. In general, the smmmerwood per cent varies in the sereral species as well as in the indiridnal with the weight of the wood, which is least in the Spruce l'ine. greatest in Cnban and Longleaf l'ine, and stauls between these in Loblolly and Shortleaf. It furnishes a very useful criterion to distinguish between these grouls and especially to select strong timber. 


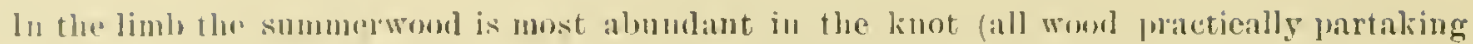

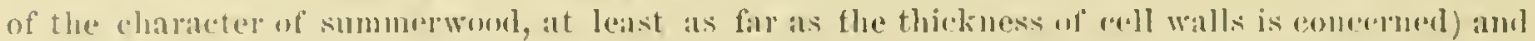
in the part uext to the stem, leneasing with the distanee from the tumls. As might lee expecterl, it also finms at larger per cent of the wood of the underside of limbs and the concave portions of bent trunks.

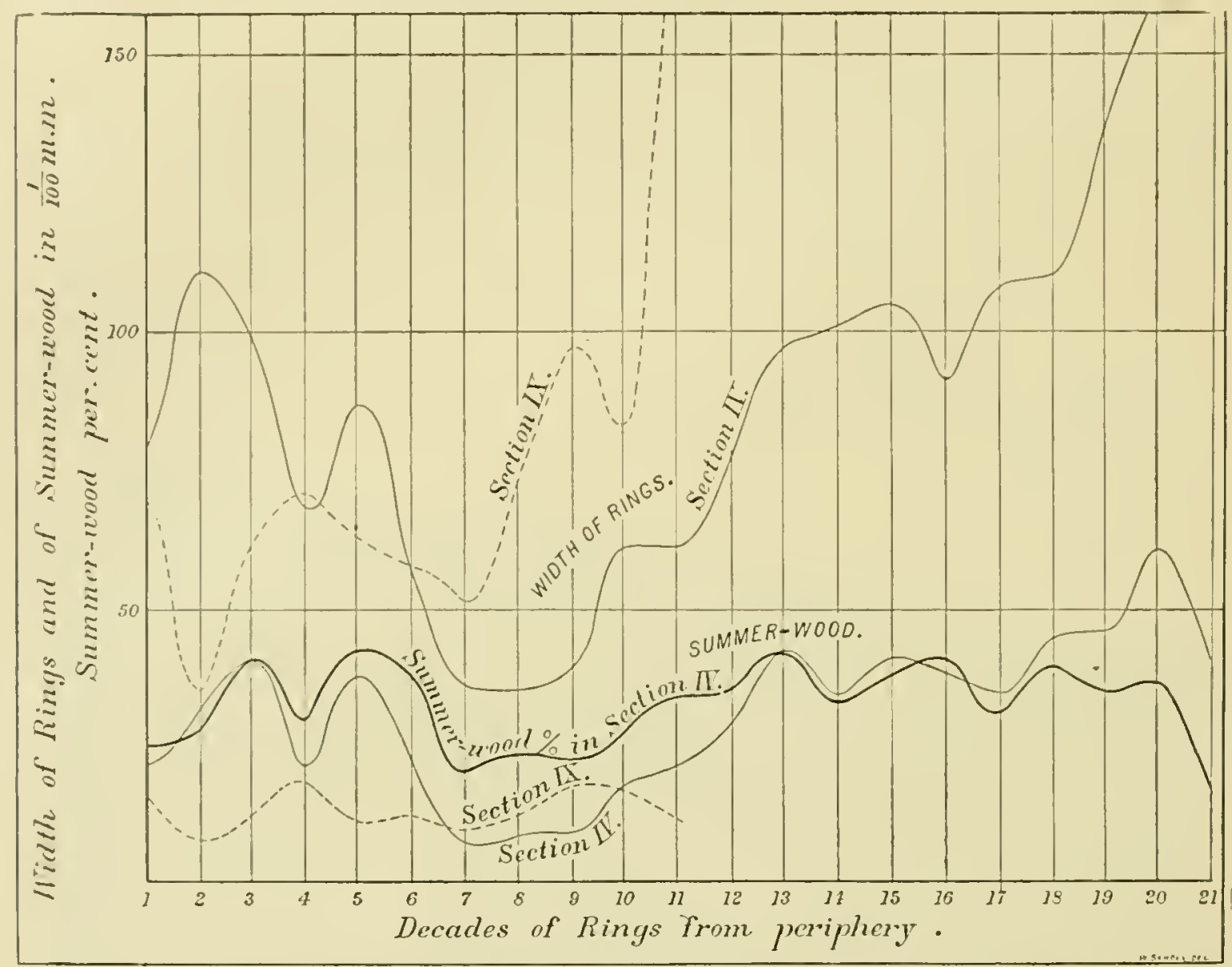

Fio. 15. - Variatinn of smmmerwool jer cent with rate of growtl (wilth of ring), in treo No. 3, Longlraf l'ine.

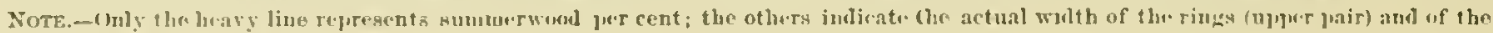

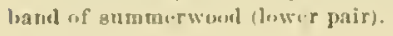

\section{GRAIN OF THI: WOOL.}

Thongh usually ruite straight grained, the woor of these species is by uo means always so.

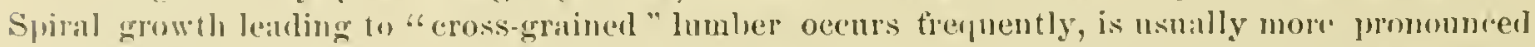
in the halsal portions at" the tree. and commonly varies from fith to bark in the same log. Wavy errain resembling that of the maple (curly maple) lats not been olserverl, but an irreanlar wavy grain, due to the fact that the surface of the trunk for mang years is covered with small, low rminences, 1 to a lew inches across, is frequently secu, especially in longleat line, and lrats to remarkahly pretty patterns. Enfortunaty the contrast of spring and summer woor heing so very funnument. the digures are somewhat wbtrusive aud, therefore, not fully alpmeciated.

\section{MIIUTE ANATUY}

Thu mimte structure or histolugy of the wool of the live species under consideration is that

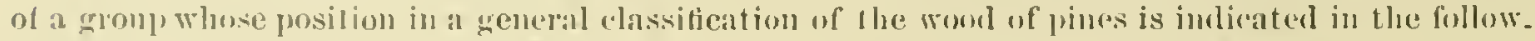

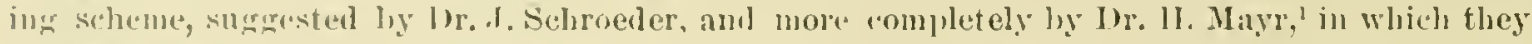
appear as part of erroup 2 of Section 1.

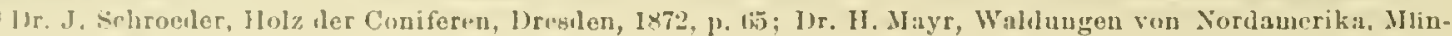
chen, $189 \%$, 1. 126. 
Sretion 1. Walle of the tracheids of the pith ray with dentate projections.

a. One to two larew, kimple pite to each tracheirl on the radial walls of the cells of the pith ray.-(irong 1. kepresured in this comtry by l'. resinosa.

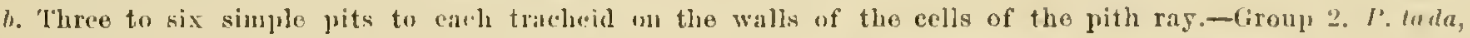
palustris, cte., including most of our "hare" and "yellow" pines.

Seretion ?I. Walls of tracheids of pith raly smooth, withont dentate projections.

a. Wne or two large pits to each trichein on the radial walls of each cell of tlu' pith ray. -Gronp, 3. I'. strobus, lamberliana, and other true white pines.

b. Three to six small pits on the radial walls of each cell of the pith ray.-Croup 4. I'. paryana, ant ot lu'r nut pines, including also I'. balfouriana.

The general features of structure of coniferous wools are represented in the accompanying cut (fig 16i).

The structural elements, as in all pine, are few and simple and consist of ( $(1)$ tracheids, the common wood fibers, forming over 90 per cent of the volume; $(b)$ mednllary or pith rays, minute cell aggregates composed of two linuls of cells, scarcely visible without magnifier and then only on the raclial section, yet forming about 7 to 8 per cent of the volume and weiglut of the wool in these spe. cies; (c) resin lncts, small passages of irregnlar length surrounded by resin-secreting cells, seat tered through the wond, but forming two mure or less connected systems, one rumning in the direction of the fibers, the other at

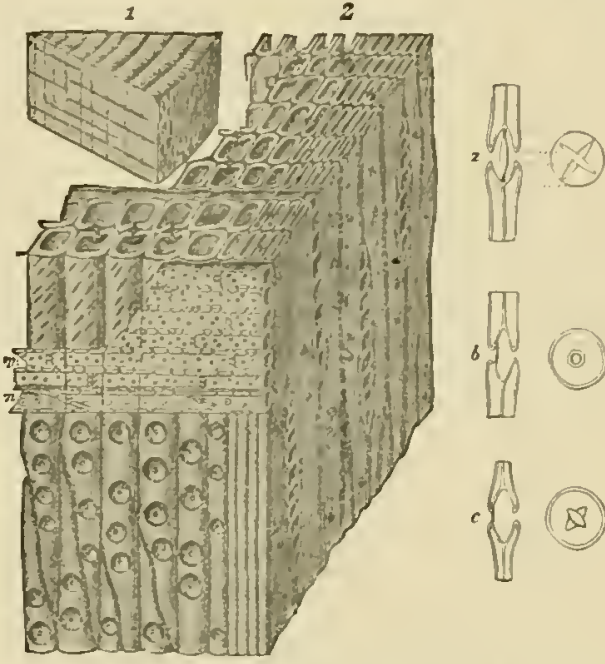

F1G. 16.-Schematic representation of coniferms wrod structure: wood of alruec-1, natural siza; 2 , small jart of one ring magniticl 100 times. The verpical tubes are wood fibers, in this case all "tracheids," $m$, medullary or pith ray; $n$, transterse tricheids uf pith ray; $a, b$, and $c$, bortered pits of the tracheids moro enlarger?.

right angles to the first, the individual ducts of the latter system alrays occupying the middle portion of melullury rays (see P'l. XXVIl).

The traeheids, ol common wond fibers, are alike in all five speeies, and resemble those of

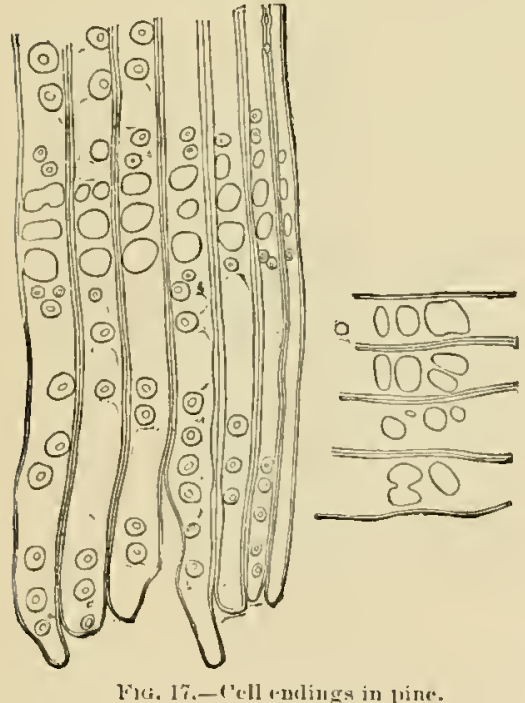

Fuc, 17.-1'cll r-wlings in pine. other pines; they are slender tubes, 4.5 to $6 \mathrm{~mm}$. (about onefourth inch) long, forty to one lumdred times as long as thick, usually liexagonal in cross section, with sliarp or more or less ronuder outlines (see l'l. XXI), flattenerl in tangential direction at both euds (see I'l. XXI, A t'), the dianeter in raclial direction being 45 to $55 \mu$ (about 0.001 inch) in the springwood, and abont lialf that, or 21 to $25 \mu$, in the summerwood, and in tangential direetion about $40 \mu$ on the arerage in their midule. They are arranged in regular ralial rows (see l'l. XXI), which are continums throngh an innlefinite number of rings, but the number of rows increasing every year to aceommolate the increasing circumference of the growing stem. (bee Pl. XXI, C c.) The fibers of the same row are practically conterminous, i. e., they all have abunt the same length, thomgh at their emls they are often bent, slightly distorted, and usilally separated (nee Pl. XXI. I) "; also fig. 1i), their neighbors filling ont the interspaces. There is no constant diflerence in the dinensions of these fibers in the different species here eonsileresl. lu every tree the libers are shortest and smallest near the pith of any section, rapilly indeasing in size from the pitl outwan, and reanhing their full size in abut the teuth to trenticth ring from the pitlo. To illustrate: In a section of Longleat l'ine, 10 feet from the gromul, the diameter of tranchess in raclial direction is in $\mu=0.001 \mathrm{~mm}$ : 


\begin{tabular}{|c|c|c|c|}
\hline $\begin{array}{l}\text { Sumber ut } \\
\text { ringe frome } \\
\text { fentur. }\end{array}$ & $\begin{array}{l}\text { Sipring: } \\
\text { wonl. }\end{array}$ & $\begin{array}{l}\text { Silummi-r. } \\
\text { womul. }\end{array}$ & A. "riges \\
\hline 1 & $\mu_{24}$ & ${ }_{15}$ & ${ }^{\mu}$ \\
\hline 2 & 31 & 33 & 32 \\
\hline is & 15 & 21 & 11 \\
\hline 4 & 43 & 26 & 36 \\
\hline 7 & 50 & 20 & 38 \\
\hline 10 & 52 & $\because \pi$ & 36 \\
\hline 2433 & 52 & 2 & 36 \\
\hline 415.8 & 52 & $2 \pi$ & $: 37$ \\
\hline
\end{tabular}

As msual in ennifers, the tracheils are latgest in the routs and smallest in the limbs. In these

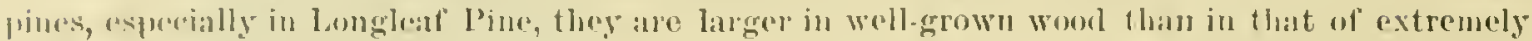

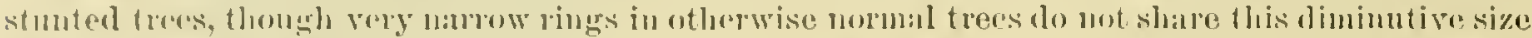

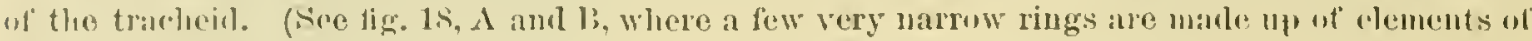
normal sime.)
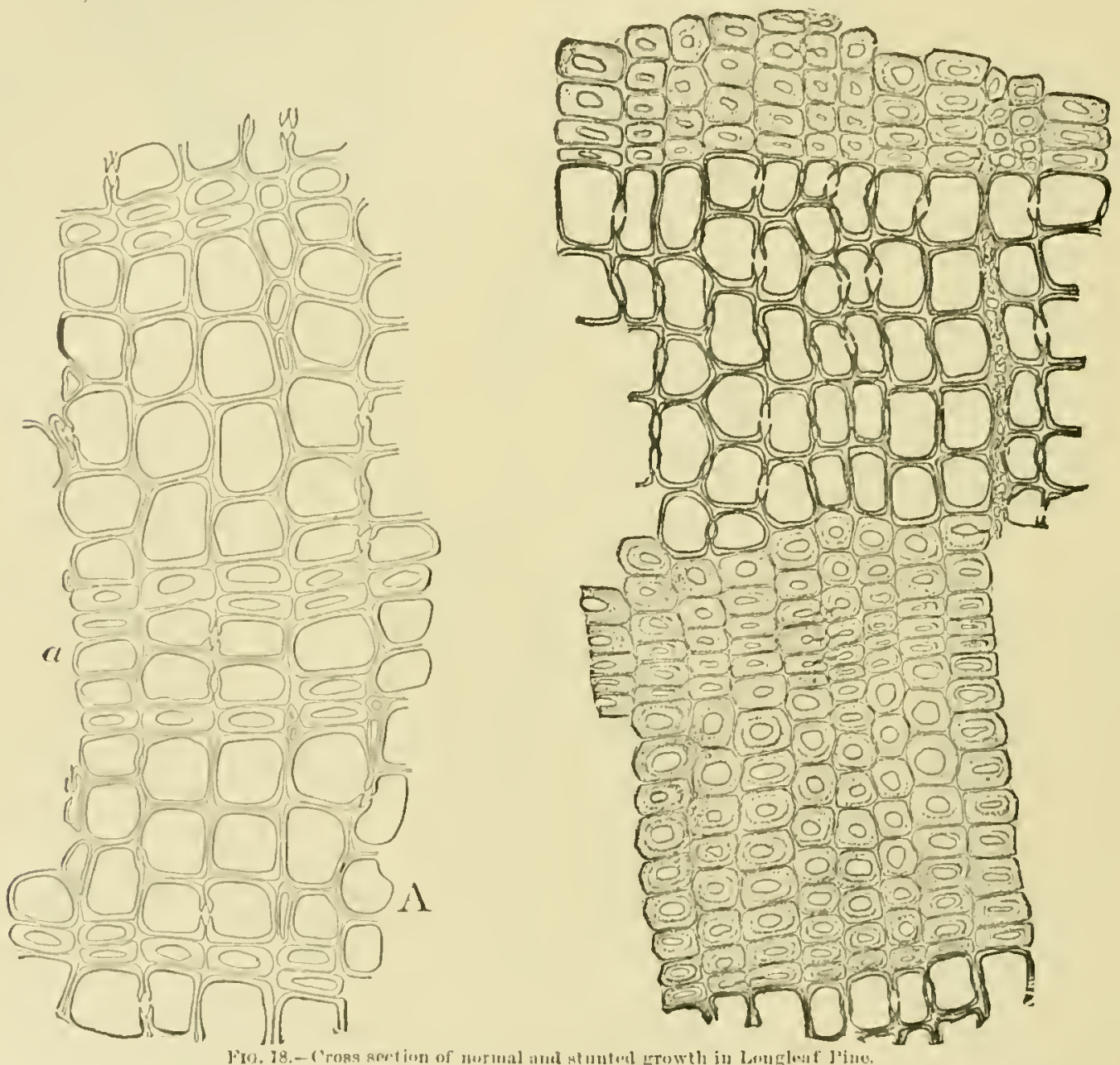

The following average figures illustrate the diblorenere between wood from very sfunted thees am that of monal trees in Longleal l'ine, of which we give an arrage from an exfeusive series examined:

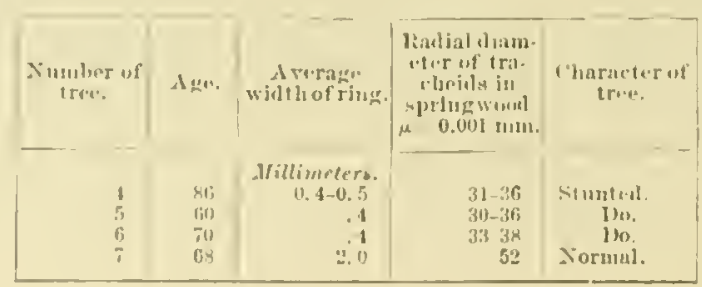


As soon as the average width of the annul rings gots above $0.5 \mathrm{~mm}$, the dimensions of the elements approateh the normal. Thus, in trees Nos. 1 and 2, with average width of anmual rings 0.5 to $0.6 \mathrm{~mm}$., the average dianeter of the tracheids in radial direction is 35 to $48 \mu$.

Normally, the diameter in radial direction is greatest in the first-formed or immer part of any ring, and decreases even before the summerwood is reached. In narrow rings witl an abrupt begiming of the smumerwood, so eommon in these Sonthern pines, the diameter is fulte constant throughout the springwood, but changes, together with the thickness of the wall, quite suddenly with the beginning of the summerwood, thus adding to the sharpmess of the outlines of the two parts. (See P'l. XX1; ako fig. 18, B.) In nearly all seetions there is an additional marked deerease in radial diameter in the last 3 to 5 eells of each row, whieh helps to emphrasize the limits of the ring. In the so-called "false" rings, mentioned betore, the cells of the false summerwood part resemble those of the normal summerwood. 'The reeognition of the filse ring as such rests mpon the difference in shape and dimensions of the last cell rows in comparison with those adjoining. In the true summerwood the last cells are mueh lattened, with small lumen and somewhit reduced walls making a sharp definition toward the springwood of the next ring, which is still further aceentuated by the wide lumen and thin wall of the cells of the latter. In the "false" summerwool, ou the eontrary, the end cells are not thattened, and the cells of the light-eolored adjoining zone of wood have but a moderately wide lnmen and comparatively thick walls. The fact that the ontline is less regular and commonly incomplete-i. e., it loes not extend around the entire section-also aids in reegnizing the false rings. In the "lnnes" of both limb and stem referred to above the fibers are smaller, more rounded in eross section, and commonly exhibit conspicnous intercellnlar spaces between them. The walls of these are often much thicker than those of the summerwood of the sane ring at this peint. Since the radial cliameter of the fibers of the smmmerwood is only about half as great as that of the slringwood, it is elear that the number of fibers of the sunmerwood forms a much greater per cent of the total number of fibers than is indicated in the per cent of summerwood given above and based upon its relative wilth. 'Thns, in wood laving 50 prer cent of summerwood there are, in number, twice as many traeheids in the summerwool as in the springwood.

The walls of the cells are generally about 3 to $3 \frac{1}{2} \mu$ thick in the springwood, while in the summerwood they are 6 to $7 \mu$ thick on the taugential side and 8 to $11 \mu$ thick on the radial side of the tiber. Generally it may be said that the thickuess varies inversely as the extent of the wall, i. e., the greater auy diameter the thinner the walls jarallel to this diameter, which gives the impression that each cell is furnished an equal quantum of material ont of which to construct its house and had the tendency of giviug an equal amount to each of its four or six sides.

Generally the absolute wilth of the ring does not affect the thickness of the cell walls, the fibers of wide rings having no thicker walls than those of narrow rings; but when the growth of a tree is unusually suppressed, so that the rings are less than $0.5 \mathrm{~mm}$. (0.02 ineh) wide and eaeh row consists of only a few fibers, the walls of the fibers of the summerwood, lilie those of the lastformed 2 or 3 fibers of ncrmal rings, are thinner, so that in these cases the wood is lighter in color and weight not only becanse there is relatively less summerwood, but also because the fibers of this summerwood have thimner walls. (See fig. 18, A and B.) In very stmuted trees, where the rings are all very narrow, the reduced thickness of the walls is eonnterbalanced by the smaller size of the cells.

All traeheids communieate with each other by means of the characteristic "bordered" pits. the structure of which is shown in tig. 16. These pits occur only on the raclial walls of the fibers, They are most abumdant near the ends of each fiber, fewest in the middle, form broken rows, single or oceasionally double. (Pl. XXIII, C.) As in other pines the pits of the summerwood differ in appearanee from those of the springwood. In the latter the pit appears in the cell lumen (radial view) as a perforated sancer-like eminence; in the former as a mere clett, elongated in the direction of the longer axis of the tiber. (See Pl. XXI, B, $d$ and $e$; Pl. XXIV, D, d and E, $a_{*}$ ) In both the essential part of the pit is similar, a circular or oval eavity resembling a donble convex lens, with a thin membrane dividing it into two equal plano-convex parts. (This membrane is shown only in the drawings, Pl. XXIV, D and L.) In keeping with the small radial diameter of 
the fibers of the summerwoon, these pits are mueh smatler in the summerworl than spungwood, and usually are rery much fewer in number.

The simple pits am in sets and occur only at the points where the fiber touches the cells

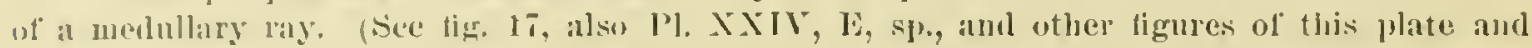

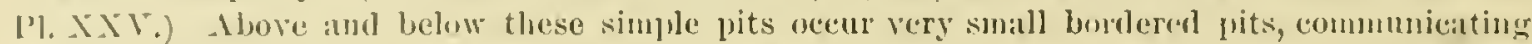
with those of the short transwerse fibers or trachejds which form bart of all medullary rays. (See Pl. XXI1, 1). 1\%.p.)

As in all pines, the medullary or pith rays are of two kinds, the one small, 1 cell wide, and 1 (1) 10-in lurge averages 5 to 7 -cells high; the other large, and earh contilining in the midhle part a thansverse resin inet. (See Pls. XXII, XXII, XXV, and XXVIJ.) Op the former there orcul about 21 to 27 on agch stjuare millimeter (abont $1.5,1000$ per square inch) of tangential section. The sccoml elass are much less abusdant and scattered rery irregularly, so that sometimes areas of several square millineters are found without any of these rays. Generally about one of these rats oecurs to every 1.5 or " square millimeters, or about 300 to 400 per sijure incle of tangential section. In all rays the cell rows forming the mper and lower enge (sce Pl. XXIII) ale composed of short fibers or tracheids (transverse tracheils), while the inner rows contain only parenchyma cells. Occasionally small rays occur which are composed of tracheids ouly. (See I'l. AXI1. C.) Frenuently the rows of parenchyma are separated by one, rarely by two, series of tradeinls (see Pl. XXIT, D, and Pl, XXV, D), giving rise to "louble" op "trijle" rays.

The number of cell rows in each mednllary or pith ray valles from "2 to 10,01 an average trom

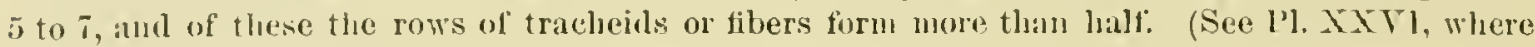
the onter cells or tracheids are markel with dots.)

The tracheicls of the rays have thick walls coveresl with point-aul bar-like jrojections, the boldest of which are on the upper and lower walls and surround the bordered pits. (See I'ls. XXII and XXIIl.) These short tracheids communicate with the common wool fibers, with each other; as well as with the parenchyma cells, by means of small bordered pits, which in this last case are burdered on one side (side of the tracheid) and simple on the other (half-bordened pits). The parenchyma cells vecupying the inner rows of each ray eommmieate in the springwoon jant of the ring with each neighboring tracheirl by 3 to 6 , commonly + to $\bar{n}$, siniple elliptical pits, in the summerwor] by a single narrow, elongated slit-like pit (see Pls. XXII and XXII), and with each other by small, irregular, seattered simple pits.

The walls of these cells are gencrally smooth, but local thickenings, especially on the upjer and lower walls and surounding the pits, occur quite frequently, thongh not regularly.

The parenchyma cells of the rays are nsually somewhat broader and higher than the fibers, the average height fin both heing about 21 to $27 \mu$, the avelage wilth about $20 \mu$, while the length of each cell and fiber, greater in springwood and least in the summerwool, is from two to ten times as great is the height. Assuming $25 \mu$ and $20 \mu$ to represent the average height and width, and allowing 25 lays of 6 cell rows each to each square millimeter of tangential section, then the rays form albont 7.5 per cent of the total volume and weight of the wool of these sprecies. An attempt to utilize for purfoses of identification the difference in the number, size, and distribution of these rays, or the proportion between the number of rows of tracheids amb thuse of parenchyma cells, as was done ly I)r. J. Srlnoeder. ${ }^{1}$ las not been successful, and appears of litthe promise.

The large rays with transierse resin ducts resemble the smaller rays described. On I'l. XXV at $A$ snch a ray is seen both in radial and tangential section. Series of transverse tracheids necupy the unfer and lower elge, but the interior, unlike that of common rays, is sereral cells wide, ancl contains an open eluct in its willest portion. (See Pl. XXVIr, r, l.) 'This duet is connonly more or less filled with resin (see I'l. XXVII, E); it is surrombled ly thin-walled secreting cells, and, in the heat wood, often divided or filled up lyy thylosis, i. e.. by very thin walled, mush funferl out cells, growing out of the surromuding secroting cells before the latter perisis.

The walls of the secreting cells are quite thin, those of the remainder of the parmelyma vary to sone extent in the different species. In the Longleaf and Loblolly l'ines the walls of the jarenchyma eomposing the principal part of the ray are generally quite thick (see Pl. XXVII, A-E), 
thicker than those of the cells of ordinary lays, and especially thickened near the simple pits l,y which these eclls communicate with each other. In Cuban and Shortleat this thickening is moth less conspicuns, and absent entirely in many eases (see $\left.I^{\prime}\right] . \widehat{X} \times \mathrm{V}, \Lambda$ ), while in the spruee l'ine it seens wanting altogether.

These dncts exist even in the very first ring (next to the pith), are smaller and more numerous near center, but lave essentially the same structure in the wood of the fitth and later yeils.

The tracheids of the pith rays are wanting next to the pith, lut oceur in all rilys in the onter part of even the tirst ring. The rays in this ring are generally lower, composed of fewer cell rons, lut the cells are larger than in the rest of the wood.

Butl slulpe and size of these medullary rays are very variable; an average of about 0.4 mm. for the height of the ray and $60 \mu$ for the wilth at the resin duet was observed. An attempt to utilize the shape, especially the appearance of the two erlges, as a means of separating the woor of these species has so fill fitiled entirely.

The large resin duets rmuing lengtliwise in the wood or parallel to the common woor fibers are much larger than the transverse ducts, measuring, inclusive of the secretive colls, on an average abont $0.2 \mathrm{~mm}$. (0.005 inch) on their smaller radial diameter and about $0.3 \mathrm{~mm}$. on the tangential. (See Pl. XXI, A, r. r.) They are usually situated in the summerwoud of each ring, often in narrow rings, eansing an irregular sutline. They are smaller and more unmerous nenp the pith, here usually forming several series in one annual ring, more numerons in wide rings thin in narrow oues, but their number per square inch of eross section as well as their dimensions appear to be independent of the width of the rings. In their structure they resemble those of other pines. They are surrounded by thin-waller resin-secreting pareuchyma, part of which often appears as if not directly conneeted with the luct. (See I'l. XXI, A.) In many wases all the tissue between two neigluboling dncts is of this parenelyyma. Longitudinal and transrerse dnets fiequently neet and thus form a continuous network of ducts throughout the wood. 


\section{ILATE XXI.CROSS SECTIONS.}

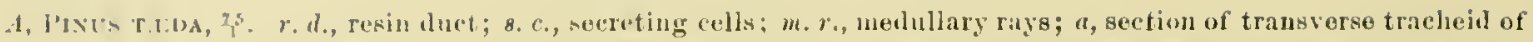
ray; b, the ray leaves the plain of the nevtion a this point, small parts of it reaplearing further on; ce, simple

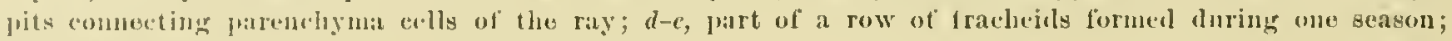
$f$, Hattenol torminal part of al tracheil.

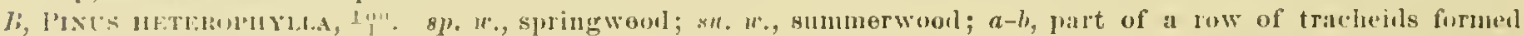
during ont season; r, tertuinal patss of tracheids; $d$, bordered pit in springwood; $e$, same ju summerwood; uther letters is in $A$.

C, l'sus glabis., 12". c, ruw of tracheids doubled; other letters as in $b$.

()riginals, all 3 ipg. 

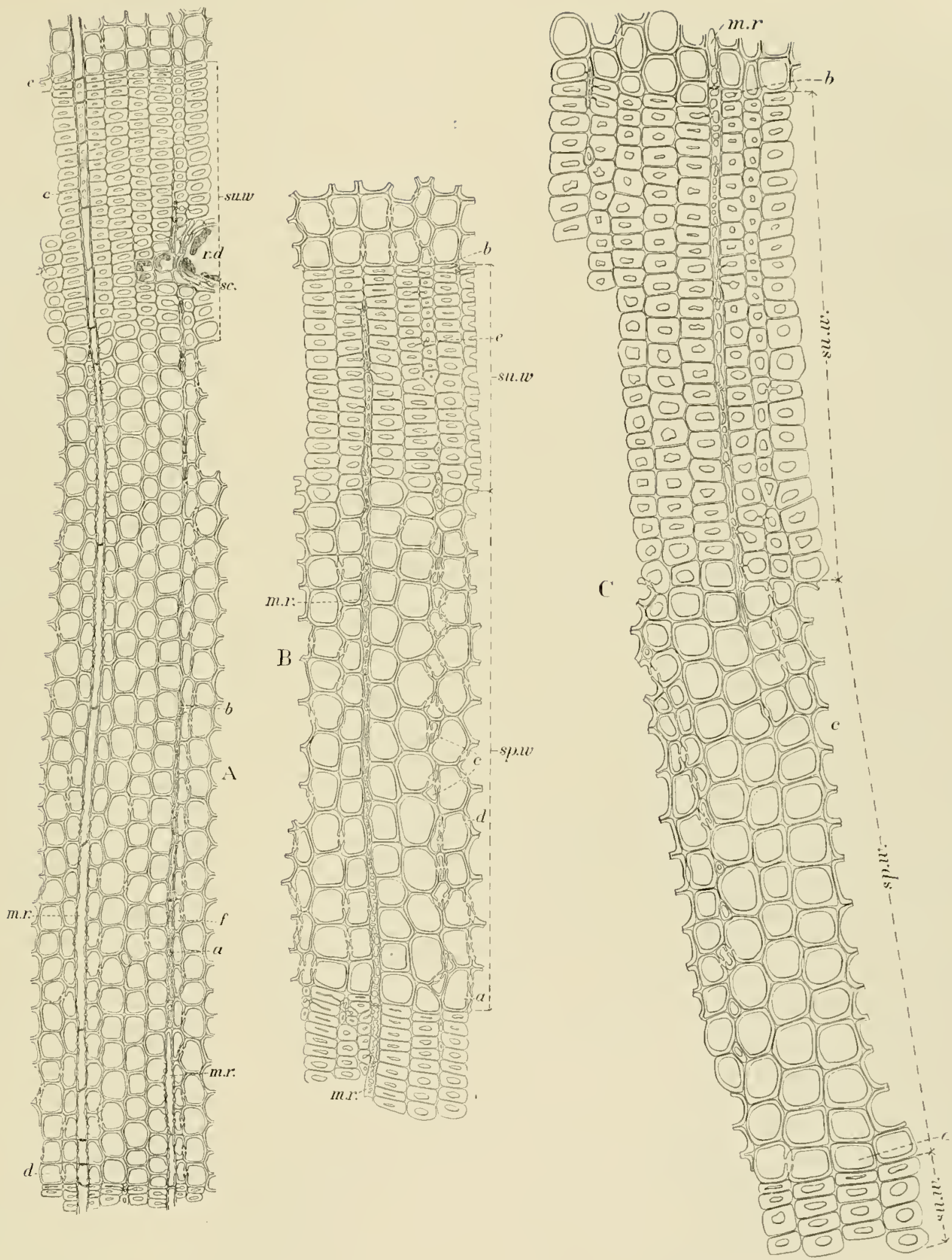

TYPICAL CROSS SECTIONS OF PINUS TAEDA, hETEROPHYLLA, AND GLABRA. 

$17433-$ No. $13-10$ 


\section{PLATE XXII.}

A, PIxUs lichixata. ('ross section of two rugs; sp. $w$. springwood; su. w., summerwomd.

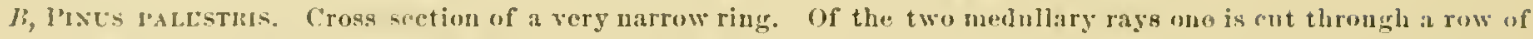
jarenchyua, tho other through a row of trachude.

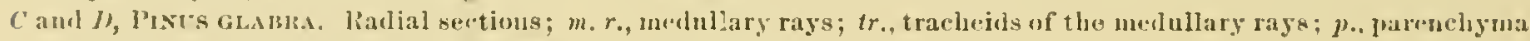
of the same; s. p., simplo pits leading from the parenchyma to the neighluring tracheids or orumon filers

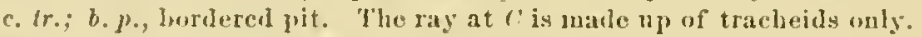

E, l'st: l'Al'stris. lindial section; lettering as in $J$.

Oricrinals marnified: $A, 3 p^{0}$, the rest ${ }^{2} p^{0}$; illustrations: $A,{ }^{1} p^{0}$, the rest $2 p^{0}$. 

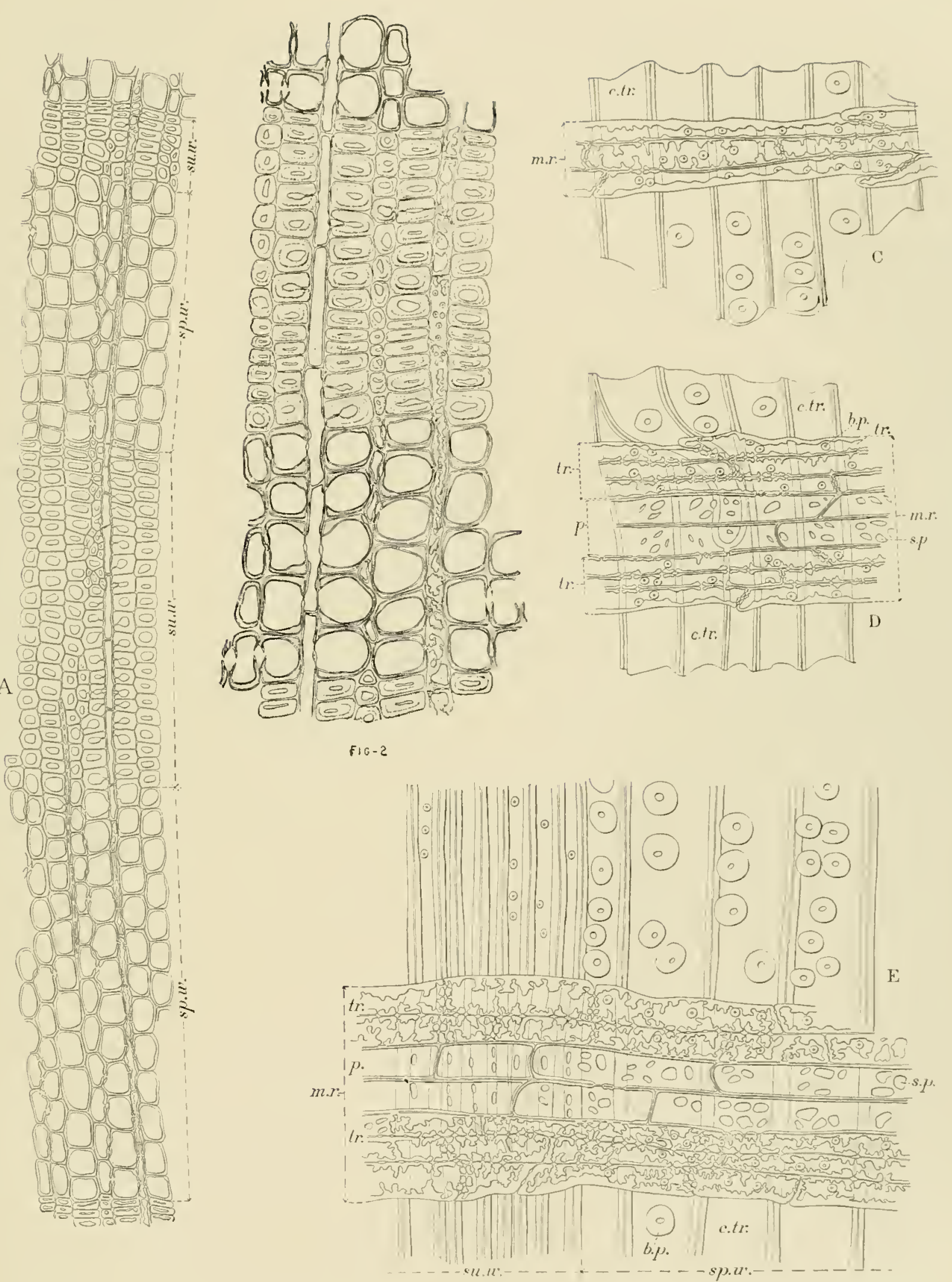

Typical CROSi SECTIONS of PINUS PALUSTRIS AND ECHINATA, AND RAdIAL SECTIONS OF PINUS PALUSTRIS AND GLABRA. 


PLATF XXIII, - RADIAL, SEGTIONS.

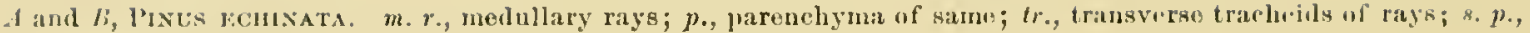
simple pits: l. p., bordered pits; c. tr., common tracheids.

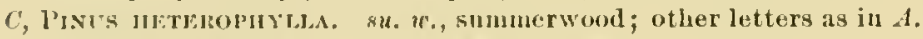

rriginals magnitied s.po; illustrations, ${ }^{2}{ }^{2}$.

118 

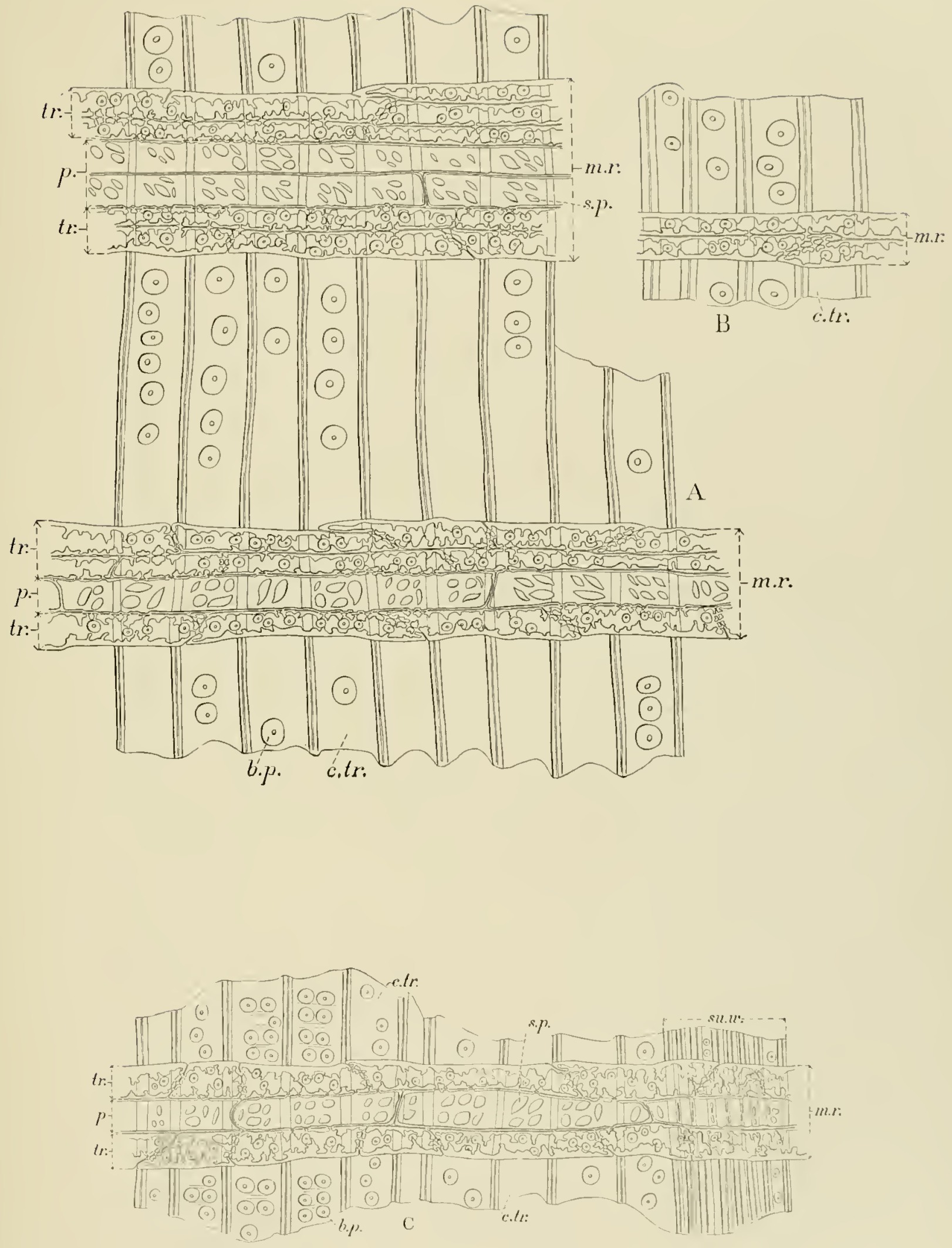

Radial Sections of Pinus echinata and heterophylla. 

PIATE XXIV.-RADIAI, ANI 'TANGENTIA, SECTIONS.

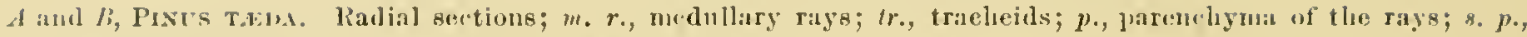
simpl. pit; b. 1 ., bortered pit; r. tr., common tracheids.

(-E, t:ungrential secetions.

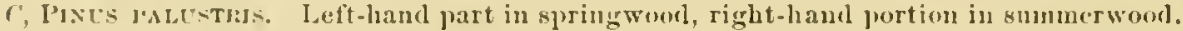

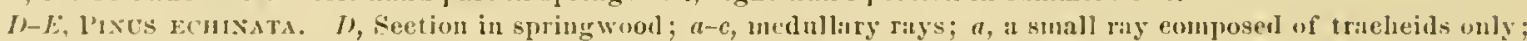

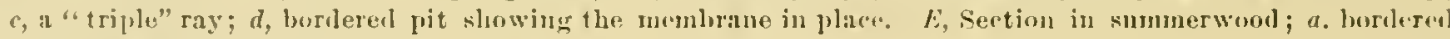
pit, wher letters as in -1 amil $/$.

Magnifieation of origrinals, sqo; of illustrations: I and $l ;, 2 \rho^{0} ; C-l:,{ }^{3} \rho^{0}$. 

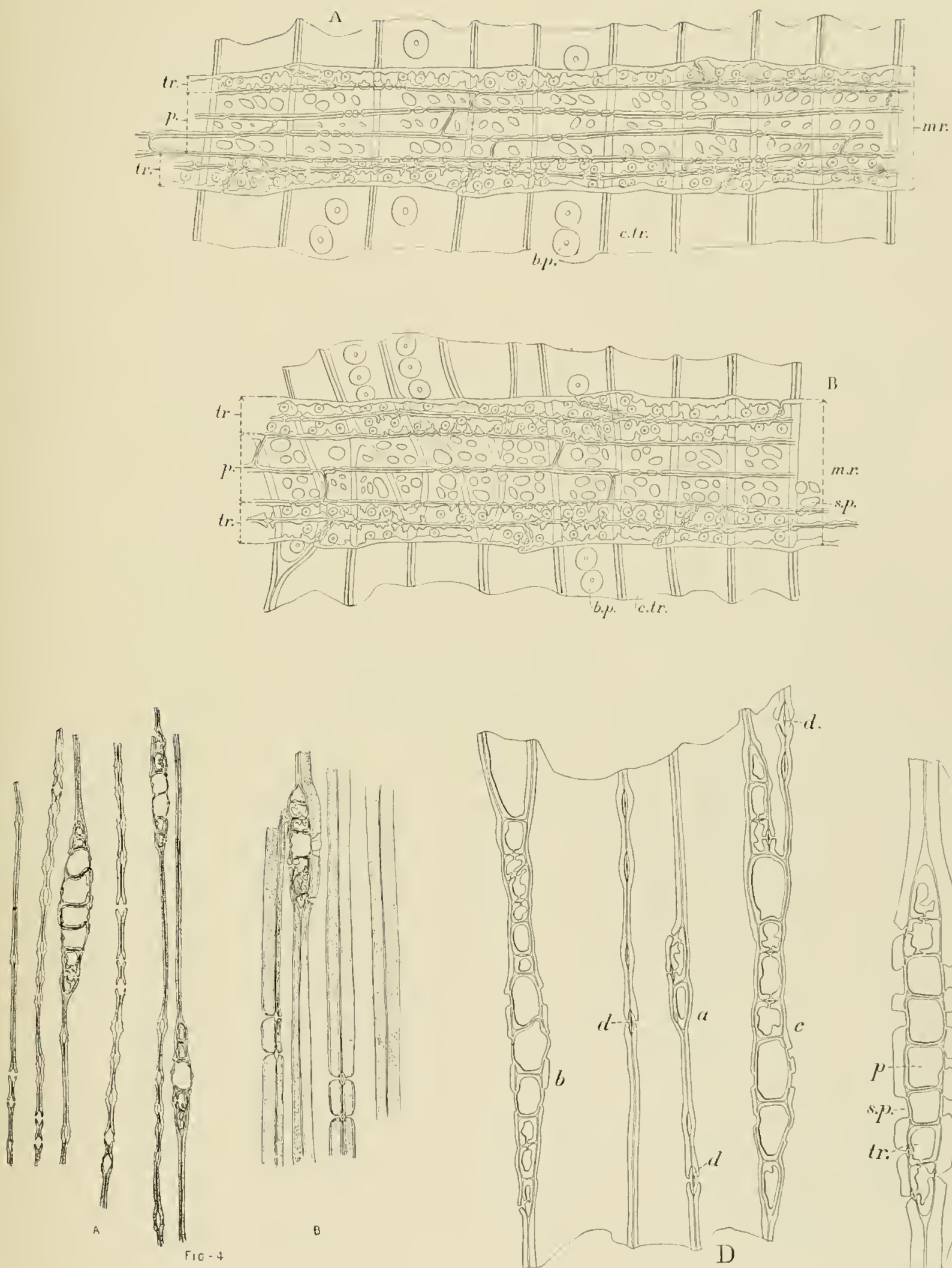

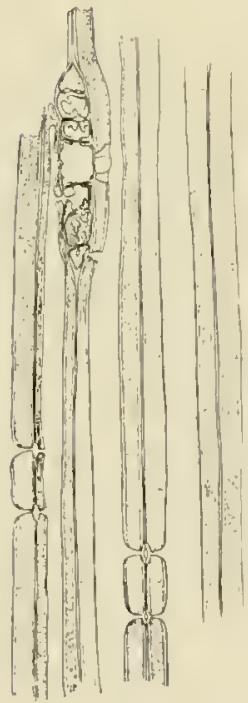

B
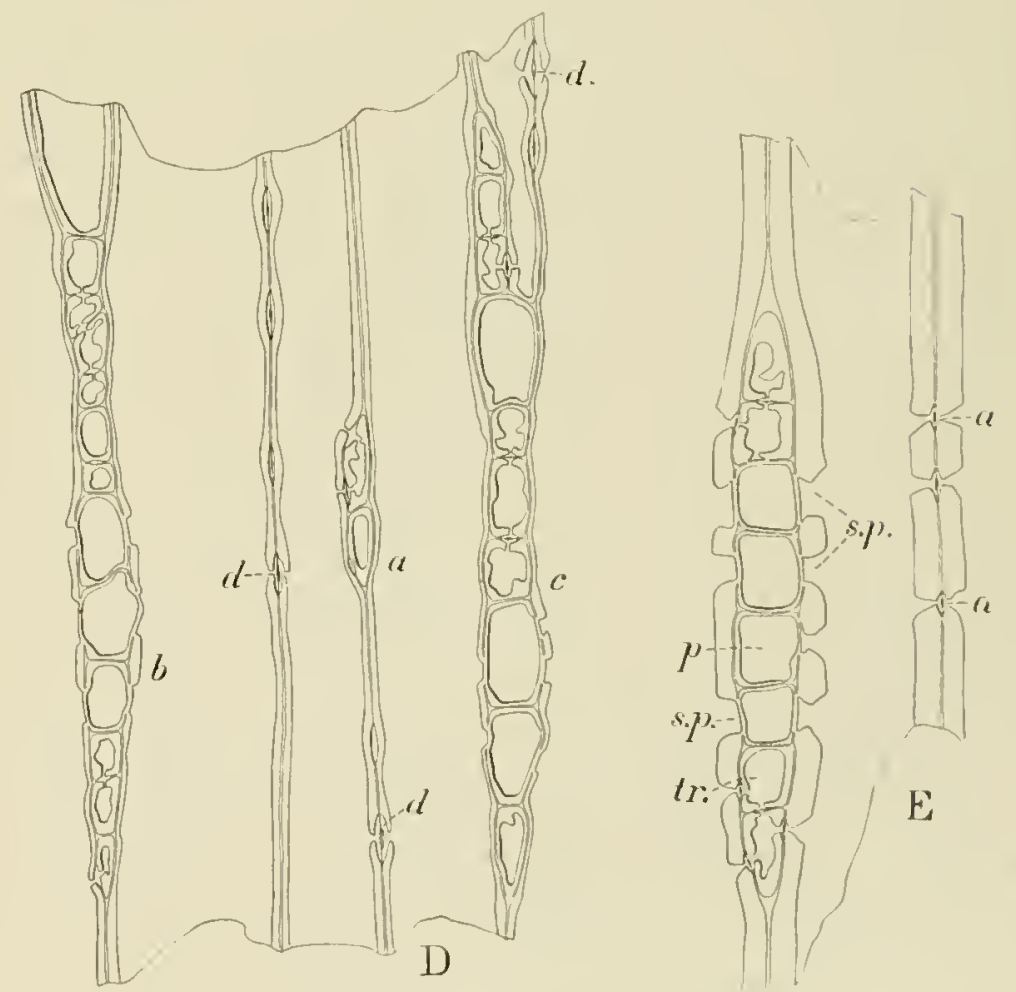

Radial Sections of Pinus taeda and tangential Sections of Pinus palustris and echinata. 




\section{PLATE XXV}

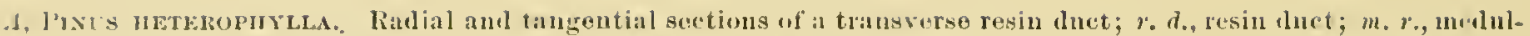

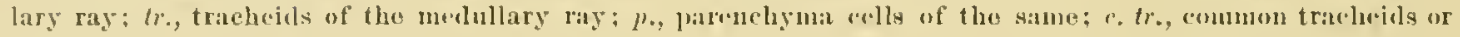
wood biliers.

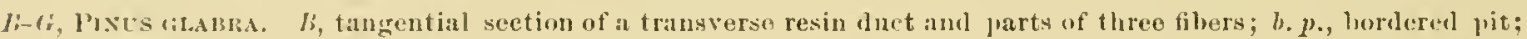
other letters as above: $C_{-} f$, tangential sections of medullary rays, of which $F$ is made up of tracheils only, whilo" $l$ is a "triple" ray.

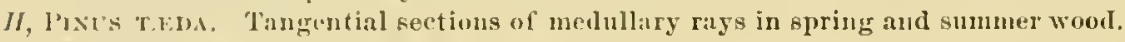

(Triginal magnified 500 times, illustrations about 3 ? 9 . 
Bulietın No. 13, Division of Forestry.

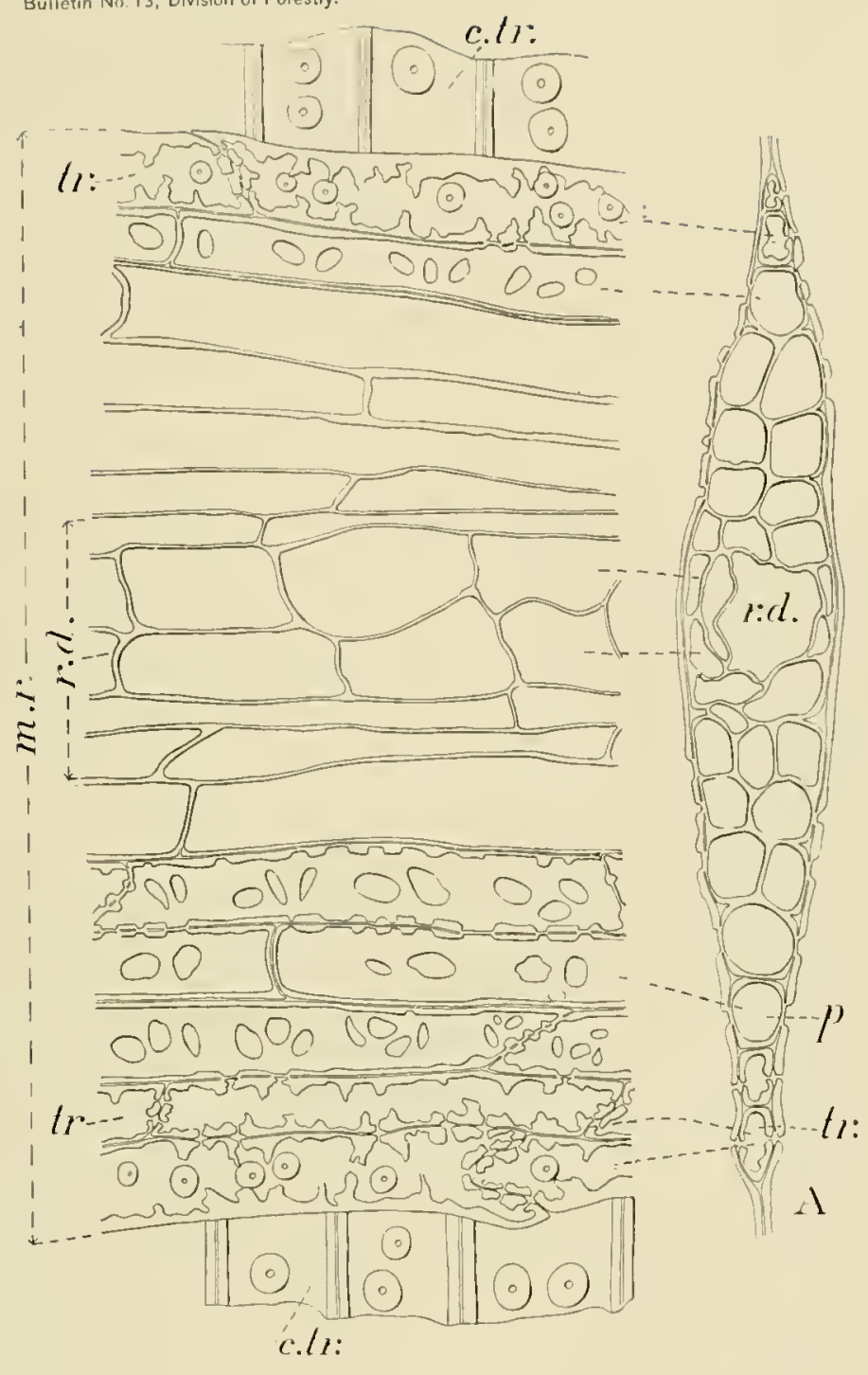

PLATE XXV.
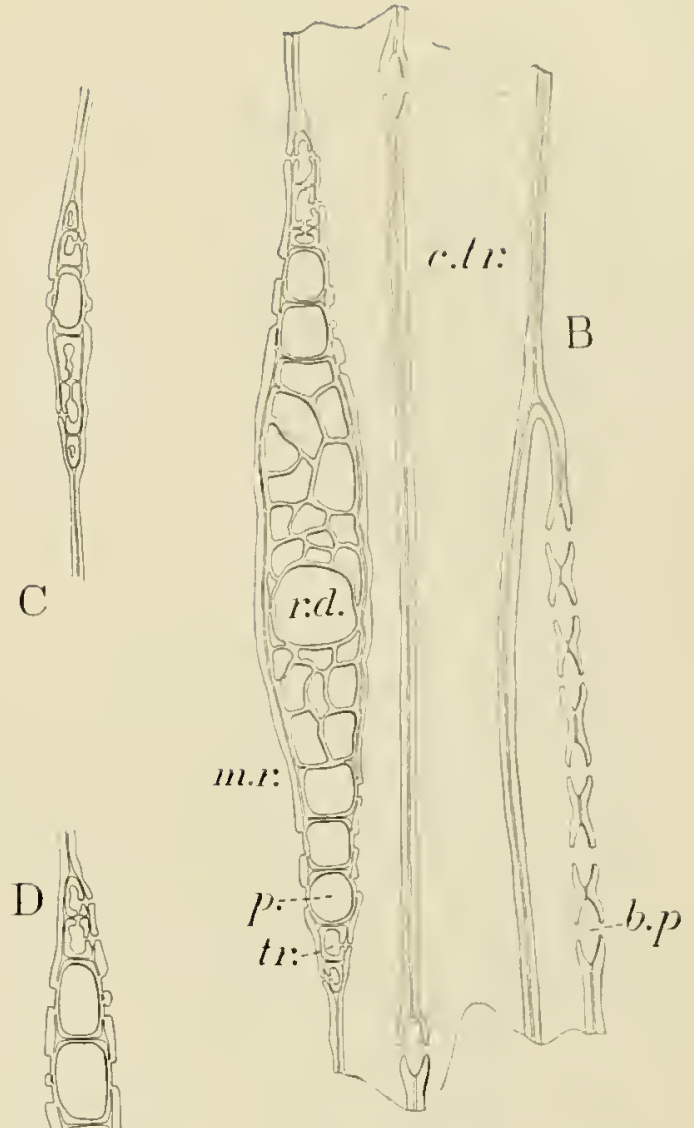

II

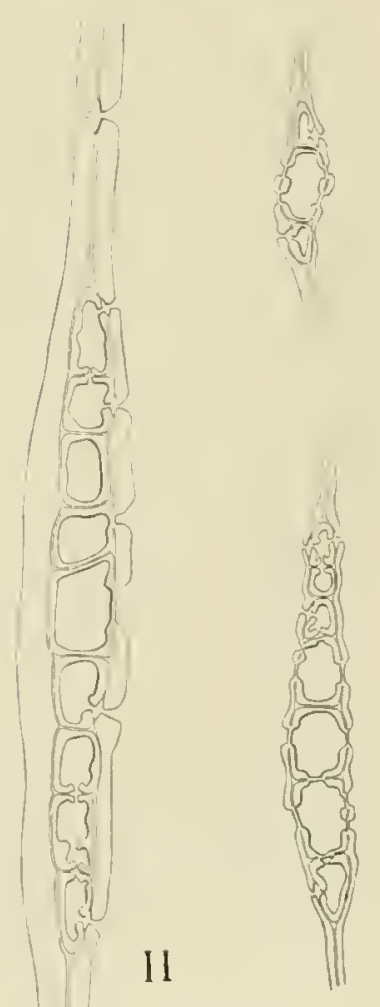

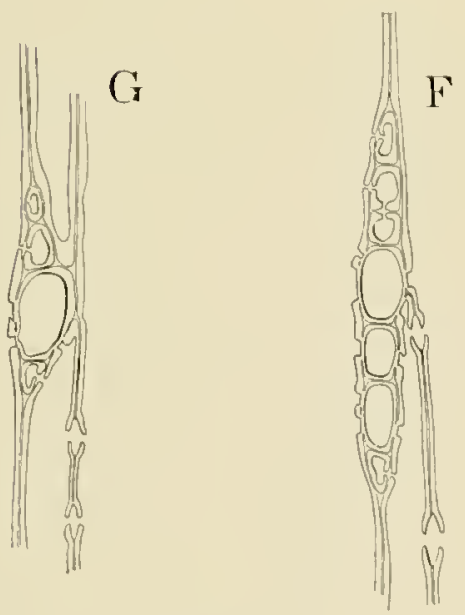

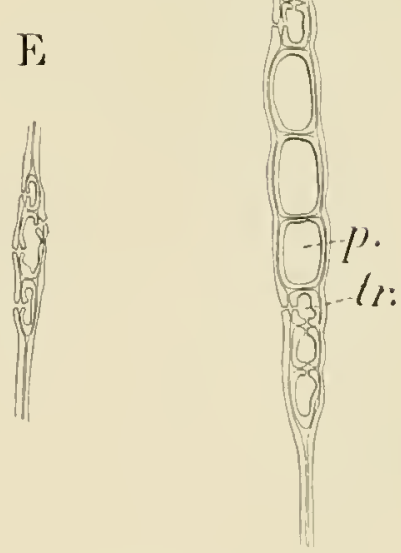

TANGENTIAL SECTIONS OF PINUS TAEA. HETEROPHYLLA, AND GLABRA. 


PIATE XXVI.-TANGENTAL SF:TIONS.

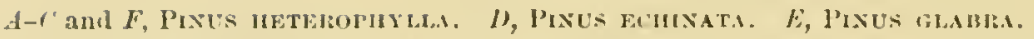

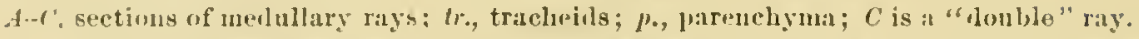

In $1 /-F$, histologieal details are ouitted : they are camera drawiugs slowing number and distribution of medullary rays, and also the proportion of the tracheids to parenehyma in eaeli rity, the former heing imbieated hy dots; $r$. d., transverse resin ducts; $m . r .$, medullary rays.

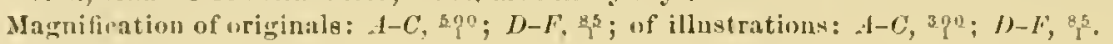

151 

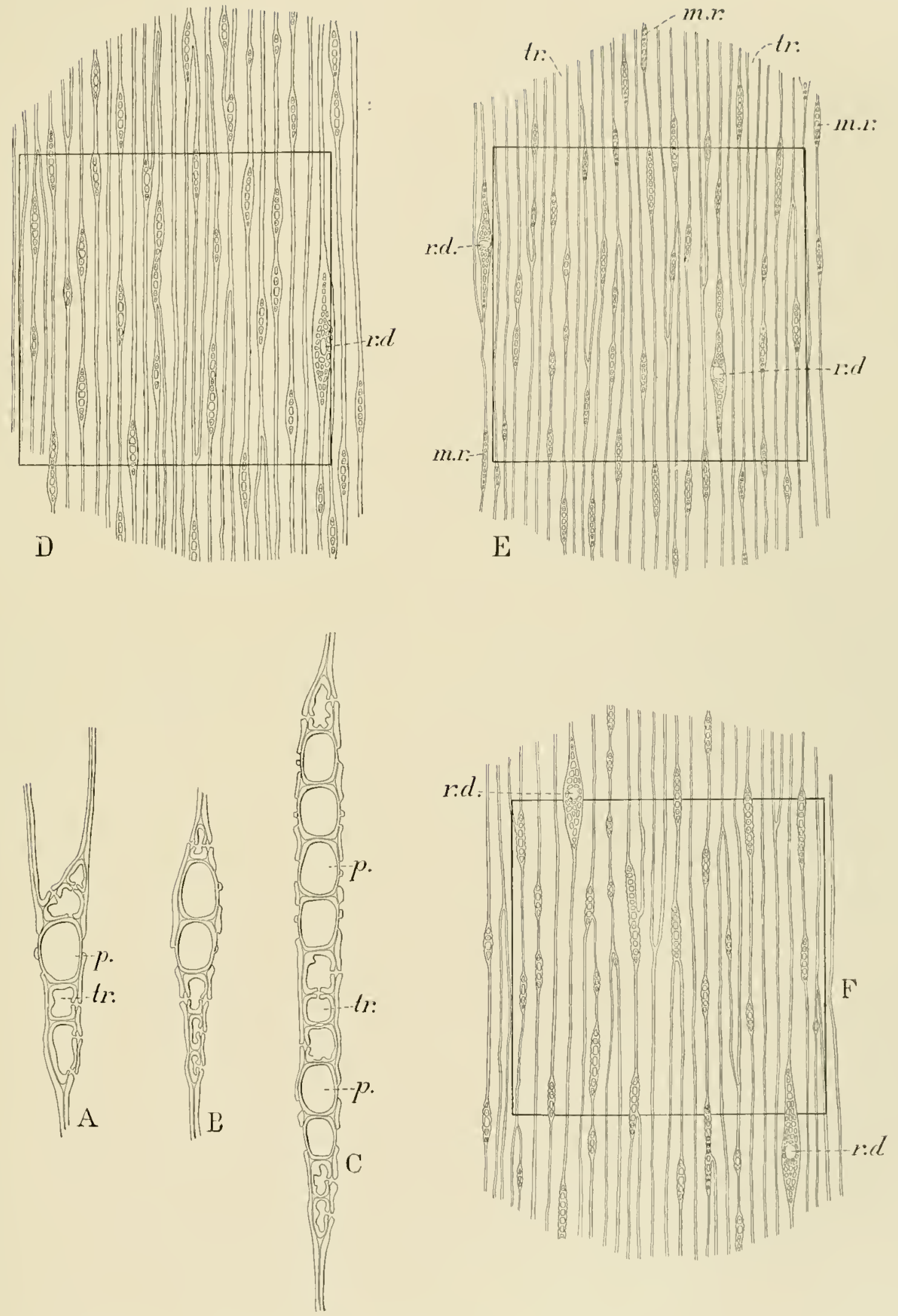

TANGential Sections of Pinus echinata, heterophylla, and gLabra, showing Number and Distribution of Pith Rays and Proportion of Pith-ray CElls. 


PLATE XXVII.TANGLXTIL. SECTIONS OF TRANSVERSE RESIN WIOTS.

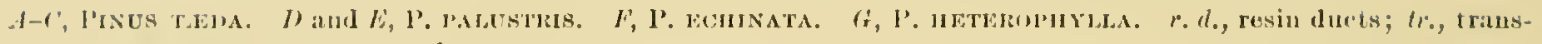
verse tracheids; p., parenehymi .

Magnification of originals, 5 q0; of illustrations, ${ }^{3}$ q0. $^{\circ}$

$15 \mathrm{f}$ 


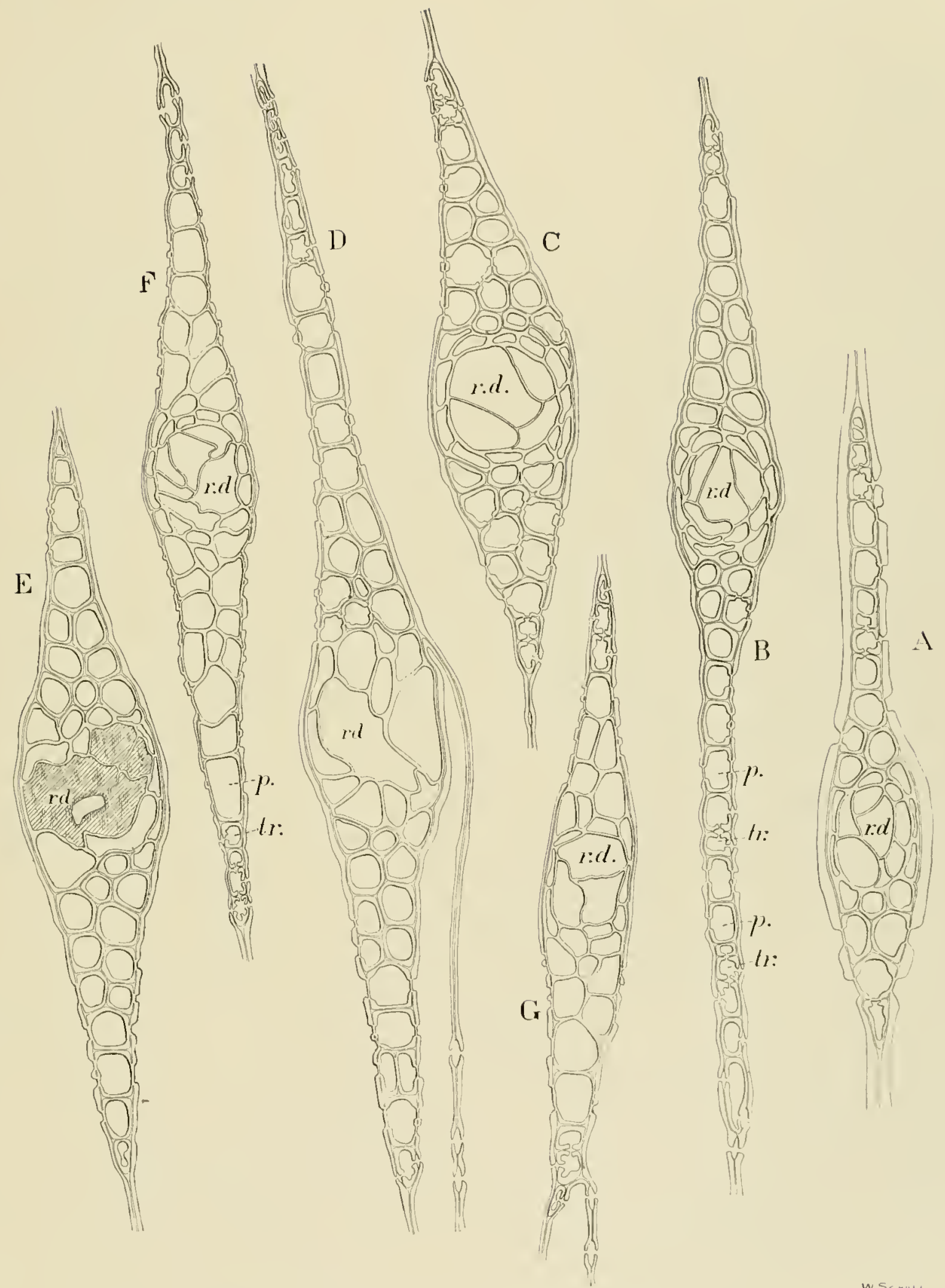

Transverse Resin Ducts tangential Views. 



\section{INDEX.}

A ge, efiect on pine rood.

A labami central pine belt Ioseription

Longleaf Pine foresta, lenction

north, Longleaf Pine forests, description ...........

shipments of timber aml lumber in 1992.

Anatony, mionte, of pine wrol .

Anoual riogs of wood, description

(n........................

Atlantic pine region, description ........................

Ileeling, effect .......................................... 21,72

Botanical description and morphology of Cuban Pine........ 7

Loblully Pine....... 113

Longleaf Pine. ......

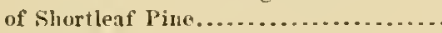
Spruco I'ine

diamnosis of Primeipal Sonthern P'ioes.............

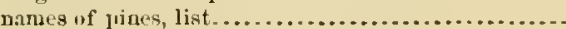

Boxing, eflect.

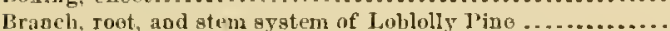
Longleaf rine.

Brunswick, Ga., exports of lumber for years 18Rt-1894....... Contral pine belt of Alabama, description.

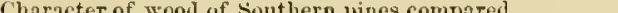

Characteristics of distribution in different regions of Shortleaf

T'ine

Charcoal burning, use of Inogleaf Pino

Charleston, S. C., luwber trade, 1880-1894.

number of barrels and total ralu' of rosis slipped $1880-1894$

casks and total value of spirit turpentine shipped 1880-1894 .

trade in uaral atores, $1880-1894 \ldots . . . . . . .$.

Classification and nomenelaturu of Cnban Pine............... Loblolly Pine ............. Longleaf Pine............ Shortleaf Pine .............

of rosio, ur colophony -

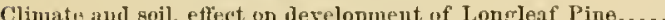
required by Loblolly Pine................. Shortleat' l'ine................. Spruce Pine.

suitable to growth of Cuban Pino.

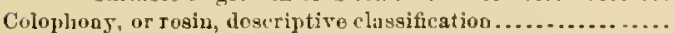

Crude turpentine, amount shipperl from Wilnington, N. C., witl total ralue, 18,80-1894.

Cuban Pine, artirle lis Charles Molu.

characteristics of

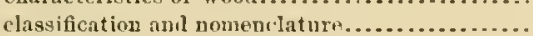

conditions requirid for develupment.............

description aul morphological characters ........ of flowr'rs..

economic importauk

geographical distrilution . . ...................

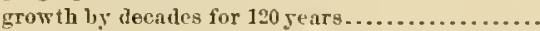

froms 4 to 20 years.

progress of derelopment

products...

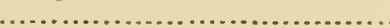

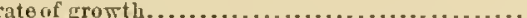

from 40 to 145 years...............

renuirements of

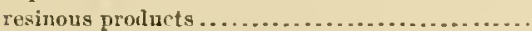

srnonsms, scientific and common ............... 13, 7

Cubiv contents of Longleat' Pine, by ulrcades.

1)arien, Ga., export of lumber, 1884-1894.
Page.

Enemies of Loblolly: Piue, remarks. . .

Longleat pine, reotarkg........................ $f_{1}$

Shortleaf Pime, romarks ..................... 1ny

Spruce I'iow, remarks......................... 130

Exploitation methorls, injurious, in Loogleaf Pioe for ists...... 61

Exports of lumber from Savounah, Brunswick, 1)arien, aod st.

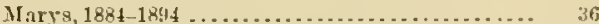
spirits turpentine aud rosio from Mobile, 1880-1894 40 timber and lumber from Pensacoln, $1 \times 80-1893 \ldots . . . .5$

Iolilo, 1 la value, $1880-1894 \ldots \ldots . .$.

False rinurs

Fernow, B. L., introduction to bulletin..................... 11

Fire, injury to Longleaf l'ine forests................... त2

Florida eastern, Lun rlaf I'ian belt...................... 36 west rn, Longleaf l'ine forests, Jescriptimn....... 37

Flown of Cuban l'ine, description........................ th

Loblully Pine, description..................... 115

Shortlaf Pine, lescription....................

Lonyleat P'ine, lescription................... 5l

Furestry, deseription ................................ 11 time for the application........................ 11

Forests, effect of prodnction of naval stores ................ 72

Loblolly Pine, nat ural reproiluctioo................ 123

Longleaf Pune, in Al:abama, description............ 41

Georgia, deseription............... 34

Louisiana, deseription ........... 43

Mississippi, alescription........... 42

Texas, description............... 45

injurious metbods of exploitation...... 61

irijury from fire................. 62

lire stock............... 62

management ...................... 64

natural reprodnction................64, 123

turpentinu orcharding............. 69

Shortleaf Pine, management ..................... 104

Fuel value of Longlenf Pino woot ...................... 48

Fungi injurious to Longleaf Pines.................... 63

Goorgia forests of Longleaf T'ine, deseription............... 3t

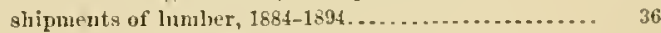

gtatiatics of Longleaf Pine......................

Grain of the pine woods, remarks....................... 139

Growth, rate compared .............................. 22

Gulf reginn, eastern, waritime pioe belt, description.......... 36

Heart and sap woml, gen!ral remarks.................... 113

Height of Loogleaf l'ine, hy dreades ...................... 60

History, economic, of Loblolly I'ine .................... 10.

of Lontlunt J'ine............................. n $n$

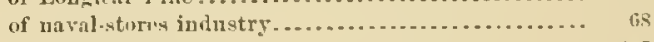

the use of loblolly Pine........................ 10i

Sliortleat' I'ine......................... sit

Insects injurims to Longlnaf I'ine trees................. 6.

Leareg of Ioblolly. Pinn deveriptiou.

Longleaf Pinc and their moditications ............ 49

Shortleaf Pine, leseription..................... 9.5

Leaf products of Inngleaf Pinc......................... Is

Light, rulatim tu Loblolly" Pino aml associated species........ 122 Slortleif Pizm and associatel specics....... 103

Limhtwond, formation am nses........................ 47

Livestork injury to LonmInat Pine forests................ 62

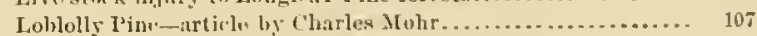
associaterl species and relation to light $\ldots . . . . \quad 128$ 


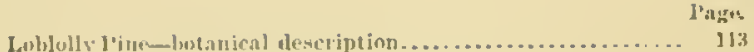

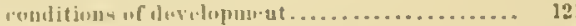

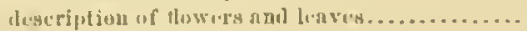

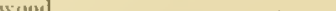

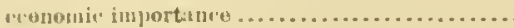
min'min's ... gangrubical hiatribution and enomic histors. growth, by docudes, to 120 years ............... frum 5 to 50 years.

50 to 156 years....................

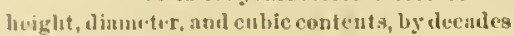
listury ut its ust..........................

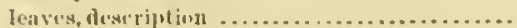
muanurements of trees frum ditlerent rogions. 110 nunuchelatnro nut classifient ion ...............

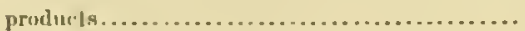
proseress of development ......................

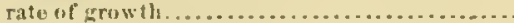

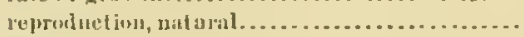

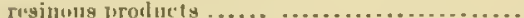
root, stem, ant lorituch system............... soil and elimato ruquired .................... usces mul valum of moot.................... 11

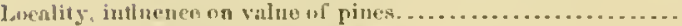

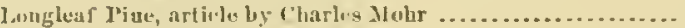
nssurialiul nuecics.

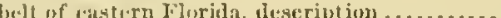

hown down hy wturns. . . . . . . . . . . . . . . . . botanical dewription and morphology - . . . . . 48, 113 courlitions of developurnt

cubic cuntents, ly ducales................... domands 1 num suil and climate.............. eroumui iumortance..................... ifliets of naval-utures indusiry ..............

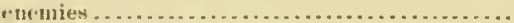
ustimate of timbr stauting ................. llowers, description ...

forests inilurull by time and liwa atock a injurioas methuls of exploitation.....

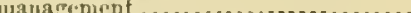
nitural production. ..............6.64, uf Alitbuma, descript jun .............. 38,41

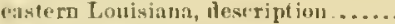
finorgia, destription ................. Missimsipupi, Me:urription ............. North Carolina, leseription.......... Sonth Carolina, description. ........ T'exas, deseription................. westurn Florilli, descriptinn ........ western Lonisiana, descrijtion ...... gupraphical ilistribatios. grows and teveleppument ..

rate of gruwth by decarles.

stage of rapid grow th

magia of sluw growth.

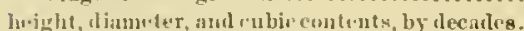
injured by frugi (Tolyporus)................ ingut in jurisus.........................

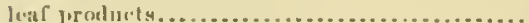

luaves and their monlitiogtion. ................. lunber prostuwn] in Lonisianat in $1892 . . . . . .$. Texils jul 180 ? mestan rements of trem............ $38,39,41,44,45,46$ from 100 to 200 צอRг old. 200 to 260 years old

voung trev.s...............

nomond lature and rlassitiention................

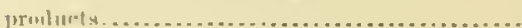
rate of growth ............................ 59,60 regin west of the Misкissippi, description.... reprouluetion, natural risinoua prolucts. (4.10.

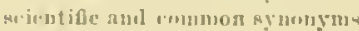
revilo, le.reription. atativticy of Georgia.

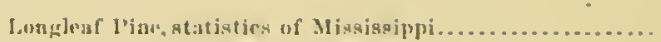

Suntli Curulina ....................

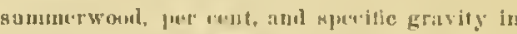

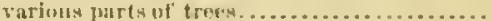

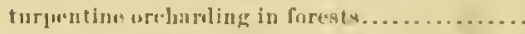
variation of sporifte cravity with sunumerwom

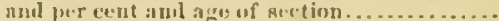
wounl, denc riptim ......................... fucl value. IIsis and value. l.misiana, eastern longleaf ['in. forents, deseription.........

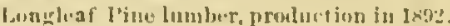

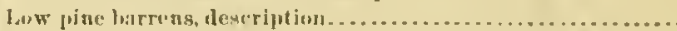
Lamber, Lomgleaf l'ine, prouluction in J.mnisiana iu $1 \times 92 \ldots . .$. Texils in 1 seg

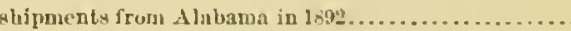
Mississippi in 18:4 so and 18*3-1893. Mlobile in 18.00-1:91 ................ l'ensacolit in 1880-1893. Savannah, lirunswick, Warien, and st. Mary, 188t-182t ............... ghiphed to forcign and donutic prorts from Cbarleston, $\therefore$. C. 188 s 1899 .

shipged to forvign and donestie ports frum Wilaing.

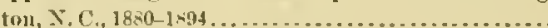
Jlaritine pine belt of tlu tasturn Gulf region, description... ITensurements of Joblolly I'ine, by" recades.............. 121 from ditlerent rogions....... 110,11

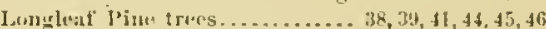
from 100 tu200 yearsuld . $\quad 58$ 200 to 260 yearsuld 59

Shortleaf l'ine trees at diti-rent ain's...... 100 of ditlurent remions..... $89-92$

Spruce I'ine trees nt ditlierent atres .......... 120

tres frmu virwin frrests................ 35

young Lungleaf Piactr.es ............... 5i

Mechanieal properties of wood uf Sonth.ru yines r'ompared... It

Meinllary rags ..................................... 139, 14

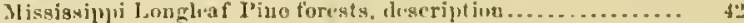

lumber slupuents, 1879-50 and 188:3-1893 ........ 4.

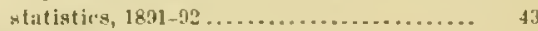

statisties of lonewlewf l'ine ................... 42

Mobile, easks of spirits of turpentito exported, 1850-1891 .... 4 4U

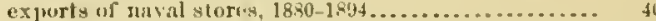

rosin in lrarrols, $1880-1891 \ldots \ldots \ldots \ldots \ldots . .40 .40$ timb.r aml lumle.r, 1860-1804............

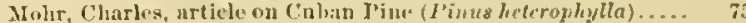

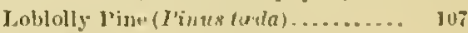
l.onglouf l'ino (l'inus palustris) . . . . . 27 Slourtleat' l'ive (I'intes echinata)...... 8. 87 Spruce l'ine (P'inus glabra) ......... 127

Mointure and wcight of pires......................... 20

influenct un st rength uf vine .................. M[orpholugy and hotanieal deseriftion of lublully l'iba...... 113

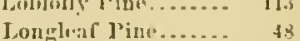

of Cuban l'ine.

Ninal stores, definition

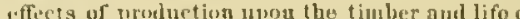

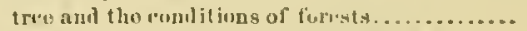
exports from Charlestou, $\triangle .1$. $18 \times 0$ 1894..... Molvile", _la., 1880 1894 .......... Savannah, Ga., 1880-1894.......... Wilunington, X. C., :

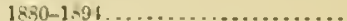

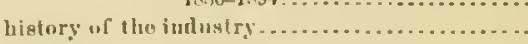

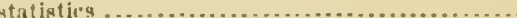
Nomem-luture and elassilication ot Loblolly I’ine........... Lungleat l'in............... Sliortluaf l'iuw .............

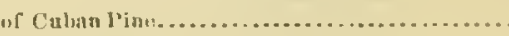

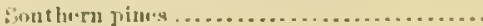

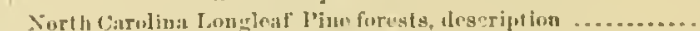
Orcharling turpentiun in forests of longhaf l'inn...........

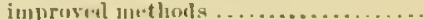
(Irehurds, "urpentim", cust of "stablishiug a plaut for working" touls 11 s.

12 3 137 69 137 53 48 43 J 5 16 43 10 3 30) 34

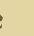
40 (1)

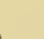

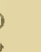

5

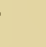

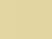

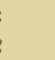

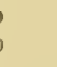

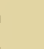

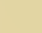

87

20

$\frac{1}{3}$


I'age.

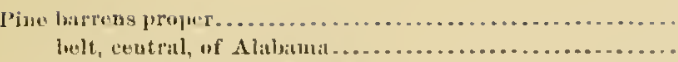
helts of the Sunth, description.

Cub:an. (Sie Culan l'iue.)

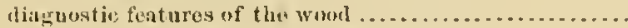

distrilution of streugth and weight thrmegliont the tree.

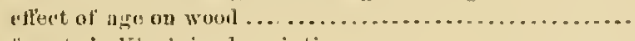
liurests in Virgiuia, description ....................... grain of wowls, remarks ............................ inllucruce of loeality on value.

Lolslolly. (See Loblully l'ine.)

Louglear. (ste Lomgleaf l'ine.)

minute anatemy of worl....

range of roliu for wointh and streng

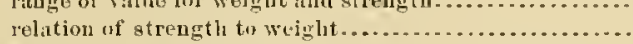

scrub, only valuablo for fireworl.....................

Shortleaf. (See shortleaf l'mo.)

spruce. (Nee sipruco l'ine.)

titr, methools of proluction.

timber, estimated anumal consumption .................. estimate of quantity .......................... stat istices

nse of the wood

weight and moristure ..................................

weiglit and strength of whol at diflerent heights in the

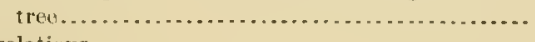
relations........................................

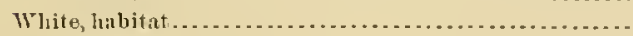

Pines, lest comnon mam+s.............................

botanical names. . .

lecal common namเs ...............................

merhanical propurties.

most important timber of worli

notes on the siraturout the wool of the five Sonthern,

article by Filibert Roth .........................

rewarks on shrinkage.

Sonther1, uomenrlature .

(n)

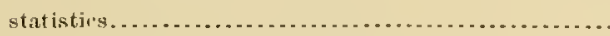

Pinus echinata, articlo by Charles Mohr synouyns, scientitic and conumon .............

ylabra, ar ticle liy Charles Mohr (Nee Sprupe l'ine) ..... synoprus, scientific ant commun...............

heternphylla, articlo loy Charles MIohr (Sive Cuban l'ines). botanical diswnosis ...................... synonyms, scicntific and common .........

palustris, article lyy Cbarles Mohr (See Longleaf l'ine) .. Imitanical tlianosis ........................ synonsms, scientific and cromon .............. 13, 28

strobus, lalintat .................................. 14

ted $a$, article by Charles Afohr ..................... 105

botanical diatnosis........................ 12 ('oumoon dames and synonyms................ 13

Pitch, common, liow oltuineel.

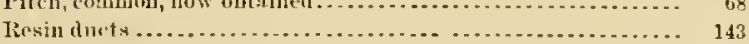

Fusin from Longleal l'ine, description abil composition ........

Resinms produrts of Cuban Pine........................ 76

Lollolly Pine....................... 112

Longleaf Pine.........................

Iiinurs, annual, dleseription.

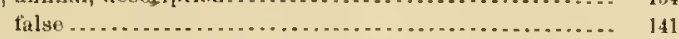

Foot, stew, abl branch system of lulbluly. Pine.... ..... 113 Longleaf Pine ............. 49

Rosin or colophony, description and tlassification............... exported from Charlestmi, S. C., in barrels, and total

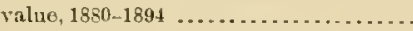
Mrobilı, Ala., in barrols, 1880-1894........ Sivannalh, Ga.. in barrels, $1880-1894 \ldots . .$. Wilmington, $\mathrm{N}, \mathrm{C}$, and tutal valne, $1880-1894 \ldots$

Itoth, Filibert, article on the structure of the wood of five Southern pines....................................... Sil aud heart wool, remarks...........................

Savinuab, Ga., amount uf naval stores exportenl, 1880-1894. exports of honleer, 1884-1894. number of harels of rosiu texprterl, 1880-1894
Sivanual, Ga., number of casks of mpirits turpentius exported,

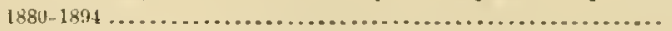

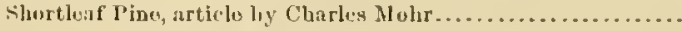
botaniral description ....................... characteristics of distribntion) in tillirent ro.

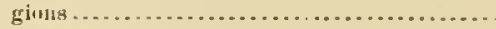
rliuatnand suil suitablo.................. conditions on dovelngment.................... erowding wot ot her нpereses................. 10 description of thwers and lenves.............. 95 characteristics of wowd......... ceononic importanw..................... 87 enemies ............................. 103 furest management ......................... 104 geographic:al elistrilution................ 87 growth after 120 yorars.................. 100 from 8 to 50 years................. 98 50 to $1: 0$ years.

leight, dianoter, and cubic cuntento ut avragn trees at various ages..................... 100

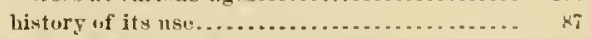
measurement of trees of dilcrent regimis. $89,90,91,92$ nomeuclature anul classification . . .......... 93 produets ............................. 93 progrens of development . . . . . . . .......... 98 rate of gruwth during alifierent periouls of lifu. 101 relation to light and assotiated speries....... 102 requirements as to light . ................ 102 shrinkuge of woukl ........................ 19 syponyms, scieutifir and rommon ........... 13,86 Soil and clinatr, demands by Lumglenf Pine............... 60 requiret ly Loblolly l'inm.................. 121 Spracr pine.................... 130 suitable to shortleat' Pinc............... 101

required for derelopment ut' Cubur I'iue.............. st sunth Carolina Longleat' Pine forekts, desoription........... 33 statisties of Longleaf Piva' . . . . . . . . . . .

Subthern jines, nonenthat woul cluaracteristics..................... 13

Spring and smmmer wook, difference................... 136

Spruce Pine, article by Charles Mohr ..................... 127

botinieal description ...................... 128

clinıate and soil reduired .................... 130

distribution . ........................... 127

veonomic impurtanre...................... 127

enemies ................................... 130

growth (height, diamorer, and eubic contents) at different ages ......................... 129

history . ...................................... 127

progress of derelopmueat . . . . . . . . . . . . . . . . 129

requ uirements of devilopment ............... 130

statistics of supply a oul proluetiun............. 23

gyonyms, scievtific and conmum . . . . . . . . . . 126

Stem, root, and hranch system of Lohlol]y line............ 113

Longlenf l'ine............ 49

St. Maryo, Ga., export of lnmber, 188t-1894.............. 36

Storms, injurions to Longleaf Pine forests ................ 62

Strength of woot of Southeru lines ................... 14

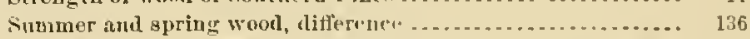

Summerwool, per ecut, and age uf sect ion in Longleaf l'ine... 13i specitic gravity of various parts of Lengleaf Pine........... 137

variation, per ennt, from pith to bark......... 136

witl rate of frowil in Longleaf Pine trow.... .

Syuonyms, acioutifie and asmumon, af Cuban Pine (l'inusleterojhillla) $\quad \ldots . . . . . . . . .$.

Loblolly Pino (I'inus terda) ............... Losugloat Pinu (Timus palustris) $\ldots . . . . . . . .$. Slurtleaf Pime (Pinus eckinatal) ............. Sprne pine (Pinus gla. hra) ...

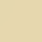

(1)

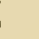

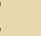

8

7

7

9

6


160

INDEX.

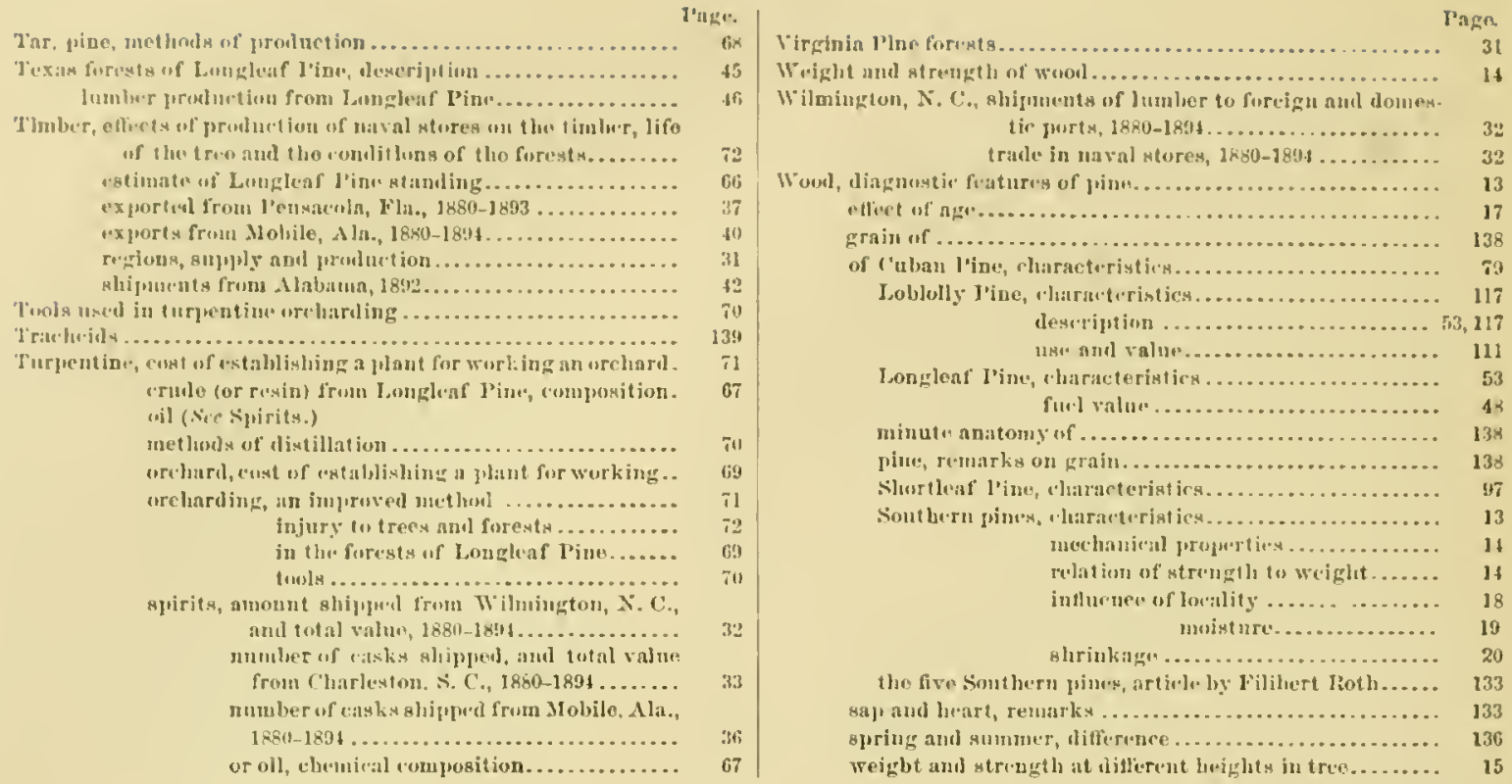





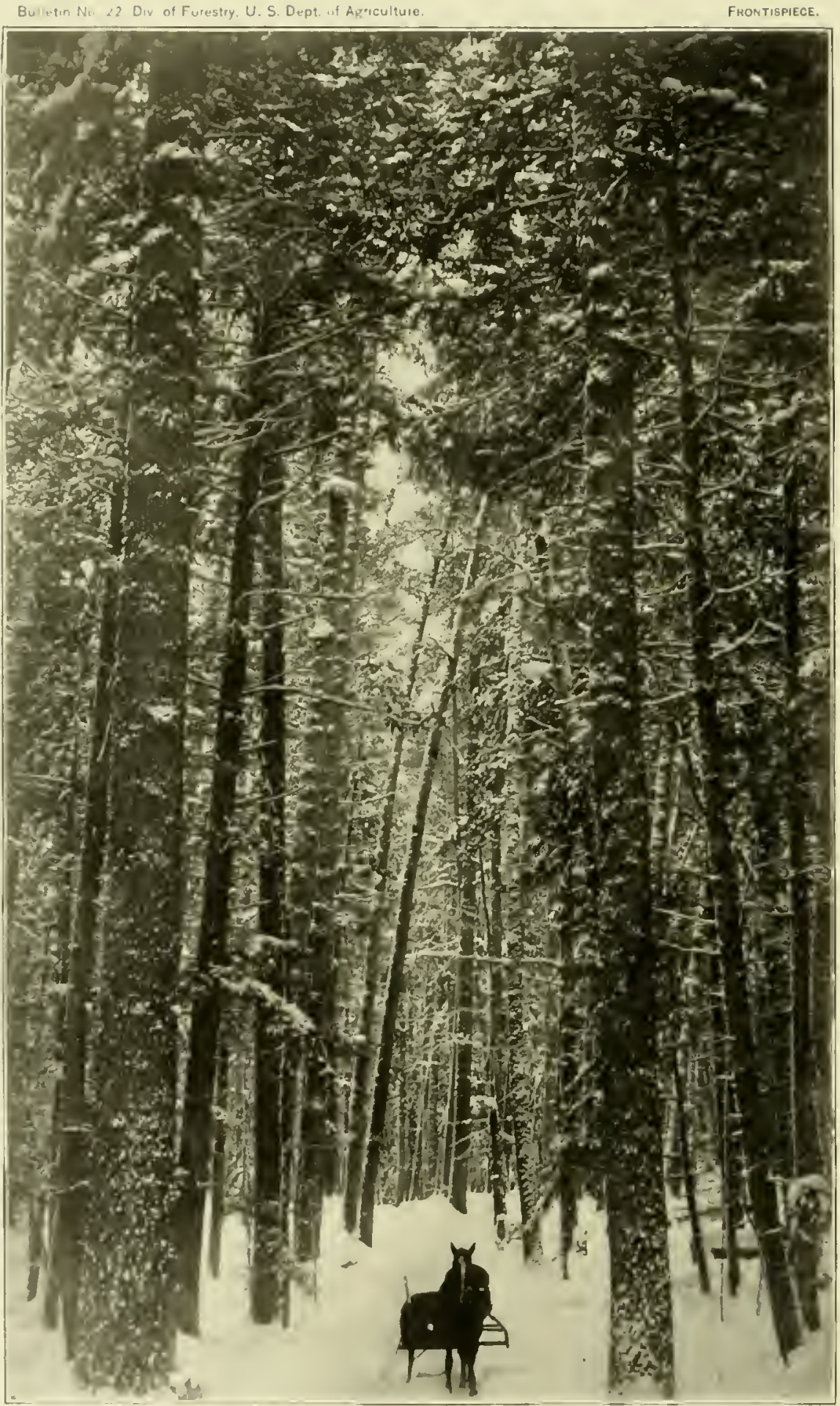

White PINE Forest. 
BULLETIN NO. 22.

U. S. DEPARTMENT OF AGRICULTURE.

DIVISION OF FORESTRY.

\title{
THE WH I T E P I N E. \\ (PINUS STROBUS Linnæus.)
}

BY้

\author{
T. M. SPALDING, \\ Professor of Botany in the University of Michigan.
}

REVISED AND ENLARGED BY

B. E. FERNOIT, Chief of the Division of Forestry.

WITH CONTRIBUTIONS:

INSECT ENEMIES OF TIIE WHITE PINE . BY F. H. CHITTEXIDEX, Division of Entomoiogy. THE WOOD OF THE WHITE PINE . .... By FILIBERT ROTH, Division of Forestry.

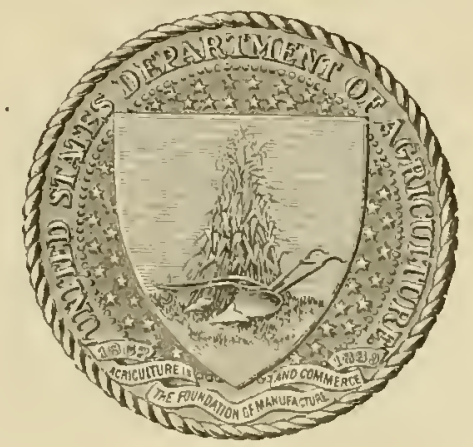

WISHINGTON :

GOYFRNANT PRINTIA OFFICE.

I 899 . 



\title{
LET'TER OF TRANSMIT'TAL.
}

\author{
U. S. DEPARTMENT OF AGRICLLTURE, \\ DIVISION OF FORESTRY, \\ Washington, I). C., Warch 15, 1598.
}

SIR: I have the honor to submit herewith for publication a monograph on the White Pine of the Northern United States.

The first draft of this monograph, like the one on "The Timber Pines of the Southern United States" (Bulletin No. 13, Division of Forestry), by Dr. Charles Moln, was preprared more than ten years ago by Prof. T. M. Spalding, of Ann Arbor, Mich.; but it was then found that muel information of praetical valne was still lacking, and hence publieation was delayed until the defieiencies could be supplien. Professor Spalding, after having made several uevisions, under the pressure of other work had to abandon the idea of amplifying and pertecting the monograph itself, and this was left to the undersigned, with the collaboration of the staft of the Division of Forestry.

The undersigned is responsible not only for the plan of the work, but especially for the portions referring to dorest conditions, forestal treatment, and for the discussion on the rate of growth, to which $11 \mathrm{r}$. Mlodziansky also contributed.

Mr. Filibert Roth, of the Division, besides furnishing the stndy on the rood of the species, has also contributed the portions on the history of the lnmbering operations, while the discussion on the injurions insects is by Mr. F. IT. Chittenden, of the Division of Entomologg.

A very comprehensive investigation into the rate of growth of the White Pine has been carried on since 1592 as opportnnity afforded and funds permitted. The results of this investigation, eomprising the analysis of over seven hundred trees, in the form of tables and notes, will he found in the Appendix. The measurements in the field were mainly executed by Mr. Anstin Cary, of Bangor, Me., and by Mr. A. K. Mlodziansky, of the Division. The latter also performen the ealculations and tabulations in the Division, and in this work developed a short and satisfactory method of tabulating, analyzing, and using the large mass of data readily for the purlose of summarizing, areraging, and generalization. This method is leseribed in Bulletin No. "un, Division of Forestry.

The situation regarling White-I'ine supplies has materially changed since this monograph was first conceiverl, so that it might almost be elarged that this publication comes too late. This would be a misconception both as to the sitnation and the objects of the monograph. No information of any kind conld have arrested the decimation of our White-Pine supplies. which proceeds throngh the momentum of eeonomie laws; and even now, when it is mell known that a few years will see their exhanstion, no change in the methorls of milling with a view to lengthening the supplies, is contemplated by the manfacturer, who is only concerned in keeping his mill ruming. The manutaeturer is a harvester, not a forest grower.

The objeet of this monogralu is to lay the basis for an intelligent recuperation of the virgin growth by the forest grower of the future, work which will surely be begun presently. but which would not have been undertaken ten years ago.

In the preparation of this monograph use has been made of all avilable sonrces of infurma. tion. Acknowledgments are lue to a large number of corrspmulents, named in the proper eomection, who have rendered valuable aid by eontributing notes on distribution or have assisten ill other ways. 
The botanical illustrations showing external characters are ly Mr. fieorge B. Sud worth; those of the anatomy of the wool are ly Mr. X. L. Pieree and Mr. Filibert lioth, and those of parasitie

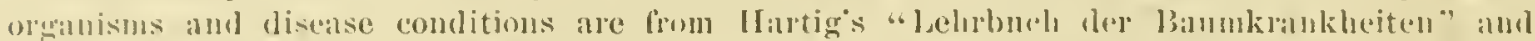
"\%ersetznngserscheinnugen des Ilolzes." The illustrations accompanying the section on injurions inserts were furnisher by the I)ivision of Entonology. 'The mip of distribution was prefaren in the Division of Furestry.

The monograph is believed to he just in time tor the use for which it is intended, namely, to prepare for the application of sylvieniture to the remnant of our pineries.

liesprectfully,

IOH. JAMLS WILSON,

B. E. FEl:xow, Chief of Division.

Secretary of algriculture. 


\section{CONTENTS}

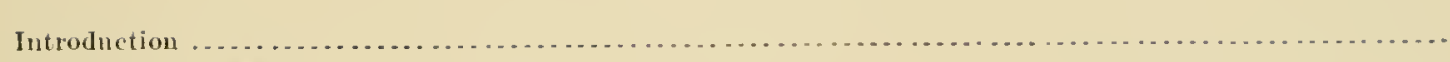

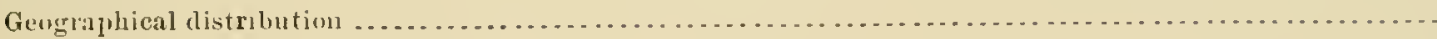

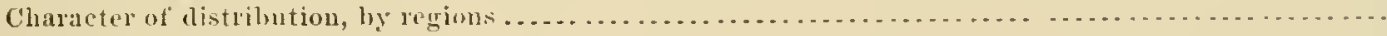

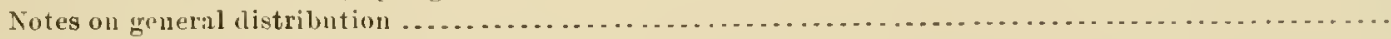

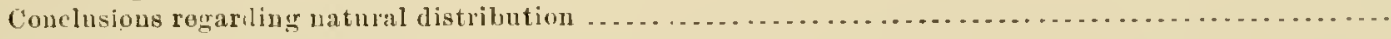

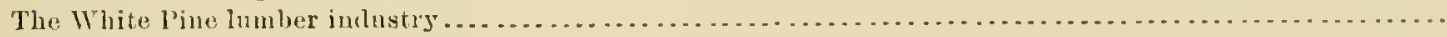

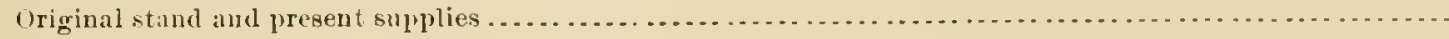

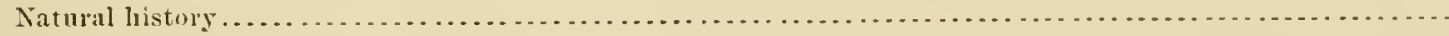

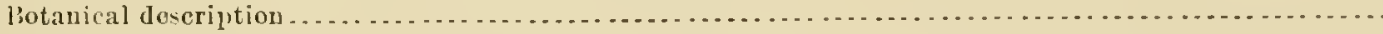

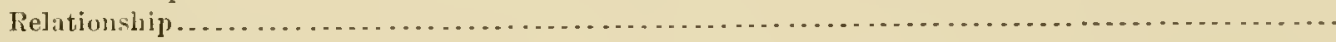

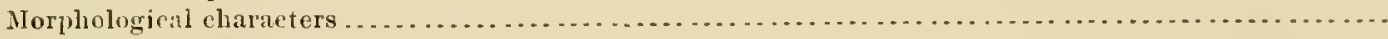

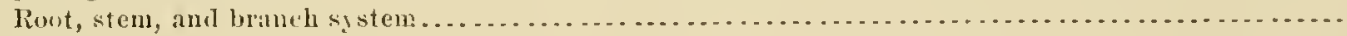

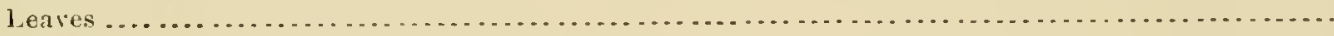

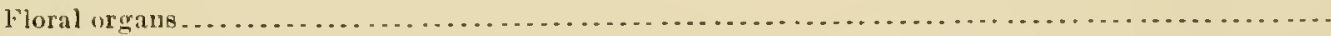

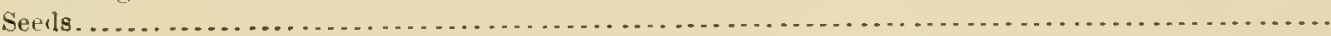

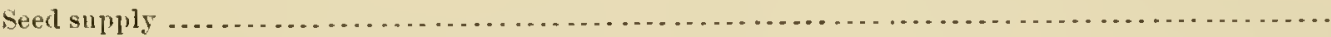

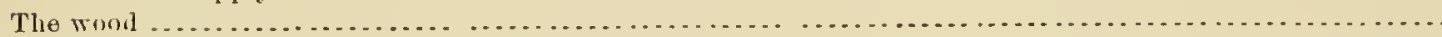

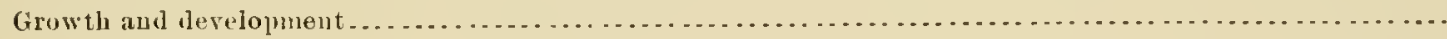

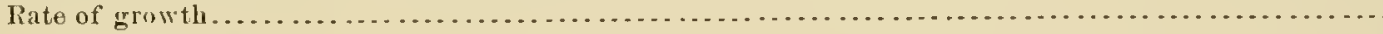

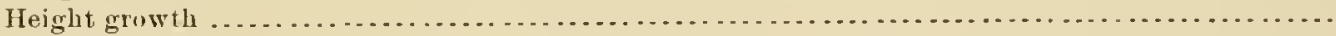

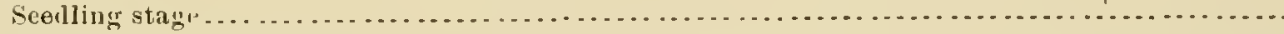

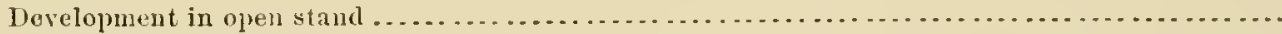

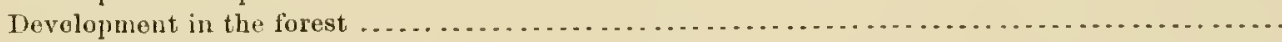

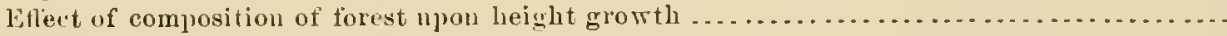

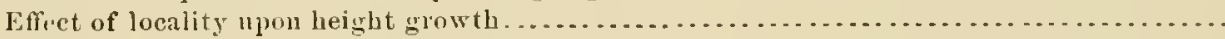

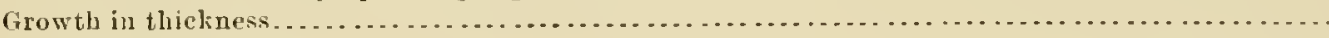

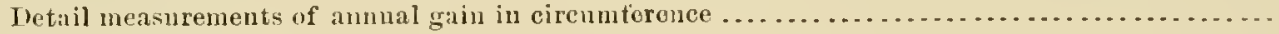

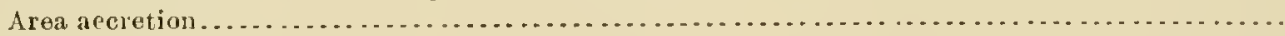

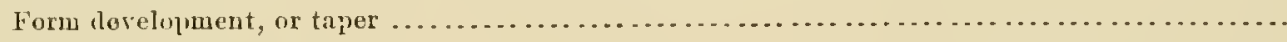

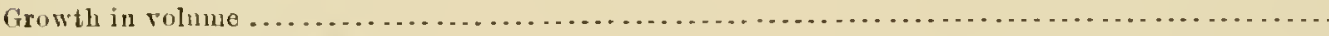

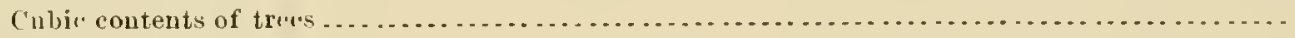

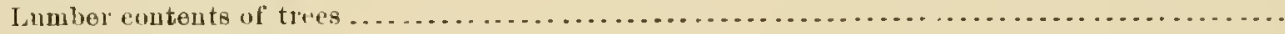

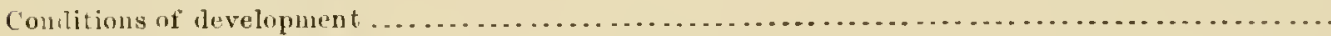

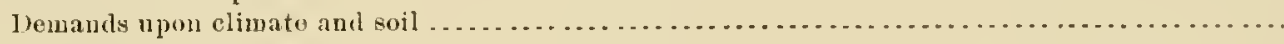

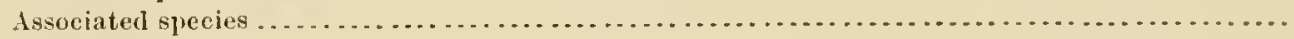

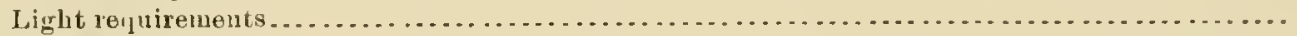

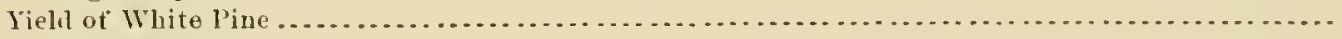

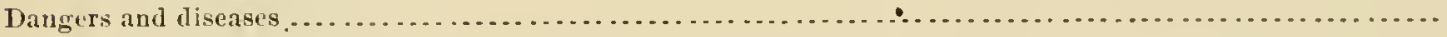

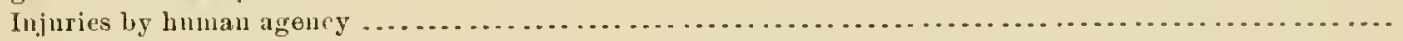

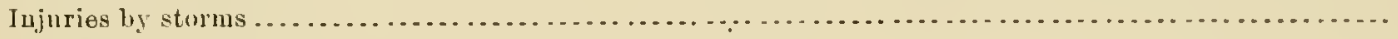

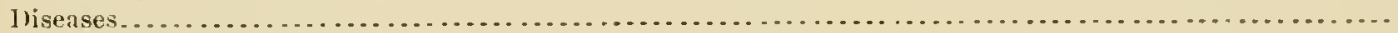

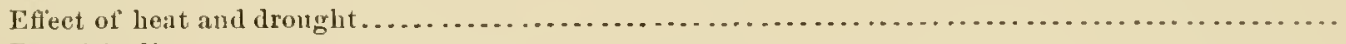

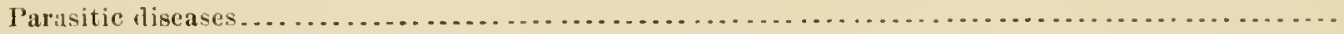

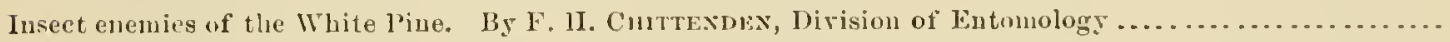

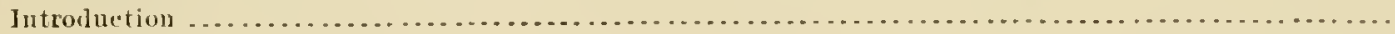

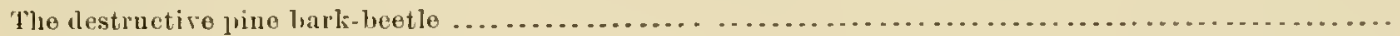

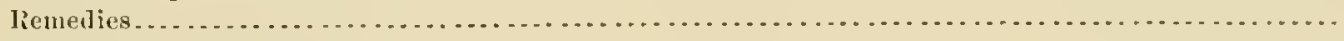

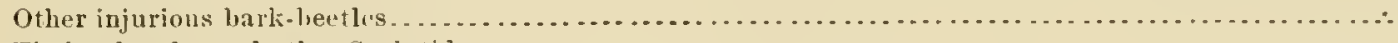

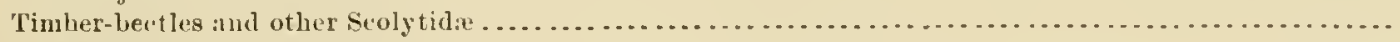

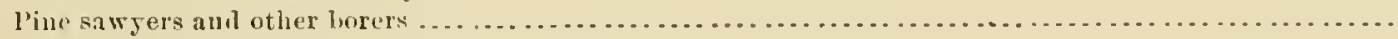

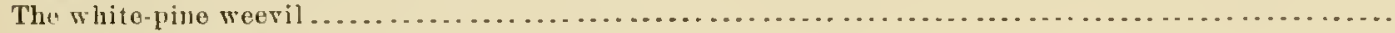

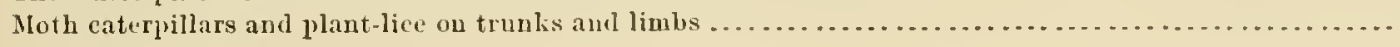

Leaf-foeding insects 


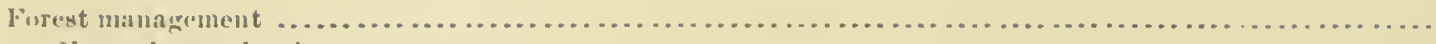

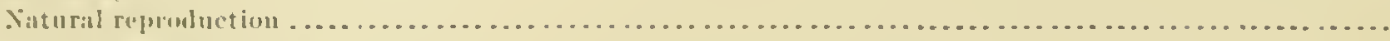

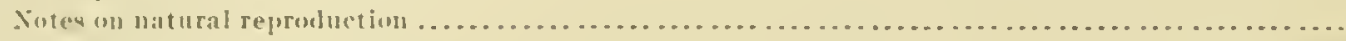

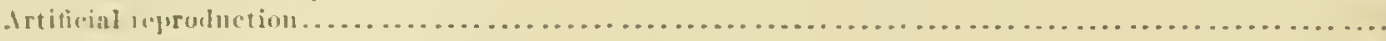

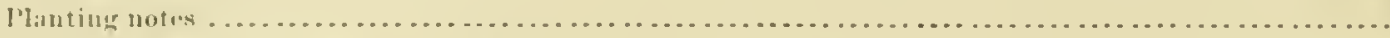

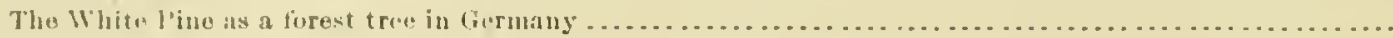

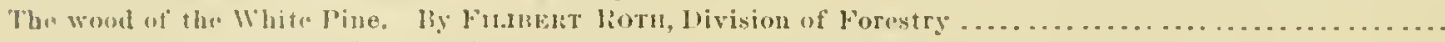

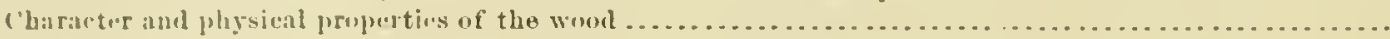

-

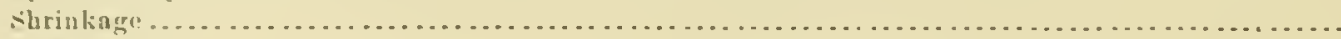

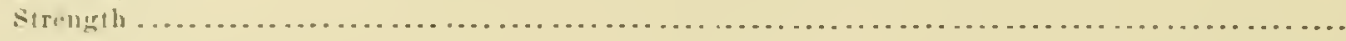

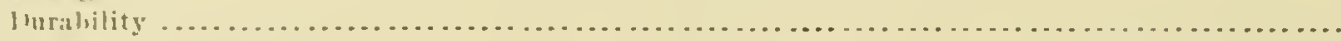

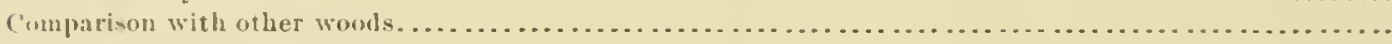

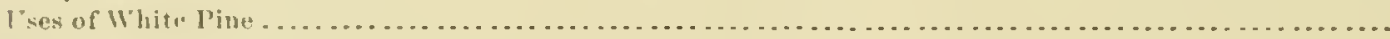
Ipjermix :

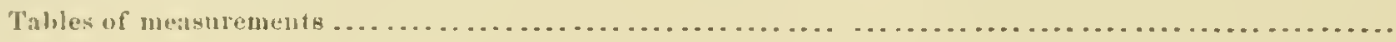




\section{ILLUSTRATIONS.}

White Pine forest

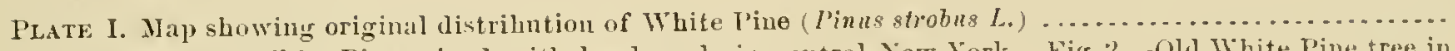

II. Fig. 1.-White Pine mixed with hardwoods in rentral New York. Fig..$\ldots n$. White Pine tree in

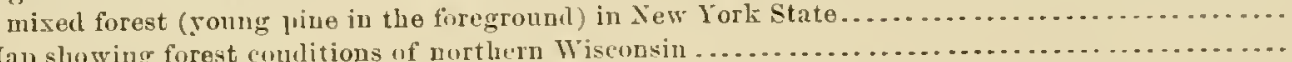

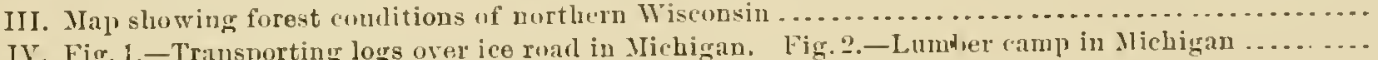

IV. Fig. 1.-Transporting logs over ice roarl in Michigan, Fig. 2.-Lumber camp in .1 ichigau .........

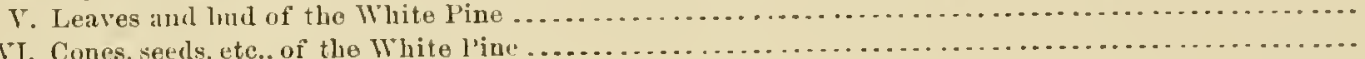

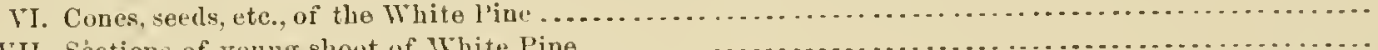

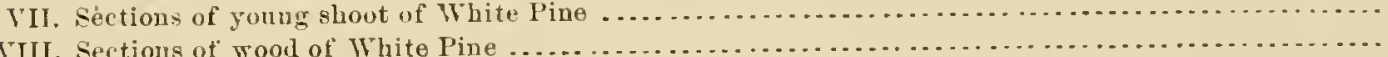

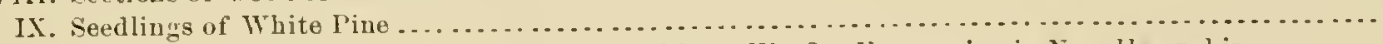

X. Fig. 1.-A thinned pine grove in New Hanpshire. Fig. 2. - Voune pine in Jew Hanpshire.......

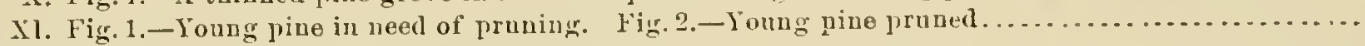

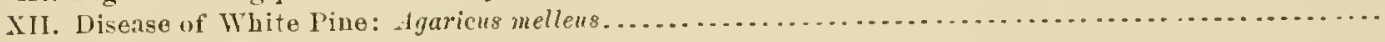

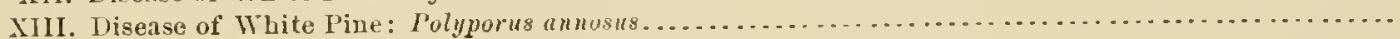

\section{TEXT FIGTIE:}

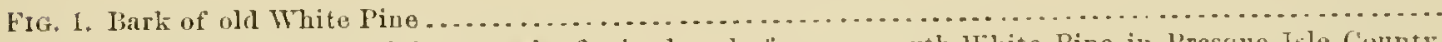
2. Diagram showing beight growth of mixcd aud of pure growth White Pine in l'resrue Isle connty, Mich

3. Diagram showing height growth of White line in forest of varying composition in Pennsylwania....

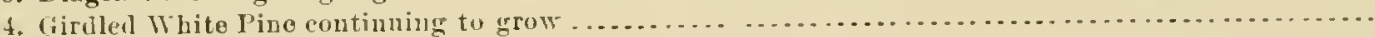

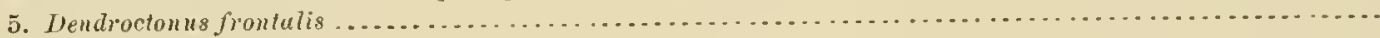

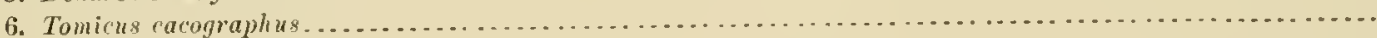

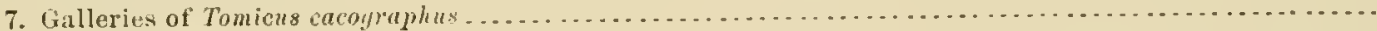

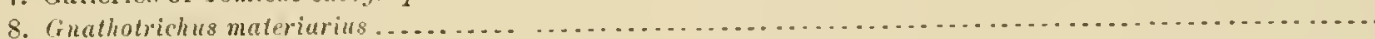

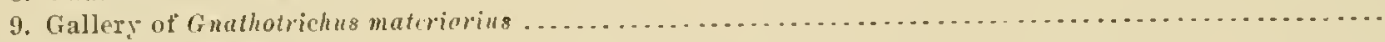

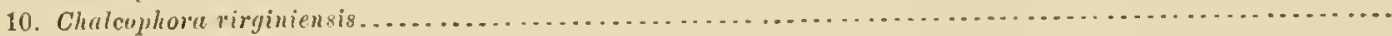

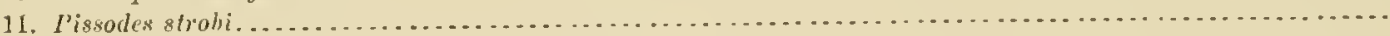

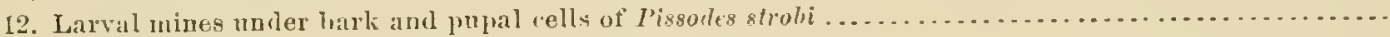

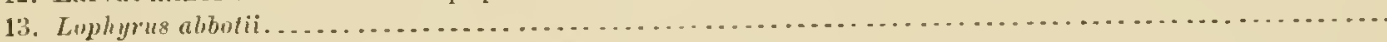

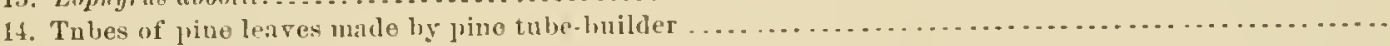

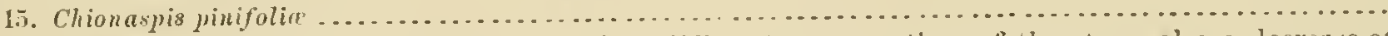

16. Diagrau showing specific weight of mood at different cross sections of the stem; also a lecrease of weight from the stump npward, and the similarity of the wood of different trem...............

17. Diagran showiug specific weight of kiln-dry wood at clitherent points in the stem from ground upwarl.

18. Diagram showing ettect of moisture on crushing strength . . . . . . . . . . . . . . . . . . . . . .

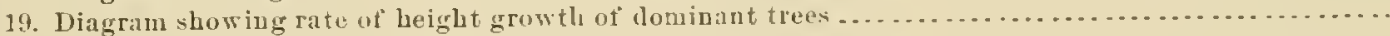

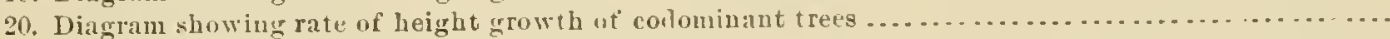

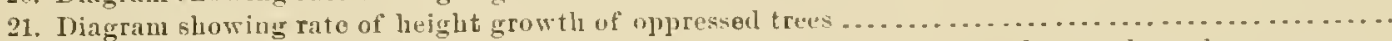

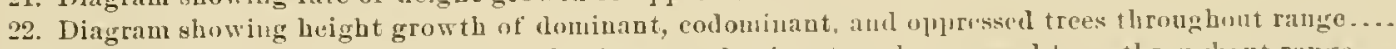

23. Diagran showing rolume growth of clominant, collominant, imel oppressed.trees thronghout range...

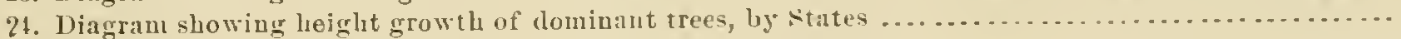

25. Diagram showing height growth of colominant trees, $b_{2}$ States . . . . . . . . . . . . . . . . . . . .

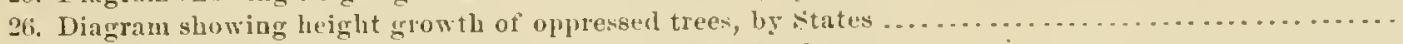

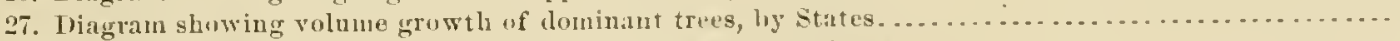

28. Diagran sluwing volumo gruwth of collominant trues, ly states . . . . . . . . . . . . . . . . . . . . .

29. Diagram showing rolume grow th of "ploressed trees, hy stat 


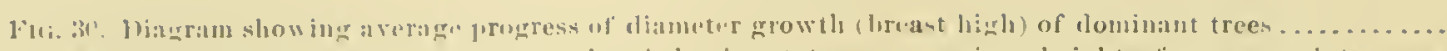

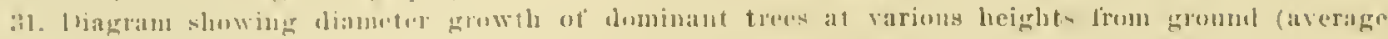

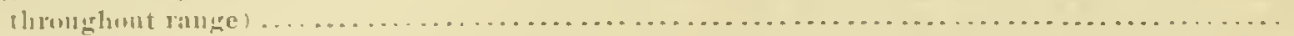

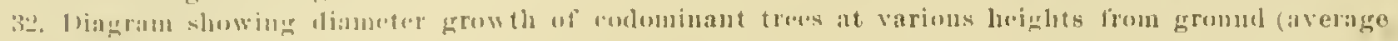

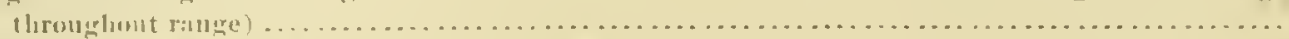

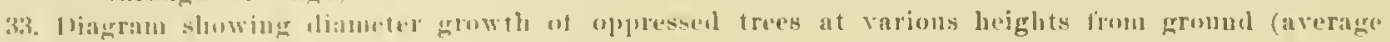

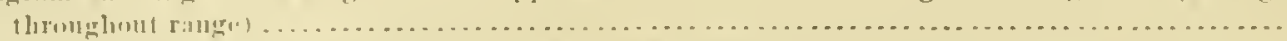

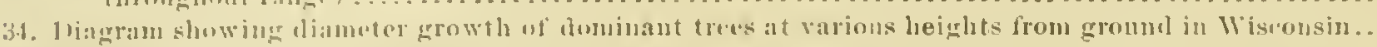

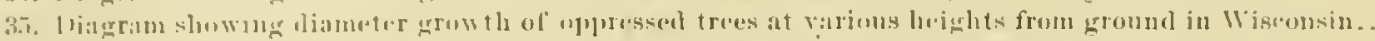

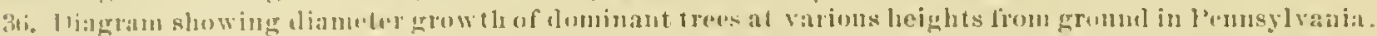

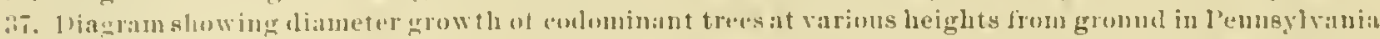

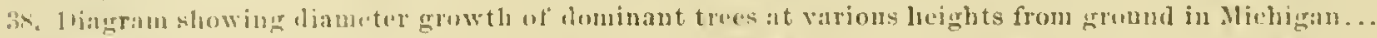

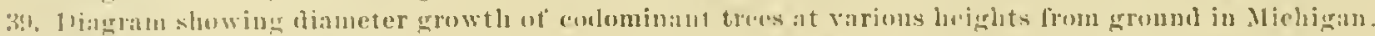

41). hiagram showing diameter gruwth of upgessed trees at varions beights from glound in .llichigan... 


\section{THE WHITE PINE. \\ (PINUS STROBUS Linnæus.) \\ NYTOXYMS.}

P'inus strobus Linuaus, spec. P'l. ecl. 1, 1001 (1731).

I'inus tentifolia Salishure, Prodr. 349 (1796).

LOCAL, OR COMMUX XAMTE.

White Pine (Maine, New Hamphire, Massachusetts, lihode IsIand, Connecticnt, Now York, New .Jerser.

Penusylunia, Delaware, Firginia, West Virginia, North Carulina, Georgia, Indiana, Illuois.

Wisconsin, Mlichigan, Mimesota, (lio, Ontario, Neluraska).

Wesmouth Iine (Massachusetts, South Carolina, European literature).

Soft I'ine (I'ennsylvauia).

Northern I'ine (South Carolina).

Spruce l'ine (Tenuessee). 


BULLETIN NO. 22, DIV. OF FORESTRY, U. 8. DEPT. OF AGR.

Plate I.

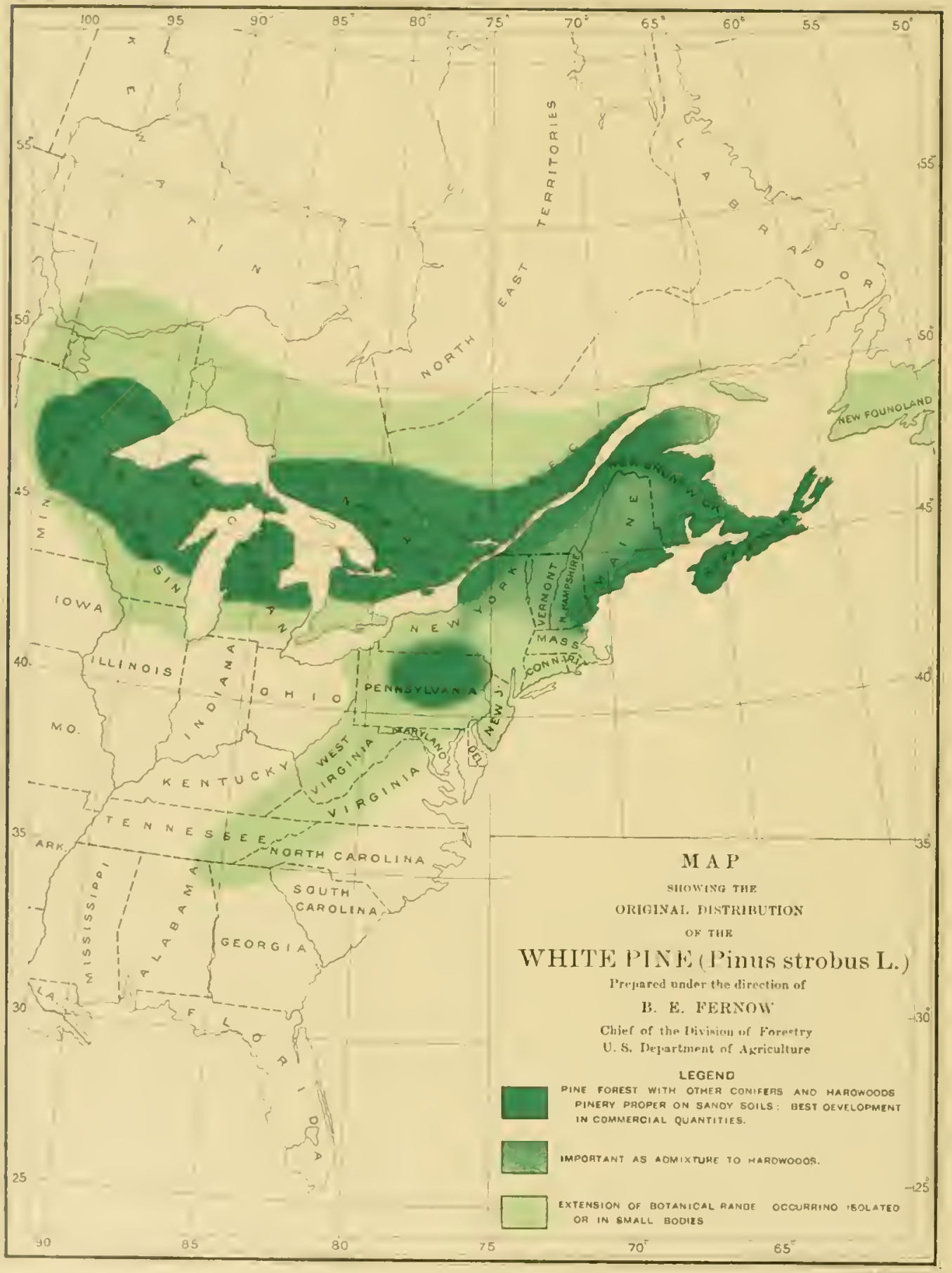




\section{THE WHITE PINE.}

\section{INTRODUCTION.}

For two centuries and a half the White Pine has been universally employed for murposes of construction in the Northern United states. Its abundance and the combination of rualities which adapts it to an almost nulimited number of uses have made it the most important and the most highly prizen of all the timber trees of the region to which it is indigenous. In several of the Northern States it has been a more constant source of wealth and has yielded larger retmrns than any other single product. Thns, for instance, in 1879, a fair year for eomprurison, the natural produets of the State of IIiehigan were estimated by Governor Jerome as follows: ${ }^{1}$

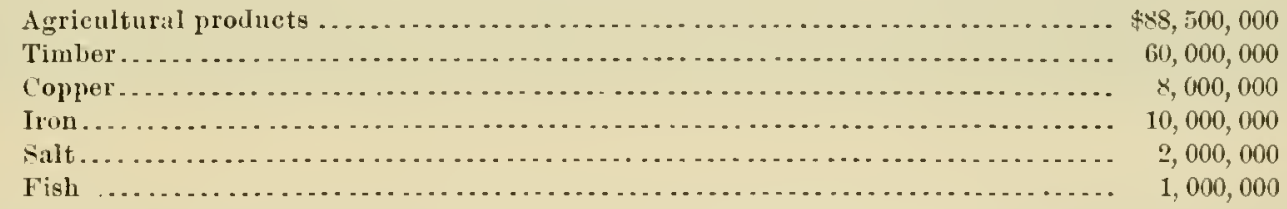

Aceording to this estimate the value of the timber prolnets, chiefly White Pine, was at that time, ill ronul numbers, six times that of the iron, sevell and one-half times that of the copper, and thirty tmes that of the salt produet of the State, and :monted to about 3is per cent of all the products of the State eombined; and if the valne of the entire White Pine product of the present year (189S), some 7 billion to 8 billion feet B. M., be taken into consilleration, it will exceed in value at first points of prodnetion the entire gold and silver output of the conntry, whieh is not much less than $\$ 100,000,000$.

Commereial interests of great magnitule, dependent npon the handling and transportation of the Trhite l'ine prouluct, have been bnilt up in Chicago and other northern cities, and the dininution or failure of the supply must inevitably result in the transler of the capital thus employed to other purposes or to other centers of distribution. In fact, such changes have already been and are now being made with great rapidity, and much of the eapital formerly invested in the pine lands and mills of the northem lake region las been transferred to those of the Gult States and the l'acific coast.

A multitude of imbstries is dependent upon a continned and large prodnction of pine lumber, and its failure, thongh perhaps not threatening such a collapse of business interests as alarmists Lare pietured, will nerertheless involve scrions if not disastrons conseqnences to the communities relying upon its contimance. The maintenanee of an adequate future supply, especially in view of the well-kunn fact that the existing forests of White P'ine can last but a few rears longer, at most, is therefore a matter of great economical importance aud can not receive too prompt attention.

\section{GEOGRAPHICAL DISTRIBUTION.}

The White Pine is a tree mannly of northern distribution, althongh it occurs along the monntain ranges as far south as northern freorgia. It ocenpies in this distribution the Boreal and Transition life zones, as defined ly Dr. C. Mart Merriam. 


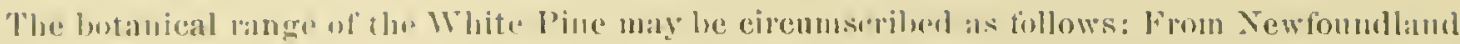

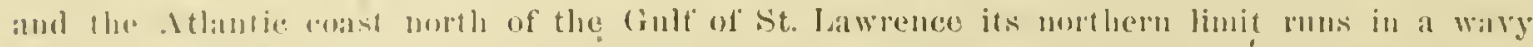

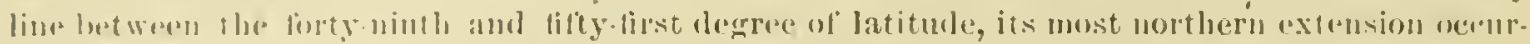
ring near its western lunit, when, skirting the sunthesstern end of lake Winnipeg, it durns sonthwat, following more or less clesely the nincty-sixth meridian of longitude, and in :1

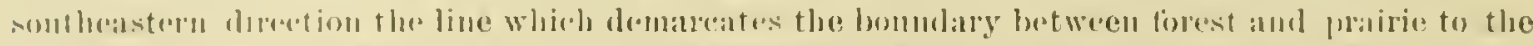

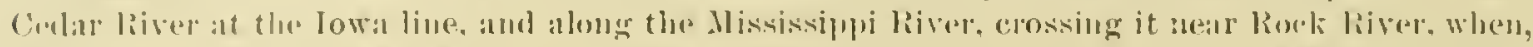

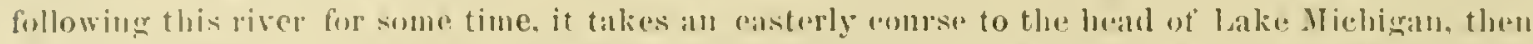

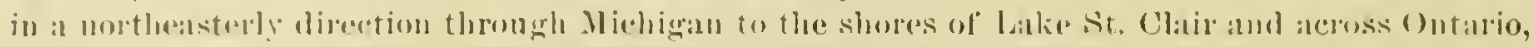
slibting the southern shores of Lake brie in the two most northeasterly anuties of (Ohin, then turus southwan thongh the aistern connties of that State, and following into West Virginia

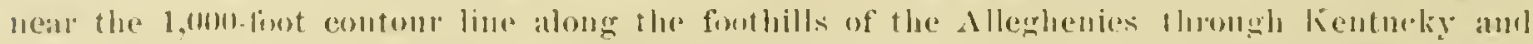

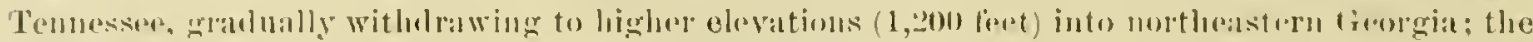

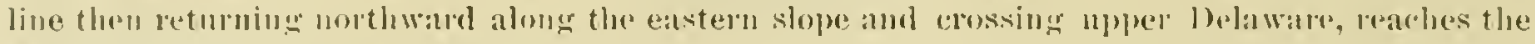
Atlantir roist in southern Lew Jerseg.

The distribution of commercially valuable timbrer is. to be sure, very diflerent and mueh

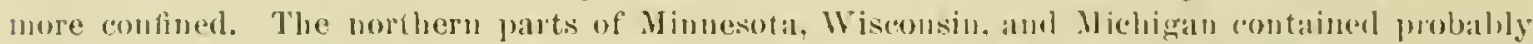
the latgest anount of White Pince the broal bolt of commereial pine of these States continuiag

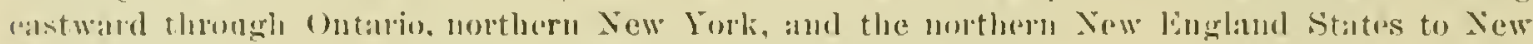

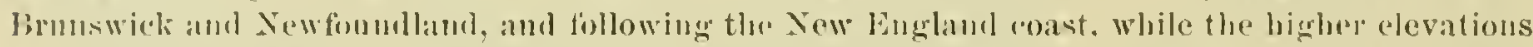
of the New bugland States showed preponderanty spmere with pine intermixed. The northern connties of western l'emsylvania also contamed a latge anonut of White l'ine timber mixed with

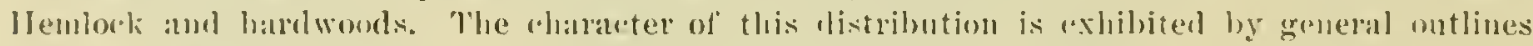
and shatiugs on the accompanying map (1'l.1). The extreme limits of its sponolie arecurrence (an not be fixed with absolute prerision, and from the nat nre of the case must remain more or less indefinite. Similary, the limits of greater or less dovelopment am mily be approximately stated.

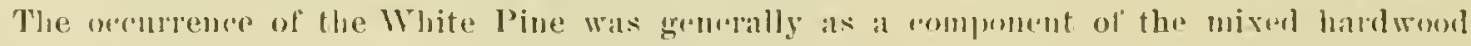
forest of the Atlantic, even in the best developerl purtions of its ange, and muler such anditions, that is, in mixtme with other species, it seems to attain its most proflect development.

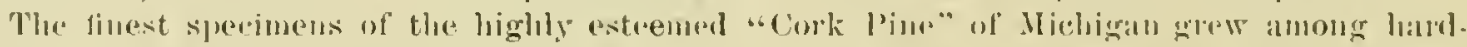

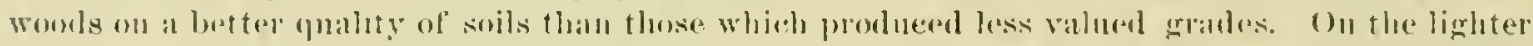

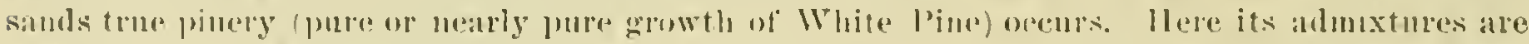

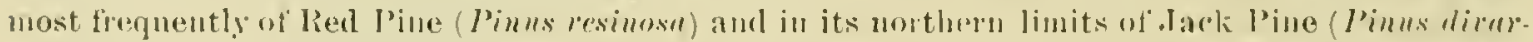

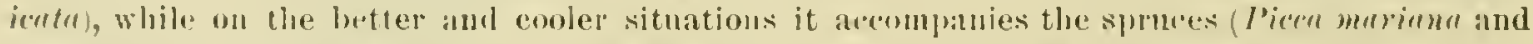

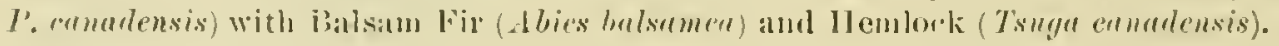

\section{CHARACTER OF DISTRIBUTION, BY REGIONS.}

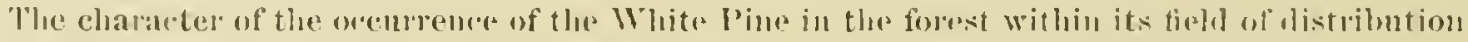

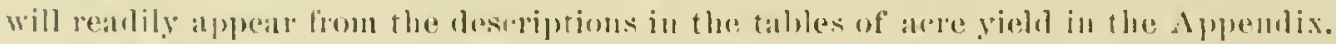

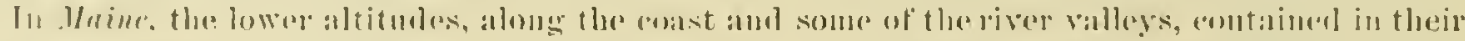

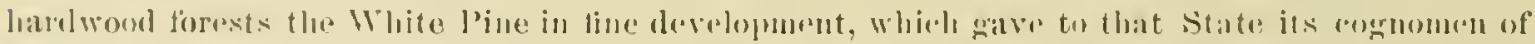

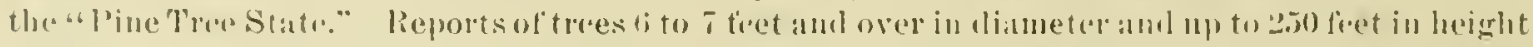
testily to the "aptacity of the species in this region." The oriminal stand of this pine in the Statr is

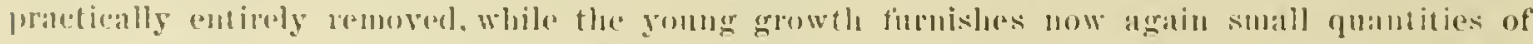
hugring material. The higher altituder, with heir slate and sratuite soils, ane storked cuthely with

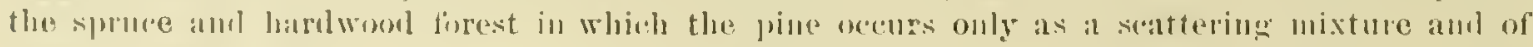
interion darishopment.

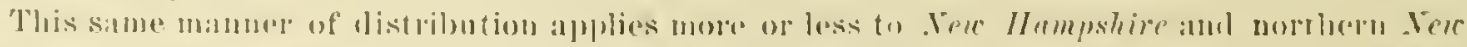

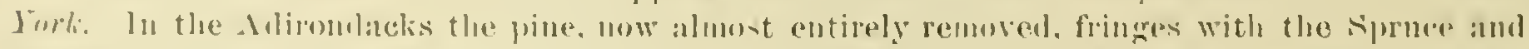
Jalsan bir the mang lakes and water andses and lieeps to the lowier altitules: mixed in with the

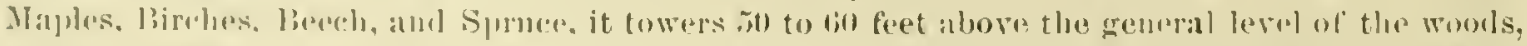

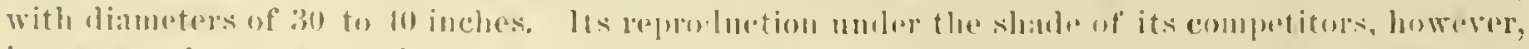

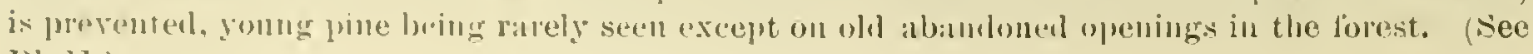
l'l. l1.) 


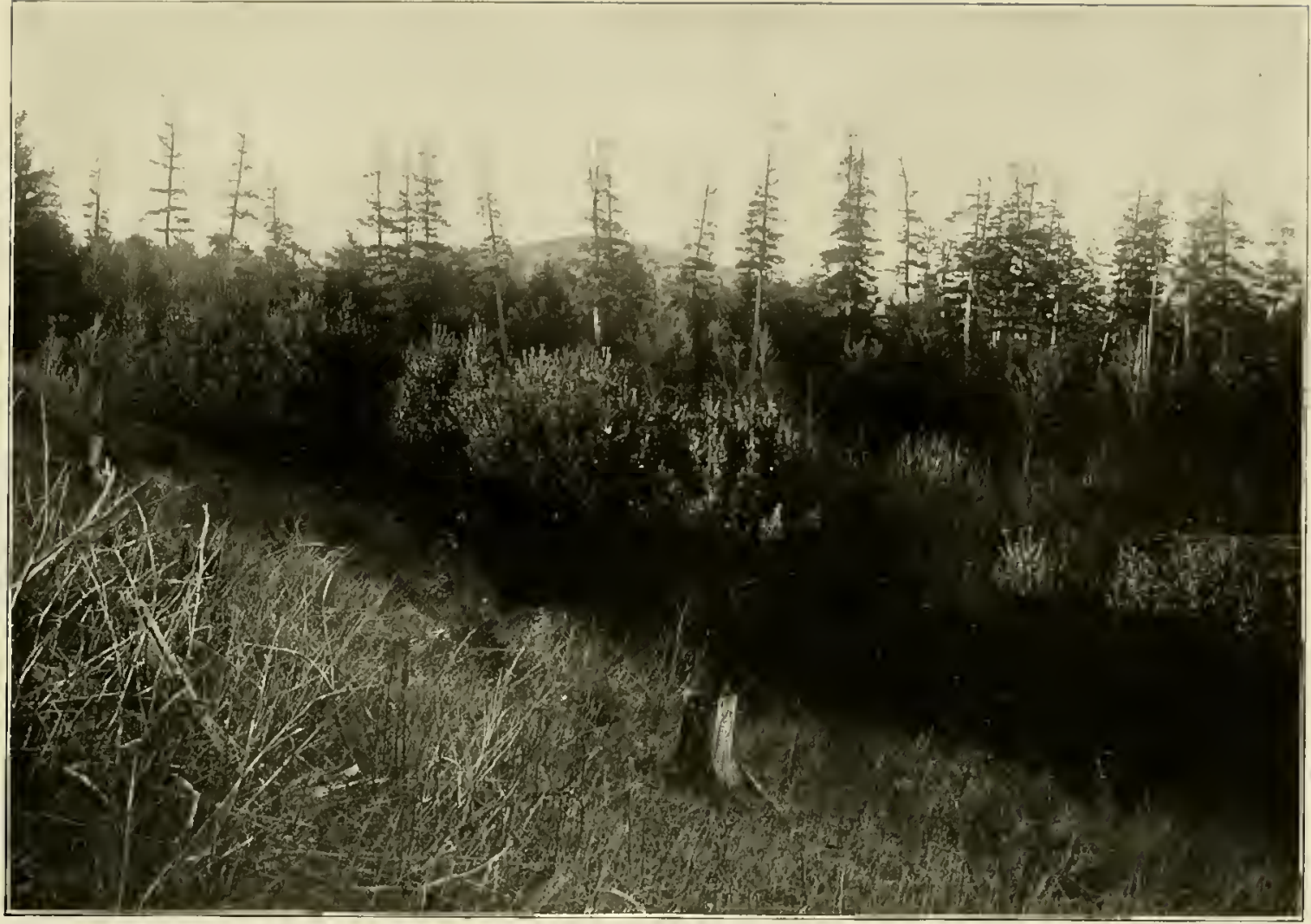

Fig. 1. - White Pine mixed With Harowoods in Central New York.

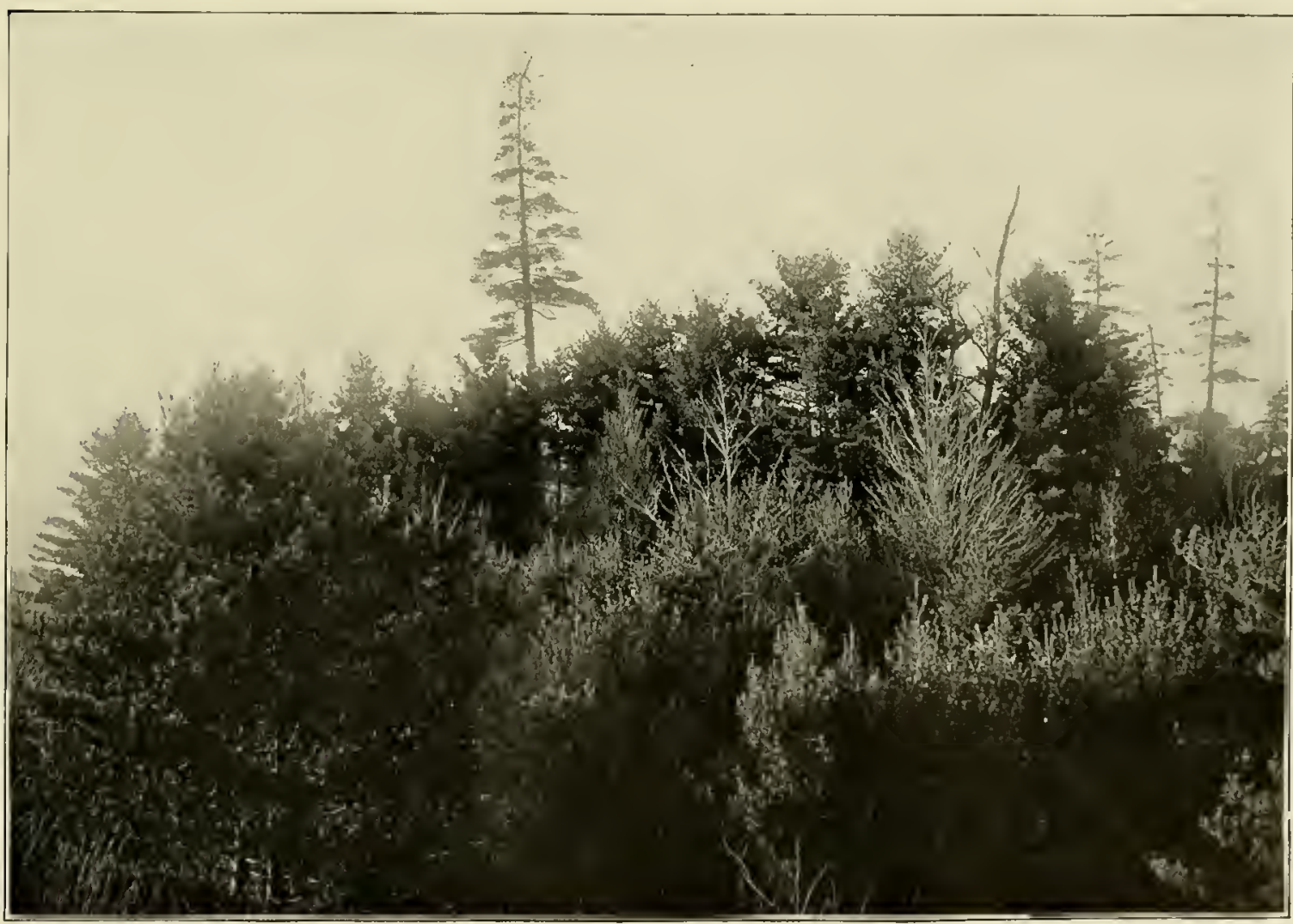

Fig. 2.-Old White Pine Tree in mixed Forest (Young Pine in the FCregroundi in New York State. 



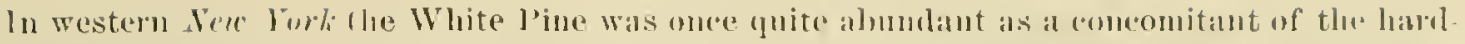

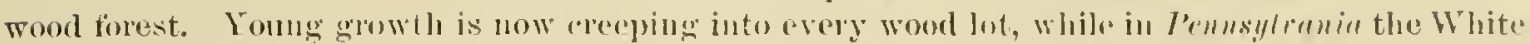

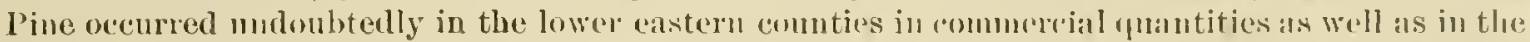

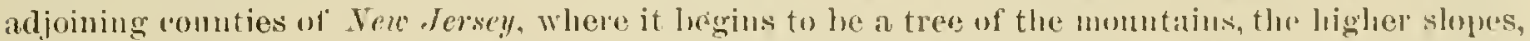
ridges, and tops leomming its fuvorite habitat. It is here langely asiociated with llemlock, which

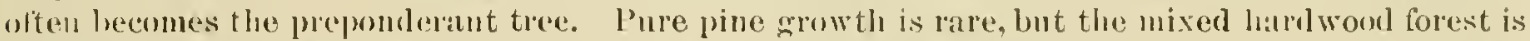

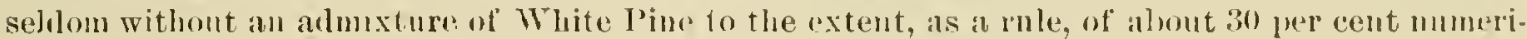
eally, the suils within the range of its onemence being secmingly everywlore guite favorable to its growth.

liesides the Hemlock, the conferons species with which it is found assoniaten are l'iteh Pinte (Pinus rigila) and Spruce, while lied Pine (Pinus resinosu), the most sucecsstul rival of the White Pine in the lake legion, is here ravely net, and then only in single indiviluals. The harlwoors most fiequently representud ale Maple, leech, and Birh, mole ralely Oak and Chestunt, with Basswood, Curmulur, Hickory, Clserry, etc, interspersen in single indiviıluals.

The best develojment of the White line is usnally lound along the water conres. Thus, in Pennsplvania, in Lnzerne Cunnty the White Pine is situated along Beal Creek and its tribntaries; in Clinton County the pine is fomd on both branches of Ilyner linn and along Ioungwomans Creek; in Clearfield Comnty there were 20,000 acres alung Sandy Creek ind its tributaries heavily timbered with White Pine, of which abont "2,000 acres of jimeval timber are left, which would cut abont 100 million fect 13. M. of White Pine. In Jefferson Connty a tract of Henlock and White l'ine forest of about 9o square miles, known as the Hay's tract, is traversed by the North Fork and its tributaries. In Forest Connty the areas heavily covered with pine were sitnated along lliekory and Tionesta creeks. There is as yet standing over 100 million feet B. M. of White Pine along ITickory creek and its tribntwies.

The heavy ent of pine in lik Connty came from Melix liun, Dents linn, and their tributaries. The eotrses of the streams follow the trend of the ridges, the substrata of which are usually of a porous matnre, consisting in most cases of slate or laminated shale, a soil very favorable to pine situated on moderately elevated grounds and slopes along the hollows and gorges, which, on account of the pervions substratmm, offer most satisfactory soil-moisture conditions.

From Ver Versey the White l'ine has practically vanished long ago as a factor in lumber production, and almost as a tree of common occurrence.

With the extension of the distribution sonthward, the White Pine becomes less lirequent and of inferior development; the climate forces it to higher and higher altitndes. It ocenrs in ruatity only in islands or in small hodies on the crests and along the slopes of the Alleghenies, both east and west, usnally accompanying water conrses in broaler ur narrower belts.

Regarding the manner of occurmence of the White Pine in these sonthern regions, the remarks of Mr. W. W. Ashe on the distribntion in North Carolina (Bulletin No. (i, North Carolina geological survey, 18:s) are more or less applicable:

The woolland in which Whito Pine is the dominant eoniferous tree is nut extensive, but lies in 1sulaterl, suall borlies along the crest anil sontbern and eastern slopes of the Bhe Ridge, or on the low hills on the wost, " " " extensive forests seldum heing found above the higher limit (3,000 feet iu llacon aml Jackson counties), or perfoct individual development attaines below the forer (2,800 feet). In a few plaees on the sonthern slope of the BIne hidge + + - the White Pine is as ociated with tellow Pines as well als with decilnous trees, hut the trees are generally short-boled, and neilher so large nor tall as those growing at il higher elevation to the west of this rauge. single specimens or smail groups of trees are loeally dispersed in the broal-leaf forests tlirongbont the moutain counties betwoen the finits of altitude given abore.

It appears from these statements that in these latitudes below the 2,000-foot level this pine can hardly be expected to be ul' commurcial or turestal value tor the tinture.

The area of greatest puantitative development is fonnd around the (rreat [uakes and in the basin of the St. Lawrence and its tributaries, in the very places most perfectly adalpted to its ready and economical exploitation and easy shipuent to markets, the lare number of streams that are "apable of carrying logs, the accessihility ol natural ports of distribution, anıl lavoralsle climatic condelus inviting the logger and haberman. Michigan, Wisconsin, and Miunesota have thus become known as the great lumber region of the Cuited states. 
In Michigan the olistribution of the speries is antirely coutmolled by the charactor of the soil,

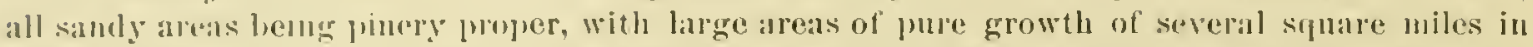
extent contaning only White P'ine. Oceasionally, and especially on the driest and poorest santy gravels, the lied l’ue (l'imus resinosi) associatos and sometimes predomintes, the llhite l'ine not rejpesenting more than 10 to 20 per cent of the numbor of trees. In the northeru rearions Jalok l'ine (Pimus dirmirnta) takes the place of the liod Pine.

The typical pine forest on tresh sambly soils consists of White l'ine (15 to 5.5 pel eent of the

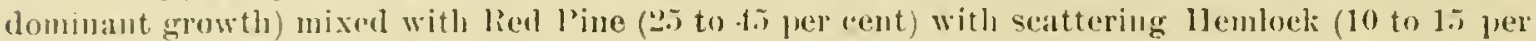
cent) and ocasional fir and haldwoods. The undergrowth, usully moderatrly dense, cousists mainly of small Hemlock, fir. and young haldwoods.

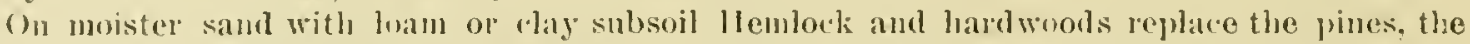
Red l'ine vanishingentiply and the White I'ine occurringonly in large isolated indivionals. Into wet or swampy plares the White l'ine also penetrates in single indivinals among $A$ rborvitie, llackiudack, and Spruce.

As the loan in the composition of the soil increases, the hardwoods increase numerically, the White l'ine ocenring only in single individnals and gromps, and lied line and llemlock only oecasimally. Finally, the heave clay solts toward the southern range of the species give absolute preponderance or exclusive pussession to the hardwoods, mainly Sugar Majule, Yellow lirrl, and Beech, althumgh oecasionally White Pine appears seattered, or even in smallir or laurep groms.

lumbering of White Jine in Nichigan began about 1S35, and was at its best in 1583 , hut now the virerin june is nualy cut ont. Reproduction is satisfactury on the sandy areas wherever fires

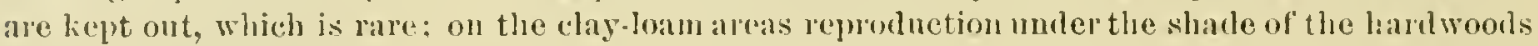
is fractically impossible.

In Hixcmusin the same degendence on soil conditions in the distribntion of the sponies prevails as in Michigan. 'The accompanying map of the forst areas of Wiseonsin, taken from Lulletin No. 16 , of the loivision of lorestry, will selve to give an ir.al of the manner in which this distribution appears witlin the belt of best development. (See l'l. 1II.) From this mal it will he secu that the distribution is to the largest extent dependent on soil eonditions, the sandy soils ropresenting the pinery areas. in which mereluantable hardwoods and llemsocks are wanting: thr. loam and elay areas are storkin with the hardwook forest, in which both llemlock and l'ine occur scattering or in isolated croves, repesented ahnost wirely by mature old timber. Saplings, lusloy young trees, and seedlings are companatively scarce, an active reproduction of the pine covidnutly not going on. This condition is fomblespecially on the heaviest soils, where the hardwoods crowel ont the pine, while on the sandy or gravelly soils the pine holds its own and forms a fail proportion of the salpling timber. In the true pinery of the sandy soils the hardwoorls are scantily rejuesonted ly small White lirelı, Aspen, and Maple. The Hemlock is entirely wanting. (On the barrens proper the White l'inc is replaced hy .Jack l'ine and Iiod l'ine, one, or both together, forming forests of "omsiderable extent. usually with lardy any undergowth or admixture sare somo seattering Sorub ()ak.

In Minneset efmatic combitions again begin to assert themselves in infmucing the distrihntion of the lloite l'ine.

The conitirs become preponderant over the hardwowds everywere. Pines, lwth lied and

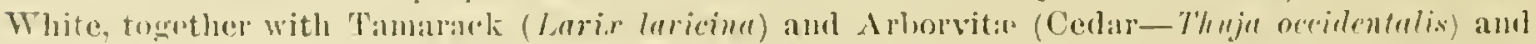
some abnixtme ut Spruce oreupy those sites, both swamp and hry lands, which elsewhere would be orenjom ly handwoods. Witle this change in composition goes a decrase in levelopment; the sizes lonth in dianeter and height are rednced.

It is an interesting fict that hoth in Wisconsin and Minnosota the pine anea does not, as in

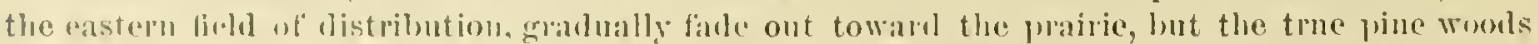
rease abmptly within 30 or 10 miles at most from the demarcation line of the praire, learing the

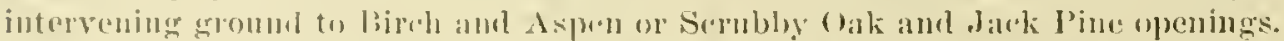

In the Canadian extension of the suecies fure pinery is very rare. The grat bulk of the most probluetive pine connty lies northwarl and westwad from the month of the (Ittana liver (1) (icolerian bay in mixed growth, which consists mainly of hardwoods, with Hemlock, Sprnce, Arborvitif (Cmlar), and lialsill, while the lower tiers of ontarie are of the same character of barkwools, with Jittle sattering pine, as in southern Michigan. The castern extension of the 


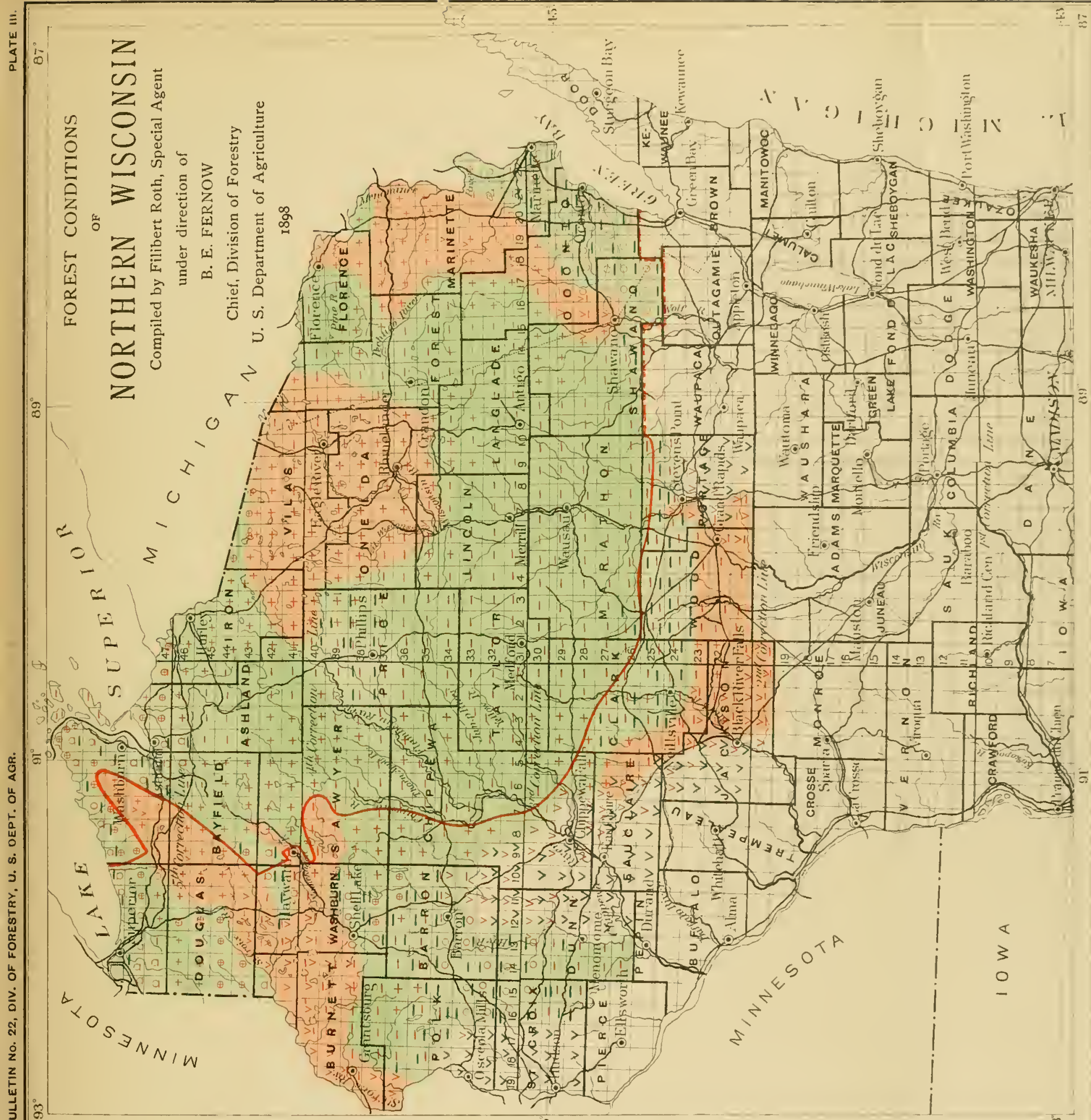



field of eommercial pine in Canada followed mainly the St. Iawronce liver as far as Quebec. On Newfoundland the species is imligenous to noarly the whole of the islaul, and in some parts pro. duces considerable ynantities of merehantable timber. At its northwestern limit the forest fades ont into prairie, the White l'ine gradually disapenring, while at the northern limit the clange is into Spruce forest.

\section{NOTES ON GENERAL DISTRIBUTION.}

Dr. N. L. Britum, for some yeal's connecterl with the geological survey of New Jerses, writes of the occurrence of White Pine in that state as follows:

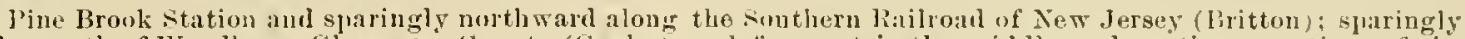
3 miles sonth of Woodbnry, Ciloucester Connty (Canhy), and frendent in the mildle and northern portions of the State. There are no White Pine forests in Now Jersey, and the largest grove known to me is of hut a few acres in extent. It eviclently prefurs a heaver suil than does $P$. rigida, which forms the forests of the pine barrens. On Staten Island, New York, there are a fi'w seattered trees of $I^{\prime}$. sivobus.

Mr. Williau M, Canby, of Wilmington, Del., reports the existence uf a grovo of White Pine trues in upper Lelaware, and Mr. Thomas Meehan, of Germantown, Pa., states that White Pine grows (or lid recently) at the Soapstone quarry, on the east sile of the Sehnylkill, some 8 or 10 miles alove lhilarleiphia. Mr. Canby arlds: "lt is a very difficult thing to detine the limit of a speeies that is being so rapidly clestroyed, and doubtless the sonthern line is being rapidly ellaced."

Prof. Lester F. Ward, of Washington, D. C., is of the opinion that P'inus strolus is not indigenous around Washington, and that the few trees met with in wild situations in its vicinity grew from seeds blown from planted trees. He has never met it in his hotanical excursions into southeastern llayland and Virginia.

Mr. F. E. Boynton writes from Highlauds, N. C. :

I have seen some rery fine specimens growing in Pickens and Oeonee counties, S. C., bnt I hare never seen it in this part of the country except in high altitudes, say from 2,500 to 3,000 feet usually. 1 have never seen or heari of its forming forests here. I have seen groves of a few acres where it might bo said to pretominate. As a rule, it is fomml seattered among other forest trees. It nearly always grows in or quito near lihododendron anil slomtain Lanrel thickets, which judicate a moist soil. It often grows to be a very large true here I measured a log in the will yarl near here last night that was 37 inehes throigh. Cousidcralile lnmber is cnt from lWhite Pine in this mountain region, but, as a rnle, tho lumber is of inferior quality, being very lnotty and often shaky. Cultivated specimens thrive and grow very fast. It is nsnally found must eoumon ou sunthem exposmes. The rock formation is granite, and soil usually a siudy or gravelly loam wherever I have ubserved the White l'ine in this region.

The following has been furnished l,y Prot. W. R. Lazenbs, of the State arri'nItural experiment station at Columlıns, Ohio:

From all the data in my possession, I should say that White Pine is rarels met with in Ohio ontside the borlers of two of onr northeastern connties, viz, Ashtahula and Lake. Geeisionally a spmadic jateh has been noted alonir the banks of streams ju some of the eastrin connties. I have never hearl of its spontanems occurrence any where thronghout the cential or sonthern portions of the State. It appiars to thrive well here at Culumbus and sillumits kinuly to change of soil. Wherever I have seen it in Obio nneler artificial cultivation it has presented a thrifty appearance, althongh the somg plants do not wake a very rapid grow th fur the lirst lew yeary. writes:

Coneerning the veenrence of White l'ine near the heal of Lake Miebigau, Prof. F. J. Hill, of Xormal Park, Jil.,

It hegins at Whiting Station, on the Nlinigan Sontheru Railroal, and extents eastwarl to Mlichigan City. I

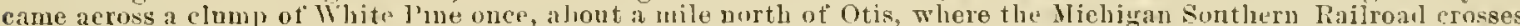
the New Albany roar. - " Von would be prettr sate in taking the calumet River as the sonthern bonndary. the New Alo not know of a single native tree in Cook County, 111 .

Mr. Ml.S. Bebb, of liockforl, 11], commuieates the following eoncerning the oreurrence of White line in the northerm portion of that State:

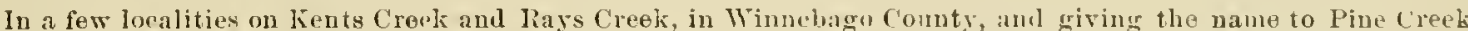
in Ogle, the combty immeliately north of this, the White Pine is artanily indigenons, but oceurring only as a sparse growth, eresting precipitous binks, where it seems to hive found a firvalile environment.

To this Mr. S. B. Watsworth, of Oregon, Ill, arlds:

The White Pine in Ogle Connty grows in some cases to a height of 10 or 50 linet. " " " Vearly all the small streams in Pine lack township hive some pines near the months of the strenme if there are any meks along the lnaks. * * The White Pine preters the St. Peters saulstone, but in sune cases grows on linestone rucks.

Mr. li. Williams, of Streator, 11l., says:

White l'ine is withont douht a native of las Sallo Connty. It ocenrs on the Vermilion and its little tributaries wherever there is an exposure of carbonilirous sandston', aud more frequently is seen eluse to the edive of the hiphest blufts, where the soil is largely composed of the disintegrated rock. 'lio tind one besond thr jutinence of the sand roek would be almost phenumenal. The n mmer is very small and their situat im thes not purmit thum to attain mmel size. I think that 10 feet is ahout the limt of height. Small thrifty plants from one to a few feet in height occur here and there, and are sonetimes transplanted to the luriniss soil, where they make a vigorous growth, ontstripping Norway Spruce. Sioteh and Austrian Pine, Hemloek, and White Cerlar. l'ines planted here in $185 \bar{f}$ or 1855 are now (1886) abont 40 feet light.

The limiting line of the White Pine leyom the Mlississippi nortluestward is tracel sulstantially as indieated by $\mathrm{Ar}$. Warren Upham in the feologieal and Natural 1 history Snrvey of Minnesota. Mr. Lphan serues the following:

The White Pine, wherever l lave sien it un New llampshire and other parts of Fin England and in the Northwest, prefors somewhat elayey land. It does not thrive ou wholy" sindy flilins ("moditied dritt" of glacialists), 
"hivh are lenominatel "pine barrens," tho comgrnial dwelling place in the lanst for the l'itch l'ine ( $P$. rigida), and

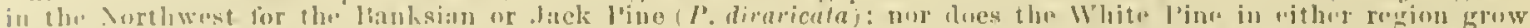

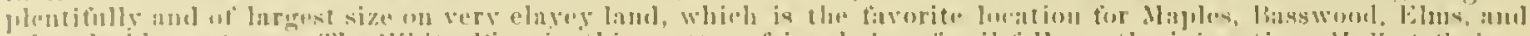

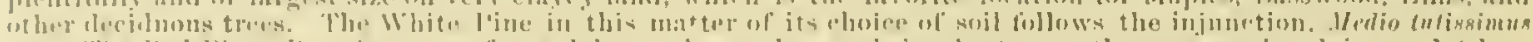

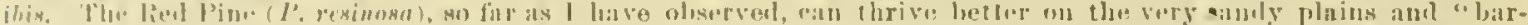

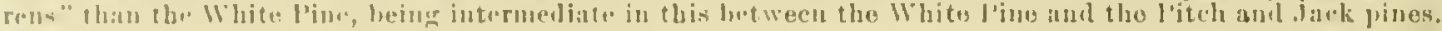

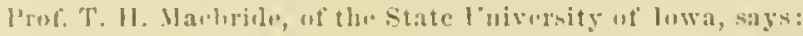

I have "ollected Whitw l'ine in tho following comtios in this state: Hitrhell, Ilowanl, Winneshiok, .llamakce,

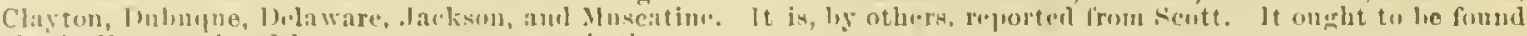
alsin in lagetta. lont l have never run across it there.

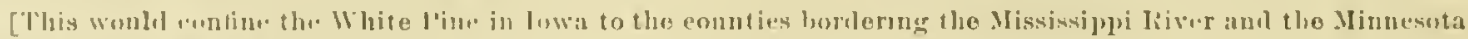
statr liut as fin west as tho Corlar River balley.]

\section{CONCLUSIONS REGARDING NATURAL DISTRIBUTION}

The learling conclusions to be traw from what lans been stated regarling the natural distribution of White l'ine serem to be the following:

(1) Leaving ont of comsileration all the outlying fortions of the requn under biscussion, there is left an area of not less thin fon,ono syuare miles in the l'nited states and Dominion of Canala within which the White l'ine is in its home and surrombled by the conditions of its own elwice, thronghut which its sueerssful cultivation is fully assures?.

(2) A mueh linger territory than this is inclunded within the linits of extreme distribution as detined above, and there is abundant evinence to show that over nearly the whole of this wide area. and in some directions fir begond it, this species makes nucler cultivation a healthy and rapid growth. There is apparently no speries of ecpual value indigenous to eastern North Amerinat that is at the same time alapterl to so wide an area.

(3) The labits of this species near the western linit of its natural ocenrence, as well as experimatul planting, indicate plainly that its sureessful growtl can unt be depended mon much beyond this limit.

\section{THE WHITE PINE LUMBER INDUSTRY.}

To speeies of Ameriean timber has been so mnch used for Inmber as the White Pine, and the development of the lumber inlustry in this country is coineident with the exploilation of the White l'ine liorests.

The eommereial nse of White Pine hegan with the first settlement of Xew England. The lirst sawmills were rstablished in the seventeenth renturg, and mmerous small sawmills, which were usually an altachusut of the neighlonphool gristmill, were in operation early in the riglufenth rentury". Timber was exchanged for merchandise, and the colloctions thus mate ware thated to jorts of shipment, whence they were exported. 'Tlis primitive industry, confined langely to White l'ine, was continned well into the third deeale ut the present century. In 18.n, . I. S. Springer, of Maine, wrote: "Thirty years agu it was unnecessary to swarch tor a localily for a lumber camp on

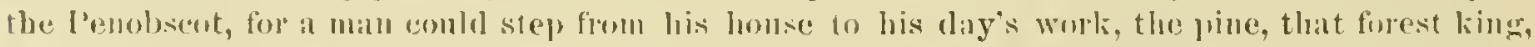
alonmoliug on every sirle. Fily years hence the vast pine forests thongh which lhe l'enobsont

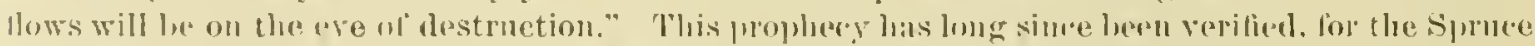
has juatically taken the place of the While line in the lumber mutgut ut Naine.

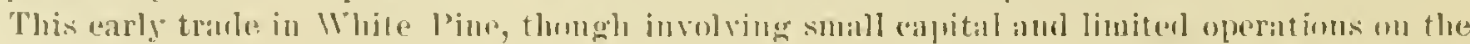

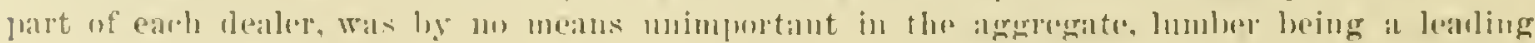

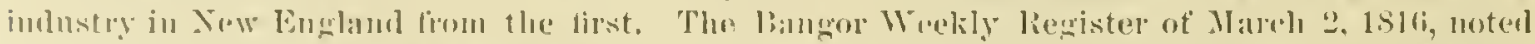

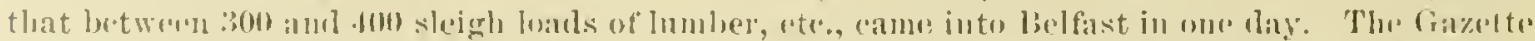

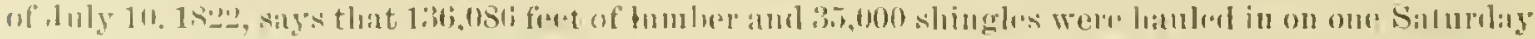

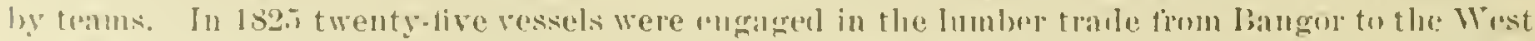

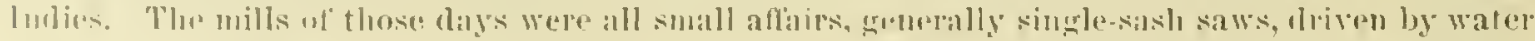

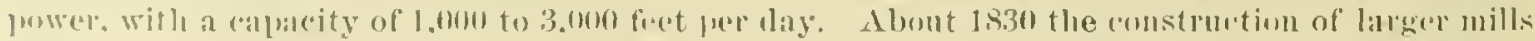

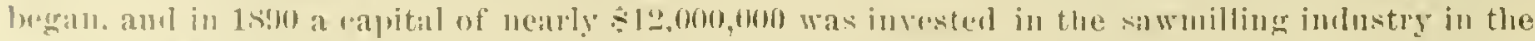
Strite of Mains alonir.

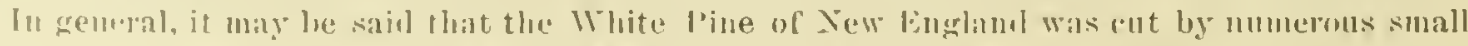

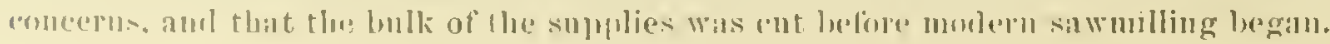


Althongl the great forests of White Pine in Mane have disappeared, a small amonnt of this material is still ent in the State every year, so that since 1ssl, on the Penobscot, fin instance, ont of a total cut of ahont 150 million teet per yeal between 23 and 30 million feet have been pine, the pine thus generally forming 15 to 20 per went of the entire output.

In Pennsylvania the explnitation of White Pine likewise began ynite early. l'nttsburg furnished pine lumber to points along the Ohio and even to St. Louis, Ho. As late as 1550 Philadelphia received its 150 million teet of lumber, largely White Pine, from the State, importing but verg little from New England and the South. It Williansport, the center of White Pine Inmbering in Pennsylvania, the first large mills were ereeterl about 1838, and the bulk of the pine was ent priol to 1870 .

In the torties the White Pine prodnet marketed at Willinmsport exeelled in prantity all other points of production. The highest prolnetion was reachel in 1573 , with nearly 300 million feet B. II. in logs boomed, which in 1893 had smik to a little over one-tenth of that amomt. While in 1873 the amount of timber stanling was estimated as 3,300 million feet B. M., in 1590 the State commissioner of forests places the remainder at 500 unillion feet B. M.

The only ment White Pine forests of Pennsylvania now standing are isolated bodies in the more inaceessible parts of Clearfieli, Lycoming, and Tioga counties.

In the state of New York, too, which in the Adiromdaeks and in the western eounties con. tainer consinerable quantities of White ['ine, the species is largely cut out. Hardly more than $\bar{y}$ per cent of the cut is now of White Prne, the ontpnt from the Idirondack mills being in the neighborhoor of 25 million feet B. II.

The exploitation of White Pine in the Lake region began luring the thirties, when small mills were erected at various points, both in Michigan and Wisconsin. The first steam sawnill at Saginaw was built in 1834 , am the first mill at Alpena was bnilt two year's later. Tevertheless the lumber industry of both Miehigan and Wisconsin remained insignificant until toward the elose of the fifties, when most of the present sites of munfacture had been establisher. Ten years later $(15 \% 0)$ the ammal ent of White Pine in Michigan and Wisconsin amonnted to nearly 4 billion feet; Minnesota had searcely begnn to eontribnte to the ontput; and in the marketing the railway was fast displacing the older method of rafting. The progress of lumbering is well illus. trated in the following figures from the Northwestern Lumberman, representing the aumal cut of lumber alone tiom 1873 to 1897 :

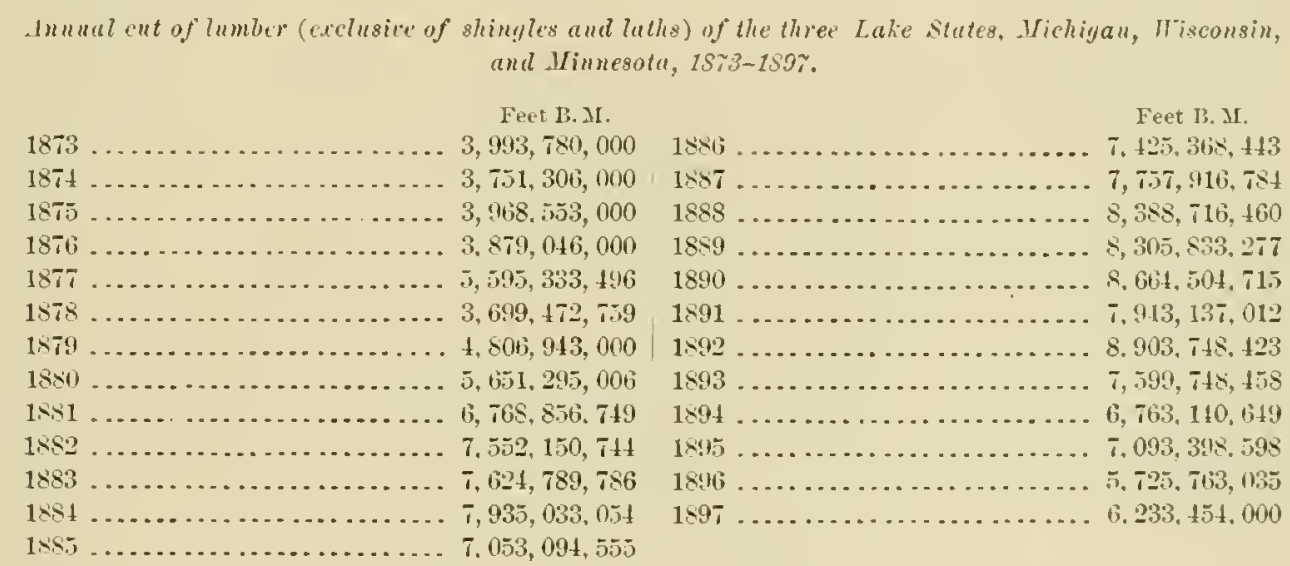

Or, dividing the time into perious of tive years each, the figures are als follows:

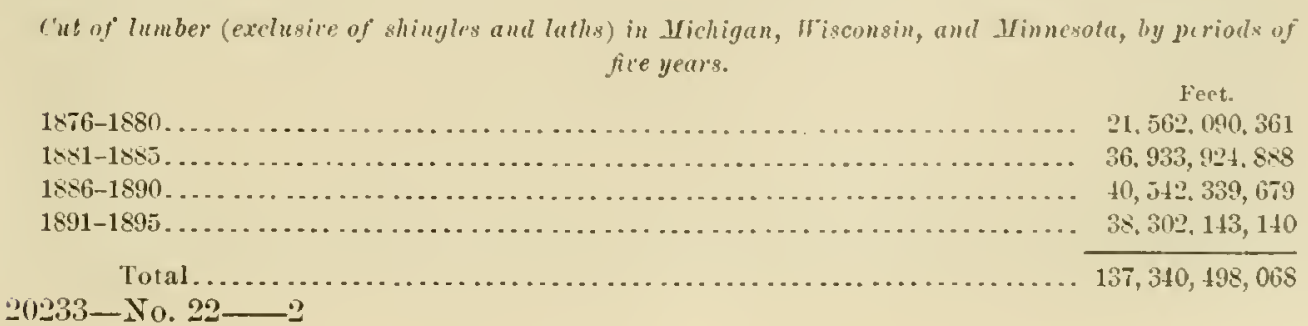

$20233-$ No. $22-2$ 
From the figures, to which about 10 per cent must be adlen for slingles, laths, ete., it appears that the yearly output dis not reach of billion teet until 189!. and that the greatest increase in the

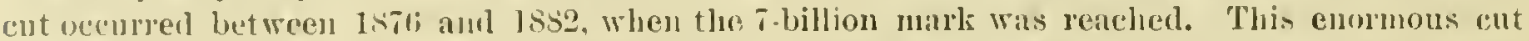
contimed until the weneral business depression of 1894 callerl a temporary halt. In IInuesota, jine lumbering began on the St. Croix and dich mot jeach conspienous dimensions until during the eiglities, when the regions along the uprer Mississippi, as well as the lnuhth district, were openerl. This progress westwind is well illustraterl by the following figures, which show the prercentage of the total ent of lumber alone from period to period, by distriets:

I'crentage of total rut of lumber, $18 \% 3$ to $15 \%$. by dintricts.

\begin{tabular}{|c|c|c|c|c|c|}
\hline \multirow{2}{*}{ bistrieta. } & \multicolumn{5}{|c|}{ Lumler rinf. } \\
\hline & $14: 83$ & $10 x 11$ & $14-5$ & $1<! 61$ & $1+11.5$ \\
\hline & Itrcent. & I'rerne. & I'er cont. & Sterent. & ler cent. \\
\hline 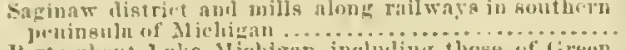 & 36 & 31 & 27 & 24 & 16 \\
\hline 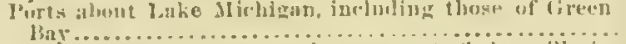 & 30 & 32 & 28 & $\because 2$ & 36 \\
\hline 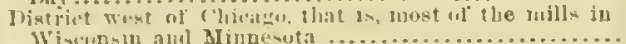 & & & & & \\
\hline & 34 & 37 & 4.) & th & 58 \\
\hline
\end{tabular}

In this connection the White Pine trade of St. Lonis prestuts an interesting illustration. The first pine lumber was received from l'ittsbure in lislg, and this point remained the principal somree of stlpplies for years. In 1543 a boom on the St. Croix liver lnoke and the liberater logs were gathered and rafted to St. Lonis. Where they were salw. In 18\%o the first regular raft of

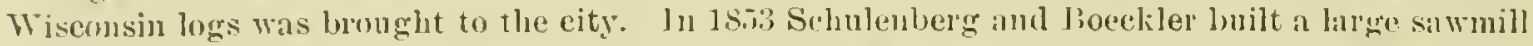
on the St. Croix, and from this time on rafts of salwed White Pine were sent to St. lonis from the northern rivers.

The receipts of White l'ine at St. Lomis ware: In 1853, abont 60 million feet: in 185., about 11i2 million feet. Similarly the lumber trate of the rity of Chicago, the greatest lumber market in the United Statrs, if not in the work, ilhstrates well the levelopment of the White Pine lumber industry. In 1817 only :3z million feet of White l'ine lumber were received. The anmal receipts at jutervals of ten years since 1855 to 181,5 were as follows:

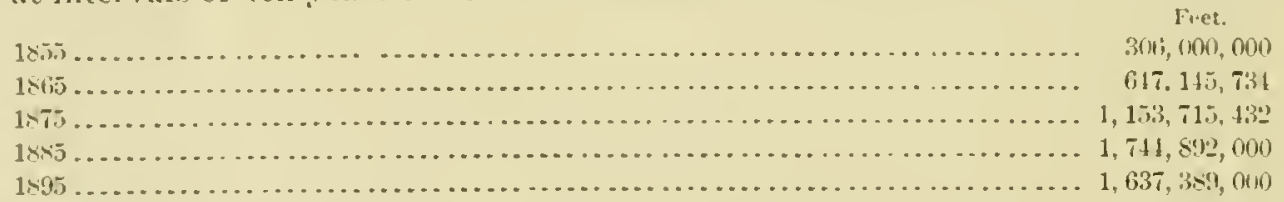

The receipts reached their maximum in 1892 with $2,203.874,000$ feet, and the heary diminution since that date is not greater than would be accounterl for by the general business depression throughent the comintry.

In Cinnala, as in New England, the exploitation of White l'ine began almost with the first settlement. Logs, hewn timbers, ant especially sliph spars, were exported in early days, and of late years an extensive trade in sawn lumber, as well as saw logs, has spung up betwern that comnty anl the Cuited States. Since reliable statistics of the lumber output of this region are wanting. tle following figures for the dues on crown timber in Ontario and Queber unst suffiee to illustrate the developurent of the industry:

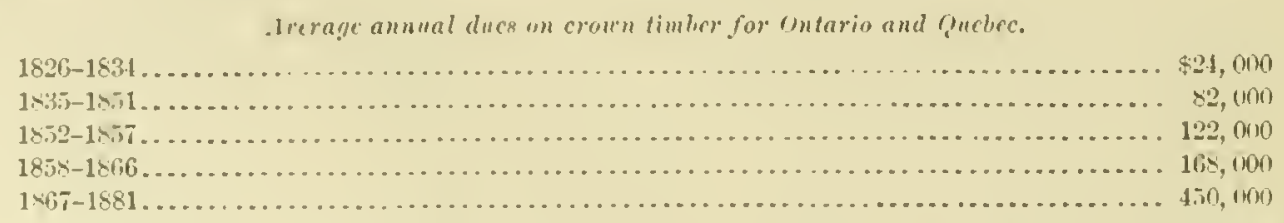

The export into the Linitel States for 1594. the henviest year, was: Immber, 1,155 million

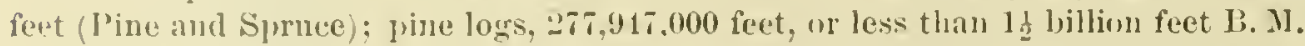

Though scattering White l'ine ncenrs in all provines of eastern Canadil, large borlies of merchantable timber ane only to be found on the upuer waters of the Ottawa. and on the shores 
of Lake Huron (Georgian liay district) and Lake Superior, and the White Pine lumbering is practically confined to these distriets. The ontput of White Pine in the Dominion is estimated at $1 \frac{1}{2}$ to 2 billiou feet per year.

\section{ORIGINAL STAND AND PRESENT SUPPLIES.}

What the original stand of White Pine was is dillicult even to estimate. The amonnt of White I'ine eut in the New Englaurl States, New York, Pennsylvania, and the eastern Provinces of Canala is not known, and the only reliable figures which give an indication of what has been harvested are the figures for the Lake States above mentioned. For the Lake region alone the estimated original stand for Wisconsiu may serve as an illustration. For the pine-stocked area of this State, a total stand of about 150 million feet per tormship ( $2: 3,(100$ acres) has been slinwn to be a fair average. This would indicate a total of about 130 billion fect, of which about 60 billion feet were cut between 1583 and $15: 17$, and abont 20 billion feet are supposed to have been cut prion to 18.3 , making a total of abont 56 billion teet as actually harvested, while about 18 billion feet were believed to be still standing in $\mathbf{1 5 9}$. These figures are based upon a thorongh eanvass made by Mr. Filibert Roth and published in detail in Bulletin No. 16 of the Division of Forestry. On the same basis, Mluhigan possessed fully 100 billion feet aud Minnesota may be assumed to have lıad abont 70 billion feet, which rould make an aggregate of about 350 billion feet of pine for the Lake States. Of this about 170 billion feet rere cut between 1873 and 1897 , and abont 50 billion feet were probably cut prior to this time, accounting for about 220 billion feet out of 350 billion feet. While it must remain mere conjecture, it seems qnite fair, nevertheless, to assume that the total supplies of White Pine aggregated pobably not less than 700 billion fect of standing timber originally. Of this total, then, not less than 50 per cent was contained in Canarla and the Eastern States, the United States portion representing about two-thirds of this heritage, the Canadian portion showing les.s than 20 per cent of total supplies.

Of this large amount of virgin supplies, a little over 15 per cent, or 100 billion fect, may be estimated as standing. These supplies may be approximately distriluter as follows:

Canada is credited by the statistician of its department of agrienlture with abont 37 billion feet of standing pine, an estimate probably far below the real truth. For the Lalie States the following estimates were made in 1897 by the best-informed man of the Lake region: Niunesota, 36 billion feet; Wisconsin, 18 billion feet: Hichigan, 10 billion feet. These estimates are consilered fuite high by many. The standing pine in Nichigan is placed by a detail township canvass in 1890 at only about of billion feet; the standing White Pine of Minnesota is estiunated by the State chief fire warlen at only about 12,600 million feet, while an estimate for Wisconsin made in 1395 places the standing pine of that State at only $S$ billion feet.

Retaining the larger figures as probably the nearest correet, there exist to-day: In the Lake States, about (if billion feet; in Canada, over 40 billion feet; in New York and Pennsylvania, not over 2 billion feet; in New Euglaud, not over 3 billion feet; in West Virginia and Tenuessee, not over 1 billion feet; making a total of about 110 billion feet, or about 22 per cent of what may fairly be believed to have been standing originally. Of this standing supply. about 100 billion feet are so located that the present rate of exploitation (over 6 billiou feet per year) ean be, and probably will be, contimed until over ij per cent of the present supply is cut, when, of course, a lack of logs will lead to a reduction in ontput. This condition may be looked for before the end of the next teu or twenty years, and from that time. unless recuperatire measures are arlopterl. White Pine will cease to be the great staple of onr lumber markets.

In former years lnmbering of all kinds was careless, and even in the White Pine forests the prevailing "incxhaustible snpply" notion led to enormons waste. Stumps were left 3 to 4 feet high, all delective trees were left, and top logs burned mp with the dobris. Many of these old slashings have been logged for the second and even the third time, often yielding a greater profit than when first enlled.

At present this is no longer the case. High stmunge prices and a jerfect market hare led to the closest economy in logging, milling, and shipling of White Pine. The trees are fellenl with the saw, the stumps are 18 inches and less, care js had in the marking and saming of logs, and the top is utilized, irrespective of linots, just as far as it will make saw timber. Defective logs 


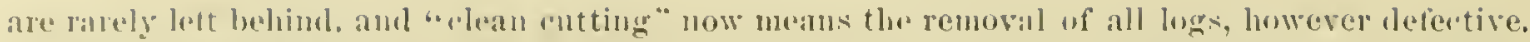

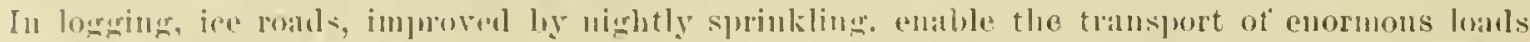

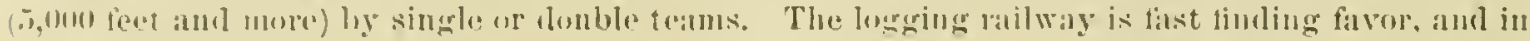

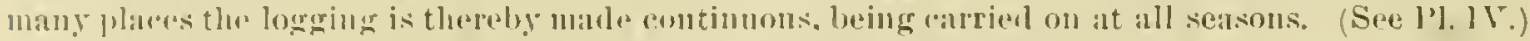

The yielch in White l'ine an'e, ans might be expreted, very villable.

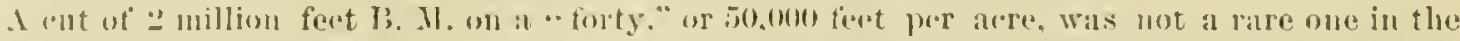

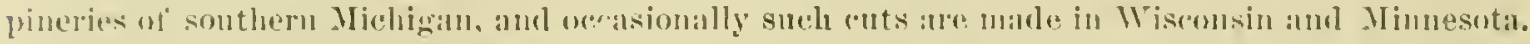

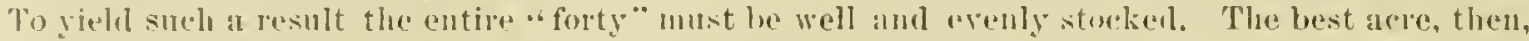

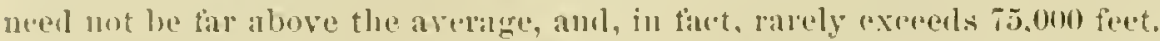

A stand of 1 million feet on a " forty", or "2., (n) feet per acre, is at gond one, but was of quite enumbn occorrence in all White l'ine listriets, and may still be foum in many places, while whole

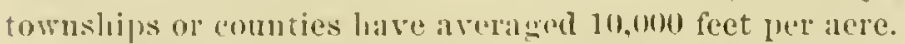

These yieldi depent, of conrse. on the claracter of the forest growth, the greater ur smaller admixture of other speries oecasimuing the differences. Thus, if any" latere territory of the pine

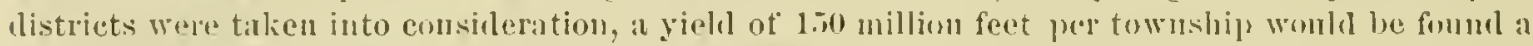
fair statement for most parts of the prineries of Wisconsin and Mjehigan.

The best yiclds do not usually come from thuse tracts which contain the hargest tress, hut where the pine is least mixed witlo other species and stands most iense.

Such areas, pineries proper, where no merehantable havd wouls were mixid with the prine, are msunlly tratets of lonmy saml, and occur in extemsive buclies in all three of the Lake states. Generally, White l'ine cuts more wastefin than Norway or lied l'ine, has a thicker bark, more large derd limbs and knots, these latter often coming to within 20 feet of the gromm, even on large trees, and is quite given to forking. This latter juenliarity seems natmral to the tree, and has been observel abrual as well as here. It seems indepenlent of the character of the soil, is it

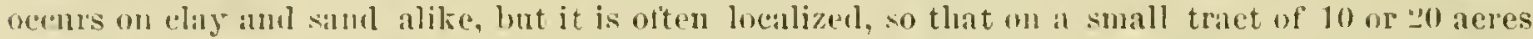
nearly all trees are forved. Trees with three and fonr forks are not rare, and tive forks ocur. In allitim. White l'ine is extensively defeetive by deeny. su meh so that in some loealities 15 to 20 per cent must be allowed for the loss from this source.

\section{NATURAL HISTORY.}

The oldest description of the White l'ine aplears to he that of Plnkenet, published in 1700. Its scintitic nane of Pinus strobus was given the speeies by Linnirns in 1753, and mulike most

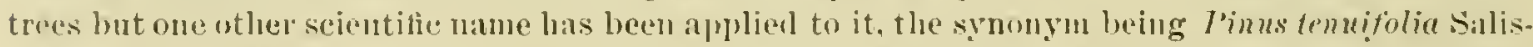
lury, 17!n. Besilles the generally aceepted commen mame of Whitr Pine, the species is lonally known in the Enited States as Soft Pine, Nortlarn Pine, and Spruce l'ine, and to a limited extent by its nsual European name of Weymouth l'ine.

The species was first intruluced in Europe at Badminton, England, and was soon after extensively planted on the estate of loor Weymoutlu, whene its emmon name abroad. It was also cxtensively plantel in (iermany at the end of the last century mone the same name, Weymuth. liefere.

\section{BOTANICAL DESCRIPTION}

White P'ine (rinus strolues L.) in its natural babitat is a tree of large size, 100 fret or more in

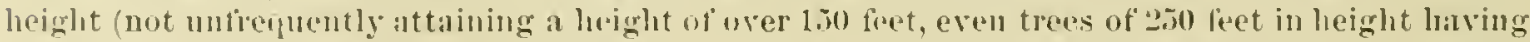
been reported), with smooth. thin, grayish hark (tig. 1). Wroming at the base thick and deeply furruwed with age. The leaves are slember, straight, triangular in section, five in a sheath, $2 \frac{1}{2}$ to $4 \frac{1}{2}$ inclues long; resin incets, chiefly two near the dorsal face: stomata in three to five rows on the fentral faces; fibro-vascular bundle, one. Cones, single or in groups of two to three, stalked anrl pendulous, $t$ to 6 indhes long. eylinulrieal, slightly tapering and enrverl, fruit-seales oblong wedge-

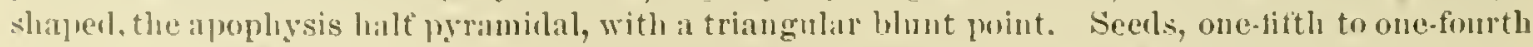
incli long, grayish-brown, with a thin membranacens wing. Cotyledons, seven to cleven.

A number of varieties, more or less distincty marked, are recognized in enltivation. Among these are nema, a lwarf, busly form, enltivated in gardens in the Old Wordd; nicea, viridis, and aurea, naned from the color of their leaves; brevifolin. and several others (umbraculiferu, minima, 


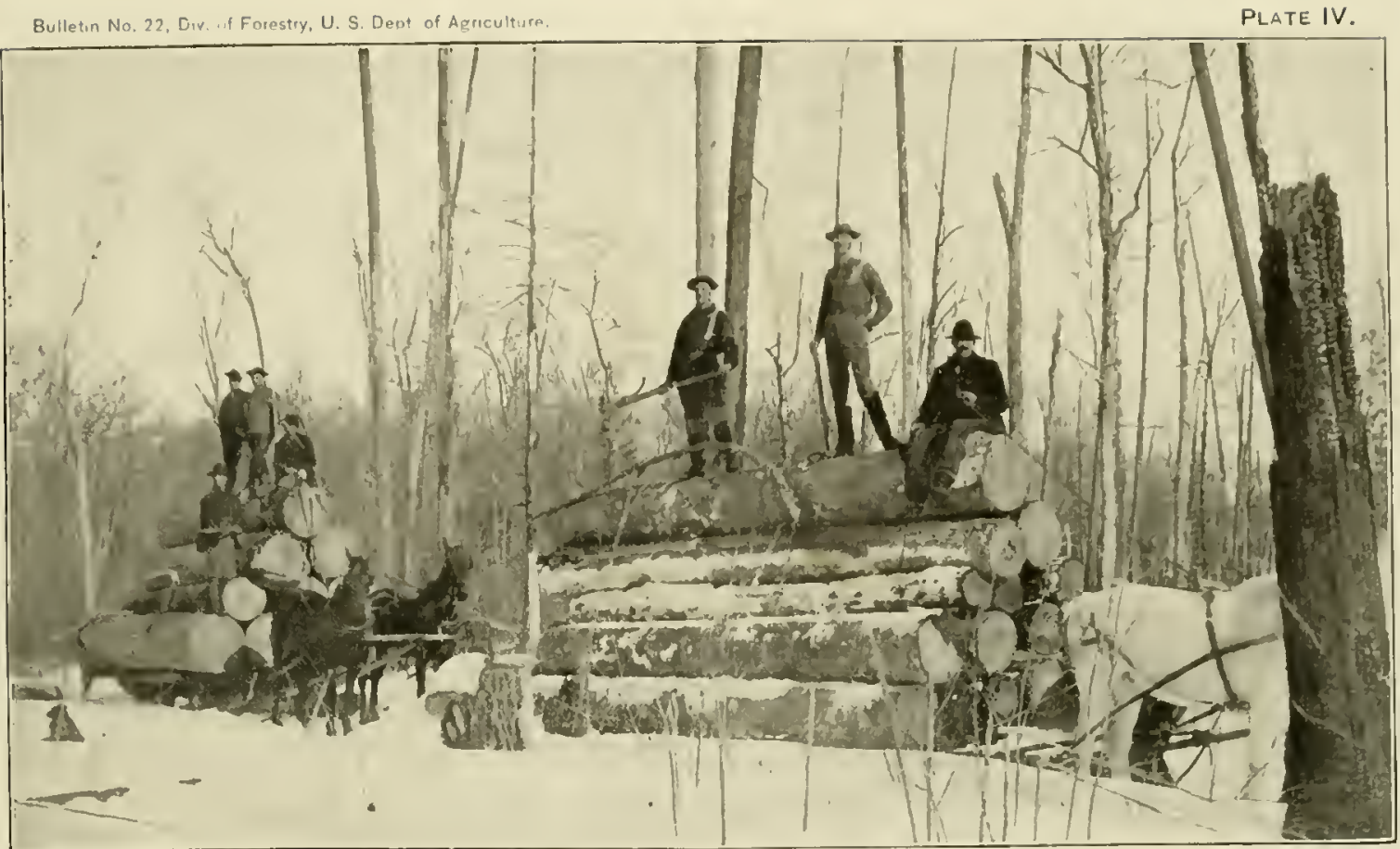

Fig. 1.- Transporting Logs over ice Road in Michigan.

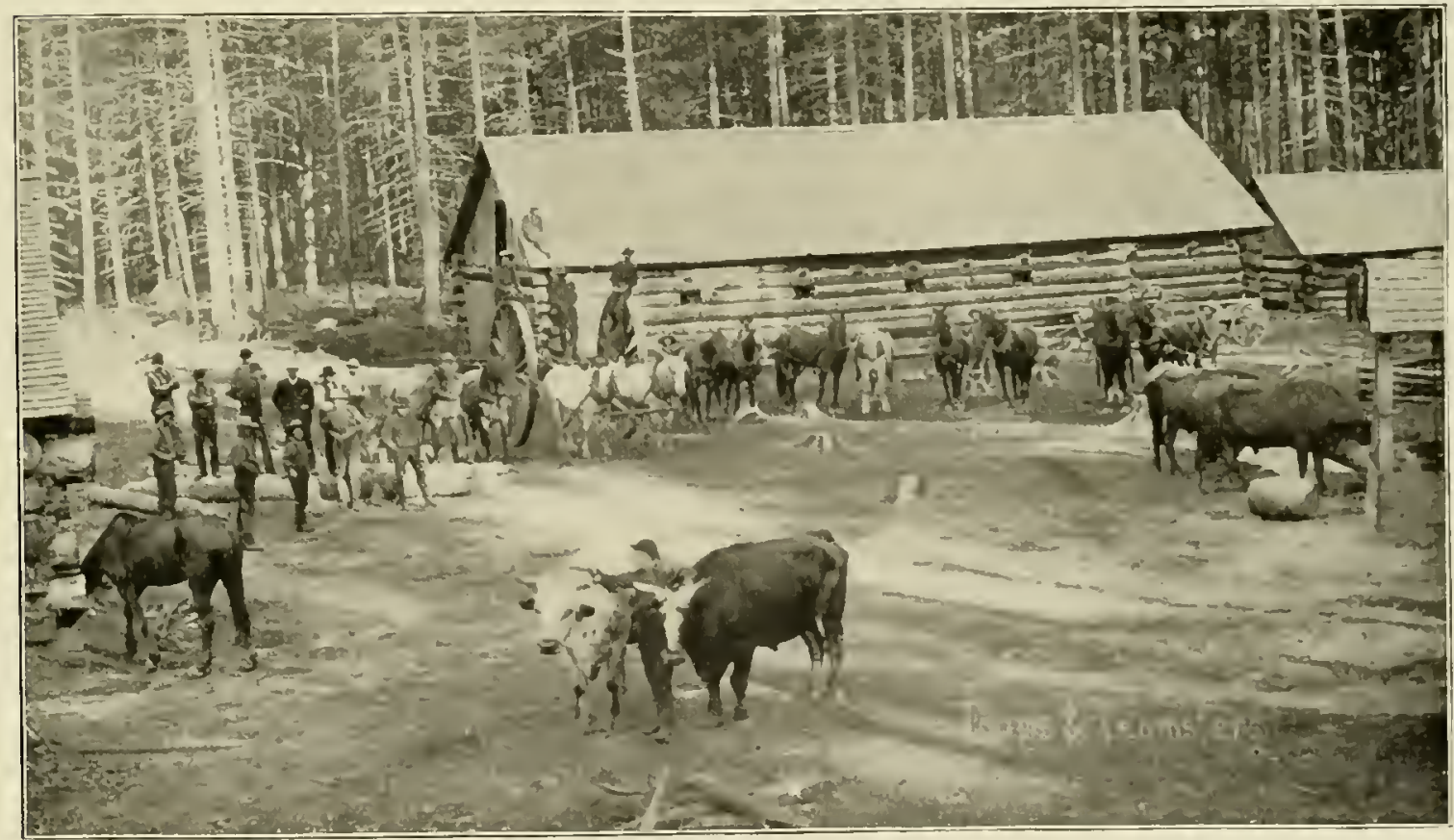

Fig. 2,-Lumber Camp in MiChigan. 



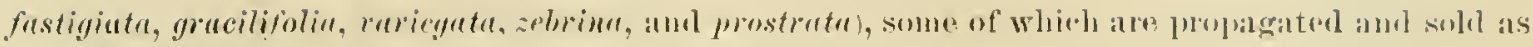
special attractious in muserios.

$$
\text { RELATIONSIIII. }
$$

The White l'ins (Pinus strobus) is closely related to tho lihotan l'ine ('inus ercelsu) of ludia, the Swiss Stone P'ine (l'imus rembra) of sonthern Europe, the White Pinc (Pinus glerilis) of the liocky Mountains, the Sugar l'ine ('Pinus lambrtiana) of the Pacifis coast, and a mumber of others less generally known, of which Pinus monticola, P. albiraulis, P. strobiformis, P. quatrifolia, I'. purryana, and $I$. cembroides are natives of the I'nited States.

The species belonging to this section of the pine gemns are ristinguished by their slender, delicate leaves, five in a sheath; by the exceptionally suft and even texture of their wool, and hy certain well-refined botanical claracters, by which they are malkef as a matural and easily recognized gumul.

The gromp of species just mamed shows a preference, generally characteristic of this scetion of pines, for elevated, mountain legions, aml a light rather than a heary soil, making, as a rule, a healthy growtl on sandy ancl rocky places, and manifestly preferriug these to low and heary soil. All are hamdsome trees, symmetrical in form, some of them, as the Sugar l'ine (Times lumbertiana), of lapid growth, aud forming magnificent specimens from 150 to orer 200 feet in lieight, while others ale of slow growth, as the Stone Pine of the Alps. Which prorluces, however, a beantiful, fine-glaned wool, extensively used by the Swiss peasants for carring. The Bhotan Pine of the Himalayas is the representative of the White Pine in Asia, resembling it rery closely in lubit. size, struetnre of wood, and various technical character's.

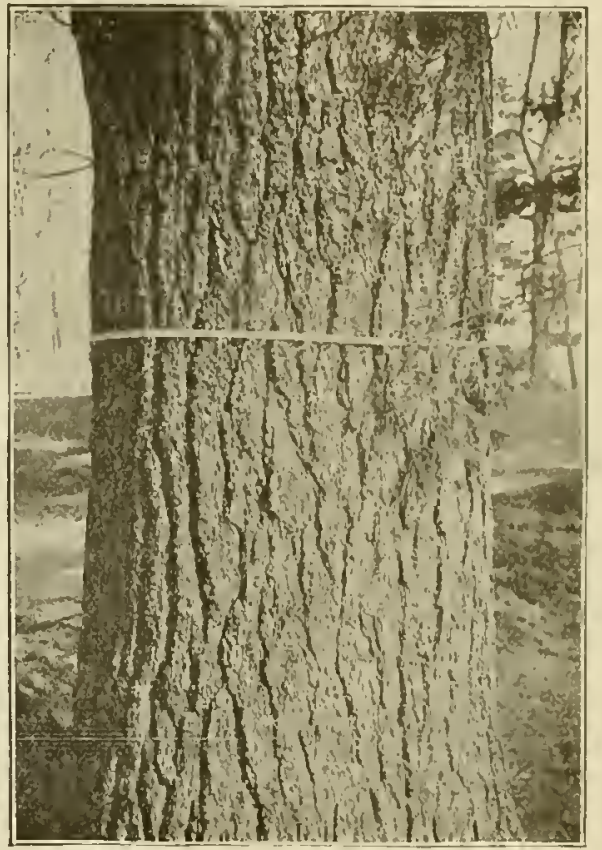

Fig. 1, lark of oll White Pine.

Admitting the common ancestry of these varions species, a more extemed compurative stumy of their preferences and habits would be of mueh interest in relation to their enltivation beyond their natural range, consirlering the fact that, whatever their enviroument, such ancestral traits are certain to manjest themselres.

\section{MORPHOLOGICAL CHARACTERS}

ROOT, STEM, AND TRANCH SISTEM.

In the natural forest. with a che amonnt of shale. the White Pine has at maturity a straight

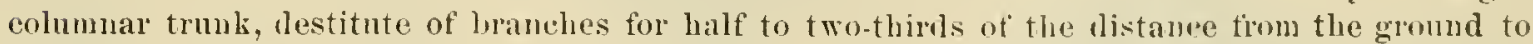
the tip of the learler.

The branches are for many years elisposed regularly in whorls, and duriug this early period the tree retains a symuetrical, conical form, and is one of the most araceful of the pines for ornamental enltivation, but, as is the case with other confers, the lower branches aje short lived. and ultimately, by their lecar, the tree becomes unsightly. This fart, which remlers this species, in common with all other conifers, mulesirable during part of their lifetime for oruamental purposes, gives it the greater value as a timber tree.

The erown, at first pyomidal, is finally less regular, although rayely tlattening, and, owing to the rapid and persistent growtl of the tree, comspicuously overtops the suromuling forest of decidnons trees. The joot system is small compared with the size of the tree and spreads near the surfare of the ground; its comparatively slight development is in larmomy with thr less pronomeed dependence of this species on the soil and its greater dependence on the atmosphere. 


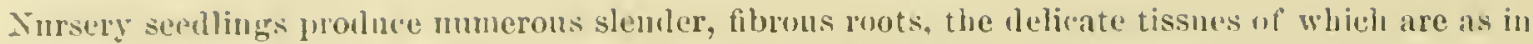
must coniter's easily dried at the time of transplinting, resulting in very serions injury or loss of plant matelial. White l'ines planted mon the dhy sand along the Lake Miehigan shore and trimmer of their lower branches have been observed restoring these fower limbs and forming a thick, green wovering over the roots hetore making any height growth, sugrgesing in a striking mam no the necessity of protecting the root system aguiust tom rapid evaporation ambl a too highly liented sui]. In the uatural forest, and in artificial groves properly planted, th fallen leaves fulfill this function by making al derp, thick coating over the roots.

\section{LEAVES.}

The leaves arise from greatly reduced short branchlets and are produced tive together, surronnded at the base by a thin decinous sheath, and are further distingushed by being more

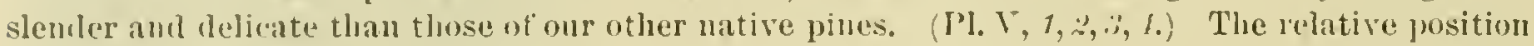

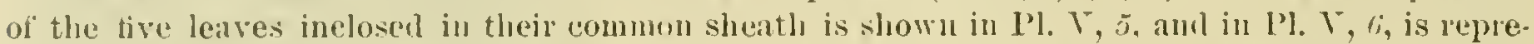
sented a cross section of a single leat, magnitied snfliviently to show the characteristic arrange. ment of the tisulus.

Writhont entering into a dotailed account of its functions, which wonld here be irrelerant, it may merertheless he remarked that the leaf of the White I'ine constitntes a lighly complicatenl and deticate piece of apparatus. Like all foliage leaves, the leaf of the White Pine fullills the important functions of respiration and the mannfucture of starehy food, duriug which processes large amomits of watery vapor are exhalem.

A healthy pine secaling, three years old, in the air of a lly rom, lost by craporation in twenty-four hours 81.1 per cent and in the following twenty-tive hours 9hi. per cent of its entire dry weight. 'The evaporation, chiefly through the leaves, is more rapin in the daytime than in the night, in clear than in cloudy weather, and most rapid of all in a drying wind. It will realily be seen that it a tree is planted on a clear, dry, and windy day, the conditions are the must unfarorable that conkl possibly be ehosen, the rapicl evaloration carrying ofl the water of the plant beyond the eapacity of the ronts, not yet alipted to their nen place, to meet the demam, which results in the drying up of the tissnes and often in the death of the tree.

The varions forms of molified leaves are characterized by extreme delieacy. Winter buds (I']. $V, z)$. with their thin and small scales, fresent a striking eontrast to those of Longleaf l'ine, for example. and other species that produce latge buls with relatively thick and corses scales. The very hose leat sheaths and scile-like leaves of the young shoots are early deciduous, a fact that contribntes to the grourtlo of the smooth, clean bark chanacteristic of the branches of White l'ine, in which it differs in so malked a way from the species of the lellow l'ine group.

In Pl. I", 1 , the modifien, scule-]ike leaves that emstitute the loose sheatlos are conspicunsly shown. Separate fascicles, with their sheaths, are rejoresentel in Pl. V at 2 and 3 , while at $f$ is an oliler one as it aprear's at the curd of the summer after the sheath has fallen.

EXIIANATION OH I'LATE V.

1. Shout showing fulinge and scal. Jeates of ditherent ages.

2. Young lascicile witli slueith.

3. Young fiscivile liurther ievelupen.

1. Still older filscicle from which the deciluous sheath has fallen.

5. Section of fiscicle incloser in sheath.

6. Section of leat maguifier?.

\%. Winter bual.

FLORAL ORGANS.

Finwers and fruit are rarely jubluced to any consilerable extent before the tree has attained the age of fifteen or twenty gear's, thongh occasionally trees may bear finit at ten to twowe years of a

The staminate and pistillate tlower's are sejarale, but produced on the same tree. They

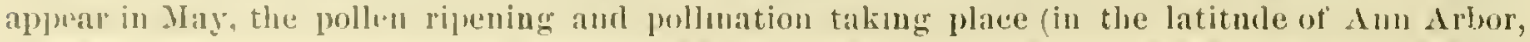

Accorlug en leterminatiom marle in the hotanical laboratory of the lonivrsity of Michinan, November $18,1886$. 


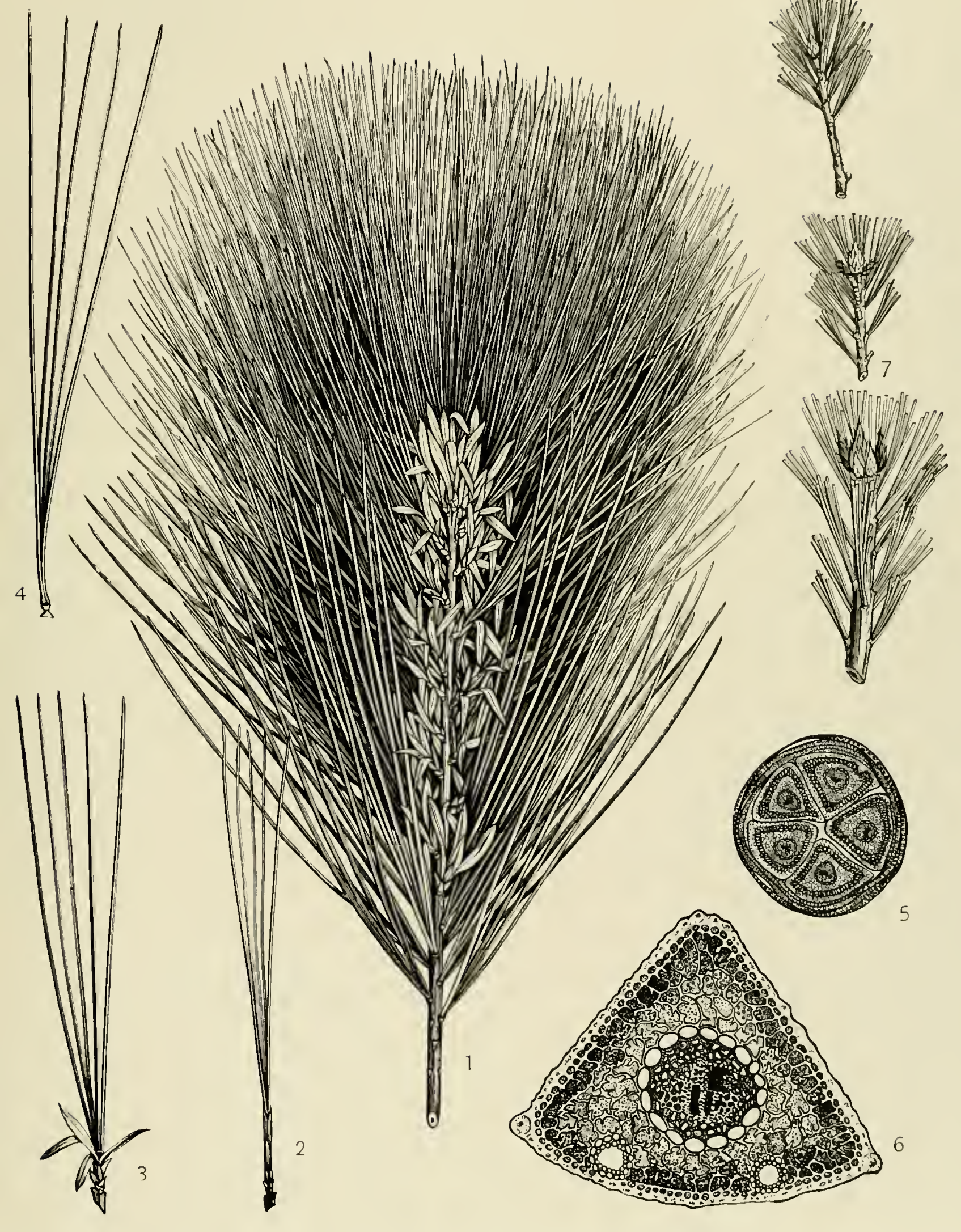






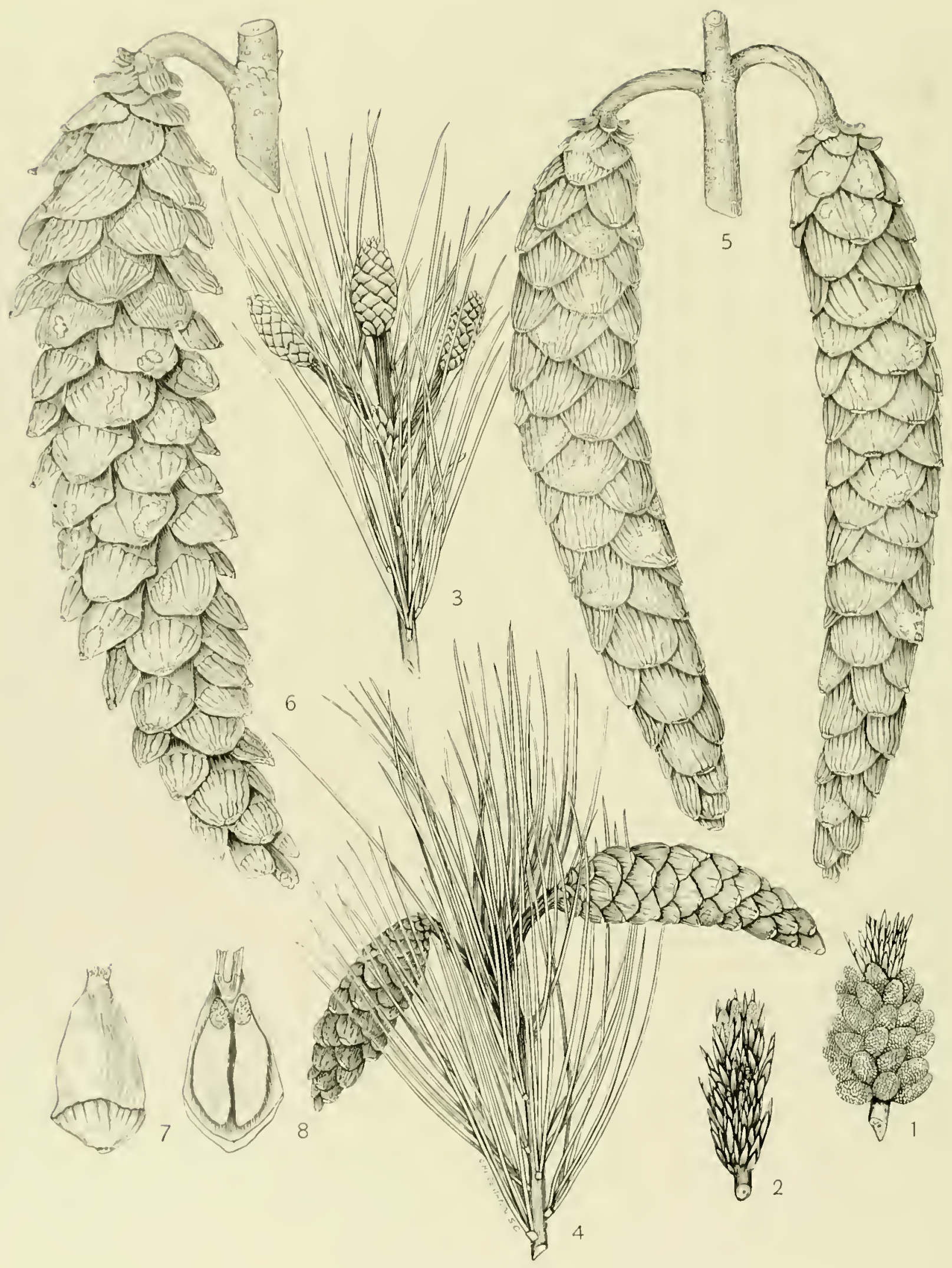


Mich.) between the middle and the end of the month. The staminate llowers are borne laterally on the shoots of the season (PI. VI, 1). 'They are extrenely simple in structure, consisting of nnmerons pollen saes borne in pairs on the miter fine of the scale-like staninal leaves. The pollen is produced in great abundance and is carried by the wind to great distances. lertilization, however, notwithstanding the profise probnetion of pollen, often lails to talie place. In fart, failure appears to be rather the rule than the exception, if we consiller the frectuency of "olf" years," in which little, if :my, good seed is producerl. But donbtless other cunses often combine to prevent the production of a full crop of seerls.

The pistillate flowers oceny the apex of the young shoot (['l. VI, 2), finally forming a bunch of cones prendent from the ends of the branches. At the time of pollination they are abont one. fourth of an inch in length and hive the alpearance of minnte tleshy cones, which by the end of the first summer's growth liave attained the length of three-fourths of an inch to an inch, and have the appearance represented in Pl. Y1, 3. They are not ripe until the fall of the succeeding year, when the cones, having now attained their full size, as shown in Pl. VI, 5 and ri, open and allow the winged seeds to escape. In order to prevent loss of seeds it is necessary to gather the cones a little betore they ripen, which occurs during early September in most localities of the natural lange. Afterwarls, if liept in a dry place, they will open readily themselves and allow the seeds to fall ont. The ripening is signalizen by the change of color to a yellow brown and the forming of a resin coat.

\section{SEEDS.}

The secds are one fourth of an inch in length by about halt that measure in breadth, of an oval form, grayish-brown in color, sprinkled with darker spots, and provided with a thin, delicate wing, by means of which they are disseminated through the agency of the wind (Pl. VI, 8). The seed coats consist of a hard onter shell, or testa, inside of which is a thinner membrane, the enclopleura. Inside of the seed coats is the whitish endosperm, constituting the food of the germinating plant, within which, ocenpying the center of the seed, is the small, straight embryo, the three parts of which, stem, radiele, and eotylerlons, are plainly distinguishable.

To get 1 pound of seed from "2 to $2 \frac{1}{2}$ binshels of cones are necessary.

Concerning the production of seed, the experience in this conntry is but fragmentary. The individual tree begins to bear guite early. Isolated specimens, or trees in olen groves. bear cones before they are twenty years old, and even trees in the dense forest seem to bear generally before they are forty years of age. The capacity to bear abundantly is retained to old age, the oldest trees seen still bearing heavily, and even mutilation by fire or otherwise does not prevent the trees from bearing.

EXILAXATION OH PLATE VI.

1. Staminate tlowers of Pinus strobus just before shedding of polleu.

2. P'istillate flowers, terminating soung shoot.

3. Young coues in autumu of first jear.

4. Young cones early in summer of second year.

5. Cones at close of seconci pear's growth before opening of scales.

6. Mature cone, the scilles separated to almit of dissemiuation of seods.

\%. Single scale, showing outer surface.

S. Single s'ale, showing inner surface with seerls in place.

SEED SUPPLY.

A full crop of seeds is usually produced by the same tree only at intervals of several years. Cones may be formed year after year, but mon examination it is often tomm that many of the sceds are abortive. Of a large number of cones gathered at Ann Arbor, Mieh., in 1886, not a siugle one showerl a prerfeet seed. Mr. John L. Hobbs states that the same year (1isSi) was a good seed year in Maine, and that trees had not prodnced so largely before siuce 1879. According to Mr. I. Dawson, of the Arnold Arboretum, a crop of seed may be looked for abont once in tive years, though others make intervals between seed years shorter. The frequency of seed years lias not been suficiently noted as yet to warant any general statement, but it is known that during certain seasons the seed prodnetion is perfectly general orer large areas, while in other years it is not. Thus, in $\mathbf{1 5 9}$ the White I'ine bore heavily in every pine county in northern Wisconsin. 


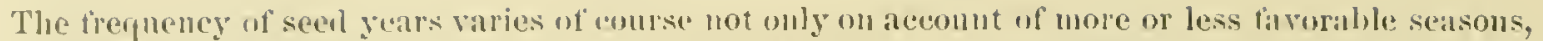
but areording to locility and climatic combitions. In linrope the White Pine is regaried as a frequent and heary seerer, one year ont of thre heing gentrally probutive. A grove of 8 acres

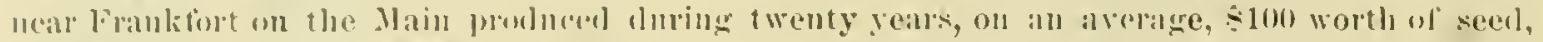

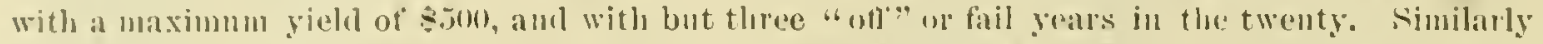
an atrea of about 40 ateres in the l'alatinate formishes as high as 1,700 hushels of cones. "Ir about 1.300 jum ls of seed, suply ying all the murseries of the l'alatinate state torests with serd.

\section{THE WOOD.}

The strueture and development of the word of the White Pine may be stmdien to the best arlsantage by beginning with a young shont cut from a vigorous tres in early summer. A cross section of sneh a shoot in the first season of its growth (l'l. VIl, l) sluws three plainly manlied

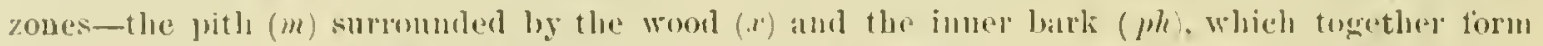
the enspienens zone crossed by radiating bands, the solealled medullaly lays, and outside of the

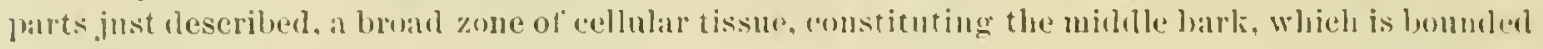
externally by the epridermis.

The pith, medullary rars. and midlle bark consist of simple cells, originally of an irregularly ronnderl form. 'Tourther they eonstitute the so-ealled glound tissue of the stem. an distinguished from the filmo-vasenlar portion, which inchules the wool and inner bark.

Within the cortical jortion of the ground tissue numepus lange npenings (I'l. VII. 1, ri) are seen, of dillerent si\%s and apparently withont definite artangement. These are the resin dnets. Each duct runs longitulinally through the stem, and consists of a central carity filled with resin, around which is a single layer of serereting cells. easily distinguished ly the nature of their cou-

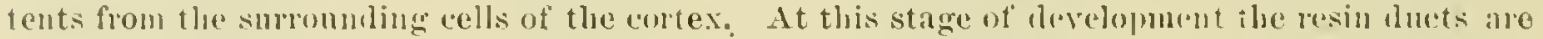
confined to the cortical parenchyan, none having yet been formed in the worrly jortion of the stem; but later in the season, as may be seen in older sections, a number of duets are formet. arianged in a circle near the periphery of the woul. These have essentially the sane structure as those of the cortex, hut are of sualler size and are surrounded ly fewer secreting cells. In cross sections of blder stems the resin duets are seen, anmuged in an irregular cirele, in each

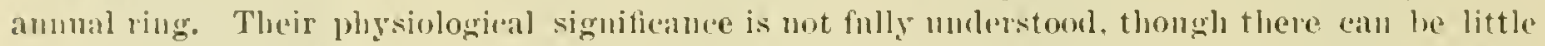
doulst that De Vries is correct in assuming that the abmulant resin is of service to the growing tree, when womded, in preventing decoy of the wood, and that its greservative influence is continuerl alter the tree his been cut into lumber.

lu such a young shoot as has been describer the cells are vitally active, and are filled with

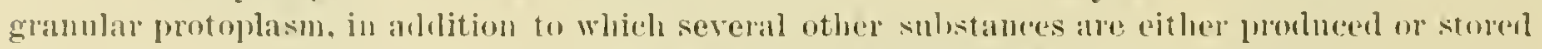
11] in them, gatticularly in the cells belonging to the ground tissue. Chlorophyll orems in the pith and medullary dars as well as in the cortical portion. It is most abumlant in the aells of the cortical parenehyma, neenring in the form of mimute grains, irewular in shape and size. Stareh, in ronntiol gramles, nceurs ahmulantly thronghont the gromel tissue, the cells of the contex con. taining a larger moportion than those of the pith. Rexin, as ahearly stated, fills the resin durts and thosecreting wells aromel them, thomegh stareh is often fonnd in the latter.

lassing now to the woody jortion immediately smroumding the pith, two dhanacteristic fea. tures at once attract attention. The clements composing the wool. d' (Pl. V'll, 1 and 3 ), have a much narower lumen than those of the pith, and are regularly disjosed in radiating rows. Those elements, the tracheids. are elongated thick-walled cells, four to six sirled. aceorling to the mumber of tratheids lye which they are surmmuled. Their walls are lignitiol and are malied by the

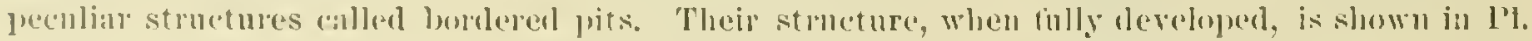

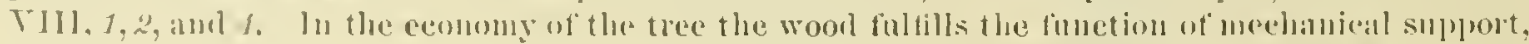
and sorves as the condurting tissne through which the water, evaporater from the loares, is carried up irom the routs.

The medullary mass are romposer of eells so thattened by the pressure of the tracheds that on longitulinal sections they alpurar as represented in Pl. Vill. 3. They eontain a conspicuons: nucleus. arre asely packed with grannlar food substances, and serve collectively as a storehuse 
of reserve materials. Communieation hetween these and the tracheirls is coffected by means of simple pits on their radial wills.

The inner birk, or phloem, ph (Pl. V1I, 1 and 3), closely resembles the young woor on eross section, its elenents being arranged in radiating rows and traverserl in like manner by the medullary rays. The eells composing it differ, however, in various important particulars from those of the wood. Their walls are of cellulose, and although important as conducting tissue. they' coutribute comparatively little to the riginlity ol' the stem.

between the wood and inner bark is the cambinm or formative tissue, represented in Pl. YII, 1, as a light band of extremely small and delicate cells, and in the sane plate as a zone of cells with thin walls and large lnmen, contrasting strongly with the wood elements and those of the inner bark between which they lie. It is from the cells of the cambinm that those of the wood are formed on the one hand and those of the bark on the other. The process is a gradnal one, and 110 absolute line of demarcation can be drawn botween the cambium and the tissues deriven fiom it. The cells of the cambium multiply by tangential division. The essential features of this process, as regards the position of the cell walls, are representer in Pl. VIII, f. in which the lightest lines represent the youngest walls and the heavier one; those of greater age, suecessively. It is by the constant repetition of this process of tangential division and the subseguent thicken. ing of the walls of the cells thus formed that the rood and inmer bark make their yearly inclease in thickness. In the spriug the cells of the cambium are large and vigorous, aud a lapid forma. tion of woml elenents with relatively thin walls and large cavitics talies place, while later in the season much smaller tracheids with thicker walls are furmed. This results iu the strong contrast between the wood last prodnced in any given year and that formed at the beginning of the next season's growth, giving rise to the sharp distinction of anmul rings so clearly bromght mut in PI. VIII. 1.

The histological characters thus briefly summarized hold true, in a general way, for other conifers as well as the White Pine. This species, howerer, presents a number of peruliarities that are of botl plyssiological and econonical interest.

The resin ducts of the White Pine are larger and more numerons in the cortes than in the wood. an arrangeneut well arlapted to secure the protective action of the resin contained in them without introducing an element of wealiness into the wood. Comprisons with othor s]ecies bring out this fact in a striking manner. Thus, npon comparing the distribution of the resin chets in stems of the White and Scoteh pines, as nearly alike as possible, it was found that in the corter of White I'ine stems of one year's growth the number of resin passages ranger from 20 to 47 , the average being abunt 33. The number in the wood was more nniform and averaged abont $13 . \quad$ In the Scoteh Pine the averige for the wood was found to be 33 and for the cortex 10 . Taking the second year's growth in the sinne way, the arerage number for cortex of White Pine in the specinens examined was 28 and for wood 27 ; in Scotch Pine, tor cortex 9 and for wood 37.1 The small size of the resin duets in the wood rontuasts strongly with the very large ones of Seoteh Pine, which serionsly interfere with the continuity of the wood and tend both to mealien it and to give it an meren texture.

The extremely small mumbe of thick-walled tracheids constituting the summer woor ot the White l'ine is in marked contrast with the broad band of summer wond formed in rarious other species. Comparing the anumal rings of White Pine with those of Longleat l'ine, Bor esample, it is seen that while the thick-walled tracheids of the former malie liardly more than the mere onter elge of each ring, those of the latter constitute one-thirl or more of its rutire wirlth. Moreover, the gradual, almost imperceptible, transition from spring to summer wool in the White line contrasts strongly with the abrupt line of demarcation so(n in I.onglent Pine and all other Yellow l'ines. It is to this rery gradual transition that the miform texture of the wond of White Pine is ehietly due. The merullary rajs of the ditlerent groups of pines show certain structural peculiarities that aplear to lie constant for the groul of species in which they occur, The writer is indebted to Mr. Filibert koth for the following uotes in regard to this feature:

In all pines the medullary bay is made up of two kinds of cells which ditter in their generil form, aud still more in the configuration of the cell wall and pits. The oue lind occupics the upper aud lower lows of each ray, 


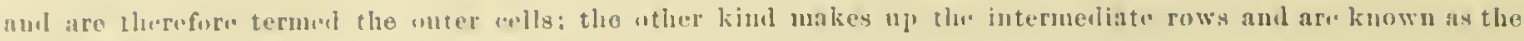
inner $\cdots \cdot 11$.

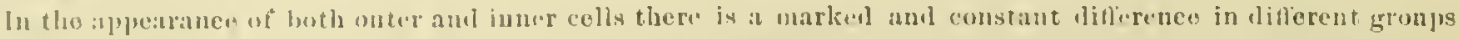

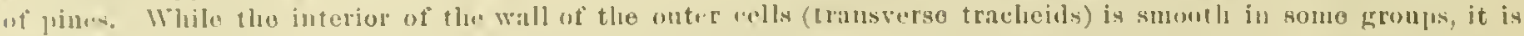

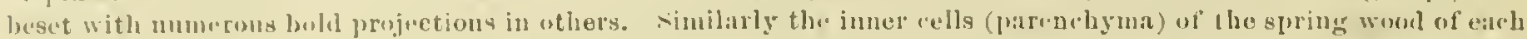

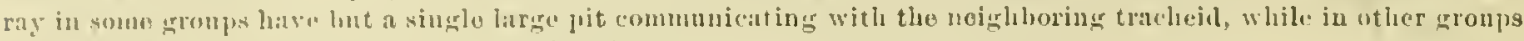
this is bronght alont ly throe to six smaller pits.

liased upon theso ilillerences, the following classitication of the wool of ditlerent spenies of pines is proposent liy lir. J. Selhroeder:

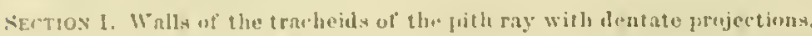

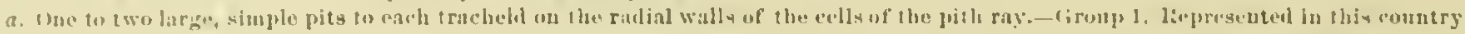
ouly log l'. resinash.

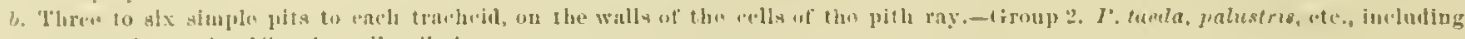
most uf eur "hard" and "sellow" pines.

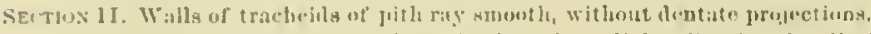

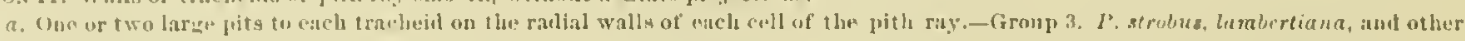
true White l'ines.

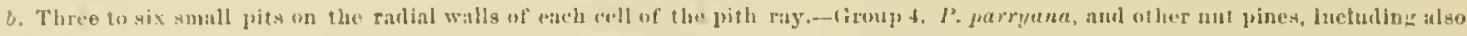
l'. Enlfourinuu.

Returning to the melullary ray of the White ['ine, it is observerl that tho walls of the onter cells are thin

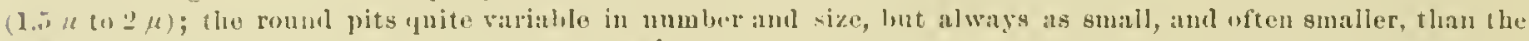
pits of tho tracheisls in the smmer wool; also that the wails of tho inuer eells are thin (1.5 $\|$ to $3 \mu$ ), for the most part very thin, buing largely weenpiel ly pits: that the pits are large ovals on the radial walls of tho cells in the spring wood, suall rent ovals in the summer wool, ant small and irregular in ontline abose and lielow where the

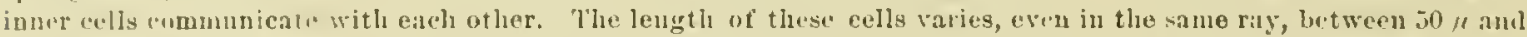

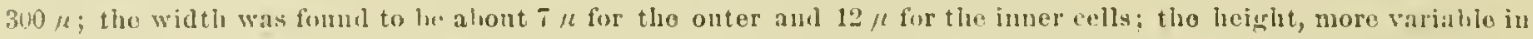
th. onter than in the inner cells, and less rariable than eithur width or length, nay lie set at about $23 \mu$ for outer aud inter cells. 'Tho average number of cell ruws in ono melnllary ray, for the specimus studierl, is 7.5 , whereof' 2.6 lill to the onter wells and 1.9 to the inuer cells. Th" limits of thr tutal mumer of cell rows wero 2 and 16 ; the

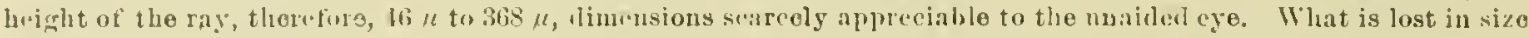
is gaineil in number; on :ul averago 21.3 meilullary rays wore conuted on 1 sipnare millimeter, or 13,312 to 1 synare iuch of tangential section.

A study of the wool ju its physienl and mechanical properties, by . Ir. Filibert Roth, will be fouml further on in this monograph.

F.XPLAXNTUON UH' I'HTE YII.

1. Transerse section of fresl shoot, cut in summer of first year $\times 25$. The zone of small cells surrounling tho pith inclusles the woul and inner bark, both of which aro traversed ratially ly the medullary rays. The thick

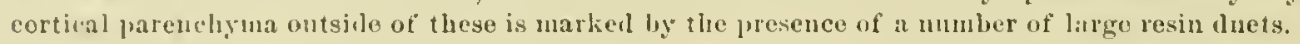

$\therefore$ Tortion of epidermie, with appoudages. lieneath the "pilermis a few cells of the cortieal prenchyma containing starels.

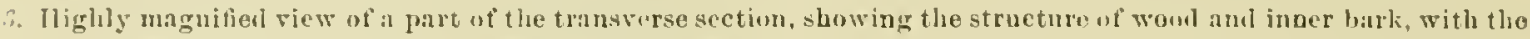
thin-wallel cells compusing the cambium lying lwtweon them.

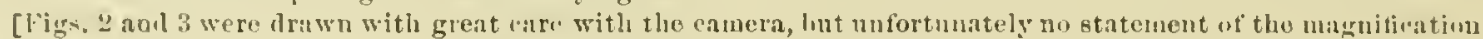
was preserved with them.]

\author{
EXILAXITUM UF PLATE Y゙HI.
}

1. C'russ section of wool $\times 175$. The section includes parts of threo medullary rays, the milllie one of whicl is cut partly throngla the inner celis and partly through tho cross tracheids. The gralual trausition from spriug to sumber wood is clearly shown. I'art of a resin dnct is seen on the riglit.

2. ladial longitulinal sertion of wood $\times 200$, showing a few of the thick-walloul tracheids of the summer woum followed lig the large thin-walied ones of the suceediag spring, both crossed by a medullarg mas. The horderel pits of tho unter eells of the ray, slown both in soction and surface viow, are in strong contrast with tho simple prits of the inuer cells.

3. Tangential section of worl $\times 20$.

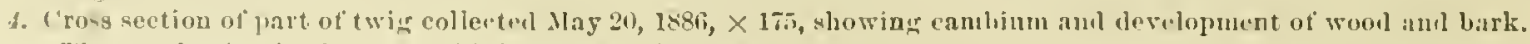
"The wody ring is abont one-thirl its timal thickness.

\title{
GROWTH AND DEVELOPMENT.
}

The scenls of the White Pine retain their vitality for a long periou. Trustwortly observers state that a fair percentage will wrow after heing kept tive years or more. The conlitions of germination and suceessful growtl are, in general, the same as for other lines, namely, a suituhle 


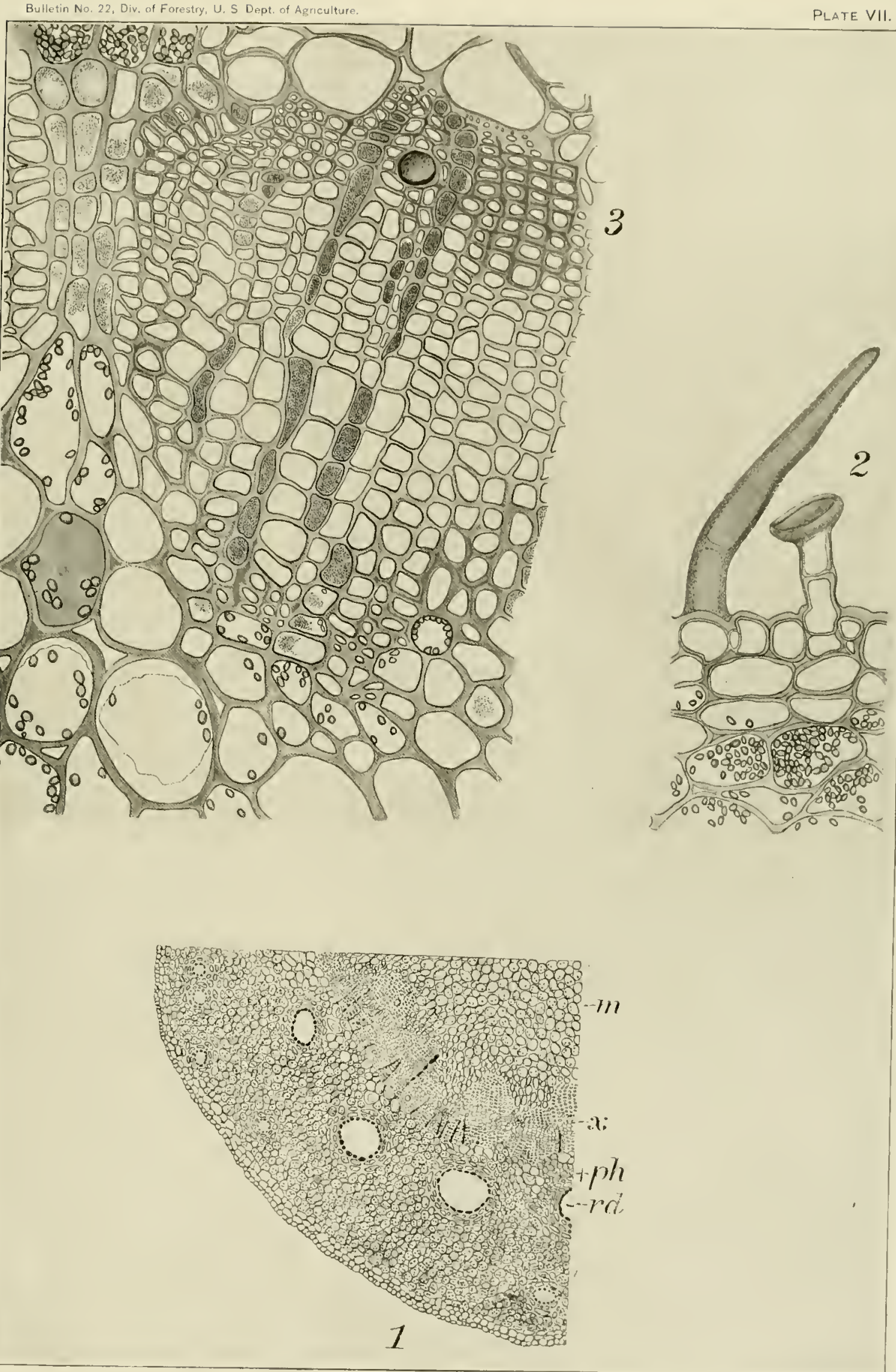




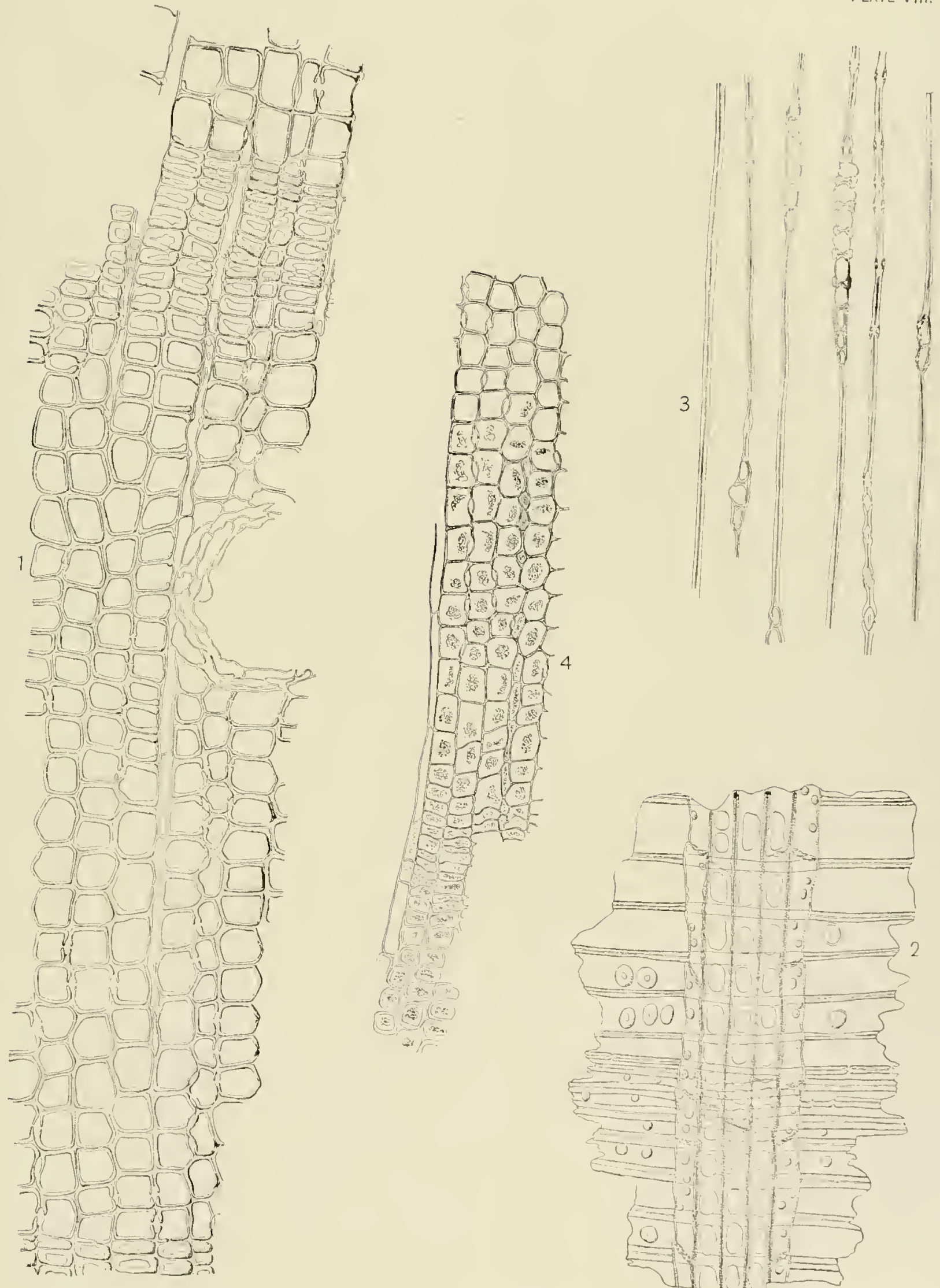



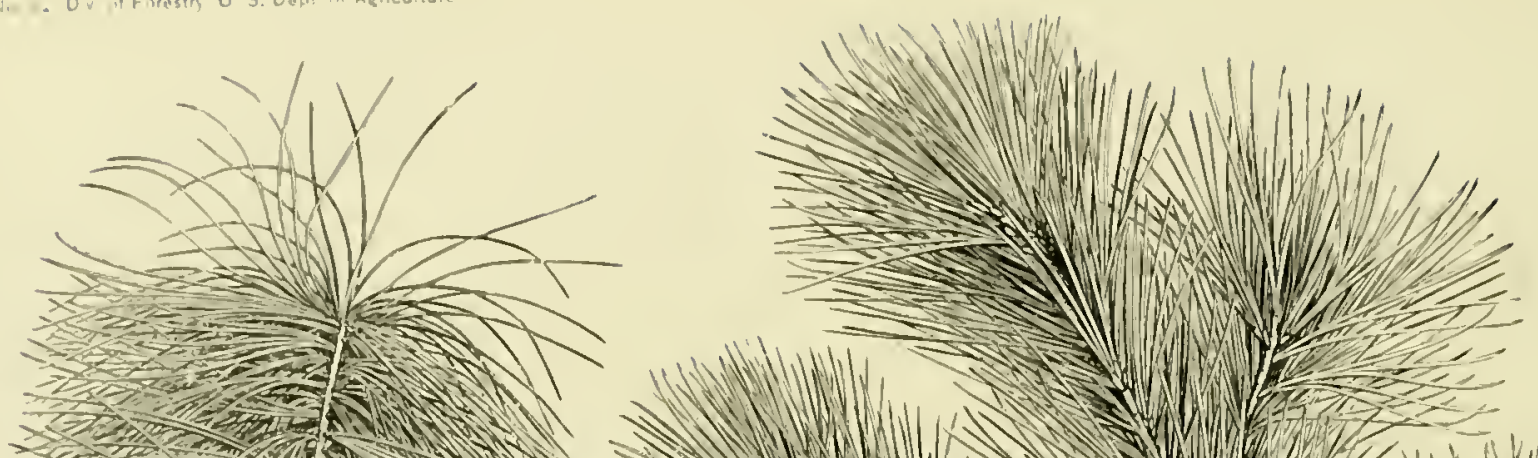

3 -

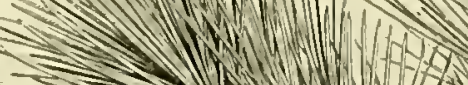

Nitis
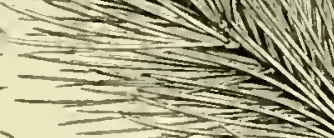

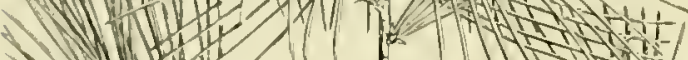
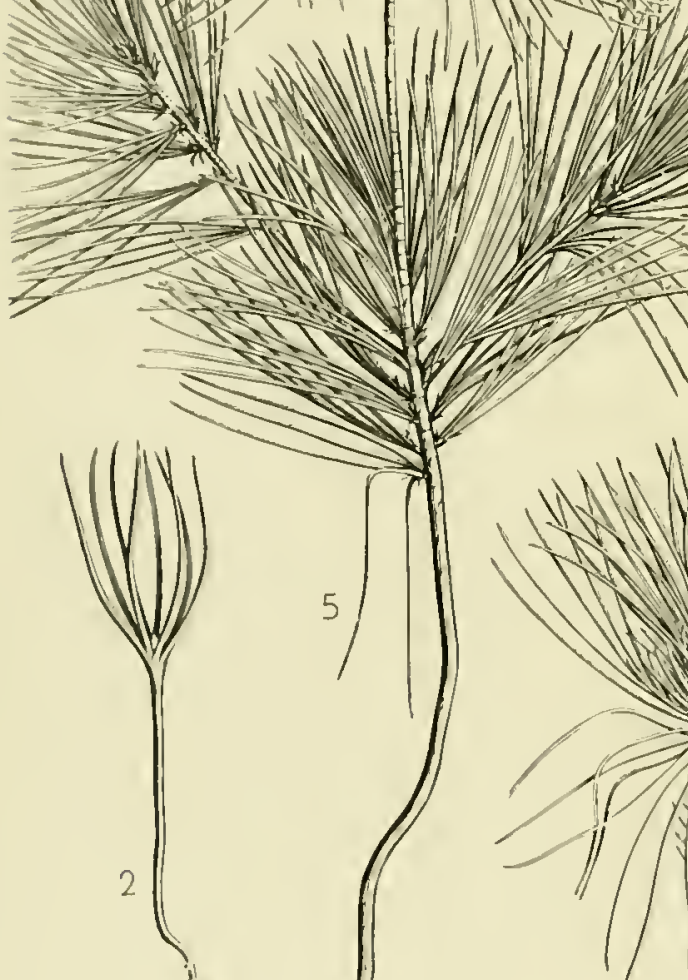
soil, molerately warm and moist (not wet), in which the seels are covered at a depth not exceeding twice their own diameter, ant, further, protection of the young seedlings against the hot sun and drying winds. Special attention is renuired in the murery to avoid undue moisture when the seedlings appear above the glwuml, as they are often attacker hy a destruetive disease very common in propagating leds, known as "damping olf." If, however', no adverse intluences lave interfered with its normal development, the young plant presents itself after some months" growth as a slender shoot, crowned by the persistent seer leaves, in tho midst of which is the terminal bud, the latter having already formed mnmerous short foliage leaves. No branches liave appearerl, and the foliage leaves arise singly instead of in groups of tive. The whole plant, as it appears at this time, with its slender stem aud long taproot, is represented, natural size, in Pl. IX, llawn from a specimen obtained in the pine woods of Nichigan, in September, 1856 . Earlier and later stages of development of the seedlings are shown in the same plate $(1,2,3, f, 5,6)$ drawn firom nursery specimens.

For the first two or three years the growth of the seelling is slow, and is so greatly intluenced by its surrounlings as to make it impossible to give averages that will fairly represent the yearly increase in height and diameter.

Thus, a healthy sieding, three years old, from the unrsery row, measured 4.6 inches, while a self-sowu specimen from Maine, four years ohl, measured only 2.7 inches in leight. But, if the circumstances are favorable, after the thirl year a growth of one to several inches is malle each year. and from this time on the yearly increase in height is elearly defined by alternating noles and internodes, a whorl of branches being formed at each node.

The leading shoot is from the first the most conspicnous and the most importunt part of the plant, branches being manifestly subordinate, tyingh off' in litter yea's as in other conifers. 'The rate of growth being of most important practieal interest, much space has been levoted to this part of the developmental listory.

The tree rarely reaches a height of more than 160 feet and diameters of more than 40 inches. more usually 30 inches. Occasionally these dimensions are exceeded; trees of 200 feet in height and of 60 inches in diameter have been reported. The largest actually measured by the Invision of Forestry was 48 inches in diameter breast high and 170 feet in height, with an age of about four hundred and sixty years, containing $73^{\circ}$ cubic leet of wood, standing in a gronp of similarly old and large pines in Michigan. Another tree of this group, with 17 inches diameter and 162 feet in height, contained 855 cubic feet, being less tapered.

EXILAXATION OF PLATE $1 X$.

1. Seedling as it first appears with sced eoat attached to seed leares.

2. Seedling witl seed coat letached.

3. Scedling with seed leaves and primary foliage leares disposed singly on stem; five montho old.

f. Suedling in its second year, showing primary leaves aud secondary leaves (mature forw), the latter in elusters of tive.

5 aud 6 . Seedlinge three to five sears ald.

RATE OF GROWTH.

The following statements regarling the progress and late of growth of White Pine are hased mainly npon the very comprehensive data collected by the Division of Forestry in Maine, New Hampshire, Massachusetts, Pennsylvania, Michigan, and Wisconsin. These data, involving measurements and detaled analyses of over seven humbed trees grown muler varying emditions, together with records of the conditions nuder which they grew, and the amounts of timber which were produced under such conditions per acre, are presented fully in the tables, with atconpanying notes, in the Appendix to this monograph. It appeared, homever, desirable to present in the text not only the generalizations and conelnsions, but also some typical cases. Some other measure. ments, male before this comprehensive investigation and recorled by the writer in his original manuscript, are also produced.

HEIGHT GROWTH.

SERDLING STMIE.

The growth of the seedling is varibble, according to the conditions muler which it grows. In the forest it is mel slower than under cultivation, as wonld naturally be expected. The common 
practice of murserymen is to sow the seed broalcast in earefully prepared beds. Where the seed lings stand from two to timl gears lufore transplanting. Stambing rery close, the trees do not makr as stocky" growth as they otherwise wonld. Finler these comditions the average growth of untransplanted seedlings, acording to statements by the wolloknown murseryuen, Thomas

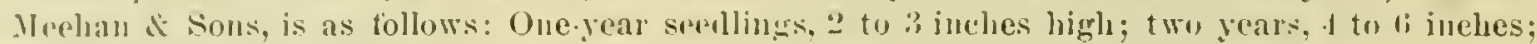

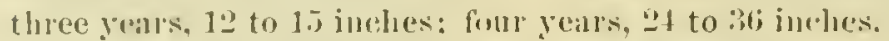

The late Mr. lohert louglas, the veteran murseryman, of Wankegan, ll., wote:

White l'ine seedtings one year ohl are 1 to 2 inches high and altogether foo small and truder fur transplanting.

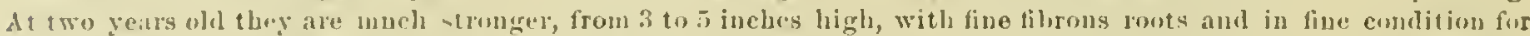
transplanting. At three years old they ar. fi to ! inches high and should not le allowed to stand anuther year, as the wonld ald alsont 10 inehes fo their height during the next year aud would not lw sutable for plantung.

The dirst season after thansplinting, the Whit. l'ine (like other fres) will met increase much in height, but will mtalblish itself, extending its ruts and formug a -trong teminal lud, so that when it is six years old it will

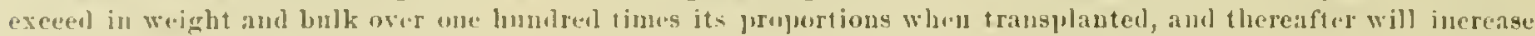
ju growtl from 18 to 30 inclues in lecight anmally in goorl soil for many years.

Ganluer \& Sons, whose nutsery is about 10 miles west of the Mississiply liver, in lowa, and therefore ontsile of the natural rauge of the speries, sulmit the following measnrements. coincirl. ing with the abure, as repuesenting average growths at their nurseries before and after trans. fuanling: One-year-ulıl scedling, 1 inches high; two-year-old seedling, 4 inehes ligh ; three-year. old seedling, $T$ inclies high. The trees are tramsplanted at three years of age and thereafter the averagr locight for the three following seasons are: Fonr years old, 12 inches hight tive years old. 16 inches light : six rears wh, 33 inches high. Another establishnent repurts ats the average height of two year.olu trees in seed ber], 32 inches: of three year seedlings. 7 inehes.

Casnal observations and masmements of some forty-five seedlings in the forest permit the following as to the height growth of secellings in the forest:

Height growth of thite l'ine in the fortst for the first sis yrars.

\begin{tabular}{|c|c|c|c|c|c|}
\hline & \multirow{2}{*}{ A ge ot kpidling4. } & \multicolumn{3}{|c|}{ Meigbt of stem. } & \multirow{2}{*}{$\begin{array}{l}\text { Current } \\
\text { aunual ac- } \\
\text { cretions. }\end{array}$} \\
\hline & & From- & $10-$ & Averag". & \\
\hline & & Inelire: & luches. & Inches. & Inclies. \\
\hline $\begin{array}{l}1 \text { yrar. } \\
2 \text { jears }\end{array}$ & 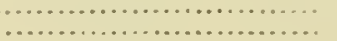 & $\frac{1}{2}$ & $\frac{2}{4}$ & $\begin{array}{l}1 \frac{1}{2} \\
3\end{array}$ & $\cdots \cdots m_{2}$ \\
\hline 3 juark & 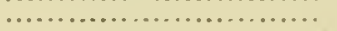 & 3 & is & 5 & 2 \\
\hline 4 yrars & 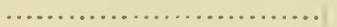 & (i) & $10^{\circ}$ & 8 & 3 \\
\hline 5 yar & & 10 & 12 & $11 \frac{1}{2}$ & 31 \\
\hline fi jeart & 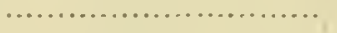 & 30 & 34 & 31 & $21^{-1}$ \\
\hline
\end{tabular}

These measurenents shuw that the rajjd height growth begins with the sixth year, when the total growth of the first five years is almost doubled in one scason. This, to be sure, holds only for seedlings firorably situated. In those less firwed the rapid stage of development comes more gratually. This slow progress in younger years is naturally reflected in a retardation of the year of maximum hejght growth, whieh in domisant tres oceurs about the twentieth year, while in oppressed trees it may not come before the for tieth year.

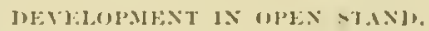

Trees on lawns and in prastmes, which grow up in full eljogment of light, are somm what dif. ferent from trem in lhe forest. The slow seenlling stage is followed hy a verg rapul increase in the rate, whinh attains its maximum before the tweutieth yeal and then declines grarlually.

Table J. on the next page, presents a complote record from year to year of the growth of eight

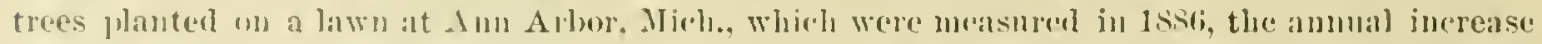
being measured between the whorls of branches. These measurements also exhibit the great varialility of growth from season to season and fiom tree to tree, even muler otherwise similar combitions. In sume of thre trens. evilently, injures or aceidents detarded development. Suels apparent ileficiencies lave been left out of consideration in averaging the data. 


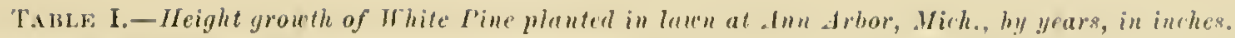

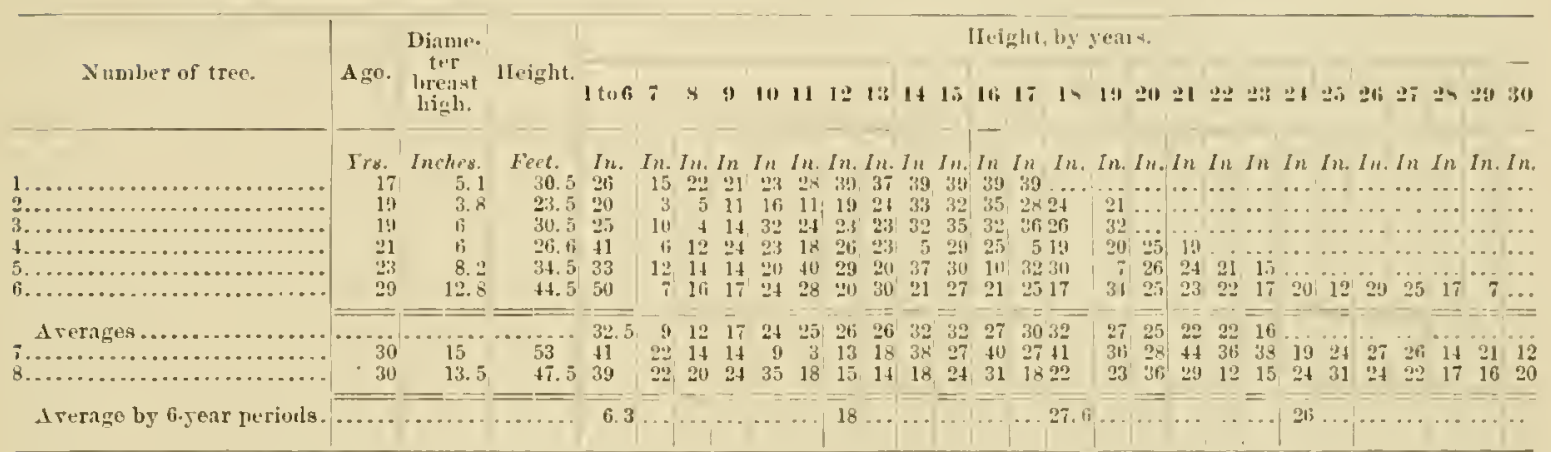

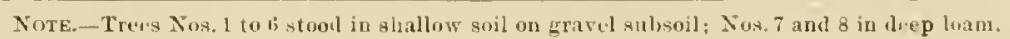

From this table it appears that these eight trees grew on an averaze landly more than $;$ inches during the first six years, more than three times as fast during the next sis years, and reached a maximum rate of over 27 inches per year during the third preriod of six years, the deeline beginning after the trentieth year and the rate decreasing until it has fallen to about $1 \tilde{j}$ inches near the thirtieth year.

To show how, muder less favorable conditions, the progress of self-sown trees is very nearly the same, the following measurements may serve, from which it appears that natural seedlings on pastmes, standing more or less crowded, reach at teu years a height of 10 feet; at the age of twenty years abont 25 feet, and trees thirty-five to forty years of age, with diameters of 6 to 9 inches, attained and even passed the height of $60 \mathrm{fect}$, showing an average growth for that period of 15 to 18 inches per year:

TarLe II.- Heasurements of self-somn White Pine on pasture.

[Furnished by Mr.J. L. Hubus, of North lierwick, Mre.; altilnde, 250 feet.]

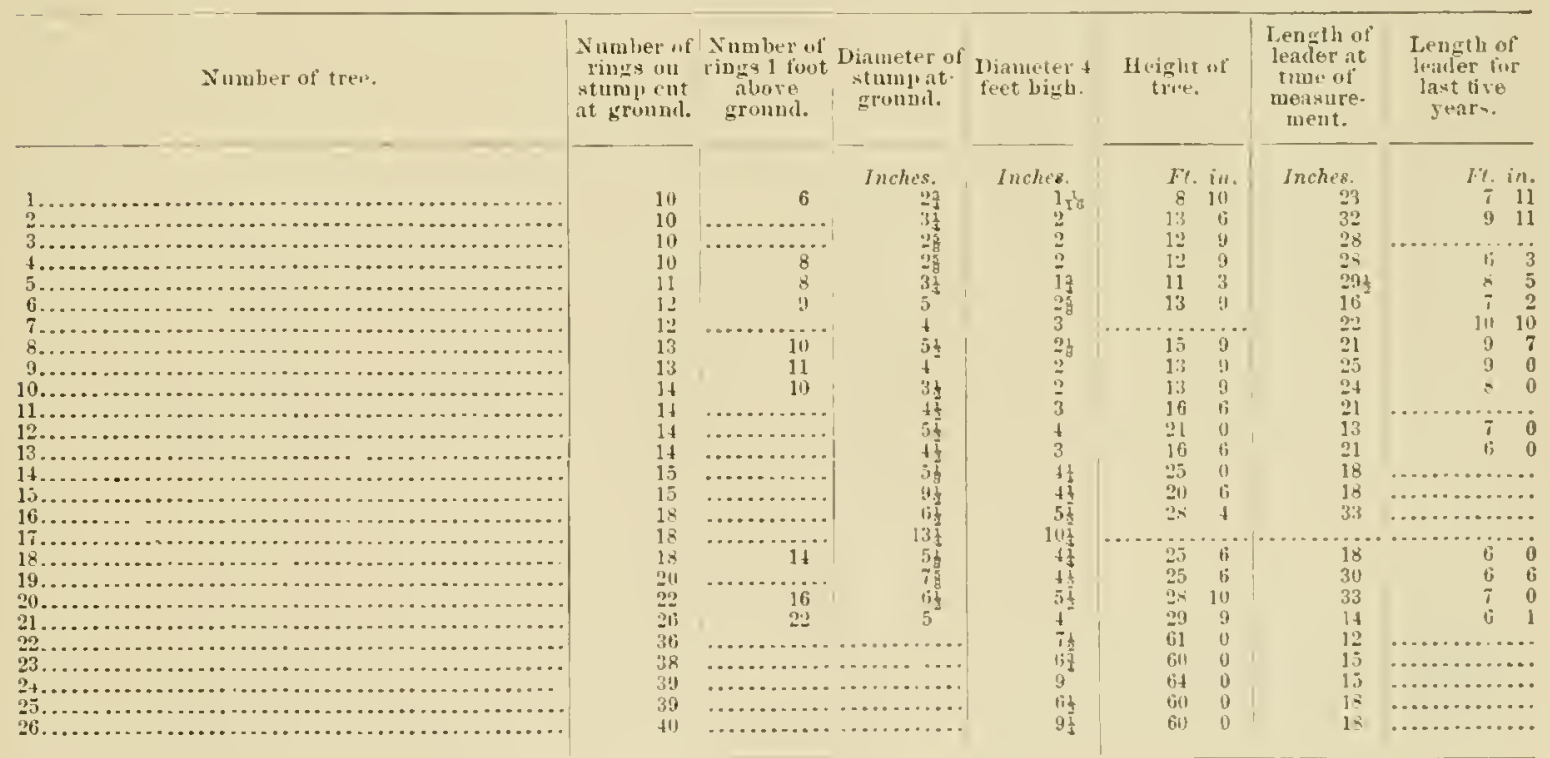

TOTES TO TAMLE 11.

No. 1. From oll pasture after one year's tillage; 5 feet from Yo, 6 ; bore cunts

No. 2. With Ňos. 1 and 3. and frotu similar trees.

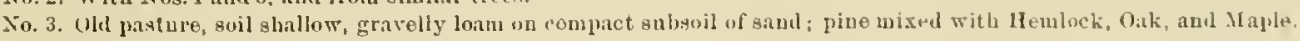

No. t. Level ground, soil heary loau, somew hat shaded.

No. 5. From uld pasture after one year's tillnge; 5 feet from No. 6 ; bore cones.

No. 6. From uld past nre after one year's tillago: 5 feet from No. 1 ; burecones.

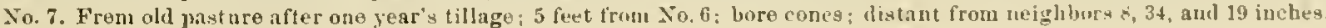

vo. 8. Fron oll pasture after one year's tillare; 5 feet frou No. 6: bore cones; touched another t.inch diameter. 


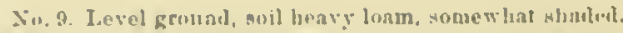

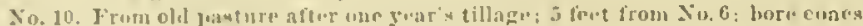

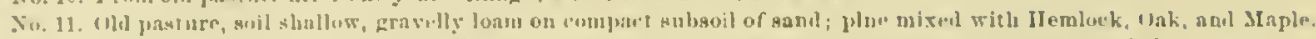

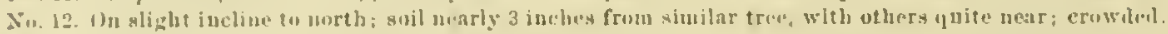

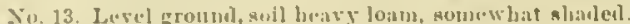

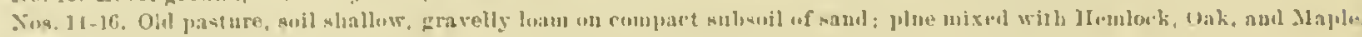

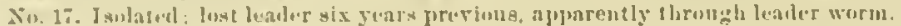

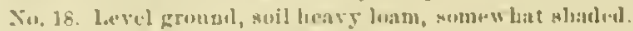

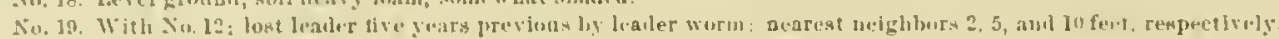

Sio. 20. level zroumt, soil heary loam, noum what shated.

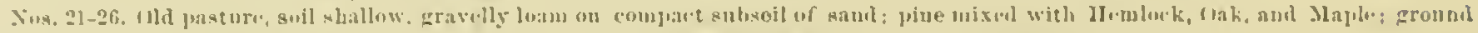

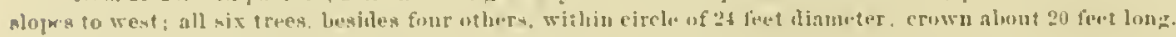

Concerning trees 1. $2,5,6,7,5$, and $[11$ (Table 11 ), Mr. IIobbs sent the following interesting communication, under dite of Inumary 11. 185i:

All these trees wer. foumel in an whl pintur. adjoining my land on the north ant having similar aspect ant soil.

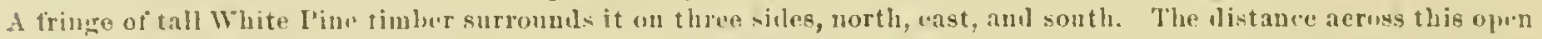
latul from north to wmith is alout to rods. This land lias hen in pasturn from fity to me hmulroul rears. It was formely thickly coverel with moss, swet fern, ant other hw-errowing loushes, in th. shatle of which animals fonmel

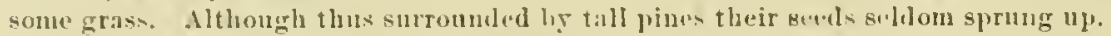

Sut may years hefore these trees started a portion of this laul was plowed and planted with potatoes one gear,

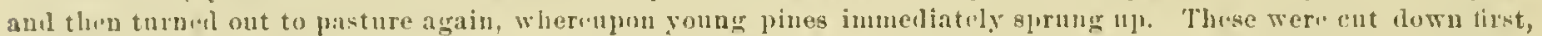
but they continned to enme uj so abundantly that they were alluwed to griw, and uow the pateh tbat wis planted

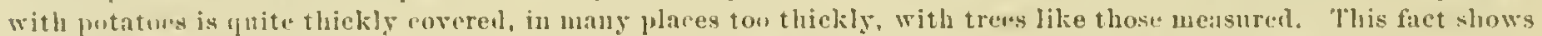

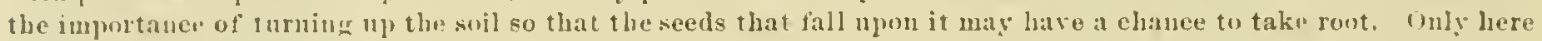
am there a seed will lind lorgment on lam that is covered with moss and low-frowing bushes, no matter how ahumlautly seeds may he sown upon it.

How such trees continue to grow is show in 'Table IlI. From the measurements it appears that a steady growth continues, which, by the lumbledth year has bronglit the tree to a lieight of II('a) 100 feet.

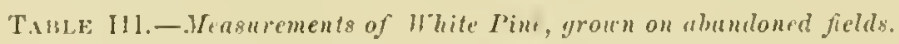

[Furnighed loy Mr.J. L. Iloblus, of Sonth Berwick. Mle.]

\begin{tabular}{|c|c|c|c|c|c|c|c|c|c|c|c|c|c|c|c|c|c|c|c|c|}
\hline \multirow{2}{*}{$\begin{array}{c}\text { Sintulus of } \\
\text { rtes. }\end{array}$} & \multirow[b]{2}{*}{$A g *$} & \multirow{2}{*}{$\begin{array}{l}\text { Diam. } \\
\text { teter } \\
\text { breast } \\
\text { ligh. }\end{array}$} & \multirow{2}{*}{$\begin{array}{l}\text { Dinus. } \\
\text { flet } \\
\text { below } \\
\text { eruwis. }\end{array}$} & \multirow{2}{*}{\multicolumn{2}{|c|}{$\begin{array}{l}\text { Length } \\
\text { of } \\
\text { erown. }\end{array}$}} & \multirow{2}{*}{ 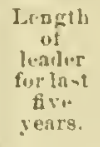 } & \multirow{2}{*}{\multicolumn{2}{|c|}{$\begin{array}{l}\text { Total } \\
\text { buight. }\end{array}$}} & \multicolumn{12}{|c|}{ Ilvight at- } \\
\hline & & & & & & & & & $\begin{array}{l}10 \\
\text { yrs. }\end{array}$ & $\begin{array}{l}30 \\
y r s\end{array}$ & $\begin{array}{c}30 \\
\text { yTs. }\end{array}$ & $\begin{array}{l}\text { yis } \\
40\end{array}$ & $\begin{array}{r}50 \\
y r 8 .\end{array}$ & $\begin{array}{c}\text { (b) } \\
\text { xrs. }\end{array}$ & $\begin{array}{l}70 \\
35 s .\end{array}$ & $\begin{array}{c}0 \\
y t s .\end{array}$ & $\begin{array}{c}90 \\
\text { yrs. }\end{array}$ & $\begin{array}{l}100 \\
91 \times\end{array}$ & $\begin{array}{l}110 \\
\text { yrs. }\end{array}$ & $\begin{array}{l}12011 \\
y=1\end{array}$ \\
\hline $\begin{array}{l}1 \ldots \ldots \ldots \\
2 \ldots \ldots \ldots \\
3 \ldots \ldots \ldots \\
4 \ldots \ldots \ldots \\
5 \ldots \ldots \ldots \\
\end{array}$ & $\begin{array}{r}\text { Tears } \\
3.8 \\
50 \\
61 \\
61 \\
70\end{array}$ & $\begin{array}{c}\text { Inclies. } \\
16 \\
141 \\
12 j \\
153 \\
15\end{array}$ & $\begin{array}{r}\text { Inclies. } \\
13 \\
101 \\
7 \\
10 \\
11\end{array}$ & $\begin{array}{l}1 \% . \\
51 \\
30 \\
33 \\
2 . \\
13\end{array}$ & $\begin{array}{r}I n . \\
0 \\
0 \\
0 \\
0 \\
0\end{array}$ & $\begin{array}{r}\text { Iaches. } \\
\text { ti6 } \\
\text { big } \\
16 \\
56 \\
50\end{array}$ & $\begin{array}{l}F t . \\
80 \\
67 \\
78 \\
70 \\
84\end{array}$ & $\begin{array}{c}\operatorname{In} . \\
10 \\
6 \\
3 \\
2 \\
6\end{array}$ & $\begin{array}{l}\text { Fret. } \\
15 \\
10 \\
12 \\
11 \\
1+1\end{array}$ & $\begin{array}{c}F e c t . \\
28 \\
20 \\
25 \\
24 \\
30\end{array}$ & $\begin{array}{c}\text { Feat. } \\
42 \\
31 \\
37 \\
30 \\
46\end{array}$ & $\begin{array}{r}\text { Feet. } \\
55 \\
45 \\
47 \\
17 \\
60\end{array}$ & $\begin{array}{r}\text { fect. } \\
68 \\
57 \\
62 \\
58 \\
62\end{array}$ & $\begin{array}{l}\text { Fet. } \\
\ldots \ldots . . \\
\cdots 77 \\
68 \\
704\end{array}$ & 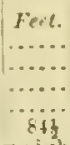 & $\begin{array}{c}\text { Fcet. } \\
\ldots \ldots \\
\ldots \ldots\end{array}$ & $\begin{array}{l}\text { Fol. } \\
\ldots \ldots \\
\cdots \cdots\end{array}$ & Fe+l. & Ferp. & $\begin{array}{l}\text { Fert. } \\
\cdots \cdots \\
\cdots \cdots \\
\cdots \cdots\end{array}$ \\
\hline $6 \ldots \ldots$. & ह2 & 113 & 81 & 3 के & 0 & 72 & 91 & 1 & & Ools & one lute & cut: & heinht & at fift & $5 \cdot 1 \cdot i g h$ & t yenr. & $8,6+f$ & et 10 is & nehes. & \\
\hline 7.... & 81 & 241 & $13^{\circ}$ & 38 & $\varepsilon$ & 4) & 100 & 8 & 9 & 21 & 39 & 54 & 71 & 82 & 21 & 99 & $\ldots \ldots$ & $\cdots \cdots$ & f.... & $\cdots$ \\
\hline $8 .$. & 85 & $23^{\circ}$ & $16 \mathrm{t}$ & 45 & is & $\begin{array}{l}66 \\
62\end{array}$ & 11 & 6 & 9 & 10 & 18 & +1 & 52 & 63 & 75 & 86 & .... & $\ldots \ldots$ & $\ldots \ldots$ & $\ldots$. \\
\hline 9. & 8.3 & $\begin{array}{l}18 \\
25\end{array}$ & $\frac{121}{1 \times 2}$ & $\begin{array}{l}3 ! ! \\
4 ! !\end{array}$ & 10 & $\begin{array}{l}62 \\
36\end{array}$ & $\begin{array}{r}92 \\
104\end{array}$ & 10 & $\begin{array}{l}8 \\
8\end{array}$ & $\begin{array}{l}10 \\
10\end{array}$ & $\begin{array}{l}26 \\
23\end{array}$ & $\begin{array}{l}30 \\
47\end{array}$ & $\begin{array}{l}52 \\
66\end{array}$ & $\begin{array}{l}64 \\
71\end{array}$ & $\begin{array}{l}76 \\
87\end{array}$ & $\begin{array}{l}87 \\
97\end{array}$ & ...... & $\cdots$ & $\ldots \ldots$ & ... \\
\hline $11 \ldots \ldots \ldots$ & 87 & $1 \div 6$ & 123 & 40 & 4 & 72 & 100 & 2 & 9 & 21 & 35 & $4 x$ & tiv & 70 & 81 & 93 & $\ldots \ldots$ & ........ & . & \\
\hline I: $\ldots \ldots \ldots$ & $10 \%$ & $32^{\circ}$ & 21 & 52 & 0 & $2 x$ & 112 & 9 & 13 & 25 & 30 & 53 & 66 & 70 & 86 & 92 & 99 & 106 & 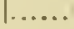 & \\
\hline ...... & 1119 & 31 & 21 & 6.1 & 1 & \$) & 112 & 9 & & & & & $\sin$ & ut in & to neCt & tioแs. & & & & \\
\hline & 117 & $\because !$ & 23 & 57 & 0 & & 101 & 10 & 14 & 27 & 41) & to & 55 & 62 & 69 & 20 & 83 & 90 & 97 & \\
\hline 15. & $13:$ & 23 & 16 & 55 & u & 30 & 107 & 5 & 8 & 16 & 25 & 36 & 49 & 62 & ill & i & 84 & 92 & 99 & l') \\
\hline & 123 & 28 & 19 & 50 & 0 & 21 & 97 & 4 & 10 & 21 & 35 & 52 & 58 & 63 & 69 & is & $=0$ & ej & 901 & 80 \\
\hline
\end{tabular}

NOTES TO TAMLE IH.

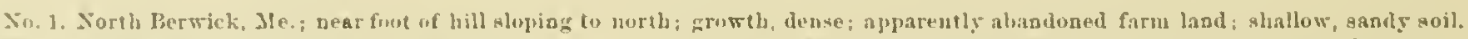

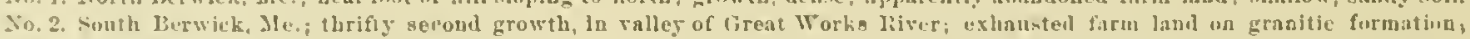

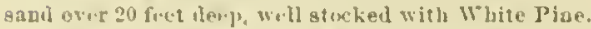

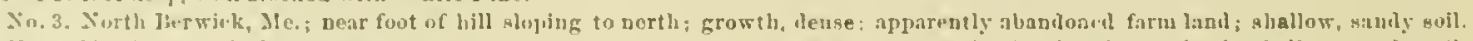

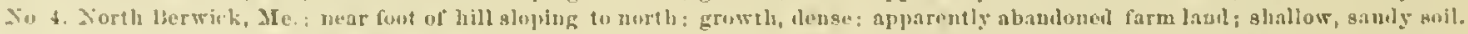

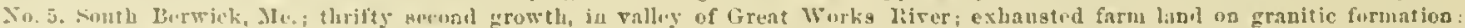
samil over 2i) feet defej, will storked? with White l'ine.

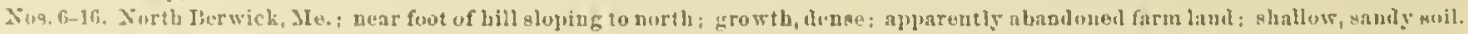

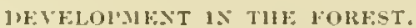

In the dense forest the same generil law of development, nimely, of slow and rapiel stages, prevails for dominant trees as is exemplified by the foregoing measurements of trees grown in the field, although the quantitative progress varies somewhat. According to the relative amount 
of light at the disposal of the crown the rate of growth differs, and there is found, therefore, in the forest trees, thongh very ucarly the same age, trees of dillerent lieights, accorling to tlie suceess of the struggle for light whieh they have had with their neighbors. At every stage of the development of a forest growth, after its juvenile perion, the trees can be chassified into dominant, the tallest, which grow with their entice crown in full enjoyment of light and space. overtopluing their neighbors; codominant, which, althongh of sane hoight, have their erows narower in, lut still mimpeded at the top; While others (oppressed) are pressed in from sides and top, and tinally are entirely snppressed and die. This relationship of individnals changes from time to time, some of the codominant gradually falling into the class of oppressed, and of these a lane number locome suppressed. Oceasionally a codominant becomes dominant, or an oppressed onc, by liberation of its oppressors, throngh stoms or accident, finds opportumity to push forward and milie up for lost time. Thus, a matmal growth may start with a lumdred thousind seedlings per acre: by the twentieth year these will have bren redneed by death to 6, (10), and ly the lindredth year liardly 300 may be left, the rest laving sueenmbed under the sliade of the survivors.

It is owing to these changes that in analyzing tree growth we find great, often muacountable, variation in the rate of growth of even the same individual, and hence, in order to recognize the average, a very large number must be measured to even ont the deviations from the law.

For the same reason it is desirable to clissify the trees as indicated above and ascertain the rate of growth of trees grom under different light conditions. To be sure trees behave also somewhat differently under varying conditions of soil, climate, and exposure; leuce, a further classification is necessary if it is desired to establish more than the mere general lam of progress and also to ascertain the inthence of these variable conditions.

In a general way, we hind, as in the trees grown in the open. the slow sedling stage followed by a very rapil imerease in the anumal rate of growth, beginuing with the sixth jear and leaching a maximun of 16 inclses with the tenth year in lominant trees. With trees which have not enjoyed access to light to the sume extent the maximum ocenrs later; lence, in conlominant trees it is reached, with 13 inches, in the twentieth year, while the opruessed trees reach their maximum curent accretion still later, namely at forty years, with less than 12 inches for the year. As soon as this highest rate is reached decline takes place gradually in all classes, mueh faster in the dominant trees than in the less-farored ones, which decline in the rate of anmul height growth much more slowly.

By the one huncleth year the anmul lueight growth is rerluced to from 6 to $i$ inches, the dominut trees showing the lower rate, which continnes to decline until abont the one hundred and sixtieth to one hundred and seventieth year, when all tree classes have come to a rate of about 2 inches, at which they continue to grow, slowly but evenly, for another century.

This persistence of the height growth, which makes oll trees tower 40 to 50 feet above their broad-leafed ueighbors, influences also the shape of the erown, which does not flatten. as is the ease with most pines. Tery old trees, four hundred years and over, rarely exceed a height of 160 feet, although exeeptional individuals have been foum of the unnsual heiglit of 200 fect.

It will thus appear that the prineipal height giowth is made luring the fiust century, the second century noting a persistent but only slow progress.

If we take the arerage of all the yearly accetions at any one gear of the life of the tree (the average annal accretion at that year), the influences which have becu at work luring the whole lifetime are of course reflected; therefore, since the juvenile periol shows a slow wrow th, the average aceretion attains its maximum moln later. This culmination of the arerage annual aceretion takes place much earlier in the more favored tree elasses. mamely, at aluout the twentieth to fortieth year, after that declining. while in the oppressed it does unt recur until the serentieth year, maintaining itself afterwarls for a long period.

This difference would also appear if we compared better aud poorer sites. In other works. when the annual rate of growth is slow it remains more persistent than when it is l'apid. The persistence noted in oppressed trees indicates also the shade enchunce of the species. From Table $I V$, which gives the accretions from decade to decale (periodic accetion). we see the eapaeity of the speeies to thrive in spite of the shate, even in later stages of its life. liven after ninety years of oppression, when the tree is given oplortunity by inerease of light, it is still able 
to make as good an inmul leight growth as its more-forored neighbors, and ean contime the same to the second century. From the table of heights at varions anes it is learned that the suecress in the jurenile stages after all tells on the total height wrowth.

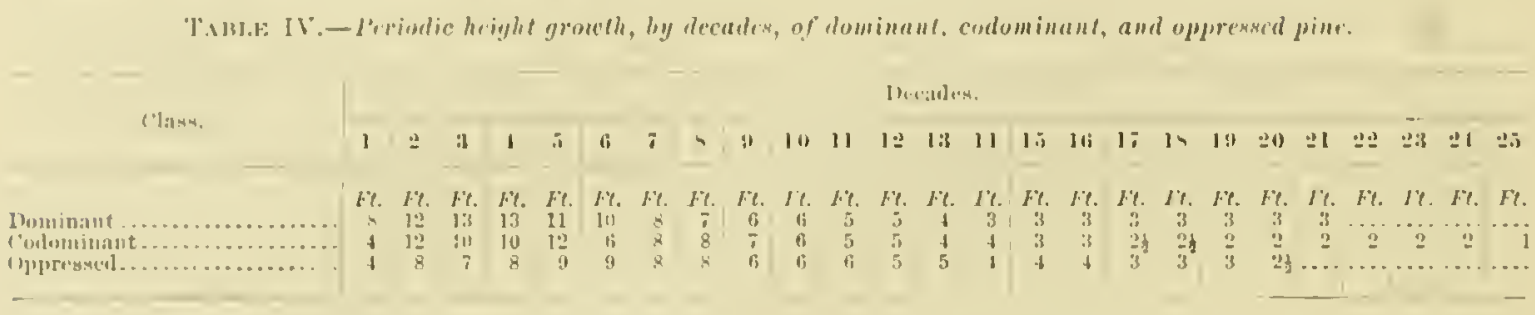

Effert of composition of' forrest "pun height arouth.

The height development of White l'ine seems to progress more rapinlly when it groms mixed witl oflue species. A striking instance showing how the height growth of White l'ine is henefited by the juesence of other species is given in the diagram (iig. 2). which represents the height growth of White "'ine tak'n from two sites (" and $b$ ) in l'resune lske ('ounty, Mich. The sites

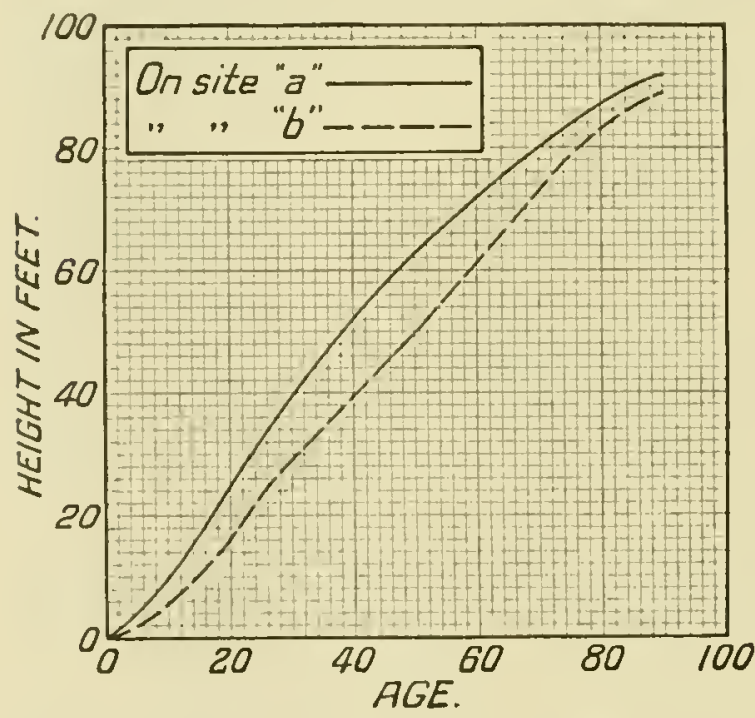

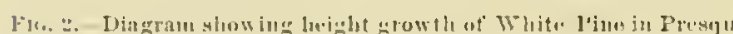
lul. (imnty, slich.: site a, in mixal growth; site b, in pur.growtl. were about io or (i miles distant from each inther. The soil and the moisture conditions on both sites were alparently identical (tresh kand), as were the total mumber of trees to the arode the sample area on site a contained 181 trees and that on site 6189 trees) and the age of the trees and their distribution over the grome (density of erown (cover). The anly ditrerence found between the salmple areas stakerl onl on both sites was the composition of the forest. Sits " consisted of" a mixed arowth of Norway and White l'ine, while situ h represented praetically a pure growtl of White l'ine save a few small Hemlock ant an oceasional Norway Pine. The diagram shows that the White Pine on site a was exceedingly stimulated in its height growth by the presence of the Sorway line.

The associated species entering into the struggle for light with the White l'ine natumally affect the progress of the height growth of the pine. The eflects of the associater species upon the height growth of White line and the period of their inthenco depent upmu the eapacity of the associatmi species to grow in height as well as 1 pon the time when the associater species are

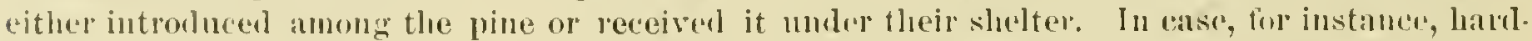
rrools accompany White Pine from the very start the influener of the latulwool mon the height growth of the pine will bist only for the first sixty or seventy years. that is, up to the age at whieh most of the hardwods practionly reach their maximum height. In mase the Norway l'ine ol" the Hemlock starts simultanemsly with the White l'ine, the height growth of the White l'ine will be stimulated to a considrably later alge, becanse the Ilemlock or Sorway l'ine contimues to grow in huight at a similar rate for a longer time. When the White l'ine lappens to start on gromul ahrealy avered with ofler sprecies in snch a manuer as not to be infertered with in its growth the assoriatul species, if "alpable of growing in height to al later age. will stimnlate the height growth of the White l'ine for" a considerably longer perion. All this is clearly demonstrated in the accom. panying hiagram (ig. 3), rejuresenting the hoight growth of White l'inc taken from three sites

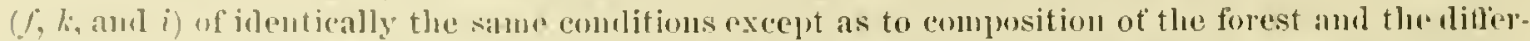
ence in the ages between the pine and assodiated species. All three sites had a wellolined

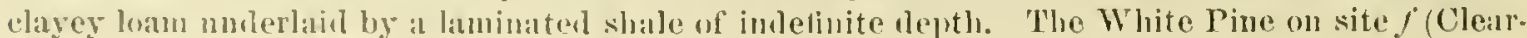
fiehl Connty, ['a.) was mixed with Hemlock of a large sire; the pine on this site had started 
among the Hemlock, which stimulated the height growth of the pine luring all its lifetime. 'Tue White Pine on site $k$ (Jefferson Comnty, l'a.) Was mixed with I embek of a small mmerehantable size. The pine hero had started simultuneously with the llemlowk, which stimnlated the loight growth of the pine only lor a certain period, after which the Ucmlock, being overtuppeel by the line, was ont of the struggle and left in the capacity of an molerwod. The White l'ine on site $i$, whieh merged into site k, was mixed with havlwools, which stimulated the height growth of the pine for the first sixty years, when the hardwools rached their maximum leaght and then withdrew from the competition, leaving the pine to juerease the lieight on its own acemut.

The influence of elimate and soil on height growth will further appear from a stuly of the tables in the Appendix. This inthence on height growth is not very great, if we confine onr infuiry to regions of hest development, the difierence rarely exceeding irom 5 to 10 per cent.

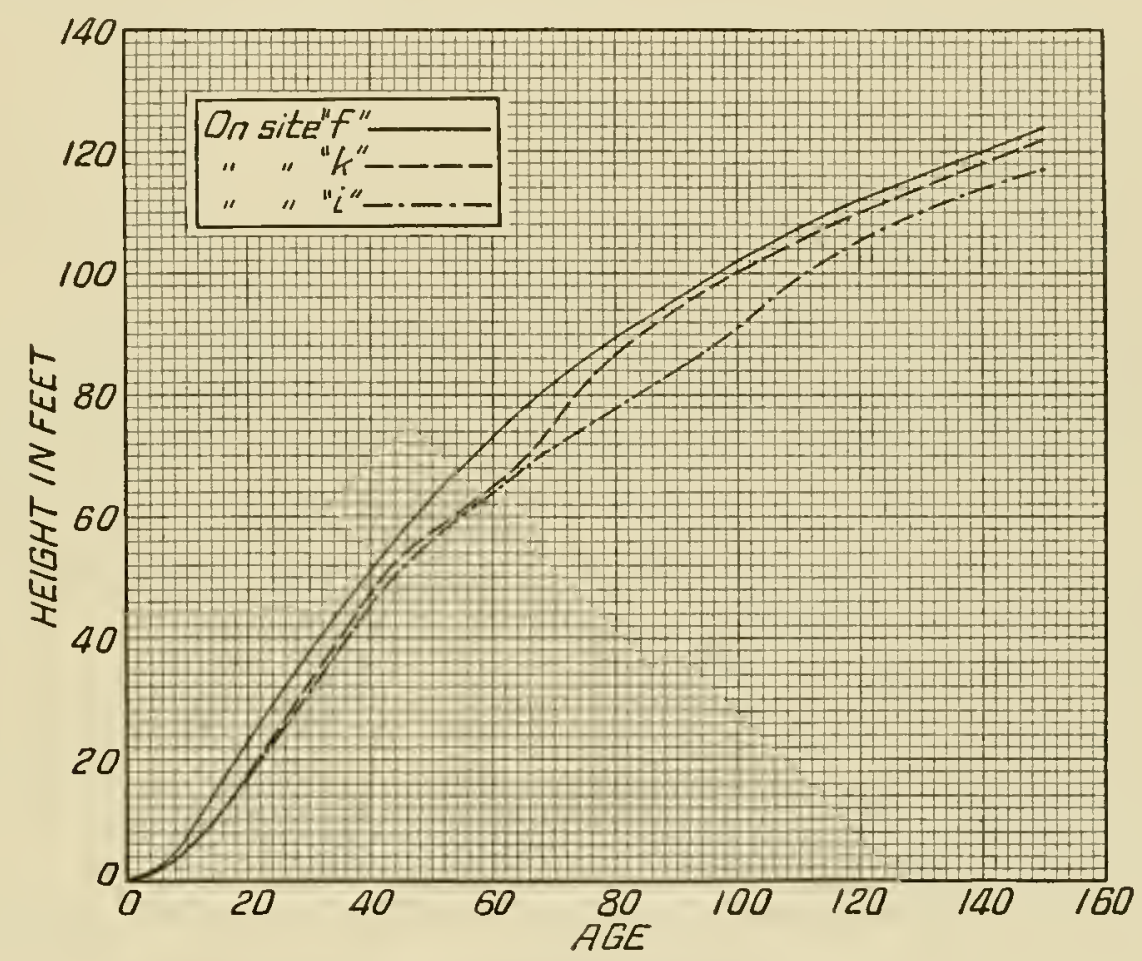

Fin. 3.-Dingrau shming leight growth of White Pine in forest of rarying comploition in Pansylvania: Sito $f$, Clearfinll County; sites k. and $i$, Jetlerson ('ounty.

\section{Effert of locality upon lecight groucth.}

Comparing the growth in ditierent localities, it appears that the trees from Fennsylvania started at a lower rate than those in all other localities, unt alter the twentieth to the twenty-fifth year they smrpass all others. If this cum be accepted as correct, the derlnction of the derelopment in early youth from old trees being subjeet to errors, it may be explained by the fact that these trees grew in mixtmre with Hemlock and were kept back by the sharle of their neighbors, but when they had outgruwn thest they felt the stimulus exerted by them.

The trees from Maine and Wisconsin, also starting more vigoronsly than those from Michigan, lecline and sink below the Michigan trees between the eightieth and nineticth year, which may for Wisconsin be possibly explained by the retarding inthence of winds atter the pines have ontgrown the hardwools, while in Maine the poorer soil may aceonnt for it. Michigan, witl its tempered lako climate, presents a must regular and persistent height eurve, coming nearest to the average of all locatious.

In codominant and oppressed trees these difierences do not come to an expression, but sinee the classification is sonewhat lonbtful and variations within wide ranges are possible, these lata are hardly to be used for comprarisou as to louality effects.

20233-No. $22-3$ 


\section{GROWTII IN THCKNESS.}

The growth in thickness, or diancter aceretion, althomgh remarkably regular in this species, is much more variable, but it is also more prersistent, than the leeight growth, as will appear trom the following comparisons: 'Thus, in tive gromps of trees from ditherent sites, nincty-tonr to one humbed and nine years old, the heights diller only by a little over s jer cent, varying from 91 to as feet, while the diameters ditlered by almost in per cent, varying tiom 16 to 23.7 inches. Arain the persistence is illnstrater by the comprison of the height growth of dive gronps fiom two hundred and seven to two humbed and thirty-three years old, which showed an increase over the gronp just mentioned of somewhat over 20 per cent, whilo the dianeters were by 30 per cent ereater; and if the poorest groups of the two sets had been compared the dillerence wonlil have heen still more striking, nanely, 15 per eent for the height as against $3 \overline{7}$ per cent for the diameters.

This is in part explained by the lact that, where the seedling springs np in the virgin forest, it is rery apt to be suppressed for a longer or shorter periol by the large mother trees and the host of deciluous aud othar forms which make up the forest cover. While the height growth is by this shade also impeled, this is not so to the same degree as the diameter, which is a direct function of the amont of foliage that is at work.

The sapling may thus remain a slemler pole for many years, and not until it is able to lift its hear above its crowding neighbors, or mitil liglit has been armitted to its branches. does it hegin to expand its crown and consequently thicken its stem.

In managed forests, or in tracts where from any canse crowding has been prevented. the growth in lianeter urogresses somewhat more in the manner of the height growtli, namely. slowly at tirst, then rapidly until the maximnm is attained, when a slowly decreasing rate sets in. In the seerling the diameter growth is exceedingly small. very rapil in the young trees, when the annul ring is often one-sixth to one-half of an inch wide. but decreases with the sluwer rate of height growtl. When the tree is sixty to eighty years old, the yearly ring is commonly not more than one-twelfth of an inch wide; it then gradnilly sinks to one fifteenth of an inch, which is then maintained thronghout life, rarely falling to one twenty-tifth of an inch.

The average anmal aceretion reaches its maximm alsont the titieth to the sixtieth rear with somewhat over one-hifth of an inch on the diameter of dominant trees. which rate is nearly maintained to the one hundred and fittieth year.

Thrity trees at forty years of age grow $n$ in the forest, measure from 6 to 9 inches in diameter breast high; at fifty years. from 10 to 12 inches; at eighty years, 1.5 to 17 inches: and they reach a diameter of 15 to 20 inches by the time they are a hundred years old.

To attain a dianeter of 30 to 40 inches, which represents the best merchantable material of days now almost passed, more than two humbed rears have been repnired, while trees four lumbled to four lumblerd and fifty years old attain diancters of 50 to fol inches and over. Trees of 40 inches diameter at three humlred years were by uo means rare.

To be snre, there are exceptional imlividuals which exceed these dimensions. and variation in the rate of growth, due to soil, climate, and surromding conditions, are naturally as frequent as in heiglit growth.

The jrogress of diameter development of dominant, corlominant, and oppressed tree rlasies, and in lifferent luealities, is exhibited in the tables and diagrans in the Aplendix.

The usual methon is to determine the dianeters at $4 \frac{1}{2}$ fect from the ground (breast high , not only because when measuring standing trees the measurement is most conveniently made at this height, but becanso the lower diameters show much more irregularity. There is also more wood deposited near the base at and above the root collar, giving rise to the so-ealled root swelling (butt swelling), nudoubtelly a provision to strengthen the stability of the tree. Unfortunately for the investigations here recorded, it was not practicable to have the trees cut and measured at breast heirht, sinee the measurements were male on trees felled in regular lumbering operations, exposing only the cross sections at the height of the stump, mostly $2 \frac{1}{2}$ feet above ground, and at log lengths. Even at that lieight (21 feet above gromul), a ditterence in the progress of diameter growth from that on ligher cross sections is noticeable and becomes especially pronounced in later life, as is sluwn in the curves representing the progress of diameter growth on cross sections at varions leights.

The diameters here given for the lowest section are. theretore, somewhat larger than those nsually employed, namely, lreast high. especially in later years. 
The higher settious exhbit not only a regula course, but an entirely similar one, from cross seetion to cross seetion. There is no reawon to assume that the course at breast lreight would not follow the same law; therefore there can be constructed a curve for this height similar to the curves of higher seetions, using for guide points the data obtained from a series of measurenents male to establish the yield of pine in which trees were measuren at breast height (compiled in tables in the Appentix). This has been done on the diagram in the Appendix, which shows the diameter development of different cross sections for dominant trees. Fron this can be real the following average dimensions as approximatiug the dianeters of ench decalde. learing out the uncertain juvenile stage:

Itameter, breast high, of Thite I'ine (averages approximated), in inches.

\begin{tabular}{|c|c|c|c|c|c|c|c|c|c|c|c|c|c|c|c|c|c|c|}
\hline & & & & - & & & & & Deca & & & & & & & & & \\
\hline$: 0$ & 30 & 411 & in & 60 & $\div 0$ & 411 & (61) & 111,1 & 110 & $1 \geq 0$ & 1311 & I41" & 150 & 160 & 170 & $\ln 0$ & 190 & $2(x)$. \\
\hline $\begin{array}{l}I n . \\
+.5\end{array}$ & $\begin{array}{l}\text { In. } \\
5.5\end{array}$ & $\begin{array}{r}I n . \\
\delta\end{array}$ & $\begin{array}{l}111 . \\
11.5\end{array}$ & $\begin{array}{l}\ln . \\
13.5\end{array}$ & $1 n_{15}$ & $\begin{array}{l}I n_{1} \\
16.5\end{array}$ & $\frac{I n .}{27.8}$ & $L_{11}$ & $\begin{array}{c}I n . \\
20.2\end{array}$ & $\begin{array}{l}I n . \\
21.3\end{array}$ & $\begin{array}{l}\text { In. } \\
22.2\end{array}$ & $\begin{array}{l}I n . \\
23\end{array}$ & $\begin{array}{l}\text { In. } \\
23.8\end{array}$ & $\begin{array}{l}I n \\
24.5\end{array}$ & ${ }_{25.2}^{I n .}$ & $\begin{array}{l}I n . \\
26.4\end{array}$ & $\begin{array}{l}\text { In. } \\
26.8\end{array}$ & $\begin{array}{l}I t_{*} \\
2.5 .5\end{array}$ \\
\hline
\end{tabular}

That these figures may be eousiderably exceederi (even by 50 to 60 per ceut) under farorable eonditions will appear from the varions tables of uneasurements in the Appendix. Especially is this the ease in the second-growth groves of pine.

As will be rearlily seen in the enrves after the jurenile stage, during which the diameter grows very slowly, an acceleration in the rate takes place. which soon reaches a maximum, continuing at that for a short time, and then slowly and persistently declining from about 3 inehes per decade betreen forty and fifty years to $1 \frac{1}{4}$ inehes at one lundred years, and half that amount at two hundred years.

DETAIL MEASURFMENTS OF ANNLAL GAN IN CIICLMAEREXCE.

An interesting set of most accurate observations have been made and rejorter by Mr. Nathaniel Morton, of Plymonth, Mass, exhibiting 38 young trees of White I'ine, which hat sprung mp anong oak and other hardwoods, mixed with White Pine and a few Pitch Pine in an old, rather-neglected pieee of wools, and which were measured every year from 1891 up to 1898. The trees stand rather open. The age varied from twenty-eight to forty-two years. most trees being between thirty and thirty-six years old and their average age thirty-six years in 1891.

In 1891 the average eross seetion 3 feet from gromnd was 131 square inches; in 189s. 197 square inches; the growth 66 synare inches, or abont 9 square inches per year, one tree making 15 square inches per year. This growth comesponis to a gromth in circumference of abont 1.3 inches per year, or a growth in diameter of four-tenths of an inch per year.

The detail measurements are given in the following table:

TABLE V. Annual fain in circumference of White I'ine tret' in Mussuchnsetts.

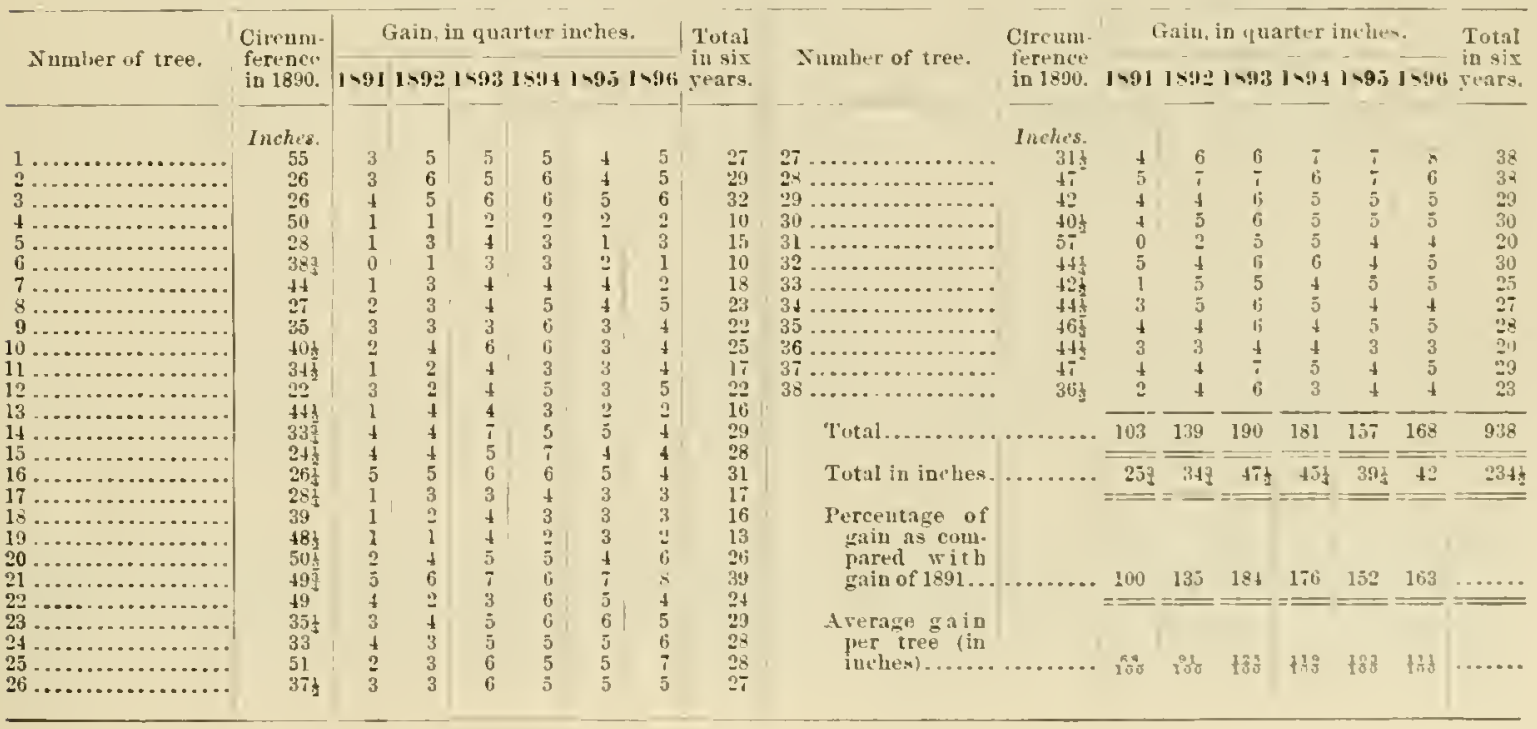


ARE, ACCLETHA.

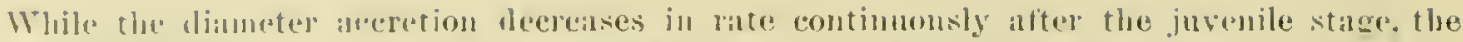

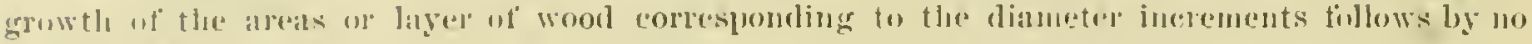
meatis the simure rouluse.

Aften the furmile stage, whichs is determined by the fomation of a definite erown, and when

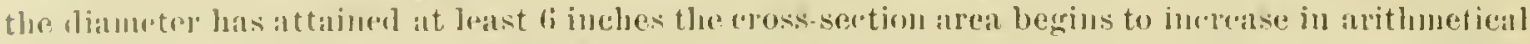
progression; a constantly inereasing rate prevails until a maximum is attained, which comes between the sixtioth and one humbed and twoutieth year, ambl then continues remarkably uniform

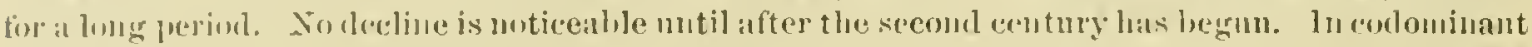

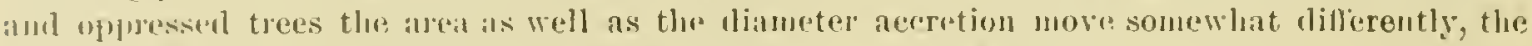
maximum rate combing later and lasting a shoster timn, the decline folinwing son alter the maxim!ı!ı.

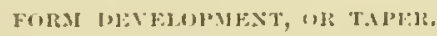

Since size of crown and light conditions regulate the anomt of dianeter growth, it is evislent that trees with well-developed fine crows form more wool than those crowded, the dominant more than the oppresied, and thuse on lawns more than those in the dense forest. Morencer, in these

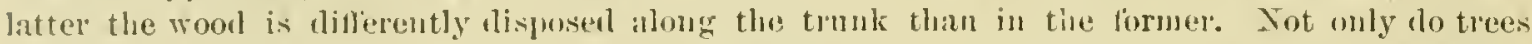
grown in the open throw their energy into branch growth, but the aceretion on the bole is laid on in layers, increasing in wirth tron top to base. The result is a more raphil taper than in forestgrown trees, in which each anmul layer is wider at the top than at the base of the tree, prolucing thereby an more cylimbrical form.

The followng table "xhibits in the measurements of six trees this variation in the wirlth of the sane aumul rings it different heights, and also in general the mode of diameter growth in these trees. More eliborite tables, showing the diameter grow th of White Pine at varions heights trom the gronul for doninant, conlominant, and oppresserl trees in various parts of its runge. together with diagrans, wall be fomed in the Appendix:

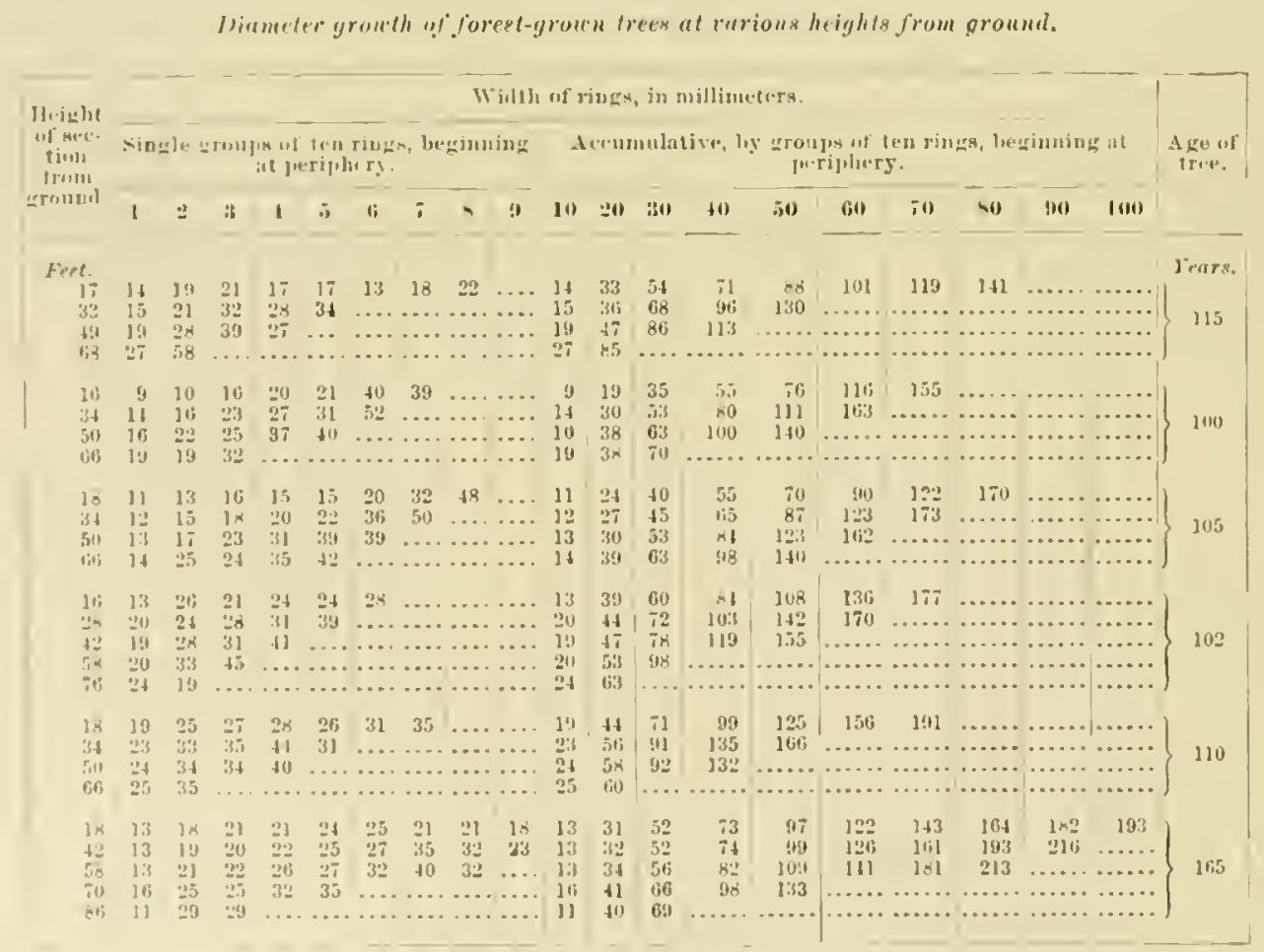

From such tabulations the taper, factor of shape, or form factor, may be derived (see Tables Il and $V^{\circ}$ in Aphendix), which denotes the deviation of the shane of the tree from a cylinder. This lar:tor varies between 0.10 for the older trees and larger rlianeters to 0.50 for younger and 
more slender trees, a fuctor of 0.45 heing about the arerage for rentwarians-that mum the volume of a humbed-sear-old tree is forty-five one-humbedths of a eylinder of the diamster, measured at breast height and the leight of the tree.

This faetor varies. of course, according to the ratio between diameter and height, and since in codominat aud oppressed trees this ratio is a diflerent one from that of dominant trees, as we liave seen, their factor of shape is also different from that for lominant trees, that is, their tiper differs, the former being more eylindrical than the latter. This will appear from a comprison of the taper of trees as recorded in Table II of the Appendix, in which small diameters with comparatively long slafts indicite the codominant and snppressell trees. Those with short lengths and large diameters are trees grown in open stand.

From Table II, Appendix, we also see that the taper varies within wille limits from less than 1 inch to 5 iuehes for every 16 feet, although in the majority of cases it lies between 2 and 3 inshes. The tops taper, to be sure, much taster than the midlle portion; and, again, in older trees espe. eially, the butt logs much faster than the npper portions, which are ontside of the influence of the root swelling.

In young trees which make three $\log$ lengths of 16 teet, it will be safe to allow 13 inehes for the first two $\operatorname{logs}$ and 2 inches for the last one as the arerage taper. In mediun sized trees, making four to tive $\log$ lengths, an allowance of 2 inches ou the whole will fairly represent the aver. age taper, or one-eighth of an inch for every foot in length. In old trees which turnish five and six or more $\operatorname{logs}$, an allowance of 4 to 5 and even 7 to 8 inches must be made for the first log and 3 to 4 inches for the two top logs, while the middle portions show a more regular aud less variable taper of about 2 inches, or one-eighth of an ineh per foot.

\section{GHOWTII IN YOLUME.}

During the jurenile stages the volume growth of the White Pine, as of most trees, is insig. nifieant, a dominant tree of trenty years measuring not more than 0.5 enbic foot, which means an average aceretion of 0.025 cubic foot per sear. For the thirl decade the ammut of wond formed is over three times what it was during the first two decades. and at fifty years the bole of a dominant tree may contain from 10 to 14 enbic fect and over, the average annal accretion having come up to one-fouth of a cubic foot, or ten times what it was at twenty years.

Now, after the rapid height-growth period, with fully developed crowns, a rapid rate of volume growth sets in, increasing with each year, in arithmetical progression, until at sixty to seventy years the current accretion has becone 1 enbic toot and over, and at one lumbled years as much as $1 \frac{1}{2}$ cubic feet is attained. After the one lundred and twenty-fifth year the increase in the rate abates, yet before the second century it has beeme "cuble feet, and remains then practically stationary for another century at least.

Some of the oldest trees (four hundred and fifty years and over) measured contained 600 to 800 enbie feet of wood in the stem alone, the largest. with 55 enbir feet. indieatiug an arerage aunual accetion for this long life of over 1.5 enbic feet.

While the current ammil accretion after the fiftieth yeall is rapiuly inereasing, the average ammal aecretion, aflected loy the earlier stages of slow growth, incleases naturally more slowly. For the first one hundred years the average is abmut two-thirds to three-fourths of a cubic foot for dominant pine, making the volume about io cubie feet. It increases to 1 enbic fot at one bundred and fifty years and $1 \frac{1}{4}$ enbic teet at two lumdred years, and, ats shown above, gains gradually mutil old age.

The progress in volume growth naturally varies under different soil conditions and with tree classes. In a general way, the oppressed trees and those on poorer sites do not begin the period of rapid volume growth as early as the dominant classes, but just as in the height growth, which is similarly delayed, the rate when once at its maximum persists with great uniformity until abont the one humdred and fortieth to one hundred aud sixtinth year, when a decrease becomes noticeable.

The tables and diagrams in the Appendix show, ly figures and graphieally, the progress of diameter, height, and rolume aceretion for dominant, codominant, and opluressen trees throughout the ringe of the sprecies. Comparing the growth from the several localities represented. a strilking 
dillerence is not olservel. It wonhl appear that in similar soils the White Pine grows at about the same rate, with sinilar persistence, and to the same limensions in all parts of its range.

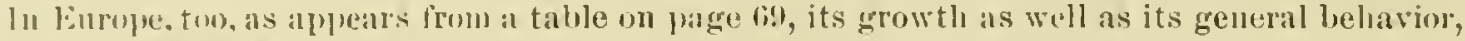
at least in the forestio of licrmany, is fully as fuvorable as at hume.

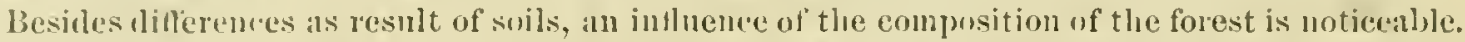
White l'ine mixed with llemlock (l'ennsylvania stations) shows a more rapid growth for the first one humlred and thirty years, while anong hamlwouls (Wisconsin stations) the nest one humlred years seen to produce the thriftiest growth. This is perhaps explained by the fact that in the latter mixtme the White l'ine has after the first one hundred years its entire erown above the shorter hardwoods, ant hence is in thll enjoyment of liglit.

The so-ealled "second growth" pine develops somewhat dillerently, becanse, as a rule, it does not start in a dense growth, enjoying the light conditions of the open staml, the single individuals make a more rapil volume growth, nutil they have closed uj, and forest conditions preval. 'This is fully exlibited in the measurements of yomg groves in Hassachsetts and New llampluire, tabulated in the Appentix.

In mallaged woods, where the number of trees allowed to grow per ace is nuder control, the Folume aceretion may also be accelerated; the growth energy of the site being then exerted on ferer individuals, each one deposits larger amounts. What this increase can be may be inferred fom the tal,e on page 69, which revorls the growth of White P'ine in Germany.

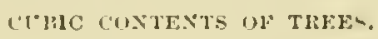

Having ascertined by a large number of measurements the dianeters, heights, and fietors of shine pussesserl by trees unler all sorts of conlitions, the cubic contents of such trees can be calculaterl and recorded in a table for lurther use, by reference, in mensing contents of trees. Snch table for White I'ine of diflerent diameters and heights will be fomd in the $\mathrm{A}$ plpendix, from which the emiteuts in enlic feet of the bole of a tree whose diameter at breast height has been measured aud whose height has heen estimated or nuasurel can at once be real onl:

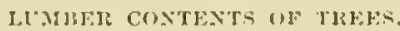

The total cubic contents, being hased on mathematical consiclerations alone, is the only rational measure of the volune. liy stating contents in board measure we introlnce at once a number of uncertain factors, which are variable in the practice, such as the lowest-size diameter to whieh logs are taken: the size of the lumber that is cut, from one-halfinch buards to square beans; the saw nsed, whieh determines the loss in kert, and the skill of the sawyer, who can waste a large proportion in slabs and inconsilurate use of the logs.

In these losses there is no allowance mile for crooks or rot, which womld rednce the results still further, so that hardly one-thind of the total volume of the tree would seem to reappear in the shape of limber, provided the log scales nsed are correct, which anticipate a luss of 4.4 pen. "(unt (Seribner) to 50 per cent (Doyle) in sawdnst, slabs, and edgings for 14-inch logs, the arerage size of logs in the northern pineries.

As a matter uf fact, in good modern mill practice, not only loes mo such waste ocenr as is indirated in these 'og scales, even if all logs were cut into inch boards, but in ahlition small logs are worked into dimension material $2, y, 4,2$ by $\mathbf{6}, 4$ by $\cdot 1$, ete., in which the loss is redueed to a minimum; thus an s.inch log may be cut to 6 by 6 inches. It then would make, if 16 feet long, not 16 to s.j feet 13. M., but is feet. Since the bulk of un pine material is now obtained from small logs (over ove-half below 1.4 inches diameter), these differences are of eonsiderable practical importance.

A careful examination and measurment of one humlred trees uf White Pine was made by .Ir. Filibert lieth to ascertain what rational allowance should lw mado on the eubic contents of trees when eonverted into lumber.

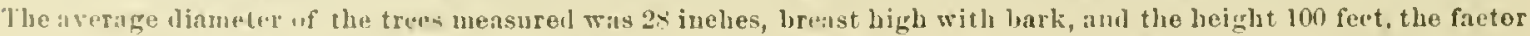

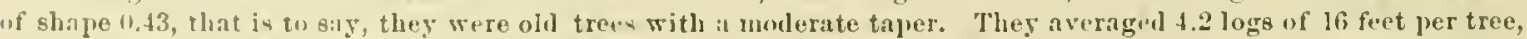
which representcul if prep cont of the total rolume of the bole with birk, 21 per cent luing lost in the top aud stump

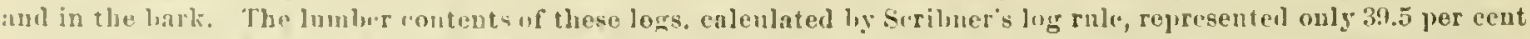
of the totil volume of the tron. that is to say, over fo pur ent of the whole tren is supposed not to reappear in the lumlwr, the wiw waste represinting 48 p.r crent of the log volnme and 36 per cent of the total volume of the tree. 
Based mon a proper consileration of these practices, it will appear that an average allowance of 30 per cent in saw waste on the volume of logs of all sizes is more than ample, and that the lumber yield given in the following table and computed on this assumption of waste, althongh being for same sizes even 100 per ceut above the log seales in use, remains still below the practically obtainable results:

Lumber contants in li. foot luys.

\begin{tabular}{|c|c|c|c|c|c|c|}
\hline \multirow{2}{*}{$\begin{array}{l}\text { Diam.tor } \\
\text { at small } \\
\text { end. }\end{array}$} & \multirow{2}{*}{$\begin{array}{l}\text { Judson's } \\
\text { farurite. }\end{array}$} & \multirow[b]{2}{*}{ Doste rnle. } & \multirow{2}{*}{$\begin{array}{l}\text { Seriboer } \\
\text { rule. }\end{array}$} & \multirow{2}{*}{$\begin{array}{l}\text { Computed } \\
\text { for } 30 \text { lier } \\
\text { cent waste. }\end{array}$} & \multicolumn{2}{|c|}{ Wante. } \\
\hline & & & & & $\begin{array}{c}\text { Py serib- } \\
\text { W(x. }\end{array}$ & ]igy Doyle. \\
\hline Inches. & Fut l. .1 . & Feet $B$ M. & Fet B. H. & Feet I: II. & I'er ent. & I're cent. \\
\hline 8 & 22 & 16 & 25 & $\begin{array}{c}32+11+8 \\
46\end{array}$ & 61 & 76 \\
\hline 10 & $: 7$ & 30 & 49 & 60 to 85 & 50 & 65 \\
\hline 12 & 64 & lits & 79 & $\begin{array}{c}100 \text { to } 130 \\
105\end{array}$ & 47 & $5 i$ \\
\hline $\begin{array}{l}14 \\
16\end{array}$ & $\begin{array}{r}45 \\
142\end{array}$ & $\begin{array}{l}100 \\
144\end{array}$ & $\begin{array}{l}114 \\
159\end{array}$ & $\begin{array}{l}1+\frac{1}{1} \\
187\end{array}$ & $\begin{array}{l}44 \\
41\end{array}$ & $\begin{array}{l}51 \\
46\end{array}$ \\
\hline 18 & 197 & 1160 & 213 & 237 & 37 & 43 \\
\hline 20 & 248 & $25 t^{2}$ & 280 & ביוביב & 33 & $3 y$ \\
\hline 22 & 324 & 324 & 334 & $3: 36$ & 34 & 36 \\
\hline 24 & $3: 12$ & 400 & 404 & +20 & 33 & 33 \\
\hline 26 & 470 & 484 & 500 & $49:$ & 31) & 32 \\
\hline 28 & 562 & 576 & $5 \div 2$ & $51 i t$ & 99 & 30 \\
\hline
\end{tabular}

In estimating the cut of lnmber that may be obtained from a given area, there must, to be sure, all allowance be made in addition for unserviceable, erooked, knotty, rotten material, whieh may reach from 1 is to 20 per cent, and, furthermore, an allowance for the loggers' risk in breakages and other losses, which may be figured at 10 to 12 per cent.

To give, however, an approximate illea of the lumber contents of trees of various diameters and heights, these have been ealcnlaten for a number of trees and reeorded in Table II, 17. S7, in the Appendix.

From these measurements, which are based npon Doyle's log seale, the following tabulation is made, showing approximately the inerease of lumber contents with diameter growth and age. From this it wonld appear that the greatest per cent of increase oecurs during the period from the fortieth to seventieth year, while in the fortieth year the average ammal growth in voinme has been about one-third of a cubie foot, in the seventieth year it is nearly '2 cubic feet, $r$ six times as great, and by the one hmudredth year this rate is doubled, centenarians containing about 100 feet B. M. During the next century the trees make trice as much lumber wool, for nom all mood deposited makes lumber:

Increase in lumber contents with size.

\begin{tabular}{|c|c|c|c|c|c|c|}
\hline $\begin{array}{l}\text { Diameter } \\
\text { bruast } \\
\text { high. }\end{array}$ & Heinht. & $\begin{array}{l}\text { Approxi- } \\
\text { mate age. }\end{array}$ & Lumbet $\mathrm{r}$. & $\begin{array}{l}\text { A rerage } \\
\text { anmual ac. } \\
\text { 'retion. }\end{array}$ & $\begin{array}{l}\text { Porivilic ac. } \\
\text { cretion. }\end{array}$ & $\begin{array}{l}\text { Perceut of } \\
\text { increase } \\
\text { perytar } \\
\text { during pre. } \\
\text { ceding } \\
\text { period. }\end{array}$ \\
\hline $\begin{array}{l}\text { Inches } \\
7 \text { to } 9\end{array}$ & $\begin{array}{c}F^{\prime} t^{\prime} t \\
50 t()\end{array}$ & $\begin{array}{l}\text { Tears. } \\
40\end{array}$ & Fect $5.3 \%$ & $\begin{array}{c}\text { Cubic feet. } \\
0.35\end{array}$ & Fcet B. $1 U$ & Per cent. \\
\hline 10 to 12 & 50 to 80 & 55 & 50 & .9 & 36 & 17 \\
\hline 13 to 15 & 55 to 115 & 70 & 130 & 1.5 & 80 & 17 \\
\hline 16 to 18 & 75 to 125 & รถั & 260 & $\dddot{3}$ & 130 & \\
\hline 19 to 21 & 80 to 135 & 110 & 440 & 4 & 150 & 3 \\
\hline 22 to $: 4$ & 85 to 140 & 14 & 650 & 4. 6 & 210 & \\
\hline 25 to 27 & 85 to 150 & 185 & 940 & 5.1 & 290 & 1 \\
\hline 28 to 30 & 85 to 150 & 230 & 1,200 & 5 & 260 & .6 \\
\hline
\end{tabular}

CONDITIONS OF DEVELOPMENT.

WEMANDS UHWX CLMATE ANI SOHL.

The wide field of its natural distribution and the thriftiness with whieh the White l'ine develops in elimates outsile of its natice home show that it is quite adaptive as far as climatie conditions are eoncerned. Yet, from the mamer of its development within the climatic range of its 
ocrurrenee, its nse for forestal purposes would seen to be eirenuseribu by ronditions of humid

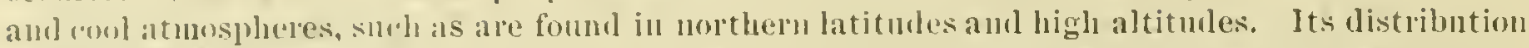
is manifestly more demulent on luminlity than on temperature. or rather, on a low transpiration factor. that is. sure a a rolation of heat and moisture, hoth at the font and at the top, that the thiu foliage can readily lorform its lunctions: hence, its failure in anltivation in the trans-Missouri states. the contraction of its southeru fielul to the high altitudes, and its best development in funutity if not in flulity within the intluence of the (ireat Lakes and to the northwarl and eastwarl.

While alanting itself realily to almost any variety of soil, the lyite l'ine manifestly prefers one with a fitr monixture of sand, insuring a molerately rapid duanage. The pine tribe in

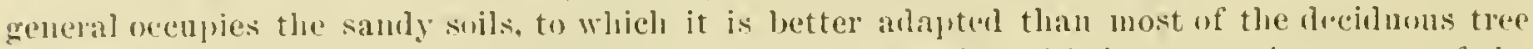
sprecios: but the White l'ine is apahle of disputing possession with its competitors even of the fresh medinm-heary loam and clay suils, making here the best indwidual growth.

Its shallow root system. in which it resembles. is in many other respects, the spruces, jermits it to aceompany the latter to the thinner soils of the roeliy slopes in the Arlirondacks am New England States, although hele its levelopment is naturubly less thrifty. Its growth on the rocky hills of IIssandusetts withil the hardwools of that region is. howerer, at least for the first sixty to righty gears not much less thrifty than in the better soils in the valleys. It does not shun even the wetter and oecasionally werflowed and swamly gromd. and is here found, together with the Fir. Arborrita. and even Tamarark: yet, ou the dry, light sandy, coarse, and gravelly soil the Red l'ine and lack Pine secm to be able to ontulo it.

$$
\text { A-ROCITHI SI'ECIES. }
$$

The White Pine is less gregarions than any other pines of the Jastern United States. Although it oceurs in pure growths as true pinery on the red elays and moister gravels, it more frequently is an admixture in the hardwoods, sharing with them the compacter, heavier soils from which the other pines are excluden.

Sprnce, lleminek, and Arborvita (Cerlar) are most frequent concomitants of the White l'ine in Canada; rarions sprecies of birel and llaple with lieech and Spruce form the composition of the forest in the Adirondacks, overtorered by the pines, and there is hardly any species of the Northern Atlantic forest which in one or the other region of its distribution may not be fonnd in association with the White Pine.

Owing to the fact that the harlwoods as a rule ocemy the better soils, the best individual development of the White Pine is also fomm in these mixtmes. In the pinery of the nortluest lied l'ine and Jack l'ine are the associates, while the P'itch l'ine (l'. riginlu), and, in the southern field, the Shortleaf I'ine ( $P$ '. echinatu) are not unfrequent? found in its company.

The samples of ". acre yielis" following will serve to illustrate more in detail the mamer of distribution. the associations, and the capacity of White l'ine in the mative folests in lifrerent parts of its range. Mole extensive tabulation will be fond in the Alpendix. 
TABLE V1.-Arre yield of Whate l'ine on sites in W'inronsin, Michigan, I'enusylrania, and Maine.

\author{
WISCONita
}

SITE a: Washburn Cunty.

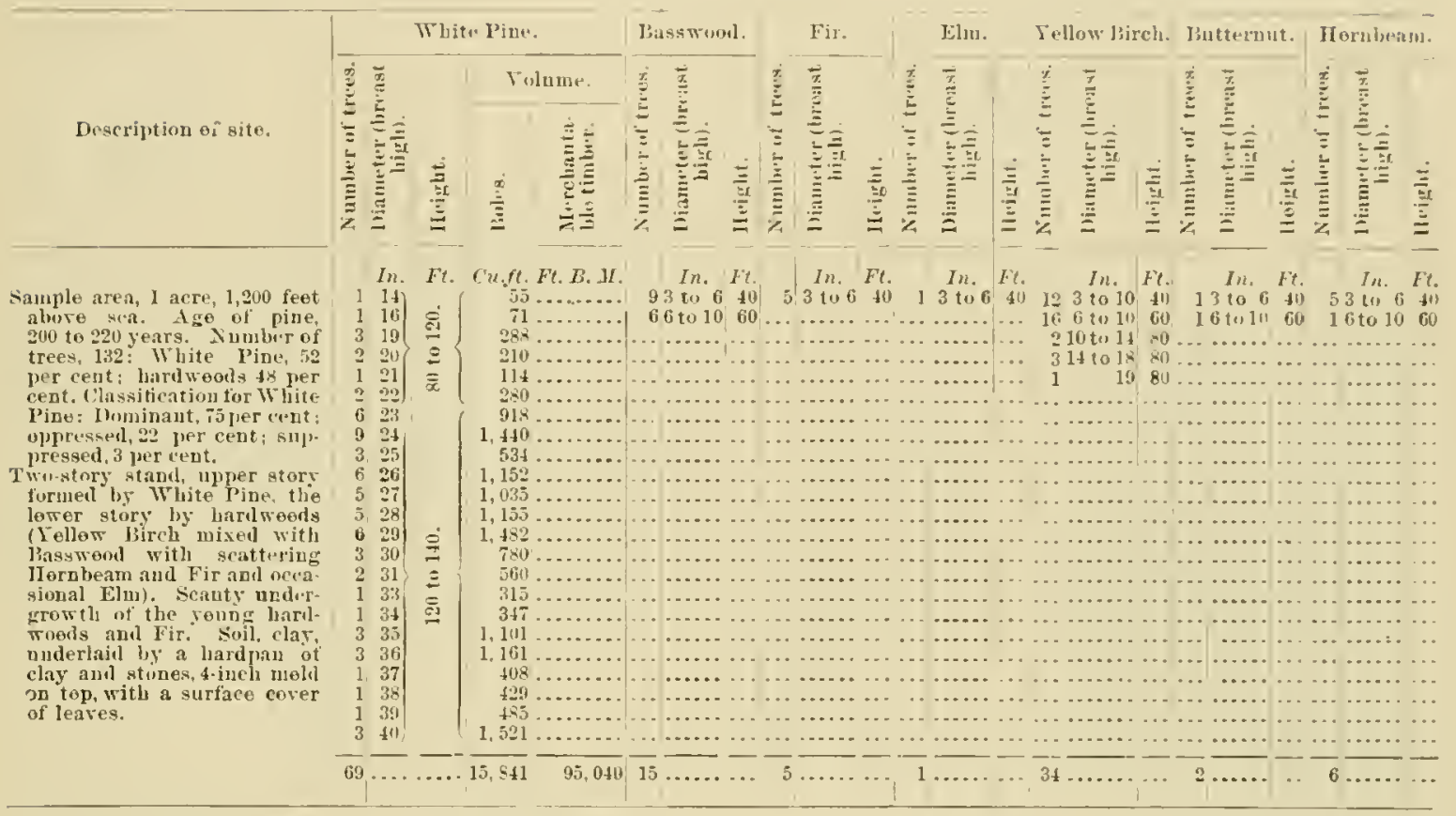

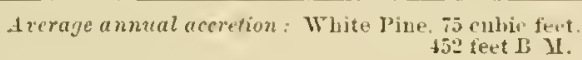

MICHIGAX.

Site $d$ : Montuorenes Cintuty.

Deseription of site.

\begin{tabular}{|c|c|c|c|c|c|c|c|c|c|c|}
\hline \multirow[b]{2}{*}{ 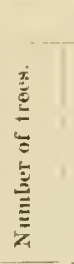 } & \multicolumn{4}{|c|}{ White I'iue. } & \multicolumn{3}{|c|}{ lied Pine. } & \multicolumn{3}{|c|}{ Hemleck. } \\
\hline & 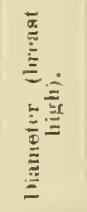 & 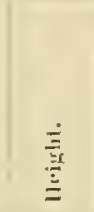 & $\stackrel{\frac{e^{\prime}}{E}}{E}$ & 童 & $\begin{array}{l}\vdots \\
\vdots \\
\vdots \\
\vdots \\
\vdots \\
\vdots \\
\vdots \\
\bar{E} \\
z\end{array}$ & $\mid$ & 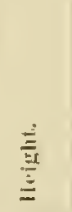 & 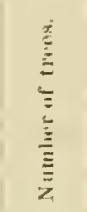 & 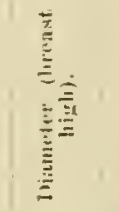 & 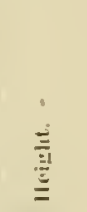 \\
\hline $\begin{array}{l}2 \\
1 \\
3 \\
1 \\
3 \\
3 \\
1 \\
1 \\
3 \\
2 \\
6 \\
5 \\
5 \\
9 \\
1 \\
1 \\
3 \\
2 \\
7 \\
6 \\
2 \\
1 \\
1\end{array}$ & $\begin{array}{c}\text { Incliex. } \\
10 \\
13 \\
13 \\
14 \\
15 \\
16 \\
17 \\
18 \\
19 \\
21 \\
212 \\
23 \\
21 \\
25 \\
20 \\
27 \\
25 \\
29 \\
29 \\
30 \\
21 \\
33\end{array}$ & 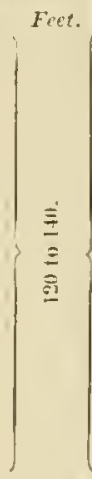 & $\begin{array}{r}r u . j t \\
36 \\
36 \\
159 \\
611 \\
207 \\
231 \\
86 i \\
96 \\
315 \\
2 \times 11 \\
906 \\
855 \\
1,611 \\
800 \\
216 \\
696 \\
498 \\
1,862 \\
560 \\
3112 \\
340\end{array}$ & 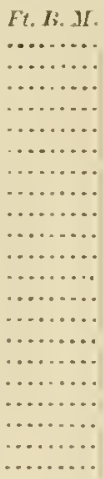 & $\begin{array}{l}2 \\
1 \\
3 \\
1 \\
3 \\
3 \\
3 \\
6\end{array}$ & 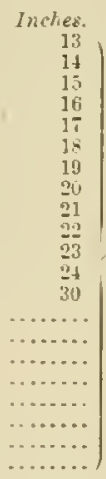 & $\begin{array}{l}\underline{\Xi} \\
\vdots \\
\bar{\Sigma}\end{array}$ & 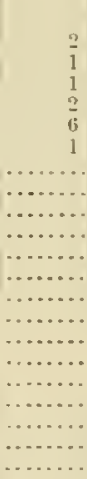 & 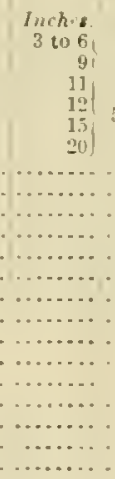 & 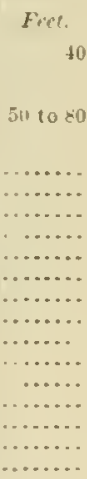 \\
\hline 61 & & & 10.154 & 60.900 & 39 & & & 13 & & \\
\hline
\end{tabular}

Sample area, 1 acre. Age of pine, 250 to 270 years. Nrumber of trees, 113: Whitw Pine, 54 per cent: Iied Pine, 35 per cent; Hemlock, 11 per cent. Locality damaged by tire trelve years lefore; 15 per cent deal trees and 20 per cent injured ly fire.

White Pint mixesl witl Iied Pine and inter. ujxed with Ifemlock. Suil, fresh, loose savi of a gray color, turuing hrown asul redl underneath, witlı a surface corter of hrakes, checker. berty. The subseil is a lirown sand, sumetimes loamy and in spots clayey. Density of crown core: 0.5 . 


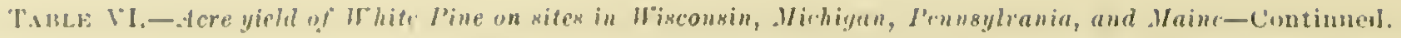

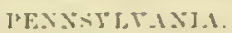

SitE: f: Whhoin, Clcartivld cuanty

\begin{tabular}{|c|c|c|c|c|c|}
\hline \multirow[b]{3}{*}{ Leseriftun uf aitu. } & \multicolumn{5}{|c|}{ Whato J'jue. } \\
\hline & \multirow[b]{2}{*}{$\begin{array}{l}\vdots \\
\vdots \\
\vdots \\
\vdots \\
\vdots \\
\vdots \\
\vdots \\
\vdots\end{array}$} & \multirow{2}{*}{ 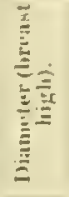 } & \multirow[b]{2}{*}{ 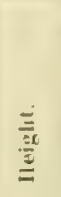 } & \multicolumn{2}{|c|}{ Volums. } \\
\hline & & & & liol... & 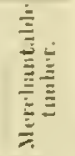 \\
\hline & & In. & Fect. & r'u. $/ t$. & Fi. \\
\hline Saruple arua, 1 acre, 1,200 to 1,510 & 2 & 15 & 120 & 360 & 1,360 \\
\hline 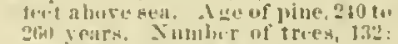 & $\frac{2}{2}$ & $\begin{array}{l}17 \\
18\end{array}$ & $\begin{array}{l}131) \\
130\end{array}$ & & 1.300 \\
\hline White l'ine, 37 ; Ilemlerk, ni; IIa- & $i$ & 19 & 1311 & & \\
\hline 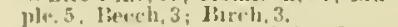 & j & 20 & 1311 & 1,370 & 6. 120 \\
\hline Hemloch underl wath White I'iue. & 4 & $2 t$ & 130 & & \\
\hline with (Hotasionat Mlaphle, Beech, and & 2 & 28 & 130 & & \\
\hline Herch, un a hill slojinge towards & $\frac{2}{1}$ & 28 & 1311 & 570 & 3,000 \\
\hline goutherest, where it is boumleal lay & $\begin{array}{l}1 \\
3\end{array}$ & 21 & $\begin{array}{l}130 \\
135\end{array}$ & 651 & 3,690 \\
\hline 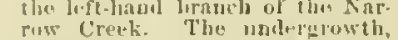 & $\begin{array}{l}3 \\
1\end{array}$ & 26 & 135 & 257 & 1,390 \\
\hline 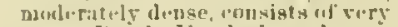 & 2 & 27 & 133 & & \\
\hline 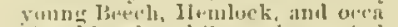 & 1 & $2 x$ & 135 & 1,160 & 6,6190 \\
\hline Sional lureh and Curumber, sml, & 1 & $2 ! 3$ & 135 & & \\
\hline yellow elayey loim uf a suedium & 2 & 30 & 145: & 6,0 & 3. 2100 \\
\hline itrain (fone shibles in it, dewlo. fresh, & 4 & 31 & 145 & 1,220 & ¡. 800 \\
\hline well drained, watl : to 3 incloes & 1 & 32 & 145 & 320 & 12. $: 000$ \\
\hline 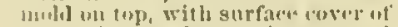 & 2 & 34 & 145 & 500 & +800 \\
\hline heanty li ares, form, toiberries, and & $\bar{I}$ & 40 & 115 & 511 & 3,300 \\
\hline sentering dogwowd thaurol, north. & 1 & 41 & $14 \mathrm{~L}$ & 511 & 3,300 \\
\hline "ast iviruer aud north sidar). sulh. & $i$ & 4.7 & 145 & $635^{\circ}$ & 4. $4(16)$ \\
\hline 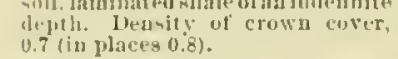 & 37 & & & 9,028 & 52,260 \\
\hline
\end{tabular}

Total vield: 911,103 tipet I3. MI

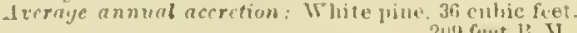

HIINE.

SITE 11: Fork County.

\begin{tabular}{|c|c|c|c|c|}
\hline \multirow[b]{2}{*}{ Ih.geription of ste. } & \multicolumn{4}{|c|}{ Whate Pine. } \\
\hline & 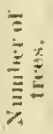 & 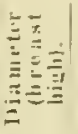 & 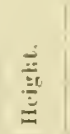 & $\begin{array}{l}\Xi \\
\vdots \\
\vdots \\
\vdots \\
\vdots\end{array}$ \\
\hline 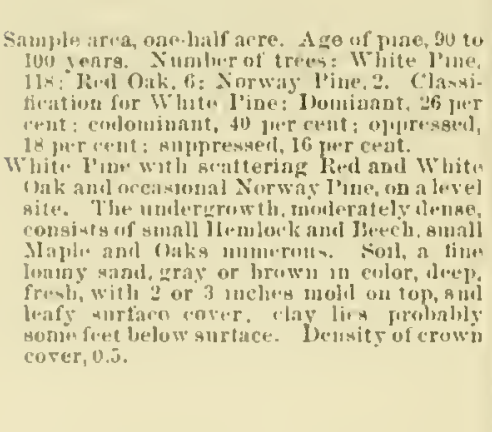 & $\begin{array}{r}2 \\
8 \\
8 \\
1 \\
6 \\
4 \\
4 \\
8 \\
8 \\
8 \\
8 \\
10 \\
18 \\
2 \\
4 \\
0 \\
6 \\
2 \\
2 \\
4\end{array}$ & $\begin{array}{c}I_{0} \\
11 \\
11 \\
12 \\
12 \\
13 \\
11 \\
14 \\
15 \\
16 \\
17 \\
18 \\
19 \\
20 \\
21 \\
202 \\
203 \\
24 \\
24 \\
25 \\
20\end{array}$ & $\begin{array}{r}\text { Fret } \\
75 \\
75 \\
75 \\
85 \\
85 \\
85 \\
75 \\
85 \\
85 \\
85 \\
85 \\
85 \\
8.5 \\
85 \\
85 \\
85 \\
85 \\
95 \\
95 \\
9.5\end{array}$ & 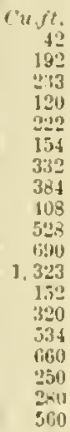 \\
\hline & 118 & & & $\overline{7,381}$ \\
\hline
\end{tabular}

Arerage annunl accetion: "White Piac it cubic fect.

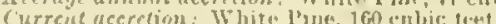

\section{MANU.}

SเTE b: Jork Iounty.

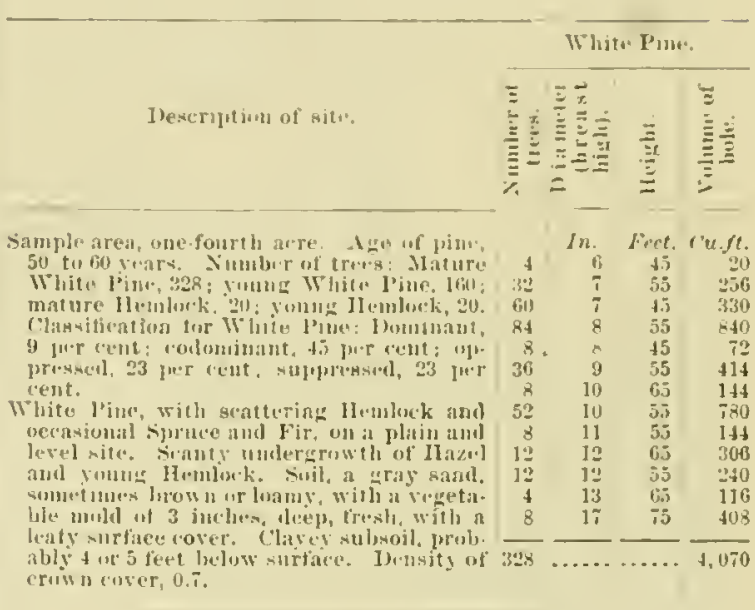

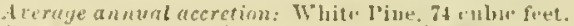

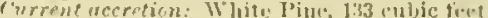

\section{MAISE.}

SITE C: Fork lounty.

\begin{tabular}{|c|c|c|c|c|}
\hline \multirow[b]{2}{*}{ Descrifutim of sit. } & \multicolumn{4}{|c|}{ Whitu I’ia*. } \\
\hline & $\begin{array}{l}\vdots \\
\vdots \\
\vdots \\
\vdots \\
\vdots \\
\vdots\end{array}$ & 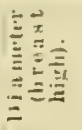 & 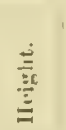 & $\begin{array}{l}\bar{y} \\
\vdots \\
\vdots \\
\vdots\end{array}$ \\
\hline 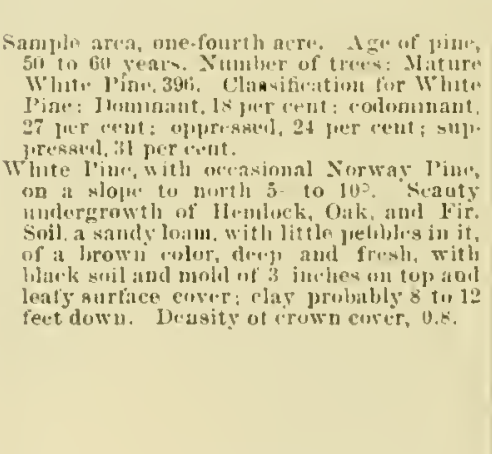 & $\begin{array}{c}4 \\
48 \\
20 \\
311 \\
46 \\
24 \\
36 \\
32 \\
8 \\
41 \\
4 \\
11 \\
24 \\
8 \\
16 \\
4 \\
12 \\
8 \\
4 \\
4\end{array}$ & $\begin{array}{c}\ln \\
1 \\
6 \\
5 \\
7 \\
8 \\
5 \\
9 \\
11 \\
10 \\
11 \\
11 \\
12 \\
12 \\
13 \\
13 \\
14 \\
14 \\
15 \\
16 \\
17\end{array}$ & $\begin{array}{r}\text { Feet. } \\
65 \\
55 \\
65 \\
55 \\
65 \\
55 \\
65 \\
65 \\
75 \\
65 \\
75 \\
65 \\
75 \\
65 \\
75 \\
65 \\
75 \\
65 \\
75 \\
75\end{array}$ & 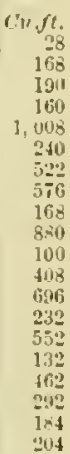 \\
\hline & 396 & & & \\
\hline
\end{tabular}

Average anmual afcretion: Whito I'ioe, 131 cubie feet. 
LITIIT REQUUREMENTS.

The capacity of the White Pine to keep its place in mixture with the latdroods is probably mainly due to its shidle enclurance. In this respect it excek all pines witl which we are acquainterl. Pines are, as a mle, rather light-needing species, and are nsmally at a disarlvantage in the mixerl forest, muless compensating inthences ane in their favor. The White l'ine is an exeeption. As a conserpence, it is capable of forming dense thickets, supporting a langer number of trees per acre and pronncing a larger amount of material than the vore light-neerling species. Also, as a consequence ot its shate enlurance, it does not clean itself of its branches as realily as other pines; not only do the lower branehes remain green for a lougteriod in spite of the shate of the superior tiers of foliage, but they persist after they are dear for many years.

As this shate endurance is, lowever, only relative, and as many of the assoeiates possess it in greater degree, the additional advantage of rapid height growth alone saves the pine from being after all suppressed by its shatier companions. Tet, these sueceed in keeping the young progeny of the pine subdued, and hence the observation that in the dense virgin forest of hardwoorls the reproduction of Thite l'ine is scanty.

The diffienlty of eleaning itself of dead branches seems to be overeome by association with sharlier companions, for, as a rule, the best quality, eleaner boles, and absence of black knots, which denotes earier eleaning, are found iu such association. Yet, in these mixtures the trees are apt to be shorter bodied, since the hardwood eompanions are shorter bodied and the stimulus to height growth ceases sooner. In the pinery proper the stimulus to height growth exerted by the neighbor's continnes longer; hence, longel shafts are found here, other conditions being the same, although the boles are less relen aml less free of knots.

Its shade endurance is decidedly less than that of the Sprnce, which maintains itself, but not thriving unler the dense shate of Naple, Bireh, and Beech, where White Pine seedlings and saplings are not to be found, although they sustain perfeetly the shade of oaks. To be sure, this shade enduranee is to some extent dependent on moisture conditions of soil, being less on the drier than on the fresher soils.

This relatively high shade endurance permits ready natural reproduction of the pine, espeeially where the hardroods have been thinned out to some extent, or where, after elearing, all speeies start their race tor reocenpation of the soil with equal elance. The piue then appears in the young lardwood growth in single indiviluals at first, somewhat behind in height, but funally, when it enters upon the period of rapid height growth, it outgrows its eompetitors and is assured of its place.

More freinently does the reprohnetion tako place in groups, smaller or larger, the many areas of "second growth" of several arres in extent, which are found thronghout the hardwood coplpice of Massachnsetts, showing that tendency tomard gregarionsuess so characteristic of the conifers. A further discussion of the conditions of rejodnetion and the yiehl oceurs in the portion devoted to the discussion of forest management and of forest yield.

lu these natural reprodnctions the trees grow close together, that is, close for unaided naturul reprodnetion, as is apparent from the following table of acre yiehls of young growtl taken at various places in New England:

TAIsI: VII.-Acre yield of young pine grotes.

\begin{tabular}{|c|c|c|c|c|c|c|c|c|c|}
\hline \multirow[b]{2}{*}{ State. } & \multirow[b]{2}{*}{ Soil. } & \multicolumn{6}{|c|}{ "Thite Pine. } & \multicolumn{2}{|c|}{ Spectes intermixul. } \\
\hline & & Aye. & Number. & $\begin{array}{c}\text { Dianiter } \\
\text { (breast } \\
\text { Ligh). }\end{array}$ & Leugth & of $\log$. & $\begin{array}{l}\text { Volnme } \\
\text { oi logs. }\end{array}$ & Sumber. & lawe and remarks. \\
\hline Massachuset ts.... & $\begin{array}{l}\text { Fresl, well-drained lonu } \\
\text { and нandy loam. }\end{array}$ & bears. & $\begin{array}{r}128 \\
284 \\
75 \\
1\end{array}$ & $\begin{array}{r}\text { Inches. } \\
14 \text { to } 15 \\
10 \text { to } 14 \\
6 \text { to } 10 \\
3 \text { to } 6 \\
\\
\end{array}$ & 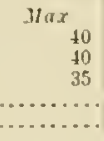 & $\begin{array}{r}\text { Min. } \\
35 \\
20 \\
20 \\
\text {. }\end{array}$ & $\begin{array}{c}\text { ('u. jet. } \\
54 \\
1,611.2 \\
3+8.4 \\
\ldots . . .6 . . .\end{array}$ & $\begin{array}{r}147 \\
52 \\
21 \\
8 \\
2\end{array}$ & $\begin{array}{l}\text { Oak. } \\
\text { Chestnut. } \\
\text { Maple. } \\
\text { All other. }\end{array}$ \\
\hline Total. & . & .......... & 490 & n......... & .......... & n...... & 2.014 .1 & 228 & All small. \\
\hline Ner 11 ampslire ... & $\begin{array}{l}\text { Iry, wull-drainul sauly } \\
\text { Joam. }\end{array}$ & 35 & $\begin{array}{r}3 \\
13 \\
79 \\
231 \\
381 \\
5\end{array}$ & $\begin{array}{ccc}18 & 60 & 24 \\
14 & 20 & 18 \\
10 & 10 & 14 \\
6 & 10 & 10 \\
3 & 10 & 6 \\
& & 3\end{array}$ & 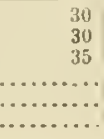 & $\begin{array}{r}18 \\
22 \\
15 \\
\cdots \cdots\end{array}$ & $\begin{array}{r}175.9 \\
372.4 \\
1,007 \\
\ldots \ldots \ldots\end{array}$ & $\begin{array}{r}13 \\
10 \\
9 \\
6 \\
\ldots . . \\
\ldots\end{array}$ & $\begin{array}{l}\text { Maple. } \\
\text { Gray Dirch. } \\
\text { l'itch l'iue. } \\
\text { Mll wtler. }\end{array}$ \\
\hline Total... & . & $\ldots \ldots \ldots$ & 512 & .... & $\ldots \ldots \ldots$ & $\ldots \ldots$ & $1,358.3$ & 38 & \\
\hline
\end{tabular}


T.ubL: YII.-Acre yield of youn! pine groves-Continuen.

\begin{tabular}{|c|c|c|c|c|c|c|c|c|c|}
\hline \multirow[b]{2}{*}{ strate. } & \multirow[b]{2}{*}{ sioil. } & \multicolumn{6}{|c|}{ Whitı" J'iแ.. } & \multicolumn{2}{|c|}{ Sinclen intormixml. } \\
\hline & & Agese. & Nombler. & 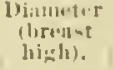 & 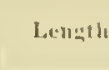 & of long. & $\begin{array}{l}\text { Tolunse } \\
\text { of loggs. }\end{array}$ & Nunbr. & 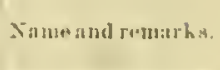 \\
\hline Massiallust 118 . & 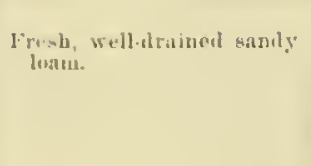 & $\underset{10}{\text { Viars. }}$ & $\begin{array}{r}14 \\
1341 \\
176 \\
: \because 2 \\
3 \\
\cdots\end{array}$ & 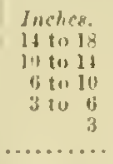 & 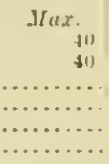 & 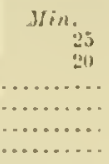 & 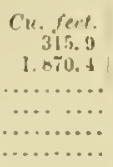 & $\begin{array}{c}133 \\
104 \\
19 \\
15 \\
11 \\
15\end{array}$ & 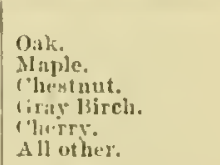 \\
\hline Tutal ...... & & . & 360 & ......... & -... & $\cdots$ & $2,184.3$ & $34 i$ & $\begin{array}{l}\text { Alllest than 3-1nch } \\
\text { dianeter. }\end{array}$ \\
\hline Sew Ilumbulire... & $\begin{array}{l}\text { lirs: wellellraiment loamy } \\
\text { sand. }\end{array}$ & 411 & $\begin{array}{r}40 \\
65 \\
184 \\
615 \\
1511\end{array}$ & 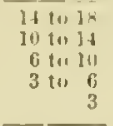 & $\begin{array}{r}33 \\
31 \\
\cdots \cdots \cdots \\
\cdots \cdots \cdots \\
\end{array}$ & $\begin{aligned} & 15 \\
& 15 \\
& \cdots \cdots \cdots \cdots \\
& \cdots \cdots \cdots \\
&\end{aligned}$ & 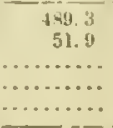 & $\begin{array}{r}r \\
2 i \\
2 i \\
1 \\
\ldots\end{array} \mid$ & 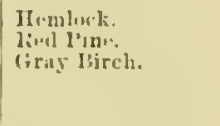 \\
\hline Trital ...... & $\ldots \ldots$ & $\ldots \ldots \ldots$ & 1. Infil & n........ & $\ldots \ldots \ldots$ & $\ldots \ldots \ldots$ & 511.2 & it & siuall. \\
\hline Mlass:iclutuset tw..... & $\begin{array}{l}\text { rowh, welldraindil saydy } \\
\text { Jonatu. }\end{array}$ & dis & $\begin{array}{r}11 \\
158 \\
277 \\
18 \\
\end{array}$ & $\begin{array}{rrr}1+t i n & 18 \\
10 & t i 1 & 14 \\
6 & t 0 & 10 \\
3 & 60 & 6 \\
\end{array}$ & $\begin{array}{r}40 \\
411 \\
\ldots \ldots \\
\cdots \\
\end{array}$ & $\begin{array}{l}30 \\
15 \\
\cdots \\
\cdots \\
\end{array}$ & 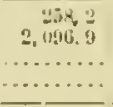 & $\cdots$ & SNOnי. \\
\hline Total........ & $\cdots$ & .......... & $46 \downarrow$ & $\ldots \ldots \ldots$ & .......... & ........... & 2.355 .1 & n......... & \\
\hline Massachusetts.... & $\begin{array}{l}\text { losy, woll-elruined loang } \\
\text { sind. }\end{array}$ & 5011155 & $\begin{array}{r}1 \\
48 \\
1: 35 \\
147 \\
15\end{array}$ & $\begin{array}{lll}18 & t 0 & 21 \\
34 & t 0 & 18 \\
10 & 611 & 14 \\
6 & 10 & 10 \\
3 & 10 & 0 \\
\end{array}$ & $\begin{array}{l}35 \\
410 \\
40 \\
30 \\
3\end{array}$ & $\begin{array}{l}20 \\
15 \\
18\end{array}$ & $\begin{array}{r}1112 \\
6112 \\
\text { J. } 311.5 \\
152.2\end{array}$ & \begin{tabular}{c}
\multicolumn{1}{c}{19} \\
$\cdots \ldots \cdots$ \\
$\cdots \cdots \cdots$ \\
$\cdots \cdots \cdots$ \\
$\cdots \cdots \cdots$
\end{tabular} & 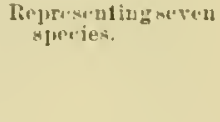 \\
\hline Total & . & & $3: 37$ & $\ldots \ldots \ldots$ & $\ldots \ldots$ & $\ldots$ & 2.467 .7 & $1 ! 1$ & \\
\hline
\end{tabular}

It wonld be possible to increase the umber of trees that conld grow per arre and develop satisfactorily by attention of the forester, as will appear fiom the statements regarding the White Pine forest plantations in Germany, where pme White Pine growths showed at sisty right years still over six lumdred and seventy trees, and in another place at eighty-two yeurs seven hunded and twenty-three trees, and at one hundred and four years over two humbed and fifty trees jer acre. Even in such close stand the crown of living branches remains long. ocenpying one-thind of the bole, and dry branches persist down to orer half the length. The stems are straight and cylindrical, in this respect also reminding one of the Norway Spruce, althongh the tendency to fork seems morc frequently developed.

\section{YIELI) OF WIITE PISE.}

The rnestion as to the amonnt of material which the White Pine is capable of producing yer acce is diflicult to answer. It "an not. of comse, be ledured from a knowlerlge of the developmont of the inclividual tree, since there remains one finctor mulnown, namely, the mumber of trees of ' ditherent classes that ean oceny an acre. Sor ean the capacity of production, as a rule. be ascertainer from the actual produrtion or are yield of natural virgin glowths, for these usually not only do nut occur in jure growtls. but also are usually not developed under most arivantageons conditions, and do mot, therefine, represent the jossible or normal yield which conld he secured. Only by selecting smaller, seemingly normally and fivorably developed groups in the forest at diflerent ages and in varous localities and measuring the sane nay we arrive at an anploximation of what the species is caplable of producing hy itself?.

Such measurements have not bern attempted, but the vieln of virgin aeres mulcre varying conditions has been ascertained to gire at least a forceast of the possibilities, althougl mot repre. senting the nomal or pussible yield of fnlly stocked aeres of White Pine. In ardition wre may utilize the results rexorded fom Germany (page 6!) of a mumber of jantations, which have liad the al vantige of at least the parlial rare of forest management.

From these indications, we are justified in the assertinn that the White P'ine problnees per acre as well as any speries with which we are acopuanterl in um northeastern woouls, and at a date which is not excellen by any of the lumber trees within its lange.

In this respect, again, it apmoaches the German. Sumce thongh it mobally exeds this species in persistency, as it thes in the limensions which it ean produce. We "an. therefore, lor the first 
hundred years at least, approximate the capacity of our White l'ine by reference to experience tables of the ferman sprnee.

As with all conifers, the rate of production at first is very slow not more than fo to io eubie feet in the average per year for the first twenty years. With the bet ter derelopment of erowns and the assertion of individual superiority in the strugglo of neighbors, which leats to the estab. lishment of deminant elasses, the production increases mapidy, and ly the fiftiet hear, in fully stocker areas, the average rate of 140 to 160 cubie feet per arre may be attained, so that at that age we may, with five hmuled to six hundred trees to the arere, find $\tau, 000$ to 8,000 cubie feet of wood stored up in the boles of the trees. The eurent anmal aeretion, then, may readily be at the rate of 160 to 150 cubie feet, keeping the a verage annal accretion of linlly stocked acres very nearly to those figmes, so that at one hundred years we should find, muler favorable conditions,

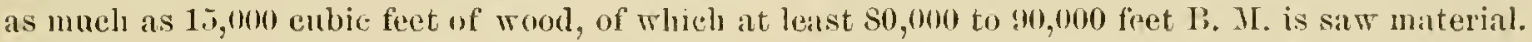

The persistency of growth seems to continue beyomd that age, and the indieations are that the decrease of the eurrent as well as average accretion per acre during the next century takes place so sradually that at one hundred and fifty years it may still he over 100 cubie feet, and not much below at two hundred years, when the buden of the acre may be near 20.000 culbie feet, with over 120,000 feet B. II., and donble the amonnt in the oldest growths of two humbled and fifty or more years, which may possibly be the limit of prodnction.

While these figmes, which differ very materially from those proposed in the tables by Messrs. Pinchot and Graves, may stand for the better soils, as ideally possible, practically, perliaps, rarely attainable, especially in older stands, poorer' soil sites will rary from them by from 20 to 40 per cent, so that a yield of 9,000 culic feet at a lundred years, or 50,000 feet of lumber, would still be quite reasonable to expect on the poorest soils on which White Pine ean he satisfactorily grown. On the sandy soils of Wisconsin whole forties are found to average jo,1000 feet prer acre of naturally grown mattemled forests of one humdred and fifty years of age.

Table VIII summarizes the measurements of sample areas, which are given in detail in the Appendix. It will serve to show what on native woods, withont attention, storked with partly useless trees and in open stand, exhibiting much wastage in nocenpied gromd, are capable of producing.

If we assume that the areas might have been stockel with pine alone, that they would have frodnced at only the same rate as they have under their present conditions, even thongh the acres had been folly stocked and not in the fractional manner which is indieated by the decimal giving density of cover (all assumptions), and if in connection with the density factor we consider the number of all trees per acre and the percentage which the pine represents, we may, as a mere matter of juclument not fit for tabulation, arrive at an indieation as to what the acre might possibly have prodnced. Such indieation of possibility has been attempted in the last column of the table, and has served in the alove disenssion in comection with all other data presented. This is all that can be done in the absence of the measmements above inclieated. These fignres are of no direct practical application exeept to give a general notion of the productivity of White Pine and the variability of yiclds.

An inspection of the table of yield in Germany, on page 69, will show that these approxi. mations are not mureasonable. The lumber contents in board feet may be aproximated by multiplying these fignres by 4 or 5 in the younger growths and loy 6 or 7 in the oliler. Assuming a moderately eareful practice of logger and sawger, by no means mathematieally tenable, the above tentative propositions for normal yields might be even inereased.

To assume, as is done by eertain anthorities, that tables of nomal yield coulil be constrncten by using the density indicuted by a decimal as a mathematical factor, using that factor as a divisor of the actnally measured yield in order to arrive at the nomal, is to mistake the value of the density factor. Not only would trees and whole acres have developed rery diflerently when grown under difierent density conditions during their life, but the estimate of the density is such a vague and uncertain one, a mere opinion, that even if the greatest care were exercised, its use as a mathematieal factor would not be admissible. It is a mere indieation of the present ennlition of the growth, and its meaning at diflerent periods of life is very different in its physiological eflects as expressed in volume accretion. 


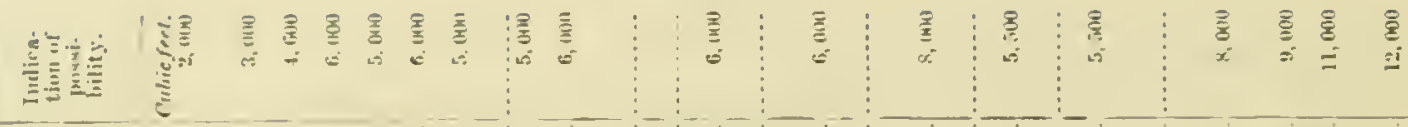

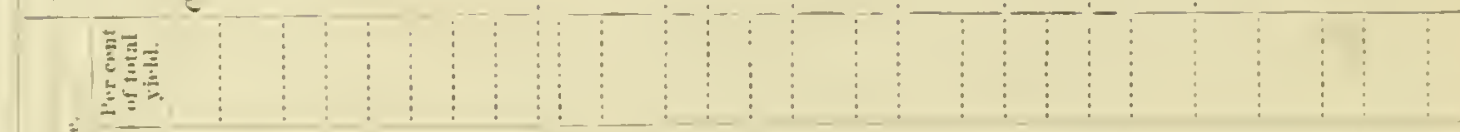

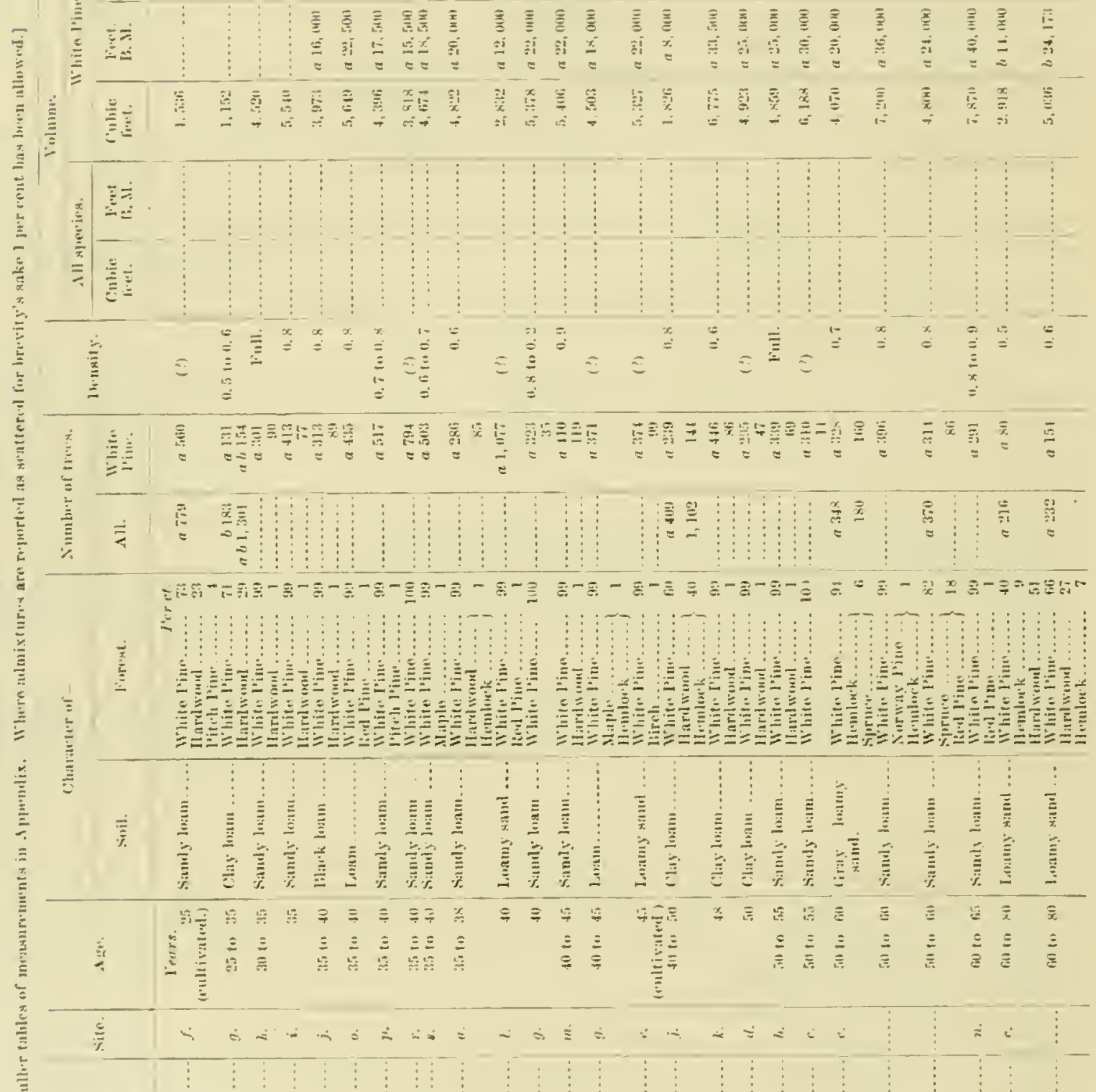




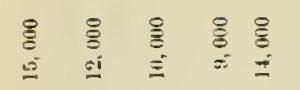

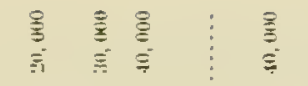

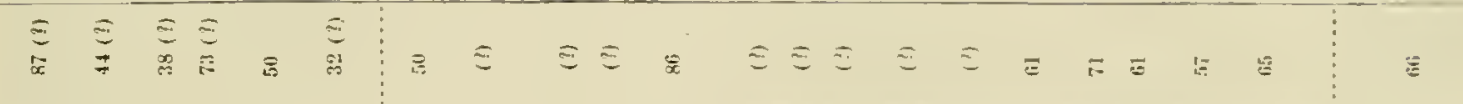

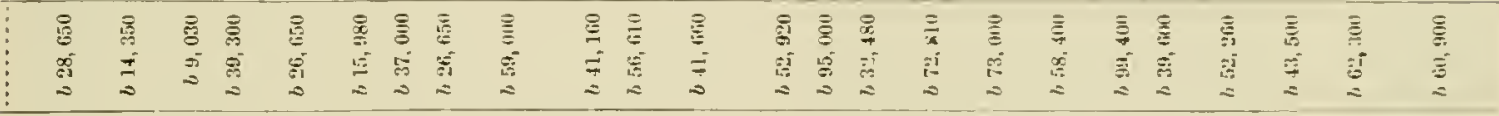

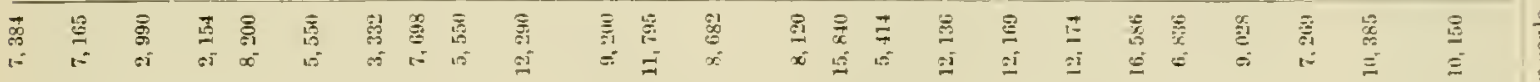

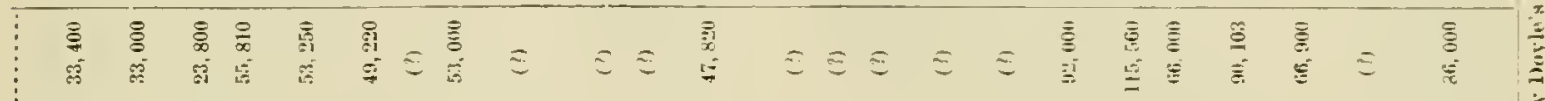

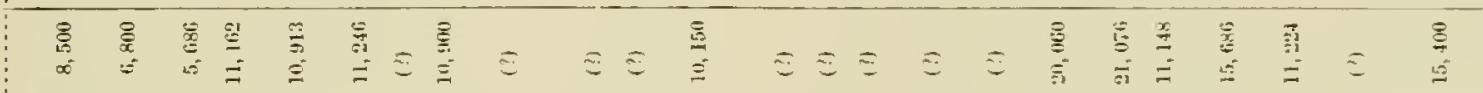

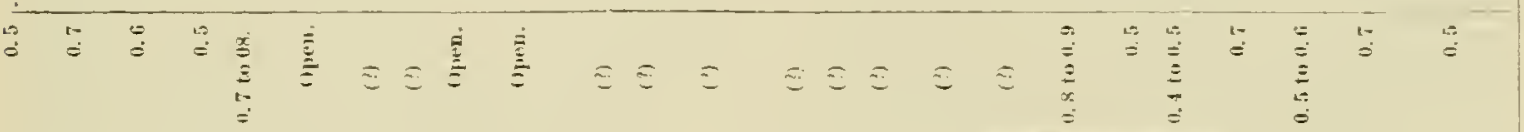

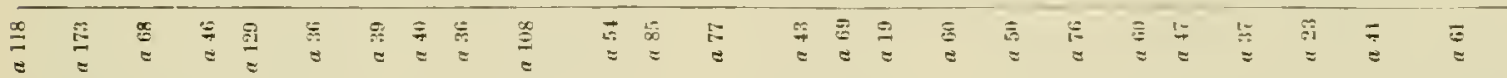

害

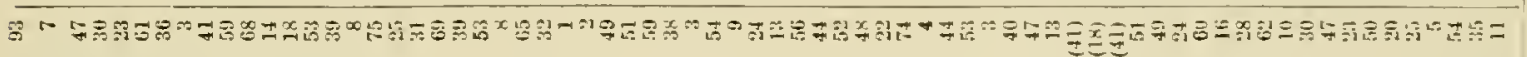
a

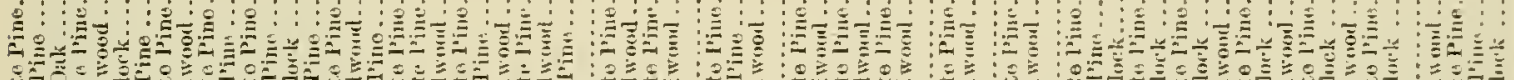

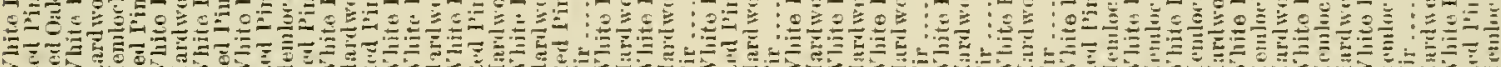

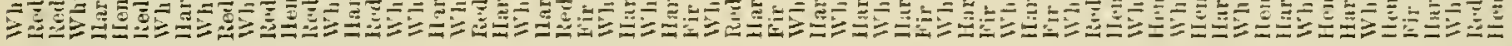

\begin{tabular}{|c|c|c|c|c|c|c|c|c|c|c|c|c|c|c|c|c|c|c|c|c|c|c|c|}
\hline $\bar{\Xi}$ & 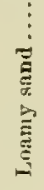 & 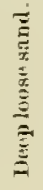 & 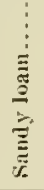 & 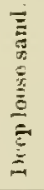 & 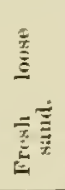 & 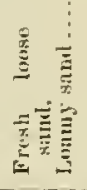 & 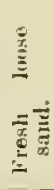 & 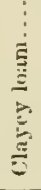 & 焉 & 吾 & 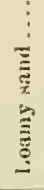 & $\begin{array}{l}\vdots \\
\vdots \\
\bar{z} \\
\bar{z}\end{array}$ & 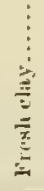 & 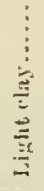 & 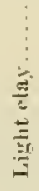 & 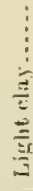 & 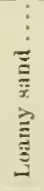 & 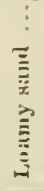 & 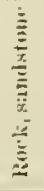 & E & 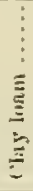 & $\begin{array}{l}\bar{E} \\
\bar{z}\end{array}$ & 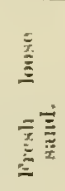 \\
\hline & $\frac{\stackrel{9}{3}}{5}$ & $\begin{array}{l}\frac{5}{5} \\
5 \\
8\end{array}$ & 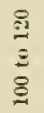 & 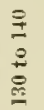 & 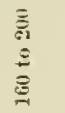 & 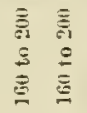 & 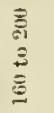 & $\stackrel{5}{5}$ & 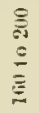 & 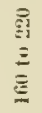 & 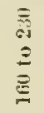 & 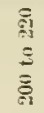 & 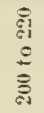 & 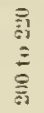 & 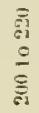 & 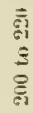 & 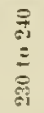 & 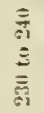 & 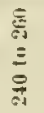 & 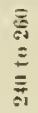 & & 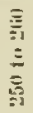 & 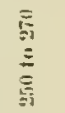 \\
\hline
\end{tabular}

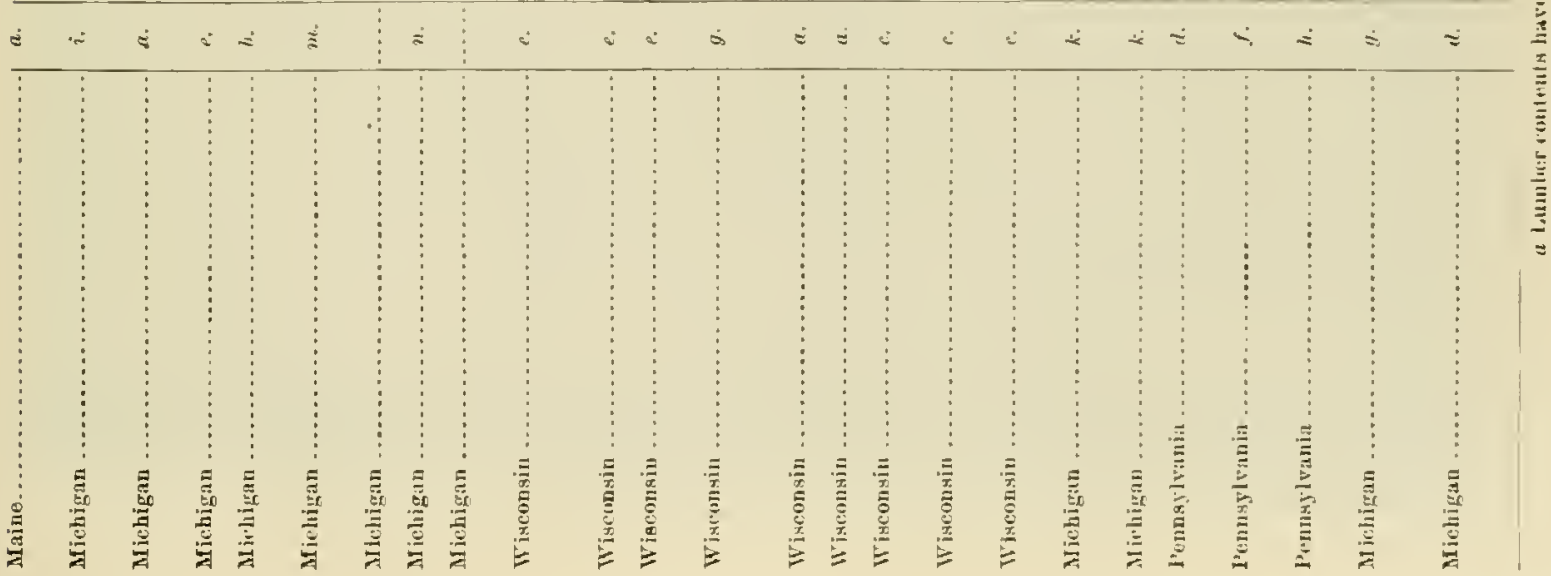


It mal be of interest to reend more especially the data of a small clump of young White

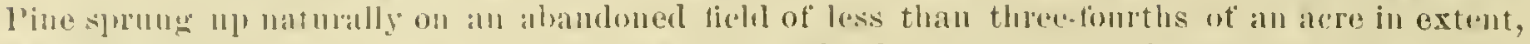
situited near Farmingem, $X$. H., which its owner (Mr. J. D. Iyman, of Exeter) had from time to time thinned out tir the last twenty two years, with a view ut accelerating the grow th of the

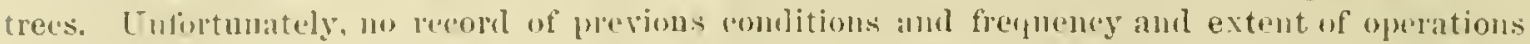
was attainable, bnt the present condition (three or four years ago) is exhibited in the finlowing table:

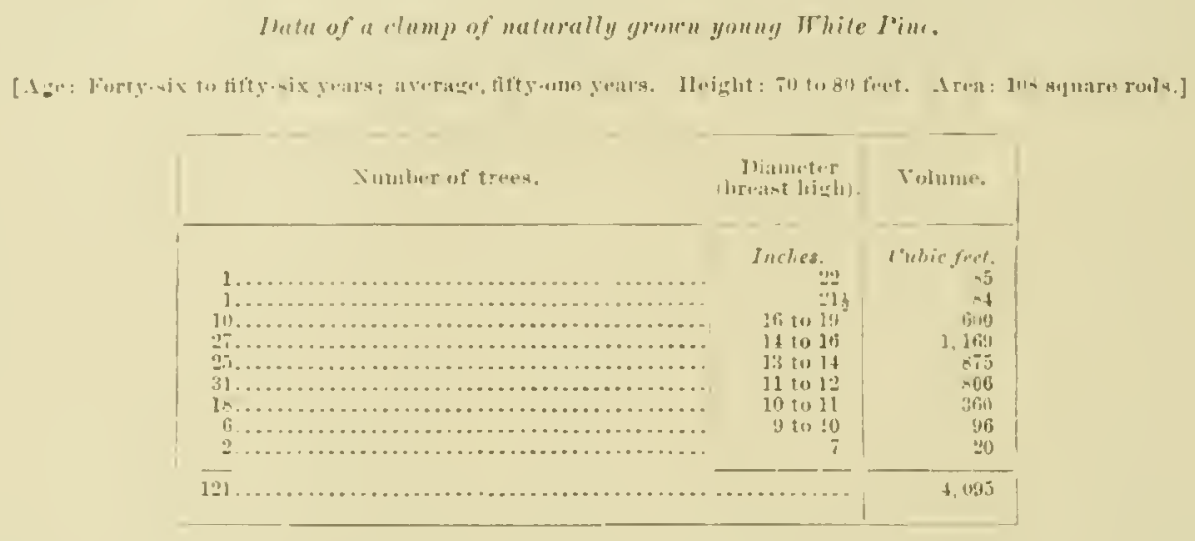

This wonld indieate a yield per ace of abont 6,000 cnbic feet, from whelh, with the dimensions attained unler eareful mill prantiee, some $36,0 m$ foet of lumber might be ent. To be sure, witl such open staul much of this must be lonotty, evell thongh the treps were prumed as far as posible.

liy comprison with the measurements of natmally gromu mothinned acres, we fund that tro to three times the number of trees of the age indicated in the above table might stand on an acre amcl make as mucl] total proluct (see Massachusetts, site $c$, which, with $32+$ trees, produced 6,158 cubic feet); and although a few trees in the thinned grove had reached larger dimensions, the tutal prodnct of trees over 12 inches in dianter is almust the same, the difterence in fivor of the thinned part being ouly 100 cubie teet. From this eomparison it would apjear that the thimning was tno severe to secure the most desirable results. Pl. X shows the conclition of the grove when the measurements were taken.

Allowance, however, should be maje for the anount utilized in thinnings. Whether this inferior material would pay in most "aises the cost of its removil is ruestimable. A veryuncertain estimate by the man who prerformed the thinnings places the amount of woml removerl equal to that now standing, among which is 5,000 shingles.

The following table show's the measurements of one of the largest trees in the grove:

Mectsurements of tree.

[.ge: Fifty-xis yearm. Ileight : Nu frot.]

\begin{tabular}{|c|c|c|}
\hline Ifaidhe ot seclion, in feet. & $\begin{array}{l}\text { Diameter, in } \\
\text { inclies. }\end{array}$ & 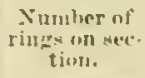 \\
\hline 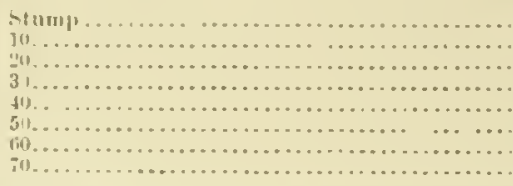 & $\begin{array}{l}103 \\
11 \\
12 \\
123 \\
103 \\
51 \\
51 \\
3\end{array}$ & $\begin{array}{r}56 \\
4 f_{1} \\
42 \\
37 \\
32 \\
24 \\
15 \\
8\end{array}$ \\
\hline
\end{tabular}

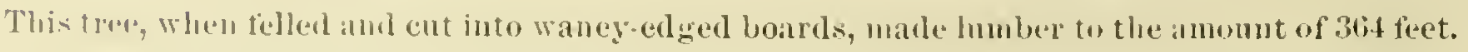




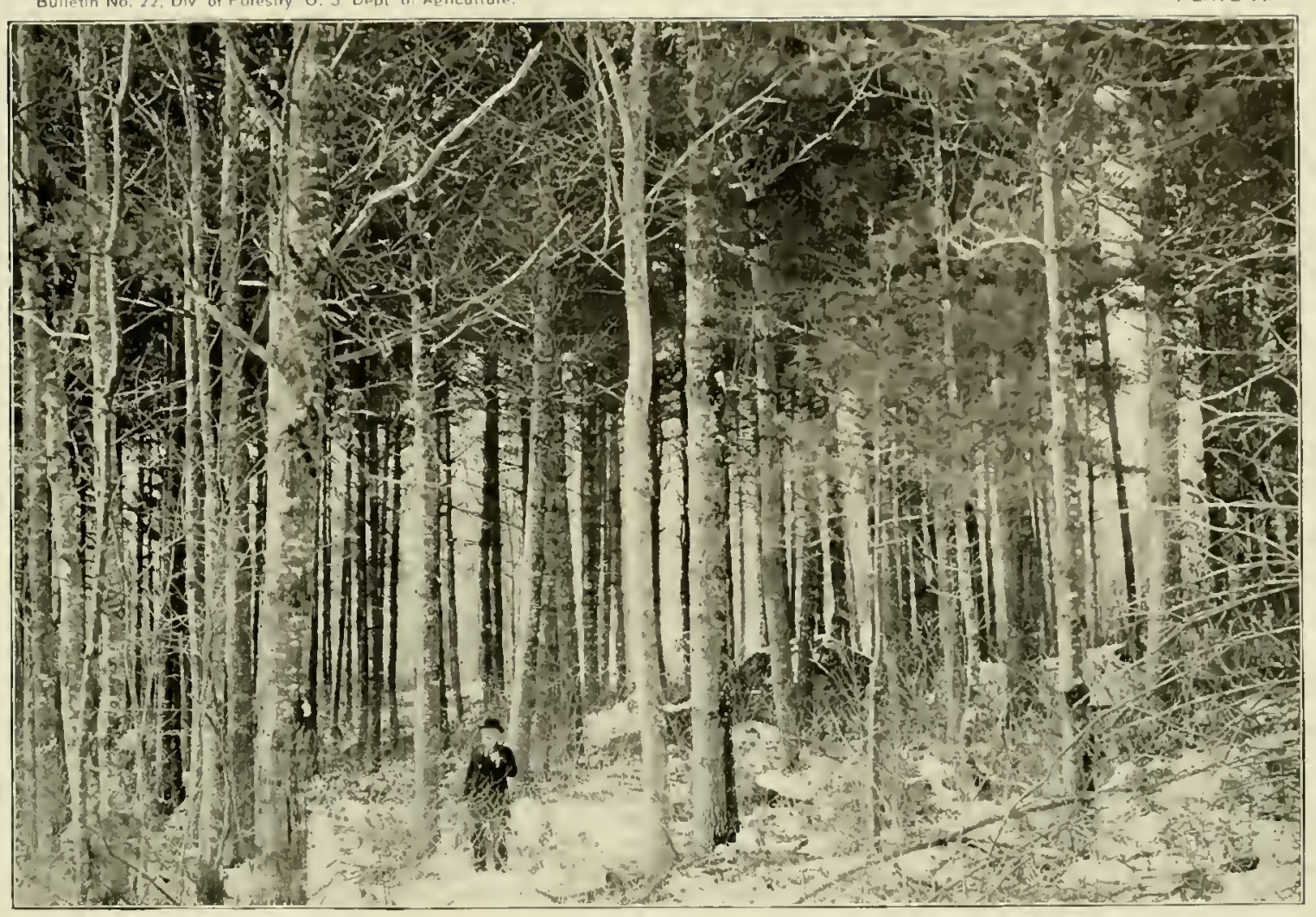

Fig. 1. A thinned Pine grove in New Hampshire (Trees 51 Years Old 186 to the Acre).

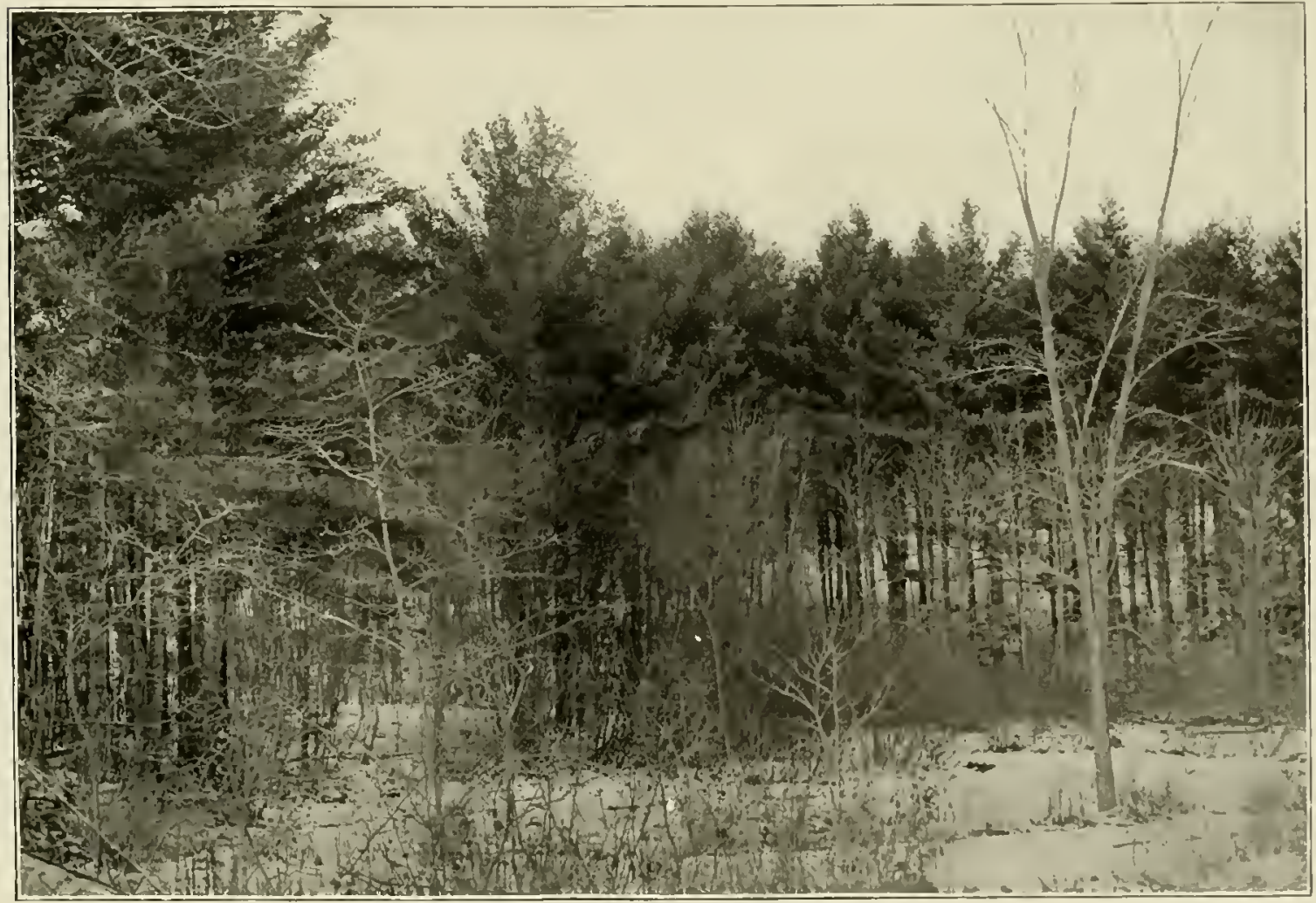

Fig. 2.- Young pine in New hampshire (TREes 20 Years Old). 



\section{DANGERS AND DISEASES.}

The White P'ine is subject to a considerable number of destuctive influrnces even when

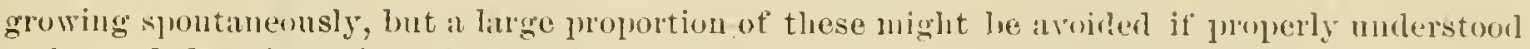
and guarded against, since tley are in great jart dne to luman agency.

\section{INJURIES BY HUMAN AGENCY.}

The subject of forest fires has been so fully discussen that it is nnnecessary lere to treat it in detail, although the pine forests of the Northeru states latre sufferen nure irreprabahle injury. from this than from all other destructive agencies combined. From the munerons sungestions that have been made respecting protertion from fire and from uneecssary injuries in general, the most important appear to be:

(1) That a rell-rligested corle of' laws, capable of jrompt enforcement, biserl npon the recommendation of a nompulitical torest commission, is of primary importance

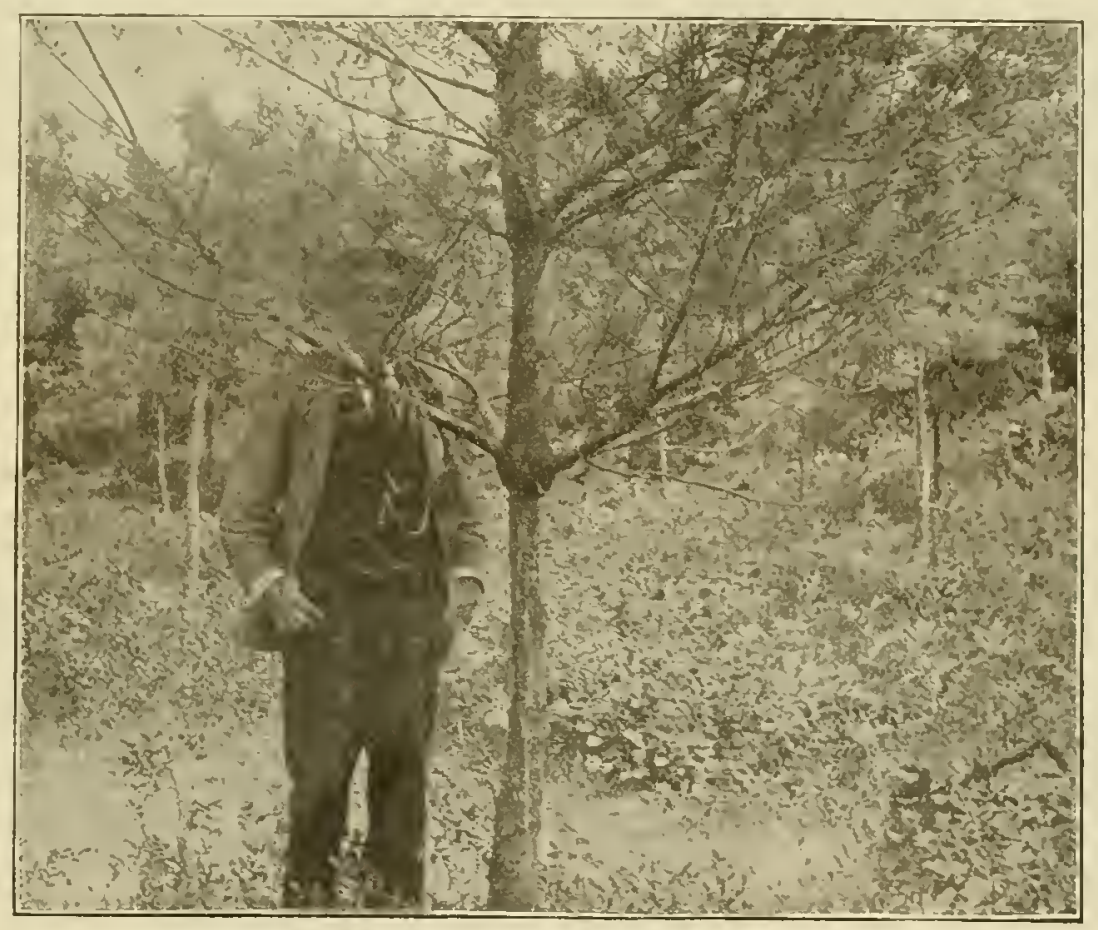

FlG. 4.-Girdled White Pine continuing to grow.

(:) That a correct publie sentiment, encouraged ly a wider dissemination of information concerning the value of forest products and the time rednired for their growth, will lave more inthence than all other means together in preventing unnecessiry destruction.

Unlike the Lohlolly P'ine of the Sonthern States, or the Jied l'ine with which it is eommonly associated, White Pine lais a thin bark during the first thirty to fifty years. which antoris but slight protection from tire. Conseruently, the species suffers much in young growths from surfice fires, whinh do little or $n 0$ harm to the thick-barked pines and liardwoods. Jn the mature trees the growing layer is mnch better protected, as the bark with age becomes proportionately thicker than that of Red Pine.

Related to the foregoing. and properly placed under the hear of injuries to be charged to lmman responsibility, are wombls oceasioned by eattle. A pine forest is less liable to injury trom the browsing of eattle than one composed of decidnons trees. and in the Eastern states old pastures commonly grow mp to pince the deciclnons slecies being kept rown by the cattle. But in $20239-\mathrm{No} .20-4$ 
any "asp, when the growth of timber is the primary olyject, lomestic animals shonla be rigorously

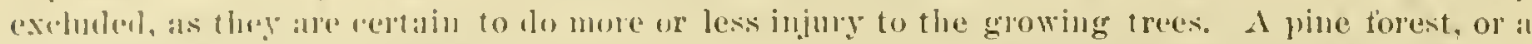
forest of any lind, is mo more properly" " "lun" for eattle than a field of standing grain, and the domage is likely to be more extensive and less capable of repair in the former than in the hatter case.

The Whito line shows amsirlerable renduerative power, whieh is exhibited in the ready renstablishment of hroken lealer and the healing of wounds. in whelh the prolife resin exulations assist ly kecping ont water and fungi.

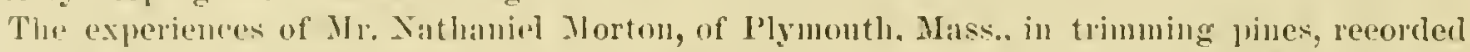
in the forester (Inue, 18 !s), show the alsolute safety of pruning live limbs of 3 to 5 inehes and more in diameter, which nre (orred in a few years by new growth (Pl. Xi). An interesting case of pertinaleity of life and reculerative power, which at the same time throws light on the much. debated yuestion of fool and water morement in trees, is also reportul from the same sonre, and represented in lig. 4.

A yomng pine in the furest was, two years ago, not only girlled, but the harli peeded off for 11 imbles all around the tree. The tree hats a perfectly healthy appearance, and has continued to grom in length, althugh apparently abont half as fist as before. The measurements of internodes of this tren during the last six years follow. The diameter gronth above the wonnd has continued. while below the wound it has remained stationary, as will alpear from the measurements made two years alter the removal of the barli.

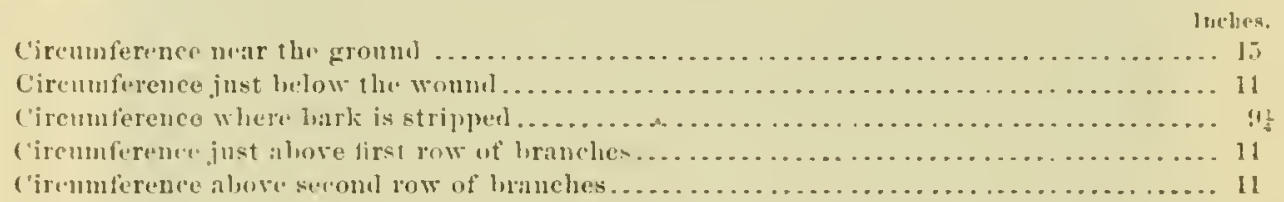

The wouml is entirely covered by piteh. The growth just above the womel has a haggy appenance, showing an acemulation of wool deposit, which shows the arrest of the food materials due to the absence of the eambium layer and bark.

It wonld appear that the routs condel either live without the food sulply from above (at least for two years), or clse that a sumiejent ammut can pass throngle the deatl wood of the trunk, and at least the water neessary for the elaboration of fool materials in the foliage can be supplied throngh the old worl. The writer inspected this tree, and "an ronch for the truthfulness of the descriptim. A similar conse with a sunthern pine (species undetermined) came to his attention. where the tree was older and had grown over twenty years above the wound: but as ouly a cut was insprecterl the pussibility of a cambial connection of the mpuer and lower parts was not aluso. lutely excluled. as in the present cisce.

\section{INJURIES BY STORMS}

Of injuries not within human control may be mentioned, first. thuse resulting from storms, snow, and ine. The sutt texture of the womb and the shuthlived branches of the White l'ine wonht naturally suggest its heing more liable to injuy by storms than are deviluous trees. This. howerer, is not the case. The angle which the branches make with the trunk admits of their readily bending, and under sucl a weight it is fomm that Mlaples and otler latrolwood trees break

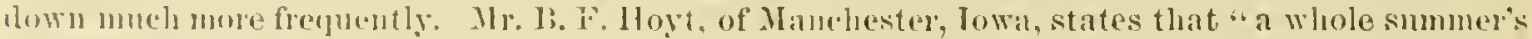
ubervation anong the White l'ines of 'Tennesse tailed to reveal a single calse in which a tree of

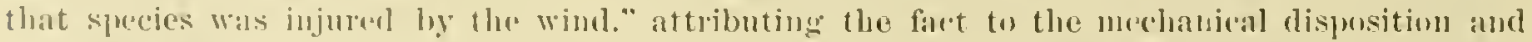
stmotum of the trumk and branches. In this respect, then, the White Pine stands at a decided

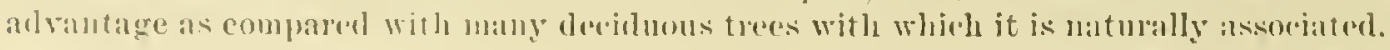

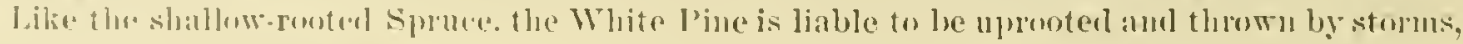
althomgla tor a less degrese.

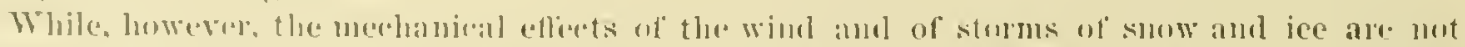

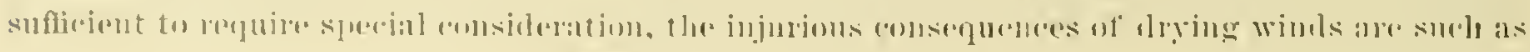


Bulletin No, 22, Div, of Forestry, U. S Dept. of Agriculture

Plate XI.
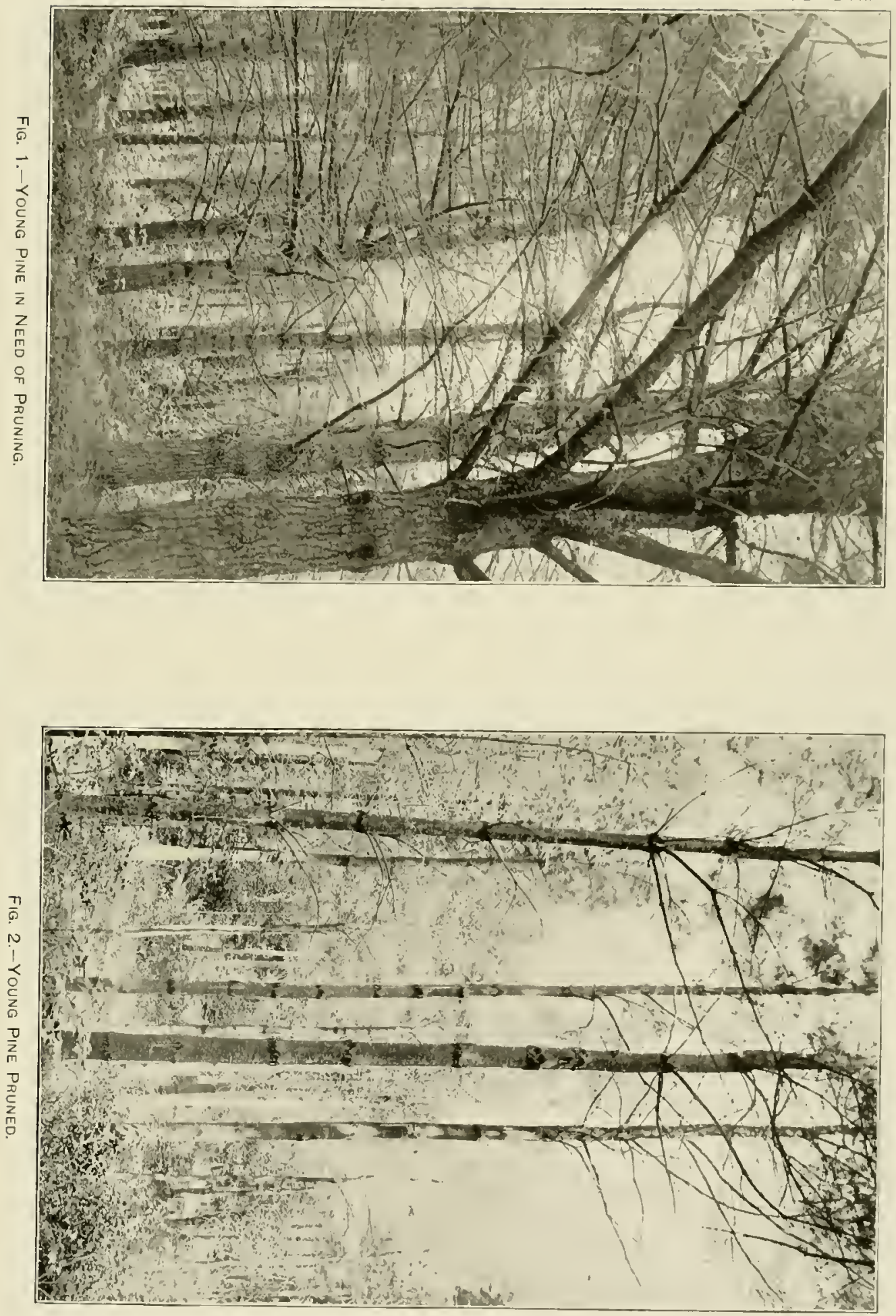

to become an important faetor in letermining the limits of the artificial enltivation of this sprecies. At the time of planting, deciluous trees are not in leaf, and accordingly there is but littlo evap). oration of water, while the leaf surface of conifer's is exposed then as much as ever to the drying elfects of the atmosphere, often resulting in their death before they are fully establisherl in the soil. It is for this reason and because of the general lack of a sufficient amount of atmosplieric mois. ture that comparatively slight suceess lats attended the eultivation of the White pine on the plains west of the Mississippi. The law winds from the Atlantic again have been found to be mnch more injarions to this species than to the Pitch Pine (P'inus riginde), and the latter is there. fore deciderly preferable for flanting in the immediate vicinity of the coast.

\section{DISEASES}

\section{EFFECT OF IIEAT AND DROUGHT.}

In Germany, plantations of White line thirty-fice to forty years old have suffered nuch injury from a discase which apjear's to be occasioned by musnal heat and drought, and which was martienlarly severe after the lot, dry snmmer of $1876 .{ }^{1}$ The disease manifests itself externally by dried-np patches on the trumk, the spots being largest 3 to 6 feet from the ground, gradually ruming out above aud below this, and often reaching a height of 15 to 18 feet. The spots mily be only an inch or two wide, but frequently the bark is dead nearly around the entire trunk. As a rule, these dead spots are on the south and west sides of the tree. The woul is often penetrated by larve of insects, but these are not the cause of the disease, since in many rases they are not jiresent.

Dr. R. Hartig, thom a comprarison of specimens and study of the disease in guestion, concludes that it is due to extreme dryess and thit the White Pine can nut be thusted to emine such extremes. He further states that it suffers greatly from dry air even in the winter time.

\section{PARASITIO DISEASES.}

The White Pine is subject to a number of parasitic diseases, some of which attack it when growing spontaneonsly in the forest, while others are highly lestructive to the tree in enltivation, especially in Emrope unter changed clinitie conditions. A few onlsy of the best known of these, including several due to fungi, will be considered in detail.

(1) Agurieus melleus Vahl.-This fungus, of common oecurrence in the United States as rell as Europe, is excedingly destructive to conferous trues, the White t'ine in particular suffering greatly from its attacks. It also fastens upon varions decidnous species as a parasite, attacking living trees of all ages, but living as well npon dead roots and stumps and on wood that has been eut and worked ml, occurring frequently on britges, railroal ties, and the like, and causing prompt decay wherever it has effected an entrance. The must conspienous part of the fongus is found frequently in the summer and fall on the diseased parts of the tree or timber infested by it. It is one of the common toadstools, this particular species beng recognized by its yellowish color: gills extending downward upon the stem, which is encireled a little lower down by a ring. and by its habit of growing in tults or little clumps of sereral or many individnals together (1'l. XII, 1 and 2$)$. It is also particularly distinguished by the formation of slender, darkecolored strings (Pl. XII, 2 and 3), consisting of compact mycelim, from which the fruiting lants just describen arise. These harl root-like strings (called rhizomorplis) extend along just beneath the surtice of the ground, often for a distinne of several feet, and penetrate the roots of somml trees. By caretully removing the bark from a loot thus invaderl the fungus is seen in the form of a dense.

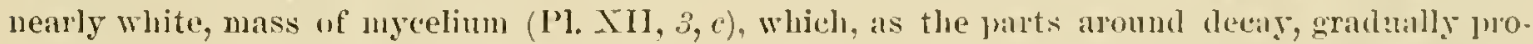
duces again the rhizomonphs already described. These rhizomorphs are a characteristic pant of the fungus. Occurring both in the decayed wood, fiom whinh they spread to the aljacrut farts, and extenling in the soil from root to root, they constitnte a most effective agrang in the extension of the disease.

The symptoms of the disease are marked, and, taken together, sulticiently charactoristic to admit of its ready recognition. Extemal symptoms, to be observed esprecially in young sprecimens

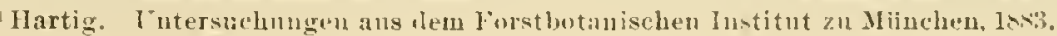




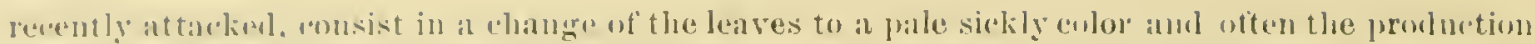
of short stumtel shruts. I still more marked symptom is the formation of great yuantities of

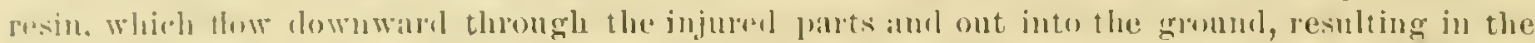

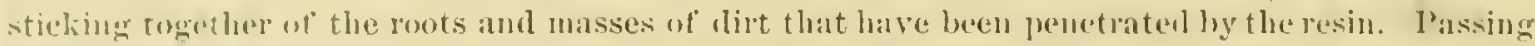
up a litgle may inte the trunk, the eanse of this is sern in the artive working of the fungus in the medullary rays and aromd the resin canals, where appirently loth eell walls and cell eontents melergo dogeneration and partial conversion into resin. This thws downwarl, as alrealy stated, and also ronks latebally into the cambium, producing great blister's in the gommer pitsts where

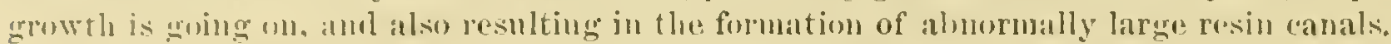

As the disease alvances the fungus continnes to at tarek the trarbeirls of the sombl woor and

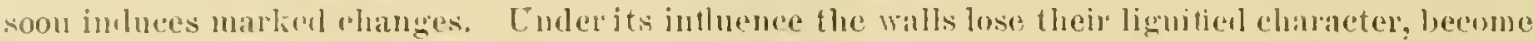
nofter, and grive the cellulwe reaction, while the myerelium of the fungus penetrates and tills the enlirired eavities of the tracheids. (II. XII, f, 5, (i.)

The whole insicle of the trunk may finally become hollow for some distance above the stmmp. its interior being filled with a loose rotting mass, penetrated by rhizonorph strings, and only

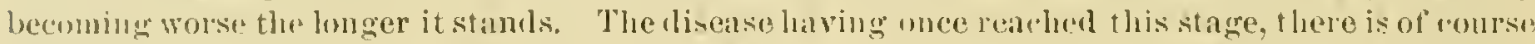
mothing to be fone for the tree but to fell it as soon as possible and salve whatever woul bemains unatiected.

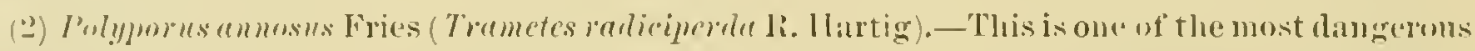
parasites of conterons trees. causing "ped rot" and the dying out of plantations hoth of young and old jines. In fierminy it infests various speeies of pines, including l'imus strolues and l'imus sylvestris: also l'iere rarelsu, Inniperus communis, and others. It is more destructive to the White I'ine than to the sooteh l'ine.

The disease alprears in plantations of varions ages, from five to one hundred years old, show. ing itself loy single plants here and there beenning pale, then yellow, and sublenly dying. These external symptoms are altogether similar to those observed in trees infoetmd ly dyaricus mellens. Other trees are attaclied in the neighborlinod of the inferted ones, and so the disease sprearls (2)itritilgally:

The fruiting portion of the fingus (1']. NII, 1 to 6) grows on the roots near the surtace of the grouml, foming yellowish-white cnshions (white on the spore-bearing surtace) that may tinally, thongla rarely, become a foot or more in dianeter. Jietwen the wool and hark of the

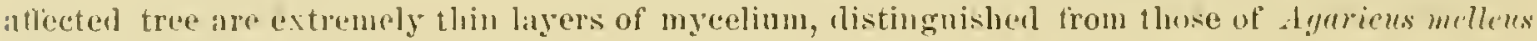
by their softuess and delicacy. The tissue of the roots and the insile of the stem is deenyed to a ennislenalıle height.

The disease is spread by the spores, which are earrien away by mice and other burrowing animals and deposited on the roots of adjacent trees, where they areminate and penetrate the living tissues of the bark. passiug thence into the wool elements and growing in them toward the sten. It is also communimated hy the roots of infected trees erossing those of somml ones in the ground (Pl. Xill, i), the fungus growing divestly from one to the uther.

1 riolet diseoloration of the wood is the external symptom of berinning decomposition. in which the contents of the parendiyma rels die and furm brow throngh the action of the myeclinm. This rolor disapleas's with the loss of the cell contents, and a clear brownish-yellow takes its place, with s'attering black sputs here and thre. These are surmmed at a later periorl with a white zone (1'l. X1I, t), and at the same time the wool beromes continnally lighter and more spongy. At last mumerous openings arise, the root is sepanted into its comstitment fibers, and becomes watery and of a elear lnownish.yellow color. The cell wall mulergoes ilecomposition, giving the

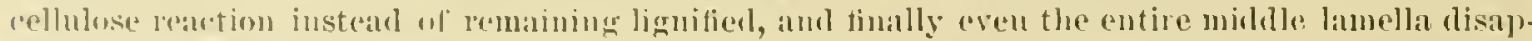

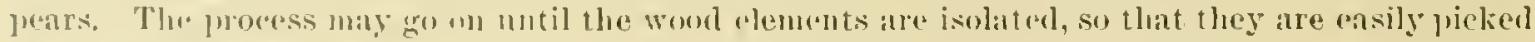
aplart like threals of asluestos.

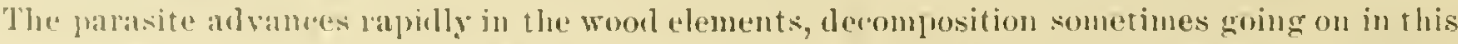
way to the lieiglit of "2.5 feet. In the bark it proceeds more slowly, but is finally none the less

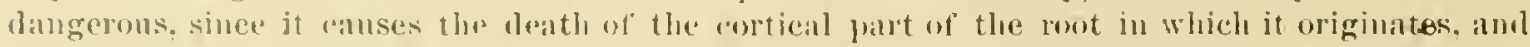
when after reaching the trunk it passus into the other routs, their death tinilly resulting in the death of the whole trees. 
In the Scotch Pine a great amonut of resin is podnecd, and this, acrmulating in the lower part of the stem, probably acts as a barrier to the growth of the mycelinm upwarl. In the White I'ine the fungus extends mnch firther in the trunl.

I'l. XII, r, represents a stmmp of White l'ine that has been attacked ly I'olyjum annosus.

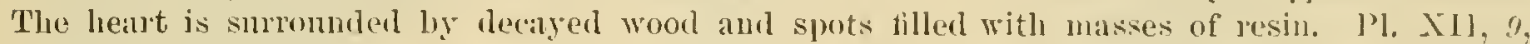
represents jarts of aljacent wonl elements of Norway surnce after they hare been acted ujion ly the fungus: the myedium lyghlir and spores, highly magnilied, are rejuresented in 11 of the same plite.

(3) C'meosporinm senecionis I'er's.-This fungus, under the name of "pine blister," jnfests varions species of pines. growing in the acidinm stage on both leaves and bark, and sometimes proving very destructive. When growing on the leaves it aftects lnt little the vitality ut the tree, but is highly injurious when the bark is the place of attack. It penetrates the bark, apparently throngh wounds occasioned by insects, woodpeckers, or other agencies, and its mycelium spreads through the cortical pareuchyma and hast, aud into the wool to the depth of sereral inches, passing through the medullary rays.

L'nder its influeuce the starch aud other cell contents disaplear and a resinous substance collects in their stead, a mass of dead tissue soon taking the place of the living cells. This change of the cell contents results in a great acenmulation of resin, which often exndes in large quantities from the diseased parts of the tree.

The mycelinm is peremial, extending itself throngh the sten from year to year, particnlarly in a longitndinal direction. Where it is present the growth of the stem is prevented and the formative materials are diverted to the opposite side of the stem, cansing there a greatly stimulated and abuormal gromth. The death of the leader often results, especially in dry summers, for the reason that the wood, thus choked with resin, is unable to sul]) ly it with sufficient water.

The researches of Wolt lead to the conclusion that this parasite of the piue lives in the form knotru as Coleosporinm sencionis on varions species of Senecio, and that it is communicated to pive shoots from them. He proposes the extermination of these hosts as a preventire measure. Later jurcstigations of Kleebahn go to show that a blister lust which he observed badly affecting the bark of I'imus strobus, in the neighborhood of Bremen, is caused by a closely relaterl parasite form which he names Peridermium strobi, aud considers to be the acidium stage of Cronutium ribicola.

All these fungi have probalyly cansed far more destruction of timber thau casnal olsservation would indicate, but the limiterl extent to which artificial enltivation of forests las thus fir been carried on in this comtry gives compratively few exact datid regardiug them. The facts, as above stated, have therefore been drawn largely from the works of Hartig and other Eurolean anthorities. With increasing cultivation of timber and probable increase of such diseases their investigation and the emplorment of protective measures jumst uecessarily receive far more attention.

Screral diseuses attributable to the action of fungi, lut as yet inperfectly investigated, are of frernent oceurrence in this country. One of these, linown as "damping off"," eharacterizer by the sndden decay of seedlings at the surface of the gromnd, is common in unrseries, and attacks yonng plants of difterent kinds, the White Pine among them.

The disease is most prevalent in plints growing in a damp soil in a warm. moist atmospliere. As observed in the Am Arbor (Michigan) greenlonses for several years in varions llants propugated from slijs, the disease apjears a few days after the slips are set, giving the lower liart of the stem a wet, unhealthy appearance, which extends to the lower leaves, particularly where these tonch the sand in which they are growing. LTon taling up the specinens, the parts nfferted are found to be in the early stages of decay, and penetrated thronghout, eren in the interior of the epiclermal appenclages, by the branching filanents of a fungus. The fungus appears to live in the sand in which the plants are propagaterl. and to sm in it from one to another, resulting often iu the rapid destruction of the plants in the bed.

"I):mping off" is the to the action of several different parasitic organisms, of which the lotting-bed fungns, Pythium de buryunum Hesse, is one of the most common. though a number of other species have been shown to be capable of proburing the disease. The relict measures recommended by those who have sturlied the disease are the use of fresh soil free from decaring 
matter, :

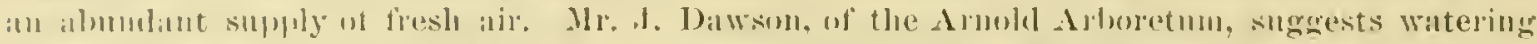
the vomm plants from helow, so as to arodel wilting the leares, as a means of prevention. Other sngerstions will be fonm in recent litesature of the subject, pratically ju the reports of varions

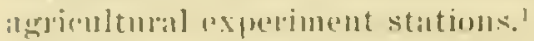

A distast which attacks the trunk of the tree, at varions ages, is very presalent in pine

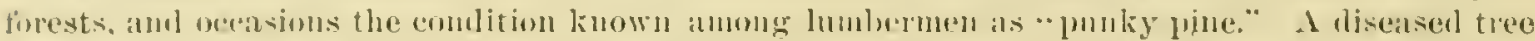

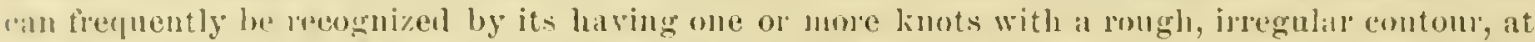

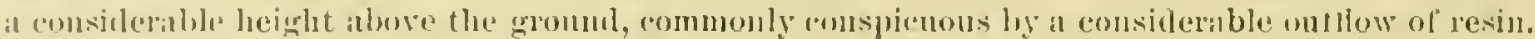

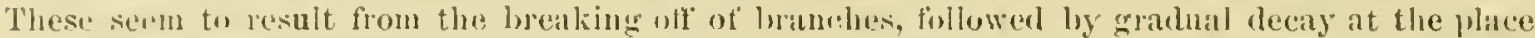
where lhey have sepanated from the tree, in such a way as to almit witer into the trunk. the

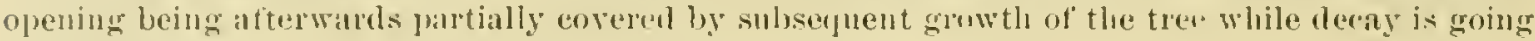
ou insille.

lipm examining the woul of sulh a tree, it is seen to be discolored and in virions stanges of daray. the diseased condition extending juwar from the knot hole, and hoth npward and downwarel from it in the trunk. By inspetisg logs ent from such trees, it will be noticel that

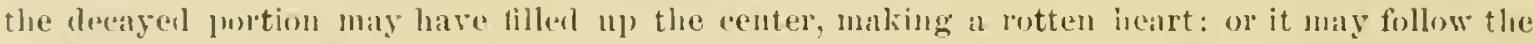
rings of growth for some aistance, millwy from the conter to the periplery: or it maly be still nearer to the surfitee, its josition and extent being very variable and following no recognizalule rule. The prats diseased are utrerly worthless, though boats eontaining a weinter or less amonut of woul thus affeeted are common $\mathrm{ju}$ the market. Hinroscopic examination shows that the woon is penetrated by the filanents of a fingus, and that the elenents of which the wood is manle up have been greatly altererl, and to a consilerable extent decomposed by its action.

Continurd observation in the pine woods of Michigan, in lifferent years, lues not so far justify the reference of this disense to any single specjes of the varions fungi found growing upon the trmuks and logs of dreaying pime trees. lint whatever the species, me or several, coneerned in froducing or hastening the condition desiribed, the gemeral ficts, as stated above. alpear to be that the disease finds its way where the sepuration and decay of a branch presents a favmoble place for the entrance of water and the spores of fungi, and that it spreads so extensively in the trumk as to entirely ruin linge and valuable trees.

In our matural forests there is, of course, neither remedy nor prevention, but in artitoial enlti. vation earefinl aml seasmalble fruming would douldess be the mont eflectual merentive, since, if

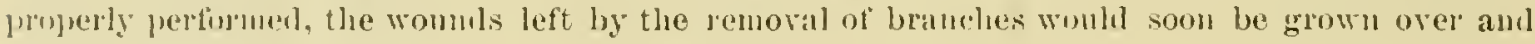
there would be no fiuthes linger from this somrce.

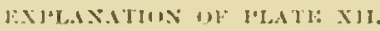

1. Agurions melleus, clnster of y oung sporophores.

$\therefore$. Igarims meliens, larerer spomphore with root-liko orgatn of at tawheluent.

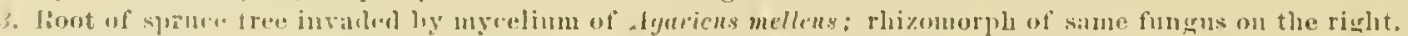

1-4. Fraguents of pine wool showing the destructive action of -lyaricus mellews.

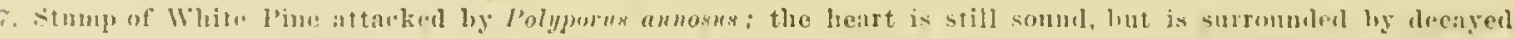
woul anl spots tillul with milsses of resin.

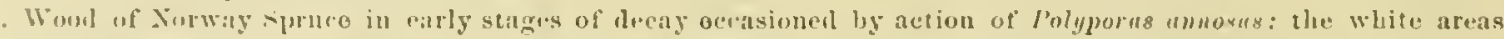

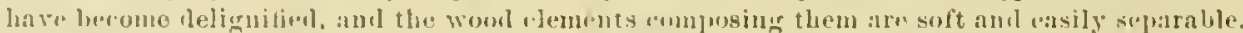

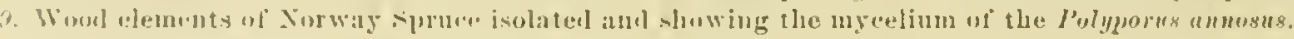

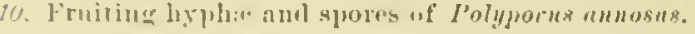

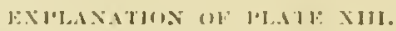

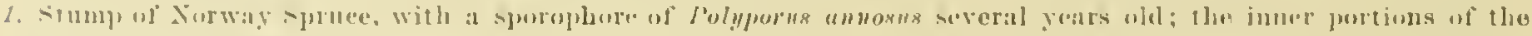
stmulp whully deratyinl.

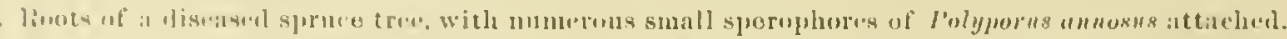

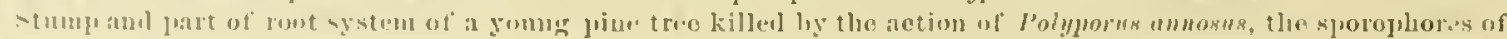

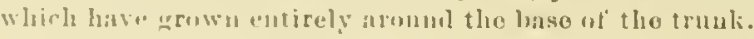

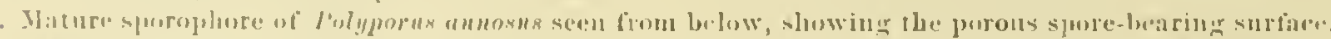

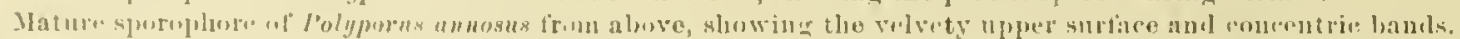

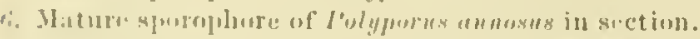

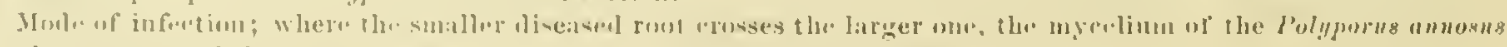

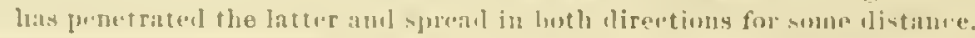



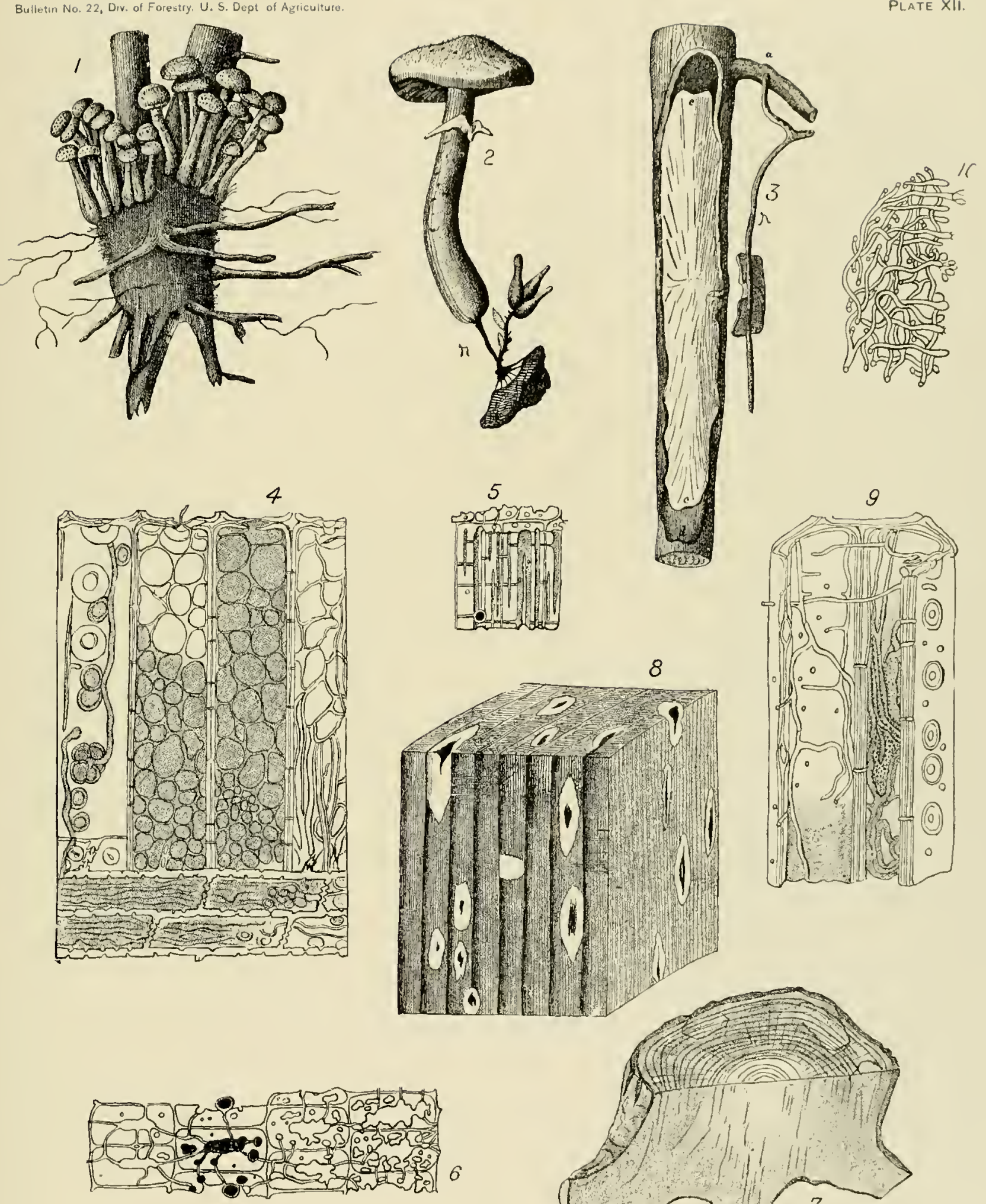

Disease of White Pine: Agaricus melleus. 


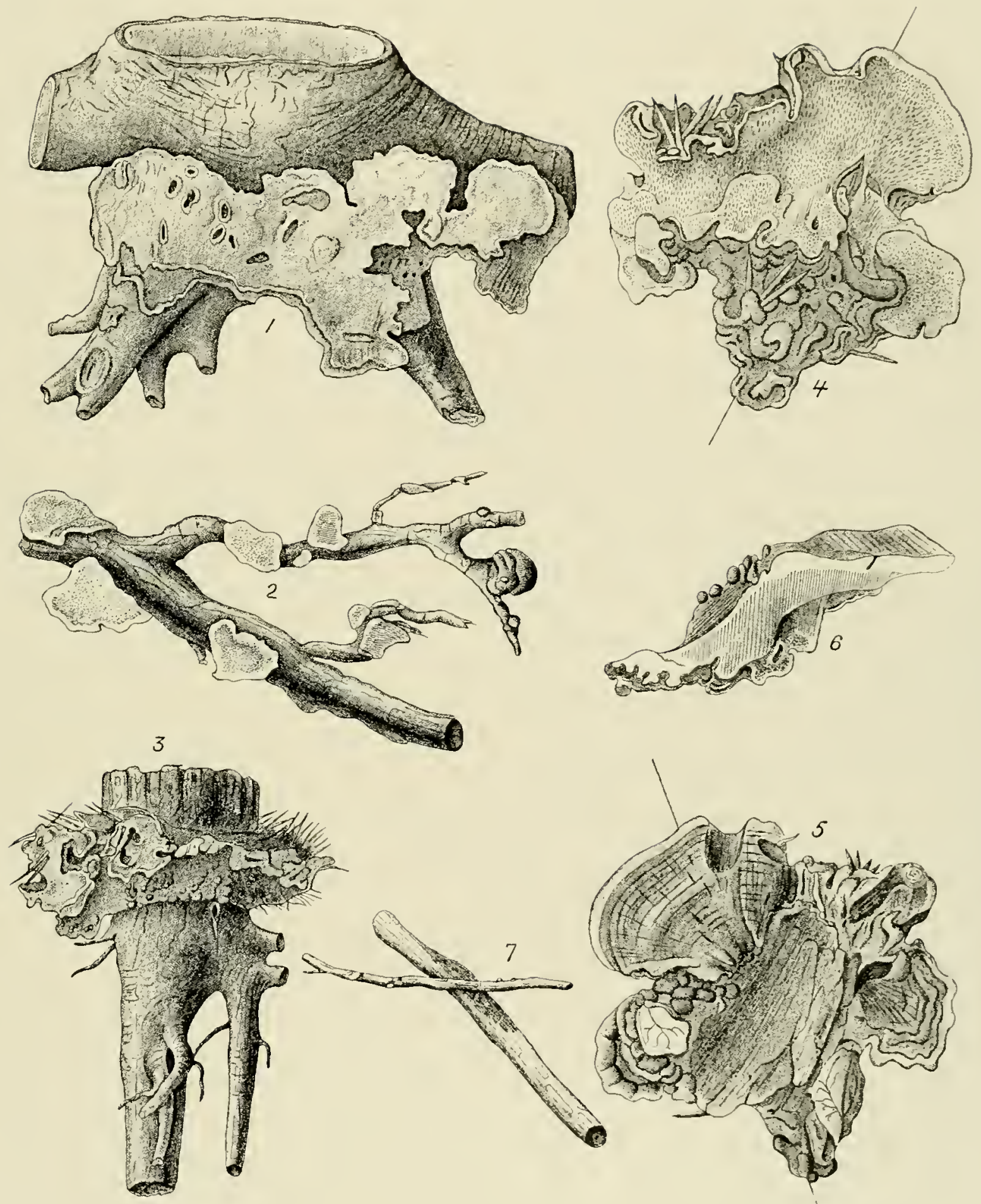



\title{
INSECT ENEMIES OF THE WHITE PINF
}

\author{
By F. H. Chtтtexues, Ificion of Lintonolosy.
}

\section{INTRODUCTION.}

Ot all eoniferous plants, perhaps none are more subject to insect attack than the White Pine. Upwanl of a lumdred species are reported to affect this tree, aml a eareful compilation of all known speeies wonld jubably ald many more to this list. The more important are found in the order Coleopteri, and of these the cylindrical balk-beetles of the family scolytidif hold the highest rank. Most of the Scolytila live within the eambium of dead or dying trees, but a few penetrate the solid rood, and sereral forms, when exeessively abundant, do not hesitate to attack healthy growth. Fumerous otluer Coleoptera belouging to the families Cerambyeidie and Buprestille sinilarly infest the White Pine, but are for the most part secondary in the nature of their attaek, and will therefore refuire only passing mention. One species, however, the white-pine weevil (I'issudes strobi Peck), is a pest of the most pernicions type. In addition to the bark-boring and wool-boring inseets, several speeies intest the roots, some only the branches or twigs, some tine cones, and others iujure growing trees by defoliation. The leaf-feeding speeies comprise the larva of several saw flies, the caterpillars of numerons notlis, and a number of beetles. Tarions species of plant-lice and seale insects also oecur upon the leaves, and often the limbs and trunks of trees are injured by them.

Most of our injurions forest insects are native to this country, in which respect they differ markedly from those which afteet field aur garden crops. Only such species as experience has shown to be more or less injurions either to living trees or to cut timber will be eousidered in this paper. Some fer forms that have not been recorled on White Pine are mentioned, as it is more than probable that they are capable of injury to this tree. The majority, however, have been observerl on White I'ine.

In the preparation of the present paper the writer has drawn frecly from the published works of Paekard, Fiteh, and IIopkins, as well as from personal prperience in pine forests, particularly of New Tork.

\section{THE DESTRUCTIVE PINE BARK-BEETLE.}

The last decade witnessed very extensive destruction of pine and surnce forests in portions of the United States east of the Roeky Mountains. The prineipal injury, whieh dates from about the year 1888 , has been attributed to the so.ealled ilestructive pine bark-beetle (Dendroctonus frontalis Zimm.), one of a genns of six deseribed speeies, all of wide distribution and all destructive to the Conifer:t. It is quite possible that some predisposing agency had first eansed a reakeued condition of the trees in the infested districts, but it is tairly certain that this species of beetle was responsible for mnch injury. The infested arta observed comprised the pine and sprnce forests from Maryland in the North to aud including Sortl Carolina in the South, an area estimated at upwarl of 10,000 square miles in extent. In some sections entire forest.s were killed.

The accompanying illustration of this species (tig. J) will

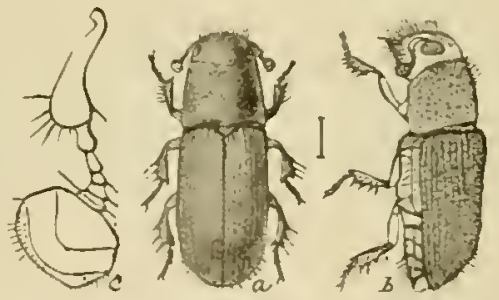

Fig. 5.-Dendructunes frontalis : a. dlorsal riem of bectle: $b$, lateral riew-rulargilatout six times: c, antenua-greatly eulargerl (ituthor's illustration).

enable its recognition. It ranges from reddish to dark brown in color, and mealsures abont oneeighth of an inch in length, being the sulllest speeies of its genus. Its crediterl distribution ineludes Lake Superior to Georgia, and it is recorded also from Arizona and California. The alult beetle appears some time in IIay, the date depenling upon season and locality, bores into living trees and its larvir develop under the green sapys balk. Copious quantities of turpentine exude from the lwoles made by the beetles and dry in masses upon the bark. The manner of work of the larvie in great mubers beneath the bark prodnc's about the same effect as that of girdling, thus entting off the tlow of sap, the natural supply of plant fool aud moisture, greatly weakeiing and eventually killing the trees. The first untwall manifestation of injury is the acenmu. latel masses of pitel, followed by the leaves turning yellow aul then red, as thongh scorehed by fire. 
A singulal feature in comection with the immpion of this species is that it was practically

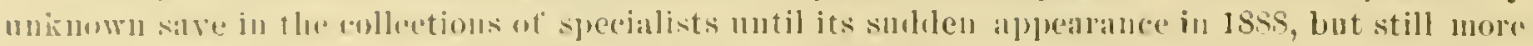

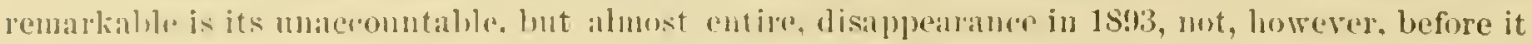

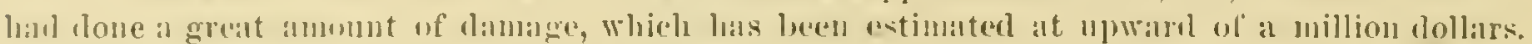
'lihe apparent extermination of this bark.bortle in the district where it was most destructive is believed to have been due to a fungohd disease.

\section{REMLIEN:}

Aftre boring insects of this class once gain access to a tree it is practically impossible to eject them. and to sive the tree recomrse must bo had to preventive measures. For this purpose varions protective washes are in 1 se. One of these consints ol lime, to which has been arded a sullicient yuantity of Paris gateen to srive it a sliglit green color and ennugh glue to canse it to be adhesive. Another wash consists of soft soaprednced to the consistency of a thick paint by the meldion of washing soda in water. A thick wash of soap, plaster of l'aris. and l'aris green is aho of value. A carbolated wash, which is in suceessful use against the peach-tree borre, is prepared by mising a pint of crude carbolic acill with a wallon of soft soap in cight gallons of solt

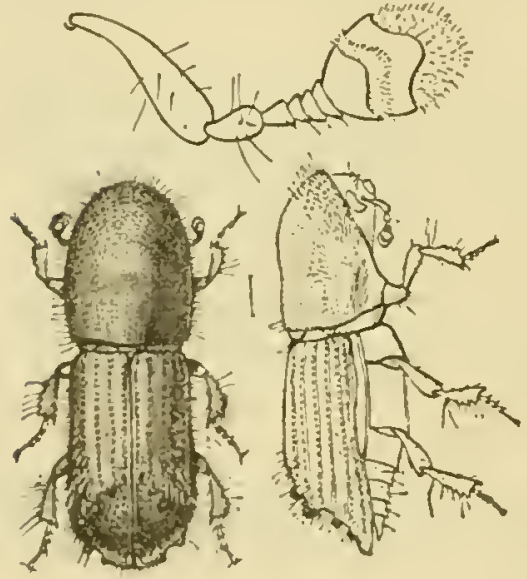

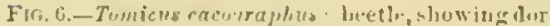
fal virw at loft, in profilo at riglit $\rightarrow$ malarad

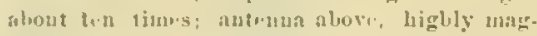
nitioll (origina). water. Fish or train oil is valuable as a deterrent, but should not be used exeept with the greatest caution upon young trees. Whatever wash is comployed should be applied to the trees on the first appearance of the beetles in May, and should be renewed if found neeessary.

Better than any other measure, lowever, is the observ. ance of clean cultural methods. Owner's of pine forests or groves will de well to ent down all dead and trim all injured treses. For the protection of pines, dead spruces and other coniferoms trees. and snch as are infested and tor mulel weilsencel to reenjerate. shomld be ent down and destroyed by burning. A great deal of guod can be accomplisherl merely by removing the bark of dean timber. The purgeny of the insects that have deposited their eggs in one season so loosen the lark that it is an easy matter to remore and lum it betore the following spring. liy pursuing this method mil. lions of the insects will be destroyed before they have an opportunity to issue and lay their eggs for the destruction of other valnable trees. A practice known as "rossing" is in use on borer-infested lumber in Canada. It consists in cutting a strip of bark along the full length of the upper sille of a log, which canses the lark to dry mp and eventually drop amay.

\section{OTHER INJURIOUS BARK-BEETLES.}

Or the other species of bendroctonus, ono las recently been reported as ravaging the spunee forests of Xew llampshire. It is the speejes at present lnown as l\% rufipennis libs., and although not known to aflicet White l'ine. it is not impossible that it misht attack this tree in ease it extends its pursent depreslations. The specios of Dendroctonus are peroliarly periodionl in

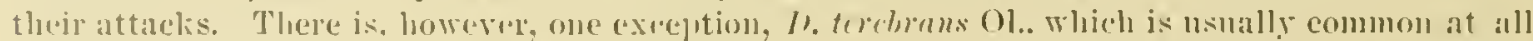

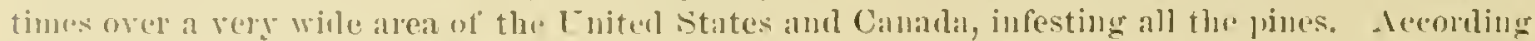
to information reneived in $\mathbf{M a y}$. 1s!s, this ur a related sueres is now ravaging the pine forests of a portion ot sontlucin lew lerser.

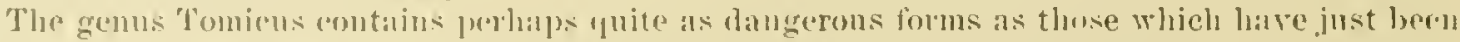
mentioned. The alpuealsone of the beet?es is somewhat similar, as is also their method of life. A speres that his leren assuriated with the mortality of pines in the regron about and south of the

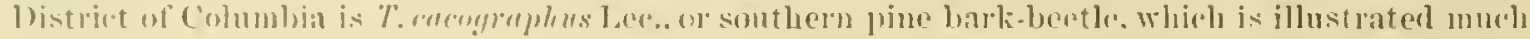
anlarged at fig. li. It is reddish in color and may he realily sejalated from any of the preceding 
speeies by the strneture of its antenne and by the toothel apex of the elytra or wing-covers. Its mine is shown as it appears ou the muler side ot the bark of a tree at tig. 7 .

Tomicus pini Say, the northern pine barl-beetle, is clestrnctive to pine forests in the North in a very similar manner to the preceding species, which it much resembles in structure as in habit, but is less injurions firther South. T. calligraphus (ierm., a similar species to the two preceding and about equally destruc tive, abounds in the pine woods of both the North and Sonth, and T. culutus Zinmu, and T.arulsus Eicl, also infest White Pine.

Among other well-known white-pine bark-beetles may be mentioned Crypturgus pusillus Gyll., Iyluryops glubrutus Zett. and several species of Uylastes aml Dryocutes.

The remedies to be employed against these insects are practically the same as for the destructive pine bark-beetle.

\section{TIMBER-BEETLES AND OTHER SCOLYTIDA.}

While the majority of the pine-infesting Scolytidic breen between the bark aud the wook, a considerable number, called timber-beetles, live entirely within the sapwool; others. the twig-beetles iu the small twigs and branches, and a third group, represented by Pityophthon coniperda Sz., inhabits the colles.

The elief danger from the bark-beetles, as bas been shown, is from their attacks on living trees. They do comparatively little damage to timber, except as they loosen the bark and thus aftord ready access to water and mold and to other destruetive inseets. The timber-beetles, or nubrosia beetles, as they are sometimes called, live almost exclusively in greenwood, preferring that which is slightly injured, of impaired vitality, or such as has been newly felled, but they often attack and kill healthy growth, and in the process of their work in timber eause a staining or "bluing" which entails a still greater loss than results from their lirect attack to living trees. The presence of these beetles in a tree is manifested by the little piles of white sardust which they" eject from the "pin-hole" entrance to their

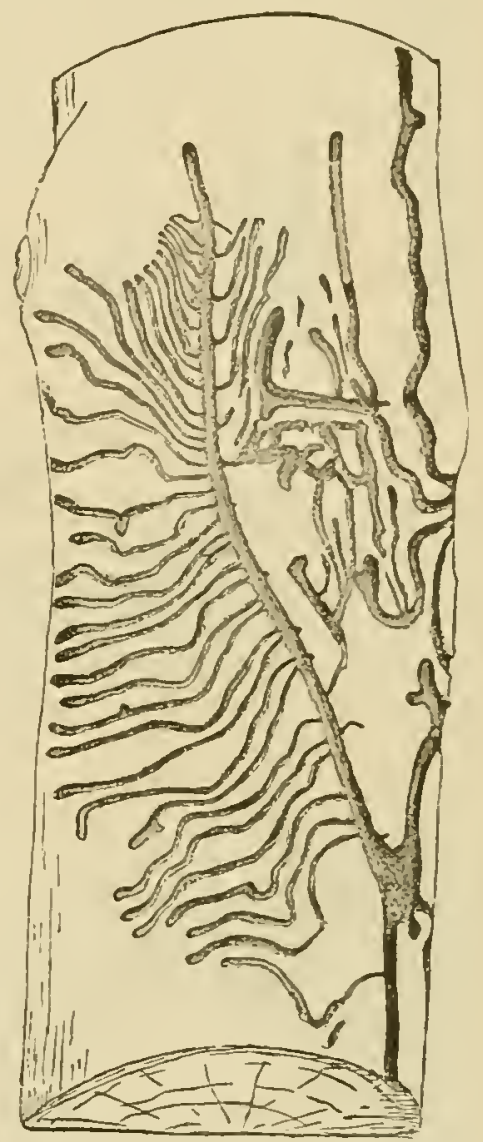

Fig. 7.-Ealleries of Tomicus cacurgraphu on rool under lark of pine (original). galleries. The pine timber-beetles are found in the genera Gnathotrichus, Xyloterns. Iyleborus, and Platypus. Gnathotrichus materiarins Fiteh is the commonest of three species of the

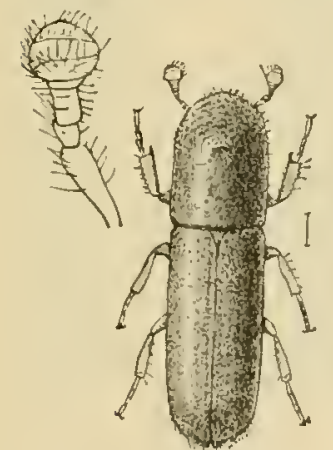

Fig. 8.- inathotrichus ma. teriurius: bettle, enlarget: antenna, still more en. laried at left (Marx del.) genus, all of which attack pine. This species is shown greatly enlanged at fig. s, and its characteristic galleries in the rood of pine are rell illus. trated at fig. 9.

The same remedies advised against bark-beetles will prove raluable "lgaiust the timber-beetles. Kerosene emulsion or a iarbolated wash would accomplish the destruction of the timber-beetles eren after they have attainerl entrance to a tree, provided the applieation be male in time.

The twig heetles are represented by the genera Pityophthorus and Hypothenemns. Of the former genus, $I$ '. sparsus Lec., curiniceps Lec., pullus Lec., luntus Eich., pluyiatus Lec., are all well-known pine species. The genus Hypothenemus inhabits alike deciluons and coniferous trees.

Remedies are the same as for bark-beetles. Pruning aud burning infested trigs and branches and the elearing away anul buming of brush lieaps during winter are indicated. For choice ormamental tree. in private grounds and in parks jul going the "pin holes" with wire am stimulating the trees with manures and fertilizers to assist them to recuperate from attack are adrisable.

\section{PINE SAWYERS AND OTHER BORERS}

Of all the insects that occur in pine timber the Cerambreid. or long-horned beetles, of the genus Monohammus, are the best known. ant are credited with being the most destructive. If 


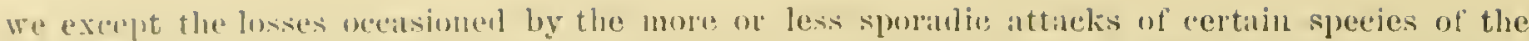

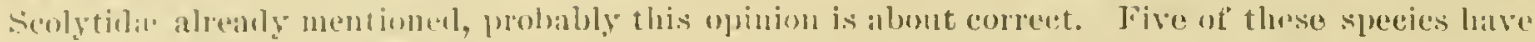

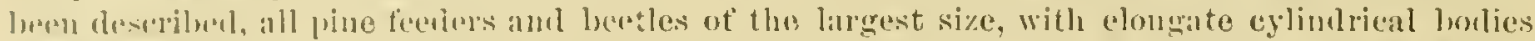
and extremely long antemun, those of the male bring two on three times as long as the remainder

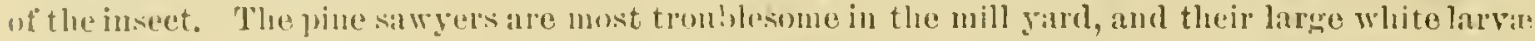
often do mul damage to lows hy eating great holes thongh their solin interor. While burowing

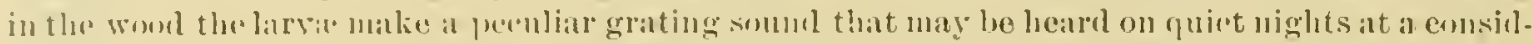

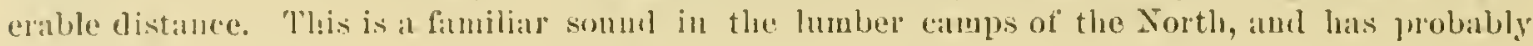

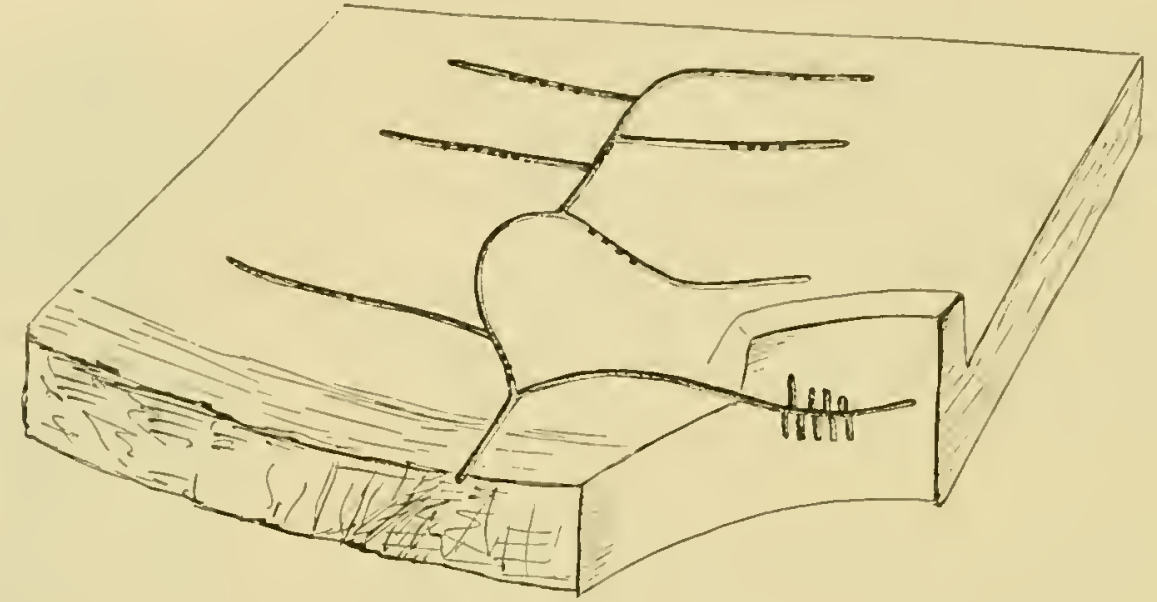

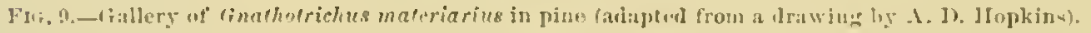

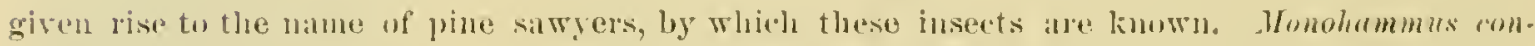

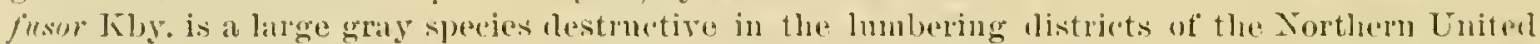

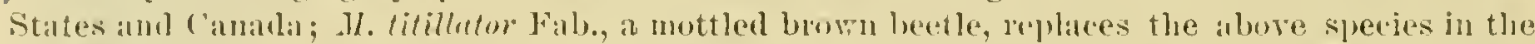

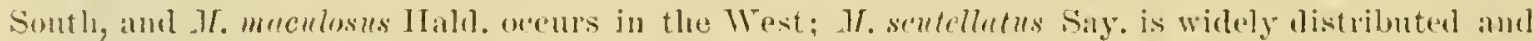

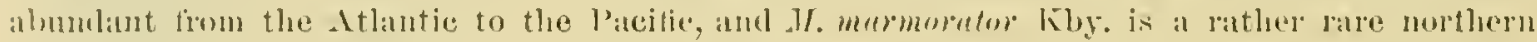
for'm.

Among other horers belonging to the same fumily as the sawgers, the majority of whin linfest

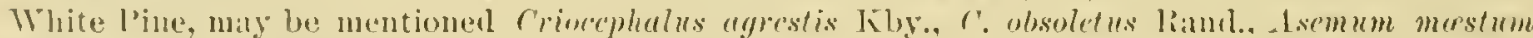

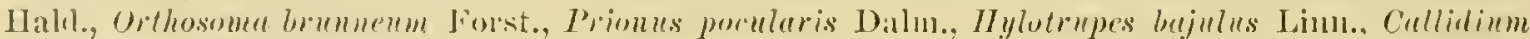

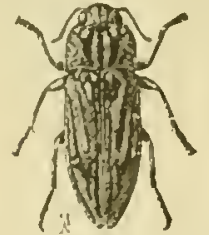

Fur. 10.- rhatcouphom rirginirusis-naturat

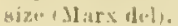

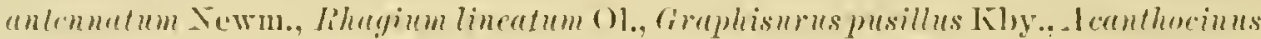

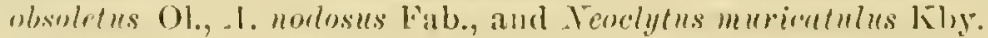

In the Coleoptorons family linpestidie are many burers which infest pine.

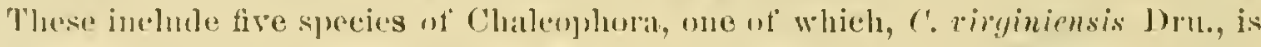
figured (1ig. 10); Diccren punctulutu Seh., 1). tenebrosa Kby., Inuprestiss strinte

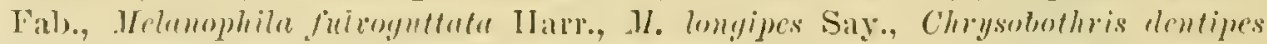
Germ., C. dloricola Gory, and ('. scubripennis Jap. and Gory. These heetles are griceful in form, hard of texture, and many are brilliantly metallie. Their larvat

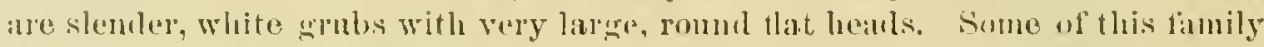
attale living trees and do injury to the sipwoml and to fellod timber in the same namer as the silwyers, but the majority of them prefer devitalized material, and their attacks ane msually sceondary to some mure injurions species.

\section{THE WHITE-PINE WEEVIL.}

In the White line forests of the Xortlerm States, particularly in those of a second growth,

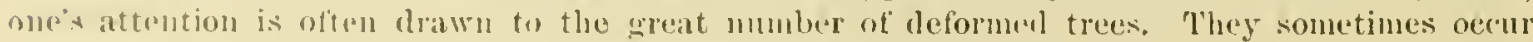
singly, but more olten in grmus. Tho insect that is responsible for this damage is the white-pine

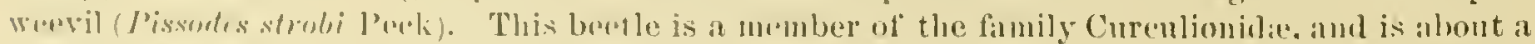
fontl of an inch in lenghth, woval form, red and brown in color, witl its elytra marlied with white 
spots, as shown in the accompanying illustration (fig. 11). It is provided with a lather long rostrum or snout to which are attached its elbowed antemur. The larva, which is white and foutless, is illustrated at ", and the pupa, also white, is figured at b.

This weevil is one of the first spring visitants in the North, oceuring as eirly als March alout Washington City am in April or May farther nerth. Its egess are deposited on the terminal shots of pine, particularly of young trees, but sometimes also in the bark of old trees. The lar'va, when hatched, bores into the pith or mines the saproml. 'loward tho end of summer it attains full growth, when it goes into hibernation until the next suring, transforming to pmpa and soon afterwarl to the mature or beetle form. The presence of this insert in a tree is first manifested by the wilting of the learling shoots, which becomes most evillent toward the close of summer. The idlentity of the species at work may be established at once from its peenliar cells beneath the bark. (See fig. 12.) These cells, which are destined for its wiuter nest and for further transformation, are sunk into the pith and covered over with long fibers of chipred
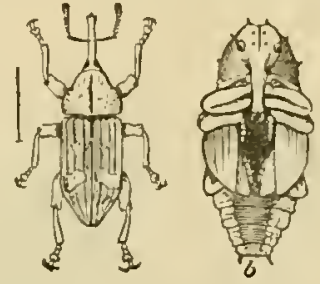

Fto. 11. - Pissodes stribi: beetle at left: $a$. larva; b, pupa-enlarged about throe times (from Packird).

wood. When a terminal shot of a small tree becomes filled in the summer with these larve, to the number sometimes of a score or more, the sloot, with its lateral branches, as well as the stock below, wilt and gradually die, the bark becomes loosenet, piteh oozes out, and by antumn the shoot turlls black, and the bark is coverel with misses of pitch. A tree thus damaged will fail sometimes for several sucessive seasons to send out a new terminal shoot, with the result that

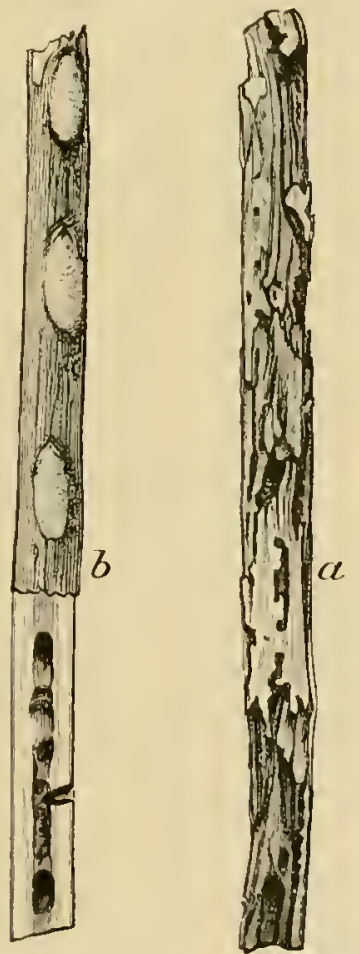

FIG. 12.-Pissodes strubi: a, larval mines under barli; $U$, jupal cells-natural aize (from riley). the lateral shoots continue to grow, and the tree becomes more or less distorted.

Owners and overseers of pine groves will ho well to make a practice of examining the young trees each year, say in Anginst, and when one with a wilting terminal shoot is fonnd to cut or break it off and conmit it to the flanes. With every blighted twig thus treaterl from a dozen to fifty or more weevils will be lestroyerl, ant thus the number's of the insects for the coming year will be greatly lessened. All dead growth or such trees as have from any eause been injured beyond recorery and which might serve as centers of intestation by larboring this weeril or other injurious speeies should be similarly treated. What is most needed is a preventive, and for this purpose a good thick fish-oil soap mixed with Paris green and carbolie acid, in the proportion of about a pound of the former and a quart of the latter to 100 gallons of the wish, is recommended. It shonld be sprayed in April and May on the terminal shots of the trees and repeated at the end of a month if necessary.

\section{MOTH CATERPILLARS AND PLANT-LICE ON TRUNKS AND LIMBS.}

The trunks and limbs of pine are also subject to the attack of sereral insects besides those in the order coleoptera that have been mentioned. Of these are three tortricin moths of the genus lietinia, which affect the pitch and other pines. Two other moths of similar habits to the above ocenr on White Pine, womling the trunk below the insertion of the brinches and cansing the resinous sap to exule. These are the pitch.drop worm (Pinipestis zimmermani Grote) and Hurmoniu pini Kell.

The same remedies advised for other boring species, and particularly those specified to be used against the white-pine weevil, are indicaterl for the present class of insects.

Several species of plant-lice affect the Whitu Pine. The white-pine aphis (Luchnus strobi Fitch) is very abmulant in the Northem states, living in colonies on the branches of trees and puncturing and extracting their juices. The so-called "pine blight," Chermes pinimenticis liteh, is sometimes very destructive, its presence being manifesterl by largo patches of a white, flocenlent 


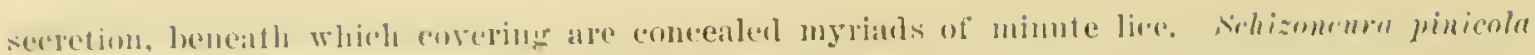

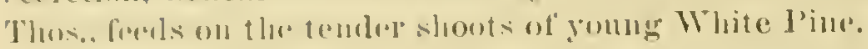

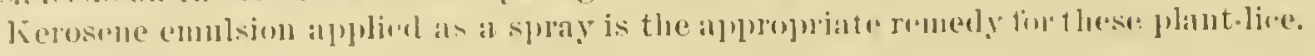

\section{LEAF-FEEDING INSECTS}

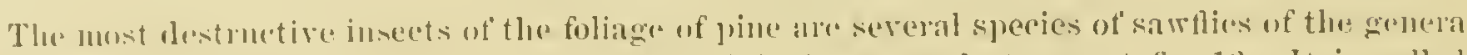

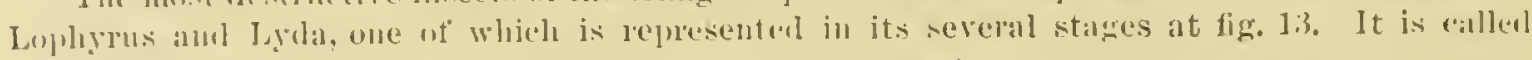

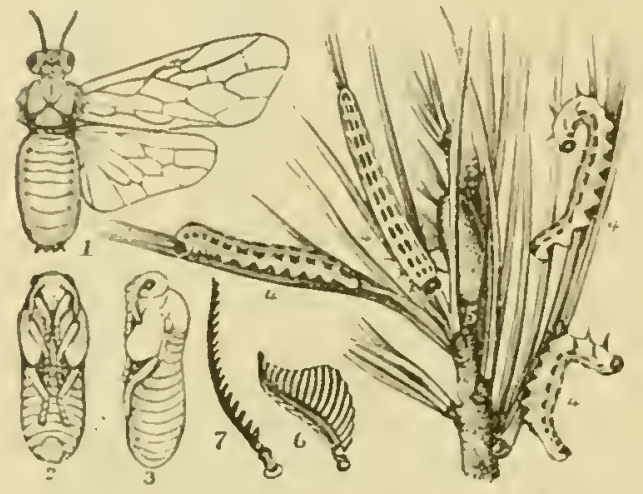

Fro, 13,-Lophurus ablotii: 1 female, rnlargidl; 2,3 ,

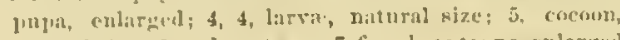

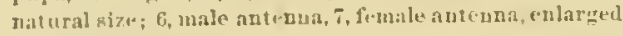
(from Rile?).

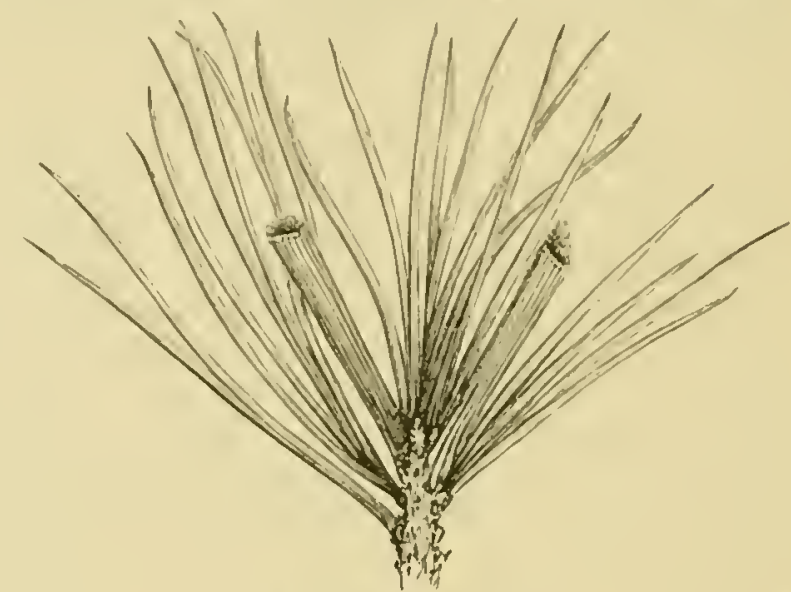

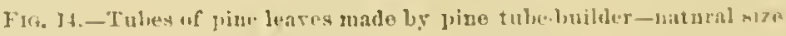
(frmu l'ackiril).

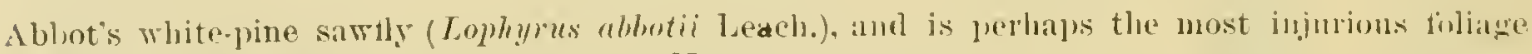
feeder which infests the pine wools of the North.

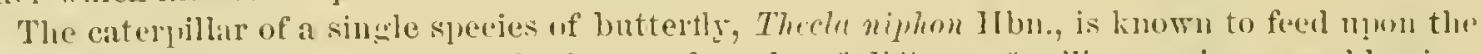
foliage of White Tine. but anong the lavie of moths of difierent fimilies are inmmerable pine-

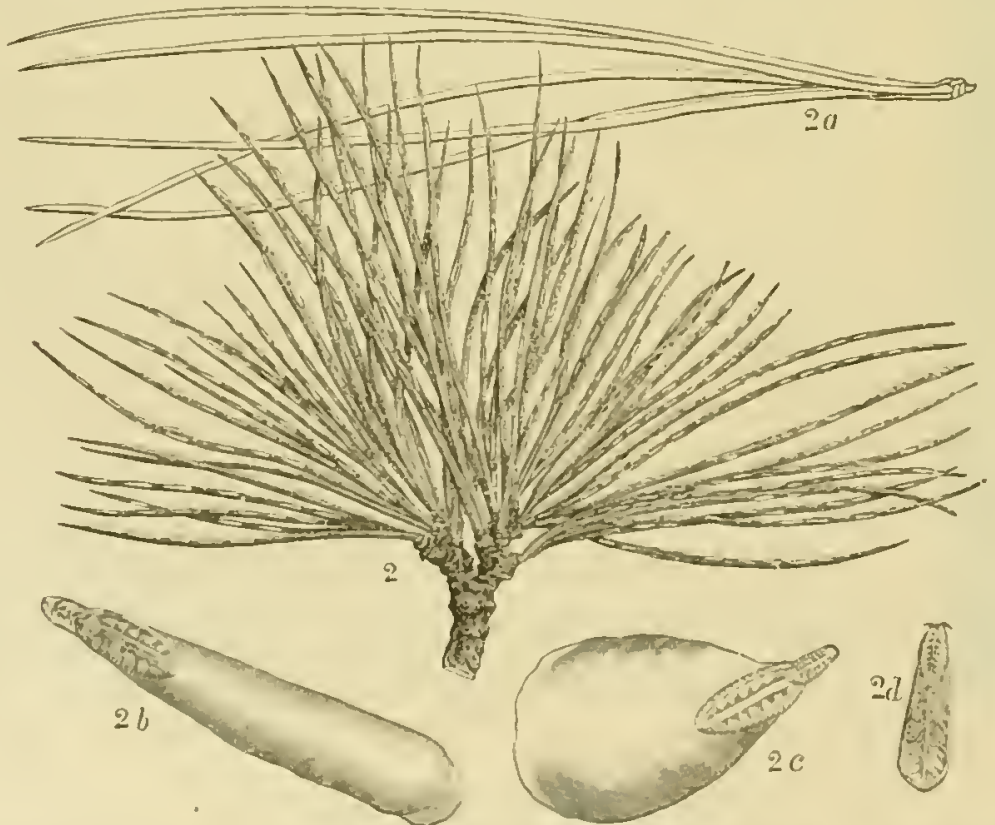

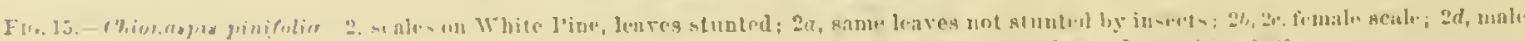

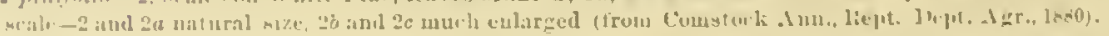

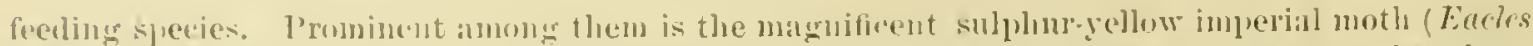

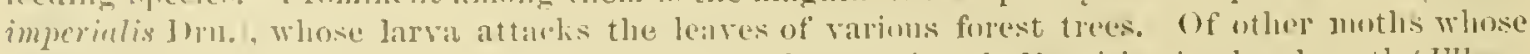

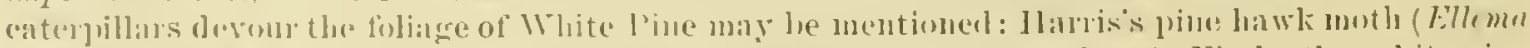

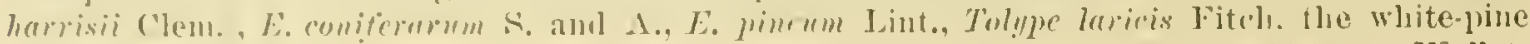

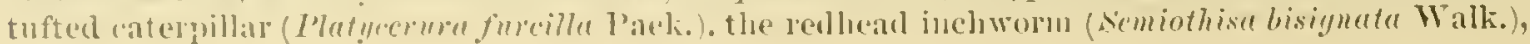


the sulphur leat-roller moth (Dichelin sulphureana Clem.), Teress ferrugena S. T., and _Lmorbia

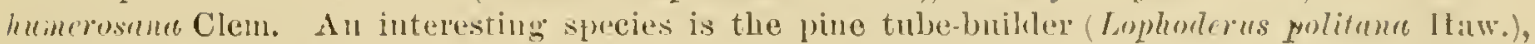
which, in its larval stage, lives within a tube formed by webbing together a number of pine neerlles as shown in fig. 14 .

A number of species of adnit Coleoptera, whose larval habits are inpertertly understoor, subsist upon the leares of Whito Pine. Of these are the Surabird, lnichelonycha albicollis Burm., and the Chrysomelicl, Cilyptoseclis pubescens Fab.

The best remedy for the sawfly larva, caterpillars, amil beetles in a spray of l'aris green, applied npon the first appenrance of these insects on the trees.

The consideration of the insect enemies of the White Pine may conclucle with the mention of the pine-leaf seale insect (Chionaspis pinifolin Fitch), whin forms its seales upon the leaves, exhansting them of their juices and causing them to turn vellow. This species is illustrated at fig. 15.

A strong splay of kerosene emulsion will be tumnl an eftieient remerly against these scale insects.

\section{FOREST MANAGEMENT.}

Is regards furest management, we have, mnfortunately, in this country uo experiences which mould permit us to form very positive opinions based on actual observation regarding this species or any other. The study of the natural history of the speries in its native occurrence permits us, nerertheless, to dran conclusions which may at least serve as a basis for its future sylvicultural treatment.

In the first place, it may be declared that the White Pine is the most important and promising species upon which to expend attention in our conning forestry operations within the limits of its natural ocenrence. Its adaptation to a variety of soils and situations within these limits, its rapid growth, its excellent form, its remarkable mass development per acre, its shade endurance, its all-ronud useful wood jrodnet, and its jropagation, both by natural and artificial reprodnction, give it a position among our timber trees hardly approached ly any other.

There are certain general Irinciples which are the result of experience in forest management in Europe and elserhere, applying to this as to most species. The first is, that mixed growth is in every respect superior to pure growth; it will therefore be proper policy to grow White Pine preferably, if not altogether, in mixture with other species. This advice is given in spite of the filct that the White Pine grows rather well in pure stand, and that, owing to its slady cromn during a long period of its lite anul the lensity of stand in which it ean develop, and the large yuantity of foliage which it sheds, the soil conditions are not in dauger of deteriorating, as would be the case with more light-needing species. But, as has been observed in its natural occurrence, its development is more favoralble in companionship, and especially is this the case with regard to the cleaning of the bole of its branches, which are peculiarly persistent. Whether it wonld pay to substitute an artificial cleaning by pruning the young growths is still doubtful; meanwhile the self-pruning performed by mixture with shady companions will have to be enconraged, espeeially as thereby other valuable advantages are secured which attach to the mixed forest in general.

Unfortuna tely, our irational exploitation has redneerl the White Pine in the natural forest areas often to such an extent that its reestablishment is possible only by artificial means. Wherever the culling has not been too severe, and either young growth has developed or seedling trees have been left, the natural reproduction should be encouraged by favoring the young growth and by removing or thiming out other species which interfere with the starting of a young growth. Fortunately, the White Pine, owiug to its shade endurance, is specially titted for uatural reproduetion from the seed of mother trees. more so than most other pines, and the rapidity of its growth, in which it excels most other shade enduring species, is also firorable in this respect.

We are not yet prepared to lletermine the most protitable rotation in which the species is to be managed nnder varying conditions. The faet that it is not only a very rapid but one of the most persistent growers, trees making wood at the rate of $1 \frac{1}{2}$ to 2 abie feet per year 11 to the one hundred and fortieth year, permits a wile range of chole for rotations, and since its wook, being rapidly ehanged into heartwood, becomes serviceable very early, the rotations may be either low or high, varying from fifty to one hundred and fifty years, accorling to local cconomic and soil conditions. 


\section{NATURAL REPRODUCTION.}

The White Pine repuratuces itself realigy in the virgin forest on all samly and loauy sand soils where the himdwoods do not interlere. On these areas thickets ot goung growth, sapling timher, and dense groves of mature trees are seattered withont regularity, and there is mo indicatinn that this pine forest has mulergone material change for centuries. ln the hambool districts of the lacavier soils of the Jake region, where the pine is met with chichly as old, overripe timber, the reprouluction of the pine seems, temporinily at least. to be interfered with by the associated growtls. Lalrge, old trees occur, thinly scattered or in clusters, but siljling timber and young growtl is oftun entirely wanting over eunsiderable areas. Similar conditions joreval, wr have prerailerl, in the monutains of Pennsyliana. and also in New Englind and in the dripondacks. Where the pine is cut and sone seed trees are left the ground soon eovers it self with young growth. This, eontrary to the eommon nution, is true even where fire has run over the slashings and the gromul for a time is stocked with P'oplar and other brush. Snch groves or thickets of young pine occur in all farts of the pinery of the lake region, and in the aggregate cover several hundrud thousand acres. Generaly, however, the fire returus from time to time, the young seedlings, as well as the mother trees, are finally all destrogen, and thus the reproduction is empletrly prerented. On such lands, imporerished by fire and exposure to sum and wind, not even the Poplan returns. In the hardroou, spruce, and llembek regions the cutting of the finc in the usual manner simply assists its competitors. and its reprorluction is seriously hampered and frequently prevented altogether. Where these elay ind loam lands are completely weared and then abandoner, as has been the case with thunsands of acres of New England forests, the White l'ine is one of the first to returu if any seed trees exist in the vicinity. II underis of groves have sprung up in New England in this way.

\section{NUTES ON NATULAL REPRODLC'IOX.}

A case of the kind above reterren to was observed in 15sti in Fork Comnty. Me.. and the following notes on the subject will. no donbt, move of interest:

In compay with IIr. Joln I.. Hobbs. who is thoroughly familiar with the hisory of the rarions pieres of forestexamined, a risit was male to a number of places on which White l'ine was growing, others on which poump pine semllings were coming in, and still others in the immentiate vicinity where none were to he seen, althongh the general contitions of soil and situation were puctically identicul. The soil, much of it, was light aud saurly, with a growtl of Comptonia, I'terix, Cirullhria, and other plants common on pine land.

A large mumber of trees latul a crop of eones, the last guar before this visit in which there was a gooul crop

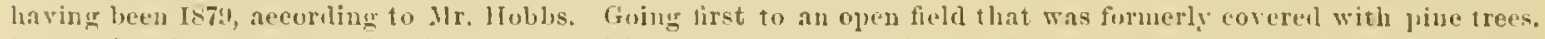
it wis found to be rery thiekly eoverol with young reedlings, from a few inelies to 2 feet or more in height, that hal sprung up in sneh ahuudaner that a hare spot was hadly to he seen over the whole tract. This piect was

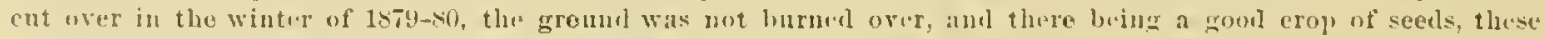
had grown promptly and a roung forest was rapielly coning on to talie the place of the one rumoverl.

"In goiner to other pieces in the vicinits, frum whieh the pine hul ben ent at ditlerent times sinee $1 \times 79$, a most striking contrast was observed. In these pieces that scemul otherwine just iike the first, and witl the conditions

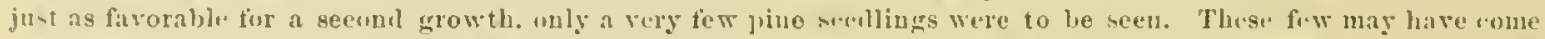

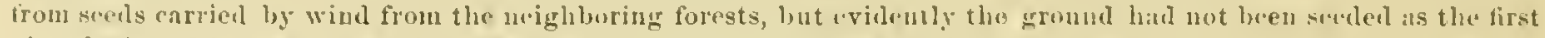
piece had, and it was impossible not to draw the conclusion that the diflerence was due eimply tut th. filct that the

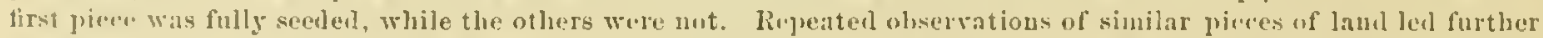

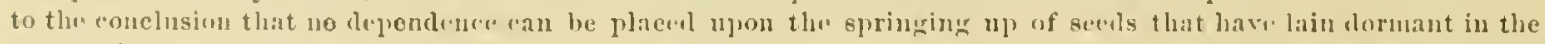

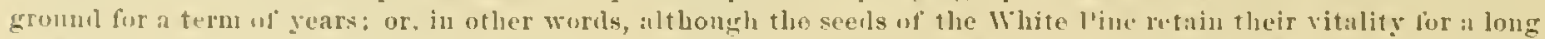

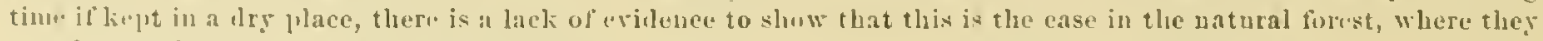
are alteruately aly :ul wet.

lither interesting comlitions of growth were noticed in the stme region. In the virinitg of otamling pine

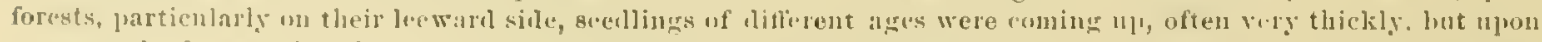

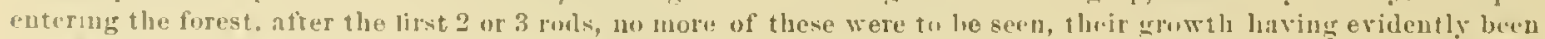

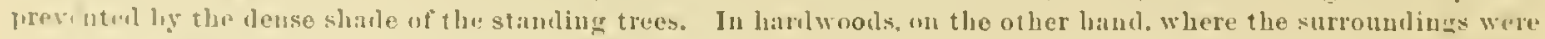
a little more fasorable, somu young pines were growing here and there.

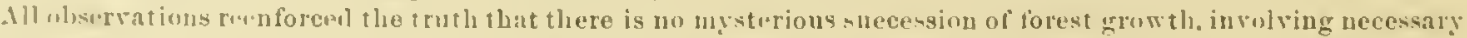
alternations, and that the White l'ine dows actually stow and flomish for an indefinitu number of geuerations on

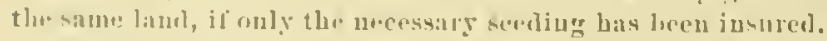

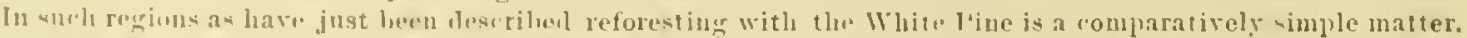
Wher nothing more is lone than to tole alvantage of natural conditions lyy folling the trees in secel years, or hy

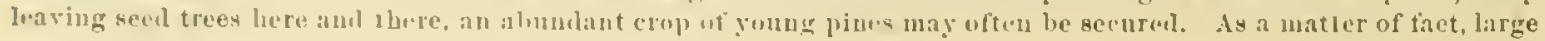


tracts in Maine and Massachusetts are coming up iu this way to second-growtl pine, and as thro profit arising fiom the protection of these youn forests is better unlerstooll, there is no re:tson to doubt that the whole matter will in a great nueasure regulale itselt.

In the Allironlack region and in the pine belt of Jichigan, Wisconsin, and Mlumesota the case is lar diflirent. Under the present system forest tires are au almost necessary result of all lumberincr operations. 'To sıart rith, all trees that are large enough are eut, and if by ehance here and there one has "scaped that might proture a crop of seels, it perishes in the fires that suon sweep over the gromml, leaving hardls a living thing behiul them, and lurning the seeds that und.r other conditious might hise sprung up tu form a sucubl growth of pine. (un all such burned tracts pine seelliugs are rarcly fonml in ay number, aul pet here and there thes are scen gruwiug where the fire had left a seed tree by the side of a stream or a piece of nuburued ground, thus giving the seed a chance to grow.

After making a careful stuls of the pine lanels of Yriehigan for several pears the conclusion seems plain that here, exactly as in New Lughul, everything practicaly dejends upon reseciliug. Ilero in th: Lorthwest th. seed trees hive been destroyed, the seels in the ground have heeu burned, aud, as an inevitalule consecjuence, the laud remains a wilderness and unst remain so until some means are fonnd of restoring the forests br artificial sowing or planting. There is nothing in the soil itsell that prevents reforesting the pime lanls of sliehigan at once. It is beeanse seeds are, to a great extent, wantiug, and the seedhugs that do start are uot protected. that these pine lands are left in their desolate aul un uruduetive coudition.

The experience rith White Pine in Europe fully confirms the correctness of the obserrations above recited. White Pine abroad reproduces mell, seeds abundantly, and is so particularly well suited to uatural reprodnction that the most experienced and competent recent writers elaim that this tree fairly "demauds" this form of regeneration.

\section{ARTIFICIAL REPRODUCTION.}

Concerniug the artificial reproclnction by seeding or planting, the experience, both in this conntry and Europe, is quite extensire. Not ouly has this species been planted frequently and for a long time in New Englaud and in other parts of its natural range, eveu for forest purposes. but thrifty groves have been established also in the Western prairies beyond the limits of natural distribution. In Germany larger oj smaller plantations were made in many localities near the beginning of the century.

The plantiug in this country has, homever, not nsuatly proceuled with a knowled ge of proper forestry practice. As a rule, plants have been set ont too old, and hence the plauting has proved expensive; usually, also. it has been too ride spaced to secure the most desirable result in form development. Another point also nsually veglected is the admixtme of other species to stimulate the gromth of the pines and possibly to rednce the expense of covering the ground.

In Europe the majority of pine plautatious made with Scotch P'ine (Pinus silvestris) is made with one-year-old seedlings, which is done very cheaply and expeditiously, often on mprepared ground, when one man may set 1,000 to 1.500 plants in a day.

For White Pine, especially under our conditions, where the young plants have much to contend with in the way of climatic ills. weed growth, etc., this method is probably not applicable.

Tro-year and even three-year old plants. grown in seed beds and once transplanted in unrsery roms, to produce a stocky root system and growth, will probal,ly be more successful, being better prejared to overeome adrersities.

The seedlings, gromn from seed som either broaleast or in drills in the seed beds, must be shaded during the first two years. as is usual with confers in this conntry. After the second year they will endure the hottest stu. The sharle must be graduated atcoriling to the weather. as the seedlings are liable to damp oft" the first season if too much shaded and to burn off if not shaded enongh.

As there are abont 1,800 seeds to the ounce, it mill take about 5 to 1 i onnces to the 100 feet of drill, uuless the seed be specially poor, when greater allowance will have to be wade in proportion

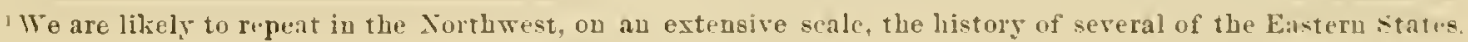
Inder inducements helil ont to cheourage inmigration, mang settlers liare lwen leil to tak. nj) limul all throum the worst part of Jichigan and Wisconsin, inchuling the "barrens." They elear the land, seed it, if they ean. rith clover, and put in other erops, work in the aljaeent pine wools tor a liviug, and "develop the country, "thus iloing for the state exaetly what needs to he dune amd what the state has negleeterl to do fur itself: but if is a disastrous

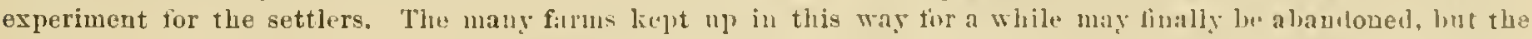

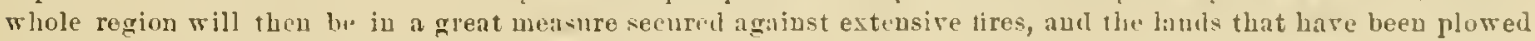
and workes over will be in a better condition fur reforesting. 


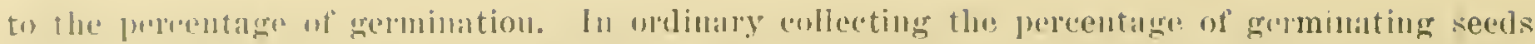

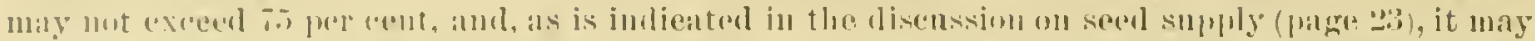

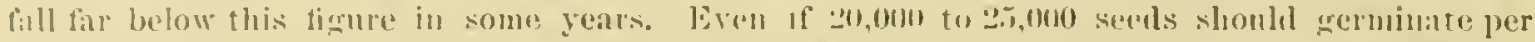

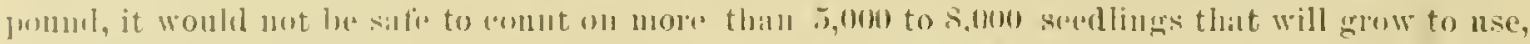
and in the transplanting to mursery bos an alluwance of at least is to 10 gere rent shonfl lu mate

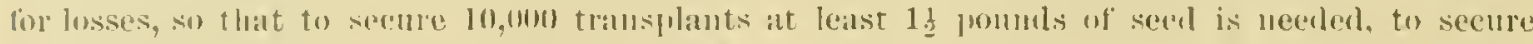
which it may take from : to 4 bushels of uones.

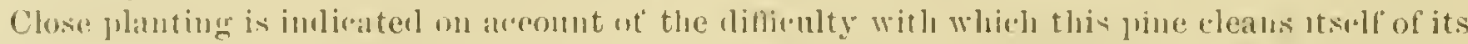

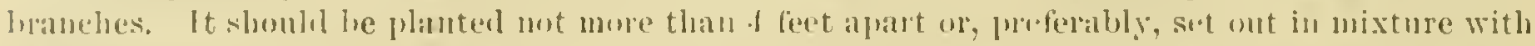

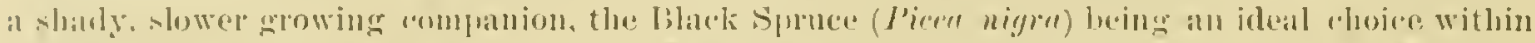

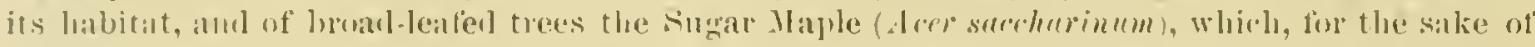
reonomy, may be sown between the willor spaced (s feet or more) plants of White P'ine. 'Tho

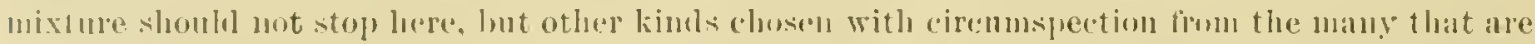
found associatol with the White l'ine in its natural habitat should he added, as Chestunt, Jellow,

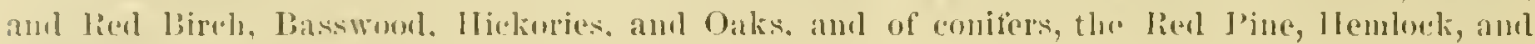
inceasionally" ins some localities Arborvitie.

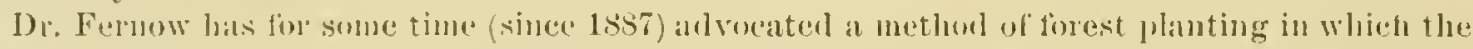

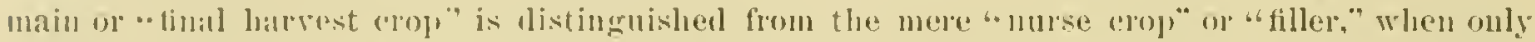

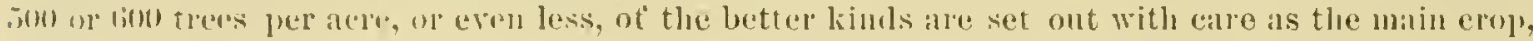

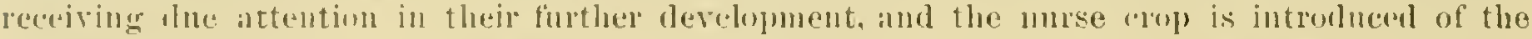
rhealpest kinds and in the cheapest mammer to aet as soil cover to check weed growth and stimulate height growth, straght him, and cleaning of the main erop. The White Pine would, of course, lae a most exrellent mitin arop.

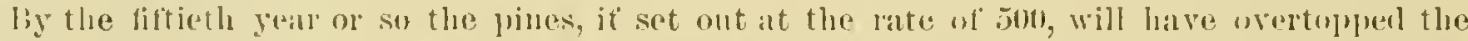

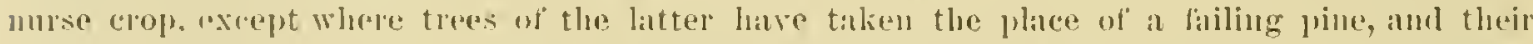
crowns will have closell 11 , their boles stragght and clean, fonthing clear lumber, if the murse erop was properly chosen and has done its duly. The further management then wonld concern itself mostly with gralual thinning ont of the main crop) to secure the diameter acoretion due to increased "ruwn development and light. by the one humberth year it will br reisonable to expect at least labli the trees sct ont to have reached their highest value in maturity and size, with 15,010 to 20,0100 enhic feet to the ane, for the White Pine is not only a rapiol grower, but a large producer, its shade emburance permitting as large a number of trees to develop satisfictorily per ace as the sunce, which it outgrows in hoight and diameter.

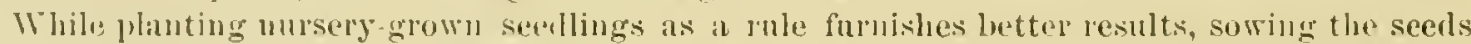

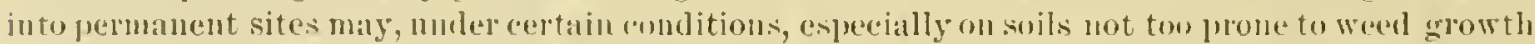

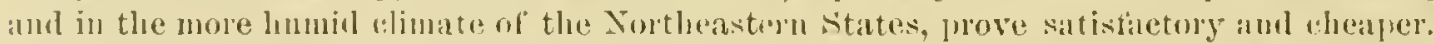

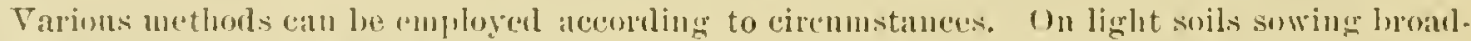

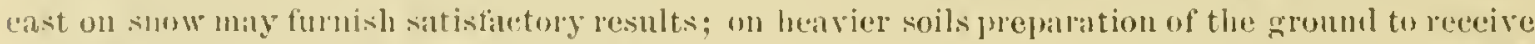
the seed will prove imlispensabla. This may be done by plowing furrows or by hoeing plats of "3

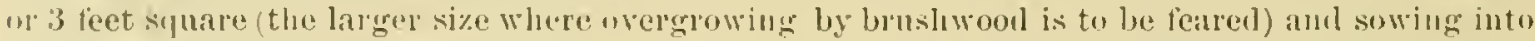
these in drills or brouldast. Dr. Fernow devised smeh a methou for reclothing ent-over lands m

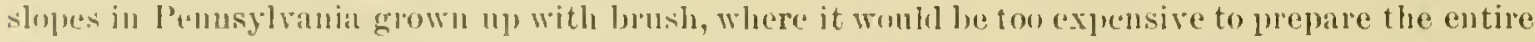
gromul. Ihere the plats were made harser, tor even 6 feet symare, and into these not only pines were eithel phated on surn but also a murse arop surrounding the pines, experetation being that this

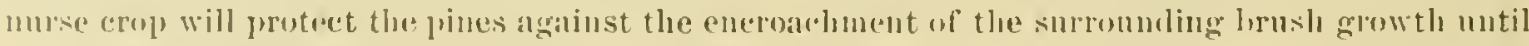

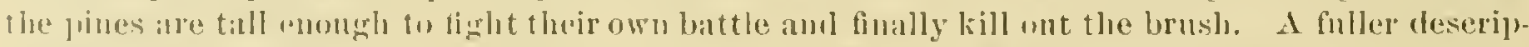

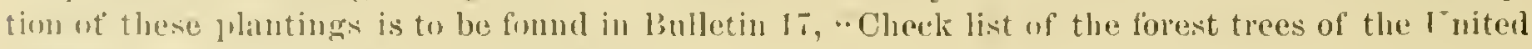
states." etc.. of the Jivision of l"urestry.

\section{PLANTING NOTES.}

The following metes on planted groves, their conclition. growth, and results are given a place

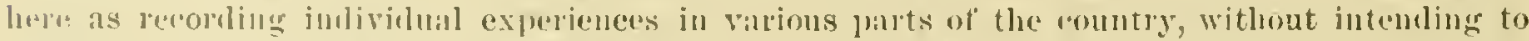

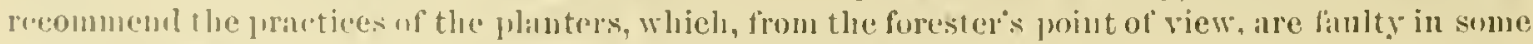
directions. esprecially in the open stand, whin is advocaterl:

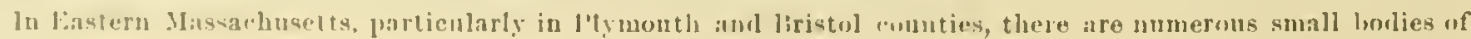

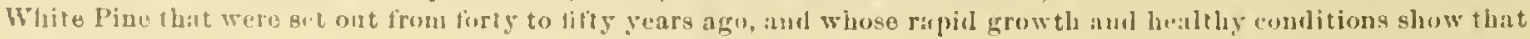


there the work of planting at least has been suecessful. The trees composing them a reraged at thirty to thirt $r$-five

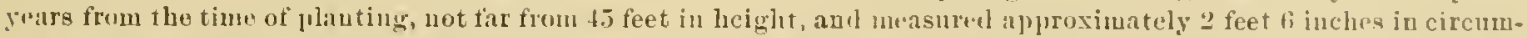

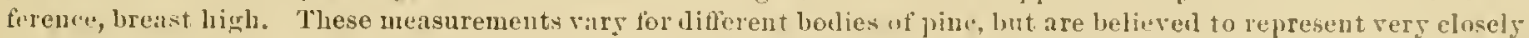

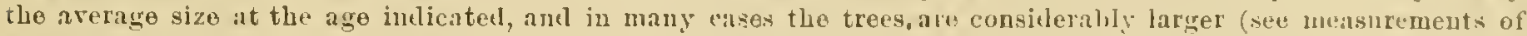
growth on page s8). This growth of pine iv of such value that aceording to emmetent jullges of puperty in that rewion, much of the land that without the pine would he worth ouly $\$ 3$ to $\$ 10$ per acre, is worth with the stauding

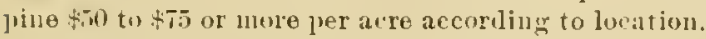

Lpon visiting these difievent grwes and couvrsing with men who had planted some of them, it was fomul that opinions and practive were quite variable, luth as to time and maner of planting. Mr. S. E. 1Lall, of RajnLam, who bas hat long experience, states that he las set the White l'ine successilly every muth in the gear. The young trees, 4 to 6 inclies, or eren a tout ligh, are taken up with a piece of soul on their roots aucl set out in a wet time. These two conditius were particularly emphasial ly Mr. Hall, who sars that if they are uhiserved the

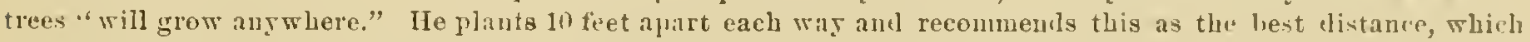
is, bowerer, not good forestry practics. In a grove set bs him forty rears ago the trees wre set in rows at the abose distance and had male a vigorons and bealthy growth. In another grore, planted alont the same time, the trees stool 8 feet apart each way aut were apparently doing inito as well as in the first one. On the other hand, Mr. Spencer Lemarel, of Hrilgewater, after nany gears of plietical trial anul obwration, state: that hariug formerly set out pine trees 10 feet apart, he is now setting them at a distance of 15 feet, with a view to rechee the expense of planting and hecance they soon hecame crowled if planted closer. He, too, sets out tho trees nith a sul, simply plowing a furrow aud setting the seedliugs at the riglit distance. Mr. Hall ligs a holo for each tree, but says that the work can be clone vers rapidly, and that he has linself set an acre a las.

One of the manc plautations in smitheastern Massachuetts known as "Leb. Pratt"s grove," is withiu less than a mile of the village of Forth Middleboro. It was set ollt forty-two fails ago. The tress were set in rows 10 feet apart each wa. The grove twelve sears ago even was practically impenetralle by reavon of the dead interlocking branches that hat nerer lees removed.

Four trees of arerage size were meisirul in $18 \times 6$ and showel diamuters of 7 to 9 inches. Some were of larger and otbers of smaller size, though the gromth was fails eren. The areragre height was estimaterl at 40 feet; the branches were dead three-rparters of the way to the top, the remaining one-fourth, say 10 leet, coustituting the crown, was green aml healthy. The soil wis poor, that passed over from the roal in reaching the grove being light sanl with some gravel.

Another grore, some 3 miles northwarl of Yorth Jidelleboro, was risited in 1886, and a greater number of measurements malle. Accorling to Mr. S. Hayward, near whose finm it stamls, this grove was set ont rather urore than thirtફ, not more than thirty-five, years ago, but lad not wade quito as gond a growth as somo uthers have. Thu trees are in rows, it to s feet apart each $\pi$ ay, and are quite uniform in size. Beginning $\pi$ itlu the thirel from the north sille, a tair arerage row, the tollowing measurements were madt of the trees taken in order as they stood. The cir'umference, breast bigh, was:

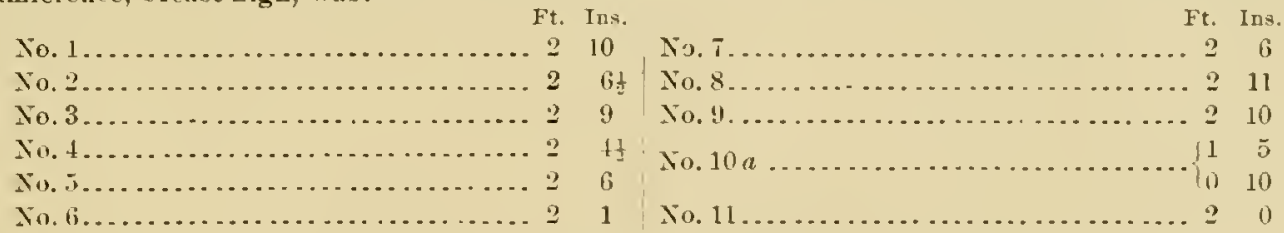

a T'wo matil stems aul hatl lost a tbirkl.

The largest tree measmed in the grove was 3 feet 1 inch in eireumference or 1 toot in diameter, breast ligh. A very few have been chokel ont awl have died after living fifteen or trenty years. An arerage tree on the sonth sicle neasured 45 feet $i n$ height. All the trees of the grove that were still living seemel healthy and vigorons. The lower brandes had dien at an earlier age than in the preceiling grove and the trunks were free fron them fur sone 8 fiet or more. Above this lin' the dead branches still remained on the trees, only thos of the crowns being green and liviug.

Fear Brilgewatel, Mass., a piece of land had been sown with pine seerls some thirty.tise sears before, the seeds being sown broalcast and lraggel in. The trees were sleuder aud two much rowded, th" smallest onrs dring out. They sermed much in need of proper thinning. Some of the best specimens ueisured 2 fiet $i$ inches in cirenmference, breast high, but the trere rery nueveru in size, and did not impress one nearly as farorably as those in the groves that hal been regularly planted at a clistince of si or 10 jeet apart.

'This second growth pine finls a reaty market at the box fietories of' Bridgewatir, Halitax, Taunton, aut

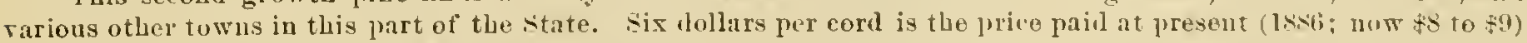
for logs lelirered at the fartory. Logs are accepted down to o inches in diameter, and iu estiblishments where stares are male a smalke size is taken. There is no troulble in blutaining all that is wantell, there being an abmant supply of pine for loxe bearls, staves, and the like in the immenliate vicinity of the town where the are manuficturetl.

A few notes on plantitions made on the Western border and outside of the natural range of the White Pine will show the alaptability of the species in those regions:

There is an instructive plit of White Pines in tho forest plantation of the State Luiversity of lllimois. This institution is loeated at Champaign, about 200 miles south of Chicago anl much besond the natural range of the $20 \div 33-$ No. $22-5$ 

follow:

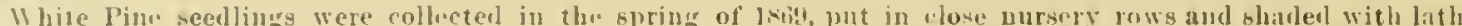

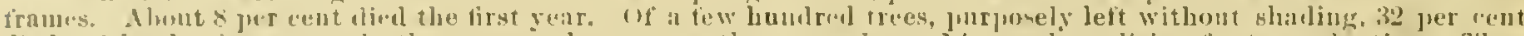

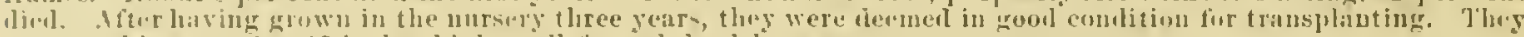

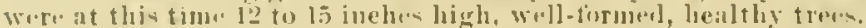

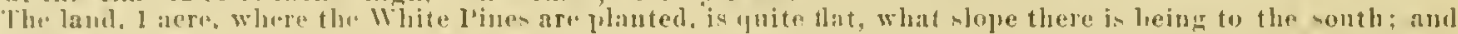

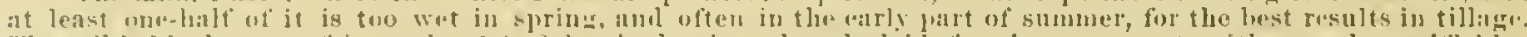

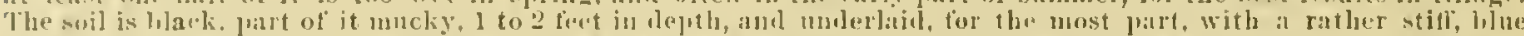

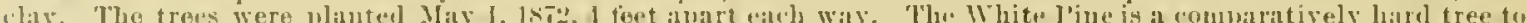

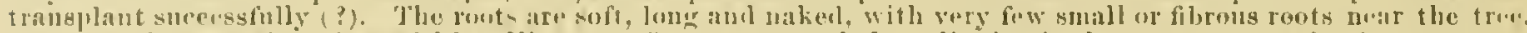

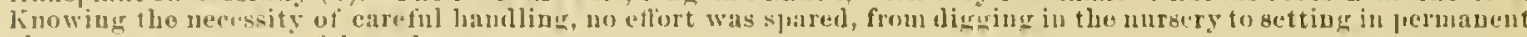
plice, to soriur. shecessin] results.

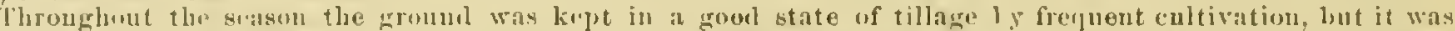

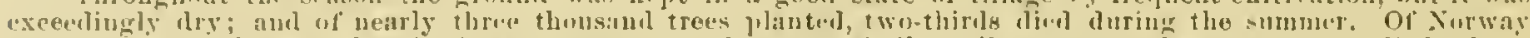

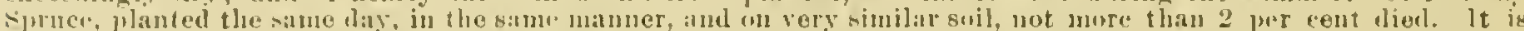

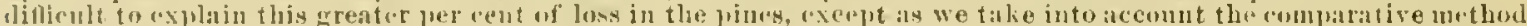

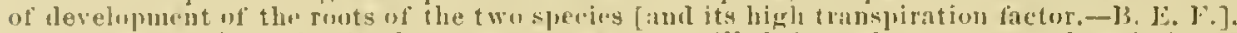

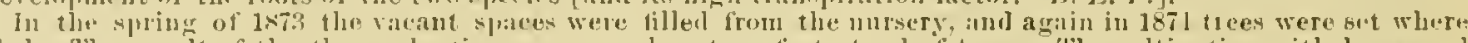

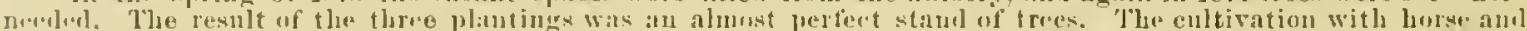

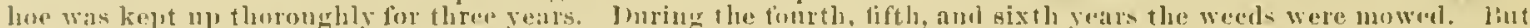

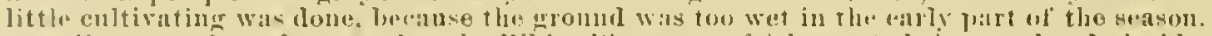

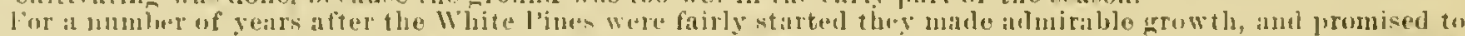

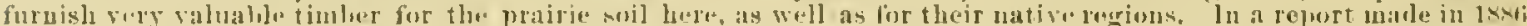

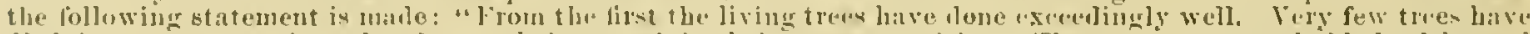

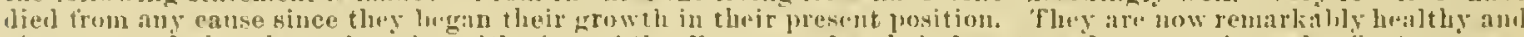

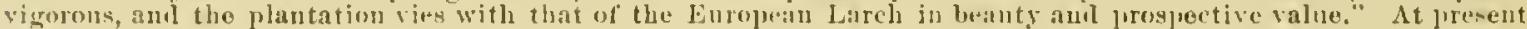
they are not inaintaining the early jurusise.

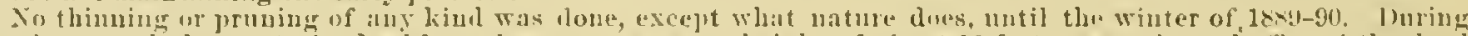

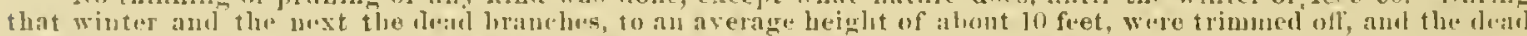

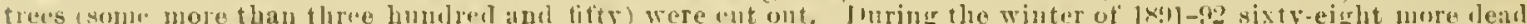

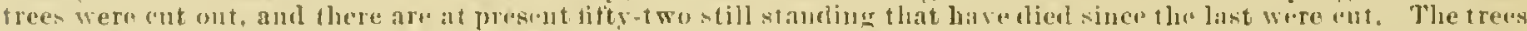

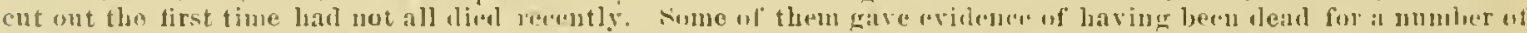

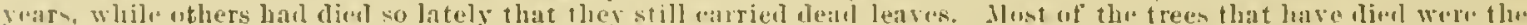

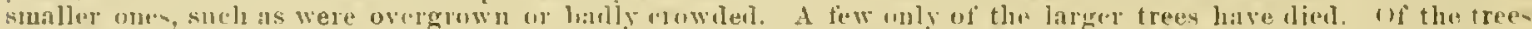

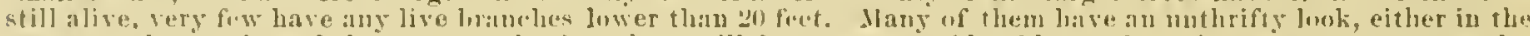

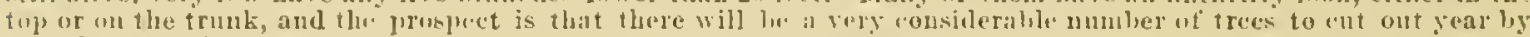
veal fur some time.

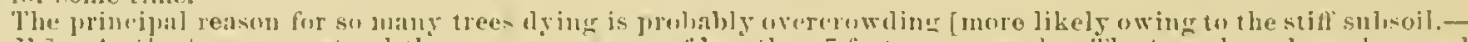

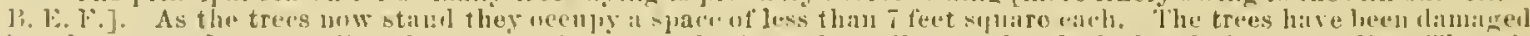

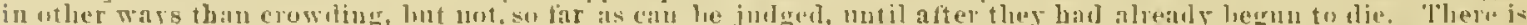

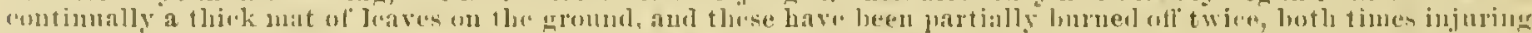

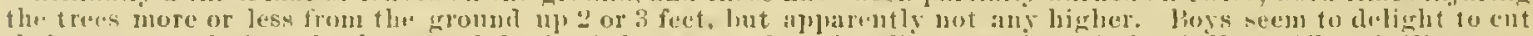

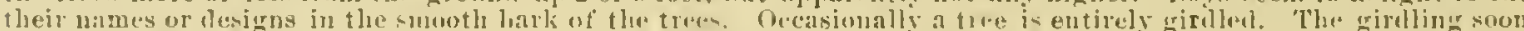

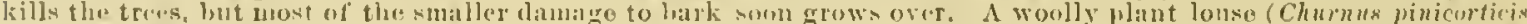

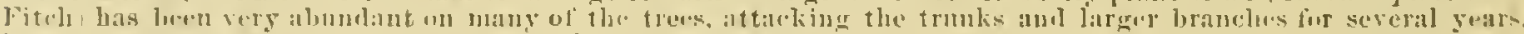

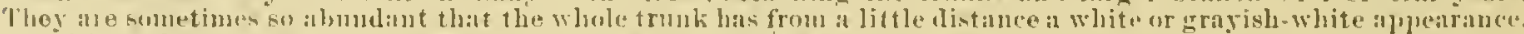

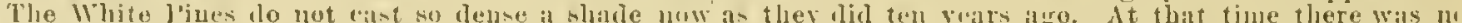

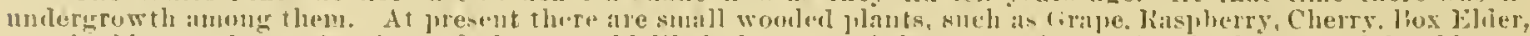

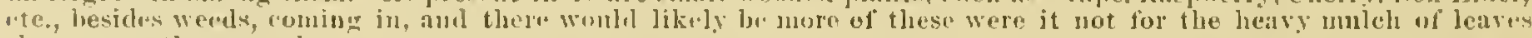
this novers tha is round.

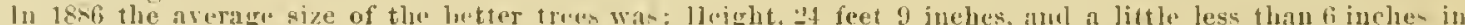

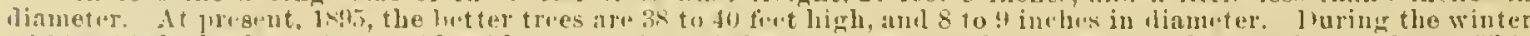

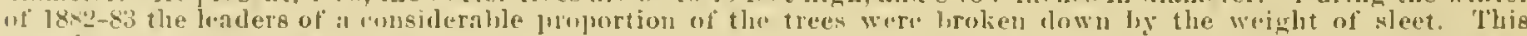

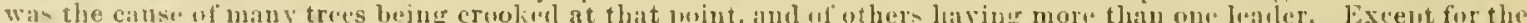

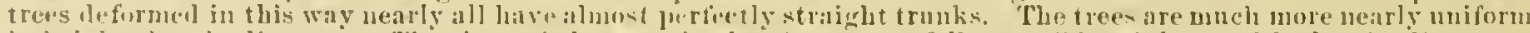

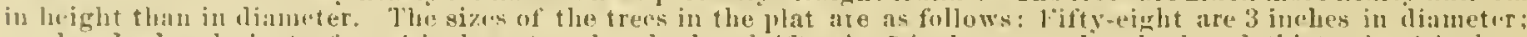

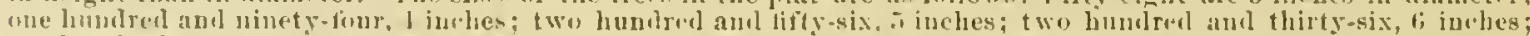

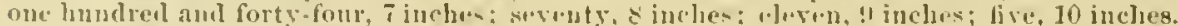

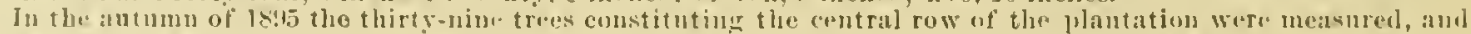

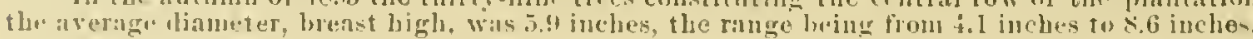

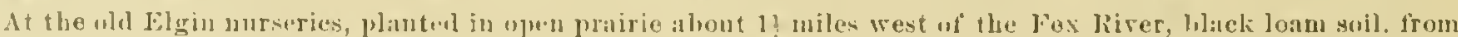

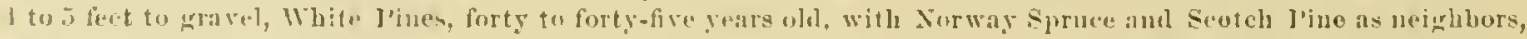

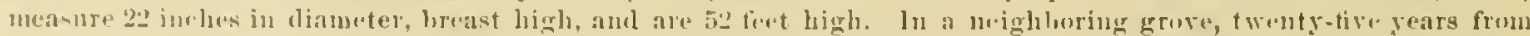

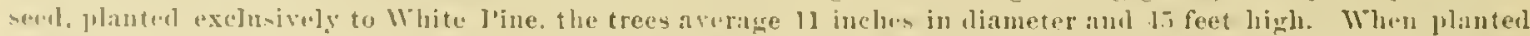

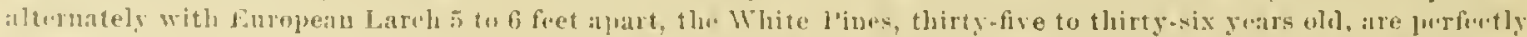

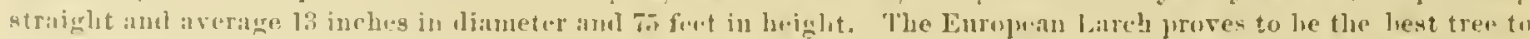

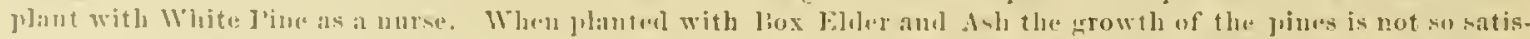

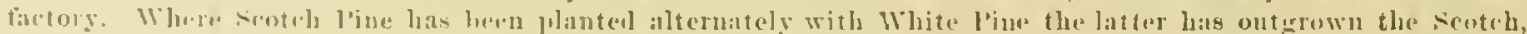

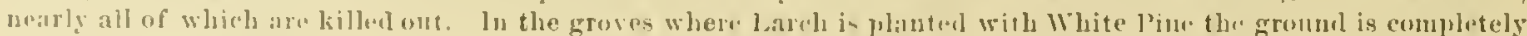

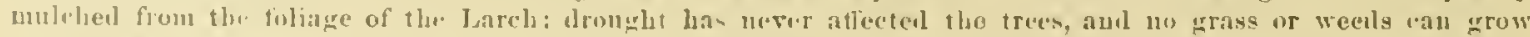

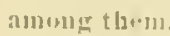

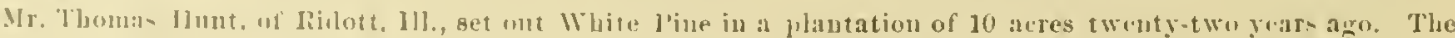

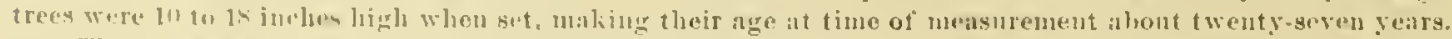

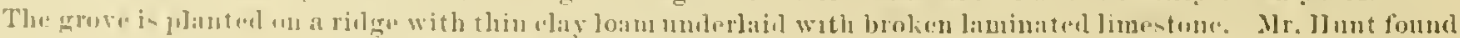

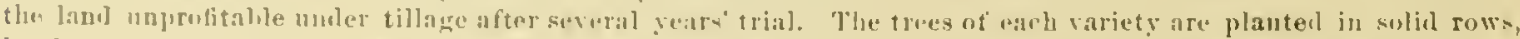

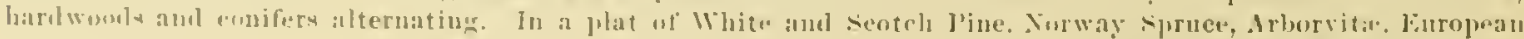

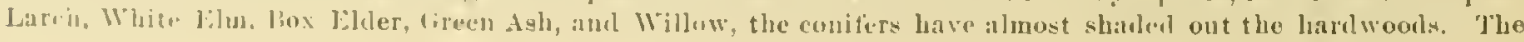




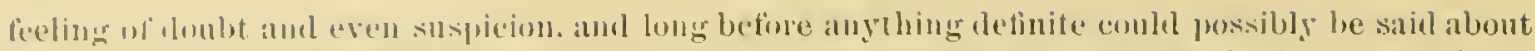

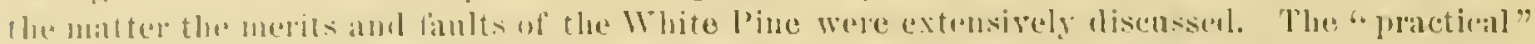

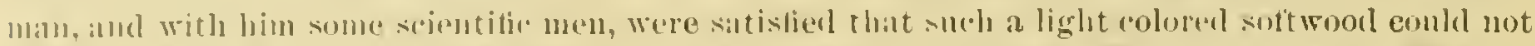

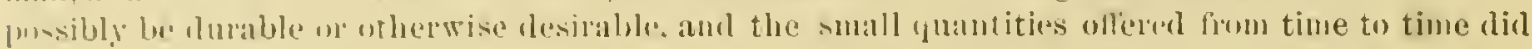

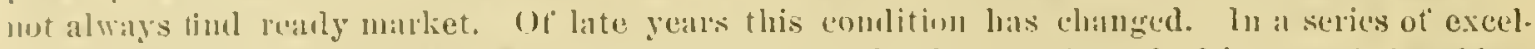
lent anticles. D)r. L. Wappes, a Bavarian forester, records the experience bad in whe of the oldest bondies of White l'ine in fiermany, in which he shows that the tree in pure growth, and also as

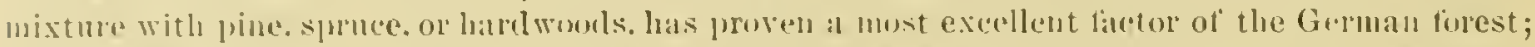

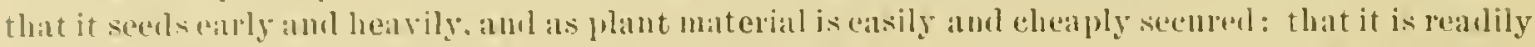

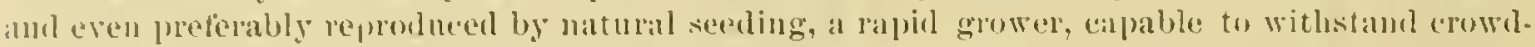
jug and shading, and that it is a tree especially calbable of prodneing a large anomnt of timber eren on pror soils. all of which eoiucides with the observations on its native habitat lairl dow in

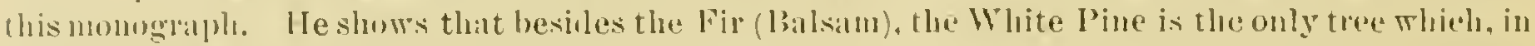
the l'alatinate and on pool soils will, at the age of one humlred and ten year's, malie timber of Class I

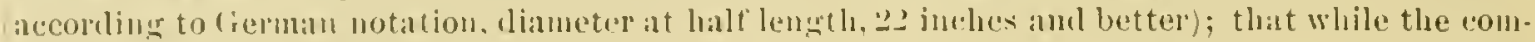
mon pino at that age lumishes mily l:3 per cent of Class Ill and better (diameter 12 inches and nver), the White l'ine furnishes $2-7$ per eent, or more than donble this amont of these and more raluable dianeter classes. Dr. Wajpes emplatieally states that White l'ine, wherever known, is eagerly bonght, and that the opinion of the cunsumers las ralically changerl. IIe proves by the tignres of large sales from the state dinests, that sinee $155^{2}$ the value of White line has nearly lonbled, while that uf spruce and conmon Scotoh Pinc has increased hy only 20 per cent, and that of Fir and Lareh has actually deched during this periot. The following figures give an idea of the growth of White l'ine abroal. The groves of the l'alatinate are stoeked on very inferior soil, nearly all other groves rited being on loamy sand. The figures for total volume are somewhat mislealing, since they do not inchue the timber which has heen removed from the older groves in thinnings, which would ald probably from 10 to 15 per rent to make w whole production.

It will be of interest to give more in detail the conditions of the last-mentioned plantation, reported this year in 1)r. Lorey's Allgemeine Forst und Jaglmeitung:

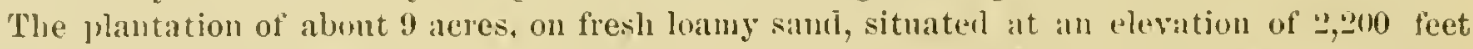
above sea level in Wurtemberg, (onsists of White Pine mixed with Seoteh P'ine, Sprnce, and Fir in single individuals or uroups. The White Pine represents, mumerically, two-thirds of the total number, scotols line is fimma anong the dominant growth in part, but the Sluruce and the small unmber of Firs show only codominant and oppressed trees.

The density of the glowth was reported as satistictory until in 1855, when a snowstorm broke down much material, so that at present the density does not average over (). $\overline{\text {. }}$.

The stand, uriginating from seed, was several times thimed, and the last time, occasioned by the smowstorm, 400 Whlite l'ines were remored, with orer 10,000 enlsie feet of woorl. The mumber of trees areraged 183 per ace, of which 142 White l'ines, with dianeters varying from $i$ to 24 inehes, and 16 inches in the average, yialded altogether 9,jlo cubic teet, while the other species

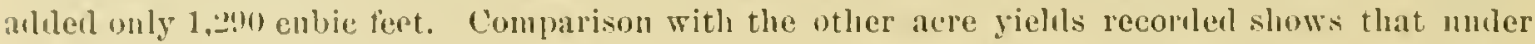
these conditions the proluct was less than in more firored situations, either the site or light couditions reducing the growth.

The cliameters represented an at simple anea were distributed as follows:

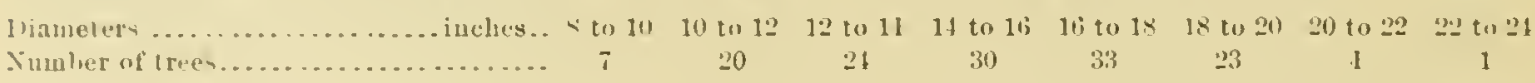

Of the Srotch Pines only fonr han reached dianeters over 16 inches, and of the Spmees mone wer I.t inelies. The superiurity of the White l'ine also appears from the comparison of height wrowth, which was establisherl for every tive years ly the measurement of avelage sample trees, ils tisllows:

Height grouth of Whic l'ue, scotch l'ine', and sipruse, by years.

\begin{tabular}{|c|c|c|c|c|c|c|c|c|c|c|c|c|c|c|c|c|c|c|}
\hline \multirow{2}{*}{ sample traes. } & \multicolumn{18}{|c|}{ A-e (gears) and height growth (in fent). } \\
\hline & $\therefore$ & 10 & iij & 0 & 9.5 & 30 & Bij & 11) & (i) & in) & inj & Go & ii.; & $\because 1$ & $\therefore$ & $\rightarrow 1$ & Sij & 96) \\
\hline Whit, l'mu luwiglat growth. & 2. 1 & 9 & 18 & 29 & 32 & 4.5 & 52 & 80 & 65 & it & 76 & $\$ 1$ & 85 & $5 ! 1$ & 92 & 95 & 47 & 1000 \\
\hline Scrulch l'ine lielght growili... & 4 & 1: & 20 & 29 & 35 & 42 & t:! & is & 60 & 65 & 69 & .ii & $\because$ & 80 & 82 & $\times 6$ & हो: & 68 \\
\hline spruce height trowth ..... & 2 & 8 & 16 & 24 & $3 i$ & 12 & fis & 34 & 39 & 63 & bi: & .2 & 75 & is & $\therefore 0$ & $8:$ & ef & $\therefore 0$ \\
\hline
\end{tabular}


The preceling table shows how the slow growth of the first five vears which the White l'ine has in eommon with the Norway Spune is oveleome hetore the fifternth yar. and ley the twen. tieth year the White Pine has distanced the Scotels l'ine, gaining un it comstantly mutil, lyg the ninctietl year, it has outgrown it l丷' per rent.

Limensions and yirlds of thite l'ine in liermen forests.

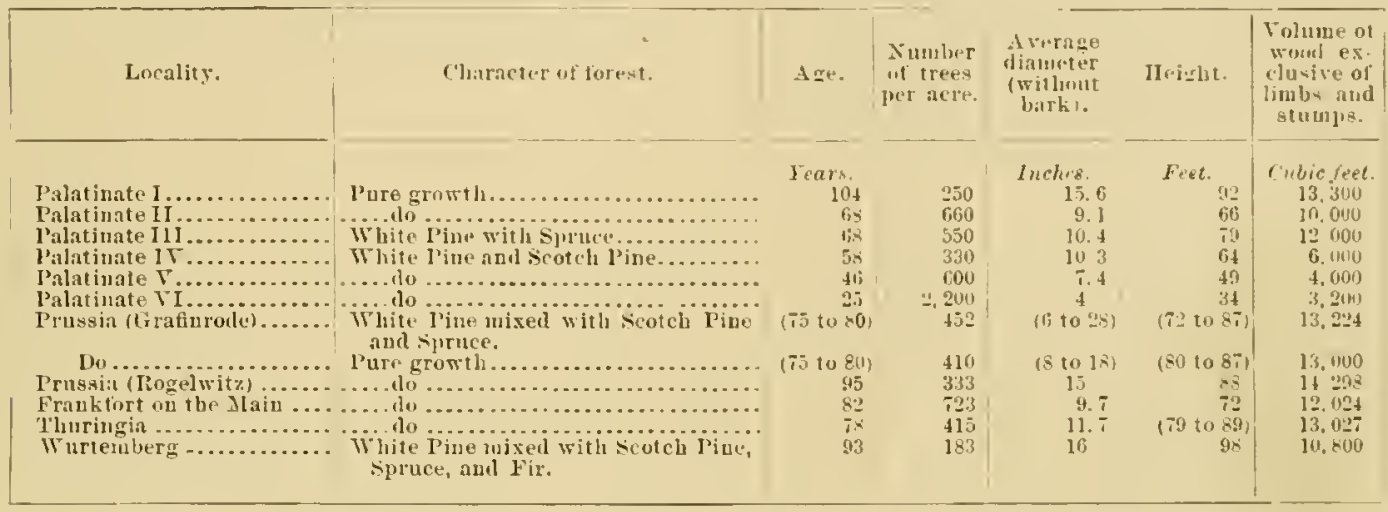

From these tigures the capacity of the White Pine to produce large amounts of valuable stcunmood is apparent. Thus, on soil on which the 100-year-old trees rleveloped only a height of as feet, over 13,000 rnbic feet of stemmood, corresponding to about 6010,000 to $71,000 \mathrm{feet}$ L. MI., American scale, whe eut per acre over and above about 1,2no eubic feet of material remorerl in previons thinnings. In every ease the White Pine excels the common pine, and even the spruee in this respect. It should be added that most of these plantations, made in the early part of this century, were not executer according to present superior methods, the species being an exotic and expensive was set ont more in orchard fashion, as most plauters in our combly have been apt to do, at distances of $\mathrm{S}, 12$, and more feet apart. Owing to this faet the development was probably not as satisfaetory in the earlier years as it might have beon had the method of close plantiug. either pure or in mixtme, prevailed.

The superiority of growth over the Gernan Spruce and Pine is more fully illustrated in the following table, which shows the distribution and proportion of trees of White I'inc and Spruce and of White Pine and Scoteh Pine that are found in given diameter classes in two mixed planted growths of these species:

Distribution and proprortion of Thite line and sprure and TThite Pine aud scotch Pine.

\begin{tabular}{|c|c|c|c|c|c|}
\hline \multicolumn{3}{|c|}{$\begin{array}{c}\text { White Pine am Norwas suruce, } \\
\text { sisty-eiglit yenrs blil. } \\
\text { [65 percent I'une: } 35 \text { per cent } \\
\text { spruce.] }\end{array}$} & \multicolumn{3}{|c|}{ 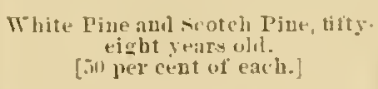 } \\
\hline $\begin{array}{l}\text { Diameler } \\
\text { of trees. }\end{array}$ & $\begin{array}{l}\text { Whiti. } \\
\text { I'ine. }\end{array}$ & $\begin{array}{l}\text { Jurway } \\
\text { spruct. }\end{array}$ & $\begin{array}{l}\text { 1) ianuter } \\
\text { of trotes. }\end{array}$ & $\begin{array}{l}\text { White } \\
\text { line. }\end{array}$ & $\begin{array}{l}\text { Seutch } \\
\text { l'inte. }\end{array}$ \\
\hline Incties. & Percent. & Per cent. & Inches. & Per cine. & Iter cent. \\
\hline $4 t 06$ & (1) & 1. 5 & 4 to1 & 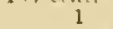 & \\
\hline if to $c$ & 15 & 30 & 8 & & 38 \\
\hline$x$ to 10 & 3i) & 27 & 8 & 18 & $3=$ \\
\hline 10 to 12 & 22 & 26 & & $\because 6$ & 24 \\
\hline 12 tol4 & 20.5 & 6. 8 & 12 to 14 & 23.5 & 49 \\
\hline 14 in 16 & 11. 5 & .... & if to & & 1.6 \\
\hline 101018 & 1.5 & $\cdots$ & Ifis to & 2.4 & \\
\hline & & & 18 to 20 & 1 & \\
\hline
\end{tabular}

It appears that nearly 32 per cent of the White Pine is over 12 inclies in diameter. as against less than 7 per cent of the Spluce, while 35 per cent of White pine, as against 6.5 per cent of Scoteh Pine, developed over 12 inches in the mixture of these two. and wrer li per cent of the former belongs to sizes above 14 inches, which is hardly reached at that age by its competitor. These figures prove clearly that the White Pine excels the Scoteh Pinc even during the and of 
mest rapiel growth, sin that the ditference. in view of the stealy growth of White l'ine amb the

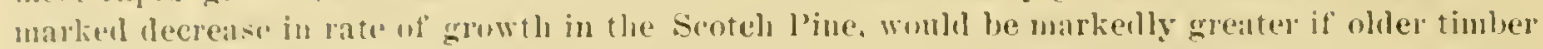
batl been compared.

Just as in its native range, the White I'ine is deedellly a heart jine, the sapwood changing

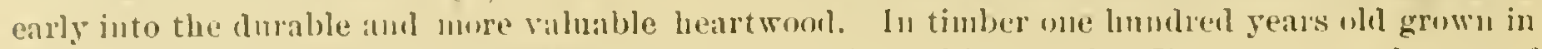

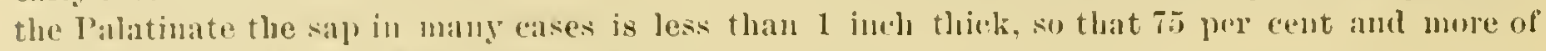
the entire sten is composed of heart wood.

In vien of these fucts it is yute safe to say that the White l'ine in the tuture will he one of the frominent forest trees of Cinmany and jerlanps of Enrope, as it will always be the ling of wools in our Fortheru and Eistern states. 
THE WOOD OF THE WHITE PINE. 



\title{
THE WOOD OF THE WHITE PINE.
}

\author{
By Fillater lioth, Nirision of Forestry.
}

White Pine is a farorite material with the wood consmuer in the Nortleastern States on accomint of the combiuation of qualities it possesses. It is a light, soft, uniform, straight.nrained timber, to be had in all markets in any quantity and in all dimensions, from the ship's mast to the clapboard. It seasons rell, slirinlis and malus but little, is quite durable, insect-proof, aud takes oil and paint and has a good color, is light to landle, easy to saw and plane, talies nails withont splitting. and is, in short, the ideal material for the carpenter and joiner, who lundles the bulk of the 30 to 40 billion feet of sawed timber and lumber ammaliy used in this conutry, of which White l'ine furnishes orer 30 per cent.

\section{CHARACTER AND PHYSICAL PROPERTIES OF THE WOOD.}

The structure of White I'ine, like that of other pines. is simple. Ninety per cent and more of the weight of the dry rood is formed by the common wool fibers, or traclieids, 0.12 to 1.20 inches long. well suited for pulp material. The spring wood ot each ammal ring passes gradually into the summer wood and thus the sharply defined bands of hard, dark and soft, light-colored naterial so conspienons in the rings of all hard pine, especially Longleaf and Cnban Pine. are absent in White Pine, makiug the entting of the rood ly either plaue or sam much easier than is the ease with hard pines. Sapwood and heartwood are quite distiuct--the former white. the latter with a slightly brownish cast. The change from saprood to heartrood takes place earlier in the young tree and the younger portions of old trees than in older timber. Thus, in a thrifty sapliug thirty gears old the sapwood shows about eighteen rings on the stump. but only ten rings 35 feet from the gromul. In trees over one hundred years old the muber of rings in the saprood is generally over thirty at the stump. decreasing often to fifteen or twenty near the top. The unmber of rings in tlue sap. as in other pines, is sualler in thrifty and greater in slow-growing trees, while the width of the sap) rood is generally least in slow-growing timber. Compared to other pines, White Pine has a narrow sap at all periods of its growtl. While in the hard pines. like the Longleaf Pine, and still more in Loblolly and Shortleaf Pines, the sa] forms gencrally from $\tilde{50}$ to $\pi j$ per cent of the log, it is generally less than $3 \pi$ per cent of nill-sizer timber in White Pine. This highly valuable property of the White Pine is found in all localities, even in Europe, where the tree has been willely jlanter?.

\section{SPECIFIC WEIGHT.}

To determine specific the reight of the rood and other physical properties a collection of serenty-three trees was male, inclubing material from the Yew England States, Michigan. and Wisconsin, and also from the mountains of North Carolina.

The specific weight of the greenwond varies ehiefly with the amount of sapwood and cousequent abundance of moisture, since the heartwood contaius but little water ontside of its rell walls (except in some cases where the heartwood neal the stump also contains liquid mater). Generally the weight of the greenwool varies from about 40 to 50 pounds per c'nbic foot, aud is greater in youngr joles than in old timber. which latter on this acconut floats readily, rarejy siuk. ing, even after years of immersion.

The specific reight of the kiludry wool varies, generally from 1.33 to 0.40 (200 to 25 pounds per cubic foot), is greater in the old tree than in the young sapling, is greater at the stmmp than 
fartluer 11 in the same strm, is indepundent of orientation (as great on the nortls sile as on the

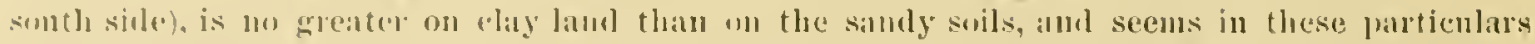
quite independent of len'ality. The wool tron the swanu trees is no heavieg nor lighter than the

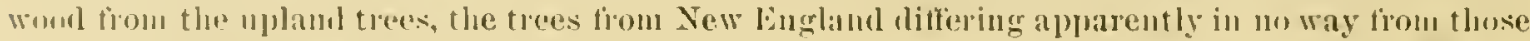
of either the Lalk" region or Yorth Cambinil.

Leaving ont of ronsideration the speritic weight of the limbs and linots (these being always heary, as in all pines), the average specitic weight of the dry wood of the stem wis fomm to be for-

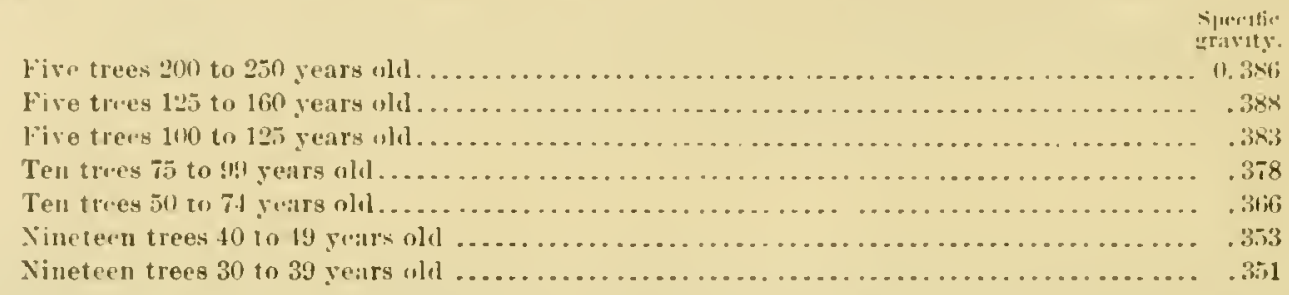

from the above, and still more from the table following, in which the trees are gronped aceorling to age, it will be seen that White Pine displays a miformity of specific weight, and otluer properties dependent on weight, such as is entirely unknown in any other jine of the Eastern United States.

Alerage weight (kiln dry and green), moisture content, and shrinkage per cent of White l'ine.

I. TILEES 200 TU 250 YEALS ULW.

\begin{tabular}{|c|c|c|c|c|c|c|c|c|}
\hline \multirow{2}{*}{ Locality. } & \multirow{2}{*}{$\begin{array}{l}\text { ")riginal } \\
\text { number of } \\
\text { trees. }\end{array}$} & \multirow{2}{*}{$\begin{array}{l}\text { Approsi- } \\
\text { mate age } \\
\text { of trets. }\end{array}$} & \multirow{2}{*}{$\begin{array}{l}\text { Dianeter } \\
\text { breast high } \\
\text { without } \\
\text { bark. }\end{array}$} & \multirow{2}{*}{$\begin{array}{l}\text { Width of } \\
\text { riugs. }\end{array}$} & \multicolumn{2}{|c|}{ Specific grarity $\times 100$. } & \multirow{2}{*}{$\begin{array}{l}\text { Moistureas } \\
\text { per cent } \\
\text { nf the } \\
\text { weight or } \\
\text { dry wood. }\end{array}$} & \multirow{2}{*}{$\begin{array}{l}\text { Shrinkage } \\
\text { in rolune }\end{array}$} \\
\hline & & & & & Filn dry. & Green. & & \\
\hline 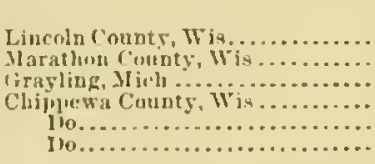 & $\begin{array}{r}5 \\
16 \\
3 \\
1 \\
2 \\
3 \\
3\end{array}$ & $\begin{array}{r}\text { Vears. } \\
525 \\
250 \\
2015 \\
219 \\
202 \\
202\end{array}$ & $\begin{array}{r}\text { Inchrs. } \\
23.0 \\
22.0 \\
19.0 \\
27.0 \\
19.4 \\
10.5\end{array}$ & $\begin{array}{l}1.1 \\
1.8 \\
1.6 \\
1.0 \\
1.2\end{array}$ & $\begin{array}{l}38.1 \\
38.5 \\
36.0 \\
39.11 \\
38.5 \\
39.2\end{array}$ & $\begin{array}{l}69 \\
62 \\
64 \\
66 \\
66 \\
67\end{array}$ & $\begin{array}{r}\text { Percene. } \\
93 \\
74 \\
95 \\
85 \\
100 \\
81\end{array}$ & $\begin{array}{r}\text { Per cene. } \\
7.6 \\
8.6 \\
4.5 \\
8.9 \\
8.0 \\
7.9\end{array}$ \\
\hline Arurage. & $\cdots$ & 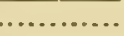 & ....... & $\cdots$ & 38.6 & 65 & 88 & 8.1 \\
\hline \multicolumn{9}{|c|}{ II.-TREES 125 TO 160 YEARS OLD. } \\
\hline 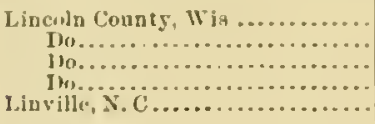 & \begin{tabular}{r|r}
1 \\
2 \\
3 \\
4 \\
458
\end{tabular} & $\begin{array}{l}146 \\
140 \\
141 \\
140 \\
158\end{array}$ & $\begin{array}{l}19.0 \\
2.0 \\
2.0 \\
15.0 \\
33.0 \\
33.0\end{array}$ & $\begin{array}{l}1.5 \\
1.9 \\
1.0 \\
1.2 \\
2.1\end{array}$ & $\begin{array}{l}42.0 \\
36.4 \\
38.4 \\
40.5 \\
37.1\end{array}$ & $\begin{array}{l}74 \\
72 \\
65 \\
72 \\
72\end{array}$ & $\begin{array}{r}92 \\
113 \\
92 \\
81 \\
110\end{array}$ & $\begin{array}{l}9.0 \\
8.7 \\
9.1 \\
9.8 \\
.7\end{array}$ \\
\hline A rerage..... & .... & $\ldots \ldots \ldots$ & ............. & n........... & 28.8 & $\pi$ & 95 & 8.3 \\
\hline \multicolumn{9}{|c|}{ III.-TIREES } \\
\hline 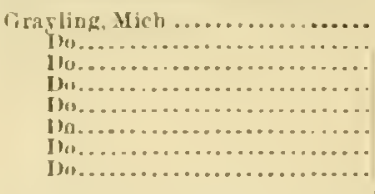 & $\begin{array}{r}1 \\
2 \\
4 \\
5 \\
7 \\
8 \\
9 \\
10 \\
\end{array}$ & $\begin{array}{l}110 \\
122 \\
114 \\
105 \\
115 \\
108 \\
112 \\
111\end{array}$ & $\begin{array}{r}17.5 \\
17.7 \\
9.5 \\
7.5 \\
7.8 \\
7.8 \\
7.8 \\
5.0 \\
\end{array}$ & $\begin{array}{r}2.2 \\
1.8 \\
1.1 \\
1.0 \\
1.2 \\
1.3 \\
.8 \\
\end{array}$ & $\begin{array}{l}36.0 \\
35.0 \\
34.8 \\
38.3 \\
41.8 \\
38.9 \\
38.0 \\
36.7 \\
\end{array}$ & $\begin{array}{r}64 \\
64 \\
79 \\
70 \\
101 \\
78 \\
85 \\
71 \\
\end{array}$ & $\begin{array}{r}96 \\
99 \\
120 \\
121 \\
138 \\
122 \\
14 \\
109 \\
\end{array}$ & $\begin{array}{r}9.2 \\
9.0 \\
9.8 \\
8.5 \\
10.5 \\
8.8 \\
8.8 \\
8.5 \\
\end{array}$ \\
\hline Iverage... & ... & ........ & ...... & …........ & 38.3 & 74 & 119 & 8.9 \\
\hline \multicolumn{9}{|c|}{ IV.-TIEES 75 TU 100 YEAIES OLD. } \\
\hline 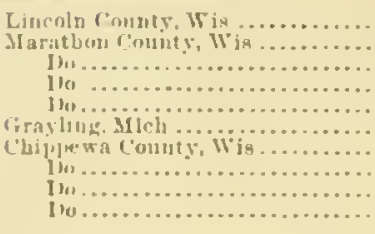 & $\begin{array}{r}6 \\
12 \\
13 \\
14 \\
15 \\
6 \\
i \\
6 \\
\vdots \\
\vdots\end{array}$ & $\begin{array}{l}75 \\
84 \\
90 \\
81 \\
95 \\
93 \\
83 \\
94 \\
44 \\
78\end{array}$ & $\begin{array}{r}4.1 \\
14.0 \\
12.0 \\
15.0 \\
10.0 \\
7.0 \\
7.0 \\
6.3 \\
10.4 \\
10.2\end{array}$ & $\begin{array}{l}0.8 \\
2.0 \\
2.1 \\
2.7 \\
1.4 \\
1.6 \\
1.5 \\
1.0 \\
2.4 \\
1.2\end{array}$ & $\begin{array}{l}30.3 \\
3: 1.4 \\
37.0 \\
37.0 \\
40.4 \\
41) .1 \\
36.3 \\
37.0 \\
37.1 \\
38.5\end{array}$ & 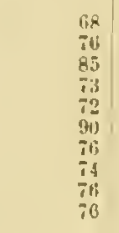 & $\begin{array}{c}111 \\
111 \\
118 \\
121 \\
84 \\
193 \\
132 \\
115 \\
118 \\
119\end{array}$ & $\begin{array}{l}8.4 \\
8.0 \\
9.8 \\
4.0 \\
9.4 \\
8.7 \\
9.8 \\
8.0 \\
19.8 \\
8.7\end{array}$ \\
\hline Arerago..... & $\cdots$ & & ....... & n......... & 37.4 & 76 & 112 & 9.0 \\
\hline
\end{tabular}


SPECIFIC WEIGHT OF WOOI.

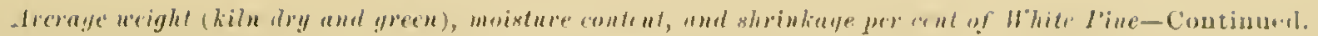

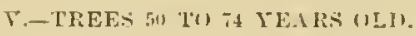

\begin{tabular}{|c|c|c|c|c|c|c|c|c|}
\hline \multirow[b]{2}{*}{ Locality. } & \multirow{2}{*}{$\begin{array}{c}\text { Orteginal } \\
\text { נmumber of } \\
\text { treeg. }\end{array}$} & \multirow{2}{*}{$\begin{array}{l}\text { A pproxi- } \\
\text { matte ages } \\
\text { of trees. }\end{array}$} & \multirow{2}{*}{$\begin{array}{l}\text { Dianct:r } \\
\text { Lreast hith } \\
\text { without } \\
\text { birk. }\end{array}$} & \multirow[b]{2}{*}{$\begin{array}{c}\text { "idith ut" } \\
\text { riugu. }\end{array}$} & \multicolumn{2}{|c|}{ Sporitle prasity - 100.} & \multirow{2}{*}{$\begin{array}{l}\text { Moisture:as } \\
\text { jer cent } \\
\text { of the } \\
\text { weight of } \\
\text { diry wool. }\end{array}$} & \multirow[b]{2}{*}{$\begin{array}{l}\text { Shrinkage } \\
\text { in rolum. }\end{array}$} \\
\hline & & & & & Kibu dry. & liretn. & & \\
\hline Lincoln Countr, Tis..... & $\pi$ & Tears. & Irehes. & mom. & 34,3 & 80 & I'er cene. & ler crut. \\
\hline 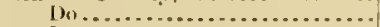 & s & 50 & 2.0 & .7 & 39.3 & 70 & & $\approx 5$ \\
\hline $\mathrm{I} \mathrm{J}_{0} \ldots \ldots \ldots \ldots \ldots \ldots \ldots \ldots \ldots$ & 11 & 52 & 5.5 & 1.7 & 33.8 & af & .. & 0.6 \\
\hline ('hiplewa County, wis ........... & 8 & 65 & 8.0 & 29 & $3 \times .7$ & 76 & 122 & 9.0 \\
\hline $10 \ldots \ldots \ldots \ldots \ldots$ & 4 & 73 & 7.0 & 1.5 & 39.0 & 64 & 84 & 10. 1 \\
\hline$\eta_{0} \ldots \ldots \ldots \ldots \ldots \ldots \ldots$ & 10 & 67 & 4.2 & 1.2 & 35.7 & $\because 2$ & 121 & 8.0 \\
\hline Plimouth County, Mass.......... & 1 & 50 & 13.0 & 4. 1 & 35.3 & 68 & 112 & 8.6 \\
\hline $10 \ldots \ldots \ldots \ldots \ldots \ldots \ldots \ldots$ & 4 & 52 & 11.0 & 2.8 & 38.5 & 73 & 106 & 8.6 \\
\hline Torcester County, Hass . . . . . . . & 16 & 54 & 14.0 & 3.6 & 39.0 & 68 & 93 & 8.4 \\
\hline Do $\ldots \ldots \ldots$ & 17 & 65 & 10.0 & 2.4 & 36.5 & 67 & 105 & 7.3 \\
\hline$D_{0} \ldots \ldots \ldots \ldots \ldots \ldots \ldots \ldots \ldots \ldots$ & 18 & 60 & 10.0 & 2.3 & 35.5 & & & 7.5 \\
\hline Arerage & & ... & o & & 36.8 & 74 & 115 & 8.0 \\
\hline
\end{tabular}

TT. TIEES 40 TO 49 VEA lis OLD

\begin{tabular}{|c|c|c|c|c|c|c|c|c|}
\hline Lincoln Connty, Wis ............ & 9 & $\$ 8$ & 2.3 & 0.6 & 43.3 & 81 & 102 & 8,3 \\
\hline Do $\ldots \ldots \ldots \ldots \ldots \ldots \ldots$ & 10 & $\$ 7$ & 6.0 & 2.0 & 31.3 & 86 & 162 & 8.9 \\
\hline Marathon County, $\mathbb{W}$ is .......... & 17 & 40 & 6.0 & 2.2 & 33.5 & 85 & 173 & 9.0 \\
\hline Do $\ldots . . . .$. & 18 & $\$ 0$ & 6.0 & 2.3 & 34.5 & N1 & 149 & 8. 6 \\
\hline 10 $\ldots \ldots \ldots \ldots \ldots \ldots \ldots \ldots$ & 19 & 40 & 2.0 & 1.1 & 33.7 & $7 I$ & 124 & 8. 3 \\
\hline Do $\ldots \ldots \ldots$ & 20 & 12 & 2.8 & 1. 0 & 35.0 & 67 & 105 & 8. 4 \\
\hline 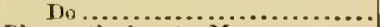 & 21 & 44 & 4.0 & I. 4 & 33.8 & 82 & 158 & 7. 9 \\
\hline Plymouth County, Mase .......... & 2 & 46 & 8.5 & 2.6 & 36.2 & 58 & 76 & 8. 4 \\
\hline Do & 3 & 45 & 9.2 & 3.0 & 36.2 & 65 & 95 & R. 5 \\
\hline Do $\ldots \ldots \ldots \ldots \ldots \ldots, \ldots, \ldots, \ldots$ & 5 & 49 & 13.7 & 3.9 & 35.0 & 61 & 93 & 8.4 \\
\hline Do $\ldots \ldots \ldots \ldots \ldots \ldots \ldots \ldots \ldots$ & 6 & 47 & 3.5 & 2.8 & 38.0 & 0 & 81 & 8. I \\
\hline Do........................... & 10 & 48 & 12.5 & 3.6 & 34.5 & 65 & 108 & 0.3 \\
\hline $1 n \ldots \ldots \ldots \ldots \ldots \ldots \ldots \ldots \ldots$ & 11 & 49 & 10.3 & 3.1 & 39.0 & 67 & $8 !$ & 9.3 \\
\hline Do & 12 & $46^{\circ}$ & 10.2 & 2.9 & 37.2 & 70 & 104 & 7.0 \\
\hline Worcester County, Iass.......... & 25 & 46 & 10.0 & 2.7 & 35.0 & 66 & 103 & 8.1 \\
\hline Do $\ldots \ldots \ldots$ & 26 & 45 & 12.8 & 3.8 & 35.5 & 67 & 306 & 8.6 \\
\hline Do & 27 & 45 & 9.1 & 2.6 & 37. 7 & -5 & 118 & 0.4 \\
\hline Merrimack Conuty, N, H $\ldots \ldots$. . & 32 & 41 & 10.3 & 3.4 & $3 \%, 0$ & 61 & 98 & 7.9 \\
\hline Do $\ldots \ldots \ldots$ & 33 & 40 & 8.6 & 3.1 & 31.7 & 64 & $1: 2$ & 8.4 \\
\hline A rerage...... & .. & ....... & 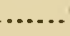 & & 35.3 & 70 & 113 & 8.4 \\
\hline
\end{tabular}

VII.-TIEES 30 TO 39 TEARS OLD.

\begin{tabular}{|c|c|c|c|c|c|c|c|c|}
\hline Maration County: Tis......... & 22 & 38 & +0 & 1.5 & 31.3 & $i$ & 162 & 8.2 \\
\hline Plymouth Connty, Mass .......... & 7 & 36 & 8.3 & 3,5 & 36.5 & 64 & 93 & 8.3 \\
\hline Do $\ldots \ldots \ldots \ldots \ldots \ldots \ldots \ldots \ldots$ & 8 & 34 & 9.1 & 3.4 & 35.2 & $66^{\circ}$ & 105 & 0.2 \\
\hline 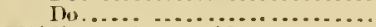 & 9 & 35 & 12.0 & 4.7 & 35.7 & 66 & 100 & 7.7 \\
\hline Milldlesex (ionts, ilass.......... & 13 & 38 & 11.0 & 3.4 & 35. 2 & it & 131 & 0.1 \\
\hline Do $\ldots \ldots \ldots \ldots \ldots$ & it & 38 & 10.8 & 3.6 & 33.7 & 74 & 147 & 8. 2 \\
\hline 10..., & 15 & 37 & 10.8 & 3.7 & 36.0 & 83 & $1+0$ & 7.5 \\
\hline Trorester County, Mass......... & 19 & 35 & 9. 2 & 3. 6 & 3f. 1 & 61 & 85 & 8.1 \\
\hline $110 \ldots \ldots \ldots$ & 20 & 33 & 11.2 & 4.8 & 33.10 & 65 & 108 & 7.0 \\
\hline Do......................... & 21 & 31 & 0.5 & 2.9 & 35.2 & 63 & 99 & 0.5 \\
\hline Do ${ }_{0} \ldots \ldots \ldots \ldots \ldots \ldots \ldots \ldots \ldots$ & 22 & 33 & 10.5 & 4.4 & 33.0 & 72 & 243 & 9.3 \\
\hline Do................................ & 23 & 36 & 9.2 & 3.6 & 35.2 & 68 & 111 & 8. 7 \\
\hline 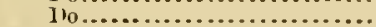 & 24 & 35 & 7,0 & 2.9 & 34.5 & 66 & 109 & 8. 2 \\
\hline Merrimack Counts, N. H .......... & 28 & 38 & 6.8 & 2.4 & 38.5 & 66 & 89 & 9.8 \\
\hline $110 \ldots \ldots \ldots$ & $8 !$ & 37 & 7.1 & 2.8 & 36.7 & 67 & 108 & 10.2 \\
\hline $110 \ldots \ldots \ldots \ldots \ldots \ldots$ & 30 & 37 & 8.2 & 3.11 & 36.7 & $i 1$ & 111 & 85 \\
\hline Do & 31 & 39 & 9.5 & 3.2 & 37.7 & 195 & 99 & 9.0 \\
\hline 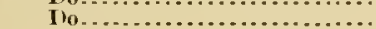 & 34 & 34 & 7.5 & 3.3 & 32.7 & 71 & 129 & $i .5$ \\
\hline 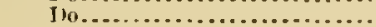 & 35 & 35 & 9.3 & 3.7 & 34.5 & 74 & 123 & 9. 2 \\
\hline Do & 36 & 35 & 10.3 & 3.9 & 30.0 & 64 & 147 & 8.0 \\
\hline A rerage.. & $\ldots$ & & & $\ldots$ & 35.1 & $6 s$ & 104 & 8.5 \\
\hline
\end{tabular}

VIII.-TTEES 20 TU 30 TEARS (ILI.

\begin{tabular}{|c|c|c|c|c|c|c|c|c|}
\hline 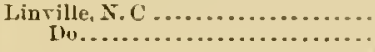 & $\begin{array}{l}450 \\
460\end{array}$ & $\frac{22}{26}$ & $\begin{array}{l}\text { 4. } 0 \\
\text { T. } 0\end{array}$ & $\begin{array}{l}2.7 \\
2.8\end{array}$ & $\begin{array}{l}3+.7 \\
36.9\end{array}$ & 83 & $\begin{array}{l}164 \\
156\end{array}$ & $\begin{array}{r}9.4 \\
10.2\end{array}$ \\
\hline Arerage.. & $\ldots$. & $\ldots$ & $\ldots$ & ... & 35.5 & 84 & 165 & 9.8 \\
\hline
\end{tabular}




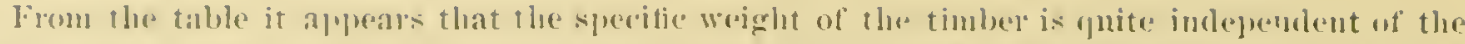

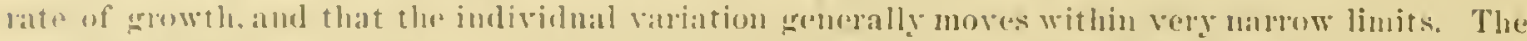

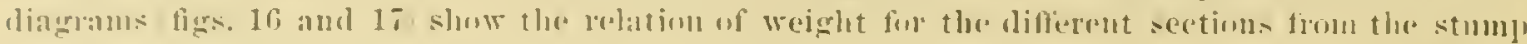

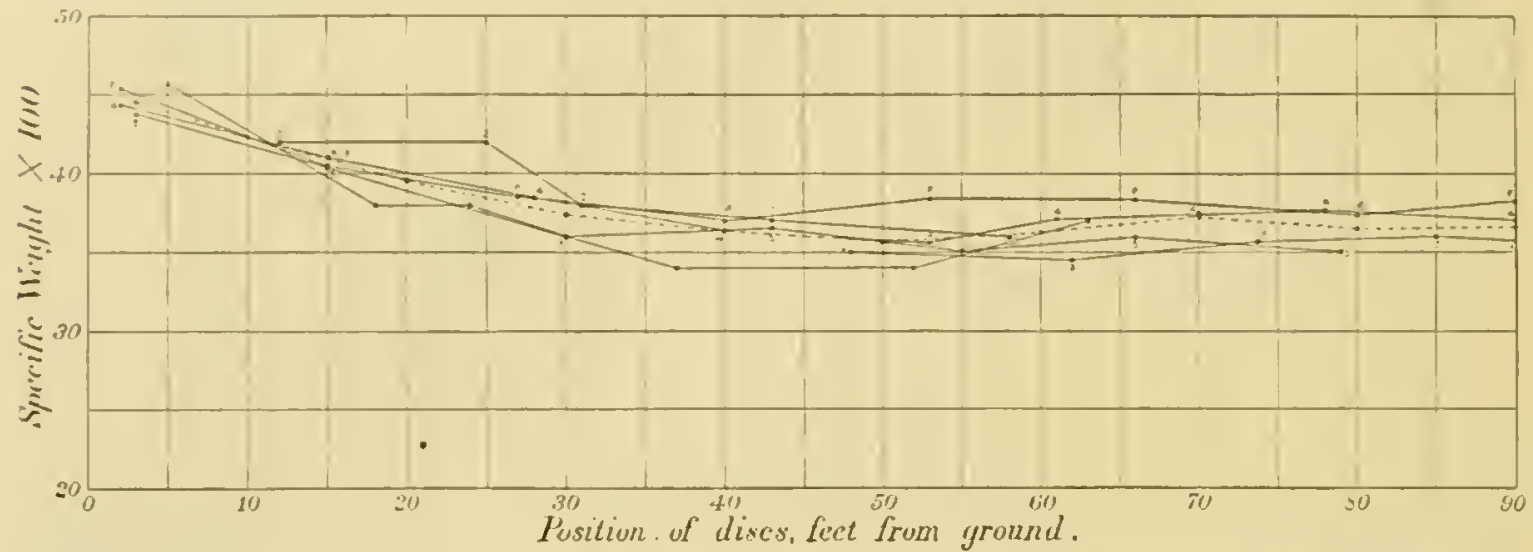

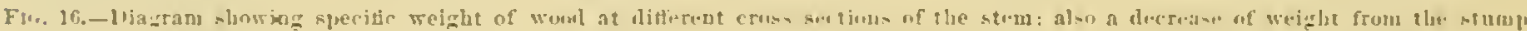

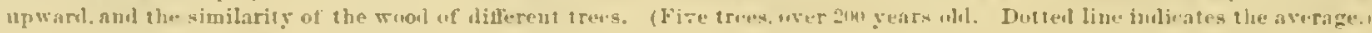

11]wal; the slightly greater weight of the older timber, as comparesl tu sajuling material. the

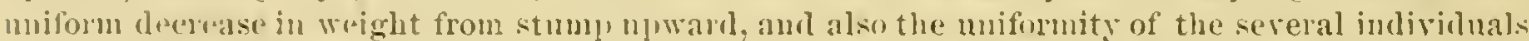
nt any grouj) of trees is (leatly apluatent from the lines. "The same decrease in weight from below

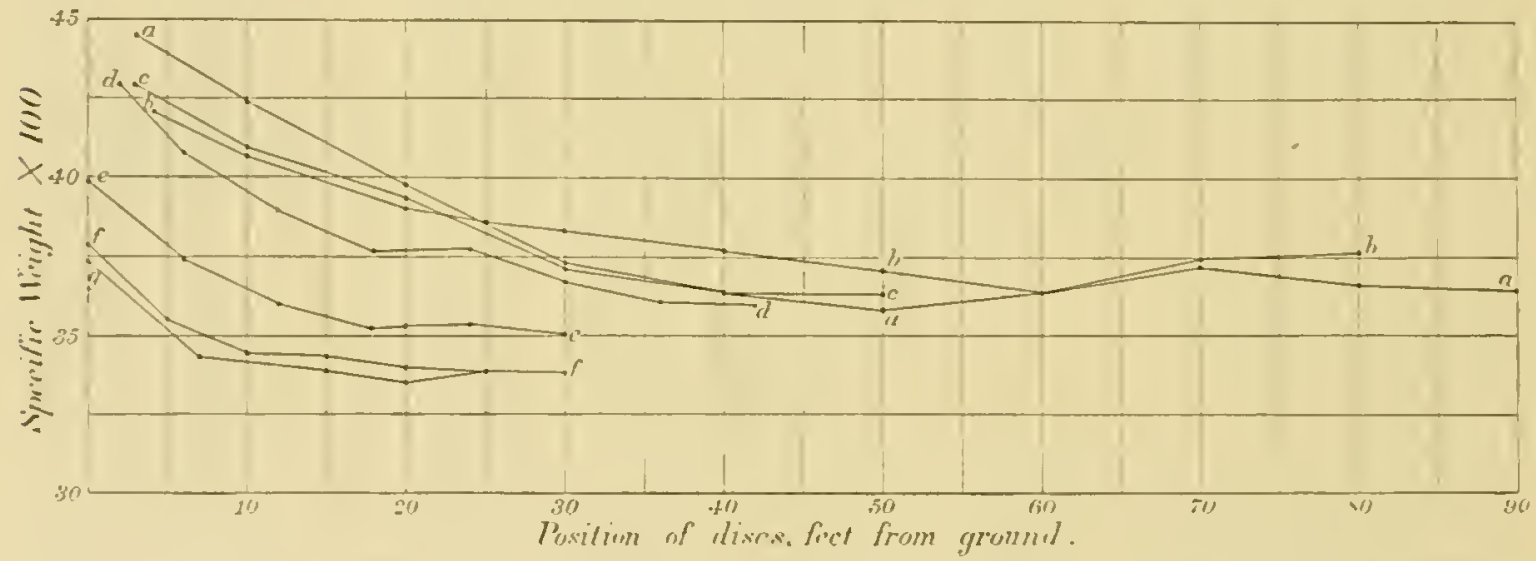

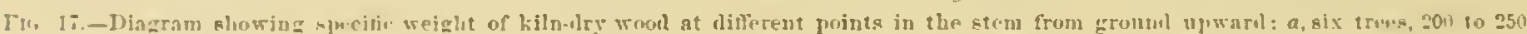

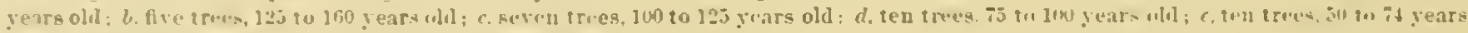

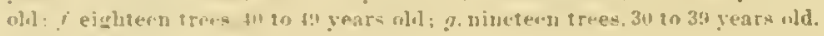

upward is observed in the wool of any given period of growth: thus, the woml uf the last forty riugs incext to the loak was fumel to le as follows:

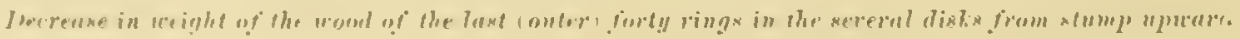

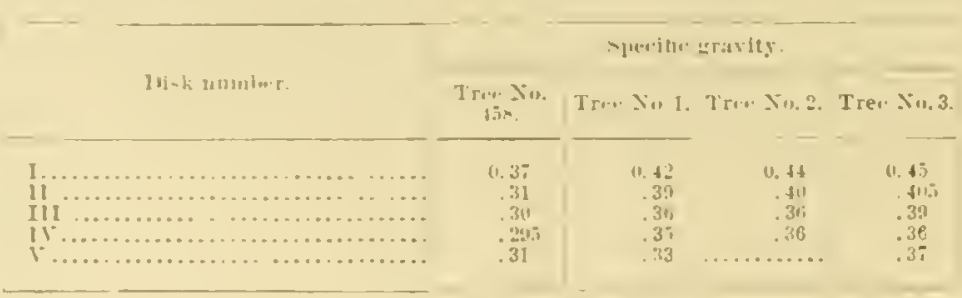


As in other pines, there is usually an inerease of weight 1 the crom, aprarently due to an influence of the limbs, but as this influence is local, so the apparent result is lombland the weiglit is very inegular for the crown part of the stem; the pronomeed increase is apmarent only in the immerliate vieinity of the limbs. The absence of a promuncel or sbarply detined summer woor makes it difficult and impucticable to apply the mieroseopic methous to deternine the variation of weiglit from pith to bark on any cross section. From the actual leterminations of weight, it appears that for the lower purtions of any normally grown tree there is usually at first an increase of weight from the pith outward, reaching a maximum somewhere hetween the tiftieth and eightieth ring, maintained for a long period and usually followerl by a fery show decrease in weight from there on ontward. 'This variation is generally small, and never reaches the proportions met in sections of haud pine, such as Longleaf P'ine, where it conmouly amounts to ij to 100 per cent of the weight of the lightest portion.

Isually alout halt the weight of a green $\log$ is water. The amount of moisture generally varies in the sapwoul from about 120 to 160 per cent am from to to bio per eent in the heartwonl, the amonnt for the (nitire log, theretore, rarging with the proportion wt salp and heart is greatest in saplings and least in large mature trees. in the latter from about 90 to 120 ler cent of tho weight of the timber after it is liin-elriel. The woor parts with its moisture as easily as any wool in the market, dries rapidly, with little injury, and may safely be kiln-dried fresh from the sitw, thongh in actual practice this method is almost unknown in the White Pine regions, the usual way of drying by carefully piling in immense piles, being the miversal way of seasoning. Well air.lried White I'ine, as in an orlinary room, still retains 8 to ! per eent noisture, and if muprotected by oil, paint, ete., is yuite susceprible to changes of humiclity, ausorbing and giving off moisture at every chauge of temperature and humility of the air.

\section{SHRINKAGE.}

In keeping with its smaller speeitic weight, the shrinkage of White Pine is less than that of other pines. It is greater for sap than heart, and therefore greater for sapling timber than for older trees. From the table on page it it appears that the shrinkage in volume varies for the several groups of trees from $s$ to 9 per cent, and, like the weight, is quite miform for the diftereut indiviluals of each group.

The ease and rapiclity with which White Pine seasons, and the manner of distribution of White Pine lumber, encouraging proper scasoniug before use, lave done much to earn for White Pine the fame of being one of the wools which to "not shrink" nor " work," a virtue which is not only iu part due to the suball weight aud couseqnent small shrinligage, but is largely the result of proper hambling.

\section{STRENGTH.}

Being the lightest, White Pine is also the weakest among the pines of the Eastern Luiterl States, as aplears from the following general arerage:

\begin{tabular}{|c|c|}
\hline & $\begin{array}{l}\text { Pounds incr } \\
\text { sutuite" incll. }\end{array}$ \\
\hline Compression end & 5,201 \\
\hline 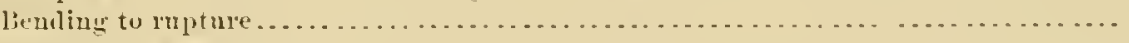 & $7,9 n \cap$ \\
\hline 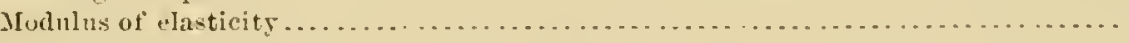 & $1.410,0100$ \\
\hline 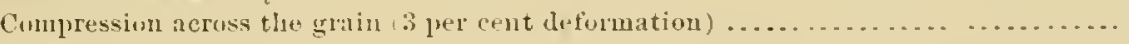 & 720 \\
\hline Shearing parallel to tiber & isto \\
\hline
\end{tabular}

Ont of about seven lundred tests male by the Division of Forestry, about is per cent fall within 10 per cent of this general average, and g0 per cent within 25 per cent of the same. Though the test series for White P'ine ras by no means as full as is desirable, the above average results will probably be fouml fuirly accurate and snticient for general purposes. The table on the next page presents the average results for the several trees. 


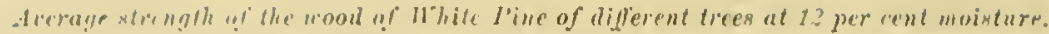

\begin{tabular}{|c|c|c|c|c|c|c|c|c|}
\hline \multirow[b]{2}{*}{ I.nculli?. } & \multirow[b]{2}{*}{$\begin{array}{l}\text { 'original } \\
\text { um!ulmet ut } \\
\text { irives }\end{array}$} & \multirow{2}{*}{ 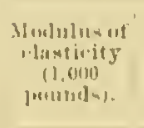 } & \multicolumn{2}{|c|}{ linmlin:: tu- } & \multirow{2}{*}{$\begin{array}{l}\text { Compres. } \\
\text { sintu winl- } \\
\text { wise. }\end{array}$} & \multirow{2}{*}{ 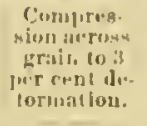 } & \multirow[b]{2}{*}{$\begin{array}{l}\text { Shearing } \\
\text { Jarallul t" } \\
\text { fllier. }\end{array}$} & \multirow[b]{2}{*}{$\begin{array}{l}\text { Avrage } \\
\text { mpitititi } \\
\text { wrightit. }\end{array}$} \\
\hline & & & liupture. & $\begin{array}{l}\text { livlative } \\
\text { "lastir } \\
\text { limit. }\end{array}$ & & & & \\
\hline & - & & $\begin{array}{c}\text { I'vormite per } \\
\text { st? ill. }\end{array}$ & $\begin{array}{c}\text { Inumels per } \\
\text { nto in. }\end{array}$ & Itommels por & $\begin{array}{c}\text { Tounds por } \\
\text { blf ill. }\end{array}$ & $\begin{array}{c}\text { Jomals per } \\
\text { ty. in. }\end{array}$ & \\
\hline Wiตrvu-iน........ & Jil & 1. 2till & ×. 100 & (i, 2, 2111) & 4 tion & 6901 & tiii) & 1). 1 ? \\
\hline Dni...... & 10:-2 & $1,5: 11$ & T. $4(1) 11$ & $\therefore 3130$ & 4.:2011 & Silin & 320 & iti \\
\hline ............ & 314 & I. 3511 & 7.8100 & ri, (ovilis & 1. 800 & $6: 0$ & 430 & (11) \\
\hline I & 112 & 1. 3isin & R. 300 & 6.300 & 5,0100 & ก:ริ) & $4+11$ & .34 \\
\hline Inw $\ldots \ldots \ldots \ldots \ldots \ldots \ldots$ & 116 & 1. 194 & $a t i, z(m)$ & 5,1300 & 4. 250 & (5:341 & tilu & $\therefore$ i i \\
\hline 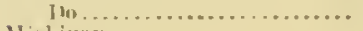 & 110 & $1,3 \pi 1$ & 2. 3110 & 5. .9110 & 5,0100 & 560 & tio & $.3 \times i$ \\
\hline M ic liginan ....................... & tiol & 1,371 & i. flil & (6.311) & $55(21)$ & -111 & 3.50 & $.3 \%$ \\
\hline Do....................... & five & ]. 470 & $7 .=1111$ & 6. 7160 & 5. $7 \mathrm{un}$ & $\sin 0$ & 4:21) & .37 \\
\hline J"1, $\ldots \ldots \ldots \ldots \ldots \ldots \ldots$ & Gi1:3 & 1,470 & T. xin & B 6.511 & $\therefore, 400$ & 796 & $3 \div 0$ & $.3 x$ \\
\hline 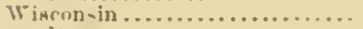 & $1 ; 1 i^{7}$ & $1,3=11$ & $\therefore 1100$ & $6,=190$ & 5, THU & 910 & (I1) & .39 \\
\hline $110, \ldots \ldots \ldots \ldots \ldots \ldots \ldots$ & fills & 1. 5kill & A, $! \cdots !)$ & 7. $4.9 \%$ & 5,700 & Gīil & 3311 & $.3 n \pi$ \\
\hline 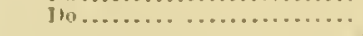 & tioy & 1,510 & ह. 2011 & 6. TiII & 6. 2010 & $8 \div 0$ & 340 & $3 \pm 2$ \\
\hline Averase. & …... & 1.410 & $T, ! 110$ & 6. 310 & 5.200 & 7919 & 380 & .384 \\
\hline Average for trees fol to giog... & $\ldots \ldots \ldots$ & 1. 4130 & 8. 100 & $1 i, 760$ & 5.700 & $\because, 2(1)$ & 350 & $3 x, 3$ \\
\hline
\end{tabular}

In the above table the data for trees 101 to 116 are insuticient. Both material and tests for tres 601 to 609 were satisfactory in erory respect, and the results, therefore, of far wrater value thilll those for troes 101 to 116 .

In lieeping with its areater weight, the wool of thr butt logs is slightly stronger than that of the top logs, and there is gemerally a regular dillerence between ditherent parts of the sime cross sertion. the center, as appears nsual in pine, boing the wealiest, the hearier intermediate prortion the strongest, and the periplieral part lying between the two.

lor a more careful st nuly uf this relation. tests were male of a set of 2 by 2 inch sticlis cut ont

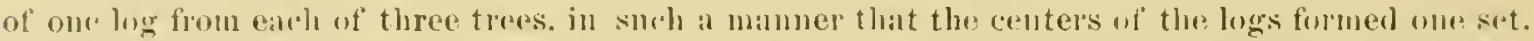

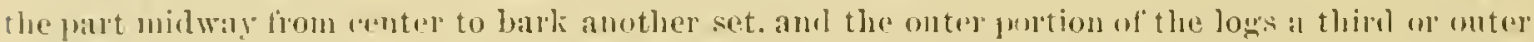
set, the latter two being all abuteresilwed pieces. The tests furnished the following average risuls:

srength of : ly s picres at t? per rent moistur.

\begin{tabular}{|c|c|c|c|}
\hline Kines of $t 1-1$. & 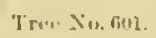 & Tree Xo.guz. & Tree 20. \\
\hline 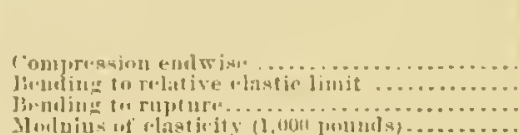 & 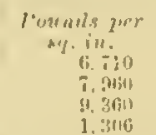 & 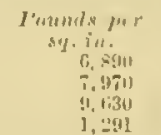 & 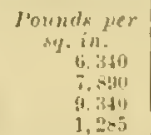 \\
\hline
\end{tabular}

It is aplarent fom the above that the perfeet pnarter-saned material contirmed the other trist results in showing the great sinilanity of the woml of these thee trees. It also shows. how.

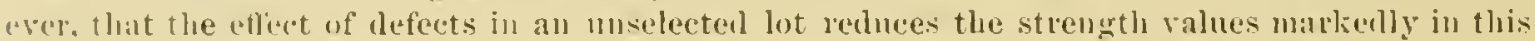
siceries.

Aranging the results aceorling to the position of the test preces in the log, it is fonmd that in

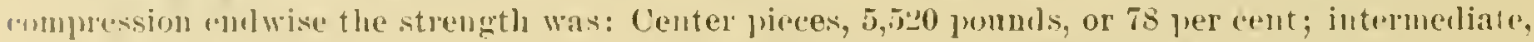

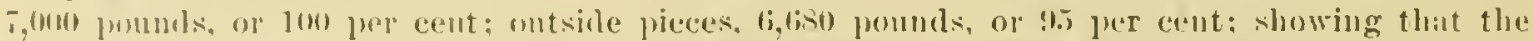
healt pieres, as las been found in uther conifers, are alwilys the wealiest. thus rerifying the results

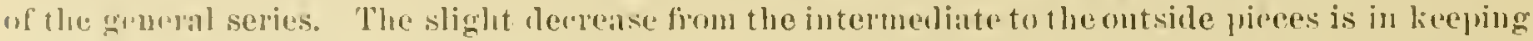
will the smaller weight of the latter and need not be aseribed to the fact that these pieces containal suall propmetions of supworl. As might be expected, the milormity of results in this properly selertiol and prejared material was greater than in the ordinary series. of os tests, all toll within

In connectim with a general study into the maximum mifolmity of wonl, the scantlings of

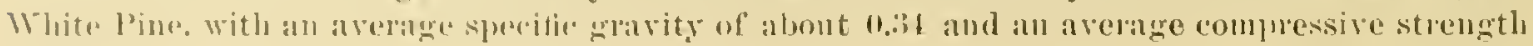

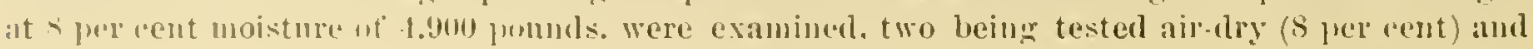


the other after being soaked for three months in cold water. 'I'le results of these tests on White Pine are embotied in the following table:

Strenglh of contiguons hlocks of the same scantling of White Jine, schert material, in compressinn entwist.

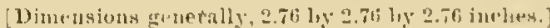

\begin{tabular}{|c|c|c|c|c|c|c|c|}
\hline \multirow{2}{*}{ Xitmbere uf lilowk. } & \multicolumn{2}{|c|}{ liry scantliny. } & \multirow{2}{*}{$\frac{\begin{array}{c}\text { Soaliend } \\
\text { serantling. }\end{array}}{\#}$} & \multirow{2}{*}{ Number ot lolerk. } & \multicolumn{2}{|c|}{ liry at:anthü. } & \multirow{2}{*}{ 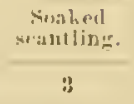 } \\
\hline & 1 & 2 & & & 1 & $\because$ & \\
\hline 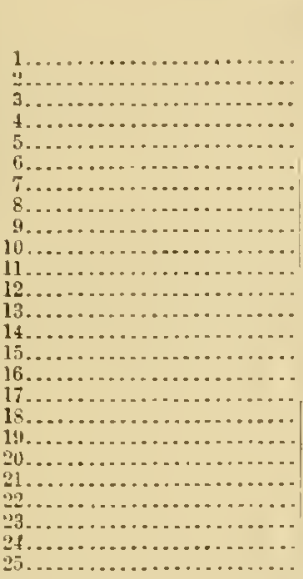 & 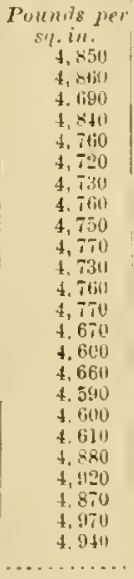 & 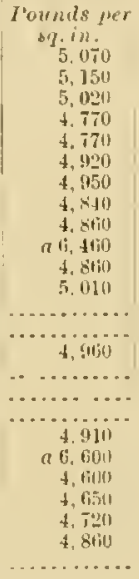 & 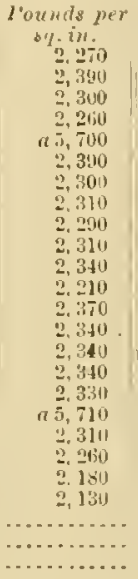 & 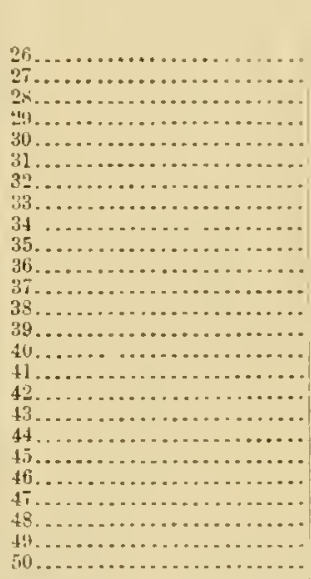 & 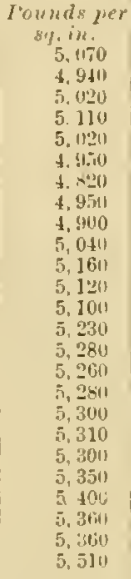 & 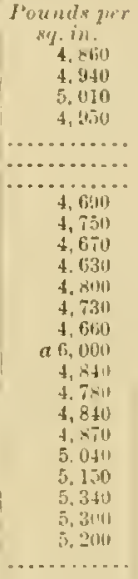 & 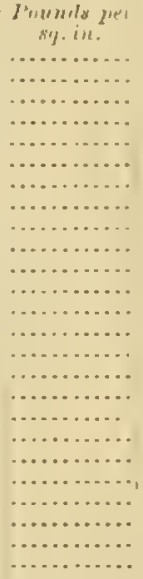 \\
\hline
\end{tabular}

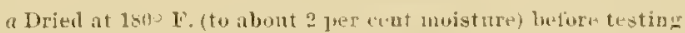

It appears that in the tests on dry material the greatest difference letween any two eontignons

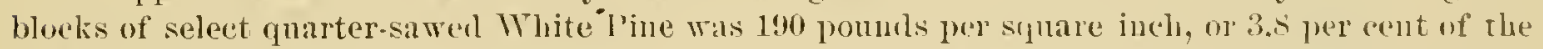
total strength: that generally it was less than : per cent, am several times only albont 11.2 per cent, but that in tests of this linul less then 200 pounds in the jesults ran not be regarled as any difference at all, this amount being dne to indeterminable differences found even in the best material, an partly due also to imperfeetions in the means and methuls of testing. It is alsu, clear that in the same scantling. though select and of small himension (ouly fi fuet long) a difference of nearly 900 poumls per sinare incl, or 18 jer cent of the strength. in compression endwise may be found, so that any infereuces from scuntling to seantling must be taken with great cantion, and any accurate relations, such as the influence of seasoning. ete.. can be narle only in a manner similar to that employed in these miformity tests.

From the general series of tests, also trom the tests on the select 2 by 2 inch pieres. int in way of inlication also from some of the tests in maximum nniformity, it appears that seanoning affects the wood of White l'ine to abont the same degree as that of other pines. The strength of greenwool, or wool soaked to a point where additional immersion no longer changes the volume. is independent of difterences in moisture. 'This is quite clear from the test in miformity ut the scantling immersed for three months. Thongh the blocks differed (espeeially near the ends) within wide limits as to the amount of moisture they coutained, yet the strength was found to be as mniform as in evenly tried timber. By drying green or fully saturated wool to about 2 per cent moisture (kihn-trying at $80^{\circ} \mathrm{C}$.) the strength is more than lonhlet; and even if pieces well airdried are kiln-dried the strength is still increased by over 40 per rent. For timber to be nsed nuder cover and hept properly rentilated, it is safe to presme that the strength, once seasonent, will be 50 per cent greater than when green, and if 11 sed in heated rooms, an increase of 100 per cent on the strength of the green timber may reasumbly be expectell. The diatgran (fig. 1S) well illustrates this feature. 


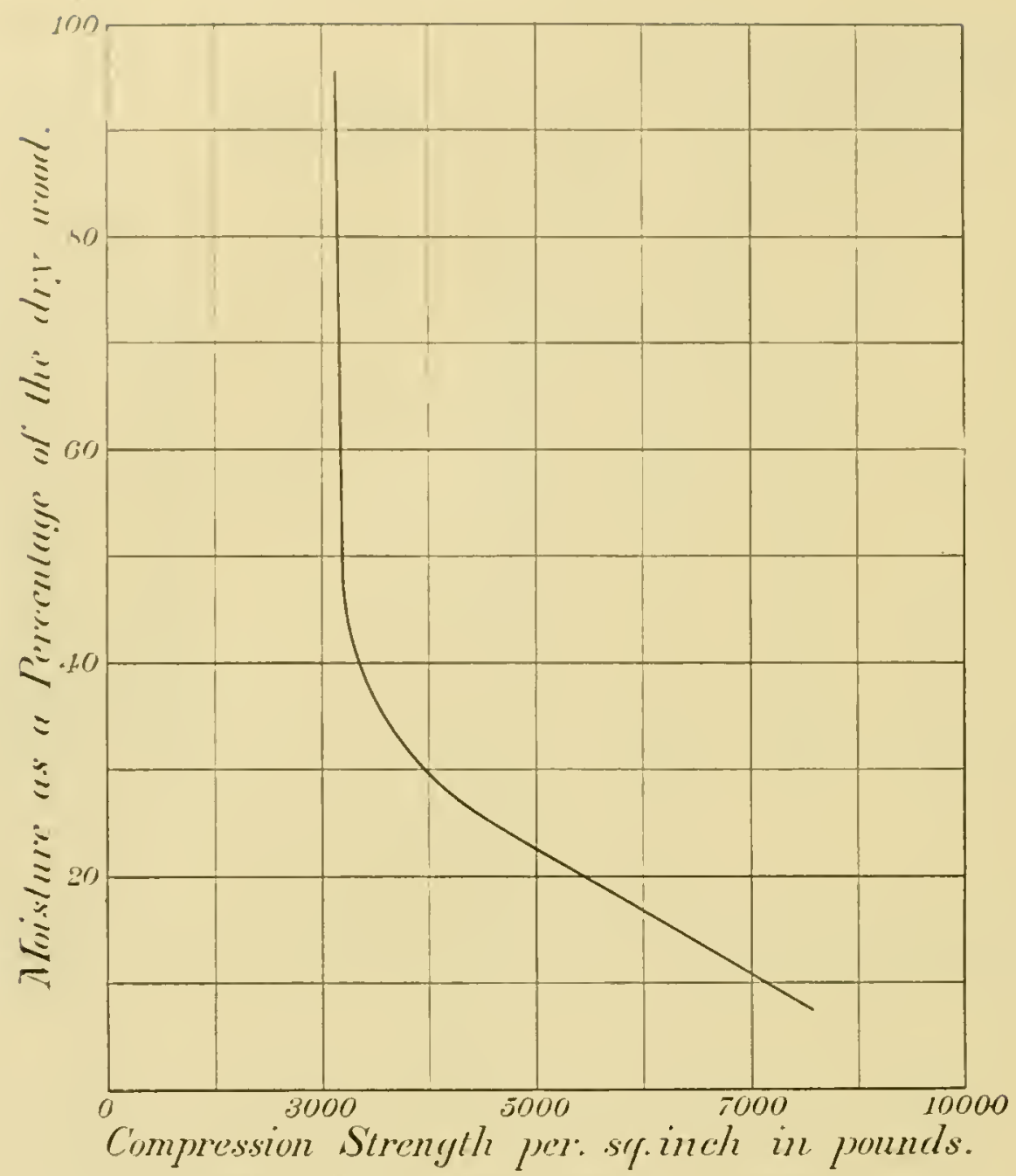

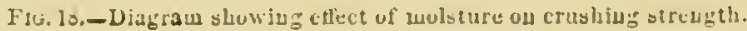

\section{DURABILITY.}

With regant to its dumability, White Pine is gemelally umererated. The soft, lightecolored wood suggests general fraily and a lack of resistance, in wheh resistance to decay is included.

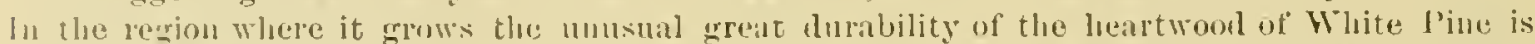
rell linown; "the stumps of White Jime last a lifetime:" old logs, covered with moss and often with youm Poplats and birch growing from theil suffece are nucovered and utilized as slingle lolts. White l'ine shingles weal" ont, lut rarely decay, and a goml sidewalk of White Pine is "onsiderent the best to be had. Is in uther pines, the sapwond decays readily, but this being narrow in goml logs, more than half of all White J'ine saned is gond durable heart, a wood which

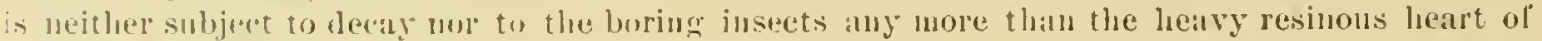
the lised line ol of the sonthem pines.

\section{COMPARISON WITH OTHER WOODS.}

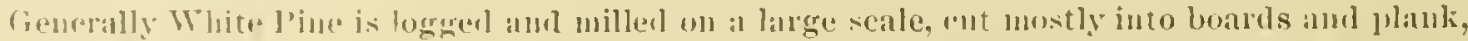

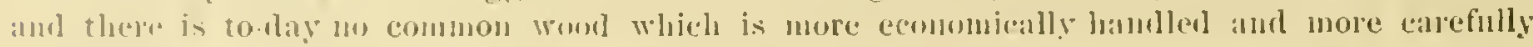
selected.

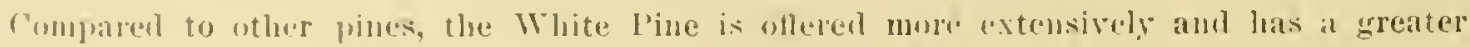
intluence on lumber markets than any other wood nsed. It is more mulorm, lighter, snfter, and 
shrinks less than auy other pine; it is durable, insect proos, and suiter to a much greater number of uses than the wool of other pine.

The following table exhibits the position of White ['ine as to weight anl strength:

Teight and stregth of Thite Fine compared with other pines.

\begin{tabular}{|c|c|c|c|c|c|c|c|c|}
\hline \multirow{3}{*}{ Name of pines. } & \multirow{2}{*}{\multicolumn{2}{|c|}{ Specific gravity. }} & \multicolumn{4}{|c|}{ Lending. } & \multirow{2}{*}{\multicolumn{2}{|c|}{ Compression endwise. }} \\
\hline & & & \multicolumn{2}{|c|}{ Inpture. } & \multicolumn{2}{|c|}{ To relative -lastic liuit. } & & \\
\hline & Actual. & Relative. & $\begin{array}{l}\text { Pounds } \\
\text { per sifuaru } \\
\text { incb. }\end{array}$ & IRelative. & $\begin{array}{l}\text { J'ounds } \\
\text { persorutire } \\
\text { inch. }\end{array}$ & Felative. & $\begin{array}{l}\text { Ponnds } \\
\text { per square } \\
\text { inch. }\end{array}$ & lielative. \\
\hline 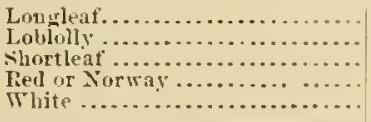 & $\begin{array}{l}61 \\
53 \\
51 \\
4 x \\
32\end{array}$ & $\begin{array}{l}110 \\
87 \\
84 \\
78 \\
62\end{array}$ & $\begin{array}{r}12.800 \\
11,800 \\
10.400 \\
7,100 \\
7,900\end{array}$ & $\begin{array}{l}100 \\
92 \\
81 \\
71 \\
62\end{array}$ & $\begin{array}{r}10,300 \\
9,50 m 0 \\
7.8100 \\
7.700 \\
6.400\end{array}$ & $\begin{array}{r}100 \\
92 \\
76 \\
75 \\
62\end{array}$ & $\begin{array}{l}8.300 \\
7,800 \\
6,300 \\
6,700 \\
5,200\end{array}$ & $\begin{array}{r}100 \\
94 \\
78 \\
81 \\
62\end{array}$ \\
\hline
\end{tabular}

Of the serelal columns, that on specitic weight being at once the simplest and most truly representative of the entire stem of matmre timber, illustrates probably the relative position of these tive pives most perteetly. The Southern pines, if ouly the saw timber is considered, will prove ereu heariel aul stronger by several per cent than appears from this table.

\section{USES OF WHITE PINE}

There is no wood in the L'nited States, perhaps in the world, of which there is a greater quantity used, nor one which is put to a gleater variety of uses than that of the White Pine. At present the great mass of White l'ine, probably not less than 95 per cent of the entire ontput, is cut into even lengths, usually 12 to 18 feet long, preferably 16 feet (full i. per cent being 16 teet), aud is converted prineipally into bouris, plank. and "dimension stuff," 1 to 4 inehes thiek and 4 inches aud upward in wilth. the widths varying always by an even number of inches.

In all the better mills the slabs are cut into laths, pickets, ete. While the thickest slabs aud the sound portious of very lefective $\operatorname{logs}$ are cut into shiugles. These "shiugle cants" are of variable sizes, nsually containing knots aud leeayed portions; these defeets in the shingle are ent out subsernently by the knot sawgers. Shingles of regular wirlths are ralyely male. In the sawing of the great mass of lumber the main saw merely cuts slices of various thicknesses from the $\operatorname{logs}$, and their conversion into certain widths, as well as the remoral ot uneren edges, is left to the edger, on whose knowledge and skill mnch of the success of the mill depents. Csually the clear stuti, whenever possible, is left in broal aud thick plauls; the lest is ent into different widths so as to insure the greatest value, in most cases bourds of extra width and seleet boarts, for siding, ete., receiviug preference and determining the conversion. The clear stuff, or "nppers," rarely torming over 15 per cent of the ent in our times, are used by mannfacturers of sash, doors, and blinds, aud by furniture meu, aud the most seleet portions by morkel makers and other special watufaeturer's where the price of the material is of secondary cousideration. For material of this kind the consumer generally pays over so pel 1,(1)n feet B. MI., aud in some eases it is retailed at orer stno. Ot the reminder, the great mass is used in the construction of tiame houses, where commonly everything of woml, trom cellar to root, is made of this material. Of the inferior grades, ewormous quantities are used for boxes, and much also is used as fencing and baru lumber.

Fol box shooks, straight-stave cooperage, pails, tubs, ete., a great deal of suall sapling pine is employed. Smaller quantities of better-grade White Pive are usen in mill construetions (for chutes, elevators, ete.); also in the mannfacture of tarm implements, for large surfaees, panelmorli, etc., aud in boat and ship buikding for deeking, in titting up eabius, for all kiuds of spars, rhere its lightuess, stiffness, and dumbility, together with its fine form and dimeusions, render it a speeial favorite.

Considerable ruautities of hewn and round timbers are still bronght to marliet for export, but ou the whole this trate is iusignificant when compared to the entire output.

White Pine is unirersally seasoned in the yard: most of the lumber dous not reach the consumer until a year after manufacture. The ease of working induces the cousumers to lo a great deal of $20: 333-1$ No, 2:-6 
resaming. The llooring, and even siding for the sualler markets, and for elieap construction are commonly the selected parts of sheathing and other inferior grmes, as chassed at the mill, and it is rare to funl, in reeent rears, the best crralles of White l'ine in the smaller retailers' yards.

In the elassificution of White Pine a great dearee of tinesse has heen introduced, and the closest attention is paid here, as well as in edging and trimning, to the probable future nse of a given piece of material.

From the enomons consunption of White Pine alone, and also from the great variety of uses to which it is put, it is clear that any material diminution of supplies must aftect extensively and intimately the wood market and wood indnstries of this conutry. The common claim of substi. tution of some other pine or conifer, and still more the belief in the use of hard woods in the place of White l'ine, have but little in their favor. A shiplng ease of White l'ine rernires abont ball the effort to make and only 50 to 6.5 per cent of the effort to hanl or hindle as one made of Sonthern l'ine. its most natural substitute. Similarly, a White Piue lath nails with hall the effort. shrinlis less, and thus is far more satisfactory than one made of hard pine. For a good dow or for satisfactory saslı and blinds only the Cypress aud White Cedar can enter as a substitute, ant both are too restricted in their ocenrrenee. and the Cypress has too little ehance of future regeneration to deserve consideration as a general substitute. The trausportation of Pacific coast timber:, a small portion of which lave the properties of White Pine, to the densely populated Easter: Inited States is not likely to occur on a large seale, for the cost of hauling alone equals the ralue of good grades of Easteru lumber. 


\section{APPENDIX.}

TABLES OF MEASUREMENTS. 



\section{A PPENDIX.}

\section{TABLES OF MEASUREMENTS.}

The following tables record the detail investigations, measurements, and tabulations which have servel as a basis for the discussion of the growth of the Thite l'ine. The measurements in the field were mate by MIr. Austin Cary, of Bangor, Me., and by Mr. A. K. Mlorlziansky, of the Invision of Forestry. Mr. Mlodziansky has also exeented the laborious calculatious, and is responsible for their accuracy.

The methods employed in this investigation have leen rescribel in general in Bulletiu No. 20, "Measmring the forest crop," of the Dirision of Forestry. They are in the main similar to those practiced by European foresters, with some minor and one important modification, which latter Mr. Mlodziansky has dereloped dnring the course of his work in collating the data. This modification, which refers to the analyzing of trees for ascertaining the rate of growtl, consists in grouping by age classes, and instead of analyzing each single-measured tree, as is nsually done in European puctice, averages the data of measurement from a number of trees gromperl and then analyzes the growth of the arerage tree thus constructel of each age elass or gronl. In this way the rork of collating is rery cousiderably reducel and the measurements of a very mueh larger number of trees ean be expeditionsly utilized for average statement. It is needful, however, in order to be quite satisfactory, that the classifieation or gromping of trees be made in the wook while measuring, a task whieh requires considerable julgment. When the classification is so done in the woods, the meehanical work is further simplified by entering the measurements for each group in sets. the measurements of eross sections taken at the same height being entered on the same sheet for all trees of the gromp, when the areraging of the measurements ean at once be performed on the same sheets.

The forms nsed in the investigation are also appended, and will serve to further elucilate the methods pursued.

Since it was not expedient to fell trees specially for these measurements, it mas not almars possible to secure all measurements in the most desirable form; for instance, the desirable measmrement and correlation to age of diameters at breast height, and at slort intervals of the height, conlil not be obtained, beeause the rork was performed on trees cut in regular lumbering oprera. tions; hence, the data had to be manipulated and interpolations nsed so as to secure satisfactory approximations for the periodie growth. The number of trees analyzed (some 700 ) is so large that any defieiency of method may be considered as neutralized.

\section{TABLES OF CUBIC AND BOARD CONTENTS OF WHITE PINE.}

The tables of enbic and hoard contents of White Pine are based upon the measurements of pine taken for analysis from the varions sites clescribed in the tabnlations of acre yielis.

The stem of each induridual tree was calipered at intervals of 4 or 8 feet, and the volunes of the portions between two sucessive diameter measurements were calculated separately, considering them as frustrums of cones. From the volumes of stems of similar height and diameter, breast high, the average volume was noted. The volumes of stems of missing dimeusions was calculated by employng the corresponding factors of shape. 'The factor of shape is determined by diviling the volume of a tree by that of a eylinder of the same height and diameter, breast high; it shows the taper of the stem and is msually expressed in decimals, thus representing arithmetieally the form of the stem. For letermining the volume of a tree by means of the factor of shape. it is neressiry only to measure the diameter and height of the tree, find the volume of a eylinder of the corresponding height and diameter, and multiply that volume by the factor of shape.

The lnmber of stems in board feet was determined by employing Scribner's rule. 


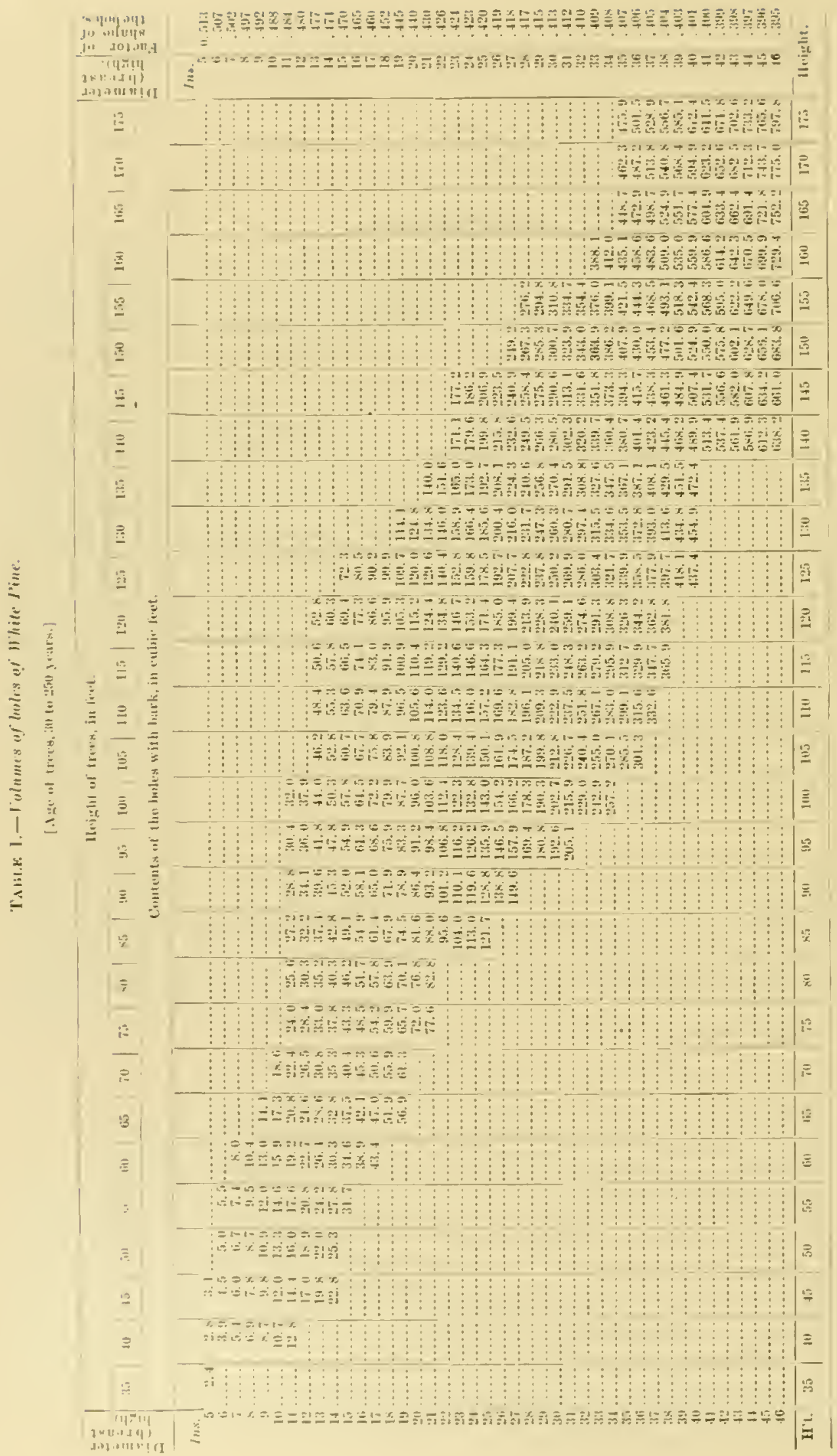


TABLES OF MEASUREMENTS.

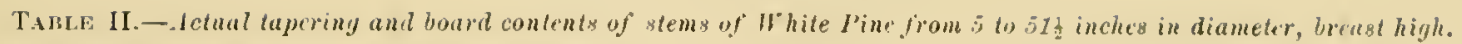
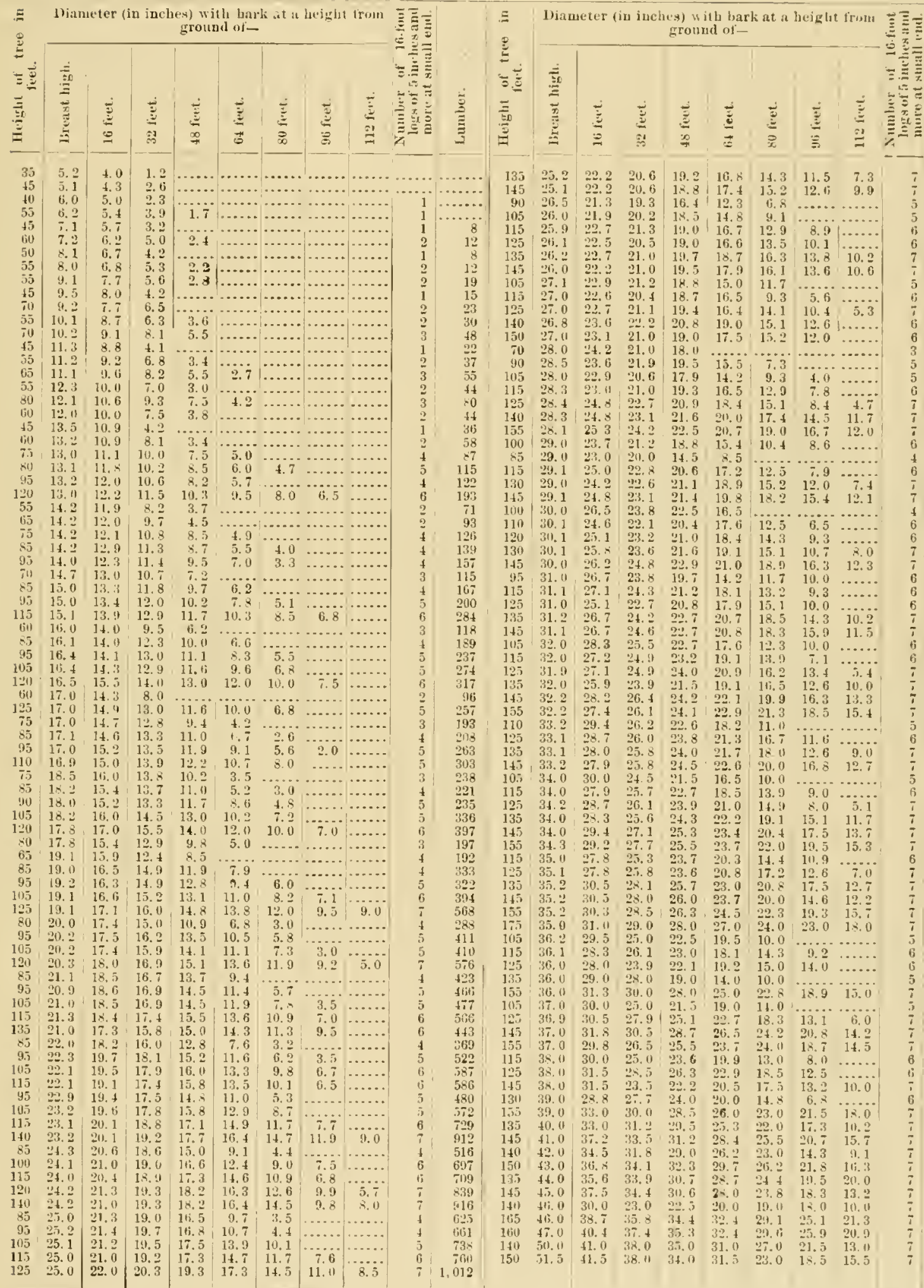

䓂

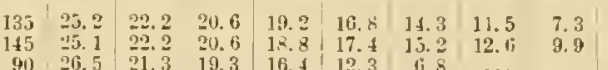

\begin{tabular}{llllll|l|l|l}
90 & 26.5 & 21.3 & 19.3 & 16.4 & 12.3 & 6,8
\end{tabular}

$\begin{array}{lllllllll}105 & 26.0 & 21.9 & 20.2 & 18.5 & 14.8 & 9.1 & \ldots \ldots \ldots\end{array}$

$\begin{array}{llllllllll}115 & 25.9 & 29.7 & 21.3 & 19.0 & 15.7 & 12.9 & 8.9 & \ldots & \ldots\end{array}$

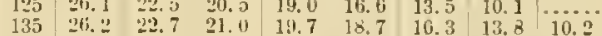

$\begin{array}{llllllllll}1+5 & 36.0 & 2.2 .2 & 31.0 & 19.5 & 17.9 & 16.1 & 13.6 & 10.6\end{array}$

\begin{tabular}{l|lllllll}
105 & 27.1 & $\cdots \cdots$ & 21.9 & 21.2 & 14.8 & 15.0 & 11.7
\end{tabular}

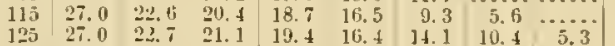

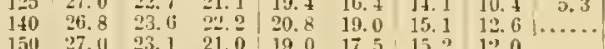

\begin{tabular}{llll|lllll}
150 & 27.11 & 23.1 & 21.0 & 19.0 & 17.5 & 15.2 & 19.0 & $\ldots . .$.
\end{tabular}

$70 \quad 28.0 \quad 14.2 \quad 21.0 \quad 18.0$

\begin{tabular}{llllll|lll}
105 & 28.0 & 23.0 & 2.9 & 2.9 & 19.5 & 13.5 & 7.3 & $\ldots \ldots \ldots$
\end{tabular}

\begin{tabular}{llllll|l|lll}
115 & 28.3 & 23.4 & 01.0 & 19.3 & 16.5 & 12.9 & 7.8 & $\ldots .$.
\end{tabular}

$\begin{array}{lllllllll}125 & 28.4 & 24.8 & 23.7 & 20.9 & 12.4 & 15.1 & 8.4 & 4.7\end{array}$

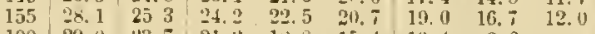

\begin{tabular}{l|lllllllll}
100 & 29.0 & 23.7 & 21.2 & 18.8 & 15.4 & 10.4 & 8.6 & $\ldots$
\end{tabular}

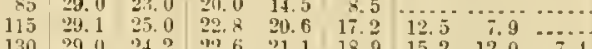

$\begin{array}{lllllllll}130 & 29.11 & 24.2 & 13.6 & 21.1 & 18.9 & 15.2 & 12.0 & 7.4\end{array}$

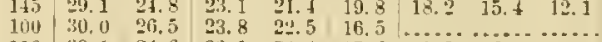

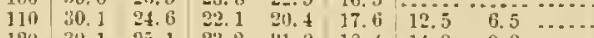

$\begin{array}{lllllllll}120 & 30.1 & 25.1 & 23.2 & 21.0 & 18.4 & 14.3 & 9.3 & \ldots \ldots\end{array}$

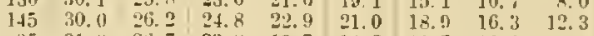

$\begin{array}{lllllllll}95 & 31.0 & 26.7 & 23.8 & 19.7 & 14.2 & 11.7 & 10.0 & \ldots \ldots .\end{array}$

\begin{tabular}{l|l|l|l|l|l|lll}
115 & 31.1 & 27.1 & 21.3 & 21.2 & 18.1 & 13.2 & 9.3 & $\ldots .$. \\
125 & 31.0 & 25.1 & 20.7 & 20.8 & 17.9 & 15.1 & 0.0 &
\end{tabular}

$\begin{array}{lllllllll}1.55 & 31.0 & 26.7 & 22.7 & 20.8 & 1.9 & 15.1 & 90.0 & \ldots \ldots\end{array}$

$\begin{array}{lllllllll}145 & 31.1 & 26.7 & 24.6 & 2.2 .7 & 20.8 & 18.3 & 15.3 & 11.5\end{array}$

$\begin{array}{lllllllll}115 & 32.0 & 27.2 & 24.9 & 23.2 & 19.1 & 13.9 & 7.1 & \ldots \ldots\end{array}$

$\begin{array}{lllllllll}125 & 31.9 & 27.1 & 24.9 & 5.0 & 190.9 & 13.9 & 7.1 & \ldots \ldots .\end{array}$

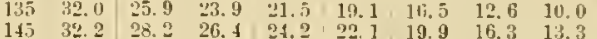

$\begin{array}{llllllllll}155 & 32.2 & 28.4 & 26.4 & 24.2 & 2.1 & 19.9 & 16.3 & 13.3 \\ 150 & 32.2 & 27.4 & 26.1 & 24.1 & 22.9 & 21.3 & 18.5 & 15.4\end{array}$

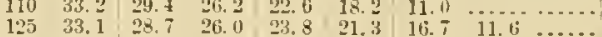

\begin{tabular}{ll|lllllll}
125 & 33.1 & 28.6 & 26.0 & 5.8 & 21.3 & 16.7 & 11.6 & $\ldots \ldots$
\end{tabular}

$\begin{array}{lllllllll}145 & 33.2 & 27.9 & 25.8 & 24.5 & 22.6 & 20.0 & 16.8 & 12.7\end{array}$

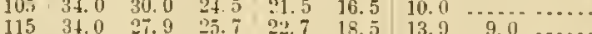

$\begin{array}{llllllll}125 & 34.2,28.7 & 20.1 & 23.9 & 21.0 & 14.9 & 8.0 & 3.1\end{array}$

$\begin{array}{lllllllll}135 & 34.0 & 24.3 & 25.6 & 24.3 & 22.2 & 19.1 & 15.1 & 11.7 \\ 145 & 34.0 & 29.4 & 27.1 & 25.3 & 2.4 & 20.4 & 17.5 & 1.7\end{array}$

$\begin{array}{llllllllll}145 & 34.0 & 29.4 & 27.1 & 25.3 & 23.4 & 20.4 & 17.5 & 13.7 \\ 155 & 34.3 & 29.2 & 27.7 & 25.5 & 23.7 & 22.0 & 19.5 & 15.3\end{array}$

\begin{tabular}{l|lllllllll}
115 & 35.0 & 97.8 & 25.3 & 23.7 & 20.3 & 14.4 & 111.9 & $\ldots \ldots$
\end{tabular}

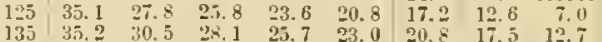

$\begin{array}{lllllllll}135 & 35.2 & 30.5 & 2.1 & 25.7 & 93.0 & 20.8 & 17.5 & 12.7 \\ 145 & 3.5 & 31.5 & 28.0 & 26.0 & 33.7 & 20.0 & 14.6 & 12 . ?\end{array}$

\begin{tabular}{l|llllllll}
145 & 35.2 & 31.5 & 28.0 & 26.0 & 23.7 & 20.0 & 14.6 & 12.2
\end{tabular}

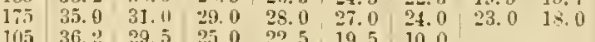

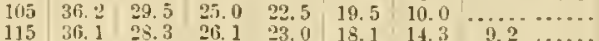

\begin{tabular}{ll|lllllllll}
410 & 115 & 36.1 & 28.3 & 26.1 & 23.0 & 13.1 & 14.3 & 0.2 & $\ldots \ldots$.
\end{tabular}

\begin{tabular}{l|l|l|l|llllll}
423 & 135 & 36.0 & 29.0 & $2 \times .0$ & 19.0 & 14.0 & 10.0 & $\ldots \ldots$ & $\ldots$
\end{tabular}

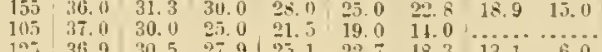

$\begin{array}{llllllllll}125 & 34,9 & 30.5 & 27.9 & 3.7 .1 & 29.7 & 18.3 & 13.1 & 6.0\end{array}$

$\begin{array}{lllllllll}145 & 37.0 & 31.8 & 30.5 & 28.7 & 26.5 & 24.2 & 21.8 & 14.2 \\ 155 & 37.0 & 29.8 & 26.5 & 25.5 & 23.7 & 24.0 & 18.7 & 14.5\end{array}$

$\begin{array}{lllllllll}115 & 35.0 & 30.0 & 25.0 & 23.6 & 19.9 & 13.0 & 8.1 & \ldots \ldots\end{array}$

$\begin{array}{lllllllll}125 & 38.0 & 31.5 & 25.5 & 213.3 & 22.9 & 18.5 & 12.5 & \ldots \ldots\end{array}$

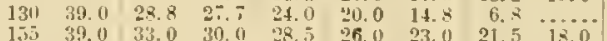

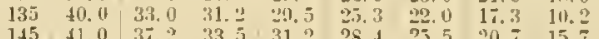

$\begin{array}{lllllllll}145 & 41.0 & 37.2 & 33.5 & 31.2 & 28.4 & 25.5 & 0.7 & 15.7\end{array}$

$\begin{array}{lllllllll}140 & 12.0 & 34.5 & 31.8 & 29.0 & 26.2 & 23.0 & 14.3 & 9.1\end{array}$

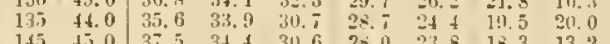

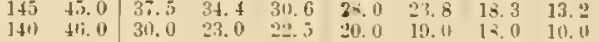

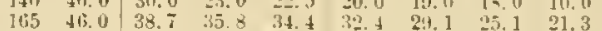

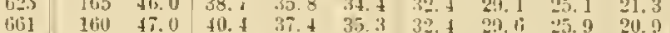

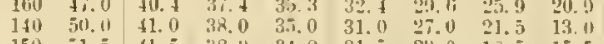

- 1,01

1,018
1.093
630

\begin{tabular}{ll}
5 & 832 \\
5 & 971 \\
97 & 971 \\
9 & 979 \\
\hline
\end{tabular}

6
7
7,227

1. 177

925
6 $\quad 887$

(6) 1,229

$3 \quad 724$

$\begin{array}{r}828 \\ 6 \quad 999 \\ \hline\end{array}$

$1, \frac{230}{2}$

$1,7+3$

671
$4 \quad 1.03$

$\div \quad 1.279$

$+\quad 1.368$

6. 1. 278

-1.825

$6 \quad 1.120$

$\begin{array}{ll}6 & 1.318 \\ 6 & 1.202\end{array}$

1 1. 150

1.654
$-1,695$

$6 \quad 1,4 n 3$

1,1521
1.391

2. 023

i. 511

$6 \quad 1.79$

1,965

1,341

$\begin{array}{r}1.445 \\ -\quad 1.70 .7 \\ \hline\end{array}$

1. 87

$7 \quad 2.259$

$\begin{array}{r}6 \quad 1.550 \\ 7 \quad 1.67 \\ \hline\end{array}$

$\div \quad 2.353$

7.309
$7 \quad 2.512$

3.047

3 . 1.521

5 1. 51.285

$\div \quad 2.000$

$\begin{array}{r}1.509 \\ 7 \quad 2.035 \\ \hline\end{array}$

i 2,390

(i) 2.201

6 1.706

7 3.107

2. 제

ข. 817

3. $1 \times 9$

3. 411

1.665
+700

+.001
4,960

4,960
4,83
4.350 1,012 


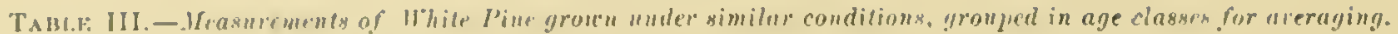
[The groupo of ireas measured are sample trewe recorded in Table VI.]

Gromp, locatiod, and ateacription of situ.

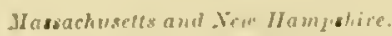

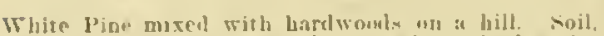
lurown or vellowish saudy loam, molum-sizenl graiu.

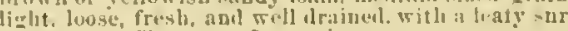
fisce curer. Irees, $400-500$ to the acre.
Arrmge.

GROTP B.

Jassachusetts and Sem Hamphire.

White Pane on a lerel pland site. Suil a lrown or ri.]. low-lurown loamy saud, nmlerlaiel hy sabul or sand with gratel in mediuin or cometimes curse grain. shallot.

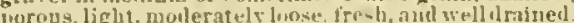
witl an alupdant leaty' surtice curer. 'Irecs, $350-100$ to the acre.

Arerage

\section{Pennsylranin}

Wh hte l'ine interuixed with bartwoulv aud nctasional

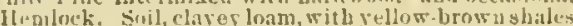
in it, decp, fresh, arid well draiued

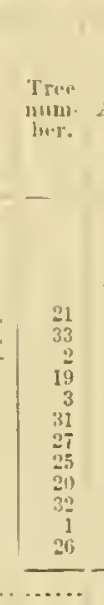

rim. Agn.

Irs liatio of the leugt $\mathrm{l}_{\text {t }}$

Thianu-ter

(l)ruitist

bighis.

Tontal

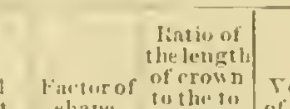

Volume

ieretion.

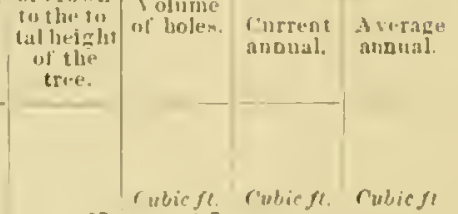

Inches.

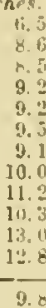

Fert

51.3 0..

ง. 37

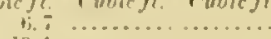

ti.;. 3

6ii. 01

62.3

6.3.11

64. 11

53.11

7U. 0

7.5

..... $-\frac{1}{4 t}-\frac{1}{9.0}$

62.3

.51

$\therefore 1$

13.

14.3

15. 6

Jti, 11

1.3. 9

(n)

:1. 3 (3)

3. 7

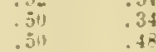

.48

33. I

$0.60-\frac{.41}{0.4}$
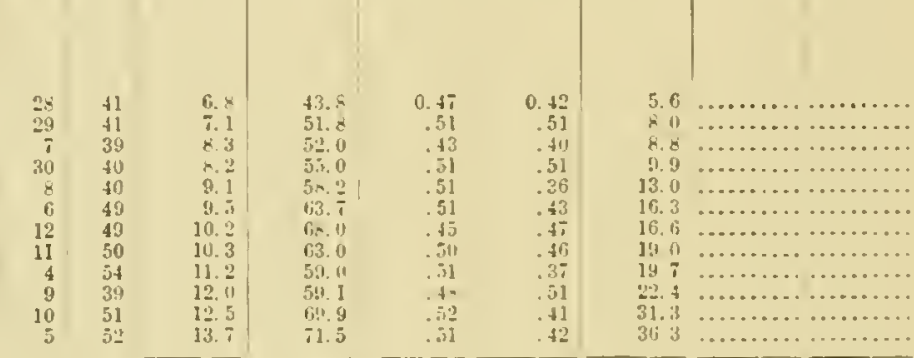

6.8
7.1
6.3
0.3

51.

$2 \div 0$

5is. 0

5.m. $\frac{2}{7}$

a.

10. 3

11.2
12.11
12.5

63. 0

59. 11

71.5

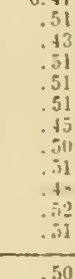

\& $010 \ldots \ldots \ldots \ldots \ldots \ldots$

8.8
!. 9

13. 0

16. 3

16. is

$3 ! 30$

197

22.9

............

.11
.42

1:.

$0 . \overline{50}-\frac{0.38}{0}$

\section{.... 45}

9.9

60.0

Average

GROL'

$$
\text { Maime. }
$$

Whito Pine with seatterung lloulork, oreasional spruc

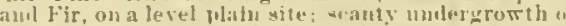
Ilizel abul roung II+mlork. Suil, eray sanet, sorm times browu or fuany, with 3 inches segetalsle mole

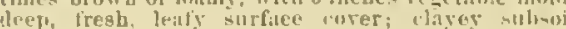
prolibly 4 or 3 feet below surtace. Densily of crowi cover, $0 . \bar{T}$. Trees. 370 to the acro.

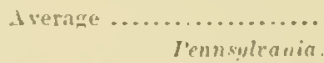

Frun a goung Thit. I'ine gros. mixed with mntnr.

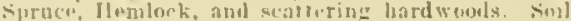
fresh samel, wetl thaiugen

Arerago

corsici' h.

Iritsumsin.

An open grote of harelwamls. in which Thite Pine is arattered in varring jorowertirns, on brithell land, with

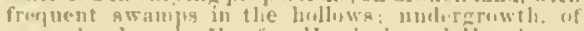

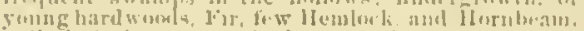

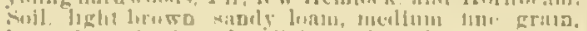

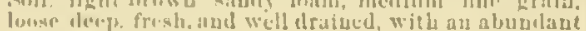
lests surtice coser.

Averas.

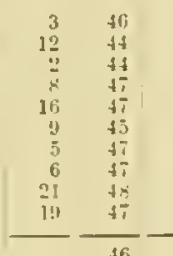

in 0

$12.5 \quad 55.4$

11.

11.

11.0

10.5

10.0

$\begin{array}{ll}56.0 \\ 58 & .1 \\ \text { tiin. } & 0 \\ 5 & 0 \\ \text { in . } & 0\end{array}$

11.0

$\begin{array}{rll}9 & 511 & 14 \\ 4 & 54 & 13 \\ 8 & 53 & 11 \\ 3 & 511 & 11 \\ 11 & 79 & 10 \\ 12 & 50 & 11\end{array}$
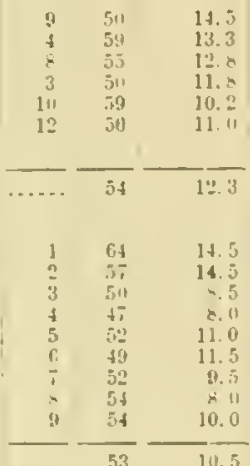

\section{....}

1.0

53.11

$5=.0$

0. 43

$4 i$

.41

.45

.51

.51

$4=$

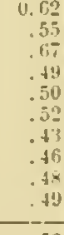

5250.2

1:. 4

18. 7

1.. is

$1 \div 3$

16. 1

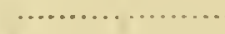

$15 .+\ldots \ldots \ldots \ldots \ldots$
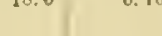

0.39
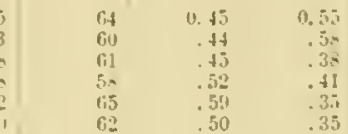

33. 1

26.4

(2................

2ii. 1

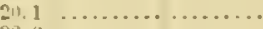

21.1 1 ...................

$62-\frac{}{4 !}-\frac{}{44}$

28.70 .694

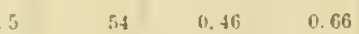

$2 n .7$

31.

95

142

15.

12.1

(n...........

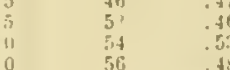

.60

16. 0

0.68

0.30
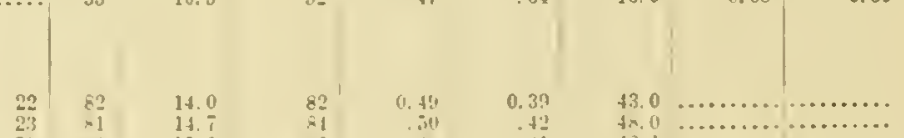

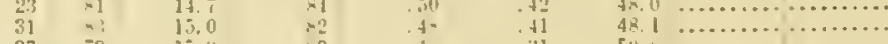


TABLES OF MEASLREMENTS.

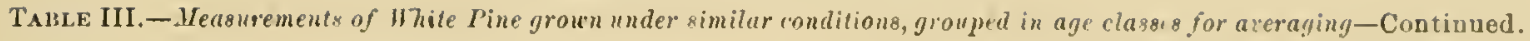

\begin{tabular}{|c|}
\hline Group, location, and description of site. \\
\hline $\begin{array}{l}\text { GROCP E. } \\
\text { Ilaine. }\end{array}$ \\
\hline 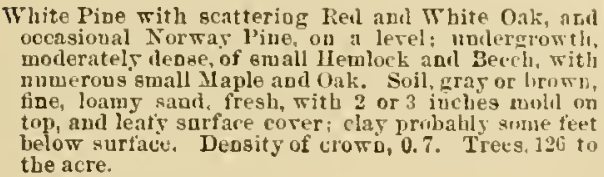 \\
\hline
\end{tabular}

Arerarro

(iROTP F.

Maine.

Thite Pine mitl scattering liel aod Thite Oak, and vecasional Norway Pine. on a lerel; modergrowth, moderately dense, of swall IIemJock and Beech, with numerous small Maple and Oak. Soil, gras or liruwn, tine, loams saud, fresh, with 2 or 3 inches molil on t"il, and leafs surtace cover; clas probal, s some teut helum snrface. Deosity of crow cover. 0.7. Trues. 126 to the acre.

Arerage.

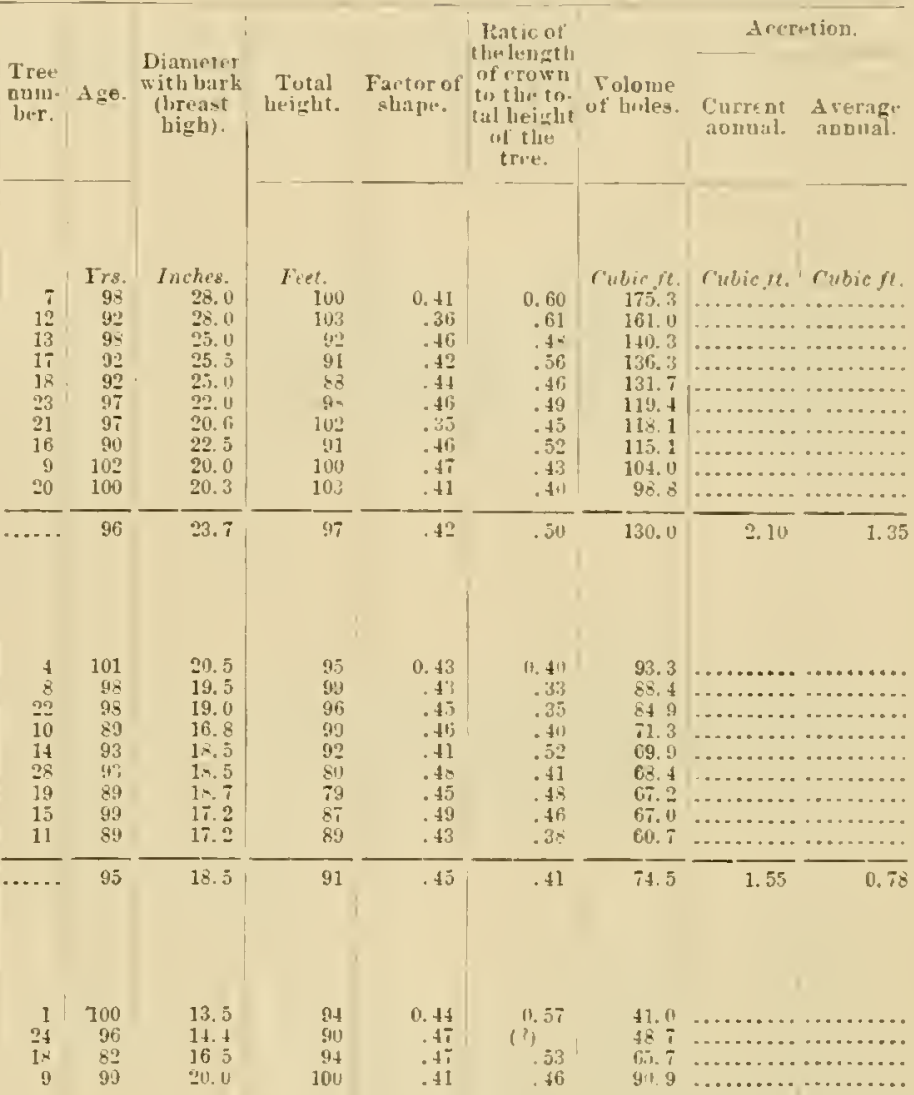

Open grore on a level plain, along the banks of a ricer. of mixed White au Nurway Pint. With ecattering Thite Birch, and occasiovally t lak. Hackmatack, anil lanksian Pine; undergromth ectuts, of roung Fir, Crdar (Thrja occidentalis), and few small Oaks. Soil, gras or light brown, sand, medium finm. grained,
porons, light, loose, dry (io places rresh), with a leafy surfice corer.
A rerage

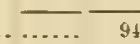

GROTP н.

Jichuan.

Open grore on a lerel plaio. along the banks of a rirer. of nixerl White aud Sintwy Pioe, with satteriog White Birch, and occasienally Oak, Hacknatack. Thite Birch, aud oc'asienalis Oak. Hackluatack. Fir, Cedar (Thuja recidentalis), and a few" smallo (hats. Soil, grar or light brown. sandy, mediun, tiue. soil, gray or light brown. sabdy mediun, tiue. graned, porous, Hght, loose

A rerage

iigotr 1.

\section{Michigan.}

Nortar Pino ( $6 \vec{t}$ per cent), mised mith Thite l'ine (32 per ceat), aud uccasional lack Maple, on a level
plain. Soil, rellow or gray sand, fresh. moderately lowe. witl a surlace corer of brakes; subsoil, sandy. Deosity of crown corer, 0.7. Trees, $18^{2}$ to the acre.

A rerage

\section{GQOt:P K}

Wisconsin

$\Delta \mathrm{n}$ open grore of hardwools, in mhich Thite Pine is scattered in sarying proportions, wo brokeu land, with frequent ewamps in the hollows: nmlererowth, of

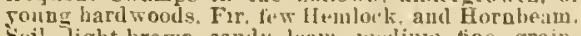
Soil. light-brown sanly loam. tuedinn tine grain. loose, deep, fresh. and well drsived, with an atruckant leaty surface cover.

Arerage

$\begin{array}{rrrr}14 & 121 & 20.2 & 91 \\ 28 & 125 & 24.5 & 89 \\ 15 & 125 & 26.5 & 91 \\ 117 & 125 & 26.3 & 105 \\ 17 & 119 & 29.0 & 97\end{array}$

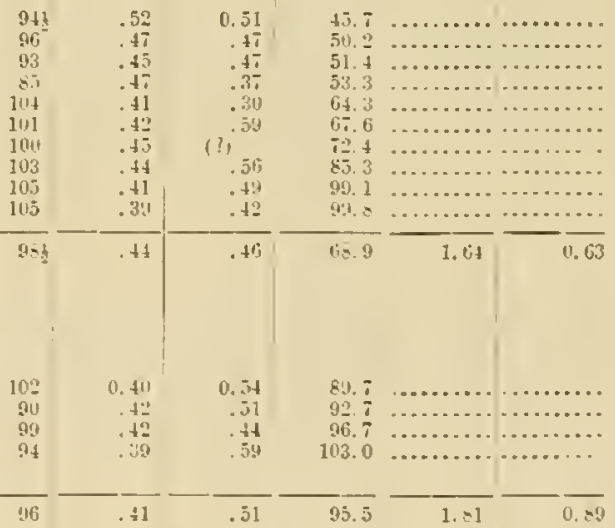

(1)




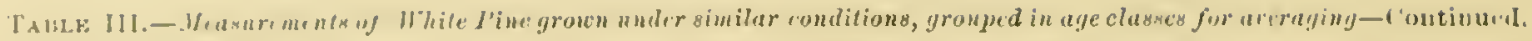

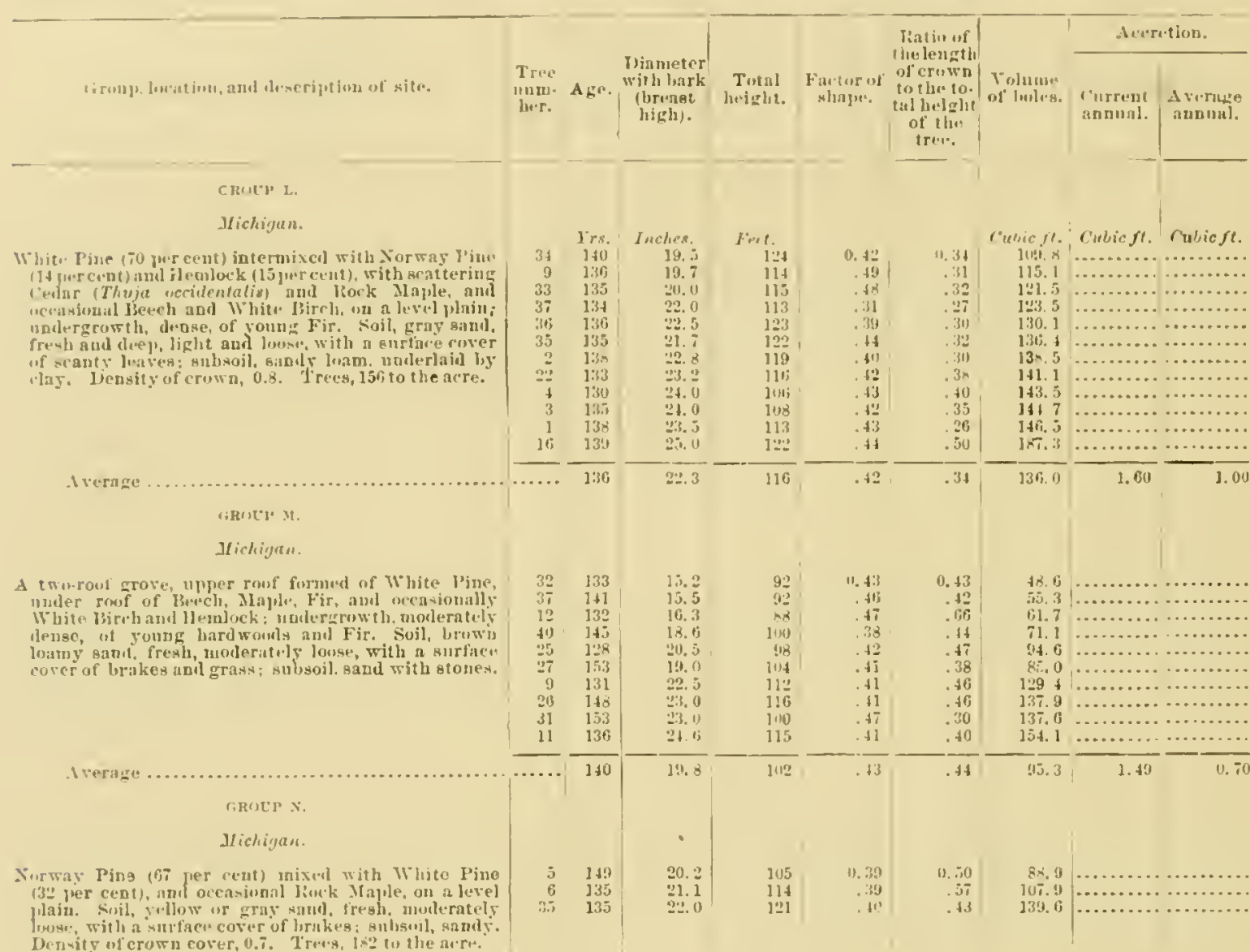

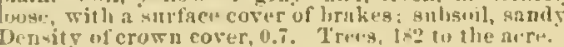

A wrerace o.

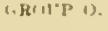 \\ Michigan.}

Whitu J'irw (7) pur ent) intermixed with Sorway l'jue

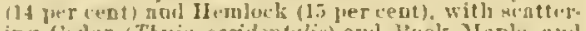

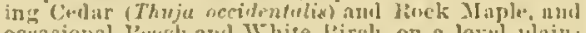
oceasional borth and White lirch, on a level pinjn; ublergrowth dertse, of young Fir. Suil, gray sand, fregh and deep. light and loose with a surface coser

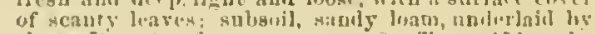

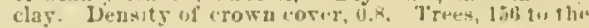
acris.

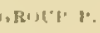 \\ Hisconsiu.}

White l'ine mixel mort or lens with Felhw birch,

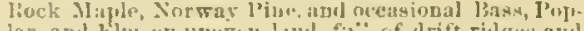

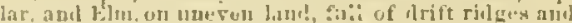

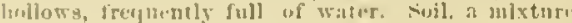

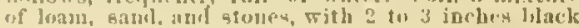

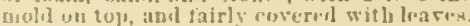

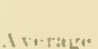

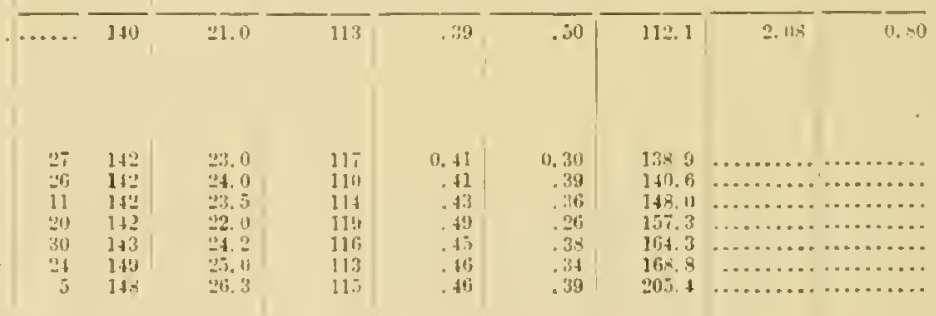

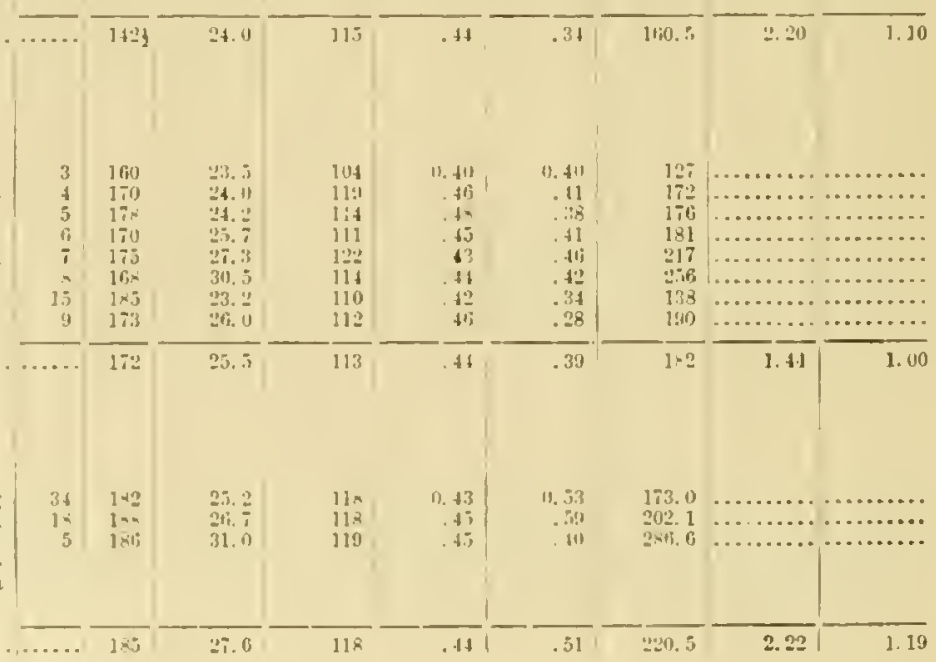

Corwag loin intormusal woh th hit. Pide in varyiug jrojportions, on rollinz litul, with ofwen jilserg of Kod

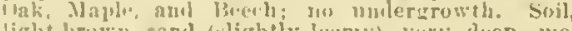
light-brow an and (mghtly loumy rery duep, me.

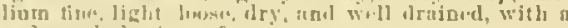
mimlerately losity surfarmenter. 
TAILES OF MEASULEMENT'S.

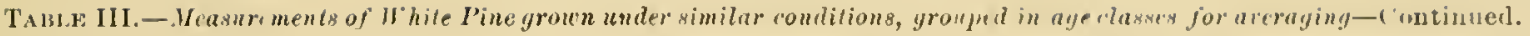

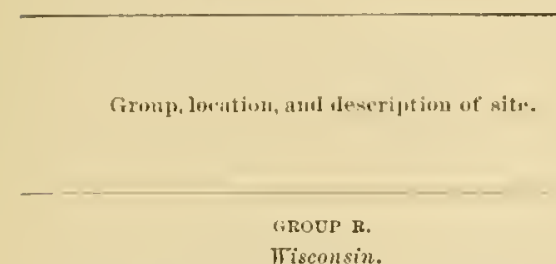

White Pine intermixel with Fellow Birch, Fock Maple, Bass, and Nol'wily I'ine, on ridgo laud, with hollows sometimes full of water, more uften open grassy swamps, with Alder and Ilackmatack, fringeil by pine. Soil, red clayey loan, mixed with sinul anil stones of all sizes, noist; subsuil, sometimes of clis, sometimes of sand.

Arerago.

$$
\text { inOLP s. }
$$

Tisconsin.

White Pine intermixel with Fellow Bireh. Fock II aple, Bass, and Torway l'ide, on ridge lanl, with hollows sometines full of water, mor'e often opeu grassy swamps, with l loler and Hackmatnck, fringed hy pine. Suil, red clarey loam, mixed with samb anil stindes of all sizes, moist ; subsoil, sumetimes of clas, sometines of sand.

$$
\text { Average }
$$

GROCl' T.

Tisconsin.

White Pine mixed with hardwuols, on alrift and some what uneven laul: under"arow th, of young harl woorl

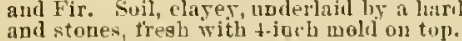

,

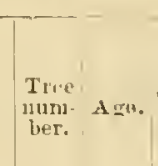

Diameter
vitlu bark

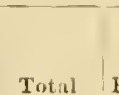

liatie of

the length

Total Factor of

of cruwn Folune

high). height.

Ah:ipe.

thejebt of bules. Current Areraze

trie.

asumet ducrano

tre.
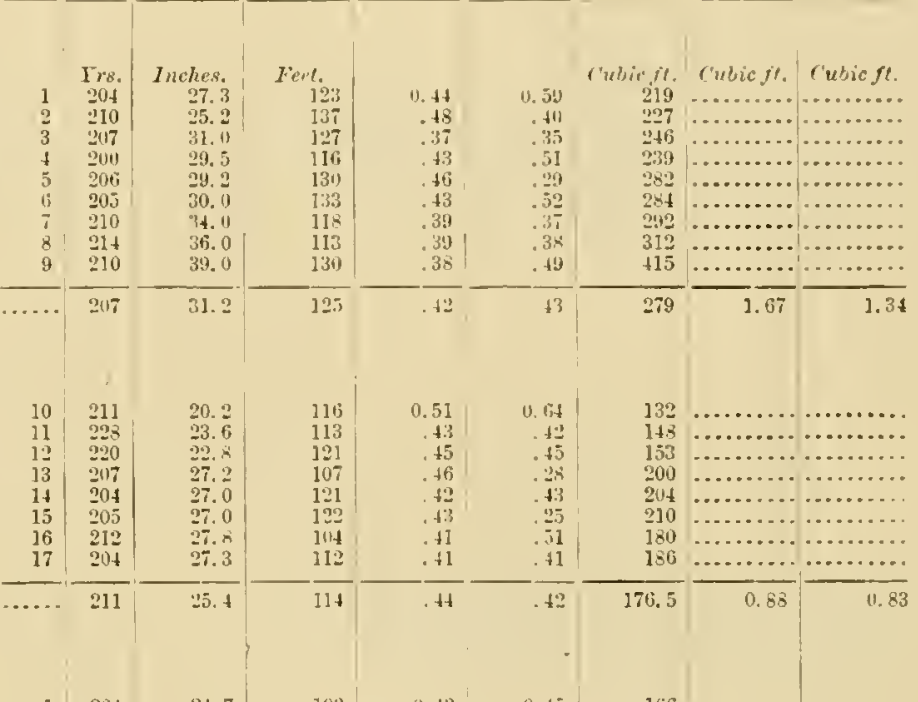

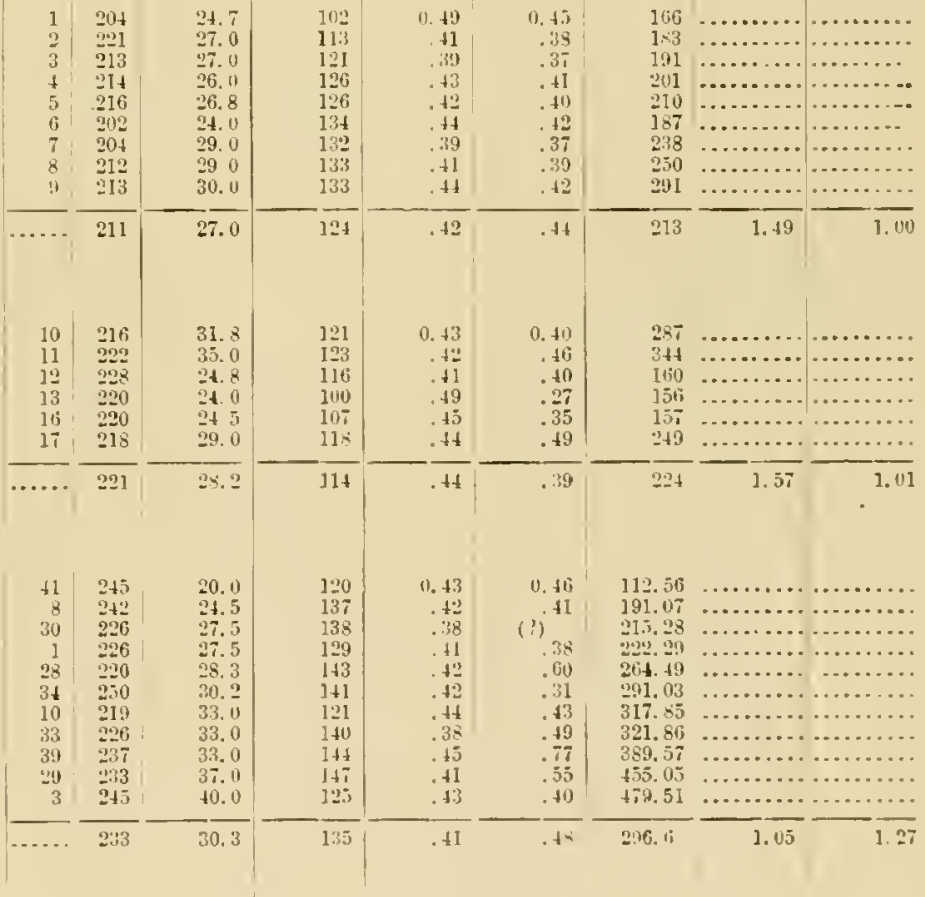

\section{GROLP W.}

A two-roof grose, upper root furmet hy White l'ide 80 per cent) aorl Sorwar Pine (20 per ceut), under ronf of five, tall Hemlock; tiadergrowth, of youn: IIemlock, lieech, and Dwart Jlaple. Suil, brown luamy sand,

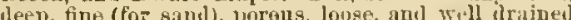

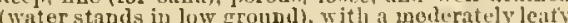
eurtace cover; sulisoil, same as soil.

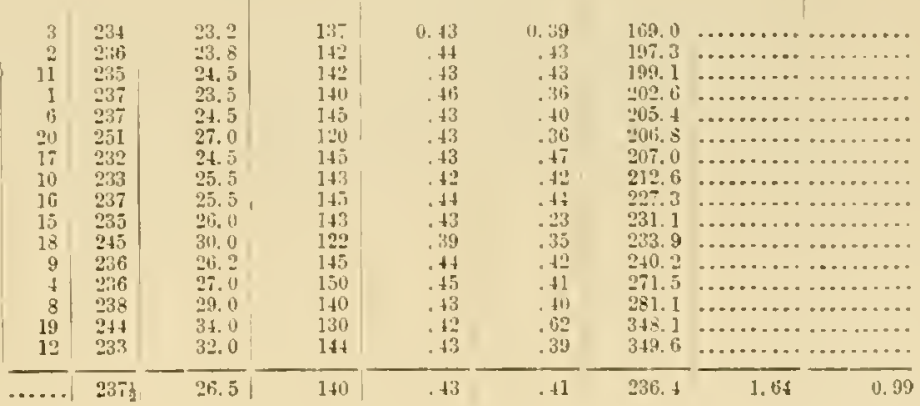




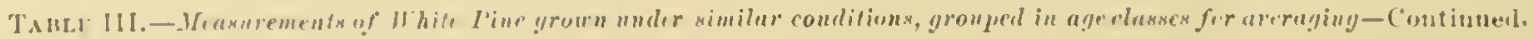

\begin{tabular}{|c|c|c|c|c|c|c|c|c|c|}
\hline lirunp, lesatina, and dearription of sltw. & $\begin{array}{l}\text { Trun } \\
\text { anmm. } \\
\text { liwr. }\end{array}$ & Ag*. & 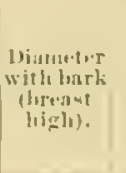 & $\begin{array}{c}\text { Total } \\
\text { bwiglit. }\end{array}$ & $\begin{array}{l}\text { Fan wor of } \\
\text { slitin. }\end{array}$ & 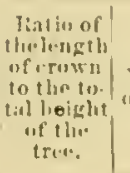 & $\begin{array}{l}\text { Volunine } \\
\text { of lools.s. }\end{array}$ & $\begin{array}{l}\text { (:urrent } \\
\text { nnmust. }\end{array}$ & $\begin{array}{l}\text { Arrag" } \\
\text { antual. }\end{array}$ \\
\hline 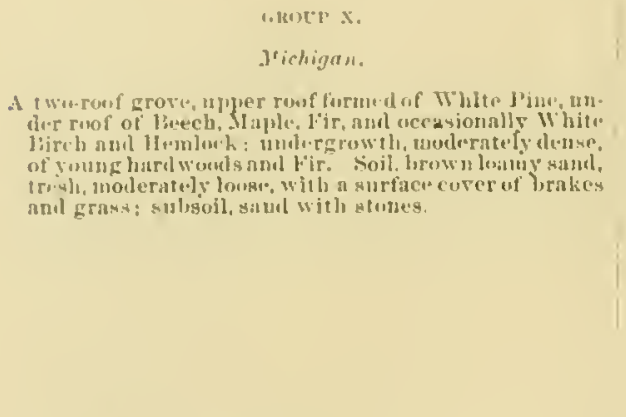 & $\begin{array}{r}14 \\
7 \\
34 \\
23 \\
13 \\
36 \\
4 \\
42 \\
16 \\
2 \\
35 \\
6 \\
17 \\
5 \\
17\end{array}$ & 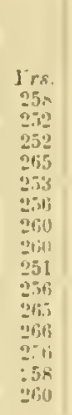 & $\begin{array}{r}\text { fuchin. } \\
21,11 \\
21.2 \\
35.5 \\
25.0 \\
30.0 \\
32.11 \\
31.5 \\
21.5 \\
33.11 \\
31.0 \\
31.5 \\
33.0 \\
32.0 \\
34.0 \\
31.0\end{array}$ & $\begin{array}{r}\text { Ir.t. } \\
119 \\
139 \\
157 \\
126 \\
135 \\
142 \\
132 \\
155 \\
144 \\
145 \\
144 \\
139 \\
354 \\
135 \\
119\end{array}$ & $\begin{array}{c}1.37 \\
.11 \\
.35 \\
.41 \\
.3 ! 1 \\
.31 \\
.39 \\
.41 \\
.33 \\
.41 \\
.80 \\
.38 \\
.41 \\
.42 \\
.35\end{array}$ & \begin{tabular}{l|l}
0.40 & \\
.46 & \\
.88 \\
44 \\
44 \\
4.3 \\
.39 \\
.40 \\
.40 \\
.41 \\
.89 \\
.39 \\
. .11 \\
.33 \\
.50 \\
.45
\end{tabular} & 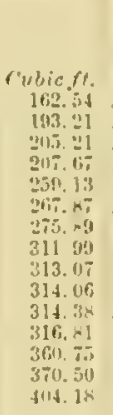 & 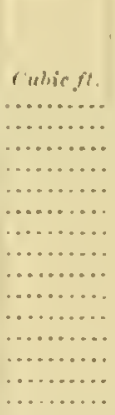 & 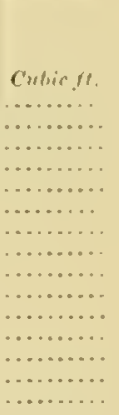 \\
\hline 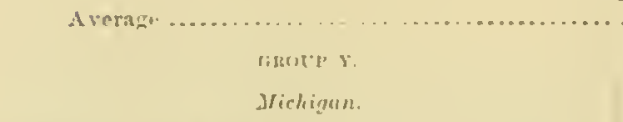 & $\ldots \ldots$ & 258 & 80.3 & 141 & .29 & .46 & 25.001 & 1.50 & 1. 10 \\
\hline 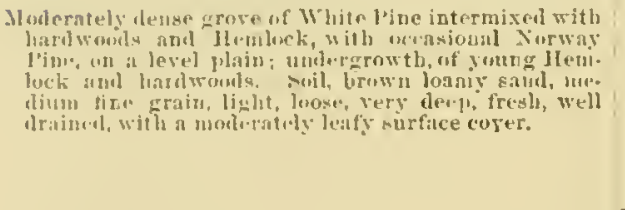 & $\begin{array}{c}3 \\
1 \\
4 \\
9 \\
8 \\
7 \\
3 \\
6 \\
10\end{array}$ & $\begin{array}{l}41 \% \\
415 \\
453 \\
421 \\
410 \\
45 i \\
451 \\
435 \\
45 \%\end{array}$ & $\begin{array}{l}3.0 \\
33.5 \\
41.0 \\
43.0 \\
46.0 \\
47.0 \\
45.0 \\
46.0 \\
47.0\end{array}$ & $\begin{array}{l}1.50 \\
141 \\
152 \\
160 \\
1.00 \\
160 \\
170 \\
168 \\
11 i^{2}\end{array}$ & $\begin{array}{l}0.37 \\
.52 \\
41 \\
.42 \\
.46 \\
.37 \\
.38 \\
.42 \\
.43\end{array}$ & $\begin{array}{l}0.4 . \\
.39 \\
.53 \\
.54 \\
.45 \\
.45 \\
.54 \\
.51 \\
.57\end{array}$ & $\begin{array}{l}433.2 \\
511.5 \\
5 \times 3.7 \\
67.7 .3 \\
694.1 \\
721.9 \\
737.9 \\
=111.6 \\
855.2\end{array}$ & 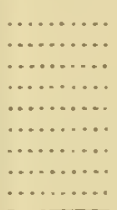 & 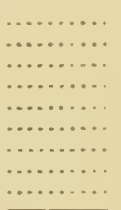 \\
\hline 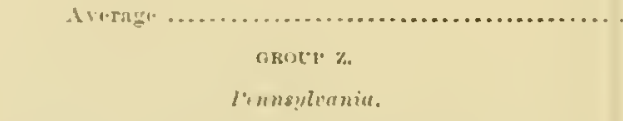 & & 446 & 43,0 & $15 i$ & .41 & .50 & $\operatorname{lis} 1.4$ & $2.6 n$ & 1. . . I \\
\hline 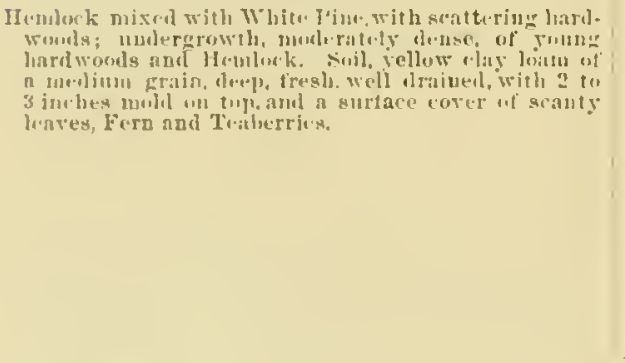 & $\begin{array}{c}1 \\
2 \\
3 \\
4 \\
10 \\
10 \\
15 \\
19 \\
211 \\
211 \\
33 \\
33 \\
34 \\
33 \\
36 \\
37 \\
\end{array}$ & 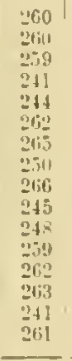 & $\begin{array}{l}33.5 \\
36.0 \\
32.0 \\
32.0 \\
33.0 \\
31.0 \\
33.0 \\
34.0 \\
41.0 \\
34.0 \\
34.0 \\
33.0 \\
33.0 \\
31.0 \\
: 11.5 \\
37.0 \\
\end{array}$ & $\begin{array}{l}159 \\
157 \\
152 \\
150 \\
146 \\
156 \\
153 \\
1.00 \\
144 \\
146 \\
142 \\
1: 33 \\
146 \\
114 \\
134 \\
140\end{array}$ & $\begin{array}{r}1.40 \\
43 \\
46 \\
41 \\
40 \\
.43 \\
43 \\
411 \\
.42 \\
41 \\
.411 \\
42 \\
.411 \\
.42 \\
.16 \\
.42 \\
41 \\
4\end{array}$ & 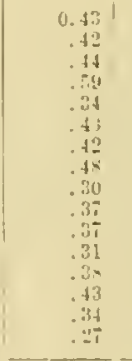 & 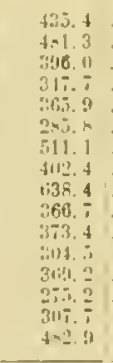 & 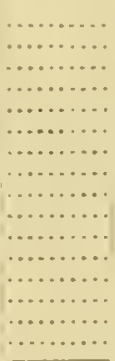 & 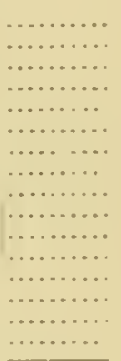 \\
\hline dvernge. & & 25.5 & 31.11 & $14 i$ & .41 & $.3 n$ & 3911,6 & 211. & 1. . : : \\
\hline
\end{tabular}


TAISES OF MEASUREMENTS.

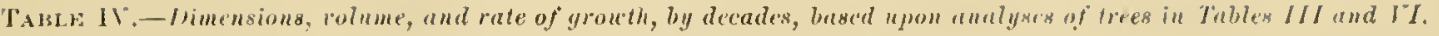

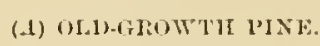

(i) MUMINANT TREE:

Areraige thronghout the range.]

(22) trees.)

\begin{tabular}{|c|c|c|c|c|c|c|c|c|c|c|c|}
\hline \multirow{2}{*}{ Agre. } & \multirow{2}{*}{$\begin{array}{l}\text { Diameler } \\
\text { nt lieighlit } \\
\text { of st foet } \\
\text { (without } \\
\text { bark). }\end{array}$} & \multirow{2}{*}{$\begin{array}{l}\text { Total } \\
\text { lieight } \\
\text { of tree. }\end{array}$} & \multirow{2}{*}{$\begin{array}{l}\text { Tolume } \\
\text { of stemu } \\
\text { (without } \\
\text { barki). }\end{array}$} & \multicolumn{3}{|c|}{$\begin{array}{l}\text { Relative lur cent of total } \\
\text { volume. }\end{array}$} & \multicolumn{3}{|c|}{ l'eriodic arcretion. } & \multirow{2}{*}{$\begin{array}{l}\text { Arerage } \\
\text { anmuil } \\
\text { aceretion. }\end{array}$} & \multirow{2}{*}{$\begin{array}{l}\text { Corrent } \\
\text { immunal } \\
\text { aceretion. }\end{array}$} \\
\hline & & & & $\begin{array}{l}\text { lienrt. } \\
\text { wowl. }\end{array}$ & Sก & liark. & Deraule. & $11+$ iuht. & Volume. & & \\
\hline $\begin{array}{l}\text { Tears. } \\
10\end{array}$ & $\begin{array}{l}\text { Inches. } \\
0.9\end{array}$ & Fept. & rubicst. & Percent. & $\begin{array}{l}\text { I'er cent. } \\
\text {............. }\end{array}$ & Perceut. & I & Foef: & $\begin{array}{l}\text { ('ubic ft. } \\
\text { (i) }\end{array}$ & ('ulic ft. & r'wlic ft. \\
\hline $\begin{array}{l}10 \\
20 \\
30\end{array}$ & $\begin{array}{r}2.5 \\
+8\end{array}$ & $\begin{array}{r}21.0 \\
33.7\end{array}$ & $\begin{array}{r}0.5 \\
2.2 \\
2.2\end{array}$ & & & & 3 & 13. 3 & (1) & 0.02 & (?) \\
\hline 41) & $\begin{array}{l}7.8 \\
6.9\end{array}$ & $\begin{array}{l}80 . \\
46.0\end{array}$ & 5.6 & & & & $i$ & 12.3 & 3.4 & .13 & 0.14 \\
\hline 30 & 8.7 & 36.7 & 111.8 & (1) & 47 & 13 & 5 & 10,7 & 5.2 & .22 & $5 \frac{1}{3}$ \\
\hline $\begin{array}{l}60 \\
70\end{array}$ & $\begin{array}{l}10.5 \\
12.1\end{array}$ & $\begin{array}{l}66.3 \\
7+.7\end{array}$ & $\begin{array}{l}18.6 \\
28.0\end{array}$ & ... & .. & ..... & $\frac{1}{6}$ & 8.1 & $\ddot{9.5}$ & .40 & .95 \\
\hline 84 & 13.8 & 82.0 & 38.8 & & & 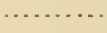 & 3 & 7.3 & 10.8 & .49 & I. 08 \\
\hline 90 & 15.5 & 89.0 & 50.9 & & & & 9 & & 12.1 & .56 & 1. 21 \\
\hline 100 & 17.2 & 91.3 & 66. 0 & & 3 & 10 & 10 & 5. & 15 & .66 & 1.51 \\
\hline 110 & 18.9 & 99.9 & 82.7 & 泣 & 83 & 12. & 11 & 4. & 16 & .75 & 1.67 \\
\hline 120 & 20.6 & 103.7 & 100.3 & & & & 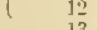 & 4. & 17. & .04 & 1. 76 \\
\hline 130 & 22.2 & & 118.5 & & & & 13 & 4. & 18. & .91 & 1.82 \\
\hline 140 & $23 . \overline{1}$ & 111.3 & 137.3 & $\cdots$ & . & $\cdots$ & $1 \ddagger$ & 3. & 18 & 98 & 1.88 \\
\hline 150 & 25.0 & 114.4 & 155.7 & ... & $\ddot{*}$ & $\cdots$ & 15 & 3. & 18.4 & 1. 04 & 1.84 \\
\hline $\begin{array}{l}160 \\
170\end{array}$ & $96-3$ & 117.3 & $\begin{array}{l}15.3 \\
194.6\end{array}->0$ & & . & $\cdots$ & $\begin{array}{l}16 \\
17\end{array}$ & $\begin{array}{l}3.0 \\
3.3\end{array}$ & $\begin{array}{l}19.6 \\
\text { 14. } 3 \\
3\end{array}$ & $\begin{array}{l}1.09 \\
1.14\end{array}$ & $\begin{array}{l}1.96 \\
1.93\end{array}$ \\
\hline 180 & 22.7 & 123.7 & 2 i. $\mathrm{s}$ & & & $\cdots$ & 18 & 3. & 20 & 1. 19 & 2.02 \\
\hline 100 & 29.8 & 140.3 & 234.7 & & & & 19 & 2. & 39 & 1. 23 & 1.99 \\
\hline 200 & 31.0 & $12 \% 0$ & 254.7 & 65 & 23 & 12 & 20 & 5 & 20) & 1.27 & 20 in \\
\hline 210 & 30.7 & 134.5 & & ...... & 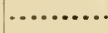 & & $2]$ & 3.0 & 20 & 1.2 & $2.0{ }^{\circ}$ \\
\hline $\begin{array}{l}290 \\
230 \\
230\end{array}$ & 31.6 & $\begin{array}{l}13.5 \\
114.5\end{array}$ & 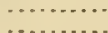 & 69 & 21 & iij & 3 & $\begin{array}{l}3.0 \\
3.0\end{array}$ & $\frac{21.5}{31.5}$ & 1. 313 & $\begin{array}{l}2.15 \\
716\end{array}$ \\
\hline & & & & & & & & & & & \\
\hline
\end{tabular}

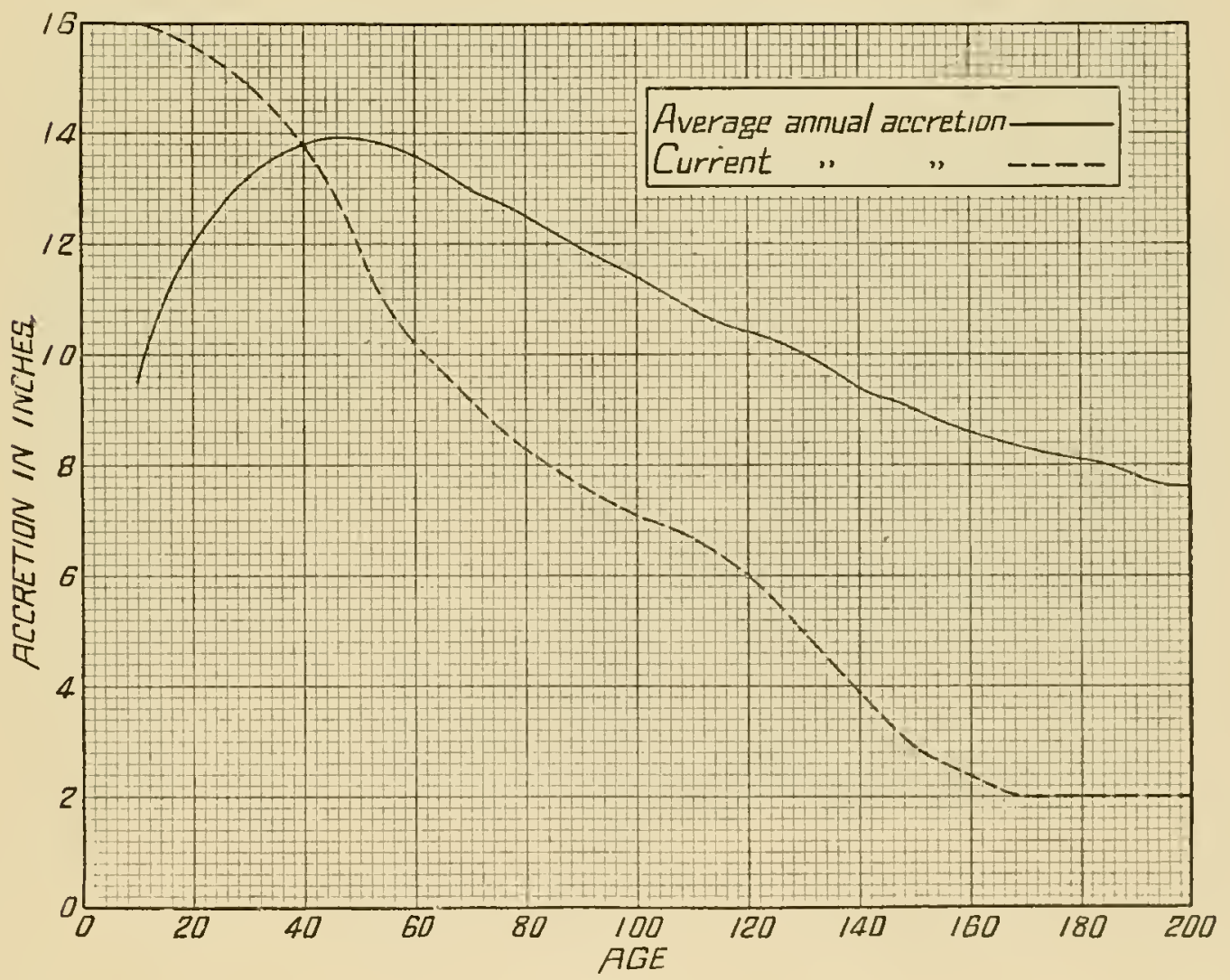

Fu. 19.-Dingrau showing rate of helght growtl of huminaut trees. 


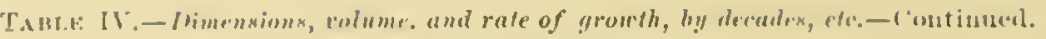

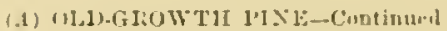

(2) CODOMUSANT THEL

[A wrage (1)roughout the range. ]

(106 trets.)

\begin{tabular}{|c|c|c|c|c|c|c|c|c|c|c|c|}
\hline \multirow{2}{*}{ A } & \multirow{2}{*}{$\begin{array}{l}\text { Jianuter } \\
\text { at helght } \\
\text { of } 23 \text { feet } \\
\text { (willout } \\
\text { lorki). }\end{array}$} & \multirow{2}{*}{$\begin{array}{l}\text { Tutal } \\
\text { hefight } \\
\text { of ireese }\end{array}$} & \multirow{2}{*}{$\begin{array}{l}\text { Voluma: } \\
\text { ot'stebu } \\
\text { (withune } \\
\text { losk). }\end{array}$} & \multicolumn{3}{|c|}{ 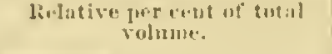 } & \multicolumn{3}{|c|}{ Periodic ancretion. } & \multirow{2}{*}{$\begin{array}{c}\text { Awrage } \\
\text { nnnual } \\
\text { netretions }\end{array}$} & \multirow{2}{*}{$\begin{array}{l}\text { Current } \\
\text { annual } \\
\text { aceretion }\end{array}$} \\
\hline & & & & $\begin{array}{l}\text { Irarg. } \\
\text { whoul. }\end{array}$ & Sajwant. & liark. & llewarle. & Hright. & Volume. & & \\
\hline $1 \times 10$ & Ineling. & Fow & rulic it. & Ter cint. & Per cent. & lererut. & & Fert. & rubic Jl. & rubic jt. & rulire jt. \\
\hline $\begin{array}{l}10 \\
20\end{array}$ & $\begin{array}{l}0.8 \\
2.3\end{array}$ & 1.0.0 & (i) & $\ldots$ & … & 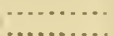 & 1 & 6.0 & (1) & (1) & (?) \\
\hline 30 & 40 & $\begin{array}{l}10.0 \\
28.5\end{array}$ & 1.6 & & & - & 3 & $\begin{array}{l}12.0 \\
12.0\end{array}$ & 1.2 & 0.05 & v. 12 \\
\hline ti) & 5.8 & 38.0 & 4.4 & & & & 4 & 3. 5 & 2.11 & .11 & .29 \\
\hline 50 & $\therefore 3$ & 47.5 & 7.7 & .... & ............ & & 5 & 9.5 & 3.3 & .15 & .33 \\
\hline 60 & 4.0 & 6ti. 5 & 11.3 & $\ldots$ & …...... & & 6 & 0.0 & 3.0 & .19 & .36 \\
\hline 70 & 10.5 & 64.11 & 17.4 & ....... & ............. & & $i$ & 7.5 & 0.1 & .25 &. \\
\hline si) & 11.9 & 71.5 & 24.9 & .... & & & 8 & T.. & $i . j$ & .31 & .73 \\
\hline 90 & 13. 3 & 79.0 & 34.4 & .... & & & 9 & 7.5 & 9.5 & .35 & .95 \\
\hline 100 & 14. 7 & 84.5 & 44.5 & .... & & & 10 & 5.5 & 10.2 & 4. & 1.02 \\
\hline 110 & 16.0 & 8. 5 & 5.. 5 & .... & & & 11 & 5.0 & 11.0 & .50 & 1. 10 \\
\hline 120 & 17.3 & 94.5 & $6 i .5$ & & & & 12 & 5. 0 & 12.0 & .56 & 1. 20 \\
\hline 130 & 18.6 & 19.0 & 78.6 & & & & 13 & 4.5 & 11.2 & .61 & 1.1: \\
\hline 140 & 19.4 & 103.0 & 91.5 & .... & & & 14 & 4.0 & 12. 9 & .66 & 1. 29 \\
\hline 150 & 20.8 & $10 \bar{i} .0$ & I014 0 & & & & 15 & 4.0 & 12. 5 & .69 & 1.25 \\
\hline 180 & 22.0 & 111.0 & 115.9 & ..... & & $\cdots$ & 10 & 4.0 & 13.0 & .72 & $1.2 n$ \\
\hline 170 & 23. 0 & $11+0$ & 127.7 & ..... & & . & 17 & 3.0 & 11. 8 & .75 & 1.18 \\
\hline & $23,:$ & 117.5 & 129. 2 & .... & & & 1) & 3.5 & 13.: & .2 & 1.39 \\
\hline 190 & 24.7 & 12 & 142. & .... & & & $1 ! 1$ & 2.5 & 13.7 & .75 & $1.3 i$ \\
\hline 200 & 25.6 & 122.5 & 152.7 & , n...... & & 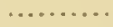 & 20 & 2.5 & 9.8 & . 66 & .98 \\
\hline 210 & 26.3 & 125.0 & 165.5 & ...... & & .. & 21 & 2.5 & 12.8 & .79 & 1.24 \\
\hline$\because 20$ & T⿱一𫝀. 0 & 12 & 179.3 & & & & $2 !-2$ & 2.5 & 13.8 & .81 & 1.38 \\
\hline 230 & 27.7 & 130.0 & 195.0 & & .... & & 23 & 2.5 & 15.7 & .84 & $1.5 i$ \\
\hline
\end{tabular}

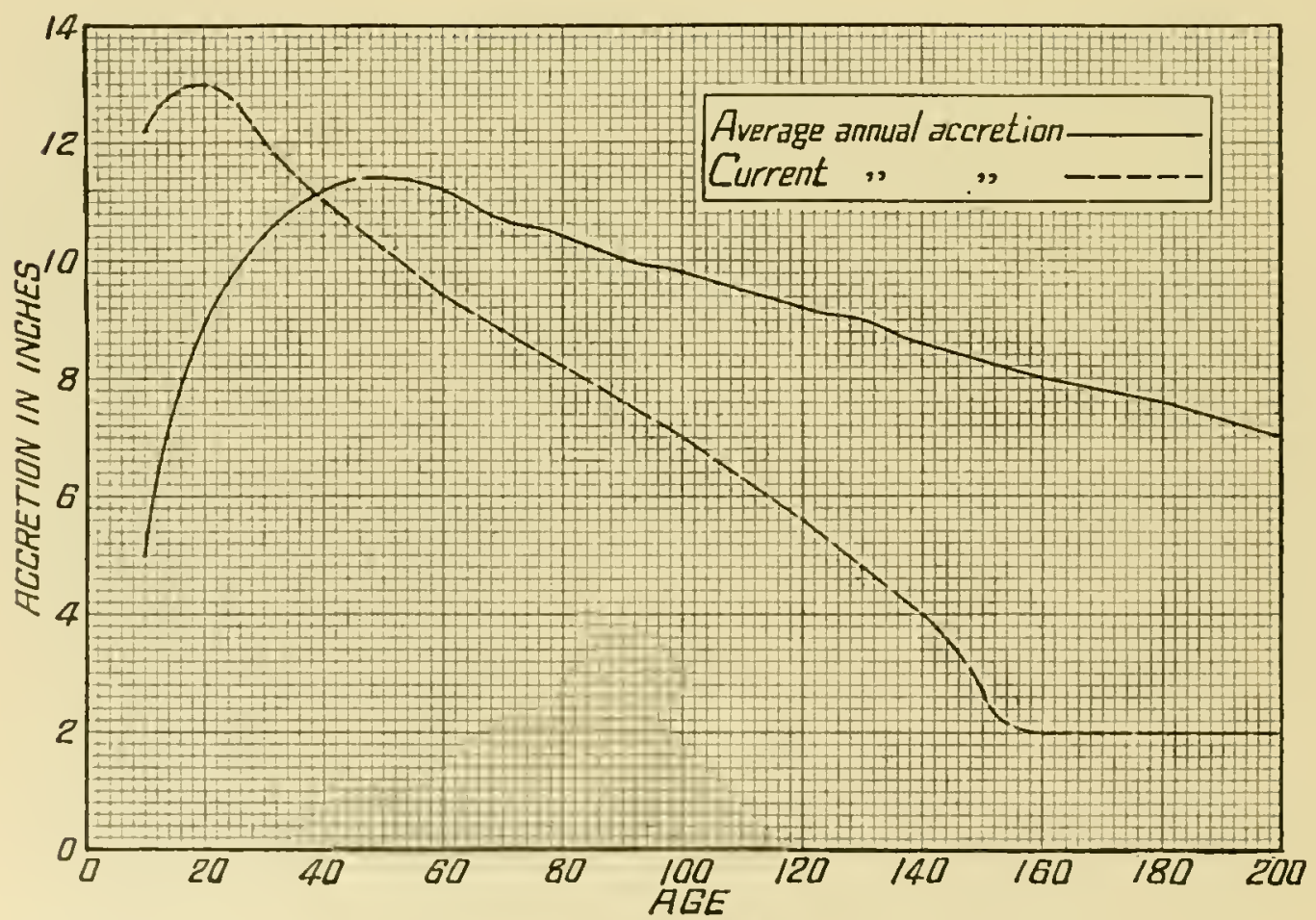

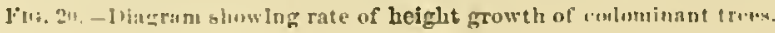


TABLES OF MEASUREMENTS.

'TABLE IV. - Jimensions, rolume, and rate of growth, by decules, re.-C'ontinued.

(1) (ILI-1:IU)WIII IXIE-Continuerl.

(3) OPREESED TREES

[A verage thronghont tlin liuge.]

(104 trees.)

\begin{tabular}{|c|c|c|c|c|c|c|c|c|c|c|c|}
\hline \multirow{2}{*}{ Age. } & \multirow{2}{*}{$\begin{array}{l}\text { Diameter } \\
\text { at lieiglit } \\
\text { of at feet } \\
\text { (without } \\
\text { bark). }\end{array}$} & \multirow{2}{*}{$\begin{array}{l}\text { Total } \\
\text { leight } \\
\text { of' tree. }\end{array}$} & \multirow{2}{*}{$\begin{array}{c}\text { Tolunis } \\
\text { of steu } \\
\text { (witlunt } \\
\text { hark). }\end{array}$} & \multicolumn{3}{|c|}{ 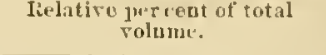 } & \multicolumn{3}{|c|}{ l'urioulie necretion. } & \multirow{2}{*}{$\begin{array}{l}\text { A rerage } \\
\text { anmuil } \\
\text { accretiun. }\end{array}$} & \multirow{2}{*}{$\begin{array}{l}\text { Corrent } \\
\text { annual } \\
\text { accrition. }\end{array}$} \\
\hline & & & & $\begin{array}{l}\text { Heart: } \\
\text { wiot. }\end{array}$ & Sapwool. & liark. & ly"cade. & Ileight. & Folunte. & & \\
\hline Years. & Inches. & Fect. & rubic ft. & Jer ernt. & I'er cent. & Per cent. & & $F i, t$. & (ubic fe. & Culic ft. & rubert. \\
\hline 10 & 0.9 & 4. 0 & (I) & .......... & & & 1 & 4. 0 & (1) & (?) & (l) \\
\hline 20 & 2.0 & 11.0 & 0.4 & 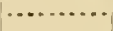 & $\cdots$ & & 2 & $\Xi 0$ & (1) & 0.02 & (?) \\
\hline 30 & $\begin{array}{l}3.7 \\
5.2\end{array}$ & 18.0 & 0.7 & .......... & 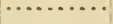 & 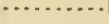 & 3 & 7.0 & 0.4 & .02 & 0.04 \\
\hline $\begin{array}{l}40 \\
50\end{array}$ & $\begin{array}{l}5.2 \\
6.7\end{array}$ & 6.0 & 1.7 & $\cdots$ & ....... & $\cdots$ & 4 & 8. & 1.0 & .04 & .111 \\
\hline $\begin{array}{l}50 \\
60\end{array}$ & $\begin{array}{l}6.7 \\
8.11\end{array}$ & 34.5 & 3. & (1). & .... & $\cdots$ & 5 & $\therefore$ & & $.0 \overline{7}$ & .18 \\
\hline 70 & $\begin{array}{l}8.0 \\
9.2\end{array}$ & 43.5 & 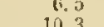 & a.......... & … & .. & 6 & 9. & $2=$ & .11 & .29 \\
\hline 80 & $\begin{array}{r}9.2 \\
10.6\end{array}$ & 51.5 & 10.3 & ...... & & ... & $\hat{i}$ & 8. & 3. & .1 & $.3 R$ \\
\hline 90 & 11.9 & a. 5 & 3.1 .5 & & & $\cdot 1$ & 9 & 8. & 4. & .19 & $.4 h$ \\
\hline 100 & 13.3 & 73.0 & 99.0 & & & & Is & 7. & 6. & .24 & (ij) \\
\hline 110 & 14.7 & 79.0 & 37.5 & 51 & 36 & 13 & 11 & 6. & 8.5 & 35 & .75 \\
\hline 120 & 15.9 & 84.5 & 46.8 & I & & & i. & 5. & 9 & .30 & .93 \\
\hline 130 & 17. I & 89,0 & 57.0 & & & & 13 & 4. & 10.3 & .44 & 1.103 \\
\hline 140 & 18. 2 & 93.5 & 63.5 & ... & & & 14 & 4 & 11.5 & .49 & 1.15 \\
\hline 150 & 19.3 & 97.0 & 78.5 & $\ldots \ldots$ & $\ldots . . . .$. & $\ldots \ldots \ldots \ldots$ & 15 & 3. & 11.0 & .54 & 1.10 \\
\hline 160 & 30.3 & 100.5 & 90.8 & - $\ldots \ldots \ldots$ & . & 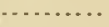 & 16 & 3. & 11.3 & .57 & 1.13 \\
\hline 170 & $\because 1.2$ & 103.5 & 102.3 & $\cdots \ldots$ & 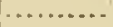 & 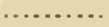 & 17 & 3.0 & 11.5 & .60 & 1.15 \\
\hline 180 & 22. 2 & 106.5 & 114.0 & $\ldots \ldots$ & & & 18 & 3. & 11.8 & .64 & 1.13 \\
\hline 190 & 23. 2 & 109.0 & 125.0 & - . . . . & $\cdots$ & 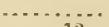 & 19 & 2. & 11. & $.66^{\circ}$ & 1.10 \\
\hline 200 & 23.9 & 111.5 & 136.0 & 60 & -2 & 12 & 20 & 2.5 & 11.0 & .65 & 1.10 \\
\hline
\end{tabular}

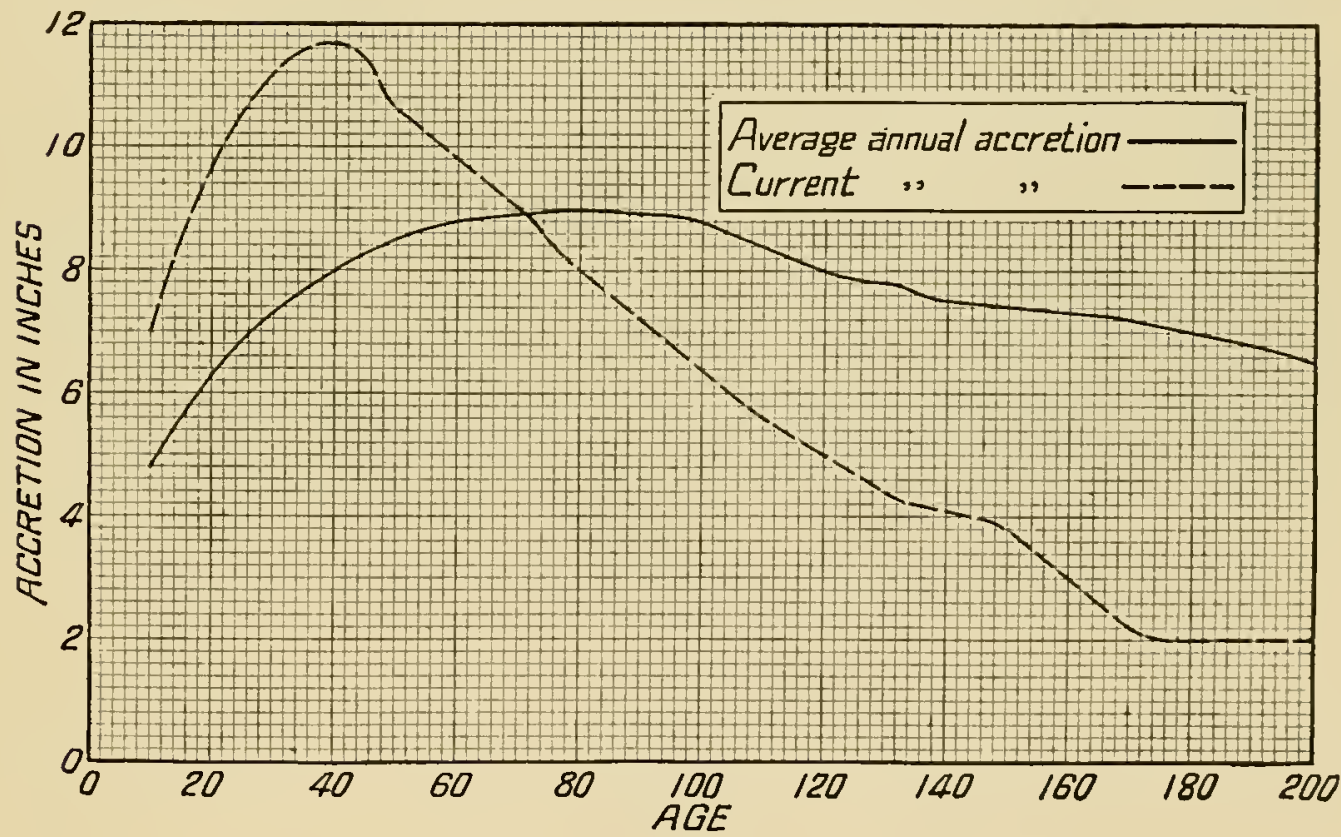

Fur. 21.-Dingran showing rate of heinht growth of uppresserl trees. 


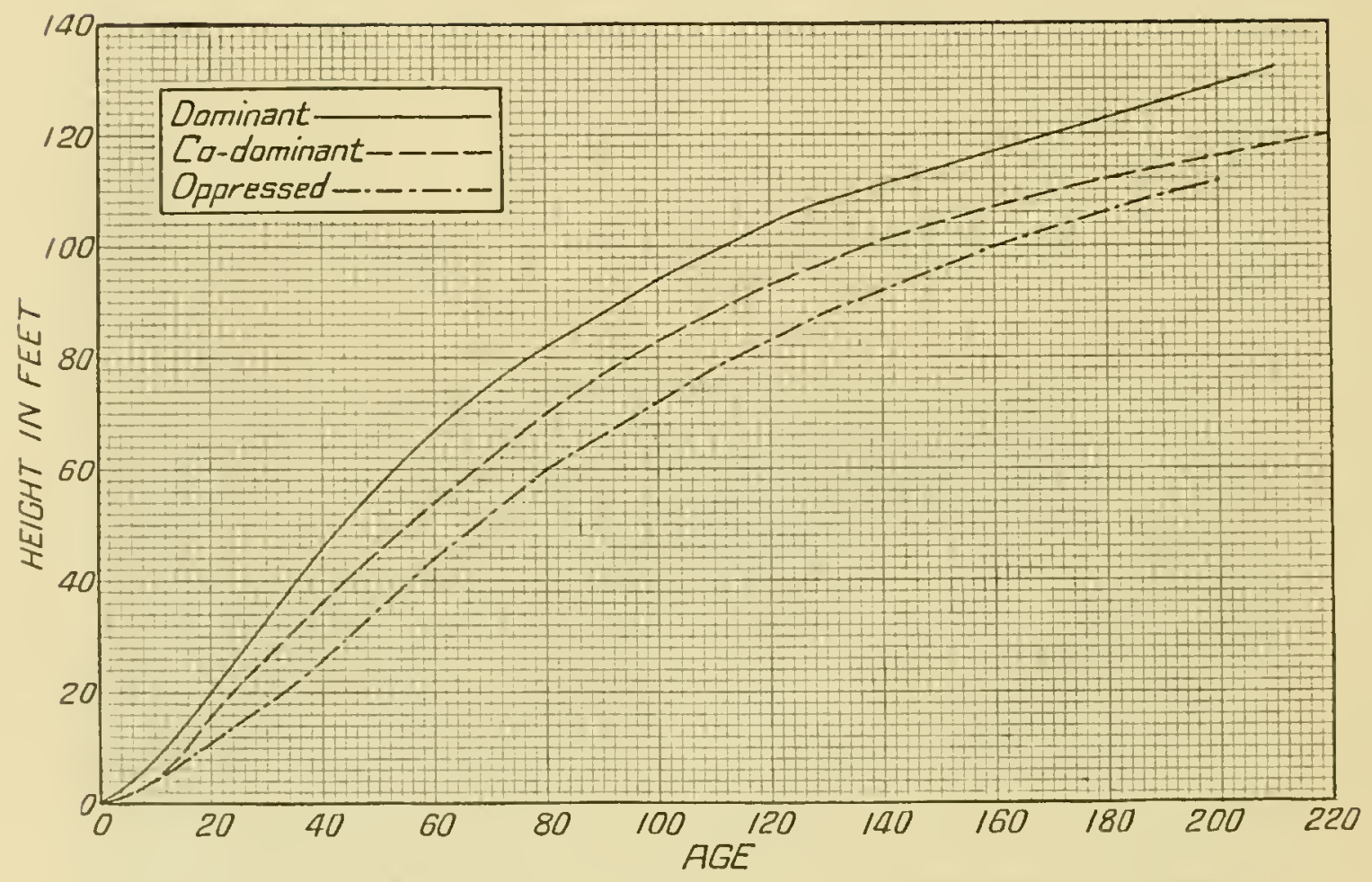

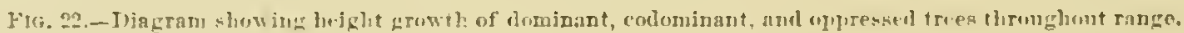


TABIES OF MEASUREMHNTS.

97

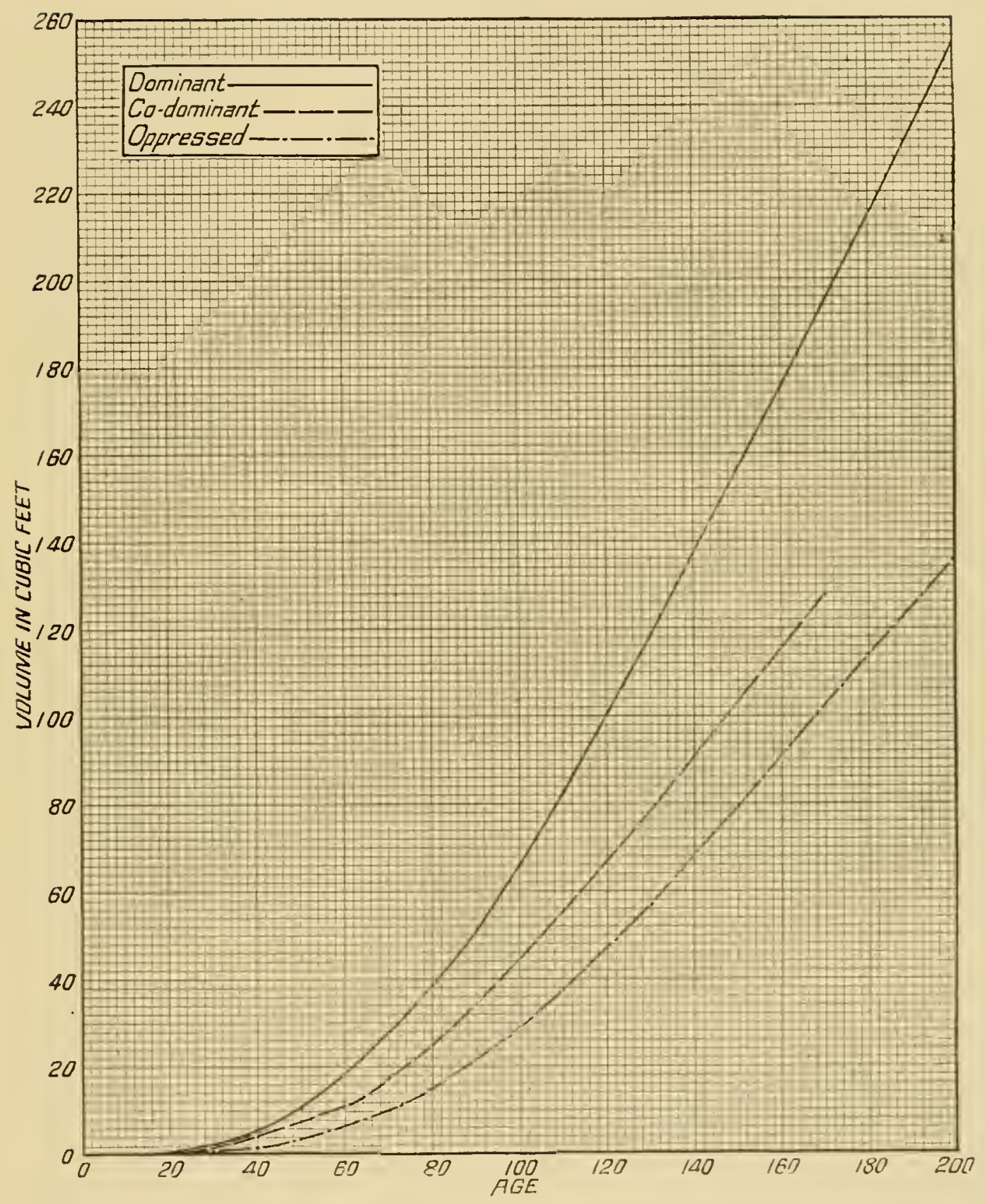

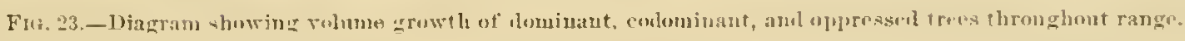
2013-10. 


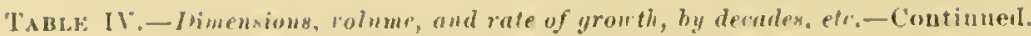

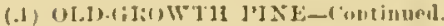

(t) DOMISANT TIKF-

[Arerage in Winc(n)min.]

$(0, \alpha$ treen.

\begin{tabular}{|c|c|c|c|c|c|c|c|c|c|c|c|}
\hline \multirow{2}{*}{ Age. } & \multirow{2}{*}{ 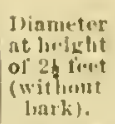 } & \multirow{2}{*}{$\begin{array}{l}\text { Tintal } \\
\text { liviplit } \\
\text { wit tree. }\end{array}$} & \multirow{2}{*}{$\begin{array}{l}\text { Volume } \\
\text { of ntmot } \\
\text { (withinut } \\
\text { bark). }\end{array}$} & \multicolumn{3}{|c|}{$\begin{array}{l}\text { Iorlative grer reut of total } \\
\text { volume. }\end{array}$} & \multicolumn{3}{|c|}{ periudio ancretion. } & \multirow{2}{*}{$\begin{array}{l}\text { A vorages } \\
\text { asmonal } \\
\text { accretiofs. }\end{array}$} & \multirow{2}{*}{$\begin{array}{l}\text { Current } \\
\text { atuminal } \\
\text { actrution. }\end{array}$} \\
\hline & & & & $\begin{array}{l}\text { II iart. } \\
\text { wotind. }\end{array}$ & Sit jowired. & Jiark. & Itergute. & Jeight. & 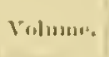 & & \\
\hline lears. & laches. & lipet. & Culic ft. & Irrcene. & I'er cent. & Jire cint. & & Fiet. & (ubic ft. & "ubic fe. & r'ubic gt. \\
\hline $\begin{array}{l}111 \\
20\end{array}$ & 1. 0 & & (i) & ........... & $\ldots$ & $\ldots$ & 1 & & (1) & $(1)$ & (?) \\
\hline $\begin{array}{l}30 \\
310\end{array}$ & 2. 2 & 20 & $0 . \overline{1}$ & & & . & $\frac{2}{3}$ & $\begin{array}{l}13 \\
12\end{array}$ & (i) & 0.02 & (!) \\
\hline to & $\begin{array}{l}3 . x \\
\text { j. } 3\end{array}$ & $\begin{array}{l}34 \\
4 i i\end{array}$ & 1.7 & $\ldots$ & $\cdots$ & ' & 4 & 12 & 1.6 & .02 & .16 \\
\hline 5i) & 6.6 & 57 & 7.6 & …… & ............ & …….. & $j$ & i1 & 4.1 & .15 & 41 \\
\hline fio & 8.0 & (i6 & 13.2 & ..... & $\ldots \ldots$ & .......... & ij & 9 & 5. & .22 & . int \\
\hline 7" & 0.3 & 71 & :11 & ........... & ........... & $\ldots \ldots \ldots$ & $i$ & 8 & 7. & .80 & .78 \\
\hline 80 & 11.0 & $\times 0$ & 30.0 & .......... & $\ldots \ldots \ldots \ldots$ & ........... & 8 & ii & 9.0 & .3 & . III \\
\hline 90 & 33.0 & mi & 11. i & …....... & $\ldots \ldots$ & n........... & 8 & c) & 11.5 & .46 & 1.15 \\
\hline 110 & I. 2 & 91 & 5.20 & ........... & ........... & .......... & 10 & 5 & 16. i & .58 & 1.65 \\
\hline 110 & 17.4 & 97 & in. 0 & ........... & .......... & ........ & 11 & 4 & $\because 10$ & i1 & $\therefore 00$ \\
\hline 120 & 10.16 & Iivi & 1110.5 & ........... & .......... & ............ & 12. & 5 & 22.5 &.$n t$ & 2.25 \\
\hline 1311 & 21.5 & jo1 & 124.0 & $\ldots .$. & ........... & ……. & 13 & 4 & 23.5 & .05 & 2.35 \\
\hline 140 & 240 & ]118 & $1+7.5$ & ............ & .......... & ........... & is & 4 & 23.5 & 1,05 & 2.35 \\
\hline i50 & 27.7 & 111 & 169.0 & $\cdots$ & .......... & ......... & 15 & 3 & 21.3 & 1. 13 & 2.15 \\
\hline 160 & 27.4 & 114 & 190.5 & ............ & .......... & ........... & If & 3 & 21.5 & 1.19 & 315 \\
\hline 1,11 & 240 & 117 & 212.5 & $\ldots \ldots \ldots$ & ............. & .......... & 17 & 3 & $y 2$. & 1.25 & 2.24 \\
\hline IR11 & 30.5 & 120 & 234.5 & ж...... & . & .......... & IN & 3 & 22.0 & 1.30 & 2.20 \\
\hline 190 & 320 & 122 & 256.0 & & & & $1 !$ & 2 & 21.5 & 1.35 & 2.15 \\
\hline 200 & $3 \% 3$ & 124 & 277.0 & 65 & 23 & 12 & 20 & 2 & 21.0 & 1.38 & $\geq .10$ \\
\hline
\end{tabular}

(5) OPPKES-ED TRER-

[Average in Winensin.]

(i5 trites.)

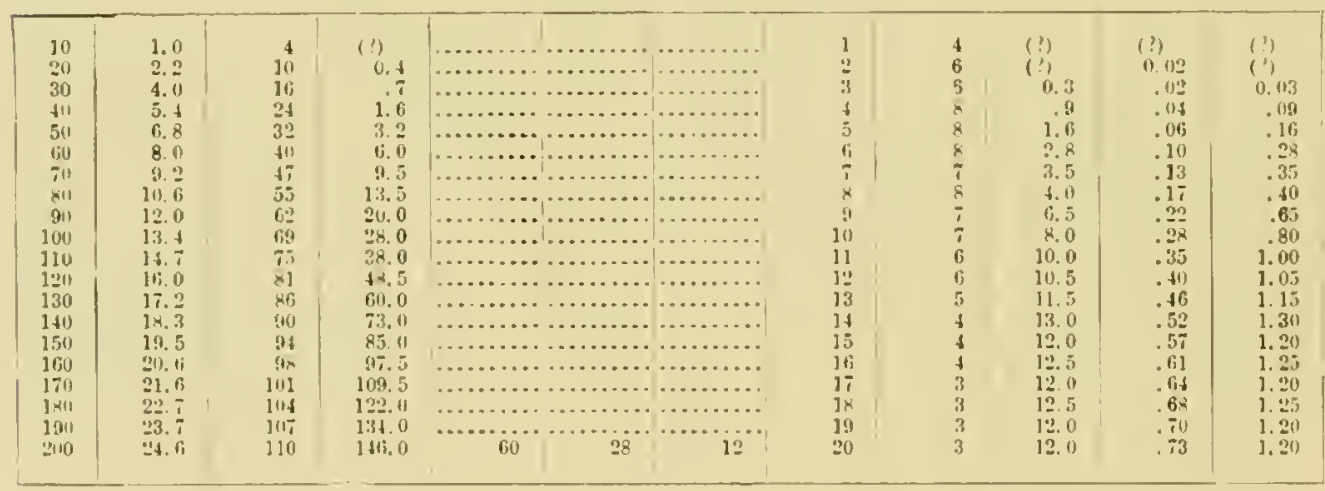

(ii) IWUMINANT TREKS.

[Average in Michigan.]

(75 trets.)

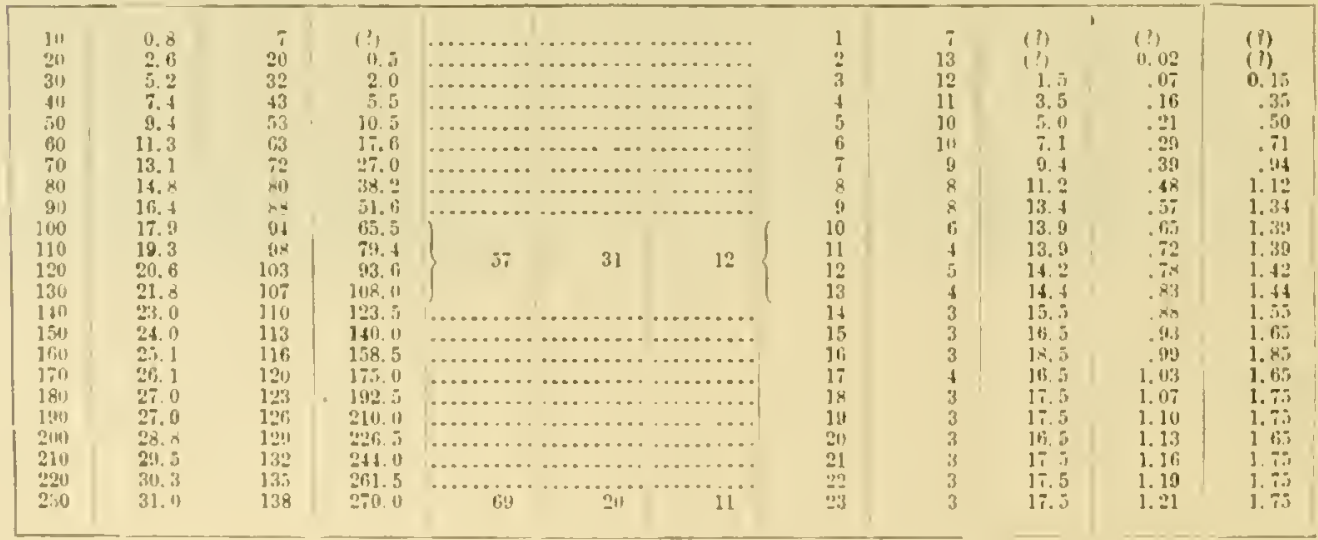


TABLES OF MEASLREMENTS.

TAsis: IV.-Dimensions, rolume, and rate of growth, by decadex, etr.-Contiumst.

(.L) Ol.1.GLOWTH P1NE-Continued.

(i) CODOMINANT TREES.

[A verage in Michicrah.]

(28 trmes.)

\begin{tabular}{|c|c|c|c|c|c|c|c|c|c|c|c|}
\hline \multirow{2}{*}{ A ree } & \multirow{2}{*}{$\begin{array}{l}\text { 1)iameter } \\
\text { at lieight } \\
\text { of a feet } \\
\text { (without } \\
\text { bark). }\end{array}$} & \multirow{2}{*}{$\begin{array}{c}\text { Total } \\
\text { height } \\
\text { of tree. }\end{array}$} & \multirow{2}{*}{$\begin{array}{l}\text { Volume } \\
\text { of stem } \\
\text { (withuut } \\
\text { bark). }\end{array}$} & \multicolumn{3}{|c|}{$\begin{array}{l}\text { lielative per cent of total } \\
\text { volume. }\end{array}$} & \multicolumn{3}{|c|}{ derionlin acerotion. } & \multirow{2}{*}{$\begin{array}{c}\text { Arumgn } \\
\text { anmal } \\
\text { arcutinn. }\end{array}$} & \multirow{2}{*}{$\begin{array}{l}\text { Curront } \\
\text { annual } \\
\text { aceretials. }\end{array}$} \\
\hline & & & & $\begin{array}{l}\text { Heart. } \\
\text { woud. }\end{array}$ & Sapiwoonl. & Bark. & lezualls. & Height. & Volune. & & \\
\hline lears. & Inches. & Feet. & rubic ft. & Ier cent. & Precent. & I'er cent. & & Fent. & Cubic ft. & Cubic ft. & Oubie $f t$. \\
\hline $\begin{array}{l}10 \\
20\end{array}$ & $\begin{array}{l}0.7 \\
0.2\end{array}$ & $\frac{7}{16}$ & (1) & (......... & $\cdots$ & $\begin{array}{l}\cdots \\
\cdots\end{array}$ & $\begin{array}{l}1 \\
2\end{array}$ & $\bar{i}$ & (?) & (1) & (3) \\
\hline 30 & 4.0 & 29 & $\begin{array}{l}0.1 \\
1.3\end{array}$ & & & $\cdots$ & $\frac{2}{3}$ & $\begin{array}{c}11 \\
13\end{array}$ & (?) & 0.02 & (!) \\
\hline 4!) & 5. & 37 & 4.0 & & .... & $\ldots$ & 4 & $\begin{array}{r}13 \\
8\end{array}$ & 0.9 & .04 & 0.09 \\
\hline 50 & 7. 3 & $4 i$ & 7.6 & & & & 5 & $\begin{array}{r}8 \\
10\end{array}$ & $\frac{3.7}{3.6}$ & $\begin{array}{r}.10 \\
.15\end{array}$ & .27 \\
\hline 60 & 8.8 & 57 & 11.5 & $\cdots$ & . & ... & 6 & 10 & $\begin{array}{l}3.0 \\
3.9\end{array}$ & $\begin{array}{r}.15 \\
.19\end{array}$ & .36 \\
\hline 70 & 10.1 & 65 & 18.0 & & ......... & .... & 7 & 8 & 6.5 & .20 & .39 \\
\hline 80 & 11.7 & it & $31 i .4$ & & & $\ldots$ & 8 & 9 & 8. & .3 & .85 \\
\hline 90 & 13. 2 & स.3 & 38.4 & & $\cdots$ & ..... & 0 & 9 & 11.6 & .12 & 1.84 \\
\hline 100 & 14.0 & 80 & 50.0 & ... & $\ldots$ & ... & 11! & 6 & 12.0 & .50 & 1. 20 \\
\hline 110 & 15.9 & 94 & 6.3. 0 & & $\ldots$ & $\ldots$ & 11 & 5 & 13.0 & .57 & 1.30 \\
\hline 120 & 17. 2 & 99 & 77.0 & & $\cdots$ & ... & 12 & 5 & 14.0 & .64 & 1.40 \\
\hline 130 & & 104 & 92.0 & & $\ldots$ & ... & 1:: & 5 & 15.0 & .71 & 1.50 \\
\hline 140 & 19.8 & 108 & 106.0 & & & & 14 & 4 & 14.0 & .76 & 1.40 \\
\hline 150 & & 112 & 119.0 & & .. & ... & 15 & 4 & 13.0 & .79 & 1.30 \\
\hline 160 & 22.1 & 116 & 130.0 & & & & 16 & 4 & 11.0 & .81 & 1.10 \\
\hline 170 & 23. 2 & 119 & 140.0 & ... & . . . . . & ... & 17 & 3 & 10.0 & .82 & 1.00 \\
\hline 180 & 24. 1 & 123 & (?) & ... & $\ldots$. & .. & 18 & 4 & ........... & ............. & . \\
\hline 190 & 25.1 & 126 & (1) & & & & 19 & 3 & . & n......... & \\
\hline 200 & 26.0 & 129 & $(?)$ & & $\cdots$ & & 20 & 3 & $\ldots \ldots \ldots$ & ............ & 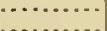 \\
\hline 210 & 26.7 & 132 & (b) & & & 13 & 21 & 3 & . n & 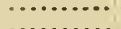 & ....... \\
\hline $\begin{array}{l}220 \\
230\end{array}$ & $\begin{array}{l}27.4 \\
28.0\end{array}$ & $\begin{array}{l}135 \\
138\end{array}$ & (?) & 5.3 & -4 & Is & 22 & $\begin{array}{l}3 \\
3 \\
3\end{array}$ & . n. & $\cdots \cdot$ & \\
\hline & & & & & & & & & & & \\
\hline
\end{tabular}

(8) OPPRESSED TREES.

[A verage in Micligau.]

(36 trees.)

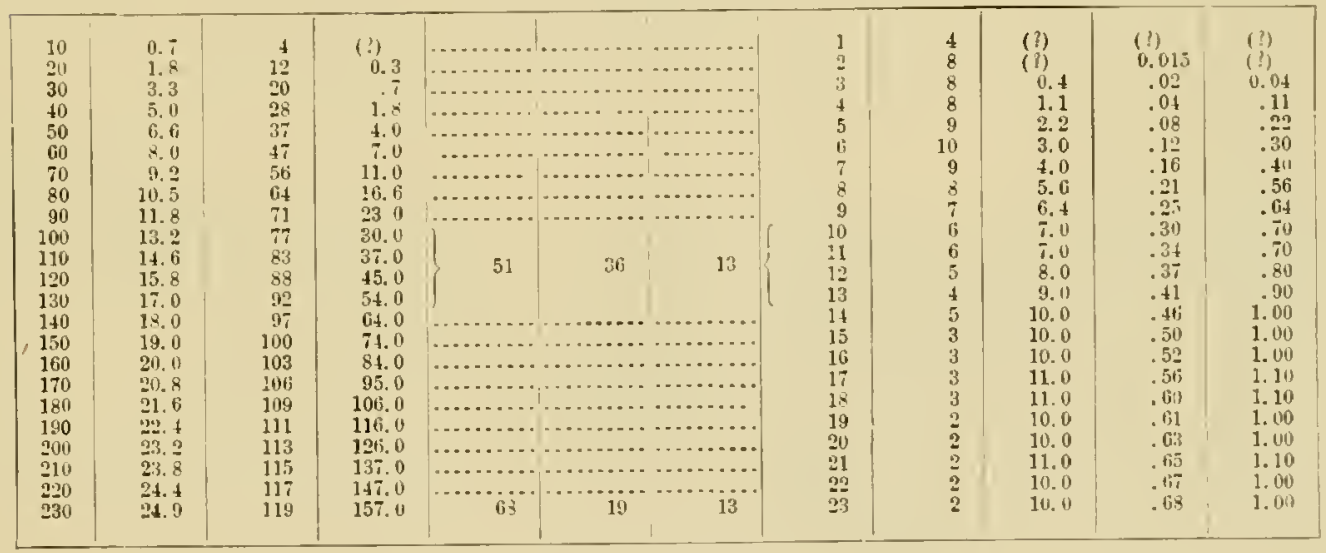

(9) TOMLANT TREES.

[Average in Peunsylvania.]

(81 trees.)

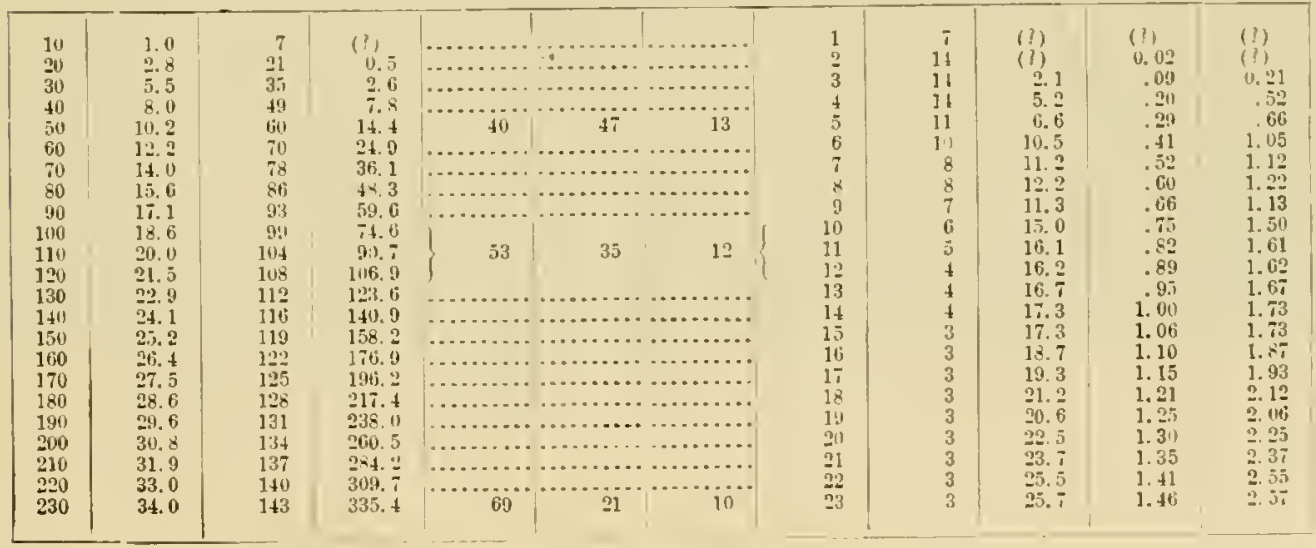




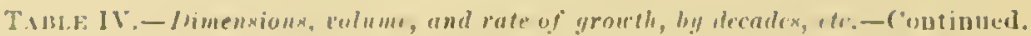

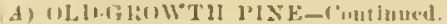

(10) CUNOMINAXT THEES.

A "eraze in lennsylrania.

(is trats.)

\begin{tabular}{|c|c|c|c|c|c|c|c|c|c|c|c|}
\hline \multirow{2}{*}{ A:t. } & \multirow{2}{*}{$\begin{array}{l}\text { Iriameter } \\
\text { at lingligh } \\
\text { of zy leet } \\
\text { (without } \\
\text { barks. }\end{array}$} & \multirow{2}{*}{$\begin{array}{l}\text { Tutal } \\
\text { lw-iglit } \\
\text { ur tree. }\end{array}$} & \multirow{2}{*}{ 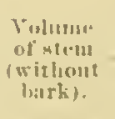 } & lielittis & $\begin{array}{l}\because p \cdot r \cdots w 8 \\
\text { valume. }\end{array}$ & of tot:al & \multicolumn{3}{|c|}{ l'riodic aceretion. } & \multirow{2}{*}{$\begin{array}{l}\text { Arerage } \\
\text { aruminl } \\
\text { accretion. }\end{array}$} & \multirow{2}{*}{$\begin{array}{l}\text { Currigl } \\
\text { annutul } \\
\text { accretiun. }\end{array}$} \\
\hline & & & & $\begin{array}{l}\text { Hears. } \\
\text { woudl. }\end{array}$ & Salliwoml. & lauk. & lloralo. & Ilefinlit. & Volume, & & \\
\hline Ieare & Inches. & $\mathrm{Fint}$ & G'uliegt. & Percene. & ler cont. & I'er cene. & & Feet & Cubicft. & rubic Jl. & rulic it. \\
\hline $\begin{array}{l}10 \\
? 0\end{array}$ & $\begin{array}{l}\text { U. } 9 \\
2.3\end{array}$ & $\begin{array}{r}5 \\
16\end{array}$ & (i) & $\cdots \cdots \cdots$ & ........... & $\cdots \ldots \ldots \ldots$ & 1 & $i$ & (!) & (!) & $111^{\circ}$ \\
\hline 30 & 10 & 18 & 1.8 & $\cdots$ & (n... & $\cdots$ & 2 & 11 & $(?)+$ & $0 . \int^{2}$ & (1) \\
\hline 40 & 5.9 & 39 & 4.8 & .......... & (n............ & …..... & 4 & ii & 3.0 & .12 & .30 \\
\hline iu & 7,6 & 48 & 7. 8 & .......... & ............ & (.......... & 5 & 9 & 3.0 & .15 & .30 \\
\hline 60 & 9. 3 & 36 & 11.1 & $\ldots \ldots$ & $\ldots \ldots \ldots \ldots$ & ......... & 6) & 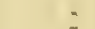 & 3.3 & .18 & .33 \\
\hline :0 & 10.2 & 63 & 16.7 & ........... & $\ldots \ldots \ldots$ & ......... & ; & $i$ & i. $1 \mathrm{i}$ & .24 & $\therefore$ itj \\
\hline a) 11 & 12.0 & 69 & 23.3 & ........... & ............ & ............ & 8 & 6 & 1i. 6 & .29 & 16 \\
\hline 50 & 13.4 & 75 & 30.7 & .......... & . . . . . . & .......... & 9 & 6 & 7.4 & 34 & .74 \\
\hline 100 & $14, i$ & 80) & 39.0 & $\ldots \ldots \ldots$ & …..... & $\ldots \ldots \ldots$ & 111 & $\vdots$ & 8.3 & .39 & .83 \\
\hline 130 & 14i, 0 & -5 & ti. 3 & .......... & ......... & …..... & 11 & $\vdots$ & 8.9 & $.4 i 3$ & 89 \\
\hline 1211 & 17.3 & $\$ 10$ & 57.9 & $\ldots \ldots \ldots$ & $\ldots \ldots \ldots \ldots$ & $\ldots \ldots \ldots \ldots$ & 12 & $\dot{3}$ & 10.0 & . An & 1.001 \\
\hline 1311 & 10.6 & 14. & 65.2 & & . & ......... & 13 & 4 & 7.3 & .54 & .73 \\
\hline 140 & 19.7 & 95 & iti, 9 & $\ldots$ & $\ldots \ldots$ & ........ & 14 & 4 & 11. $z$ & $\therefore i$ & 1.17 \\
\hline 150 & 20.7 & 1112 & o8. 2 & $\ldots$ & 列 & ..... & 1.5 & 4 & 12.0 & .59 & $1.2 * 1$ \\
\hline 160 & 21.8 & 106 & 101.8 & ........... & $\ldots \ldots \ldots \ldots$ & $\ldots \ldots \ldots$ & 16 & $t$ & 12..9 & .633 & $1.2 !$ \\
\hline 170 & 2.7 & 109 & 115.3 & .......... & .......... & ......... & 1: & 3 & 13.5 & . $f \mathrm{i}^{2}$ & 1.35 \\
\hline 1 \&at & 23.5 & 112 & $129 \cdot=$ & ......... & $\ldots \ldots \ldots$ & ........ & 18 & 3 & $13 . !$ & $\because 2$ & 1.39 \\
\hline 160 & 24.13 & 114 & 142.9 & …….. & ........... & . . . . . . . . & 19 & 2 & 13.7 & .75 & 1.37 \\
\hline 2110 & 25.1 & 116 & $13: 7$ & ........... & .......... & .......... & 20 & 2 & 9. $\mathrm{A}$ & .76 & 9 \\
\hline 210 & $25 .=$ & 118 & His. $:$ & ........... & .......... & $\ldots \ldots$ & $\because 1$ & 2 & 12. $\mathrm{A}$ & .79 & 1.28 \\
\hline 20 & :6.: & 120 & 179.3 & .. & & & $2 !$ & 3 & 13.8 & 1 & 1. $3 x$ \\
\hline 2.0 & $\because 7.3$ & 122 & 195.0 & iis & $\because$ & IJ & 23 & 2 & 15.7 & .81 & $1.5 i$ \\
\hline
\end{tabular}

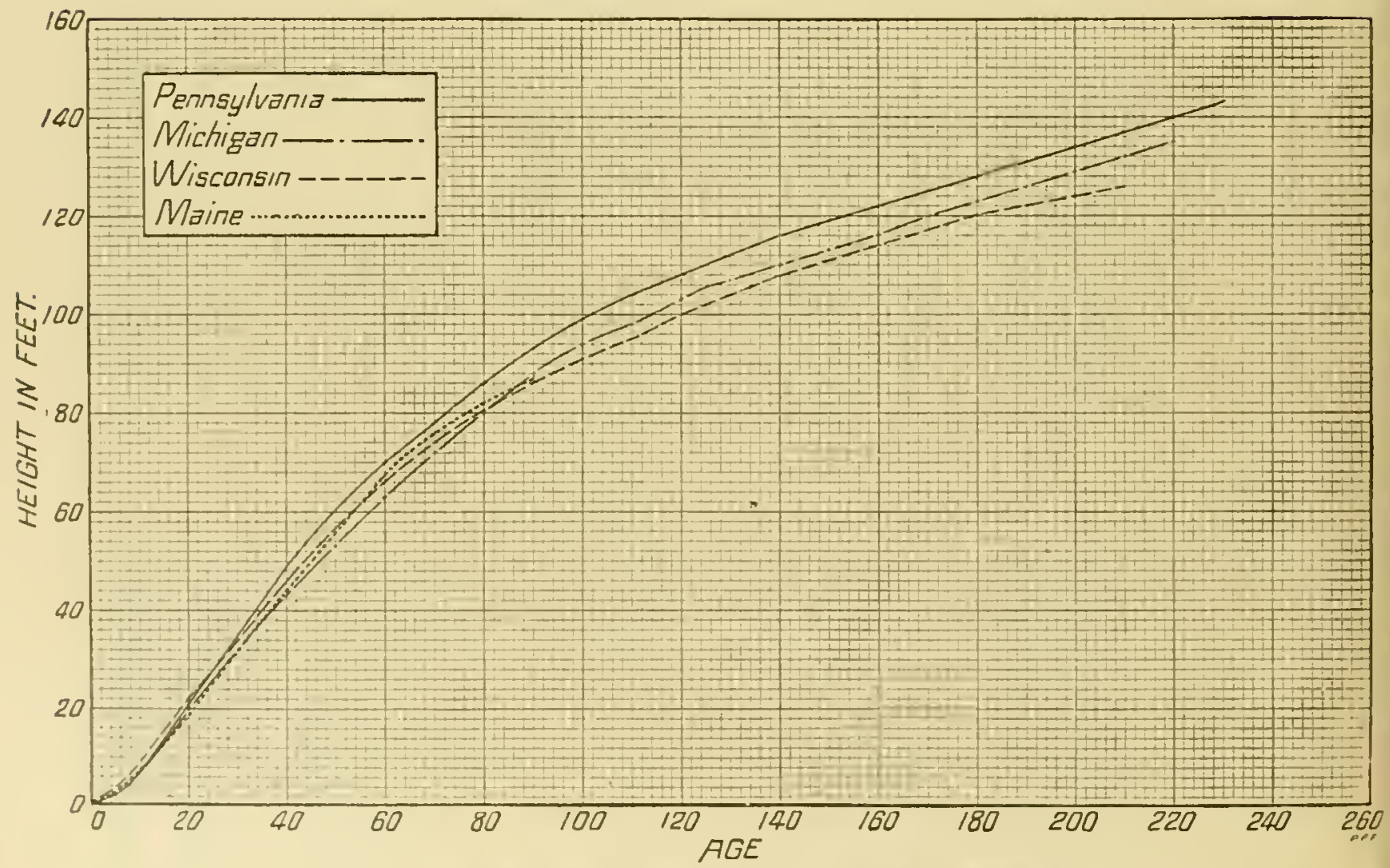

F1. 21 -Dinfraus showing belght gruwth of duminant trecs, by States 


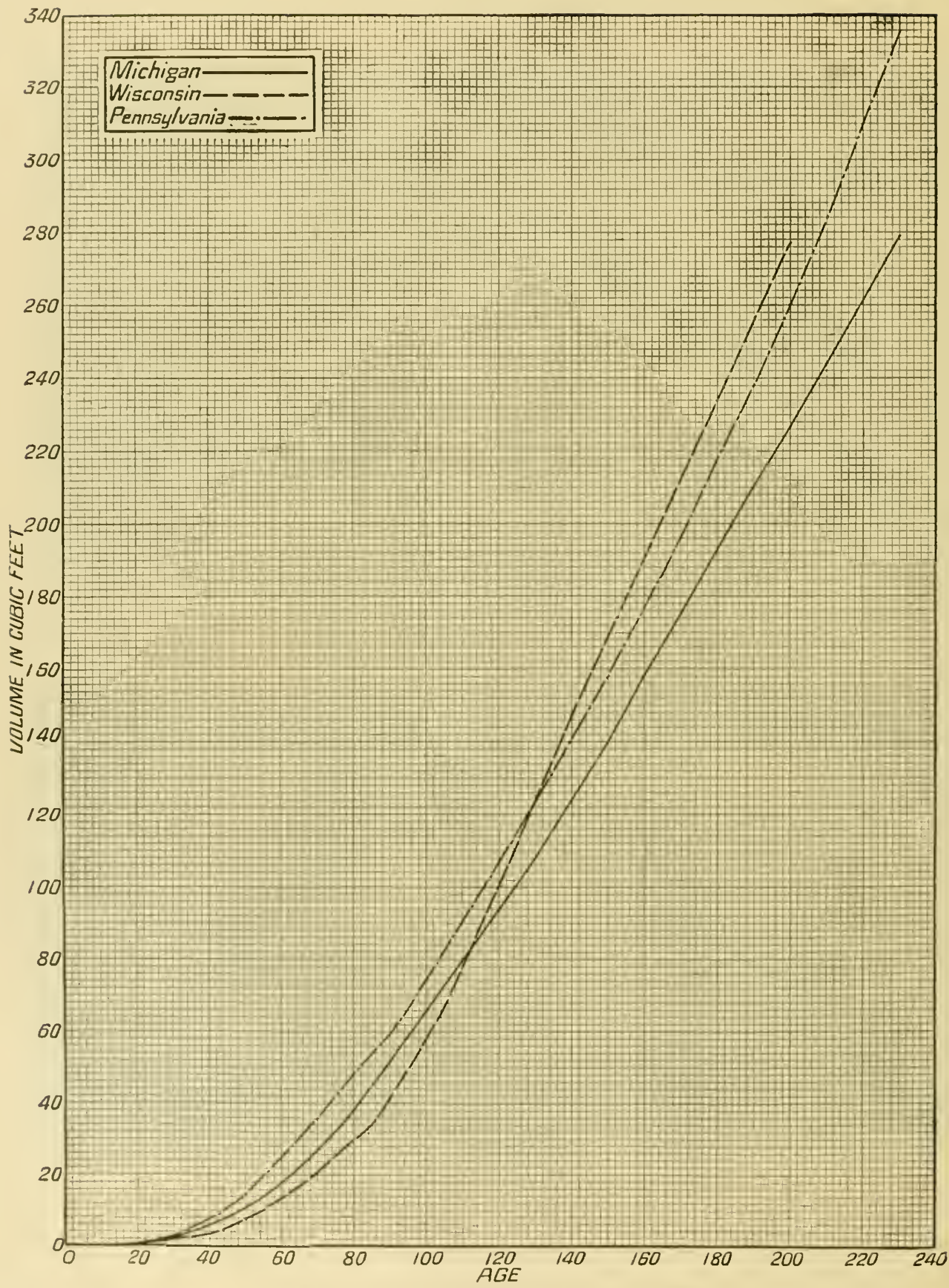




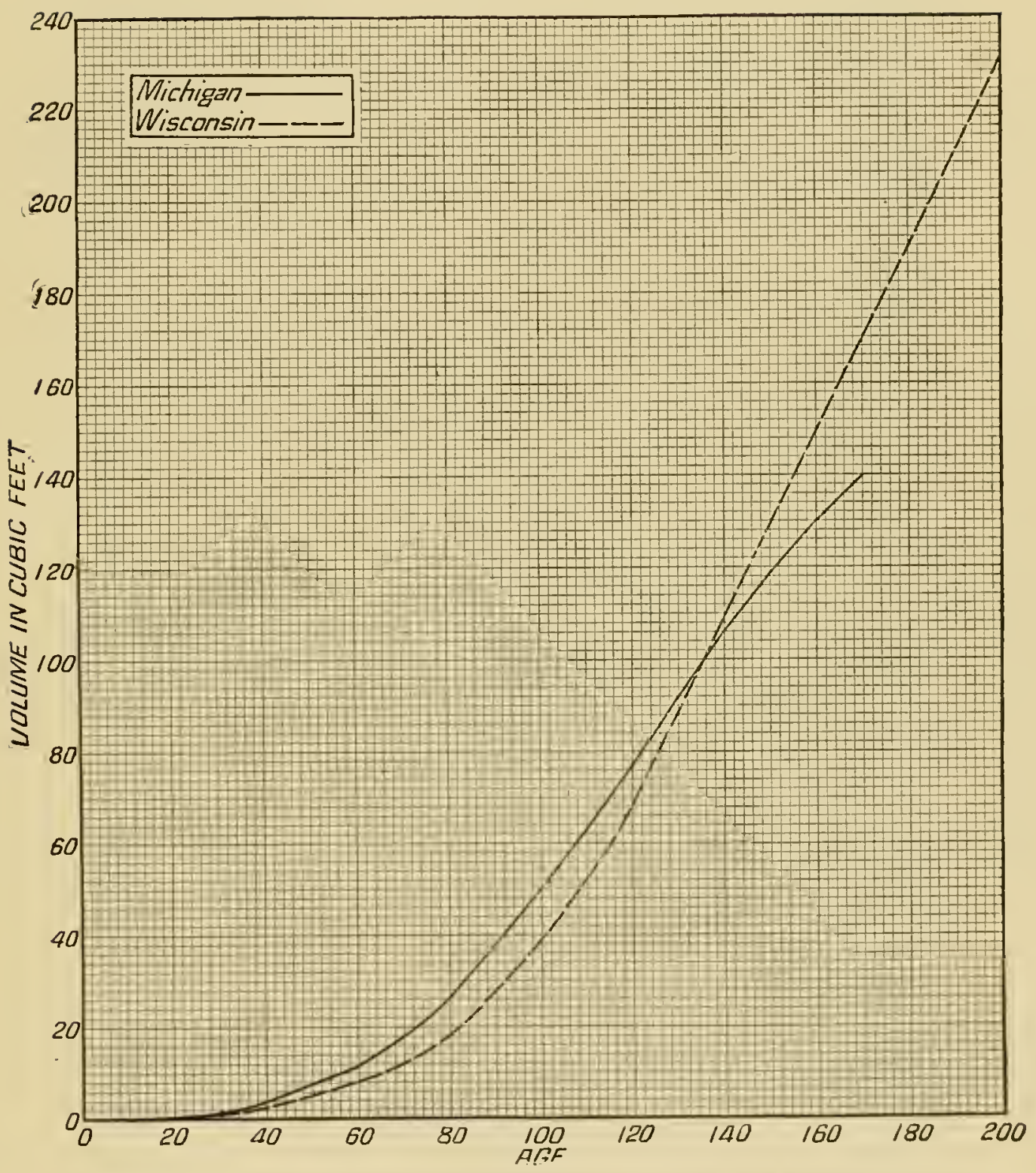

Fu, 28.-Diagram showing volume growth of couluminant trees, by Statew. 


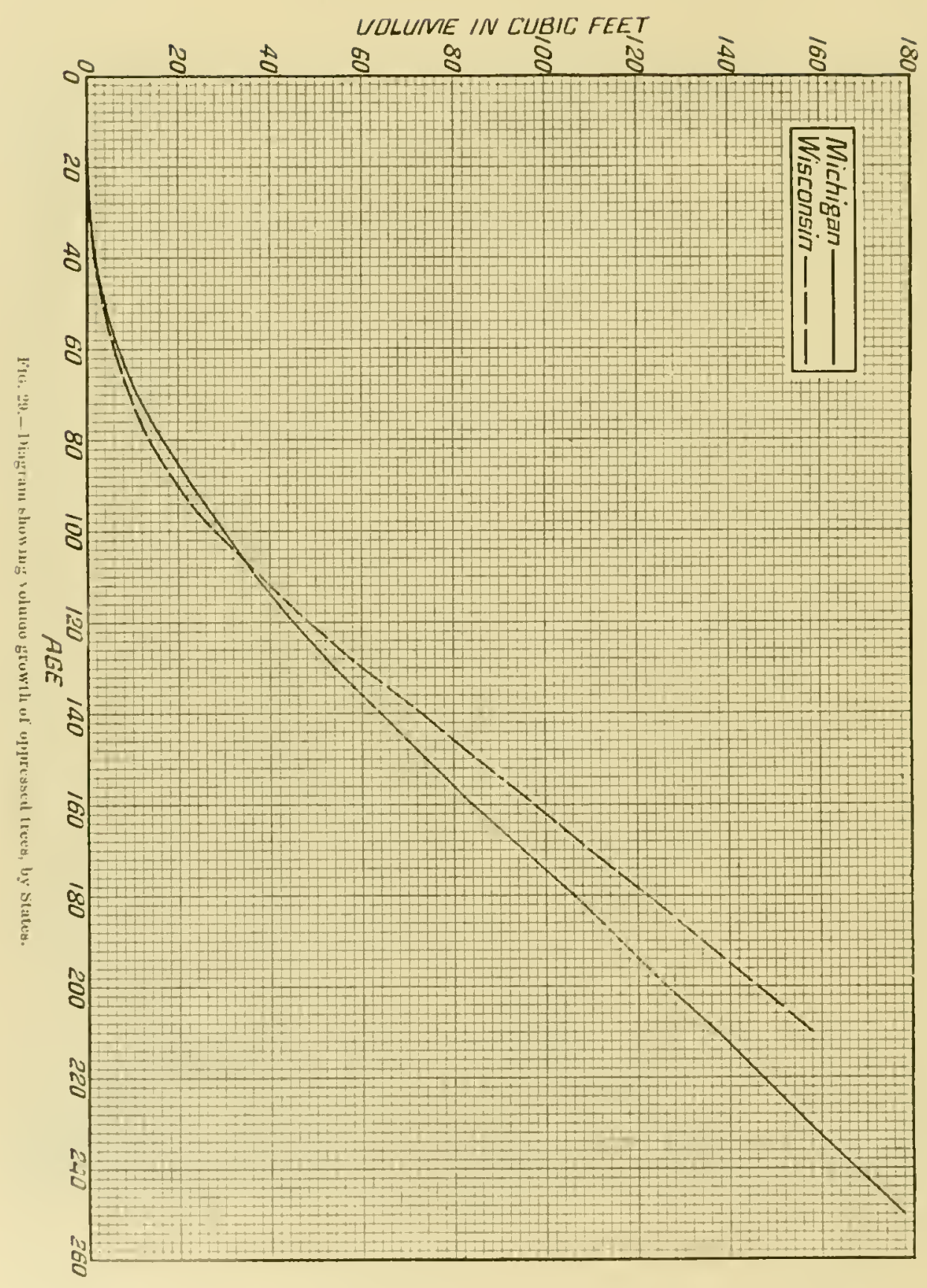


'TAHLES OF MEASTREMENTS.

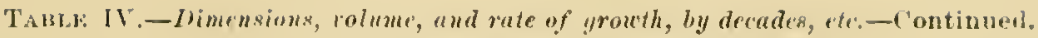

(b) SECON1)(BROWT TIXE.

(11) SITE $a$ : YoRk ro'NTY, Mi:.

TOMINANT TREES

(11 trees.)

\begin{tabular}{|c|c|c|c|c|c|c|c|c|c|c|c|}
\hline \multirow{2}{*}{ Age. } & \multirow{2}{*}{$\begin{array}{l}\text { I iamu-ter } \\
\text { at heiglit } \\
\text { of } 21 \text { tent } \\
\text { (without } \\
\text { bav's). }\end{array}$} & \multirow{2}{*}{$\begin{array}{l}\text { Tutal } \\
\text { leight } \\
\text { of truet. }\end{array}$} & \multirow{2}{*}{$\begin{array}{c}\text { Tolnmo } \\
\text { of } \times \text { toun } \\
\text { (without } \\
\text { lork). }\end{array}$} & \multicolumn{3}{|c|}{$\begin{array}{l}\text { Tielative perrent of total } \\
\text { ralmue. }\end{array}$} & \multicolumn{3}{|c|}{ Porionlis: arcrutiont. } & \multirow{2}{*}{$\begin{array}{l}\text { Arirnge } \\
\text { aumal } \\
\text { aceretiou. }\end{array}$} & \multirow{2}{*}{$\begin{array}{l}\text { Cirrent } \\
\text { annusl } \\
\text { acoretions }\end{array}$} \\
\hline & & & & $\begin{array}{l}\text { Heart- } \\
\text { "unke. }\end{array}$ & Sapwows]. & liark. & thecalle. & 11eiglit. & Vulume. & & \\
\hline Iears. & Inches. & Fiet. & reubic ft. & Irrecont. & Jer efut. & Peremt. & & Feet. & rubicft. & Cubic it. & rubic nt. \\
\hline $\begin{array}{l}10 \\
30\end{array}$ & 2.1 & it & 0.5 & $\ldots$ & & & 1 & & 0.8 & 0.05 & u. 0.3 \\
\hline $\begin{array}{l}20 \\
30\end{array}$ & 5.7 & $\frac{21}{3 i}$ & 2. 1 & & & 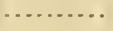 & 2 & $13 \frac{1}{2}$ & 1.6 & .10 & .16 \\
\hline 40 & $\begin{array}{l}10.2 \\
14.2\end{array}$ & $\begin{array}{l}31 \\
49 !\end{array}$ & $\begin{array}{r}6.0 \\
17.0\end{array}$ & … & ..... & . & $\begin{array}{l}3 \\
4 \\
4\end{array}$ & 16 & 4.4 & 2.21 & .44 \\
\hline 50 & 18.6 & $60 \frac{1}{2}$ & 34.0 & . & , & … & 5 & 11 & 17.0 & fis & $\begin{array}{l}1.00 \\
1.70\end{array}$ \\
\hline 60 & 22.1 & $091^{2}$ & 60.3 & & . & ........ & (i) & 8 & 26.3 & 1,00 & 263 \\
\hline 70 & 24.0 & 77 & 83.2 & $5 \%$ & 29 & 10 & 7 & $8^{\circ}$ & 21.9 & 1.17 & 2. 19 \\
\hline 81) & 26.2 & 8.5 & 1011.0 & (11) & tor & to & 8 & 8 & 17.8 & 1.25 & 1.78 \\
\hline (1) & $\ldots$. & 90 & (1) & 150 & 32 & 11 & 9 & 5 & & & \\
\hline
\end{tabular}

CODOMLANT TREES

(33 11tes.)

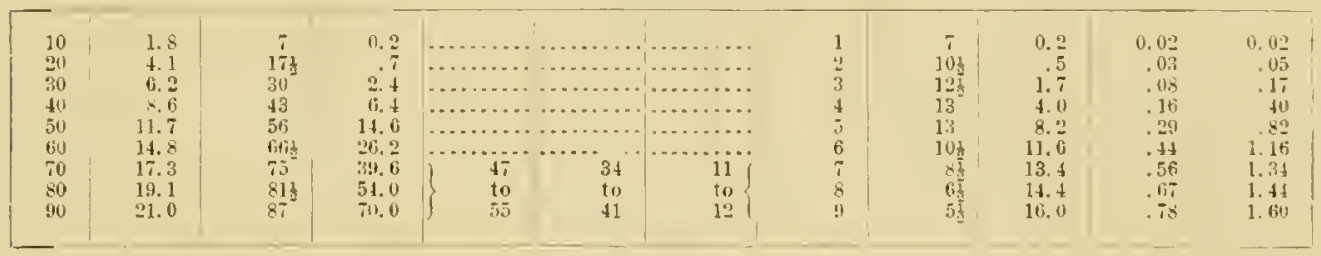

OPPRERSED TREE-

(12 trens.)

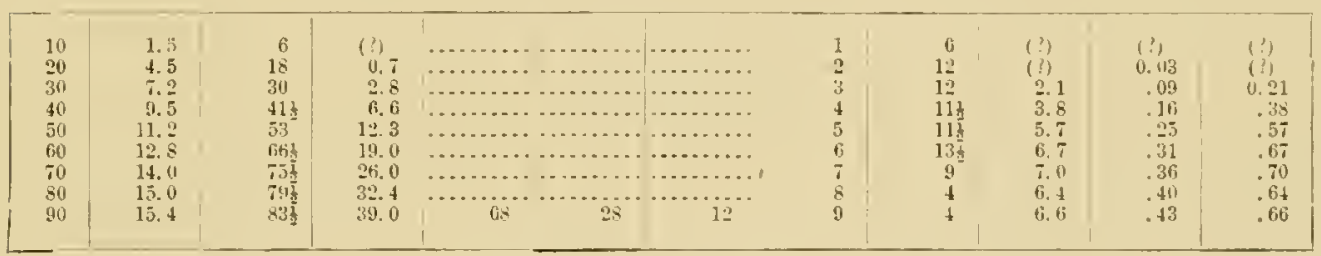

(12) SITE $C$ : TORK CUUXT, ME.

DOMINANT THEE-

(10 trees.)

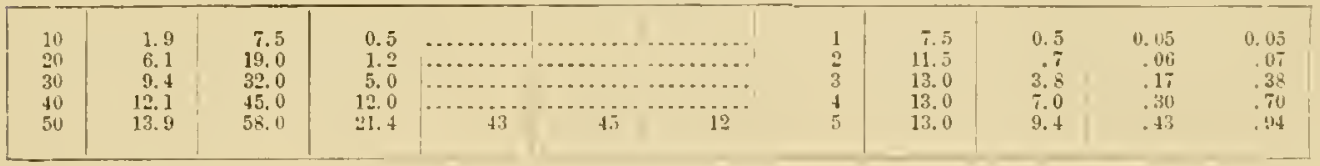

IONIVAYT TREES.

(8 trees.)

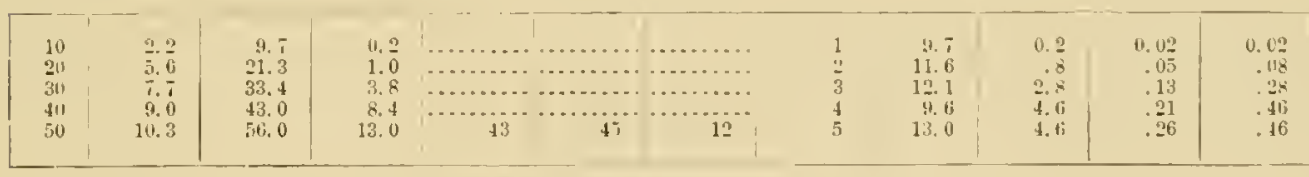

(13) MA SACHUSETTS AND NEW HAMPSHRE.

DOMINANT IREES.

(12) trues.)

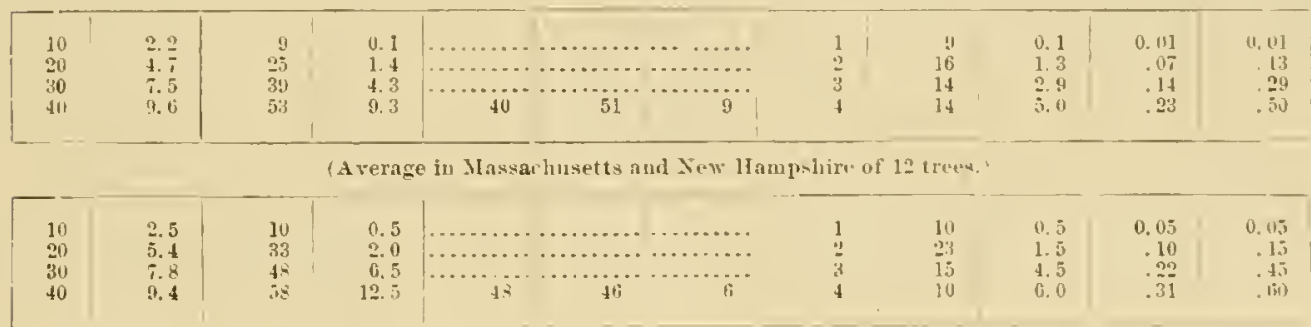




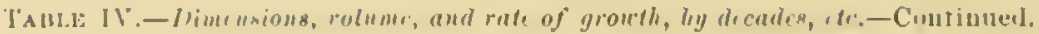

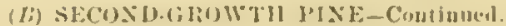

(14) Nite y: Clearfield Cutsty, d's. HOMISANT TREES

(A trein.)

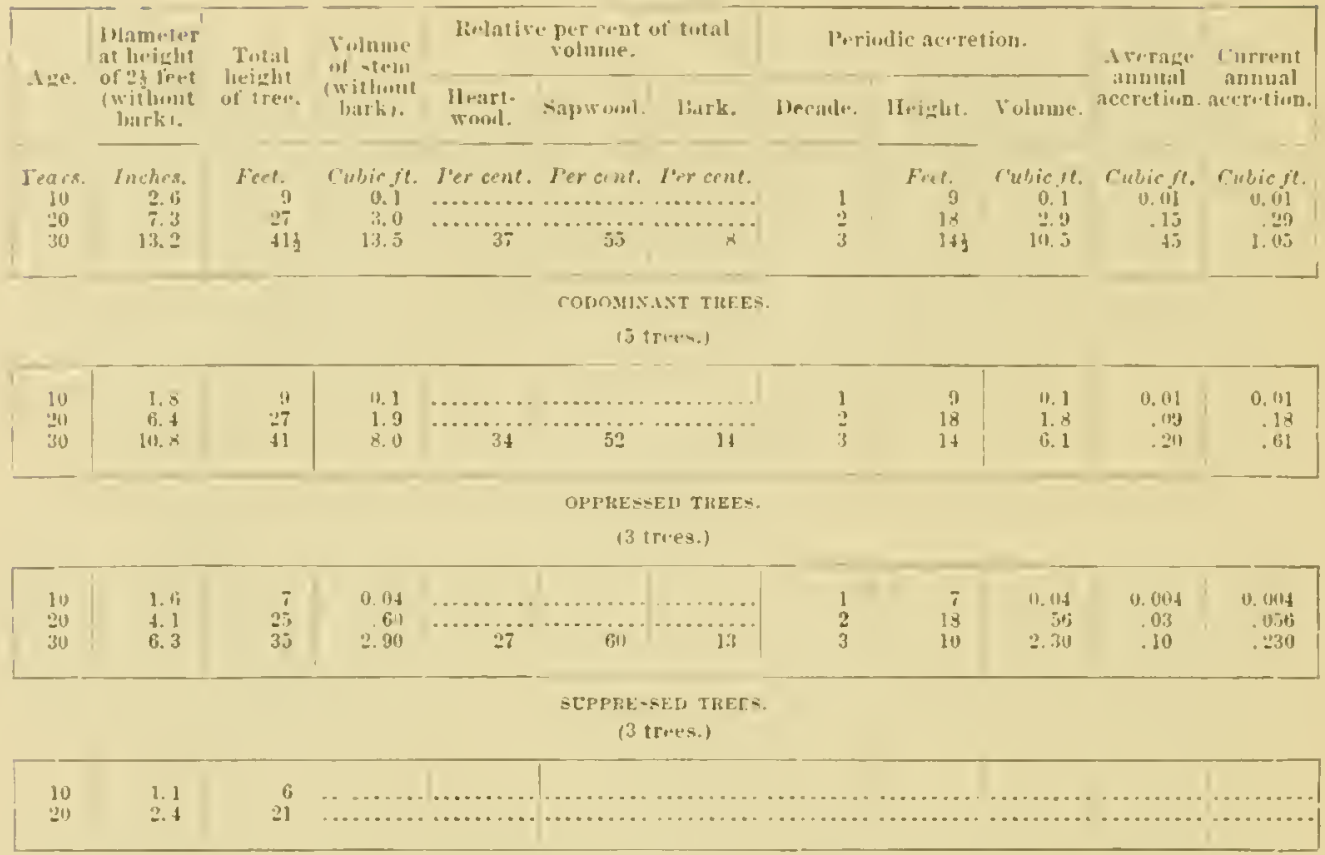

15) SITE $i$ : FORE $-T$ I"OLYTY, PA.

DOMINANT TREET.

(2 trues.

\begin{tabular}{|c|c|c|c|c|c|c|c|c|c|c|c|}
\hline 10 & 1.8 & 9 & (I) & & .... & & 1 & 9 & (?) & (1) & (?) \\
\hline 20 & b. 9 & 204 & 2.5 & & & & 2 & $20\}$ & (?) & 11. 12 & $1: 1$ \\
\hline 30 & 10.4 & 111 & 9.7 & . $\ldots \ldots$ & $\ldots \ldots \ldots$ & $\ldots$. & 3 & $12^{8}$ & T. 2 & .32 & 0. .2 \\
\hline (1) & 12.9 & 321 & 19.0 & 36 & 54 & 10 & 4 & 11 & 0.3 & .17 & .93 \\
\hline
\end{tabular}

DONISANT THEE-

(10 1T.N.)

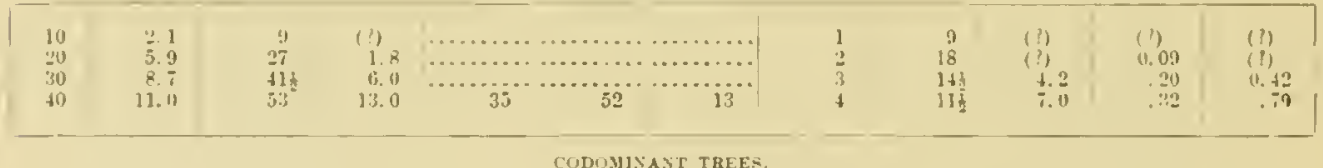

(10 irera.)

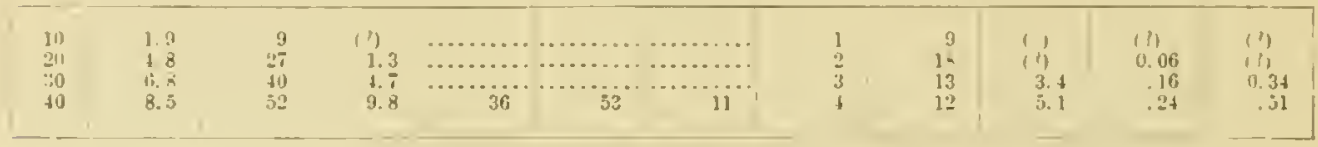

OPIRES-EEI, TREES.

(j traks.)

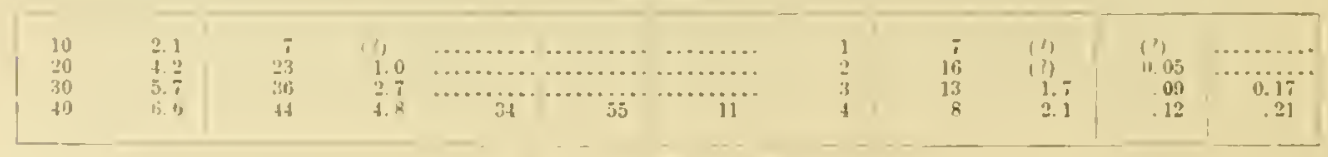

116) SITE E: LT\%FNAE COCNTY. I'. DOMISANT TREE-

(9) trets.

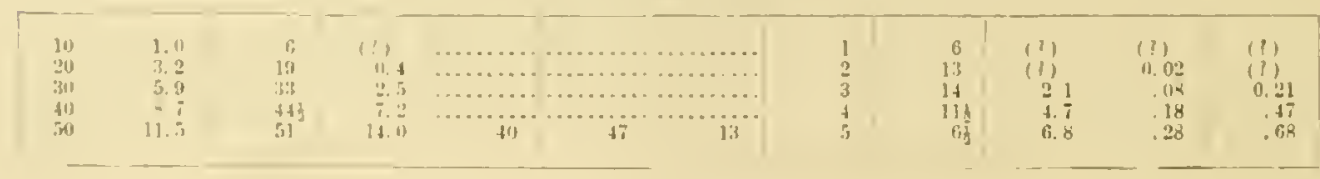


TABLES OF IF EASUREMENTS.

TABLE V. - Growth of diameter and crosx-section area at ravious heights from thr' yround.

(1) AVERAGE THLUTGHOLT TIE IRANGE.

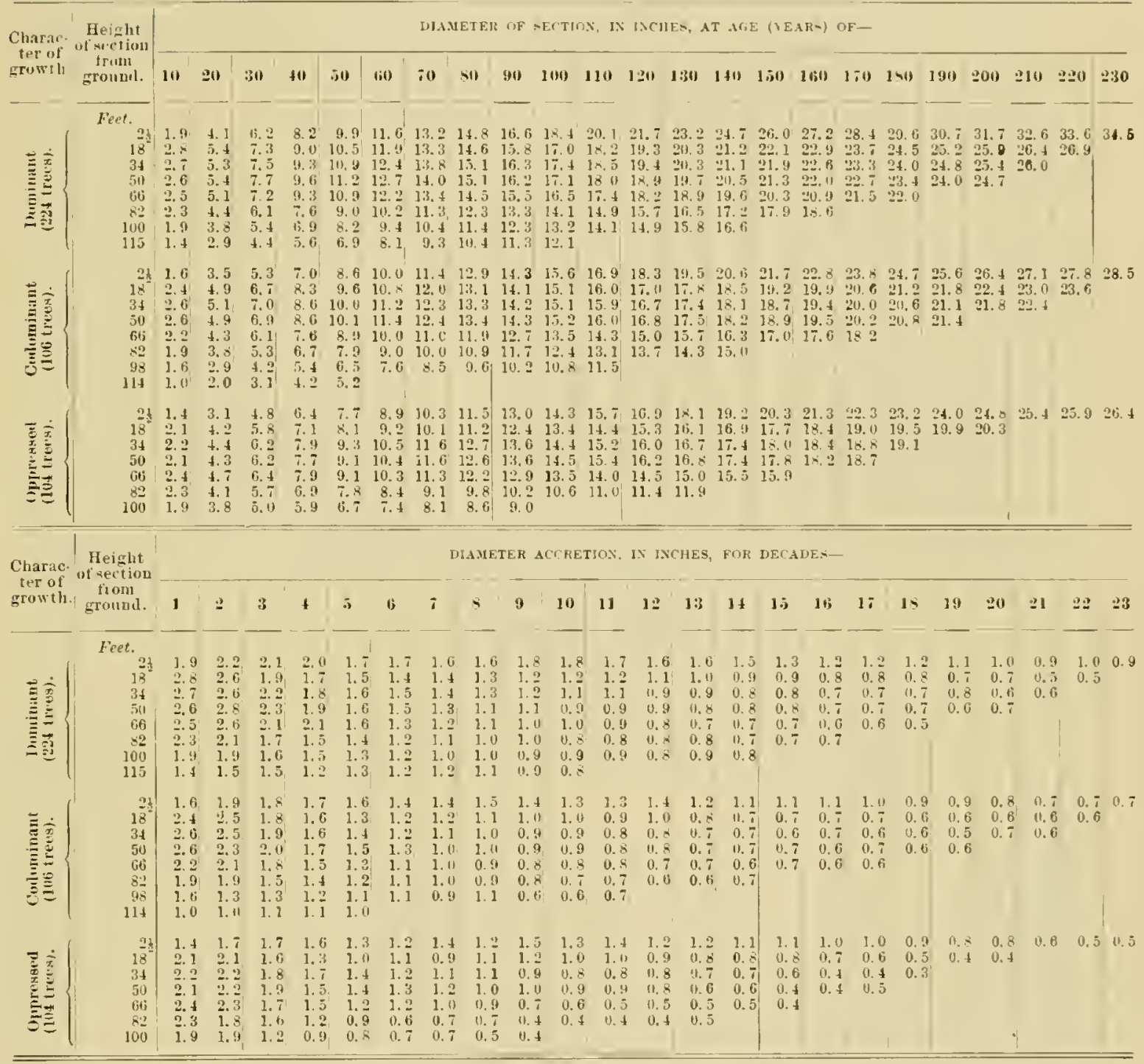

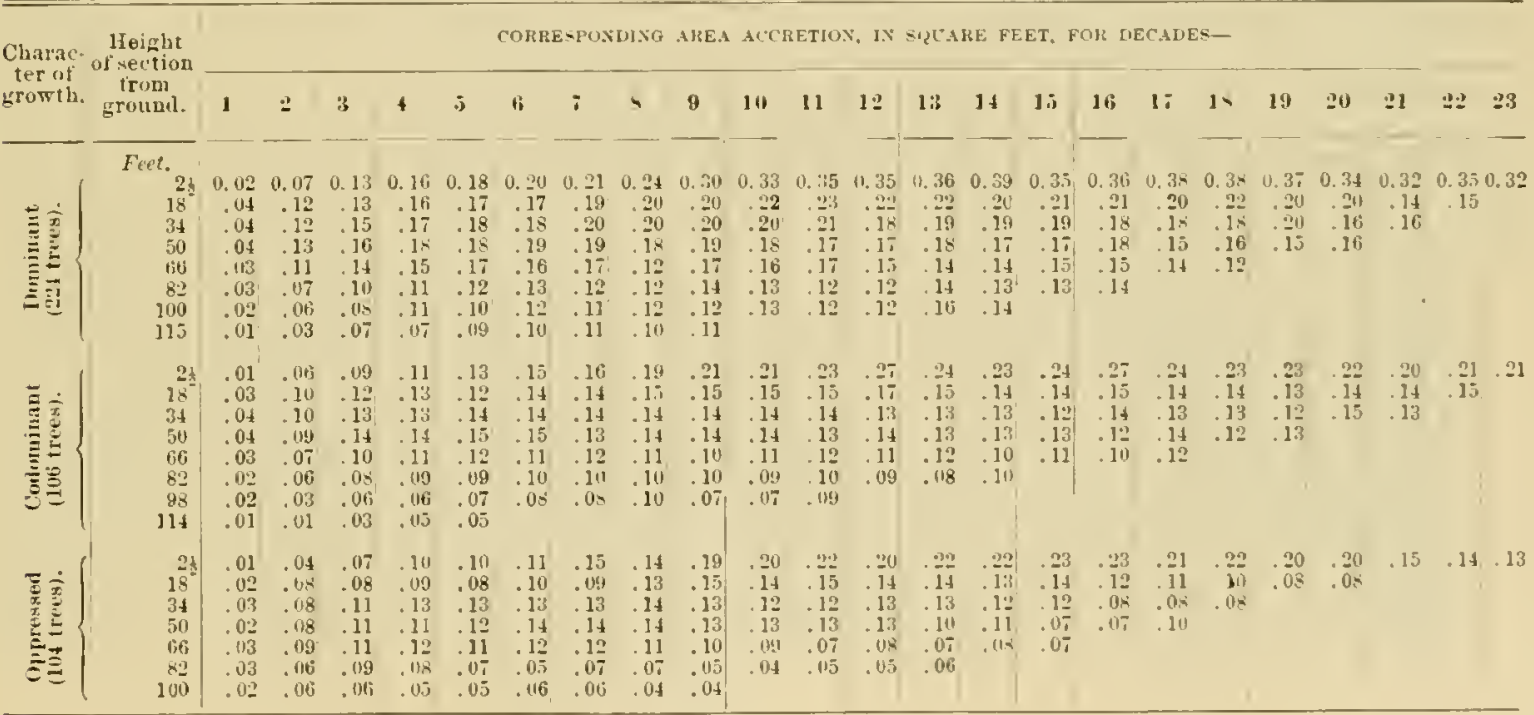




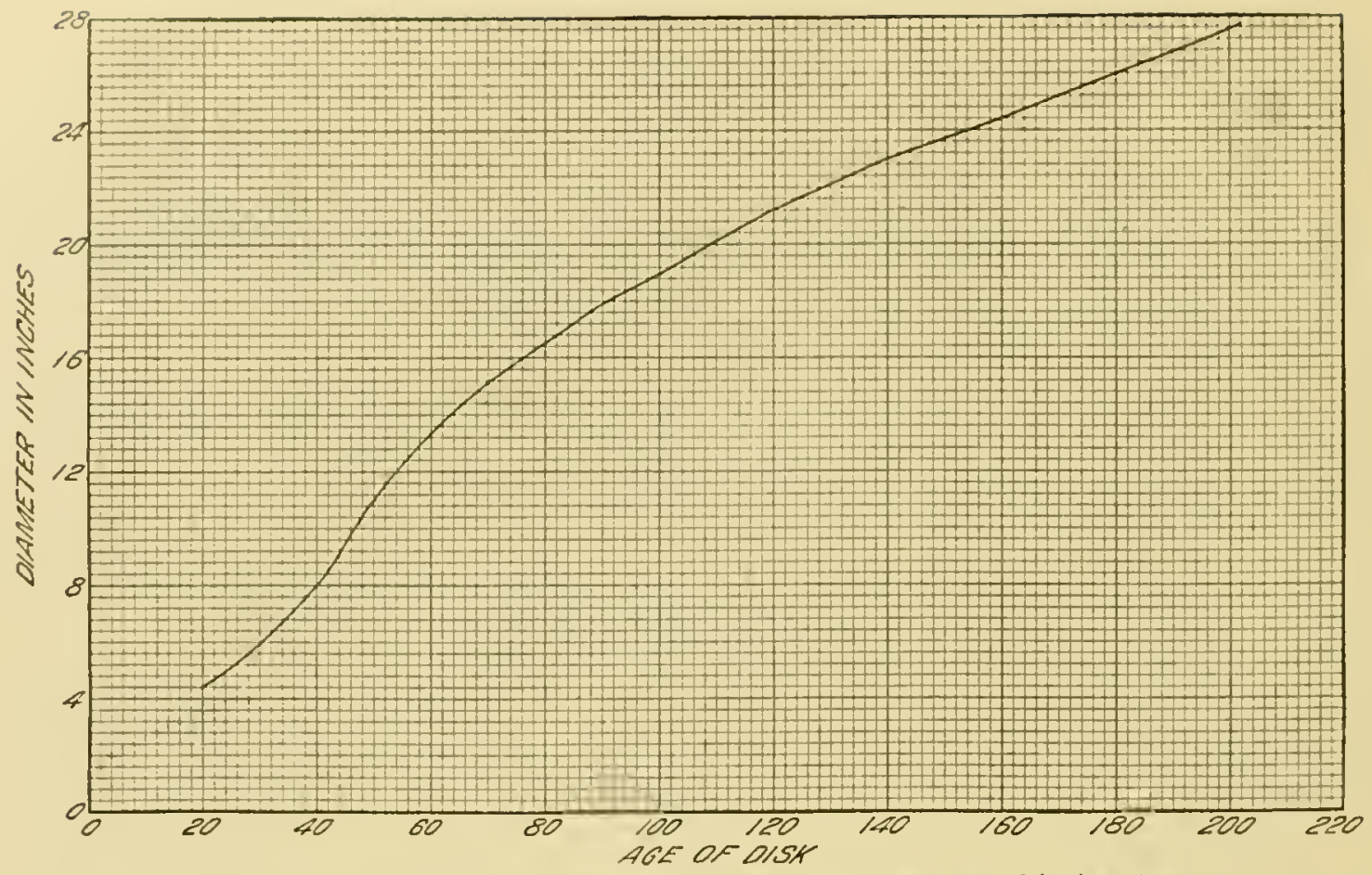

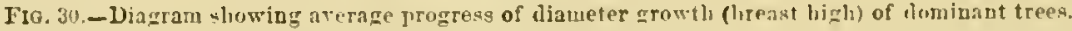

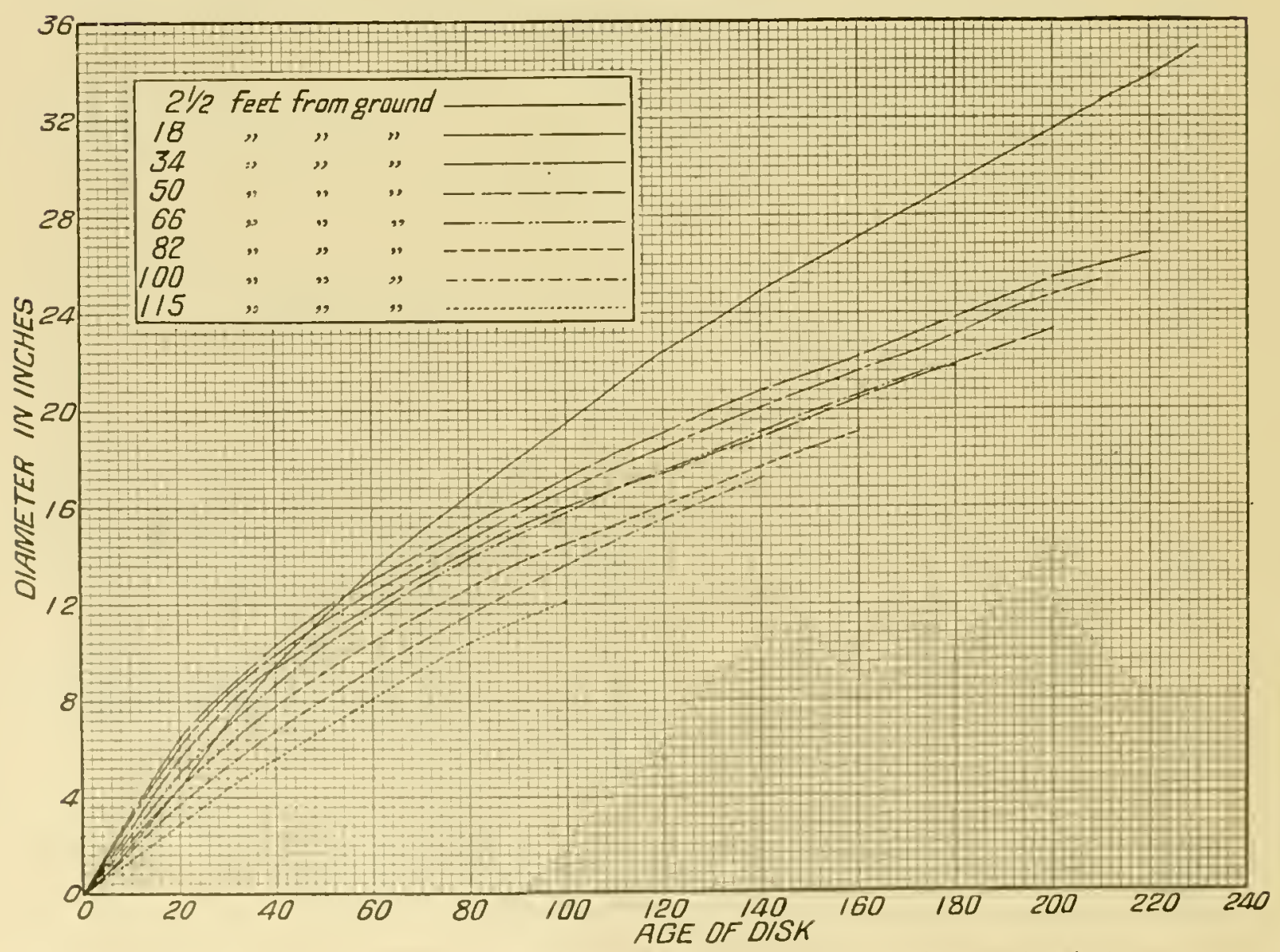

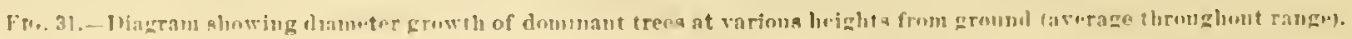




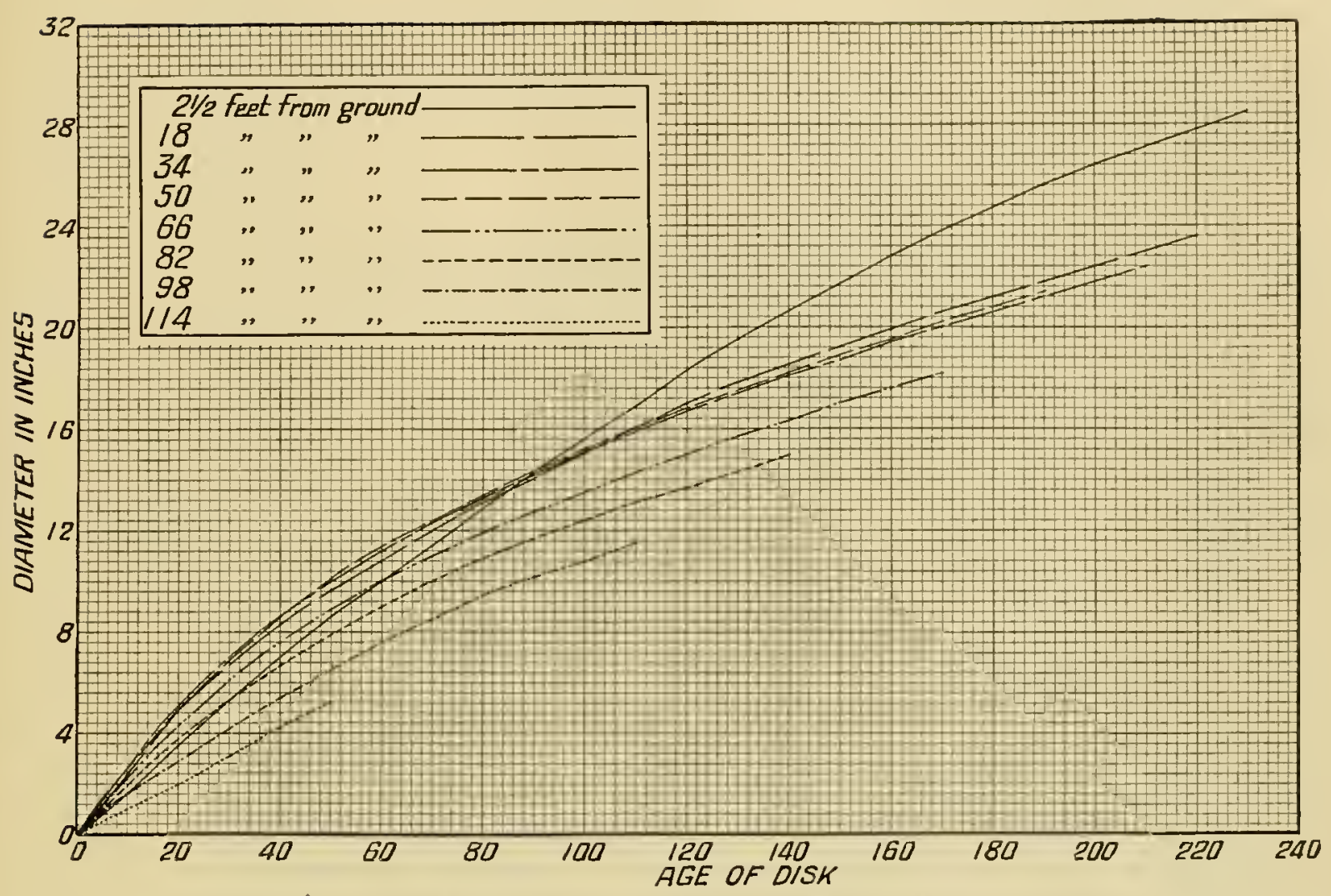

Fia. 32.-Diagram shoming iliameter growth of colluwinant trees at rarious heights frun ground (arerage throughout range).

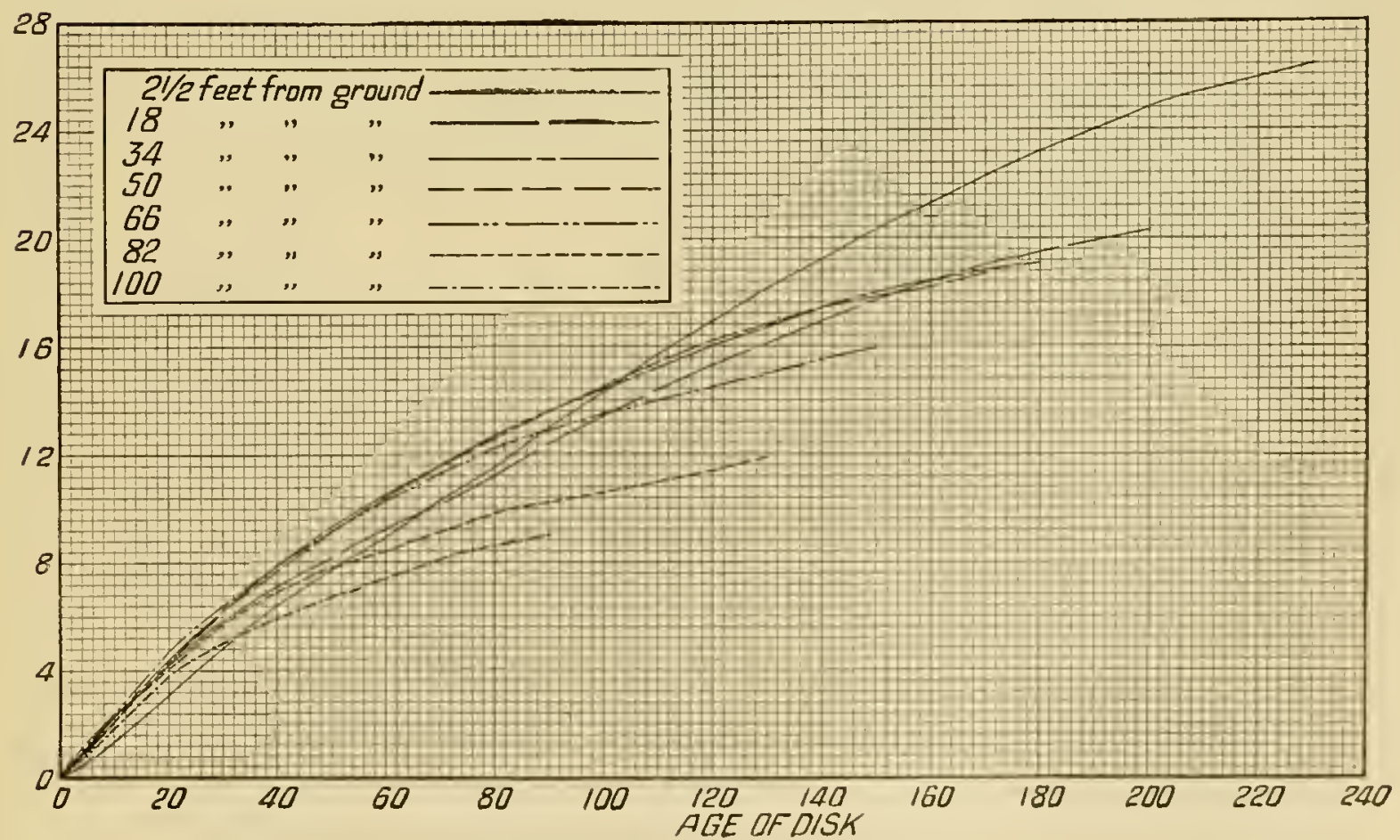

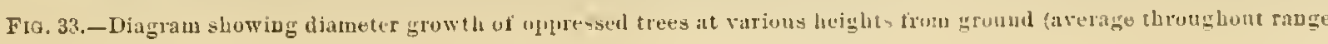


TABLF: V, - Grouth of diameter aud cross-section area at rarious heights from the grom (2) I VEAGG: FU: WISCOXIIS.

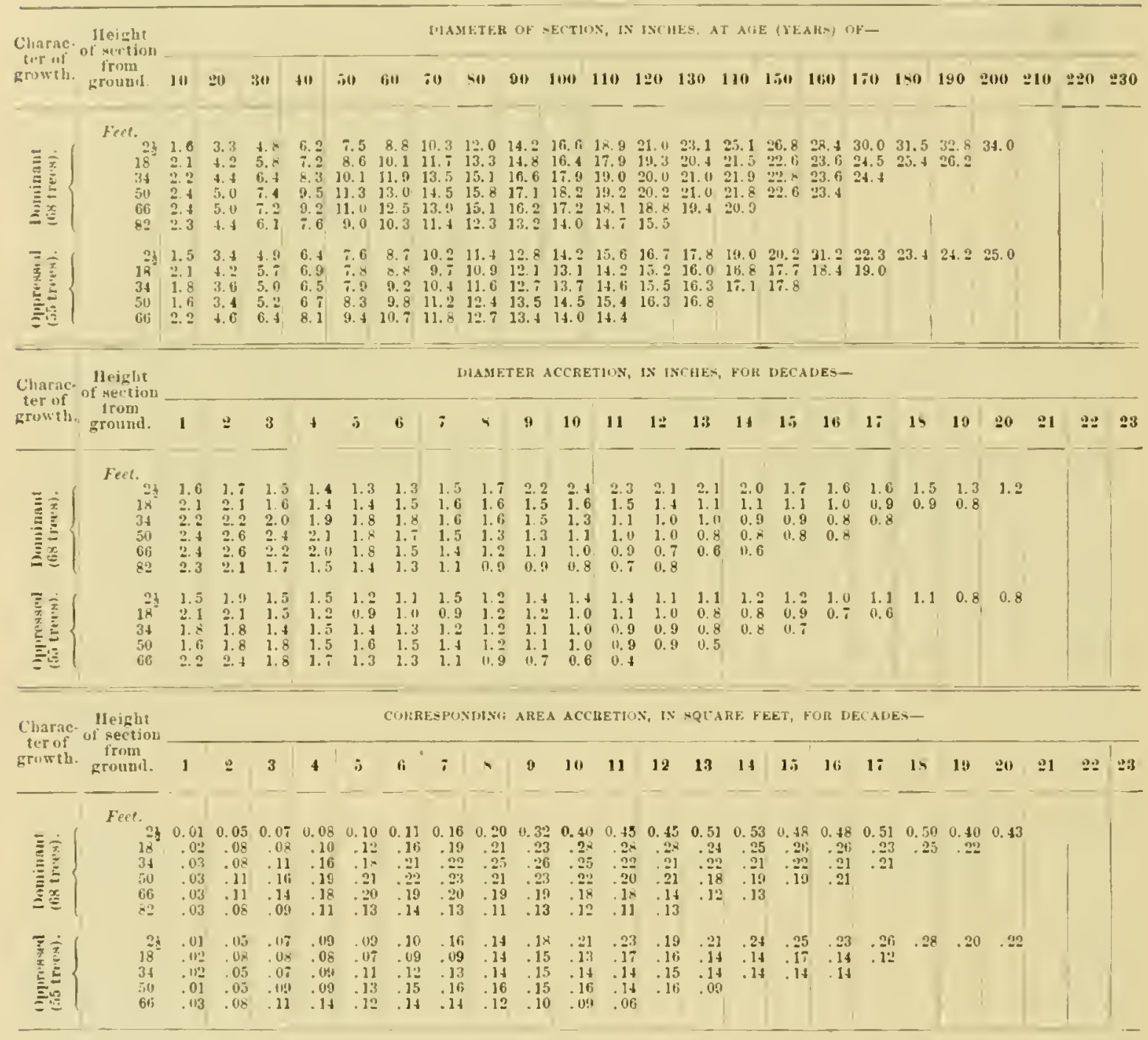




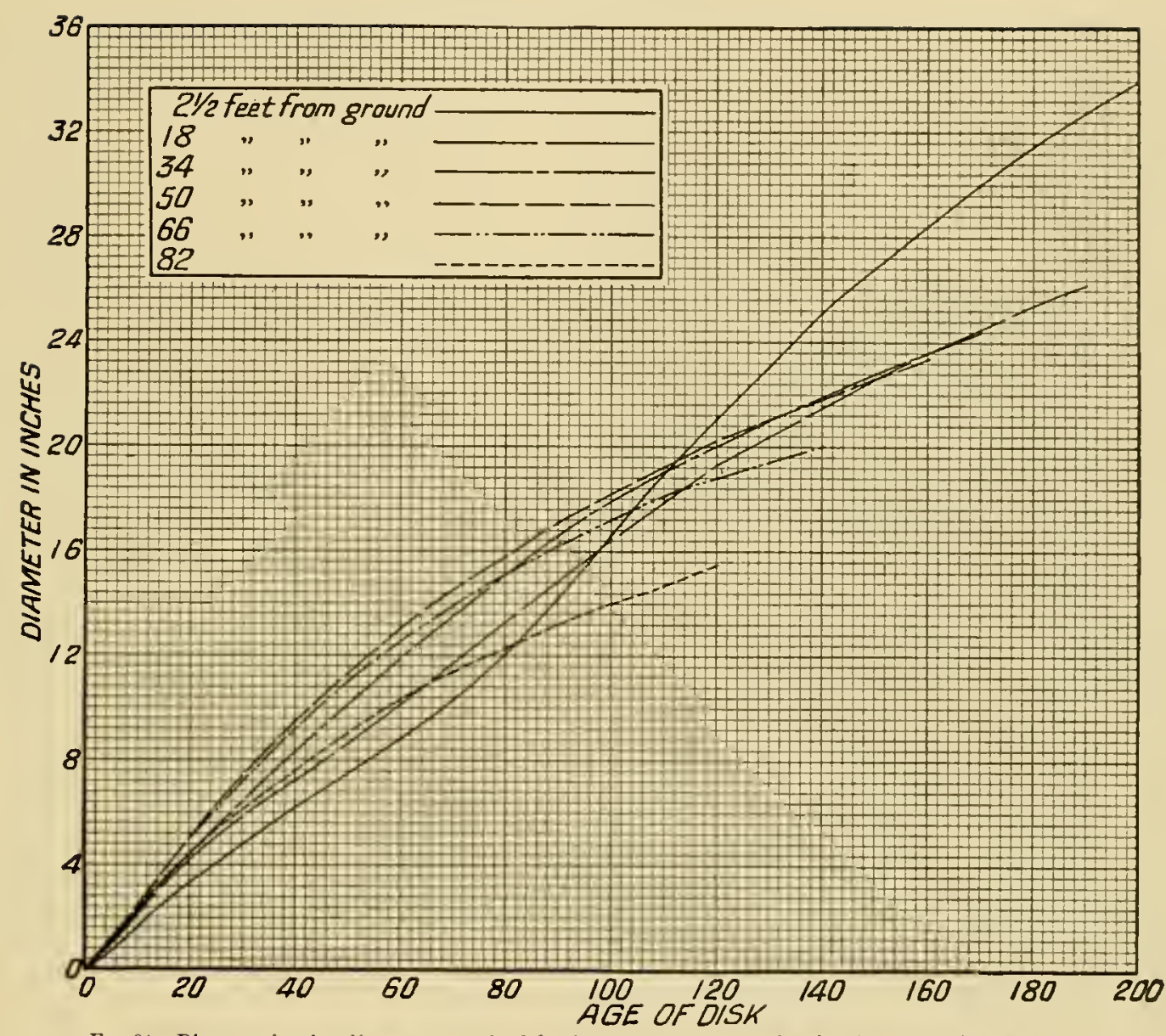

FIG. 34.-Diagram showing diameter growth of dominant trees at varions heights from ground in Wisconsin.

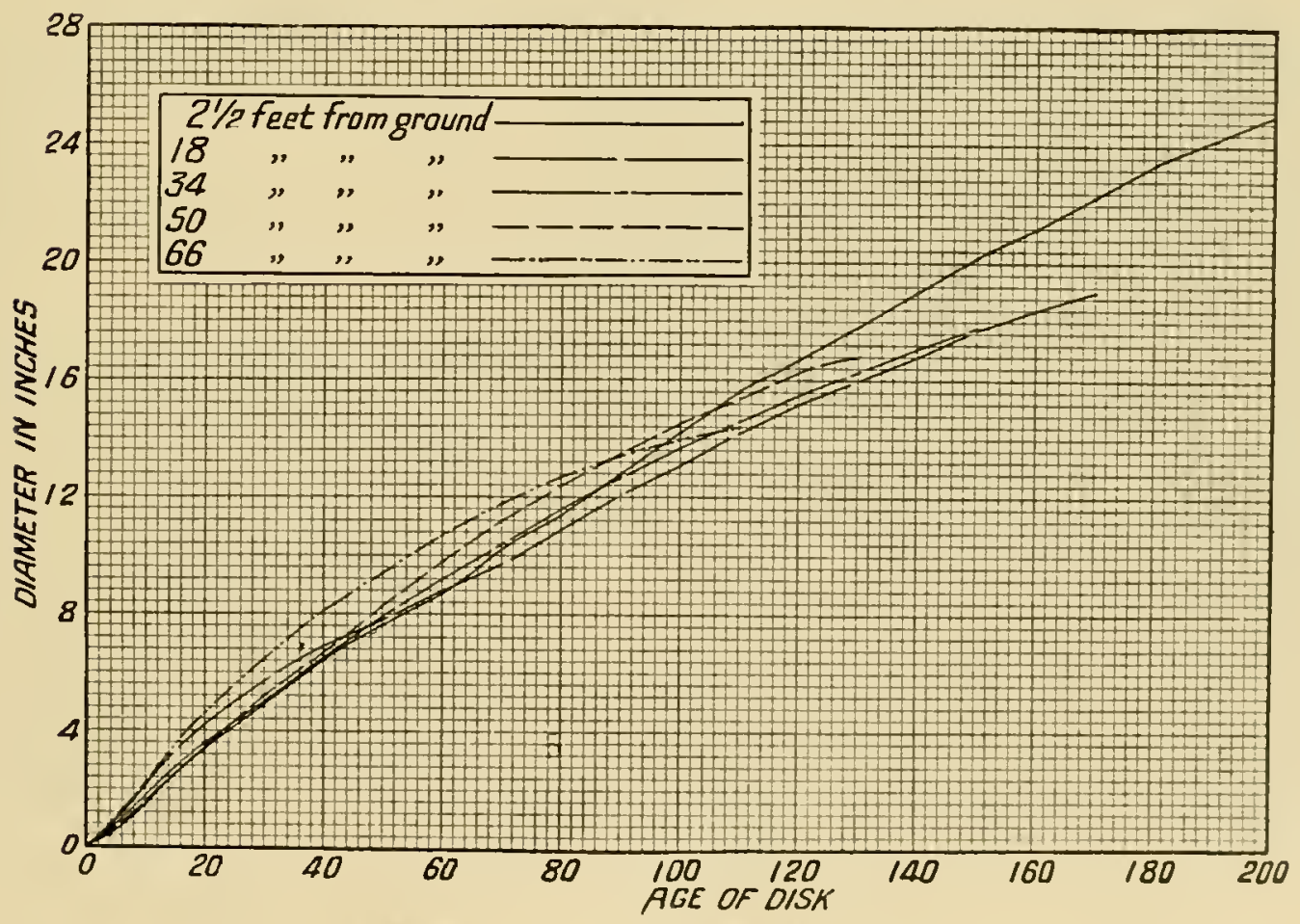

FIG. 35.-Diagram showing diatueter growth of oppressed trees at various heights from ground in Wiscongin. 


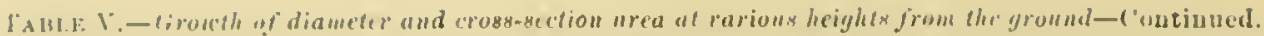

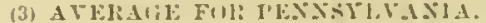

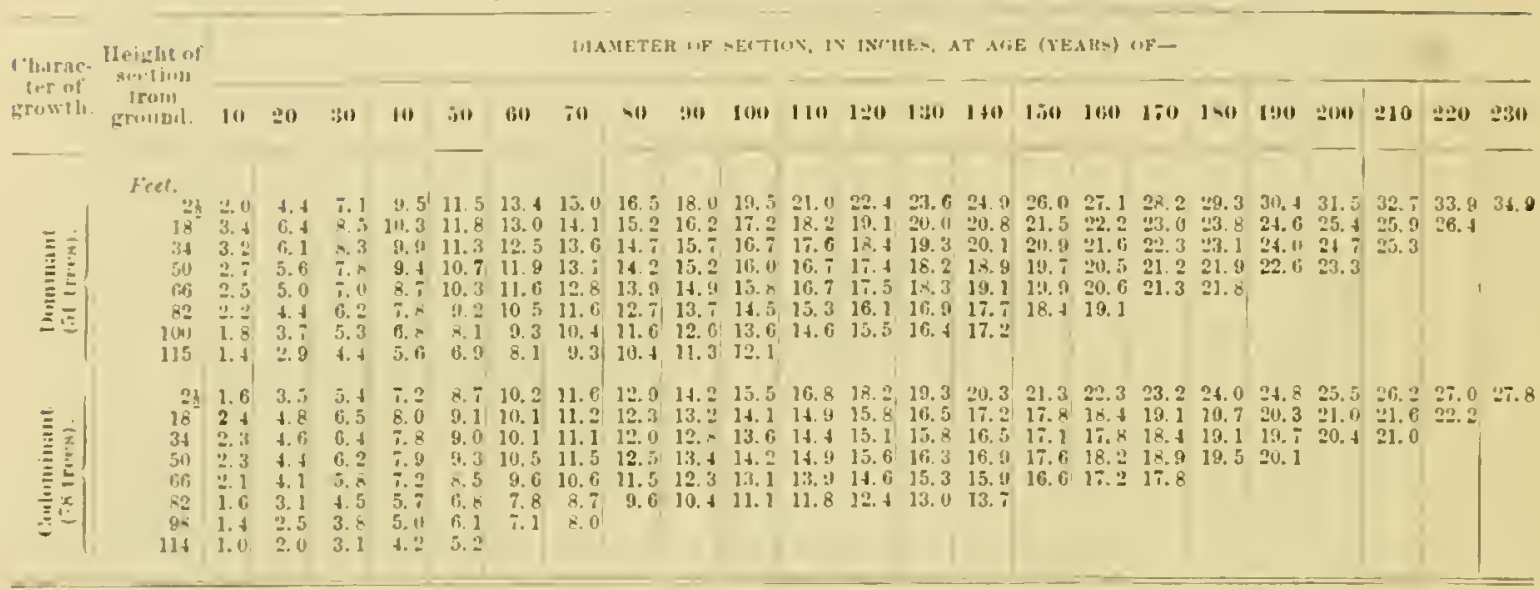

Clans:ue. Heiclat of

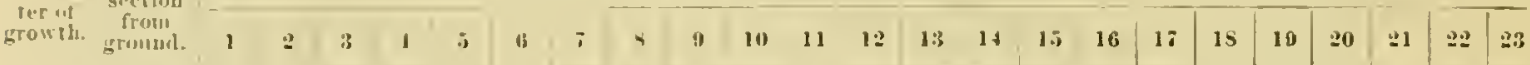

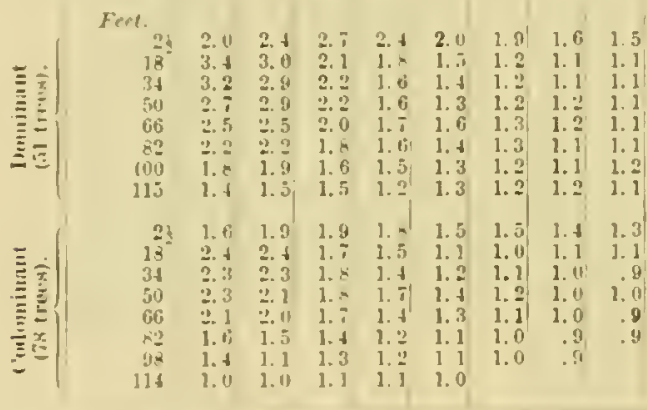

114 i.u 1.11 1.1 1.1 2.0

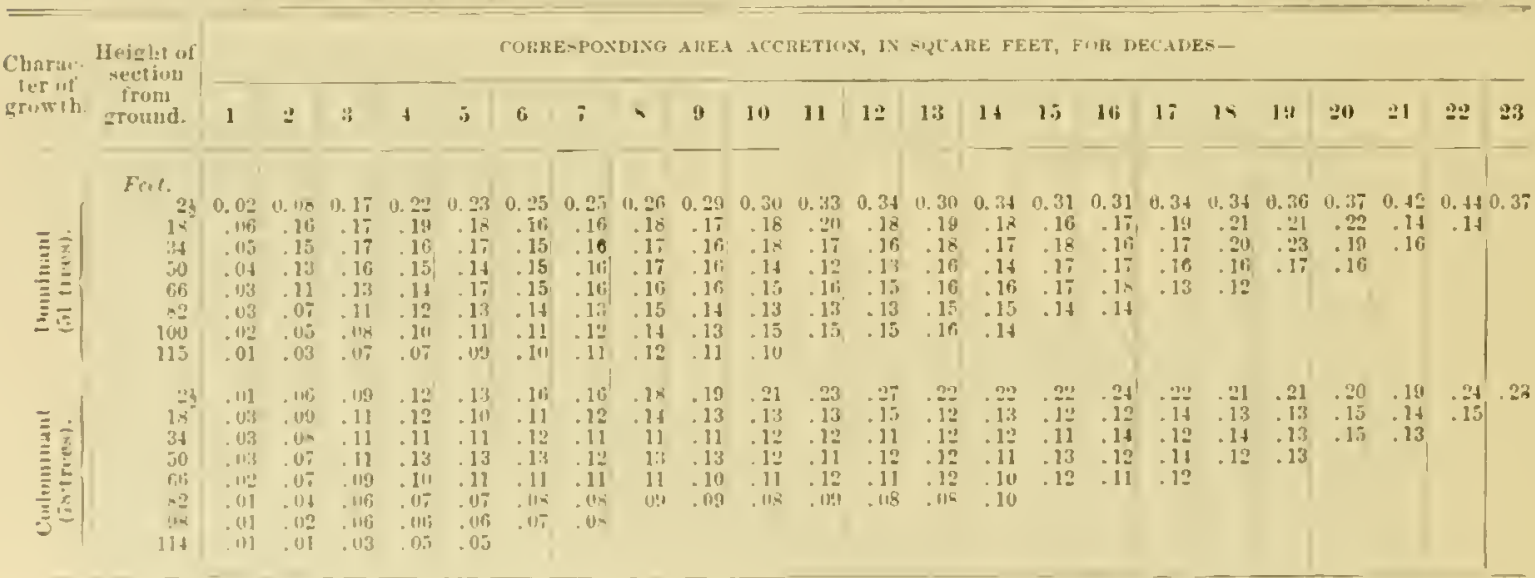




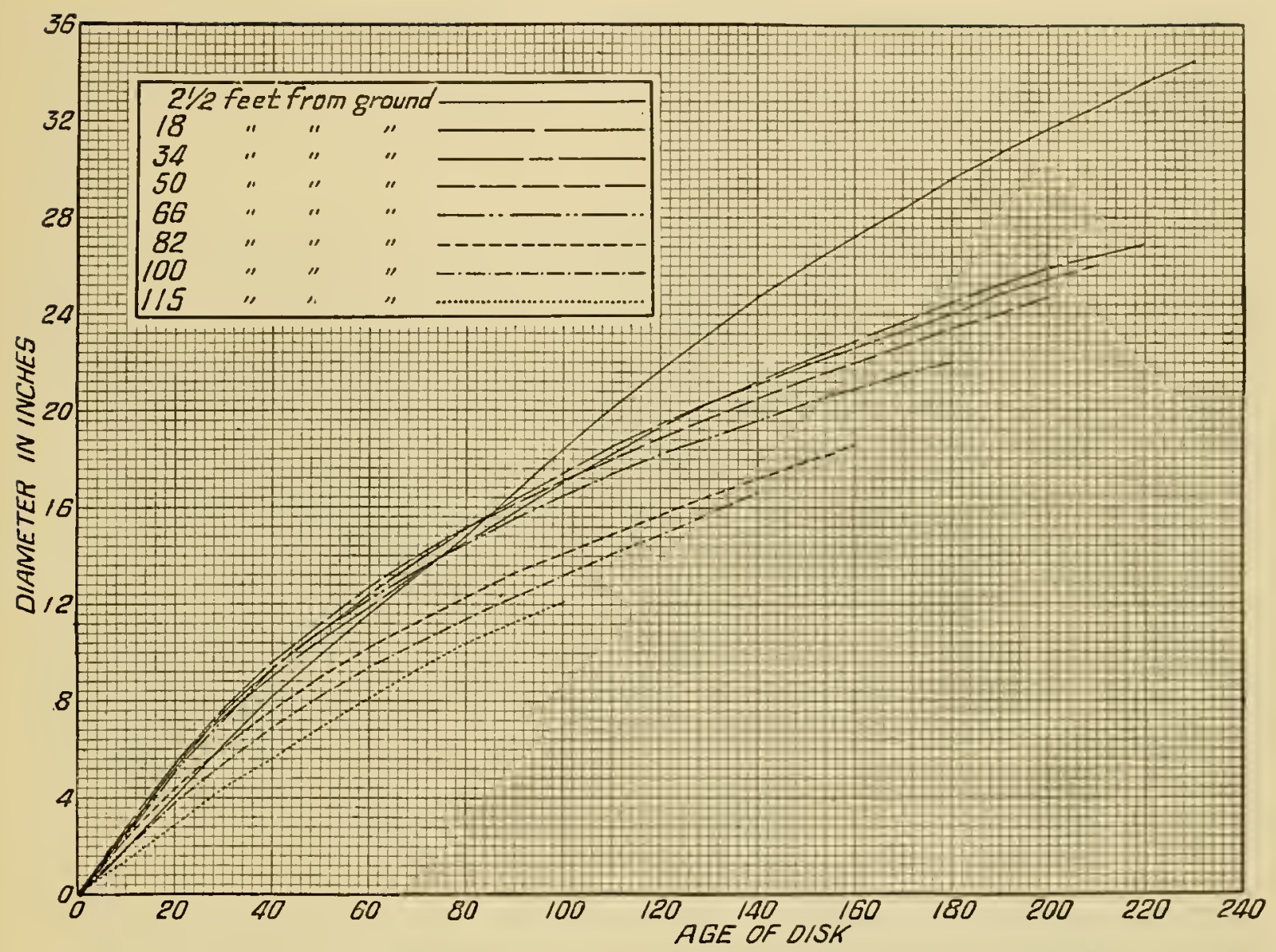

Fig. 36.-Diagram showing diameter growth of domiuant trees at various heights from gionnd in Pennsylrania.

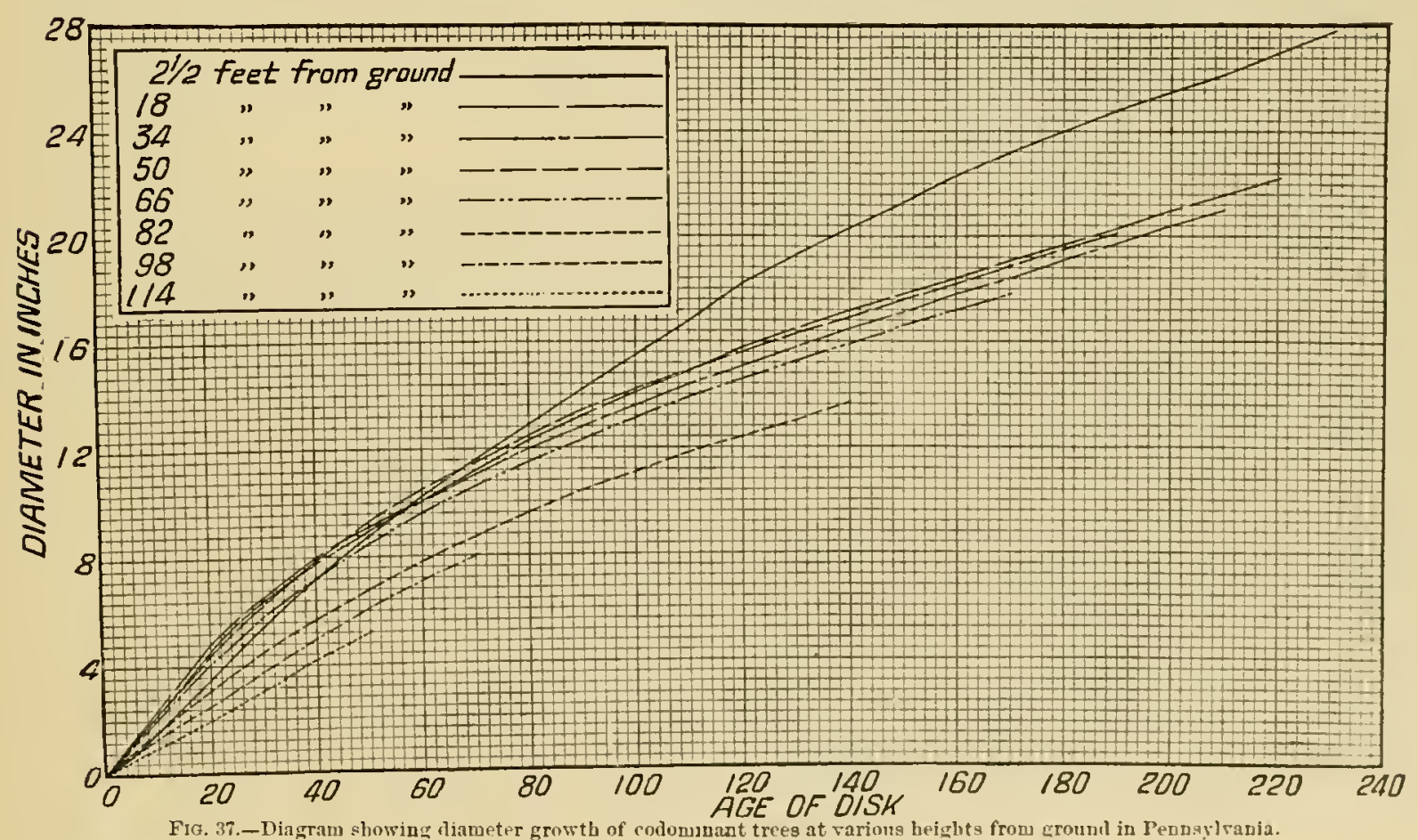

$20233--$ ก $2.2 \longrightarrow 3$ 


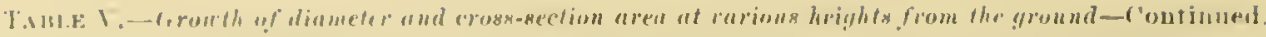

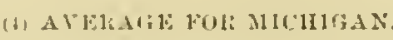

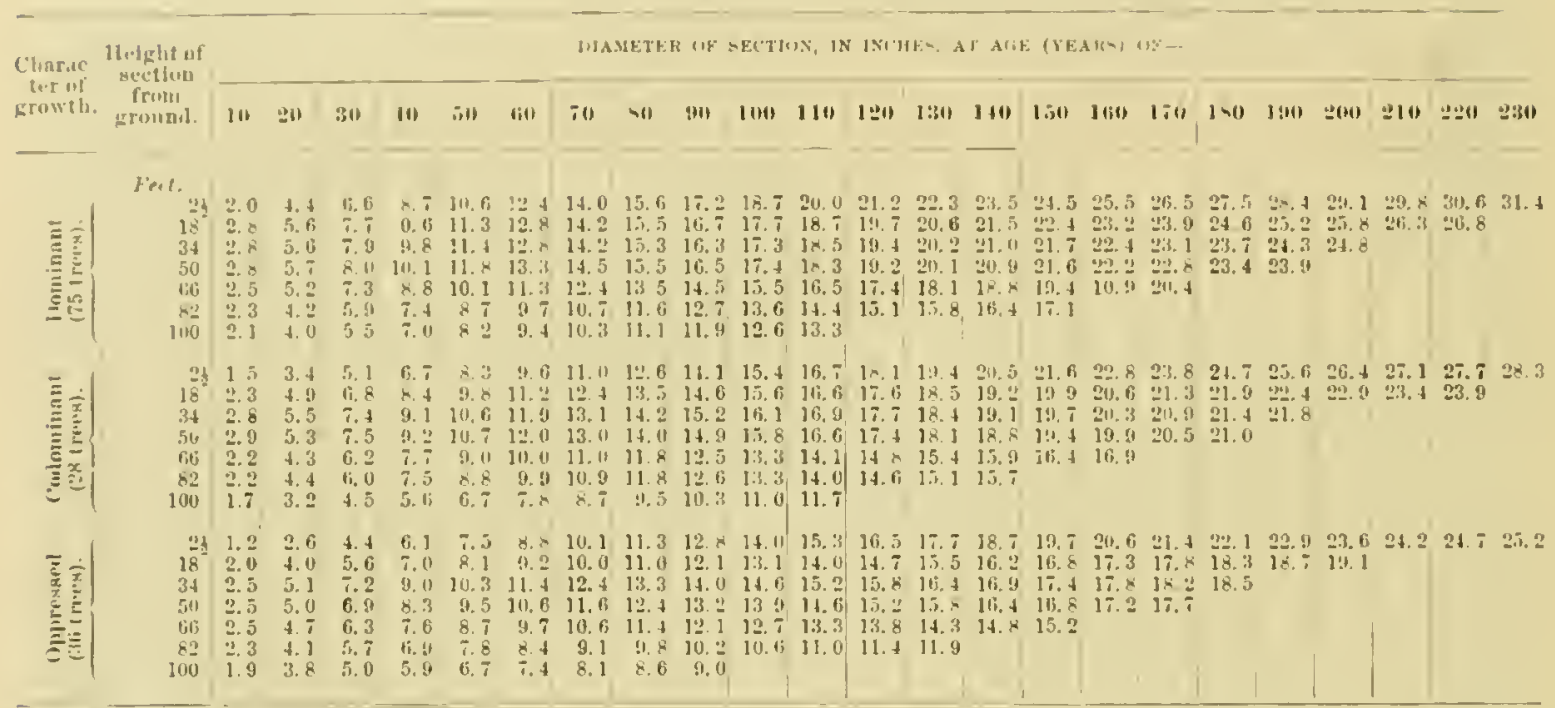

\begin{tabular}{|c|c|c|c|c|c|c|c|c|c|c|c|c|c|c|c|c|c|c|c|c|c|c|c|c|}
\hline \multirow{2}{*}{$\begin{array}{c}\text { Cluarac- } \\
\text { tur of } \\
\text { griurth. }\end{array}$} & \multirow{2}{*}{$\begin{array}{l}\text { Height of } \\
\text { mection } \\
\text { from } \\
\text { gromuil. }\end{array}$} & \multicolumn{22}{|c|}{ DIAMETEU } & \multirow[b]{2}{*}{23} \\
\hline & & I & $\stackrel{2}{2}$ & 3 & 4 & $i$ & iti & $i$ & $\rightarrow$ & ) & 10 & 11 & 12 & 13 & 14 & 15 & 316 & 17 & 1* & 10 & $=11$ & $\because 1$ & \&.2 & \\
\hline 政 & $\begin{array}{l}\text { Fert. } \\
18 \\
31 \\
510 \\
615 \\
80 \\
1+11 \%\end{array}$ & $\begin{array}{l}3.0 \\
3.8 \\
2.8 \\
2.8 \\
3.5 \\
3.3 \\
2.1\end{array}$ & $\begin{array}{l}3.4 \\
2.8 \\
2.8 \\
2.9 \\
1.9 \\
1.9 \\
\text { 3. }\end{array}$ & $\begin{array}{l}2.2 \\
2.1 \\
2.3 \\
2.3 \\
2.1 \\
1.7 \\
1.5\end{array}$ & $\begin{array}{l}2.1 \\
1.9 \\
1.9 \\
2.1 \\
1.5 \\
1.5 \\
1.5\end{array}$ & $\begin{array}{l}\text { 1. } \\
\text { 1. } \\
1.6 \\
1.7 \\
\text { 1. } 3 \\
1.3 \\
1.2\end{array}$ & $\begin{array}{l}1.8 \\
1.5 \\
1.4 \\
1.5 \\
1.9 \\
1.0 \\
1.2\end{array}$ & $\begin{array}{l}1.6 \\
1.4 \\
1.4 \\
1.2 \\
1.1 \\
1.11 \\
0.9\end{array}$ & $\begin{array}{l}1.6 \\
1.3 \\
1.1 \\
1.0 \\
1.1 \\
0.9 \\
1.8\end{array}$ & $\begin{array}{l}1.6 \\
1.2 \\
1.11 \\
1.0 \\
1.0 \\
1.1 \\
0.6\end{array}$ & $\begin{array}{l}1.5 \\
1.0 \\
1.0 \\
0.5 \\
1.0 \\
0.9 \\
0.7\end{array}$ & $\begin{array}{l}1.3 \\
1.0 \\
1.3 \\
1.3 \\
1.0 \\
1.5 \\
1.7\end{array}$ & $\begin{array}{l}1 . \\
1 . \\
0 . \\
0 . \\
0 . \\
0 .\end{array}$ & $\begin{array}{l}1.1 \\
0.9 \\
0.8 \\
0.9 \\
0.7 \\
0.7\end{array}$ & $\begin{array}{l}1.2 \\
0.91 \\
11.8 \\
0.8 \\
11.7 \\
1.8\end{array}$ & $\begin{array}{l}1.0 \\
0.5 \\
0.7 \\
0.7 \\
0.6 \\
0.7\end{array}$ & $\begin{array}{l}1.0 \\
1.8 \\
0.7 \\
0.5 \\
0.5\end{array}$ & $\begin{array}{l}1.4 \\
0.7 \\
0.7 \\
0.6 \\
0.5\end{array}$ & $\begin{array}{l}1.0 \\
0.7 \\
0.6 \\
0.6\end{array}$ & $\begin{array}{l}0.8 \\
0.6 \\
0.6 \\
10.5\end{array}$ & $\begin{array}{l}0.7 \\
0.6 \\
0.5\end{array}$ & $\begin{array}{l}11.7 \\
10 . j\end{array}$ & $\begin{array}{l}0.7 \\
0.5\end{array}$ & $0 . \mathrm{R}$ \\
\hline 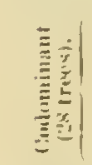 & $\begin{array}{r}518 \\
381 \\
34 \\
511 \\
600 \\
8: 2 \\
9001\end{array}$ & $\begin{array}{l}1.5 \\
2.3 \\
2.0 \\
2.0 \\
2.2 \\
1.2 \\
1.7\end{array}$ & $\begin{array}{l}1.9 \\
2.6 \\
2.7 \\
2.4 \\
2.1 \\
2.2 \\
1.5\end{array}$ & $\begin{array}{l}1.7 \\
1.4 \\
1.9 \\
2.2 \\
1.9 \\
1.4 \\
1.3\end{array}$ & $\begin{array}{l}1.6 \\
1.6 \\
1.7 \\
1.7 \\
1.5 \\
1.5 \\
1.1\end{array}$ & $\begin{array}{l}1.6 \\
1.4 \\
1.5 \\
1.5 \\
1.3 \\
1.3 \\
1.1\end{array}$ & $\begin{array}{l}1.3 \\
1.4 \\
1.3 \\
1.3 \\
1.0 \\
1.1 \\
1.1\end{array}$ & $\begin{array}{l}1.4 \\
1.2 \\
1.2 \\
1.0 \\
1.11 \\
1.11 \\
1.4\end{array}$ & $\begin{array}{l}1.6 \\
1.1 \\
1.1 \\
1.0 \\
11.8 \\
11.9 \\
0.8\end{array}$ & $\begin{array}{l}1.5 \\
1.1 \\
1.0 \\
0.9 \\
11.7 \\
0.8 \\
0.8\end{array}$ & $\begin{array}{l}1.3 \\
\therefore .11 \\
0.11 \\
0.9 \\
10.8 \\
0.7 \\
0.7\end{array}$ & $\begin{array}{l}1.3 \\
1.0 \\
0 . \\
0 . \\
0 . \\
0.7 \\
0.7\end{array}$ & $\begin{array}{l}1 . \\
1 . \\
1 . \\
0 . \\
0 . \\
0 .\end{array}$ & $\begin{array}{l}1.3 \\
10.9 \\
0.7 \\
0.7 \\
0.6 \\
11.5\end{array}$ & $\begin{array}{l}1.1 \\
11.7 \\
11.7 \\
0.7 \\
0.5 \\
11.6\end{array}$ & $\begin{array}{l}1.1 \\
0.7 \\
0.6 \\
11.6 \\
11.5\end{array}$ & $\begin{array}{l}1.2 \\
11.7 \\
0.6 \\
11.5 \\
0.5\end{array}$ & $\begin{array}{l}1.13 \\
11.7 \\
11.6 \\
11.6 \\
0.4\end{array}$ & $\begin{array}{l}0.9 \\
0.6 \\
0.5 \\
0.5\end{array}$ & $\begin{array}{l}0.9 \\
0.5 \\
0.4\end{array}$ & $\begin{array}{l}0.5 \\
0.5\end{array}$ & $\begin{array}{l}0.7 \\
11.5\end{array}$ & $\begin{array}{l}0.4 \\
0.5\end{array}$ & \\
\hline 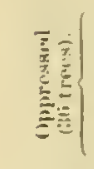 & $\begin{array}{c}21 \\
14 \\
34 \\
50 \\
64 \\
82 \\
100\end{array}$ & $\begin{array}{l}1.2 \\
2.11 \\
2.5 \\
2.5 \\
2.5 \\
2.3 \\
1.9\end{array}$ & $\begin{array}{l}1.4 \\
2.13 \\
2.6 \\
2.5 \\
2.2 \\
1.8 \\
1.0\end{array}$ & $\begin{array}{l}1 . \\
1.41 \\
21.1 \\
1.9 \\
1.0 \\
1.1 \\
1.0\end{array}$ & $\begin{array}{l}1.7 \\
1.4 \\
1.8 \\
3.4 \\
1.3 \\
1.2 \\
11.9\end{array}$ & $\begin{array}{l}1.4 \\
1.1 \\
1.3 \\
1.2 \\
1.1 \\
0.4 \\
0.8\end{array}$ & $\begin{array}{l}1.3 \\
1.1 \\
1.1 \\
1.1 \\
1.0 \\
11.6 \\
11.7\end{array}$ & $\begin{array}{l}1.3 \\
0.8 \\
1.11 \\
1.0 \\
0.8 \\
1.7 \\
1.7\end{array}$ & $\begin{array}{l}1.2 \\
1.0 \\
11.9 \\
0.8 \\
0.8 \\
11.7 \\
11.5\end{array}$ & $\begin{array}{l}1.5 \\
1.1 \\
11.7 \\
11 . \\
0.7 \\
11.4 \\
11.4\end{array}$ & $\begin{array}{l}1.2 \\
1.0 \\
0.1 \\
0.7 \\
0.6 \\
04\end{array}$ & $\begin{array}{l}1 . \\
1 . \\
0.1 \\
11 . \\
0 . \\
0 .\end{array}$ & $\begin{array}{l}1 . \\
0 . \\
0 . \\
0 . \\
11 . \\
11 .\end{array}$ & $\begin{array}{l}1.2 \\
0.8 \\
0.1 \\
0.0 \\
0.5 \\
0.5\end{array}$ & $\begin{array}{l}1.0 \\
0.7 \\
0.5 \\
0.6 \\
11.5\end{array}$ & $\begin{array}{l}1.0 \\
0.6 \\
0.5 \\
11.4 \\
0.4\end{array}$ & $\begin{array}{l}11.9 \\
0.5 \\
0.1 \\
11.4\end{array}$ & $\begin{array}{l}11.8 \\
0.5 \\
0.4 \\
0.5\end{array}$ & $\begin{array}{l}0.7 \\
0.5 \\
0.3\end{array}$ & $\begin{array}{l}0.8 \\
11.4\end{array}$ & $\begin{array}{l}0.7 \\
0.7\end{array}$ & 0.6 & 0.5 & 11.5 \\
\hline
\end{tabular}

\begin{tabular}{|c|c|c|c|c|c|c|c|c|c|c|c|c|c|c|c|c|c|c|c|c|c|c|c|c|}
\hline hara & $\begin{array}{l}\text { 1fright of } \\
\text { rertion }\end{array}$ & & & & & & t & & $\mathrm{si}$ & r & & & , 1. & $\therefore, 0$ & FE: & T, & 16 & & - & & & & & \\
\hline Erowt & $\begin{array}{l}\text { fromi } \\
\text { Ecromind }\end{array}$ & 1 & 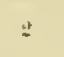 & 3 & i & ij & ti & i & $\rightarrow$ & $!$ & 111 & 11 & $1:$ & $1: 1$ & 14 & $1 .:$ & 14 & 17 & Is & 1!1 & 90 & 21 & $\because 2$ & $2: 1$ \\
\hline 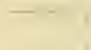 & rite & $=$ & & 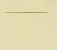 & 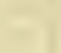 & 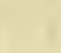 & & & - & & & 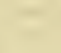 & & & & & & & & & & & & \\
\hline & & 0.112 & 11.08 & 11. 14 & 0.17 & 0.21 & (1. 23 & 1). 23 & 11. 20 & 11. In & 0. 30 & 0.27 & 11, & ט. 20 & 11. 311 & 0.37 & 11,2 & 0.38 & (1. 29) & 1), $22^{2}$ & 0.22 & (1.22 & 0.97 & 0. \\
\hline & $1=2$ & (1)1 & .13 & .15 & 1 & 0 & . 14 & .21 & $\therefore 1$ & .21 & .19 & 30 & $2:$ & .32 & ix & 2. & 10 & ia & 19 & .16 & i & .11 & $3 i$ & \\
\hline & 31 & .01 & .13 & .17 & .18 & $.1 !$ & .38 & 21 & .18 & .17 & & .1 & 18 & .17 & $\therefore$ is & 17 & 17 & .17 & .35 & 16 & 13 & & & \\
\hline & 50 & .114 & il & .17 & .21 & .211 & .30 & .111 & Iiti & 17 & .17 & 18 & $1 *$ & 19 & is & $10 \mathrm{i}$ & .15 & is & 10 & 12 & & & & \\
\hline & fiti & .03 & 12 & .14 & 13 & 14 & 14 & 14 & 1.7 & $i_{i i}$ &.$i t i$ & 17 & 17 & .14 & . it & 12 & i1 & .11 & & & & & & \\
\hline & $x \geq$ & .113 & 07 & .08 & .11 & .11 & iII & ii & 11 & .15 & 13 & .12 & i1 & 12 & .11 & .12 & & & & & & & & \\
\hline & 1110 & .12 & .11 & 07 & il & .115 & 18 & .10 & . 11!! & .10 & .10 & (19) & $.0 x$ & & & & & & & & & & & \\
\hline & -1 & .01 & $.0 i$ & $.0 \%$ & .11 & .18 & .13 & 11 & . 211 & .23 & .21 & .33 & $\therefore$ & .26 & .24 & .9 & $.3 ! 4$ & $\therefore$ & $.2 t$ & .24 & .83 & . 20 & .18 & .1 \\
\hline & $1 x^{2}$ & .11 & .111 & . 1! & 13 & 14 & 160 & j & $1:$ & .37 & .17 & .17 & 1 & .18 & 1 & .15 & in & 1 & 31 & .13 & .32 & 13 & & \\
\hline & i.t & .01 & .12 & .11 & 15 &.$I_{i}$ & $.10 i$ & .17 & .16 & .11 & .15 & 15 & 15 & .14 & is & 13 & 13 & 1 & .11 & .10 & & & & \\
\hline & 5.11 & .05 & .111 & . $t_{i}$ & .15 & .10 & .165 & 1 & .15 & .14 & .85 & .11 & 15 & .11 & .14 & .12 & 11 & .13 & .11 & & & & & \\
\hline & aif & $.1 \div 3$ & .117 & .11 & ij & $i=$ & . 111 & i2 & .10 & $0 ! 1$ & .11 & 12 & .11 & (II & . $0 ! 1$ & .04 & . $10 !$ & & & & & & & \\
\hline & $\times 2$ & 03 & $11 \%$ & 10 & ii & .ii & 11 & 12 & 11 & .11 & .09 & .11 & .110 & . Us & . 14) & & & & & & & 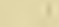 & & \\
\hline & I(n) & .02 & .114 & .15 & $01 ;$ & $n$ & .119 & ilin & 115 & 118 & .198 & .09 & & & & & & & & & & & & \\
\hline & 21 & .11] & .113 & Whi & I11 & .11 & .11 & 11 & .11 & 1!? & .18 & 21 & . & $.2: i$ & טu & 21 & . & .16 & . It & (20) & ת I I . & .15 & 14 & .13 \\
\hline & 18 & .02 & $.11 \%$ & lim & i1) & in: & iii & iin & $1:$ & il & .14 & 13 & 11 & .13 & .1 & 11 & .8 & . & . 10 & . IR & $.11 x$ & & & \\
\hline & 34 & .183 & .11 & .11 & $11 i$ & 11 & .13 & $1:$ & 13 & 11 & 109 & . 110 & io & .11 & .169 & $0 !$ & .1 & .1 & $116 b^{\circ}$ & & & & & \\
\hline & 50 & . 11.. & .11 & .12 & $1: 2$ & 11 & 113 & 1: & .11 & . II & . ]11 & 11 & il & . III & 11 & 07 & .07 & . III & & & i & & & \\
\hline & 66 & .0 & .119 & III & 09 & jo & 10 & .11 & .80 & . 11:1 & .11, & $.0 x^{2}$ & (1) & $0 \%$ & is & 117 & & & & & & & & \\
\hline & 82 & .0 & $.01 i$ & $.0 ! 1$ & $0=$ & .17 & .115 & 0 & (1) & .115 & .114 & . 115 & 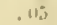 & IIIi & & & & & & & & & & \\
\hline & ] (4) & $.0: 1$ & .1931 & . wi & .185 & 1.3 & lifi & (ini & 111 & .111 & & & & & & & & & & & & & & \\
\hline
\end{tabular}




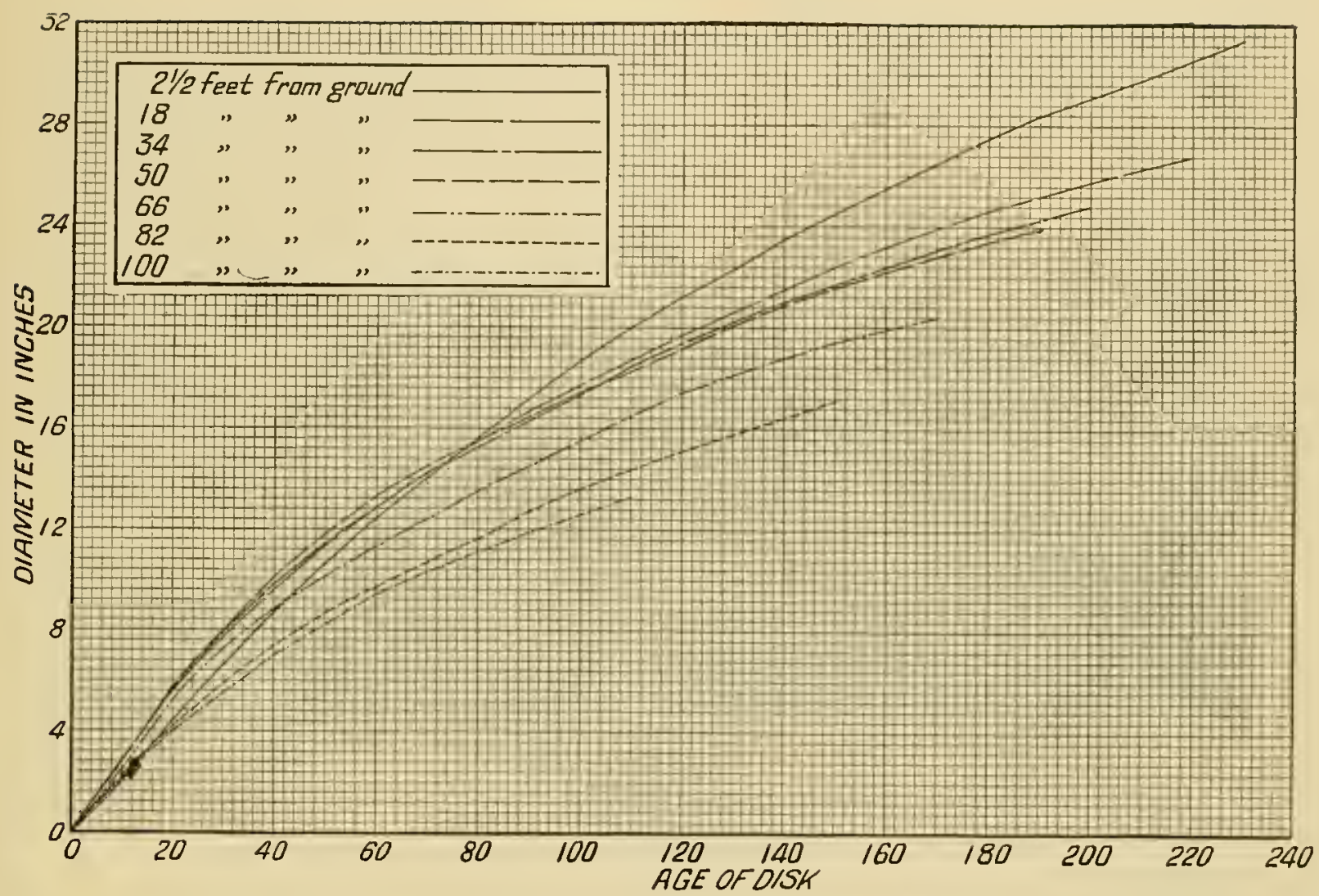

FiG. 38.-Diagram showing diameter growth of dominant trees at variuus heights from groum in Michigan.

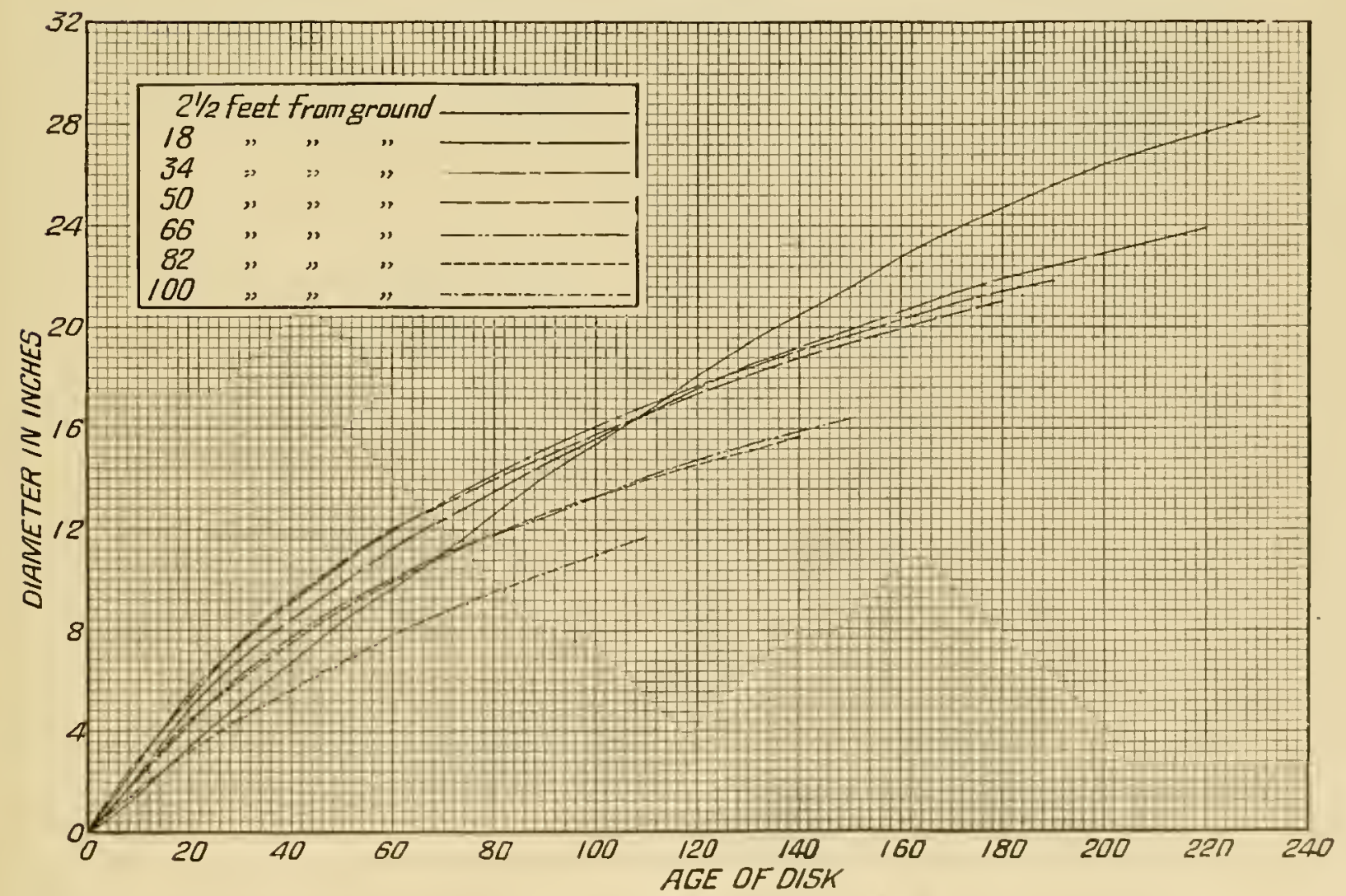

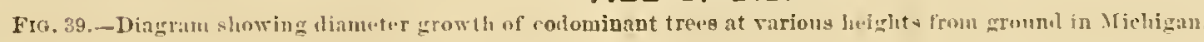




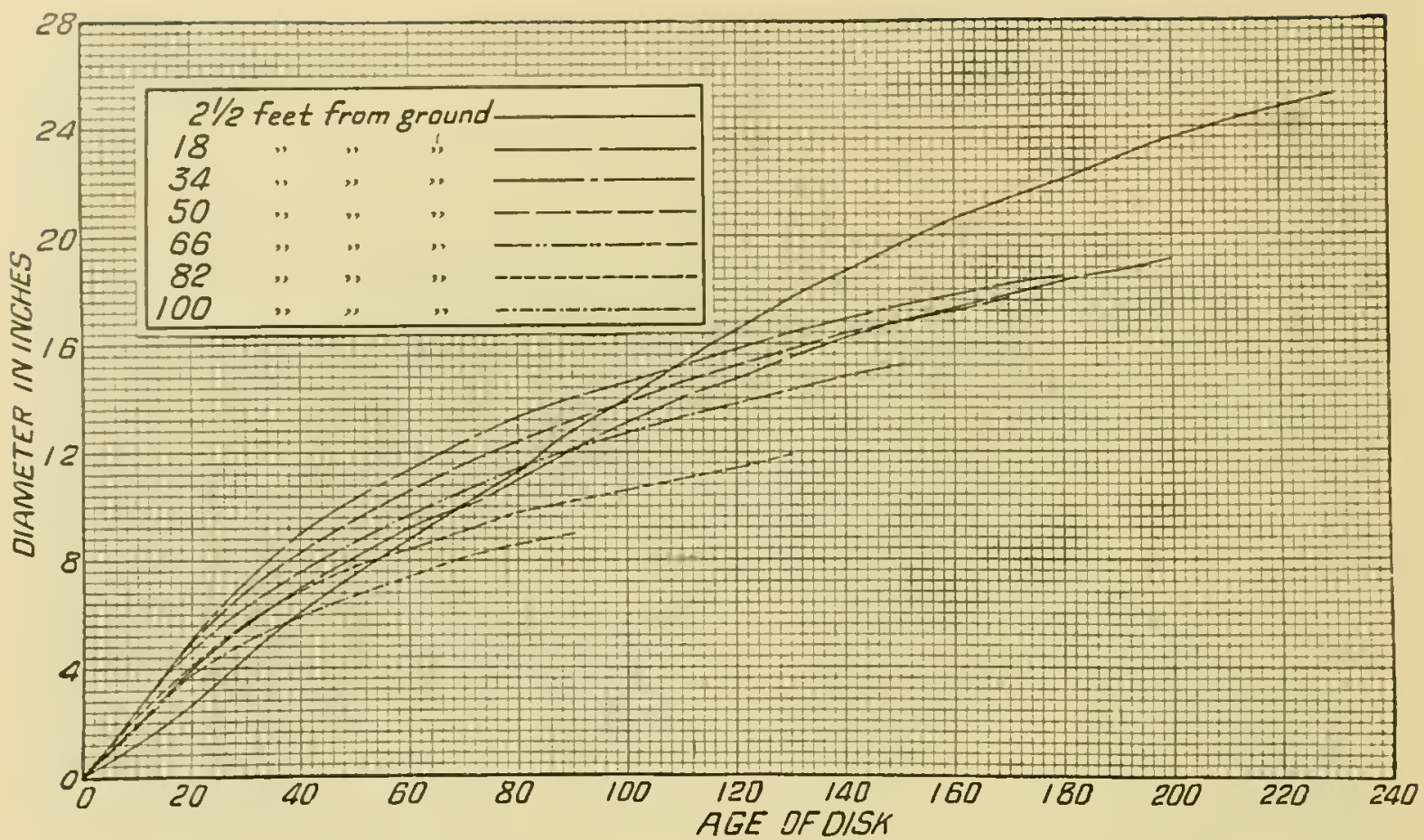

Fin. 40.-Diagram showiug diameter growtb of oppressent trees at rariots lueights from gronvd in Micbigno.

A.-MILIIfiax:

(1) SITE a

CABLE V1.-Acre giclds of White I'ine and measurcments of sample trete.

Presque Isle Condtr.

[700 10 800 teet above sea l.rel.]

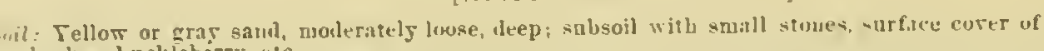
brakes, buckleberry tetc.

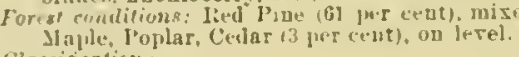

Claspification:

Dumidenat

i....

\footnotetext{
Ir bite l'ille. Iitel l'iue. supprensed.
Sinuple area : 1 acre.

1 ge of pine: 100 to 150 sears. T)ensity of ('Tow a cover: 0.6 .

Number w trees: $1 \cdot 1$.

ACILE TIELU

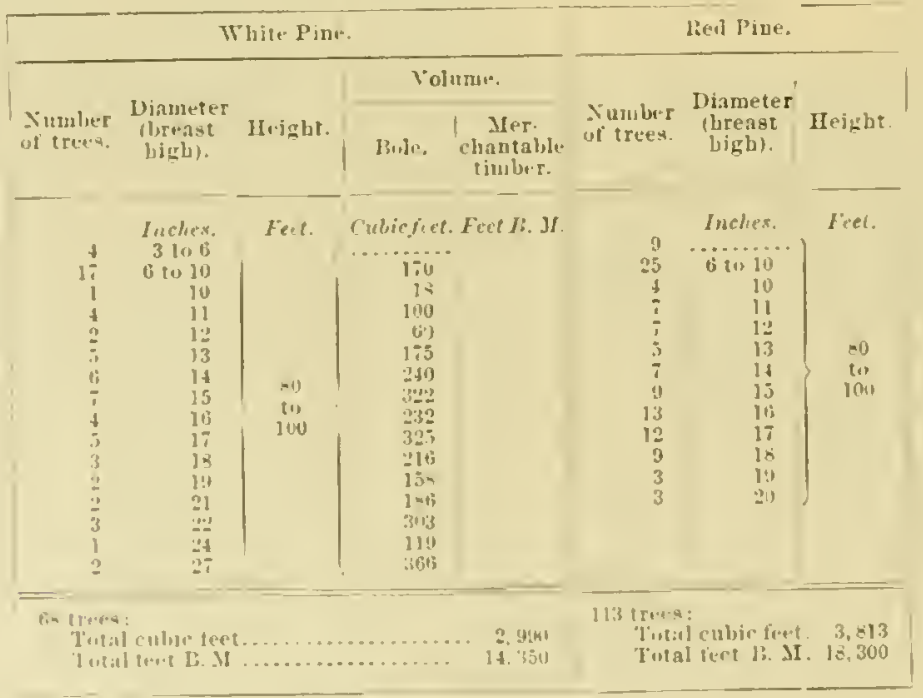

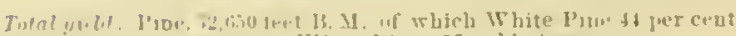


TABLES OF MEASUREMENT'S.

TABLE VI.-Acre yields of Thite Pine and masurements of sample tres-Continued.

A.-MICIIG $\triangle \times$-Coutinued

MEASTREMENTS OF SAMPLE TLEES.

A ge class: 80 to 100 years.

עOMISAST OROWTH

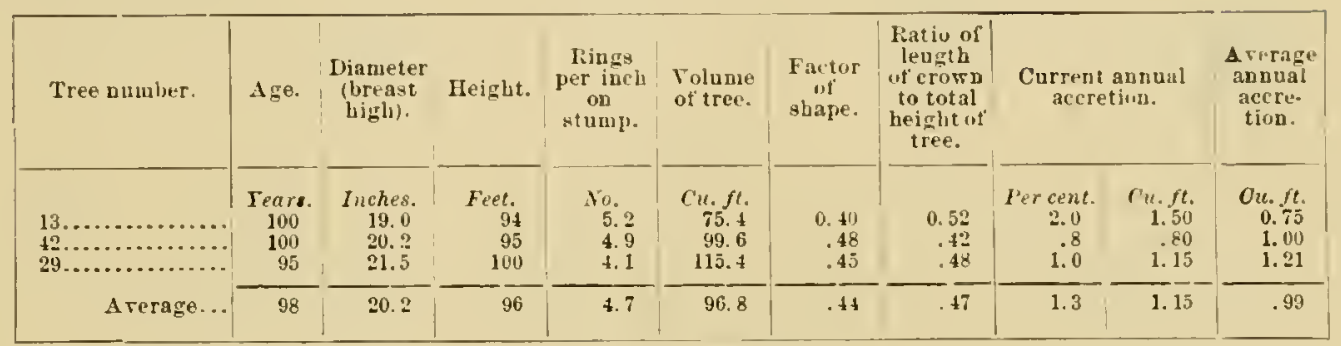

ORPRESSED GROWTH.

$\begin{array}{r}{[66 \ldots \ldots \ldots \ldots \ldots} \\ \hline\end{array}$

SLPPRESED GROWTH.

\begin{tabular}{|c|c|c|c|c|c|c|c|c|c|c|}
\hline $19 \ldots \ldots \ldots \ldots \ldots \ldots$ & $\begin{array}{l}92 \\
84\end{array}$ & $\begin{array}{l}10.5 \\
10.0\end{array}$ & $\begin{array}{l}72.0 \\
73.0\end{array}$ & $\frac{8.2}{7.6}$ & $\begin{array}{l}20.6 \\
20.9\end{array}$ & $\begin{array}{r}0.47 \\
.53\end{array}$ & $\begin{array}{r}0.26 \\
.48\end{array}$ & $\begin{array}{l}1.2 \\
3.7\end{array}$ & 0.25 & $\begin{array}{r}0.22 \\
.25\end{array}$ \\
\hline Arerage... & 88 & 10.2 & 72.5 & 7.9 & 20.7 & .50 & .37 & 2.4 & .51 & .23 \\
\hline
\end{tabular}

Age class: 100 to 150 years.

DOMINANT GROWTH

\begin{tabular}{|c|c|c|c|c|c|c|c|c|c|c|}
\hline 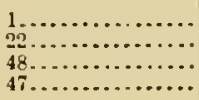 & $\begin{array}{l}123 \\
101 \\
105 \\
104\end{array}$ & $\begin{array}{l}20.0 \\
20.8 \\
20.5 \\
22.7\end{array}$ & $\begin{array}{l}10.2 \\
90.0 \\
99.0 \\
94.0\end{array}$ & $\begin{array}{l}5.5 \\
4.7 \\
5.1 \\
4.7\end{array}$ & $\begin{array}{r}89.7 \\
92.7 \\
96.7 \\
103.0\end{array}$ & $\begin{array}{r}0.40 \\
.42 \\
.42 \\
.39\end{array}$ & $\begin{array}{r}0.54 \\
.51 \\
.14 \\
.59\end{array}$ & $\begin{array}{l}2.9 \\
2.0 \\
1.3 \\
1.5\end{array}$ & $\begin{array}{l}2.60 \\
1.85 \\
1.26 \\
1.55\end{array}$ & $\begin{array}{r}0.73 \\
.91 \\
.92 \\
.99\end{array}$ \\
\hline Average. & 108 & 21.0 & 96.0 & 5.0 & 95.5 & .41 & .52 & 1.9 & 1.81 & .89 \\
\hline $\begin{array}{l}5 \ldots \ldots \ldots \ldots \\
6 \ldots \ldots \ldots \ldots \ldots \\
35 \ldots \ldots \ldots \ldots\end{array}$ & $\begin{array}{l}149 \\
135 \\
135\end{array}$ & $\begin{array}{l}20.2 \\
21.0 \\
22.0\end{array}$ & $\begin{array}{l}105.0 \\
114.0 \\
121.0\end{array}$ & $\begin{array}{l}7.6 \\
6.2 \\
5.5\end{array}$ & $\begin{array}{r}88.9 \\
107.9 \\
139.6\end{array}$ & $\begin{array}{l}.39 \\
.39 \\
.40\end{array}$ & $\begin{array}{l}.50 \\
.57 \\
.43\end{array}$ & $\begin{array}{l}2.0 \\
2.2 \\
1.5\end{array}$ & $\begin{array}{l}1.78 \\
2.37 \\
2.11\end{array}$ & $\begin{array}{r}.60 \\
.80 \\
1.03\end{array}$ \\
\hline Arerage... & 139.7 & 21.1 & 113.0 & 6.4 & 112.1 & .39 & .50 & 1.9 & 2.08 & .81 \\
\hline
\end{tabular}

OPPRESSED GHOWTH

\begin{tabular}{|c|c|c|c|c|c|c|c|c|c|c|}
\hline 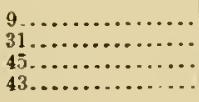 & $\begin{array}{l}102 \\
102 \\
102 \\
105\end{array}$ & $\begin{array}{l}16.0 \\
15.1 \\
17.0 \\
16.8\end{array}$ & $\begin{array}{l}85.0 \\
86.0 \\
84.0 \\
87.0\end{array}$ & $\begin{array}{l}6.6 \\
6.7 \\
6.0 \\
6.1\end{array}$ & $\begin{array}{l}48.8 \\
49.4 \\
58.5 \\
67.3\end{array}$ & $\begin{array}{r}0.41 \\
.46 \\
.44 \\
.49\end{array}$ & $\begin{array}{r}0.46 \\
.40 \\
.61 \\
.42\end{array}$ & $\begin{array}{r}2.5 \\
1.4 \\
1.7 \\
.7\end{array}$ & $\begin{array}{r}\text { 1. } 22 \\
.69 \\
.99 \\
.47\end{array}$ & $\begin{array}{l}0.47 \\
.48 \\
.57 \\
.64\end{array}$ \\
\hline Average. & 103 & 10.2 & 85.5 & 6.3 & 56.0 & .45 & $.4 i$ & 1.6 & .84 & .54 \\
\hline $\begin{array}{l}4 \ldots \\
40 . \\
3 .\end{array}$ & $\begin{array}{l}197 \\
134 \\
147\end{array}$ & $\begin{array}{l}17.0 \\
15.0 \\
18.0\end{array}$ & $\begin{array}{l}88.0 \\
94.0 \\
91.0\end{array}$ & $\begin{array}{l}6.7 \\
8.6 \\
7.9\end{array}$ & $\begin{array}{l}56.9 \\
5 \% .6 \\
66.0\end{array}$ & $\begin{array}{l}.41 \\
.50 \\
.41\end{array}$ & $\begin{array}{r}.54 \\
.30 \\
.44\end{array}$ & $\begin{array}{l}5.2 \\
2.2 \\
4.9\end{array}$ & $\begin{array}{l}2.96 \\
1.26 \\
3.23\end{array}$ & $\begin{array}{l}.44 \\
.43 \\
.44\end{array}$ \\
\hline Arerage... & 136 & 16.7 & 91.0 & 7.7 & 60. 2 & .44 & .43 & 4.1 & 2.48 & .44 \\
\hline
\end{tabular}

SUPPRESSED GROWTH.

\begin{tabular}{|c|c|c|c|c|c|c|c|c|c|c|}
\hline $39 \ldots \ldots \ldots \ldots$ & 127 & 11.0 & 69 & 1. 2 & $2 \pm 6$ & 0.54 & 0.22 & 3.2 & 0.79 & 0.19 \\
\hline
\end{tabular}

Age clase: 250 to 300 years.

DOMINANT GROWTH.

\begin{tabular}{|c|c|c|c|c|c|c|c|c|c|c|}
\hline 7................ & 281 & 33.0 & 135 & 8.7 & 319.2 & 0.39 & ........... & 19.6 & 1. 91 & 1.12 \\
\hline
\end{tabular}




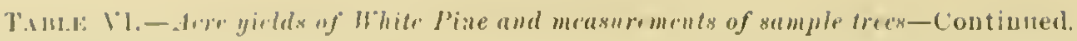

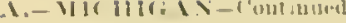

(2) STE:

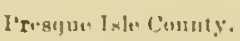

[ivo to 800 fer: aborio aria le ral.] ]

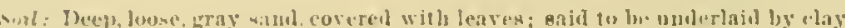

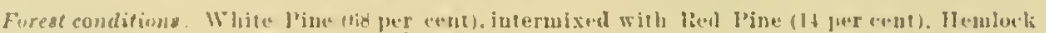
118 jur entl, witls realtring Cedar.

Chasijication:

Dominand.

Oppreanil
Suppresged
Whif Irine nerer 1 nut.. 32
Simple area : 1 acre.

Agu of pine: 130 to 140 rears. Deusity of crown corr: 11. I II $^{\circ}$ 0.8 .

nuwber of trees: 181

\begin{tabular}{|c|c|c|c|c|c|c|c|c|c|c|}
\hline \multicolumn{5}{|c|}{ White Pins. } & \multicolumn{3}{|c|}{ lictl I'ine. } & \multicolumn{3}{|c|}{ Hrmlock. } \\
\hline \multirow[b]{2}{*}{$\begin{array}{l}\text { Xiumber } \\
\text { of trees. }\end{array}$} & \multirow[b]{2}{*}{$\begin{array}{l}\text { Dianeter } \\
\text { (breast } \\
\text { Ligh). }\end{array}$} & \multirow[b]{2}{*}{ Heiglit. } & \multicolumn{2}{|c|}{ Tulını: } & \multirow[b]{2}{*}{$\begin{array}{l}\text { Numbir } \\
\text { of trees. }\end{array}$} & \multirow[b]{2}{*}{$\begin{array}{l}\text { bianuetur } \\
\text { (brenst } \\
\text { lights. }\end{array}$} & \multirow[b]{2}{*}{ Height. } & \multirow[b]{2}{*}{$\begin{array}{l}\text { Simblese } \\
\text { of trees. }\end{array}$} & \multirow[b]{2}{*}{$\begin{array}{l}\text { Dianueter } \\
\text { (lireast } \\
\text { blali). }\end{array}$} & \multirow[b]{2}{*}{ Height. } \\
\hline & & & Bole. & $\begin{array}{l}\text { Yur. } \\
\text { chantable } \\
\text { timber. }\end{array}$ & & & & & & \\
\hline $\begin{array}{r}28 \\
5 \\
6 \\
6 \\
6 \\
11 \\
0 \\
6 \\
10 \\
8 \\
7 \\
1 \\
15 \\
7 \\
1 \\
1 \\
3 \\
1 \\
1\end{array}$ & 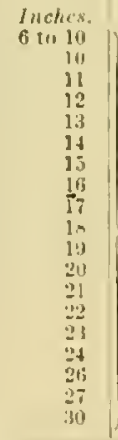 & Fiet. & $\begin{array}{c}\text { Culuicfict. } \\
280 \\
115 \\
192 \\
266 \\
264 \\
530 \\
5: 2 \\
384 \\
720 \\
19410 \\
616 \\
690 \\
714 \\
145 \\
117 \\
153 \\
555 \\
199 \\
210\end{array}$ & Fect 13.31. & $\begin{array}{ll}1 & \\
1 \\
1 \\
5 \\
6 \\
1 \\
3 \\
3 \\
2 \\
3 \\
1 \\
1\end{array}$ & $\begin{array}{l}\text { Anches. } \\
6+10 \\
14 \\
15 \\
16 \\
17 \\
18 \\
11 ! \\
20 \\
21 \\
22\end{array}$ & $\begin{array}{l}\text { Feet. } \\
\text { I0u } \\
10 \\
120\end{array}$ & $\begin{array}{r}20 \\
11 \\
3\end{array}$ & $\begin{array}{l}\text { Inches. } \\
\text { otulo } \\
10 \text { to } 14 \\
14 \text { to } 18\end{array}$ & $\begin{array}{c}\text { Fent. } \\
\text { to } \\
\text { to } \\
\text { tio }\end{array}$ \\
\hline $\begin{array}{l}129 \text { trees } \\
\text { T'uta } \\
\text { 'Tuta }\end{array}$ & $\begin{array}{l}\text { i eulvic fe } \\
\text { l ter B. B. }\end{array}$ & I $\ldots \ldots \ldots$ & $\begin{array}{l}{ }^{2} \\
\ldots \ldots \ldots \ldots \\
\ldots \ldots \ldots\end{array}$ & $\begin{array}{r}8,202 \\
\ldots \quad 39,300\end{array}$ & $\begin{array}{l}\text { 2hi tress: } \\
\text { Tot: }\end{array}$ & al eubic fi. & 2.440 & $\begin{array}{l}\text { 3f trees: } \\
\text { Tota }\end{array}$ & al subie foe & t... 520 \\
\hline
\end{tabular}

Total yeld: All speries. 11,162 cuhic feet, of which White J'iue 73 jro cent.

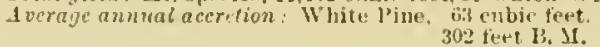

MEA.TUIEMENTS OF SAMILE THEES.

Age class: 130 to 150 years.

DOMPNAT ใB:WTH.

\begin{tabular}{|c|c|c|c|c|c|c|c|c|c|c|}
\hline 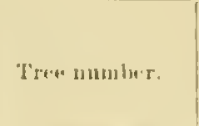 & $\operatorname{Ag} r_{*}$ & $\begin{array}{c}\text { Diameter } \\
\text { (breist } \\
\text { bigh). }\end{array}$ & Jeight. & $\begin{array}{l}\text { lings } \\
\text { geer unvh } \\
\text { (m) } \\
\text { st amy. }\end{array}$ & $\begin{array}{l}\text { Volatize } \\
\text { of iree. }\end{array}$ & $\begin{array}{l}\text { Factur } \\
\text { of } \\
\text { sluape. }\end{array}$ & $\begin{array}{c}\text { liatio of } \\
\text { langtl: } \\
\text { of rrown } \\
\text { to total } \\
\text { beiglit of }\end{array}$ & \multicolumn{2}{|c|}{$\begin{array}{l}\text { Current aunual } \\
\text { aceretiou. }\end{array}$} & $\begin{array}{c}\text { A verage } \\
\text { anbual } \\
\text { acele. } \\
\text { tiou. }\end{array}$ \\
\hline & lears & Inche'n. & Fent. & So. & $C u . f t$ & & & l'er cent. & C'u. jl. & ('u. It \\
\hline & $1: 36$ & 19.7 & 114 & 6.7 & 1159 & .49 & .31 & 1.2 & 1.39 & 0.88 \\
\hline , & 135 & 211,0 & 115 & 6. 2 & 121.3 & 14 & 3 & $1 . \overline{5}$ & 1.94 & .90 \\
\hline .............. & 134 & 200 & 113 & ii. 0 & 123.5 & 31 & $\because 7$ & 7 & .86 & 92 \\
\hline .............. & 1360 & 22.5 & 123 & 6.5 & 130.1 & .34 & .30 & 1.4 & 1. 82 & sin \\
\hline , & 1.25 & 21.7 & 122 & 5.9 & $1: 64$ & it & 32 & .7 & .43 & 1.01 \\
\hline ............ & I.th & 20,2 & 110 & 0.1 & 138.5 & (1) & .30 & 1.0 & $1.3 \mathrm{~K}$ & i. 00 \\
\hline $21 \ldots \ldots \ldots \ldots \ldots$ & 133 & 23.2 & 116 & 5.5 & $1+1.1$ & .12 & .38 & 1.2 & 1.69 & 1. 06 \\
\hline t................ & 130 & 24.0 & lins & 5. 3 & 143.5 & 43 & .40 & 1.8 & 3.58 & 1.10 \\
\hline 3............... & 135 & 240 & 100 & $5 . t i$ & 144.7 & .42 & .35 & .3 & 1.30 & i. $0 \%$ \\
\hline $1 \ldots \ldots \ldots \ldots$ & 138 & 23.5 & 113 & 5.7 & $1+13.5$ & 43 & .26 & 1.0 & 1.46 & 1.1115 \\
\hline $16 \ldots \ldots \ldots \ldots \ldots$ & 134 & 25.0 & 122 & 5.? & 187.3 & .14 & .30 & 3.5 & 2.81 & 1. 27 \\
\hline Avorilge .. & $1: 15.7$ & $2: 3$ & $111 j$ & 5.9 & $1: 36.6$ & .42 & 31 & 1.2 & 1. 61 & 1.00 \\
\hline $27 \ldots \ldots \ldots \ldots \ldots$ & $14:$ & 23.0 & 117 & 5. & $1: 32, y$ & 41 & .30 & 1.2 & $10 \%$ & .96 \\
\hline $4 i \ldots \ldots \ldots \ldots \ldots$ & 142 & 24.0 & 110 & $5 R$ & 1411. 6 & .11 & .34 & 1,15 & 2.11 & .99 \\
\hline $11 \ldots \ldots \ldots \ldots \ldots$ & 162 & 23.5 & i1t & ร. 7 & $14 x, 0$ & .43 & .34 & 1.8 & 2.66 & 1.14 \\
\hline $211 \ldots \ldots \ldots \ldots \ldots$ & 142 & 22.0 & $11: 1$ & if. 0 & $15 \% .3$ & $.4 ?$ & .26 & 1.5 & 2.36 & 1.31 \\
\hline 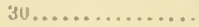 & 143 & $\because 4.2$ & 116 & i. 6 & 164.3 & .45 & .38 & 1.7 & $2.7 y$ & 1. 14 \\
\hline $44 \ldots \ldots \ldots \ldots \ldots$ & 180 & 27.0 & II: & 5. 7 & i 1 in 8 & .46 & $.3 t$ & .4 & 1.35 & 1. 160 \\
\hline & IfA & 26.3 & 315 & 5. 5 & $? 05.4$ & 46 & $3 ! 1$ & 1.2 & 2.46 & 1. 39 \\
\hline Areragr... & 141 & $2+0$ & $11: 5$ & . 5. & 160.5 & At & .34 & 1.4 & 2.20 & 1.10 \\
\hline
\end{tabular}




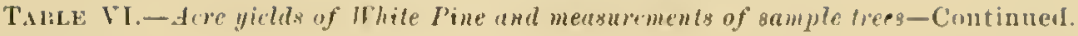

UY'IRESAED GROW'TH.

\begin{tabular}{|c|c|c|c|c|c|c|c|c|c|c|}
\hline Tree number. & Age. & $\begin{array}{c}\text { Diameter } \\
\text { (breast } \\
\text { high). }\end{array}$ & Hejught. & $\begin{array}{l}\text { lijugy } \\
\text { fer inch } \\
\text { oul } \\
\text { stutujb. }\end{array}$ & $\begin{array}{l}\text { Folume } \\
\text { of tree. }\end{array}$ & $\begin{array}{l}\text { Factor } \\
\text { of } \\
\text { shape. }\end{array}$ & $\begin{array}{l}\text { liatio of } \\
\text { length } \\
\text { ot' crown } \\
\text { to total }\end{array}$ & \multicolumn{2}{|c|}{$\begin{array}{c}\text { Current annual } \\
\text { areretions. }\end{array}$} & $\begin{array}{l}\text { Arronge } \\
\text { antmal } \\
\text { acre. } \\
\text { tion. }\end{array}$ \\
\hline 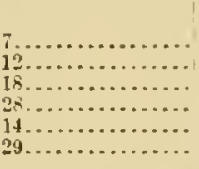 & $\begin{array}{c}\text { Fears. } \\
132 \\
139 \\
135 \\
13.5 \\
135 \\
140\end{array}$ & $\begin{array}{r}\text { Inches. } \\
17.8 \\
18.5 \\
18.0 \\
17.5 \\
19.5 \\
18.5\end{array}$ & $\begin{array}{l}\text { Fete } \\
114 \\
112 \\
116 \\
110 \\
107 \\
102\end{array}$ & $\begin{array}{r}8.7 \\
7.8 \\
7.2 \\
7.3 \\
6.8 \\
\therefore .5\end{array}$ & $\begin{aligned} \text { Cu. } 11 . \\
83.6 \\
88.4 \\
91.2 \\
92.0 \\
95.6 \\
98.2\end{aligned}$ & $\begin{array}{r}0.41 \\
.42 \\
.44 \\
.49 \\
.43 \\
.51\end{array}$ & $\begin{array}{l}0.42 \\
.32 \\
.27 \\
.36 \\
.42 \\
.27\end{array}$ & $\begin{array}{c}\text { Percent. } \\
1.2 \\
1.1 \\
.9 \\
1.6 \\
.5 \\
1.9\end{array}$ & $\begin{array}{r}C u . j 1 . \\
1.00 \\
.97 \\
.82 \\
1.47 \\
.48 \\
1.87\end{array}$ & $\begin{array}{r}C u . f 1 \\
\text { U. } 7.3 \\
.63 \\
.67 \\
.67 \\
.70 \\
.70\end{array}$ \\
\hline Arerage. & 136 & 18.3 & 110 & 7.2 & 91.5 & .45 & .35 & 1.2 & 1.10 & $.6 \bar{i}$ \\
\hline
\end{tabular}

SEPURESSED GROWTH.

\begin{tabular}{|c|c|c|c|c|c|c|c|c|c|c|}
\hline 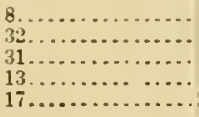 & $\begin{array}{l}131 \\
135 \\
238 \\
131 \\
138\end{array}$ & $\begin{array}{l}15.0 \\
17.5 \\
17.4 \\
16.4 \\
19.0\end{array}$ & $\begin{array}{l}115 \\
(1) \\
104 \\
114 \\
103\end{array}$ & $\begin{array}{l}8.5 \\
7.2 \\
7.3 \\
7.7 \\
7.0\end{array}$ & $\begin{array}{l}66.2 \\
73.9 \\
78.6 \\
79.7 \\
80.6\end{array}$ & $\begin{array}{l}0.47 \\
(1) \\
.45 \\
.47 \\
.39\end{array}$ & $\begin{array}{l}0.35 \\
1 ?) \\
.29 \\
.28 \\
.28\end{array}$ & $\begin{array}{l}1.0 \\
2.4 \\
1.7 \\
1.3 \\
1.6\end{array}$ & $\begin{array}{l}0.66 \\
1.71 \\
1.34 \\
1.04 \\
1.29\end{array}$ & $\begin{array}{l}0.50 \\
.55 \\
.57 \\
.51 \\
.58\end{array}$ \\
\hline Arerage... & 134.6 & $1 \% .0$ & 109 & 7.5 & 75.8 & .44 & .30 & 1.6 & 1.:2 & .56 \\
\hline $\begin{array}{l}6 \ldots \ldots \ldots \ldots \ldots \ldots \\
25 \ldots \ldots \ldots \ldots \ldots \ldots\end{array}$ & $\begin{array}{l}142 \\
154\end{array}$ & $\begin{array}{l}21.0 \\
19.0\end{array}$ & $\begin{array}{r}109 \\
97\end{array}$ & 7.2 & $\begin{array}{r}121.7 \\
78.6\end{array}$ & $\begin{array}{l}. \pm 6 \\
.41\end{array}$ & $\begin{array}{l}.44 \\
.41\end{array}$ & $\begin{array}{l}1.5 \\
1.4\end{array}$ & $\begin{array}{l}1.82 \\
1.10\end{array}$ & .85 \\
\hline A renige... & 149 & 20.0 & 103 & 7.5 & 100.0 & .43 & .42 & 1.4 & 1.46 & .67 \\
\hline
\end{tabular}

(3) SITE $d$ :

Moutuorency County.

:-ars] area: 1 acre.

Swil: Fresh, loose gras sand, tnrning brown and red below, with surface corer of lrakes and

Forest couditions: White Pine (5t per cent) mixed with Red Pine (35 per cent) and Heulock (11

ler cent).
Damagel by tire twelve Jears before; sample area shows 15 per cent deall trees and 20 per

Age of pine: 250 to 270 jears. Densit of cruwn corer: 0.5 . cent damaged by tire.

ACRE TIELD.

\begin{tabular}{|c|c|c|c|c|c|c|c|c|c|c|}
\hline \multicolumn{5}{|c|}{ W hite Pine. } & \multicolumn{3}{|c|}{ Red Pino. } & \multicolumn{3}{|c|}{ Hemlock. } \\
\hline \multirow[b]{2}{*}{$\begin{array}{l}\text { Number } \\
\text { of trees. }\end{array}$} & \multirow[b]{2}{*}{$\begin{array}{c}\text { Diameter } \\
\text { (breast } \\
\text { high). }\end{array}$} & \multirow[b]{2}{*}{ Beight. } & \multicolumn{2}{|c|}{ Volume. } & \multirow[b]{2}{*}{$\begin{array}{l}\text { Sumber } \\
\text { ol trees. }\end{array}$} & \multirow[b]{2}{*}{$\begin{array}{l}\text { Hiawoter } \\
\text { (ureast } \\
\text { high). }\end{array}$} & \multirow[b]{2}{*}{ Ileight. } & \multirow[b]{2}{*}{$\begin{array}{l}\text { Number } \\
\text { of trees. }\end{array}$} & \multirow[b]{2}{*}{$\begin{array}{l}\text { Diameter } \\
\text { (breast } \\
\text { high). }\end{array}$} & \multirow[b]{2}{*}{ Height. } \\
\hline & & & Bole. & $\begin{array}{c}\text { Her. } \\
\text { chantalue } \\
\text { timber. }\end{array}$ & & & & & & \\
\hline $\begin{array}{l}2 \\
1 \\
3 \\
1 \\
3 \\
3 \\
1 \\
1 \\
3 \\
2 \\
6 \\
5 \\
9 \\
1 \\
1 \\
3 \\
2 \\
7 \\
2 \\
1 \\
1\end{array}$ & $\begin{array}{r}\text { Inches. } \\
10 \\
12 \\
13 \\
14 \\
15 \\
16 \\
17 \\
18 \\
19 \\
21 \\
23 \\
23 \\
24 \\
25 \\
26 \\
27 \\
28 \\
29 \\
30 \\
31 \\
33\end{array}$ & Feet. & \begin{tabular}{|c} 
Cubicfeet. \\
30 \\
38 \\
159 \\
60 \\
207 \\
231 \\
86 \\
96 \\
315 \\
280 \\
906 \\
855 \\
1,611 \\
.000 \\
216 \\
696 \\
493 \\
1.862 \\
560 \\
342 \\
341
\end{tabular} & Feet R.M. & $\begin{array}{l}2 \\
1 \\
3 \\
1 \\
3 \\
3 \\
6 \\
5 \\
4 \\
8 \\
1 \\
1 \\
1\end{array}$ & $\begin{array}{r}\text { Inclus. } \\
13 \\
14 \\
15 \\
16 \\
17 \\
18 \\
19 \\
20 \\
21 \\
22 \\
23 \\
24 \\
30\end{array}$ & $\begin{array}{c}\text { Feet. } \\
\\
120 \\
\text { to } \\
1411\end{array}$ & $\begin{array}{l}2 \\
1 \\
1 \\
2 \\
1 \\
1\end{array}$ & $\begin{array}{r}\text { Inches. } \\
3 \text { to } 6 \\
9 \\
11 \\
12 \\
15 \\
20\end{array}$ & $\begin{array}{c}\text { Feet. } \\
40 \\
50 \mathrm{tu} \\
80\end{array}$ \\
\hline $\begin{array}{r}61 \text { trees } \\
\text { Total } \\
\text { Total }\end{array}$ & $\begin{array}{l}\text { cubic feet. } \\
\text { feet } \mathbf{B} \text {. } \mathbf{I l} \text {. }\end{array}$ & ............ & . $\ldots \ldots$ & $\begin{array}{l}10,154 \\
\therefore \quad 60,900\end{array}$ & $\begin{array}{r}39 \text { trees } \\
\text { Total } \\
\text { Total }\end{array}$ & $\begin{array}{l}\text { culic feet. } \\
\text { fert B. II.. }\end{array}$ & $\begin{array}{r}5,256 \\
25,2110\end{array}$ & 13 trer.s. & & \\
\hline
\end{tabular}

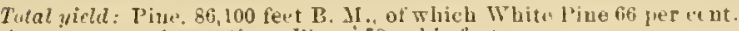

Averafe annual accrction: 'bine," 59 cubje feet. 


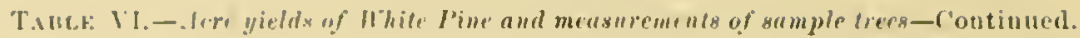

A.- M11 1116is-cintinuml.

(1) SITE- $:$

Moutumreucy Comuty.

Sample area ourbalf arre.

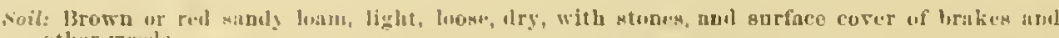

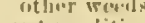

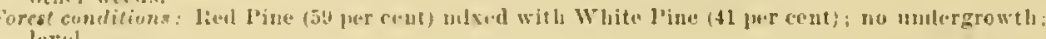
levil.

11.?

Alinget of trees : 110 .

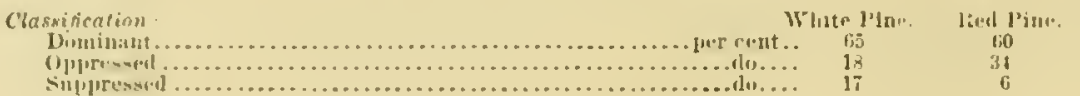

HALF.A(IIE IIELL.

\begin{tabular}{|c|c|c|c|c|c|c|c|}
\hline \multicolumn{5}{|c|}{ White I'ine. } & \multirow[b]{3}{*}{$\begin{array}{l}\text { Sinmluer } \\
\text { of trees. }\end{array}$} & \multicolumn{2}{|l|}{ Iited l'inr. } \\
\hline \multirow[b]{2}{*}{$\begin{array}{l}\text { Sinmber } \\
\text { of trees. }\end{array}$} & \multirow[b]{2}{*}{$\begin{array}{c}\text { Diameter } \\
\text { (lireant } \\
\text { light). }\end{array}$} & \multirow[b]{2}{*}{ Height. } & \multicolumn{2}{|c|}{ Folume. } & & \multirow[b]{2}{*}{$\begin{array}{l}\text { Diameter } \\
\text { (breast } \\
\text { ligh). }\end{array}$} & \multirow[b]{2}{*}{11 eight } \\
\hline & & & 13ule. & $\begin{array}{c}\text { Mler- } \\
\text { chantable } \\
\text { timber. }\end{array}$ & & & \\
\hline $\begin{array}{l}2 \\
3 \\
4 \\
2 \\
2 \\
6 \\
7 \\
3 \\
6 \\
6 \\
2 \\
4 \\
6\end{array}$ & $\begin{array}{r}\text { Inches. } \\
3 \text { to } 6 \\
0 \text { to } 10 \\
10 \\
11 \\
10 \\
13 \\
14 \\
15 \\
16 \\
17 \\
18 \\
10\end{array}$ & $\begin{array}{l}\text { Feet. } \\
80 \\
\text { 101 } \\
1011\end{array}$ & $\begin{array}{r}\text { Cubicfee } \\
20 \\
72 \\
50 \\
65 \\
234 \\
3601 \\
164 \\
348 \\
130 \\
348 \\
174\end{array}$ & Feet S. H. & $\begin{array}{l}4 \\
6 \\
4 \\
2 \\
6 \\
4 \\
6 \\
2 \\
2 \\
4 \\
4 \\
11 \\
6 \\
4 \\
2 \\
2\end{array}$ & 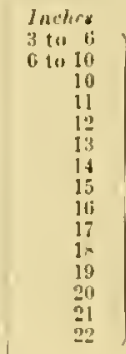 & Fept. \\
\hline $\begin{array}{l}46 \text { trees } \\
\text { 'Tot } \\
\text { Tot }\end{array}$ & $\begin{array}{l}\text { al culbix } 1+6 \\
\text { al fuet } 13 \text {. . }\end{array}$ & t................ & ...... & $\begin{array}{lll}\ldots & 2 & 1.54 \\
\cdots & 9 & 030\end{array}$ & $\begin{array}{r}64 \text { trees: } \\
\text { Tota } \\
\text { Tota }\end{array}$ & $\begin{array}{l}\text { al cubic teet } \\
\text { I feet I3. II }\end{array}$ & $\begin{array}{r}3.532 \\
14.800\end{array}$ \\
\hline
\end{tabular}

Totalyield: P'iue, 23,830 feet 13. M. of which White l'ine 38 perrent. A rerayc annmal accretion: P'ime, 51 cuhic feet.

\section{MEASLIEMENTS OF SAMPLE TIEES}

DOSIXANT GROWTH.

\begin{tabular}{|c|c|c|c|c|c|c|c|c|c|c|}
\hline Tree nunber. & Age. & $\begin{array}{l}\text { Diameter } \\
\text { (briast } \\
\text { high). }\end{array}$ & Height. & $\begin{array}{c}\text { lings } \\
\text { dier inch } \\
\text { on } \\
\text { gtume. }\end{array}$ & $\begin{array}{l}\text { Valmue } \\
\text { of trice. }\end{array}$ & $\begin{array}{l}\text { Factor } \\
\text { of } \\
\text { Hhape. }\end{array}$ & $\begin{array}{l}\text { Ratio of } \\
\text { length } \\
\text { of crown } \\
\text { to total } \\
\text { lototh of }\end{array}$ & $\begin{array}{l}\text { Current } \\
\text { aecrit }\end{array}$ & $\begin{array}{l}\text { anmual } \\
\text { tior". }\end{array}$ & $\begin{array}{l}\text { Arerage } \\
\text { annual } \\
\text { acere. }\end{array}$ \\
\hline 3............... & $\begin{array}{c}\text { Vears. } \\
120\end{array}$ & $\begin{array}{c}\text { Incher. } \\
18\end{array}$ & Fint. & Po. & $\begin{array}{c}\text { Cu.feet. } \\
\text { i1. } 6\end{array}$ & 0.42 & $0 . \$ 1$ & $\begin{array}{c}\text { Percent. } \\
\text { l.1 }\end{array}$ & $\begin{array}{c}\text { Cu. feet. } \\
0.79\end{array}$ & $\begin{array}{c}C u_{0} \text { feet. } \\
060\end{array}$ \\
\hline
\end{tabular}

OHPRESELI VIRONTH,

\begin{tabular}{|c|c|c|c|c|c|c|c|c|c|c|}
\hline 4 & 118 & 14 & 95 & 7.1 & 55.0 & 0.53 & 0.31 & 1. 1 & 0.60 & 0.46 \\
\hline
\end{tabular}


TARLE VI.-Acr yields of White Pine and mensurements of gample trex-Continuol.

\section{A.-MICIIISAN-C'ontinuent.}

(5) SITE $f$ :

soil: lBrown, dres sand, with stones, nod surface cover of hrakes and grass.

Forest condition: : lied Pine (94 percent) with scattorin Whit Pine (6 por crent) on a level plain; no undergrowth sive very amall shrubs of acottererl (Jilk (characteristic of this lucality). About 15 per cent of tries injured lif tire in 1831.

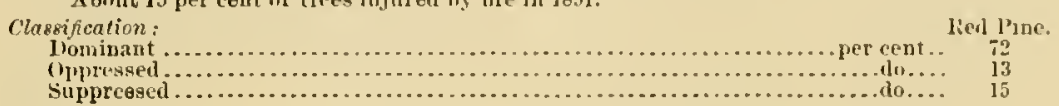

Sample area: 1 is.re.

Age of piot: 160 to 181] years

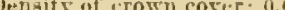
Number of treee : 115

ACLE YIELI.

\begin{tabular}{|c|c|c|c|c|c|c|c|}
\hline \multicolumn{5}{|c|}{ White Pine. } & \multicolumn{3}{|c|}{ Red Pine. } \\
\hline \multirow[b]{2}{*}{$\begin{array}{l}\text { Number } \\
\text { of' trees. }\end{array}$} & \multirow[b]{2}{*}{$\begin{array}{c}\text { Diameter } \\
\text { (breast } \\
\text { bigh). }\end{array}$} & \multirow[b]{2}{*}{ Height. } & \multicolumn{2}{|c|}{ Volume } & \multirow[b]{2}{*}{$\begin{array}{l}\text { Number } \\
\text { if trees. }\end{array}$} & \multirow[b]{2}{*}{$\begin{array}{c}\text { Diamoter } \\
\text { (hreast } \\
\text { high). }\end{array}$} & \multirow[b]{2}{*}{ lleight. } \\
\hline & & & Bule. & $\begin{array}{c}\text { Mer- } \\
\text { chantable } \\
\text { timber. }\end{array}$ & & & \\
\hline $\begin{array}{l}1 \\
2 \\
1 \text { (dead) } \\
1 \text { (dead) } \\
1\end{array}$ & $\begin{array}{r}\text { Incheg. } \\
15 \\
16 \\
18 \\
21 \\
22 \\
\mathbf{2 3}\end{array}$ & $\begin{array}{c}\text { Eeet. } \\
90 \\
10 \\
100\end{array}$ & $\begin{array}{r}\text { Cubicfee } \\
52 \\
116 \\
\ldots . . . \\
112 \\
122\end{array}$ & Feet B.M. & $\begin{array}{l}1 \\
1 \\
5 \\
5 \\
8 \text { (2 dead) } \\
8 \text { (3 lead) } \\
13 \text { (1 lead }) \\
18 \text { (1 tead) } \\
30 \text { (3 dead }) \\
24 \text { (4 dead) } \\
5 \\
5 \\
2 \\
1\end{array}$ & $\begin{array}{r}\text { Inches. } \\
10 \\
11 \\
12 \\
13 \\
14 \\
15 \\
16 \\
17 \\
18 \\
19 \\
20 \\
21 \\
22\end{array}$ & $\begin{array}{c}90 \\
\text { to } \\
100\end{array}$ \\
\hline $\begin{array}{l}7 \text { trees: } \\
\text { Tutal } \\
\text { I'ota }\end{array}$ & $\begin{array}{l}\text { ubie feet } \\
\text { eet } \mathrm{B} . \mathrm{MI} \text {. }\end{array}$ & ...... & …..... & $\begin{array}{l}\ldots 02 \\
\ldots \quad 1,600\end{array}$ & $\begin{array}{l}108 \text { trees: } \\
\text { Total } \\
\text { Total }\end{array}$ & $\begin{array}{l}\text { bic feet } \\
\text { et B. MI... }\end{array}$ & $\begin{array}{r}6,863 \\
28,800\end{array}$ \\
\hline
\end{tabular}

Total yield: Pine, 30,490 feet B. M., of which White l'ide 5 per cent Averagr annual accretion: Pine, 42 cnbic feet.

(6) SITE $g$

Crairford rounty

A bout 1,200 feet abore sta lerel.

Soil: Brown, loamy and, leep, fresh, moderately loose, with surface cover uf tern and grans: sand with otoces underlies the soil.

Forest conditions: Two-stors stand, upper story of White Pine (I liell 1 ine of 26 inches in dianeter), with 0.3 density of crowa coter, lower story of Fir (22 from 4 to 10 incbes in diameter, Beech ( 4 from 4 to 10 inches in diameter), and Hi-mlock (19 from 4 to 10 inches in dianeter) nndergrowth morlerately dense, of Maple. Fir, Hemlock, and Beocls. Percentages: White l'iae, 50; Hemlook, 20; Fir, 25; harlwoorls, 5 .

Classification

Dominan

Oppressed per cent.. do.... supluressed.

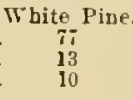
White Pine.

Sample area: 1 acre.

Age of piae: 250 to 260 year Density of crown cover: 0.7 Number of trees: (1).

ACRE YIELD.

\begin{tabular}{|c|c|c|c|c|}
\hline \multicolumn{5}{|c|}{ White Pine. } \\
\hline \multirow[b]{2}{*}{$\begin{array}{l}\text { Number } \\
\text { of trees. }\end{array}$} & \multirow[b]{2}{*}{$\begin{array}{c}\text { Piameter } \\
\text { (hriast } \\
\text { bigh). }\end{array}$} & \multirow[b]{2}{*}{ Height. } & \multicolumn{2}{|c|}{ Tolume. } \\
\hline & & & Bole. & $\begin{array}{c}\text { Mer- } \\
\text { chantalie } \\
\text { timber. }\end{array}$ \\
\hline & Inches. & Feet. & Oubiefiet. & Feet B. . . \\
\hline 3 & 16 & & 213 & \\
\hline & 18 & 100 & & \\
\hline$?$ & 21 & to & 134 & \\
\hline i & 24 & 120 & 146 & \\
\hline 3 & 25 & & 471 & \\
\hline 3 & 26 & & 432 & \\
\hline 4 & 27 & & 464 & \\
\hline 7 & 28 & & $1,7 \$ 3$ & \\
\hline 2 & 29 & & 532 & \\
\hline 5 & 30 & 130 & 1,400 & \\
\hline 2 & 31 & to & 604 & \\
\hline 5 & 32 & 150 & 1,600 & \\
\hline 3 & 33 & & 1,020 & \\
\hline 1 & 35 & & 381 & \\
\hline 1 & 36 & & 401 & \\
\hline 1 & 42 & & $53 i$ & \\
\hline
\end{tabular}

41 trees

l'otal cubic teet. 


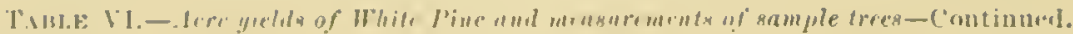

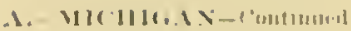

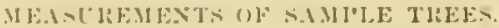

Itro clasa: 1301010 yrara

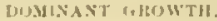

\begin{tabular}{|c|c|c|c|c|c|c|c|c|c|c|}
\hline Tre.n nurnloor. & $A L^{2}$ & $\begin{array}{l}\text { Miganeter } \\
\text { liresast } \\
\text { lightu. }\end{array}$ & H(tig)t & 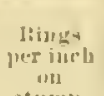 & $\begin{array}{l}\text { Jolsume } \\
\text { of trike. }\end{array}$ & $\begin{array}{c}\text { Jacetor } \\
\text { of } \\
\text { thaju. }\end{array}$ & 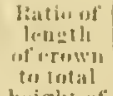 & $\begin{array}{l}\text { Currumt } \\
\text { ancrit }\end{array}$ & $\begin{array}{l}\text { แแแal } \\
\text { a11. }\end{array}$ & $\begin{array}{l}\text { A veratgu } \\
\text { :mumal } \\
\text { aurro. }\end{array}$ \\
\hline 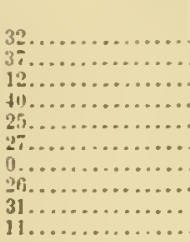 & $\begin{array}{l}\text { liard } \\
1: 33 \\
111 \\
132 \\
145 \\
128 \\
152 \\
131 \\
116 \\
153 \\
1: 4 \%\end{array}$ & $\begin{array}{l}\text { Indher. } \\
15.2 \\
15.5 \\
16.3 \\
1 \times .13 \\
20.5 \\
19.0 \\
22.5 \\
23.11 \\
\geq 3.11 \\
2415\end{array}$ & 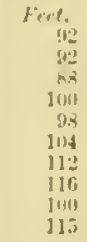 & $\begin{array}{l}10 . \\
7.3 \\
0.2 \\
7.5 \\
7.0 \\
7.0 \\
7.3 \\
5.1 \\
8.2 \\
5.9 \\
5.2\end{array}$ & $\begin{array}{l}\text { Cu. } 71 . \\
\text { +R. } 59 \\
55.32 \\
01.70 \\
11.11 \\
94.50 \\
4.97 \\
129.42 \\
137.91 \\
137.63 \\
13612\end{array}$ & $\begin{array}{l}0 .+3 \\
16 \\
17 \\
58 \\
12 \\
11 \\
+1 \\
41 \\
47 \\
41\end{array}$ & $\begin{array}{l}0.43 \\
+42 \\
.66 \\
.44 \\
.47 \\
.31 \\
.46 \\
.46 \\
.30 \\
.411\end{array}$ & $\begin{array}{l}\text { ler erut. } \\
2.2 \\
3.3 \\
.8 \\
2.0 \\
1.5 \\
1.4 \\
1.7 \\
1.9 \\
1.7 \\
1.4\end{array}$ & $\begin{array}{r}\text { 'u. } 16 . \\
1.07 \\
1.27 \\
.49 \\
1.42 \\
1 .+2 \\
1.19 \\
.91 \\
2.62 \\
2.40 \\
\because .11\end{array}$ & $\begin{array}{r}r u . J t \\
0.36 \\
.39 \\
.46 \\
.49 \\
.73 \\
.55 \\
.92 \\
.913 \\
.40 \\
1.13\end{array}$ \\
\hline Arrrage & $1+0$ & 19. 8 & 102 & 6.3 & 97.5 &.+3 &.+3 & 1. 6 & 1.49 & .09 \\
\hline
\end{tabular}

OPPRES-EL GHOWTII.

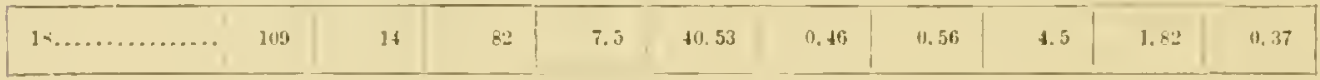

Aur class: 220 tos 240 years.

DONISANT MROWTH.

\begin{tabular}{|c|c|c|c|c|c|c|c|c|c|c|}
\hline 41. & 245 & 20.0 & 121) & 91.0 & 112.56 & $0 . \$ 3$ & 0.40 & 0.9 & 1,111 & 0.10 \\
\hline 8................ & 112 & 24.5 & 137 & 9.9 & 191. 17 & 42 & .11 & .5 & .95 & .79 \\
\hline $30 \ldots \ldots \ldots \ldots \ldots$ & $2: 20$ & 27.5 & 1.38 & 7. 6 & 215.28 & .38 & $\ldots \ldots$ & 4 & $\therefore \approx 5$ & .95 \\
\hline 1................ & 236 & 27.5 & 125 & 7.6 & 222.90 & .41 & .32 & .1 &.-4 & $.9 x$ \\
\hline ............ & 240 & 20.3 & 113 & 7.1 & 264.49 & t:2 & .170 &.$x$ & 2. 11 & 1.20 \\
\hline $3+\ldots \ldots \ldots \ldots$ & 250 & 30.2 & (i) & 8.7 & 291.03 & 12 & .31 & .4 & 1. It & 1. It \\
\hline $10 \ldots \ldots \ldots \ldots \ldots$ & 219 & 33.0 & 121 & 6.3 & 317.85 & .41 & .13 & .7 & 2. 22 & 1.4 .5 \\
\hline $33 \ldots \ldots \ldots \ldots \ldots$ & $2: 6$ & 33.0 & 140 & 7.1 & $x \geq 1.86$ & .38 & +4 & .3 & $\because 57$ & $1 .+2$ \\
\hline ............. & 237 & 3.3 .0 & itt & $\because 2$ & $3 \times 9.57$ & .45 & $\because$ & .6 & 2.34 & 1.64 \\
\hline ............ & 333 & 37.0 & 147 & 6. 1 & $\$ 55,05$ & .41 & .5 .5 & .6 & 2.73 & 1.95 \\
\hline 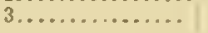 & 245 & \$1. 0 & 125 & 5.4 & 479.51 & .13 & .10 & .5 & $2.4(1)$ & 1. 90 \\
\hline Areragro. & 233 & 30.4 & 13; & 7.6 & $: 965.11$ & 11.41 & tis & .6 & 1.75 & 1.27 \\
\hline 16. & $2 \pi x$ & 26.11 & $11 !$ & $10.0)$ & 162 . it & 0.37 & $0 .+11$ & 0.1 & 0.65 & 0.63 \\
\hline & 352 & 25.2 & $1: 39$ & 3.5 & $1 ! 3.31$ & .11 & $4 i$ & 4 & .75 & .76 \\
\hline $38 \ldots \ldots \ldots \ldots \ldots$ & 252 & 25.5 & $11 i$ & 9.5 & 20.5 .21 & .35 & $.5 \%$ & .9 & 1. $\mathrm{ki}$ & .81 \\
\hline $23 . . . . \ldots \ldots \ldots \ldots$ & 26.3 & 27.0 & 126 & 10.4 & 207.07 & .11 & .14 & .5 & 1.05 & .78 \\
\hline $13 \ldots \ldots \ldots \ldots \ldots$ & Zis & 30.0 & 135 & $x .8$ & 259.13 & .39 & bi & .4 & 1. 03 & 1.02 \\
\hline $36 \ldots \ldots \ldots \ldots \ldots$ & 256 & 32.11 & $1+2$ & 8.1 & 267.87 & .34 & $.5 !$ & .4 & 1.07 & 1.04 \\
\hline 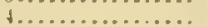 & 2fio & 31.5 & 132 & 83 & 275.89 & .36 & $.4 \%$ & .7 & 1.93 & 1. 013 \\
\hline & $\leq+10$ & 29.5 & 155 & $\therefore 9$ & $311.9 !$ & . 13 & $.4 i$ & .3 & .93 & 1. 20 \\
\hline $16 \ldots \ldots \ldots \ldots \ldots$ & $2: 1$ & 33.0 & $1+4$ & $\therefore 1$ & 313.07 & .33 & (i) & .0 & 2.82 & 1.21 \\
\hline a............. & $25 t$ & 31.0 & 14.5 & 7.6 & $31+64$ & .11 & $.3 n$ & .5 & 1.57 & 1.22 \\
\hline $35 \ldots \ldots \ldots \ldots \ldots$ & 2655 & 31.5 & ifs & 8.2 & 311. : 8 & .60 & .33 & .1 & 1.25 & 1. 18 \\
\hline 6..................... & 263 & $\$ 3.0$ & 139 & 8.0 & 316.81 & $3 x$ & .51 & .1 & 1. 27 & 1. 19 \\
\hline $1 \mathrm{~s}, \ldots \ldots \ldots \ldots \ldots$ & 250 & 32.0 & 154 & 7.4 & 360.75 & .11 & .33 & .7 & 2. 52 & 1. 41 \\
\hline …........ & $2 i n$ & is 11 & 138 & 7.6 & 370.50 & +2 & .59 & .8 & 2.96 & 1.43 \\
\hline $17 \ldots \ldots \ldots \ldots$ & 20 & 31.11 & 14! & 7.5 & (1) 113 & .37 & 4.7 & .2 & .81 & 1. 55 \\
\hline Avirage & $25 x$ & $30 . ;$ & 138 & $x . .3$ & $\pm \times 5.15$ & .39 & .45 & .5 & 1.50 & 1. 10 \\
\hline
\end{tabular}




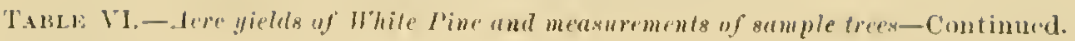

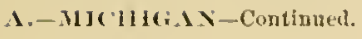

(7) SITE $h$ :

Crawfurd Cunnty.

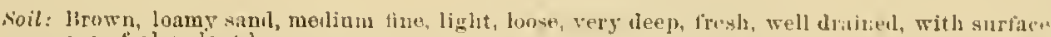

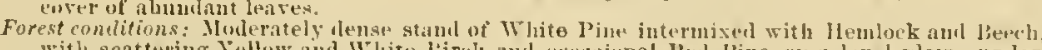

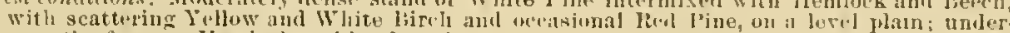
growth of joung Hemlork and hardwoxts.

MLASULEMENTS G* SIMULE TIREES.

.1 ge class: 120 to 450 yetirs.

DOMIXAXT GROWTH.

\begin{tabular}{|c|c|c|c|c|c|c|c|c|c|c|}
\hline Tree number. & & $\begin{array}{c}\text { Dianeter } \\
\text { (breast } \\
\text { bigli). }\end{array}$ & Height. & $\begin{array}{c}\text { lings } \\
\text { per ibeh } \\
\text { us } \\
\text { sturup. }\end{array}$ & $\begin{array}{l}\text { Folnuse } \\
\text { of tree. }\end{array}$ & $\begin{array}{l}\text { Factor } \\
\text { of } \\
\text { shape. }\end{array}$ & $\begin{array}{l}\text { Ratio of } \\
\text { lenuth } \\
\text { of erown } \\
\text { to totat }\end{array}$ & $\begin{array}{c}\text { Corrunt } \\
\text { acere }\end{array}$ & $\begin{array}{l}\text { annual } \\
\text { ion. }\end{array}$ & $\begin{array}{l}\text { Arerage } \\
\text { annual } \\
\text { accro. }\end{array}$ \\
\hline 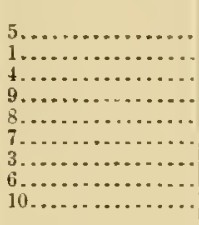 & $\begin{array}{c}\text { Fetrs. } \\
417 \\
445 \\
455 \\
426 \\
460 \\
457 \\
461 \\
435 \\
458\end{array}$ & $\begin{array}{r}\text { Thchis. } \\
37.0 \\
35.5 \\
41.0 \\
43.0 \\
46.0 \\
47.0 \\
46.0 \\
46.0 \\
47.0\end{array}$ & $\begin{array}{r}\text { Fett. } \\
155 \\
141 \\
152 \\
1+0 \\
150 \\
160 \\
170 \\
168 \\
162\end{array}$ & $\begin{array}{l}\text { Yo. } \\
14.0 \\
10.0 \\
11.0 \\
10.5 \\
(?) \\
\text { ? }) \\
10.0 \\
(?) \\
10.5\end{array}$ & $\begin{array}{r}C u . f t . \\
433.2 \\
510.5 \\
583.7 \\
677.3 \\
694.1 \\
721.9 \\
737.9 \\
819.6 \\
855.3\end{array}$ & $\begin{array}{l}0.37 \\
.52 \\
.41 \\
.12 \\
.40 \\
.37 \\
.37 \\
.42 \\
.42\end{array}$ & $\begin{array}{l}0.45 \\
.39 \\
.53 \\
.56 \\
.48 \\
.45 \\
.56 \\
.51 \\
.57\end{array}$ & $\begin{array}{c}\text { Percent. } \\
0.4 \\
.6 \\
.2 \\
.4 \\
.3 \\
.4 \\
.3 \\
.4 \\
.5\end{array}$ & $\begin{array}{r}\text { Cu. } r t . \\
1.73 \\
3.06 \\
1.17 \\
2.71 \\
2.08 \\
2.89 \\
2.21 \\
3.28 \\
4.28\end{array}$ & $\begin{array}{r}r u . r e, \\
1.03 \\
1.15 \\
1.28 \\
1.59 \\
1.51 \\
1.59 \\
1.60 \\
1.88 \\
1.86\end{array}$ \\
\hline Arerage... & 446 & 43.0 & 157 & 11.0 & 670.4 & .41 & .50 & .4 & 2.60 & 1.50 \\
\hline
\end{tabular}

A ge class: 270 to 2910 years.

\begin{tabular}{|c|c|c|c|c|c|c|c|c|c|c|}
\hline $2 \ldots \ldots \ldots \ldots$ & 274 & 45.0 & 150 & i. 1 & 604.3 & 0.36 & Q.52 & 0.4 & 2,4 & 2.20 \\
\hline
\end{tabular}

(8) SITE $i$ :

Crawfurcl Comnty.

Soil: Brown, lonmy sand of medum grain, light, loose, deep, fresh, whll draned, with 2 to 3 inches mold on top' and surtine cover of leares.

Forest conditions: White l'ine ( 47 per cent) mised with hardwoots (30 per cent) and Hemlock (23 per rent), on a gentle slope; undergrowth seanty, of youg Hemlock amd IIaple.

cassification:

Dominant.

Opluressed
suppressed White I'ine?

\section{ACFI TIEL1)}

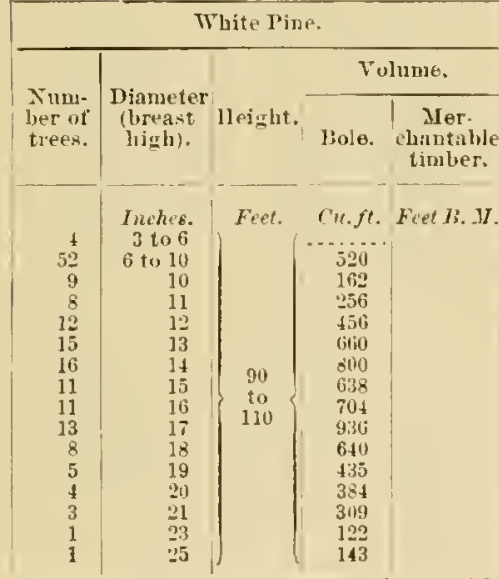

173 trees:

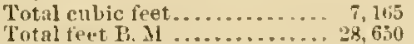

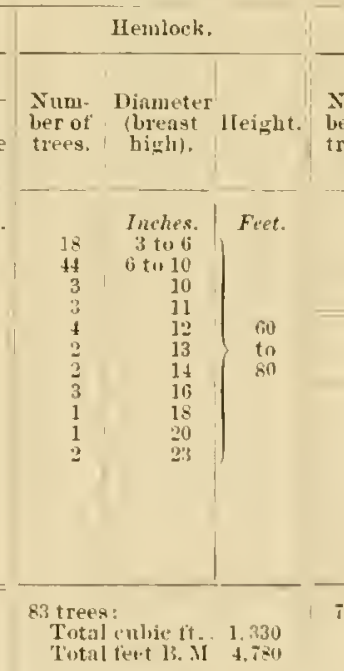

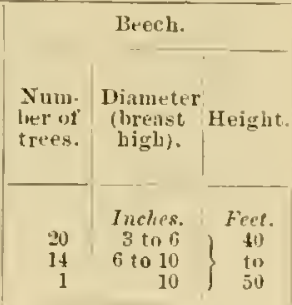

Thitm Bircls.

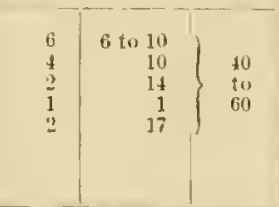

il trees.
Yellow Birch.

$26 t 410$

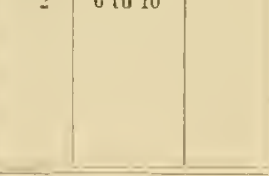

37 treps.

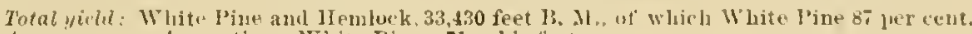
Arerage uninal accretion: White Pive, 71 cubic teet. 
Tame: VI.-Acre gields of Thite l'ine and measurements of anmple trees-Continued.

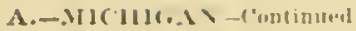

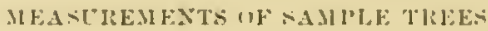

DOMSANT GROWII

\begin{tabular}{|c|c|c|c|c|c|c|c|c|c|c|}
\hline Triee nunber. & 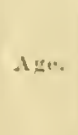 & 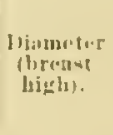 & Iteight. & $\begin{array}{l}\text { Risugs } \\
\text { Lurer inch } \\
\text { run } \\
\text { stump. }\end{array}$ & $\begin{array}{l}\text { Volmuite } \\
\text { of tree. }\end{array}$ & $\begin{array}{l}\text { lartor } \\
\text { of } \\
\text { shapes. }\end{array}$ & $\begin{array}{c}\text { Latio of } \\
\text { length } \\
\text { of crown } \\
\text { to total } \\
\text { liesglit of } \\
\text { tree. }\end{array}$ & $\begin{array}{l}\text { Current } \\
\text { weri }\end{array}$ & $\begin{array}{l}\text { Inrual } \\
\text { ion. }\end{array}$ & $\begin{array}{l}\text { Averafe } \\
\text { unmual } \\
\text { accre. } \\
\text { tiou. }\end{array}$ \\
\hline 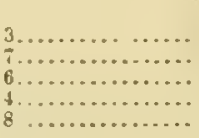 & $\begin{array}{c}\text { Yenrs. } \\
1110 \\
1: 0 \\
103 \\
100 \\
103\end{array}$ & $\begin{array}{r}\text { Inclies. } \\
10.5 \\
16.5 \\
17.0 \\
19.5 \\
18.5\end{array}$ & $\begin{array}{l}\text { Fent. } \\
\text { !is } \\
11+1 \\
101 \\
100 \\
109\end{array}$ & $\begin{array}{l}\text { Nin. } \\
\text { (?) } \\
1 ? \\
5.3 \\
4 . ! \\
4.8\end{array}$ & $\begin{array}{r}\text { ru.fe. } \\
64.5 \\
6 \times .4 \\
71.7 \\
94.6 \\
95.9\end{array}$ & $\begin{array}{l}0.44 \\
43 \\
.43 \\
.45 \\
.47\end{array}$ & $\begin{array}{l}0.45 \\
.40 \\
\text { (i) } \\
.37\end{array}$ & $\begin{array}{c}\text { Jercent. } \\
\text { 1. } 7 \\
4.2 \\
1.5 \\
1.7 \\
2 . \mathrm{i}\end{array}$ & 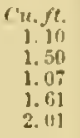 & $\begin{array}{r}r u . j t . \\
0.68 \\
.70 \\
.70 \\
.08 \\
.08\end{array}$ \\
\hline Aver:iget & 101 & 17.6 & 1113 & 5. 0 & 79.0 & .44 & .42 & 1.8 & $1.4 B$ & .78 \\
\hline
\end{tabular}

(UDOMINANT GROWTH

\begin{tabular}{|c|c|c|c|c|c|c|c|c|c|c|}
\hline $\begin{array}{l}5 \\
1 \\
2 \ldots \ldots \ldots \ldots \ldots\end{array}$ & $\begin{array}{l}95 \\
101 \\
3111\end{array}$ & $\begin{array}{l}14.0 \\
15.3 \\
15.5\end{array}$ & $\begin{array}{l}91 \\
91 \\
91\end{array}$ & $\begin{array}{l}6.6 \\
5.0 \\
60\end{array}$ & $\begin{array}{l}496 \\
50.1 \\
62.8\end{array}$ & $\begin{array}{r}0.4 ! \\
.43 \\
.49\end{array}$ & $\begin{array}{l}0.38 \\
\text { (i) } \\
.57\end{array}$ & $\begin{array}{l}2.0 \\
4.2 \\
2.6\end{array}$ & $\begin{array}{l}0.99 \\
2.46 \\
1.63\end{array}$ & $\begin{array}{r}0.52 \\
.51 \\
.62\end{array}$ \\
\hline Iverage... & $m$ & 15.0 & 94 & 6.1 & 54.8 & .47 & .44 & 2. 9 & 1.69 & .53 \\
\hline
\end{tabular}

(9) SITE $j$ :

Crawtoril Count:

Noil: Gras of light sand, medium the grain, porous, liwht, louse, dry (in plates fresh), with is monlerately leatyo surface cover.

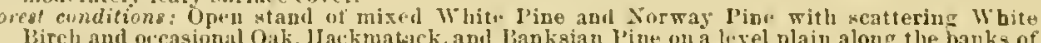
Birch and oucasional Oak. IIackmatirk, apul Lanksian Y'ine on a l.vel plain along the banks of a river: undergrowth scavty, of youvg Fir. Cerlar (Thuja occideutalis), aud n few swall Uaks.

\section{MEASLIRHEXTS OF SAMILE TREES.}

Age clase : 90 to 110 yenrs.

DOMINANT GROWTH.

\begin{tabular}{|c|c|c|c|c|c|c|c|c|c|c|}
\hline Tree number. & Aye. & $\begin{array}{c}\text { Diameter } \\
\text { (breast } \\
\text { lighlis. }\end{array}$ & IItight. & $\begin{array}{c}\text { lings } \\
\text { per inely } \\
\text { on } \\
\text { stump. } \\
\text { Jo. }\end{array}$ & $\begin{array}{l}\text { Folmaw } \\
\text { ot tret: } \\
\text { ru.ft. }\end{array}$ & $\begin{array}{l}\text { Factor } \\
\text { of } \\
\text { shaje. }\end{array}$ & $\begin{array}{l}\text { Ratio of } \\
\text { length } \\
\text { of crown } \\
\text { lo total }\end{array}$ & \multicolumn{2}{|c|}{$\begin{array}{l}\text { Currint annual } \\
\text { accretion. }\end{array}$} & $\begin{array}{l}\text { A vernge } \\
\text { anulal } \\
\text { necto. } \\
\text { tion. }\end{array}$ \\
\hline 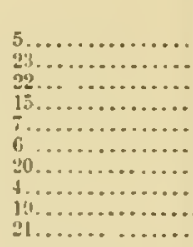 & $\begin{array}{l}\text { Tears. } \\
1119 \\
112 \\
109 \\
106 \\
110 \\
119 \\
112 \\
112 \\
1118 \\
109\end{array}$ & $\begin{array}{r}\text { Inclirs. } \\
13.0 \\
14.11 \\
14.8 \\
15.3 \\
16.5 \\
17.0 \\
17.0 \\
18.3 \\
20.5 \\
20.8\end{array}$ & $\begin{array}{l}\text { Feet. } \\
940 \\
00.11 \\
98.0 \\
85.0 \\
104.11 \\
111.0 \\
100.0 \\
103.0 \\
105.0 \\
105.0\end{array}$ & $\begin{array}{l}\text {.1o. } \\
7.6 \\
7.3 \\
6.7 \\
6.5 \\
6.5 \\
6.3 \\
6.1 \\
5.8 \\
4.8 \\
5.0\end{array}$ & $\begin{array}{r}\text { Cu.ft. } \\
45.7 \\
50.2 \\
51.4 \\
53.3 \\
64.3 \\
67.6 \\
72.4 \\
85.5 \\
99.1 \\
90.8\end{array}$ & $\begin{array}{r}0.52 \\
.47 \\
.45 \\
.47 \\
.11 \\
.42 \\
.45 \\
.44 \\
.41 \\
.34\end{array}$ & $\begin{array}{l}0.51 \\
.47 \\
.47 \\
.37 \\
.31 \\
.59 \\
(i) \\
.56 \\
.49 \\
.42\end{array}$ & $\begin{array}{c}\text { Per cent. } \\
3.2 \\
3.5 \\
2.2 \\
2.5 \\
2.2 \\
1.8 \\
3.4 \\
2.5 \\
1.9 \\
1.6\end{array}$ & $\begin{array}{l}C u . f 1 \\
1.16 \\
1.75 \\
1.14 \\
1.33 \\
1.11 \\
1.20 \\
2.46 \\
2.13 \\
1.88 \\
1.60\end{array}$ & $\begin{array}{r}C u . f t \\
0.42 \\
.44 \\
.47 \\
.50 \\
.58 \\
.62 \\
.65 \\
.76 \\
.81 \\
.91\end{array}$ \\
\hline Arerage & 1118.6 & 16.7 & $9+8.6$ & 6. 3 & 68.9 &.+4 & .46 & 2.5 & 1.64 & .63 \\
\hline
\end{tabular}

CWOMINAST GRUWTH.

\begin{tabular}{|c|c|c|c|c|c|c|c|c|c|c|}
\hline 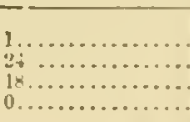 & $\begin{array}{r}100 \\
965 \\
82 \\
93\end{array}$ & $\begin{array}{l}13.5 \\
14.4 \\
16.5 \\
20.0\end{array}$ & $\begin{array}{r}94.0 \\
90.0 \\
94.0 \\
\text { נin!. } 0\end{array}$ & $\begin{array}{l}7.0 \\
6.6 \\
4.8 \\
4.4\end{array}$ & $\begin{array}{l}+1.0 \\
4.7 \\
6.5 .7 \\
80.9\end{array}$ & $\begin{array}{l}0.44 \\
.47 \\
.47 \\
.41\end{array}$ & $\begin{array}{l}0.5 i \\
(1) \\
.53 \\
.16\end{array}$ & $\begin{array}{l}2.0 \\
4.3 \\
40 \\
3.3\end{array}$ & $\begin{array}{l}0.82 \\
2.08 \\
2.6 .3 \\
3.00\end{array}$ & $\begin{array}{r}0.41 \\
.50 \\
.80 \\
.31\end{array}$ \\
\hline Averag. & 94 & 16.1 & 84.5 & 5. 1 & (j). 6 & .45 & .52 & 3.4 & 2.13 & .65 \\
\hline
\end{tabular}

Age class 150 to 160 years.

LOMINANT GROWTH.

\begin{tabular}{|c|c|c|c|c|c|c|c|c|c|c|}
\hline 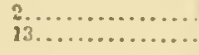 & 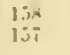 & $\begin{array}{l}22.5 \\
21.8\end{array}$ & $\begin{array}{l}\text { 114.0 } \\
\text { 1.1.i. } 0\end{array}$ & $\begin{array}{l}6.6 \\
7.0\end{array}$ & $\begin{array}{l}124.9 \\
1 \geq 1.1\end{array}$ & 0.411 & $\begin{array}{l}0.36 \\
.54\end{array}$ & $\begin{array}{l}2.4 \\
1.2\end{array}$ & $\begin{array}{l}\text { 3. } 00 \\
\text { 1. } 4 \text { i }\end{array}$ & $\begin{array}{r}0.80 \\
.011\end{array}$ \\
\hline Areragt... & 157.5 & 221 & 114.5 & 6. $x$ & 123.0 & .10 & 47 & 1.8 & 2. 22 & 80 \\
\hline
\end{tabular}




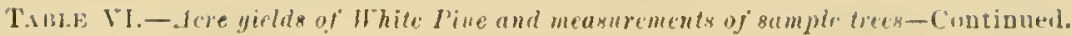

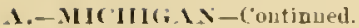

(10) $\operatorname{siTE} k$ :

Rinscomanom County.

sample aren: 1 ncre.

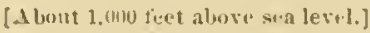

$$
\text { Ilulf ucre vo. } 1 \text {. }
$$

Shil: Brown, Ioamy saud, deeln, thue (for sand), porous, loose, fresh, a mil well drained (water stands in low gromed, with a moderately leary murace cover: subsoil. same as soil.

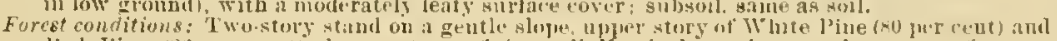

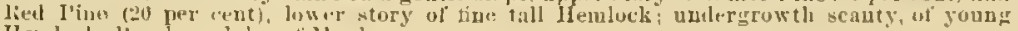
Heulock, liesoh, and iwart Maple.

Claesification:

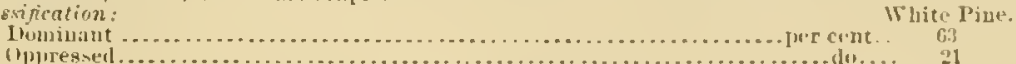

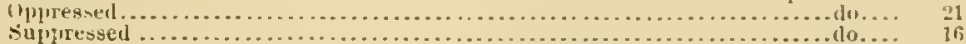

HALE-ACRE; Y IELIV.

\begin{tabular}{|c|c|c|c|c|c|c|c|c|c|c|}
\hline \multicolumn{5}{|c|}{ White Pine. } & \multicolumn{3}{|c|}{ lie-1 Pine. } & \multicolumn{3}{|c|}{ Herulock. } \\
\hline \multirow[b]{2}{*}{$\begin{array}{l}\text { Number } \\
\text { of trees. }\end{array}$} & \multirow[b]{2}{*}{$\begin{array}{l}\text { Diameter } \\
\text { (breast } \\
\text { bigb). }\end{array}$} & \multirow[b]{2}{*}{ Height. } & \multicolumn{2}{|c|}{ Volume. } & \multirow[b]{2}{*}{$\begin{array}{l}\text { Nomber } \\
\text { of trees. }\end{array}$} & \multirow[b]{2}{*}{$\begin{array}{l}\text { Dianueter } \\
\text { (breast } \\
\text { bigh). }\end{array}$} & \multirow[b]{2}{*}{ Height. } & \multirow[b]{2}{*}{$\begin{array}{l}\text { Jumber } \\
\text { of trees. }\end{array}$} & \multirow[b]{2}{*}{$\begin{array}{c}\text { Dianteter } \\
\text { (bri:ant } \\
\text { high). }\end{array}$} & \multirow[b]{2}{*}{ Height. } \\
\hline & & & Bole. & $\begin{array}{l}\text { Mer- } \\
\text { ehantible } \\
\text { timber. }\end{array}$ & & & & & & \\
\hline $\begin{array}{r}6 \\
2 \\
2 \\
4 \\
5 \\
6 \\
2 \\
4 \\
5 \\
12 \\
8 \\
6 \\
8 \\
5 \\
4\end{array}$ & $\begin{array}{r}\text { Incher. } \\
11 \\
15 \\
16 \\
17 \\
18 \\
19 \\
20 \\
21 \\
22 \\
24 \\
25 \\
27 \\
28 \\
30 \\
33\end{array}$ & $\begin{array}{c}\text { Fcet. } \\
\text { s0 } \\
\text { to } \\
125\end{array}$ & $\begin{array}{r}\text { ru. pet. } \\
192 \\
116 \\
123 \\
288 \\
160 \\
528 \\
250 \\
540 \\
1,216 \\
3,076 \\
1,544 \\
1,344 \\
1.920 \\
540 \\
1,312\end{array}$ & Fet B.Jl. & $\begin{array}{r}2 \\
2 \\
1 \\
14 \\
6 \\
2 \\
2 \\
2\end{array}$ & $\begin{array}{r}\text { Inches. } \\
34 \\
16 \\
18 \\
19 \\
21 \\
23 \\
24 \\
25\end{array}$ & $\begin{array}{c}\text { Fect. } \\
\cdot \\
80 \\
10 \\
150\end{array}$ & $\begin{array}{r}32 \\
4 \\
6 \\
2 \\
6 \\
8 \\
2 \\
2 \\
4 \\
2 \\
2 \\
2 \\
2 \\
2\end{array}$ & $\begin{array}{l}\text { Inches. } \\
6 \text { to } 110 \\
10 \\
11 \\
12 \\
11 \\
15 \\
17 \\
18 \\
19 \\
20 \\
21 \\
22 \\
23 \\
21\end{array}$ & $\begin{array}{c}\text { Fe+t. } \\
60 \\
=0 \\
10 \\
80\end{array}$ \\
\hline $\begin{array}{r}76 \text { trees } \\
\text { Total } \\
\text { Total }\end{array}$ & $\begin{array}{l}\text { cubie teet } \\
\text { fert B. MI }\end{array}$ & .... & . & $\begin{array}{l}12,174 \\
\therefore 53,400\end{array}$ & $\begin{array}{r}3+\text { trees } \\
\text { Tota } \\
\text { Tota }\end{array}$ & $\begin{array}{l}\text { I eubic feet } \\
\text { I feet } \mathrm{B} \text {. II }\end{array}$ & $\begin{array}{r}4,270 \\
20,500\end{array}$ & $\begin{array}{r}76 \text { trees } \\
\text { Tota } \\
\text { Tota }\end{array}$ & $\begin{array}{l}\text { labic fect } \\
\text { feet } B .3\end{array}$ & $\begin{array}{r}3.616 \\
13.000\end{array}$ \\
\hline
\end{tabular}

Total yield: All species $20,060 \mathrm{rul}$ he feet, of which $\mathrm{Th}$ hite Pine $\pi$ as 61 per cent. Arerage annual accretion: White Pine, $5 \%$ culic teet. Age of pine: 230 to 2419 year4.
Dernity of erowu corer: 0.5 to Sumbrer of trees: 180 .

MEASUREMEXTS OF SAMPLE TREES.

Aye cluse : 230 to 250 years.

DONIXANT GROWTH.

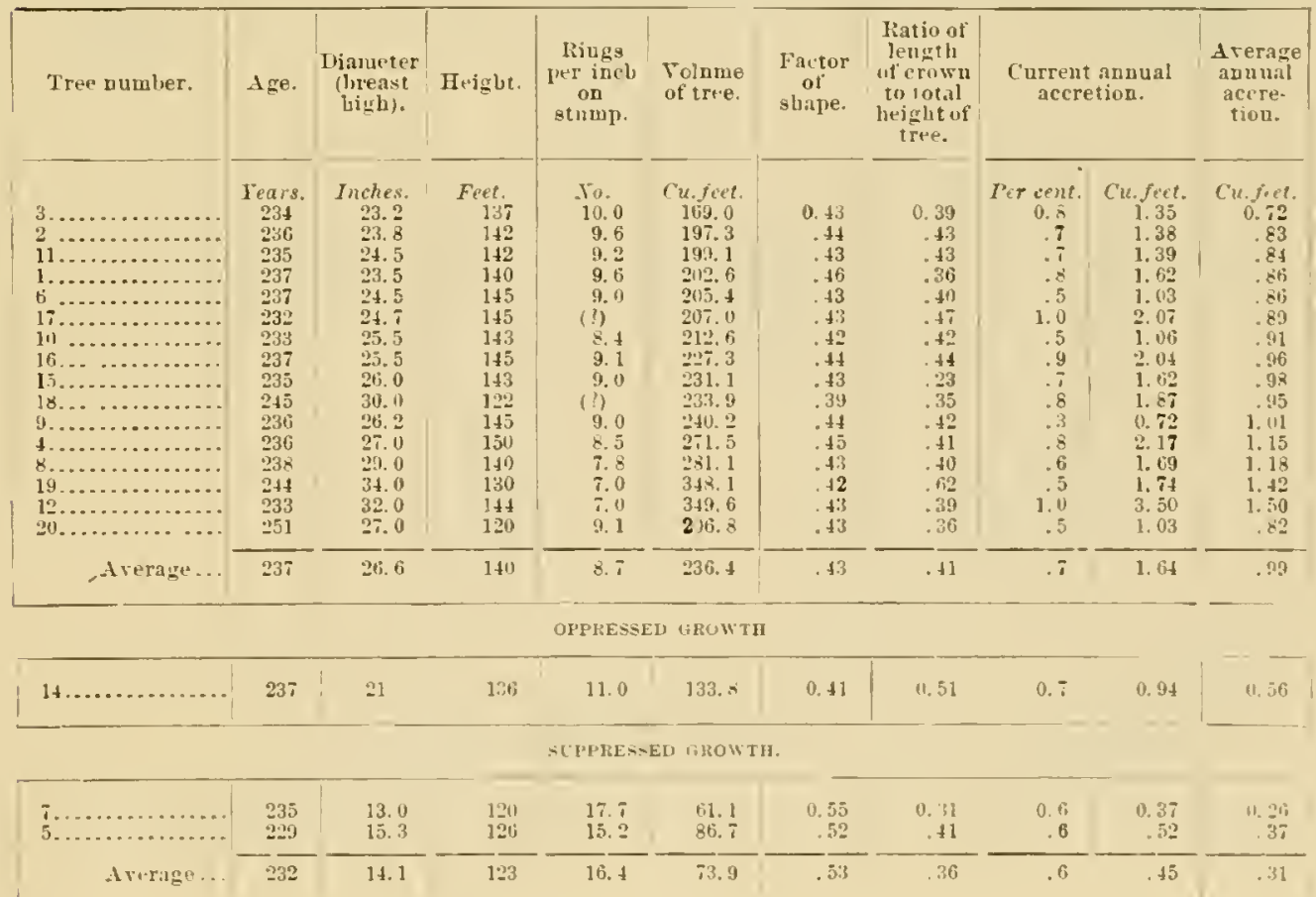




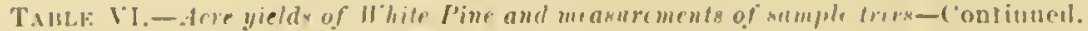

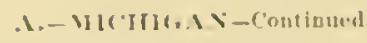

anil: Moist, low grombul, wear stram

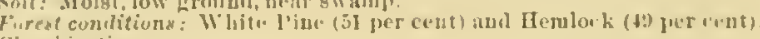
rlansificatiun :

Ihiminant.

Oplitenated silpipressed

Hali acre Xo. 2

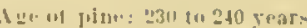

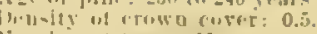

IIALF.Ar'LE: YHEL.J.

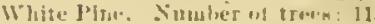
su I0

\begin{tabular}{|c|c|c|c|c|c|c|c|}
\hline \multicolumn{5}{|c|}{ White l'inc. } & \multicolumn{3}{|c|}{ Ilrmlork. } \\
\hline \multirow[b]{2}{*}{$\begin{array}{l}\text { Similwer } \\
\text { of treies. }\end{array}$} & \multirow[b]{2}{*}{$\begin{array}{l}\text { Diameter } \\
\text { (hrivist } \\
\text { biglit). }\end{array}$} & \multirow[b]{2}{*}{ Height. } & \multicolumn{2}{|c|}{ Volnume. } & \multirow[b]{2}{*}{$\begin{array}{l}\text { Number } \\
\text { of treis. }\end{array}$} & \multirow[b]{2}{*}{$\begin{array}{l}\text { Diamcter } \\
\text { (loreast } \\
\text { hiah). }\end{array}$} & \multirow[b]{2}{*}{ Huflit. } \\
\hline & & & Bole. & $\begin{array}{l}\text { JI'T- } \\
\text { clinintilule } \\
\text { ginber. }\end{array}$ & & & \\
\hline $\begin{array}{c}2 \\
4 \\
3 \\
2 \\
2 \\
2 \\
3 \\
4 \\
2 \\
4 \\
4 \\
2 \\
2 \\
4 \\
13 \\
2 \\
2 \\
2 \\
1 \\
2 \\
2 \\
2\end{array}$ & 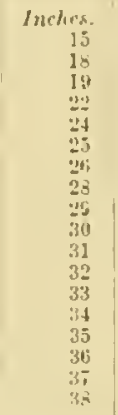 & $\begin{array}{c}101 . \\
80 \\
10 \\
125\end{array}$ & 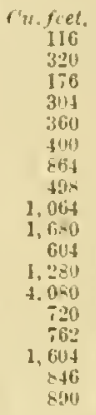 & Feet $\boldsymbol{H}, \mathrm{H}$. & $\begin{array}{r}15 \\
6 \\
4 \\
1 \\
4 \\
15 \\
13 \\
10 \\
20 \\
10 \\
2 \\
2 \\
2\end{array}$ & $\begin{array}{c}\text { Inhes. } \\
6 \text { ti) } 10 \\
11 \\
12 \\
13 \\
11 \\
15 \\
16 \\
17 \\
19 \\
211 \\
21 \\
25\end{array}$ & $\begin{array}{c}F+1 . \\
60 \\
70 \\
111 \\
x 0\end{array}$ \\
\hline $\begin{array}{l}\text { bu [rows } \\
\text { I'otal } \\
\text { T'utal }\end{array}$ & 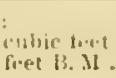 & & ....... & $\begin{array}{l}16,506 \\
99,400\end{array}$ & $\begin{array}{l}58 \text { rrees } \\
\text { Tula } \\
\text { Tuta }\end{array}$ & $\begin{array}{l}\text { culoie firet } \\
\text { teet } 1 \text { l. } \mathrm{Jl} \text {. }\end{array}$ & $\begin{array}{r}4,490 \\
16,160\end{array}$ \\
\hline
\end{tabular}

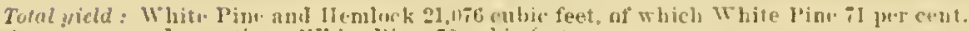

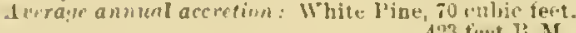

(I1) SITE I:

lioscom:non finut i:

Simule area: 1 acre.

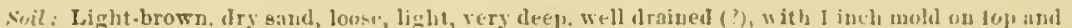
surfave curver of leaves

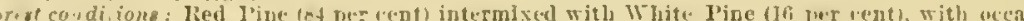

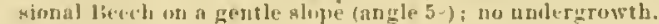

Clansificrition

I) (ruituant

(1)

sinpressed

........

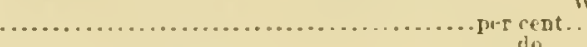
Whit o. l'inw lied Pine.

Afrent unge: ?

in. IN

Xinmber of trees: 130 .

\section{ACHE TIELI}

\begin{tabular}{|c|c|c|c|c|c|c|c|c|c|c|}
\hline \multicolumn{5}{|c|}{ - Whitu lins. } & \multicolumn{3}{|c|}{ Iiesl I'ine. } & \multicolumn{3}{|c|}{ berchl. } \\
\hline \multirow[b]{2}{*}{$\begin{array}{l}\text { Sumlier } \\
\text { of tries. }\end{array}$} & \multirow{2}{*}{$\begin{array}{l}\text { liaureter } \\
\text { (uragat } \\
\text { liigh). }\end{array}$} & \multirow[b]{2}{*}{ Hejeft. } & \multicolumn{2}{|c|}{ Tơรut. } & \multirow[b]{2}{*}{$\begin{array}{l}\text { Jumber } \\
\text { of tries. }\end{array}$} & \multirow[b]{2}{*}{ 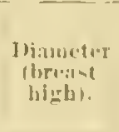 } & \multirow[b]{2}{*}{ Heiglit. } & \multirow[b]{2}{*}{$\begin{array}{l}\text { Nimulier } \\
\text { of irees. }\end{array}$} & \multirow[b]{2}{*}{$\begin{array}{l}\text { Miameter } \\
\text { (bruast } \\
\text { high). }\end{array}$} & \multirow[b]{2}{*}{ Iltight } \\
\hline & & & I'ole. & $\begin{array}{l}\text { Mier. } \\
\text { cliantalile } \\
\text { timlier. }\end{array}$ & & & & & & \\
\hline $\begin{array}{l}3 \\
1 \\
1 \\
2 \\
1 \\
2 \\
0 \\
3 \\
1 \\
0 \\
2 \\
1 \\
1\end{array}$ & 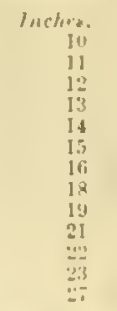 & $\begin{array}{l}100 \\
101 \\
1201\end{array}$ & 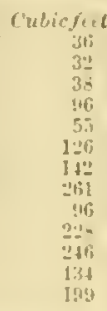 & Feet T. It & $\begin{array}{c}1 \\
2 \\
3 \\
7 \\
13 \\
213 \\
16 \\
18 \\
11 i \\
5 \\
5 \\
1\end{array}$ & 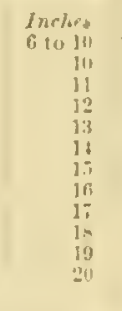 & $\begin{array}{l}90 \\
\text { in } \\
\text { InIII }\end{array}$ & 1 & $\begin{array}{c}\text { Inehes. } \\
3 \text { to } 0 \\
6 \text { to } 10\end{array}$ & \}$_{\text {Fint. }}$ \\
\hline $\begin{array}{l}21 \text { irees } \\
\text { Tintil } \\
\text { linal }\end{array}$ & $\begin{array}{l}\text { anbrc funt } \\
\text { teut li. II }\end{array}$ & t....... & $\ldots \ldots \ldots$ & ․ $1.62 ! 11$ & $\begin{array}{r}113 \text { tries } \\
\text { Turtir } \\
\text { Tuta }\end{array}$ & 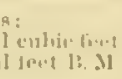 & 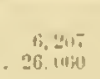 & 2 trets & & \\
\hline
\end{tabular}


TAHIES OF MEASLIREMENTS.

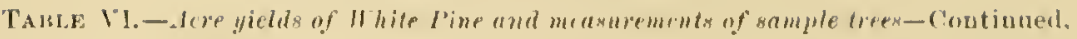

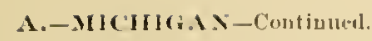

(12) NITE $w$ liовгоншии Cимиту.

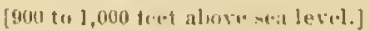

fere tio. 1.

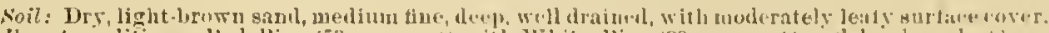

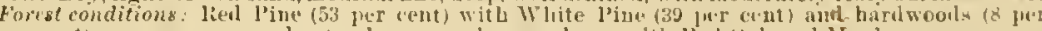

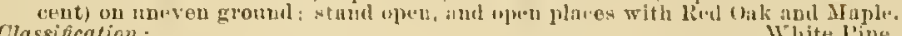
lassification:

Diminant

Spressed

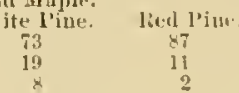

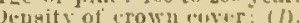
Sumber of treis: 9 ? sanupte ares 1 acres.

ACHE YIELD

\begin{tabular}{|c|c|c|c|c|c|c|c|c|c|c|}
\hline \multicolumn{5}{|c|}{ White l'ine. } & \multicolumn{3}{|c|}{ Tiend Pine. } & \multicolumn{3}{|c|}{ nak. } \\
\hline \multirow[b]{2}{*}{$\begin{array}{l}\text { Number } \\
\text { if trees. }\end{array}$} & \multirow[b]{2}{*}{$\begin{array}{l}\text { Diameter } \\
\text { (brenst } \\
\text { liigh). }\end{array}$} & \multirow[b]{2}{*}{ Hroight. } & \multicolumn{2}{|c|}{ Tolume. } & \multirow[b]{2}{*}{$\begin{array}{l}\text { Numbur } \\
\text { of treeg. }\end{array}$} & \multirow[b]{2}{*}{$\begin{array}{l}\text { Dimuetur } \\
\text { (hreast } \\
\text { higlt). }\end{array}$} & \multirow[b]{2}{*}{ Ileight. } & \multirow[b]{2}{*}{$\begin{array}{l}\text { Number } \\
\text { of treers. }\end{array}$} & \multirow[b]{2}{*}{$\begin{array}{l}\text { Dianeter } \\
\text { (lireast } \\
\text { bigh). }\end{array}$} & \multirow[b]{2}{*}{ IInight. } \\
\hline & & & Bole: & $\begin{array}{c}\text { Mer } \\
\text { chantalie } \\
\text { timulnet. }\end{array}$ & & & & & & \\
\hline $\begin{array}{l}1 \\
1 \\
1 \\
1 \\
3 \\
2 \\
\frac{2}{5} \\
5\end{array}$ & $\begin{array}{c}\text { Inches. } \\
1 \pm \\
17 \\
18 \\
19 \\
30 \\
21 \\
23\end{array}$ & Fert. & $\begin{array}{r}\text { Cubicjict } \\
55 \\
79 \\
84 \\
285 \\
210 \\
228 \\
615\end{array}$ & Fet IS. 11 . & $\begin{array}{l}1 \\
2 \\
1 \\
2 \\
2 \\
6 \\
5 \\
7\end{array}$ & $\begin{array}{r}\text { Inches. } \\
13 \\
14 \\
15 \\
114 \\
17 \\
18 \\
19\end{array}$ & Fept. & $\begin{array}{l}1 \\
3\end{array}$ & $\begin{array}{c}\text { Inches. } \\
\text { Under } 3 \\
3 \text { to } 6 \\
\\
\text { MInole. }\end{array}$ & $\begin{array}{c}\text { Feet. } \\
40\end{array}$ \\
\hline $\begin{array}{l}2 \\
3 \\
2 \\
2 \\
5 \\
1 \\
2 \\
1 \\
1 \\
1 \\
1\end{array}$ & $\begin{array}{l}23 \\
24 \\
25 \\
26 \\
27 \\
28 \\
23 \\
33 \\
34 \\
39\end{array}$ & $\begin{array}{l}100 \\
t 01 \\
1 \leq 0\end{array}$ & $\begin{array}{l}268 \\
435 \\
314 \\
815 \\
7332 \\
312 \\
267 \\
283 \\
451\end{array}$ & 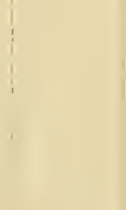 & $\begin{array}{l}8 \\
3 \\
3 \\
\vdots \\
2 \\
2 \\
1\end{array}$ & $\begin{array}{r}19 \\
20 \\
21 \\
5.2 \\
23 \\
24 \\
25\end{array}$ & $1: 11$ & $\frac{2}{2}$ & $\begin{array}{rlr}3 & 111 & 6 \\
6 & 10 & 10\end{array}$ & 40 \\
\hline $\begin{array}{r}30 \text { trees } \\
\text { Tot } \\
\text { Tot }\end{array}$ & $\begin{array}{l}\text { coubic fee } \\
\text { finet L. Ml }\end{array}$ & $t \ldots .$. & .......... & $\begin{array}{r}5,553 \\
\ldots .26 .600\end{array}$ & $\begin{array}{l}\text { 47 trees: } \\
\text { Tota } \\
\text { Tot: }\end{array}$ & $\begin{array}{l}\text { lowbic feet } \\
\text { feet Is } \mathrm{II}\end{array}$ & $\begin{array}{r}5,360 \\
-26,000\end{array}$ & otreen. & & \\
\hline
\end{tabular}

Total yield: Pine, 10,913 cubiu feet.

52,600 feet $\mathrm{I}$. M., of which $W$ hith Piue 50 per cent.

Arerane annual accretion: l'jue, bi culsi. teet.

$$
\text { Acre Xio.?. }
$$

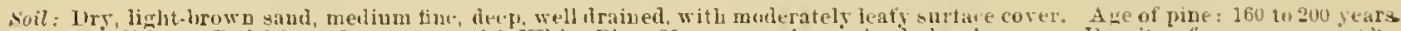
Forest conditions: lied l'ine (-5 per cent) with White Pine (25 jet cent) intermised; level. Classificatiun:

Douninaut.

upresserl

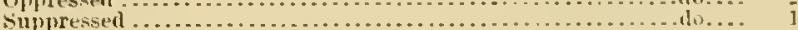
- per cent. Thite Pinte

$$
\begin{array}{cc}
62 & \text { Rinl } 1 \\
25 & 23 \\
13 & 3
\end{array}
$$

Anensity ut crown rover: lino. Number of trees: 1503.

\begin{tabular}{|c|c|c|c|c|c|c|}
\hline \multirow[b]{2}{*}{$\begin{array}{l}\text { Number } \\
\text { if trees. }\end{array}$} & \multicolumn{3}{|c|}{ White Pine. } & \multicolumn{3}{|c|}{ Iterl I'ine. } \\
\hline & $\begin{array}{l}\text { Diameter } \\
\text { (breant } \\
\text { liuld). }\end{array}$ & Height. & $\begin{array}{c}\text { Mer. } \\
\text { Bole. chautable } \\
\text { timbir. }\end{array}$ & $\begin{array}{l}\text { Numiner } \\
\text { of trees. }\end{array}$ & $\begin{array}{l}\text { Dianutler } \\
\text { (liretistst } \\
\text { Light). }\end{array}$ & Hיiglit. \\
\hline $\begin{array}{l}2 \\
1 \\
1 \\
4 \\
1 \\
7 \\
4 \\
3 \\
3 \\
1 \\
0 \\
2 \\
3 \\
3 \\
1\end{array}$ & 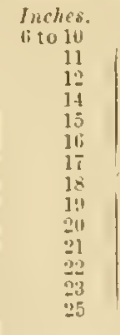 & $\begin{array}{l}100 \\
\text { to } \\
120\end{array}$ & Cubic feet. Feet li. M. & $\begin{array}{c}3 \\
5 \\
12 \\
8 \\
32 \\
11 \\
10 \\
8 \\
4 \\
2\end{array}$ & $\begin{array}{c}\text { Inches. } \\
6 \text { 10 } 10 \\
111 \\
12 \\
13 \\
14 \\
11 \\
16 \\
17 \\
11 \\
10 \\
20\end{array}$ & $\begin{array}{l}1011 \\
111 \\
120\end{array}$ \\
\hline $\begin{array}{r}\text {.39 trees: } \\
\text { Juta } \\
\text { 'I'utat }\end{array}$ & $\begin{array}{l}\text { ubic feef } \\
\text { eet ls. II }\end{array}$ & $\cdots$ & c........ & $\begin{array}{r}113 \text { tron: } \\
\text { rinal } \\
\text { lotal }\end{array}$ & 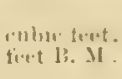 & $\begin{array}{r}7, ! 114 \\
33,24+1\end{array}$ \\
\hline
\end{tabular}

\section{A'IIE' YIELD,}

Total yicld: 1'101, 11.246 mbic linet.

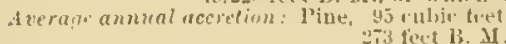




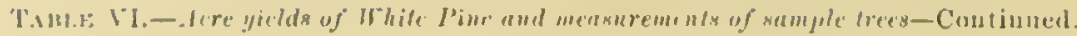

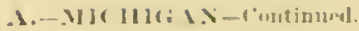
Icre vio.s.

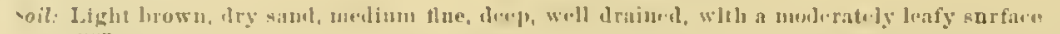

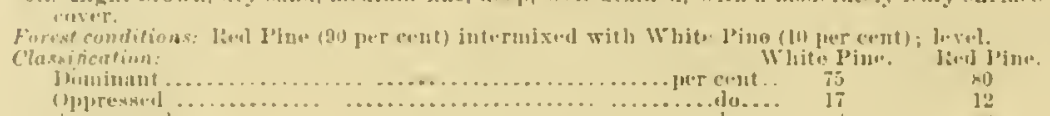

Age of pin : : Ifo (1) 2 an years 19"nsity of "rown rover: (l) inilure

ACRL: YILL1).

\begin{tabular}{|c|c|c|c|c|c|c|c|}
\hline \multicolumn{5}{|c|}{ White J'int. } & \multicolumn{3}{|c|}{ Jitel I'ine. } \\
\hline \multirow[b]{2}{*}{$\begin{array}{l}\text { Xumlerer } \\
\text { of trees. }\end{array}$} & \multirow[b]{2}{*}{$\begin{array}{l}\text { Dianuter } \\
\text { (lirenst } \\
\text { hijeli). }\end{array}$} & \multirow[b]{2}{*}{ Hright. } & \multicolumn{2}{|c|}{ Tolunu". } & \multirow[b]{2}{*}{$\begin{array}{l}\text { Dumbler } \\
\text { of trutus. }\end{array}$} & \multirow[b]{2}{*}{ 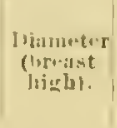 } & \multirow[b]{2}{*}{ II:Iglit. } \\
\hline & & & Lith. & $\begin{array}{l}\text { Mur- } \\
\text { clautalsh. } \\
\text { timliere. }\end{array}$ & & & \\
\hline $\begin{array}{l}1 \\
1 \\
2 \\
1 \\
1 \\
1 \\
3 \\
3 \\
3\end{array}$ & 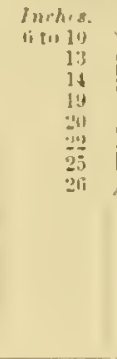 & $\left\{\begin{array}{c}\text { Font. } \\
\\
100 \\
110 \\
120\end{array}\right.$ & $\begin{array}{c}\text { rubicfint } \\
10 \\
43 \\
1111 \\
606 \\
105 \\
36,9 \\
311 \\
169\end{array}$ & Heet R.M & $\begin{array}{r}5 \\
1 \\
1 \\
6 \\
3 \\
12 \\
10 \\
1.5 \\
25 \\
12 \\
4 \\
6 \\
2 \\
2 \\
1\end{array}$ & 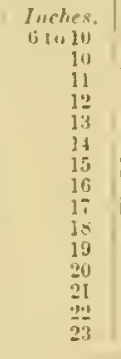 & $\begin{array}{l}100 \\
10 \\
1211\end{array}$ \\
\hline $\begin{array}{l}\text { 32 trues } \\
\text { Totst } \\
\text { Total }\end{array}$ & $\begin{array}{l}\text { cubic foet } \\
\text { fथ.t } 3, \mathbf{M l} .\end{array}$ & n........ & ............. & $\ldots$ 1, 201 & $\begin{array}{l}\text { J05 true: } \\
\text { Jotal } \\
\text { Total }\end{array}$ & $\begin{array}{l}\text { : } \\
\text { "ubir foct. } \\
\text { fot B. MI. }\end{array}$ & $\begin{array}{r}8,170 \\
31,300\end{array}$ \\
\hline
\end{tabular}

Total yicld: I'ine, 9.38] cubie te+t.

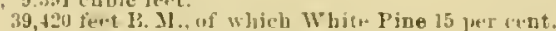

lverage annul accretion: Hinn, 52 collic foet.

Acre Io.

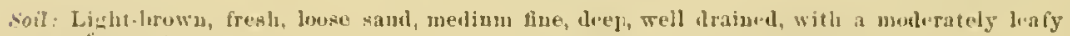
sliffice curet.

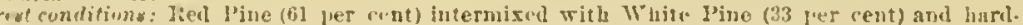
whorls (6 prerent); kcatterod young Oak and beech on uneven grouml.

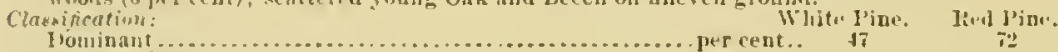
Tominamit

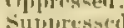 per cent..
(1)

Al. of june: lio 10 -00 years.

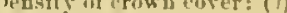

Xinuber of trees: (?).

ACIE IEIELD.

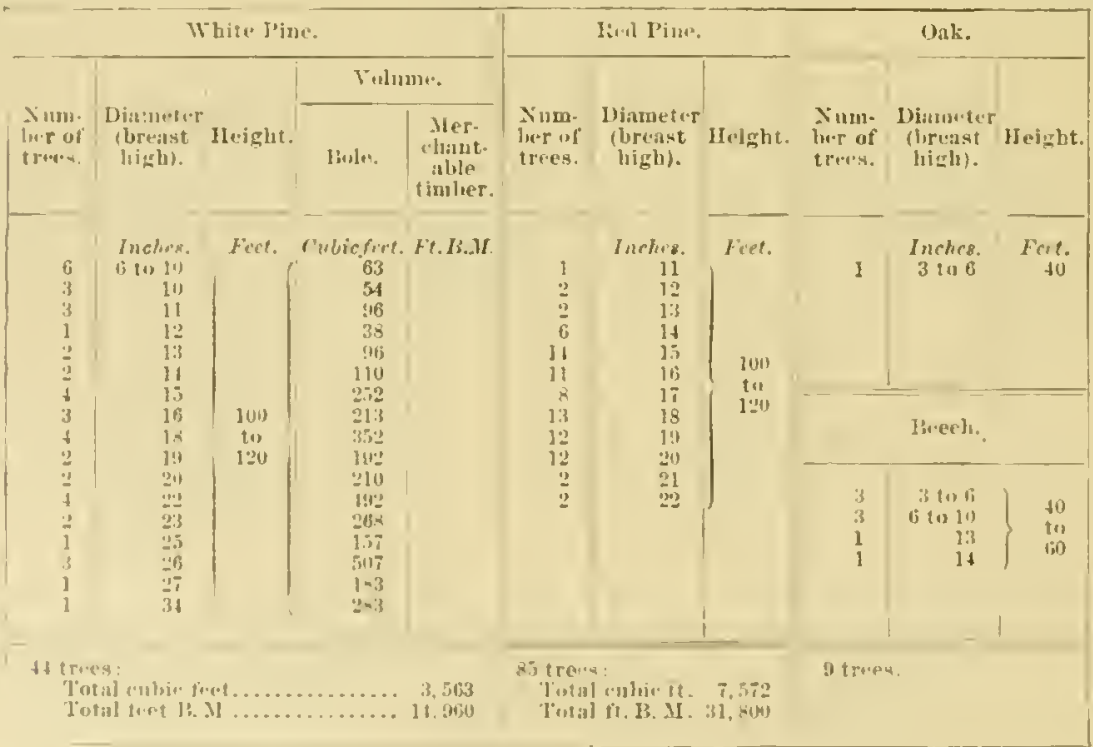

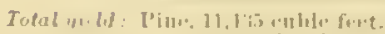

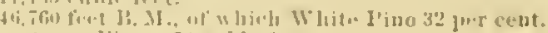

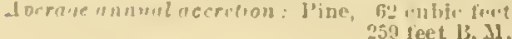


TABLE VI. Acre yiduls of White l'ine and measurments of sumple trees-Continned.

MEANILWMENTS UL SAMPLF THEES.

fyre class. 160 to 1 sio years.

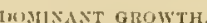

\begin{tabular}{|c|c|c|c|c|c|c|c|c|c|c|}
\hline 'Tree number. & Age. & $\begin{array}{l}\text { Dianueter } \\
\text { (briast } \\
\text { limbly. }\end{array}$ & Heiglit. & $\begin{array}{l}\text { Jijugh } \\
\text { ler inch } \\
\text { "ull }\end{array}$ & $\begin{array}{l}\text { Tolume } \\
\text { of tree. }\end{array}$ & $\begin{array}{l}\text { Factor } \\
\text { of } \\
\text { shaje. }\end{array}$ & $\begin{array}{l}\text { Lution of } \\
\text { length } \\
\text { of crow } \\
\text { to total }\end{array}$ & \multicolumn{2}{|c|}{$\begin{array}{l}\text { Current anmua! } \\
\text { atereliou. }\end{array}$} & $\begin{array}{l}\text { Average } \\
\text { antual } \\
\text { aterer- }\end{array}$ \\
\hline $\begin{array}{l}9 . . \\
29 . \\
21 . .\end{array}$ & $\begin{array}{c}\text { Tears. } \\
176 \\
173 \\
163\end{array}$ & $\begin{array}{c}\text { Inches. } \\
94.2 \\
27.2 \\
26.5\end{array}$ & $\begin{array}{r}\text { Fret. } \\
118 \\
1: 1 \\
120\end{array}$ & $\begin{array}{r}\text { Xo. } \\
7.5 \\
6.2 \\
6.2\end{array}$ & $\begin{array}{r}\text { Cu.ft. } \\
170.1 \\
218.8 \\
211.0\end{array}$ & $\begin{array}{r}0.415 \\
.45 \\
.46\end{array}$ & $\begin{array}{r}0.54 \\
.28 \\
.31\end{array}$ & $\begin{array}{c}\text { Percent. } \\
1.2 \\
. \frac{7}{1}\end{array}$ & $\begin{array}{r}\text { Cu. il. } \\
\because .04 \\
1.53 \\
1.47\end{array}$ & $\begin{array}{r}\text { ru. fl. } \\
0.115 \\
1.26 \\
1.29\end{array}$ \\
\hline Average... & 171 & 26.0 & 120 & 0.6 & $200.1)$ & .46 & .32 & .9 & 1.68 & 1.17 \\
\hline $\begin{array}{l}34 \ldots \ldots \ldots \ldots \ldots \ldots \\
18, \ldots \ldots \ldots \ldots \ldots \ldots \\
5 \ldots \ldots \ldots \ldots \ldots \ldots\end{array}$ & $\begin{array}{l}182 \\
188 \\
1<6\end{array}$ & $\begin{array}{l}25.2 \\
26.7 \\
31.0\end{array}$ & $\begin{array}{l}118 \\
118 \\
119\end{array}$ & $\begin{array}{l}7.4 \\
6.9 \\
5.5\end{array}$ & $\begin{array}{l}173.0 \\
002.1 \\
0865.6\end{array}$ & $\begin{array}{l}.43 \\
.45 \\
.45\end{array}$ & $\begin{array}{l}.53 \\
.54 \\
.40\end{array}$ & $\begin{array}{r}1.3 \\
1.2 \\
.7\end{array}$ & $\begin{array}{l}\frac{2.25}{2.42} \\
2.0\end{array}$ & $\begin{array}{l}.05 \\
1.07 \\
1.54\end{array}$ \\
\hline Arernge.. & 185 & 27.6 & 118 & 6. 6 & 230.5 & .44 & .51 & 1.1 & 2. 22 & 1.19 \\
\hline
\end{tabular}

CODOMISANT GROWTTH.

\begin{tabular}{|c|c|c|c|c|c|c|c|c|c|c|}
\hline $15 \ldots \ldots \ldots \ldots \ldots$ & 179 & 19.0 & 125.0 & 9. 9 & 118,4 & 0.48 & 0.26 & 0.8 & 0.95 & 0. 66 \\
\hline 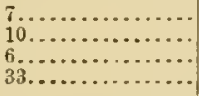 & $\begin{array}{l}1,85 \\
1 \times 5 \\
184 \\
1 \leqslant 1\end{array}$ & $\begin{array}{l}17.0 \\
-31,3 \\
24.3 \\
2.20\end{array}$ & $\begin{array}{l}125.0 \\
105.0 \\
109.0 \\
111.0\end{array}$ & $\begin{array}{r}11.5 \\
0.1 \\
7.4 \\
7.7\end{array}$ & $\begin{array}{l}79.2 \\
111.8 \\
128.6 \\
134.3\end{array}$ & $\begin{array}{l}.41 \\
.46 \\
.36 \\
.45\end{array}$ & $\begin{array}{l}.51 \\
32 \\
38 \\
.41\end{array}$ & $\begin{array}{l}1.5 \\
1.8 \\
1.0 \\
1.5\end{array}$ & $\begin{array}{r}1.19 \\
.39 \\
1.39 \\
2.01\end{array}$ & $\begin{array}{l}.42 \\
.60 \\
.70 \\
.73\end{array}$ \\
\hline Average... & 184 & 20.9 & 112.5 & 8.4 & 113.5 & .42 & .41 & 1. 2 & 1.34 & .61 \\
\hline
\end{tabular}

OPPRESSED GROIYTH.

\begin{tabular}{|c|c|c|c|c|c|c|c|c|c|c|}
\hline $36 \ldots \ldots \ldots \ldots \ldots$ & 165 & 13 & 103 & 8.7 & $8 \div .9$ & $0 .+7$ & $0.41^{\circ}$ & 1.2 & 1.05 & 0.53 \\
\hline
\end{tabular}

hye class: Orer 200 yenrs.

DOMINAXT GROWTH

\begin{tabular}{|l|l|llllll|l|l|l|}
\hline $19 \ldots \ldots \ldots \ldots \ldots$ & 211 & 23.5 & 119 & 7.3 & 218.9 & 0.41 & 0.63 & 1.3 & 2.84 & 1.03 \\
\hline
\end{tabular}

OPLRESEED GROWTH.

\begin{tabular}{|l|l|l|l|l|l|l|l|l|l|l|}
\hline $13 \ldots \ldots \ldots \ldots \ldots \ldots$ & 206 & 22 & 119 & $9 . \vec{i}$ & 144.4 & 0.46 & 0.35 & 0.6 & 0.37 & 0.70 \\
\hline
\end{tabular}

20233-No. $22-9$ 


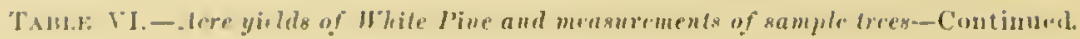

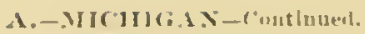

(13) $\operatorname{sit} n$
I:อscommun f'ounty.

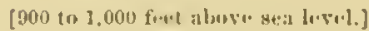

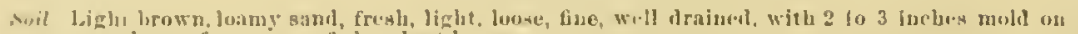
toln, and a nurface cover of almulant leasms.

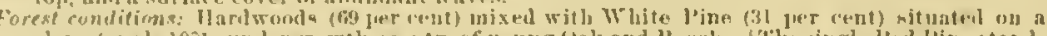

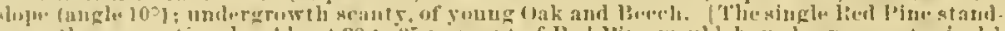

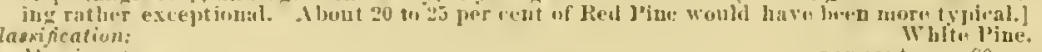
lastificatiun:

Jubiuant

jercent

Ojpririnsed ...lo... 10

Silupl. arva: lacre

1 ge of pine: 16026200 y.n. (1) Number of trins: 130 ACRE: YIKL1).

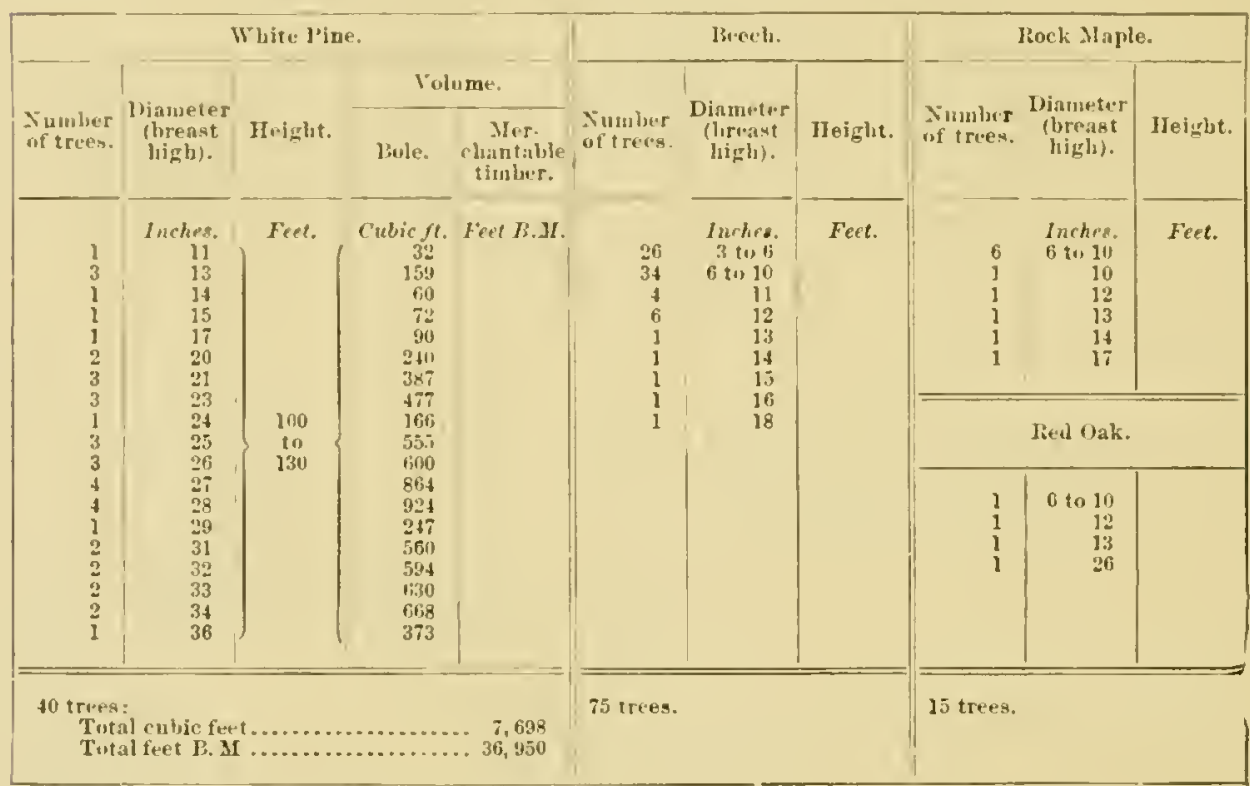

Average annual aceretion: White Pine, $12 \cdot$ ubic feet. 


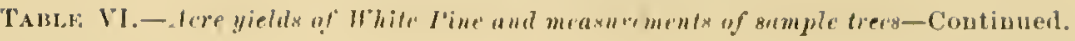

\section{H. Wraconalis:}

(1) SITE $a$ :
Wamhluru county.

Satuple area: 2 acres

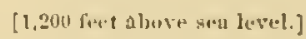

Icre .jo.1.

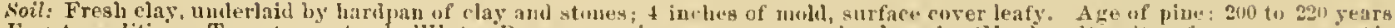

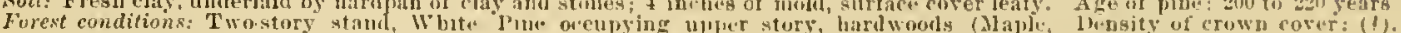

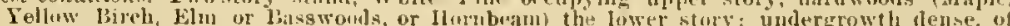

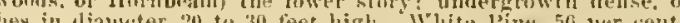
bardwomls, 44 per cent. Classificafion:

Dumitant White ['ine

Nimber of trees: it: Onpressed reut.. 7 : Supruser. , lin.....

ACIE TIELL.

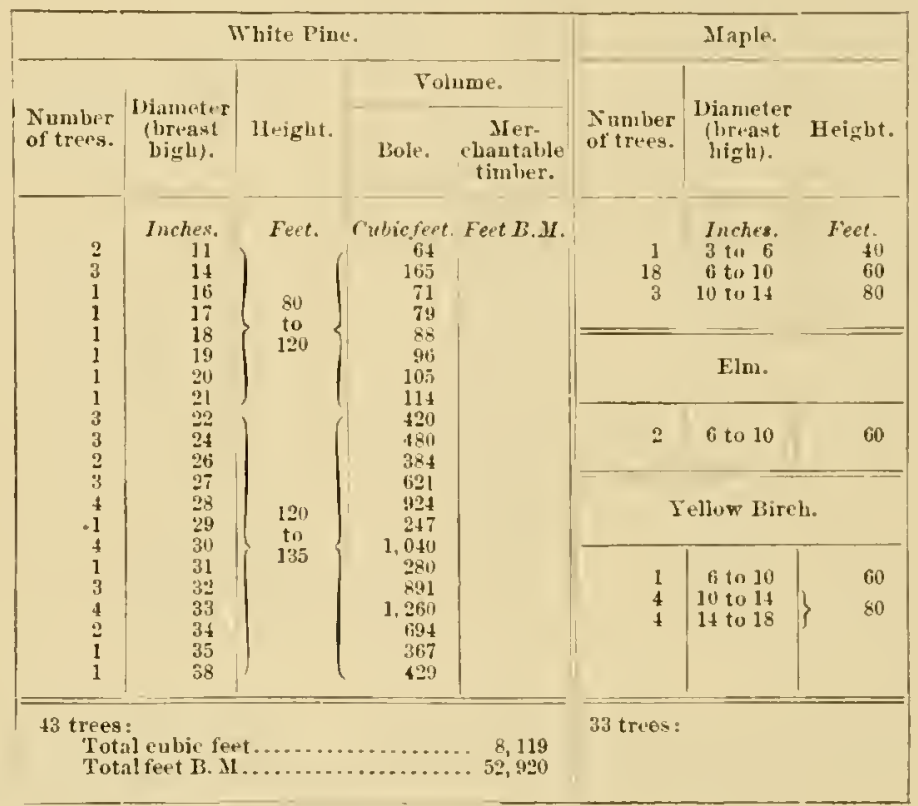

Average annual accetion: White Pine, 38 cubie feet. 


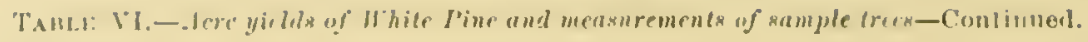

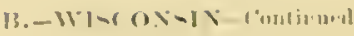

Iere Ju. 2.

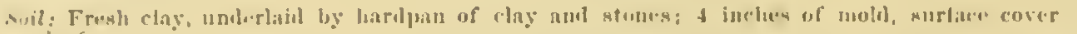
lonfs:.

(I:ule

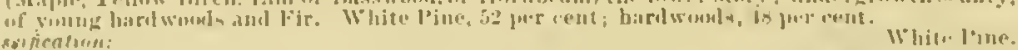

A go uf jille: 200 to 320 rente.

erown rasir: $($ in

Theninanis

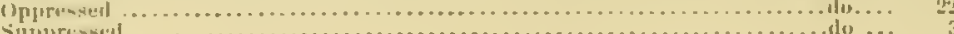
jerercint.. is

ACIILYIILU.

\begin{tabular}{|c|c|c|c|c|c|c|c|}
\hline \multicolumn{5}{|c|}{ White Piuw. } & \multicolumn{3}{|c|}{ Fir. } \\
\hline \multirow[b]{2}{*}{$\begin{array}{l}\text { Dismber } \\
\text { if traes. }\end{array}$} & \multirow[b]{2}{*}{$\begin{array}{c}\text { Dianweter } \\
\text { (breast } \\
\text { higls). }\end{array}$} & \multirow[b]{2}{*}{ Il eight. } & \multicolumn{2}{|c|}{ Volunse. } & \multirow[b]{2}{*}{$\begin{array}{l}\text { Xinuluer } \\
\text { of traes. }\end{array}$} & \multirow[b]{2}{*}{$\begin{array}{l}\text { Diator.tur } \\
\text { (breast } \\
\text { hish). }\end{array}$} & \multirow[b]{2}{*}{ II eight. } \\
\hline & & & Hele. & $\begin{array}{c}\text { dlir. } \\
\text { ebnutalue } \\
\text { timbur. }\end{array}$ & & & \\
\hline \multirow{8}{*}{$\begin{array}{l}1 \\
1 \\
3 \\
2 \\
1 \\
2 \\
6 \\
6 \\
3 \\
3 \\
6 \\
5 \\
5 \\
3 \\
3 \\
3 \\
2 \\
1 \\
1 \\
3 \\
3 \\
1 \\
1 \\
1 \\
3 \\
3\end{array}$} & \multirow{8}{*}{$\begin{array}{c}\text { Incher. } \\
14 \\
16 \\
15 \\
319 \\
91 \\
30 \\
23 \\
34 \\
23 \\
\because 6 \\
27 \\
23 \\
29 \\
30 \\
31 \\
33 \\
34 \\
35 \\
30 \\
37 \\
38 \\
39 \\
40\end{array}$} & \multirow[t]{8}{*}{$\begin{array}{l}\text { Feel. } \\
\text { nu } \\
111 \\
120\end{array}$} & \multirow{8}{*}{ 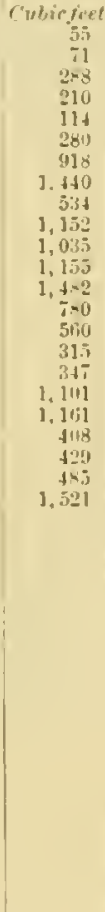 } & \multirow[t]{8}{*}{ t. Feet L. U. } & 5 & $\begin{array}{l}\text { Inches. } \\
\text { I to ii }\end{array}$ & Feet. \\
\hline & & & & & \multicolumn{3}{|c|}{ II ornbean. } \\
\hline & & & & & $\begin{array}{l}5 \\
1 \\
Y \\
Y\end{array}$ & $\begin{array}{r}3 \text { tor } \\
6 \text { to } 10 \\
- \\
\end{array}$ & $\begin{array}{r}40 \\
40 \\
0 . \\
\end{array}$ \\
\hline & & & & & $\begin{array}{r}12 \\
16 \\
2 \\
3 \\
1\end{array}$ & 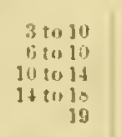 & $\begin{array}{l}40 \\
60 \\
80 \\
811 \\
86\end{array}$ \\
\hline & & & & & \multicolumn{3}{|c|}{ Lutternut. } \\
\hline & & & & & I & $\begin{array}{l}3 \text { tor } \\
\text { is }(11)] 19\end{array}$ & $\begin{array}{l}10 \\
100\end{array}$ \\
\hline & & & & & \multicolumn{3}{|c|}{ Itass rroorl. } \\
\hline & & & & & $\begin{array}{l}9 \\
6\end{array}$ & $\begin{array}{l}3100 \\
68010\end{array}$ & $\begin{array}{l}40 \\
60\end{array}$ \\
\hline $\begin{array}{r}69 \text { tress } \\
\text { Tota } \\
\text { Trota }\end{array}$ & $\begin{array}{l}\text { al culhis lin } \\
\text { al fore I?. }\end{array}$ & $\ldots$ & (n........ & $\begin{array}{l}\ldots 1,519 \\
\ldots 95,010\end{array}$ & 63 सrets. & & \\
\hline
\end{tabular}

Lrerage annual accretion: White Fine, i5 culir feet.

MEASUREMENTS UF S.MIILE TIEE.S.

\begin{tabular}{|c|c|c|c|c|c|c|c|}
\hline Tree number. & I ge. & $\begin{array}{c}\text { Dinmeter } \\
\text { (bre:sts } \\
\text { lifgh). }\end{array}$ & Helght. & $\begin{array}{l}\text { Folimet } \\
\text { of tree. }\end{array}$ & $\begin{array}{c}\text { Finctur } \\
\text { of } \\
\text { mliaje. }\end{array}$ & 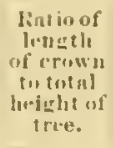 & $\begin{array}{c}\text { A rerage } \\
\text { anmul } \\
\text { accre- } \\
\text { tirn. }\end{array}$ \\
\hline 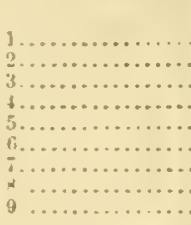 & $\begin{array}{c}\text { Fears. } \\
204 \\
221 \\
213 \\
214 \\
211 \\
202 \\
2114 \\
212 \\
213\end{array}$ & $\begin{array}{r}\text { Inehen. } \\
24.7 \\
27.0 \\
27.0 \\
260 \\
215.8 \\
31.0 \\
29.0 \\
24.0 \\
30.0\end{array}$ & $\begin{array}{l}\text { Feet. } \\
102.0 \\
113.0 \\
121.5 \\
126.0 \\
126.0 \\
131.11 \\
1.2 .11 \\
133.0 \\
1331.5\end{array}$ & $\begin{array}{c}\text { (re. } 71 . \\
166 \\
1 \times 3 \\
1 ! 11 \\
2111 \\
210 \\
1 \times 6 \\
2: 28 \\
250 \\
2101\end{array}$ & 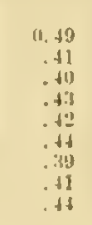 & $\begin{array}{r}0.15 \\
.37 \\
.53 \\
.52 \\
.15 \\
.10 \\
.13 \\
.12 \\
.17\end{array}$ & $\begin{array}{r}r y . j 1 \\
0.41 \\
.82 \\
.60 \\
.94 \\
.117 \\
.93 \\
1.17 \\
1.17 \\
1.37\end{array}$ \\
\hline Averng" & 211 & 2i. 0 & 124.0 & 213 &.+2 & .41 & 1.01 \\
\hline
\end{tabular}




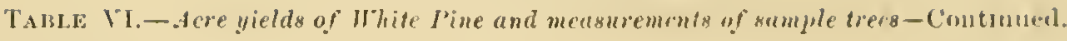

13.ーWISCONー1X-Continued.

(2) SITE $r$ :

W':ahlurn county.

Samp̧lit area : 3 acres.

[1.400 liet above sea level.]

dere Niv. 1.

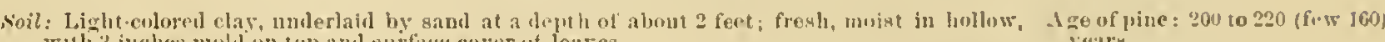

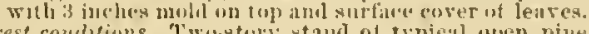

Dimats of rown vover: (i)

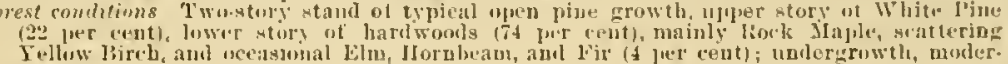

atcly dense, of young larel wools.

Nomblu.r of trees: 8 s

ACRE YIEIJ.

\begin{tabular}{|c|c|c|c|c|c|c|c|c|c|c|c|c|c|}
\hline \multicolumn{5}{|c|}{ W' hite I'ine. } & \multicolumn{3}{|c|}{ Rock Maple. } & \multicolumn{3}{|c|}{ Jelluw Jirrh. } & \multicolumn{3}{|c|}{ Elm. } \\
\hline $\begin{array}{l}\text { Num. } \\
\text { ber of } \\
\text { trees. }\end{array}$ & $\begin{array}{l}\text { Diame. } \\
\text { ter } \\
\text { (breasi } \\
\text { bigh). }\end{array}$ & Jluight. & Jole. & $\begin{array}{l}\text { Mer. } \\
\text { absint. } \\
\text { aline } \\
\text { timber. }\end{array}$ & $\begin{array}{l}\text { Xum- } \\
\text { hier of } \\
\text { trees. }\end{array}$ & $\begin{array}{c}\text { Viamuter } \\
\text { (liri:ist } \\
\text { higlis). }\end{array}$ & lleight. & $\begin{array}{l}\text { Numb } \\
\text { bis of } \\
\text { 1 reces. }\end{array}$ & $\begin{array}{l}\text { Diameter } \\
\text { (lireast } \\
\text { hishi). }\end{array}$ & Ileoight. & $\begin{array}{l}\text { Yum. } \\
\text { ber of } \\
\text { trees. }\end{array}$ & $\begin{array}{c}\text { Diameter } \\
\text { (breast } \\
\text { highl. }\end{array}$ & IIfiglit. \\
\hline \multirow{5}{*}{$\begin{array}{l}2 \\
1 \\
1 \\
2 \\
2 \\
1 \\
1 \\
1 \\
1 \\
2 \\
3 \\
1 \\
1\end{array}$} & \multirow{5}{*}{\begin{tabular}{|c|} 
Jnch 8 \\
18 \\
19 \\
21 \\
23 \\
26 \\
28 \\
32 \\
33 \\
34 \\
35 \\
38 \\
40 \\
40
\end{tabular}} & \multirow{5}{*}{$\begin{array}{c}\text { Fret. } \\
80 \\
\text { to } \\
120 \\
\\
\\
120 \\
t 0 \\
140\end{array}$} & \multirow{5}{*}{$\begin{array}{c}r u, j t . \\
160 \\
81 \\
113 \\
318 \\
400 \\
231 \\
2417 \\
315 \\
334 \\
706 \\
1,333 \\
4911 \\
638\end{array}$} & \multirow[t]{5}{*}{ FL.I.JI. } & \multirow{5}{*}{$\begin{array}{r}18 \\
24 \\
6 \\
1 \\
1\end{array}$} & \multirow{5}{*}{$\begin{array}{r}\text { Jnches. } \\
310 \text { 10 } \\
6 \text { to } 10 \\
10 \text { to } 14 \\
17 \\
19\end{array}$} & \multirow{5}{*}{$\begin{array}{c}\text { Fete } \\
10 \\
611 \\
80 \\
80 \\
80\end{array}$} & \multirow{5}{*}{$\begin{array}{l}1 \\
3 \\
2 \\
1 \\
1 \\
1 \\
1 \\
1\end{array}$} & \multirow{5}{*}{$\begin{array}{r}\text { luches } \\
3 \text { to } 6 \\
6 \text { to } 10 \\
10 \text { to } 14 \\
15 \\
16 \\
17 \\
20 \\
31\end{array}$} & \multirow{5}{*}{$\begin{array}{r}\text { Feet. } \\
40 \\
60 \\
80 \\
811 \\
80 \\
80 \\
80 \\
\text { over } \\
80\end{array}$} & \multicolumn{2}{|r|}{$\begin{array}{r}\text { Juches. } \\
15\end{array}$} & $\begin{array}{c}\text { Fert. } \\
80\end{array}$ \\
\hline & & & & & & & & & & & \multicolumn{3}{|c|}{ Hormbean. } \\
\hline & & & & & & & & & & & 3 & $x$ to 6 & 10 \\
\hline & & & & & & & & & & & \multicolumn{3}{|c|}{ Fir. } \\
\hline & & & & & & & & & & & 4 & 3106 & 4 \\
\hline 19 tre & $\begin{array}{l}\text { otal } \\
\text { otal cul } \\
\text { otal fee }\end{array}$ & $\begin{array}{l}\text { firet } \\
\text { II .. }\end{array}$ & .... & $\begin{array}{r}5,414 \\
32,480\end{array}$ & \multicolumn{3}{|c|}{50 trues. } & \multicolumn{3}{|c|}{12 trees. } & \multicolumn{3}{|c|}{8 trees. } \\
\hline
\end{tabular}

1 verage annual aceretion: White I'ine, 26 cuhje feet.
155 fiet $\mathrm{B}$. $\mathrm{I}$.

Acre No.?.

Soil: Lighteelored clas, underlaid by sand at a depth of abont 2 feet; fresh, woist in bollow, Age of pipe: 200to 220 (fer 160) with 3 inches uold on toj and surface cover of leares.

Forest conditions: Two-story stand of White l'ine ( 44 per cent) mixed with haritwonls (53 juer

cent). upper story of pine, the lower story of. hardwoods (linek Maple intermixed with

Yellow Lircb and scattering Hornbeam and Elm) and oceasional Fir (3 per cent); no noder. growth.

Classification:

Dominant

Thite Pine.

Oppressid.

.

ACRE YIELD

\begin{tabular}{|c|c|c|c|c|c|c|}
\hline \multicolumn{4}{|c|}{ White Pine. } & \multicolumn{3}{|c|}{ Rock Iraple. } \\
\hline \multirow[b]{2}{*}{$\begin{array}{l}\text { Number } \\
\text { of treos. }\end{array}$} & \multirow[b]{2}{*}{$\begin{array}{c}\text { Hianeter } \\
\text { (breast } \\
\text { lighlis. }\end{array}$} & \multicolumn{2}{|c|}{ Tolume. } & \multirow[b]{2}{*}{$\begin{array}{l}\text { Number } \\
\text { of trees. }\end{array}$} & \multirow[b]{2}{*}{$\begin{array}{c}\text { Diameter } \\
\text { (brea4t } \\
\text { high). }\end{array}$} & \multirow[b]{2}{*}{ Jleiglut. } \\
\hline & & Bule. & $\begin{array}{l}\text { Mer- } \\
\text { chantible } \\
\text { timber. }\end{array}$ & & & \\
\hline \multirow{8}{*}{$\begin{array}{r}1 \\
4 \\
4 \\
4 \\
4 \\
12 \\
4 \\
4 \\
8 \\
8 \\
4\end{array}$} & \multirow{8}{*}{$\begin{array}{r}\text { Juches. } \\
61011 \\
14 \\
18 \\
19 \\
20 \\
24 \\
26 \\
29 \\
31 \\
32 \\
45\end{array}$} & \multirow{8}{*}{$\begin{array}{r}\text { rubicfeet } \\
40 \\
20 \\
320 \\
348 \\
384 \\
1,992 \\
800 \\
988 \\
2,340 \\
2,376 \\
2,448\end{array}$} & \multirow[t]{8}{*}{ Feet B.JI } & $\begin{array}{l}36 \\
16\end{array}$ & $\begin{array}{l}\text { Juches. } \\
3 \text { to } 6 \\
6 \text { to } 10\end{array}$ & $\begin{array}{r}\text { Fert. } \\
40 \\
60\end{array}$ \\
\hline & & & & \multicolumn{3}{|c|}{ Yellow Jirch. } \\
\hline & & & & & & \\
\hline & & & & 12 & 6 tu 10 & 60 \\
\hline & & & & 4 & $\begin{array}{l}10 \text { to } 14 \\
14 \text { to } 18\end{array}$ & 80 \\
\hline & & & & & - & \\
\hline & & & & \multicolumn{3}{|c|}{ Fir. } \\
\hline & & & & 4 & $3 t w 6$ & 40 \\
\hline $\begin{array}{c}60 \text { trees } \\
\text { 'lou } \\
\text { 'lo }\end{array}$ & $\begin{array}{l}\text { cubic } f \\
\text { feet } b \text {. }\end{array}$ & ….... & $\begin{array}{l}\text {. } 12,136 \\
\text {.. } 72,810\end{array}$ & \multicolumn{3}{|l|}{76 trces: } \\
\hline
\end{tabular}

Average anmal aceretion: Whito Pine, $\begin{array}{r}58 \text { cnbic feet. } \\ 347 \text { feet } 13 \text {. II }\end{array}$ 


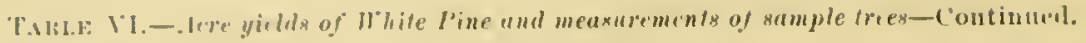

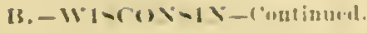

Icr. .0 .3

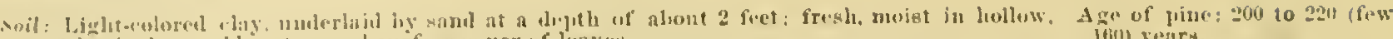

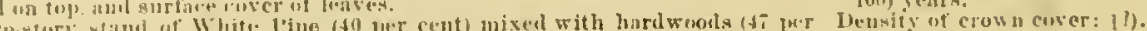

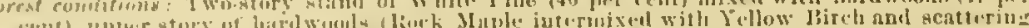

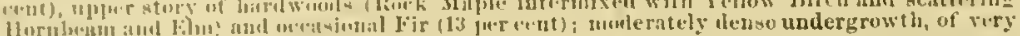

yeutus hardwods.
White I'ine.

Cleverifeution:

1 hinuisumt

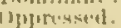

perecent..

silulurtaserl.

ACIRE T1LLD

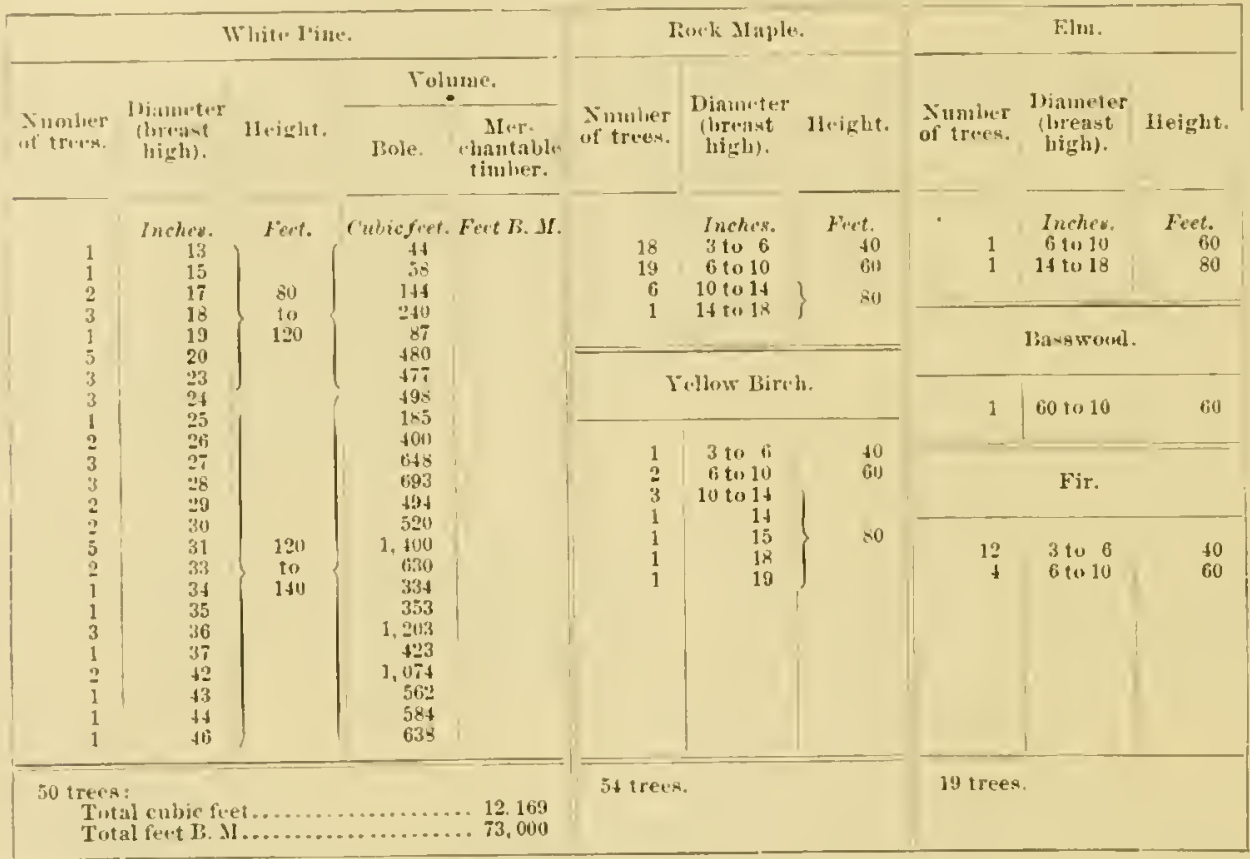

Average annual aceretion: White Jine, sis enbic feet.

MEASUUEMENTS OF SAMILE TREES

Age class: 100 to 150 years.

\begin{tabular}{|c|c|c|c|c|c|c|c|}
\hline Ттес ийын. & Age. & $\begin{array}{c}\text { 1)iameter } \\
\text { (lireast } \\
\text { bigli). }\end{array}$ & Meight. & $\begin{array}{l}\text { Volume } \\
\text { of tree. }\end{array}$ & $\begin{array}{l}\text { Factor } \\
\text { of } \\
\text { sbajue. }\end{array}$ & $\begin{array}{c}\text { Iintio of } \\
\text { lengti } \\
\text { of clown } \\
\text { to tutal } \\
\text { betight of } \\
\text { tree. }\end{array}$ & $\begin{array}{l}\text { A retaze } \\
\text { annuial } \\
\text { actre" } \\
\text { tins. }\end{array}$ \\
\hline 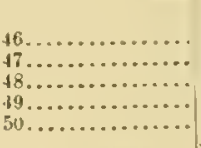 & $\begin{array}{l}\text { Feary. } \\
107 \\
104 \\
102 \\
120 \\
101\end{array}$ & $\begin{array}{r}\text { Inches. } \\
18.5 \\
18.0 \\
18.7 \\
19.3 \\
14.0\end{array}$ & $\begin{array}{l}F+t . \\
86.0 \\
80.0 \\
86.5 \\
90.0 \\
73.0\end{array}$ & $\begin{array}{r}C u . f \ell . \\
63 \\
70 \\
74 \\
81 \\
41\end{array}$ & $\begin{array}{r}0.39 \\
.49 \\
.47 \\
.46 \\
.52 \\
\end{array}$ & $\begin{array}{l}0.44 \\
.63 \\
.61 \\
.55 \\
.40\end{array}$ & $\begin{array}{r}C w .7 t \\
0.59 \\
.68 \\
.73 \\
.68 \\
.11\end{array}$ \\
\hline A тегаg"... & 107 & 17.7 & 83.5 & 66 & .46 & .52 & .61 \\
\hline 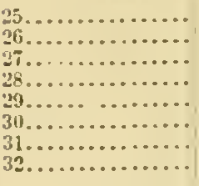 & $\begin{array}{l}1112 \\
1012 \\
100 \\
102 \\
1113 \\
112 \\
112 \\
105\end{array}$ & $\begin{array}{r}12.8 \\
13.21 \\
14.0 \\
19.7 \\
22.2 \\
18.8 \\
17.0 \\
5.6\end{array}$ & $\begin{array}{l}77.5 \\
73.5 \\
75.0 \\
79.5 \\
\times 3.0 \\
86.0 \\
86.5 \\
+1.5\end{array}$ & $\begin{array}{l}34 \\
36 \\
46 \\
56 \\
97 \\
81 \\
69 \\
4\end{array}$ & $\begin{array}{l}.49 \\
.51 \\
.51 \\
.92 \\
.43 \\
.49 \\
.50 \\
.50\end{array}$ & $\begin{array}{l}.30 \\
.48 \\
.37 \\
.58 \\
.49 \\
.50 \\
.41 \\
.51\end{array}$ & $\begin{array}{l}.34 \\
.35 \\
.41 \\
.54 \\
.94 \\
.70 \\
.59 \\
.38 \\
\end{array}$ \\
\hline Arerige... & 105.5 & 15.0 & 75.0 & 53 & .51 & .46 & .54 \\
\hline 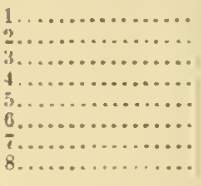 & $\begin{array}{l}104 \\
104 \\
101 \\
105 \\
100 \\
105 \\
102 \\
105\end{array}$ & $\begin{array}{l}15.3 \\
13.5 \\
16.5 \\
19.5 \\
14.11 \\
17.0 \\
16.5 \\
18.5\end{array}$ & $\begin{array}{r}91.0 \\
96.11 \\
98.0 \\
1411.11 \\
18.0 \\
104.0 \\
1160 \\
119.11\end{array}$ & $\begin{array}{l}52 \\
133 \\
6.5 \\
15 \\
50 \\
7.5 \\
110 \\
96\end{array}$ & $\begin{array}{l}.45 \\
.50 \\
.44 \\
.45 \\
.50 \\
.44 \\
.43 \\
.47\end{array}$ & $\begin{array}{c}.51 \\
.41 \\
\ldots .3 \% \\
.38 \\
.45 \\
.41 \\
.38\end{array}$ & $\begin{array}{l}.50 \\
.61 \\
.64 \\
.90 \\
.30 \\
.60 \\
.67 \\
.01\end{array}$ \\
\hline iserage ... & 1113 & 16.6 & (III). II & io & .46 & .42 & .08 \\
\hline $\begin{array}{l}1 \\
2 \ldots \ldots \ldots \ldots\end{array}$ & 137 & $\begin{array}{l}2411 \\
27.2\end{array}$ & $\begin{array}{l}105.0 \\
10 \% .0\end{array}$ & $\begin{array}{l}118 \\
201\end{array}$ & $\begin{array}{l}34 \\
.14 \\
\end{array}$ & $\begin{array}{l}.31 \\
.43 \\
\end{array}$ & $\begin{array}{l}.86 \\
1.42\end{array}$ \\
\hline Avrrage... & $1: 89$ & 26. 0 & 106.5 & 1.19 & .40 & $.3 \overline{1}$ & 1.14 \\
\hline
\end{tabular}


TAIIISS OF MEASTRIMENTS.

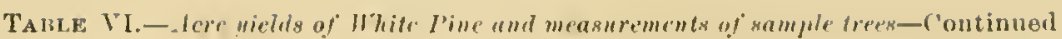
13.-WLACONSINーCOntinued.

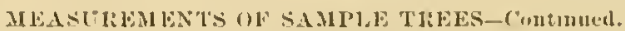

Lye class : 150 to 200 rente.

\begin{tabular}{|c|c|c|c|c|c|c|c|}
\hline Tree number. & Ag. & $\begin{array}{l}\text { Dianuter } \\
\text { (hienet } \\
\text { lijglis. }\end{array}$ & Ileight. & $\begin{array}{l}\text { Tolnme } \\
\text { of triv. }\end{array}$ & $\begin{array}{l}\text { liactor } \\
\text { of } \\
\text { shatio. }\end{array}$ & $\begin{array}{c}\text { Iatio of } \\
\text { lengtli } \\
\text { of crown } \\
\text { to total } \\
\text { buichlit of } \\
\text { tree. }\end{array}$ & $\begin{array}{c}\text { A rerage } \\
\text { annual } \\
\text { acero. } \\
\text { tion. }\end{array}$ \\
\hline & $\begin{array}{c}\text { Jentr. } \\
207\end{array}$ & $\begin{array}{c}\text { Inclies. } \\
113,0\end{array}$ & $\begin{array}{l}\text { Fert. } \\
94.5\end{array}$ & Cu.ft. & 0.50 & 0.45 & $\begin{array}{r}r u . r t \\
0.45\end{array}$ \\
\hline (n........... & 200 & 20,3 & 101.0 & 100 & .44 & .55 & $\begin{array}{r}0.40 \\
.50\end{array}$ \\
\hline . & 208 & 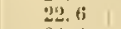 & 910.0 & 121 & .45 & .40 & .58 \\
\hline $16 \ldots \ldots \ldots \ldots$ & $1 ! 15$ & 24.3 & 97.0 & 133 & 43 & .32 & .198 \\
\hline $17 \ldots \ldots \ldots \ldots \ldots$ & 197 & 24.2 & 112.5 & 146 & .41 & .54 & .74 \\
\hline $18 \ldots \ldots \ldots \ldots \ldots$ & 196 & 23.0 & 116.0 & 154 & $.4 i$ & .16 & .79 \\
\hline ........... & 20,5 & 23.5 & 113.5 & 161 & .78 &.+2 & .78 \\
\hline ............ & 198 & 25.8 & 1116.5 & 166 &.+3 & .12 & .84 \\
\hline ............ & 217 & -6.5 & 114.5 & 192 & .35 & .58 & .88 \\
\hline (n....... & 197 & 29.0 & 115.0 & 230 & .45 & .63 & 1. 20 \\
\hline a........ & 210 & 31.0 & 115.0 & 253 & .42 & .59 & 1.20 \\
\hline ............ & 202 & :311. & 127.5 & 282 &.+4 & .47 & 1.40 \\
\hline ............ & 305 & 33.3 & $3 \geq 0.0$ & 304 &.+2 & .43 & 1.45 \\
\hline n.......... & 205 & 25.6 & 101.5 & 161 & .44 & .39 & .78 \\
\hline …....... & 204 & 25.3 & 116.5 & 175 &.+3 & .51 & .86 \\
\hline .......... & 925 & $2 \pi .2$ & 110.0 & 175 & .87 & .50 & .78 \\
\hline ............ & 2006 & 28.5 & 103.0 & 183 & .30 & .43 & .89 \\
\hline . . n & 207 & 28.5 & 119.0 & 213 &.$\$ 0$ & .34 & 1.03 \\
\hline $31 .$. & $20 t$ & 32.0 & 111.5 & 274 & .44 & .54 & 1.34 \\
\hline 32. & 205 & 32.0 & 115.0 & $28 \mathrm{~L}$ & .44 & .69 & 1.37 \\
\hline 33. & 200 & 34.19 & 117.0 & 285 & .39 & .43 & 1.43 \\
\hline$\cdots \cdots$ & 201 & 38.3 & 119.0 & 208 & .411 & .61 & 1. 03 \\
\hline Arerage. & 204 & 27.0 & 111.0 & 195 & .47 & .49 & 1. 75 \\
\hline $40 .$. & 195 & 16.0 & 108.0 & 75 & $.1 i$ & .44 & .38 \\
\hline 35. & 201 & 22." & 95.0 & 115 & 11.45 & 0.63 & 0.57 \\
\hline 36. & 191 & 29.0 & 116.0 & 216 & .41 & .55 & 1.13 \\
\hline & 216 & 28.5 & 120.0 & 362 & .49 & .52 & 1.21 \\
\hline $38 \ldots$ & 2211 & 34.5 & 128.0 & 308 & .37 & .56 & 1.10 \\
\hline $39 .$. & 207 & 35.0 & 126.0 & 342 &.+1 & .34 & 1.65 \\
\hline A rernge... & 207 & 29.8 & 117.0 & 249 & .43 & .53 & 1.19 \\
\hline$\ldots \ldots$ & 204 & $3 \pm 0$ & 118.0 & 274 & .37 & .51 & 1.34 \\
\hline & 209 & 35.5 & 121.0 & 305 & .37 & .55 & 1. 46 \\
\hline ............. & 200 & 35.0 & 116.0 & 306 & .40 & .41 & 1.53 \\
\hline ... & 212 & 34.0 & 120.0 & 313 & .42 & 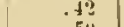 & 1.48 \\
\hline ........... & 210 & 33.5 & $1+1.0$ & 323 & .37 & .50 & 1. it \\
\hline $6 .$. & 212 & 37.0 & $1: 8.0$ & 355 & .37 & .64 & 1. 68 \\
\hline , n...... & 214 & 38.0 & 114.0 & $35 \overline{1}$ & .40 & .47 & 1. 67 \\
\hline .......... & 206 & 38.0 & 127.0 & $3 i 1$ & .37 & .46 & 1.80 \\
\hline $9 \ldots \ldots \ldots \ldots \ldots$ & 200 & 37.0 & 127.0 & 399 & .42 & .61 & 1.81 \\
\hline $10 \ldots \ldots \ldots \ldots \ldots$ & 210 & +2. 0 & 140.0 & 506 & .38 & .60 & 2. $\$ 1$ \\
\hline $11 \ldots \ldots \ldots \ldots \ldots$ & 210 & 43.0 & 141.0 & 577 & .40 & $.5 t i$ & 2.75 \\
\hline $12 \ldots \ldots \ldots \ldots \ldots$ & 210 & 50.0 & 138.0 & 726 & .39 & .51 & 3.46 \\
\hline A trerage... & 210 & 38.11 & 128.0 & 401 & .39 & .52 & 1.91 \\
\hline $41 \ldots \ldots \ldots \ldots \ldots$ & 166 & 25. 0 & 105.0 & 158 & .44 & $.3 s$ & .95 \\
\hline$\$ 2 \ldots \ldots \ldots \ldots \ldots$ & 151 & 241.5 & 103.0 & 175 & .36 & .52 & 1.16 \\
\hline $13 \ldots \ldots \ldots$ & 167 & $\because 8.7$ & 96.0 & $17+i$ & .41 & .55 & 1.05 \\
\hline$\$ 4 \ldots \ldots \ldots \ldots \ldots$ & 155 & 29.0 & 101.5 & 201 & .43 & .52 & 1.30 \\
\hline $45 \ldots \ldots \ldots$ & 155 & 28.0 & 113.5 & 217 & .45 &.+1 & 1.40 \\
\hline Averago... & 159 & 28.0 & 104.0 & 185 & .12 & .47 & 1.17 \\
\hline
\end{tabular}


TAlst: VI.- Arre gielils of Ithite line and measurenents of sample trees-Continued.

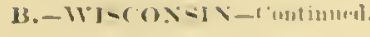

(3) Sitr.e. liarrun f'untity.

lere lio. 1.

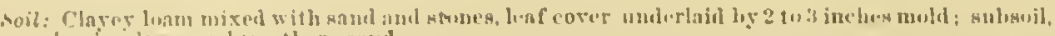

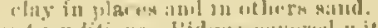

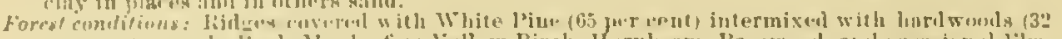

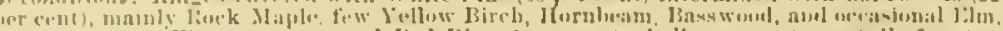

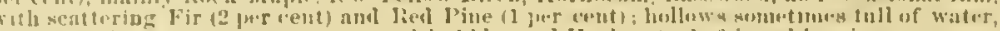

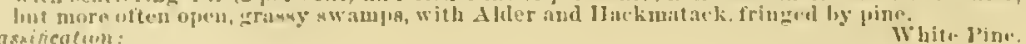
Clasrificalum:

IDiminimt.

ippreasul

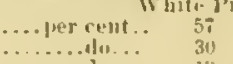

Samplo area: 3 acris.

Aye of pine: 100 to 200 if (44) te 10011 y.n

Tresin

Ximber of tren: 106.

ACIE: III:I1

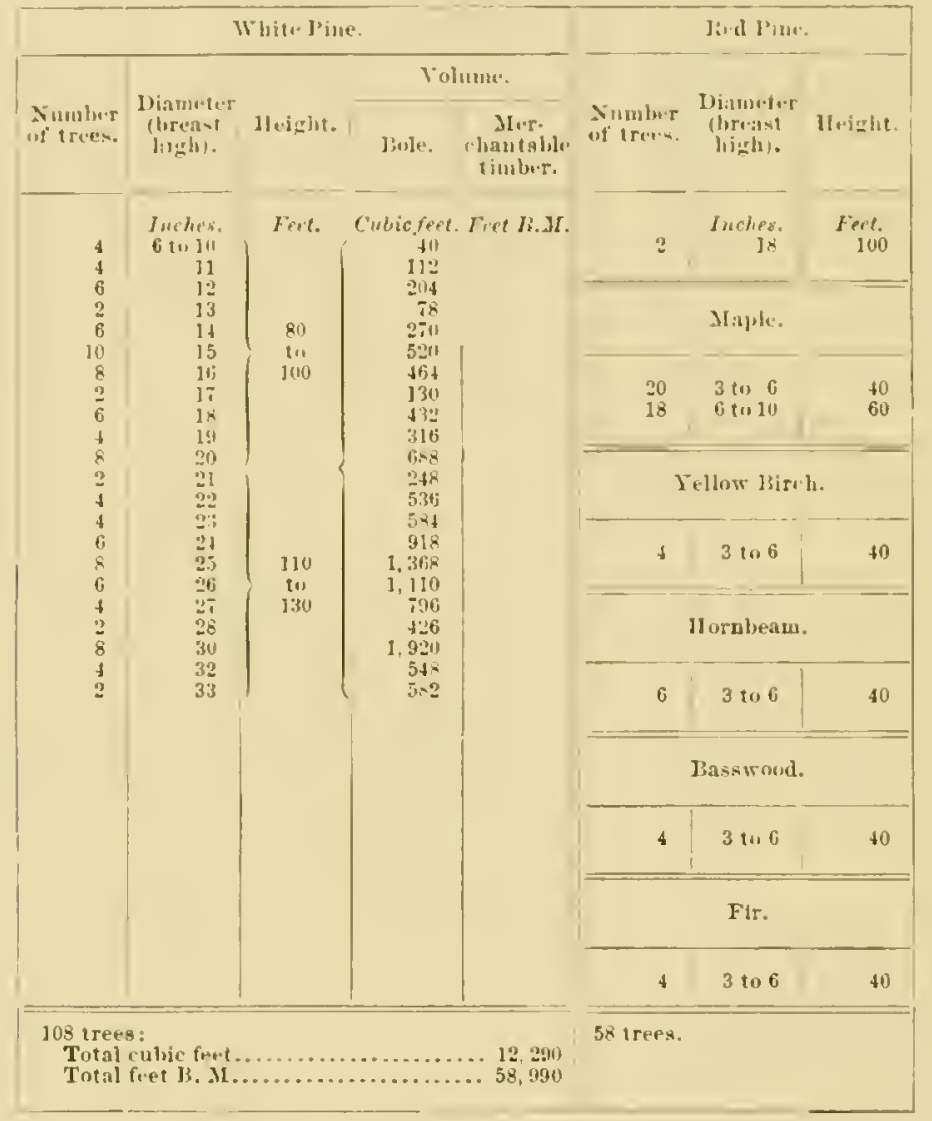

Average annual accetion: Whito I'ine, 05 euhic feet. 


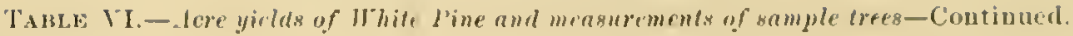

13. - WISCUNiT-Continued.

$$
\text { At cre Sio. 2. }
$$

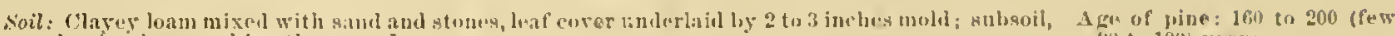

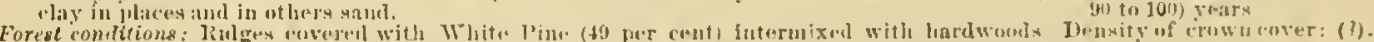

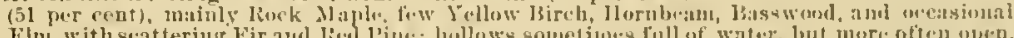

graws swamps, with Aliler and llackmatack, fringrol ly pine.

Classification:

(1)

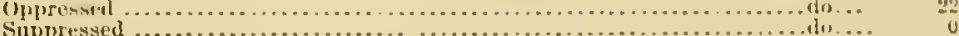

ACliE YIELI.

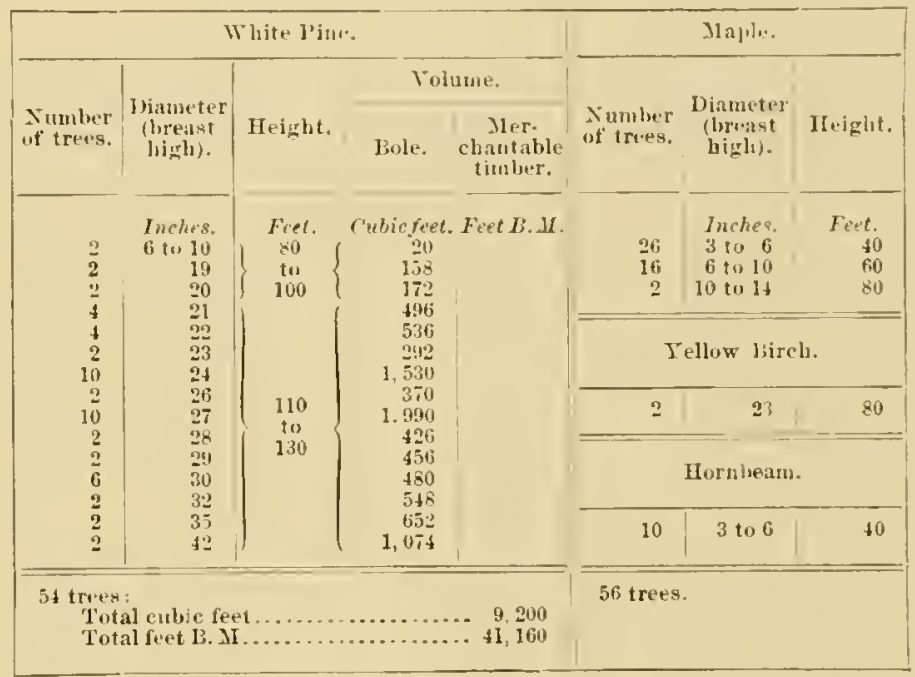

Average annual accretion: White Pine, 48 cubic fert. 


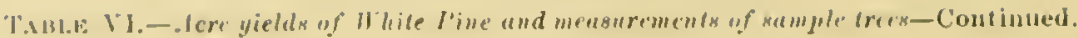

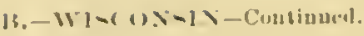

lere lin. is

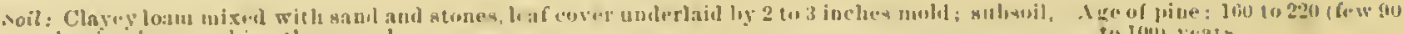

clay in jlates aul in othere sand.

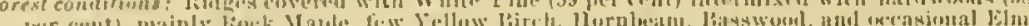
$j^{m+r}{ }^{2}$

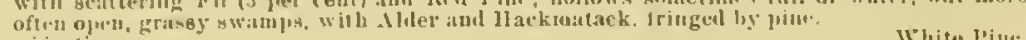
Whito l'ill.

Classificafion:
Duminant

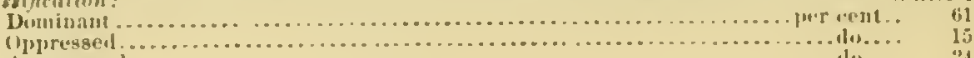
(IPIressed 15 Nimber of treen: ] th.

ICI:I: IELD.

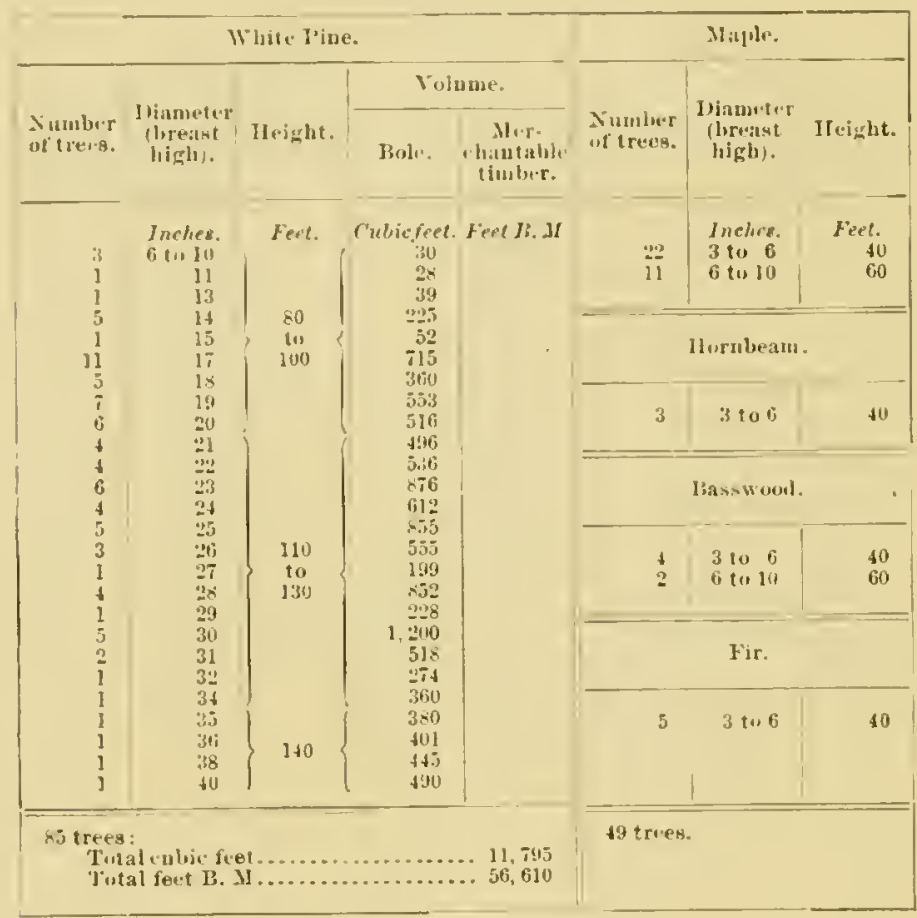

Average annual accetion: White $1^{\prime}$ imr, 62 cobic feet. 
TABIs: VI.- fore yields of White P'in and merasurmenta of sample trees-Continued.

33.-Wincoxistx-1'ontinnet.

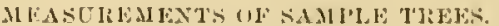

1 ge class: 2010 tu 220 years.

\begin{tabular}{|c|c|c|c|c|c|c|c|}
\hline 'Treo number. & Age. & $\begin{array}{l}\text { Dimmeler } \\
\text { (breist } \\
\text { highlis. }\end{array}$ & Jligight. & $\begin{array}{l}\text { Volume } \\
\text { of trise. }\end{array}$ & $\begin{array}{c}\text { Factor } \\
\text { of } \\
\text { shitive. }\end{array}$ & $\begin{array}{l}\text { liation } \\
\text { lengtli } \\
\text { of crown } \\
\text { to totul } \\
\text { height of } \\
\text { tire. }\end{array}$ & $\begin{array}{l}\text { A rurage } \\
\text { anuuit } \\
\text { acure- } \\
\text { tion. }\end{array}$ \\
\hline 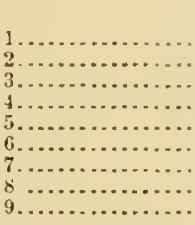 & $\begin{array}{c}\text { Fours. } \\
204 \\
210 \\
207 \\
200 \\
206 \\
20.5 \\
210 \\
214 \\
210\end{array}$ & $\begin{array}{r}\text { Inches. } \\
27.3 \\
25.2 \\
31.0 \\
29.5 \\
29.2 \\
30.0 \\
34.0 \\
36.0 \\
39.0\end{array}$ & $\begin{array}{l}\text { Feet. } \\
123.0 \\
137.0 \\
127.5 \\
116.0 \\
130.5 \\
131.0 \\
118.5 \\
113.5 \\
130.0\end{array}$ & Cu. it. & $\begin{array}{l}0.41 \\
.48 \\
.37 \\
.13 \\
.46 \\
.43 \\
.39 \\
.39 \\
.38\end{array}$ & $\begin{array}{l}0.59 \\
.11 \\
.35 \\
.31 \\
.39 \\
.52 \\
.37 \\
.38 \\
.49\end{array}$ & $\begin{array}{r}\text { ('t. } f . \\
1.07 \\
1.08 \\
1.19 \\
1.20 \\
1.37 \\
1.38 \\
1.40 \\
1.46 \\
1.98\end{array}$ \\
\hline Averigo... & 207 & 31.0 & 125.0 & 280 & .42 & .43 & 1.35 \\
\hline 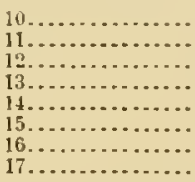 & $\begin{array}{l}211 \\
211 \\
208 \\
200 \\
207 \\
204 \\
205 \\
212 \\
204\end{array}$ & $\begin{array}{l}20.2 \\
23.6 \\
29.8 \\
27.2 \\
27.0 \\
27.0 \\
27.8 \\
27.3\end{array}$ & $\begin{array}{l}116.0 \\
113.0 \\
121.0 \\
107.5 \\
121.0 \\
112.0 \\
104.5 \\
112.0\end{array}$ & $\begin{array}{l}132 \\
145 \\
153 \\
200 \\
204 \\
210 \\
180 \\
1815\end{array}$ & $\begin{array}{l}.51 \\
.43 \\
45 \\
.46 \\
.42 \\
.43 \\
.11 \\
41\end{array}$ & $\begin{array}{l}64 \\
.42 \\
.45 \\
.28 \\
.43 \\
.13 \\
.25 \\
.51 \\
.41\end{array}$ & $\begin{array}{r}.63 \\
.65 \\
.70 \\
.97 \\
1.00 \\
1.02 \\
.85 \\
.91\end{array}$ \\
\hline Average... & 211 & 25.0 & 114.0 & 1i: & .14 & .42 & .84 \\
\hline
\end{tabular}

Ige class: 160 to 180 years.

\begin{tabular}{|c|c|c|c|c|c|c|c|}
\hline 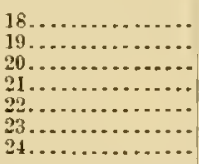 & $\begin{array}{l}168 \\
165 \\
173 \\
163 \\
162 \\
174 \\
166\end{array}$ & $\begin{array}{l}30.1 \\
28.1 \\
28.1 \\
17.8 \\
23.0 \\
28.0 \\
25.4\end{array}$ & $\begin{array}{r}121.5 \\
120.0 \\
127.0 \\
91.5 \\
101.0 \\
108.5 \\
161.0\end{array}$ & $\begin{array}{l}2116 \\
221 \\
257 \\
72 \\
130 \\
167 \\
166\end{array}$ & $\begin{array}{l}0.35 \\
.41 \\
.16 \\
.46 \\
.46 \\
.36 \\
.45\end{array}$ & $\begin{array}{r}0.49 \\
.50 \\
.35 \\
.34 \\
.34 \\
.34 \\
.52\end{array}$ & $\begin{array}{r}1.30 \\
1.36 \\
1.49 \\
.44 \\
.80 \\
.90 \\
1.00\end{array}$ \\
\hline Arerago... & 167 & 26.0 & 110.0 & lit & .42 & .47 & 1.04 \\
\hline
\end{tabular}




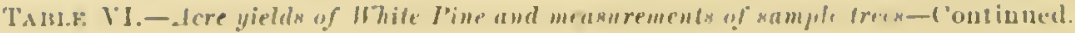

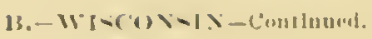
(1) SITEi:
Waaburn rimntr.

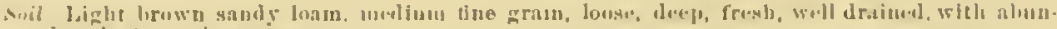

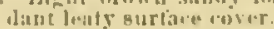

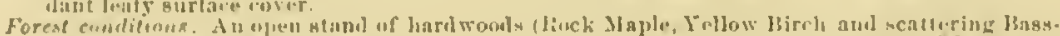

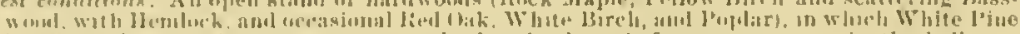

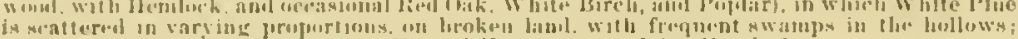

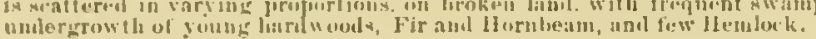

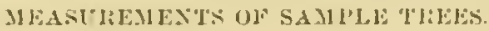

Age class: 811 10 100 suars.

\begin{tabular}{|c|c|c|c|c|c|c|c|c|c|}
\hline True numlur. & $A=0$. & $\begin{array}{l}\text { Ihameier } \\
\text { (hirenst } \\
\text { liishlil. }\end{array}$ & Hejult. & $\begin{array}{l}\text { Jiags } \\
\text { jer iurh } \\
\text { oun } \\
\text { stump. }\end{array}$ & $\begin{array}{l}\text { Folntme } \\
\text { of treen. }\end{array}$ & $\begin{array}{l}\text { Jouctor } \\
\text { of } \\
\text { shinjere. }\end{array}$ & 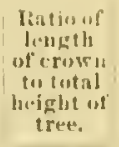 & $\begin{array}{c}\text { Current :umual } \\
\text { ateretioa. }\end{array}$ & $\begin{array}{l}\text { Averagen } \\
\text { sunual } \\
\text { incere. } \\
\text { ifon. }\end{array}$ \\
\hline 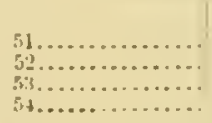 & $\begin{array}{l}\text { linns. } \\
54 \\
6 \pm 1 \\
6,8 \\
90\end{array}$ & $\begin{array}{r}\text { Inchirg. } \\
5.5 \\
6.0 \\
6.8 \\
6.8\end{array}$ & $\begin{array}{l}\text { Feel. } \\
37 \\
10 \\
46 \\
38\end{array}$ & 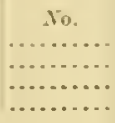 & $\begin{array}{c}\text { Cubicjeet. } \\
3.2 \\
4.2 \\
5.5 \\
4.8\end{array}$ & $\begin{array}{r}0.52 \\
.53 \\
.48 \\
.50\end{array}$ & $\begin{array}{l}0.57 \\
.511 \\
.79 \\
.47\end{array}$ & 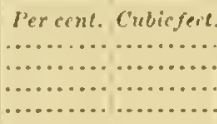 & $\begin{array}{c}\text { rubicjeet. } \\
.067 \\
.07 \\
.04 \\
.115\end{array}$ \\
\hline Average... & $6 \times 5$ & 6.3 & 411 & $\ldots \ldots \ldots$ & 4.4 & .31 & $.36 t^{\circ}$ & .. & .06 \\
\hline
\end{tabular}

LONIXANT GRWWH

\begin{tabular}{|c|c|c|c|c|c|c|c|c|c|c|}
\hline 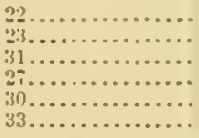 & $\begin{array}{r}82 \\
81 \\
\times 3 \\
79 \\
81 \\
801\end{array}$ & $\begin{array}{l}14.0 \\
14.7 \\
15.0 \\
15.0 \\
13.0 \\
18.7\end{array}$ & $\begin{array}{l}82 \\
84 \\
82 \\
83 \\
85 \\
96\end{array}$ & $\begin{array}{l}5.5 \\
5.6 \\
4.6 \\
4.8 \\
3.9 \\
3.9\end{array}$ & $\begin{array}{l}43.0 \\
48.0 \\
48.1 \\
50.8 \\
78.2 \\
85.7\end{array}$ & $\begin{array}{l}0.49 \\
.50 \\
.44 \\
.48 \\
.46 \\
.47\end{array}$ & $\begin{array}{r}0.39 \\
.42 \\
.41 \\
.31 \\
.37 \\
.51\end{array}$ & $\begin{array}{l}\text { 4. } 0 \\
2.7 \\
5.2 \\
3.2 \\
2.4 \\
\text { 1. } 6\end{array}$ & $\begin{array}{l}1.72 \\
1.31 \\
2.30 \\
1.62 \\
1.88 \\
3.24\end{array}$ & $\begin{array}{l}0.52 \\
.611 \\
.58 \\
.64 \\
.98 \\
.640\end{array}$ \\
\hline Average & 82.5 & 16. 0 & 83 & 4. 6 & 59.0 & .45 & .40 & 3. 7 & 2. 113 & .71 \\
\hline
\end{tabular}

OPPRESSED GROWTH.

\begin{tabular}{|c|c|c|c|c|c|c|c|c|c|c|}
\hline $\begin{array}{l}26 \ldots \ldots \ldots \ldots \ldots \\
32 \ldots \ldots \ldots \ldots \ldots \ldots \ldots \\
29 \ldots \ldots \ldots \ldots \ldots \ldots\end{array}$ & $\begin{array}{l}82 \\
81 \\
811 \\
412\end{array}$ & $\begin{array}{l}11.3 \\
11.8 \\
11.9 \\
11.5\end{array}$ & $\begin{array}{r}101 \\
77 \\
81 \\
79\end{array}$ & $\begin{array}{l}6.6 \\
\text { f. } \\
5.7 \\
5.6\end{array}$ & $\begin{array}{l}30.7 \\
30.5 \\
32.8 \\
39.7\end{array}$ & $\begin{array}{l}0.43 \\
.50 \\
.51 \\
.43\end{array}$ & $\begin{array}{r}0.40 \\
.37 \\
.33 \\
.54\end{array}$ & $\begin{array}{l}3.1 \\
4.0 \\
4.6 \\
3.6\end{array}$ & $\begin{array}{l}0.83 \\
1.22 \\
1.51 \\
1.43\end{array}$ & $\begin{array}{r}0.36 \\
.37 \\
.41 \\
.43\end{array}$ \\
\hline Averagf... & 84 & 12.4 & 81.5 & 6.0 & 33.3 & .40 &.+1 & 3.8 & 1.27 & .39 \\
\hline
\end{tabular}

SCPYRESSED HKOW'M.

\begin{tabular}{|l|l|l|l|lll|l|l|l|l|}
\hline $18 \ldots \ldots \ldots \ldots \ldots$ & $12 \pi$ & 14 & 73 & 6.5 & 39.7 & 0.50 & 0.31 & 4.3 & 1.71 & 0.31 \\
\hline
\end{tabular}

Age class: 120 to 130 years.

HOMIAXT GHOWTH.

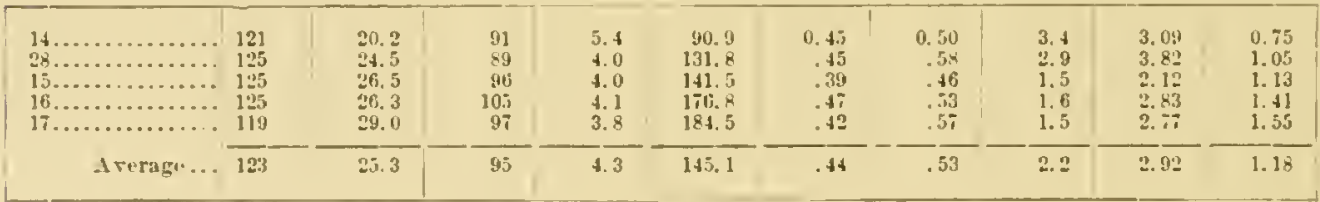

A je clase: 220 tu 230 years.

DOMMAX] GROWTU.

\begin{tabular}{|c|c|c|c|c|c|c|c|c|c|c|}
\hline 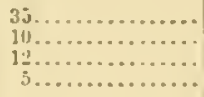 & $\begin{array}{l}223 \\
223 \\
228 \\
210\end{array}$ & $\begin{array}{l}30.5 \\
31.0 \\
35.3 \\
35.0\end{array}$ & $\begin{array}{l}116 \\
112 \\
124 \\
118\end{array}$ & $\begin{array}{l}7.0 \\
7.0 \\
6.0 \\
6.0\end{array}$ & $\begin{array}{l}237.4 \\
240.6 \\
3: 22.2 \\
359.4\end{array}$ & $\begin{array}{r}0.41 \\
.12 \\
.411 \\
.45\end{array}$ & $\begin{array}{r}0.38 \\
.56 \\
.48 \\
.44\end{array}$ & $\begin{array}{r}0.8 \\
.6 \\
.5 \\
.7\end{array}$ & $\begin{array}{l}1.510 \\
1.48 \\
1.61 \\
2.52\end{array}$ & $\begin{array}{l}1.00 \\
1.10 \\
1.41 \\
1.64\end{array}$ \\
\hline Averagn ... & 223 & 33.0 & 117 & 6.5 & 291.5 & .42 & .413 & .0 & 1.88 & 1.30 \\
\hline
\end{tabular}


TABI.: VI.-Acre yichls of White Pine and mensurmenls of xample trees-Continned.

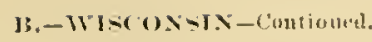

(5) SiTE $g$

Wasluburn County.

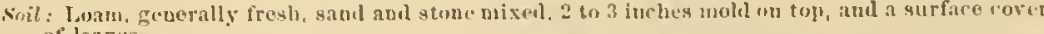

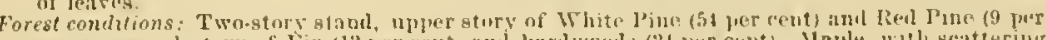

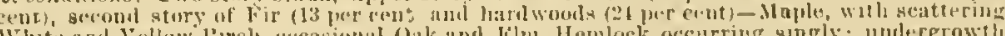

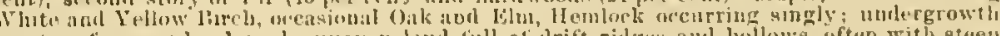

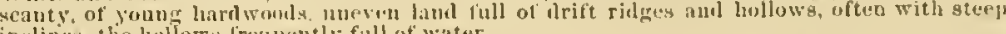
inclines, the loblow frepurantly full of water.

Classigiction

()ominatit.

Sulpressed Whitr. Pine.
Samplearia 1 awre.

1 ige of pine: 180 to 230 yenrs. bensity of rown cover: (1)

Numbr of tren: I 143

\section{AClil IIEL,}

\begin{tabular}{|c|c|c|c|c|c|c|c|c|c|c|}
\hline \multirow[b]{3}{*}{$\begin{array}{l}\text { Numker } \\
\text { of treses. }\end{array}$} & \multicolumn{4}{|c|}{ White Jinu. } & \multicolumn{3}{|c|}{ Rivd P'ine. } & \multicolumn{3}{|c|}{ Maple. } \\
\hline & \multirow[b]{2}{*}{$\begin{array}{l}\text { Diameter } \\
\text { (bretist } \\
\text { high). }\end{array}$} & \multirow[b]{2}{*}{ Iloinht. } & \multicolumn{2}{|c|}{ Folume. } & \multirow[b]{2}{*}{$\begin{array}{l}\text { Number } \\
\text { of tires. }\end{array}$} & \multirow[b]{2}{*}{$\begin{array}{l}\text { Diameter } \\
\text { (brinst } \\
\text { highis. }\end{array}$} & \multirow[b]{2}{*}{ Ileight. } & \multirow[b]{2}{*}{$\begin{array}{l}\text { Numler } \\
\text { of trees. }\end{array}$} & \multirow[b]{2}{*}{$\begin{array}{l}\text { Divmeter } \\
\text { (breast } \\
\text { liivla). }\end{array}$} & \multirow[b]{2}{*}{ Ileight. } \\
\hline & & & Jiole. & $\begin{array}{l}\text { Mur. } \\
\text { chantable } \\
\text { timbrer. }\end{array}$ & & & & & & \\
\hline $\begin{array}{l}3 \\
3 \\
3 \\
1 \\
3 \\
3\end{array}$ & \multirow{5}{*}{$\begin{array}{c}\text { Inches. } \\
6 \text { to } 10 \\
11 \\
12 \\
13 \\
14 \\
15 \\
16 \\
17 \\
18 \\
19 \\
20 \\
21 \\
22 \\
23 \\
24 \\
25 \\
26 \\
27 \\
29 \\
31 \\
32 \\
33 \\
34\end{array}$} & \multirow{5}{*}{$\begin{array}{l}100 \\
20 \\
120\end{array}$} & \multirow{5}{*}{$\begin{array}{c}\text { rubicfret. } \\
30 \\
54 \\
34 \\
117 \\
180 \\
260 \\
116 \\
325 \\
176 \\
4 \times 0 \\
525 \\
512 \\
492 \\
4112 \\
438 \\
785 \\
1,014 \\
364 \\
627 \\
237 \\
251 \\
367 \\
560\end{array}$} & \multirow[t]{5}{*}{ Feet B.M. } & \multirow{5}{*}{$\begin{array}{l}3 \\
2 \\
1 \\
1 \\
2 \\
1 \\
3 \\
1 \\
1 \\
1\end{array}$} & \multirow{5}{*}{$\begin{array}{r}\text { Ihehes: } \\
15 \\
16 \\
17 \\
18 \\
19 \\
20 \\
24 \\
25 \\
26\end{array}$} & \multirow{5}{*}{$\begin{array}{c}\text { Fert. } \\
\\
80 \\
t 11 \\
120\end{array}$} & $\begin{array}{r}9 \\
16 \\
3\end{array}$ & $\begin{array}{r}\text { Inches. } \\
3 \text { to } 6 \\
6 \text { to } 10 \\
10 \text { to } 14\end{array}$ & $\begin{array}{r}\text { Fert. } \\
40 \\
611 \\
80\end{array}$ \\
\hline $\begin{array}{l}4 \\
5 \\
5 \\
5\end{array}$ & & & & & & & & & Bireh. & \\
\hline $\begin{array}{l}2 \\
3 \\
3 \\
8 \\
4 \\
3\end{array}$ & & & & & & & & $\begin{array}{l}2 \\
3 \\
1 \\
1\end{array}$ & $\begin{array}{rlr}3 \text { (1) } & 6 \\
6 \text { (1) } & 10 \\
& 14 \\
& & 16 \\
& & \\
\end{array}$ & $\begin{array}{l}40 \\
60 \\
80\end{array}$ \\
\hline $\begin{array}{l}3 \\
3 \\
6\end{array}$ & & & & & & & & & Fir. & \\
\hline $\begin{array}{l}2 \\
3 \\
1 \\
1 \\
1 \\
2 \\
\end{array}$ & & & & & & & & $\begin{array}{r}16 \\
2\end{array}$ & $\begin{array}{l}3 \text { to } 6 \\
6 \text { to } 10\end{array}$ & $\begin{array}{l}40 \\
60\end{array}$ \\
\hline \multicolumn{5}{|c|}{ 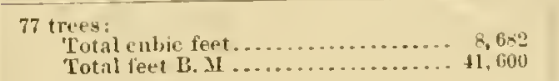 } & \multicolumn{3}{|c|}{$\begin{array}{l}13 \text { trees: } \\
\text { Total euhie feet . } 1,469 \\
\text { Total fiet B. } .11 \ldots 6,160\end{array}$} & \multicolumn{3}{|l|}{53 trees. } \\
\hline
\end{tabular}

Averagc annual accetion: 1'ine, $51 \mathrm{cubic}$ feet.
339 feet $\mathrm{F}$. II.

MEASTLEMLNTS CF SAIILE TREES

Alye closs : 220 to 230 years.

\begin{tabular}{|c|c|c|c|c|c|c|c|}
\hline Tree mumber. & Age. & $\begin{array}{c}\text { Piameter } \\
\text { (breast } \\
\text { ligh). }\end{array}$ & IIeight. & $\begin{array}{l}\text { Volume } \\
\text { of tree. }\end{array}$ & $\begin{array}{l}\text { Fiaetur } \\
\text { of } \\
\text { shape. }\end{array}$ & $\begin{array}{l}\text { Iatio of } \\
\text { length } \\
\text { of crown } \\
\text { to total } \\
\text { beight of } \\
\text { trec. }\end{array}$ & $\begin{array}{c}\text { A rernge } \\
\text { annwal } \\
\text { acerte } \\
\text { timn. }\end{array}$ \\
\hline 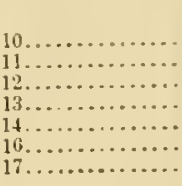 & $\begin{array}{c}\text { 1'ars. } \\
=16 \\
222 \\
218 \\
220 \\
208 \\
220 \\
218\end{array}$ & $\begin{array}{r}\text { Iwches. } \\
31.8 \\
35.0 \\
34.8 \\
34.0 \\
15.0 \\
24.5 \\
29.0\end{array}$ & $\begin{array}{r}\text { Feet. } \\
121.5 \\
123.5 \\
116.5 \\
100.0 \\
96.0 \\
107.5 \\
118.0\end{array}$ & $\begin{array}{c}\text { Culbicfice } \\
287 \\
344 \\
16 i 1 \\
3 i t i \\
5 x \\
1,5 \\
240\end{array}$ & $\begin{array}{r}0.43 \\
.42 \\
.41 \\
.49 \\
.50 \\
.45 \\
.44\end{array}$ & $\begin{array}{l}0.40 \\
.46 \\
.40 \\
.27 \\
.47 \\
.35 \\
.49\end{array}$ & $\begin{array}{c}\text { Cubicfect. } \\
1.33 \\
1.55 \\
.70 \\
.78 \\
.28 \\
.71 \\
1.10\end{array}$ \\
\hline Arerage. & 219 & 26. 3 & 112.0 & 200 & .45 & .40 & .92 \\
\hline
\end{tabular}

Aye class: 1 till to 180 y"urs.

\begin{tabular}{|c|c|c|c|c|c|c|c|}
\hline 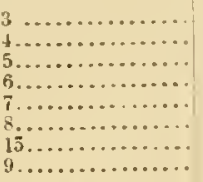 & $\begin{array}{l}164 \\
170 \\
178 \\
170 \\
175 \\
168 \\
185 \\
173\end{array}$ & $\begin{array}{l}23.5 \\
24.0 \\
34.2 \\
25.7 \\
37.3 \\
30.5 \\
3.3 .2 \\
36.0\end{array}$ & $\begin{array}{l}104.5 \\
119.0 \\
114.0 \\
111.5 \\
122.11 \\
114.0 \\
110.5 \\
112.1\end{array}$ & $\begin{array}{l}127 \\
172 \\
176 \\
181 \\
217 \\
230 \\
138 \\
190\end{array}$ & $\begin{array}{l}0.40 \\
.415 \\
.48 \\
.45 \\
.43 \\
.44 \\
.42 \\
.46\end{array}$ & $\begin{array}{l}0.40 \\
.41 \\
.38 \\
.41 \\
.46 \\
.42 \\
.34 \\
.28\end{array}$ & $\begin{array}{r}0.79 \\
1.111 \\
.99 \\
1.07 \\
1.24 \\
1.52 \\
1.74 \\
1.70\end{array}$ \\
\hline Arerige. . & 172 & 25.5 & 113.0 & $1 \leqslant 2$ & .41 & .39 & 1.06 \\
\hline
\end{tabular}




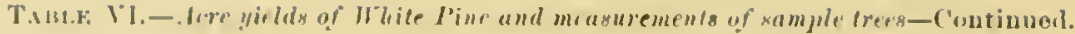

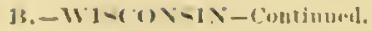

(i) SiTt: $\%$

Lincolu Counts.

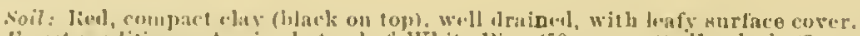

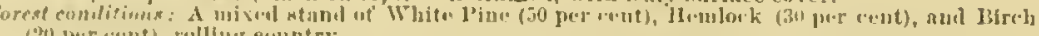
20 jwr cont), rulliug eountry.

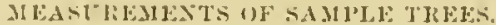

1.7e clans: $10 \mathrm{us}$ to 150 venrs.

\begin{tabular}{|c|c|c|c|c|c|c|c|c|c|}
\hline Tree numlse:. & $\begin{array}{c}\text { Dimueter } \\
\text { (breastst } \\
\text { bighlo. }\end{array}$ & IIviglit. & $\begin{array}{l}\text { Volume } \\
\text { of tree. }\end{array}$ & $\begin{array}{l}\text { Factur } \\
\text { uf } \\
\text { shaje. }\end{array}$ & Tree naubser. & $\begin{array}{c}\text { 1)imueter } \\
\text { (lireast } \\
\text { bigh). }\end{array}$ & Helght. & $\begin{array}{l}\text { Tolume } \\
\text { of tree. }\end{array}$ & $\begin{array}{c}\text { Facior } \\
\text { of } \\
\text { Hhaje. }\end{array}$ \\
\hline $\begin{array}{r}60 \ldots \ldots \ldots \ldots \ldots \\
5, \ldots \ldots \ldots \ldots \ldots \ldots\end{array}$ & $\begin{array}{c}\text { Inrhes. } \\
21.0 \\
20.5\end{array}$ & $\begin{array}{r}\text { Feet. } \\
97 \\
97\end{array}$ & $\begin{array}{c}\text { Cue.ft. } \\
\text { lus. } 1 \\
105.8\end{array}$ & $\begin{array}{r}10.48 \\
.45\end{array}$ & 25. & $\begin{array}{c}\text { Inchis. } \\
30.5\end{array}$ & $\begin{array}{l}\text { Fieet. } \\
114\end{array}$ & $\begin{array}{c}C w ., t \\
308.5\end{array}$ & .38 \\
\hline $86 \ldots \ldots \ldots \ldots$ & 313.5 & 104 & 276.2 & .37 & Average..... & 28.6 & 103 & 190.0 & .43 \\
\hline
\end{tabular}

Lye class: 150 to 210 yours.

\begin{tabular}{|c|c|c|c|c|c|c|c|c|c|}
\hline 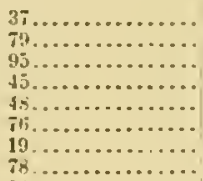 & $\begin{array}{l}24.0 \\
24.0 \\
27.0 \\
24.0 \\
25.0 \\
240 \\
24.0 \\
33.0\end{array}$ & $\begin{array}{r}117 \\
518 \\
101 \\
104 \\
87 \\
121 \\
121 \\
107\end{array}$ & $\begin{array}{l}122.2 \\
137.7 \\
1411.5 \\
136.7 \\
140.1 \\
17.4 \\
180.7 \\
236.8\end{array}$ & $\begin{array}{l}0.33 \\
.44 \\
.35 \\
.42 \\
.47 \\
.47 \\
.47 \\
.37\end{array}$ & 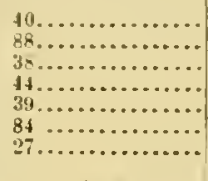 & $\begin{array}{l}31.0 \\
35.0 \\
34.0 \\
35.0 \\
32.0 \\
36.0 \\
36.0\end{array}$ & $\begin{array}{l}132 \\
118 \\
133 \\
138 \\
140 \\
127 \\
157\end{array}$ & $\begin{array}{l}273.2 \\
387.7 \\
313.8 \\
311.4 \\
318.6 \\
281.2 \\
365.8\end{array}$ & $\begin{array}{l}.41 \\
.317 \\
.37 \\
.34 \\
.41 \\
.35 \\
.33\end{array}$ \\
\hline $\begin{array}{l}9 \\
4 \ldots \ldots \ldots \ldots \ldots \ldots \ldots \ldots \ldots \ldots\end{array}$ & $\begin{array}{l}31.0 \\
33.0\end{array}$ & 105 & $\begin{array}{l}249.0 \\
257.1\end{array}$ & $\begin{array}{l}.38 \\
.32\end{array}$ & Average... & 30.0 & 120 & 231.2 & .38 \\
\hline
\end{tabular}

Age clars: 200 to 250 years.

\begin{tabular}{|c|c|c|c|c|c|c|c|c|c|}
\hline $90 .$. & 25.0 & 105 & $102 .=$ & 0.29 & 75. & 36.0 & 103 & 263.5 & .30 \\
\hline $22 \ldots \ldots \ldots \ldots \ldots$ & 25,0 & 111 & 105.2 & .88 & .............. & 33,5 & 114 & 267.8 & 38 \\
\hline $13 . . . \ldots \ldots \ldots \ldots \ldots$ & 2.00 & 118 & 129.9 & .42 & 89. & 33.5 & 115 & 267.8 & $.3 x$ \\
\hline tit................. & $2 \% 0$ & 97 & 136.6 & .41 & ....... & 24.0 & 123 & 277.3 & is \\
\hline $92 \ldots \ldots \ldots \ldots \ldots \ldots$ & 25.0 & 101 & 139.4 & .40 & 99. & 37.0 & 110 & 274.1 & .33 \\
\hline $6 \ldots \ldots \ldots \ldots \ldots$ & 24.0 & 115 & 151.7 & .42 & ............. & 32.0 & 120 & $2 \times 6.2$ & .40 \\
\hline $57 \ldots \ldots \ldots \ldots \ldots \ldots$ & 24.0 & 115 & 153.5 & .42 & .............. & $\$ 8.0$ & 123 & 290.5 & .30 \\
\hline $81 \ldots \ldots \ldots \ldots \ldots$ & 27.0 & 106 & 173.5 & .41 & 55. & 35.0 & 133 & 314.0 & .35 \\
\hline $33 \ldots \ldots \ldots \ldots \ldots$ & 30.0 & 119 & 180.4 & .31 & 17. & 38.0 & 149 & 315.7 & .27 \\
\hline of .................... & 31.0 & 97 & 181.5 & .36 & & 35,0 & 149 & 3350 & .34 \\
\hline $100 \ldots \ldots \ldots \ldots$ & 29.0 & $9 i$ & $18 \% .7$ & .41 & git.................. & 35.0 & 148 & $3: 39.8$ & .31 \\
\hline 71................ & 27.0 & 98 & 185. 6 & .48 & $0 . . . \ldots \ldots \ldots \ldots \ldots \ldots$ & 34.0 & 138 & 361.5 & .11 \\
\hline $\begin{array}{l}31 \ldots \ldots \ldots \ldots \ldots \\
65, \ldots \ldots \ldots \ldots \ldots\end{array}$ & $\begin{array}{l}27.0 \\
30.0\end{array}$ & $\begin{array}{l}196 \\
11.5\end{array}$ & $\begin{array}{l}194.2 \\
194.6\end{array}$ & $\begin{array}{l}.39 \\
.34\end{array}$ & $10 \ldots \ldots \ldots \ldots \ldots$ & 51.5 & 148 & 6i34. 8 & .30 \\
\hline $58 \ldots \ldots \ldots \ldots . .$. & 28.5 & 127 & 2020 & .36 & A rerage... & 31.7 & 119 & 235.5 & .36 \\
\hline $73 \ldots \ldots \ldots \ldots \ldots \ldots$ & 35.0 & $10 \pi$ & 208.6 & .29 & & & & & \\
\hline $28 \ldots \ldots \ldots \ldots \ldots$ & 29.0 & 135 & 209.7 & .34 & $8 .$. & $2 t ;, 0$ & 126 & 154. 1 & .34 \\
\hline $50 \ldots \ldots \ldots \ldots \ldots$ & 26.0 & 117 & 215.4 & .50 & $69 \ldots$ & 27.0 & 119 & 1 ifit. 0 & .35 \\
\hline $11 \ldots \ldots \ldots \ldots \ldots$ & 26.0 & 117 & 216.0 & $.51)$ & $51 . \ldots \ldots \ldots \ldots \ldots$ & 360 & 126 & 167.0 & .36 \\
\hline 63............... & $2 x .5$ & 127 & 216.8 & .38 & $52 \ldots \ldots \ldots \ldots \ldots$ & 27.0 & 152 & $18 \times, 3$ & .31 \\
\hline $54 \ldots \ldots \ldots \ldots \ldots$ & 30.0 & 129 & 217.2 & .34 & $12 \ldots \ldots \ldots \ldots \ldots$ & 27.0 & 152 & 104.3 & .32 \\
\hline G* $\ldots \ldots \ldots \ldots \ldots$ & 31.0 & 94 & 218.8 & .44 & $83 \ldots \ldots \ldots \ldots \ldots$ & 30.0 & 126 & 207.9 & .34 \\
\hline f0 $0 \ldots \ldots \ldots \ldots$ & 31.0 & 101 & 200.7 & .42 & $56, \ldots \ldots \ldots \ldots \ldots$ & 31.0 & 113 & $2 \div 7.1$ & .38 \\
\hline $32 \ldots \ldots \ldots \ldots \ldots \ldots$ & 32.0 & $13 t i$ & 2211 & .29 & $80 \ldots \ldots \ldots \ldots \ldots$ & $34.1)$ & $1: 9$ & 210.6 & .30 \\
\hline $7 \ldots \ldots \ldots \ldots . . . .$. & 31.11 & 114 & 223.5 & .37 & & 33.0 & 110 & 2616.9 & .37 \\
\hline $59 \ldots \ldots \ldots \ldots \ldots$ & 31. 0 & 121 & 228.4 & .36 & tien.......... & 32.0 & 137 & $25 \% .0$ & .34 \\
\hline $91 \ldots \ldots \ldots \ldots \ldots$ & 32.0 & 119 & 2311.8 & .35 & $3 \ldots$ & 32.0 & 137 & 263.0 & .34 \\
\hline $2 \ldots \ldots \ldots \ldots \ldots$ & 31.0 & $1 \pm 2$ & 233.1 & 0.36 & 85. & 32.0 & 108 & 272.3 & .45 \\
\hline $87 \ldots \ldots \ldots \ldots \ldots$ & $3+i .0$ & 110 & 237.6 & .31 & $21 \ldots .$. & 34.0 & 137 & 276.2 & .32 \\
\hline $26 \ldots \ldots \ldots \ldots \ldots$ & 3i. 0 & 110 & 399.6 & .28 & $18 \ldots . . . . . . . . .$. & 30.0 & 126 & 271.0 & .31 \\
\hline $30 \ldots . . . . . . . . .$. & 38,0 & 137 & $2 \pm 3.2$ & .22 & $26 \ldots \ldots \ldots \ldots \ldots$ & 32.0 & $13 x$ & 293.4 & .38 \\
\hline $1 \ldots \ldots \ldots \ldots \ldots$ & 35.0 & $12 \alpha$ & 247.5 & .99 & & 36.0 & $13 \%$ & 313,6 & .32 \\
\hline iii..... & 35.0 & 128 & 2482 & .29 & $29 \ldots \ldots \ldots \ldots \ldots$ & 34.0 & 134 & 310.0 & .37 \\
\hline y & 33. 0 & $10 \overline{3}$ & 255.1 & .41 & 70.............. & 34.0 & 131 & 321.9 & 38 \\
\hline qu.................. & 37.0 & 101 & 256.8 & .34 & $11 \ldots . . . \ldots \ldots \ldots$ & 35.0 & 129 & 341.6 & .40 \\
\hline $74 \ldots \ldots \ldots \ldots$ & 38.0 & 119 & 258.8 & $\begin{array}{r}.28 \\
39\end{array}$ & \multirow{2}{*}{ Aruruge } & 315 & 170 & 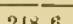 & 35 \\
\hline $11{ }_{11}^{11}$ & $\begin{array}{l}33.5 \\
34.0\end{array}$ & $\begin{array}{l}139 \\
104\end{array}$ & $\begin{array}{l}260.1 \\
261.4\end{array}$ & .32 & & 31.5 & 130 & 20.6 & .35 \\
\hline & & & & & & & & & \\
\hline
\end{tabular}

Age class: 300 to 350 yenrx.

\begin{tabular}{|c|c|c|c|c|c|c|c|c|c|}
\hline $\begin{array}{l}98 \ldots \ldots \ldots \ldots \ldots \\
42 \ldots \ldots \ldots \ldots \ldots \ldots \\
53 \ldots \ldots \ldots \ldots \ldots \ldots\end{array}$ & $\begin{array}{l}31.0 \\
311.0 \\
311.0 \\
30.0\end{array}$ & $\begin{array}{l}115 \\
132 \\
120 \\
121\end{array}$ & $\begin{array}{l}215.9 \\
219.8 \\
231.9 \\
240.3\end{array}$ & $\begin{array}{r}0.36 \\
.34 \\
.39 \\
.27\end{array}$ & $\begin{array}{l}15 \ldots \ldots \ldots \ldots \ldots \\
64 \ldots \ldots \ldots \ldots \ldots \ldots \ldots\end{array}$ & $\begin{array}{l}33.0 \\
36.0 \\
34.0\end{array}$ & $\begin{array}{l}130 \\
124 \\
1415\end{array}$ & $\begin{array}{l}332.0 \\
237.0 \\
380.1\end{array}$ & $\begin{array}{r}0.41 \\
.27 \\
.41 \\
\end{array}$ \\
\hline$\left\{\begin{array}{l}4 \\
11 \ldots \ldots \ldots \ldots \ldots \ldots \ldots \ldots\end{array}\right.$ & $\begin{array}{l}33.0 \\
\text { Afi. } 0\end{array}$ & $\begin{array}{l}129 \\
110\end{array}$ & $\begin{array}{l}290.2 \\
309.4\end{array}$ & $\begin{array}{l}.39 \\
.19\end{array}$ & A rurag & 34.3 & 129 & 273.6 & .33 \\
\hline
\end{tabular}


TABLE VI.-Acre yields of White line and measurments of anmple trees-Continued.

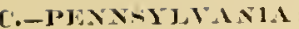

(1) SITE $d$ :
Clintm rounty.

2,000 foet aluse sea level.]

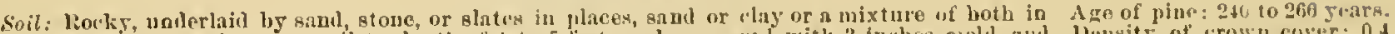

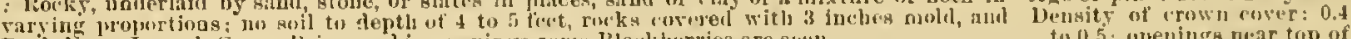

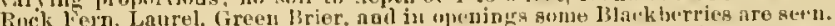

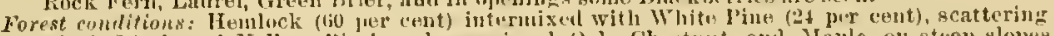

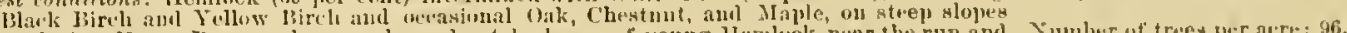

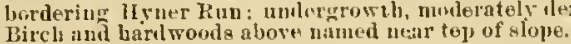

TIELD FOR THE TWO ACIES.

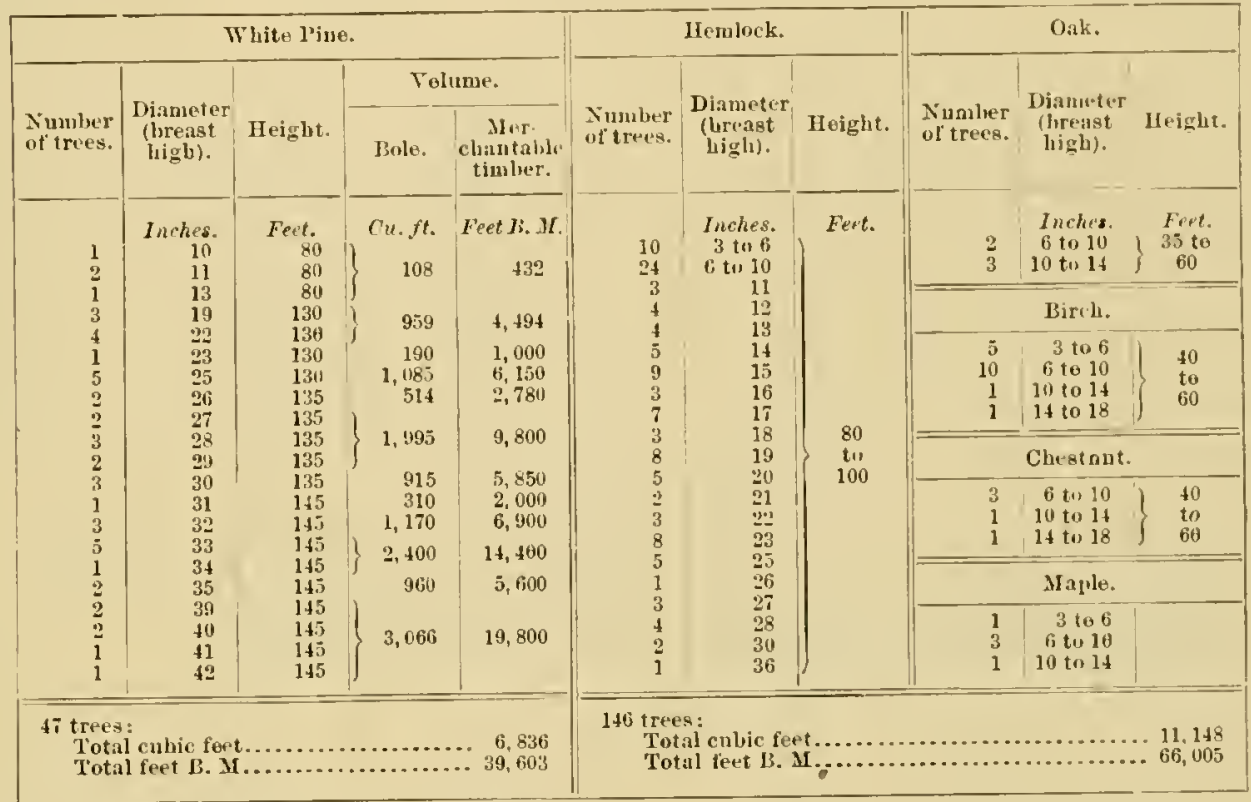

Average annual aceretion: All specios, 49 cubic fiet.

MEASEREMENTS OF SAMPLE TREES.

Age cluss: 180 to 200 years.

\begin{tabular}{|c|c|c|c|c|c|c|c|c|c|c|}
\hline \multirow[b]{2}{*}{ Tree number. } & \multirow[b]{2}{*}{ Age. } & \multirow[b]{2}{*}{$\begin{array}{l}\text { Diametur } \\
\text { (breast } \\
\text { bigh). }\end{array}$} & \multirow[b]{2}{*}{ Hejght. } & \multirow[b]{2}{*}{$\begin{array}{l}\text { Height to } \\
\text { bist of } \\
\text { erown. }\end{array}$} & \multirow[b]{2}{*}{$\begin{array}{c}\text { Rings } \\
\text { per ioed } \\
\text { on } \\
\text { stmuly. }\end{array}$} & \multicolumn{2}{|c|}{ Solume. } & \multirow[b]{2}{*}{$\begin{array}{l}\text { Facter } \\
\text { ol } \\
\text { shape. }\end{array}$} & \multirow[b]{2}{*}{$\begin{array}{l}\text { Ratio of } \\
\text { leugth } \\
\text { of crown } \\
\text { to total } \\
\text { leiglit of } \\
\text { tree. }\end{array}$} & \multirow{2}{*}{ 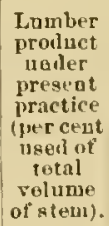 } \\
\hline & & & & & & Tree. & $\begin{array}{l}\text { Mer. } \\
\text { cliautable } \\
\text { timber. }\end{array}$ & & & \\
\hline 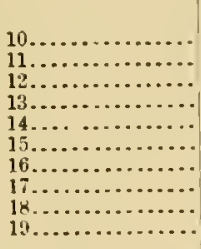 & $\begin{array}{c}\text { Year. } \\
194 \\
199 \\
197 \\
196 \\
199 \\
189 \\
186 \\
189 \\
197 \\
183\end{array}$ & $\begin{array}{l}\text { Inches. } \\
26.0 \\
30.0 \\
26.5 \\
23.0 \\
29.0 \\
23.0 \\
22.0 \\
25.5 \\
26.0 \\
26.5\end{array}$ & $\begin{array}{r}\text { Feet. } \\
116 \\
114 \\
105 \\
95 \\
103 \\
104 \\
104 \\
105 \\
101 \\
88\end{array}$ & $\begin{array}{r}\text { Feet. } \\
56 \\
56 \\
56 \\
40 \\
52 \\
60 \\
54 \\
45 \\
50 \\
40\end{array}$ & $\begin{array}{l}\text { Yo. } \\
6.6 \\
5.4 \\
7.0 \\
7.4 \\
6.3 \\
8.0 \\
7.8 \\
6.9 \\
7.3 \\
7.2\end{array}$ & 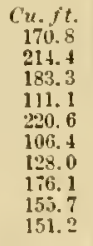 & \begin{tabular}{|r|} 
Feet 13.34 \\
905 \\
1,273 \\
997 \\
$4 ! 0$ \\
1,290 \\
534 \\
643 \\
892 \\
791 \\
760
\end{tabular} & $\begin{array}{l}0.40 \\
.38 \\
.45 \\
.40 \\
.413 \\
.35 \\
.46 \\
41 \\
.42 \\
.45\end{array}$ & $\begin{array}{r}0.51 \\
.51 \\
.46 \\
.58 \\
.49 \\
.42 \\
.18 \\
.57 \\
.50 \\
.54\end{array}$ & $\begin{array}{l}44 \\
49 \\
45 \\
37 \\
48 \\
41 \\
42 \\
42 \\
41 \\
41\end{array}$ \\
\hline Average . & 193 & 26.0 & 103 & 51 & 7. 0 & 162.0 & 8.58 & .42 & .51 & 43 \\
\hline
\end{tabular}

A ye class: 230 tu 250 years.

WOMINANT GROW'H.

\begin{tabular}{|c|c|c|c|c|c|c|c|c|c|c|}
\hline $\begin{array}{l}21 \ldots \ldots \ldots \ldots \ldots \ldots \ldots \\
22 \ldots \ldots \ldots \ldots \ldots \ldots\end{array}$ & $\begin{array}{l}256 \\
242\end{array}$ & $\begin{array}{l}\text { 34. } 0 \\
35.0\end{array}$ & $\begin{array}{l}158 \\
150\end{array}$ & $\begin{array}{l}94 \\
82\end{array}$ & $\begin{array}{l}7.5 \\
6.5\end{array}$ & $\begin{array}{l}416.3 \\
376.1\end{array}$ & $\begin{array}{l}2,600 \\
2,261\end{array}$ & $\begin{array}{r}0.12 \\
.37\end{array}$ & $\begin{array}{r}0.4 \theta \\
.45\end{array}$ & $\begin{array}{l}53 \\
50\end{array}$ \\
\hline Average... & 249 & 34.5 & 154 & 88 & 6. 8 & $3 y+0$ & 2.460 & .40 & .42 & 51 \\
\hline $4 \ldots \ldots \ldots \ldots \ldots$ & 201 & 411. 0 & $1: 9$ & 64 & 5.0 & $\$ 01.7$ & 2,300 & .36 & . 5n & 17 \\
\hline
\end{tabular}




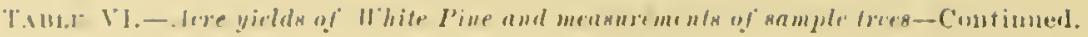

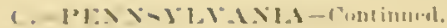

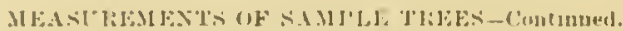

Atre class: 230 to 250 yistrs.

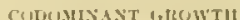

\begin{tabular}{|c|c|c|c|c|c|c|c|c|c|c|}
\hline Troe numler. & $\lg *$ & 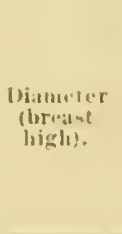 & II Hight. & $\begin{array}{l}\text { IIright t" } \\
\text { laiste of } \\
\text { "rown. }\end{array}$ & 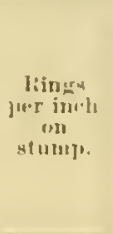 & Trene. & $\begin{array}{l}\text { Mers. } \\
\text { chantalibe } \\
\text { timber. }\end{array}$ & $\begin{array}{l}\text { Factor } \\
\text { uti } \\
\text { shap". }\end{array}$ & $\begin{array}{l}\text { leationt } \\
\text { lonintli } \\
\text { of erewn } \\
\text { to tothl } \\
\text { heiglit of } \\
\text { trine. }\end{array}$ & 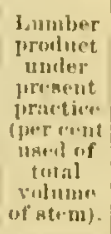 \\
\hline $20 \ldots \ldots \ldots \ldots \ldots \ldots$ & $\begin{array}{c}\text { Iears. } \\
245 \\
2012 \\
2516\end{array}$ & $\begin{array}{l}\text { Inclues. } \\
23.5 \\
23.0 \\
33.5\end{array}$ & $\begin{array}{l}\text { Fe+f. } \\
132 \\
13: 1 \\
1+1\end{array}$ & $\begin{array}{r}\text { Fett. } \\
94 \\
78 \\
91 j\end{array}$ & $\begin{array}{r}10 . \\
7.0 \\
9.3 \\
10.1\end{array}$ & $\begin{array}{l}r u, r l . \\
25 i, 13 \\
160,6 \\
192.7\end{array}$ & 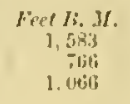 & $\begin{array}{l}0.44 \\
.42 \\
.45\end{array}$ & $\begin{array}{r}0.9 ! 1 \\
.41 \\
32\end{array}$ & $\begin{array}{l}51 \\
3 ! 1 \\
415\end{array}$ \\
\hline Averag". . & $2+4$ & $2: 0.10$ & 135 & 59 & $\therefore 8$ & $2 \because 3.0$ & 1. $13 x$ & .41 & .34 & 45 \\
\hline 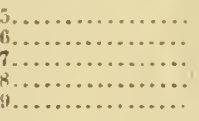 & $\begin{array}{l}2091 \\
234 \\
111 \\
231 \\
239\end{array}$ & 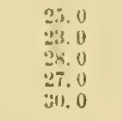 & $\begin{array}{l}1211 \\
116 \\
121 \\
110 \\
120\end{array}$ & $\begin{array}{l}60 \\
601 \\
72 \\
60 \\
52\end{array}$ & $\begin{array}{l}7.1 \\
9.3 \\
(?) \\
7.8 \\
7.7\end{array}$ & $\begin{array}{l}197.6 \\
160.4 \\
224.2 \\
190.2 \\
308.0\end{array}$ & $\begin{array}{l}\text { 1. } 3143 \\
884 \\
1,348 \\
1,170 \\
1.535\end{array}$ & $\begin{array}{l}.18 \\
.18 \\
.42 \\
43 \\
.45\end{array}$ & $\begin{array}{l}.50 \\
.48 \\
.42 \\
.45 \\
.56\end{array}$ & $\begin{array}{l}40 \\
411 \\
511 \\
47 \\
48\end{array}$ \\
\hline Aserate. & 231 & 26.5 & 118 & 61 & 8.11 & 208.0 & 1,180 & .45 & .48 & 47 \\
\hline
\end{tabular}

(2) $\operatorname{sit} \operatorname{si}_{j}$

Clearficlel counuty.

Sample urea: 1 acre.

$[1,200 \div 01,500$ feet above nen ],recl.

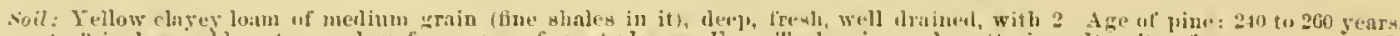

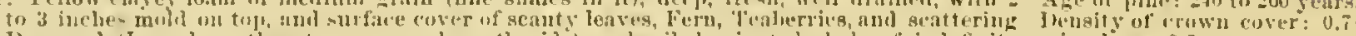

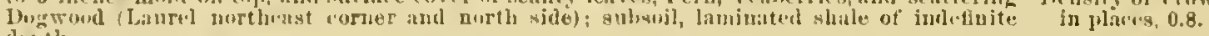
depith.

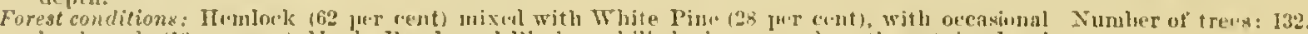

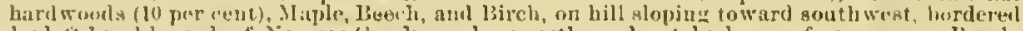

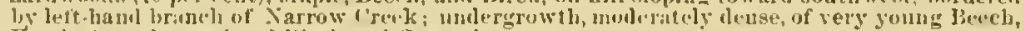
Hemlock. and oecasional birch and Cucumlter.

ICIE YIEL,

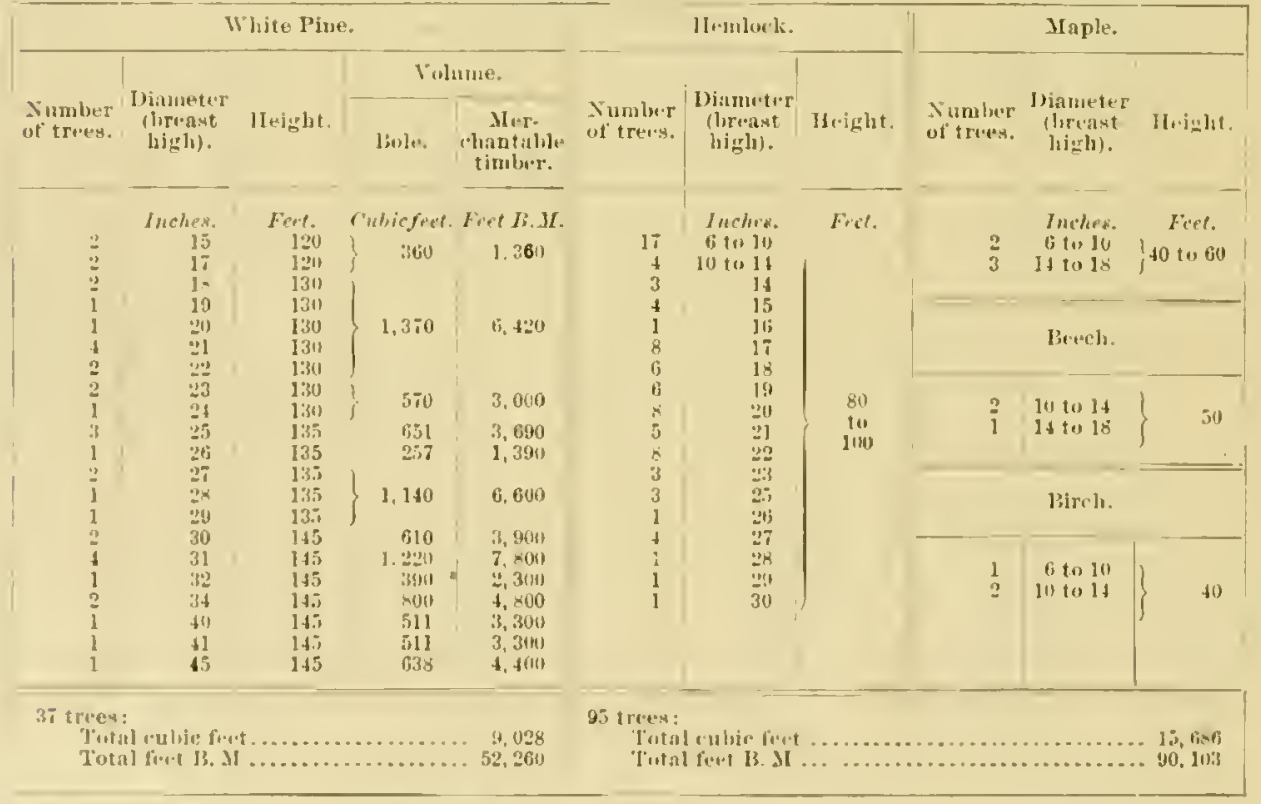

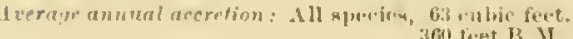




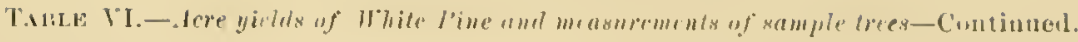

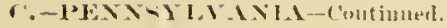

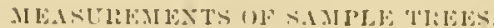

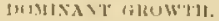

\begin{tabular}{|c|c|c|c|c|c|c|c|c|c|c|}
\hline \multirow[b]{2}{*}{ Tre. number. } & \multirow[b]{2}{*}{ 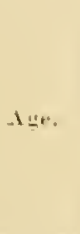 } & \multirow[b]{2}{*}{$\begin{array}{l}\text { Diameter } \\
\text { (trriast } \\
\text { lijalis). }\end{array}$} & \multirow[b]{2}{*}{ lteight. } & \multirow[b]{2}{*}{$\begin{array}{l}\text { Mejuht in } \\
\text { bitste of } \\
\text { crown. }\end{array}$} & \multirow[b]{2}{*}{ 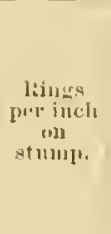 } & \multicolumn{2}{|c|}{ Volume. } & \multirow[b]{2}{*}{$\begin{array}{c}\text { Fiator } \\
\text { ot } \\
\text { wha pu. }\end{array}$} & \multirow[b]{2}{*}{ 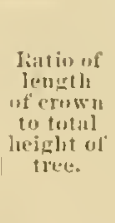 } & \multirow{2}{*}{ 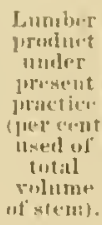 } \\
\hline & & & & & & Tret. & $\begin{array}{l}\text { Mer- } \\
\text { rhimtahle } \\
\text { timborl. }\end{array}$ & & & \\
\hline & Tears. & Incluss. & Feet. & $F \sim t$. & . To. & $C_{u} f t$. & $F$ F. I: $M$. & & & \\
\hline $1 \ldots, \ldots$ & $\frac{160}{300}$ & 35.5 & 158 & & 7.6 & $43 \% .4$ & 3,030 & 0.411 & 0.43 & 58 \\
\hline $3, \ldots, \ldots$ & 200 & 36.0 & $15 i$ & 90 & i. 0 & 481.3 & 3,401 & .433 & .42 & 59 \\
\hline $4 \ldots \ldots \ldots$ & 241 & $\begin{array}{l}320 \\
320\end{array}$ & 152 & 84 & 7. 8 & $3 m 3.0$ & 2,637 & .66 & .44 & 55 \\
\hline $10 \ldots \ldots \ldots \ldots \ldots$ & 244 & 33.0 & $1+13$ & 90 & $\begin{array}{l}6.6 \\
6.8\end{array}$ & $\begin{array}{l}347.7 \\
305.9\end{array}$ & $\begin{array}{l}2.079 \\
2,34 t\end{array}$ &.+1 & .59 & $\begin{array}{l}50 \\
54\end{array}$ \\
\hline $12 \ldots \ldots \ldots \ldots, \ldots$ & 262 & 28.0 & $15 t:$ & 85 & 9. 11 & $28.5,8$ & $1,6+8$ & 43 & .43 & 54 \\
\hline $18 \ldots \ldots \ldots \ldots \ldots$ & 363 & 39.0 & $15: 3$ & an & 6. 0 & गิ11. I & 3,318 & .40 & 42 & 54 \\
\hline (........ & 250 & 34.0 & 150 & $7 x$ & 6. 3 & 402. 4 & 2,347 &.+2 & .18 & 49 \\
\hline $20 \ldots \ldots \ldots \ldots \ldots$ & 266 & 44.0 & 144 & 1001 & $5 . i$ & (i3) 4 & 4,388 & 42 & .30 & 57 \\
\hline $21 \ldots \ldots \ldots \ldots$ & 245 & 34,0 & $14 t^{\circ}$ & 92 & 7.1 & 366.7 & 2.48 & .40 & $.3 i$ & 51 \\
\hline $23 \ldots \ldots \ldots \ldots \ldots$ & 218 & 34,0 & 142 & (p) & i. 2 & 373.4 & 2.318 & $.4 \div$ & .37 & 51 \\
\hline $33 \ldots \ldots \ldots \ldots \ldots$ & 259 & 33.11 & 138 & 91 & 8.0 & 304.5 & 1.770 & .40 & .31 & IA \\
\hline $34 \ldots \ldots \ldots \ldots \ldots$ & 262 & 33. 0 & $1 \pm 6$ & 90 & 7.4 & 369.2 & $\because 2=20$ & 42 & .38 & iv \\
\hline $35 . \ldots \ldots \ldots \ldots \ldots$ & 263 & 31.0 & 114 & 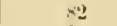 & 8.5 & 275.2 & 1. 458 & .36 & .43 & 44 \\
\hline $36 . \ldots \ldots \ldots \ldots \ldots$ & 241 & 31.5 & 134 & 88 & 7.1 & $30 \% .7$ & 1. 4.73 &.+2 & .34 & 50 \\
\hline $37 \ldots \ldots \ldots \ldots \ldots$ & 361 & 37.0 & 146 & 106 & 6. 7 & $48: .9$ & 2.970 & .44 & .27 & 50 \\
\hline Arerage... & 255 & 34 & $1+7$ & wis & T. 0 & 390.0 & $\because, 50 T$ & .41 & .39 & 52 \\
\hline
\end{tabular}

CODOMINANT GROWTH

\begin{tabular}{|c|c|c|c|c|c|c|c|c|c|c|}
\hline $28, \ldots$ & 262 & 28.5 & 138 & iis & 9.8 & 204.3 & 1,551 & 0.43 & 0.45 & 49 \\
\hline 25. & 244 & 28.5 & 138 & 107 & 7.7 & 298.1 & 1.9 .16 & .49 & .20 & 54 \\
\hline & 245 & 25.0 & 130 & 84 & 1.3 & 192.1 & 1,102 &.+3 & .35 & 48 \\
\hline 20. & 246 & 31.0 & 130 & 82 & 7. 3 & 320.3 & 1,731 & .45 & .37 & 56 \\
\hline $5 \ldots \ldots \ldots \ldots \ldots \ldots$ & 264 & $2 \% .11$ & $1+11$ & 1011 & 8. 1 & 300.4 & 1.905 & .47 & $.2 k$ & 52 \\
\hline $6 \ldots \ldots \ldots \ldots \ldots . . . . .$. & 264 & 201.0 & 110 & 110 & 8.5 & 391.4 & 1.631 & .45 & $\because 1$ & 47 \\
\hline 7.................. & 262 & 29.0 & 152 & 112 & $9 . \overline{5}$ & 302.8 & $1,-54$ & .46 & .26 & 51 \\
\hline $8 \ldots \ldots \ldots \ldots \ldots$ & 235 & 290 & 142 & 86 & ...... & -48.6 & $1,31 \%$ & .38 & $.3 ! 1$ & 14 \\
\hline $9 \ldots \ldots \ldots \ldots \ldots$ & 336 & 32.0 & 142 & 84 & $\ldots$ & 287.7 & 1,648 & .36 & .41 & 43 \\
\hline $11 \ldots \ldots \ldots \ldots \ldots$ & 244 & 311.0 & $1+1$ & 81 & 7.5 & 305.3 & 1. 847 &.+4 & .42 & 53 \\
\hline $13 \ldots \ldots \ldots \ldots$ & 258 & 23.0 & $1+7$ & 93 & 9.6 & 201.0 & 1,048 & .43 & .37 & $4: 3$ \\
\hline $14 \ldots \ldots \ldots . . . .$. & 242 & 25.0 & 139 & 45 & ..... & 217.1 & 1. 233 & .16 & .30 & 47 \\
\hline $15 \ldots \ldots \ldots \ldots \ldots$ & 262 & 26.0 & 136 & 98 & & 257.2 & 1,389 & .31 & 25 & 45 \\
\hline $16 \ldots \ldots \ldots \ldots \ldots$ & 235 & 24.5 & $1=4$ & 93 & . & $163 . x$ & 815 & .80 & .95 & +1 \\
\hline $17 \ldots \ldots \ldots \ldots$ & 262 & 25.0 & 198 & 108 & .... & 214.4 & 1. 183 &.$\$ 9$ & .16 & 40 \\
\hline $26 \ldots \ldots \ldots \ldots \ldots$ & 245 & 26.0 & 131 & 98 & 9.3 & $199=$ & $1,0 \div 1$ & .40 & .23 & 67 \\
\hline $311_{\ldots} \ldots \ldots \ldots \ldots \ldots$ & 259 & 26.5 & 134 & 901) & 9.2 & 228.6 & $1,3: f_{i}$ & .14 & .32 & tS \\
\hline $29 \ldots \ldots \ldots \ldots \ldots$ & 264 & 28.0 & 141 & 84 & 9.2 & 276.5 & $1.37 \%$ & .40 & .40 & $4 \pi$ \\
\hline $31 \ldots \ldots \ldots \ldots \ldots$ & 262 & 25.5 & 132 & R8 & 10.0 & 191. 8 & 863 &.$\$ 1$ & .33 & it \\
\hline $32 \ldots \ldots \ldots$ & 261 & 20.0 & 142 & 49 & 9.1 & 230.9 & $1,3=2$ & .46 & .30 & 46 \\
\hline Arerage... & 253 & 97 & 138 & $\$ 3$ & 9.0 & 250.0 & 1,121 & .44 & .32 & $4 i$ \\
\hline
\end{tabular}

OPPRESEEN GHOWTHL

\begin{tabular}{|c|c|c|c|c|c|c|c|c|c|c|}
\hline $\begin{array}{l}27 \ldots \ldots \ldots \ldots \\
38, \ldots \ldots \ldots \ldots \ldots \\
39 \ldots \ldots \ldots \ldots \ldots \\
40 \ldots \ldots \ldots \ldots\end{array}$ & $\begin{array}{l}259 \\
2001 \\
258 \\
261\end{array}$ & $\begin{array}{l}19.0 \\
23.0 \\
20.5 \\
16.5\end{array}$ & $\begin{array}{l}132 \\
137 \\
123 \\
120\end{array}$ & $\begin{array}{r}94 \\
6115 \\
119 \\
82\end{array}$ & $\begin{array}{l}11.6 \\
11.1 \\
13.0 \\
13.7\end{array}$ & $\begin{array}{l}138.8 \\
189.6 \\
130.9 \\
84,6\end{array}$ & $\begin{array}{l}6 \times 3 \\
5 \times 7 \\
358 \\
339\end{array}$ & $\begin{array}{l}0.53 \\
.4 .5 \\
.46 \\
.50\end{array}$ & $\begin{array}{r}0.39 \\
.30 \\
.11 \\
.31\end{array}$ & $\begin{array}{l}41 \\
43 \\
35 \\
31\end{array}$ \\
\hline Arerage... & 259 & 201,0 & $12 x$ & 9.5 & 12.3 & 137.0 & $6+2$ & 69 & .25 & $3 \vec{i}$ \\
\hline
\end{tabular}

$20233-10.22-10$ 


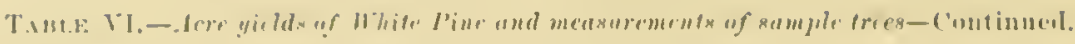

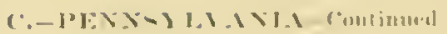

(3) Sis: :

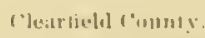

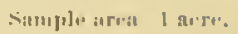

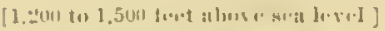

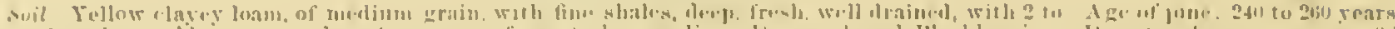

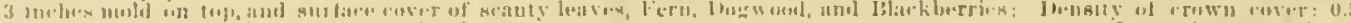

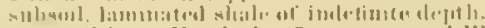

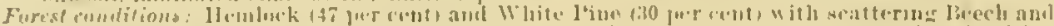

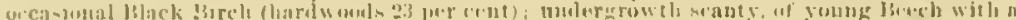
few lblach lifich iand basswion! A LEE YIELD.

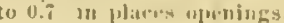

Number of tries: in.

\begin{tabular}{|c|c|c|c|c|c|c|c|c|c|c|}
\hline \multicolumn{5}{|c|}{ Ẅbite I'jue. } & \multicolumn{3}{|c|}{ ii (esuluek. } & \multicolumn{3}{|c|}{ Iteech. } \\
\hline $\begin{array}{l}\text { Sumbler } \\
\text { if tries. }\end{array}$ & 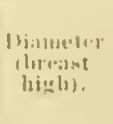 & Ileight. & I'asle. & 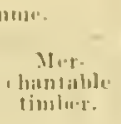 & $\begin{array}{l}\text { Numilure } \\
\text { of tries. }\end{array}$ & $\begin{array}{l}\text { Hinureter } \\
\text { (liruist } \\
\text { ligah). }\end{array}$ & II eizlst. & $\begin{array}{l}\text { Dumber } \\
\text { if tret-4. }\end{array}$ & $\begin{array}{l}\text { l)ianjeter } \\
\text { (lireasist } \\
\text { lijghi). }\end{array}$ & Ileight. \\
\hline $\begin{array}{l}1 \\
1 \\
1 \\
1 \\
1 \\
1 \\
2 \\
2 \\
3 \\
4 \\
4 \\
1 \\
1 \\
1 \\
1 \\
1\end{array}$ & 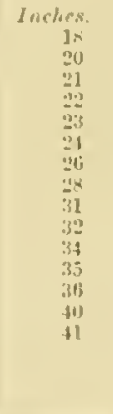 & 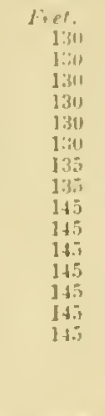 & 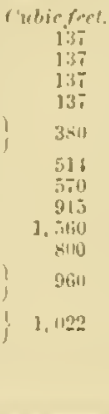 & 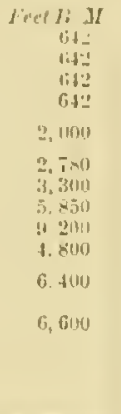 & $\begin{array}{l}1 \\
2 \\
2 \\
2 \\
1 \\
2 \\
1 \\
1 \\
1 \\
2 \\
3 \\
3 \\
3 \\
2 \\
3 \\
1 \\
1 \\
1 \\
3 \\
3 \\
1\end{array}$ & 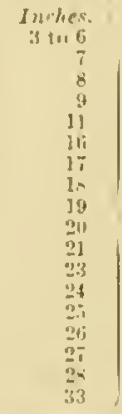 & $\begin{array}{c}80 \\
10 \\
100\end{array}$ & 16 & $\begin{array}{l}\text { Inches. } \\
\text { to } 10 \\
\text { Hack Birch. }\end{array}$ & $\begin{array}{l}\text { Fent } \\
30 \mathrm{Bu}\end{array}$ \\
\hline $\begin{array}{r}23 \text { tries: } \\
\text { Twita } \\
\text { Tut is }\end{array}$ & 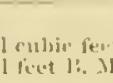 & $1, \ldots \ldots \ldots$ & ….... & $\begin{array}{r}7.269 \\
43.4911\end{array}$ & $\begin{array}{r}05 \text { Trese: } \\
\text { Tout:11 } \\
\text { Tot:il }\end{array}$ & 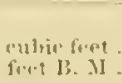 & $\ldots \ldots$ & $\cdots$ & & $\begin{array}{r}11.206 \\
.186 .9100\end{array}$ \\
\hline
\end{tabular}

Arrage annualaccretion: All -pucis's, 45 cubic fore.

(b) SITE $i$

Jethersons rit:znty.

Simple arı:a: 1 sere.

[1.310 to 1,800 firt abuse sea level.]

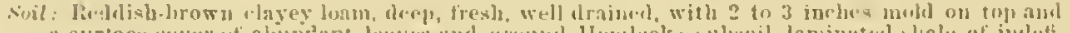
it aurlace ctreng

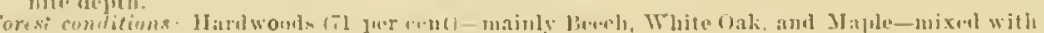

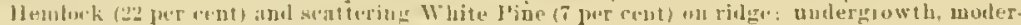

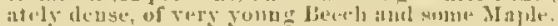

Age of gine: 231 to 219 yers

Density uf aruwn enter: 0.5 . in places 0.8

Sumber as trees: lin.

\section{A'IEE TIELII}

\begin{tabular}{|c|c|c|c|c|}
\hline \multirow{3}{*}{$\begin{array}{l}\text { Simm. } \\
\text { birr of } \\
\text { trees. }\end{array}$} & \multicolumn{4}{|c|}{ White Hon. } \\
\hline & & & $\mathrm{Vi}$ & 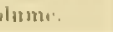 \\
\hline & $\begin{array}{l}\text { ctors } \\
\text { liroant } \\
\text { ligrh). }\end{array}$ & Ilvight. & Jinle. & $\begin{array}{l}\text { Mer. } \\
\text { cliansule } \\
\text { timlu-r. }\end{array}$ \\
\hline & Inrherg. & Fete. & ru. feet & Ient IS .II \\
\hline 1 & 12 & (111) & 30.0 & 130 \\
\hline i & 17 & 9 & 70.2 & zowi \\
\hline ] & 19 & lii: & (1). 3 & $3 \times j$ \\
\hline$i$ & 23 & $1 \div 2$ & 152.3 & 6.36 \\
\hline$i$ & 24 & $1: 6$ & iis.! & $x \geq 0$ \\
\hline i & $30 \mathrm{t}$ & $1: 313$ & 3011.0 & 1, lix2 \\
\hline 1 & 311 & ifi1 & $\because 7=2$ & 1.6 \\
\hline 1 & 35 & (11) & 4111. 2 & $2 . \mathrm{kil}$ \\
\hline 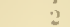 & $37^{2}$ & 117 & 194. 4 & 57,35 \\
\hline$i$ & 4. & $13=$ & 18:. 1 & 3. 11.30 \\
\hline
\end{tabular}

11 tre.pen:

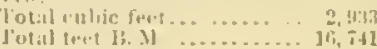

\begin{tabular}{|c|c|c|c|c|c|c|c|c|}
\hline & lien $h$. & & & Ilaple. & & \multicolumn{3}{|c|}{ IItrulork. } \\
\hline $\begin{array}{l}\text { Tinzs. } \\
\text { li.ruf } \\
\text { trees. }\end{array}$ & $\begin{array}{l}\text { Diameter } \\
\text { lbreast } \\
\text { lights. }\end{array}$ & Iriglit. & $\begin{array}{l}\text { Simn: } \\
\text { ly.tot } \\
\text { trines. }\end{array}$ & 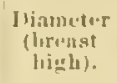 & 1leight & $\begin{array}{l}\text { Suni- } \\
\text { lurs uf } \\
\text { tre\%s. }\end{array}$ & $\begin{array}{l}\text { Jyanetes } \\
\text { (lireastst } \\
\text { ligigh). }\end{array}$ & II $(\cdot j z)$ lit \\
\hline $\begin{array}{l}37 \\
14 \\
14\end{array}$ & 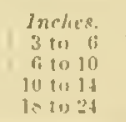 & $\begin{array}{l}\text { Ient. } \\
\text { fo } \\
\text { in } \\
\text { fin }\end{array}$ & $\begin{array}{l}5 \\
9 \\
2 \\
3\end{array}$ & 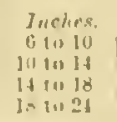 & $\begin{array}{c}\text { Fot. } \\
50 \\
1+1 \\
00\end{array}$ & \multirow{3}{*}{$\begin{array}{r}5 \\
15 \\
4 \\
3 \\
7 \\
3\end{array}$} & \multirow{3}{*}{ 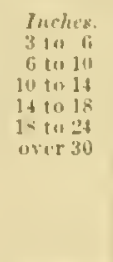 } & \multirow{3}{*}{ 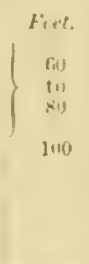 } \\
\hline & Whimotilk & & & chustuut. & & & & \\
\hline$\frac{1}{6}$ & $\begin{array}{l}14 \text { to } 1 \mathrm{x} \\
18 \text { to } \\
21 \text { to } 30\end{array}$ & 80 & 2 & $3+116$ & $\begin{array}{l}20 \\
111 \\
341\end{array}$ & & & \\
\hline
\end{tabular}

14trens:

rutal rulie seet. $5,5: 0$

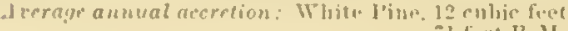




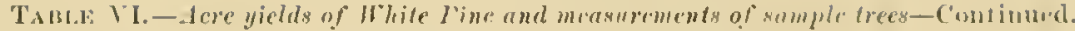

C.PPNTEYLTANIA Continnel.

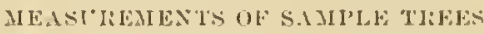

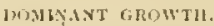

\begin{tabular}{|c|c|c|c|c|c|c|c|c|c|c|}
\hline & & & & & & $1 \%$ & lume. & & & Laumlner \\
\hline 'Tree number. & A fre. & $\begin{array}{c}\text { 1)ianeter } \\
\text { (breast } \\
\text { lighlis). }\end{array}$ & Heigbt. & $\begin{array}{l}\text { Hoight to } \\
\text { hase uf } \\
\text { crowa. }\end{array}$ & $\begin{array}{l}\text { Ringa } \\
\text { pre jull } \\
\text { on } \\
\text { stump. }\end{array}$ & "lret:. & $\begin{array}{l}\text { Mer. } \\
\text { Chantihle } \\
\text { limber. }\end{array}$ & $\begin{array}{l}\text { Jateror } \\
\text { ot } \\
\text { slanpe. }\end{array}$ & 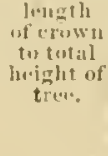 & 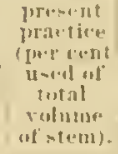 \\
\hline $\begin{array}{l}1 \ldots \ldots . \\
3 \ldots \ldots . \\
3 \ldots \ldots \ldots \\
5 \ldots \ldots \\
6 \ldots \ldots \\
6 \ldots \ldots\end{array}$ & $\begin{array}{c}\text { Jears. } \\
228 \\
239 \\
234 \\
241 \\
23 ! \\
231\end{array}$ & $\begin{array}{r}\text { Inches. } \\
31.5 \\
41.0 \\
37.0 \\
31.5 \\
37.0 \\
35.5\end{array}$ & $\begin{array}{r}\text { Fept. } \\
133 \\
338 \\
114 \\
\mathrm{~J}+11 \\
148 \\
1+0\end{array}$ & $\begin{array}{r}\text { Fret. } \\
80 \\
811 \\
72 \\
86 \\
913 \\
811\end{array}$ & $\begin{array}{r}\text { So. } \\
5.6 \\
5.6 \\
5.4 \\
19.6 \\
6.1 \\
6.1\end{array}$ & 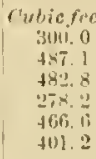 & 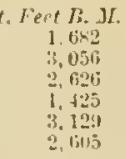 & $\begin{array}{r}0.43 \\
.40 \\
.41 \\
.37 \\
.42 \\
.42\end{array}$ & $\begin{array}{r}0.41 \\
.42 \\
.51 \\
.39 \\
.35 \\
.43\end{array}$ & $\begin{array}{l}47 \\
50 \\
43 \\
43 \\
513 \\
51\end{array}$ \\
\hline Arer & 236 & 35.0 & $1+1$ & $8 *$ & 6.4 & 403.0 & $2+20$ & .41 & .42 & 49 \\
\hline
\end{tabular}

OPPRESSED GROWTH.

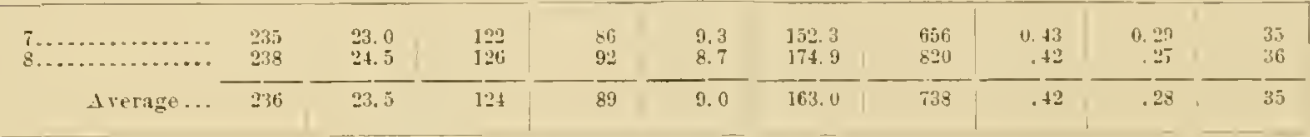

ATPRESSEU RROWTH.

\begin{tabular}{|c|c|c|c|c|c|c|c|c|c|c|}
\hline $10 \ldots \ldots$ & $\left\{\begin{array}{l}230 \text { tor } \\
240\end{array}\right.$ & $\begin{array}{l}19 \\
17\end{array}$ & $\begin{array}{r}102 \\
94\end{array}$ & $\begin{array}{l}50 \\
80\end{array}$ & $(?)$ & $\begin{array}{l}911.3 \\
710.2\end{array}$ & $\begin{array}{l}386 \\
236\end{array}$ & $\begin{array}{r}0.44 \\
.44\end{array}$ & $\begin{array}{r}0.51 \\
.19\end{array}$ & $\begin{array}{l}3.5 \\
28\end{array}$ \\
\hline Arerage... & $\ldots$ & 18 & 100 & 65 & & 80.0 & 311 & .44 & .35 & 31 \\
\hline
\end{tabular}

(5) SITL $k$ :

Jeffersun ('ounty.

[1,500 to 1,600 fiet abore seal lirel.]

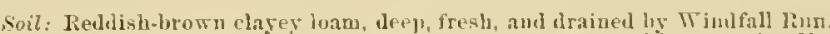

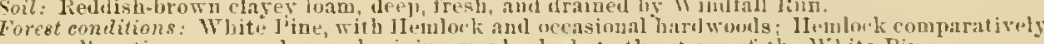

small, acting as au uuderwood, giving amply shade to the stems ot' the White Pine.

\section{MEASCLEMENTS UF SAMI'LE TLEES.}

\begin{tabular}{|c|c|c|c|c|c|c|c|c|c|c|}
\hline \multirow[b]{2}{*}{ Tree number. } & \multirow[b]{2}{*}{ A } & \multirow[b]{2}{*}{$\begin{array}{l}\text { Diameter } \\
\text { (breast } \\
\text { higli). }\end{array}$} & \multirow[b]{2}{*}{ Пtight. } & \multirow[b]{2}{*}{$\begin{array}{l}\text { Helgivit io } \\
\text { base of } \\
\text { crows?. }\end{array}$} & \multirow[b]{2}{*}{$\begin{array}{l}\text { Rings } \\
\text { [xt' inch } \\
\text { ol] } \\
\text { st uw }\end{array}$} & \multicolumn{2}{|c|}{ Folums. } & \multirow[b]{2}{*}{$\begin{array}{l}\text { Fitrier } \\
\text { oit } \\
\text { als:ilu". }\end{array}$} & \multirow[b]{2}{*}{ 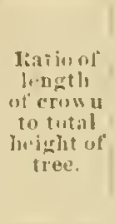 } & \multirow{2}{*}{ 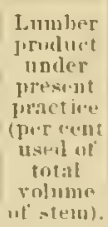 } \\
\hline & & & & & & Tree. & $\begin{array}{l}\text { MLer. } \\
\text { bantiblo } \\
\text { tumber. }\end{array}$ & & & \\
\hline & loars. & $\begin{array}{c}\text { Inches. } \\
325\end{array}$ & $\begin{array}{l}\text { Fect. } \\
\text { 146 }\end{array}$ & Fiet. & $\underset{t i .3}{x}$ & $\begin{array}{c}\text { cubis fiet } \\
\text { Bus } 0\end{array}$ & FUd $R, J$. & (1. 17 & 0.34 & $4 i j$ \\
\hline 12..... & 241 & 35.0 & 176 & 90 & 7.3 & $4 ! 14:$ & 3.1813 & 42 & .49 & so \\
\hline $13 \ldots \ldots \ldots \ldots$ & $2 ! 3$ & 32.5 & $1+2$ & 96 & 6. 2 & 3.59 .7 & 210,33 & .41 & .32 & th \\
\hline $14 \ldots \ldots$ & $2: 36$ & 32.5 & 15 & 96 & $\therefore .2$ & $3=6,3$ & 2,244 & .42 & .10 & tis \\
\hline $15 \ldots \ldots \ldots \ldots$ & $\because \cdots$ & 34.0 & 148 & 96 & ii. 2 & is:- 4 & $2.231 i$ & .41 & .33 & 19 \\
\hline $16 \ldots \ldots \ldots \ldots \ldots$ & 211 & 30.11 & $1+3$ & !6 & $\therefore 0$ & $32 \cdot 2$ & $1,83: 2$ & .413 & .33 & 47 \\
\hline $17 . . .2$. & $23 i 3$ & 31.0 & 145 & 90 & 6.5 & :i2:3. 1 & $2 .+134$ & 42 & $.3 k$ & $\because \because 3$ \\
\hline $18 \ldots \ldots \ldots \ldots$ & - & 29.3 & 142 & $\times 8$ & 6.6 & $2.5 . x$ & 1. 391 & .38 & .3. & 45 \\
\hline $19 . \ldots \ldots \ldots \ldots \ldots$ & 312 & 33.0 & $15: 3$ & 1110 & $\because 2$ & 333.5 & 1. 985 & .39 & .34 & 40 \\
\hline & 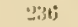 & 35.11 & 158 & 112 & i. 2 & tsis is & 2. 745 & $46 \mathrm{i}$ & .39 & 1.5. \\
\hline $21 \ldots \ldots \ldots \ldots \ldots$ & 211 & 34.5 & $1: 2$ & 90 & 6.. & $3: 41 i$. & $2, * 11$ & 45 & .41 & 19 \\
\hline $22 \ldots \ldots \ldots \ldots \ldots$ & $331 i$ & 32.5 & 1.88 & 92 & 3.8 & $3+2,5$ & 2.243 & .42 & .41 & tis \\
\hline Average... & 238 & 32.5 & 152 & $9 . j$ & 6.7 & 378.0 & 2. 231 & .43 & .37 & 43 \\
\hline
\end{tabular}




\section{YIELD OF SECOND-GROWTH WHITE PINE, WITH MEASUREMENTS OF YOUNG PINE TAKEN FOR ANALYSIS.}

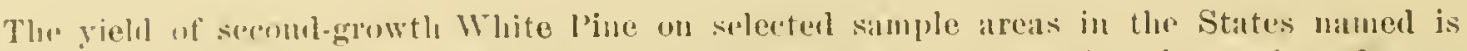
shown in tho lollowing motes and tabulations, which also give. for illustration, the number of trees,

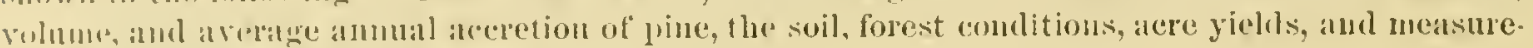
mpllts of simule young pines tilien for analysis:

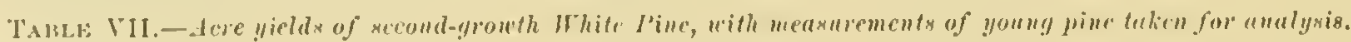

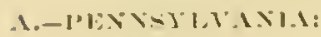

(1) SITEC:

I.uz:rone Connty.

Sample area: 1 aere.

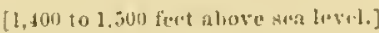

Holf acre No. 1 .

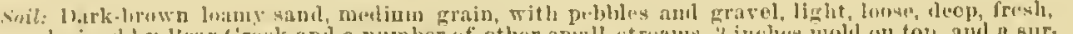

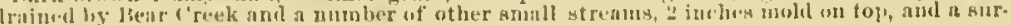

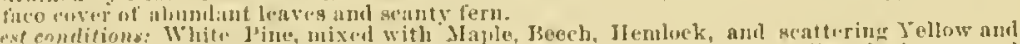

Sgo of jinu: 60 to 80 years.

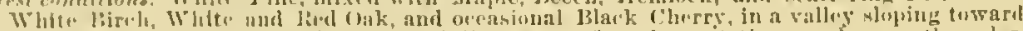

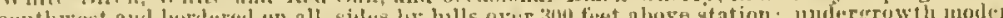

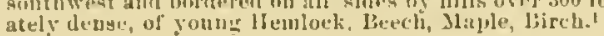

1 h.nsity of cruwn coser: 11,5

Niunber of troes: 216.

IIALF-ACLE: FIELI.

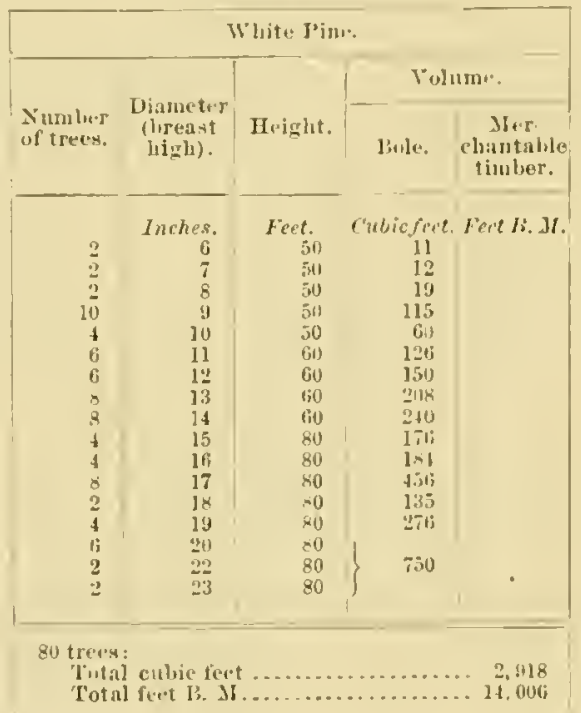

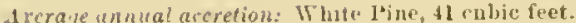

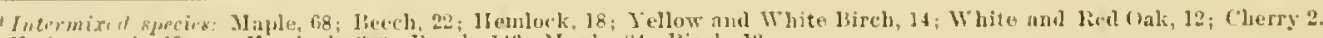

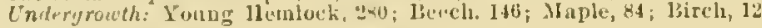




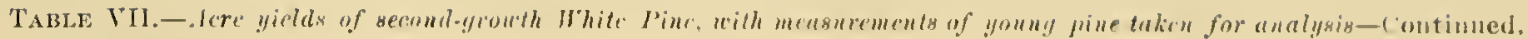

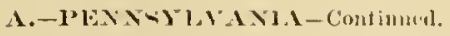

$$
\text { Half acre sio. } \therefore \text {. }
$$

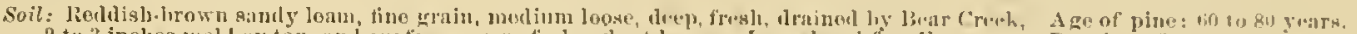

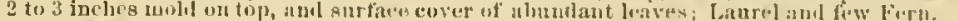

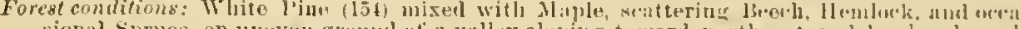

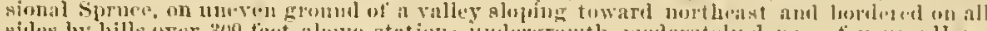

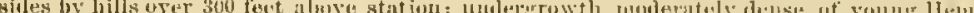
lock, Beech, Majle, abil a few young șirucı.

HALF.ACFE JIEI, I).

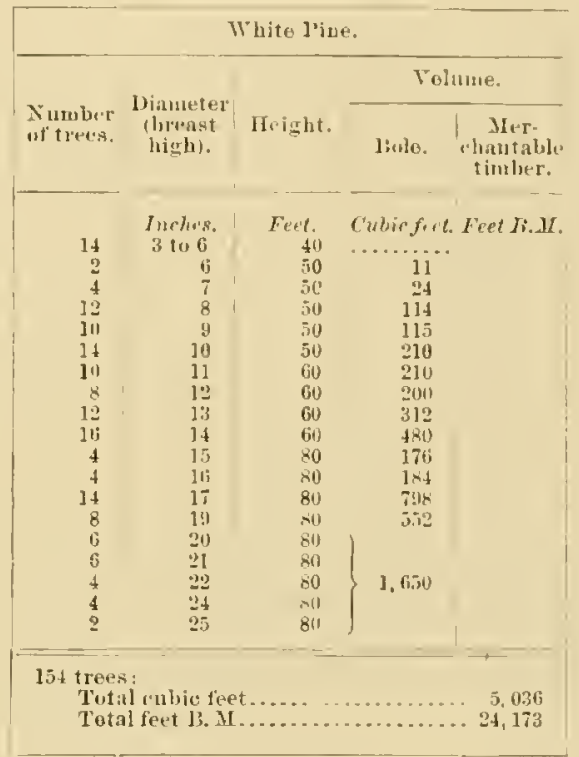

Acerage annual accetion: White Pine, i2 cuhis fiet

MEASULEMLNTS OF SAMPLE YOLMG PISE TIEES.

Forest conditions: Ridge land densely corered with yeung lardwools-mainly. White onk and liel Oak, amung which White J'ine is scatterid.

\begin{tabular}{|c|c|c|c|c|c|c|c|c|c|c|}
\hline \multirow[b]{2}{*}{ Tree number. } & \multirow[b]{2}{*}{ Ag*. } & \multirow[b]{2}{*}{$\begin{array}{c}\text { Uiameter } \\
\text { (breast } \\
\text { higli). }\end{array}$} & \multirow[b]{2}{*}{ leight. } & \multirow[b]{2}{*}{$\begin{array}{l}\text { Hight to } \\
\text { bistse of } \\
\text { crown. }\end{array}$} & \multirow[b]{2}{*}{$\begin{array}{l}\text { Riugs } \\
\text { per inth } \\
\text { un } \\
\text { stump. }\end{array}$} & \multicolumn{2}{|c|}{ Volume. } & \multirow[b]{2}{*}{$\begin{array}{l}\text { Factor } \\
\text { of } \\
\text { shatere. }\end{array}$} & \multirow{2}{*}{$\begin{array}{l}\text { Fatio of } \\
\text { length } \\
\text { of crown } \\
\text { to total } \\
\text { beight of } \\
\text { treas. }\end{array}$} & \multirow{2}{*}{ 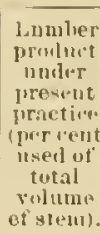 } \\
\hline & & & & & & True. & $\begin{array}{l}\text { Mrer } \\
\text { chantablo } \\
\text { timber. }\end{array}$ & & & \\
\hline $\begin{array}{l}1 \\
2 \\
3 \\
4 \ldots \ldots \ldots \ldots\end{array}$ & $\begin{array}{c}\text { Feare. } \\
193 \\
132 \\
134 \\
128\end{array}$ & $\begin{array}{r}\text { Inclie'x. } \\
29.0 \\
30.0 \\
30.0 \\
31.0\end{array}$ & $\begin{array}{l}\text { Fett. } \\
84 \\
\text { ol } \\
81 \\
90\end{array}$ & $\begin{array}{l}\text { Fett. } \\
34 \\
20 \\
16 \\
20\end{array}$ & $\begin{array}{l}\text { Yo. } \\
3.5 \\
5.7 \\
5.7 \\
3.8\end{array}$ & $\begin{array}{c}\text { rubie feet } \\
140.6 \\
7.1 \\
81.6 \\
393.8\end{array}$ & $\begin{array}{c}\text { Fet R.. } \\
627 \\
369 \\
369 \\
935\end{array}$ & $\begin{array}{l}0.31 \\
.44 \\
.38 \\
.41\end{array}$ & $\begin{array}{l}0.80 \\
.75 \\
.80 \\
.76\end{array}$ & $\begin{array}{r}37 \\
a 39 \\
a 34 \\
40\end{array}$ \\
\hline Arerage.. & 129 & $\$ 5.5$ & 84 & 22 & 4.7 & $1 \div 4.0$ & 575 & .40 & .73 & $3 n$ \\
\hline
\end{tabular}

a "pprossed for the last forty years.

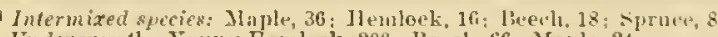

Endergrouth: Fonng Femlock, 200; Betch, 60; Jraple, 24. 


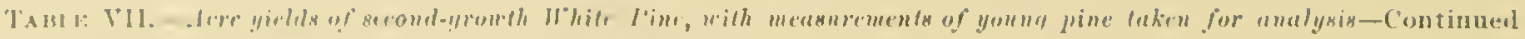

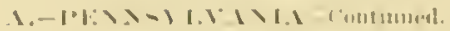

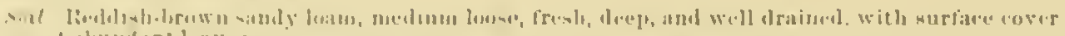

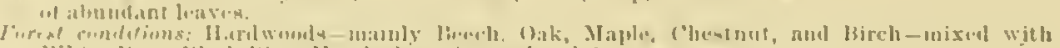

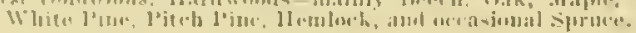

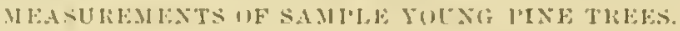

movixase mown.

\begin{tabular}{|c|c|c|c|c|c|c|c|c|c|c|}
\hline \multirow[b]{2}{*}{ 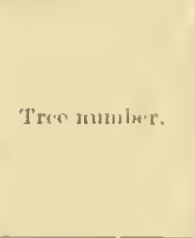 } & \multirow[b]{2}{*}{ Agrn. } & \multirow[b]{2}{*}{$\begin{array}{l}\text { Jianuser } \\
\text { lbrenst } \\
\text { loghl. }\end{array}$} & \multirow[b]{2}{*}{ Jludult. } & \multirow[b]{2}{*}{$\begin{array}{l}\text { Huglot tu } \\
\text { lase ut } \\
\text { cruwn. }\end{array}$} & \multirow[b]{2}{*}{ 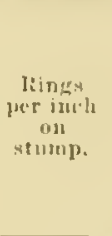 } & \multicolumn{2}{|c|}{ Volume. } & \multirow[b]{2}{*}{$\begin{array}{l}\text { Faclor } \\
\text { wif } \\
\text { shatis. }\end{array}$} & \multirow{2}{*}{ 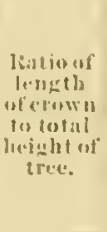 } & \multirow{2}{*}{ 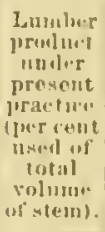 } \\
\hline & & & & & & T'ree. & $\begin{array}{l}\text { Mrr. } \\
\text { rhantible } \\
\text { timber. }\end{array}$ & & & \\
\hline & $\begin{array}{l}\text { learrs } \\
1038\end{array}$ & $\begin{array}{c}\text { Iuchers. } \\
-29\end{array}$ & Iint. & $\begin{array}{l}\text { Iret. } \\
50\end{array}$ & $\begin{array}{c}V_{11 .} \\
5.01\end{array}$ & $\begin{array}{c}\text { reibic foe } \\
191.4\end{array}$ & 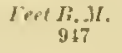 & $0.36)$ & $(0.57$ & to \\
\hline 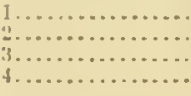 & $\begin{array}{l}918 \\
\vdots 1+i \\
1 \div 3 \\
17\end{array}$ & $\begin{array}{l}15.0 \\
\because(1,1) \\
31 \\
11+5\end{array}$ & $\begin{array}{l}\text { sid } \\
73 \\
17 \\
76\end{array}$ & $\begin{array}{l}32 \\
32 \\
32 \\
26\end{array}$ & $\begin{array}{l}3.5 \\
4.3 \\
2.5 \\
4.3\end{array}$ & $\begin{array}{r}121.2 \\
711.1 \\
211.0 \\
\text { tii. } 11\end{array}$ & $\begin{array}{l}330 \\
x+i 11 \\
0 i t \\
36 i 3\end{array}$ & $\begin{array}{l}.42 \\
.4 .8 \\
.41 \\
.42\end{array}$ & $\begin{array}{l}.62 \\
.545 \\
.67 \\
.65\end{array}$ & $\begin{array}{l}313 \\
40 \\
10 \\
45\end{array}$ \\
\hline lvera & mi & 21,0 & $\therefore 2$ & 30 & 3.5 & 118.0 & $55 i$ & .43 & .133 & 40 \\
\hline
\end{tabular}

Sinil: Frosh sand, well \&lruizul.

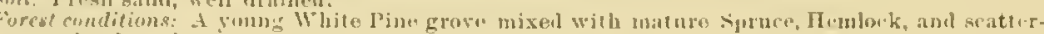
ing landwood:

\begin{tabular}{|c|c|c|c|c|c|c|c|c|c|c|}
\hline \multirow[b]{2}{*}{ 'Tre⿻ nutuler. } & \multirow[b]{2}{*}{$\lg u$} & \multirow{2}{*}{$\begin{array}{l}\text { Jiauneler } \\
\text { (liperast } \\
\text { higli). }\end{array}$} & \multirow[b]{2}{*}{ II,ight. } & \multirow[b]{2}{*}{$\begin{array}{l}\text { Huight to } \\
\text { hase of } \\
\text { "rown. }\end{array}$} & \multirow[b]{2}{*}{ 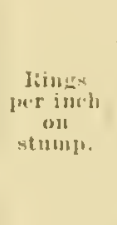 } & \multicolumn{2}{|c|}{ Voluster. } & \multirow[b]{2}{*}{$\begin{array}{c}\text { Fututor } \\
\text { of } \\
\text { shate. }\end{array}$} & \multirow{2}{*}{ 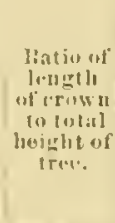 } & \multirow{2}{*}{ 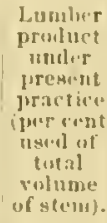 } \\
\hline & & & & & & 'Tren. & $\begin{array}{l}\text { Mres } \\
\text { chantahle } \\
\text { tinuer. }\end{array}$ & & & \\
\hline 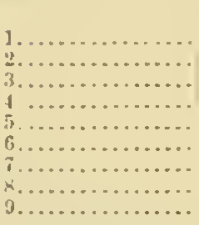 & $\begin{array}{c}\text { lines. } \\
\text { 154 } \\
\text { i7 } \\
\vdots 11 \\
47 \\
32 \\
49 \\
5: 2 \\
31 \\
51\end{array}$ & $\begin{array}{r}\text { Inch. } 8 . \\
14.5 \\
14.5 \\
8.5 \\
\vdots .0 \\
11.0 \\
11.5 \\
9.5 \\
8.0 \\
111.0\end{array}$ & $\begin{array}{r}\text { Fiet. } \\
54 \\
54 \\
513 \\
46 \\
i 11 \\
46 \\
53 \\
54 \\
56\end{array}$ & $\begin{array}{l}\text { Feet. } \\
18 \\
20 \\
20 \\
18 \\
20 \\
18 \\
18 \\
18 \\
18\end{array}$ & $\begin{array}{l}\text {. } 0 . \\
4.0 \\
3.7 \\
4.0 \\
5.0 \\
3.7 \\
3.6 \\
1.0 \\
3.7 \\
1.5\end{array}$ & $\begin{array}{r}\text { Cuber } \\
45.7 \\
31.4 \\
9.5 \\
14.2 \\
15.7 \\
12.1 \\
10.1 \\
117\end{array}$ & 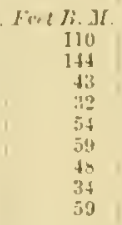 & $\begin{array}{l}0.417 \\
.17 \\
.42 \\
.45 \\
.43 \\
.47 \\
.46 \\
.53 \\
.18\end{array}$ & $\begin{array}{l}0.613 \\
.66 \\
.60 \\
.61 \\
.60 \\
.61 \\
.66 \\
.66 \\
.68\end{array}$ & $\begin{array}{l}31 \\
38 \\
36 \\
37 \\
31 \\
31 \\
33 \\
27 \\
33\end{array}$ \\
\hline Irerage... & 53 & 10.5 & 52 & 1!) & 1.2 & 16.0 & 65 & .47 & .64 & 33 \\
\hline
\end{tabular}

(3) MIE:

Clintusu County:

Sample aren: 1 nire.

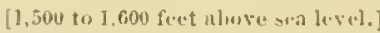

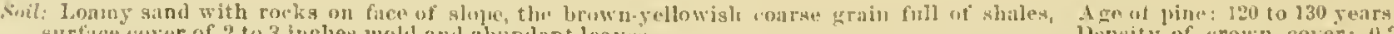
surfice cover of 2 to 3 inches mold and abumant leavers.

Forest comelitions: l'rusla of

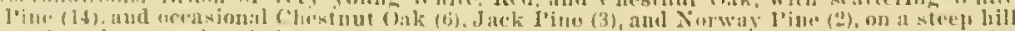

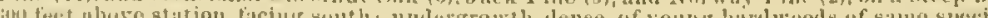

is abuite.

ArIiL YIliL, (seatierist).

rimulu.r uf trues: 05

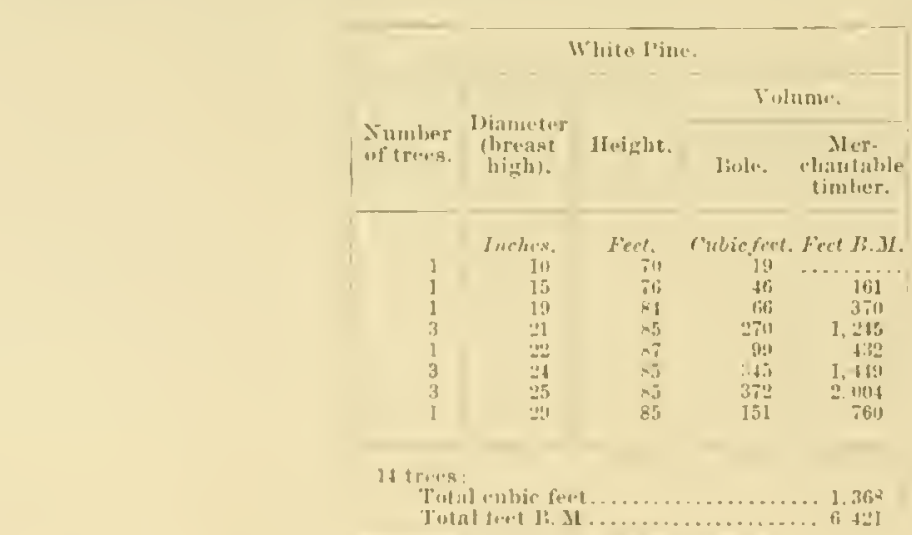

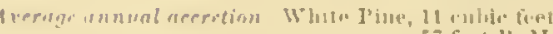




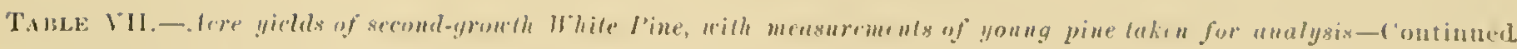

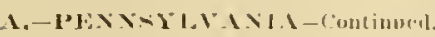

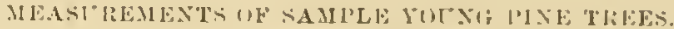

\begin{tabular}{|c|c|c|c|c|c|c|c|c|c|c|}
\hline 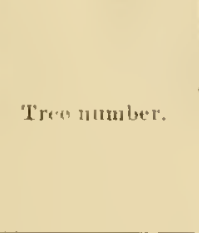 & A tre. & $\begin{array}{c}\text { Diameter } \\
\text { (brwist } \\
\text { high). }\end{array}$ & Heisht. & $\begin{array}{l}\text { "leiglut tu } \\
\text { lovend } \\
\text { "rown. }\end{array}$ & 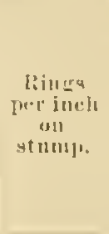 & rres. & $\begin{array}{l}\text { Mer. } \\
\text { Mantable } \\
\text { timber. }\end{array}$ & $\begin{array}{l}\text { Jiaceor } \\
\text { w' } \\
\text { sha!n.". }\end{array}$ & 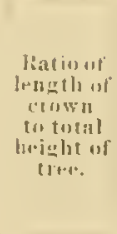 & 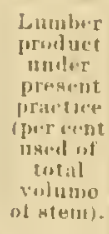 \\
\hline 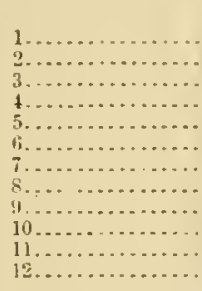 & $\begin{array}{l}\text { Yeur } \\
125 \\
124 \\
124 \\
116 \\
122 \\
111 \\
120 \\
125 \\
127 \\
122 \\
125 \\
11)\end{array}$ & $\begin{array}{l}\text { Inches. } \\
21.0 \\
2.0 \\
2.0 \\
2.01 \\
16.5 \\
19.5 \\
24.5 \\
21.0 \\
19.1 \\
19.5 \\
15.1 \\
17.0 \\
20.5\end{array}$ & $\begin{array}{l}76 \\
76 \\
86 \\
87 \\
79 \\
89 \\
83 \\
89 \\
84 \\
89 \\
76 \\
84 \\
76\end{array}$ & $\begin{array}{l}\text { Fint } \\
40 \\
34 \\
34 \\
36 \\
40 \\
36 \\
36 \\
40 \\
40 \\
34 \\
36 \\
38\end{array}$ & $\begin{array}{l}\text { Xo. } \\
4.8 \\
5.4 \\
5.5 \\
13.2 \\
5.9 \\
(1) \\
5.4 \\
6.4 \\
5.7 \\
7.1 \\
6.9 \\
(1)\end{array}$ & 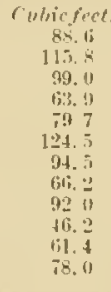 & 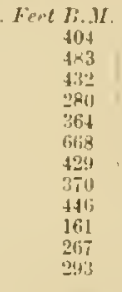 & $\begin{array}{l}0.47 \\
.42 \\
.43 \\
43 \\
45 \\
413 \\
41 \\
.10 \\
.511 \\
.41 \\
.16 \\
.45\end{array}$ & $\begin{array}{r}0.47 \\
.67 \\
.41 \\
.54 \\
.53 \\
.56 \\
.57 \\
.32 \\
.54 \\
.52 \\
.57 \\
.50\end{array}$ & $\begin{array}{l}39 \\
34 \\
36 \\
36 \\
30 \\
41 \\
37 \\
416 \\
411 \\
30 \\
36 \\
31\end{array}$ \\
\hline Areinge.. & 123 & 20 & 83 & 37 & 6.0 & 84.0 & 383 & .45 & .55 & 37 \\
\hline
\end{tabular}

(3) SITE ! :

Clarartielol Conuty.

¿ample areis: 1 irre.

[1.200 tu 1,5no feet abore sea level.]

Suil: Fellow clarey loam, melium grain, leep, fresh, well drained (tbree small streams cross the bollow in different direntions). With 2 to 3 inches mold on top, surfizce corer of leates, Frr. of iml-finite clepth.

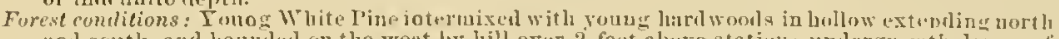

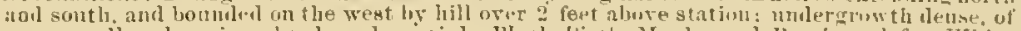
verf small and various hardwook, nainly Black lirch, Maple, and beech, aud few Whito Birch and Inembel 1

A gre uf pine: 25 to 35 years.

Densits of crown corer: 0.5 100.6 .

Sutuher of trees: (?) ACIE YIELI

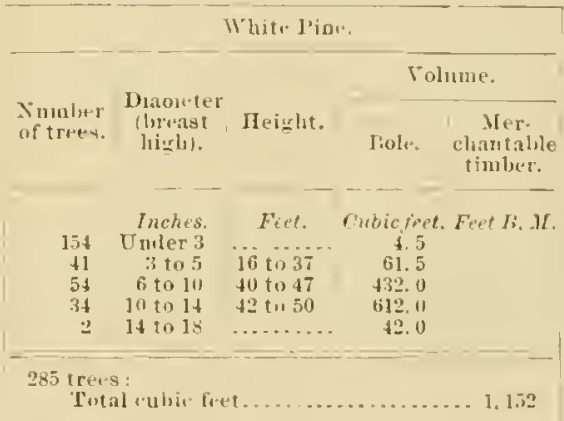

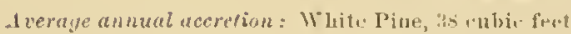

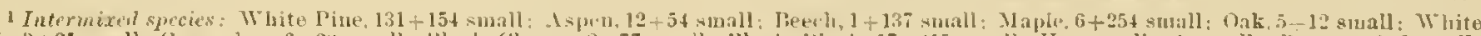

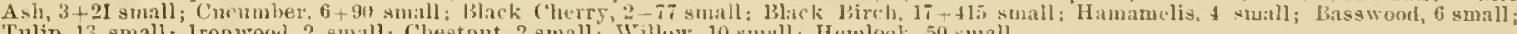
Tulip, 13 small; Iroawool, 2 small; Chestant, 2 small: "Willuw, 10 suall; Hemlock, 50 suall. 


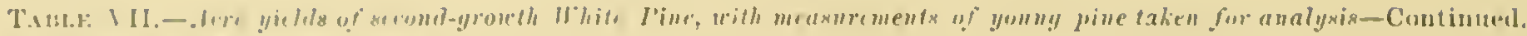

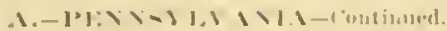

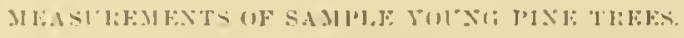

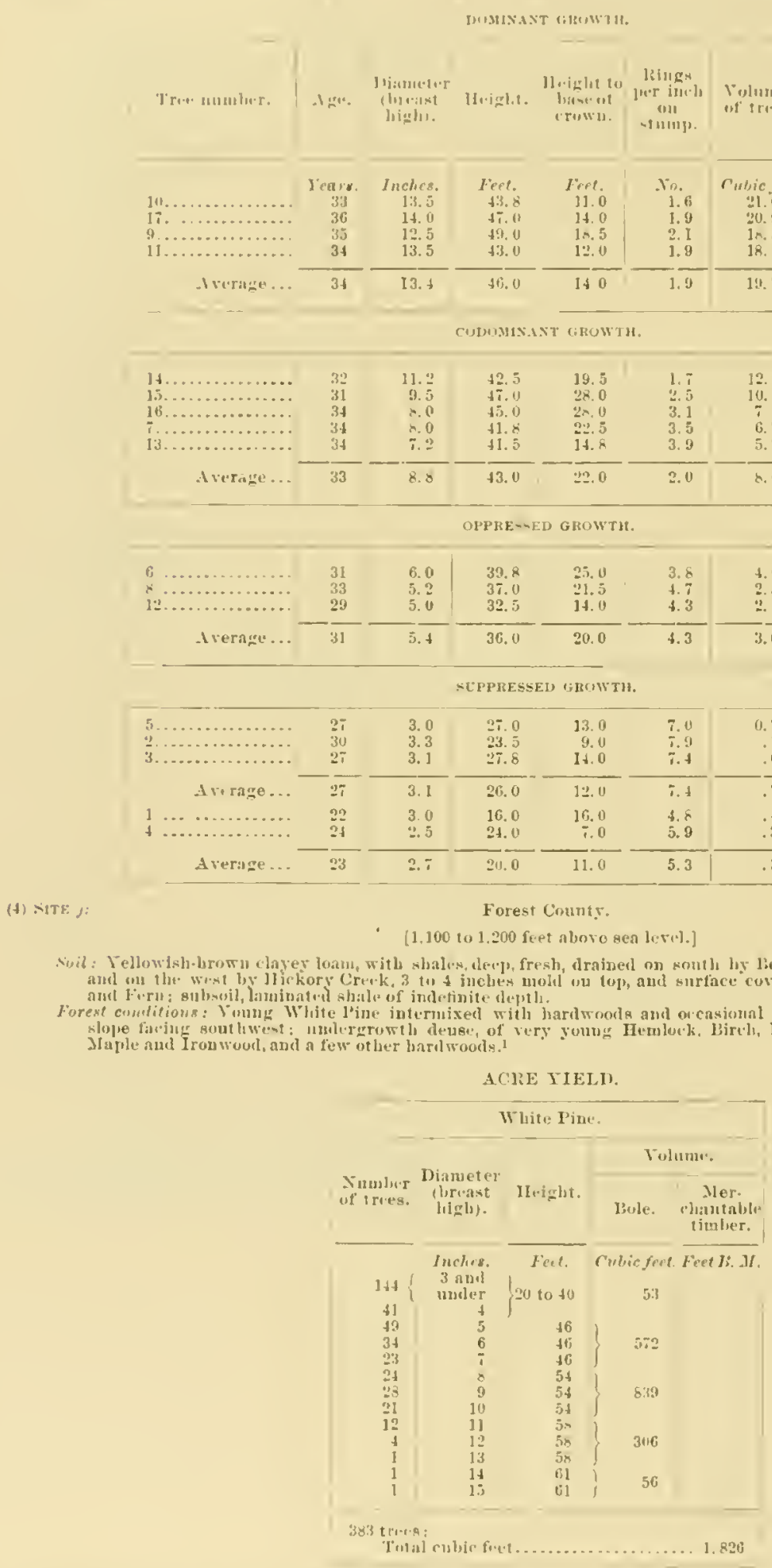

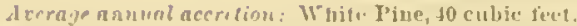

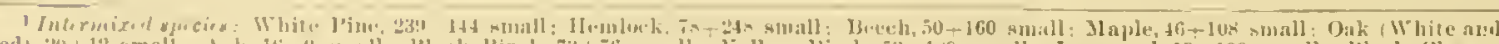

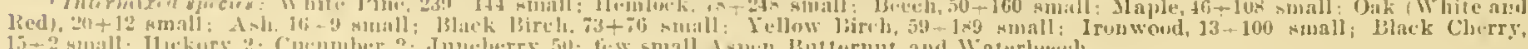

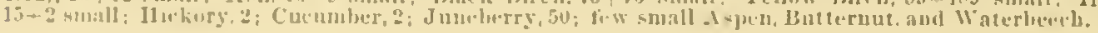




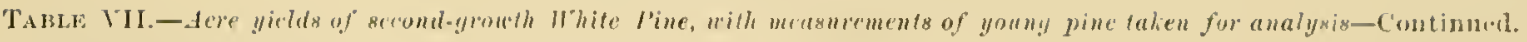

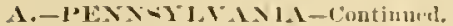

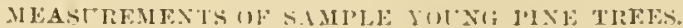

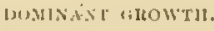

\begin{tabular}{|c|c|c|c|c|c|c|c|c|}
\hline Tree number. & Aget。 & $\begin{array}{c}\text { Diameter } \\
\text { (lureast } \\
\text { higli). }\end{array}$ & $11 \cdot i$ mht. & $\begin{array}{l}\text { Jeight to } \\
\text { lisatot" } \\
\text { "rwin. }\end{array}$ & $\begin{array}{c}\text { lings } \\
\text { yer inch } \\
\text { on } \\
\text { stump. }\end{array}$ & $\begin{array}{l}\text { Folume } \\
\text { of tiace. }\end{array}$ & $\begin{array}{l}\text { Fartor } \\
\text { of } \\
\text { Bluil }\end{array}$ & $\begin{array}{l}\text { liatio of } \\
\text { length } \\
\text { of rown } \\
\text { to tutal } \\
\text { lieight ot } \\
\text { :rete. }\end{array}$ \\
\hline $\begin{array}{l}3 \ldots \ldots \\
12 \ldots \ldots \ldots \\
2 \\
8 \\
16 \ldots \ldots \\
9 \\
9 \\
5 \\
6 \\
6 \\
21 \\
19 \ldots \ldots \ldots\end{array}$ & $\begin{array}{l}\text { Years. } \\
46 \\
44 \\
41 \\
47 \\
47 \\
45 \\
47 \\
47 \\
48 \\
47\end{array}$ & $\begin{array}{r}\text { Indhes. } \\
12.0 \\
11.5 \\
12.5 \\
11.0 \\
11.5 \\
11.0 \\
10.5 \\
10.0 \\
10.5 \\
11.0\end{array}$ & $\begin{array}{l}\text { Fot. } \\
60.0 \\
58.5 \\
55.0 \\
59.0 \\
61.0 \\
58.0 \\
60.0 \\
59.0 \\
58.0 \\
55.0\end{array}$ & $\begin{array}{l}\text { Feet. } \\
23 \\
317 \\
10 \\
30 \\
3 x \\
28 \\
34 \\
32 \\
30 \\
20\end{array}$ & $\begin{array}{r}\text { lo. } \\
3.5 \\
3.4 \\
3.4 \\
3.3 \\
3.3 \\
2.7 \\
3.7 \\
3.3 \\
3.6 \\
3.1\end{array}$ & $\begin{array}{c}\text { rubir jt. } \\
310.2 \\
20.0 \\
19.4 \\
18.7 \\
18.3 \\
17.4 \\
17.3 \\
16.4 \\
16.3 \\
15.4\end{array}$ & $\begin{array}{l}0.43 \\
.47 \\
.41 \\
.48 \\
.45 \\
.49 \\
.45 \\
.51 \\
.46 \\
.42\end{array}$ & $\begin{array}{l}0.62 \\
.55 \\
.67 \\
.49 \\
.50 \\
.52 \\
.43 \\
.16 \\
.40 \\
.49\end{array}$ \\
\hline A rerage.. & 46 & 11.11 & 58.0 & $2 x$ & 3.3 & 18.0 & .45 & .52 \\
\hline $1, \ldots \ldots \ldots \ldots \ldots \ldots$ & $\begin{array}{l}47 \\
4 f 5\end{array}$ & $\begin{array}{l}14.0 \\
14.0\end{array}$ & $\begin{array}{l}64.0 \\
58.0\end{array}$ & $\begin{array}{l}34 \\
20\end{array}$ & $\begin{array}{l}2 . ! 1 \\
3.11\end{array}$ & $\begin{array}{l}39.0 \\
36.9\end{array}$ & $\begin{array}{l}.43 \\
.43\end{array}$ & .87 \\
\hline A verage... & $4 t 5$ & 14.0 & 61.0 & 28 & 3.0 & $2 \times .2$ & .43 & .54 \\
\hline
\end{tabular}

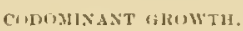

\begin{tabular}{|c|c|c|c|c|c|c|c|c|}
\hline $18, \ldots \ldots \ldots \ldots \ldots$ & 43 & 9.5 & 5ti. 0 & 28 & \$. 1 & $13 . ?$ & 0.50 & $0.5 n$ \\
\hline $14 \ldots \ldots \ldots \ldots$ & 43 & 10.0 & $5 \div 5$ & 30 & 4. 2 & 13.9 & . In & .43 \\
\hline $4 \ldots \ldots \ldots$ & 46 & $3(0,1)$ & 53.11 & 20 & 3.9 & 33.7 & .47 & .47 \\
\hline $11 .$. & 45 & 0.5 & 58.0 & 30 & 4.9 & 13.1 & .46 & .48 \\
\hline $17 \ldots \ldots \ldots \ldots \ldots$ & 44 & 9.0 & $5 \times 0$ & 32 & 3.9 & $12 . !$ & 47 & .44 \\
\hline $4, \ldots \ldots \ldots \ldots \ldots$ & 45 & 9. 0 & 46.0 & 23 & 4. 9 & 11.4 & in & .59 \\
\hline $26 \ldots \ldots \ldots \ldots \ldots$ & 45 & 8.5 & 511.0 & 311 & $\pm i$ & 10.0 & .51 & .40 \\
\hline $13 . \ldots \ldots \ldots \ldots \ldots$ & 13 & 8.11 & 54.11 & 2* & 3. 7 & 9.6 & .51 & $.4 s$ \\
\hline $1 \ldots \ldots, \ldots$ & 47 & 8.0 & 50.0 & 20 & 5. 1 & 9.2 & .53 & 60 \\
\hline $10 \ldots \ldots \ldots \ldots \ldots$ & 14 & 8.11 & $5 t j . v$ & 36 & 5.1 & 8.6 & .14 & .53 \\
\hline Arerage ... & 14 & 0.0 & 54.0 & $? s$ & 4.4 & 11.5 & .45 & .49 \\
\hline
\end{tabular}

OPPRE:SOED G1:OWTH

\begin{tabular}{|c|c|c|c|c|c|c|c|c|}
\hline 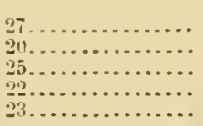 & $\begin{array}{l}43 \\
42 \\
43 \\
43 \\
44\end{array}$ & $\begin{array}{l}7.5 \\
7.0 \\
7.5 \\
5.0 \\
5.5\end{array}$ & $\begin{array}{l}42 \\
46 \\
46 \\
45 \\
46\end{array}$ & $\begin{array}{l}22 \\
30 \\
30 \\
24 \\
34\end{array}$ & $\begin{array}{l}5.0 \\
5.0 \\
5.2 \\
6.9 \\
6.8\end{array}$ & $\begin{array}{l}7.0 \\
6.6 \\
6.1 \\
3.1 \\
3.6\end{array}$ & $\begin{array}{l}0.54 \\
.53 \\
.43 \\
.50 \\
.47\end{array}$ & $\begin{array}{l}0.54 \\
.34 \\
.35 \\
.32 \\
.17\end{array}$ \\
\hline Arerage... & 43 & 6.3 & 40 & 30 & 5.8 & 5.4 & .49 & .35 \\
\hline
\end{tabular}




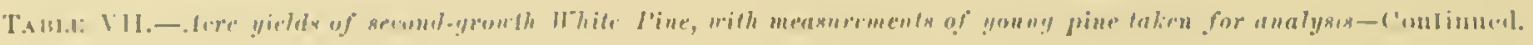
16.- \I. \INI:

(1) Site a:

Fork County.

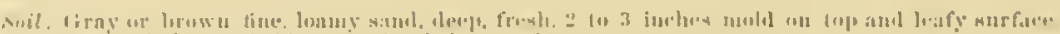

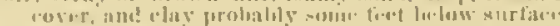

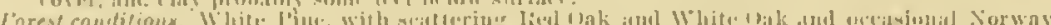

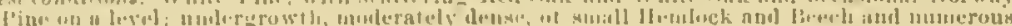
small II aplo nowl lak.

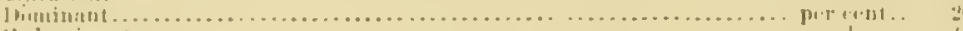

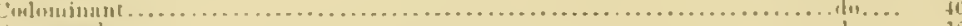

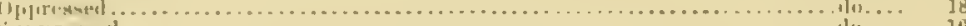

Silluristat

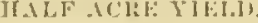

\begin{tabular}{|c|c|c|c|}
\hline \multicolumn{4}{|c|}{ White Jime. } \\
\hline \multirow[b]{2}{*}{$\begin{array}{l}\text { Numbler } \\
\text { ut ifeon. }\end{array}$} & \multirow[b]{2}{*}{ 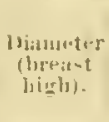 } & \multirow[b]{2}{*}{ Height. } & Violusur. \\
\hline & & & 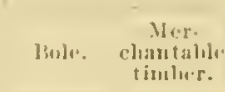 \\
\hline & Inches. & Fet. & r'ubirfeet. Fort fl. $\mathrm{J}$. \\
\hline$\frac{2}{8}$ & $\begin{array}{l}10 \\
11\end{array}$ & 75 & $\frac{42}{302}$ \\
\hline 8 & 12 & 75 & 233 \\
\hline 1 & 12 & 8.5 & 130 \\
\hline i & 13 & $\therefore ;$ & 228 \\
\hline 4 & 14 & 75 & [5t \\
\hline - & 14 & 85 & $33:$ \\
\hline$\therefore$ & 15 & $\therefore$ & :Bat \\
\hline 8 & ilf & 25 & $\sin x$ \\
\hline 8 & 17 & ง. & 528 \\
\hline III & Is & $\therefore 5$ & 6!III) \\
\hline lim & 19 & 8. & 1, 3ะs \\
\hline 2 & ב & $x ;$ & 152 \\
\hline I & 21 & sit & $3 \pm 0$ \\
\hline ii & sut & $x \bar{j}$ & 5.44 \\
\hline (i) & $\$ 3$ & 87 & ibibo \\
\hline 2 & 24 & 9.5 & 250 \\
\hline 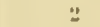 & $2 \div$ & 9. & 280 \\
\hline 1 & 26 & 1,7 & iljo \\
\hline & $=$ & & $=8$ \\
\hline $\begin{array}{l}118 \mathrm{two} \\
\mathrm{T}\end{array}$ & ubic f & & $\ldots 7$ \\
\hline
\end{tabular}

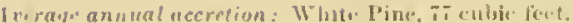

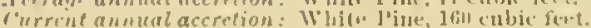

Simple areit: 1)m.half arre.

Age of pime: an to jou venra.

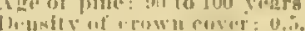

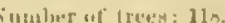

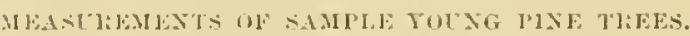

fige elusx: 00 tu 1110 yeitrs.

INOMIXANT GHWWTH.

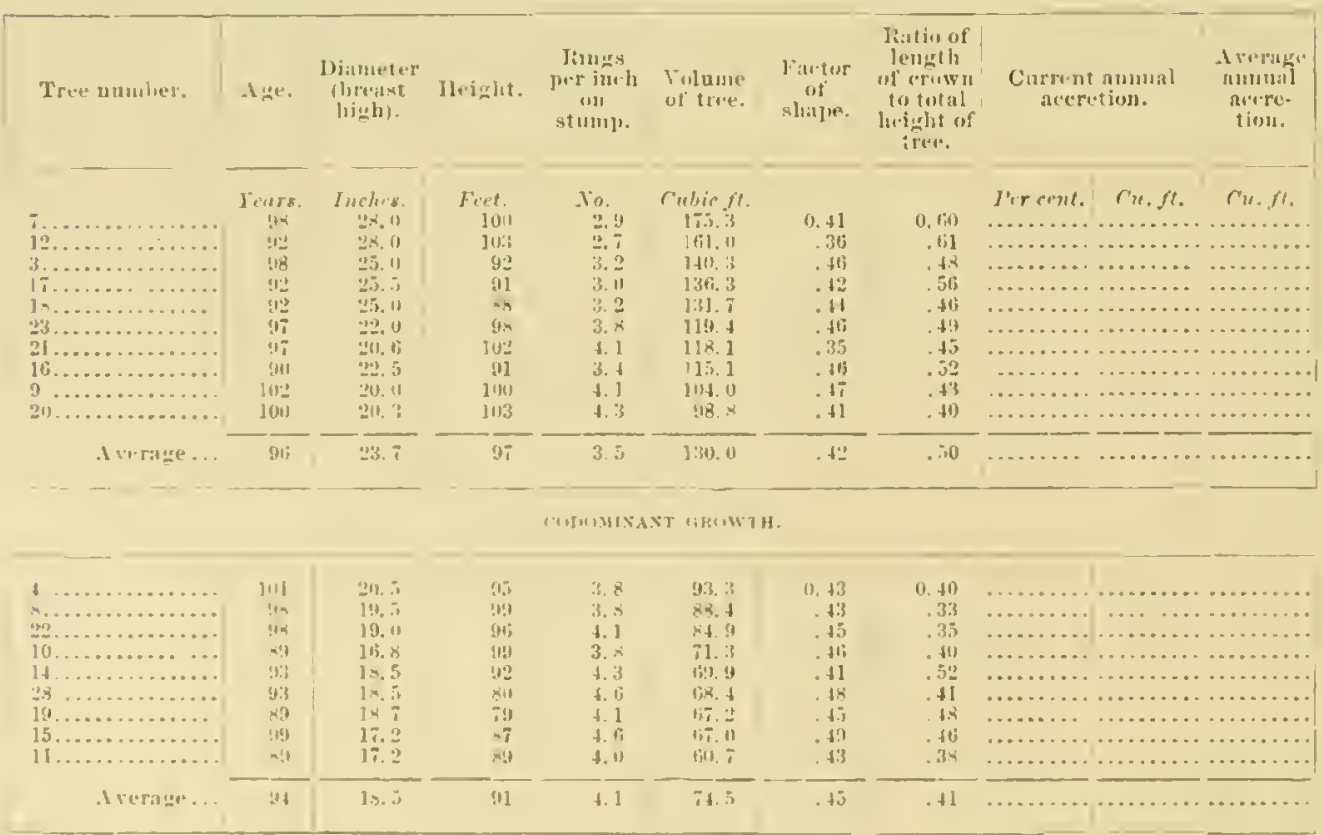




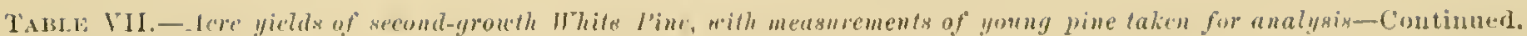
13. -MaIIXE-Conutinuml.

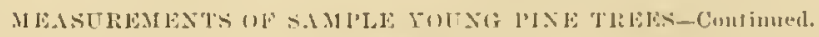

(IPPHEFSEI) (,RUWTH.

\begin{tabular}{|c|c|c|c|c|c|c|c|c|c|}
\hline 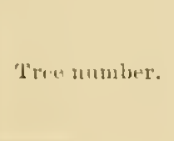 & Age. & $\begin{array}{c}\text { Diansetor } \\
\text { (hrivist } \\
\text { higha). }\end{array}$ & Hejght. & 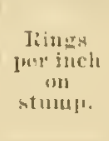 & $\begin{array}{l}\text { Volumen } \\
\text { of trice. }\end{array}$ & $\begin{array}{c}\text { Finctor } \\
\text { otit } \\
\text { sh:ipe. }\end{array}$ & 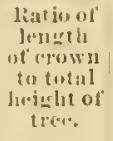 & $\begin{array}{l}\text { Current anuwal } \\
\text { acertion. }\end{array}$ & $\begin{array}{c}\text { A verago } \\
\text { anumal } \\
\text { accre. } \\
\text { tion. }\end{array}$ \\
\hline $\begin{array}{l}25 \ldots \ldots \ldots \\
1 \ldots \ldots \ldots \\
26 \ldots \ldots \ldots \\
6 \ldots \ldots \ldots \\
24 \ldots \ldots \ldots \\
5 \ldots \ldots \ldots \\
13 \ldots \ldots \ldots \\
27 \ldots \ldots \ldots\end{array}$ & $\begin{array}{c}\text { Years. } \\
100 \\
100 \\
99 \\
86 \\
97 \\
99 \\
91 \\
99\end{array}$ & $\begin{array}{r}\text { Inclues. } \\
15.0 \\
15.0 \\
14.0 \\
14.3 \\
13.5 \\
13.6 \\
13.2 \\
12.0\end{array}$ & $\begin{array}{r}\text { Fret. } \\
93 \\
90 \\
90 \\
26 \\
81 \\
86 \\
-0 \\
80\end{array}$ & $\begin{array}{l}\text { Yo. } \\
\text { i. } 1 \\
6.5 \\
6.0 \\
5.0 \\
5.8 \\
7.2 \\
5.0 \\
6.3\end{array}$ & $\begin{array}{c}\text { rutie jt. } \\
55.5 \\
5.3 \\
47.3 \\
43.1 \\
37.3 \\
37.1 \\
35.9 \\
311.7\end{array}$ & $\begin{array}{l}0.48 \\
.51 \\
.41 \\
10 \\
.11 \\
.50 \\
.48 \\
.19\end{array}$ & $\begin{array}{l}0.37 \\
.315 \\
.21 \\
.18 \\
.20 \\
14 \\
.30 \\
.22\end{array}$ & 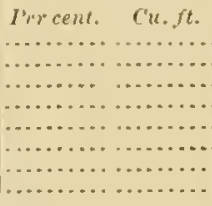 & 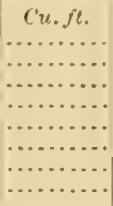 \\
\hline Average & 96 & 13.. & $8 i j$ & 6.0 & 43.8 & .43 & .23 & 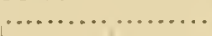 & \\
\hline
\end{tabular}

Aige cluse : all to 60 yeirs.

DuMNANT GHWTII

\begin{tabular}{|c|c|c|c|c|c|c|c|c|c|c|}
\hline $\begin{array}{l}2 \ldots . . \\
3 \ldots \\
4 \ldots\end{array}$ & $\begin{array}{l}53 \\
6311 \\
60 \\
59\end{array}$ & $\begin{array}{l}14.0 \\
11.7 \\
17.0 \\
19.1\end{array}$ & $\begin{array}{l}61 \\
613 \\
61 \\
\text { (i5) }\end{array}$ & $\begin{array}{l}3.2 \\
3.3 \\
3.1 \\
2.8\end{array}$ & $\begin{array}{l}34.2 \\
34.8 \\
1 \% .8 \\
60.7\end{array}$ & $\begin{array}{r}0.52 \\
.511 \\
.44 \\
.47\end{array}$ & $\begin{array}{r}0.69 \\
.47 \\
.64 \\
.69\end{array}$ & $\begin{array}{l}5.4 \\
4.0 \\
4.6 \\
4.4\end{array}$ & $\begin{array}{l}1.85 \\
1.59 \\
1.97 \\
2.67\end{array}$ & $\begin{array}{r}0.62 \\
.66 \\
.71 \\
1.03\end{array}$ \\
\hline Areragge... & 58.5 & 16.2 & 64 & 3.1 & 44.1 & .48 & .03 & 1. 6 & 2.02 & .75 \\
\hline
\end{tabular}

(2) SITE $c$ :

Tork County.

Sample area : 1 acri. ()nefourth acre to. 1.

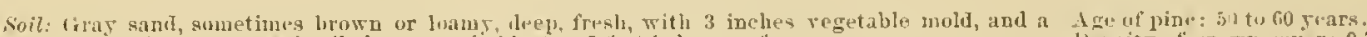

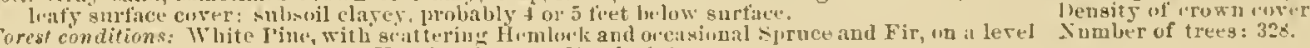

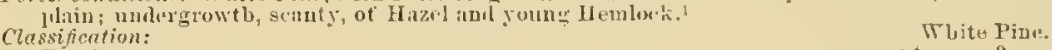

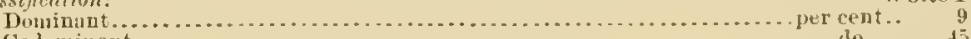

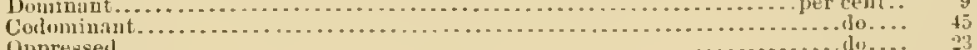

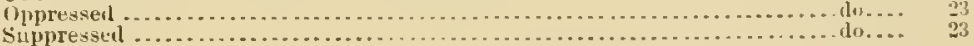

ONE-FOCITII ACIEE VIILII.

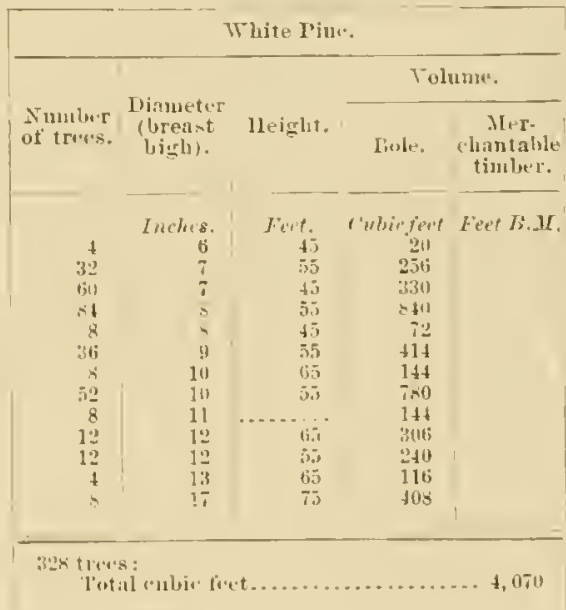

ferreys annual accretion: Th hite Piw, it euhir fort.

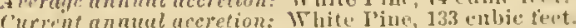

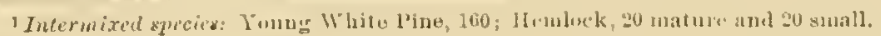




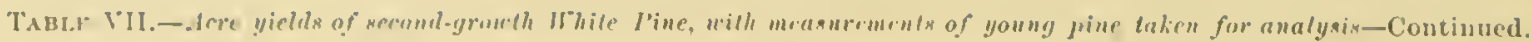
I1. M.IIN:-Contisund.

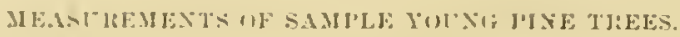

DUMSANT GRUWTU.

\begin{tabular}{|c|c|c|c|c|c|c|c|}
\hline Trees tumber. & Age. & $\begin{array}{l}\text { Diamuter } \\
\text { (lireant } \\
\text { bighi. }\end{array}$ & IJ-jght. & $\begin{array}{l}\text { Jings } \\
\text { per inch } \\
\text { แn } \\
\text { stump. }\end{array}$ & $\begin{array}{l}\text { Volinus" } \\
\text { "it troxo. }\end{array}$ & $\begin{array}{l}\text { Fintert } \\
\text { wit } \\
\text { yliape. }\end{array}$ & 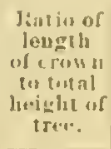 \\
\hline $\begin{array}{l}9 \ldots \ldots \ldots \ldots \ldots \\
4 \ldots \ldots \ldots \ldots \ldots \\
{ }_{1} \ldots \ldots \ldots \ldots \ldots \ldots \\
10 \ldots \ldots \ldots \ldots \ldots \\
12 \ldots \ldots \ldots \ldots \ldots\end{array}$ & $\begin{array}{c}\text { Years. } \\
50 \\
30 \\
55 \\
519 \\
59 \\
50\end{array}$ & $\begin{array}{r}\text { Inclies. } \\
14.5 \\
13.3 \\
11.8 \\
11.8 \\
11 . .5 \\
11.0\end{array}$ & $\begin{array}{l}\text { Fert. } \\
\text { 6it } \\
6 \text { in } \\
6 i \\
5 . \\
6.1 \\
62\end{array}$ & $\begin{array}{l}\text {.1o. } \\
2.8 \\
3.8 \\
3.3 \\
3.5 \\
4.4 \\
3.7\end{array}$ & 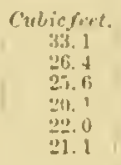 & $\begin{array}{l}0.95 \\
.44 \\
.45 \\
.52 \\
.59 \\
.50\end{array}$ & $\begin{array}{r}11.55 \\
.58 \\
.3 x \\
.41 \\
.35 \\
.35\end{array}$ \\
\hline Arurage... & 54 & 12.3 & 62 & 3. 6 & 24.7 & .49 & .14 \\
\hline
\end{tabular}

COPOMISANT GROWTH.

\begin{tabular}{|c|c|c|c|c|c|c|c|}
\hline 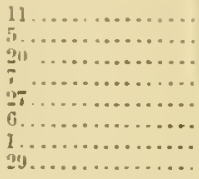 & $\begin{array}{l}52 \\
50 \\
51 \\
50 \\
51 \\
511 \\
19 \\
52\end{array}$ & $\begin{array}{l}1011 \\
9.0 \\
8.8 \\
1.4 \\
8.1 \\
8.4 \\
8.1 \\
8.0\end{array}$ & $\begin{array}{l}59 \\
5 \\
58 \\
54 \\
54 \\
55 \\
56 \\
58\end{array}$ & $\begin{array}{l}4.3 \\
+.3 \\
4.6 \\
4.3 \\
5.1 \\
+.3 \\
5.0 \\
5.5\end{array}$ & $\begin{array}{l}16.1 \\
13.4 \\
13.3 \\
12.3 \\
10.7 \\
10.6 \\
11.2 \\
10.1\end{array}$ & $\begin{array}{l}0.50 \\
.52 \\
.54 \\
.40 \\
.55 \\
.50 \\
.52 \\
.50\end{array}$ & $\begin{array}{l}0.41 \\
.11 \\
.34 \\
\text { (1) } \\
.37 \\
.40 \\
.34 \\
.37\end{array}$ \\
\hline Average... & i1 & 8.7 & 37 & 4. 7 & 12.1 & .51 & $3 ! 1$ \\
\hline
\end{tabular}

OPIRESALD GIUGWTH.

\begin{tabular}{|c|c|c|c|c|c|c|c|}
\hline 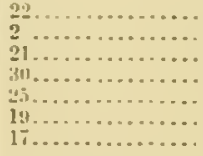 & $\begin{array}{l}49 \\
52 \\
49 \\
40 \\
50 \\
51 \\
510\end{array}$ & $\begin{array}{l}\pi .7 \\
7.8 \\
8.01 \\
7.7 \\
8.4 \\
8.2\end{array}$ & $\begin{array}{l}53 \\
54 \\
51 \\
54 \\
58 \\
48 \\
54\end{array}$ & $\begin{array}{l}\text { i. } 2 \\
5.11 \\
5.11 \\
5.1 \\
5.6 \\
5.1 \\
5.6\end{array}$ & $\begin{array}{l}8.6 \\
11.5 \\
9.5 \\
9.0 \\
3.0 \\
8.9 \\
8.0\end{array}$ & $\begin{array}{l}0.56 \\
.50 \\
.53 \\
.52 \\
.511 \\
.51 \\
.50\end{array}$ & $\begin{array}{r}0.30 \\
.26 \\
.39 \\
.411 \\
.33 \\
.34 \\
.30\end{array}$ \\
\hline Average... & ju & i. 8 & .3 & 5.2 & 9.1 & .52 & .33 \\
\hline
\end{tabular}

-CPPRE TSEI FOLUWTII.

\begin{tabular}{|c|c|c|c|c|c|c|c|}
\hline 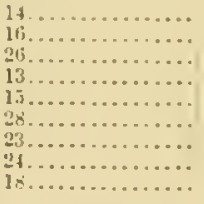 & $\begin{array}{l}5.3 \\
40 \\
415 \\
46 \\
45 \\
50 \\
4= \\
5 \% \\
52\end{array}$ & $\begin{array}{l}\text { 6. } 3 \\
6.9 \\
0.3 \\
6.2 \\
5.10 \\
0.0 \\
5.3 \\
5.0 \\
5.0\end{array}$ & $\begin{array}{l}57 \\
49 \\
51 \\
47 \\
50 \\
38 \\
415 \\
48 \\
46\end{array}$ & $\begin{array}{r}(?) \\
5.7 \\
5.5 \\
5.8 \\
7.0 \\
5.0 \\
7.4 \\
7.3 \\
10.0\end{array}$ & $\begin{array}{l}6.3 \\
5.8 \\
5.5 \\
5.1 \\
4.3 \\
3.7 \\
3.6 \\
3.4 \\
3.2\end{array}$ & $\begin{array}{l}0.51 \\
.44 \\
.47 \\
.51 \\
.52 \\
.48 \\
.47 \\
.52 \\
.50\end{array}$ & $\begin{array}{l}0.31 \\
.28 \\
.25 \\
.27 \\
.20 \\
.56 \\
.26 \\
.43 \\
.27\end{array}$ \\
\hline Average... & 50 & 5. 8 & th & $\div 2$ & 4.5 & $.4 !$ & .31 \\
\hline
\end{tabular}




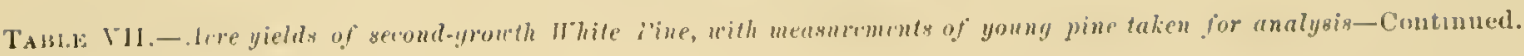

B.-MMYE-Continacul.

One poterth acre .to. 2 .

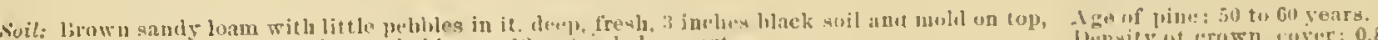

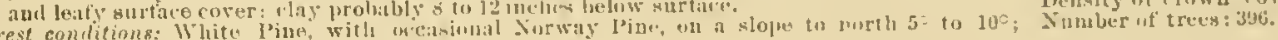

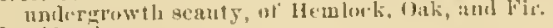

Classification:

biminant. White lib.

Corlominaut ........

(1) piriosised . du...

(OSE. HOLRTI ICRE TIHID.

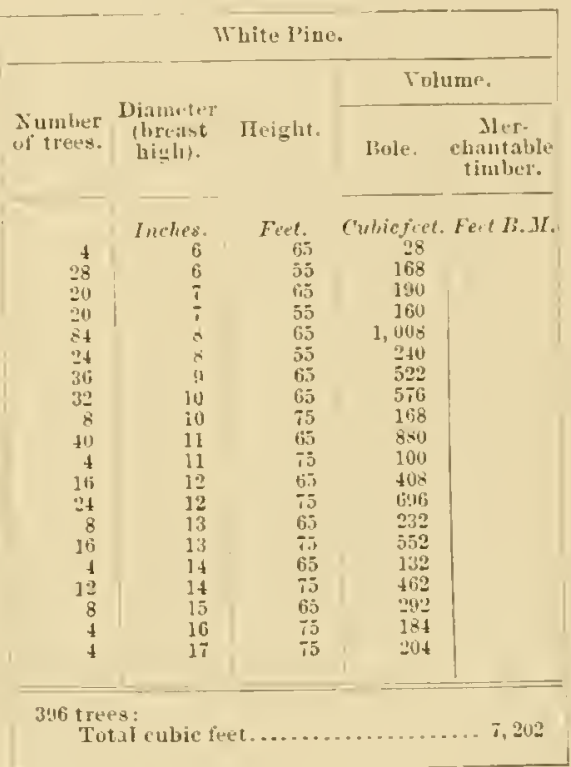

Averue annual accretion: White Pine, 131 cubie feet

$$
\text { One-half acre Vo.3. }
$$

Soil: Brown sand, leep, fresh, and leafy surface corer; clay probably 4 to 6 feet below surface. Forest conditions: White Pine intermised with fortrar Pios and occasinal spruce and Fir, on clasuifcation: Domvinant

Dominant

Copressent

supprensed

\begin{tabular}{|c|c|c|c|c|}
\hline \multirow[b]{3}{*}{$\begin{array}{l}\text { Sumber } \\
\text { of trees. }\end{array}$} & \multicolumn{2}{|c|}{ Whito Pine. } & & \\
\hline & & & \multicolumn{2}{|c|}{ Tolnme. } \\
\hline & $\begin{array}{c}\text { Diameter } \\
\text { (i)reast } \\
\text { bigh). }\end{array}$ & Height. & Bole. & $\begin{array}{l}\text { Mer' } \\
\text { 'hantable } \\
\text { timber. }\end{array}$ \\
\hline & Inehes. & Fett. & C'ulicfeet. & Feet B. If. \\
\hline 18 & 7 & 65 & 162 & \\
\hline $\begin{array}{l}48 \\
60\end{array}$ & 8 & $\begin{array}{l}53 \\
6.5\end{array}$ & $\begin{array}{l}384 \\
720\end{array}$ & \\
\hline$\because 6$ & 8 & 55 & 260 & \\
\hline 41 & !) & 65 & 635 & \\
\hline 6 & 9 & 33 & 69 & \\
\hline 4 & 10 & 75 & 82 & \\
\hline 38 & 10 & is & $6 n t$ & \\
\hline 10 & 11 & 75 & 250 & \\
\hline$\because$ & 11 & 65 & 616 & \\
\hline 14 & 12 & 75 & 110 & \\
\hline 14 & 12 & 65 & 357 & \\
\hline 1 & 13 & 75 & $13 R$ & \\
\hline $\begin{array}{l}6 \\
2\end{array}$ & 13 & 65 & $1: \pm$ & \\
\hline$\frac{3}{2}$ & $\begin{array}{l}14 \\
15\end{array}$ & 65 & 73 & \\
\hline
\end{tabular}

Age of pine: 50 to 60 years. Nentisty of crown cores 


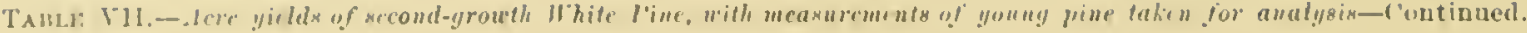

13.-. IIIIVI-Coutinuel.

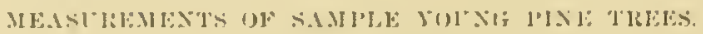
DONISAST HRIWTH.

\begin{tabular}{|c|c|c|c|c|c|c|c|}
\hline "Tree number. & I 19 & 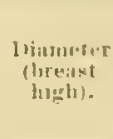 & Heislte. & 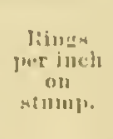 & $\begin{array}{l}\text { Sulume. } \\
\text { of tree. }\end{array}$ & $\begin{array}{c}\text { Jiatur } \\
\text { nif } \\
\text { mbigue. }\end{array}$ & 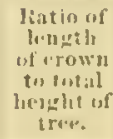 \\
\hline 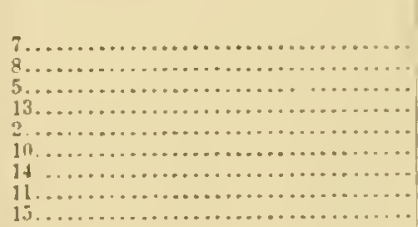 & 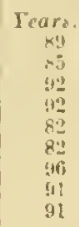 & $\begin{array}{r}\text { Inches } \\
21.8 \\
19.6 \\
17.3 \\
19.3 \\
18.8 \\
17.7 \\
18.5 \\
17.2 \\
17.2\end{array}$ & 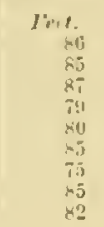 & $\begin{array}{r}\text { Va. } \\
3.7 \\
4.0 \\
4.4 \\
4.2 \\
3.8 \\
4.4 \\
4.4 \\
4.5 \\
4.4\end{array}$ & $\begin{array}{r}r y . r t . \\
69.3 \\
76.5 \\
69.5 \\
6 ! 1.3 \\
6.6 \\
67.4 \\
60.6 \\
6+1.4 \\
63.7\end{array}$ & $\begin{array}{l}0.40 \\
41 \\
4 \times \\
.42 \\
413 \\
46 \\
42 \\
49 \\
49\end{array}$ & $\begin{array}{l}0.42 \\
.517 \\
.52 \\
.47 \\
.39 \\
.41 \\
.45 \\
.45 \\
.45\end{array}$ \\
\hline 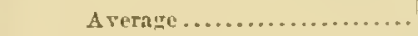 & 89 & $1 \times 6$ & 83 & 4. 2 & 70.8 & .45 & .46 \\
\hline$\ldots \ldots \ldots+\cdots, \ldots$ & 89 & 24.0 & $8 ;$ & 3. 3 & 123.5 & .45 & .54 \\
\hline
\end{tabular}

SCPPRESSED GHOWTH.

\begin{tabular}{|c|c|c|c|c|c|c|c|}
\hline $\begin{array}{l}3 \ldots \ldots \\
1 \ldots \ldots\end{array}$ & $\begin{array}{l}100 \\
190\end{array}$ & $\begin{array}{l}12.6 \\
10.11\end{array}$ & 69 & $\begin{array}{l}8.0 \\
8.7\end{array}$ & $\begin{array}{l}24.9 \\
210.1\end{array}$ & $\begin{array}{r}0.50 \\
.53\end{array}$ & $\begin{array}{r}0.54 \\
.39\end{array}$ \\
\hline Areragu & 93 & 11.3 & 63 & 8.3 & 22.5 & I. & 46 \\
\hline
\end{tabular}

PENOBSCOT CULNTY

\begin{tabular}{|c|c|c|c|c|c|c|c|c|c|}
\hline Tree number. & Agge. & $\begin{array}{l}\text { Uinumeter } \\
\text { (lireast } \\
\text { hight). }\end{array}$ & 11 tight. & $\begin{array}{l}\text { Tolnme } \\
\text { of trec. }\end{array}$ & $\begin{array}{c}\text { Foctur } \\
\text { of } \\
\text { shape. }\end{array}$ & $\begin{array}{c}\text { Jatiouf } \\
\text { ledgth } \\
\text { of crown } \\
\text { fo total } \\
\text { bight of } \\
\text { tri\%. }\end{array}$ & \multicolumn{2}{|c|}{$\begin{array}{l}\text { ('urrent anmual } \\
\text { aecretion. }\end{array}$} & 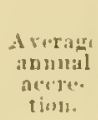 \\
\hline 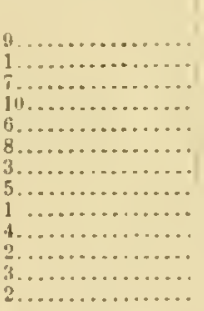 & $\begin{array}{c}\text { Jears. } \\
68 \\
77 \\
73 \\
74 \\
70 \\
69 \\
73 \\
75 \\
70 \\
73 \\
79 \\
79 \\
72\end{array}$ & $\begin{array}{c}\text { Inclues. } \\
12.5 \\
16.11 \\
12.0 \\
13.0 \\
13.0 \\
13.2 \\
13.5 \\
14.7 \\
15 . \\
14 . \\
17.0 \\
16.5 \\
15.2\end{array}$ & $\begin{array}{r}\text { Feet. } \\
76 \\
62 \\
70 \\
811 \\
77 \\
72 \\
83 \\
24 \\
81 \\
82 \\
74 \\
78 \\
45\end{array}$ & $\begin{array}{r}r w . f t . \\
31.83 \\
34.53 \\
35.31 \\
36.011 \\
35.15 \\
38.41 \\
40.43 \\
43.20 \\
42.34 \\
45.11 \\
51.11 \\
31.2 .4 \\
51.41\end{array}$ & 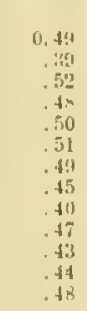 & $\begin{array}{l}0.41 \\
.191 \\
.45 \\
.411 \\
.52 \\
35 \\
.32 \\
.35 \\
13 \\
.39 \\
.13 \\
.65 \\
.30\end{array}$ & $\begin{array}{c}\text { Iercent. } \\
2.8 \\
3.3 \\
3.7 \\
3.1 \\
3.0 \\
3.6 \\
2.1 \\
2.5 \\
3.0 \\
3.2 \\
\vdots 10 \\
3.0 \\
2.0\end{array}$ & $\begin{array}{r}\text { Cu. } 19 . \\
0.81 \\
1.14 \\
1.31 \\
1.12 \\
1.115 \\
1.38 \\
\text { 1. } 53 \\
1.51 \\
1.41 \\
1.112 \\
1.113 \\
1.115\end{array}$ & 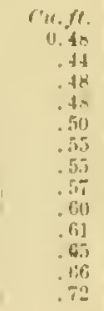 \\
\hline Avirage... & 73 & 11.4 & 79 & 41.30 & 46 & .44 & 3.0 & 1.21 & .06 \\
\hline
\end{tabular}




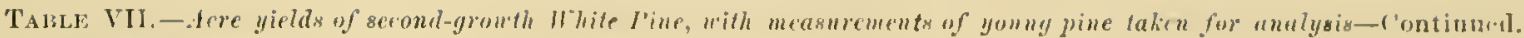

\section{C.-MASTACHISTETS:}

(1) SITE $a$ :

[1ollnouk, Norfolk Ciunty.

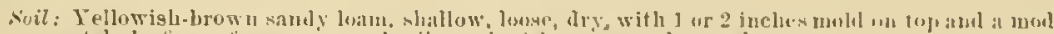

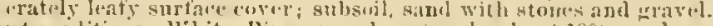

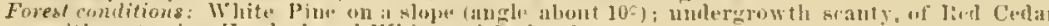
with scatteriug Hemlock and Whith and livel hak.

ACRE SIELU.

\begin{tabular}{|c|c|c|c|c|}
\hline \multirow[b]{3}{*}{$\begin{array}{l}\text { Simbiuer } \\
\text { of troes. }\end{array}$} & \multicolumn{4}{|c|}{ White I'ine. } \\
\hline & \multirow[b]{2}{*}{ 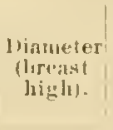 } & \multirow[b]{2}{*}{ If eigltt. } & \multicolumn{2}{|c|}{ Volnue. } \\
\hline & & & linle. & $\begin{array}{l}\text { Mer. } \\
\text { hliantable } \\
\text { timlrer. }\end{array}$ \\
\hline 169 & Inclies. & Feep & $\begin{array}{l}\text { Cubicfret } \\
1,690\end{array}$ & Fet L.M. \\
\hline 5 & 1i) & 60 & 811 & \\
\hline 18 & 10) & 70 & 342 & \\
\hline 24 & 11 & 70 & $52 \mathrm{n}$ & \\
\hline 23 & 12 & 70 & $5 ! 1$ - & \\
\hline 28 & 13 & 70 & $86 \mathrm{sin}$ & \\
\hline 11 & 14 & 70 & $3 \times 5$ & \\
\hline 7 & 15 & 70 & $2 \times 0$ & \\
\hline 1 & 17 & 70 & 51 & \\
\hline
\end{tabular}

Arerage anual accretion: White Pine, 131 enbic fret.

(2) SITE: U:

Peombrolir, Plymouth County

Sanple area: I acre.

Soil: Fellowish-brewn sands loam, medinm grain, light, lunse, fresh, with 2 to 3 inebes mold on top and surface enver of alundaut leitres.

作 :ntl Hornbesm; undergrowth moderately dense uf ubove splecies of hatrdwoods.2
Samule ariat: 1 aure.

Ige uf pille: 33 tes 35 grats. Nimber of treen: 280 .

\section{ACRE TIELIS.}

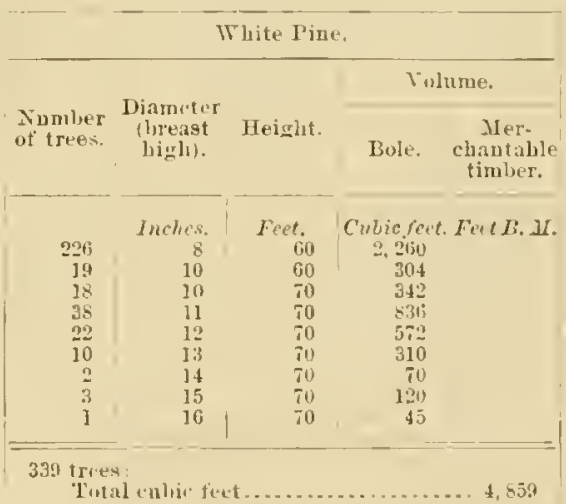

Seraye anmual accretion: Thito P'jue, 92 cubic feet.

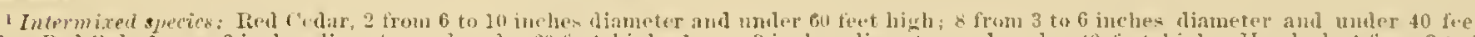

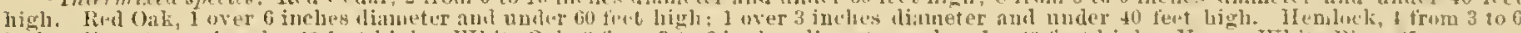

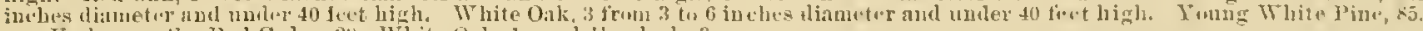

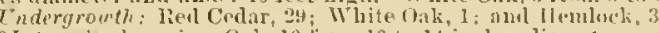

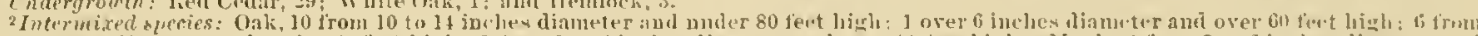

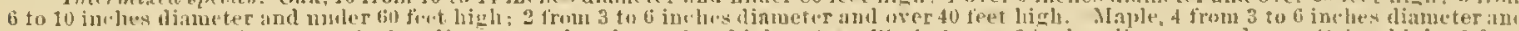

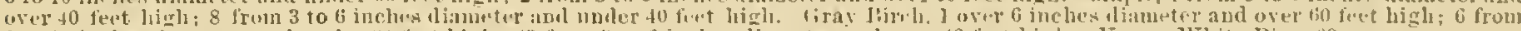

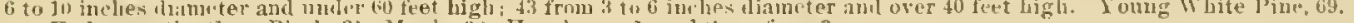

Cnderrowth: Gray Birch, 21; Japle, 38; Horn beatw, 1, and Silssiffias, 3. 


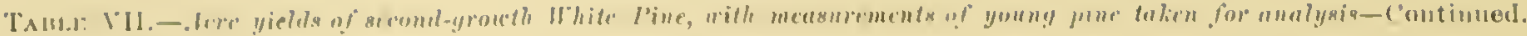

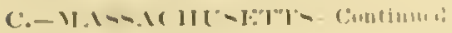

(3) Sitrs 6 .

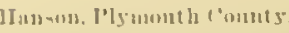

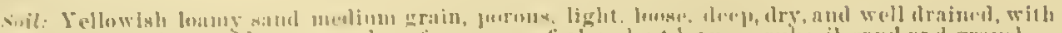

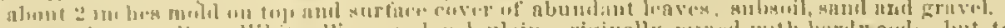

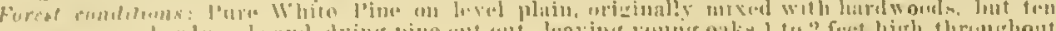

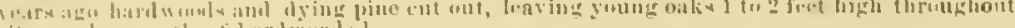

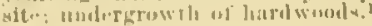

ACКЕ YILI).

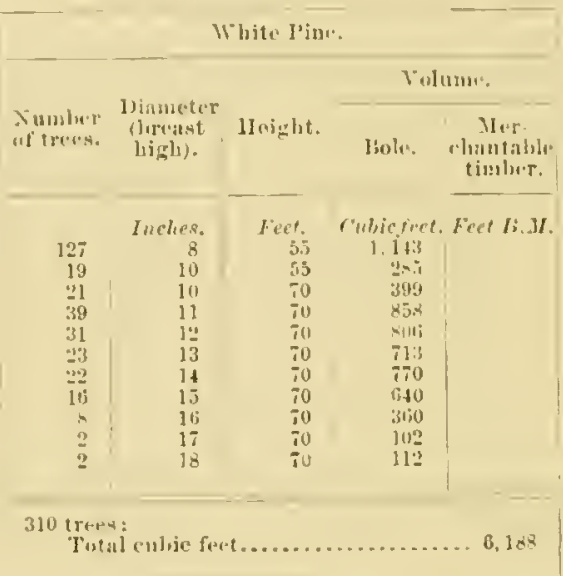

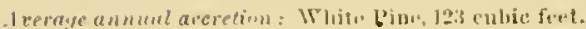

(4) - YITE d:

Weymonls, Forfolk Connty.

[180 feet above sisa dever.]

Sample aria: 1 arre.

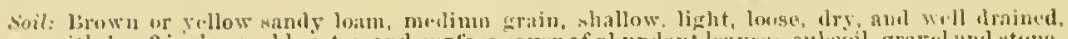

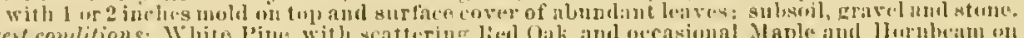

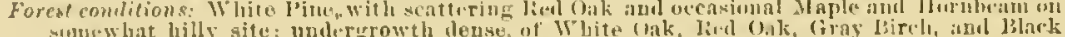
Bircll.

ATIIE TIFI,I)

\begin{tabular}{|c|c|c|c|c|}
\hline \multirow[b]{3}{*}{$\begin{array}{l}\text { Xinulwer } \\
\text { of trees. }\end{array}$} & \multicolumn{3}{|c|}{ Whito J'ins. } & \\
\hline & \multirow[b]{2}{*}{$\begin{array}{l}\text { lianueter } \\
\text { (lineilst } \\
\text { higli). }\end{array}$} & \multirow[b]{2}{*}{ Heiglit. } & \multicolumn{2}{|c|}{ 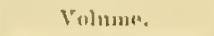 } \\
\hline & & & Inile. & $\begin{array}{l}\text { Mer. } \\
\text { chantible } \\
\text { timbror. }\end{array}$ \\
\hline & Inches. & Fere. & Cubiefert. & Fint It. I. \\
\hline $\begin{array}{l}174 \\
: 65\end{array}$ & $\begin{array}{r}8 \\
10\end{array}$ & 65 & $\begin{array}{r}1,7+1 \\
612\end{array}$ & \\
\hline 26 & 11 & (1) & $5 i=$ & \\
\hline 21 & 12 & 71 & $511^{\circ}$ & 1 \\
\hline iii & 13 & 70 & t!mi & \\
\hline 10 & 14 & 70 & 350 & \\
\hline 4 & 15 & i11 & Jiin & \\
\hline 3 & 16 & i11 & 1:35 & \\
\hline 1 & 17 & i0 & 51 & \\
\hline 3 & 19 & 70 & 1:3 & \\
\hline 1 & 21 & iu & is & \\
\hline $\begin{array}{c}\text { 295 } 1 \text { ree } \\
\text { re }\end{array}$ & 1. & & & $\ldots+1023$ \\
\hline
\end{tabular}

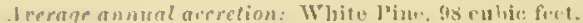

He

2 furer Grus ling 11

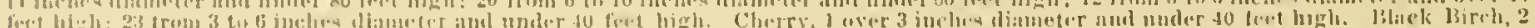
the to alinserter and

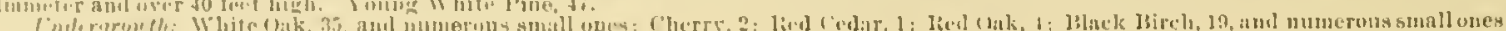

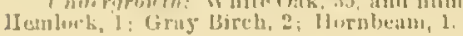




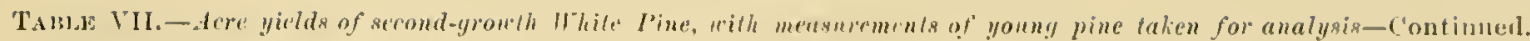

C. MASSACII'SETP-Coutinued.

(5) SITE $\rho:$

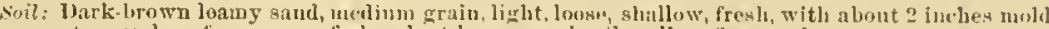
on top, and surfico cover of abuadant leaves; subsoil, yellow finc sabl.

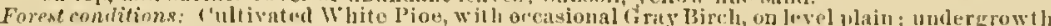
of stattering Oak aud II IIple. ACIR YIELI,

\begin{tabular}{|c|c|c|c|c|}
\hline \multicolumn{5}{|c|}{ Whito Pint. } \\
\hline \multirow[b]{2}{*}{$\begin{array}{l}\text { Nunber } \\
\text { of treeso. }\end{array}$} & \multirow[b]{2}{*}{$\begin{array}{l}\text { Hianoter } \\
\text { (lirenst } \\
\text { high). }\end{array}$} & \multirow[b]{2}{*}{ II ciglit. } & \multicolumn{2}{|c|}{ Tolume. } \\
\hline & & & linglo. & $\begin{array}{l}\text { Mer. } \\
\text { rlantable } \\
\text { timuler. }\end{array}$ \\
\hline & Iurkes. & Feet. & rubicfret. & Fent D. Mr \\
\hline $\begin{array}{r}241 \\
1\end{array}$ & $\begin{array}{r}8 \\
10\end{array}$ & 55 & 2,160 & \\
\hline 12 & 10 & 60 & 672 & \\
\hline 22 & 11 & 60 & 418 & \\
\hline 27 & 12 & 60 & 621 & \\
\hline 15 & 13 & 60 & 390 & \\
\hline 13 & I4 & 65 & +29 & \\
\hline 6 & 15 & 65 & 222 & \\
\hline 2 & 16 & 65 & 81 & \\
\hline 4 & 17 & 70 & 204 & \\
\hline 2 & 18 & 70 & 112 & \\
\hline
\end{tabular}

374 trens

Total cubie feret .................. 5,397

tverage annual aceretion: White l'ine, 118 cubic fret.

(6) SITE $y$ :

Bridgewat:r. Plyuouth County.

[100 feet alove sua level.]

Soil: Light-brown sandy loam, medium grain, shallow, light, loose, drs, well drained, witb alsout 2 iuebes mold on top, and surface cover of abuadaut leaves: subsoil, grarel of all sizes.

Forest conditions: Cultivated Vhite Pine, intermixed with romg hardwools and Pitch Pide. (1)iue seerllings from woods, 1 to 2 feet bigh, set in furrowa at 6 or 8 feet each way.)

\section{A('LE TIELI).}

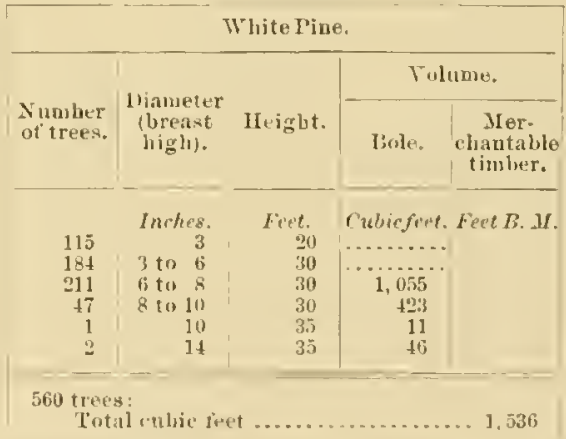

imerase anualaceretion: Yibte l'ine, fil embe fact.

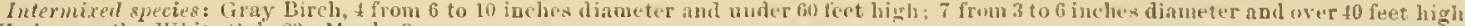

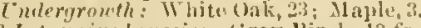

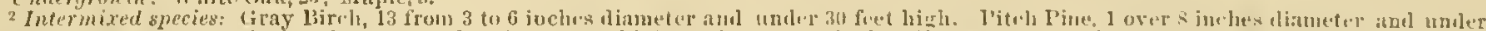

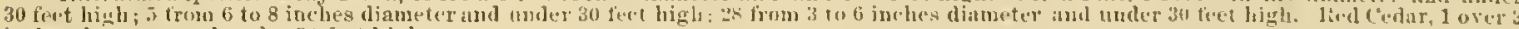
inclus dirineter at uniler 30 feet higl.

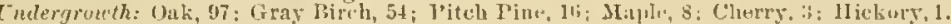

2033 - Yo. '2: 11 


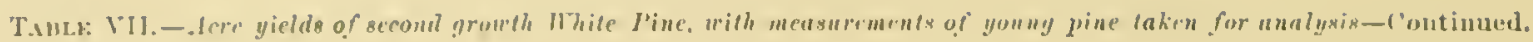

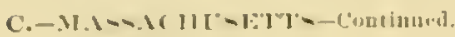

(I) SITE!)

Girafton, Mindless.x Connty.

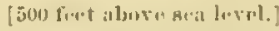

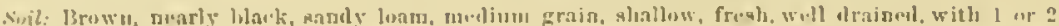

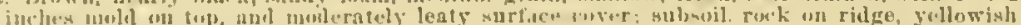
sanul on low

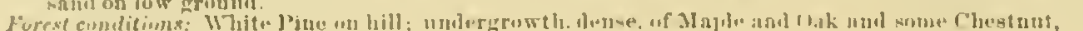

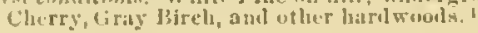

ACI:I Y ITISU

\begin{tabular}{|c|c|c|c|c|}
\hline \multicolumn{5}{|c|}{ White Plw. } \\
\hline \multirow[b]{2}{*}{$\begin{array}{l}\text { Jumber } \\
\text { of tries. }\end{array}$} & \multirow[b]{2}{*}{$\begin{array}{l}\text { Hiamotor } \\
\text { (breast } \\
\text { hish). }\end{array}$} & \multirow[b]{2}{*}{ Mr.jelst. } & \multicolumn{2}{|c|}{ Volinms. } \\
\hline & & & Busle. & 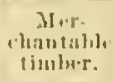 \\
\hline & Inchos. & Fent. & rwbirfeet. & Fel Ji.M. \\
\hline $\begin{array}{r}1.6 \\
2\end{array}$ & 10 & tio & $\begin{array}{r}1+100 \\
32\end{array}$ & \\
\hline 43 & 10 & 70 & 817 & \\
\hline 41 & 11 & Ti & $! 11 \%$ & \\
\hline 23 & $1 \div$ & 71 & 594 & \\
\hline 21 & 13 & 70 & 6.51 & \\
\hline 8 & 14 & 70 & $\because x i 1$ & \\
\hline 4 & 15 & 70 & lis, & \\
\hline 4 & 1s & 70 & 112 & \\
\hline $\begin{array}{l}23 \text { tre } \\
\text { Tot }\end{array}$ & cubieft & & & $\ldots 5,37$ \\
\hline
\end{tabular}

Irerayr annual accretim: Whito Pise, 134 cubis siet.

(i) SITE h:

Worewster, Worenter Conuty.

Simple area: I are.

[Aliont 6i)u feet aluse sea le.r.

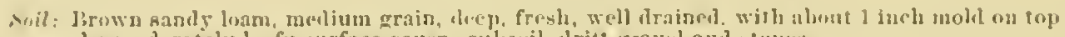

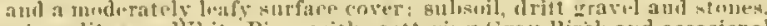

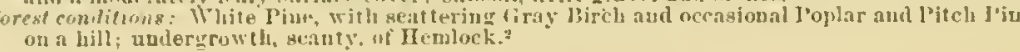

ACRE ป̈IELL.

\begin{tabular}{|c|c|c|c|c|}
\hline \multirow[b]{3}{*}{$\begin{array}{l}\text { Simulwer } \\
\text { of trites. }\end{array}$} & \multicolumn{4}{|c|}{ Thlile Paor. } \\
\hline & \multirow[b]{2}{*}{$\begin{array}{l}\text { Liameter } \\
\text { (breast } \\
\text { high). }\end{array}$} & \multirow[b]{2}{*}{ 11eigut. } & \multicolumn{2}{|c|}{ Tulume. } \\
\hline & & & livle. & $\begin{array}{l}\text { M1.r. } \\
\text { vhaufable } \\
\text { timbluer. }\end{array}$ \\
\hline & Inches. & Fon. & Cubiefort. & rent R.M. \\
\hline $1: 13$ & \& & 6i) & $1,9: 0$ & \\
\hline$: 39$ & 10 & 70 & $T+1$ & \\
\hline 34 & 11 & 70 & 74 & \\
\hline 13 & $1:$ & Fil & 334 & \\
\hline 12 & 13 & ill & 372 & \\
\hline 5 & if & 70 & 175 & \\
\hline 3 & 3.5 & 70 & $1 \geq 0$ & \\
\hline 1 & 16 & ;1) & 45 & \\
\hline i & 17 & 70 & $j 1$ & \\
\hline
\end{tabular}

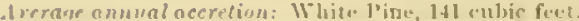

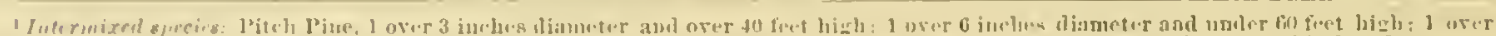

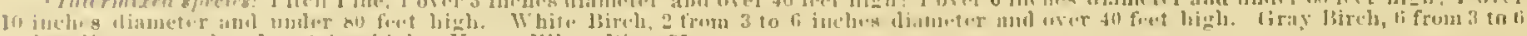

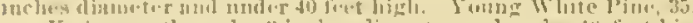

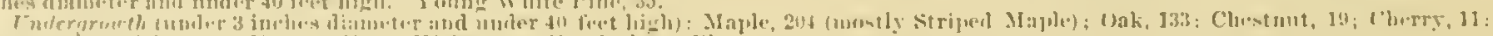

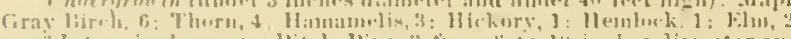

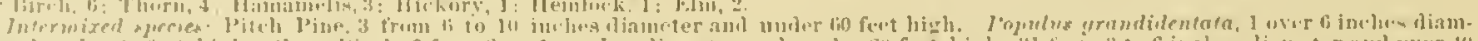

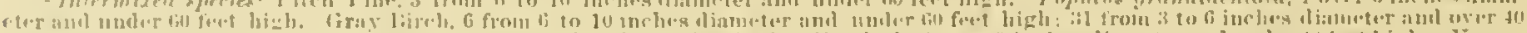

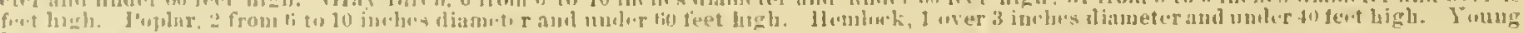
Whitu. line. (A)

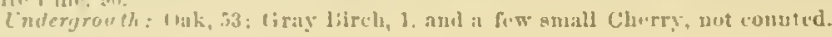




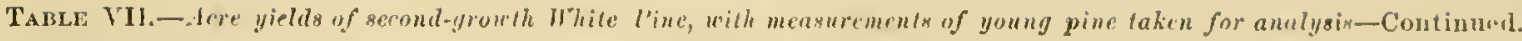

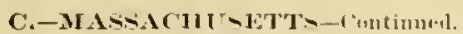

(9) SITE i:

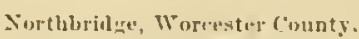

[500 fent ahove sara level.

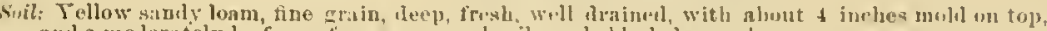

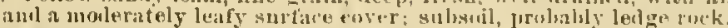

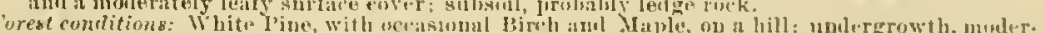
atoly deuse, of Oitk, Iaple anl Che'stnut.

A 'liE' Y'lEL1).

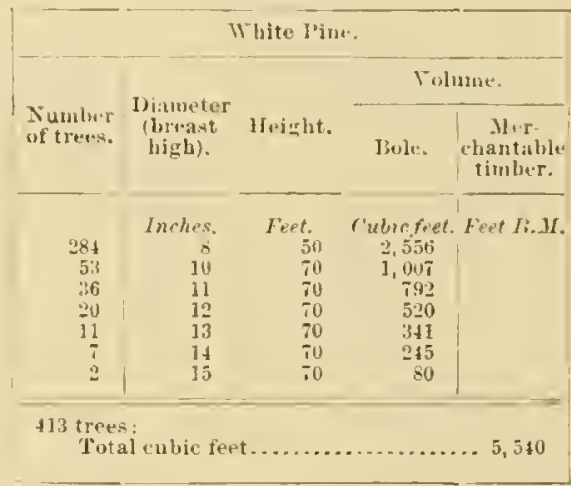

Averaye annual accretion: Whit. Pine, 158 cubie fert.

(10) $\operatorname{SITE} j$ :

Tiroukfieli, Worcester Connty.

Sample area: 1 acre

[800 wo s0o feet abore ser level.]

Soil: Dark brown or l, lack loam, fine grain, light, deep, fresh, wrll drainde. with about a ioches muld on top and a nuderately leafy surfure coser; subsoil, ruch mot fitg luelow surface.

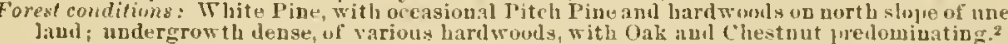

\section{ACl:E TIELD.}

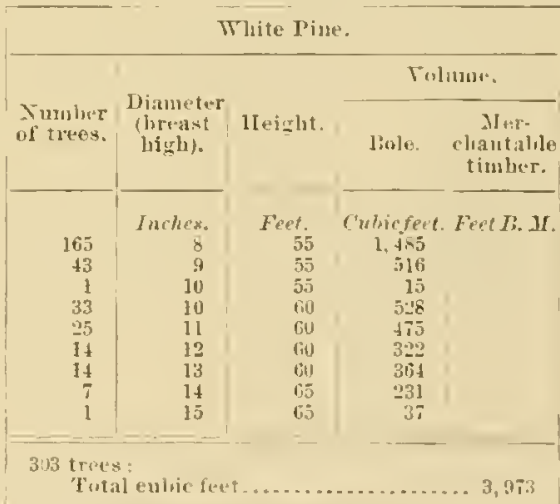

Average anmal accetion: White Pinn, 104 rubic fent.

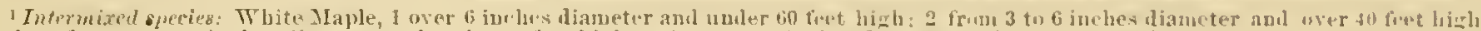

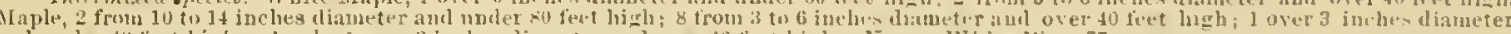

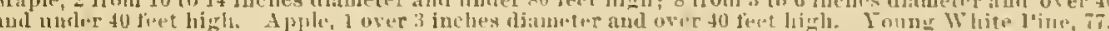

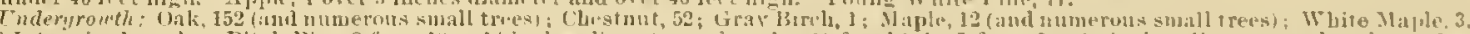

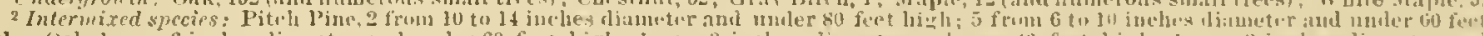

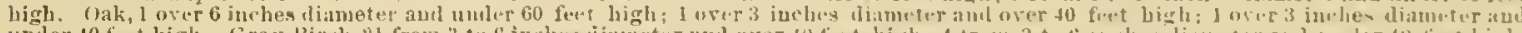

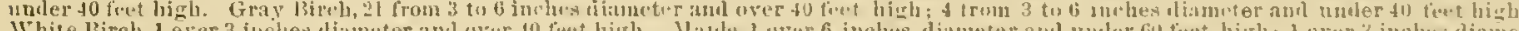

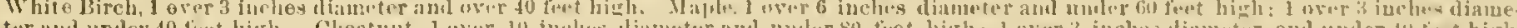

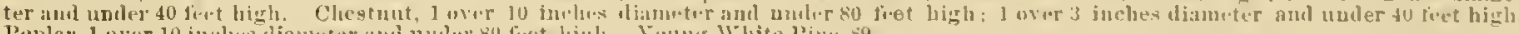

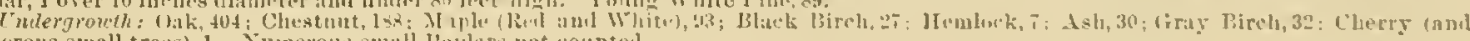
numerous small trees), 1. Siunerous small l'oplats jot iounterl. 


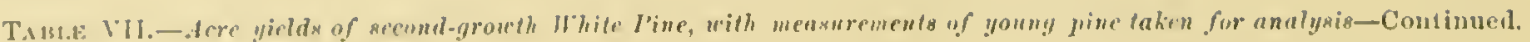

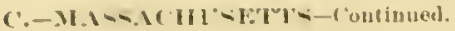

(11) Siт\& $k$ :

Charton, worceatur County.

Sanplu area: I new.

[A bont 800 fert ahose suan lover].]

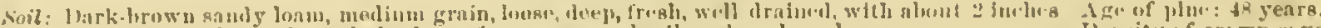

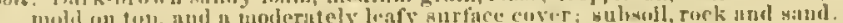

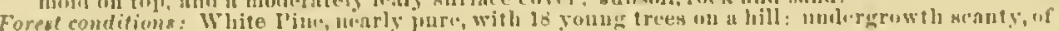

Chestmu, Jluple, Oak, ind C'lu'rry. ACIE YIEI.I.

\begin{tabular}{|c|c|c|c|c|}
\hline \multirow[b]{3}{*}{$\begin{array}{l}\text { Xumber } \\
\text { of tres.s. }\end{array}$} & \multicolumn{2}{|c|}{ Whito loue. } & & \\
\hline & \multirow{2}{*}{$\begin{array}{l}\text { Jianeto-g } \\
\text { (brwant } \\
\text { hifgh). }\end{array}$} & \multirow[b]{2}{*}{ Iteight. } & \multicolumn{2}{|c|}{ Vulume. } \\
\hline & & & Berte. & $\begin{array}{l}\text { Mor- } \\
\text { rhantable } \\
\text { timber. }\end{array}$ \\
\hline 277 & $\begin{array}{r}\text { Inchrs. } \\
8\end{array}$ & Fect. & $\begin{array}{c}\text { Cubirfeet. } \\
2,7 i 11\end{array}$ & Fet IS. MS. \\
\hline 62 & 10 & 70 & 1.178 & \\
\hline 50 & 11 & 70 & 1,1111 & \\
\hline 29 & 12 & III & 754 & \\
\hline 13 & 13 & 70 & 4113 & \\
\hline 8 & 14 & 70 & 315 & \\
\hline 3 & 15 & 70 & 1218 & \\
\hline 3 & 16 & 70 & 135 & \\
\hline
\end{tabular}

Average annual accerion: Whito l'ine, 14I cubic fert.

ME.ISUIREIENTA OF SAMPLF IOENIF INE TREES.

SITE $b$

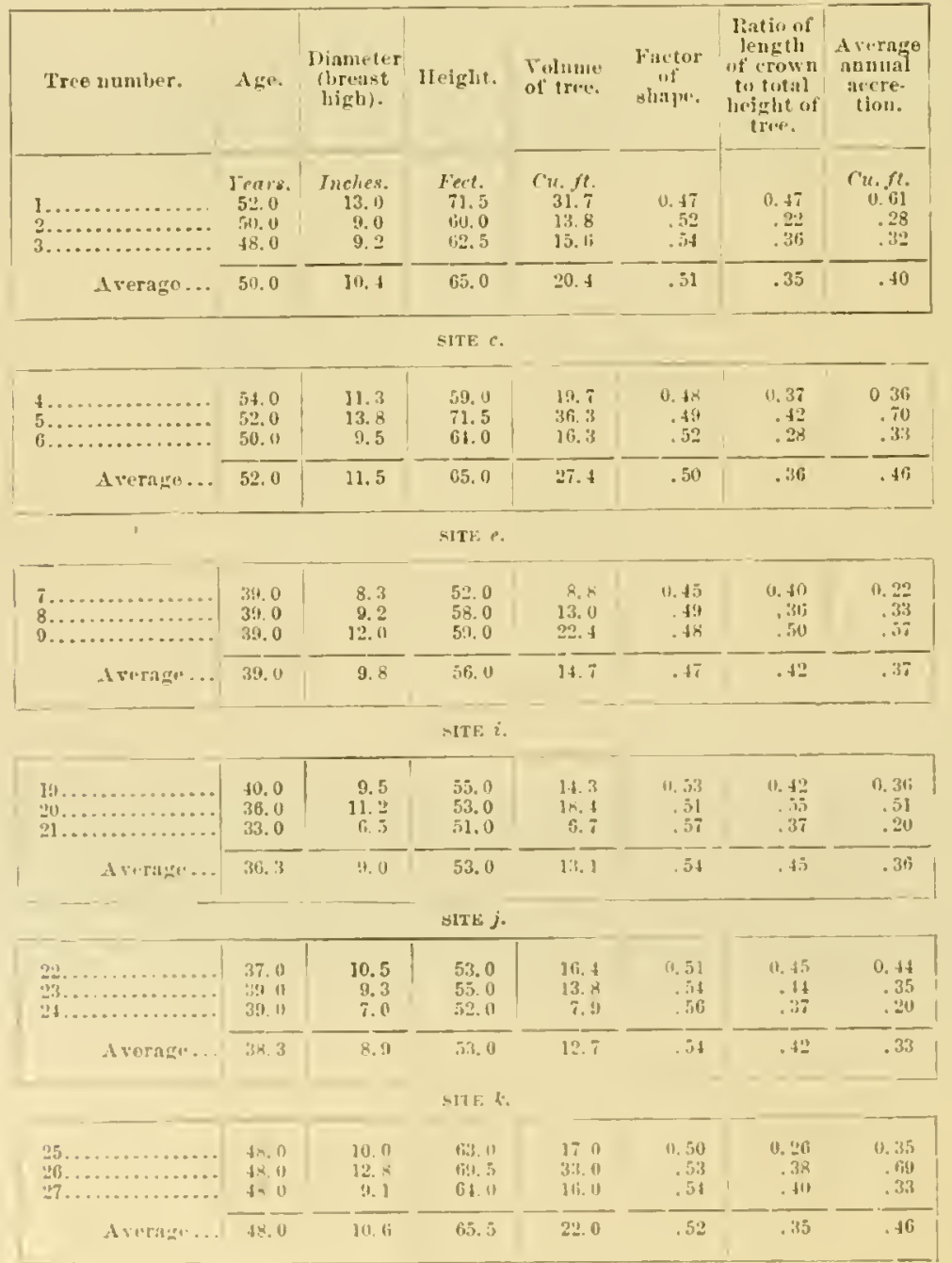




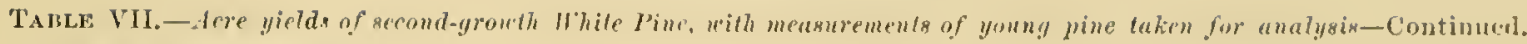

\section{1).-NEW IIAM1PIII:1:}

(1) SITE $l$ :

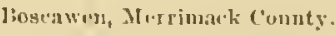

[300 fiet above gea level.]

Soil: Dark.lurown loany sand, coarse grain, porous, Jonst, shalluw, try, well drainwl, with 1 inc,

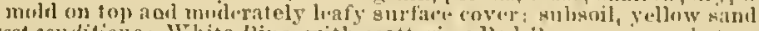

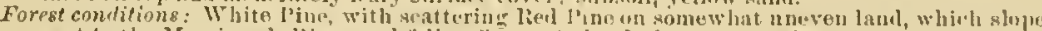

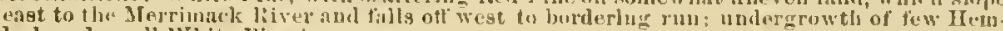
lock and kwall White I'inc.

ACIRE YEIELD.

\begin{tabular}{|c|c|c|c|c|}
\hline \multicolumn{5}{|c|}{ White Pine. } \\
\hline \multirow[b]{2}{*}{$\begin{array}{l}\text { Ninmber } \\
\text { of trees. }\end{array}$} & \multirow[b]{2}{*}{$\begin{array}{l}\text { Diameter } \\
\text { (hrwast } \\
\text { high). }\end{array}$} & \multirow[b]{2}{*}{ IIvight. } & \multicolumn{2}{|c|}{ Tolume. } \\
\hline & & & Bule. & $\begin{array}{c}\text { Mer. } \\
\text { chantable } \\
\text { timber. }\end{array}$ \\
\hline 150 & $\begin{array}{l}\text { Inehe. } \\
\text { Iondut } 3\end{array}$ & $\begin{array}{l}\text { Feet. } \\
20\end{array}$ & rubicteet & Feet $J . M$. \\
\hline 619 & $3 \operatorname{ton} 6$ & 40 & . & \\
\hline 195 & 6 to 8 & 50 & 1.365 & \\
\hline 65 & 8 to 10 & 50 & 715 & \\
\hline 30 & 10 & 50 & 390 & \\
\hline 7 & 11 & 50 & 112 & \\
\hline 4 & 12 & 50 & 76 & \\
\hline 5 & 13 & 50 & 110 & \\
\hline 1 & 14 & 50 & 25 & \\
\hline 1 & 16 & 50 & 39 & \\
\hline $\begin{array}{r}1,077 \mathrm{tr} \\
\text { Tot: }\end{array}$ & nhis fe & & & 2,832 \\
\hline
\end{tabular}

Acerage annul accretion: White I'jue, 71 unlü fict

(2) SiTE in:

Franklin, Merrimakk County.

[900 to 1,000 fret abore sea lerel.]

Soil: Bromn andy loan, nedium qrain, compat, must, well alrained, with 1 to 3 inches mold on top and moderately leity surfise orer; subsoil, ruck.

Forest conditions: White Pine intermixed with Maple aod Birch, on a hill; ir adorgrowtl, modl.r. ately deuse, of yonng Maple. Birch, and other scattering bardwoods."
Samplen area: ] atr.r.

A the of prine: so years.

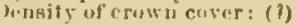

Niumber of trees: 1,077 .

ACII: SIELI).

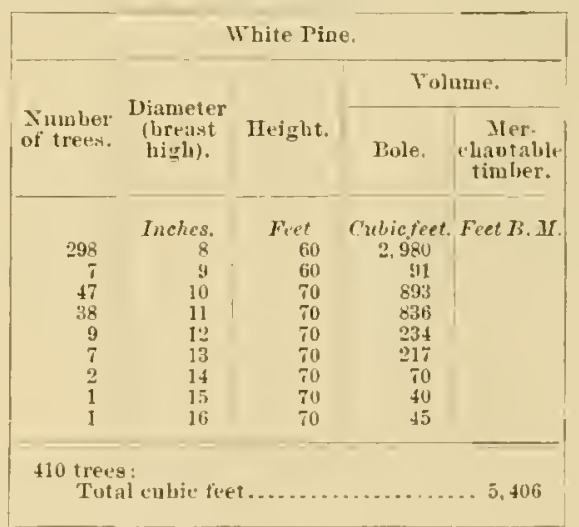

Average anmual accetion: White l'iup, 120 eubic feret.

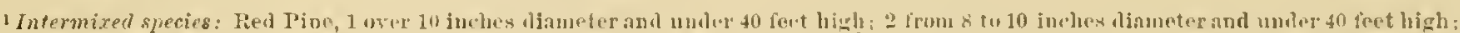

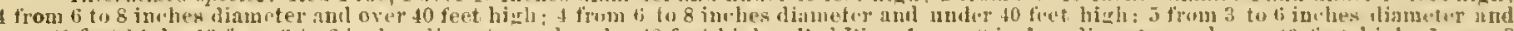

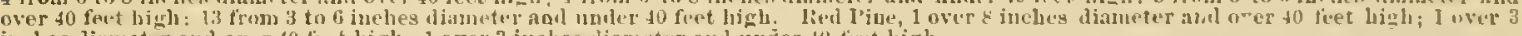
inche diametw and over 40 fent high; 1 over 3 inches diamater and under to hat high.

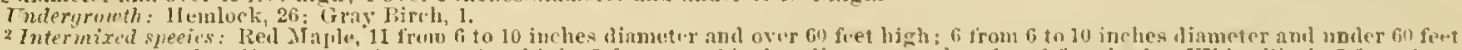

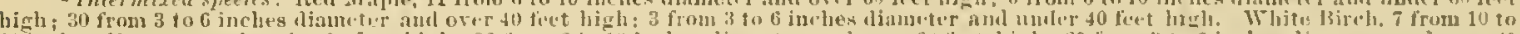

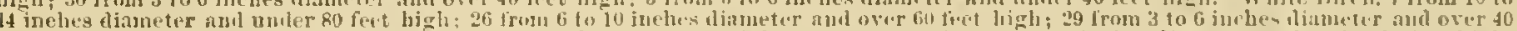

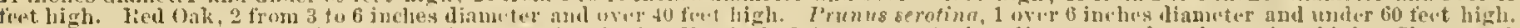

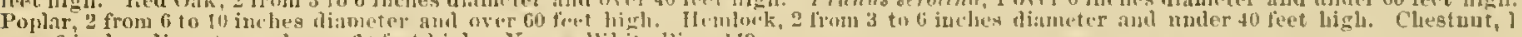

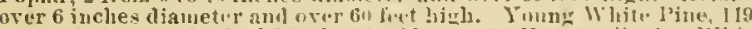

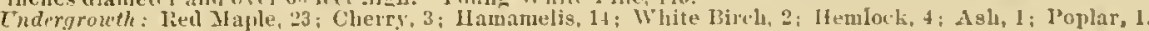




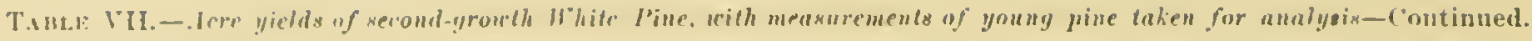

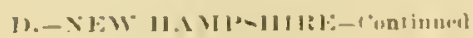

(3) Sitr: $n$

Ilıjkinton. Merrimarkk (imunty.

$$
\text { 4ton to } 900 \text { fret ulave sira loverel.] }
$$

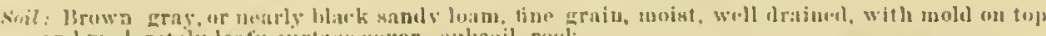

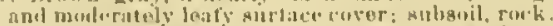

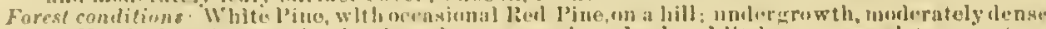

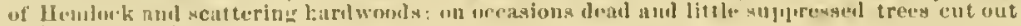
and trimusug atwet.?

ACIE: IIULL.

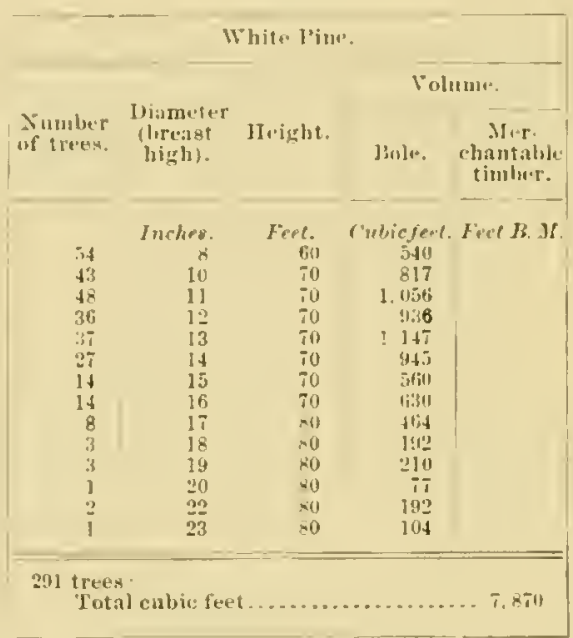

Averane amual accetion: White l'ine, $12-1 \cdot n$ hic feet.

(1) SITE $\theta$ :

Hopkinton, Merrimatk rounty.

[800 to 900 feet aburin sen level.]

Suil: IBrown loan, tine grain, molerately loose, fresls. well drainer, with 3 to 4 irwhes moll or top and lisfy suriace cover

iurth slope of lill: umberrowth,

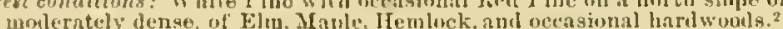

ICIE YIELI)

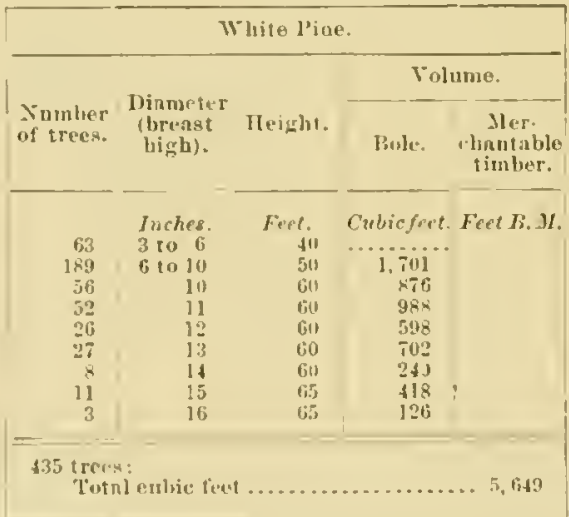

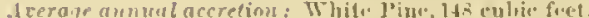

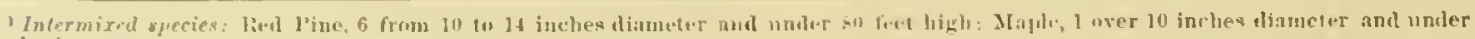
So foret high.

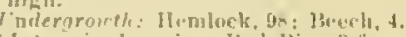

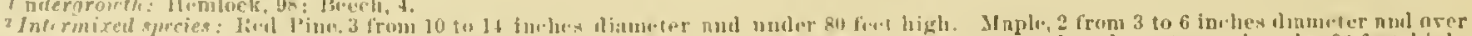

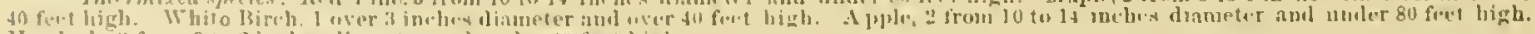

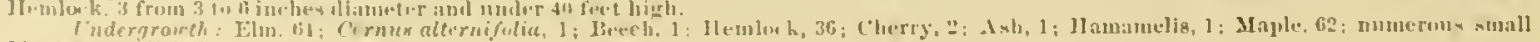
At aplew: sunill (jokk 


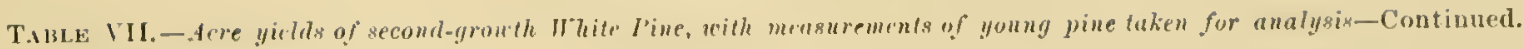

1).-NEW IILMTPIIIIL-Continted.

(5) SITE $J$.

Litc-liticlal, Hillsbora County.

Sinlubl. arma: 1 arre.

[Alunt 25ll feet abwe ara level.]

Soul: Dith-hrowu sande loam, tiue grain, purons, bight, louse, whallow, d]ry, well draind, with about 2 inche's mold on top atul usderately leary surface cover; Hubsoil, rellowiuls line sand about 2 inches

prest Ifaple, Bircb, and fow ot her laritwouls.'

A'LEE YIELL.

\begin{tabular}{|cccc|}
\hline & \multicolumn{3}{c|}{ Whito Pine. } \\
Number \\
of tret.9.
\end{tabular}

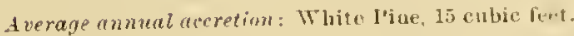

(6) SITE $\eta$ :

Hilliboro Coututy.

[A bont 7nu feet above sta level.]

Soil: Brown loam, fine grain, dewe noist, well trainerl, witl .

ant lea

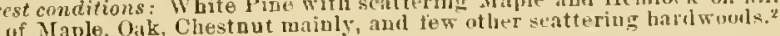

\section{ACIRE TIELD.}

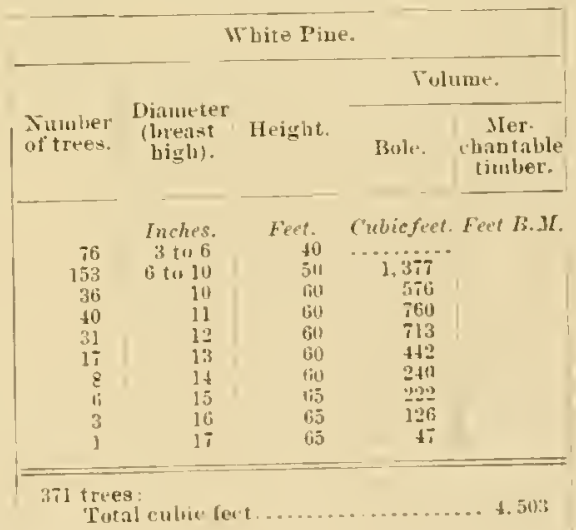

Age of jine: 35 to 40 years. Ihetaityof crown cover: 0.7 to 0.8

Ninther of tras: 517 


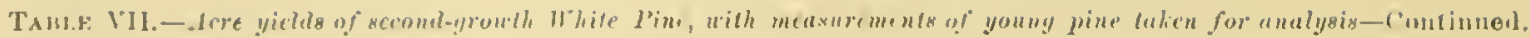

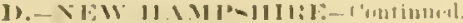

1;) StTE $r$ :

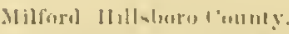

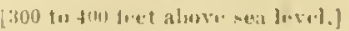

$$
\text { Lere Iro. } 1 \text {. }
$$

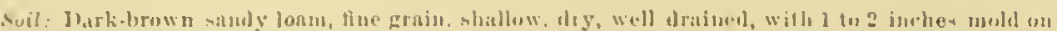

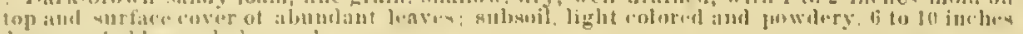
dereje probalile santrly lorwer down.

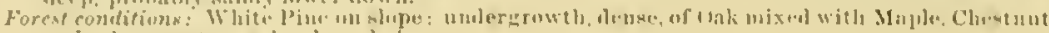
sud other sattemill haril womb.

AI:LE YIELA.

\begin{tabular}{|c|c|c|c|c|}
\hline \multicolumn{5}{|c|}{ White I'in". } \\
\hline \multirow[b]{2}{*}{$\begin{array}{l}\text { Niminer } \\
\text { of trees. }\end{array}$} & \multirow[b]{2}{*}{$\begin{array}{c}\text { Diameler } \\
\text { (breast } \\
\text { ligh). }\end{array}$} & \multirow[b]{2}{*}{ II.ight. } & \multicolumn{2}{|c|}{ Folume. } \\
\hline & & & Julle. & 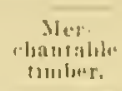 \\
\hline & Inches. & Fint. & rubicfetet & Frof li, Jr. \\
\hline 339 & $3 \operatorname{tn} 6$ & 40 & $\ldots \ldots \ldots$ & \\
\hline 323 & 6 to 8 & 50 & 3. 261 & \\
\hline 1118 & 81010 & 50 & ]. I 85 & \\
\hline 11 & 10 & 50 & 143 & \\
\hline 9 & II & 50 & 141 & \\
\hline 2 & 12 & 50 & 38 & \\
\hline 2 & 13 & 50 & it & \\
\hline
\end{tabular}

I veruze anmual accrefion: White Pine, lug cubic feet.

Acre Po.?

Age of pine: 35 to 40 ywars.

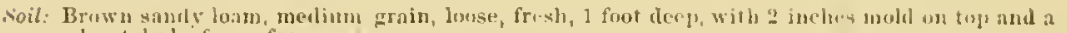
moderately laify alleface ens.er.

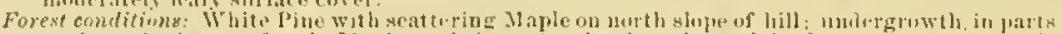

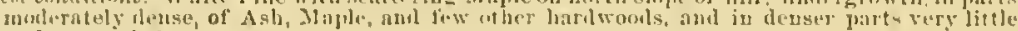
mulerately iak
Samplla areat: 2 acres.

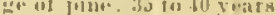
1. nsity of a rown cover: Full.

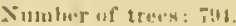

I"nsity o! irowa cover: 0.0 to

Numler of trees: 503

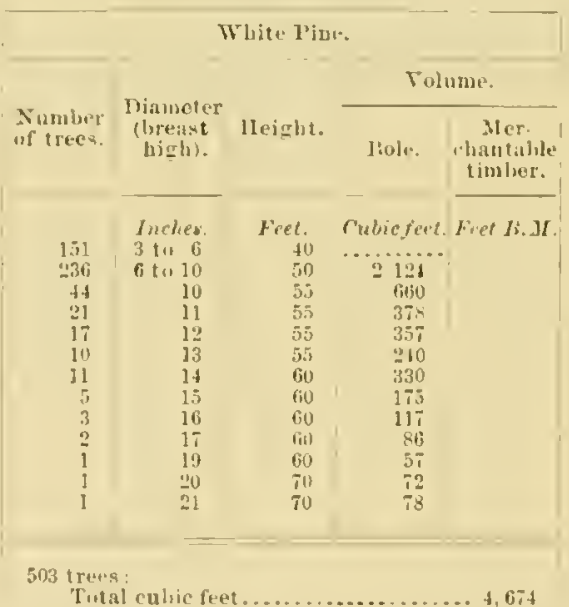

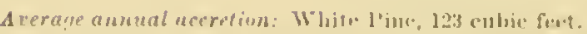

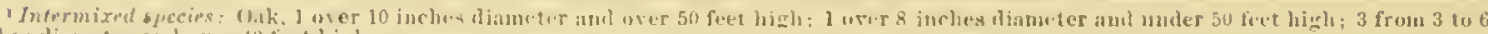

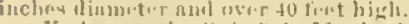

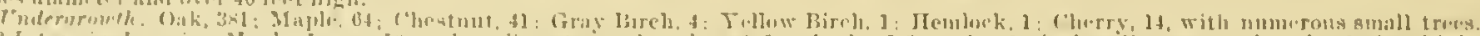

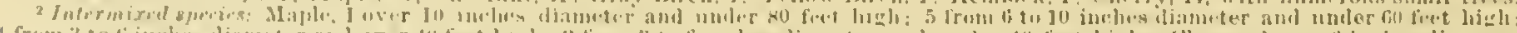

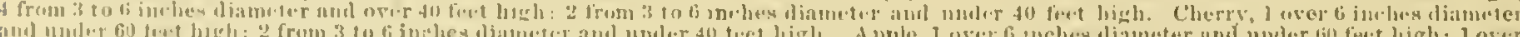
Inf

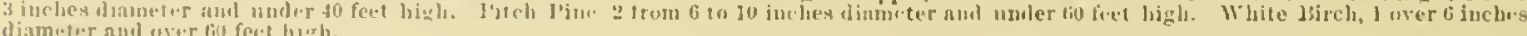

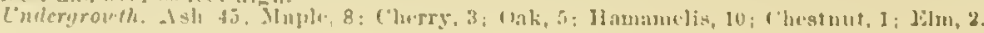




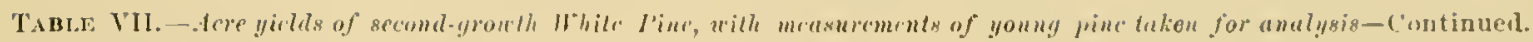

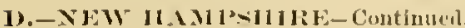

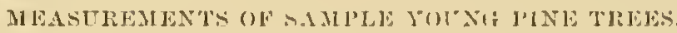

A.je cluss: I'niler 50 years.

TIIE

\begin{tabular}{|c|c|c|c|c|c|c|c|c|c|c|}
\hline Tree number. & Age. & $\begin{array}{l}\text { Diameter } \\
\text { flivalat } \\
\text { lighls. }\end{array}$ & Ileight. & $\begin{array}{c}\text { limgs } \\
\text { per inch } \\
\text { isil } \\
\text { atwin1. }\end{array}$ & $\begin{array}{l}\text { Vulume" } \\
\text { of trev. }\end{array}$ & $\begin{array}{l}\text { Finction } \\
\text { of } \\
\text { shiape. }\end{array}$ & $\begin{array}{l}\text { liationf } \\
\text { losintil } \\
\text { of crown } \\
\text { to total } \\
\text { height of } \\
\text { tree. }\end{array}$ & 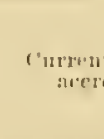 & $\begin{array}{l}\text { tinumal } \\
\text { rtivt. }\end{array}$ & 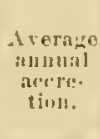 \\
\hline 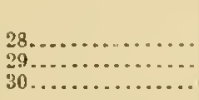 & $\begin{array}{c}\text { Fears. } \\
41 \\
41 \\
41\end{array}$ & $\begin{array}{c}\text { Inchrs. } \\
\text { ti. } 8 \\
7.1 \\
\text { 8. } 2\end{array}$ & $\begin{array}{r}\text { Feet. } \\
41 \\
52 \\
55\end{array}$ & $\begin{array}{c}\text { No. } \\
\ldots \ldots \ldots \\
\ldots \ldots \ldots \\
\ldots \ldots \ldots\end{array}$ & $\begin{array}{r}\text { rubic ft. } \\
5.1 \mathrm{i} \\
8.0 \\
10.0\end{array}$ & $\begin{array}{r}0.51 \\
.56 \\
.51\end{array}$ & $\begin{array}{r}0.43 \\
.51 \\
.51\end{array}$ & $\begin{array}{c}\text { I'er cint. } \\
\cdots \ldots \\
\cdots \ldots \\
\cdots \ldots\end{array}$ & \begin{tabular}{c} 
rubic ft. \\
$\ldots . . .6$ \\
\hdashline$\ldots \ldots$
\end{tabular} & $\begin{array}{r}\text { fubir } f t . \\
\text { v. } 30 \\
.20 \\
.21\end{array}$ \\
\hline Averago... & 41 & 7.4 & 50 & $\ldots \ldots \ldots$ & 7. 4 & .53 & .48 & ... & .......... & .25 \\
\hline
\end{tabular}

SITE $m$

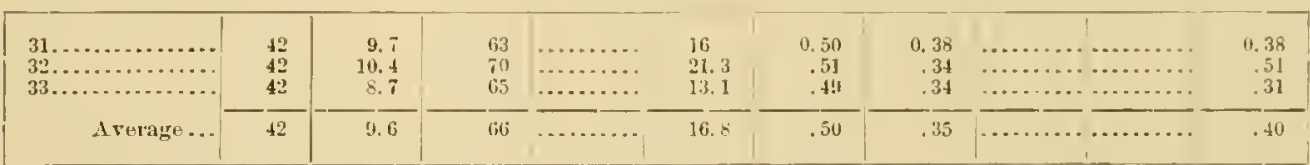

ITE 0

\begin{tabular}{|c|c|c|c|c|c|c|c|c|c|}
\hline $\begin{array}{l}35 \ldots \ldots \ldots \ldots \\
36 \ldots \ldots \ldots \ldots\end{array}$ & $\begin{array}{l}38 \\
39\end{array}$ & $\begin{array}{r}9.3 \\
111.3\end{array}$ & $\begin{array}{l}57.5 \\
1625\end{array}$ & . & $\begin{array}{l}13.8 \\
18.0\end{array}$ & $\begin{array}{r}0.51 \\
.50\end{array}$ & $\begin{array}{r}0.39 \\
.40\end{array}$ & 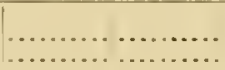 & $\begin{array}{r}0.36 \\
.413\end{array}$ \\
\hline A rerage... & 38.5 & 9.8 & 60 & $\ldots . . . . .$. & 15.9 & .50 & $.3 !$ & 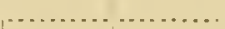 &.+1 \\
\hline
\end{tabular}

$\operatorname{siTE} r$.

\begin{tabular}{|c|c|c|c|c|c|c|c|c|c|c|}
\hline 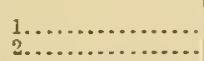 & $\begin{array}{l}81 \\
77\end{array}$ & 17 & $\begin{array}{l}73 \\
74\end{array}$ & 4 & $\begin{array}{l}45.2 \\
52.4\end{array}$ & 0.42 & $\begin{array}{r}0.53 \\
.55\end{array}$ & $\begin{array}{l}4.6 \\
3.0\end{array}$ & $\frac{2.29}{1.57}$ & $\begin{array}{r}0.59 \\
.68\end{array}$ \\
\hline Average... & 79 & 17 & 73.5 & 4 & 50. 3 & .43 & .54 & 3.0 & 1.89 & .63 \\
\hline
\end{tabular}



SCHEDULES AND SAMPLE RECORDS. 



\title{
SCHEDULES AND SAMPLE RECORDS.
}

\author{
FORMS USED IN THE INVESTIGATION.
}

FORM NO. 1 .

\author{
Lnited States Department of Agriculture. \\ DIVISION OF FORESTIY.
}

\section{RECORDS OF TREE MEASUREMENTS.}

Name of eullector: $\mathrm{X}$.

Sprecies: White Pine.

lear: 1897 .

GENFIRAL IUESTIPTIUN UF STATIOX.

[Denoted lig eapital letter.]

State: Pennsplrania. Connty: Clearlelel. 'Town: Dubois.

Longitude: $73-45$. Latitude: 4103 . Altitude: 1,200 to 1,500 feet.

General configuration: Ilains hills plitea mountainous.

(iencral trend of valleys er hills: (Not noted.)

Climatie features: (Neteorologrieal tables firnisbel.)

General forest conditions of the resion: This region in 1876 extended over 20,000 acres. The lumbriperation carrien on for twenty years by Mr. Dn Bois left for the present only from 1,000 to 2,000 ale res staudiug timber in al primeral enulition.

Thre typical forms of forest conditions are suggested to the observer:
(1) Jemlock and White Pine forest, with an inlmixture of matmre hardwools am a mumber of young bardwoods and sonnt [lanluek, which form the untergrowth.

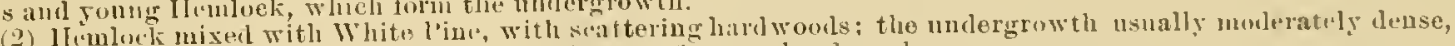

ists mainly of yonug Hemlock witl the al mixtme of yound harid woorls.

consists nainly of yong Hemlock mithlite Pino and seattering Hemlock. The nulergrowth here cousists manarg

of young birkw wols.

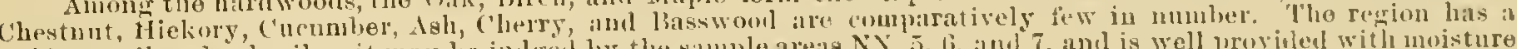

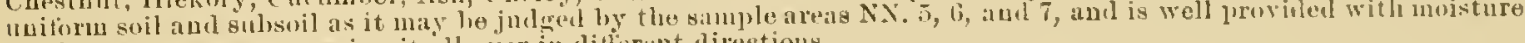
loy the mang streams erussing it ill over in ditierent directions. 
FORM NO. 2.

\section{W:SCHPTIOX WF SITF.}

Sample area, Si). $\because$ : (One arre.)

[Venosed by sinall liettor.]

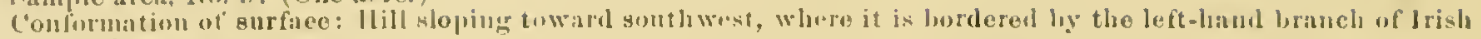
Lisruw C'repk.

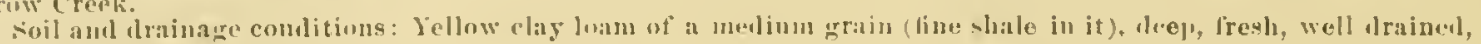
witl. " 103 inthes mold on top.

Subril: Janminates! shale of an inlelinite dejth.

Suil covir: simuty leaves, leru, and tubluerrios.

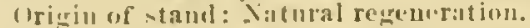

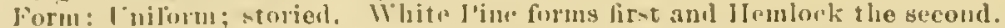

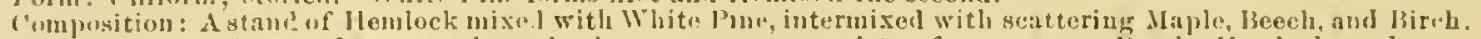

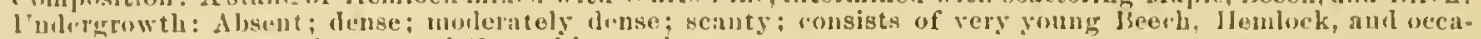

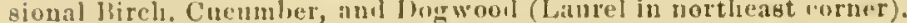

Dinsity of stind: 0.7 (in places 0.5 ).

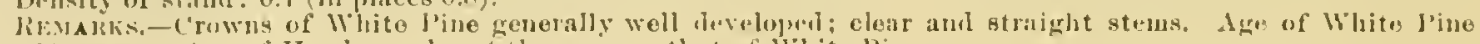

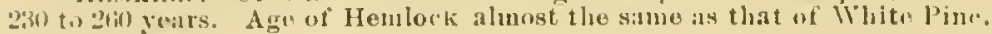

ACRE.YIELD ME.ASLREIENTS.

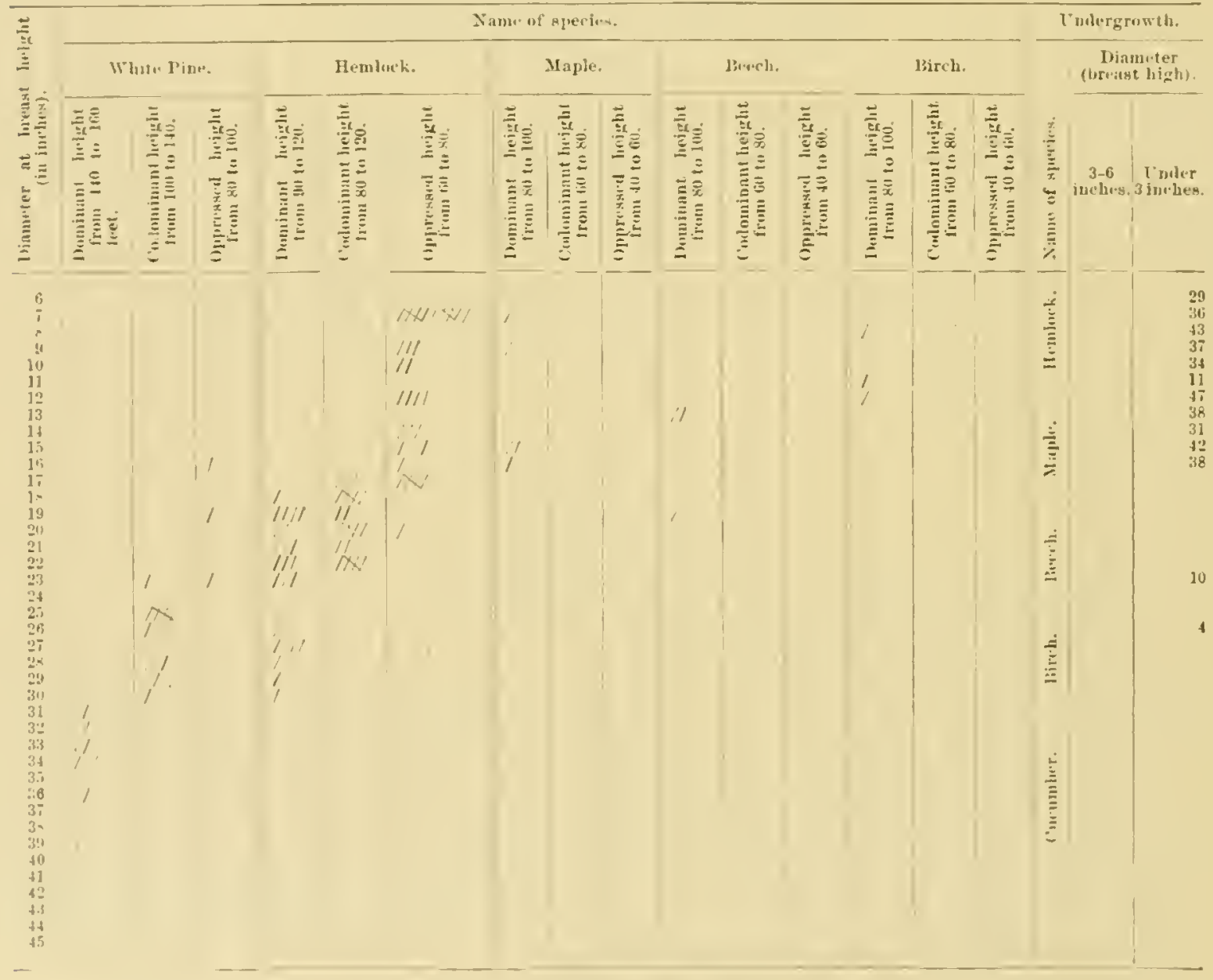

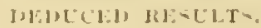

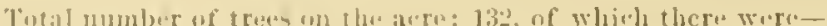

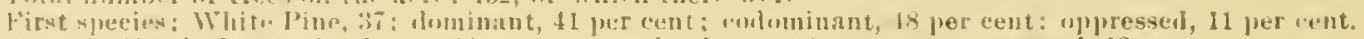

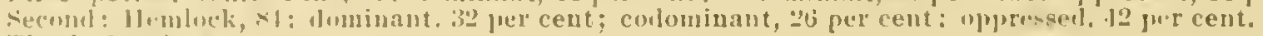

Thirel: Maple, ,

Jindrth: $130 \cdot(m \cdot)_{3}, 3$.

Fifh: Jirrh, :

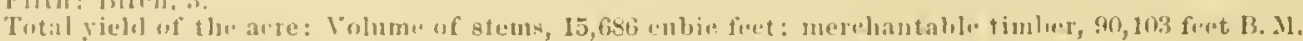

fif which there ware-

lirst specius: White ]'inu, in prer cent of tutal sield.

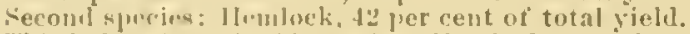

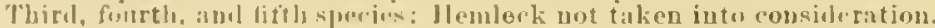

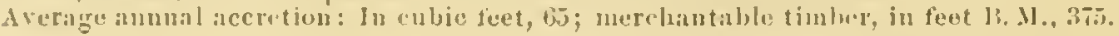




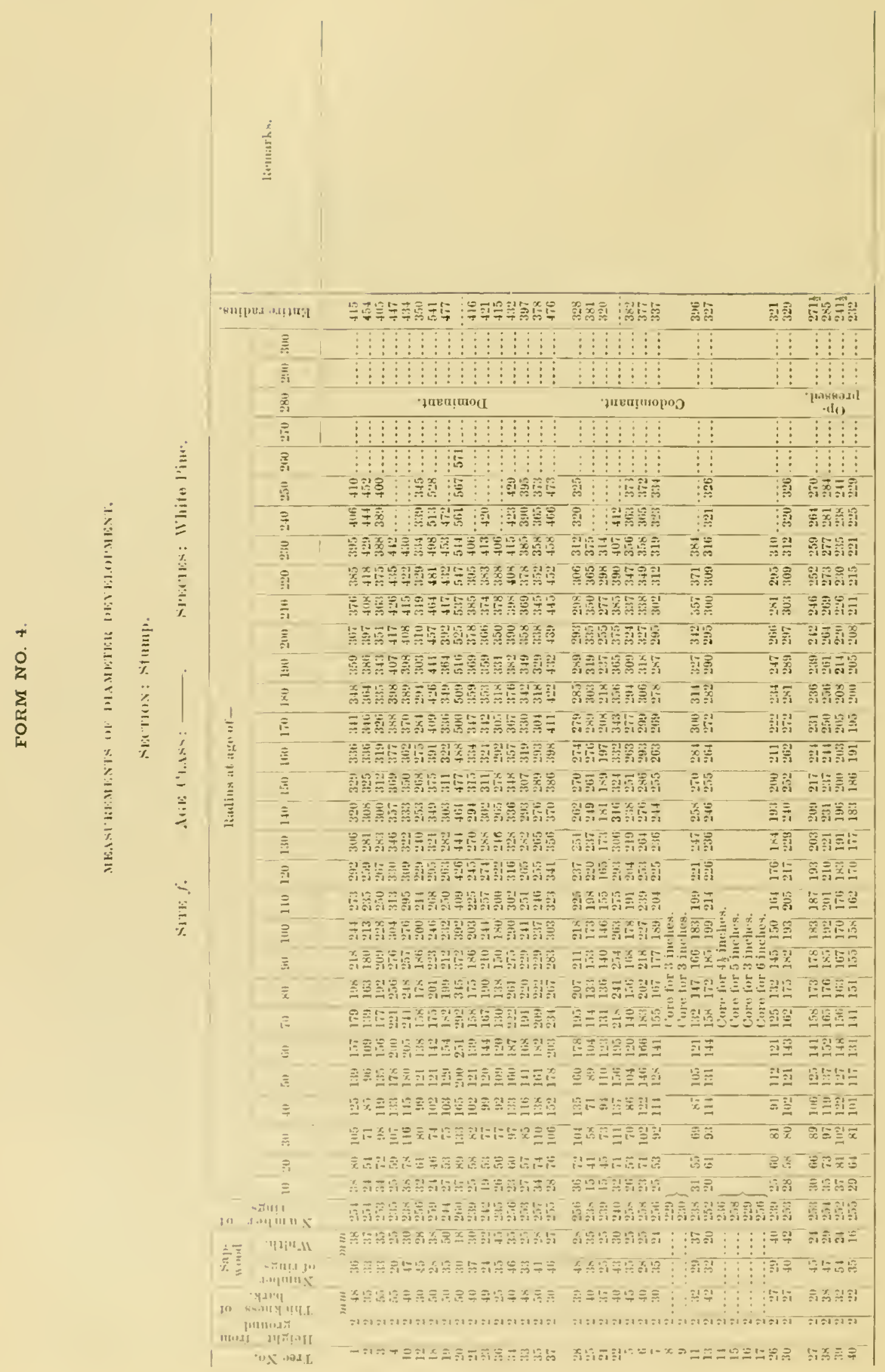


SCIIUULES AND SAMLLE RECORDS.

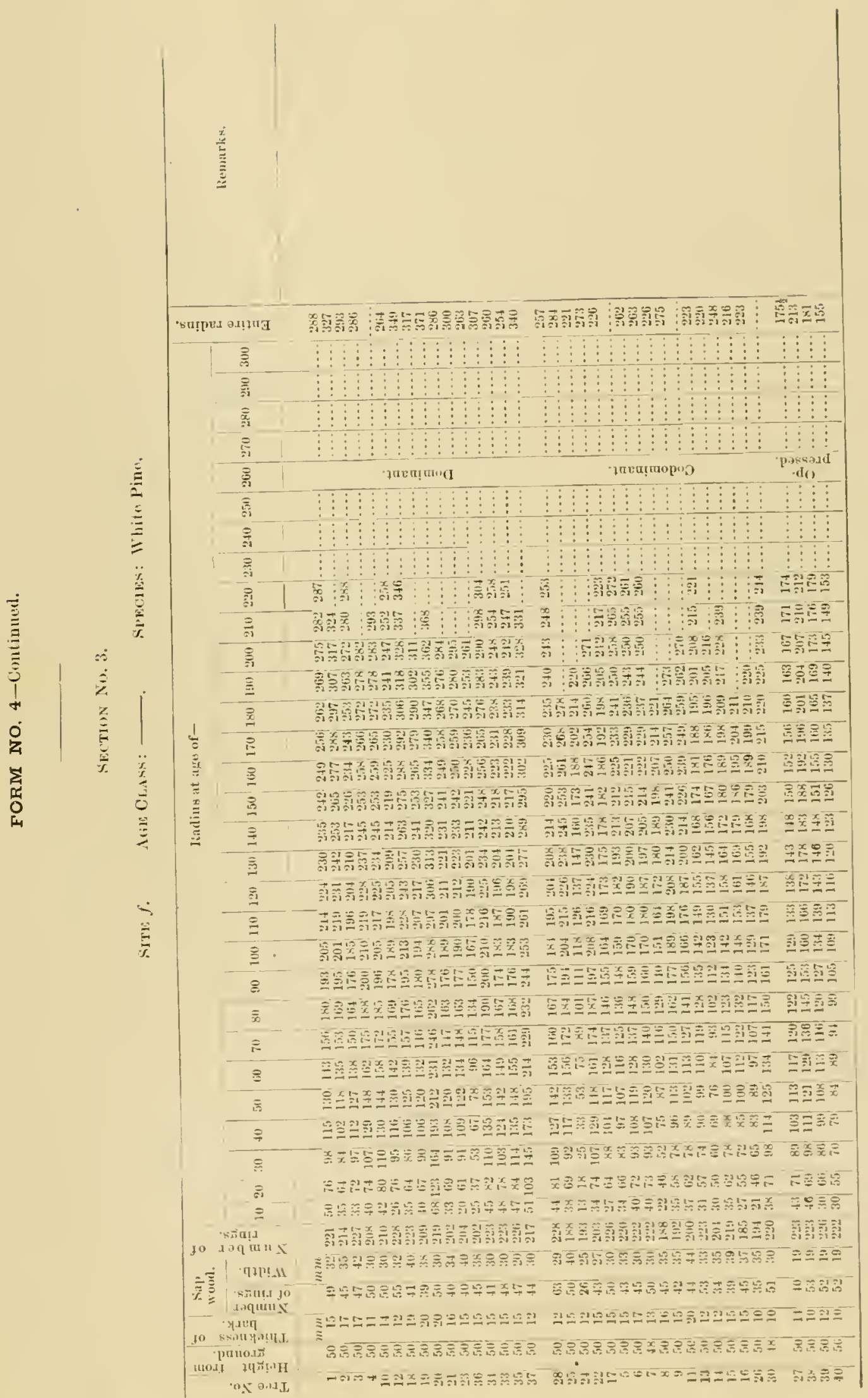

$20233-$ ก $0.22-12$ 
FORM NO. 5.

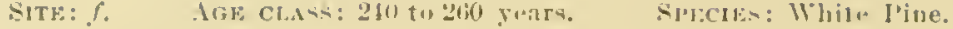

\begin{tabular}{|c|c|c|c|c|c|c|c|c|c|c|c|c|c|}
\hline Lareation. & Hearription of ajte. & 咅 & $\frac{5}{10}$ & 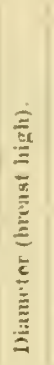 & $\frac{1}{\frac{\bar{E}}{2}}$ & 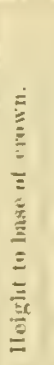 & 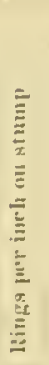 & 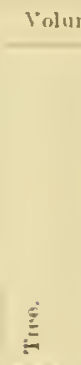 & 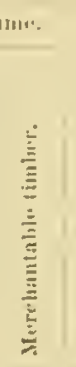 & 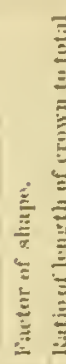 & 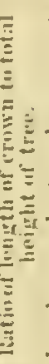 & 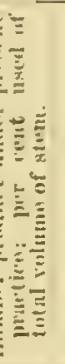 & $\begin{array}{l}\frac{D}{E} \\
\frac{D}{E} \\
\frac{E}{E}\end{array}$ \\
\hline \multirow[t]{6}{*}{ 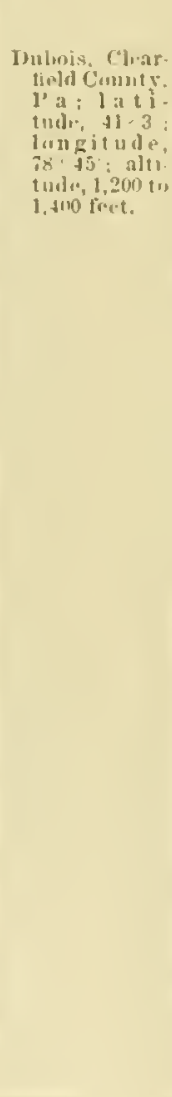 } & \multirow[t]{2}{*}{ 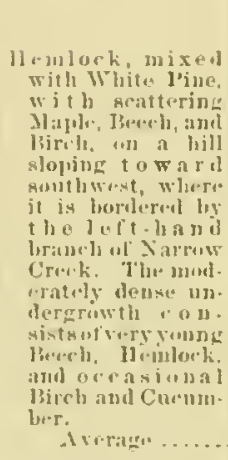 } & $\begin{array}{r}1 \\
2 \\
3 \\
4 \\
10 \\
12 \\
18 \\
19 \\
90 \\
21 \\
23 \\
33 \\
31 \\
35 \\
36 \\
37\end{array}$ & 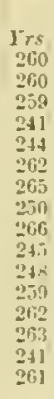 & $\begin{array}{l}I n \\
331 \\
36 \\
32 \\
32 \\
33 \\
28 \\
39 \\
34 \\
44 \\
31 \\
34 \\
33 \\
33 \\
31 \\
314 \\
37\end{array}$ & 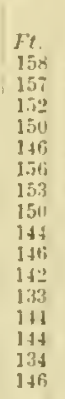 & $\begin{array}{c}90 \\
90 \\
94 \\
62 \\
96 \\
88 \\
8 \\
78 \\
100 \\
92 \\
91 \\
91 \\
91 \\
90 \\
80 \\
100\end{array}$ & 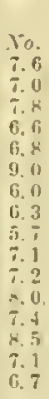 & 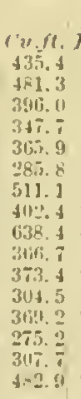 & 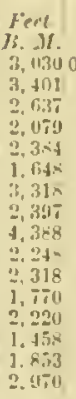 & $\begin{array}{c}0.400 \\
43 \\
463 \\
41 \\
.42 \\
.43 \\
40 \\
42 \\
42 \\
.40 \\
.42 \\
40 \\
.42 \\
.36 \\
.42 \\
.44\end{array}$ & $\begin{array}{l}0.43 \\
.42 \\
.41 \\
.59 \\
.34 \\
.43 \\
.42 \\
.48 \\
.30 \\
.37 \\
.37 \\
.31 \\
.34 \\
.43 \\
.34 \\
.97\end{array}$ & $\begin{array}{l}58 \\
541 \\
55 \\
51 \\
54 \\
47 \\
51 \\
49 \\
51 \\
51 \\
51 \\
48 \\
51 \\
4 \\
50 \\
5 ! 9\end{array}$ & \multirow[t]{2}{*}{$\frac{\ddot{E}}{\stackrel{\Xi}{E}}$} \\
\hline & & .. & 25 & 31 & 147 & $s=$ & 7. 0 & 390.0 & $2,50 \pi$ & .41 . & .39 & 32 & \\
\hline & 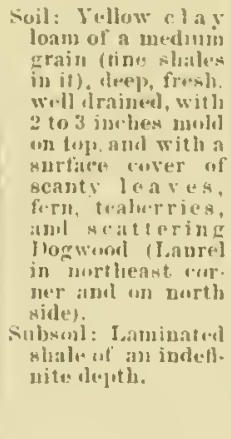 & $\begin{aligned} 23 \\
05 \\
05 \\
24 \\
22 \\
5 \\
6 \\
7 \\
8 \\
9 \\
11 \\
13 \\
14 \\
15 \\
16 \\
17 \\
24 \\
311 \\
29 \\
31 \\
32\end{aligned}$ & 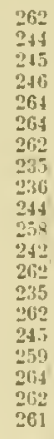 & 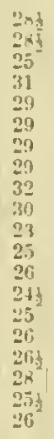 & $\begin{array}{l}13 x \\
13 x \\
1311 \\
1311 \\
1411 \\
1411 \\
152 \\
144 \\
142 \\
141 \\
111 \\
139 \\
136 \\
114 \\
128 \\
136 \\
134 \\
141 \\
132 \\
112\end{array}$ & 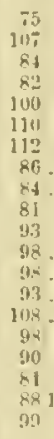 & $\begin{array}{c}9.8 \\
7.7 \\
0.3 \\
7.3 \\
8.4 \\
8.5 \\
9.5 \\
\ldots . . \\
7.5 \\
9.6 \\
\ldots . .\end{array}$ & 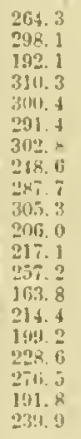 & 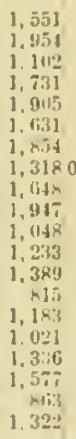 & $\begin{array}{l}.43 \\
.49 \\
.43 \\
.45 \\
.47 \\
.45 \\
.46 \\
0.3 \times 0 \\
.36 \\
.44 \\
.44 \\
.41 \\
.51 \\
.40 \\
.49 \\
.411 \\
.41 \\
.46 \\
.41 \\
.46\end{array}$ & $\begin{array}{l}.+5 \\
.22 \\
.35 \\
.35 \\
.28 \\
.29 \\
.26 \\
0.39 \\
.+1 \\
.+2 \\
.37 \\
.30 \\
.28 \\
.25 \\
.16 \\
.24 \\
.32 \\
.410 \\
.33 \\
.311\end{array}$ & $\begin{array}{l}49 \\
34 \\
48 \\
46 \\
42 \\
47 \\
51 \\
44 \\
48 \\
53 \\
42 \\
47 \\
45 \\
41 \\
46 \\
47 \\
48 \\
47 \\
37 \\
40\end{array}$ & 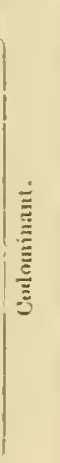 \\
\hline & A vrape... & & $\overline{253}$ & $\overline{27}$ & $\sqrt{133}$ & 513 & $\overline{10.0}$ & $\overrightarrow{25110.0}$ & $\overline{1.421}$ & .44. & .32 & 47 & \\
\hline & & $\begin{array}{l}37 \\
3 n \\
34 \\
411\end{array}$ & $\begin{array}{l}2: 0 \\
2100 \\
2: 0 \\
201\end{array}$ & $\begin{array}{l}191 \\
23 \\
203 \\
101\end{array}$ & $\begin{array}{l}132 \\
1: 37 \\
19: 1 \\
120\end{array}$ & 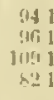 & $\begin{array}{l}11.6 \\
11.1 \\
13.0 \\
1.6 .7\end{array}$ & $\begin{array}{r}138 . \times \\
1 \times 9.6 \\
1309 \\
80.6\end{array}$ & $\begin{array}{l}6,3-3 \\
987 \\
535 \\
335\end{array}$ & $\begin{array}{r}53 \\
.46 \\
46 \\
50\end{array}$ & $\begin{array}{l}.29 \\
.311 \\
.11 \\
.31\end{array}$ & $\begin{array}{l}41 \\
43 \\
33 \\
31\end{array}$ & 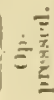 \\
\hline & Arera:to... & & 231 & 20 & 12 & & 12. 3 & 137.0 & 64 & .49 & 5 & 37 & \\
\hline
\end{tabular}


SCHEDLLWE AND SAMPLE RECOKUS.

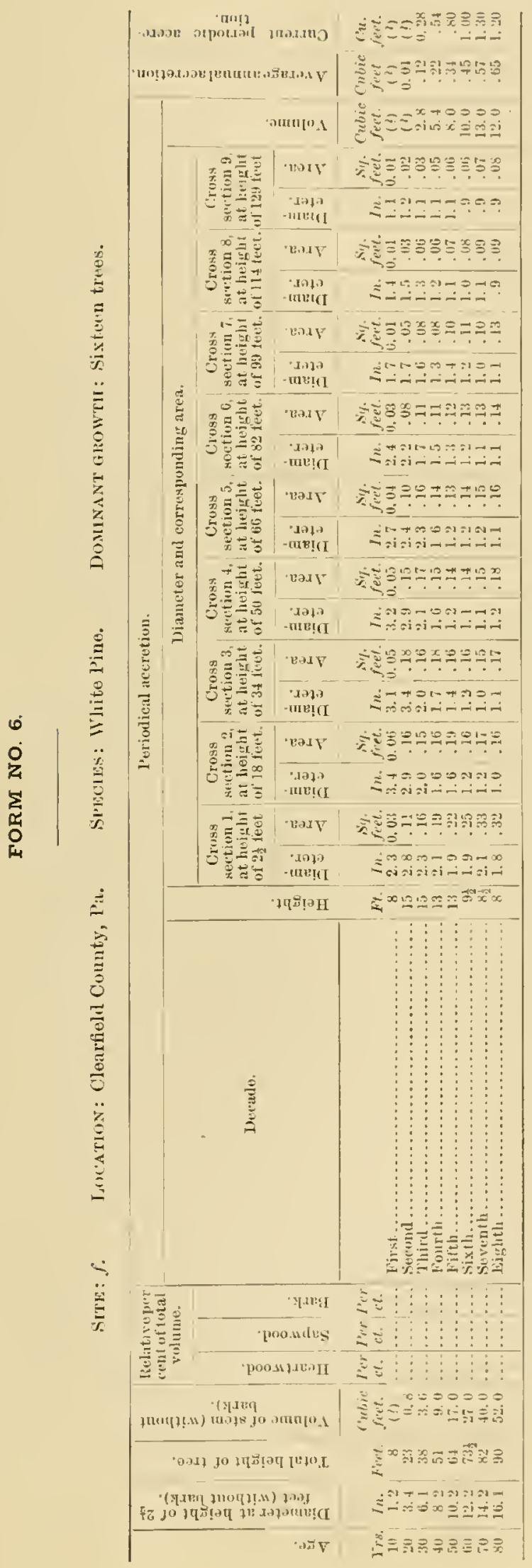





\section{INDEX.}

l'agu.

Abbot's white print sawfy, not"

Aceretion, area, in ir lute Pine. average nnn diameter, of pine, diseussion yearls, of Whato Pine, notes.

Acre yield of secomd rrowth Whito Ploc, with measurements of

young pine .......................... 148-10

White live in atural forest.................

yourg juine groves ..............

vields of $1 \mathrm{~h}$ hito l'ive aud measurements of sample trees. 116-14

Adirondack mills, outpnt uf Th hute l'ino. region, destrution of young pine growth by tire.

Adirondarks, compesition of forest ....................... condition as to reluoduction of Whita l'ine.....

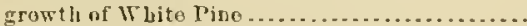

Agaricus melleus, injury to Wute Pin .................... A ge classes of White Pine, tables of measurements.... . . . . . 85-92

Alloghenies, oeeurrence of White Pine ................... 13

Alpena, Mich., first s:awmull .

Ann Arlor, Mich., growth of pioe. rings, comprarison for rarieties of pmes.............

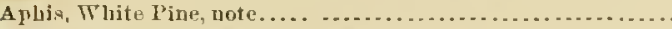

Arborvitre, concomitant of White line mixture with $\mathrm{Wh}$ hito Pine

Areat acertion of White Pioe.

of phre, discrission....................

Asb, result of flanting witb White line.

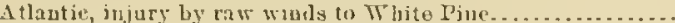

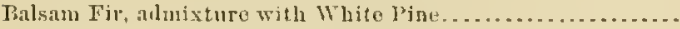

Bark-ivetle, destructivi to piou, diacussion uno, dewerigtiou aml injurs

Bark of pine, mamery of growll and funetion.

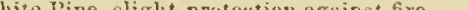

Barn lumber, use uf pine

BeLb, MI.S., nots on White Pino in Illinois

Beetlos, bark, destructivo to yine........................ $35-57$

Buprestida, injurious to nine, description.......... 5

Belfast, Me., trade in Wlite Pine.......................

lihotan Pine, relationshily to White Pioe.

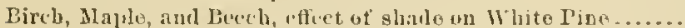
with pine in Alirendacks.

ktack spriae, ngetirluoss fur placting witl pinu .

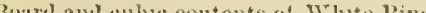

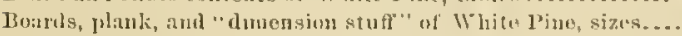

Buat lmilutur, uso of Whito l'ine.

Dules of jinew, variation with charmer of assuchatud trees....

Borers aud pine saw wers, lisenssion . . . . . . . . . . . . . . . . .

Botanical llestriptiou of Thite Pius... range uf White l'sue

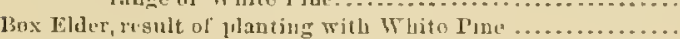
Boxen, nxo of White I'mus

Boyntoa, F. E., note on ocerrence of White rine in the Carn. linis.

Brancli, ruot, aul stem ay

Britton, X. L nute on accurrence ut Wh lute I'ine in Xew Jurseg. Brookıgrs, \$. Dak., faslure of platutuge of Whute Pine....... l'aine.

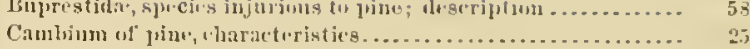

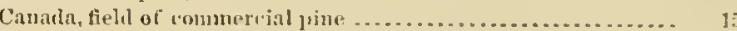
occurrence of White Pine ......................... origiaal and present supplies of Whitw Pinr......... 1? "rossiag" as frotwion from pino bark.borer........ to trale in Whitu Pine..........................

Canalian pinery, note ................................. is

Canby, William II., nute on occurrence of White J'jne in Dela.

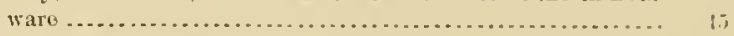

Carbolated wasb, remedy for lientles un pine ...............

Carbolic acid, usi afrainst poe wecril...................... 59

Cary, Austin, measurements $10^{\circ}$ Whitu I'ju..............

Caterpillar injurjous to pine, notes...................... no sio

Cattle, injuriurs tu pino furests....................... 19

Cenlar, Trbitu, and Cypross as substitutes for Whito l'iur.... $\times$."

Cells in pine wool, discrusion. ...................... 25,217

Cerambycid beetles, injury to pine..........................

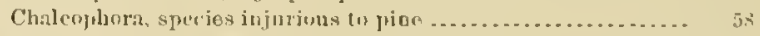

Champign, lll., instructive plat of White J'ine............ ti5

Chermes pinicortiris, " pine blight," nut ................. 50.

Chicago, growtb of 1 hito l'ino tralle................... 18

Chionaspis pinifolie, manuer uf injury 10 pine.............. ril

Curtendex, F, 11., discussion of "lnsect "minges ut Whito l'ine

Chlorophyll, oecurren.e in youmor

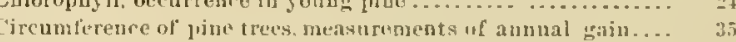

Classifeation of White Pine.......................... 52

Clay and loan linuls, reproductiun of Whit. 1'in".......... Ge

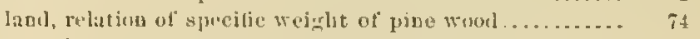

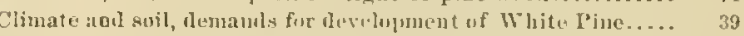
influcher og heigltt gruw th.............. 33

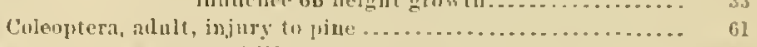

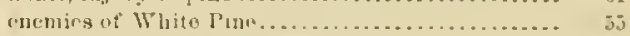

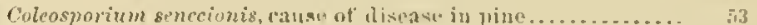

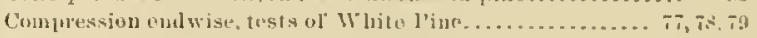

Cones, ane of troes at lisst jurduetiun ..................... 23

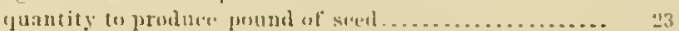

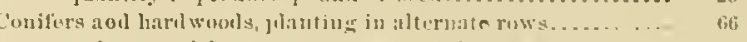

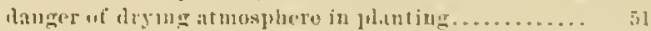

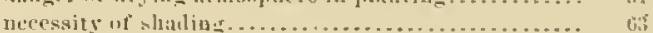

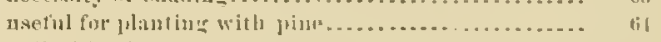

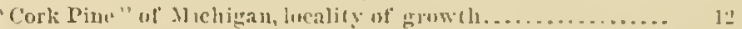

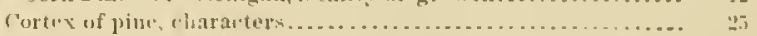

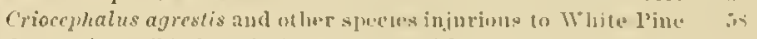

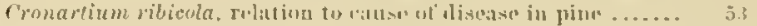
Crepr of Whitu l'ue, time for matmeity................. lif

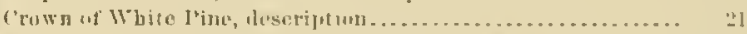

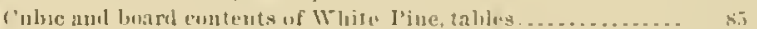

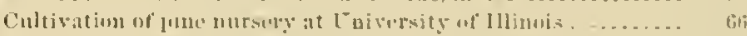

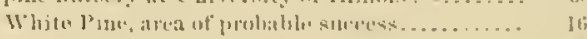

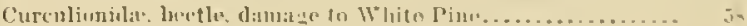

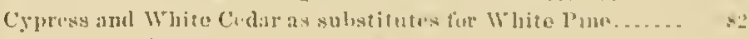

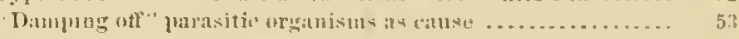

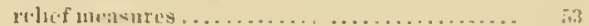

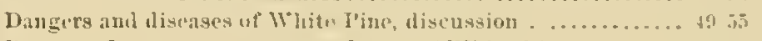

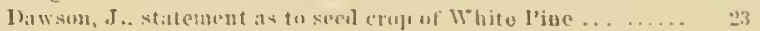
10) Vries, as

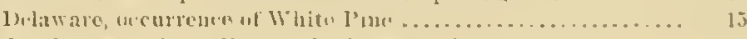

Dendroctonus frontalis, pino lark-betth, discriplet........ \$5 
J'agr.

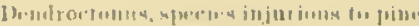

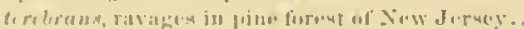

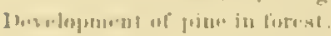
opme st:usul

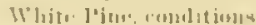

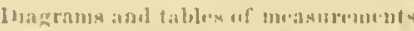

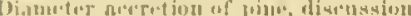

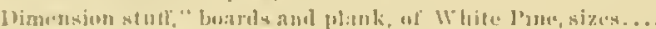

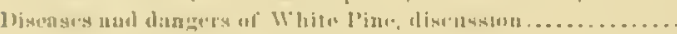

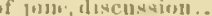

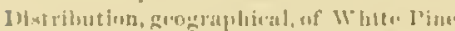

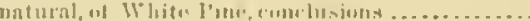

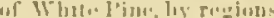

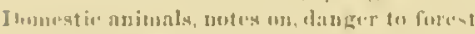

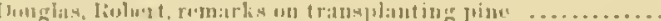

Hrompht and heal uflect as gine

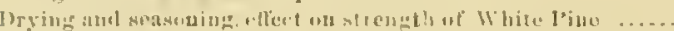

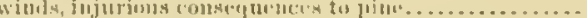

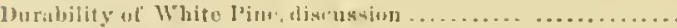

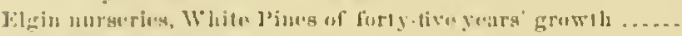

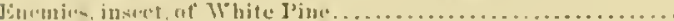

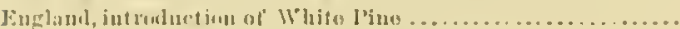
note ous intranluction of Whit. l'im ......

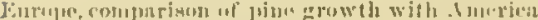

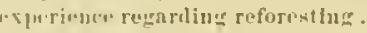
mutur on Simm l'ime.

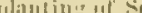

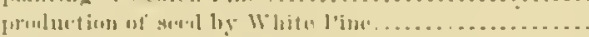

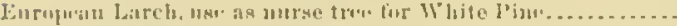

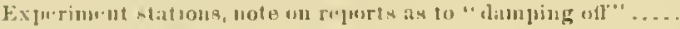
lix furt of White l'inu, nute...

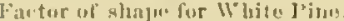

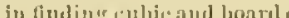

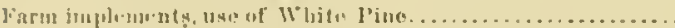

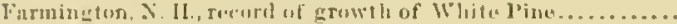

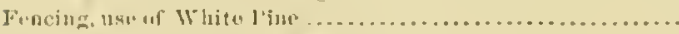

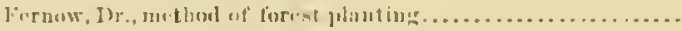

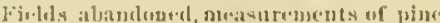

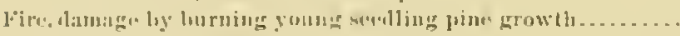

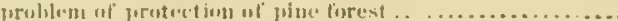

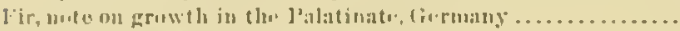

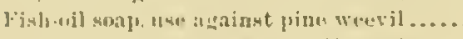

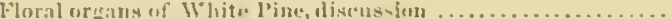

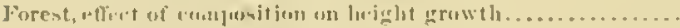

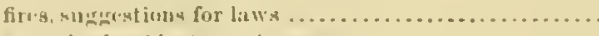

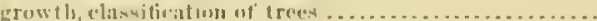
of fint, vlisgiflitation

inme.te, jujurions, natwity.

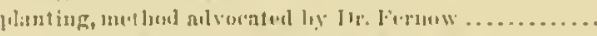

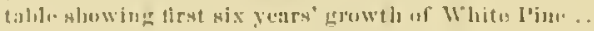

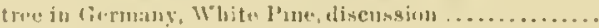

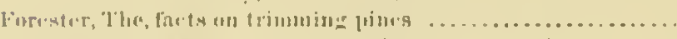

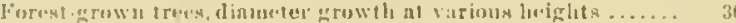

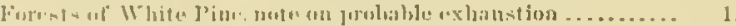

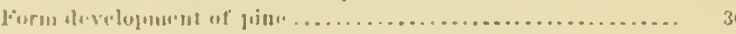

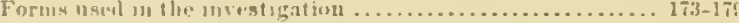

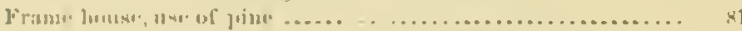

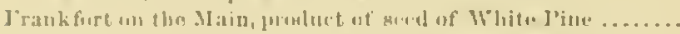

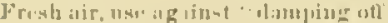

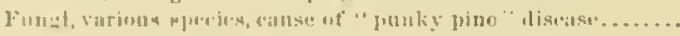

Funens, dena ricus mrllests, injury to 11 luitu l'ius

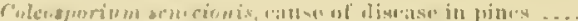

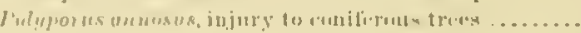

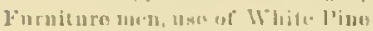

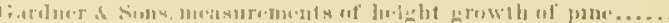

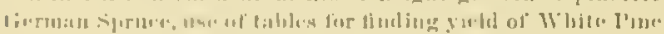

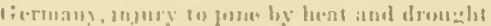

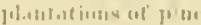

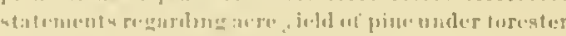

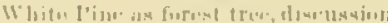

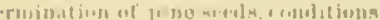

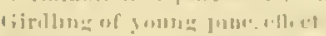

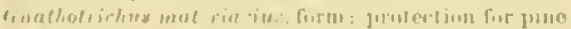

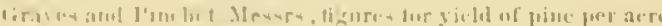

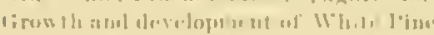

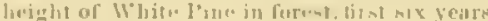

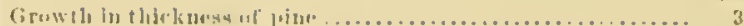

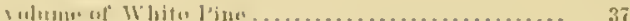

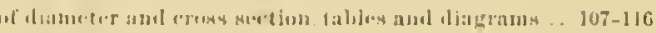

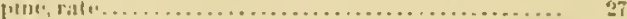

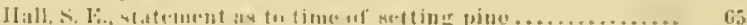

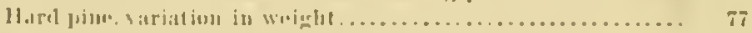

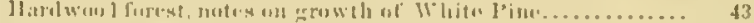
infermixture with to hit, l'itu................ 12

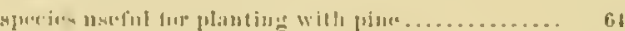

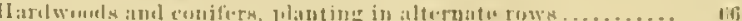

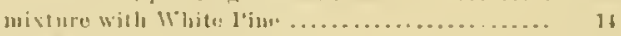

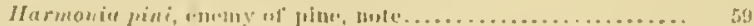

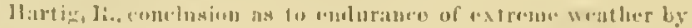

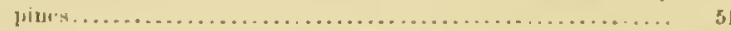

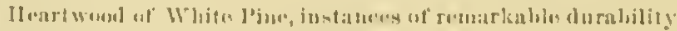

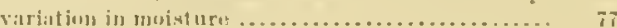

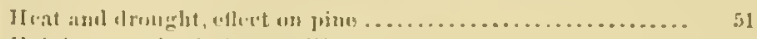

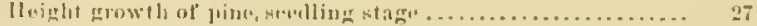
treses atter tirst contury of lito ............ Whit, linw, tithles ..................... 29

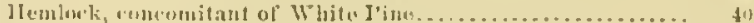
aruwtls uf Whitu I'int in mixtur".............. 33

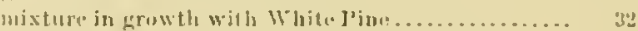

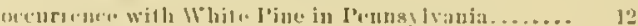

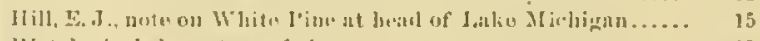

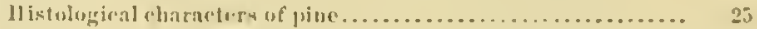

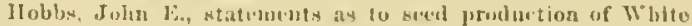

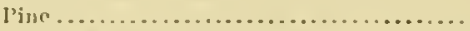
table we height growth of piss. .............

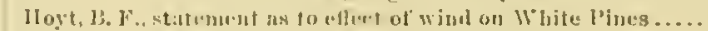
II

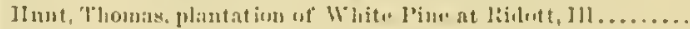

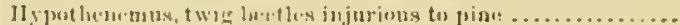

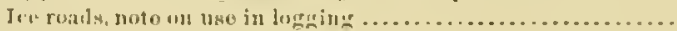

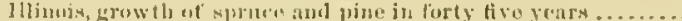

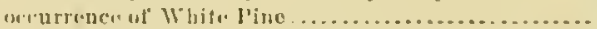

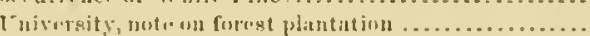
India, noter an lihotin l'ino.

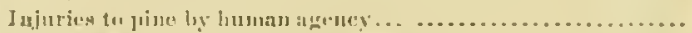

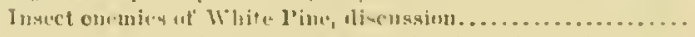

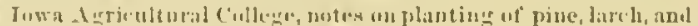

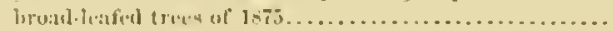

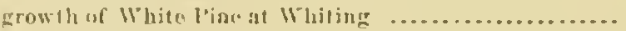

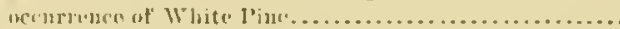

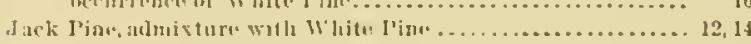

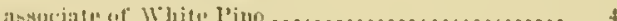

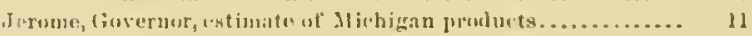

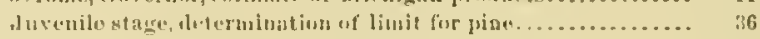
Ficrosedo umulsion, remelly lor bectles un pine............. 57

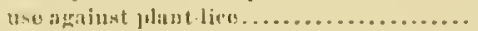

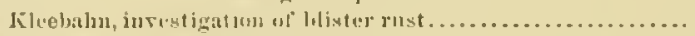

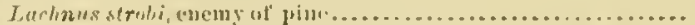

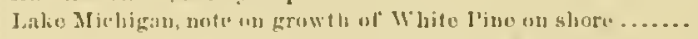

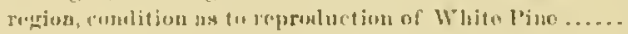
orieitual stame and prestout supplies of Whijte Pin

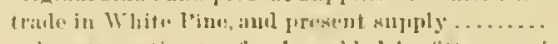

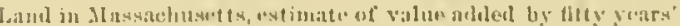

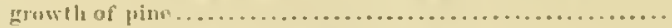

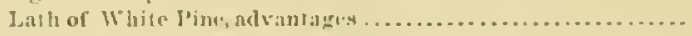

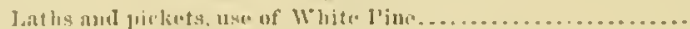

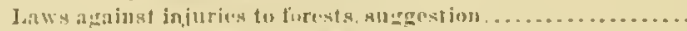

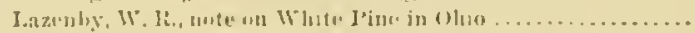

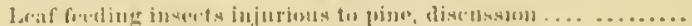

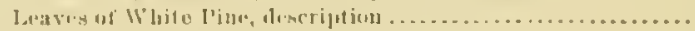

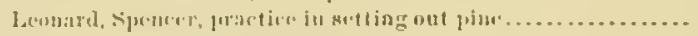

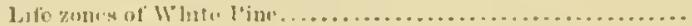

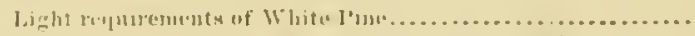

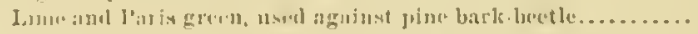

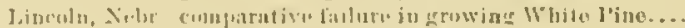

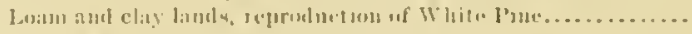

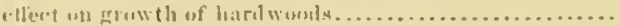

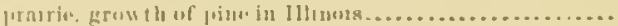

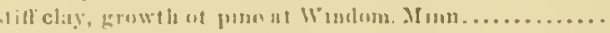

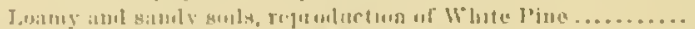

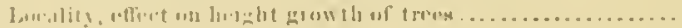

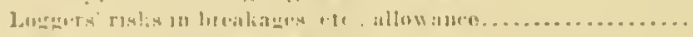

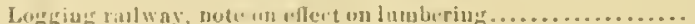


1 mine.

Logs, small, reduetion of loss.

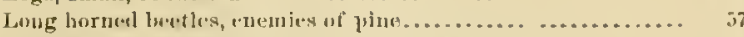

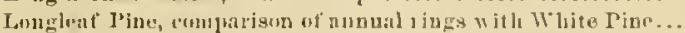
sjurife weight for crown pratt of stcull..

Lumlur contents in 16-fot logs. of tries ...

cut in Lakn regiom, by dintrints, 1873 to 189,

ininstry, White Pine, disenssion. .

markets, inthe'ne of Thlite Pine

of atcm of true, reckonine

jine, injurtare of proiluction.

ratio to testal volumes of pino troe.

Lumbering districts for IVhito l'ine in Cansul

of Whita l'ine, rhinge wi nethoils

iu Mlicluiray, noto.$$
\text { wiste. }
$$

Lumbermen, namo tior tisengte of pine true

Lym:in, J. J). recorel uf growtle of White I'ime.

Macbride, T. П., notu on White Pine in Iowa.

Hainc, acre yichl of White line..

charideter of White ['ine growth .

seconcl.arrowil prive, note

trate in Whita Pine, and supply.

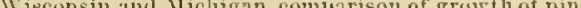

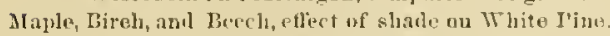
witb line b and pine in Adiroulacks.

Market for securi-growth jiue in Mssachusets........... White l'inc, chato in Germany

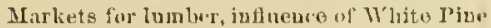

Mlarylaud. oceurreneo of Th hito Pine

Massachusetts, market for sw'ond-growth piub. hote ou trevers of pium set fifty sears aro ...... second-growth pine, wot te soil uf piue groves and ralno of young pine growth... talik of gnenal gain in eireunferruer.

Leasurements, lettil, of anmual gain iu circunference of pine liamster, of trees......................

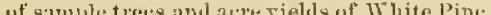

White Pine, tibles................... $85-179$

Medullary rays in pine, notis

Meelan, Thomas, of sous, statements as to growtl of secollim pine............................... nate on occurrence of I'hita P'ine in I'enu.

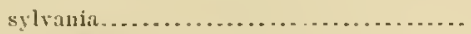

Miev, sprearl of fungus discosm...........................

Michigun, are sieln of Whitu I'inc, table..................

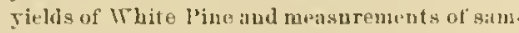

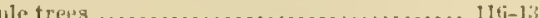

destruction of young piun growth by fire ........ . .

Maine, and $T$ isconsiu, comparison of growt bo pints need of seet for reforesting bare pinc lande.

oeeurrene" of Irluite l'inc.

original staud aml present supply of White Pinc

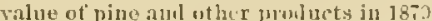

Wiscossit, ami Mingesula, amual cut of Whit

Pine, 1873-1097.

rield of white Jine, per acre..................

Mill constructou uso of White Piuc ...................... s.

Minnesota, heriuning of pine l 1 mbering

liestruction of young fine growth by firn ........

Michigan, ancl $W^{*}$ jisce. an, anumal cut of White

l'ine, 1873-1817

ocrurrence of White Pine . .

original staud and present supplies.

W'iorlom, wrowth of White Pin....

Missunri (river) bottoms, growtli of Whate l'ine.

growing specimens of Whitu I'ine at Columbia .....

Mixed growth, advantiere for pino ......................

Mloblausky, A. K., measurements and "alculatius of Whitu P'ine...

Itodel makers, nso of White Pinu

Modulus of elisticity of Wlinte l'ine.

Ioisturo conteut of White l'iue, talus. confusor aud ot lier species injurious to pine....

Morpbological cluaracters of W" lite Piu.

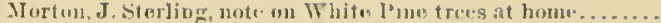

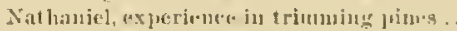

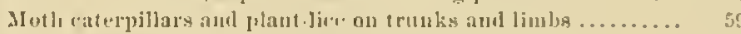

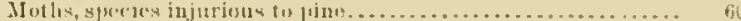

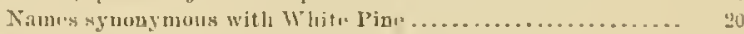

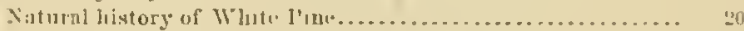

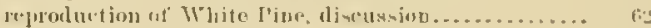

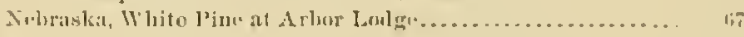

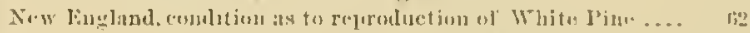
early somuercial use ut White l'ine.......... If

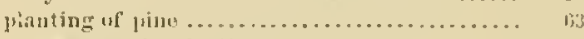

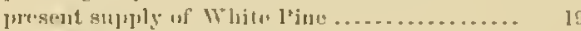

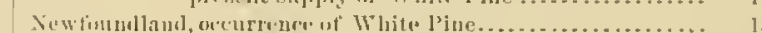

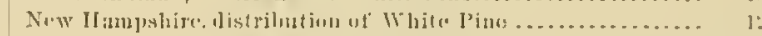

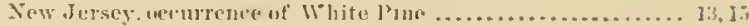

Now Yurk and Ponusylvama, presont supply of Whitu ['ine... 15 distribution of White l'inc .................. 12, 1? mentrene of White l'ine..................... 1: trade in W" hite l'ine: prexent supuly ........... 17

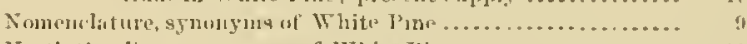

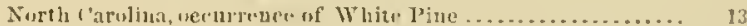

Ifidlleboro, Matss, notes on pino groves of forty years'

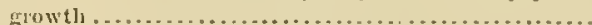

Nurthwextern Lumberman. ligures for anmal cut of lumler in

Lake s1ates, 1893-1597 ............................

Norway Pide, growth in mixtme with 10 hite l'ine............ Surlue, growth in forty-five years at Princetor, IHI...

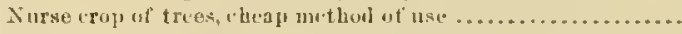

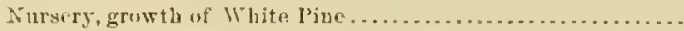

Nurseryourb, pract ine in sowing jine sevel. ................

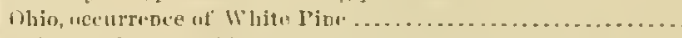

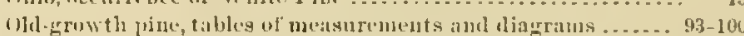

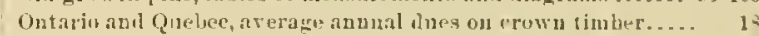

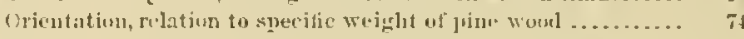

Pavifi: coast timbers, birrior to substitution for ITlite Pine on

Eistern markets ...............................

Pillatinate, report un grout ls of pine and tir................. tig sujuly of cones fir sereit . . .................... 2t

l'arasitic diseases uf White l'inc.........................

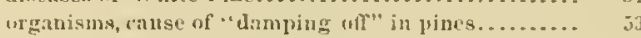

Paris grien and lime, usis agninst pine bark-beetle ......... 50 nse nqaiost pin wertil................... 5

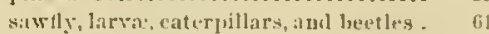

Penusylyoulin, ace yiuld of sceoml-growtl Whito I'ine, witl meisuresuents of young jine.. 148169 lihite l'iue ..................

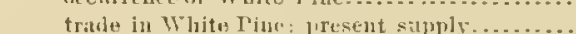

Tenolat, White l'ine trulo and supply.................. 17

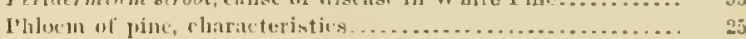

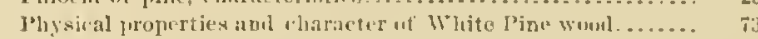

Pickets ant liths, ust of Wh hite I'um..................... \$1

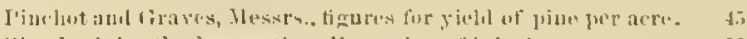

l'ine bark-luertle, lestruetire, l liseussiun uf injuries..........

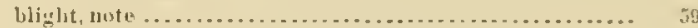

blist or diseatse enused ly colcuspurium senecionis........ 53

leat seale iundet minner ut injury to jime ............. Gl

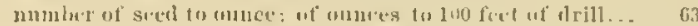

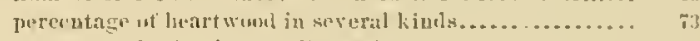

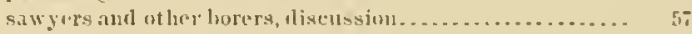

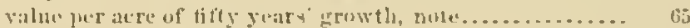

Pincs, comp:urisum wejght and strength, tuble............ si

mulu to shrinkigr............................ it

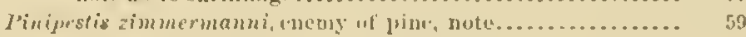

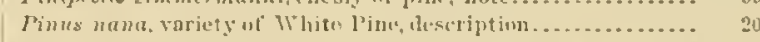

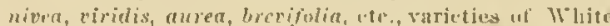

l'ine...................................... 21

I'issoles strubi, cuemy" wi Whitw ['ine, discussion; deseriptinu. 58

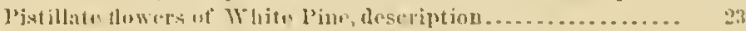

Pituh l'un, associute uf Whito Pin, .................... to

value for plantiog on Atlintic roast............ 5l

I'jts in pine wood, loction, number, and size .............. 25,26

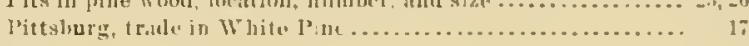

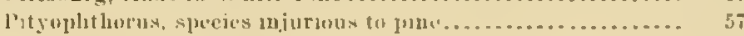




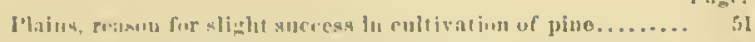

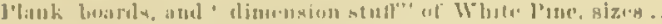

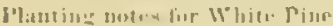

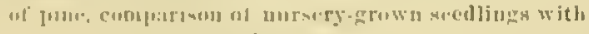

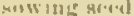

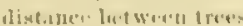

$$
\text { marte. }
$$

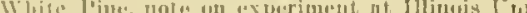
arsity

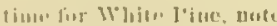

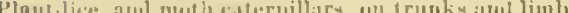

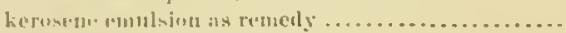

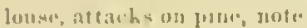

Follen, ri [urnimg, atul pollumations.

Follituation of Wlith. l'ine, mote.

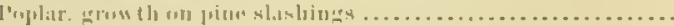

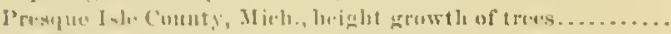

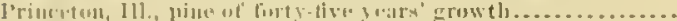

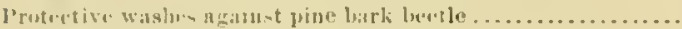

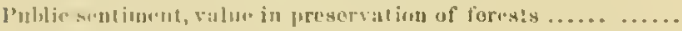

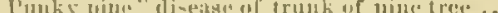

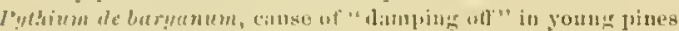
1) 1 -

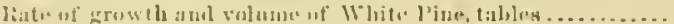

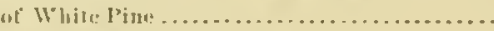

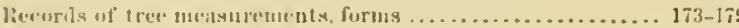

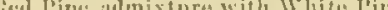

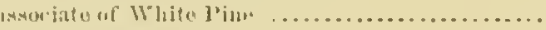$$
\text { tuixturt witl, whitu l'ine }
$$

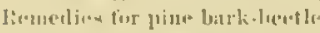

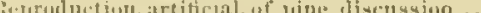

of Whote l'jute, watural, likcussiun

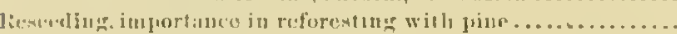

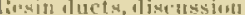

$$
\text { in cort.x }
$$

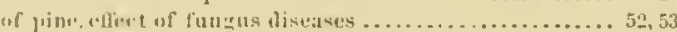

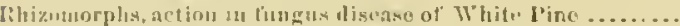

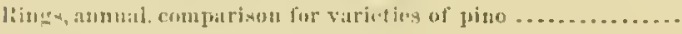

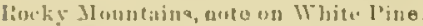

systrm of White ]'ine, relation to jlate of grow th .......

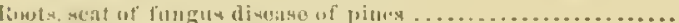

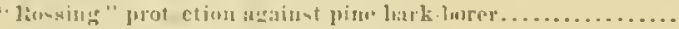
lintution of thes in forest nan nagement ...................

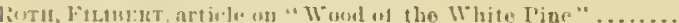
(1) init...........

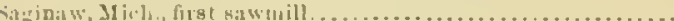

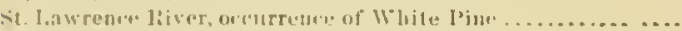

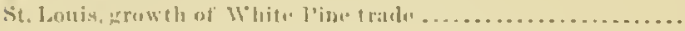

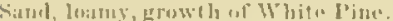

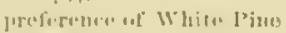

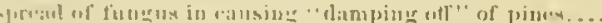

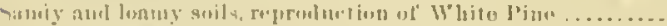

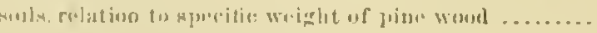

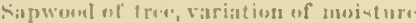

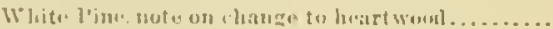

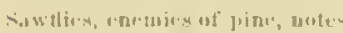

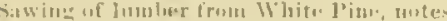

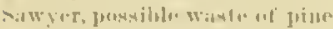

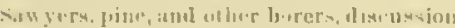

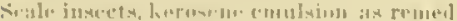

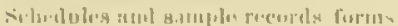

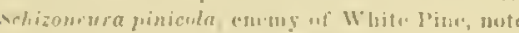

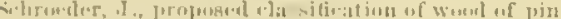

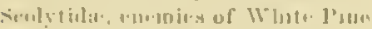

$$
\text { ut lier, imbler lowetlies }
$$

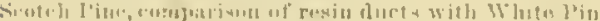

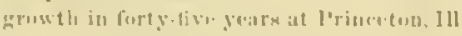
limmaty

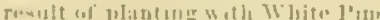

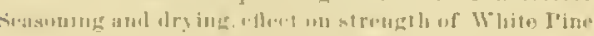

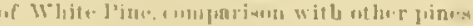

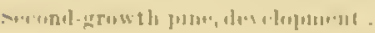

Li. Page

64

01

fis

$61 ;$

(1)

60

fifis

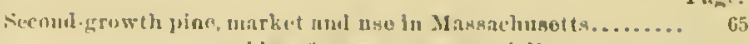

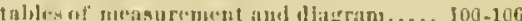

White l'ine, geres yeld, with rocasurentents of

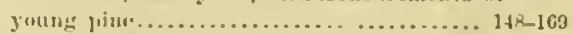

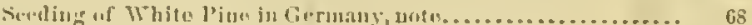

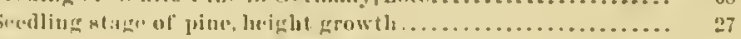

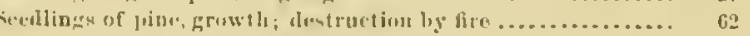
protuctinin ......................... 27

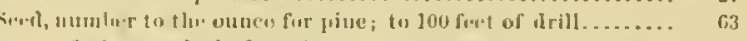

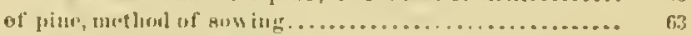

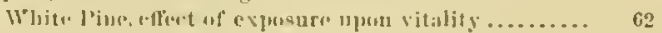

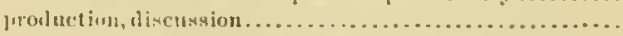

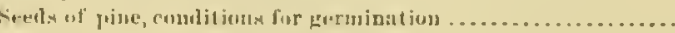

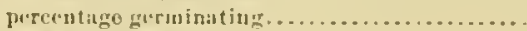
relutim of ritality.

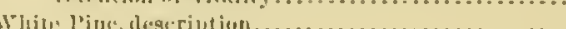

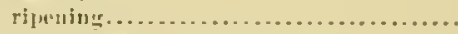

Sharle molurance of White l'jue, note.

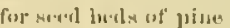

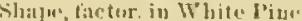

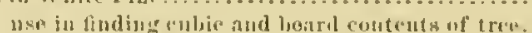

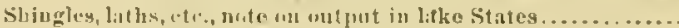

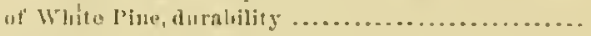
11, of 17 lite Prne......

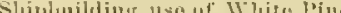

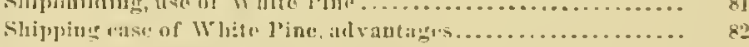

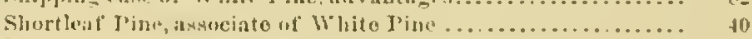

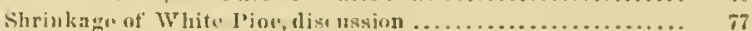

Size uf White l'juc

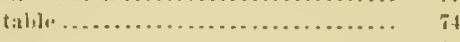

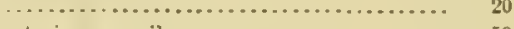

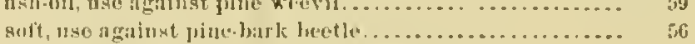

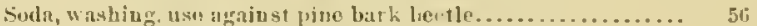

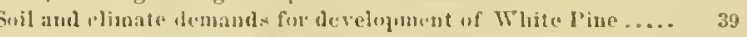
inlluener un height growth of tree. ........ 33

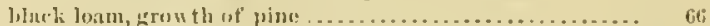

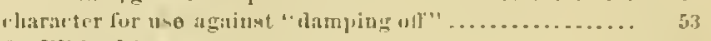

fir. Wilute l'ine, Jute.......................... 15

of l'ulatinate, (d)aractur fur growth of pone........... 6x

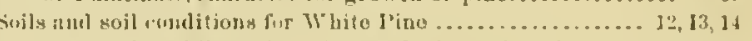

light, adrisability of sowing sed of pine hroadeast ..... 64

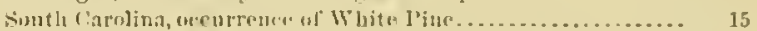

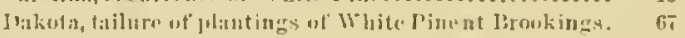

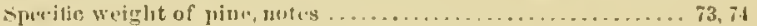

Spurs of 1 olynorne annosus, spreal at uliseatse in pines...... 52

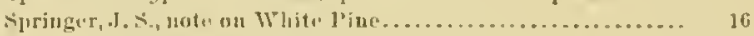

Siruce, concomitatut of White litac .................... to

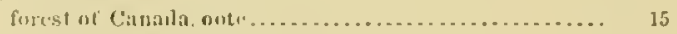

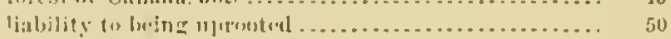

mixture with whit, I'ine...................... 14

forwily, recurel of growth in finmany.............. 69

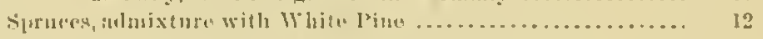

Statuinstl. flowers of White I'ine, description .............. 23

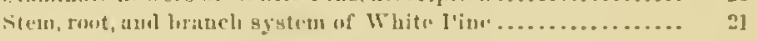

Storns, itujuring qu furest ............................ 50

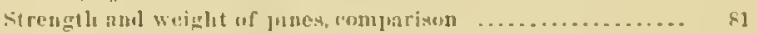

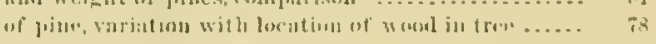

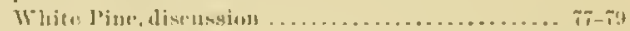

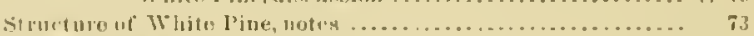

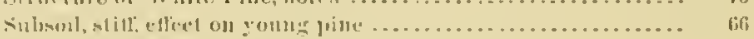

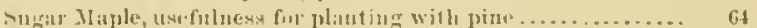

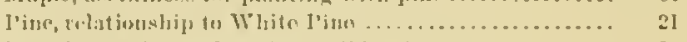

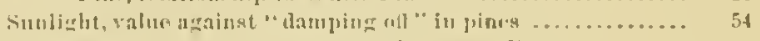

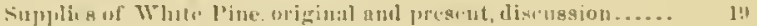

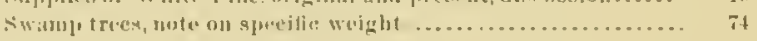

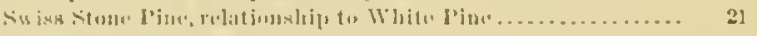

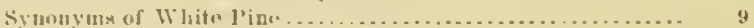

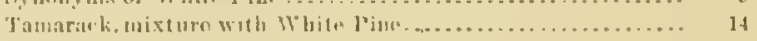

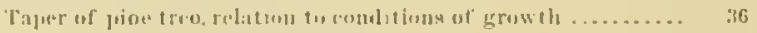

What. l'ino, vitratums........................ 35

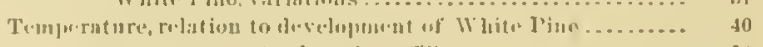

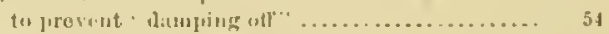

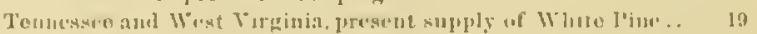

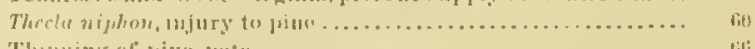

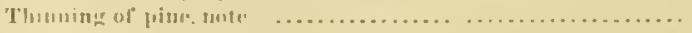

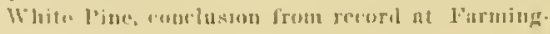

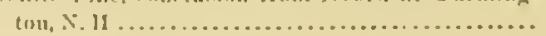


Timber beetleg and other Scolytida, discussion "ommerially valubblv, distribution of White Pine ... w" Whito l'jne, diagrams wn weight ................. vitution in strungth with lexitiu ju

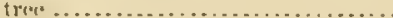

prolucts of Jichigan, comparison for lsig wit] otlute production.........

Tomicus rucugraphus, injury to pines, descriptiou ............. pini and ot her speecies, injury to pine. . .............

Tortririd mutho, rumins of pine, remedies.................

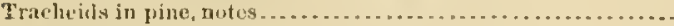

Trumetes radiciperda, injury to coniferous tres. .............

Transplantiug jine secdlings, ontes......................

Tret, largest pine actually measured.

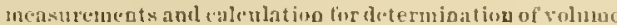

Trees, culsic and lumber contents, not lorent-grown, lim living, langer of attacks f'rom bark bettles ........... of different ages, tuble slowing averago wejht, moist ure content, and sliriokage..................... $74, \tau$ youlog, averago tajer. . . . . . . . . . . . . . . . . . . . . . .

Trunks and limbs of pine, moth caterpillars amd plat lice .... 59 (Nee also stemis and Lolı.s.)

Trlue-builder, pive, Iusnor of injury.

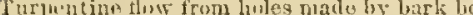

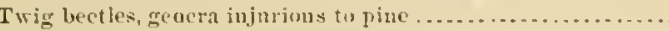

Tpham, Warren, note on soil fir Whito ]'ino.................

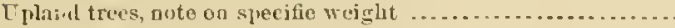

Uprooting, dauger of White Pins.......

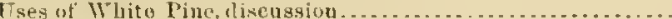

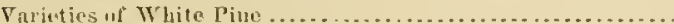

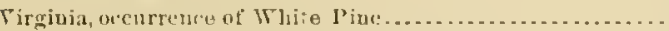

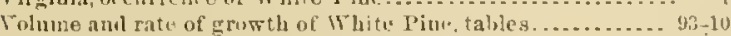
growth of vive, rariatien with soil ................ of treo, measurements and cilculatiou ...............

Wadsworth, S. [3., aote on White Piue in Illinois ..............

Wapues, L., lbasarian furester, repmrt ou White Pine

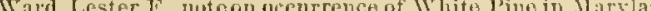
and Tirginia

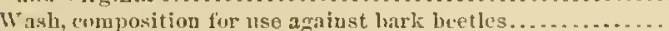
or protuction agninst white Pine weeril .

Washes, proteetive, against piue bark.bietl Waslington City, first sjuing visitation of White Pinn weril Watering, metluw? for juevention of "damping otf" ..........

Teather. relation to slading of" piuo scedlings.

Wect growth. drawback to reprouluction of pise ............

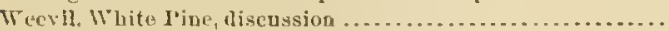
measures for protuction of pine .......... time of appearance ....................

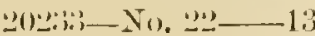

'agu'.

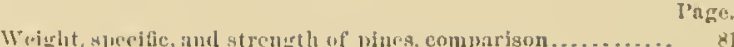

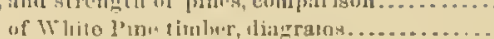

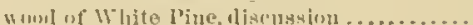

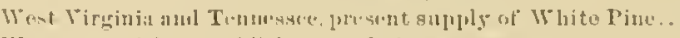

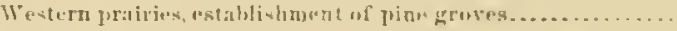

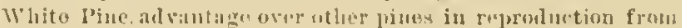

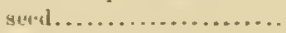

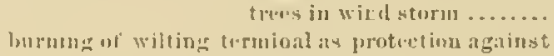

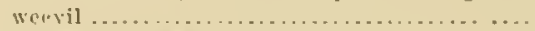

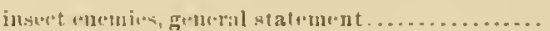

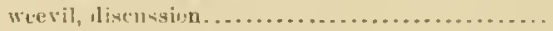

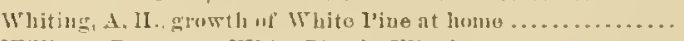
IF illians, R., note on Writ. Ping in Illingis..................

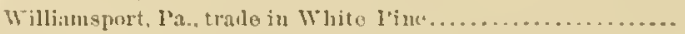
"Ind, immunity of Wh hitu Jin. from iujury................

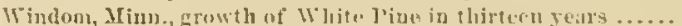

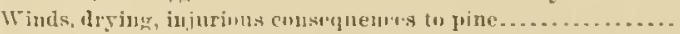

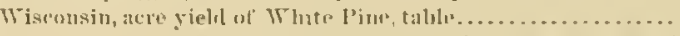

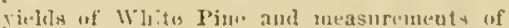
sample treps........................ 131-14i destruction of youx pine growth by firr........ G. first logra taken to it. Louis . . . . . . . . . . . . . . . heary prodution of prine sect ................ 23 Iaiur ancl Jlichigan, complarison of growth of pine Michican aul Minnesuta, anoual tut of White

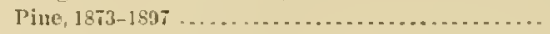

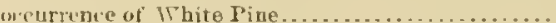
uriginal stant and presint supply of White Pine. rield if Whitu Fine. prer acr. .................. Wworl, amonnt formed is give in different decaldes of growth. Innetion in pconomy of tree ........................

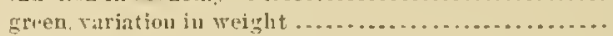
lillu-lry. variation in speific wejght ................ unte on ehangus in White Pino..................... of White Pioe, chitracter and plyssical proprerties.......

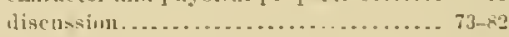
renarks............................ $24=6$ Thorls, other, comparivon with Th hite Pine .............. so Wurtembure, growtle uf White [ime.................... lis

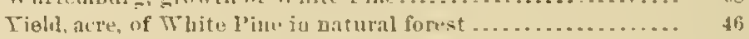

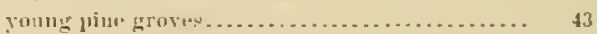

of White I'int, liscussion ....................... 44

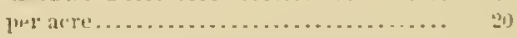

scarod-growel, White Pine with metsurements of

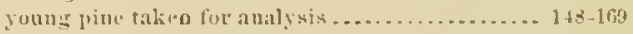
Yiekls, acre, of Whito Pine and mossteremente of samplo trees...................................... 116147

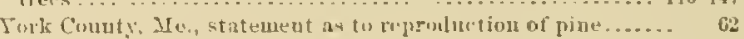




U. S. DEPARTMLNT OI $\triangle$ GRICULTLRL.

4... DIVISION, OF FORESTRY.

\section{T II E}

\section{TINBELR PINES OF TIIE SOMTIIERI INTEED STITES.}

BY CHARLES MOHR, Ph. D.

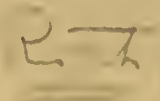

TORHTHE WITH

A bISCTSSION (OF THE STRLCTTRE O]: THEIR W()(O).

By FILIBERT ROTH.

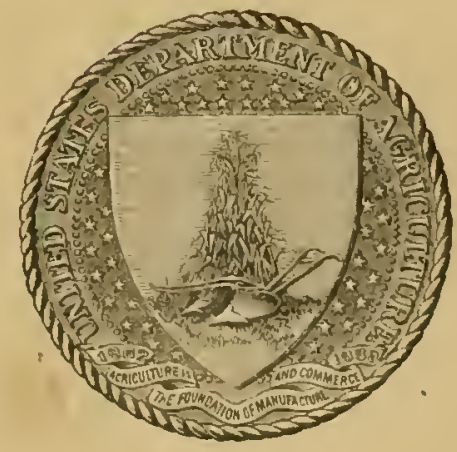

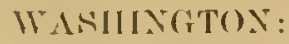

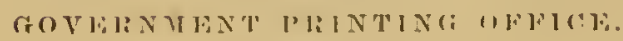

$1 ; i l i$ 



BULLETIN NO. 22.

\section{U.S. DIPARTMINT OF ICRICULTURE. DIVISION OF FORESTRY.}

\section{THE: WHI T E P I N E. (PINUS STROBUS Linnæeus.)}

$\mathrm{Br}$

T. AI. SPALDING,

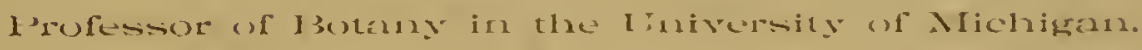

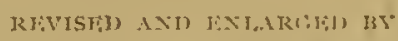

B. F. FFRNOM,

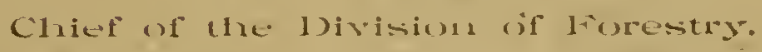

\section{WITH CONTRIBUTIONS:}

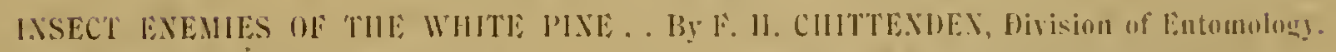
THE WOOL UF THE WHITE PISE . . . . R R FILIBERT ROTH, Division of Forestr.

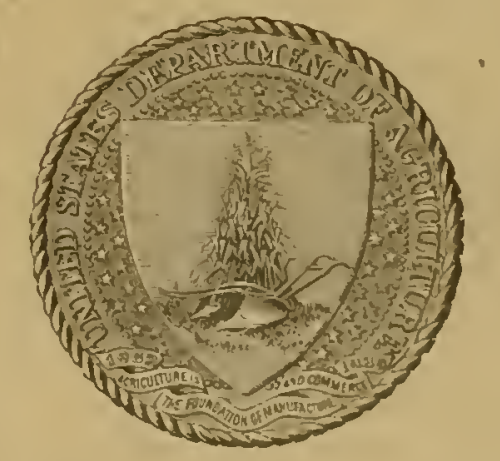

II:ASHINCYOON :

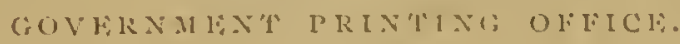

$$
18 \text { (). }
$$







Q

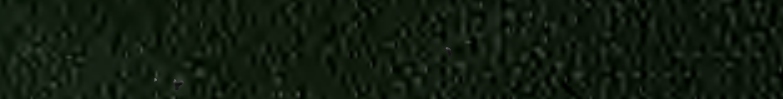

